

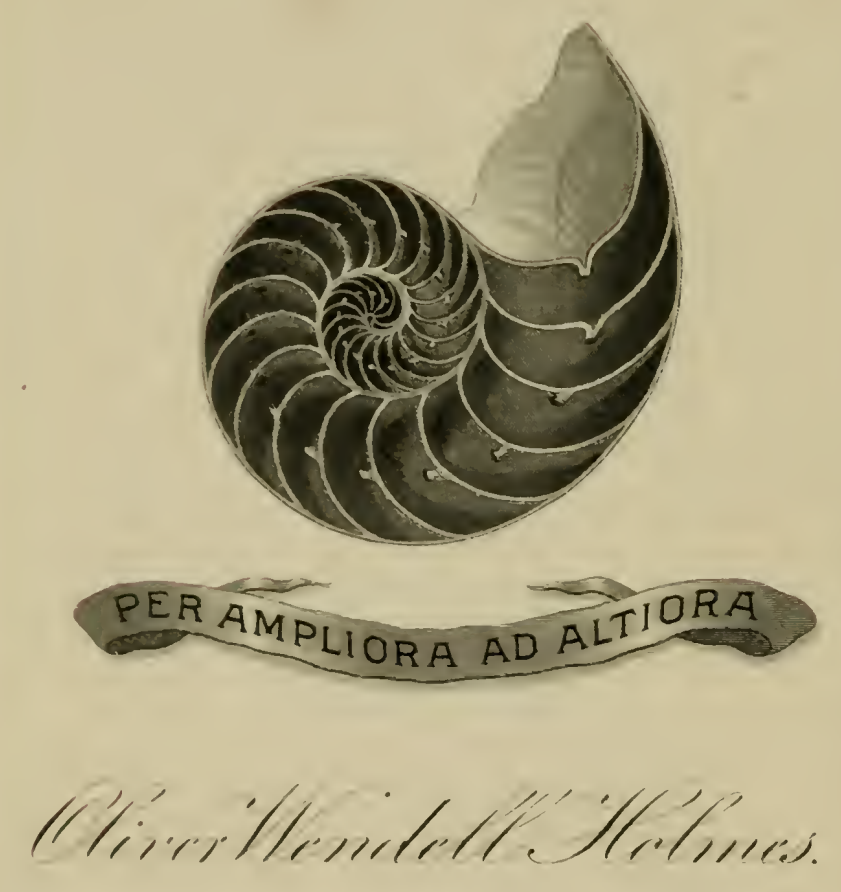

Boston Medical Library in the Francis A. Countway Library of Medicine - Boston 


$$
\text { , }
$$

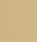




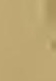


; 

Digitized by the Internet Archive in 2011 with funding from

Open Knowledge Commons and Harvard Medical School 



\section{O M P E N D I U M}

of

HUMAN \& COMPARA'TIVE

\section{PATHOLOGICAL ANATOMY.}





\section{COM PEN D I UM}

oF

HUMAN \& COMPARATIVE

PATHOLOGICAL ANATOMY.

BY

ADOLPH WILHELM OTTO, M.D.

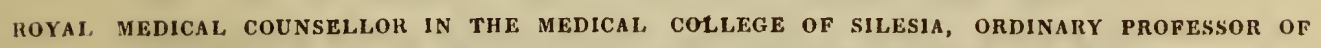
MEDICINE IN THE UNIVERSITY AND MEDICO-CHIRURGICAL ACADEMY AT BRESLAU,

\&c. \&c. \&cc.

Translated from the Serman, with adoitional Notes and Jeferences,

BY

JOHN F. SOUTH,

LECTURER ON ANATOMY AT ST. THOMAS'S HOSPITAL.

LONDON :

B. F E L L O E S, L U D GATE STREET. 1831. 



\section{TRANSLATOR'S PREFACE.}

I feel no need of apologizing to the Profession for the translation of a work, the value of which I am convinced will be fully appreciated by every reader into whose hands it may chance to come. The importance of the subject on which it treats, the advantage of shewing at one view what has been already done in pathology, and the facility it renders to the student of classing such additional facts as he may meet with in his reading or experience, require no comment; and, as such, $I$ trust it will be found no mean help in professional inquiry.

The additional references given by the author in his Appendix I have incorporated in the body of the work, as he proposed; and to these I have added further references and notices of cases which have come within my own knowledge, all of which are bracketed and marked T. to prevent confusion.

As to the minor share I have borne by the translation, I have to beg the reader's indulgence if, in my endeavour to 
viii

render the author's views in, as nearly as possible, his own language, I may seem to have made my translation too literal. Occasionally I have encountered much difficulty in finding suitable expressions; and for one word which the author frequently employs I can find no equivalent, and have been compelled to adopt the term loosening, which certainly does not give the full meaning of the term he makes use of, which implies that kind of separation of fibres produced by shaking up a bag of feathers, or by scribbling wool: whereever, therefore, the term loosening is used, it must be understood as employed in this sense.

JOHN F. SOUTH.

October $10,1831$. 


\section{P R E F A C E.}

My Manual of Pathological Anatomy having been out of print several years, I was anxious to publish a second edition; but I found that, in the meanwhile, there had been not merely a great change in the science about which I purposed writing, but also my own views upon the subject were so much altered, that I rather preferred writing a new book to improving the old one. Hence originates the present work, the first volume of which I recommend to the kind consideration of the honoured reader; and in consequence of having a different publisher, has the new title been employed.

I have but little to say with reference to the plan and arrangement of the book. My own experience, and the advice of well-informed friends, have convinced me that the arrangement commonly employed in Anatomy, would also best suit Pathological Anatomy; but that it was advisable to premise the special pathology by a General Part, which should treat of the irregularities in connexion with each other, which plan I had always hitherto adopted in my Lectures on $\mathrm{Pa}$ thological Anatomy.

Not forgetting that one principal character of a good book is its brevity, I set out with this view, as much from principle as from inclination, and have endeavoured, wherever explanation was necessary, to supply it in the Notes, to which I must therefore refer in all matters of doubt. A Compendium should, on no account, treat subjects circumstantially, but merely note them; and in lectures, the teacher may very easily spin out, according to his pleasure, the short threads herein provided.

In order that the book might serve for private study and reference, I thought ${ }^{*}$ it advisable to add a more copious list 
of Pathological Literature. The latter I have arranged, as far as I could, with much time and labour, in a chronological order, so as at once to exhibit, to a certain extent, a history of the science; and the influence which the various prevalent theories in medicine have had in the treatment of the several chapters, will not escape the attentive reader.

I very much regret that the literary notices are not more perfect, but especially the Dutch and Italian, to which I have had no opportunity of referring: be it, however, kindly remembered, that I live on the eastern borders of Germany, and could hardly employ any other than my own single library. Further, I have in part purposely not cited the innumerable isolated observations of the younger practitioners, which have been published in both German and foreign periodicals, as they are often neither interesting nor correct anatomical observations. I have also but rarely employed the copious literary references contained in Voigtel's Handbuch der Pathologischen Anatomie, because I found them very unsatisfactory. I have, instead, commonly referred to preparations in the Anatomical Collection at Breslau, which has been done for the sake of my auditors; and the addition to my Catalogue, which will shortly appear, will more fully announce the nine thousand preparations in this collection.

I must, however, observe, that the printing of the work commenced two years ago, but that a severe illness, with an accumulation of official engagements, have prevented its more rapid progress, by which several additions, required to make the work useful, are now added in an Appendix.

The Pathological Anatomy of Craigie, Andral, and Lobstein, unfortunately reached me so late, that I could not make use of them; however, they will certainly be used in the second and last volume, which, I hope, will very soon follow the first. 


\section{O N T E N T S.}

INTRODUCTION • . . . . . . . . . . . . . 1

FIRST, OR GENERAL PART.

First Section . Of the Vices of Animal Organization in general . . . . . . . . 13

Second Section . Of Vices relating to Number • . . 18

Third Section . Of Vices relating to Size . • • . . 21

Fourth Section . Of Vices relating to Form . . . . 27

Fiftr Section . Of Vices relating to Position . • . 28

Sixth Section . Of Vices relating to Connexion . . . 31

Seventh Section . Of Vices relating to Colour . . . . 33

Eighth Sectron . Of Vices relating to Consistence • • 38

Ninth Section . Of Vices relating to Continuity • • 39

Tenth Secrion . Of Vices relating to Texture . . . 41

Eleventh Section. Of Vices relating to Contents . . . 73

SECOND, OR PARTICULAR PART.

FIRST BOOK.

OF THE PARTICULAR ORGANS, OR THE ORGANIC SYSTEMS.

Twelfth Sectron . Of Cellular or Mucous Tissue . . 90

Thirteenth Section. Of Cellular Membranes . . . 95

First Chapter . Of Serous Membranes. • . . 96

Second Chapter. Of Mucous Membranes . . . 99

. Third Chapter . Of External Skin . . . . . . 103 
Fourteenth Section . Of Homy Tissue . . . . . 110

First Chapter . Of the External and Internal Cuticle 114

Second Chapter . Of the Nails and Hoofs . . . . 116

Third Chapter . Of Hair and Feathers . . . . 120

Fifteenth Section. Of the Bony System . . . . . 125

First Chapter . Of Bones in general . . . . . $i b$.

Second Chapter. Of Bones in particular . . . . . 157

A. - Of the Bones of the Head . . . . . . $i b$.

B.-Of the Bones of the Trunk . . . . . . 194

C. - Of the Bones of the Upper Extremities . . . 216

D.-Of the Bones of the Lower Extremities . . . 220

Sixtente Section . Of the Cartilaginous System • . 225

Seventemath Sectron. Of the Fibrous System in general, and of the Joints in particular . 229

Eigitenth Section. Of the Muscular System . . . 243

Nineteenth Section. Of the Vascular System . . . . 253

First Chapter : Of the Pericardium . . . . . . $i b$.

Second Chapter . Of the Heart. . . . . . . 260

Third Chapter . Of the Arteries . . . . . . 294

Fourth Chapter . Of the Veins . . . . . . 335

Fifth Chapter . Of the Lymphatic Vessels and Glands 355

Twenticti Section . Of the Nervous System • • . 363

First Chapter. Of the Brain . . . . . . . $i b$.

A.-Of the Membranes of the Brain . . . . . $i b$.

B.-Of the Brain itself. . . . . . . . . 385

Second Chapter. Of the Spinal Marrow . . . . . 423

A.-Of the Membranes of the Spinal Marrow . . ib.

B.-Of the Spinal Marrow itself. . . . . . 428

Third Cli(ip)er. Of the Nerves . . . . . 439 


\section{N T R O D U C T I O N.}

ANATOMY, or the science of the structure of organic bodies, is divided into two principal parts, according as it treats either of healthy and regular, or of diseased and irregular structure; the former is briefly called Anatomy, Normal or Physiological Anatomy; the latter, Pathological, Morbid, or Practical Medical ${ }^{1}$ Anatomy.

The very nature of the subject prevents our setting distinct limits to Pathological Anatomy. For as during life no direct boundary can be drawn between health and disease, so also does the healthy and regular structure of organized bodies merge so imperceptibly and in so many different ways into the diseased and irregular, that normal and abnormal or pathological anatomy cannot be strictly separated from each other, just so intimately and firmly is pathological anatomy connected with pathology, symptomatology, and surgery, that a strict distinction between them might be difficult. In consequence of the close connexion of these sciences with pathological anatomy arises the necessity of making oneself master of them for the purpose of learning and prosecuting it with advantage. But before all, a very intimate knowledge, perfected by practice, not merely of the coarser, but especially of the more delicate structure of organic bodies, that is, a knowledge of human and comparative anatomy, is necessary for the study of pathological anatomy ${ }^{\text {. }}$

(1) Morgagni præf. ad lib. IV. Epistolar. de sed. et calls, morbor.

(2) Ib. præf. ad lib. I. 
As, however, man forms but one link in the chain of organic beings, so, for the perfection of pathological anatomy, nothing would operate more advantageously, than the investigation of the diseased structure of the other organic bodies, and particularly those of animals. As soon as we have collected a considerable number of such observations, we may expect, in a general view of the vices of structure in organic bodies, to penetrate deeper into their nature and causes. Even now whilst pathological anatomy, in comparison with most other medical sciences, is only in its infancy, its utility is traced in almost all the branches of medicine; it is the common and absolute source of all, ${ }^{3}$ but particularly of anatomy, physiology, and pathology. ${ }^{\circ}$

Hence is the intimate knowledge of pathological anatomy equally indispensable, both to the practical physician, the medical jurist and the surgeon, and if subsequently this be more studied as a comparative science, for the veterinary physician also.

Pathological anatomy has only in later times been pursued successfully, although in the earliest periods, ${ }^{5}$ and some hundred years before GALEN, human bodies had been examined in Egypt ${ }^{6}$ in order to ascertain the seat and causes of disease. In the beginning of the sixteenth century, the first work on pathological anatomy was written by Antonio Benivieni at Florence. When in this century, the love of anatomy revived,

(3) Morgagni præf. ad lib. I-V. Gerh. Andr. Müller Progr. de utilitate anatomiæ practicæ. Gies. 1753. Pauls Gräuwen Oratio de anatomiæ pathologicæ utilitate et necessitate. Groning. 1771 .

Ladevéze et Monfalcon De l'influence de l'anatomie pathologique sur le progrès de la médecine, etc. in Journ. complém. du Diction. des Sc. médic. T. XI. p. 193-215. T. XIV. p. 289 ct T. XV. p. 98. Bayle Considérations générales sur les secours que l'anatomie pathologique peut fournir a la Médecine; v. Artic. A natomie pathologique, in Dict. des Scienc. médicales, T. II. p. 61-78. Lobstein in Journ. complémentaire du Dictionnaire des Sciences médicales. Paris, 1818. T. II. p. $3-23$.

Bousquet Quelques réflexions sur l'anatomie pathologique, considérée dans ses rapports avec la Science des maladies, in Journ. complém. du Dict. des Sc. médical. T. VII. p. $289-303$.

$J$. Smith D. de utilitate morborum naturam cadaveribus sectis explorandi. Edinb. 1812.

I. Pacini Intorno la necessità dello studio dell' Anatomia patologica. Lucca, 1828.

(4) F. A. Stürmer D. exl. meletemata quxdam generalia in pathologiam. 8 vo. Dorpati, 1814.

Ons.- Not merely local cliseases, but fevers and nervous diseases are likewise connected with pathological anatomy, as undoubtedly many of these have organic changes for their cause, and all have them, though perhaps transiently,
as an effect.

(5) The Writings of Hippocrates.

(6) Plinius Nat. Hist. I. XIX.c. 8. 
and the science was ardently pursued by Fallopius, Vesalius, and Eustachius with most brilliant success; individual observations of interest in pathological anatomy were occasionally made, and pathological examinations were frequently instituted both in this and in the subsequent century. But the deficiency of the necessary ancillary sciences, and the superstition and prejudice at that time prevailing, prevented the speedy progress of this science. Bonetus and Mangetus, towards the end of the seventeenth century, collected the single, and in some measure, important observations made before their time, and endeavoured to arrange them, though not very successfully. It was only in the eighteenth century that pathological anatomy began to advance rapidly, especially by the extraordinary labour of Morgagni, who must be considered as the founder of this science, by the rich and instructive collections of anatomicopathological preparations of Hove, RAU, Ruysch, Walter van Doeveren, Vater, Walter, the Meckels, the Monros, the Sandiforts, and the Hunters, which were further added to by Lobstein, LODER, and others, as well as by the excellent contributions and works of later, and in some instances still living, anatomists. ${ }^{7}$

The pathological anatomy of animals has been relatively, as yet, but little investigated, and needs, as well as comparative pathology, further attention. It arises indeed from the circumstance, that only of late comparative anatomy has began to be studied with ardour; that anatomists and pathologists rarely possess sufficient zoological and zoomedical knowledge, whilst the veterinary physicians, on the other hand, have as rarely sufficient knowledge of physiology and patho$\log y$, and further that the rarity of most animals much increases the difficulty of anatomico-pathological examinations. Animals are also subject to much fewer diseases than man living in a civilized state, ${ }^{8}$ and those only of them which he appropriates to himself, and about which he evinces the greatest concern, are most frequently subject to diseases.

Besides the numerous and important contributions to pathological anatomy, which are found dispersed in the writings of

(7) A short view of the History of Pathological Anatomy is given by Morgagni, præf. ad lib. II. Hecker Magazin für die pathol. Anat. and Physiol. Altona, 1796, Voigtel, p. 3. and P. Rayer Sommaire d'une histoire abrégée de l'Anatomie pathologique. 8vo. Paris, 1818.

(8) G. E. Stahl D. de frequentia morborum in corpore humano præ brutis. 4 to. 1695 .

Don Bern. Dominguez Rosainz Porque son mas frequentes las enfermedades en los racionales que en los brutos? \&c. Mem. Acad. de la R. Soc. de Sevilla T. V.p. 191. (Why are diseases more common in man than in brutes?) 
anatomists, physiologists, ${ }^{9}$ and physicians, the best general works, either exclusively or preeminently, relating to pathological anatomy, are the following: $:^{10}$

Axton. Benivenius De abditis nomnullis ac mirandis morborum et sanationum causis. 4to. Florent. 1507.

*Jo. J Aco $_{\text {B }}$ Chiffletius, Singulares tam ex curationibus quam Cadaverum sectionibus observationes. 12mo. Paris, 1612.

*T. Corbeus Pathologia sive Morborum et Affectuum omnium præter naturam qui Corpus Humanum invadere solent enumeratio. 12mo. Francof. 1616.

*J. Riolanus, (filius) Encheiridium Anatomicum et Pathologicum in quo ex naturali Constitutione Partium Recessus à naturali Statu demonstratur. 8vo. Lugd. Batav. 1649.

* Gualt. Charleton, M.D. Exercitationes Pathologicæ novis Anatomicorum inventis sedulo inquiruntur. 4to. London. 1661.

Th. KerckringiI Spicilegium anatomicum, continens observationum anatomicarum rariarum centuriam unam, etc. 4to. Amstel. 1670.

Th. Bartholinus De anatom. practica ex cadaveribus morbosis adornanda consilium. 4to. Hafniæ, 1674.

Theophili Boneti Prodromus anatomiæ practicæ. 8ro. Genevæ, 1675.

Ejusd. Sepulchretum anatomicum s. anatomia practica ex cadaveribus morbo denatis. Vol. II. fol. Genev. 1679. Mangeti, Vol. III. fol. Lugdun. 1700.

GregoriI Horstil Specimen anatomiæ practicæ. Francof. 1678.

Steph. Blancardi Anatomia practica rationalis, s. rariorum cadaverum morbis denatorum anatomica inspectio. 12mo. Amstel. 1688.

* Jac. Am. Long, D. de Differentia inter Hominum morbos com brutis communes. 4to. Alt. 1689.

Bibliotheca anatomica illustrata et aucta. Digesserunt DaNiel Chericus et J. J. Mangetus. Vol. II. fol. Genev. 1699.

H. BidLoo Exercitationum anatomico-chirurgicarum Decades dure. 4to. c. tab. Lugd. B. 1708.

Jo. Salzmann Specimen anatomiæ curiosæ et utilis. 4to. Argent. 1709.

(9) Viz. Haller, Blumenbach, J. Hunter, Pinel, Bichat, and many others.

(10) Compare Buldinger Neues Magazin für Aerzte, Leipzig, 1799. Vol. IX. Part I. p. 87, and Vol. XVI. Part VI. p. 481. Hecker, The Manuals of Ludwig, Conradi, Voigtel, and Consbruch, as well as Heusinger System der Histologie, Vol. I. Part I. p. 50-103.

* All the authoritics marked thus * are additional.-Translator. 
Jo. Mauriti Hoffmann Disquisitio corporis humani anatomico-pathologica rationibus et observationibus veterum et recentiorum singulari studio collectis, confirmata. 4to. Altdorf. 1713.

Ph. Conr. Fabrizir Idea anatomiæ practicæ. 8vo. Wetzlar, 1741.

F. BARRÈre Observations anatomiques tirées de l'ouverture des cadavres. 4to. Perpignan, 1751. 2d ed. enlarged, with engravings. 4to. 1753.

*C. N. Jenty, M.D. A Course of Anatomico-Physiological Lectures on the Human Structure and Animal CEconomy, \&c. and Pathological Observations, deduced from the Dissection of Morbid Bodies. Including whatever is most valuable in the Works of all the eminent Professors on these subjects. 3 vols. 8 vo. London, $1751-65$.

Albini Variæ annotationes anatomico - pathologicæ in LamBRECHT's Oblectationes et observationes anatomicæ. Francof. 1751.

J. D. Metzger Observationes nonnullæ anatomico-pathologicæ c. Epicrisi. Regiom. 1757.

Pet. Camper Demonstrationes anatomico-pathologica. fol. Lib. I. et II. Amstelod. 1760-62.

Jo. Baptista Morgagni De sedibus et causis morborum per anatomen indagatis. Vol. II. fol. Venet. 1761. - fol. Patav. 1767.- Vol. II. 4to. Amstel. 1768.-Ebroduni in Helvet. ex edit. Tissoti, 1799. Vol. III. 4to. Translated into German by Koenigsdoerfer. 5 vols. 8vo. Altenb. 1771. Edid. J. Radius. Lips. 1828.

* Samuel Clossy, Of some Diseases of the parts of the Human Body, chiefly taken from the Dissections of Morbid Bodies. 8vo. London. 1763.

Alb. v. Haller Opera minora. 4to. Laus. 1762-68. Vol. III. and Opuscula pathologica. 8vo. Laus. 1768.

Rich. Browne Cheston, Pathological Inquiries and Observations in Surgery from the dissection of morbid bodies. 4to. Glocester, 1766 . Pathologische Untersuchungen und Beobachtungen in d. W. A. K. durch Zergliederung krankhafter Leichname; nebst cimen Anhange von 12 versch. Wahrnehmungen v. J. C. F. Scherf. 8vo. Gotha, 1780 .

Joh. Lievtaud Historia anatomico-medica, sistens numerosissima cadaverum humanorum extispicia, quibus in apricum venit genuina morborum sedes. Edit. ab Ant. Portal. Vol. II. 4to. Paris, 1767. recudi curavit, correxit et suppl. complet. J. Chr. Fr. Schleger. Vol. II. 8vo. maj. Longosaliss. 1786-87.

Ed. Sandifort Observationes anatomico-pathologica. Vol. IV. c. fig. 4to. Lugd. B. $1777-80$.

Chr. Fr. Ludwign Primæ linex anatomiæ pathologicæ. 8vo. Lips. 1785. 
VICQ d'Azyr Artic. Anatomie pathologique, in the Encyclopédic méthodique. 1789.

Chr. Fr. Ludwigi De quarundam ægritudinum h. c. sedibus et causis, tabulis 16, meditat. nonn. illustr. fol. Lips. 1798.

Matthew Baillie, The morbid anatomy of some of the most important parts of the Human Body. 8vo. 5th edition. London, 1818. Translated from the 1st edition into German, with additions, by S. Tir. Soemmerring. 8vo. Berlin, 1794. and the Appendix, with the 5 th edition, translated by Dr. C. Honnbaum, and with additional remarks by S. Th. v. Soemmerring. 8vo. Berlin, 1820. -translated also into Italian by $Z_{\mathrm{ANNINI}}$, and into French by Guerbois.

Ib. Series of Engravings, accompanied with Explanations, which are intended to illustrate the morbid anatomy of some of the most important parts of the human body. 2d ed. 4to. London, 1812.

$I b$. The morbid anatomy and other works of the late, by J. Wardrop. 2 vols. 8vo. Lond. 1827.

Georg. Christoph Conradi Handbuch der pathologischen Anatomie. 8vo. Hannov. 1799.

J. C. Flachsland Observationes anatomico-pathologicæ. Rastad. 1800. c. tab. æn.

Spry Ueber die Anatomie des kranken Körpers v. Friese Annalen der neusten britt. A. K. u. W. A. K. Bd. I. St. I. 1801.

C. Berl, A System of Dissection, explaining the anatomy of the human body, the manner of displaying the parts, and their varieties in disease. fol. Edinb. 1798.

*Ib. Engravings of specimens of morbid parts in the Author's collection. fol. London, 1813.

V. Malacarne Ricordi della Anatomia chirurgica raccolti. 2 tom. 8vo. Padova, 1801-2.

G. Dupurtren Propositions sur quelques points d'anatomie, de physiologic et d'anatomie pathologique. Paris, 1803.

A. R. Vetter Aphorismen aus der pathologischen Anatomie. Wien. 1803.

G. H. Thruow Beschreibung anatomisch-pathologischen Gegenstäinde durch Wachspräparate und Kupfer versinnlicht, nebst verschiedenen Anmerkungen. Bd. I. L. I. Gotha, 1804.

Prost Médecine éclairée par l'observation et l'ouverture des corps. 2 tom. 8vo. Paris, 1804.

Portal Cours d'Anatomic médicale, ou élémens de l'anatomie de l'homme avec des remarques physiologiques et les resultats des observations sur le siège et la nature des maladies d'après l'ouverture des Corps. 5 tom. 8 vo. Paris, 1804. 
F. G. Vorgtel Handbuch der pathologischen Anatomie. Mit Zusätzen von P. F. Meckel. 3 bde. 8vo. Halle, 1804-5.

C. J. Kellethout Sectiones cadaverum pathologicx. Lugd. Batav. 1805.

Flor. Catddani Osservazioni anatomico-patologiche. Memoria I. in Memor. di Matemat. e di Fisica della Societ. Italian. T. XII. P. II. Modena, 1806.

Pir. Fr. MECKEL Journal für anatomische Varietäten, feinere und pathologische Anatomie. 8vo. Bd. I. H. I. m. k. Halle, 1805.

*F. I. V. Broussa1s Histoire des Phlegmasies on inflanmations chroniques. 2 tom. 8 vo. Paris, 1808-1816.

Joh. Fr. Mecker Handbuch der pathologischen Anatomie, Bd.I. Bd. II. Abth. 1 und 2. 8vo. Leipzig, 1812-18.

J. M. D. Herord D. exh. Observata quædam ad corp. hum. partium structuram et conditionem abnormem. 8vo. Marburg. 1812.

Arex. Monro, jun. Outlines of the Anatomy of the Human Body in its sound and diseased state. 8vo. Edin. 1812. 3 vols. and 1 vol. engravings.

Jon. Fr. Blunenbach De anomalis et vitiosis quibusam nisus formativi aberrationibus commentatio. 4to. c. duob. tab. an. Gotting. 1813.

* Kercu Beiträge zur patholog. Anatomic. Berl. 1813.

J. FARre, Pathological Researches in Medicine and Surgery. 8 vo. London, 1814.

A. F. Fow E D. s. animadversiones in anatomiam pathologicam. 8vo. Berol. 1815.

Gottfr. Fleischmann Leichenöffnungen. 8vo. Erlangen, 1815.

*J. W. Francis, M.D. Cases of Morbid Anatomy. 4to. New York, 1815.

C. H. Parry, Elements of Pathology and Therapeutics, illustrated by numerous Cases and Dissections. Vol. I. 8vo. Lond. 1816.

Jean Cruveilhier Essai sur l'Anatomie pathologique en général et sur les transformations et productions organiques en particulier. 2 tom. 8 vo. Paris, 1816.

Ib. Médecine éclairée par l'Anatomie et la Physiologie pathologique. 8vo. Cah. I. Paris, 1821.

Ib. Anatomie pathologique du corps humain, ou descriptions avec figures lithographiées des diverses altérations morbides, dont le corps humain est susceptible. fol. Liv. I. to X. Paris, 1828 -.1831.

A. W. Oтто Seltene Beobachtungen zur Anatomie, Physiologie und Pathologic gehörig. 4to. m. k. 1tes. Heft. Breslau, 1816, 
2tes Heft. Berlin, 1824. (Also under the title, Neue seltene Beobacht.)

JoHs Howship, Practical Observations in Surgery and Morbid Anatomy illustrated by cases, with Dissections and Engravings. 8vo. Lond. 1816. Translated into German by Scuulze. 8vo. Halberst. 1819.

J. F. Meckel Tabulæ anatomico-pathologicæ, modos omnes, quibus partium corp. hum. forma externa atque interna a norma recedit, exhibentes. fol. Fasc. I.-IV. Lips. 1817-26.

Rob. Allan, A System of pathological and operative Surgery, founded on Anatomy, illustrated by Drawings of diseased Structure and Plans of Operations. 3 vols. 8vo. Edinburgh, 1819-24.

J. B. Palletta Exercitationes pathologicæ. c. tab. æn. 4to. maj. Mediol. 1820. P. II. Mediolani, 1827.

Consbrucin's Taschenbuch der pathologischen Anatomie für praktische Aerzte und Wundärzte. 8vo. Leipz. 1820.

P. J. WASSERMANN D. de mutationibus pathologicis primitivarum in organismo humano formationum. 8vo. Padua, 1820. v. Dissertazioni inaugurali d'argomento medico-clinico publicate nell' J. R. Universitad di Padova. 8vo. Padova, 1821.

Fr. Nasse Leichenöffnungen, 1te Reihe. 8vo. Bonn, 1821.

L. Ceruttr Pathologisch-anatomisches Museum, enthaltend eine Darstellung der vorzüglichsten krankhaften Veränderungen und Bildungsfehler der Organe des menschlichen Körpers u. s. w. Bd. I. Heft I. und II. 4to. Leipz. 1821-24.

H. F. Jsenflam Anatomische Untersuchungell. 8vo. Erlang. 1322 .

Tacheron Recherches anatomico-pathologiques sur la Médecine pratique, etc. 3 tom. 8vo. Paris, 1823.

Poilroux Nouvelles Recherches sur les maladies chroniques et principalement sur les affections organiques et les maladies héréditaires. 8vo. Paris, 1823.

Xav. Bicirat Anatomie pathologique, ed. par Borsseau. 8vo. Paris, 1825. Translated into German, with Notes, by Pestel. 8vo. Leipz. 1826.

Heusinger Berichte von der Königl. anthropotomischen Anstalt uz Würzburg. 1ter Bericht. 4to. m. k. Würzburg, 1826.

Louis Memoires, ou Recherches anatomico-pathologiques. 8 vo. Paris, 1826.

Repertoire général d'anatomie et de physiologie pathologiques et clinique chirurgicale, ou Recueil de mémoires et d'observations sur la chirurgie et sur l'anatomic et la physiologie considerées dans les tissus sains et les tissus malades. 8 tom. 4to. with lithog. plates. Paris, 1826. An almost complete system of Pathological Anatomy is 
given in three Essays, by Merat, in Diction. de Scienc. médicales : Lésions organiques, Vol. XXVII. p. 485 ; Lésions physiques des organes, Vol. XXXVIII. p. 138; and Lésions organiques des tissus, Vol. LV. p. 210.

Laennec Note sur l'anatomie pathologique in Journ. de Médec. Chir. et Pharm. par Corvisart, Leroux, etc. T. IX. p. 360, and his Essay, Anatomie pathologique in Diction. des Sc. médic. Vol. II. p. 46.

Sprtra Die Leichenöffnung in Beziehung auf Pathologie u. Diagnostik. Stendal, 1826.

Berard D. sur plusieurs points d'Anatomie pathologique. Paris, 1826.

Ribes De l'anatomie pathologique considerée dans ses vrais rapports avec la science des maladies. T. I. 8vo. Paris, 1828.

*L. C. Roche and L. I. Sanson Nouveaux Elemens de Pathologie Medico Chirurgicale. 5 vols. 8vo. Paris, 1828.

Craigie, Elements of general and pathological Anatomy adapted to the present State of Knowledge in that Science. 8vo. Edinb. 1828.

R. Bright, Reports of Medical Cases, selected with a view of illustrating the Symptoms and Cure of Diseases by a reference to morbid Anatomy. 4to. with 16 coloured engravings. London, 1827.

J. R. FarRe, Journal of morbid Anatomy, or Researches, etc. London. Vol. I. 4to. with engravings. 1828.

Bakon, Delineations of the Origin and Progress of various Changes of Structure which occur in Man and some of the inferior Animals, etc. 4to. with engravings. London, 1828.

G. Andral Precis d'Anatomie pathologique. 3 tom. 8vo. Paris, 1829.

J. F. Lobstein Traité d'Anatomie pathologique. T. I. Paris, 1829.

*W. Money, A Vade-Mecum of Morbid Anatomy. 8vo. London, 1831.

* Clocquet Pathologie Chirurgicale. Plan et Méthode qu'il convient de suivre dans l'enseignement de cette science. 4to. Paris, 1831.

\section{Descriptions of Anatomical Collections which are of import- ance to Pathological Anatomy.}

Ruyschil Thesaurus anatomicus I.-X. 4to. c. fig. æn. Amstelod. $1701-16$.

Ejusd. Curæ posteriores seu Thesaurus omnium maximus. 
8ro. Amstelod. 1724. Curæ renovatæe, etc. 4to. Amstel. 1728. (in operibus.)

Vateri Museum anatomicum proprium. 4to. c. tab. æn. Helmst. 1750.

Ed. Sandifort Museum anatomicum Academiæ Lugdumo-Batav. T. I. with 9 plates. T. II. with 127 plates. fol. Lugd. Bat. 1793.

Koenler Beschreibung der" physiologischen und pathologischen Präparate, welche in der Sammlung des Herin Hofiath Loder enthalten sind. 8vo. Abth. I. Jena 1794.

Museum anatomicum Boltenianum. 8vo. Hamb. 1796.

J. G. Walters Anatomisches Museum, beschrieben von F.A. WAlter. 2 thl. 4 to. with plates. Berlin, 1796.

Ejusd. Museum anatomicum, etc. venale offert. 8vo. Berol. 1802.

Ejusd. Museum anatomicum, etc. 4to. Berolini, 1805.

F. B. Osiander Enigrammata in complures Musei anatomici res. 8vo. Gotting. 1807. 1b. enlarged. 1814.

Bírinayer Museum anatomico-pathologicum Nosocomii universalis Vindobonensis. 8vo. Vindob. 1816.

Catalogue of the Museum of Heaviside. London, 1818.

Burdacir Berichte von der Königl. anatomischen Anstalt zu Königsberg. 1ter bis 6ter Bericht. 8vo. Leipzig, 1818-1823.

Seidel Index Musei anatomici Kiliensis. Kìliæ, 1818.

Cerutti Beschreibung der pathologischen Präparate des anatomischen Theaters zu Leipzig. 8vo. Leipzig, 1819.

Faxzago Memoric sopra alcuni pezzi morbosi conservati nel gabinetto patologico dell' J. R. Università di Padova. 4to. with engravings. Padova, 1820.

Lobstein Compte rendu à la Faculté de Médecine de Strasbourg sur l'état actuel de son Museum anatomique, suivi du catalogue des objets qu'il renferme. 8vo. Strasbourg, 1820 .

Ejusd. Compte rendu etc. sur les travaux anatomiques cxécutés à l'amphithéatre pendant les années 1821-1823. 8vo. Strasbourgr, 1824 .

Loner Index preparatorum, aliarumque rerum ad anatomen spectantium, qux in Museo Univ. Mosquensis servantur. 8vo. Mosqux, 1823. Edit. altera emendata et aucta. Mosqux, 1826.

A. K. Hesseracu Beschreibung der pathologischen Präparate, welche in der Königl. anatomischen Anstalt zu Würzburg aufbewahrt werden. 8vo. Giessen, 1824.

A. W. Oтто Ver\%cichniss der anatomischen Präparaten sammlung des Königl. Anatomic-Instituts zu Breslau. 8vo. Breslau, 1826. 
Bleuland Descriptio Musei anatomici academix Rheno-Trajectinæ. 4to. maj. Traj. ad Rhen. 1826.

Ib. Icones anatomico-pathologicæ partium corporis humani, quæ in descriptione Musei Acad. Rheno-Trajectinæ inveniuntur. 4to. Fasc. I. \& II. Traj. ad Rh. 1827.

SANDifort Museum anatomicum academiæ Lugduno-Batavæ. Vol. III. descriptum a Ger. SANDifort. fol. Lugd. Batav. 1827.

*J. Laskx, General Account of the Hunterian Museum, Glasgow. 8vo. Glasgow, 1813.

* Catalogue of the Hunterian Collection in the Museum of the Royal College of Surgeons in London. 4to. Parts I. to V. London, $1830-31$.

*Thomas Hodgkin, M.D. A Catalogue of the Preparations in the Anatomical Museum of Guy's Hospital. 8vo. London, 1830 .

\section{Principal Works on the Pathological Anatomy of the Lower Animals.}

*M. Paulet Recherches Historiques et Physiques sur les Maladies Epizootiques. 2 vols. 8vo. Paris, 1775.

*C. Bougelat Memoires sur les Maladies contagieuses de Betail. 4to. Paris, 1776.

*James Clark, First Lines of Veterinary Physiology and Pathology, 1 vol. 8vo. Edin. 1788-1806.

A. G. Camper's Abhandlung von den Krankheiten, die sowohl den Menschen als Thieren eigen sind. Deutsch von Herbell. 2te aufl. 8vo. Lingen, 1794 .

E. L. W. Nebel De nosologia brutorum cum hominum morbis comparata. 8vo. Giessæ, 1798.

*D. Blaine, Anatomy of the Horse, accompanied with Remarks, Physiological, Pathological, Chirurgical, and Natural. Illustrated with tables. 8vo. London, 1799.

*Ib. Canine Pathology. 8vo. London, 1800-1817.

* Ib. The Outlines of the Veterinary Art; or, the Principles of Medicine, as applied to a Knowledge of the Structure, Functions, and Economy, of the Horse, the Ox, the Sheep, and the Dog, and to a more scientific and successful Manner of treating their various Diseases. 2 vols. 8vo. London, 1802-1816. 
*D. Blaine, A Domestic Treatise on the Diseases of Horses and Dogs. 12mo. London, 1803-1810.

Bergmann D. s. primas lineas pathologiæ comparatæ. 8vo. Gotting. 1804.

C. A. Rudolphi Bemerkungen aus dem Gebiet der Naturgeschichte, Medizin und Thierarzneikunde, auf einer Reise durch einen Theil von Deutschland, Holland und Frankreich gesammelt. 2 thle. 8vo. Berlin, 1804-5.

*'Temuinck Histoire Naturelle Générale des Pigeons et des Gallinaces. 3 vols. 8vo. with plates. Amsterdam, 1813. 1814 .

*Reich Belekung fur den Landman über die Rindviel seuche.

*J. R. Jourson, Treatise on the Medicinal Leech, with Remarks upon the Diseases, \&c. of Leeches. 8vo. London, 1816.

*Further Observations, \&c. 8vo. London.

*M. Dupur De l'affection tuberculeuse, vulgarement appelée Morve Pulmonie, Gourme, Farcin, Fausse Gourme, Pommelière, Phthisie du Singe, du Chat, du Chien, et des Oiseaux domestiques, comparée à l'affection hydatideuse, ou pourriture, du Mouton, du Lapin, du Lièvre, et à la ladrerie du Cochon. 8vo. Paris, 1817.

Gaxdolpu Cenni di confronto tra le malattie dell' Uomo e dei Brutti in Opusc. scientif. Tom. I. Fasc. VI. 4to. p. 357372. Bologna, 1817.

K. E. Scriwa B Materialien zu einer pathologischen Anatomie der Hausthicre. 1ter Bericht. 8vo. München, 1817.

Mundigl Comparativ physiol. und nosolog. Ansichten von den Krankheiten des Menschen und der vorzüglichsten Hausthiere u.s.w. 8vo. München, 1818.

Greve Erfahrungen und Beobachtungen über die Krankheiten der Hausthiere im Vergleich mit den Krankheiten der Menschen. Bd. I. und II. Oldenburg, 1818-21.

*W. Percival, Elementary Lectures on the Veterinary Art. 3 vols. 8 vo. London, 1823.

O. J. W. Remer D. exh. Pathologiæ comparatæ Specimen. 8vo. Vratisl. 1825.

*H. Bürger Die veterinair Diagnostik oder die Kunst, die innern und aussern Krankheiten unserer Hausthiere zu erkennen und ron einander zu unterscheiden. fol. Berlin, 1830.

*Flourens Sur quelques Maladies des Oiseaux, in the Memoires de l'Acad. Royale des Sciences. 'Tom. X. p. 607, for 1831 . 


\section{F I R S T, \\ OR \\ G E N E R A L P A R 'T.}

\section{FIRST SECTION.}

Of the Vices of Animal Organization in general.

\section{$\S 1$.}

THE essence of all deviation from the healthy organic condition of animal bodies, is either the DISTURBANCE OF THEIR NORMAL NUTRITIVE ACTIVITY IN QUANTITY OR QUALITY, Or the MECHANICAL SEPARATION OF THE NATURAL CONNEXION OF THEIR PARTS, whence again are necessarily produced changes of the nutritive activity.

\section{§2.}

The Vices of both kinds must, if they can be generally recognised, relate to the sensible physical peculiarities of animal bodies, viz. to NUMBER, SIZE, FORM, POSITION, CONNEXION, COLOUR, CONSISTENCE, CONTINUITY, TEXTURE, and conTENTS, according to which we shall therefore consider them. The chemical peculiarities naturally belong to pathological chemistry, on which account, pathological anatomy excludes generally from its sphere the animal fluids, and only concerns itself incidentally with the more important fluids, in reference to their quantity, colour, and consistence.

\section{$\S 3$.}

Very rarely is a part of the body found deficient only in one of the above-mentioned physical properties - but very commonly in several at the same time, which often act alternately as cause 
and effect. Thus, for instance, vices of form and position, not unfiequently produce those of texture, colour, consistence, $\& c$. , nay, by stoppage of the juices, give rise to coagulations and formations of extraneous bodies; more frequently the morbid texture of a part induces a change also of form, size, and position.

\section{$\$ 4$.}

According to the PERIOD, at which vices of the animal organization occur, are they distinguished into the CONGENITAL, vitia congenita, and those at a period subsequent to birth, the ACQUIRED, vitia acquisita; ${ }^{1}$ the former are for the most part vices of form and position, whereas the latter, because they occur at a period, in which the proportional size of the part is more or less perfectly completed, seem to refer more to the texture of the part.

(1) This division is of little value, as the period of its origin is less important, than the cause and nature of the vice; and at a later period the two kinds are often not at all to be distinguished. Still the Congenital Vices are often more closely connected with the life of the whole, and are more difficult to cure than the Acquired Vices; for example-coalescence of the fingers.

\section{$\S 5$.}

According to their CAUSAL RELATIONS, are all organic vices ORIGINAL MALFORMATIONS, vitia primce conformationis, ${ }^{1}$ that is, arising out of a variation of the formative impulse, in the first stage of the animal organism, or of that of its single parts; or they are produced by MECHANICAL CAUSEs, LESIONS and wound, lasiones et vulnera; or finally, they are occasioned by DISEASES, LOCAL Or ORGaNic, morbi locales, DisorganizaTIONS, \&c.

(1) J. Fr. Blumenbachii De anomalis et vitiosis quibusdam nisus formativi aberrationibus commentatio. 4to. with plates. Götting. 1813. Svo. Leyden, 1821.- Suringar D. de nisu formativo ejusque erroribus.

\section{$\S 6$.}

Such malformations, if they be trifling and not injurious to the individual in which they occur, we call sports of NATURE, husus naturce, ${ }^{1}$ ol VARIETIES of FORMATION, varietates; if they mar the external appearance, DEFormities, deformitates, turpidines; - if they be strange, considerable, and striking, we name them Monstrosities, monstrositates, and the individual so circumstanced a Monster, monstrum-finally, such malformations as are so merely at a later period of life, whilst at an early period they belong to the normal form, which arise as it were out of a staying, at an early stage of 
formation, of the gradual development of the whole body or of a part of it, and consequently are incomplete developments, are called RETARDED FORMATIONS, evolutiones retardate. ${ }^{2}$ These are usually congenital, they may however occur also at a later period. To the Retarded formations belong for the most part the distant resemblances which human monsters sometimes bear to animals; however, on closer comparison, the supposed resemblances greatly disappear, or are merely accidental, occurring always with reference to single parts alone and with great difference in the remaining parts. Still less has the brute monster any real resemblance ${ }^{3}$ to the higher form of man; we can always distinguish in each monster, by a more exact examination, the class, kind, and species to which the malformed animal belongs; and the same laws of formation which prevail in the normal series of animals, are active in the abnormal, prevent an endless deviation, ${ }^{4}$ and are the ground of the great resemblance of many monsters.

(1) Timmermann D. de notandis circa naturæ lusus in machina humana. 4to. Rintel. 1765.- Jnsfeldt D. de lusibus naturæ. 4to. L. B. 1772 . Ottens D. de lusibus naturæ naturam illustrantibus. Harderov. 1799. [Fortun. Liceto De monstrorum natura, causis et differentiis. Libri duo, with engravings. 4 to. Patav. 1634.-J. Hofer Observ. Monst. human. in Acta Helvet. Vol. III. p. 373. 4to. Basil, 1751-1767.-Vinc Malacarne De'Mostri Umani, de caratteri fondamentali su cui se ne potrebbe stabilire la classificazione, e delle Indicazione che presentano nel Parto 4to.- Ib. Osservazioni anatomiche in conferma d'una proposizione circa l'origine de'Mostri. 4to. Modena, 1805. - J. M. de la Sarthe Description des principales Monstruosités dans l'homme et dans les animaux précédée d'un discours sur la physiologie et la classification des Monstres, with coloured engraving:s. fol. Paris, 1808.]

(2) Harvey De generatione. Amstel. 1662. p. 300.-Wolff in N. Comm. Petrop. T. XVII.-Reil Archiv f. die Physiol. Vol. IX. p. 63, 64.-Meckel Handbuch der pathologischen anatomie, Vol. I. p. 48-61.-Mansfeld in Meckel's Archiv f. Anat. und Phisiol. 1826. No. I. p. 96. von Walther in his and Graefe's Journal f. Chir. Vol. II. p. 4.

(3) Blumenbach, p. 6.

(4) S. Th. v. Sömmerring Abbildungen und Beschreibungen einiger Missgeburten, etc. fol. Mainz, 1791. p. 38. \$ 91.-Geoffroy-Saint-Hilaire Philosophie anatomique, T. II. des monstruosités humaines. Svo. Paris, 1822. p. 101.

\section{$\$ 7$.}

No class of animals is free from malformations, lesions, and disorganizations ; but each of them, and frequently even single orders, families, and kinds, are very differently affected by them according to the peculiarities of their organization, kind of life, \&c. There are malformations and organic diseases which belong only to certain kinds, ${ }^{1}$ or are particularly frequent in them. ${ }^{2}$ It sometimes even happens that the morbid direction of the formative impulse, accidentally excited in the parents, is so permanent and innate, that several young born at the same time are similarly malformed, ${ }^{3}$ or that the young of several 
successive births are subjected to similar malformations or disorganizations. ${ }^{4}$ Mechanical causes affecting the mother, can also produce a change in several of the children subsequently born. ${ }^{5}$

(1) J. Hister, Observations on certain parts of the Animal Economy. 2d edition. 4to. Loudon, 1792. p. 75.

The siren-formation and cancer are peculiar to man;-to cats, the elongation of the hind feet, with contemporaneous shortening of the tail;-to cattle, the upward curvature of the ribs; - to snails, the inverted winding and separation of their volutes (cornu copiæ) Sc.

(2) For instance, the proboscis in cyclopic swine, the supernumerary feet in cattle, the shortening of the face in carp, \&c.;-ruptures in man; inflammation, dropsies more frequent in one kind than another.

(3) For example, two children with hydrencephalus and curvature of the extremities. v. Walter Museum anatomicum, 4to. 1805, p. 123, No. 818.-Four dogs, with defective fore feet and with the hare fissure (hare lip). v. Aucante in Roux's Journal de Médecine, Vol. XXXII. p. 14.-Two monstrous swine in the Breslau Museum, No. 2981 and 2982.-Three rattle snakes, with double heads. v. Mitchell in the American Journal of Science and Arts, 1825, Oct. p. 48. All ten pigs of one sow were littered without eyes, in the neighbourhood of Breslau.

(4) Meckel has collected many cases, Handb. der pathol. anat. Vol. I. p. 15. Three brothers and sisters with shortening of the right thigh. v. Schreger Chir. versusche, Vol. II.-Three brothers and sisters with deficient brain. v. Penada Saggio d'osservazioni e memorie, etc. Padua, 1793. - Seven children of the same parents were affected with hydrencephalus. v. Rolph in London Medic. Reposit. Sept. 1824.-Four brothers and sisters died of cancer of the eye. v. Lerche in Verm. Abhandl. a. d. G. d. Heilk. von einer Gesell. prakt. Aerzte, Petersb. Part I. 1821, No. 14.-I know a case of three brothers and sisters without an eye-ball, and another case of umbilical rupture in several brothers and sisters.

(5) A woman who had in the back part of the pelvis a pointed bony tumour, bore four children, each of whom had a deep indentation, and an unossified spot on the forehead. v. Frank in Textor's Neuem Chiron. Vol. I. Part II. p. 261.

\section{$\S 8$.}

Very frequently is the irregular form transmitted from the parents to their children and grandchildren, ${ }^{1}$ and even becomes permanently hereditary; even the more peculiar Vices of the parents, whether Congenital, or Acquired from disease, are sometimes inherited for many generations $;^{2}$ we find this especially the case with reference to the extremities, ${ }^{3}$ and it gives rise in brutes to particular varieties. ${ }^{4}$ Even intentional dismemberments may easily become hereditary. ${ }^{5}$

(1) For example, the habitus apoplecticus and phthisicus.

(2) To wit, the thick joints of rickety parents, fissured nose in dogs, an exostosis on the head of a bull. v. Rudolphi's Bemerkungen aus d. Geb. d. Naturgesch. u. s. w. 8vo. Berlin, 1804, Vol. I. p. 75. - The goitre, wolf's and hare lip. v. T'rew. N. Act. N. C. I. p. 4.45, and Amia in Hartenkeil's Med. chir. Zeitung, 1805, Vol. IV. p. 212; - the hypospady, or termination of the urethra beneath the glans penis. v. Heuermann med. Beob. Vol. II. p. 234, \&c.

(3) For examplc, six fingers and toes, or junction of them, occur in whole families; the short great toe is hereditary in all of us; further, club-feet, spavin, capped heels, discased hoofs; for some instances in man, v. Otto Selt. Beob. Part I. No. 22, 1) 60. 
(4) In the American short-legged sheep, in swine with one hoof and with three, dogs with wolf's claws, fowls with five or six toes.

(5) For instance, in man, the circumcised prepuce; in dogs and liorses, the shortened ears and tails. [To this belong the crooked-tailed cats, of which an account is given by $G$. Bennett, in London Med. Gazette, Vol. VIII. p. 332. 1831 , On a peculiar formation of the tail in the Malay and Manilla cats. T.]

\section{$\S 9$.}

The disposition towards this or that kind of irregularity also varies according to the difference of SEX, AGE, CLIMATE, MODE of LIVING, \&c. The FEMALE Body, for instance, is more subject to malformations, softening of the bones, spurious formations, especially fatty tumours, cancer, femoral rupture, \&c. than the MALE BODY, which, on the other hand, is more frequently affected with aneurysms, inguinal ruptures, and, on account of the mode of living, with mechanical lesions. Each AGE, climate, and occupation has its peculiar diseases $^{1}$ which often alter the organization. Domestic animals are also more frequently subject to pathological states than the wild of the same species; viz. to malformations which are the more common, the more artificially the animals are influenced by man. ${ }^{2}$ Still the reason why our domestic animals produce monsters in so much greater proportion than others, appears to rest either on the particular operation of man upon certain animals, or on their particular condition. ${ }^{3}$ Even the artificial hatching of eggs is said frequently to produce deformed chickens. ${ }^{4}$

(1) Almost all foreign animals which have died in menageries, have presented to me the appearance of scrofula, diseases of bone, and a morbid state of the viscera. [A. Wilson, M. D. Some Observations relating to the influence of climate on vegetables and animal bodies. 8 vo. London. 1780.-M. Roulin, M.D. Inquiries respecting certain changes observed to have taken place in domestic animals transported from the old to the new world, in Jamieson's Journal, new series. Vol. VII. p. 326. 8vo. Edinb. T.]

(2) Among beasts, in the domestic animals of this class; among birds, in the domestic fowls and pet birds; and among fishes, in the carp and gold fish. [F. Cuvier, on the domestication of mammiferous animals, in Jamieson's Journal, new ser. Vol. IV. p. 60, 292. 8vo. Edinb. T.]

(3) For example, oxen and sheep, much more commonly than swine, goats, and particularly horses; cats more frequently than dogs, \&c.

(4) With deficient limbs. v. Shaw, On the nature and treatment of the distortions to which the Spine, \&c. 8vo. p. 39. London. 1823.-Gerson and Julius Magaz. d. ausländ. Lit. d. ges. Heilk. 1824. Iuli u. Aug. p. 91.Geoffroy-Saint-Hilaire in Memoirs du Museum d'Hist. nat. Vol. XIII.

\section{$\$ 10$.}

Finally, particular regions and parts of the animal body present great variety in the proportionate frequency of their congenital or acquired vices. The left side, usually the weaker, although not from malformation, is however affected by organic disease more frequently than the right $;^{1}$ the right 
half of the brain alone makes an exception to this rule, in consequence of the stronger flow of blood through it. ${ }^{2}$ 'The irregularly increased number of parts is more common in the upper half of the body; on the contrary, in the lower, consolidation is most frequent. The upper extremities are more subject to variety in the blood-vessels; the lower extremities more to diseases, to wit, ulceration. Those organs which are situated nearest to the heart are subject to many diseases, on account of the strong circulation in them; whilst those farther distant are disposed to other diseases, depending on a weaker circulation. Finally, the heart, the bloodvessels, the digestive, urinary, and sexual organs, are more frequently subject to vicious formations than the nervous system, the organs of sense, of respiration, \&c. ${ }^{3}$

(1) Du Pui Diss. de homine dextro et sinistro, Lugd. Batav. 1780, reprinted in Schlegel's Thes. pathol. therap. Fasc. I. No. 1.-Monteggia De morbis symmetricis et asymmetricis in Fasc. pathologicis, No. 1. Mediol. 1789.-Courmette in the Journ. de Médecine, p. 85.-Isenflanm in his and Rosenmüller's Beitr. f. die Zergliederungskunst, Vol. I. Part I. No. 2.-Osiander in Abhandl. der phys. med. Soc. zu Erlangen, Vol. I. p. 331.-Ardieu Considérat. anat. et physiol. sur la ligne mediane, qui divise le corps en deux moitiés symmetriques. Strasb. 1812.Mehlis Comment. de morbis hominis dextri et sinistri. 4to. Gött. 1818.-Hemsing D. de privilegio lateris dextri in corpore humano. Groening. 1822. - Kopp Ueber die Verschiedenheit zwischen der rechten und linken Seite beim Menschen, besonder's im krankhaften Zustande, in Hufeland's Journal d. prakt: Heilk. Febr. 1827, p. 3. (Is the left side in brutes also more frequently afiected than the right?)

(2) This is the (ase, at least according to my own experience, as I have found likewise the lungs, kidneys, testicles, and ovaries more frequently diseased on the left than on the right side, though some writers maintain the reverse.

(3) For the rest moreover, all parts belonging to a particular system have a disposition to the same discases, which was first noticed by Bichat; compare also Hohnbanm über das Fortschreiten des Krankheitsprocesses, insbesondere der Entzündung u. s. w. 8vo. Hildburghausen, 1826, p. 52-299.

SECOND SECTION.

\section{Of Vices relating to Number.}

$\S 11$.

These naturally arise out of the DIMINUTION or INCREASE of the normal number of animal parts; still, however, both of these abnormal conditions occur not unfrequently in the same individual, so that whilst in one part a deficient formation is observed, in another it is seen in excess. ${ }^{1}$ 
(1) For example, monsters with prominent deficiency exhibit perhaps a supernumerary finger or toe; and double monsters perhaps a deficiency in some one part. To the latter observations those cases in some measure belong, in which, of twins or triplings one only is found very deficiently formed; [ of which an instance is given by $J$. Warner, in Phil. Trans. Vol. LX. 1770, in which a woman was delivered of a live child of full growth, together with a very small fœtus, which had no visible connexion with the placenta, but was squeezed flat, and seemed shrivelled, but not at all putrid. In the Mus. Coll. Surg. Lond. is a similar very beautiful instance in a twin abortion of six months; one of the embryons had attained its perfect size, whilst the other does not exceed lualf an inch in its total length, and, like Warner's case, is not in the least connected to the placenta, but near its edge attached to the chorion; it was at first mistaken for a hydatid. T.J

\section{$\$ 12$.}

The COMPLETE DEFICIENCY, defectus, of a particular part, or the diminished number of such organs as are multiplicate, is very frequent. We distinguish the orIGINAL from the ACQUIRED DEFECT; the former is observed chiefly in respect to every part of an animal body, without the conformation of the remaining parts being necessarily disturbed by it $;{ }^{1}$ although, indeed, we observe oftentimes, in this respect, certain sympathetic proportions between certain organs. ${ }^{2}$ Frequently the external form of the body is tolerably regular, whilst one or other of the internal parts are wanting. Again, some organs are more frequently wanting than others, ${ }^{3}$ and sometimes so many at once, that, instead of a foetus, merely a head, or an extremity, or nothing more than an unseemly lump of flesh, is produced; still, however, of the general systems, the external skin and cellular tissue, and, perhaps, also the nervous and vascular systems, are never wholly deficient. As in the first stage of the embryon, almost all organs are as yet wanting, so does this want of parts principally belong to retarded formations.

A peculiar kind of numerical diminution of some parts arises out of the original consolidation of two similar, usually separate organs, into one. ${ }^{4}$

(1) Compare below, Monstra per defectum.-The comparison of the deficiency of parts, with the possibility of preserving life, is of considerable interest to physiology.

(2) Thus, for instance, generally, though not always, the peripheral parts of a system are deficient at the same time with its central, v. Mayer, p. 228, and Meckel, p. 310, in Archiv f. Anat. und Physiol. 1826, No. II.; the heart commonly with the head; the renal glands frequently with deficient brain; the external organs of generation with deficient lower extremities, \&c.

(3) For example, the brain, urinary and genital organs, much more frequently than the heart, the liver, or intestinal canal ; the deficiency of the upper half of the body is not quite rare; that of the lower half, with complete formation of the upper, is unheard of, \&c.

(4) Compare $\$ 30$. 
$\S 13$.

The ACQUIRED DEFICIENCY of certain limbs or parts arises either from mechanical causes or from disorganization. To the first cause belong the accidental or intentional mutilations, ${ }^{1}$ viz. amputations, extirpations, \&c., which are sometimes very similar to the original defective formations; - to the latter we refer the rare total wasting of single organs by increased absorption, and the more frequent destruction by ulceration, mortification, \&c.

(1) The subsequently reproduced parts of inferior animals, occasionally present a diminished number of their component parts ; for instance, the feet of salamanders have fewer toes. v. Spallanzani's Physical and Mathematical Treatises, p. 62.

\section{$\$ 14$.}

The IRREgUlar mULtiplication of the parts of a body is also frequently observed $;^{1}$ in the higher classes of animals it is always congenital, whereas in the lower classes it also occurs subsequently, and can sometimes be even artificially produced. ${ }^{2}$ The degree of multiplicity ascends from the reduplication of single parts only in manifold degrees up to that of almost the whole body, ${ }^{3}$ but extends only in very rare cases beyond the doubling of the normal number. ${ }^{4}$ The frequency of reduplication also varies very much in the several parts of the body. ${ }^{5}$ The superabundant parts are in general connected with the similar normal parts, yet there are also exceptions to this law. ${ }^{6}$

Finally, it is proper to distinguish from the real multiplicity of organs, that which is only a seeming increase owing to the congenital division of an organ into two halves or into several smaller pieces, and which belongs rather to Vices of Form. ${ }^{7}$

(1) Meckel De duplicitate monstrosa commentarius, fol. Halæ, 1815, with eight engravings. - Brésohet in Archives générales de Médecine, Paris, Dec. 1823.-J. C. L. Barkow Commentatio Anatomico Plyysiolog. de Monstris duplicibus, 4 to. Leipzig, 1828, with engravings.

(2) The reproduced fore feet of salamanders acquire occasionally five toes instead of four, v. Platteretti, in Opusc. scelti di Milano, Vol. XXVII. p. 26, note. In lizards we can, by a particular injury of the tail, easily occasion the production of a second; the reproduced claws of a crab have occasionally a supernumerary finger, (claw) \&c.

(3) Compare below, Monstra per excessum.

(4) There are a few examples of monsters with three heads, three tails, three thumbs on the claw of a crab, Sc.

(5) Accessory intestines and organs of sense, for example, are much more rare than a multiplicity of the extremities and their parts.

(6) For instance, the bronchi of accessory lumgs opened in one instance into the stomach, v. Otto Selt. Beob. Part I. p. 15.

(7) Compare $\$ 23$. 


\section{THIRD SEC'TION.}

\section{Of Vices relating to Size.}

\section{$\S 15$.}

Vices of this kind deviate from the normal bulk in two ways, that is, by diminution and by enlargement; they may be, further, either original or produced at a later period, but in many cases it is difficult to distinguish between the two ' $^{1}$ finally, they may exist only at the time when they are observed.

(1) [Changeux Sur les Nains et sur les Geants, Journ. de Physique, Vol. XIII. p. 167. T.]

\section{$\S 16$.}

The ORIGINAL IRREGULAR DIMINUTIVENESS, magnitudo imminuta, seu parvitas genuina, may affect the whole body or only particular parts; consequently it is either GENERAL or LOCAL. The first we call DWARFishness, microsomia, and the beings so circumstanced DWARFs, pumiliones, nani pygmai. ${ }^{1}$ Such individuals are either born very small or grow but little at a subsequent period. Sometimes dwarfishness is hereditary, or affects many brothers and sisters,${ }^{1 *}$ especially twins and triplings; and this not unfrequently occurs in animals, especially the domestic. ${ }^{2}$

(1) Compare G. Fr. Jäger Vergleichung einiger durch Fettigkeit oder kolossale Bildung ausgezeichneter Kinder und EINIGER Zwerge, 8vo. Stuttgart, 1821. -Plouquet Repertor. Art. Pygmæus.-Virey Histoire naturelle du genre humain, 2d edit. Vol. II. p. 265.-Reuss Repertor. Commentat. Vol. I. p. 104, and Vol. X. p. 44 and 299. -Wünsch Unterhaltungen über den Menschen, 2d edit. Vol. I. p. 319. - The oberamtsactuarius Joseph Hoedle, of Endingen, is 30 inches high; Elizabeth Ralph, of Devonshire, was, in her twenty-first year, only 2 feet 10 inches high, and 20 pounds in weight, \&c. There are said to have been adults of 18 and even 16 inches height. [The smallest authentic case is that of Madlle. Crachami, whose skeleton is in the Museum of the Royal College of Surgeons, No. 7 of the Osteological Series, and measures exactly 20 inches in height; but Mr. Clift informs me that when exhibited, she was said to be only 18 inches, which must of course have been incorrect. She died in her tentl year, in the summer of 1824, at London. v. Catalogue of the Mus. Roy. Coll. Surg. in Lond. There is also in the College Museum, a painting of the Corsican fairy, which measures 2 feet $7 \frac{1}{2}$ inches high. She was exhibited in London about the same time as Byrne. v. Section 20, note 2. Among Mr. Hunter's papers there is a memorandum, unfortunately without name or date, of " $\mathrm{A}$ little dwarf woman, at Norwich, 34 inches in height," which is believed, by Mr. Clift, to refer to this painting. And it goes on to state, that she cohabited "with a great fellow she called her husband," and became pregnant. She went her full time, but as might have been expected, from the smallness of the pelvis, the labour was difficult, and it was necessary to open the child's head; after which, the delivery was effected. The child measured 22 inches; "so that," says the writer of the memorandum, "if it could have stood upright in utero, it would have risen above 
its mother's head." The woman died four hours after delivery. Boruwlaski, the celebrated Polish dwarf, measured 39 inches in height when thirty years old. He was, till very lately, if not at present,'living at Durham. T.]

(1*) [It is remarkable, that of the six children of which Boruwlaski's father's family consisted, they were born alternately short and tall; - the eldest son was 3 feet 6 inches, and lived to sixty years of age ; the second, 5 feet 10 , and died at twenty-six years; Boruwlaski himself was the third; the fourth and sixth were of the common lieight; but a daughter, who was the fifth child, measured only 2 feet 2 inches, and died at twenty-two. T.]

(2) Especially the case in dogs; I have likewise seen it in horses and goats.

\section{$\S 17$.}

The irregular diminutiveness is more frequently but PARTIAL, so that particular organs only do not acquire their proper size, and are therefore disproportioned to the rest of the body: thus the head,' the trunk, or, finally, the extremities $^{1 *}$ may be too small in proportion to the other parts. Such malproportions occur frequently in giants and dwarfs. In monsters, the enlargement of a particular part is frequently effected as it were at the expense of other parts; the accessory parts in double monsters, as well as the reproduced parts in animals, as the tails of lizards and serpents are usually too small, and so remain. General weakness, lameness, and continued pressure, ${ }^{2}$ diminished flow of the juices, \&c. not unfrequently retard the growth. Often, together with the natural size of the other parts, the whole systems are backward in their development, and either remain small or are developed at an unusually late period; this is most commonly observed in the sexual parts, ${ }^{3}$ more rarely in the respiratory organs, and least frequently in the vascular and bony systems. ${ }^{4}$

In hollow organs, and especially in certain canals, an IRREguLAR NARROWING, and even COMPLETE IMPERviousNESS, is often the consequence of deficient development; the latter is called, especially if it affect the mouths of such canals, conGENITAL CLOSURE, atresia congenita, which, as it is always observed in the early stage of fotal existence, in new-born infants has been found as an irregular appearance in all the openings of the body.

(1) A remarkable instance given by Ifell D. de concretione digitorum, 8 vo. Jandsh. 1820 , with figures.

(1*) [A rery good instance of disproportionate limbs, was a man, who, some years ago, might have been secn on Blackfriars' Bridge, sitting in a little chair, making pens, and from his habits, known as Drunken Andrew (the King of the Beggars). IIe was altogether of small make, save his head, which was that of in adtult; but his lower extremities did not exceed those of a child of four years old, and were not capable of supporting his weight; he was, therefore, obliged to whicel his little chair about on crutches. 'T.]

(2) For example, the small fect of the Chinese.

(3) With which also the pubie hair, and in man the beard and larynx-in women the breasts usually sympathize. In the male sex I have seen smallness 
of the genitals most frequently occasioned by onanism; a remarkable example of impeded development from caries, and of quick maturity after amputation of the diseased nember, is given by Martini in Rust's Magaz. d. ges. Heilk. Vol. XIX. Part III. p. 590. Complete development of the whole body and of the genital organs from pressure on the medulla oblongata is described by Lenhoss in the Medic. Jahrb. d. K. K. Oesterreich. Staates. N. I. Vol. III. Part I. p. 96.

(4) Most frequently, however, with respect to the teeth.

$\S 18$.

The ACQUIRED DIMINUTIVENESS differs in this respect from the original, that parts which are already developed and of their natural size, as it were, retrograde and diminish; this can but seldom occur generally, and can then, in the higher animals, whose bodies by means of the skeleton possess a certain permanent proportion, only affect the soft parts, ${ }^{1}$ which, deprived more or less of their interstitial, fatty, gelatinous and serous parts, exhibit a morbid DRYNESS, LEANNESS, and WASTING, macies, macor, marasmus, tabes or atroplia universalis. ${ }^{2}$ The diminution is more frequently only local or in one system, and then is called WASTING, atrophia or tabes partialis, also aridura ; ${ }^{3}$ it is either merely the consequence of diminished nutrition, ${ }^{3 *}$ or it is also connected at the same time with degeneration of the tissue, particularly often with hardening and ossification. Almost every part of the body, even the hardest parts, as the bones and cartilages, are subject to wasting, which may arise from manifold causes; but especially from external or internal pressure, from tearing, from the contraction or closing up of the nutrient blood vessels, from palsy of the nerves, from long continued rest, ${ }^{3 * *}$ and from inflammation, and in rare cases attains such a degree, that the parts affected by it entirely disappear. ${ }^{4}$ If wasting occur in the hollow organs, their sides become unnaturally thin, and sometimes so weak, that they can no longer resist the force which expands them.

(1) Sometimes, however, the whole body becomes somewhat shorter and smaller by wasting of the intervertebral ligaments, of the articular cartilages, and even of the bones. Injuries, also, may, without the cause being recognized at the time, diminish the size of the body; thus I know a man, who, by fracture of both thigh bones, has become about four inches shorter, without being otherwise deformed. The shrivelling of animals, as the mollusca, belongs rather to emaciation than to the present subject.

(2) Perhaps more correctly Oligotrophia. A striking example of this is the so called 'living skeleton,' Claude Ambroise Seurat, who, on account of his extreme leanness, has been exhibited for money. v. Froriep's Notizen, Vol. XI. No. 20, p. 313, with a figure. The emaciation is greatest in diseases of the digestive organs; on the other hand, it is occasionally not consequent on ulceration and other diseases of the urinary organs, of the breast, cancer of the rectum, \&c. Compare Pemberton's Practical Treatise on various diseases of the abdomen, p. 186. Compare Art. Atrophia in Plouquet's Repertorium. 
(3) Nürnberger D. de atrophia partiali, s. de ariduris. 4to. Wittenb. 1792.

(3*) [A remarkable instance of wasting from this cause occurred several years since, when a part of Dover cliff fell down, by which a pig, known to have weighed, just before the accident, eight score, or 160 pounds, was buried. The animal remained entombed during one hundred and sixty days, when, as the workmen were clearing away the rubbish, they thought they heard a weak moan, and directing their labours in the direction of the noise, soon met with the pig, the life of which had been preserved by a piece of the cliff having lodged over its stye; during this time it had had no food, beyond perhaps the litter and biting the chalk, on which its teeth marks were visible, and the water which had run through the cliff. When taken out, it weighed only two score, or 40 pounds. T.]

$\left(3^{* *}\right)$ [There is a fine specimen of this state of the thigh bone in the Mus. Coll. Surg. Lond. No. 448, in which the body of the bone does not exceed $\frac{5}{8}$ ths of an inch in diameter, but the cause is not known. There is also a similar instance in the Mus. Lond. Univers. of the upper arm bone. T.]

(4) For instance, the chrystalline lens after depression; the testicles in syphilitic persons.

$\S 19$.

A peculiar form of morbid diminution is the contraction of CANALS and CAvities, strictura, coarctatio, produced by the contractility existing in almost all animal tissues, and often much increased by morbid irritants ; - by deficiency of expansile power $;^{2}$-by thickening of the walls of the canal $;^{3}$ -by external pressure, \&c. The highest degree of narrowing is the MORBID CLOSURE, atresia morbosa, which, however, is much more rare than the congenital.

(1) For example, by stones in the biliary and urinary bladder.

(2) Thus, blood-vessels and excretory ducts which convey no fluids, contract themselves in consequence,- - the intestinal canal below the foecal fistula,articular cavities after dislocation,- - the sockets after extraction of the teeth, - -all bony canals when the vessels or nerves passing through them disappear, even the cavities of the orbits and chest, when their contents collapse.

(3) Frequently in the alimentary canal and urethra.

\section{$\S 20$.}

To the excessive smallness is opposed the IRREgular MaGNITUDE, magnitudo aucta, which may be either originaL or ACQUiRED subsequently. The former is not unfrequently GENERAL, affecting the whole body, for children may be born unusually large and strong, ${ }^{1}$ or during youth, they may have an unnaturally active growth, ${ }^{1 \bullet}$ and thus attain a size which remarkably exceeds the ordinary bulk. This is called GIANTISM, macrosomia, magnitudo gigantea, and individuals so affected are called GIANTS, homines pragrandes, gigantes. ${ }^{2}$ 'This giantism occurs also, though not so commonly in brutes. ${ }^{2 *}$ In many instances irregular magnitude is united with unusual fatness, ${ }^{3}$ not unfrequently, also, a premature puberty, and 
development of the whole body $;^{4}$ the latter, however, also occurs without irregular enlargement. ${ }^{5}$

The PARTIAL and original irregular magnitude is also not unfrequently consequent on too great nutrition of certain parts of the body, and occurs most frequently in such monsters as have defective formation in other parts.'

(1) Compare below the foetus.

(1*) [A very remarkable instance of precocious development is given in Phil. Trans. Vol. XLIII. 1745, by Rev. Mr. Almon and Mr. Dawkes, of a boy, aged three years and one month, who was 3 feet 11 inches high. But a more remarkable instance is Philip Howorth, of whom an account is given by Mr. White, Surgeon to the Westminster Hospital, in Med. Chir. Trans. Vol. I. p. 276, who arrived at premature puberty between two and three years old, and at three years measured 3 feet 2 inches in height. Mr. White has kindly informed me that he arrived at 5 feet, his full height, at the end of six years: he is now alive, and twenty-two years old, is married, and has one child, a girl, and follows the occupation of a ladies' shoemaker. His appearance does not differ from that which persons of the same period of life possess; that is, no marks of premature old age, either by grey hairs, or the countenance. T.]

(2) Compare Plouquet Repertorium Art. Gigas.-Reuss Repertor. Commentat. Vol. I. p. 101, and Vol. X. p. 42.-Wünsch Unterhaltungen über den Menschen, $2 \mathrm{~d}$ edit.-Virey Histoire naturelle du genre humain, 2d edit. Vol. II. p. 257. The greatest size in man appears to be 8 feet $1-2$. [Charles Byrne, commonly called the Irish Giant, was twenty-two years old at the time of his death, in 1783 ; he measured, when dead, 8 feet 4 inches; neither of lis family were of extraordinary size. His skeleton is in the Hunterian Collection, Mus. Royal Coll. Surg. Lond. and measures 7 feet $8 \frac{1}{2}$ inches in height. T.]

(2*) [Mr. Clift mentioned to me, that about twenty-five years ago he had seen a horse 20 hands high, which was exhibited in Piccadilly. T.]

(3) G. F. Jäger Vergleichung einiger durch Fettigkeit oder kolossale Bildung ausgezeichneter Kinder und einiger Zwerge. 8vo. Stuttgart, 1821.-1Meckel Handb. der pathol. Anat. Vol. II. Part II. p. 121.-Diez, in the Russ. Sammlung f. Naturwissenchaft und Heilkunst, Vol. II. Part II. p. 243, describes two very fat children of the same parents.

(4) Meckel Vol. II. Part I. p. 2.-Jäger-—Reuss Vol. X. p. 298.-Later cases are described, by Harless Rhein. Jahrb. der Medic. und Chir. Vol. I. Part II.Ulrich in the same, Vol. II. Part II. p. 194.--v. Lenhossek in d. medic. Jahrb. d. K. K. Oester. Staates. Vol. VI. Part II I.-Bréschet in Journ. général de Médec. No. 291, Feb. 1821.-J. F. South in London med. chir. Transact. Vol. XII. Part I. p. 76.-Descuret in Nouv. Journ. de Médecine, Vol. VII. p. 100.-v. Duchamp Maladies de la croissance. Paris, 1823.-D'Outrepont Gemeinsame deutsh. Zeitschr. f. Geburtskunde. Vol. I. Part I. p. 151._Diefenbach, in Meckel's Archiv f. die Anat. u. Physiol. 1827, No. 3, p. 367.-Hufeland's Journal, Sept. 1827, p. 124.

(5) For example, in the silk worms, Bомв Yx MoRI, which occasionally, after the fourth casting of the skin, and previous to spinning, change into moths, which retain considerable resemblance to the grub, and thus at once present an instance of premature development and retarded formation. v. Müller Decouverte d'un papillon à tête de chenille (Phalæna Vinula) in the Mémoir présent, Vol. VI. p. 508. - Majoli in the Giornale di fisica, etc. del regno Italico, 1813, Vol. V. p. 399. Compare Mecklel's D. Archiv. f. d. physiol. Vol. II. p. 542.

$$
\S 21 .
$$

The ACQUIRED MAGNITUDE appear's as a general condition of the animal body, only in the form of excessive and morbid 
collections of lymph, jelly, and fat in the tissues of the body, polysarcia, obesitas, pinguetudo, corpulentia nimia, ${ }^{1}$ by which, often the circumference and weight of the body, both in man and animals, is extraordinarily increased. ${ }^{2}$ The abnormal enlargement of SINGLE PARTS is also very frequent, it occurs without or with, which last is much the more frequent, MORBID TEXTURE; the FORMER is the consequence either of an excessive local nutrition, hypertroplia, arising from increased local vital activity, when, for example, one viscus undertakes the office of another, ${ }^{3}$ or of itself is much overexerted, ${ }^{4}$ or there is too great deposition of fat in particular spots. ${ }^{5}$ The ENLARgENENT OF PARTICULAR PARTS UNITED WITH CHANGE OF TEXTURE, is produced very frequently, and in manifold ways, by morbid turgescence and expansion of the vessels of an organ, INFLAMMATORY TUMOURs, phiysconia, infarctus, obstructio ${ }^{6}$ by actual change of the internal tissue, by the formation of tumours, \&c. From this kind of irregular enlargement, is in its nature, the MORBID EXTENSION OF HoLLOW organs, extentio, very different, as in the latter the walls are usually unable, from cotemporaneous RELAXATION, relaxatio, and THINNING, extemuatio, nay, sometimes even from thickening, ${ }^{7}$ to withstand the extending force of the contained fluids, and are thus not unfrequently disposed to burst. Oftentimes, also, such partial extensions of canals are the consequence of strictures of the same organ at other spots; lastly, there is one particular form of enlargement which appertains here, viz. the STRETCHING or EXPANSION, expansio, of solid parts, ${ }^{8}$ by mechanical tearing, and by tumours.

(1) Quelmaz D. de pingucline ejusque sede tam secundum quam præter naturam constituta. 4to Lips. 1748. - Jansen Pinguedinis animalis consideratio plyysiol. et patholog. 8vo. L. B. 1784.-Reussing D. de pinguedine sana et morbosa. Ienæ, 1791.-Seifert D. phys. pathol. de pinguedine. Gryph. 1794.Clark D. de pinguedine. Ediub. 1797.-Lorry Adhandl. über das Fett in dem menschl. Körper, iiber dessen Eigenschaften und Fehler, etc. translated from the French by Lindemann. 8vo. Berlin, 1797.-Dandouville D. sur l'obesité. 4.to. Paris, 1811.-Dupuytren in Journ. de Médec. Vol. XII. 1). 262.-Marcuse D). de obesitate nimia. Svo. Berol. 1819.-Maciari, in Giorn. della Soc. med. chir. di Parma, Vol. IX. p. 168.-Many instances in Reuss, Vol. XIV. p. 181-183.Amputations of the larger limbs, and castration, are frequently causes of umatural fatucess.-Adiposis, Dict. des Sc. médicales, article Obésité, Corpulence, Graisse.

(2) The most striking example is the London butcher, Falstaff, who died in his thirty-second year, and weighed 800 pounds. [I believe the most authentic cases, liowever, are those of Edward l3right, of Malden, who weighed 584 pounds, and died at twenty-nine years of age; and Danicl Lambert, of Leicester, who weighed 739 pounds, and died at forty years.

(3) 'The spleen for the liver, and the reverse-one kidney for the other, Sc.

(4) The thicliening of particular muscles which have been much exercised, the inuscular coats of hollow organs, from obstructed evacuation of their contests, \&ic.

(5) For eximuple, on the neck and face of ancnceplialons monsters, from great 
flow of blood into the carotis facialis, with diminution or closure of the carotis cerebralis -in the belly - in the spermatic cord (the so called liparocele,) -in the cellular tissue under the skin, (compare below lipomata,) - near cancerous tumours, \&c.

(6) Rezia De viscerum, quam dicunt obstructione cum molis incremento in ej. Specimen observationum anatom. et pathologicar. Ticini, 1784, and Venedig, 1802.-Rubini in Memorie di Matem. e. Fisica di Verona, Vol. VII. in Weigel's Italiän. Biblioth. Vol. IV. p. 33.-Cassan in Mémoir. de la Soc. médic. d'émulation, An. V. p. 68.-Infarctus and obstructio are also called, particularly by the older writers, vices of the intestines.

(7) For example, the heart in active aneurysms, and the womb, in case of tumours in its cavity.

(8) For instance, artificial elongation of the lobes of the ear, of the hips, of the labra, by the introduction of foreign bodies;-expansion of membranes, tendons, muscles, by tumours.

\section{FOURTH SECTION.}

\section{Of Vices relating to Form.}

$\S 22$.

The vices of Form, MALFormations, deformitates, formce aliene, ${ }^{1}$ are likewise either original or acquired-general or local-simple or compound, that is, connected with changes of another kind. General deformity is very rare; on the contrary, partial deformity is very frequent and in endless variety, according to the individual parts in which it occurs. ${ }^{2}$

(1) Maisomnabe Recueil d'observationes sur les difformités dont le corps humain est susceptible à toutes époques de la vie et surtout ce qui se rapporte en général à la Mécanique et aux instrumens employés en chirurgie, avec fig. Paris, 1825. As difference of figure in a minor degree is the character of all organic bodies, we can here regard the higher degrees only.

(2) It will be therefore treated of specially under these subjects.

\section{$\$ 23$.}

The principal species of malformation are: first, the simple, in which a part is too long, too broad, too round, too angular, \&c.; then that which arises from vice of number, followed very naturally by vices of conformation, which originate in the division of an elsewhere single organ into two or more parts, often improperly accounted true duplications; sometimes the organ is not entirely divided, but merely marked by a deep cleft, or if it be a hollow viscus, divided more or less perfectly, sometimes by a stricture, sometimes by an internal partition. This division of an organ into several parts is often a kind of 
retarded formation, and as such, is frequently exhibited in the bony system, by the nonconsolidation of the original bony germs, in the lobular form of the kidneys, as in the embryon, and in the womb by its division into two horns; so also on the muscles, tendons, nerves, blood-vessels, and some of the viscera, we frequently observe their abnormal division into more or less distinct parts.

\section{$\S 24$.}

There are still other kinds of vices of conformation, in which the size of individual organs is unnatural, and consequently there is a want of symmetry and proportion; further, those depending on ALTERED POSITION and CONNEXION OF PARTS for instance, ruptures, prolapses, and those which are conjoined with CHANGE OF TEXTURE, as contractions, tumour's, excrescences, dropsies, \&c.,-finally, such as are consecutive to MECHANICAL INJURIES, viz. amputations, extirpations, divisions, scars, ligatures, \&c. The most frequently occurring deformities are produced by VICES OF THE BONY SYSTEM which draw the soft structure after them; to these belong curvatures, incurvationes, curvitura, of the neck, the back, and the long bones, -Distortions, distortiones, ${ }^{1}$ of the spine, of the feet, for instance, club-hands, and club-feet,-DisLocations, luxationes - unnatural joints-the shortening or oblique direction of united fractures, \&c.

(1) On Congenital distortion, v. Bourquenod, in Annal. de la Soc. de Médec. de Montpellier, Vol. I. Part I. p. 182.-Devilher Diss. sur l'entorse. Paris, 1812.--Matthias præs. Reil D. diversis morborum localium formis ad contracturæ genus revocandis. Svo. Berol. 1811.-Joerg Ueber die Verkrümmungen des menschl. Körpers, etc. 4to. Leipzig, 1816, with six copperplates.

\section{FIFTH SECTION.}

\section{Of Vices relating to Position.}

\section{$\S 25$.}

Unnatural position, situs alienus, perversus, dislocatio, is never GENERAL, as all parts of the body cannot be affected by it, but only PARTIAL. It may be either original or acquired; but in the more advanced periods of life we cannot distinguish the two kinds with certainty. To the first 
species belong especially the LATERAL TRANSPOSITION Or MISPLACEMENT of the organs contained in the thoracic and abdominal cavities, ${ }^{1}$ so that the parts ordinarily lying on the left, are placed on the right, and those on the right, on the left side. This irregularity is sometimes found merely in one or several organs, now and then only in the viscera of the chest, or in those of the belly; ${ }^{2}$ but most commonly in the parts contained in both those cavities, ${ }^{3}$ and usually without disturbance of the health. Not unfrequently certain parts are situated either too high or too low, as original or acquired conditions; viz. the heart in the belly, the kidneys in the pelvis, \&c., or the abdominal viscera in phrenic hernia in the chest, the testicles, at an advanced age, in the belly, \&c. Should the viscera become too weighty, or the parts by, which they are supported too lax, they sink down, according to the laws of gravitation, oftentimes very low. In other cases, one portion of a hollow organ is received into another, INTUssusception, intussusceptio. They are often thrust out of their proper place, either by curvatures of the body, by collection of fluids, or by tumours, and even squeeze themselves out of their proper cavity, if morbidly swollen, as is the case with the eye-ball, tongue, and the articular ends of bones.

(1) Situs Mutatus, Transpositio, Inversio Viscerum, also Anastrophe.

(2) See examples in the description of the thorax and abdomen.

(3) Metzger Pr. de translocatione viscerum. Regiom. 1797. Many old examples in Haller, Opera min. Vol. III. p. 16. note 9.-Morand Hist. de l'Acad. roy. des Sc. 1688, p. 44.-Bertrand s. Cattieri o. m. XVII.-Hoffmann Cardianastr. Lips. 1771.-Mohrenheim Wiener Beiträge. Vol. II. p. 305.-Sampson, in Phil. Transact. Vol. IX. No. 107, p. 746.-Gauteron Mém. de Montpellier. I. Hist. p. 110. and VIII.-Stoll Rat. medendi. I. p. 290. - Holt in Phil. Transac. Vol. XXII. No. 225, p. 992. - Sandifort Observ. anat. pathol. lib. I. cap. 2, p. 39 ; lib. IV. cap. 6 , p. 54-60.-Baillie in Lond. med. Journ. 1789. Vol. X. Part II. No. 6. - Lentin Beitr. zur ausüb. Arzneiw. Vol. II. p. 76.-Roemer Sylloge Opusc. Ital. Fasc. I._Hufeland Journal. Vol. XXII. p. 110.-v. Siebold Sammlung chir. Beobacht. Vol. II. p. 331.-Aubertin in Journ. de Médec. Vol. LXV. p. 408.-Bichat Sur la Vie et la Mort. - Jacob in Journ. de Médec. cont. Sept. 1811. p. 214. - Larrey Mém. de Chir. milit. Vol. I. Paris, 1812. - Bérlard in Bullet. de la Soc. médic. d'emulation, Dec. 1816. p. 328, and Bullet. de la Soc. philomat. 1817.-Herhold v. Thomson's Annals of Philos. July, 1819, p. 55. (to which belong two unpublished plates, for which I am indebted to the author.) - Nacquart and Piorry in Journ. génér. de Med. Vol. LXXII. p. 48.-Omer in Observat. des Sc. médic. März, 1822._Ullersperger pathol. anat. Beschreib. zweier Missgeburten. p. 44. Würzburg, 1822.-Wetzler s. Berliner Nachrichten v. Staats-u. gelehrten Sachen. No. 2. 1817.-Remsay in Medic. Repository, New York, new ser. Vol. IV. Part II. 1817.-Heger præs. Emmert D. de inversa corp. hum. structura. Tübing. 1816.-Desrouelles in Bull. de la Soc. médic. d'émulation, Févr. 1821, p. 41.-Bryan in Transact. of the Associat. of Irish Physic. Vol. IV. No. 14.-Douglas Fox in Lond. med. and surg. Journ. June, 1824.- Doubled in Archiv. général. de Médec. Dec. 1824. - Scoutetten v. v. Froriep's Notizen, Vol. VI. No. 8, p. 128. - Nägele in d. Heidelb. klin. Annalen. Vol. I. Part IV. p. 507.-Sue in Auserl. Abhandl. der Akademie d. Winsensch. zu Paris übers. von Beer. Leipz. 1754. Vol. II. 
p. 315.-J. F. Meckel D. de cordis conditionibus abnornibus. 4to. Halæ, 1802. 'Tab. I. Fig. 4.-G. Gamage in New-England Journ. of Medec. and Surgery, Vol. IV. p. 224-246. -My Selt. Beob. Part II. p. 173.-Rose in London med. and physic. Journ. Oct. IS26._Baron in Medic. chir. Trans. 1827. Vol. III. p. 153. - Serre in Archives générales de Médecine, 1827. Vol. XVI. and in Nouvelle Bibliothèque médicale, December, 1827. - F. G. Wette D. de situ viscerum inverso. (in one instance.) 8vo. Berol. 1827.-Moncreiff in Edinb. med. and surg. Journal, No. 95, April, 1827, p. 440. - Barbieux in Annales de la méd. physiol. Paris, 1828. I have seen since a case of an adult man in the Anatomico-pathological Museum at Vienna, No. 1800; and also found a similar instance in a brewer's servant, æt. 45 . v. No. 8870 , of the Breslau Museum. I know no instance of it in animals.

\section{$\$ 26$.}

Two particular, and as frequent as important, forms of dislocation are, RUPTUREs, hernia, and PRolaPsEs, prolapsus. In the FORMER, one or more of the viscera pass either partially or completely from their proper cavity into an unnatural sac or bag $;^{1}$ in the LATTER, a viscus wholly or partially protrudes, without its investing membrane, through an original aperture, and is then either simply protruded, or at the same time inverted, inversio. Finally, the altered position of parts in ruptures and prolapses is to be distinguished from original or accidental misplacement, propendentia, evisceratio, of the viscera, consequent on separation of the parieties of the cavities in which they are otherwise contained, either congenital, or dependent on ruptures and wounds.

(1) The so-called internal herniæ are strangulations; the diaphragmatic hernia, however, with the exception of those which have a sac, belong to the original or accidental misplacement, evisceratio.

\section{$\S 2 \%$}

When certain parts have, at one period, an actual progressive motion, or are supposed to continue it, their unnatural situation has been named Deviation, aberration, deviatio, aberratio. To this, for instance, belong the descent of the testicles under the crural arch, or into the perinæum, and the anomalous course of the vessels.

\section{$\S 28$.}

Finally, the position of parts may be so far irregular, that although not out of their usual place, they may have an ABNoRMAL DIRECTION, direciio perversa, obliquitas, \&c., so that their axis is changed. These vices are observed in several viscera, viz. in the eye, heart, stomach, kidneys, and womb, indeed, even in the bones; thus, for example, the teeth are 
placed sometimes obliquely, sometimes transversely, and sometimes even turned round. ${ }^{1}$

(1) [In the Mus. Coll. Surg. Lond. there is one specimen of an incisive tooth, the crown of which protrudes into the nose. T.]

\section{SIXTH SECTION.}

\section{Of Vices relating to Connexion.}

\section{\$29.}

Vices of CONNEXION, vitia nexus, may consist in the diminution or entire suspension, and in the increase of the natural connexion and contiguity of a part with those in its neighbourhood. To the FORMER KIND belong the NON-ATTACHMENT of a part, in consequence of defective formation, for instance, of the intestines, from absence of the mesentery; the REMOVAL of two viscera from each other dependent on laxity of the cellular and membranous parts by which they are connected; the SEPARATION, diastasis, of two immovably connected bones from each other, and the removal of the articular ends of two bones from each other, DISLOCATION, luxatio, as it is called.

\section{$\S 30$.}

The irregular INCREASED CONNEXION of two organs may be either original or acquired; the first is especially noticed in the CONGENITAL COALESCENCE ${ }^{1}$ of two or more parts into one common part, which assumes more or less the trace of duplication. As the abnormally consolidated parts have at their commencement, either sprung from a common centre, or are so close that they touch each other, so it may be explained how partly the confused activity of development in the organ itself, partly deficiency of room, and in fine partly the want of power to separate in the parts otherwise interposed, may produce such consolidated formations. As instances of these, may be given the consolidation of two neighbouring vertebræ, ribs, muscles, the fingers and toes, the two kidneys and the renal glands; CYCLOPY, in which both eyes, the front of the brain, and sometimes also the two nostrils, are seen running into one; next, the imperfect development of the lower part of the face, in which the ears, the muscles, the salivary glands and ducts of 
both sides are found consolidated; further, the CLOACAL FORMATION, ${ }^{2}$ as it is called, which is produced by the union of the lower part of the urinary, generative, and alimentary organs into one common cavity, similar to, although sufficiently distinct from the cloaca of animals; and lastly, the most perfect degree of coalescence in the human subject, the SYREN FORMATION, in which even the whole of the lower extremities are united into one common limb.

(1) Meckel iiber die Verschmelzungsbildungen in his Arehiv. f. Anat. und Physiol, 1826, No. II. p. 238.

(2) Handbuch der pathol. Anatomie. Vol. I. p. 698.

\section{$\S 31$.}

Much more frequent than the original abnormally increased connexion of different organs, is that which is acquired, the AGGLUTINATION, or COALESCENCE, concretio,${ }^{1}$ arising from the effusion of fibrine consequent on inflammation. Sometimes this occurs merely locally between neighbouring parts, at other times more generally between many parts; it can affect all parts of the body, and can be produced artificially by the approximation of sore surfaces. The coalescence is either close and intimate, so that the parts are every where in contact, or it is looser, so that newly formed fibres and bands connect the organs. The coalescence can occur also in a single organ, if it be hollow, and agglutinate one side of the canal with the other, as in the blood-vessels; sometimes also the excretory ducts of secreting organs, the alimentary canal, \&c. are seen closed, atresia morbosa. If two otherwise movable bones become united, it is called a STIFF JOINT, anchylosis. ${ }^{2}$

(1) Bergen D. de coalitu viscerum. Francof. 1736. - Hebenstreit D. de partium coalescentia morbosa. Lips. 1738.-Haller's Diss. pr. VI. No. 209.Orell D. de viscerum nexibus insolitis. Helmst. 1743.-Reil D. de concretionibus organorum morbosis. Halæ, 1795. - Cruveilhier Essai sur l'anatomie pathologique en général. 8vo. Paris, 1816. Vol. I. p. 142-181.- Plouquet Repertor. Art. Viscer. Coalitus. Compare below Inflammatio Exsudativa.

(2) Compare Fifteenth Section, On the Bones. 


\title{
SEVENTH SECTION.
}

\section{Of Vices relating to Colour.}

\author{
$\S 32$.
}

The irregular colouring of animal parts is very frequently conjoined with vices of texture, and may then consist, as in scirrhus, in the change into fat, in ossifications, \&c. in diminution of colouring; or as in inflammations, caries, cancer, mortification, \&c., in the deepening of colour, and frequently also in an entirely different colouring. But this abnormal colouring can also occur without any, or at least without any visible vice of texture, and then for the most part depends upon change in quantity or quality of the colouring fluids found in the organs, and especially of the blood.

\section{$\S 33$.}

First, as to what concerns diminished colouring: this is itself sometimes original; thus a particular part does not possess the proper degree of colour belonging to it, and remains pale as in the embryon, ${ }^{1}$ such is one kind of retarded formation; yet, however, deficiency of texture is usually connected with this state. To this belongs, also, the more common state of ALBInorsm, leucathiopia, leucopathia, albinoismus, ${ }^{2}$, which occurs both in man and animals, in which the skin, the hair, and the eyes, are found unnaturally pale; this morbid state is sometimes hereditary in man, but more frequently in animals, and in the latter, then produces distinct varieties. ${ }^{3}$

(1) For instance, the muscles, the intestines, \&c.

(2) Among beasts, albinos are observed in the monkeys, mole, bear, badger, polecat, marten, fox, dog, beaver, rat, mouse, squirrel, rabbit, hamster, opossum, horse, swine, elephant, deer, roebuck, goat, cattle, buffalo, dromedary, and among very many birds. [T. Trail, On Albinos in Nicholson's Journal. London. 8vo. No. 19, p. 81 . T.]

(3.) For instance, the white horse, the silky hare, the white mouse.

\section{$\S 34$.}

Unnatural paleness is more generally an acquired diseased state, a change of colour or bleaching, and is especially produced by a diminution of the blood generally, and of its cruor in particular, on which account it is the usual attendant of long continued disease, of cachexia, and especially of consumption and dropsy. ${ }^{1}$ 'To this place also we refer the more local change of colour, viz. in the skin of coloured persons, the change to grey and white of the hairs ${ }^{1 *}$ and. 
feathers, the bleaching of dark eyes, \&c.; the cause of this bleaching of the above-named parts is found in the diminution or total removal of the colouring matter. The frequent loss of colour in the mucous membrane of the mouth, and of the alimentary canal after poisoning with the concentrated acids and with tartar emetic, ${ }^{2}$ is also worthy of notice.

(1.) Very frequently also in animals, to wit, in diseased fishes. [The Anemia of Andral. v. his Précis d'Anatomie Pathologique, Vol. I. p. 74. The paleness of the bocly after severe or repeated hæmorrhage arises from the same cause, viz. diminution of the blood generally, and of its cruor in particular. Butchers are therefore accustomed to bleed their calves, for the purpose of rendering the veal whiter. T.]

(1*) [W.P. Dewces, A singular case of alteration of the colour of the hair during parturition, in which all in front of the coronal suture changed completely white in the course of an hour, in consequence of alarm. On the following day it was much less white, and in four or five days its usual colour had returned. v. Philadelphia Medical Museum, edited by Dr. Cox. Vol. III. p. 219, 1807. 'T.]

(2) I have seen it more than once after poisoning by sulphuric acid, and the very white colour of the mucous membrane is by no means merely dependent on thickening and relaxing of the epithelium.

\section{$\S 35$.}

The abnormally increased colour of an organ, or the DEEPENING OF ITS Colour, depends in some cases, and especially in muscles originally pale, upon hypertrophy; but most commonly on the gorging of a part with blood, which has been augmented in it by congestion and stagnation, stasis; this is very often observed in the lungs, the liver, the spleen, and the mucous membrane of the alimentary canal.* Sometimes it happens that the congested blood is itself unnaturally deep coloured, and thus doubly deepens the colour of the part in which it is collected; this is especially the case after suffocation, apoplexy, poisoning with narcotic substances, and hydrocyanic acid, adynamic fevers, and especially in the blue disease. ${ }^{1}$ A red or bluish colour is often observed in certain parts of the body, produced by congestion of blood in the most delicate vessels, for instance, DEATI spots, lividitas, nigror, sugillationes spuria, the form, extent, and colour of which are very variable, according to circumstances; further, we notice similar red and dusky spots on the internal parts, arising from the same causes, as on the intestines, and more especially on their mucous coat; and the dusky colouring of those parts into which, if they be lowest, the blood sinks according to the laws of gravitation ${ }^{2}$ such spots are produced, even sometime after death, on the putrefaction and thawing of frozen corpses.

(*) [Some few years back, I saw a very remarkable instance of this gorging with blood, in the nucous membrane of the stomach of a man who had fallen deal in the street, and was brought into St. 'Thomas's Hospital. 'The whole 
internal surface of the stomach was of a bright red colour, and looked like velvet there were no other morbid appearances, nor was any history of his previous life obtained. T.]

(1) A good engraving of a person affected with the blue disease is to be found in the Cliirurg. Kupfertafeln. Weimer, 1820. Pl. 53-55.

(2) In the common position on the back, also in the soft structures on the side of the spine, in the hinder part of the lungs and liver, as well as those parts of the small intestines which lie in the lesser pelvis.

\section{$\S 36$.}

From this kind of dusky spots we must distinguish other similar colourings which originate in the percolation of the darker juices after death; thus we sometimes observe in persons who have died of inflammation of the lungs accompanied with their adhesion to the pleura, large livid or violet-coloured spots on the chest; on the stomach there are seen dusky red spots, where it is in contact with the blood-gorged liver and spleen. The large venous trunks filled with blood often colour the neighbouring parts, ${ }^{1}$ and the gall-bladder very frequently tinges a part of the adjacent stomach and duodenum with its bile. Sometimes, also, the naturally pale surfaces immediately in contact with the blood become equally red, for instance, the inner surface of the heart, the great arterial trunks, the rectum in piles; a peculiar change in the blood seems to be the cause of this colouring.

(1) We easily distinguish these spots by the neiglibouring causes, and because the external surface of the organ merely is coloured, or the colouring, if it have penetrated deeper, still diminishes gradually.

\section{$\$ 37$.}

A particular kind of deeper colouring is also produced by EXTRAVASATION, ecchymosis, ecchymoma, effusio, suffusio, sugillatio, either under the skin, or more deeply, but which differs from the above described similar spots, as it is produced by the actual effusion of blood from the vessels into the cellular membrane of the part. This usually accompanies a BRUISE, contusio; but it is not unfrequently consequent on severe strains of a part, on suckling in delicate skinned women, on great muscular exertions, on coughing, vomiting, and on many diseases, especially scurvy, petechial fevers, the morbus hæmorrhagicus of Werlhof, \&c. These extravasations are at first blackish or blue, and distinctly circumscribed, but by degrees become more extended, as it were, fade, and by little and little assume a violet, greenish and yellow colour. ${ }^{1}$

(1) Importance of distinguishing these spots from inflamnatory redness. $\$ 35-37$. 


\section{$\$ 38$.}

Further, the irregular colouring of animal bodies is often caused by the reception of various extraneous colouring matters into the body. This is observed almost generally in the lower animals, especially in the parasitic, when living on different kinds of food $;{ }^{1}$ also locally, as the consequence of various medicines and poisons $;^{1 *}$ thus the bones of men, beasts and birds, are more or less reddened by food of a red colour. ${ }^{2}$ The taking of rhubarb often tinges light parts yellow; hydrocyanic acid renders many organs bluish or greenish; nitrate of silver, ${ }^{3}$ quack medicines, of which the composition is unknown, ${ }^{4}$ and other medicines, ${ }^{5}$ often render the skin blackish.

(1) For instance, the aphis, the louse, fresh oysters, \&c.

(1*) [I. Ingenhousz, Some further considerations on the influence of the vegetable kingdom on the animal creation, in Phil. Trans. Vol. LXXXII. p. 426.]

(2) This also occurs in wild animals; for example, in the water rat, of which I have seen one instance. [H. Baker, On the effects of the Opuntia or Prickly Pear, and of the Indigo Plant, in colouring the juices of living animals, in I'hil. Trans. Vol. L. p. 296.-Gibson, On the effect of Madder Root on the Bones of A nimals. Manchest. Mem. new ser. Vol. I. p. 146. T.]

(3) Swediauer in Fourcroy La Médecine éclairée par les Sc. physiques. Vol. I. p. 342.-Albers in Medic. chir. Transact. Vol. VII. Part I. p. 284; and Roget, ib. p. 290.-Butini De usu interno proparationum argenti. Genf. 1815.-Baillie s. N. Samml. auserl. Ablandl. z. Gebr. pr. Aerzte. Vol. IX. Part III. p. 379. - Wedemeyer in Rust's and Casper's Krit. Repertorium. Vol. XIX. Part III. p. 454.

(4) A secret of my grandfather's on my mother's side, Dr. Weigel, of Stralsund, produced, in some instances, to my own knowledge, a general dark colour of the skin.

(5) Transiently after the use of sulphur and quicksilver, by which a kind of Etriops is formed. v. Rigby, in London Medical Repository, Jan. 1817.

\section{$\$ 39$.}

Finally, we oftentimes observe some peculiar colouring matter or pigment ${ }^{1}$ spontaneously produced in animal bodies, and colouring certain parts more or less completely; such is the case in jaundice, icterus, and in melanosis. In the former disease there is formed in the body a yellow animal extractive or colouring matter, which has great similarity to the pigment of the bile, and tinges almost all the solid and fluid parts of the body more or less yellow and dusky, however, so that many of the systems assume a yellow colour more frequently than others. ${ }^{2}$ Diseases of the liver, asthenic fevers, as the plague, the American yellow fever, ${ }^{2^{*}}$ typhus fever, \&c., are commonly attended with jaundice; the same also occurs in animals, but much less frequently. In melanosis, ${ }^{3}$ on the contrary, a deep brown or more frequently a blackish tinted pigment is morbidly produced, which occurs sometimes generally, sometimes to a limited extent; in the former, it is either mingled with the particular excretions, as the urine, the perspiration, the 
mucus from the lungs, in certain cases also, perhaps (in the matter evacuated) in Melcena, ${ }^{3}$ or the BLACK DISEASE of Hippocrates, and colours them blackish ; or it may be deposited as a fluid or semi-coagulated mucus on the expanded surface of serous membranes, particularly the peritoneum and pleura. ${ }^{4}$ In the confined state the black pigment is found accumulated either in the otherwise healthy substance of an organ, especially of the skin, of the lungs, of the bronchial glands, \&c., or it may accompany the various vices of texture, as mortification, particularly of the dry kind, false membranes, soft swellings, scirrhus, cancer, medullary sarcoma, and most commonly, at least in animals, tubercular swellings. ${ }^{5}$

(1) G. Jaeger Ueber das Vorkommen von Kolıle in menschl. Gallensteinen, nebst einigen Bemerkungen über Verkohlung organischer Körper ïberhaupt, in Meckel's Archiv f. d. Physiol. Vol. VI. p. 485.-Heusinger Uritersuchungen über die anomale Kohlen und Pigmentbildung in dem menschlichen Körper, mit besonderer Beziehung auf Melanosen, u. s.w. Eisenach, 1823. - A. Retzius in Svenska Lakare-Pällskapets Handlingar. Vol. X.

(2) The skin, the cellular tissue and muscles, for instance, more commonly than bone and cartilage; most rarely the nervous system.-The KIRRHONOSE of Lobstein (v. his papers in the Zeitschrift f. Physiol. of Tiedemann and G. R. and L. C. Treviranus, Vol. II. Part I. p. 79, and in Repertoire gén. d'Anat. et de Physiol. pathol. Paris, 1826, Vol. I. Part I. p. 141). A yellow colouring of the serous membranes and nervous medulla in the foetus I liave also occasionally observed, but have considered it not actually different from the jaundice.

(2*) [Pariset Observations sur la fièvre jaune. 4to. Paris, 1820. 'T.]

(3) Dupuytren appears to have first drawn attention to this disease. vo Journ. de Médec. de Corvisart, Vol. X. p. 89-96.-Bayle, in Recherches sur la Phthisie pulmonairc, Paris, 1810, Obs. XX. and XXI.; and Laennec, in Journ. de Médec. de Corvisart, Vol. IX. p. 368, first employed the name, Melanose, and distinguished thereby, especially, a kind of sarcom ; on Melannsis in general, compare Laennec de l'auscultation médiate, etc. 8vo. Paris, 1819, Vol. I. p. 299.Bréschet in Mugendiè's Journ. de P'hysiol. expérim. Vol. I. No. 4. p. 354-M Merat in the Journ. des Sc. médicales. Vol. XXXII. Art. Mélanose, p. 183.-Heusinger. - Nouck Comment. de Melanosi cum in hominibus tum in equis obveniente, etc. 4to. c. trib. tab. æn. Lips. ct Paris, 1826. - Savenco Tentamen pathologico-anatomicum de Melanosi. Petropoli, 1825. - Schier D. de morbo quodam maculoso, quem Melanosin recentiores appellant. 8vo. Berol. 1826.- [Graves M. D. Clin. Observ. in Dublin Hosp. Reports. Vol. IV. p. 69. Svo. Dublin.-G. Breschet Considerations sur une alteration organique appelée Degenerescence Noire, Melanose, Cancer, Melané, etc. 8vo. Paris, 1821.-B. Travers, Observations on the local diseases called Malignant, in Med. Chir. Trans. Vol. XV. p. 195. T.]

(3*) J. Cheyne, M. D. Case of Melæna in Dublin Hosp. Rep. Vol. I. p. 259, 1817; a remarkable instance, in which the production of the secretion peculiar to this disease, alternated with increased activity in the serous membranes.--A. Portal Observations sur la nature et sur le traitement du Melæna in Mem. de la Societ. d'Emulat. Vol. II. p. 167.

(4) Melanosis membranacea in Merat and Noack.

(5) See the Tenth Section, On Vices of Texture. 


\section{EIGHTH SECTION.}

\section{Of Vices relating to Consistence.}

\section{$\$ 40$.}

The irregularities of animal parts with reference to their soliditr, CONSISTENCE, consistentia, ${ }^{1} i$. e. the normal degree of the intimate connexion of their elementary parts, originate in the vices of solidity and power of cohesion; therefore, whatever disturbs these, diminishes or increases the power of an organ to resist mechanical influences. The difference of consistence, according to age and individuality, the latter of which the antients distinguished by the terms FIBRA LAXA, MOLLIS and DENSA, RIGIDA, \&c., do not belong here; but such changes of consistence as are produced by morbid activity of nourishment, disproportion of the fluid to the solid parts, and especially by vices of texture. Only in few instances are the vices of texture not perceptible in irregular consistence, although they are in fact always present.

(1) Meckel Handb. d. pathol. Anat. Vol. II. Part. II. p. 6.

$$
\S 41 \text {. }
$$

The DIMINUTION of CONSISTENCE, or the MORBID SOFTNess, laxity, pulpiness, mollities, laxitas, marcor, \&c., is most frequently the consequence of irritation and inflammation, under which both the thickness and power of cohesion, as well as the texture of an organ, are changed. Diminished consistence, therefore, is not merely the concomitant of suppuration and mortification, but also of the less distinguishable changes of nourishment in quality and quantity occurring with and after irritation and inflammation. Whatever produces relaxation of the tissue, be it an increased influx of the juices, for instance, as in dropsy of the organ, or a morbidly increased internal absorption, produces softness 'or pulpiness, from which the hardest and toughest parts, as the bony, cartilaginous and horny tissues, do not escape, which is most striking on account of their opposite state. Sometimes the morbid softening, it appears, is connected with peculiar proportions of mixture, and so great, that the parts affected are converted into an actual inorganic pultaceous mass, for instance, the brain and spinal marrow, and especially the stomach and neighbouring parts, in the so called suftening of the stomach; but in other cases, the consistence of a part is considerably diminished without any ob- 
servable vice of mixture or texture. This is most frequently found in the brain and in the muscles.

\section{$\$ 42$.}

The opposite state or the unnaturally INCREASED CONSISTENCE of a part, the morbid HARDNESS, RIGIDITY, induratio, rigiditas, \&c., arises from the increased compactness and power of cohesion in the part, which may originate either in the mere unnatural contraction of the animal tissues and the diminution of the part; in the diminution of the juices and the augmentation of the solid and especially earthy parts; in the effusion of more or less coagulated fluids into the parenchymatous structure of the part, for instance, in the induration, induratio, consequent on inflammation; and finally, in those peculiar changes which can neither be reckoned as vices of mixture or structure, although, perhaps, they really are so; to the latter kind belong a peculiar kind of solidity and dryness of the muscles and of the brain.

\section{NIN'TH SECTION.}

\section{Of Vices relating to Contimuity.}

\section{$\$ 43$.}

Vices of consistence very naturally lead to those of conTINUITY, which consist in the breaking up, in the actual SEPARATION OF THE INTIMATE CONNEXION OF AN ORGAN, solutio continuitatis. If the power of resistance in an animal tissue be diminished, then even a relatively moderate mechanical power will act in proportion too strongly, and produce a separation of the intimate composition of a part; but more frequently this is also efiected by the actual operation of external causes, even where the normal degree of consistence exists. The first more properly belongs here, the last rather to surgery.

\section{$\$ 44$.}

The breach of continuity of a part may be either ORIGINAL or ACQuired. To the former belong the not unfrequent 
CLEFTS OF THE FRONT AND BACK OF THE BODY, in the mesial perpendicular line ${ }^{1}$ these are perhaps in part retarded formations, but more commonly the consequence of early morbid distension of the walls of the cavities, from the too early development and size of the parts therein contained, from dropsies, \&c. They occur also in different degrees, so that the organs found in the cavities of the body are either entirely exposed, or rather are covered by their investing membranes, which are then much thinned, and occasionally expanded like bags, and even found torn. ${ }^{2}$ In this manner are observed clefts of the spine, of the skull, of the lips and palate, of the breast, belly, and front of the pelvis, either alone or several of them at the same time.

(1) Meckel's Haudbuch der pathol. Anatom. Vol. I. p. 93.-The particular kinds will be treated of in the separate organs.

(2) It is incorrect, when these thin membranes are described as mere dura mater, peritoneum, \&c. as the common integuments always exist at the same time, although indeed they are very thin.

\section{$\$ 45$.}

The ACQUIRED vices of continuity are more fiequent; they are the consequence of mechanical causes, and are commonly called Lesions, lasiones. To these belong the recent divisions of continuity by mechanical penetrating violence, $i$. $e$. wounDs, vulnera, to wit, both the simple, as cuts, chops and stabs, and the complicated, as contused, gunshot wounds, burns, \&c.; further, partial or complete lacerations and ruptures, dilaceratio, ruptura, of parts violently extended or shaken ; ${ }^{\prime}$ and, lastly, FrACTURES of BONEs, fractura ossium. Similar lesions now and then occur without any external violence, especially in the vices of consistence, from mechanical causes existing in the body itself, for instance, fractures of bones and ruptures of tendons by the action of the muscles, the bursting of cavities, from their too great distension by the fluids which they contain, \&c.

(1) For instance, of the internal viscera without wounds of the sides of their inclosing cavities-remarkable transmission of concussion from distint parts.Janson Essai sur les ruptures des tissus et des organes du corps humain. 4to. Paris, 1813.

\section{$\S 46$.}

Lastly, we must here also mention that spontaneous and MoRBiD separation of parts from the general organism which occurs, not from violence, but consequent on their irregular nourishment or total decay, viz. the shedding of the cuticle, the hair, the nails, horny excrescences, the teeth, the separation of 
mortified parts, indeed of whole limbs destroyed by mortification, the drying up and falling off of supernumerary parts in monsters, ${ }^{1}$ and the throwing off of polyps, and growths of other kind, which have separated themselves completely from the parts out of which they had grown.

(1) I possess a full grown goose, yet alive, of which the greater portion of the hind part of the body is double; two supermumerary feet dried up to the heel, and fell off.

\section{TENTH SECTION.}

\section{Of Vices relating to Texture.}

\section{$\S 4 \%$.}

As in healthy animal bodies their component parts are in a continual state of change and growth, so must we naturally expect this should occur still more in many diseases, and easily amount to a perceptible change of the tissues. Hence, then, vices of TEXTURe or DEgenerations OF THE TISSUE, vitia textura, desorganisationes, ${ }^{1}$ are very common, and in regard to their cause, in most intimate connexion with the already mentioned vices of size, form, colour, and consistence.

(1) Dumas Sur les transformations des organes in Sedillot Journ. génér. Vol. XXIII-XXV.-Laennec in Corvisart, etc. Journ. de Médec. Vol. XI. p. 360, and in Dict. des Sc. méd. Vol. II. Art. Anatomie pathologique.-Bugayski D. de part. corp. hum. solidar. simil. aberrationibus. 4to. Berlin, 1813.-Cruveilhier Essai sur l'anatomie pathologique en général, et sur les transformations et productions organiques en particulier, 2 vols. 8vo. Paris, 1826.-Meckel Handb. der pathol. Anatomie. Vol. II. Part II. - Heusinger System der Histologie. Part I. p. 87-103, 4to. Eisenach, 1822, and in the first Berichte von der königl. anthropotomischen Anstalt zu Würzburg, p. 1-41. 4to. 1826.-Boulland in Révue médic. Française et étrangère, etc. Sept. Paris, 1825.

\section{$\S 48$.}

All degenerations of the animal tissue are either conversion of the normal into an abnormal substance, as MORBID METAMORPHOSES, transformationes, degenerationes, or entirely NEW FoRMATIONS, in their stead; or specially substances not previously existing, sPUR1ous FORMATIONS, pseudoplasmata, pseudorganisationes; or, finally, a MIXED STATE of the changed and new formations. ${ }^{1}$ We often find many kinds of 
morbid changes and spurious formations existing together, and the diseased part a diversified compound of the extraneous tissue, which is so circumstanced, that the newly presented morbid substance perforates the original tissue, and is deposited between its fibres and layers, or is more or less distinctly defined; the latter is especially the case with the spurious formations, which, lying in their proper bed, are attached as it were by roots to the diseased organ, but sometimes are connected extensively with its surface, or still distinctly circumscribed in it, and even enclosed in their proper surrounding membrane or bag, and merely displace by their position the original substance, or produce its absorption by pressure.

(1) The diagnosis of this state, as well as of its various kinds, is often very difficult and even impossible; much which appears to be a mere change of the tissue is a new formation; thus, many cartilaginations and ossifications by which the loose extraneous body is enclosed in fine plates of normal tissue; further, the apparent conversion of a muscle into fat, whilst the muscular fibres exist pale and wasted, but at the same time the fat deposited between them is also lost ; the spurious formations are also often at first very similar to each other, but these, at a subsequent period, vary from each other according to the difference of the organ to which they are attached. One kind also frequently runs into another.

\section{$\S 49$.}

All the parts of an animal body are subject to vices of texture, however, not in a similar degree; some indeed are more subject to morbid metamorphosis; others, for example the skin, mucous membrane, and glandular organs, rather incline to spurious formations. Hence also many arise from age, inasmuch as disorganizations generally appear to occur less frequently in the earlier than in the later periods of life; but almost every age has its peculiar or more common vice of texture. ${ }^{1}$

(1) For example, in childhood, tubercles; in later life, cancer and ossification.

\section{$\$ 50$.}

According to the nature of a part, a certain though very obscure change both in quantity and quality of the activity of nutrition, must be considered as the next cause of the vicious condition of its tissue; but this again, especially, is derived from the defective development of the organism, from the termination of activity in a part, or from certain diseases. From the first cause arises the RETARDED FORMATION OF THE Tissue, in which a part remains in the same state as during fortal existence; ${ }^{1}$ from the second, the so called RECEDING rORMATION of the no more used tissue, which, in such calses, is not merely diminished, but frequently at the same 
time again resolves itself into the original pre-existing cellular tissue; ${ }^{2}$ finally, from the third cause, viz. from various diseases, but especially from morbid irritation and inflammation, whence arise by far the greater number of vices of texture.

(1) Thus we find the bones cartilaginous, the tendons soft, the muscles jellylike; some of the viscera, as thin membranous bags, filled with mucous-like fluid, \&c. Restored parts sometimes exhibit a very imperfect texture ; thus, for instance, I find in lizards, of which the tail had been broken off two years before, and had perfectly recovered its normal length and thickness, that the caudal vertebræ were still cartilaginous, and the muscles less fibrous and tough than usual.

(2) For example, muscles, blood-vessels, glands, and their excretory ducts, nerves, tendons, \&c.

\section{$\S 51$.}

Morbid IRRITATION, irritatio morbosa, may be either GENERAL, as in fevers, or more commonly only LOCAL; it has also various degrees, in the higher of which, for instance catarrh, it approaches to inflammation. It has in many cases, when it attacks the lymphatics and veins, an increased resorption; more commonly, when it acts upon the arteries, an increased flow of blood passes to the irritated part, which therefore, after death, appears turgid, reddened, and as it were injected, and easily changes the quantity and quality of the secreted substances. Thus does morbid irritation lay, not merely the foundation for new and extraneous chemical operations, for coagulations, for partitions, but also produces the various diseased collections which are so often met with in dead subjects. To this belong the presence of various kinds of GaSES, which doubtless arise not unfrequently from putrefaction, between the membranes of the brain, in the cavities of the brain, in the bags of the lungs, in the pericardium, in the belly, in the urinary bladder, in the womb, in the heart and blood-vessels, in the parenchyma of the intestines and in the cellular membrane $;^{1}$ further, the collection of WATER in almost every part, especially in the cellular tissue and in the serous membranes which line the cavities, whereby the different kinds of the common dropsies are produced: then the increase of muCOUS-LIKE, GELATINous, or rather albuminous masses, which are observed particularly in the mucous membranes spread over the cavities or canals of the body; and finally, the pouring out of blood, either pure or mingled with water, which escapes not from ruptured vessels, but actually exudes from the extreme branches of arteries, and indeed has been found in all the cavities of the body. ${ }^{2}$

(1) On all these parts have I observed collections of air, and partially several times. J. Halliday, D. de Pneumatosi. Edinb. 1806. - Briere in Nouv. Biblioth. Févr. et Mars, 1826. 
(2) It appears to me to be more frequent in the intestinal canal, in the pericardium, and the ventricles of the brain, where I have found it, as also in the thorax and abdominal cavities, more than once; also in the horse, decr, and dog.

\section{$\$ 52$.}

The most frequent cause of vice of texture is INFLAMmation, inflammatio, phlegmasia ; here, however, only belong its essential symptoms, redness and swelling. The INFLAMMATORY BLUSH, rubor inflammatorius, depends on an unusual quantity of blood, ${ }^{1^{*}}$ essentially changed in its composition, contained in the inflamed part, partly indeed in the larger and smaller sanguiferous vessels, partly also in those extreme branches of the arteries which commonly convey no red blood (vasa-decolora), and lastly, in part in the cellular tissue surrounding the arteries, in which it frequently appears exuding under the form of numerous small red spots. Under high degrees of inflammation, new small vessels are probably produced from the effused blood, which subsequently innosculate with the original vessels. During life, the blood-vessels of inflamed parts, usually at the commencement, exhibit a quicker motion, as well as a slight narrowing of their calibre, dependent on the degree of excitement operating on them; but the stream of blood gradually becomes slower, and at last entirely ceases, in most of the vessels, which then also expand, and are stopped up with the globules of cruor which they contain; some of these are dissolved in the fluid part of the blood, and so enter the vasa decolora. In the latter stages of inflammation, and as it runs on into other morbid states, the inflammatory blush is changed in various ways, especially by the solution and mingling of the globules of the blood; it is also visibly diminished in many organs after death. ${ }^{2}$ The inflammatory SWELLING, tumor inflammatorius, which is regularly accompanied with distinct tension, turgor, depends for the most part both on the extension of many small blood-vessels, and on the simultaneous, often very great effusion of blood, fluid fibrous matter, and lymph into the tissue of the inflamed organs. After death, the inflammatory swelling subsides on account of the cessation of the living tension, and perhaps also on account of the activity of absorption, which the lymphatic vessels and veins both possess for a longer time, and if then felt, it is found less tense.

(1) V'acca L. de inflammationis morbosæ, quæ in hum. corp. fit, natura, causis, effectibus et curatione. 8vo. Flor. 1765.-Brambilla Chir. prakt. A bhandl. von der Phlegmone und ilren Ausgängen, aus d. Ital. 2 'Thle. 8vo. Wien, 1773-75. - J. Iluner, Treatise on the Blood, Inflimmation, and Gun-shot Womds. Hto. London, 1795.-Burns, Dissertation on Inflammation. 2 vols. 8 vo. Glasgrow, 1800. - Broussais Hist. des Phlegmasies, ou Inflammations chroniques. l'aris, 1802, 2 vols. 8vo.; th edit. 3 vols. 1826.-P'erret $A$ perçu sur les phé- 
nomènes généraux de l'inflammation, considérés dans les différens systèmes. 8 vo. Paris. An. XI. - Jolly Phlegmasies des organes parenchymateux. 4to. Paris, 1812.-J. Thomson, Lectures on Inflammation, \&c. Edinburgh, 1813.1)zondi De inflammatione Aphorismor. 8vo. lib. I. Halæ, 1814.-Gruithuisen Theorie der Entzïndung, in der Salzb. medic. chir. Zeitg. Vol. Il. p. 129. 1816. (v. also $i b$. Vol. I I. p. 298, 1811.) - Dohlhof D. de phlegmore. 8vo. Halæ, 1819.-Philip, An experimental inquiry into the laws of the Vital Functions. Svo. $2 d$ edit. Lond. 1818. - Nichol in Lond. med. Repository, Vol. XVI. Aug. 1821.-James, Observations on some of the general principles and on the particular nature and treatment of the different species of Inflammation, \&c. 8vo. Lond. 1821. - C. E. Lucas, M. D. On the Principles of Inflammation. 8vo. Lond. 1821. - Scholefield D. de theoria inflammationis. Edinb. 1822.Waring D. de inflammatione. Edinb. 1823.-_Spörer D. de inflammatione, morbo animalium et vegetabilium. 8vo. Dorpati Livonor. 1824.-Koenig D. s. experimenta quædam circa sanguinis inflammatorii et sani qualitatem diversam instituta. 4to. Bonnæ, 1824.-Prus De l'irritation et de la Phlegmasie, etc. 8vo. Paris, 1825. - Koch D. de observationibus nonnullis microscopicis sanguinis cursum et inflammationem spect. etc. 8vo. Berol. 1825.-Burdach D. observat. nonnullæ microsc. inflammationem spectantes. 8vo. Regiom. 1825. - Black, A short Inquiry into the capillary Circulation of the Blood, with a comparative View of the more intimate nature of Inflammation, \&c. 8vo. London, 1825.-Gendrin Histoire anatomique des inflammations. 8vo. Paris. 1826.-Kaltenbrunner Experimenta circa statum sanguinis et vasorum in inflammatione. 4 to. c. tab. novem. Monachii, 1826.-Hohnbaum Ueber das Fortschreiten des Krankheitsprocesses, insbesondere der Entzündung, etc. 8vo. Hildburghausen, 1826. v.-As to Literature, Scavini, Précis historique de la doctrine de l'inflammation depuis Hippocrate jusq'à nos jours. 8vo. Turin, 1811.-Meier Versuch einer krit. Geschichte der Entziindung. 1ter Thl. 8vo. Berlin, 1812. v. Plouquet Repertor. Art. Inflammatio. - Reuss Repertorium Commentat. T. XIV. p. 21.-Göllner D. de inflammatione. 8vo. Halæ, 1821. - A. Goldoni Sulla inflammazione, trattato diviso in tre parti. Part I. Modena, 1825.-Gisbert van Beers D. de texturæ organorum per inflammationem mutatione. Bonnæ, 1826.-Bargen D. de inflammatione ejusque theoriis. 8vo. Berol. 1827.-Wedemeyer Untersuchungen über den Kreislauf des Blutes. Hanover, 1828.-J. Syme in Edinb. med. and surg. Journ. No. 97, Octob. 1828. - J. Scott, Surgical Observations on the treatment of chronic Inflammation. London, 1828.-J. Brown, Medical Essays on Fever, Inflammation, \&c. London, 1828.-Kï.pper D. de inflammatione et præsertim de puris generatione. 8vo. Berol. 1828.-M. Naumann Zur Lehre v. der Entzündung. Bonn, 1828. - Gendrin Histoire Anatomique des Inflammations. 2 vols. 8vo. Paris, 1822.-Dzondi Pathologiæ inflammationis systematum corp. hum. succincta adumbratio. Halæ, 1829.

(1*) [The Hyperémie Sthenique of Andral, which however is not merely confined to inflammation, although then more enduring; but in every state in which, from irritation, more blood is sent to a part than usual, as in blushing, \&c. v. his Précis Anat. Path. Vol. I. p. 12. T.]

(2) It is very important to distinguish the inflammatory redness from the above described red colouring (Seventh Section); most difficult, and sometimes even impossible, is the certain distinction of the redness produced by milder degrees of inflammation from the injection produced by violent irritation, or from congestion. The examination with a lens, and observation of the consistence of the part, afford, in such cases, the best results. Compare Boulland in Révue médicale Franç. et étrangère. Mai, 1825.

\section{$\S 53$.}

Inflammation attacks all parts of animal bodies, ${ }^{1}$ but in very different degrees of frequency, thus, the cellular tissue, the common integuments, the serous and mucous membranes, the intestines, and among these, especially such aś have an 
abundance of cellular tissue and vessels, as the lungs; then the muscles, great vessels, nerves, are most usually affected with the consequences of inflammation, whilst the tendons, ligaments, cartilages, and bones, are least so. In general external parts are more frequently affected by inflammation, than internal; further, it may be confined merely to a single spot, or many parts may be affected by it at one and the same time, even the whole limb; now it attacks merely the surface or investiture of a part, as the ERYSIPELATOUS INFLAMMATION, inflammatio erysipelacea, or at the same time it penetrates into the deeper parts, and into the parenchyma of the intestines as PHLEgmonous inflammation, phlegmone. It is uncommonly varied, in proportion as the parts affected have a different structure; thus the redness and swelling are much greater in the organs abundantly supplied with vascular and cellular tissue, than in the reverse; the duration and termination of inflammation is therefore also very different. Inflammation also varies exceedingly, according to the difference of age and constitution ${ }^{2}$ next according, to the variety of the morbid causes, in proportion as they are internal, dynamic, chemical, or lastly, mechanical $;^{3}$ finally, in reference, to the character of the disease itself, it may be either a common or SIMPLE, or a SPECIFIC INFLAMMATION. ${ }^{4}$ Here also we must make particular mention, on account of their importance, of the OCCUIT or HIDDEN INFLAMMATIONS, so called, which are seated especially in the intestines of the three great cavities of the body, and during life often exhibit no distinct or determinate symptoms. 'They occur both in men and animals, accompanying especially the true or sporadic fevers, many exanthematous diseases, hydrophobia, and very frequently, in the puriform consumption, in the intestines of the belly. ${ }^{5}$

(1) The horny system is usually excepted, although many kinds of horny softenings and excrescences on the frog of the horse's foot, (bleym), and the swellings of the bulb and pith of the hair, must be analogous to inflammation in other organs.

(2) There certainly does occur an inflammation of a peculiar kind in debilitated bodies, but no ASTHENIC INFLAMMATION, as this disease is always an increased local vital activity;-neither do I know a cIrRoNIC INFLAMMATION continuing for months or years; for that which is so considered is either irritation or disposition to inflammation, or the inflammation subsiding in one spot successively affects the others in disorganized, and especially in indurated parts.

(3) As the inflammation produced by wounds, contusions, frost, burns, corrosion with aquafortis, differs from the common spontaneous inflammation.

(4) For example, rheumatic, arthritic, scrofulous, syphilitic, carcinomatous, anthracic, \&ic.

(5) 1 have often seen the most decided marks of inflammation and incipient suppuration in the bodies of such persons as have died of sporadic and contagious typhus, as well as in animals which have been affected with similar poisons; in two instances also in men who had been destroyed by the small-pox; 
often also in sheep which had been attacked with pockenkrankeit, but much more frequently the signs of inflammation are entirely wanting, and when they are present, they are equally to be considered as merely the consequence and not the cause of such diseases. The common reddening of particular viscera in persons who have died of adynamic fevers, which Broussais and Tommassini have considered as a sign of inflammation, is not in the least so, but the consequence of mere irritation, congestion, obstruction, \&c. The most important writings on this subject are, Stoll Ratio medendi, Vol. VII. p. 73.-Wienholt D. de inflammationibus occultis viscerum. Gött. 1772.-Meyer D. de inflammationibus latentibus generatim, etc. Frankf. 1785. - Meckel D. clubia quædam circa inflammationes occultas in febribus putridis. Halæ, 1788.-Reyland Abhandlung von verborgenen und langwierigen Entzündungen. 8vo. Wien, 1790.Hartmann D. de inflammatione, præsertim occultarum natura in genere. Götting. 1796.-Nietsch Ueber verborgene Entzündungen und die daraus entspringenden bedeutenden körperl. Uebel. 8vo. Frankf. 1819.-Collineau: Peut on mettre en doute l'existence des fièvres essentielles? etc. 8vo. Paris, 1823. -Gendrin Rechcrches sur la nature et les causes prochaines des fièvres. 8vo. Paris, 1823. - Dujes Essai phys. pathol. sur la nature de la fièvre, de l'inflamination et des principales neuroses. 2 vols. 8vo. Paris, 1823. - Laso Coleccion de inspecciones anatomicas relativas a la fiebre amarilla. 4to. Cadiz, 1821. - Medic. Geschichte des gelben Fiebers, etc. aus dem Franz. von Liman. 8vo. Berlin, 1824.-J. Wendt Die alte Lehre von den verborgenen Entzündungen durch neuere Beobachtungen bestätigt. 8vo. Breslau, 1824.-Caffin 'Traité analytique des maladies dites fièvres essentielles. 8vo. Paris, 1824.-Castel Refutation de la Doctrine medicale de M. Broussais, etc. 8vo. Paris, 1824. Bailly Traité anat. pathol. des fièvres intermittentes simples et pernicieuses, etc. Paris, 1825.-Boisseau Pyretologie physiologique, etc. Paris, 1824.-Gilbert Mémoire: Existe-t-il toujours des traces d'inflammations dans les viscères abdominaux après des fièvres putrides et malignes? etc. 8vo. Paris, 1825.-On this question, v. Vacquie in Journ. compl. du Dict. des Sc. medicales, Nov. 1825. Chauffard Traité sur les fièvres prétendues essentielles, etc. 8vo. Paris, 1825. Bouilland Traité clinque et expérimental des fièvres dites essentielles. 8vo. Paris, 1826. - Upon the internal false inflammations, v. L. E. Polidoro in Omodei's Annali univers. di Medicina, Vol. XXXVIII. Ap. 1826, (against Broussais.)

$$
\S 54 \text {. }
$$

If the inflammation abate without the occurrence of its essential phenomena, the blood congested in the delicate vessels is dispersed; the vessels themselves resume their normal number, and revert to their former calibre, the tissues gorged with blood again become emptied of it, and in a word, the normal condition of the tissue is restored: this is called resolution, resolutio. Should it not terminate thus happily, the inflammation is followed by the critical EFFusion OF VARIOUS FLUIDS, SUPPURATION, SOFTENING, HARDENING, MORTIFICATION, and VARIOUS SPURIOUS FORMATIONS, all of which must be here separately treated of.

\section{$\S 55$.}

As to the morbidly secreted FLuIDs, ${ }^{1}$ they may be produced now from the EXPANDED SURFACE OF THE ORGAN, and IN THE CAVITY receiving them, or they may be poured out in the PARENCHYMA OF THE PART ITSELF; - in the former, they give 
rise to the collection of fluids, partly of the same kind as in morbid irritation, viz. gaseous, lymph-like, ${ }^{2}$ mucous, and bloody $;^{3}$ partly peculiar, as fibrous matter and pus. The first, called PLASTIC LYMPH, fibrina, lympha coagulabilis, ${ }^{*}$ is poured out in a fluid form under certain inflammations, therefore named inflammationes exsudativa, and adhasiva, ${ }^{5}$ in greater or less quantity, and then forms, if mingled with much serum, a turbid milky fluid containing flakes and fibres; but if it be pure, an homogeneous, thickish, rather yellowish fluid, not convertible into pus, which soon becomes solid, still harder, fibrous or membrane-like, and finally organized, ${ }^{6}$ and assumes the name of PLASTIC COAGULA, or FALSE MEMBRANES. ${ }^{7}$ These plastic coagula are the cause of the adhesion of organs with each other, ${ }^{8}$ are partly threadlike and shaggy processes, partly true membranes completely enveloping the parts. If such coagula be formed on the expanded surface of canals lined with mucous membrane, as in the windpipe, the alimentary canal, the urinary and generative parts, they frequently assume the shape of the tubes, and produce solid cylinders, which have the form of the canal itself, as if formed by it, and are frequently thrown off.

(1) Wendelstedt D. de cognatione et differentia inter inflammationem et profuvia. Marburg, 1809.

(2) In acute dropsy.

(3) Weislircher D. de similitudine, quæ plurimas inter hæmorrhagias naturales verasque inflammationes intercedit, harumque natura et sede. Hal. 1771. v. Weiz N. Auszüge. Vol. IV. p. 115.

(4) Dowler, On the products of acute inflammation, in Med. Chir. Trans. Vol. XII. p. 86 .

(5) John IHunter On the Blood, Inflammation, and Gun-shot Wounds

(6) That is called cellular, and is furnished with vessels which are partly new, partly elongations from the original neighbouring vessels. Whether they possess also nervous fibres, is undecided. Upon the accidental formation of vessels in pseudo membranes, v. Berard $\mathrm{D}$. sur plusieurs points d'anatomie pathologique. No. 4. Paris, 1826.

(7) Portal Mémoires sur la nature et le traitement de plusieures maladies. 8vo. Paris, 1800. Vol. III. and in Mémoires de l'Irstitut. Nat. de France, 1807, Vol. VIII. Part II. p. 67. - Clarus Progr. de partibus pseudorganicis. etc. Lips. 1805. - Nepple D. sur les fausses membranes et les adliérences. Paris, 1812.-Villermé Essai sur les fausses membranes. 4to. Paris, 1814.Cruveilhier Transformations et productions lamineuses in essai sur l'anatomie pathologique. Vol. I. p. 14.2, with plates.-On the cliemical composition of these nembranes, v. Lassaigne in the Journal de Chimie Med. Part I. p. 68._Junge D. de pseudo-plasmatum in c. l. obviorum natura et indole. 4to. Erlangen, 1822.

(8) Compare above, $\S 31$.

\section{$\S 56$.}

The secretion of fibrous matter is also the means which nature employs in the REUNION, reunio, of the divided parts of bodies, as well as for the RESTORATION, reproductio, of parts destroyed by injuries, tumours, and gangrene. ${ }^{1}$ In the former, 
the fluid fibrous matter of the blood is poured out as a thin layer between the wounded surfaces, at first glues them together, by ADHESION or per primam intentionem, and subsequently heals them, when the exuded layer becomes organized and contains new blood-vessels, which open into the vessels of the wounded surfaces; in a similar way also can soft and hard parts, which have been completely separated from the body, and even a part of a foreign organism, be made to adhere. In cases of restoration there may also be formed on the wound, from the effused fibrous matter, little, soft, reddish, and cornlike congelations, called GRANULATIONS or FLESHY FUNGUSES, ${ }^{2}$ which run together with the adjoining membrane into a kind of skin, are converted into cellular tissue, possess many fine blood-vessels, and whilst recent, continue to produce fleshy substances uniting in layers, until the cavity is filled up and the divided parts are united, upon which, then, finally a new skin is produced; this at first is very vascular and red, but gradually becomes white, expanded, often also somewhat thicker, or descends and becomes at the same time tendinous, and is called a SCAR, cicatrix. The granulations may rise too luxuriantly above the surface of the neighbouring parts, and are then very spongy and easily bleed, whence arises their name PROUD FLESII, caro luxurians, fungosa, hypersarcosis.

(1) Tagliacozzi De curtorum elirurgia per insitionem. Tenet. 1597.-Fabre Mém. de l'Acad. de Chir. Vol. IV. p. 74.-Louis p. 106.-Bezcet D. de modo, quo natura solutum reintegr. 4to. J.. B. 1763, in S'mdifort's Thesaur. Diss. Vol. III. p. 149. - Eyting De Consolidatione vulnerum cum deperditione substantiæ. Argent. 1770.-Murray Comm. de reintegratione part. corp. animal. 4ito. Götting. 17S1. - Haeberle Beantwortung de Preisfrage, welche geschnittene und gebauene Wunden sollen durch Vereinigung und welche durch Eiterung. geheilt werden? 8vo. Wien, 1781.-Domeier D. de viribus naturæ medicatricis in reparandis et coadunandis partibus corp. human. abscissis. Gütt. 1784.Hahn D. de regeneratione partium mollium in vulnere. 4to. Gött. 1787.-J. Moore, On the process of nature in the healing of Wounds. Lond. 1789.-White, On the Regeneration of Animal Substances, in Mem. of the Soc. of Mancliester, Vol I.-Hoorn De iis, quæ in partibus membri, præsertim osseis, amputatione vulnerati, notanda sunt. L. B. 1803. - Baronio Degli Innesti animali. 8vo. Milano. 1804.-Eggers Von der Wiedererzengung. Svo. Leipz. 1821.-E. $A$. Carus D. de vi naturæ medicatrice in formandis cicatricibus. Part I. 8vo. Lips, 1822.-Suringar Comm. med. de modo, quo natura versatur in restituendo omni. quod in corp. hum. solutum est. 4to. L. B. 1823. - Wiesmann De coalitu partium a reliquo corpore prorsus disjunctarum Comm. etc. c. tab. æn. 4to. Iips. 1824. - Paul Comm. physiol. chir. de vulneribus sanandis, in certam. liter. præm. ornata. 4to. Götting. 1825. cum duob. tab. æn.-Sulfelder D. de reunione partium corp. hum. elementarium. Svo. Jenæ, 1826.-Fr. Paul Comm. phys. chir. de vulneribus sanandis, etc. 4 to. Göett. 1825, c. duob. tab æn.-[J. C. Carpue, An account of two successful Operations for restoring a lost Nose from the integuments of the forehead, with historical and physiological observations on the nasal operation, including descriptions of the Indian and Italian methods. 4to. Lond. 1816. - C. F'. Graeft De rhinoplastice seu arte curtum uasum ad vivum restituendi comnentatio. Latine edidit J.F.C. Hecker. 4to. Berol. 1818. T.] 
(2) Gerardin Essai sur les phlogoses sarcopée et ostéopée ou l'inflammation considerle dans sus deux seules terminaisons le sarcose et l'ostéose. 4to. Paris, 1 S23.

\section{$\$ 5 \%$.}

Suppuration, suppuratio, pyosis, pyogenia, is the secretion, ${ }^{1}$ produced by inflammation, of a peculiar fluid, viz. MATTER, pus, ${ }^{2}$ a yellowish, bland, pappy or ointment-like substance, which especially consists of many little globules and serum, ${ }^{3}$ and, according to the difference of the organs by which it is secreted, and the characters of the preceding inflammation, presents manifold differences in reference to its consistence, colour and composition. ${ }^{4}$ The pus is often mixed with blood, mucus, mortified and thrown off animal fibres, and contains in consumption even little worms $;^{5}$ should it be very watery, ill coloured, disagreeable, and pungent, it is then called ichor, sanies. Pus can be secreted either from irri-. tated and inflamed surfaces, particularly from mucous membranes, without abrasion or erosion of their surface; or there may exist at the same time with suppuration, a more or less important loss of substance from absorption, viz. ULCERATION, ulceratio. ${ }^{6}$ In the latter case, the pus-secreting. and eroded spot is either open on the external or internal surface of the body, and then called an ULCER, ulcus, ${ }^{7}$ or it is deeply concealed under the investing membranes of the body and of the particular organ itself, forming a cavity filled with matter, an ABSCESS, abscessus, apostema, ${ }^{8}$ which may vary much in size and form, and by the subsequent effusion of fibrous matter, is lined with a smooth mucous-like membrane, still, however, secreting matter. Only in rare cases are such abscesses cured by the absorption of the matter which they contain; more usually they make their way outwards, although sometimes also inwards, break, and allow the matter to escape, till the cavities are filled up by granulation. Should the abscess be situated deeply, and the passages by which the matter proceeds to the surface be narrow, long, and lined with a membrane resembling mucous membrane and secreting lymph, ${ }^{,}$such passages are then called sinuses or fistulas, fistula; and these may also connect two or more abscesses with each other. If the sides of the abscess be destroyed, and various lateral outlets or sinuosities be produced, then the matter is poured into the surrounding cellular tissue; still, however, we sometimes find abscesses without any outlet, particularly if the tissue of the part be very tough, and the inflammation not active. All parts of the body have not the same disposition to suppuration, nor run thereinto with equal quickness after inflammation $;^{10}$ vascular and cellular 
parts, as the mucous membranes, the common integuments, the cellular tissue, the muscles, and the parenchyma of the viscera, suppurate much more easily than the non vascular parts, as cartilage, bones, and the fibrous organs.

(1) Old writers erroneously imagined that pus consisted of a resolution of the fibrous and fluid parts of the animal body.-Morgan Puopoiesis s. Tentamen med. de puris confectione. Edinb. 1763.

(2) Compare Plouquet Repertorium Art. Pus. Salmuth D. de diagnosi puris. Goett. 1783.-Brugmanns D. de Pyogenia, sive mediis, quibus natura utitur in creando pure. Grönig. 1785.-Nicolai Theoret. und prakt. Abhandlung iiber Entziindung und Eiterung. Jena, 1736.-Quesnay Traité de la suppuration. 12mo. Paris, 1770.-Home, On the properties of Pus. 8vo. London, 1789; and also in Plil. Transact. 1819. p. 1-11.-Pearson, on the same. Part II. p. 294317. 1810._Hoffimann D. sententia de suppurationis natura. 8vo. Erlang. 1818.Microscopische Untersuchungen über die Bildung des Eiters von Kallenbrunner in Heusinger's Zeitschrift f. organ. Physik. Vol. I. Part III. p. 314._Fr. Pelgold D. de diagnosi puris. Kil. 1327.-A. Pramann D. de puris indole et genesi. 8 vo. Berol. 1828.-[Andral, Vol. I. p. 388. T.]

(3) On the distinction and difference between pus and mucus, compare Darwin, Experiments establishing a criterion between mucilaginous and purulent matter, Lichfield, 1780._Grasmeyer Abhandlung von dem Eiter, und den Mitteln ihn von allen andern Feuchtigkeiten zu unterscheideri. Svo. Gött. 1790.-Waldmann D. disquisitiones de discrimine inter pus et pituitam. Marburg, 1807.-Rizzetti in Mém. de Turin, Vol. II. and III.-_Rossi and Michelotti, on the same, Vol. III. p. 109.-Brande in Phil. Transact. 1809, p. 373.-v. Pau!a Gruithuisen Naturhist. Untersuchung über den Unterschied zwischen Eiter und Schleim durch das Mikroskop. 4to. München, 1S09, with engr.-Pearson.Klaproth's Chem. Wörterbuch, Vol. II. p. 45, 46.-Goebel in Schweigger u. Meinecke's N. Journ. f. Chemie und Physik. Vol. IV. Part IV. p. 408.-Kock D. de observationibus nonnullis microscopicis sanguinis cursum et inflammationem spectantibus, atque de suppuratione, adjecta analysi puris chemica. 8 vo. Berol. 1825. The best means of distinguishing them is, in my opinion, the microscope.

(4) Daucher D. Momenta circa variam puris indolem in variis corporis hum. partibus suppuratis. Würzburg, 1804.-Callisen's System der neueren Chirurgie. Copenhagen, 1822. p. 559. note.

(5) Rogers in London medic. Journ.

(6) I. Hunter, Inflammatio suppurativa.-A. Cooper, Lectures on the Principles and Practice of Surgery, by Tyrrell.-De Morin D. Considérations générales sur l'erosion. Paris. 1806.

(7) There is great difference in ulcers, according to their seat and specific character; - if an ulcer be not covered, the pus hardens and forms a SCAB, crusta. -B. Bell, A Treatise on the Theory and Management of Ulcers. 8vo. Edinb. 1778. - Bertrandi Theoret. und prakt. Abhandlung von den Geschwüren, aus d. Ital. Svo. Erfurt, 1790.-Weber Allgem. Helkologie, oder nosolog. therapeut. Darstellung der Geschwïre. Berlin, 1792. - Hebenstreit, Zusätze zu Bell's Abhandlung von d. Geschwuiren. Leipzig, 1793._Underwood, Surgical Tracts on Ulcers, \&c. 8vo. 1799.-Rust Helkologie, oder über die Natur, Erkenntniss und Heilung der Geschwüre. 2 vols. 8vo. Wien, 1811. [Andral, Vol. I. p. 189. T.]

(8) Severinus De recondita abscessuum natura. 4to. Francof. 1643, and 4to. Lugd. Batav. 1724. - David Ueber die Eitergeschwülste, u. s. w. in Prix de l'Acad. de Chir. Vol. IV. p. 119. - Clarc Ueber die Eitergeschwülste, aus d. Engl. in d. Samml. f. Wundärzte. Part IV. p. 127-143. N. Samml. Part I. p. 64-88.Du Roi Cogitata quædam de abscessibus. Jenæ, 1798. - Dupuy de Saint-Julie Mémoire sur les A bcès ou Tumeurs purulents en général.-There is great difference in abscesses; the peculiar kinds are Boil, Carbuncle, Lymph-abscess, Pest-boil, \&c.

$$
\text { E } 2
$$


(9) Villermé in Roux' Journ. de Médec. July, 1815, p. 212-261. v. Meckel's Archiv. f. d. Physiol. Vol. II. p. 471. [Andral, Vol. I. p. 252. 'T.]

(10) In many cases the suppuration takes place very quickly; earliest, and even after a few hours, in the mucous membranc.

\section{$\S 58$.}

If the morbid effusion which is consequent on inflammation occur not on the surface of the affected organ but in its interior structure, vicES OF CONSISTENCE, WITII OTHER DISTINCT Changes of texture, and softening as well as hardening, will be easily excited, from this cause as well as from the more active change of substance produced by inflammation. ${ }^{1}$ The softening and Loosening, emollitio, mollities, ${ }^{2}$ of inflamed tissues appears to arise thus: when a considerable quantity of serum is poured out into the parenchyma of a part and loosens it, the hard parts at the same time also are removed by absorption, or their cohesion is diminished. However, it appears that there must be sometimes also an unknown chemical process acting to explain the softening. We observe this softening and loosening occur with and after inflammation in all the systems and parts of animal bodies; it is especially frequent and distinct in the brain, spinal marrow, and spleen; then also in the muco-serous and synovial membranes ; $;^{3}$ but it is not unfrequently observed in the hardest parts, as the tendons, ligaments, aponeuroses, cartilages, the horny substances, and even in the bones. The degree and kind of softening and loosening is in other respects subjected to many varieties, dependent partly on the texture of the organ, partly on the character of the inflammation itself; especially the so called acute inflammations, which cause the softening of the tissue; these may in rare cases be so violent, that the diseased part is resolved into a kind of jelly or pap, in which we cannot observe the least trace of an earlier existing organization.

(1) Compare above, the Eighth Section, on Vices of Consistence, without distinct vice of texture. But it is a question, whether many of these are not produced by morbid irritation and inflammation. This, in my opinion, is by no means doubtful, as relates to watery cancer, noma, and the so-called putrescence of the womb. It is still morc the case as regards softening of the stomach; but it is disputed, as in metastatic abscesses, traces of inflammation are often indistinct both in life and death; notwithstanding that these must necessarily be present, although in a very trifling degree. Gisbert van Beers D. de tenturæ organorum per inflammationem mutatione. Bonnæ, 1825.

(2) Hesse Ueber die Erweichung der Gewebe und Organe des menschl. Körpers. 8vo. Leipzig, 1827.- [ Andral Précis d'Anat. Path. Vol. I. p. 21\%. 'T.]

(3) The relaxation of such membranes, as well as the unusual easy separation of the various membranes from each other; to wit, in the alimentary canal, is one of the most certain signs of existing inflammation. 
In HARDENING, induratio, ${ }^{1}$ the fluid poured into the tissue of the diseased part under inflammation is more or less coagulated, mingled with the normal elementary parts of the organ, and consolidated into a firm mass. The substances effused are fibrous matter, and sometimes also albumen; in proportion as both are coagulated in a greater or less degree, and retain the animal fluid enclosed in them, or have been deprived of it by previous absorption, is the degree of hardening very different, till at length the effused and coagulated substance becomes organized, that is, assumes the character of cellular tissue, forms meshes, plates, fibres, $\&$ c., acquires small blood-vessels, and has now become a permanent part of the tissue. The more often inflammatory irritation recurs in an already hardened part, the greater becomes the degree of induration, which, in itself, also naturally varies, both according to the difference of the usual consistence of the organ attacked, as well as to the difference of the character of the inflammation; thus, especially, if inflammation occur in torpid or debilitated parts, it assumes this termination. Thickening and hardening of a part is also not unfrequently produced by long continued pressure. Should they be membranes which have become thickened and hardened, they remain mostly thick, and become opake, although they had been previously transparent; has a part, in its healthy state, a loose and soft texture, it can be rendered by the hardening as firm and tough as the liver, a vice which, when occurring in the lungs, has been named hepatisatio. ${ }^{2}$ If with hardening already set up in the cellular tissue, we find, accompanying inflammation, an increased flow of blood, and increased redness, this condition is called the RED HARDENING, induratio rubra: ${ }^{3}$ but on the contrary, if the inflammation have entirely subsided, and the quantity of blood and redness in the diseased parts are diminished, owing to the compression and adhesion of the vessels, then such is called WHITE HARDENING, induratio alba. ${ }^{4}$ The latter not unfrequently becomes so exceedingly hard, that the indurated parts assume a true sinewy appearance, nay, even actually run into bone.

(1) IIoernigk D. de induratione partium præmatura. Lips. 1750.-Haller Pr. de induratis corp. hum. partibus. Goett. 1753.-Bayle in Corvisart, etc. Journ. de Médec. s. Edinb. med. and surg. Journ. Vol. II. Part VIII. No. 2,-Wenzel Ueber die Induration und das Geschwür in indurirten Theilen. 8vo. Mainz. 1815. - v. Walther in Graefe's, and v. Walther's Journ. der Chir. Vol. V. Part II. p. 196. [G. Andral, Précis d'Anat. Path. Vol. I. p. 199. T.]

(2) Morgagni De sedib. et caus. morbor. Ep. XXI. 2, 17, 19, 27.

(3) This is, however, divisible, and easily resoluble by suppuration; we com- 
monly observe it in the neighbourhood of ulcers and abscesses, but sometimes also the parenchyma of a whole intestine is affected by it.

(4) To these belong, for example, the callous edges of many ulcers, the so-called cold swelling, the hardening and swelling of the almonds of the uvula from repeated attacks of inflammation, and the hardening in many organs; which, by the old practitioners, were improperly termed scirrhi. This kind of hardening must not be confounded with the equal whitish scirrhous and tubercular hardening.

\section{$\$ 60$.}

Morbid ossification, ossificatio seu osteogenesis preternaturalis, ${ }^{1}$ presents indeed very different degrees of hardening, but in general less than that of the ordinary bones, so that the diseased mass is but in a cartilaginous, (CARTILAGINATIoN,) fibro-cartilaginous or horny-like pliable state. ${ }^{{ }^{*}}$ In other cases the proportion of earth to the animal parts is more favourable, and the morbid growth has the accidental composition, consistence, and, in rarer cases, also the structure of true bones. If the earth be in still greater quantity, the mass more solid, gypsum-like, creaking when cut, and without any trace of organization, we properly call this disease PETRIFAction, petrificatio. ${ }^{2}$ Repeated inflammation, rickets, tubercular disease, syphilis, gout, and all the diseases by which an increased absorption of the earth of bones is produced, or the bony earth is removed, contrary to law, from one part and morbidly deposited in another, must be considered as the principal causes of morbid ossification. A general or local debility of the living power seems always to precede ossification; it therefore occurs at a later period of life, and although it may be found in almost all the systems and parts of animal bodies, yet it occurs most fiequently in the torpid parts of the organism. ${ }^{3}$ A general and uniform penetration of the normal substance of an organ with bony accretion, ${ }^{4}$ or a true conversion of the tissue, rarely occurs; more frequently is the extraneous matter collected merely on single spots, and more loosely connected with the normal tissue, ${ }^{5}$ is then of very different forms, viz. as numerous isolated specks, as drops of cartilàginous and bony substance running as it were out of each other, and coagulated, as larger or smaller thin plates, ${ }^{6}$ or as more roundish, thicker, but often also as angular and unequal pieces, \&c. ${ }^{7}$ We also see not unfrequently in the cavities of the joints, in the mucous bags, in diseased synovial bags, in the vaginal membrane of the testicles, also in the pericardium, in the membranes of the chest and belly, one or several LOose, MOSTLY ROUNDISII CARTILAGES, OI BONY AND STONE-LIKE CONCRETIONS, which in the beginning, always, and also commonly in later years, 
are attached by threads or necks, and seem to be contained in a kind of bag, of which the neck is subsequently ruptured. ${ }^{8}$

(1) Salzmann D. de ossificatione præternaturali. Argent. 1720.-Schacher Pr. observ. circa materiam ossificationis præter naturam factæ. Lips. $1726 . \mathrm{v}$. Haller's Coll. Diss. Part VI. No. 205.-Vater D. de osteogenia naturali et præternaturali. Viteb. 1726. v. Haller's Coll. Diss. Part VI. No. 206.-Vater D. de ossificatione præternaturali. Viteb. 1728,- de Haller, Pr. de ossificatione, ut vocant præternaturali. Gött. 1749, and Element. Physiol. Vol. VIII. Part II. p. 78.-Hoernigk 1. c.-Konigl. Vetenskaps Academiens Handlinger; Vol. XI. p. 12.-Sandifort in Observat. anat. pathol. lib. II I. cap. II. p. 42.-van Heekeren D. de osteogenesi præternaturali. 4to. Lugd. Batav. 1797, with engr.-Penada in Saggio di osservazioni, etc. P. II. p. 36. Padua, 1800.-Meckel Handb. d. pathol. anat. Vol. II. Part II. p. 160. - [L. V. Brugnatelli Litologia Umana, Ossia Ricerche chimiche e mediche sulle Sostanze petrose che si formano in diverse parti del corpo umano, etc. fol. Pavia, 1819. T.]-Cruveilhier, P. II. p. 1.-Gerardin Essai sur les phlogoses sarcopée et osteopée, ou l'inflammation considérée dans ses deux seules terminaisons, la sarcose et l'ostéose. 4to. Paris, 1828. - Rayer in Archives générales de Médecine, March and April, 1823.Concerning the chemical analysis, v. Duncan, jun. in Edinb. med. and surg. Journ. Vol. I. p. 407.-John Chem. Tabellen des Thierreichs. fol. p. 60. Berl. 1814.- - J . B. Boyer De Suppuratione et curatione inflammationis per suppurationem terminandæ. 8vo. Monsp. 1766.-Andral Précis d'Anat. Path. Vol. I. p. 3S8. T.]

(1*) [G.Andral, Précis d'Anat. Pathol. Vol. I. p.275. T.]

(2) The earth which is collected in morbid ossification, is in general phosphate of lime; but in GOUTY concretions, Tophi make an exception to this, as they consist of urate of soda. Tennant first discovered this. v. John, p. 59.Wollaston and Fourcroy confirmed it. Not unfrequently, such earths are poured out in great quantities in the urine, sweat, ulcers, spittle, \&c. We also sometimes find it collected as a whitish thickish pap, as a viscid chalk in the thyroid and bronchial glands, under the inner coat of the arteries, and in other places.

(3) For instance, cartilage, fibrous parts, cellular tissue, serous membranes, glands which have been emaciated or destroyed by disease, arteries, encysted tumours, dead hydaticls, sarcom, even the dead child, with its membranes, if it have been retained for a long time in the mother's womb;-in many instances, this ossification is a fortunate effect of the healing process. It appears, in general, to occur more frequently in the male than in the female organism.

(4) Perhaps only in cartilage and in tendinous parts.

(5) In these cases we are accustomed to distinguish the morbid formations by the names concrementa ossea, lapidca, \&c.; if they lie very lonsely, they form the transition to stones, which have no organic connexion with the body.

(6) Thus it appears most frequently in and between the membranes, and then sometimes produces a kind of hard crust around an organ.

(7) These lie usually in the parenclyma of an organ, and in the loose cellular tissue, although sometimes not far distant from the surface of membranes; for example, of the peritoneum, the pleura, and the inner surface of the dura mater, \&c. and then, by their sharpness and irregularity, irritate the neighbouring organs. Here also belong the very common, and oftentimes very large, fibrocartilaginous tumours in the substance of the womb.

(8) Lacmec in Dict. des Sc. médical, Vol. IV. p. 123.-Cassan in Archiv. général de Médec. May, 1826. - Wardrop in Edinb. med. and surg. Journ. Vol. IX. p. 14. - Fuhrmann D. de tumoribus cysticis humorem synoviæ similem et corpuscula cartilaginea continentibus. Jenæ, 1822. - Compare the several parts in Cruveilhier in Archiv. général de Médec. Jan. 1824.

$\$ 61$.

The most unfavourable termination of inflammation is MORTIFICATION, gangrcena, sphacelus, sideratio, morlificatio, ${ }^{3}$ 
which is the gradual destruction of the vital activity, and the actual death of the affected part. A higher degree of inflammation which puts an end to the living power of an organ, or a moderate, sometimes scarcely perceptible, inflammation connected with a high degree of general or local weakness, are the causes of mortification. ${ }^{2}$ So also do the parts most distant from the heart, as the toes and fingers, and certain parts endowed with little vitality, as the scrotum, the bones and tendinous parts, morbid growths, \&c. run more readily into mortification than others. The condition of the mortified organs is very different according to the degree, the exciting causes, and the character of the disease, as well as the difference of the organic texture. ${ }^{3}$ The transition of inflammation into mortification, or the lower degree of this disease, is called in the strictest sense gangrena, MoIsT, ACUTE, INFLAMmatory, or HOT MORTIFICATION ; ${ }^{4}$ but the highest degree of mortification, or actual destruction of a part, and the mortification which occurs without distinct preceding inflammation, we are accustomed to call sphacelus, DRY, CHRONIC, IDIOPATHIC, and COLD MORTIFICATION. In the former, the red colour of the impeded blood is changed to yellowish brown, the diseased part itself, although at first a red blush had extended over it, becomes purply red, discoloured, lead-coloured, and at last blackish; vesicles rise filled with ichor, and the skin, together with the subjacent parts, becomes more or less deeply discoloured, broken up, and destroyed. In splacelus, on the contrary, the violent inflammatory blush is absent, the diseased part becomes gradually black, shrinks together, and often dries up like a mummy. 'To the latter kind also belongs, sENiLE Mortification, gangrana senilis, gangrana ex senio, melasma, ${ }^{5}$ which especially first attacks the toes and fingers, often extends further, and for the most part seens to be produced by vices of the heart and arteries, especially by the ossification of their smaller branches. We must also notice as particular forms of mortification, CARBUNCLE, BLACK-VESICLE, Or MALIGNANT BUBo, carbunculus, anthrax, pustula maligna, ${ }^{6}$ vespajus, PLAGUE-BUBo, \&c. similar diseases, in which, by endemic, epidemic, or frequently even contagious influence, as mortification of the spleen, and plague, one or many malignant inflammatory swellings are produced on the external and internal parts of men and beasts, birds, and even fish, which run on to mortification; and lastly, the so called WATERY CANCER, noma, cancer aquosus, cheilocace, ${ }^{7}$ a malignant tumour rapidly spreading and running into gangrenous corruption and jelly-like solution, which occurs, especially, on the lips and cheeks of children. 
(1) Compare with reference to Literature, Reuss Repertor. commentat. Vol. XIII. p. 365-383. - Ploucquet Repertor. Art. Gangræna \& Sphacelus. - Maitland D. de gangræna. Edinb. 1775. - [F. Quesnay Traité de la Gangrene. 8vo. Paris, 1749.-.Vic d'Ayr Suite des observations sur les concretions animal, in Hist. de la Soc. Roy. de Méd. 4to. Vol. IV. p. 279. Paris, 1779-98. . T.] - Himly Abhandl. über den Brand der weichen und harten Theile. 8vo. Gött. 1800.-Neumann Abhandl. vom Brande und Heilsmethode desselben. 4to. Wien, 1801.-Leslie D. de gangræna contagiosa. Edinb. 1804.- Johnston D. de gangræna contagiosa nosocomiali. Edinb. 1805. Heffter Doctrinæ de gangræna brevis expositio. Lips. 1807.-Lassus Pathol. chir. Edinb. 1809, Vol. I. - Liesching D. de gangræna. 4.to. Gött. 1811.Thomson, Lectures on Inflammation, \&c. 8vo. Edinb. 1813. - Brugmann Den Hospitalbrand. - J. Delpech Mém sur la complication des Plaies et des Ulcères connue sous le nom de Pourriture d'Hôpital. 8vo. Paris, 1815.-Gerson Ueber den Hospitalbrand, etc. 8vo. Hamb. 1817.- Ericson præs. Akerman Observationes circa gangrænam. 4to. Upsal. 1817.- Hilson D. de gangræna nosocomiali. Edinb. 1818.-Brauer Observat. quædam de gangræna nosocomiali. 4to. Lips. 1820. - Henzschel D. de gangrænæ atque sphaceli natura, indole et curatione. 4to. Lips. 1821. - Gregory D. de gangræna nosocomiali. Edinb, 1822.-Arnold D. de gangræna. Landishut. 8vo. 1823.Hancke Ueber den heissen und kalten Brand, etc. Einladungsprogramm. 8vo. Breslau, 1826. - Renard Ueber hospitalband. Mainz, 1815. - Dussaussoy Dissertation et observations sur la gangrène des hôpitaux, etc. Lyons, 1807.C. P. Hilserberg D. de gangrenâ nosocomiali. Svo. Berol. 1828 .

(2) Old age, scarlet fever, measles, and erysipelas clispose to mortification; so also syphilis, the mercurial disease, the contagion of typhus, \&c. It very commonly arises from burns, or severe cold; fiurther, from the cessation of the circulation in a part; also from ligature, compression, or stoppage of the large blood-vessels; very commonly also from continued pressure of very tight ligatures, from the pressure of a tourniquet in the cure of aneurism ; from continued lying on a part; hence the wounds produced by lying, DEcuBITUS, on the sacrum, edges of the hip bones, the blade bones, and heels, in long continued illness, with great weakness of the living powers. Aneurism of the heart, and large vessels, sometimes cause mortification of the limbs.

$(2 *)$ [An instance of mortification of the cheek, consequent on looping cough in a child, has lately occurred in St. Thomas's Hospital. She died in nineteen days from the commencement of the attack. T.]

(3) For example, soft juicy parts are much more easily destroyed by mortification than hard parts, as tendon, cartilage, and bone; in the latter, this disease is named Necrosis.

(4) Boyer, in his Treatise on Surgical Diseases, Vol. I. improperly calls the mortification, which does not penetrate beyond the skin and subjacent cellular tissue, GANGRÆNA, and that which penetrates deeper into the flesh, and to the bones, SPHACELUS.

(5) Pott Obs. on the mortification of the toes and feet in Chir. Works. 8vo. Vol. III. Lond. 1791.-Cooper, in Phil. Transact. Vol. XXIII. p. 1195 ; Vol. XXIV. p. 1970.-Thomson, p. 537.-Hodgson, Treatise on the diseases of arteries and veins, \&c. p. 65. 8vo. Lond. 1815.-Buuer in der Dresdner Zeitschrift $\mathrm{f}$. Natur-und Heilkunde. Vol. II. Part II.--Weinech D. de gangræna senili. 8vo. Halæ, 1821. I have seen a man, about thirty years of age, who had lost by this disease all his toes and fingers, his ears, and a part of his heels. I have seen this disease sometimes produced by vices of the heart. The mortification which arises, after living on blighted corn, is very similar. v. Dodard in Journ. des Savans. 1676. - Noël in Mém. de l'Academ. des. Sc. 17 10. - [In the Medical Museum, 1763, Vol. I. p. 442, a very interesting history is given, by Dr. Woollaston, of a whole family, who were all affected with mortification of the legs, in consequence, it was believed, of eating bread made with bad corn, (it being then, 1762 , a time of great scarcity;) and also, that the mother and her six children were all affected within three days, and the father in a fortnight after. T.] Langius Descriptio morborum ex esu clavorum secalinorum Campaniæ. Lucern, 
1817.-Pessier in Mém. de la Soc. royal de Médec. Vol. I. and II.-Prescott, On the natural History and medicinal Effects of the Secale cornutum, or Ergot. London, 1S13. See the observations on Raphany. - [Raphany, or Kriebelkrankheit, as the Germans call it, is a disease produced, it is believed, by eating the bastard radislı. T.]

(6) We find in the midst of carbuncle, a viscous mortified core, the skin also covering it is at the beginning, perforated by ulceration like a sieve, and sometimes many holes are formed near each other, like a wasp's nest, whence the term respajus is applied to it. Compare Guidetti and Malvani in Journ. général de Médec. No.294.-Fosbrooke in Ediub. med. and surg. Journ. Jan. 1821. - Kopp gives a good plate of carbuncle in the Jahrb. der Staatsarzneik. Jahrg. VI. 1813, p. 96. -- Very many authors in Ploucquet Repertor. Art. Anthrax. - Callisens System Chirurgix hodiernæ. 2 vols. Svo. Hafn. 1S24. - Hoffmann D. de Anthrace. Svo. Halæ, 1S20. - Hoffmann in Rust's Magazin f. d. ges. Heilk, Vol. XXI. Part I. p. 70. - Erdmann Annales Scholæ clin. Dorpartensis, 181S-20, and in Horn's Archiv f. medic. Erfalır. 1822, Jan. Febr. p. 182.Hoffmann der Milzbrand oder contagiöse Carfunkel der Menschen u. s. w. Svo. Stuttgart, 1827. - Pagliati Sopra un vastissimo Antrace, memoria teoreticopractica. Messina, 1821. - Krahn D. de pustula maligna. Svo. Berol. 1826.IHelbich D. de carbunculo polonico. Berol. 1S27.-L. Schrader Ueber die natur des Milzbrandes der Thiere des Milzbrandcarbunkels bei den Mcnschen, \&c. Svo. Magdeburg, 1S28.-C. F. Schroeder Ueber die schwarze Blatter in Rust's Magazin, Vol. XXIX. Part II. p. 236.

(7) Eyselius D. de nomis. Erf. 1701.-van Swieten Comm. in Boerhav. Aphor. Vol. I. p. $749-766$. Vol. IV. p. 746.-Bierchen Abhandl. von den wahren Kennzeichen des Krebsschadens. Gött. 1775. - de Meza in Act. Reg. Soc. med. Hafn. Vol. II. No. 7.-Thomassen à Thuessink in Geneeskond. Magazyn. Vol. III. Part III. No. 13.-Pittschaft in Hufeland's Journ. d. prakt. Heilk. 1821. Part VI. p. 14. - Kluatsch ib. Jan. and Feb. 1823. - Reimann D. de nomate, etc. Svo. Berol. 1S24.-E. Thompson, On the gangrenous erosion of young children, in Lond. Med. and Phys. Jouru. June, 1827.-A. L. Richter Der Wasserkrebs cler Kinder, a monograph, with two plates. Berl. 1828.

\section{$\S 62$.}

A remarkable consequence of mortification which does not prove mortal, is the separation of THE DEAD PART From THE REST of THE organism. ${ }^{1}$ This is effected by a fresh inflammatory swelling of the living parts, whilst the dead fall together, are distinctly bounded by an ulcerated groove, at first well marked by a white line, and subsequently by elevation of the skin and by suppuration. 'The skin and cellular membrane separate first, next the muscles, nerves, and vessels, the latter of which are found partly plugged by coagulated blood, partly closed by active adhesive inflammation, and therefore no blood escapes - and at last, the tendons and bones also, so that sometimes the whole limb is thrown off spontaneously. ${ }^{2}$ If the bones, cartilages, and tendons, be only partially destroyed, layers of greater or less thickness separate from their surface, EXFOLIATION, exfoliatio, which retain the form of the part; in the soft formations, however, this occurs very seldom, and is only observed in parts composed of several layers or coats. ${ }^{3} \quad$ In rare instances also, cancerous tumours, sarcoms, 
polyps, and other growths, are separated by mortification, and even entirely cured. ${ }^{4}$

(1) Compare $\$ 46$.

(2) Ploucquet Repertor. Art. Necrosis; also Aepli in Hufeland's Journ. d. prakt. Heilk. Vol. XXV. Part III. p. 136. - Springfield Nov. Act. Acad. Nat. Cur. Vol. III. p. 464.-Gignoux in Mem. de l'Acad. Chir. Mém. Vol. V. p. 778. - Pyaloux, Ibid. Vol. II. p. 477. - Butschka in Badischen Annalen f. d. gesammte Heilkunde, Jahrg. II. Part I. p. 110 ; also both legs at the hip joint, - Noel.-Both arms at the elbow joint. v. Mém de Paris, An. 1703. Mém. p. 41. Most frequently the foot at the calf. Two instances of this kind have been given by $A$. Cooper, Principles and practice of Surgery, edited by Tyrrel, Vol. I. p. 216 and 226 ; and another by Bleuland in Genees-natuur-en Huisloud-kundig Kabinet van Voegen van Engelen, Part II.

(3) So also large pieces are lost by mortification, from the mucous membrane of the alimentary canal, or of the urinary organs.

(4) See several instances in Cruveilhier Essai sur l'Anatomie Pathol. Vol. I. p. 127. I have, a short time since, observed a complete spontaneous separation, by mortification, of a large sarcom from the shoulder; after some time, however, it was reproduced.

\section{$\S 63$.}

The last kind of vice of texture, which occurs in consequence of inflammation or a similar state, depending on a greater degree of plasticity, is not, as the already mentioned vices, a morbid change of the normal part of the organism, but the FORMATION OF NEW SUBSTANCES EITHER NOT previously existing aT THIS PARTICULAR SPOT, OR GENERALLY NOT IN THE BODY, which are called SPURIOUS FORMATIONS, pseudoplasmata, pseudorganisationes, ${ }^{1}$ and as they also usually produce local swellings, must be numbered among TUMours, tumores, phymata. ${ }^{2}$ Some of these spurious formations are accurately separated from the normal parts, are of a nonmalignant cliaracter, and with reference to their texture, sometimes in a measure resemble the natural tissue ${ }^{3}$ - others are less defined, have a disposition to seize upon and destroy the neighbouring parts, are at first hard, but gradually soften, are all more or less of a malignant kind, and in their texture have but little resemblance to the natural tissues. To the former kind belong the ENCYSTED SWELLING, to the latter TUBERCLES, SARCOMA, and CANCER, all of which must be here particularly treated of.

(1) v. Clarus, Cruveilhier, Junge, Sect. 55, note 7.-von Olfers de Vegetativis et animatis corporibus in corporibus animatis reperiundis Comment. 8vo. Vol. I. Berolini, 1816. - Casper Zur Lehre von den Afterorganisationen in Horn's Archiv f. med. Erfahr. 1821. Nov. Dec. p. 385.-Heusinger first Bericht von d. königl. anthropotomischen Anstalt zu Würsburg. 4to. 1826. p. 9. ff.Ritgen Pathologie u. Therapie der Afterbildungen. Berl. 1828, and in $v$. Graefe and v. Walther's Journal f. Chir. u. Augenheilk. 1828. Vol. XI. Part I. p. 1. Part II. p. 181-229. Part III. p. 405. - Meyer Untersuchungen über dic Natur parasitischer Geschwïlste im Mensch. Körper, etc. 8vo. Berl. 1828.[Andral, Vol. I. p. 478. T.] 
(2) Reuss Repertor. Comment. Vol. XV. p. 25, ff.-Plouquet Repert. Art. Tumor.-Severinus de recondita abscessum natura. 4to. Francorf. 1613.de Sauvages D. Theoria tumorum. Monsp. 1753. - Astrue Traité des tumeurs et des ulcères, Paris, 1759. translated into German by Rumpelt. Leipz. 1761. with remarks and additions by Hebenstreit. 3 d edit. 1805. 2 Parts.-Bertrandi Abhandl. v. d. chir. Operation. 8vo. Nizza, 1763.-Opere. 8vo. Turin, 1786. Vol. I. II.A bhandl. von den Geschwülsten. deutsch von Spohr. 8vo. with plates. Leipz. 1788. van Gesscher Proeve over de voornaamste langduurige Gezwellen. 8vo. Amst. 1767.-Plenk Novum systema tumorum, etc. 8vo. Vienn. 1767.-J. Bell The principles of Surgery, as they relate to wounds, ulcers, \&c. 4 vols. 8vo. London.-Abernethy, Surg. Observat. \&c. Lond. 1S04.-16. Surgical Observations on tumours and on lumbar abscess. 2 vols. 8vo. London, 1827. - Pelletan in Clinique chirurgicale, etc. Vol. I. Paris, 1810.-Crane, in Edinb. med. and surg. Journ. Vol. IX. p. 409.-Baron, An inquiry illustrating the nature of tuberculated Accretions of serous membranes, and the origin of Tubercles and Tumors in different textures of the body. Svo. London, 1819 .

(3) The resemblance of such spurious formations to healthy parts and tissues of the body, which especially Laennee, in Journ. de Médec. par Corvisart, etc. Vol. IX., Pluviose; and in Dict. des Scienc. médical, Vol. II. p. 46-61.; Fleischmann, in Leichenöffinungen, Erlangen, 1815, p. 111, and many others, have pointed out, is however but little in an anatomical view, as will be seen in the following observations.

\section{$\S 64$.}

The ENCYSTED or BAGLIKE TUMOURs, tumores cystici, tunicati, cystides, lupiae, are equally common spurious formations both in men and animals, originate one or more at a time in almost all parts of the body, in consequence either of a general disposition, or of mechanical causes; still, however, their especial seat is in the cellular membrane beneath the skin. They are composed of an external perfectly closed cyst, which secretes the substances contained within, ${ }^{2}$ and may be of a very different thickness and texture. Sometimes it is extremely thin, and merely resembles condensed cellular tissue; in other cases it is firmer, and has some similarity to serous, ${ }^{3}$ fibrous, or mucous membranes; it may also consist of many layers, has naturally but few and small blood-vessels and often none at all, in which latter case it seems nourished merely by absorption. Usually these encysted tumours lie loosely in the surrounding cellular membrane, although they are sometimes more firmly connected to the neighbouring parts, if by their pressure they have given rise to inflammatory irritation; mostly they present a roundish, smooth, though sometimes also, if lying between unyielding parts, a more compressed form, and an endless variation of size, acquiring a diameter even of several feet, which sometimes remains the same for a long period, at other times increases more or less quickly. They rarely disperse of themselves; if artificially emptied, they soon fill again; should they be only partially removed, they soon attain their former size; sometimes, if they be much irritated, they run into fungous, cancerous destruction; the 
cysts frequently become bony, and then cease to grow. 'The contents of these encysted tumours differ very much; as a general rule, however, they always consist of inorganic, fatty, or lymph-like fluids. If they contain animal fat, they are called LARDY or FATTy TUmours, lipoma, steatoma ${ }^{4}$ if they contain a clearish serous fluid, and the bag itself is no where attached, but loosely enclosed in the tissue of the organ, in the cavities of the body, or in their own more common capsules, they are called HYDATIDS, hydatides $;^{5}$ should the fluids be similar, whilst the sacs are firmly attached, as other encysted tumours, they obtain the name hygroma, tumor serosus, lymphaticus, cystis serosa, hydrops saccatus, \&c. ; if they contain a thicker substance similar to the lubricating fluid of joints, they are called SYNOvial Tumours, tumores synoviales, or ganglia; ${ }^{7}$ finally, if the contents be more or less coagulated and granular, such are called GRANULAR TUMOURS, atheroma, or HONEY-LIKE TUMOURS, meliceris ${ }^{8}$ \&c. We not unfrequently find also besides the substances already mentioned, hairs, ${ }^{9}$ pieces of bone, and teeth ${ }^{10}$ in encysted tumours.

(1) Compare Reus Repertor. Comment. Vol. XV. p. 29. - de Plouqust Repert. Art. Tumor cysticus.-Littre in Mém. de Paris, A. 1709. Hist. p. 22. Lafaye in Mém de la Soc. de Méd. pr. de Montpellier, Vol. XXXII. p. 340.Slevogt D. de tumoribus tunicatis, Jan. 1719. - Salzmann D. de quibusdam tumoribus tunicatis externis, Argent. 1719, in HALIerr Coll. Diss. chir. Vol. V. No. 150.-Fitzgerald D. de tumoribus tunicatis. Monsp. 1733.-Gouraigne D. de tum. tunic. 4to. Monsp. 1733.-Heister D. de. tumor. cyst. singularibus. Helmst. 1744. - Rey Traité de tumeurs encystés. 8vo. Bruxell. 1752.Girard Lupiologie, ou Traité des tumeurs connues sous le nom de loupes. Paris, 1775. - Chopart Essaie sur les loupes, in Prix de l'Acad. de chir. 4to. Vol. IV.Chambon Mémoires sur les loupes. Ib. - Pohl D. de tumorum tunicatorum genesi. Lips. 1778. - Klose D. de tumor. cyst. Duisb. 1790.-Loder D. de tumor. cyst. Jenæ, 1791. - Jacobsen D. de tumor. cystic. 4to. Jenæ, 1792. Abernethy. - Boudet Essaie sur les loupes. 4to. Strasb. 1806.-Akerman, resp. Ekelund D. de tumore cystico. Ups. 1817. - Munch D. s. animadversiones nonnull. de tumor. cyst. etc. Wirceb. 1818, with plates.-A. Cooper and T'ravers, Surgical Essays, in Two Parts.-v. Walther in his and Graefe's Journ. d. Chir. u. Augenh. Vol. IV. Part III. p. 379--399. - Fuhrmann D. s. varior. auctor. observata de tumor. cysticis, etc. Jenæ, 1822.-Schaefer D. quædem de tumor. cyst. 4to. Lips. 1825.-Bricheteau in Dict. des Sc. médic. Art. Kyste. Vol. XXVI. p. 13.-Manfalcon, ib. Art. Lupia. Vol. XXIX. p. 76.-Adam's Opinion, who considers all encysted tumours as inferior animals, as hydatids, v. On the cancerous breast. London, 1801. [E. Bisset, M. D. Observations on lymphatic and encysted tumours, in Medic. Comment. Vol. IX. p. 244.-Andral, Précis, Vol. I. p. 242, \&c.-Thos. Hodglin, M. D. On the anatomical characters of some adventitious structures, in med. chir. Trans. Vol. XV. p. 272. T.] I have seen several in the horse, cattle, dogs. At Alfort, one from a horse weighing fifty pounds; moles, and the swellings on the elbows of horses, are very often encysted; Rignt Ueber die Balgbildung in den Thieren. Recueil de Médec. vetérin. par Girard T. V. April, 1825. p. 169.-Delpech in Chir. clinique de Montpellier, Vol. II. Paris, 1828. (Twenty-third Observation.)

(2) In this respect they differ from the false encysted tumours, which are 
formed by exsudative inflammation around effused fluids, as the blood, and around extraneous substances remaining in the boly, and neither grow nor secrete. I however know one such instance, in which, besides the hard extraneous body, lymph also was contained in such sac. Compare Cruveillier Essaie sur l'Anat pathol. Vol. I. p. 202, ff.

(3) Bichat first observed this in his Anat. Géner. Vol. I. p. 103. Paris, 1801; they, however, always want the principal character of serous membranes, viz. that they are circumscribed within.

(4) These are the most common and the largest of all encysted tumours, and occur especially on the trunk, and on parts which are naturally fat:-frequently is the fat contained within them similar to the common fat of the body; oftentimes, however, it is very different, more like oil or lard; or very hard, being mixed witl adipocire and coagulated albumen. Fatty tumours have always, according to my observations, a cyst, often indeed very delicate; but one kind, which is to be considered more as a disease of the skin, and forms in it sometimes very numerous knots and swellings, appears to have no distinct bag, but is only surrounded by thickened cellular tissue. For example, the cases in Ludwig Hist. pathol. singularis cutis turpitud. fol. witl plates. Lips. 1793 . v. Walther Ueber diè angebornen Fetthautgeschweilste, etc. fol. with plates. Landshut, 1813. -Renard in the Salzb. Med. Chir. Zeit. No. 41, p. 251. 1815. (The case was hereditary.) Concerning the LIPOMATA lying under the skin, which are situated in the subcutaneous mucous bags, v. Schreger de Bursis mucosis subcutaneis. fol. p. 12. Erlang, 1825. - Willudovius s. Remer in Hufeland's Journ. der prakt. Heilk. Sept. 1819. - I have seen also a similar case in a hospital here. Perhaps here also belongs the case related by Alibert, in his Nosologie Naturelle, Vol. I. pl. 17.- Fatty tumours also not unfrequently depend from narrow necks, of which the roots are very deeply imbedded. For instance, Cruveilhier, Vol. I. p. 197.-Kohlrusch Comm. chir. s. exstirpationem steatomatis in pelvis cavitate radicantis. 4to. c. tab. æn. Lips. 1826. I have seen several similar. On fatty tumours, compare the literature in Reuss Repert. Vol. XV. p. 26 and 34. - cle Plouquet Art. Steatoma; and further, the individual parts of the body; there are some novel remarkable instances; in Weidmann Annotatio de steatomatibus additis quinque figuris in ære ductis. 4to. Moguntiaci, 1817. - Brennecke in Allg. med. Annal. Oct. 1811, p.930 (25 Pf.)Roher's Medic. Repository, 1816. Hufeland's Journ. 1816, Part VIII. p. 12, with engravings, - (hanging down from the breast to the knees, and 3 feet 3 inches long.) - B. v. Siebold in Chiron. Vol. J. No. 3, p. 671. - Dorsey in Transact. of the American philos. Soc. Plilad. 1818, new ser. Vol. I. (3 feet 9 inches in circumference, 25lbs.)-Berndt in Rust's Magazin fiir die ges. Heilk. Vol. XIII. Part I, p. 160. (22 lbs.) - Hille in the Dresdner Zeitschr. f. Natur-u. Heilk. Vol. II. Part II. p. 255. - A. Cooper, in med. chir. Transact. Vol. XI. Part II. p. 440. (1 $1 \frac{1}{4}$ yards in circumference, $37 \mathrm{lbs}$.) -Compare Rust's Magaz. Vol. XII. Part I. p. 204. two plates-Klein in Graefe and $v$. Walther Journ. f. Chir. Vol. I. p. 106. Berl. 1820. (3 feet 1 inch long, 27 $\frac{3}{4}$ lbs.) $-P h$. d'Osernyanszky D. s. steatomatis insignis adumbrationem. 4to. c. tab. Regiomonti, 1821, (on the fore arm). - Dagorn Observations chirurg. sur une jeune fille, qui portait sur le tronc huit lompes. 8vo. with plates. Paris, 1822.-Compare Cerutti Pathol. anat. Mus. Vol. I. Part IV. p. 33. Taf. XX-XXIII.Liston, in Edinb. med. and surg. Journ. No. 77, October, 1823. (44길 lbs.)-Portalupi Storia ragionata dell' enorme tumore del Nob. Sign. Luigi Tedeschi, etc. 8vo. Venez. 1823, (52lbs.) -Otto Verzeichniss d. anat. Präparatsammlung zu Breslau 8vo. 1826. No. 2085-2099.

(5) Also DEAD Hydatids, as distinguished from the living, which belong to the intestinal worms; - Akephalocystes of Laemec, Bullet. de la Faculte de Médec. 1805, chap. 10.-These are spheroidal smooth bodies, varying in size from that of a millet seed to an orange, and are especially contained in bags, either singly, or in many thousands; their membranes are white, mostly transparent, entirely deficient of vesscls, more or less thick, consisting at least of two, and often of several layers; their fluid is usually thin and clear, sometimes, however, turbid, and mingled with lymphatic coagulations: they also often contain within them 
little hydatids, which either swim in the fluid, or sprout from the internal surface of the large liydatid. Compare as to Literature, Reuss Repert. Comment. Vol. XIII. p. 480.- de Plouquet Repert. Art. Hydatis, and on the individual parts. Hunter, in Transact. of a Soc. for the improv. of med. and chir. Knowledge. Vol. I. p. 34. London, 1793.-Veit Einige Bemerk. über die Entstehung der Hydatiden, in Reil's Archiv. f. die Physiol. Vol. II. p. 486.-Rudolphi Entozoorum s. verm. intestinal. hist. nat. Amstel. 1808-10, 2 vols. 8vo. in several passages. - Ludersen Dis de hydatidibus. 4to. with a plate. Gött. 1808.-Himly in his and Hufeland's Journ. der prakt. Heillk. Dec. 1809, p. 140. - A. Monro, An Essay upon the Hydatids of the human body. 8vo. Edinb. 1811. - Meckel Handb. d. pathol. Anat. Vol. II. Part II. p. 394. - Fosbroke in Lond. med. Repository, Vol. XXI. No. 122-125. - Baron, an Inquiry, illustr. the nature of tuberculated accretions of serous membranes, \&c. Svo. Lond. 1819.$\boldsymbol{J}$. Carlevarius D. de hydatidum origine et mutationibus successivis. 8vo. Savona, 1825. - Encysted tumours, containing hydatids are often enormously large, particularly in the belly; for some examples of such cysts in the general cellular tissue of the body, v. Reuss and Plouquet. - Janin in Sedillot Recueil period. Vol. XXIII. p. 254.-Bisset in Duncan med. Comment. Dec. I. Vol. IX. p. 244.-Baird, in Edinb. med. and surg. Journ. July, 1821. - Otto Verzeichu. der Bresl. anat. Präparatensammlung. No. 2077 and 2078. They are not unfrequently discharged in various ways,-they also ulcerate. v. ile Plouquet Art. hydatis ex ulcere. - Bisset. - J. Carlevarini D. de hydatidum origine et mutationibus successivis. 8vo. Paris, 1825. - Opinion of the older writers on the origin of dropsy from rupture of hydatids.

(6) Reuss Repertor. Comment. Vol. XIII. p. 547.- de Plouquet Repertor. Art. Hydrops cysticus et hydatidosus.-Salzmann D. de tumoribus quibusdam, serosis externis. Argentor, 1719. - Morgagni De sed. et caus. morbor. Epist. XXXVIII. p. 63, seq.-Cruvcilhier Essay sur l'anat. pathol. Vol. I. p. 256-296.Meckel Hand. der patbol. Anat. Vol. II. Part II. p. 144-15S. They occur most frequently, and are largest in the belly. Compare the several places.

(7) As they are really situated in the neighbourhood of joints and tendons, so are they mostly diseases of the mucous bags (bursæ mucosæ vaginales, vesiculares subcutaneæ). Compare those in Criveillier, Vol. I. p. 296 and 303. Meckel, Vol. VIII. Part II. p. 15.-Fuhrmann D.s. varior. auctor. observata de tumoribus cysticis humorem synoviæ similem et corpuscula cartilaginea continentibus. Jenæ, 1822.

(8) Schnidt D. de atheromate manu curato. Halæ, 1798.-Reuss Repertor. Comment. Vol. XV. p. 33, 34.- de Plmuquet Art. Atheroma et Meliceris. [This secretion is considered by Andral, Vol. I. p. 440, to be merely a variety of Laennec's ' matiere colloïde.' T.]

(9) Generally, in fatty tumours, the hair resembles the normal hair of animals; as wool in sheep, feathers in birds. - de Plouquet Repertor. Art. Pilus in insolitis locis. - Meckel Ueber regelwidrige Haar-und Zahnbildung in the Archiv f. d. Physiol. Vol. I. p. $519 \mathrm{ff}$. and Handb. d. pathol. Anat. Vol. II. Part II. p. 270. - Cruveilhier, Vol. II. p. 166 and 181. - Hoffmann in Ephem. N. C. Dec. II. A. V. p. 433. Ann. VIII.-Wepfer Pæon et Pythag. Ann. XI. p. 53.-Hunter s. Baillie, in Phil. Transact. Vol. LXXIX. p. 77.--Malpighi Opera posth. p. 95. --Ruysch Thes. anat.Vol. VI. Tab. VI. fig. 5 and 6.-Recent Observations are in the American medic. Recorder. Philad. Vol. I. No. 3.A. Cooper and Travers, Surgic. Essays, P. II. - Delpech Précis des maladies reputées chirurg. Vol. III. p.412.-Zethermann in Hufeland's and Hinly's Journ. d. prakt. Heilk. July, 1811, p. 121.-Bricheteau in Journ. compl. du Dict. des Sc. médic. Vol. XV. p. 298.-Denis in Journ. de Méd. Chir. et Pharm. milit. par Biron et Fournier, Vol. II. p. 357. - Tainturier ib. Vol. XI. p. 271. Bobillier ib. p. 273; from a horse; v. Rudolphi's Bemerkungen auf einer Reise u. s. w. Part I. p. 80. Berlin, 1804. - In the Hunterian Museum at London, I saw two encysted tumours completely full of hair, from a cow; also another similar one under the skin of the head in a calf._Otto Seltene Boebacht. Part II. p. 159. -- v. Bresl. Mus., No. 388. - Three steatomes, with feathers from a goose and hen, ib. No. 2096 - 2098. Encysted tumours, witl 
hair, were described in Barlholimus Cent. I. Hist. 100. - Acta Hafn. Vol. II. p. 40.-Mémoir de. l'Acad. 1731, p. 450, Sc.

(10) Meckel. Compare the several places.

\section{$\S 65$.}

Still more common and also more malignant than the encysted, are SCROFUlous TUMOURS, TUBERCLES and LUMPS, scrofula, tubercula, nodi, struma, ${ }^{1}$ a disease which is sometimes congenital, but is especially common in children, though frequent also in manhood, even in later years also under certain forms, and first originates in inflammatory and dyscracic irritation. The essential character of this proteuslike disease is the formation of an inorganized, transparent, crumbling substance, consisting principally of albumen and animal lime, ${ }^{2}$ which, excepting the horny structures, is found deposited in all the systems and parts of the body, often in many of them at once and in great quantity. ${ }^{3}$ The form of the spurious formation produced by the scrofulous disease is very various; commonly indeed it produces on the parenchyma of an organ, more or less numerous, little, roundish, greyish white bodies, which at first are transparent, but gradually become opake; sometimes they are more flat and irregular little excresences, of the same substance however, upon the surface of serous and mucous membranes; whilst, in other instances, the scrofulous matter is deposited in the cellular tissue of very different parts in undefined masses, and then produces a whitish hardening, devoid of vessels, which must not be confounded with that arising from inflammation or scirrhus ; ${ }^{4}$ lastly, we not unfrequently find the scrofulous matter contained in distinct bags $^{5}$ composed of cellular tissue. These various forms of scrofula have this general property, that at first they are small, hard, and contain but little lime, that by degrees they increase very much, usually become soft in the middle, and then contain a yellowish-white, crumbling matter, containing more lime, similar to new cheese. At this period the tubercles and the surrounding cellular tissue usually run on to inflammation ${ }^{6}$ and suppuration $;^{7}$ sometimes, however, the scrofulous matter is removed by absorption, or the diseased structure is as it were destroyed by ossification. Not frequently from scrofula and its complication with other diseases, arise the various Tumours, ${ }^{8}$ which even in certain cases, produce a gradual TRANSITION into SARCOMA and CARSINOMA.

The tubercular disease is very common in animals, particularly in domestic and foreign animals retained in captivity; ${ }^{9}$ thus are the GLANDERS, MALIGNANT TUBERCLE, FARCY, and the melanosis tuberculos of the horse, the GLANDER-LIKE 
DISEASES of sheep and cattle, a kind of MURRAIN among dogs, the TUBERCULAF DISEASES in cattle, horses, and dogs, and other diseases, if they be not the same disease as scrofula, are still more nearly allied to it.

(1) Rcuss Repert. Comment. Vol. XIV. p. $423 \mathrm{ff}$. Vol. XV. p. 45. - de Plouquet Repertor. Art. Scrophula.-Dict. des Science médical. Art. Scrophules.Bayle in Journ. de Méd. Chir. et Pharm. par Corvisart, etc. Vol. VI. p. 3 ; Vol. IX. p. 285, et 427 ; Vol. X. p. 32. - Lambe, Inquiry into the origin, \&c. of Scrofula, Consumption, Cancer, \&c. 8vo. London, 1805. - Robertson D. de Scrophula. Edinb. 1809.-Russel, A treatise on Scrofula. Edinb. 1808.Baume Traité sur le vice Scrophuleux. 8vo. Paris, 1808. - Rogers D. de Scrophula. Edinb. 1810.-Armstrong, Essay on Scrofula, \&c. 8vo. London, 1812. - Newsom D. de Scrophula. Edinb. 1814. - Henning, A critical inquiry into the pathology of Scrofula. 8vo. Lond.1815. - Carmichael, WV. Goodlad, A practical essay on the diseases of the vessels and glands of the absorbent system. 8vo. Lond. 1814. - Le Pelleticr 'Traité complet sur la maladie scrofuleuse et les différents variétés qu'elle peut offrir, etc. 8vo. Paris, 1818.--Baron, An inquiry illustr. the nature of tuberculated accretions of serous membranes, and the origin of Tubercles and Tumours in different textures of the body. 8 vo. Lond. 1819, and Illustrations of the inquiry respecting tuberculous diseases. 8vo. with 5 plates. Lond. 1822. - Farre on Scrofula. 8vo. Lond. 1820.-E. A. Lloyd, A treatise on Scrofula, describing the morbid alterations it produces in the structure of all the different parts of the body, \&c. London, 1821. - Sleyer D. de morbo scrofuloso inprimis adultorum. 4to. Lips. 182 1.-Keddle D. de Scrophula. Edinb. 1821._-Orr D. de Scrophula. Edinb. 1821.-Macher Ueber die Ursachen und das Wesen der Scrofelkrankheit, u. s. w. 8vo. Wien, 1821.-Adelson D. s. casum singularem morbi tuberosi. 4to. with plates. Gütt. 1822. - Home, D. de Scrophula. Edinb. 1823.-Alison, Observations on the pathology of scrofulous Diseases, \&c. Edinb. 1820.-4bercrombie in Transact. of the med. chir. Soc. of Edinb. Vol. I. p. 682,1824 ; v. also Freudenberg D. de tuberculorum in hepate et pulmonibus causis atquæ cura. 4to Bonnæ, 1824, and Laennec De l'auscultation médiate, etc. Vol. I. p. 9. 8 vo. Paris, 1819. - v. Opinions of Morgagni (de sedib. et caus. morbor. lib. III. Epist. XXXVIII. p. 35.) Adam and Baron, that tubercles consist of burst hydatids. - Hartmann D. de tuberculorum præternaturalium natura et origine. Halæ, 1826.- Lombard Essai sur les tubercules. 4to. Paris, 1827.Joln Baron, Delineations of the origin and progress of various changes of structure, Sc. 4to. with plates. London, 1828.-Alison in Transactions of the Med. Chir. Soc. of Edinb. Vol. III. p. 1. 1828.

(2) According to Abercrombie, the secretion of albumen into the glands constitutes the disease, the same substance also produces tubercles in the lungs; but in the belly they contain a mucous-like extractive matter.

(3) I have many times observed in children, also in adults, and in monkeys, that there was scarcely a part free from tubercles.

(4) The peculiar scrofulous matter which can be squeezed out by violent pressure, may be often distinguished with certainty; besides there is wanting the coagulated fibrine and sinewy fibres of inflammatory and scirrhous hardening.

(5) These bags are formed merely of loose cellular tissue compressed together, and are very different from encysted tumours; the thick tough cysts which we sometimes find around scrofulous Vomice in the lungs and scrofulous glands, are produced partly by exsudative inflammation, partly in the latter instance by nothing more than the outer not yet dissolved substance of the organs.

(6) On these points, notice particularly Thompson, Lectures on Inflammation, and Burns, Dissertation on Inflammation, Vol. II. I could never discover vessels in tubercles, but $I$ have very frequently seen them surrounded by a very red and vascular layer of the organ containing them.

(7) Most of the glandular suppurations, the common suppurative consumption of the lungs, and the various kinds of PнTHIsis A в Dominalis belong here.

(8) Stark D. s. scrofulorum naturam præs. steatomatosarum, causu rariori 
adjecto et tabul. æn. illustrato. 4to. Jenæ, 1803. - Hebréard Essai sur les tumeurs scrophuleuses, etc. Sro. Paris, 1803.-Calvert D. de tumoribus scropluulosis. Edlinb. 1804.-Hamilton, Observations on Scrophulous Swellings in Edinb. med. and surg. Journ. Vol. V. p. 363.-Alibert Description des maladies de la peau. p. 22S. (scrophule cancereuse) Pl. 4.S.-Adelson, Vol. I. and II.

(9) Dupuy De l'affection tuberculeuse, vulgairement appellée Morve Pulmonie, Gourme, Farcin, fausse Gourme, Pommelière, Phthisie du singe, du chat, du chien, et des oieaux domestiques. Svo. Paris, 1817. According to him it occurs in the horse, cattle, sheep, swine, monkeys, dogs, cats, rabbits, hares, fowls, turkies; I have found it not merely in these, but also in the lemur, lion, coati mondi, wolf, seal, rat, guinea-pig, deer, roe, antelope, eagle, pheasant, and many domestic birds._- [H. Bürger, Veterinaire Diagnostik, p. 14, 3, 30. fol. Berl. 1830. T.]

\section{$\S 66$.}

A third and very important kind of spurious formation is the FLESHY TUNOUR Or' SARCOM, sarcoma, sarcosis, ${ }^{1}$ which according to the difference of the tissue in which it is seated, the degree of its development, and its complication, assumes a series of various forms and textures, of which the general characters are principally negative, have moreover a near resemblance to flesh, ${ }^{2}$ and a structure consisting of cellular tissue and albuminous-like fluids. Some are as malignant as cancer, with which they have otherwise many resemblances; but all, and even the most favourable of them, must be removed by chemical or mechanical means, in order that they should not become hurtful to the organism; all have a disposition, even though artificially removed, to be reproduced, and a morbid disposition to thcir growth is not, in most instances, to be mistaken. According to their form and consistence, they are now FLESHY EXCRESCENCES, excrescentice carnosa, - now funguses, fungi, or Polyps, polypior SARCOMATOUS SWELLINGS, sarcomata, in the strictest sense, without always being accompanied with definite characters. As vices of the external skin, here belong the various FLESHY EXCRESCENCES, the FIG-LIKE WARTS, condylomata, ${ }^{3}$ the common FLESHY GrowTIS on the nose and generative organs, \&c.; as vices of the mucous membrane, the epulis and POLYPS; in the bony system osteosarcom; in the fibrous organs, runguses, fungi; in the vascular system, the FLESHY GROWTHS ON THE: INTERIOR OF THF IIEART AND OF THE BLOOD-VESSELS, but particularly in the loose and parenchymatous cellular tissue, the TRUE SARCOM. ${ }^{4}$ The latter usually produce tumours of a tolerable size, mostly roundish, although sometimes uneven, hilly, and extending by roots as it were among the neighbouring parts ; always, however, bounded by a fine investing membrane or a layer of cellular tissue, whilst the tissue in which they grow is not connested with them, but only perforated or de- 
stroyed by pressure. Their mass is at first toughish and close, mostly of a greyish red, although sometimes of a darker colour, and consists of much fine and soft cellular tissue, into which a more or less solid albuminous fluid is deposited, either loosely or in little sacs. They are not unfrequently divided into greater or less lobes, by processes of membrane, but are always connected immediately or by a kind of neck; they also contain small or large bags filled with fluid lymph, and may also be accompanied with hydatids and tubercular formations; their blood-vessels are at first few and small. From this firm, and at the same time, quiet state, in which they either do not increase at all, or only after a very long period, often, indeed, remaining so for many years, ${ }^{5}$ they run spontaneously, or, if irritated, into an inflammatory excitement, increase then very quickly, become soft, acquire more bloodvessels, especially veins, and according to their situation take a very different course. Should they be found, indeed, in the intestines, they rarely burst externally, but increase to an astonishingly large size, and destroy by pressure on other organs, and by a peculiar weakening of the living activity; but should they lie under the common integuments, they destroy it by distension, break outwardly, and produce large fungous swellings, bleeding easily, and secreting lymph, which partly mortify and are thro'wn off, but are soon reproduced; lastly, if they have their seat in the tissue beneath the mucous membranes, they first elevate, and then perforating them, form on their open surface similar fungous tumours, which are called poLyPs, polypi ${ }^{6}$ and assume various colour, consistence, and form; the last are usually disposed to form cavities, in which they grow, although by their increased size, they destroy and extend themselves into the surrounding parts. Sarcoms and polyps are very rare in animals, and the former appear to exist but as sarcomatous growths on the testicles of some beasts.

(1) Reuss Repertor. Comment. Vol. XIII. p. 103. Art. Excresc.- de Plouquet Repertor. Art. Sarcoma.-Grashuys Exercitatio medico-chir. de scirrho et carcinomate, in qua etiam fungi et sarcomata pertractantur. 8vo. Amstel. 1741.De Gorter D. d. sarcomate. Harderowyck. 1761.-Bertrandi Opere publ. dai Penchienati e Brugnone. Turin, 1786. p. 189.-Abernethy, Surgical Observations, \&c. London, 1804.-Meckel Handb. d. pathol. Anat. Vol. Il. p. 291. -Among the ancients, observations on sarcoma are mostly treated of under the name of Scirrhus.-Aberncthy divides SARcoma into S. commune, S. vasculosum, S. adiposum, S. pancreaticum, S. mastoideum, S. mammarium, S. tuberculosum, S. medullare, and S. carcinomatosum; of these, I have described the fatty sarcom among encysted tumours, as Lipoma; the tubercular sarcom, at $\S 65$, and the carsinomatous sarcom, at $\S 68$, as cancer. Of the other kinds, the medullary sarcom is only to be distinguished in some degree, although it also corresponds, by its gradual transition, with the common sarcom; but the pancreatic and mammary sarcom of Abernethy liave not the least resemblance F 2 
to the parts to which they are likened, and also gradually run into the usual sarcom. Sometimes all these kinds are found in one tumour. In Abernethy's private museum, at St. Bartholomew's Hospital, London, I could distinguish no particular kinds.

(2) Not of flesh, anatomically speaking, i.e. of muscle, but of flesh generally, soft parts, i.e. muscle, cellular tissue, skin, fat, and vessels together.

(3) Fici, Mariscae, etc. Compare Wernher D. de condylomatibus. Berol. 1826. -B. Vossen D. de condylomatibus venereis. 8vo. Bcrol. 1827.

(4) Besides those which I have recently had the opportunity of mentioning, I have observed and examined three sarcoms as large as the head; two on the thigh bone, the third on the left hip, and all three in males.

(5) One woman I knew who, for more than thirty years after she had a scirrhus removed from her breast, had a sarcom in her thigh, which, under more proper treatment, increased but little, and is still umbroken, although it has already sereral times seemed as if it would break.

(6) Comp. Reuss Art. Excrescentia polyposa. - De Plouquet Art. Polypus.Portal in Mémoire sur la nature et le traitenıent de plusieures maladies. Svo. Vol. III. Paris, 1800.-v. Hecker Annalen der ges. Medicin, etc. Vol. II. Part IV. No. 1.-Eichliorn D. de polypis. Gött. 1804.-A. Monro, On the Anatomy of the Human Gullet, etc. Edinb. 1811.-Meckel, p. 304.-Cruveilhier Essai sur l'anat. pathol. Vol. I. p. 38s.-Polyps are not the loose ends of deeply situated sarcoms, into which they immediately run, as may be easily seen in the womb, as well also as in other parts. For instance, Otto Selt. Beob. Part II. No. 85 , pl. 4, fig. 3 ; very properly may be here compared, Palletta in Exerc. pathol. Cap. I. and II. p. 2 and 9; some polyps with sarcoms; all polyps from mucous membranes originate in the subjacent cellular tissue, or in the periostcum; even subsequently we can trace their firm roots to these parts. The division of polyps into tendinous, fleshy and mucous, arises merely from the situations in which they are observea; if the mucous membrane be perforated, then they usually have only one narrow necklike root, sometimes two; hence they differ from the fungus of the mucous membrane, which consists only of the flocculence and growth of this membrane, and usually has a broad base.

\section{$\$ 6 \%$}

The MEDULLARY SARCOM, sarcoma medullare, ${ }^{1}$ is distinguished from the common sarcom by certain peculiarities of structure and progress, as, according to circumstances, a more or less distinct degeneration; it is, however, more malignant than the common sarcom, usually proceeds more quickly; if removed, it returns more readily; occurs in almost all parts of the body both primarily and secondarily, and especially in youth. From the very onset it is softer than the common sarcom, feels very elastic, and commonly so, as it contains fluids, and consists of a tolerably homogeneous, whitish, and softish mass, at first sight similar to the brain of children, cooked fish-spawn, or clotted cream; it also, at the same time, contains albumen, and is perforated in different directions by soft cellular tissue or membrane, by few, and for the most part, large veins, and frequently by more or less coagulated blood or its fibrine. When it bursts and forms a fungus, it presents inany blood-vessels, especially veins, and secretes a yellowish green lymph; sometimes the fungus separates in 
large pieces. Not unfrequently is the medullary sarcom connected with MELANOSE, in consequence of which, as well as by the addition of the clotted blood, the original white substance of the tumour is coloured, either completely or partially, yellowish, dusky-red, brown, and dusky-black. Sometimes also, medullary sarcom is accompanied with hydatids, ${ }^{2}$ scrofula, ${ }^{3}$ polyps, ${ }^{4}$ osteosarcom, ${ }^{5}$ \&c., and seems to have an indistinct causal relation to these. True medullary sarcom does not appear to exist in animals, for under the terms melanosis tuberculosa, tubercula nigra, charbon, and morilles, of the French, ${ }^{6} \&$ c. especially in horses, the disease is as it were intermediate between tubercles and medullary fungus, whilst particularly upon the vent and about the generative organs, although also on other parts of the body, in the cellular tissue and in the skin, tumours arise which are roundish, gibbous, increase to the size of eggs, penetrate the neighbouring tissues, break also by ulceration, and consist of an external delicate, cellular envelope, and similar internal partitions, into which a fluid, mostly pap-like, but sometimes a clotted and firm mass is effused, which especially consists of fibrous matter, albumen, and black pigment. Sometimes these tumours approximate in character to the encysted, but never are they so malignant as medullary fungus.

(1) Also BLOODY FUNGUS, fungus hamatodes, $f$. medullaris, MEDULLARY FUNGUS, SOFT CANCER, CARCINOMA, spongoid inflammation, burns, FISHSPAWN-LIKE Tumour, Monro's,-Melanosis, Cancer melanoticus of the French, Encéphaloide of Laennec, \&c. There is no difference in the nature of medullary and bloody fungus, both frequently occur in the same tumour, and run imperceptibly into each other; a bloody fungus, if it be removed, returns again as a medullary fungus, and vice versa ; the so-named bloody fungus arises out of medullary fungus, from effusion of fibrous natter and blood into its cellular tissue.* The best writings on medullary sarcom are, Burn's Dissertations on Inflammations, Vol. II. p. 302, spongoid inflamm. - Hey, Practical observations on Surgery. Lond. 1803; fungus lıæmatodes.-Laennec in Bulletin de l'école de Médec, 1800 ; in Dict. des Sc. médic. Art. Anat. pathol. Vol. II. and Art. Encéphaloides, Vol. XII. p. 165.-Wardrop, Observations on fungus hæmatodes, or soft cancer, \&c. Edinb. 1809, witl plates. - Abernethy.-Maunoir Mémoire sur les fongus medullaire, et hematode. 8vo. Paris et Généve. - Breschet in Dict. des Sc. méd. Vo!. XX. p. 126, Art. Fungus hæmatodes, and $i b$. Considérations sur une alteration organique appellee dégénérescence noire, melanose, cancer, melané, etc. 4to. Paris, 1821, with a plate; also in Magendie's Journ. de Phys. expérimentale, Vol. I. No. 4. Oct. 1821. p. 354. - von Walther in his and Graefe's Journ. d. Chir. u. Augenh. Vol. V. Part II. p. 189.-Langenbeck in his N. Biblioth. f. d. Chir. u. Ophthalm. Vol. III. Part IV. No. 4. - Schneider D. de fungo hæmatode. 4to. Berol. 1821, with plates. - T'ruckmüller D. de fungo hæmatode et medullari. 8vo. Landish. 1821. - Wagner D. de fungo medullari. 8vo. Vratisl. 1823.-Redlich D. de fungo medullari. 8vo. Regiomont.-Hasse D. de fungo medullari. 4to. Berol. 1823, with lithographs.-Calliot D. Essai sur l'encéphaloide ou fongus medullaire. Strasb. - Günther Analecta ad anatomiam fungi medullaris. 8vo. Lips. 1824. - v. Ammon Beiträge zur Erkenntniss nd Behaudlung des bis jetzt unheilbar gebliebenen Fungus II EMATODLS. Svo, 
Leipz. 1825, with six lithographs. - Savenko Tentamen pathol. anat. de Mclanosi. 4.to. Petropoli, 1825. - Fawdington, A case of Melanosis, with general ubservations on the Pathology of this interesting disease. 8vo. Lond. 1826, with two plates.$J$. Casper D. de fungo medullari quædam. 8vo. Berol. 1826. - Of the many individual cases, only some more important are here mentioned. - Bidloo Op. omnia Dec. I. Exerc. 8. Dec. II. Exerc. I. Taf I. in the inguinal region.-Cases recorded by Wardrop, Earle, Lawrence, and Langstaff, in Med. chir. Transact. Vol. III. VIII. IX.-Matussiere, v. Giorn. della Soc. med. chir. di Parma, Vol. VI. p. 300, in Journ. de Médec. contin. Vol. XVI. p. 359, on the back.Fine in Sedillot Journ. de Médec. Vol. XLV. p. 34 and 151.-M'Kechnie in Edinb. med. and surg. Journ. Vol. VII. p. 168, 1811.-Briickmann in Horn's Archiv f. med. Erfahr. July, 1811, p. 71, on the face.-Rowen in New England Journ. of Med. and Surg. No. IV. Oct. Boston, 1814, with plates, on the arm.Fanzago in Mémorie sopra alcuni pezzi morbosi. Fasc. I. p. 65. Padov. 1820, pl. 4, on the leg. - M'Clellan in the American medic. Recorder, Vol. V. No. 4. Oct. New-York, 1822, on the neck.-Wedemeyer in Rust's Magazin f. d. ges. Heilk. Vol. XIII. Part 1. on the breast, the arm, and foot.-Gerson and Julius Magazin der ausl. Lit, d. ges. Heilk. Sept. and Oct. 1823, p. 197, on the wrist. - Halliday in Medical Intelligencer, No. 43 and 46, June and Sept. 1823.Rhades in Horn's Archiv f. d. med. Erfahr. Nov. and Dec. 1823, p. 489, on the thigh.-Allan, System of pathol. and operat. Surgery, Vol. I. p. 264, note, on the hip; Archives générales de Médec, Vol. IV. Feb. 1824. - Salomon in Petersburg. vermischte Abhandl. a. d. Gebiete d. Heilkunde, Part III. Leipz. 1825.-Velpeau in Revue médic. franc. et étrang. Vol. I. p. 217 and 343, with plates, in the left armpit.-Nicolai in Rust's Magazin. Vol. XX. Part III. p. 540. Otto Verzeichniss der anat. Präparatensammlung. No. 2102--2106, p. 30. Breslau, 1826.-I have lately observed one case on the shoulder.--Alibert, in his Nosologie naturelle, Vol. I. p. 336, pl. B, gives a good engraving of medullary sircom on the shoulder. - Arnold D. de fungo medullari. Vratisl. 1822.-W. Cullen and R. Carswell on Melanosis, in Edinb. med and surg. Journal, Jan. 1827.-Meyen Untersuchungen über die Natur parasit. Geschwülste im menschl. Körper, insbesond. über den Mark und Blutschwamm. Berl. 1828. - Kastagne D. de fungo medullari. 8vo. Kil. 1828.- O. Zimmermann D. de melanosi. 8 vo. 1828, with plates. - Fr. Kerlisig D. de fungo medullari. Halæ, 1828.

* [According to Andral's account of bloody fungus, or, as it has recently been named, " tissu érectile accidentel," this does not seem to be really the case; in true fungus hæmatodes the little vessels seem to vegetate, (ils semblent comme végéter,) and form tumours supported by cellular tissue; the vessels increase, and produce a structure very closely resembling that of the spleen, the blood is staycd in the little areolas thus produced, and in the veins, with which they freely communicate, and produces, by its variable quantity, rapid change in the consistence, colour and form of the tumour; and, if it burst, severe hæmorrhage occurs. But out of this vascular development there often arise lesions of nutrition and sccretion; and hence we often find, commingled with this vascular base, fibrous, scirrhous, purulent, melanotic and other morbid productions; all of which are generally included under the term fungus hixmatodes. Andral, Vol. I. p. $176-179$. 'T.]

(2) Adlams, Baron, v. Hydatids.

(3) P'allelta Exerc. pathol. etc.-Panizza Annotazioni anat. chir. sul fungo midollare dell' occhio. fol. Pavia, 1821. - Wedemeyer. - F'reudenberg D. de tuberc. in hepate et pulm. causis atque cura. p. 16. Bonna, 1824,-Proulfoot in Elinb. med and surg. Journal, A pril, 1826.-Otto Selt. Beob. Part II. No. 56 .

(4) v. Walther, and myself one case.

(5) M'Clollan and Rhades.

(6) The preparations which I saw in the veterinary cabinet at Alfort were marked Morilles and Poireaux; sometimes the black pigment is also wanting, (compare above, $\S 39$, and the tumours have then a whitish or flesh coloured ap)pearance; this is the case, according to the verbal observation of Godline, especially in mules, and most commonly it occurs in white or grey horses, in rare cases in 
roan, dun, and spotted horses ; v. Henon in Gohicr, p. 328 ; even in dark-coloured horses, v. Flandrin Instruct. et Observat. sur les maladies des animaux domestiques par Chabert, Flandrin et IHuzard. Vol. IV. p. 298. Paris, 1822. Sometimes the disposition thereto seems to be hereditary.-v. Brugnone.-Dietrichs Gestüts-und Züchtungskunde. p. 580. Berlin, 1824. - Besides the horse, it has also been seen in the ass, the mule, dog, rabbit, cat, rat, mouse and white spoonbill; I have also found it in the stag; v. Otto's Verzeichniss der anat. Präparatensammlung zu Breslau, No. 2108; on these tumours, v. Brugnone von der Zucht der Pferde, Esel. u. s. w. a. d. Ital. von Fechner, p. 61. Prag. 1790.Viborg Veterinair-Sellskabets Skrifter. D. II. III. p. 398, 484, under the title TUBercula Nigra ; Gohier in Compte rendu des travaux de l'école rétérinaire de Lyon. 1811, and Mém. et Observat. sur la chir. et la médic. vétérin. Vol. I. Lyon, 1813.-Breschet.-W. Cullen and Rob. Carswell in Transact. of the med. chir. Soc. of Elinb. 1824, Vol. I. No. 13. - Noack Comment. vet. med. de Melanosi cum in hominibus tum in equis obveniente, etc. 4to. Lips. et Paris, 1826 , with three plates.

\section{$\$ 68$.}

There now remains only to treat of the last and most malignant kind of spurious formations, CANCER, scirr/us, carcinoma, or cancer, ${ }^{1}$ a disease which, distinguished at a general, often even at a first glance, and commonly originating in a strong hereditary disposition, occurs usually only in the middle and later stages of life. ${ }^{2}$ It commences with scirrhus, a knob, or large tumour, which is separated from the neighbouring healthy parts $;^{3}$ usually single, and but rarely occurring in many parts at once, distinguished by its hardness, coldness, insensibility, whiteness, and weight, contains few or hardly any red blood-vessels, and presents, as a characteristic symptom, a great quantity of tendinous or cartilaginous fibres or plates, which pass either from the centre in a radiated form to the circumference, or decussate, and lie irregularly upon each other, and contain between them an inorganic jelly-like, albuminous, or half-coagulated fluid, mostly transparent and light coloured, but sometimes also turbid and yellow, or brownish, in greater or less quantity. ${ }^{4}$ Such scirrhus, early or later, runs into an inflammatory state, in consequence of which it relaxes, softens mostly in the centre, becomes more hilly, infects the neighbouring tissue, and often attains a considerable size. It sometimes also contains several large bags full of lymph, has but few arteries, but at its commencement many large varicose veins, is commonly surrounded by much hard yellow fat, and presents in its interior, one or more ulcerated spots; in this state it is called HIDDEN CANCER, cancer occultus. The skin lying over the tumour is gradually connected with it, becomes wrinkled, knotty, discoloured, and even bluish-red, or lead-coloured, and ultimately breaks with effusion of much lymph. Now is the disease called open CANCER, cancer apertus,, 5 and becomes a "malignant ulcer, 
with a hard base and circumference, secretes a very foul and specific copious corroding ichor, has its surrounding edge jagged, destroys the neighbouring parts much more in circumference than in depth, and often produces a growing, easily bleeding fungus, secreting ichor. ${ }^{6}$ Cancer occurs originally only in the external skin, in which case, instead of a true scirrhus, a malignant wart, a cartilaginous callosity, or a hard blackish varix precedes it; in the inner or mucous membrane, particularly in the mouth, throat, stomach, intestines, larynx, and mouth of the womb; next, particularly in the conglomerate, and lastly, very rarely in the lymphatic glands $;^{7}$ but it occurs secondarily in almost all organs. ${ }^{8}$ True cancer is only curable in its first stage, by the total removal of the diseased structure, for the occasional production of a thin spreading skin upon the sore does not bound its malignancy, and the peculiar dryness and scarring of cancer, which is sometimes observed, is not less deadly ; however, a few cancerous tumours have been destroyed and cured by mortification. ${ }^{10}$ Cancer never occurs in animals. ${ }^{11}$

(1) Compare Reuss Repertor. Comment. Art. Carcinoma, Vol. XII. p. 217235; Scirrhus, Vol. XIV.p. 405; Tumor cancrosus, Vol. XV. p. 28 ; Tumor scirrlosus, Vol. XV. p. 43. - de Plouquet Repert Art. Carcinoma et Scirrhus.S. Cooper, First lines of Surgery-Cuncer; also Hill, Cases of Surgery, particularly of Cancer, \&c. 8vo. Edinb. 1772.-Hopkins D. de Scirrho et Carcinomate. Edinb. 1777. - Bierchén introedes-tal om kaerftskaders, skrophuloese och veneriske Svers, etc. Stockh. 1778. - Jaenisch vom Krebs und dessen Heilart. 8vo. Leipz. 1784._Camper Sämmtl. kleine Schriften deutch von Herbell. Vol. III. p. 156. Leipz,_Abernethy._Lacombe Propositions sur le cancer. Paris, 1805.-Ross D. de carcinomate. Edinb. 1805.-Home, Observations on Cancer, connected with histories of the disease. 8vo. London, 1805. - Gillichan D. de carcinomate. Edinb. 1809.-Akerman resp. Toppeiius D. in carcinoma observationes. 4to. Upsal, 1811.-Skipton D. de carcinomate. Edinb. 1814.- Wentzel Ueber die Induration und das Geschwiir an indurirten Theilen. 8vo. Mainz, 1815._Bmmann Ueber den Krebs u.s.w. 8vo. Leipz. 1817.Westring Erafhr. über die Heilung der Krebsgeschwüre. a. d. Schwed. mit Zus. von K. Sprengel. 8vo. Halæ, 1817.-Young, Minutes of cases of Cancer and of cancerous tendency, \&c. Vol. II. Svo. London, 1816-18.-Rouzet Recherches et observations sur le cancer. 8vo. Paris, 1818. - Wolfers D. de scirrho et carcinomate. 8vo. Gött. 1820._Scarpa in Memorie dell' J. R. Istituto del' Regno L mbard. Vol. I1. p. 123-153. Venet. 1821, and Sullo Scirro e sul Cancro Mémorie. 4to. Mailand, 1822. with a plate.-Farre, An Essay on Cancer. London, 1922. - Werneeke D. Nonnulla de cancro. Svo. Berol. 1823. - Roth D. de Scirrho et carcinomate. Svo. Berol. 1823. - v. Walther in his and Graefe's Journal d. Chir. and Augenh. Vol. V. Part II. p. 196. - Rambach D. de scirrho ejusque decursu. Svo. Berol. 1824. - van Wy and Schrage in Handel. van het Genootsch. Servandis Civibus. D. IV. p. 1-207. - Vorstmann V. u. S. Verhandeling over den Kanker. Svo. Utrecht. 1824.-Graham, Observations on Cancer, comprising numerous cases of cancer in the breast, lip, and fitce, Sc. London, 1824.-Velpean Exposition d'un cas remarquable de maladie cancereuse. Svo. Paris, 1825. - Costin in Archives génér. de Médec. June, July, and Aug. 1826. - Boedecler D. de scirrho et carcinonate. Berol. 1826.-Heusinger Erster Bericht von der anthropotom Anstalt zu Würzburg. P. 27-33. 4to. 1826.--[B. Peyrillie, Dissertation on Cancerous Diseases, trans- 
lated from the Latin, with Notes. 8vo. London, 1777.--Ledran Mémoire de plusieurs observations sur le Cancer, in Mém. de l'Acad. Roy. de Chirur. Vol. VII. p. 223.-M. Akenside, Observations on Cancer, in Med. Traus. of Coll. of Phys. Vol. I. p. 45.-C. T. Johnson, Practical Essay on Cancer. 8vo. London, 1810.-Howard, Practical Observations on Cancer. 8vo. Lond. 1811. T.]

(2) Wardrop, p. 176, however, saw it in a boy of twelve years old, and Home in a man of fifteen years.

(3) A kind of cyst is said sometimes to be found surrounding it. I could never see it.

(4) According to the difference of organization of the parts affected with cancer, is the tumour of more or less loose texture, the jelly more abundant, fluid or thicker, and coloured, \&c.; the appearance of the scirrhus also varies somewhat; hence arises the observation, not founded in fact, of scirrlus lardosus, hydatidosus, nodulosus, tuberculosus, \&c. and the opinion of Hunter, Adams, and Baron, that cancer consists of broken-down hydatids. [According to Andral's view, cancer is not a distinct alteration, but only the ulceration, which, after a certain period, occurs in all lesions, either of nutrition or secretion. Vol. I. p. 501 . T.]

(5) It is to be understood that the disease is also so called when it occurs in internal parts.

(6) Himly in his and Hufeland's Journ. der prakt. Heilk. 1809, Part XII. p. 126, once found in a closed cancer a perfectly formed fungus growth. I have twice found similar small ones.

(7) Scarpa denies this; however, Klein, chir. Bemerkungen, 8vo. Stuttg. 1801 , p. 262 ; Home, p. 161 ; Wardrop, p. 175 , note; and von Walther, have seen instances; I have also at this moment an opportunity of seeing such a case in an inguinal gland of an old woman of eighty.

(8) I am very doubtful, if malignant ulcers, badly treated swellings, \&c., are actually converted into cancers; even NOLI ME TANGERE and CANCER SCROTI arC only malignant ulcers, but not true cancer; in secondary cancer several parts are not unfrequently affected at once.

(9) Poutean CEuvres posthumes. Vol. I. p. 164.-Bayle and Cayol in Dict. des Sc. médic. Vol. III. p. 555.-Nicod in Bulletin de la Faculté, etc. No. 1. 1810.

(10) Bayle and Cayol.-Garneri v. Bulletin des Sc. médic. par la Soc. médic. d'Emulation, Dec. 1810 and Sept. 1811.-Richerand Nosographie chirurgic. 2d edit. Part I. p. 387.-Cruveilhier Essai sur l'anat. pathol. Part I. p. 127.

(11) Camper Abhandlung von den Krankheiten, die sowohl den Mensclien als Thieren eigen sind etc.; deutsch von Herbell. 2te Aufl. p. 48. § 7. 8vo. Lingen, 1794. To cancer of the sole in the horse, of the ear in dogs, scirrhus of the cow's udder, this name does not apply. v. Greve Erfahrungen und Beobachtungen über die Krankheiten der Hausthiere, in Vergleich mit den Krankheiten der Menschen, Part II. p. 65. 8vo. Oldenburg, 1821.

\section{ELEVENTH SECTION.}

\section{Of Vices relating to Contents.}

$\S 69$.

The last object of pathological anatomy is the consideration of vicious contents, or the presence of Extraneous SUbSTANCES (corpora peregrinal) WHICH HAVE No ORGANIC 
CONNEXION WITH THE ANIMAL BODY. 'These may be introduced into the body from without, either accidentally or intentionally, or they may be here situated owing to a morbid activity of formation, and an irregular chemical action. Although they are not parts of the animal body, yet we must here treat of them, in so far as they are partly the consequence and the certain sign of a morbid condition existing during life ; partly, and by no means seldom, as they produce very many diseases, as the highest irritation, inflammation, suppuration, tumours, plugging up of canals, mechanical injuries, and even complete destruction of individual parts. But these extraneous bodies are sometimes LIVING, as ANIMALS and PLANTS; sometimes DEAD, as STONES, EARTHS, SALTS, and the VARIOUS SUBSTANCES, partly NATURAL, partly ARTIFICIAL, which have entered into the body.

(1) Reuss Repertor. Comment. Art. Peregrinorum in corpus humanum Ingestio, Remora, Expulsio, Vol. XIV. p. 294-322.-de Plouquet Repertor. Art. Acus, Bufo, Dejectio, Lacerta, Peregrina, Vermes, Vomitus, etc. ; and the several parts below. - Schmidt $\mathrm{D}$. de corporum heterogeneorum in plantis animalibusque genesi. 4.to. Berlin, 1825.

\section{$\S 70$.}

The AnImals, ${ }^{1}$ which we very fiequently find unnaturally situated in and upon animal bodies, are either such as get into them accidentally, but can remain and even support their existence there a long while, or such as, according to their nature, remain in the body for a certain period of their life, hospites, or always, incola, find in it their necessary protection and food, and are, therefore, called PaRASITIC animals, animalia parasitica et entozoa. The following are the principal animals which we meet with in and upon the bodies of men and animals, according to the zoological scale : ${ }^{2}$

I. To the class of amphibia belong here toads, Frogs, and especially SALAMANDERs, which being accidentally swallowed, are discharged alive by vomiting, or going to stool. ${ }^{3}$

II. Of the Mollusca we have sNiILS, cochlea, and slugs, limaces ${ }^{4}$ which, if they have been swallowed fresh, are passed by the mouth and the vent.

III. Among the crustacen there are some which, as they have very soft coverings, live for protection or for other purposes even in the double-valved muscles, viz. in the pinna, and the sea muscle, mytilus, more rarely in the oyster, as it appears, without much inconveniencing the animals in which they are contained; this is particularly the case with the genus pinnolheres, palcemon also, and the young cancer moenas, 
portunis puber, galathea strigosa, \&c. The genus phronima prefers animals of the genera beroe, pyrosoma, and medusa for its habitation; and we find also little crustacea, particularly of the branchiopodous order, in the gills of fishes and mollusca. ${ }^{6}$ Certain crustacea actually live like parasites on other animals, and nourish themselves from their juices; here, too, belong the WHALE LOUSE, cyamus, which is more commonly found in the skin of the cetacea, although met with also in some fishes; the SEA Louse, cymothoa, Fabr. which is found sometimes also under the skin of many fishes and of some other sea animals; the genus bopyrus, the species of which are found at the lateral edges of the shell of the crab kind, palamon; and, lastly, from the entomostracous order we have the calygus, which live on the soft spots in the skin, the palate, ${ }^{8}$ and other parts of fish; the argulus, which is found in the stickleback, gusterosteus, and in the spawn of frogs; the cecrops and dichelestium, which are found on the gills of the tunny and the sturgeon; and, finally, the different kinds of lerncea, ${ }^{9}$ which introduce themselves into the jaws, lips, fins, and other soft parts of many sea and fresh-water fishes. ${ }^{9 *}$

IV. Of the class INSECTA, ${ }^{10}$ there are also some found in the body, either as eggs, larvæ, or perfect insects, which remaining there for a shorter or a longer time, excite often a very considerable degree of inconvenience, and may be got rid of whilst alive. Thus we frequently see insects of very different kinds proceeding out of the ear, the nose, or more commonly from the mouth and vent. For instance, water palmers and WOodLIce, asellus, armadillo, porcellio, MILLIPEDEs, scolopendra, julus, many CHAFERS, COCK-ROACHES, blatta, EARWIGS, forficula, CATERPILlaRs, and especially the MAGOTS or larvæ of dipterous insects, viz. of CRANE-FLIES, tipula, and particularly of fLIEs, musca; the latter occur very commonly in unadhering wounds and in foul ulcers of men and animals. Sometimes insects remain so long and in so great number that we might notice their propagation in the extraneous organism. ${ }^{11}$ Certain insects instinctively and continually deposit their eggs in and upon the bodies of other animals, where their larva may find shelter and food. To these belong the GADFLY kind, cestrus, Lin., of which some, as the ocstrus humanus of America, $\propto$. bovis, also in deer, goats and camels, $\infty$. antilopa, c. tarandi, and $\propto$. cuniculus, in hares and rabbits in America, deposit their eggs beneath the skin by means of their ovipositor, where the larvæ called вотs become developed, and produce large tumours, till they pierce and creep out of the 
skin; but other kinds, as the $\alpha$. ovis, also found in goats, chamois and deer, and the $\propto$. trompe, in rein deer, deposit their eggs in the nostrils, whence the larvæ make their way into the frontal sinuses; lastly, there are some, as the $\propto$. equi, $\propto$. hamorrhoidalis, $\infty$. veterinus, \&c. which deposit their eggs on the skin and lips of horses, whence, by the animal licking itself, they are conveyed into the stomach, to which the larvæ attach themselves, till they pass out by the vent. Hereto also belong many insects which deposit their eggs in other perfect insects, ${ }^{12}$ or in the larvæ of insects, ${ }^{13}$ or in the eggs of insects, ${ }^{14}$ in which the larvæ remain till their perfect development, and partially destroy the internal organs of the animals which they inhabit.

Finally, there are many insects which we call PARASITIC or ANIMAL INSECTS ${ }^{15}$ because they always or generally live upon and in other animals, on the juices of which they feed, and even bury themselves deeply in them. To these belong, first, of the ARACHNID ORDER, the MITES, acarus, holetra of Herm., and indeed the subgenera, gamasus, ${ }^{16}$ cheyletus, uropoda, ${ }^{17}$ sarcoptes, ${ }^{18}$ the Ticks, ixodes, ${ }^{19}$ argus,${ }^{20}$ caris, ${ }^{21}$ leptus,${ }^{22}$ ashlysia, ${ }^{23}$ atoma or trombidium and ocypete ${ }^{24}$ then of the INSECTS, in a more confined sense, of the APTEROUS ORDER, Aptera, the mallophaga, CARnivorous or PELLIVorous INSECTS of Nitzsch, pediculi, Linn., namely, the orders philopterus, ${ }^{25}$ trichodectes, ${ }^{26}$ liotheum, ${ }^{27}$ and gyropus, ${ }^{28}$ and the SUCKING ANIMAL InseCts, as the Louse kind, pediculus, ${ }^{29}$ and FLEA, pulex; $;^{30}$ and then also the double-winged insects, Diptera, the genera carnus, ${ }^{31}$ the FonEST FLY, hippobosca, ${ }^{32}$ nictyribia ${ }^{33}$ and braula ${ }^{34}$

$\dot{V}$. Of the worms or AnNelida, here belong the LEECH kind, hirulo, certain species of which, now and then, are accidentally situated on and in the body, remain there for some time, and give rise to numerous affections $;^{35}$ but others, as the parasites, live upon turtle and fish, ${ }^{36}$ the gordius aquaticus, which has been vomited up $;^{37}$ next the NEREIDs, nereis, which frequently perforate the shells of mollusca $;^{38}$ the nemertes borlasii, a sea-worm, which buries itself with its head in the anomia, and lastly, especially the INTESTINAL WORMs, vermes intestinales,$^{39}$ which live in the interior of men and almost all classes of animals, often increase there spontaneously in very great quantities, although they also often propagate in us, and are more or less hurtful. This order of worms comprehends the following kinds: the THRFAD WORMS, ${ }^{40}$, filaria, which are met with in the cellular membrane, the cavities of the body, and sometimes also in the intestines of men, beasts, birds, 
amphibia, and fishes, and even of insects; trichosoma or capillaria, HAIRY-BODIED WORMS, especially in the alimentary canal of birds ; tricocephalus, HAIRY-HEADED WORMS ${ }^{41}$, in the larger intestines of men and beasts, and also of amphibia; oxyuris, a small kind in the intestinal canal of beasts $;^{42}$ cucullanus, HOODED WORMs, in the intestinal canal and belly of fishes, and perhaps also of some amphibia ; spiropter ${ }^{43}$ in the alimentary canal of man, and in many other parts of vertebral animals, sometimes forming knots of worms; physalopterc, in the alimentary canal of beasts, birds, and amphibia; strongylus ${ }^{44}$ in the intestinal canal, the kidneys, the air-tube, and many other parts in men, and animals of the first four classes; ascaris, ROUND wORM ${ }^{45}$ a very numerous kind which are found, especially in the alimentary canal, from man downwards to insects; ophiostoma, ${ }^{46}$ in the alimentary canal of beasts and fishes; and lastly, liorhynchuss, ${ }^{46 *}$ a little kind found in the alimentary canal of beasts and fishes.

VI. We find many of the class zoophyta living as parasitic in and upon other animals, and one particular order, zooplyyta parasitica, ${ }^{47}$ appear to be formed there. To these belong first, the family acanthocephala, with the peculiar but very numerous kind echinorhynchus, ${ }^{48}$ which by means of their hook-like proboscis pierce into the alimentary canal of beasts, birds, amphibia, and fishes; then the family trematoda, which have openings or sucking points, by which they stick upon other animals, although they cannot perforate them $;{ }^{49}$ these embrace the monostoma kind, which are found in the alimentary canal of a few beasts and amphibia, and of many birds and fishes; the amphistoma, in the alimentary canal of birds, but not so frequently in beasts and amphibia; distoma, ${ }^{50}$ of which very many species are found, especially in birds and fishes, more rarely in beasts and amphibia, one even in crabs, in the most dissimilar parts, although especially in the alimentary canal and the biliary system; pantastoma, in the different organs of certain beasts and a few amphibia; polystoma,${ }^{51}$ in men, some amphibia, and on fish, in various parts; tristoma, Cuv. or phylline, Oken, on the gills and external skin of some fishes; axine of Abildgaard, on the gills of the garpike; cyclocotyla milit, ${ }^{52}$ on the skin of the garpike, and phonicurus varius, or vertumnus tethydicola, ${ }^{53}$ externally on the tethys; further, the family of the BANDSHAPED zoOPHYTES, cestoidea, containing the genera caryophylleus, of which the only species is found in the alimentary canal of many fishes; scolex, also but one species in the alimentary canal and belly of fishes and in the sepia dilopodia; gymnorhyncluss, of which 
a peculiar kind is found in the flesh of the brama raji $;^{54}$ tetrarlynnchus, of which a few species are found in different parts of the sea turtles, fishes, and also of the cuttle fish, which they seem able to perforate; ligula, which kind are found in an imperfect state in the belly of many fishes, but in a more perfect state in the alimentary canal of animals living on fish, viz. in seals and sea-birds, and they are besides remarkable, as they perforate the living fish; $;^{55}$ trianophorus, of which the only species lives in the intestines of many fishes; botricephalus, TAPE WORM, ${ }^{56}$ in the intestines of man, seals, birds, and fishes, and lastly, the tenia, CHAIN wOrm, ${ }^{57}$ a very common kind living in the intestines of men, beasts, birds, amphibia, and fishes. Finally, the family of CYsT worms, cystica, ${ }^{58}$ consisting of the genera anthocephalus, ${ }^{59}$ which is found in some southern fishes; cysticercus, ${ }^{60}$ peculiar to men and beasts; coenurus, in the brain of sheep, antelopes, and cattle, affected with the gid, and echinococcus, ${ }^{61}$ which occurs in men, monkeys, and some of the cloven-footed animals.

(1) v. Baer Beitrïge zur Kenntniss der niedern Thiere in Nov. Act. N. Cur. Vol. XIII. Part II. p. 525. - S. Mitchill in Francis and Beck's New-York medic. and physical Journ.; and compare Redi Osservazioni intorno agli animali viventi che si trovano negli animali viventi. 4to. Firenze, 1684, with plates.-P. S. Pallas Diss. de infestis viventibus intra viventia. 4to. Lugd. Batav. 1760 ; recus. in Eduard Sandifort Thesauri Diss. Vol. I. p. 247. 4to. Roterod.. 1768.-C. A. Rudolphi Entozoorum s. Vermium intestinalium historia naturalis. Vol. II. 8vo. Amstel. 1808-10; also upon insects and other animals. - de Olfers De vegetativis et animatis corporibus in corporibus animatis reperiundis Commentarius. Pars I. 8vo. Berol. 1816. - Virey Mémoire sur les Insectes parasites de l'homme et de divers animaux, ou les entozoaires; in Journ compl. du Dict. des Sc. médic. Vol. XIV. p. 193.-[M. Bloch Traité de la Génération des Vers des Intestins, translated from the German. 8vo. Strasbourg, 1788.Boonaerts De Vermibus crebrioribus intestinorum humanorum. Lovan. 1770.R. Hooper, M. D., Observations on human intestinal Worms, being an attempt at their arrangement, with plates, in $\mathrm{Mem}$. of Med. Soc. of London, Vol. V. p. 224 . T.]

(2) I prefer this, because we do not know indeed, of the many parasites living on aquatic animals, whether they do not live sometimes by themselves, or whether the different species of the same kind, as leeches, support themselves in very different ways.

(3) Passing over the fabulons accounts of moles, cats, mice, chickens, and fish, which have been cngendered in the bodies' of men, and evacuated, there are however observations on amphibia which have been evacuated alive, not to be rejected as valueless, on account of the great tenacity of life in these animals; probably, however, a prudent scepticism with regard to them is very wholesome; but of the batrachial animals there have occurred some instances worthy of credit.-Schenk, in Harless Rhein. Jahrb. fiir Medic. u. Chir. Vol. VIJ. Part III. p. 138, gives a recent instance of a salamander; in the Bresl. Mus. No. 2542 , is found a bufo variabilis, which, according to the evidence of a very circumspect and credible physician, was passed by stool.-Spence, in Edinb. med. and surg. Journ. Vol. IX. (a living salamander by stool.)-On one hundred live lizards, v. Beobaclıt u. Ablandl. von den östreich. $\Lambda$ erzten. Vol. I. p. 155. 1819. [F. R. Zuingeri Lacertus Aquaticus apuella quadam per alvum redditus, in Acta Helvet. Vol. I. p. 22. T'] 
(4) A fresh instance in Rust's Magazin für die ges. Heilkunde, Vol. XIX: Part III. p. 509.-Eyting in Hufeland's Journ. d. prakt. Heilk. April, 1822, p. 16.

(5) For instance, Palcmon pinnophylax mihi. v. Otto Conspectus animalium quorundum maritimorum nondum editor. 4to. Pars I. p. 12. Vratisl. 1821. [Pinnotheres veterum, Mus. Roy. Coll. Surg. No. 293, in the shells of pinnæ and oysters ; P.pisum, No. 294, J. B. in the shells of mytili and modioli. T.]

(6) I have seen these often also in sea fish; viz. once in Blennius Phycis, in the gills of which were attached a great number of animals of the Praniza kind. p. 13, under the word Mesosoma.-Nicotho $\ddot{e}$ astaci in the gills of the lobster, and the female of the Oniscus thoracicus of Montague, under the shell of the Callianassa subterranea.

(7) To wit, Cymothoa bopyroides. v. Lesueur in Bulletin des Sc. par la Soc. philom. p. 4.5. 1814 .

(8) To wit, Caligus minimus on the palate of the Perca Labrax. v. Otto, p. 14.

(9) Although some lernææ are very similar in form to worms, it however seems to me best to include them here, although this remarkable, little known race, may certainly be divided into many genera. [Lernaea pectoralis, Mus. Roy. Coll. Surg. No. 284, from the pectoral fins of a haddock; Dichelestium sturionis, No. 285, from the gills of the sturgeon; Lernaopenua exoceti, No. $285 \mathrm{~A}$, from the back of the flying-fish; $L$. - No. 286, from fin of a diodon? $L$. No. 286 A, from the cornea of the Greenland shark; Lernaca, No. 287, from the margin of the anus of a small squalus; L. Spratti, No. 287 A, and 287 B, from the sprat. T.]

(9*) [Here also may be added of the CiRRIPED $\Lambda$ the following:-Cineras hunteri, Mus. Roy. Coll. Surg. No. 265, on the tail of the hydrophis bicolor; Tubicinella balanarum, No. 279, Mus. Roy. Coll. Surg. in the skin of whales; Coronula diadema, No. 280-282 A, in same ; Balanus glacialis, No. $282 \mathrm{~B}$, on the spine of a dog fish; No. $282 \mathrm{C}$, on the arcturus tuberculatus; Acasta, No. $232 \mathrm{E}$, on a sponge. T.]

(10) Heise D. d. insectorum noxio effectu in corpus humanum. 4to. Halæ, 1757.- $A$. Ascona degl' insetti nocivi all'uomo, alle bestie, all'agricoltura, etc. Milano. 1824.-Rudolphi, Vol. I. p. 131, 161. and 513.-Reuss Repertor. Comment. Vol. I. p. 377, and Vol. XIV.p. 294, ff. and p. 318._-de Plouquet and Virey.Several inapplicable, but one particularly apposite case, is related by Yule, in Edinb. Phil. Journ. No. 25, p. 72, July, 1825. I myself know some authentic cases of the Meloe majalis, caterpillars and fly maggots which were vomited; in reference to the latter, we must make strict inquiry; thus, I have seen fly maggots, said to have been vomited, produced from uncleanliness of the spitting-pot, and similar animals, said to be voided by stool, from the filthiness of a padded closestool. [Observations sur des Chenilles expulsées vivantes de l'estomac et des intestines d'un homme, in Journ. de phys. Vol. IX. p. 230. T.]

(11) Acrel in Nov. Act. Soc. Upsaliensis. Vol. VI. p. 98.-Osiander's Denkwürdigkeiten, Vol. I. Part I. p. 1. Part II. p. 424.-Pickel in Transact. of the Association of Irish Physicians, 1824. Vol. IV. and V. No. 22 and 23 ; above 340 larvæ pupæ, and perfect animals of the Blaps mortisaga, passed by stool, and by vomiting above 700 similar animals, Tenebrio molitor, and thousands of the larvæ of flies. [Larvæ of the Curculio and Scarabaus, discharged by the urethra, frequently for the space of six weeks, W. Henry, Edinb. Med. and Surg. Journ. Vol. VII. p. 146. Similar larvæ were also in one case vomited, and in another passed by stool ; case related by T. Batcman, v. Edinb. Med. and Surg. Journ Vol. VII. p. 41. I have before me specimens of the Dermestes Murinus, both in the larval and perfect state, which were passed per anum. Three hexapod larvæ, voided by stool, v. Jessop in Phil. Trans. Vol. X. p. 391, are considered by Kirby as belonging to the Dermestes, Fab. or Byrrhus, Lin. Probably also those mentioned by Chichester in a case of Hæmatemesis, in Edinb. Med. and Phys. Journ. Vol. VII. p. 326, belonged to this genus, perhaps are D. Lardarius; but his account is very unsatisfactory; he says that many hundreds were vomited and passed per anum. Mention is made in Kirby and Spence's Entomology, Vol. I. 1. 140, of the larva of an insect probably belonging to the Tipulide, which was 
passed by the urethra. In Lempriere, On the diseases of the Army in Jamaica, Vol. II. p. 182, is mentioned the case of a lady who died in consequence of the larvæ of some species of Muscida making their way from the cavity of the nose in which their eggs had been deposited, through the crybriform plate of the ethmoid bune into the brain. There is also a horrible case mentioned in Kirby and Spence, Vol. 1. p. 138, in which a man, who was accustomed to place his superabundant food within his shirt, and next to his skin, having been taken ill and laid down in a field on a very hot day, the meat soon became putrid, flies were attracted to it, and deposited their eggs not only in it, but also in the body of the man himself, who, being found some little time after, was so eaten by the maggots that he died in a few hours. - Elophilus Pendulus, in the larval state, was found in the stomach of a woman. v. Bonnet Luvres d'histoire naturelle et de philosophie, Vol. X. p. 144. Svo. Neufchatel, 1779. 'T.]

(12) To wit, $\boldsymbol{X} \in$ nos and Stylops, under the abdominal plate of wasps, and Andrena; Cleptes coccorum, Fabr. on the coccus kind, Cryptus aphidum, Fabr. on the vine fretters; Conops rafipes in the Bombus lapidarius and terrestris; Conops ferruginea in Apis mellifica.

(13) For instance, in the Diploleparic, Nees, or Ciniptera, Latr., in the larvæ of the gall fly; the genus Foenus in the larvæ of bees; all Ichneumonides in caterpillars and other larvæ; the Musca larvarum in caterpillars.

(14) Some species of the genus Chalcis, and some Ichneumonides gemini.

(15) Redi Esperienze intorno alla generazione degl' Insetti. 4to. Firenze, 1788. 5th edition, lat. Anıstel. 1671, 1686, 1712. - de Géer Mémoires pour servir à l'histuire des Insectes. 7 vols. 4to. Stockh. 1752-78.--Hermann Mémoire aptérologique. fol. Strasb. 1804. - Nitzsch Die Familien und Gattungen der Thierinsecten, insecta epizoica, als Prodromus einer Naturgeschichte derselben, in Germar and Zinken Magazin der Entomologie. Vol. III. p. $261 \mathrm{ff}$.

(16) The G. marginatus in the diseased skin of men, even in the brain and eye-ball; also in swallow's nests; other kinds on mammalia and birds. Here, perhaps, the observations of Bory de St.-Vincent. v. Rapport des trav. de l'Acad. des Sc. pour l'an 1823, p. 42 , with engravings. -- Ib. Sur un nouveau genre d'Acaridiens sorti du corps d'une femme, in Annal. des Sc. naturell. Vol. XV. p. 125. Oct. 1828. [Gammasus gymnoptorum, Mlus. Roy. Coll. Surg. No. 370 B, in a humble-bee; G. coleoptratorum, No. $370 \mathrm{C}$, in a cetonia; Cellularia bassani in cellular tissue of gannet, Montagu, in Wern. Trans. Vol. I. p. 191. T.]

(17) Especially on chafers.

(18) Here Sarcoptes, or Acarus siro, or Scabiei, in the itch pustules of men; also in those of horses, dogs, cats, and on birds, sc. such animals occur.

(19) Especially $I$. ricinus, the dog-tick, and reticulatus, which live upon hair, but commonly bury themselves deeply in the skin of dogs, oxen, horses, and other quadrupeds. I found them also in the hare, even in the tortoise, and sometimes they multiply astonishingly; both occur also on men; also in Norway, I. sanguisugus, in America, I. nigra, in Egypt. I. agypticus. [Ixodes ricinus, No. 373, Mus. Roy. Coll. Surg. in dogs and cattle; I. splendens, No. 373 A, from a tiger, and $373 \mathrm{~B}$, from a tapir; $373 \mathrm{C}$, from the perineum and vulva of a rhinoceros; 374 , from an iguana. T.]

(20) Upon pigeons.

(21) Upon bats.

(22) T'o wit, the Leptus autumnalis, which lives on grass, \&c., and buries itself in the human skin, where it produces painful itching.

(23) Under the wings of the Ditiscus marginalis. v. Indouin in Bullet. des Sc. par la Soc. philom. 1822, p. 12. Drawings in Dict. classique d'histoire nat. Paris, 1822.

(24) The two latter kinds from insects.

(25) Subgenera are Docophorus, Nirmus, Lipeurus and Gonioides, all of which occur as parasitic in hirds.

(26) On mammalia, viz. the dog, cat, sheep, goat, oxen, Sc.

(27) 'The Subgenera are Colpocephalum, Menopon, Trinoton, Eureum, Lamobothrion and Physostomum, entirely in birds.

(28) 'T'wo species of these from Cavia Cobriya. 
(29) In man, the following species occur: - Pedic. capitis, head-louse; Ped. vestimenti, clothes-louse; Ped. tabescentium, Ped. nigritarum and Ped. pubis, crablouse ;--cattle, swine, and deer have also their peculiar lice. In diseased men, lice are seen in the skin in pustules (even in the inner parts?);--often in astonishing quantity, and produce the so-called lousy disease, Phthiriasis v. Plouquet Repert. Art. Phthiriasis.-Hufeland Journ. d. prakt. Heilk. 1813. Part III. p. 122-127. - - Rust in Bremser Ueber lebende Würmer in lebenden Menschen. p. 54, 55. 4to. Wien, 1819.-Alt Comm. de Phthiriasi. 4to. Bonnæ, 1824; with good drawings, and apposite observations.-Sichel D. Historiæ Phthiriasis internæ veræ fragmentum. Berol. 1825. - Harder in Petersb. vermischt. Abhandlungen a. d. Gebiete d. Heilk. Part II. p. 207. Petersb. 1823. - Ib. and Müller in the same. Part III. p. 254. Petersb. 1825, (in gouty persons).According to Kirby, the supposed lice in pustules of the skin are acari, therefore he calls the disease Acariasis. [Pediculi, Mus. Roy. Coll. Surg. No. 375-381, from man, swine, turkey, dove, and crane. T.]

(30) For instance, the conmon flea, Pulex irritans, and the chigoe, Pulex penetrans, which, in America, buries itself deeply in the human skin, and produces very malignant and even fatal consequences; in beasts and birds other kinds, besides the common flea, occur.

(31) Carnus hemapterus, on starlings.

(32) The Subgenera are Ornithomyia on birds; Normomyia, especially on mammalia; Lipoptena upon stags and roes; Melophila, for instance, the sheeptick, M. ovina.

(33) On bats.

(34) The Br. cocca on the honey-bee.

(35) Not unfrequently in the throats of men, in the nostrils of lorses, and on the naked parts of the heads of water-birds.

(36) To wit, $H$. branchiata, $H$. piscium, and $H$. muricata, $H$. sturionis, $H$. hippoglossi, \&c. in the gills of crabs. [Lacretelle in Gazette de Santé, Feb. 1828. Death by suffocation in a soldier who had swallowed a leech in drinking water; it was found in the right ventricle of the larynx. - Vanderbach in Journ. Univ. Hæmatemesis, for fifteen days after swallowing a leech in drinking water; the animal found its way into the pharynx, whence it was then pulled out alive by the patient. T.]

(37) Deglaud in Rec. d. trav. de la Soc. de Lille. 1820, p. 22 . Lille, 1823. p. 166. v. Leveillé in d. Ann. de la Soc. Linn. Paris, May, 1825. p. 132.

(38) They appear to do this by a corroding juice, which dissolves the lime ; in consequence, the mollusca fill up the hole with a peculiar yellow indissoluble animal substance.

(39) Under this head I understand the true intestinal worms, i.e. Rudolphi's Entozoa nematoidea, or Cuvier's Cavitaires, which, according to my opinion, are not to be separated from the Annelida. Concerning the intestinal worms in general, v. Bloch Abhandlung von der Erzeugung der Eingeweidewürmer und den Mitteln wider dieselben. 4to. Berlin, 1782, with ten plates.-Goeze Versuch eincr Naturgeschichte der Eingeweidewürmer thierischer Körper. 4to. Leipz. 1782, with forty-four plates. Erster Nachtrag zur Naturgeschichte der Eingeweidewürmer von Goeze, mit Zus. u. Anmerk. von Zeder. 4to. Leipz. 1800, with six plates. - Zeder Anleitung zur Naturgeschichte der Eingeweidewürmer. 8vo. Bamberg, 1803, with four plates. -- Rudolphi above, and Entozoorum Synopsis cui accedunt Mantissa duplex et Indices locupletissimi. 8vo. Berol. 1819, with three plates. - Bremser Ueber lebende Würmer in Lebenden Menschen u. s. w. 4to. Wien, 1819, with four plates. - $I b$. Icones Helminthum systema Rudolphii entozoologicum illustrantes. fol. Fasc. I-III. Vienn. 1824.-C. Fischer, D. de entozois. 8vo. Viennæ, 1822..-Gerardi de Vos Disqu. med. de entozois humanis in Belgio repertis, \&c. 8vo. Traj. ad Rhen. 1828. - Creplin Observationes de Entozois. P. I. 8vo. Gryphisw. 1825, with plates. - Fr. S. Leukart Versuch einer naturgemässen Eintleilung der Helminthen. 8vo. Heidelb. 1827, and Handb. der Helminthologie in naturhist u. medic. Hinsicht zu Vorlesungen. Heidelb. 1827, with plates. -- J. C. Zenker Parasitæ corp. hum. internæ v. vermes intestinales hominis. Lips, 1827.--C. B. C. Martius 
D. de vermibus in corpore humano. Würceb. 1828. - Creplin Novæ observationes de Entozois. Berol. 1829, with two plates.

(40) In men occur the skin-worm, guinea-worm, \&c. F. medinensis in the tropical regions of Africa and Asia, especially on the feet, often occasioning much inconvenience, bore through the skin, and may then be drawn out. J. Duncan, D. de Filaria medinensi s. Gordio medinensi. Edinb. 1821.Kennedy and Smyttan, v. Gerson and Julius Magazin d. ausl. Lit. d. ges. Heilk. 1825, Sept. and Oct. p. 242. It is doubtful whether it was the Filaria bronchialis or Hamularia lymphatica, which Treutler found in the neighbourhood of the bronchia of a man.-[Filaria, No 167-173, in Mus. Roy. Coll. Surg.; among which $F$.gracilis in a cyst close to the trachea of simia satyrus, between pleura costalis and pulmonalis in sim. capucinus; $\boldsymbol{F}$. papillosa, behind peritoneum and pleura, and in trabhea and globe of the eye in the horse ; $F$. macropi majoris, a doubtful specimen, marked, 'Worms found alive within the capsular ligament of the knee-joint of the kangaroo ;' $F^{\prime}$. apis terrestris, doubtful, in the abdomen of the humble-bee. - Paton, Cases of guinea-worm, with Obs. in Edinb. med. and surg. Journ. Vol. XI. p. 151.-Filaria in the belly of a spider. v. Vicat, in Lond. med. and surg. Journ. Vol. XXX IX. p. 478. T.]

(41) In man the Trichocephalus dispar: other kinds in cattle, sheep, dogs, and swine.-[Trichocephali, No. 173-174, in Mus. Roy. Coll. Surg.-1 T' dispar in cœcum of man, which was 'perforated as it were by a number of pinholes ;' T. depressiusculus? in cœecum of dog and fox. T.]

(42) Bremser here includes also the Oxyuris vermicularis of men, according to Rudolphi an Ascaris; in the horse, Ox. curvula.

(43) It is doubtful whether the Spiroptera hominis is in the human bladder. [There is, however, a specimen of S. hominis, No. 174, Mus. Roy. Coll. Surg. on the bladder of a man; for Lawrence's account of which, v. Med. Chir. Trans. Vol. 1I. p. 382. T.]

(44) In men, the Strnngylus gigas in the urinary organs; the same in many beasts; the Str. armatus is common in horses.- [Strongyli, No. 175-180a, in Mus. Roy. Coll. Surg.-S. armatus, in aneurysms of mesenteric artery in horse and ass; S. gigas, two specimens in man, a third in the racoon, all from the kidneys, rarely in other parts; S. filaria, in bronchi of sheep; S. inflexus, in pulmonary artery of porpes; $S$. minor, from tympanum, custachian tube and venous sinuses of the base of the brain; S.criniformis, from intestines of badger; $S$. vulturis, in a vulture. 'T.]

(45) In men, the Ascaris lumbricoides and vermicularis; the former occurs also in swine, cattle, horses and asses, and was found also in man, in a popliteal aneurysm, as well as in abscesses on the spine. v. Otto Selt. Beob. Part II. p. 41. No. 17.-Velpeau in Archiv. général. de Médec. Vol. VII. March. [Ascarides, No. 181-189, in Mus. Roy. Coll. Surg.-A. lumbricoides, from small intestines of man, and intestines of sus, bos, equus, and asinus; $A$. marginata, from small intestines of dog; $A$. vermicalaris, from large intestines of man; A. spiculigera, from esophagus and proventriculus of cormorant; A. testudinis terrestris, from rectum of land tortoise; $A$. pythonis, doubtful species from stomach of a python; Case of ascarides, found in biliary ducts of a child, in Med. and Phys. Journ. Vol. XV. p. 28. - W. Heberden, Observations on ascarides, in Med. Trans. Coll. Phys. Vol. I. p. 45.-A. lumbricoides? from the cellular tissue of the belly. v. M. Willius in Act. Helvet. Vol. I. p. 73; from the cellular tissue of the arm, D. C. E. Berdot in ib. Vol. VII. p. 177. T.]

(46) A still doubtful kind which occurs in the stomach of men is the Oph. Pouterii, v. H. Cloquet in Nouv. Journ de Méd., Chir. et Pharm. Vol. XIII. Feb.

(46*) [Liorhrynchi, No. 189, in Mus. Roy. Coll. Surg. L. gracilescens, in the stomach of the great seal, in Mus. Roy. Coll. Surg. T.]

(47) That is, Rudolphi's last four orders of intestinal worms, Cuvier's Parenchymateux, and some parasites of this class living on animals; we may divide them into Zoophyta crtozoa and extozoa.

(48) The largest and most cominon kind is the Ech. gigas from tame and wild swine.-Westrumb Comment. de Helminthibus acanthocephalis. fol. Hanov. 1821. 
with three plates. - [Echinorhynchi, No. 190-194, Mus. Roy. Coll. Surg. - E. porrigens, from intestines of whalebone whale; $\boldsymbol{E}$. balanocephalus, two specimens from the intestines of balæna rostratus; $E$. filicollis, two specimens from the intestines of eider duck. T.]

(49) For instance, the Distoma ferox bores itself pits in the intestine. v. Goeze p. 177. pl. 15, fig. 1.-[Distomata, No. 196-202, in Mus. Roy. Coll. Surg.-D. hepaticum, from the liver and gall-bladder of man and sheep; D. variegatum, from gall-bladder of wolf fish; D. lineare, three specimens from the windpipe of the eommon fowl and partridge. This animal is the cause of the disease called the 'gapes' in clicken. D. hydrophidis, doubtful, from the ovarium of the watersnake. T.]

(49*) [Amphistomala, No. 164, -195, Mus. Roy. Coll. Surg.-A. conicum, two specimens from the first stomach of the rein deer; $A$. saletriquetrum, from small intestines, cœcum and colon of beaver. T.]

(50) In man, in the gall-bladder, the Distoma hepaticum; the same in the liver and alimentary canal of many mammalia, viz. the horse, cow, sheep, goat and swine; most commonly in the sheep, the liver of which is thereby very frequently knotted. Some Distomata make the transition to the Trematodoa extozoa, as they are found in the gills of fishes, and externally on the skin. [Fasciola trachea, in chickens and young turkeys.-Wiesentha in Med. and phys. Journ. Vol. II. p. 204; also in young partridges and pheasants, Montagu in Werner. Trans. Vol. I. p. 194-198. T.]

(51) Pol. pinguicola was found by Treutler on a human ovary; the Pol. venarum, which he also found in a burst tibial vein, seems to me only a Planaria; - the $\boldsymbol{P o l}$. duplicatum on the gills of the tunny, on account of its habitat, makes also the transition to the following kinds.

(52) Otto in Nov. Act. Acad. Nat. Cur. Vol. XI. Part II. p. 300, pl. 41, f. 2.

(53) Rudolphi Entozoorum Synopsis, p. 573.-Otto, p. 294. pl. 41, f. 1.

(54) I also found it in three instances of this fish in Nizza and Naples.

(55) Goeze engraves on plate 16, a Ligula, which had bored its way out of the spine of a fish. [Ligula, No. 203, Mus. Roy. Coll. Surg.-L. cyprini, from the abdominal cavity of a carp, perhaps C. Brama. T.]

(55*) [Trianophorus, No. 203a, Mus. Roy. Coll. Surg.-T. nodulosus, from the stomach of the haddock. T.]

(56) In the intestinal canal of man occurs the Bothryorpehalus latus, otherwise called Tania lata, in a remarkable manner, especially only in Switzerland and Russia-now and then in France; in Germany, Holland and England, but very rarely; hardly ever in the dead body. [Bothryocephali, No. 204-206d, Mus. Roy. Coll. Surg.-B. latus, three specimens from intestines of a Swiss girl; B. punctatus, from stomach and intestines of a turbot; $B$. macrocephalus, from stomach of a greenland dove; $B$. pythonis, from intestines of a species of Python. T.]

(57) In man the Tania solium, Lin., which however is also sometimes found not singly, but numerous, especially in Germany, Holland, England and the East; also, though rarely, occurs in spawn; it is then easily distinguished, as it attaches itself to the orifices of the ovaries on the edge of the organ, whilst the Bothryocephalus latus attaches itself to the surface. The head extremity is in both very thin and threadlike; the hinder joints of the $T$. solium, which are often shed singly, and which we formerly erroneously called flat worms; Tanice occur in all our domestic animals, except swine. [Tania, No. 207-222, Mus. Roy. Coll. Surg. - $T$. denticulata, three specimens from the intestines of the genus Bos ; $T$. plicata, from the small intestines of a horse; $T$. perfoliata, from the colon and cœecuni of a horse ; $T$. anthocephala, from the rectum of the great seal ; T. omphalides, from the intestines of the short-tailed field mouse; $T$. pusilla, from the common mouse and rat; $T$. solium, four specimens from the small intestines of man; $T$. marginata, from the intestines of a wolf; $T$. serrata, three specimens from the small intestines of dogs ; $T$. crassicollis, three specimens from the small intestines of a common cat.- $T$. solida of Gmelin, in cellular tissue of gasterosteus aculeatus, v. F. I. Dicl, in Thomson's Annals of Philosophy, Vol. VII. p. 106. T.] 
(58) Called also living hydatids; and it is well to distinguish them from the dead hydatids above described, $\S 64$, to which they form the transition.

(59) H. floriceps, Cuvier's. [Anthocephalus, No. 222a, Mus. Roy. Coll. Surg.$A$. macrourus, from the genus sparus. T.]

(60) In man, in the brain, heart, but especially in the muscles, the Cyst. cellulosa; also in monkeys, and particularly common in swine; in most other domestic animals the Cyst. tenuicollis; in the horse Cyst. fistularis. [Cysticerci, No. $222^{b}-227$, Mus. Roy. Coll. Surg.-C. fasiolaris, two specimens from livers of mouse and rat; C. tenuicollis, three specimens from the pleura and peritoneum of ruminant animals and sow ; C. cellulosus, two specimens in the heart of hog. C. tenuicollis? Mus. Roy. Coll. Surg. No. 593, from the urethra. v. J. C. Letsom, Mem. of Med. Soc. of Lond. Vol. II. p. 32; also F. B. Finney, ib. p. 516. T.]

60* [Conuri, No. 228-229, Mus. Roy. Coll. Surg.-C. cerebralis, two specimens from the brain of giddy sheep. T.]

(61) The species are the Ech. hominis, Ech. simia, and Ech. veterinorum; the latter in swine, sheep, oxen and camels. Upon the Ech. hominis, v. Bremser in Meckel's D. Archiv f. d. Physiol. Vol. VI. p. 292.

\section{$\S 71$.}

The existence of vegetable substances, producta phytoidea, is much more rare and restricted in living animal bodies, than the animals already noticed; and here only belong the formation of MOULD, byssus, and of FUnGUSEs, fungus, which rarely occur in foul wounds, ${ }^{1}$ and on dirty, moist parts of the skin, ${ }^{2}$ and such as are disposed to moisture from lying still, consisting of confervi, oscillatoria, tangæ, spongiæ, tremelli, \&c., which are not unfrequently seen on the old or diseased skins of many animals living in sea or fresh water; for instance, of fish, particularly the carp, of the mollusca, the crustacea, and the water chafers, \&c.

(1) It usually occurs in foul bandages, but sometimes also in the wound itself. I agree with Jaeger, Vol. II. p. 354, and with Rudolphi, in his Grundriss der Physiol. Vol. I. p. 292, 8 vo. Berl. 1821, that we must entirely doubt the assertions as to the production of mould in living animals, respecting which, $v$. Thayer Verschimmelung, Mucedo in lebenden Thiere in Meckel's D. Archiv. f. Physiol. Vol. I. p. 310. - Heusinger De metamorphosi rostri pici et degeneratione mucosis in organismo animali vivente Progr. Jenæ, 1821.-On the growth of vegetables on living animal bodies, v. Mitchill in Silliman's Journ. Vol. XII. No. I. p. 21, March, 1827. - Neue Beobachtungen über Schimmelbildung am lebenden Körper. v. Theile in IHeusinger's Zeitschrift. f. organ. Physik. Vol. I. Part III. p. 331.

(2) For example, after severe corrosive sweat mushrooms upon the vertebræ between the hairs. v. Memoire della Soc. med. di Bologna, Vol. I. p. 350. Harless in his and Hufeland's Journ. d. prakt. Heilk. Nov. 1815, p. 118.

\section{$\S 72$.}

The first and most important kind of DEAD EXTRANEOUs SUBSTANCES found in the animal body, are sTones, calculi, ${ }^{1}$ so named from their hardness, composition, and inorganic form. But the stone Formation, lithiasis, is the product of a morbid mixture of the animal fluids, and of a changed 
dynamic influence of the solid parts containing it; hence in advanced age, and in the male sex, ${ }^{2}$ in which dyscraciae and the production of earth are frequent, it is more common than in young persons and in females; it is also very generally connected with other dyscracic diseases, viz. GOUT, ${ }^{3}$ HEMOR RHOIDs, ${ }^{4}$ so also in children with RICKETS and sCROFUlA; CLIMATE and the MODE OF LIFE also appear to have great influence on the production of stone. Stones very frequently occur in animals, and are found in great quantity in beasts, birds, amphibia, and fishes, and even in invertebral animals $;^{5}$ in animals, however, they vary very considerably with respect to their frequency, inasmuch as they are very common in some kinds, whilst in others they are rarely seen at all. ${ }^{6}$ As to the LOCALITY in which stones are formed, almost all parts of animal bodies seem disposed to this formation, although some parts are more especially so ; thus we observe the stony deposit in the membranous system, in the organs of sense, and in the brain, in all cavities lined with serous membranes, very commonly in the alimentary canal and its adjuncts, as the salivary organs, the tonsils, the liver, \&c., in the organs of respiration, circulation, and generation, but more especially in the urinary organs and the neighbouring parts, where the urine is in a morbid state. Not unfrequently are such stones produced in the body, voided by the natural openings, or by abscesses in very different parts. The number, size, colour, form and hardness of such stones vary without end, partly depending upon the localities in which they are formed; most of them are roundish and tolerably smooth, sometimes, however, they are also rough, angular, beset with points, so that they excite mechanical irritation; in other cases they stop up the canals of the body, or may be prejudicial in many other ways. They are also very different in structure; some consist of a close homogeneous mass, others are as it were chemical deposits, that is, incrustations of extraneous bodies which have remained some time in the organism, and are often hidden in them like kernels, ${ }^{7}$ or frequently as concentric layers: in other instances they assume a more crystallized form, or consist of crystallized and uncrystallized layers alternately. Sometimes the earth and salts of which the stone is usually formed are not compounded into a stone, but are either collected in the body, as sand, dust or small crystals, ${ }^{8}$ or are passed in large quantity with the urine, spittle, perspiration and ulceration, ${ }^{9} \& \mathrm{c}$.

(1) Reuss Repertor. Comment. Art. Calculus, Vol. XII. p. 156-216. - de Plouquet Repertor. Art. Calculus. - Walther's Anatom. Museum. Vol. I. 4to. 
Berlin, 1796, with eugrav. Fourcroy Sur le nombre, la nature et les caractères distinctifs des différens materiaux, qui forment les calculs, les bezoards et les diverses concretions des animaux, in the Annal. du Museum d'hist. natur. Vol. I. p. 93. 1802, with engrav.-Marcet, An Essay on the chemical history and medical treatment of calculous disorders. London, 1817.-Bremmer D. de calculis corporis humani propriis. Edinb. 1818.-Brugnatelli Lithologia umana, ossia ricerche chimiche e mediche sulle sostanze petrose, che si formano in diverse parti del corpo umano, etc. fol. Pavia, 1S19, with engrav.-Henry, On urinary and other morbid concretions in Medic. chir. Transact. Lond. 1819. Vol. X. p. 410; and in 'Thomson's Annals of Philos. Febr. 1820. p. 10. - Voelkel D. de formatione concrementorum calculosorum corp. hum. Svo. Vratislav. 1822. [Prout on the nature and treatment of Gravel, Calculus, \&c. 2d ed. 8vo. Lond. 1825.-C. Scudamore, on the nature and cure of Rheumatism. 8vo. Lond. 1S27.-A. Fourcroy Observations sur les Calcules Urinaires de la vessie de l'homme, in the Mém. de la Soc. Med. de l'Emulation, Vol. II. p. 63. 'T.] Compare above, $\S 60$, and different places. - On ANIMAL STONEs, compare particularly Vicq $d^{\prime} A z y r^{\prime}$ Observations sur les coneretions animales in Hist. et Mém de la Soc. Roy. de Médec. A. 1779. H. p. 204. A. 1780 et 1781. H. p. 279.- - de Lens in Secillot Rec. period. de la Soc. de Médec. de Paris, Vol. XLV. p. 3. - Pelletier fils et Double par Lens, ib. p. 129.-Fourcroy. - Rudolphi Uebersicht der bisher bei den Wirbelthieren gefundenen Steine, in the Abhandl. der Berl. Akademie. p. 171. Berlin, 1816. - Suckow Ueber die steinartigen Concremente der Wirbelthiere, mit bes. Rücksicht auf die Haus-und landwirthschaftlichen Thiere, in the Badischen Annalen für die ges. Heilk. Jahrg. I. Part II. p. 7. with engravings. [Gaitskell, On the intestinal calculi of horses, in Med. Facts and Obs. Vol. IV. p. 31. T.]

(2) Steinmann D. de causis, cur frequentius viri præ fominis calculosi fiant. Argentor. 1750.

(3) Compare de Plouquet Repert. Athritis et Calculus. Heim D. de origine calculi in viis urinariis, quatenus est arthritidis effectus. Halæ, 1772.-Murray D. de cognatione inter arthritidem et calculum. Gött. 1767, in Opusc. med. Vol. I. Gött. 1785. - Forbes, Treatise upon gravel and upon gout, \&rc. Svo. London, 1793. - Wollasion, On gouty and urinary concretions. 8vo. London, 1796. - Moore, On gouty concretions or chalk-stones. Med. chir. Trans. Vol. II. p. 112. - Poth Bestimmung der Gicht und ihr Verhältnis zum Rheumatismus und zu der Steinkrankheit. Svo. Speier, 1825.

(4) Alberti D. de hæmorrhoidum consensu cum calculo et podagra. Halæ, 1720.

(5) To these especially belong the PEAnLs of bivalve muscles, which are formed partly as a growth on the inner surface of the shell, especially after wounds, and also in the flesh of the animal itself; indeed they can be artificially produced by introducing small portions of the muscle shell. Oriental pearls are derived from the Avicula Margaritifera, especially from the Persian Gulf; the German from the MYA MaRgaritifera; they may also be obtained from many other shells, viz. from the Haliotis tuberculata, Mytilus edulis, Anomia Ephippium, Spondylus Gædaropus, Arca Noæ, Anomia Cæpa, Pecten Jacobæus, Barbula plicata, etc. v. Poli 'Testacea utriusque Siciliæ. Vol. I. Introductio. Cap. IV. p. 18.-Floerke Repertorium, Vol. I. Part III. No. 20.-Gray, in Annals of Philosophy, Jan. 1825, p. 27.-Ev. Iome, ib. June, 1826, p. 452. - Stones may be produced even in insects; thus I found a gallstone in a crab, and a stone in the stomach of the Dytiscus Marginatus, in Otto Verzeichniss der anat. Präparatensammlung $\mathrm{zu}$ Breslau. No. 4126 and 4220 .

(6) In vegetable more commonly than in animal feeders; very frequently in the horse; not very rare in the dog; in the cat, as far as I know, it has not been observed, \&c.

(7) Such incrustations appear not merely in the intestinal canal and bladder, but also in the organ of hearing, in the nose, in the salivary ducts, in the airtube, in the vagina, \&re.

(8) I have twice found little crystalline bodies in tumours; for instance, in sarcoms. - Howship's Observations on the healthy and diseased formation of Bone, p. 176; found similar in morbid masses of fat, sea salt in wounds. - v. Angeli Sale 
marino uscito della piaga di un piede, etc. 8vo. Imola, 1819.-v. Nuovi Commentar. Medicina, Juli, 2820.

(9) For instance, in one case, more bone tlian the weight of the whole body. [v. Richter's Spec. Therap. Vol. IV. p. 551. T.]

\section{$\S 73$.}

Lastly, we frequently find, both in men and animals, DEAD EXTRANEOUS SUBSTANCES, WHICH HAVE BEEN INTRODUCED ACCIDENTALLY OR PURPOSELY FROM WITHOUT, either through the natural openings of the body, as the ears, nose, mouth, fundament, and urethra, or by violence, viz. by gunshot, stabs, $\& c$., into other parts of the body. These extraneous substances are of the most varied kinds, viz. bones, fish bones, muscle and crab shells, hair, kernels, nutshells, seeds, ${ }^{1}$ bits of wood, thorns, straw, ears of corn, money, nails, rings, the points of daggers and swords, needles and bullets especially, pieces of tobacco pipe, case knives, forks, pieces of cloth, glass, and a thousand other things. It is remarkable that such bodies will remain for a considerable length of time, indeed even during the whole life, without producing any injury or inconvenience to the person; this is especially the case if a plastic bag has been formed around, so as to isolate them from the rest of the body. ${ }^{2}$ Often are they after a long time coughed up or sneezed out, or if they be in the alimentary canal, are sometimes easily passed by vomiting or by stool. In other instances they produce very serious and even fatal consequences, as the perforation of important parts, inflammation and suppuration, stoppage of the alimentary canal $;^{2 *}$ if in the air-tube, to suffocation or consumption; they give rise, as has been already observed, to stones, of which they form the kernels; bullets, small shot, pieces of cloth, \&c., sticking in deep wounds, prevent union, and irritate the nerves $;^{3}$ bodies capable of swelling, as beans and peas, grow and violently distend narrow parts, as, for instance, the nostril and the auditory, passage, \&c. Frequently, extraneous bodies travel very far in the body, ${ }^{4}$ partly according to the laws of gravitation, partly according to the various motions of the parts, then appear at entirely different parts, often perforate, especially if they be pointed, many parts, and so sometimes get into those canals which open externally, or into the skin, and so become discharged; frequently, also, are they discharged by abscess, ${ }^{5}$ and from bones by exfoliation: such wanderings we have most frequently seen in needles ${ }^{6}$ and ears of corn. ${ }^{7}$

More than once quicksilver, which had been taken or rubbed in as an oxydule or an oxyd, has been observed to recompose itself in the body, and after remaining for a long time, to be 


\section{discharged as pure quicksilver, ${ }^{8}$ through the skin, ${ }^{9}$ or with the urine, ${ }^{10} \& \mathrm{c}$.}

(1) They also penetrate the body through the skin; thus, the very pointed seeds of the STIPA PENNATA and CAPILLATA, which not only in Portugal, Greece, and Barbary, very much annoy the cattle, but in Hungary are fatal to the flocks of sheep. v. Raspail in the Annales des Sc. Naturelles, Sept. 1826. p. 82 .

(2) I have found such many times; for instance, around a needle, around shots. Compare Otto Verzeichniss der anatom. Präparatensammlung zu Breslau, No. 2124 and 2125 ; the first is the sac described by Benedict, around six bits of metal and lead which had been shot in ten years previously. v. Graefe's and Walther's Journ. d. Chir. u. Augenh. Vol. V. Part I. p. 12.- [G. Arnott, a piece of iron which remained encysted in the arm for fourteen years, Med. Chir. Trans. Vol. XIII. p. 281 . T.]

(2*) [A very remarkable instance of a man occasionally swallowing caseknives, which sometimes were vomited up, sometimes passed by stool, related by A. Marcet, in Med. Chir. Trans. Vol. XII. p. 52. Some of these, however, were retained for ten years, and the patient died of the consequent irritation. But it is very remarkable, that although the point of one of the knives retained had passed through the side of the rectum, there was no extravasation of foculent matter into the cavity of the peritoneum. T].

(3) For instance, pain in the face from a piece of porcelain sticking in the integuments during fourteen years. Jeffreys v. Froriep's Notizen, 1823, No. 83, p. 271 .

(4) Remarkable examples of such wanderings are to be seen in Haller, Element. Physiol. Vol. I. p. 15. - Schwed. Abhandl. übers. v. Kaestner, Vol. XXX1V. v. Siebold's Chiron. Vol. I. Part III. No. 9. p. 10.-Doering's Journ. f. d. neuste. Holländ. med. u. naturhist. Lit. Vol. I. Part IV. No. 2. [A needle found in the heart of a sheep, in Mém. de l'Acad. de Dijon, Vol. I. p. 107.Ledran Observations sur des Epingles avallées et trouvés a diverses partres du corps sous la peau, in Mém. de l'Acad. Roy. de Chirurg. Vol. 1II. p. 91. T.]

(5) Many instances in de Plouquet, Art. Apostema; - two pieces of iron forks which were swallowed came out of the belly by ulceration. v. Sonderland in Harless N. Jarhb. d. deutsch. Medic. u. Chir. Vol. VII. Part III. p. 155, with engravings, Vol. X. Part IIJ. p. 127. - A seton needle, which had been stuck into the uterus for the purpose of producing abortion, escaped from the belly by ulceration after seventy-nine days. - Crouzit in Archiv. général. de Médec. Sept. 1823.

(6) Compare de Plouquet, Art. Acus, besides Westring in Kgl. Svenska Vet. Akadem. Handlingar, 1810. Part II. (vomited.) - Hall, ib. (passed by stool.) - Wagner in Rust's Magazin. Vol. XVII. Part III. p. 556, (by vomiting, from the upper eyelid into the neck.) - Bouzel in Hufeland's Journ. d. prakt. Heilk. Nov. 1815 , p. 112, (ncedles which had been swallowed came out at the fect.) - Alibert Nosologie naturelle, Part I. Gen. 2. Heterorexia (1500 needles, which had been swallowed at various times, passed through the skin in the urinary bladder and vagina.) - Biermayer Museum anat. pathol. No. 205, (a needle which had been swallowed, in the psoas muscle.)-Lobstein Compte rendu sur les travaux anatomiques, etc. 8 vo. Strasburg, 1824, p. 42, (swallowed needles in many parts of the belly.-Tourtual in Hufeland's Journ. der prakt. Heilk. Feb. 1823, p. 110, (in the upper arm of a child.)-Villars in Mémoirs de la Soc. des Sc. de Strasbourg, 1823, Vol. II. p. 292, (300 needles and 50 pins, which had been swallowed, were removed by incision; - a second case was fatal.) - Büchner in IIenke's Zeitschr. f, d. Staatsarzneikunde, 1823. Part IV. No. 14, (344 needles.) Diction. des Sc. médical. Vol. VII. p. 65.Duret aus d. Journ. univers. des Sc. médical. in Horn's Archiv f. d. med. Erfahrung, Jan. and Feb. 1825, 1. 173, (ncedles which had been stuck into the skin passed by stool).-Herholdl Observatio de affectibus morbosis Havniensis, cui plurinx acus e varis corporis partibus excisæ et extractx sunt. Havniæ, 1822. Although the needles, as IIcrholdt has subsequently ascertained, were 
purposely introduced, the case is still interesting on account of the length of time they remained under the skin. I have myself seen, in the Friederich Hospital at Copenhagen, in another girl, needles which had been swallowed, cut out of the skin. - $[F$. Bush, a knife lodged in the back above thirty years, 'after which time it excited irritation, and was removéd by excision, in Med. Chir. Trans. Vol. II. p. 102. T.]

(7) Plouquet, Art. A postema. Spica.-Reuss, Vol. XIV. p. 321.-Haller Elem. Phys. Vol. I. p. 15. - Mirandolle van Ghert in v. Siebold's Chiron. Vol. I. Part III. No. X. (escaped after ten years from the chest).-Bottomley in London medic. chir. and Pharm. Repository, March, 1814, Vol. I.-Marikowski in Hufeland's Journ. d. prakt. Heilk. 1821. - Bally in Révue médicale franc. et étrang. Vol. II. April, 1825, (ears of grass which had been swallowed, were thrown out by the lungs and kidneys.) In the Lazaretto of St. Anna, at Brün, I saw an ear of corn which had protruded in the lumbar region. In a person I knew, I saw several portions of barley-corns which had been swallowed, thrown out two years after from the neck.- [A pin, which had been swallowed by a woman, extracted fifteen months after, covered with oxalate of lime, from the urethra. v. J.F. Jones, in Mitchill and Miller's Med. Repos. Vol. V. p. 236. Now-York. T.]

(8) Particularly common on and in the bones, in the cavity of the skull, in the brain, in the cartilages of the larynx, about joints, \&c. Compare Fallopius De morbo gallico, Cap. 76 and 78; Fernelius De luis vener. curat. Cap. 7, lin. 15 ; Fourcroy in Journ. d. Erfindungen. Part XL. p. 92; Autenreith Pliysiologie, Vol. I. p. 265; Otto Selt Beobacht. Part II. p. 36; and many old observations. v. de Plonquet Repert. Art. Mercurius.

(9) Bartholinus Hist. anat. Cent. I. Hist. 7.-- Memoirs of the medic. Soc. of London, Vol. V. 1799.-Brückmann in Horn's Archiv f. d. medic. Erfahr. 1810. Vol. II. Part II. p. 252. - Elll Bericlit über die Ergebnisse im chir. Clinicum $\mathrm{zu}$ Landstrut. 1826.

(10) Hochstetter Observ. med. Dec. III. cas. 4.--Rhodius Cent. III. Obs. 37.-[Dr. Mead also states, that he found pure mercury in a vein. T.] 


\section{S E C O N D, \\ OR \\ P A R T I C U L A R P A R T.}

FIRST BOOK.

OF THE PARTICULAR ORGANS, OR THE ORGANIC SYSTEMS.

\section{TWELFTH SECTION.}

\section{Of Cellular or Mucous Tissue. ${ }^{1}$}

\section{$\S 74$.}

THE quantity of cellular tissue in animal bodies is found sometimes irregularly DIMINisheD, sometimes irregularly INCREASED, according to the variation of individual or morbid formation; the FORMER inasmuch as certain individuals are naturally devoid of cellular tissue, or in which it has either generally or locally WASTED, in consequence of disease or pressure; the LATTER also partly as an individual condition of man or animals, partly as a MORBID GROWTH, since it is not merely the foundation of all spurious formations, as encysted, scrofulous, sarcomatous, and cancerous tumours, as well as the so-called proud flesh, caro luxurians, in wounds, but also supplies, either for a considerable time or permanently, the place of parts which are deficient either as original vices or as the consequence of injuries and diseases. ${ }^{2}$ The cellular tissue is often merely seemingly increased, when it is very much loosened.

(1) Pohl Progr. de morbis contextus cellulosi in genere. Lipsix, 1765.Thierry $\Lambda \mathrm{n}$ in celluloso textu frequentius morbi et morborum mutationes, in Inalleri Coll. Disp. ad morb. hist. etc. Vol. VII. p. 855.--Leipold D. de morbis telæ cellulos $x$. Erlang. 1782.

(2) If the viscera be congenitally deficient, the cellular tissue often occupies their place; viz. in the orbit, in the chest in acephala; in the pelvis, in imperfect or entirely deficient formation of the pelvic organs. 


\section{$\$ 75$.}

Just as variable is the consistence of the cellular tissue. Sometimes we observe as a permanent individual condition, its unusual LAXITY or EXTENSIBILITY, or on the contrary its too great TENACITY and soLIDITY; more frequently the MORBID CHANGE of consistence in the cellular tissue is, especially if it be very loose and moist, abnormally LAX and EXTENSILE, or if it be compressed, and have been deprived by various diseases of its semifluid state, and have been consolidated into fibres and leaves, it is found unnaturally soLID and TOUGH.

\section{$\$ 76$.}

Among the peculiar diseases of the cellular tissue, its very frequent infLAMmation, inflammatio tela cellulose, or common phlogosis ${ }^{1}$ with its consequences, deserves first to be mentioned; this especially attacks the cellular tissue beneath the skin, is often very wide-spreading, and easily runs into large abscesses and sinuses, or even into mortification. ${ }^{2}$ The cellular tissue is very frequently SWOLLEN and HARDENED in consequence of the inflammatory effusion of albuminous and gelatinous fluids into it; to these belong many gouty, scrofulous, and other hard swellings, the thick foot, the often recurring, imperfectly cured erysipelas-the swelling in pellagra, in elephantiasis, the mallenders in horses, \&c.; then the white swelling of the thigh, phlegmasia alba dolens, ${ }^{3}$ a white, chronic, expanded, hot, very painful swelling of the thigh in lying-in women; indeed also in rare cases even in young women ${ }^{4}$ and men, ${ }^{5}$ and also attacking the arms $;{ }^{6}$ and especially that peculiar INDURATION OF THE CELLULAR TISSUE, induratio tela cellulosa, scleremia, scleroma, \&c., ${ }^{7}$ which particularly occurs in new-born children, and results from vices of circulation and respiration; ${ }^{8}$ it is also observed in very rare cases, in later years, even in adults, and only on particular parts of the body. ${ }^{9}$

(1) Compare above, § 52.--Neumann D. de inflammatione telæ mucosæ. Berol. 1820.-Pauli in Rust's Magaz. f. d. ges. Heilk. 1828. Vol. XXVII. p. 127.[A.J.Testa De cellulosæ telæ affectibus, in Rœmer Dissert. Med. Ital. 8vo. note.-D. Craigie, Elem. of gen. and pathol. Anat. p. 33. 8vo. Edinb. 1828. T.]

(2) Many cases of far-spreading diffused inflammation of the cellular tissue consequent on blood-letting, wounds in dissection, \&c. are related by $A$. Duncan, jun. in the Trans. of the Med. chir. Soc. of Edinburgh, Vol. I. 1824, No. 21; and Scott, in the Edinb. Med. Surg. Journ. Vol. XXIV. p. 225. [Also B.Travers, on Constitutional irritation. 8vo. London, 1826, p. 223. T.]--Inflammation of the cellular tissue with sinuses from the foot to the trunk, v. Bailey, in Lond. Med. Repos. March, 1826.-Inflammation and suppuration of the cellular 
tissue sometimes occur simultaneously in many parts of the body, which has been named Necrosis TELE cellulose; v. Creutzwieser in Rust's Magaz. f. d. ges. Heilk. Vol. XXII. Part II. p. 338.-Otto Selt. Beob. Part II. p. 41.

(3) Zinn in Comment. Soc. reg. scient. Götting. Vol. II. p. 364.-White on the swelling of the lower extremities in pregnant women. $8 \mathrm{vo}$. Lond. 1803.Sankey in Edinb. med. and surg. Journ. Vol. X. p. 401.-Casper Commentarius de Phlegmatia alba dolente. 8vo. Halæ, 1819.-Velpeau in Archiv. Gener. de Médec. Vol. VI. p. 221. Pfeiffer D. de. phl. a. d. quædam, adnexa hujus morbi historia: 8vo. Marburg. 1825.- Struve Comm. de Phl. a. d. quindecim observationes practicas continens.' Svo. Tübing. 1825.-Reuter D. de Phl. a. d. 8vo. Berol. 1826. - Sellheim D. de Phlegmasia dolente. 8vo. Dorpat. 1826. - de Hübschmann D. de Phlegmasia serosa. 8vo. Mitav. 1825. - James Munn in Medical Communications of the Massachusetts medical Society, Vol. II. p. 1. Boston, 1813.-Freyberg D. s. Annotationes quasdam in phlegmatiam albam sic dictam dolentem. 8vo. Halæ, 1820.-Grimm D. quædam de phlegmasiæ albæ dolentis pathologia. 8vo. Berol. 1826.-Goldmann, v. Ammon and Feist in der gemeinsamen deutschen Zeitschrift für Geburtskunde, Vol. II. Part II.Böhr v. Siebold's Journal für Geburtshülfe, Vol. VII. Part. II. p. 420.-Hugh Fraser and Lizars in Edinb. med. and surg. Journ. January, 1827.-O. Fr. Schunann D. s. Phlegmatiæ albæ puerperarum dolentis observationem, adjectis nonnullis animadversionibus in ejusdem naturam. 4to. Jenæ, 1828.-Fricke Annalen der chirurg. Abtheilung des allgem. Krankenhauses zu Hamburg, 1826, Vol. I. p. 88. This disease is sometimes the consequence of stoppage or adhesion of the veins. - [ Robert Lee, M.D. Two very excellent papers on Phlegm. Dolens, showing it to originate in inflammation of the iliac and femoral veins, in Med. Chir. Trans. Vol. XV. p. 132 and 369.-W. Lawrence, Case of Phlegm. Dolens from inflammation of veins in the lower extremity, ib. Vol. XVI. p. 58 . T.]

(4) Hazeltine in med. papers communicated to the Mussachusetts Med. Soc. Vol. III. p. 1. Boston, 1819.

(5) Davies in Lond. Medical Repository and Review, July 1825.-Francis in New-York Medical and Physical Journ. No. 1.--Struve.-[Case of Phlegm. Dol. in a phthisical boy, is given by $T$. H. Holberton, in Med. Chir. Trans. Vol. XVI. p. 63 . T.]

(6) Francis.

(7) Reuss Repertor. Comment. and de Plouquet Repertor. Art. Tela cellulosa. - Carus Ueber die Zellgewebsverhärtung neugeborner Kinder in Hufeland's Journ. Vol. XLII. Part II. p. 110.-Schönberg D. de induratione telæe cellulosæ in neonatis. Gött. 1808.- Wiesner D. de tela cellulari infantum indurata. 8 vo. Berol. 1816. - G. Jaeger in Harless Rhein. Jahrb. fiir Medic. u. Chir. Vol. III. Part II. p. 42, and Harless in same, p. 85. - Alibert Nosologie naturelle. Vol. I. p. 494.-Liberali in Nuovi Commentarj di Medicina e di Chirugia, 1818, p. 337. - Breschet in Bulletin de la Soc. d'Emulat. de Paris. Avril, 1822.-Carminali and Palletta in Omodei's Annali universali di Medicina. Vol. XXVIII.-Leger. Considérations sur l'endurcissement du tissu cellulaire chez les nouveau-nés. 4to. Paris, 1823.-Wudoffsky D. de telæ cellulosæ induratione. 8vo. Dorpati L. 1824.-Barmann D. le tel. cell. ind. Berol. 1823, in a boy of six years. - Michaelis De ind. tela cellul. recens nator. Commentatio. Svo. Kilia, 1825.-Denis Recherches d'Anatomie et de Physiologie pathologiques sur plusieurs Maladies des Enfans nouveau-nés, p. 145. Svo. Paris, 1826.-Palletta in Omodie's Annali, etc. Vol. XXXV. Luglio-Settem. 1825.-Billarl in Archiv. générales de Médec. Vol. XIII. p. 204. Feh. 1827.-Baumgarten D. de induratione textus cellulosi neonatorum. Svo. Halx, 1821.-P. Fleischhanmer D. de scleremate. 8vo. Berol. 1828.- [ Andral Précis d'Anat pathol. Vol. I. p. 201. T.]

(8) According to Denis, it arises in comexion with inflammation of the stomach and intestines.-- [D. Craigie, p. 45.-Andral, Vol. II. Part II. p. 577. 'I.]

(9) Especially in the cheeks, in the pubic region, and on the extremities; in children, particularly such as are fat, there is observed at the time of teething, and continuing for many months, a laard swelling in the checks. A similar 
hardening of the cellular tissue, connected with too great production of fat, has already been observed as a rare disease in one fœtus. v. Otto, Selt. Beob. Part II. p. 166. tab. 4. f..3.

\section{$\$ 7 \%$}

We frequently observe irregularities in respect to the conTENTS of the cellular tissue, inasmuch as, not only are the fluids usually found, viz. the FAT and the SERUM, irregular, but entirely EXTRANEous subSTANCES are also contained in it. As to the FAT, it is not merely found in very small quantity in great meagreness, and in too great quantity in morbid fatness, adiposis, in every part, or only in certain parts in the cellular tissue, ${ }^{1}$ but it also often deviates in colour, composition, and CONSISTENCE: thus it may be too pale, or too dark, reddish, merely discoloured, and not unfrequently in cachetic persons, too soft, jelly-like and smeary; but in other cases, on the contrary, it is found too hard, horny, and even like wax. Similar vices are also observed in the serum of the cellular tissue, which may be entirely deficient, in great general, or local meagreness and dryness of the body; but it is more frequently in too great quantity in the cellular tissue, anasarca, leucophlegmasia,${ }^{2}$ or in particular places, cedema, ${ }^{3}$ for instance, especially in the eyelids, the scrotum, the pudenda of women, the hands and feet. Often is the serum Discoloured; thus, it is yellowish in jaundice, in yellow fever, ${ }^{4}$ in typhus, in diseases of cattle, viz. in mortification of the spleen, \&c.; turbid and milky in the so-called milk change, and if it be mingled with pus; reddish with blood, \&c. The serum frequently varies in reference to its consistence; thus, on account of the decay of animal substance, it is too watery, as in dropsy; or by the unnatural mixture of albumen and fibrous matter, it even becomes as thick as jelly. To the very extraneous productions in the cellular tissue belong those of AIR AND OF ANIMAL GASES, by which AIRY AND WINDY TUMOURs, pneumatosis, emplyysema, ${ }^{5}$ are produced, which most commonly originate in the escape of air from the respiratory organs into the cellular tissue on the neck and breast, consequent on penetrating wounds of the lungs, broken ribs, contusions, violent strains, as in delivery, violent coughing, \&c., and these often extend very far, indeed almost over the whole of the body. ${ }^{{ }^{*}} \mathrm{We}$, however, also observe these airy swellings in the cellular tissue in other parts of the body, viz. after convulsions and fevers, under the skin of the head, of the joints, and among the muscles-in the arm-pit after the reduction of dislocated arms; without suspicion of any putrefaction between the membranes of the alimentary canal, the gall-bladder, \&c. ${ }^{6}$ EFfusions of 
BLOOD INTO THE CELlULAR TISSUE, sugillatio, effusio, ecchymosis, ${ }^{7}$ are very frequently found. If internal abscesses burst, the PUs escapes into the neighbouring cellular tissue, and by apertures in the urinary passages, the URINE also, which often extends very far in the cellular tissue of the back, in the pelvis, and beneath the muscles of the belly, even up to the breast. We also find various kinds of gases and fluids in the cellular tissue in consequence of the great penetrability of animal membranes. Further, PARAsitic ANIMALs, viz. acari or mites, larvæ of the ostrus, filaria, and cysticerci, ${ }^{8}$ are found in every part of the cellular membrane of man and animals ; next, not unfrequently BONY and sTONY CONCRETIONs; and lastly, many DEAD EXTRANEOUS SUBSTANCES, which are conveyed from without into the organism, remain in the cellular tissue often for a long time without any apparent injury, and often, even travel about to a very great extent.

(1) Compare above, $\$ 18$, in which, however, it is also to be observed that organic diseases of the brain and heart rarely induce consequent wasting; further, $\$ 20$ and $\S 21$. Grüne D. de sana et morbosa pinguedinis in corpore secretione. 8 vo. Berol. 1826. Alibert, in his Nosologie Naturelle, Vol. I. p. 490 , pl. A, gives an engraving of a very fat boy of twelve years old. An instance of the cure of a case of very large adiposis is given by v. Graefe in Journ. für Chir. und Augenlieilk, Vol. IX. Part III. p. 367, with an engraving. [Dr. Cheyne also, who, when thirty-five years of age, weighed 448 pounds, by proper management, reduced his weight to 280 pounds, and lived to the age of seventy-three. A.P. Cooper's Lectures, MSS. T.] Compare also the articles Obesite, Corpulence and Graisse in the Dict. des Sciences Médic.-G. M'Crake D. de pingue et pinguitudine. Edinb. 1805. [There is in the Mus. St. Thomas's Hosp. a piece of fat from the abdomen of a woman, which is about four inches thick. T.]

(2) Breschct Recherches sur les hydropisies actives en général, et sur l'hydropisie active du tissu cellulaire en particulier. Diss. inaug. 4 to. Paris, 1812. Compare above, $\S 51$ and $\S 55$. In brutes ANAsARcA is less frequent than in man, although often to be observed in monkeys, sheep, calves, dogs, and in poultry; the opposite state of the fat and serum is also very interesting, as when the one is unnaturally increased, the other appears to be decreased.

(3) In nervous and gastric diseases, particularly in hypochondriac and hysterical persons, there sometimes occur suddenly tumours of very different size, which, after a few hours or days, or at death, immediately subside, and are produced by effusion of SERUM. OEDEMA not unfrequently occurs as the consequence of the obstructed reflux of blood, owing to compression or adhesion of the veins.

(4) De l'état anatomique de la peau et du tissu cellulaire dans la fievre jaune, \&c. by Desmoulins, in Magendie's Journ. de Physiol. expérim. Vol. III. No. 3, p. 255.

(5) J. P. Frank de curand. lom. morb. Epitoin. lib. VI. de Retentionibus.Wuilz D. de emphysemate. 4to. Lips. 1803.-Hebenstreit D. de emplyysemate. Lips. 1803. - Halliday de Pneumatosi D. Edinb. 1806, and Observations on Emphysema in Edinb. merl. and surg. Journ. Vol. IV. p. 351.-Verdeyen Essai sur I'Empliyseme, etc. Paris, 1809.-Cheync D. de Emphysemate. Edinb. 1820. v. also Vidal Essai sur le gaz animal considéré daus les maladies, etc. Marseille, 1809. v. Scdillot Journ. Vol. XXXV. p. 422.-Also in animals, especially in birds, enpllyysema occurs, [of which No. 599, Mus. Roy. Coll. Surg. is an example. 'T.] 
$\left(5^{*}\right)$ [I once saw a case of emphysema of the face, in consequence of fracture of the outer table of the frontal sinuses and the escape of air from the nose. T.]

(6) Compare above, $\S 51$.

(7) v. $\$ 37$.

(8) Compare above, $\$ 70$.

\section{THIRTEENTH SECTION.}

\section{Of Cellular Membranes.}

\section{$\S 78$.}

The animal membranes which either entirely or for the most part are composed of cellular tissue, are, in reference to their vices and diseases, so closely connected with the cellular tissue, that what has been already said in the preceding section generally applies to them. We, therefore, here merely premise that these membranes can AS LITTLE BE ENTIRELY WANTING AS THE CELLULAR TISSUE IN GENERAL, since the circumscription of the external extent of the organism, as well as the internal organic separations, necessarily depend upon them, and that they CAN BY NO MEANS ALWAYS EXHIBIT THOSE REMARKABLE VARIETIES which they show in a higher development of the organism. They still, indeed, sometimes retain for a longer period, that is, as a retarded formation, that indeterminate character which they possess in the early stage of foetal existence ; or they appear often, even in adults, in spurious formations, especially in encysted tumours, not less indistinct, so that it is difficult to distinguish whether it be a serous, a mucous, or a skinny membrane. The cellular membranes also, when subsequently diseased, become so changed, that they are mutually converted into each other; so that for instance the external skin, in violent and continued extension, by which the vessels, nerves and glands in it disappear, assumes the appearance of a serous membrane; in other cases, by loosening, expansion and exclusion from the air, it resembles a mucous membrane, ${ }^{1}$ and on the contrary a mucous membrane unnaturally subjected to the influence of air, assumes not unfrequently the nature of skin, ${ }^{2}$ as is the case in protrusion of the rectum and of the vagina.

As the cellular membranes stand in close formal connexion with the systems and organs to which they as essential parts belong, so it will be in part better to treat of them together; 
and we shall, therefore, at present, only consider the more common of them, namely, the serous and mucous membranes, and the external skin.

(1) Hebréard Mémoire sur l'analogie qui existe entre les systèmes muqueux et dermoide in Mém. de la Soc. médic. d'Emulat. Vol. VIII. Part I. [Andral Précis d'Anat. Path. Vol. I. p. 263. T.]

(2) In monsters with extensive congenital clefts, of which the cavities are lined with mucous and serous membranes, I have several times seen these membranes too thick and firm, and very nearly approximating to leather in appearance.

First Chapter.

\section{Of Serous Membranes. ${ }^{2}$}

\section{$\S 79$.}

Entire DEFICIENCY of the serous membranes can only occur in such imperfect monsters as have neither the larger cavities of the body nor even the cavities of the joints formed, with both of which these membranes necessarily and simultaneously exist. More commonly they are absent only at certain parts, viz. the pleura, the pericardium, a portion of the mesentery, some of the mucous bags, \&c.; they also sometimes at a later period degenerate by resolution into cellular tissue, viz. in unreduced dislocations, in anchylosis after smashing of the mucous bags, \&c. Sometimes, also, we observe in them EXCESS OF FORMATION, inasmuch as irregular processes and sacs of serous membrane are occasionally found congenital, whilst at every period of life serous membranes can be produced, and always are produced, when there is formed in the body a permanent and perfectly closed cavity, as for instance, in new joints and encysted tumours.

(1) To which also, on account of the similarity of their texture, the synovial membranes and mucous bags belong. On the diseases of the latter compare Koch D. de norbis bursarum tendinum mucosarum, 4to. Lips. 1790; and Untersuchung des natürl. Baues und der Krankheiten der Schleimbeutel, 8vo. Nürnb. 1795.-Herwig D. de morbis bursarum mucosurum. 4to. Gött. 1795.

$$
\S 80 \text {. }
$$

The SIZE and FORM of serous membranes, as they merely line the interior of cavities, depend entirely on them, and are therefore subject to many deviations; wherefore we 
must only remember that they possess a CONSIDERABLE EXTENSIBILITY, and often become expanded, together with the other parts of the walls of the cavities, into large sacs. Also, in reference to CONNExion, they sometimes present irregularities, as, in the non-existent separation of the several cavities of the body, the usually distinct serous membranes run into each other. ${ }^{1}$ BREACH of CONTINUITY does not often occur in them, on account of their great pliancy; to this, however, belong dislocations with rupture of the articular capsule, and the rupture of the serous membranes alone, especially of a hernial sac, is sometimes observed consequent on external injury or very violent extension. Irregularities as to colour are not very rare, as, for instance, in dropsy they become dim, cloudy, and too white; in other instances, on account of the excessive filling of the vascular tissue lying beneath, they are as it were injected, spotted, even more or less red; in high degrees of jaundice they appear yellow; in mortification and melanosis, blackish, \&c.; in rare instances also we have observed petechial spots upon them.

(1) To wit, the pericardium may run into the pleura; these into the peritoneum; this larger bag, in consequence of the imperfect closing of the abdominal ring, into the external process of the peritoneum (tunica vaginalis testis); mucous bags as congenital vices, or as consequent on friction, into the neighbouring articular cavities, \&c.

\section{$\S 81$.}

Among the vices of texture of serous membranes must be mentioned, before all other, their Inflammation, ${ }^{1}$ which is very frequently idiopathic, in consequence of mechanical and other causes, particularly when they are brought in contact with atmospheric air; not unfrequently is it also sympathetic and metastatic in eruptive diseases, in gout, puerperal fever; sometimes has an acute, sometimes a chronic course, and creeping along as it were by degrees, can extend itself very widely. This inflammation rarely runs into true supPuRATION ${ }^{2}$ and MORTIFICATION, ${ }^{3}$ but is especially disposed to the EXUDATion of serum and fibrous substance, from the latter of which are very frequently produced on the open surface of serous membranes, PLASTIC CONCREMENTS, which assume the form of fibres, bands, cells, and false membranes, and very commonly effect close or loose aDHESIONS of the outer and inner surfaces of serous membranes. We often find the serous membranes THICKENED in consequence of the inflammatory state, and indeed either LOOSENED and EDEMATOus, or more frequently HARDENED, and not rarely CARTILAGINOUS and BONY in certain spots. A more common morbid state of 
the serous membranes in man and animals is the deposition of SCROFULOUS MATTER in them, and the formation of the so-called TUBERCLES $;^{4}$ more rare are EXANTHEMATOUS PUSTULES and KNOTS, TUMOURS ATTACHED BY THIN NECKS, ENCYSTED FORMATIONS, FUNGOUS and SARCOMATOUS EXCRESCENCES. ${ }^{5}$ Hydatids, on the contrary, are often found on the serous membranes of man and animals, either singly or in large cysts.

(1) Latralle D. sur l'inflammation du système séreux. Paris, 1802.-Sauceur D. sur les inflammations des systèmes séreux et du système synovial. Paris, 1812.As serous membranes possess no blood-vessels, the seat of intlammation is, in the strictest sense, rather in the adjacent layer of cellular tissue, and on the surface of the organs covered with serous membrane, than in the serous membrane itself. These, however, participate in the disease.-Mroffait D. sur les Phlegmasies des membranes synoviales des articulations. Paris, 1810.-Flormann resp. Lorich D. de signis inflammationis membranarum serosarum. 4to. Lund. 1812.-Chomel D. sur le Rheumatisme. Paris, 1813.-Villerand de la Fosse D. sur Rheumatisme. Paris, 1815.-Roche Phlegmasies du système fibro-sereux des articulations. 4to. Paris, 1819.-[Andral, Vol. I. p. 281. T.]

(2) The disposition to malignant ulceration in mucous bags which are opened and exposed to atmospheric air is very remarkable, it can even give rise to fungous growths.

(3) This never occurs singly and primarily in the serous membranes, but only secondarily, and simultaneously in the neighbouring organs.

(4) An Inquiry, illustrating the nature of tuberculated accretions of serous membranes and the origin of tubercles and tumours in different textures of the body, by John Baron. Svo. London, 1819, with plates.

(5) Zink Reflexions et observations sur les fongus des membranes séreuses, in Jouru. coppl. du Dict. des Sc. Méd. Vol. XXI. p. 24.

\section{\$82.}

The contents of the cavities formed by serous membranes also vary considerably from the rule; we observe, indeed, sometimes AIR, as consequent on an exhalation which has occurred during life-next, PUs and BLOoD, ${ }^{1}$ collected in them, and very frequently wATER, of which the quantity, colour, consistence, and composition varies remarkably, ${ }^{2}$ and produces large swellings of the head, chest, belly, scrotum, the capsules of joints, and the so-called ganglia. ${ }^{3}$ 'The latter are partly tumours of the mucous sheaths and bags (bursarum mucosarum vaginalium, vesicalium and subcutanearum) partly new formations, that is, serous cysts; they sometimes acquire a large size, and when of long standing, are often very hard, as the secretion contained in them becomes thick, albuminous, and jelly-like, even cartilaginous, and not rarely coagulated into little LOOSE CARTILAGES which are of various forms, and often in great quantity. ${ }^{4}$ Similar Loose cartilages, although in other respects mostly fibro-cartilage, and even bony in their centre or bony throughout, are not unfrequently found in other 
serous and synovial cavities; they seem always to be formed in the above-mentioned tumours with necks of these membranes, and are therefore often found hanging by long fine threads, which at a later period are broken. ${ }^{3}$

(1) Compare above, $\S 51$.

(2) John Chemische Tabellen des Thierreiclss, p. 42-44. fol. Berlin, 1814. - Schreger fluidorum corp. animal. chemiæ nosologicæ specimen. p. 16-24. Erlang, 1800.-Marcet, A Chemical account of various Dropsical Fluids, in Med. chir. Trans. Vol. II. p. 342.-Berzelius, ib. Vol. III. p. 251.-Bostock, ib. Vol. IV. p. 52.-Annals of Medicine, Vol. VI. p. 126, \&c. The water is sometimes clear, at other times turbid, milky, yellow, merging to greenish, brownish, reddish, from the mixture of blood, often quite thin, or rather thickish, like white of egg; sometimes it is su acrid, that pustules on the hands are produced by it, \&c.

(3) Juncker D. de gangliis generatim consideratis. Halæ, 1740.-Eller in den Schr. der Berl. Akademie d. Wissencl. p. 108. 1746.-de Büchner D. de gangliis. Halæ, 1748.-Vinckler D. de ganglio. Budæ, 1783.-de Reimer D. de ganglio. Duisburg, 1796.-Assalin Considérations sur les tumeurs des bourses ou capsules muqueuses du genou. Strasburg, 1803.-J. Clocquet in Archives générales de Médecine, Vol. IV. Paris, Feb. 1824. A case of a very large ganglion under the knee, where, as well as on the hand and on the tendo achillis, it is most common, is given by Suchet in Journ. compl. du Dict. des Sc. Médicales, Vol. XI. Cap. 43. Ganglions most generally originate in blows, pressure, violent extension, \&c. although also from internal causes, particularly gout, rheumatism, scrofula, and painters' colic. Ganglions are also very common in the tendinous sheaths of the flexor muscles of horses, and are called windgalls. In asses and mules they also occur, though rarely; but in other animals they have not been observed within my knowledge.

(4) Albinus in Annot. academ. lib. VII. c. 15.-Monro, Description of all the bursæ mucosæ of the human body. fol. Edinb. 1788, translated into German, with notes, by Rosenmüller. p. 66. fol. Leipz. 1799, pl. 15.-Wedekind in the Annalen der Wetterauischen Gesellschaft f. d. ges. Naturkunde. Vol. I. Part I. No. 4. - Abernethy, Surgical observations.-Beauchene in Journ. de Médec. Chir. et Pharm. Oct. 1813. Vol. XXVII I. p. 137.-Clocquet.-Cruveilhier, Kystes contenant de petits corps blancs, in Essai sur l'anat. patholog. Vol. I. p. 306, relates ten cases from Dupuytren, Pelletan, Patissier, \&c.-I saw at Mr. Wardrop's, in London, fifty such cartilages from a ganglion on the back of the hand, and above one hundred roundish pieces and little linseed-like cartilages in the Museum of Ch. Bell.-C. M. Fuhrmann D. s. variorum auctorum observata de tumoribus cysticis humorem synoviæ similem et corpuscula cartilaginea continentibus. Jenæ, 1822 .

(5) v. more particularly below, in several places.-Compare Laennec, Art. Cartilages accidentelles in Dict. des Scienc. médicales, Vol. IV. p. 123 ; Meckel Handb. der pathol. Anatomie. Vol. II. Part II. p. 198-214; Cassan Notes sur les concrétions dites albumineuses, in Archives générales de Médecine, May, 1826.

\section{Second Chapter.}

\section{Of Mucous Membranes.}

$\S 83$.

As the Mucous membranes form the internal boundaries of animal bodies, they can only be wanting, when the organs 
which they line do not exist; their partial DEFICIENCY can only be acquired and not long continued. The ExcESS of FORMATION of the mucous membrane occurs but rarely; we must here include the congenital irregular length of some of the mucous folds, also the congenital closing of the mucous canals at their usually open extremities, or at other parts by cross bands; unnatural mucous membranes are also formed in all irregular cavities and canals, which, like the normal mucous membranes, are connected with the surface of the body, or tend to represent them at certain spots, as in abscesses and fistulas; finally, the MUCOUS MEMBRANES ARE COMMONLY REPRODUCED, if they have been destroyed, either of the usual kind, or somewhat changed, as by a cicatrix. ${ }^{1}$

(1) The reproduction of mucous membrane does not appear to me to be doubtful, as it is not an unfrequent occurrence, for instance, in the mouth, the nose, and the vagina ; in the alimentary canal it appears also to be reproduced, although generally somewhat changed; at least I have seen newly produced skin on certain spots of an intestine which has been affected by ulceration in dysentery, although without true villi, yet villous-like, and it may be said further, with little mucous glands. [In examining the body of the late M. Beclard, who had some years previously been affected with gastric disease, supposed to be chronic inflammation, there was found in the lesser curvature of the stomach, a cicatrized ulcer, about the size of a sixpence, with a flat surface, and traversed by a solid cellular band, on each side of which were two lacunæ formed by peritoneum; the margins were neither red nor swollen, and the rest of the stomach was sound.--v. C. Billard De la membrane muqueuse gastro intestinale. T.]

\section{$\S 84$.}

Mucous membranes assume, together with the canals which they line, the most varied Form and SIZE, as they CONTRACT themselves, even to the closing of their canal, and on the contrary are capable of great ExTENsion; sometimes they alone are expanded, and project like bladders through clefts in the surrounding parts. ${ }^{1}$ Their THICKNess as an individual formation varies exceedingly, and is often very much diminished, either locally or generally, by excessive extension and atrophy, as well as increased to a great extent by hypertrophy, and still more by disease. The coLour is frequently irregular, sometimes it is too pale in the atrophic state of the membrane; white from the effect of sulphuric acid; frequently red in the most various shades and extent, as a consequence of irritation, congestion, effusion of blood on the surface, and inflammation; ${ }^{2}$ and in consequence of the latter disease, sometimes also brown, slate-coloured, and in the mortified state and melanotic deposits, even blackish; the mucous membrane may also sometimes be irregularly coloured by food, drink, and medicines containing pigment. ${ }^{3}$ RUPTURE of the mucous membrane, 
merely from violent extension, is very rare, more commonly it is wounded by sharp bodies thrust into it, especially in the alimentary and urinary canals.

(1) For instance, in the air-tube, the alimentary canal, the urinary bladder, \&c.

(2) The redness is sometimes produced merely by certain large vessels filled with blood, as if they were injected; in other cases it appears in little spots, in others streaky, speckled, or as it were washed, \&c.

(3) v. further below, in the alimentary eanal.

\section{$\S 85$.}

We observe, not unfrequently with reference to their DISEASES, a great sympathy in the mucous membranes of different parts with each other, and particularly also with the external skin; thus they are often found affected altogether more or less by exanthematous diseases, by continued fevers, \&c., and vices of TEXTURE are very common in them. The latter, as is generally the case, so also here, frequently, arise from INFLAMMATION of the mucous membrane, which has a peculiar character, is called inflammatio catarihalis, and shows itself in lower degrees of the disease by moderate redness, swelling, and increased secretion of the mucous fluid; in higher degrees by more excessive redness and swelling, connected with dryness, or with great disposition to the effusion of fibrous matter. This produces the PLASTIC SPOTS of various kinds, ${ }^{1}$ or gives rise to ADHESIONS of the mucous membranes to each other, and so to the closing up of their canals. Inflammation of the mucous membrane has often consequent to it, sofTENING, SPONGY LOOSENING, CDEMA, FLABBINESS, and FOLDS; in other cases SwELling, with infiltration of coagulable lymph, consequent THICKENING and HARDENING, even of a cartilaginous character, ${ }^{2}$ in all which states a speedy coalescence, and even imperviousness of the canals lined by the mucous membrane, is readily produced. The higher, more phlegmonous degree of inflammation, not unfrequently runs into sUPPURATION and MORTIFICATION, in the latter of which, large pieces of the mucous membrane are sometimes separated from the adjoining parts, and thrown off. Ossification of the mucous membrane alone does not appear to occur. ${ }^{3}$

(1) Compare $\S 55$.-Turush, Aptha, are a peculiar kind of such false membranes which occur in the mouth, gullet, and stomach, and are situated on or bencath the epithelium of the mucous membrane, and have very various form and colour.-Lelut Mémories sur le muquet, in Répertoire général d'anat. et de physiol. pathol. Vol. III. Part I. p. 145.-[G. Macilwain, Surgical observations on the more important diseases of the mucous canals of the body. 8vo. Lond. 1830. T.]

(2) Here also belong the changes which affect the mucous membrane of protruded parts. v. above, $\S 78 .-[$ v. Andral Précis d'Anat. Path. Vol. I. p. 266. T.] 
(3) The few instances of ossification mentioned by writers appear to me either to have their seat in the cellular tissue investing the mucous membrane, or to be an earthy deposit on their expanded surface, and in the mucous glands. It has not been my luck to find true ossification of this membrane, nor to see it in any collection, and this great analogy with the external skin induces one to believe in the want of this vice of texture.

\section{$\S 86$.}

Among the compound vices of texture of the mucous membrane must be first named, especially, the EXanthematous DISEASES not unfrequently observed in many parts, as the BRAN-LIKE SCALING of their epithelium, the various kinds of Spots, KNots, pustules, vesicles, and even the true PoCKs, \&c.; further, the VARICES and degenerations of the bloodvessels found in them, then the great DEVELOPMENT, EXTENSION, sUPPURATION, which occur in the MUCOUS GLANDS contained in them, especially in chronic catarrh and mucous fevers; finally also, a number of spurious FORMATIONS. 'To these belong the HAIRs, which in rare cases are produced upon them, HYDATIDS, the more rare peculiar ENCYSTED TUMOURS, TUBERCLES, FUNGOUS GROWTHS, and the POLYPS, which are very common on many places, as well as the sarcomatous TUMOURs allied to them, and finally, sCIRRHUS and CANCER, which particularly affect those parts of the mucous membrane in which there are many mucous glands.

$\$ 8 \%$

The contents of the mucous membrane lining cavities also present irregularities. To these especially belong the peculiar SECRETIONS OF GAS, varying in quality and quantity, and of WATER, which can sometimes be retained for a long while in certain regions in the morbid interlacing of the muscular parts surrounding mucous membrane ; further, of mucus, which is frequently collected in incredible quantity, sometimes thickish and viscous, like frog spawn or white of egg, even forming tubes, but in other instances, has a purulent appearance, and indeed in the alimentary canal is not unfrequently mixed with the various morbid excretions, and coloured by them; then of BLOOD, which not unfrequently may be equally poured out upon the mucous membrane without rupture of the larger vessels, in inflammatory, hemorrhoidal, and other conditions of the membrane; finally, of EARTHY ${ }^{1}$ and SALINE substances of various kinds, which are found upon them either in a fluid form, or coagulated and formed into incrustations and stones, which are produced in the canals of the mucous membrane capecially. INTESTINAl, worms are also very commonly 
produced, both in man and animals, in the cavities formed of mucous membrane, and where they open externally, we find also various other ANIMALS and DEAD EXTRANEOUS SUBSTANCES.

(1) I knpw one person, in whom, during an atonic attack of gout, the whole mouth, throat, and gullet were largely covered with a whitish mucus, which, when dried on blotting paper, left behind a large quantity of phosphate of lime.

\section{Third Chapter.}

\section{Of External Skin.'}

$\S 88$.

As no organic body can exist without a covering, so DEFICIENCY OF THE EXTERNAL SKIN CAN NEVER EXIST AS A VICE OF FORMATION: but it is so much the more common as an acquired vice, since large patches of skin are often destroyed by suppuration, mortification, burns, \&c. The formation of the skin is, however, frequently seen imperfect, so far, as that in man and animals it is often found at the time of birth as thin and transparent, on certain spots, as in the youngest embryon, and then, in consequence of its simultaneous connexion with the subjacent membranes, it appears at first sight to be really deficient. This is most common in hemicephaly, spina bifida, and the clefts on the front of the body, in which internal pressure prevents the evolution of the skin. ${ }^{2}$

On the contrary, we sometimes also observe an ExCEssive FORMATION OF sKIN, in which are seen, on certain parts, as congenital vices both in man and animals, unnatural PROCESSES of SKIN ; and as acquired vices, ENCYSTED TUMOURS, especially those which are internally beset with hair, are frequently formed of a membrane very analogous to the cutis. ${ }^{3}$ The skin is also very easily reproduced, ${ }^{4}$ after having been destroyed by disease or operation; but at such spots it generally becomes changed, viz. is thin, expanded, at first red, but subsequently white from poverty of vessels, has neither hair nor sebaceous glands, and is then called a SCAR, cicatrix. ${ }^{5}$

(1) Plenk Doctrina de morbis cutaneis. Vindob. 1776. - Lorry De morbis cutancis. Paris, 1777.-Jackson, Observations on the diseases of the skin.Schmidt Cutis morbi ex materiæ animalis mixtura et forma mutatis cognoscendi D. Halæ, 1799.-Willan's Description and treatment of cutaneous diseases. 4to. Lond. 1798.-Alibert Description des maladies de la peau observées a 
l'hôpital Saint-Louis, etc. fol. Paris, 1806-1826, with plates.-Bateman, Practical synopsis of Cutaneous Diseases, according to the arrangement of Dr. Willan, illustrated by a coloured plate. 3d edit. London, 1813; and Delineations of the Cutaneous Diseases, Sc. 4to. London, 1814-1816.-Nushard Skizze einer Dermato-Pathologie. 8vo. Prag. 1816.-Bergmann die Krankheiten der Haut, der Haare und Nägel am menschl. Körper. 8vo. Leipz. 1824.-Klaatsch Tabellarische Uebersicht der Hautkrankheiten nach Willan's System. fol. Berlin, 1824. - Plumbe A practical treatise on Diseases of Skin, \&c. 8vo. London, 1824. - Rayer Traité thÉrique et pratique des maladies de la peau, etc. Paris, 1826, with an atlas.-v. de Plouquet Rejertor. Cutis morbi. [Craigie's Elements, p. 604 . T.]

(2) I have already observed, in the above cases, that the common integuments covering the other membranous sacs are not deficient, but only thinned; and this will be found to be confirmed subsequently by a host of cases; I have always endeavoured to distinguish the thinned skin from the subjacent fibrous or serous membranes, and often also to separate them.-Compare my Monstror. sex humanor. anat. et plyysiol. disquis. p. 12.-Selt. Beob. Part I. p. 26.Handb. der pathol. Anatomie. 1st edit. p. 152.

(3) For instance, my Selt. Beob. Part II. p. 159.

(4) I once saw the skin of the whole belly from the navel, of the penis and testicles, and a part of that of the thigh, soon reproduced, after having been destroyed by gangrene, consequent on a syphilitic bubo.

(5) Compare $\$ 56$. - From the appearance of the scar, we can sometimes distinguish the character of the preceding ulceration of the skin, whether it had been a scrofulous, syphilitic, or variolous ulcer which had given rise to the scar, \&c.

\section{$\S 89$.}

The Extent, THICKNess, and Form ${ }^{1}$ of the skin is subject to great variety. Sometimes it is found congenitally so NARrow, as to produce S'TRICTURes and deep indentations ${ }^{2}$ it is more frequently narrowed and shortened in consequence of a diseased state, especially in the destruction of burnt parts, tumours, and wounds, with loss of substance, so that it restricts the motions of a part. Oftentimes the skin is too WIDE, WITHERED, and WRINKLED, sometimes to a very great extent $;^{3}$ in many cachectic diseases $;^{4}$ and when it has been previously very much expanded by tumours, this is especially the case. The ExTensibility of the skin is very great, particularly if it have been long in taking place. With great extension there also occurs THINNing of the skin, and sometimes to such extent that it becomes quite smooth, shining, transparent, and similar to a serous membrane, and then not unfiequently bursts. Not less common is also the thickenING of the skin in consequence of various diseases, for instance, badly cured erysipelas, elephantiasis, \&c. in consequence of which it can be thickened to a quarter of an inch. 'There is also commonly found at the same time, HARDNEss, which, however, may exist without any thickening, and is occasionally so great, that the skin becomes as dry and firm as tanned leather or parchment, not unfrequently breaks and produces CRACKS, rhagades; the skin is also found in many men, for 
instance, sometimes in barren women, naturally too hard and rough. The contrary vice of consistence, viz. the soFTENING and LoosENING of the skin, occurs in many diseases, on parts which have been long deprived of the influence of air and have continued moist, in habitual sweating, and on the hands of little children, who are accustomed to suck them, \&c. ${ }^{5}$

(1) Many muscles alter the form of their sliell to that of the body, on which they fasten themselves.

(2) I have twice observed deep circular strictures on the thigh and leg of new born children. One such case has been described by Cornelison in the Medical Repository of Original Essays and Intelligence, New York, 1817, new ser. Vol. IV. Part II.

(3) One young man could draw the skin of the neck and shoulder over the whole face. v. Tulpius Observ. medic. p. 100. Amstel, 1672.

(4) For instance, the disease Cosz, in the country of Nogays, between the Black and Caspian seas.

(5) A few remarkable cases of softening and dissolution are communicated and drawn by Heusinger in the first Bericht. von der anthropotomischen Anstalt zu Würtzburg, p. 34. ff. plate 3. Similar strong development of the papillæ of the skin have been often noticed in elephantiasis, under the thickened cuticle.

\section{$\S 90$.}

The COLOUR ${ }^{1}$ of the skin presents very many variations from the normal state, which are usually situated only in the upper layer of the cutis itself, although in rare cases in the cuticle also at the same time; these are sometimes general, sometimes only local. Too GREAT whITENESS of the skin occurs originally and often hereditarily in LEUCETHIOPY, or ALBINOISM of men and animals, ${ }^{2}$ and rarely as a bleaching in the coloured nations $;^{3}$ the YELLOW colour, as a morbid state in JAUNDICE, icterus; ${ }^{4}$ the RED colour, particularly in high inflammation, and in the eruptive diseases, although also without these. ${ }^{5} \quad$ There is observed further in Europeans a BROWNISH, ${ }^{6}$ in rarer instances a LEADEN $;^{7}$ more commonly a BLUISII, ${ }^{8}$ and even a BLACKISH ${ }^{9}$ state of the skin, partly as the consequence of a morbid state, partly from certain colouring substances. ${ }^{10}$ We also not unfrequently observe upon the skin, spots of various colour, number, size, and form; for instance, Europeans with the skin entirely white, yellow, red, brown, and blackish; coloured nations, on the contrary, with light spots. ${ }^{11} \quad$ Here belong also sun-Blisterings, epleclides; FRECKLES, lentigines, cloasmata; the BLACKISH SPOTS IN OLD PERsons, melasmata; ${ }^{12}$ then the bluish and dark spots which arise from congestion or from actual effusion of blood in and beneath the tissue of the skin, as death spots, sugillations, petechiæ, scorbutic spots, $\& c_{.} ;^{13}$ and finally, the various spots in which, at the same time, the skin is morbidly changed. In animals also, we sometimes observe morbid spots on the skin, 
particularly in the murrain among swine, sheep, fishes without scales, viz. eels, even in crabs, silkworms, \&c.

(1) Blandus De maculis corporis. 4to. Romæ, 1544.-Fr. Hoffmann D. de morbis cum colore cutis depravato. Halæ, 1714.-Bose De mutato per morbum colore corp. Lips. 1785.-Blumenbach De generis humani varietate nativa. p. 150. edit. tertia. Gotting. 1795. $\mathrm{ff}$.

(2) Compare $\$ 33$. Blumenbach, $\$ 78$, p. 274, and in Comment. Soc. Reg. Scient. Gotting. Vol. VII. p. 29, and in the Medic. Bibliothek. Vol. II. p. 537.-G. T. L. Sachs Historia natur. duorum leucæthiopum auctoris ipsius et sororis ejus. Svo. Solisbaci, 1812, accompanied with observations by Schlegel in Neuen Materialien für die Staatsarzneiwiss. Vol. III. p. 1-148. - Mansfeld Ueber das Wesen der Leukopathie oder des Albinoismus, nebst Beschreibung eines in Braunschweig lebenden Albinos. 4to. Bramschweig, 1822 , with a plate.A. Retzius Bericht ïber zwei schwedische Albinos, nebst Bemerkungen über die Pigmentbildung in Svenska Lälare-Säslskapets Handlingar. Vol. X.-Description of an Albino which was born at Görlitz, by Dr. Bauernstein, in Neuen Lausitzer Magazin. Vol. V. Part III. Gorlitz, 1 \$26. v. also § 33, note 2.- $[J . R$. Cox, an account of an Albino, in a note to which, Jefferson's account of three Albino negro women in the same fanily, in Cox's Philadelph. Med. Mus. Vol. I. p. 151. _J. Vaughan, account of two Albinos, in ib. Vol. II. p. 2S5. T.]

(3) Partly in congenial climates, partly in disease. v. Blumenbach, p. 160 and 161, and in Voigt's Magazin, Vol. V. p. 36s. Recent instances of bleaching in the negro, are given by Fisher in Mem. of the Soc. of Manchester. Vol. V. Part I. p. 314. - Hamilton in Edinburgh, Med. chir. Trans. 1824, No. 22. - Dwight, Travels in New-England and New-York.-Another case in the Norfolk Beacon.Bleaching of Americans is described by Dwight and Knisht in Transact. of the pliysico-medical Soc. of New York. Vol. I. 1S17.

(4) v. \$39.-Desmoulins De l'état anatomique de la peau et du tissu cellulaire dans la fièvre jaune, etc. in Magendie's Joum. de Physiol. experim. Vol. III. No. 3. p. 255.

(5) For instance, a red negress. Marcgrarii Brasil. p. 12.

(6) Frank's Kleine Schriften medic.-prakt. Inhalts, a. d. Lat. v. Eyerel, p. 274. 8vo. Leipz. 1810.- Johnson in London med. chir. Transact. Vol. XIII. Part I.; sometimes also in jaundice.

(7) IIagedorn Hist. med. phys. Cent. IIl. Hist. 56.

(8) Especially in the blue disease, cyanosis; from grief, Fardeau in Foumier's Recueil de Mémoires de Médicinc, Chir. et Pharmac. militaires. Vol. VIII. p. 237.

(9) Occurring especially in pregnancy and in disturbed menstruation; not unfrequently in several parts. v. Albinus De sede ct causa color. æthiop. p. 9.Haller's Elem. Physiol. Vol. V. p. 18.-Blumenbach De gen. hum. var. nativ.Heusinger Untersuchumgen über die anomale Kohlen-und Pigmentbildung, u. s. w. p. 58. Eisenach, 1523.-On the leg of a dropsical person, Wurfbain Misc. Acad. N. C. Dec. II. Ann. V. p. 325 ; - on the face, Cassini Mém. de Paris, 1702. Hist. p. 29.-Yonge in Phil. Trans. 1709, p. 424 and 432.-Chomel Bullet. de la Facult. de Méd. et de la Soc. de Paris, 1814, p. 113._Goodwin in Sellillot's Recueil period. de la Soc. de Méd. de Paris. Vol. XLVI. p. 339.--from the breast to the knee downwards. Liugieri Storia ragionata di una Donna avente gl'an parté del corpo coperta di pile et pelle negro. Svo. Vened. 181j̃.-Hells, 'Two Essays, \&c. and an $\Lambda$ ccourit of a Female of the white race of mankind, part of whose skir resembles that of a negro. 8vo. Edinb. 1819.-I'arsons in P'hilos. Transact. Vol. LIII.-General black colouring is noticed in Ludwig Epistol. ad Hallerum seript. Vol. I. p. 393. - Strack, Observat. de febrib. intermitt. p. 194. 8vo. Offenb. 1785. - Leske auserl. AbhandI. Vol. I. p. 1.-Chomel in Journ. génér. de Méd. Chir. et Pharm. Vol. XXX. Jun. in Bulletin.-Bernstein in Salzb. medic. chir. /eitung, 1813, Vol. IV. No. 87. p. 143; and in Kleinen inedic. Aufsäitzen. Frankf. 1S14.-P'ascalis in Medic. Repository, New York, 1817, Vol. IV. Part IV.-Rostan in Leroux Journ. de Méd. Chir. et Pharm. Vol. XI. Nov. and Decbr.-Bulletin de la Soc. de lat laculté de Médec. 1S17, No. IX. 
and X.- Chamseru in Hist. de la Soc. Roy. de Méd. Vol. IV. p. 264, mentions the case of a child born with a violet-coloured skin, which gradually darkened to nearly black, on the lips, cheeks, tongue, interior of the mouth, and ends of the fingers; at the same time, the white of the eyes, and the irides more especially, became violet-coloured. The child was eight years old when the account of the case was given. T.]

(10) Compare $\S 38$. Baillie also observed two instances of black colouring of the skin from continued internal use of the Argentum Nitratum. v. N. Samml. auserl Abhandl. z. Gebr. präkt Aerzte. Vol. IX. Part II I p. 379.-Many muscles, viz. oysters, plicatula, anomia, balari, \&c. change the colour of their shells to that of the bodies on which they are fastened. v. Defrance in the Annales des Sciences Naturelles. Vol. I. p. 16.

(11) The scars of coloured nations are at first lighter, but subsequently they become as dark as the original skin.-[Pied negro, v. Morgan, in Amer. Phil. Trans. Vol. II. p. 392. T.]

(12) Bruckmann in Horn's Archiv f. medic. Erfahrung. Vol. II. Part II. p. 247.

(13) I know a lady who has a weak chest, in whom oftentimes sundry large skin spots, of a beautiful cerulean blue, appear on the extremities, without the slightest cause, and when she is in perfect health; after several hours they gradually subsicle.

\section{$\S 91$.}

Among the vices of texture in the skin, inflammation, dermatitis, must be first mentioned, which is usually designated by the name of St. Anthony's FIRE, erysipelas, ${ }^{1}$ and can exhibit very different degrees and peculiarities. In the higher degree of inflammation, the skin is not only ADHERENT to the parts beneath, but also to the external surface of other parts of the skin with which it is in contact. ${ }^{2}$ This inflammation frequently runs into SUPPURATION, in consequence of which, ULCERS of the skin occur; these indeed present a very different appearance, according as they arise from external or internal causes, and in the latter case are, for instance, either of a syphilitic, scrofulous, or gouty nature. ${ }^{3}$ 'THICKENING and HARDENING of the skin are also a very usual consequence of inflammation, which sometimes attains a very high degree, but never runs into TRUE OSSIFICATION, a condition which never occurs in the skin. ${ }^{4}$ On the contrary, the skin is very subject to MORTIFICATION, in consequence of which large patches of it are destroyed. The skin also undergoes various kinds of degenerations in man and animals, in the ERUPTIVE DISEASES, both in the exanthematous and impetiginous, in which are produced the various kinds of spots, elevations, knots, pustules, bladders, scabs, chaps, \&c. The texture of the skin is also sometimes more extensively changed in SCROFULA, SYPHILIS, PELLAGRA, ${ }^{4 *}$ RADESYGE, in EASTERN and WESTERN LEPRA, which may occur on almost all animals; so also may it be congenital in various ways, in the so-called MOTHERs' MARKs, neevi materni, ${ }^{5}$ which, however, do not seem to occur in animals. 'The sebaceous follicles, cryplec sebucece, found in the skin, 
also not unfrequently appear somewhat diseased; thus they often become enlarged, especially in atrophic children, in whom the sebaceous matter is collected in too great quantity and hardness, and appears at the mouth of the follicle as a black spot, and may be squeezed out in form of a maggot, MAGGOTS, comedones, as they are called; BoILs, furunculi, ${ }^{6}$ hard, very painful circumscribed tumours, in which are produced a viscid kernel or core, are usually seated in the sebaceous follicles, although they appear sometimes to be formed also in the cellular tissue of the skin. HaIr has been once found in a boil. ${ }^{7}$ Sometimes CalCareous ConCRETIONS ${ }^{8}$ are formed in the sebaceous follicles. To the more distinct and important vices of texture of the skin belong ENCYSTED TUMOURS ${ }^{8^{*}}$ which may be developed, if small, in the cellular tissue of the skin itself; the FATTY TUMOURS are the most common; ${ }^{9}$ sometimes HORNY sUBSTANCES present themselves in a kind of bag of skin. Various FUNGOUS and SARCOMATOUS GROWTHS occur not unfrequently on the skin, as EXCRESCENCES, condylomata, the YAWS and PIANS, ${ }^{10}$ certain SCROFUlous GrowTHS, ${ }^{11}$ the frequent SARCOMATOUS GROWTHS ON THE NOSE, and above all MEDULLARY SARCOM, which is not unfrequently seated in the skin, and the MALIGNANT WARTS and GIBBOUS TUMOURS, ${ }^{12}$ which run into TRUE CANCER OF THE SKIN. In animals, of which the skin is consolidated into scales, crusts, \&c., these often exhibit various diseases, thus curvings, abrasions, perforations, and wounds of different kinds; ${ }^{13}$ growths, to which also especially belong, the brilliant PEARLS found on the inside of bivalve shells, \&c.

(1) The lowest degree we commonly call also erythema; the highest, erysipelus phlegmonodes. Erysipelas is most commion on the face and on the feet; its occurrence after operations is dangerous, and it resembles the state of the skin in scarlet fever. Inflammation of the skin frequently arises from wounds, blisters, burns, frost-bites, insect stings, from pressure in consequence of lying down, decubitus, \&c. The galling or abrasion, intertrigo, of very fat persons and newborn children also belongs here, as well as in beasts, the so-called ignis sacer, ferus, sylvestris, persicus, St. Antonii, \&c.

(2) For example, especially the fingers and toes after burns : in one instance, the fore-arm adhered to the lip._Cruveillier Essai sur l'Anatom. pathol. Vol. I. p. 181, the hecl with the tuberosity of the ischium. - Otto Verz. d. anat. Präparatensimmlung, No. 2902.-The adhesion of separate parts to each other is pretty frequent, and with the investing membranes of the foetus. Observe in these the importance of the ready union of the skin for operative surgery.

(3) Compare § 57.--Here belong especially watery cancer, the corroding spots, herpes exedens, chimney-sweepers' cancer, and other malignant ulcerations of the skin.

(4) The bony concretion in the Cabinet d'Ecole de Médicine at Paris, which, according to the description, was produced in the skin of a young girl of eighteen; I found, on a closer investigation, in the year 1S18, to be rather fat, alinost like adipocire.

(1**) [Pellagra or the Lombard evil; the scherlievo, radesyge, spedalsked, liktrail, or the Northern evil; mal di rosa of the $\Lambda$ sturias, and a cutancous 
disease prevalent in Crim Tartary, are all considered, by Craigie, as prohable varieties of the same morbid action. v. his Elem. p. 640. He also gives the following authorities.-On the Pellagra, v. N. X. Jansen de Pellagra. Ludg.1787; Holland, M. D. in Med. Chir. Trans. Vol. VIII. p. 317 ; on Radesyge, Morbus quem Radesyge vocant, etc. Commentatio Auct. Fred. Holst, M. D. Christianæ, 1817; Geographische Nosologie von Fr. Schnuner, M. D. ; on mal di rosa, Thiery Observations de Physique et Médec. Vol. Il. Chap. VI. ; on Scherlievo, Annali de Medicina; for Crim Tartary diseases, the travels of Falk, Guldenstadt, and Pallas. T.]

(5.) Reuss De nævis maternis. v. Repertor. Commentat. Vol. X. p. 268, and Vol. XII. p. 332.--de Plouquet Repertor. Art. Nævus.-Wienhold Sieben Vorlesungen über die Entstehung der Missgeburten. Bremen, 1807.-Krause Abhandlung von den Muttermälern. Leipz. 1758.-Jouard Des monstruosités et bizarreries de la nature, etc. Paris, 1806.-A good plate of a mother's mark is to be found in Alibert's Nosologie Naturelle, Vol. I. pl. E, p. 350.--Another kind in Walther, Ueber die angebornen Fetthautgeschwïlste und andre Bildungsfehler. fol. Landshut, 1814.--J. Wardrop, in London Medic. Chir. Trans. Vol. IX. Part I. - One kind of mother's mark is near akin to angiectasy, described in the vascular system.--No. 2877, of Bresl. Mus. exlibits a mother's mark affecting the back of the head, the neck, and the whole of the upper part of the back.-- $[J$. S. Elsholz Antliropometria et Doctrina Nævorum. 4.to. Pat. 1654.--P. Phinella Libri tres Nævorum. 12mo. Antw. 1632. T.]

(6) Astruc Traité des Tumeurs, I.--Stahl D. de abscessu et furunculo. Halæ, 1714.-Berlin D. de furunculo. Gött. 1797. -- Heim's Erfahrungen über die Furunkeln in Horn's Archiv f. Medic. Erfahr. Vol. VII. Part I. and II. -Ritter in Graefe's and v. Wulther's Journ. of Chir. Vol. III. Part I. p. 81.

(7) Gilibert Adversar. med. pract. p. 140. Lyon, 1791.

(8) Voigtel, Hand. der pathol. Anat. Vol. I. p. 85, describes a few very interesting cases from Meckel's collection. Also in the sebaceous follicles of brutes concretions are sometimes formed, viz. the so-called STAGS' TEARS, in stags, which even become bony. v. Eph. N. C. Dec. II. Ann. IX. Observ. 15, p. 45.

(8*) [The only kind of encysted tumours which occurs in the skin is, according to Craigie, the meliceris; v. his Elements, \&c. p. 644 . T.]

(9) Compare $\S 64$.

(10) Good plates in Alibert, pl. 35 and 36. - Ludwig Histor. pathologica singularis cutis turpitudinis Reinhurdi. fol. Lips. 1793, with engravings.

(11) For example, in Adelson, D. s. casum singularem morbi tuberosi, etc. 4 to. Gött. 1822, with two engravings. A peculiar kind of fungous growth on the tip of the finger was observed by Boerhave, De morb. nervor. p. 282, and Stiebel Kleine Beiträge zur Heilwissenschaft, p. 111. 8vo. Frankf. a. M. 1823.

(12) Alibert gives good plates of such ulcers under the name of ScropHulE cancereuse; further, in the Nosologie Naturelle, Vol. I. p. 548, pl. H, and p. 554 , pl. $\mathrm{K}$.

(13) If mollusca be penetrated by boring muscles and worms, they do not close the opening with lime, but with a yellowish insoluble animal substance.

\section{$\S 92$.}

Parasitic animals ${ }^{1}$ are very often produced in and upon the skin of man and animals ; EXTRANEOUS BODIES also remain there either permanently or for a long time. ${ }^{2} \quad$ Frequently also there is noticed some PECULIARITY in reference to the SECRETION FROM THE SKIN, thus the PERSPIRATION, ${ }^{2 \mathrm{a}}$ is produced only at certain parts, on one half of the body, acrid and corroding, or stinking, containing urine, ${ }^{2 \mathrm{~b}}$ unusually sour, or discoloured, reddish, yellow, green, bluish, ${ }^{2 \mathrm{c}}$ even blackish ${ }^{2 \mathrm{~d}}$ - too thick, clammy, milk-like, \&c. ${ }^{2 \mathrm{e}}$ further, bloody-sweat, ${ }^{2 f}$ and the ex- 
cretion of the menstrual fluid through the skin ; the SECRETION OF EARTHY AND SALINE MATTER, especially in gouty persons ; ${ }^{3}$ even the exudation of PURE QUICKSILVER, through the skin. ${ }^{4}$

(1) Compare $\$ 70$.

(2) For instance, gunpowder, which has been burnt in, and colouring matter used in tattooing.

(2a) [J. Abernethy, Surgical and Physiological Essays, Part II. An Essay on the nature of the matter perspired and absorbed by the skin. T.]

(2b) H. Halford, Urinous smell in the perspiration, v. Med. Trans. Coll. Phys. Vol. VI. p. 389.

$\left(2^{c}\right)$ [An instance of blue sweat is mentioned in Southwell's Medical Essays, Vol. III. p. 53. T.']

( $2^{d}$ [ $A$ case of back sweat is mentioned in a paper, 'De morbo quodam sudoribus urinisque nigerrimis insigni,' in Comment. Bonöens. Vol. VI. p.60. T.]

(2e) Jahn, Oily perspiration in general emphysema, Magaz. f. d. Gesammt. Heilk. Vol. XXVIII. p. 59.

(2f) [Bloody sweat is mentioned by Blainville in his Cours de Physiol. Gen. et Comp. Vol. III. p. 57. Paris, 1830, as occurring under severe mental excitement, and in the disease called Diapédèse, but he considers that "il n'y a pas une véritable transpiration, mais qui consititue plutôt une hémorrhagie par exhalation, comme celle que l'on observe à la surface de la membrane pituitaire." A very curious case of this disease is mentioned by Samuel du Gard, in Phil. Trans. Vol. IX. No. 109, p. 193. A child about three months old began to bleed from the nose, ears, and back of the head; in three days that from the nose and ears subsided; upon which the blood flowed more violently from the head, and streamed down to some distance. She bled also from the shoulders and waist, also at the shoulders, bends of the arms, hands, and toes. She died in six days from the commencement of the attack, and there appeared in those places where the blood came, little holes like the pricking of a needle. T.]

(3) Albrecht in Miscell. Acad. N. C. Dec. II. Ann. 1690, p. 144- -Paullini in A pp. Misc. N. C. Dec. II. Ann. V. Obs. 85.-Bartholinus Hist. anat. rar. Hafn. 1654, Cent. I, Obs. 34. Vol. II. p. 55.-Medicinisches Wochenblatt von Müller und Hoffmann, 1787, No. 10.-Richter Specielle Therapie, Vol. VI. p. 551.Compare de Plouquet Repertor. Calculus in sudore. According to Dandalo, the sweat of gouty persons contains uric acid; thus the concretion might be urate of soda.

(4) Memoir of the medical Soc. of London, 1799. Vol. V.-Brückmann in Horn's Archiv f. med. Erfahr. 1810, Vol. 1I. Part II. p. 252._Biet in Kopp's Aerztl. Bemerkungen, veranlasst durch eine Reise, u.s.w. p. 116. 8vo. Frankf. a. M. 1825 .

\section{FOURTEENTH SECTION.}

\section{Of Horny Tissue. ${ }^{1}$}

\section{$\$ 93$.}

The already mentioned vices of the skin lead very naturally to those of the HORN-LIKE PAR'TS which are most intimately connected with it, to wit, of the cuTicLE, of the epithelium, the various kinds of CALlositils, HORNY WARTS, SCALES, and SHELLS of animals, the HORNY BEAKS, NAILS, TALONS, CLAWS, 
Hoofs, true Horss, so far as they do not belong to the bony system, the hairs, bristles, spines, Feathers, \&c. As these parts are all composed of the same substance, viz. horn; they have also the same vices, some only of them therefore will, on account of their various peculiarities, be treated of more at length below.

(1) Rudolphi Ueber Hornbildung in den Abhandlungen der königl. Akademie der Wissenschaften in Berlin, aus den Jahren, 1814-1815, p. 175. Berlin, 1818.-J. F. Meckel, Hornbildungen im Allgemeinen und insbesondere an der menschlichen Eichel, im D. Archiv für die Physiol.Vol. I. p. 298.

\section{$\S 94$.}

The ENTIRE WANT of the horny system cannot naturally occur throughout its whole extent; the PARTIAL DEFICIENCY, however, exists not unfrequently both as a congenital and acquired state, and may attack almost all the several parts of this system. ${ }^{1}$ Deficient formation of the horny tissue is often connected with debility of the skin, as well as of the whole body ; sometimes also, however, with peculiarity of race. The opposite vice, viz. EXCESS OF FORMATION OF THE HORNY Tissue, ${ }^{2}$ is commonly observed, and almost in every kind of variety; to this especially belong the existence of irregular HORNS and WARTS upon the skin. The former, the cornua cutanea, ${ }^{3}$ are usually composed of a kind of encysted tumour, sometimes also in consequence of blows, pressure, wounds, burns, \&c., frequently even without any distinct cause, but as mere growths of the cuticle; they occur on all parts of the body, although most commonly on the head; in old women, especially, they attain oftentimes an uncommon size and firmness, and are periodically thrown off and again renewed; sometimes several exist at the same time, or one is cleft in two, \&c. In animals we also notice them, particularly in horses and sheep, and even in birds. ${ }^{3} \mathrm{WARTS}_{\text {, verruca, }}{ }^{4}$ are little, mostly roundish, though sometimes also flat, pedicular, threadlike, or on the contrary, gibbous horny swellings, more or less deeply attached to the skin, which, in man and animals, are either separate and scattered, or in masses, and connected with other malformations of the skin, as for instance, with mothers' marks,${ }^{5}$ or they are observed covering entire parts, ${ }^{6}$ even including almost the whole body. The latter occurs in the so-called PORCUPINE-MEN, or in the highest degree of ICTHYOSIS CORNEA, and in part appears to be hereditary. ${ }^{7}$ If the horny tissue be destroyed on any particular part, it is REPRODUCED NATURALLY and without DIFFICULTy, as soon as the separated skin has been reproduced; still the reproductive power is not the same in all horny parts ; thus, the cuticle is always reproduced, the 
hair with more difficulty, the nails with still more, \&c. The opinion $^{8}$ that horny parts, viz. the hair and nails, grow after death, is founded on false accounts.

(1) I have more rarely observed, for instance, the deficiency of the horny excrescences, or chestnuts as they are called, on the insides of the legs of the horse, the size of which also varies very much. Their absence in the horse and mule is described by Havemam Anleitung zur Beurtheilung des äussern Pferdes, p. 194, 3d edit. Hannov. 1822; and Greve Bruchstiicke zur vergleichenden Anatomie und Physiologie, p. 38. Sro. Oldenburg, 1818.

(2) Plenck Lehre von den Hautkrankheiten, a. d. Lat. p. 141. Svo. Leipz. 1789.-Piccinelli Memoria sull' origine e cura di quelle escrescenze impropriamente chiamate corna umane. 8vo. Bergamo, 1816.-Meckel in Handb. der pathol. Anat. Vol. II. p. 276. ff.-Ernst D. de corneis hum. corp. excrescentiis, quarum generali brevique notitiæ singularis casus de hominis cujusdam corneis excrescentiis adjectus est. 4to. Berol. 1S19.-Many similar cases have been collected by Plouquet, Repertorium, Art. Corn. hominum. - Other instances are Mamnagetta and Detharding in Misc. Acad. N. C. Dec. I. Ann. I. p. 103; Dec. III. Ann. V. and VI. App. 148.-Lanzoni Misc. Acad. N. C. Dec. III. Ann. IV. p. 152, on the forehead of a boy.-Lauchmund ib. 1673 and 74. p. 239, Dec. III. Ann. III. App. p. 109, on the top of the foot.-Koenig ib. Dec. II. Ann. X. 1691, p. 208, on the great toe.-Gcguelin s. Sedillot Rec. périodique de la Soc. de Médec. de Paris. Vol. LIV.p. 96, on the back of the head.-Rochefort in Mém. de l'Acad. de Chir. Vol. III. Hist. p. 7, on the loins.-Majorat in Gazette salutaire de Bouillon. 17S8. v. Hufeland's Annalen. Vol. I. p. 447, No. 109, on the forehead.-Caldani in Mem. di Verona. Vol. XVI. p. 127, on the head.-Rigal in Dict. des Sc. médical. Vol. IV. p. 251, on the breastbone and on the tuberosity of the ischium.-Alibert, $i b$. two horns on the back of the head.-Otto Selt. Beob. Part I. p. 109, on the back of the hand.-Bertrand in Archives générales de Médecine, August 1824, on the head.-v. Plönnies in v. Froriep's Notizen, 1824, No. 135, p. 33, with plates, on the head; other cases, $i b .-P e n s a$ in Giornale medico Neapolitano, Settembre, 1825 ; v. Froriep, Vol. XVI. p. 89, one on the head, the other on the back. Vol. VIII. p. 112. Description and engraving of knobby growths on the hands and feet of Lorenz Ruff by Belirends, translated by Dr. W. Soemmerring, fol. p. 10. Frankf. a M. 1825, two cases on the head.-A. Cooper, in his and T'ravers' Surg. Essays, Part II. pl. 8. fig. 8 and 9.-Wiesenthal in New England Journ. of Medic. and Surgery. Boston, 1819, on the breast.-Ansianx Clinique chirurgicale. Liege, 1816, on the forehead. - Medical Repository, New-York, 1819, n. series, Vol. V. Part I. on the head, very large and divided. I have scen two twisted horns, several inches long, from the head of a woman, in the Museum of $C h$. Bell in London; another from the head in the Museum of St. Thomas's Hospital, London; another $2 \frac{1}{2}$ inches long, and as thick as one's finger, from the back of the head, in the Ashmolean Museum at Oxford. Concerning horns on the glans penis, v. Penis. - [Vic d'Azyr Observation sur une corne humaine, in Hist. de la Soc. Roy. de Méd. Vol. V. p. 294.-E. IIome, Observations on certain horny excrescences of the human body, in which are given Mr. Hunter's notions respecting the production of such excrescences. v. Phil. Trans. Vol. LXXXI. p. 95 . T.

(3) Malpighi found a horn hanging on the neck of an ox. v. Phil. Trans. 1684 , p. 601 . In oxen, especially in those of southern countries, the horns are not unfrequently attached merely by skin; in the IIunterian Museum, London, I saw a misshapen horny growth from the forchead of an ox, and a similar one in the Anat. Mus. at Oxford, hollow, an inch and a half in length, and an inch in diameter at the base. [J. Parsons, M.D. On a sheep shewn alive to the Royal Soc. in Nov. 1754, having a monstrous horn growing from his throat, Sc. which weighed twenty-six pounds. Phil. Trans. Vol. XLIX. p. 1S3. T.] A very large horn fiom the side of a sheep. v. Museum regium Danicun Olig. Jacobai, p. 6, engraved in Valentin's amphith. zootomicum, p. 130; 
on the same place I found a smaller one, about four inches long. v. Otto Selt. Beob. Part I. p. 109. In the horse they have been several times observed, for instance, Commerc. litter. 1739, p. 212.-Mannagetta.-Acta phys. med.' N. C. Vol. VII. p. 289,-a spiral shaped, as if turned, long, hornlike growth on the beak of a canary bird, v. Bemerkungen über einen monströsen Kanarienvogel, u. s. w. 4to. Hamburg, 1780, with engravings. I have also seen similar growths on the beak of a partridge ; an enormously large horny growth on the pelvis of a dove is described and figured by Rudolphi, p. 183 .

(4) Compare Reuss Repertor. Commentat. Vol. XII. p. 334.-de Plouquet Repert. Art. Verruca. - We loosely distinguish warts from their form and consistence Verruca vulgaris s. topica; V. pensilis s. Acrochordum; V. sessilis s. Porrum, s. Myrmecia; V. filiformis ; V. rhagadoidea, \&c. ; the Verrucæ carneæ, madidæ, the Mariscæ, \&c. do not belong here, but to the sarcomatous formations of the skin.

(5) I have seen this several times; amongst others, in a boy in the AlBERgo DE' Poveri, at GenoA, who had a mother's mark affecting the neck, the left side of the breast, and the greater part of the back, covered with black hair, and with horny warts and points.

(6) To this belongs, for instance, the so-called Leontiasis corniculata of Sauvages, Nosologia methodica, Part II. p. 417, tab. 3, in which he includes Ash's case, in the Phil. Trans. No. 176. To this belongs the case observed by Behrends and $W$. Soemmerring. v. above, note 2.

(7) Machin, in Philos. Transact. 1731, No. 424, p. 299. - Baker, ib. 1755, Vol. XLIX. Part I, p. 21.-Tilesius Ausführliche Beschreibung und Abbildung der beiden sogenannten Stachelschweinmenschen, u.s.w. fol. Altenburg, 1802.-Buniva in Mem. de Turin, 1809-1810, p. 364-403.-Ascanius in Journ. de Médec. etc. Vol. IV. p. 216. - Lauth Mémoires sur les frères Lambert, etc., in the Mémoires de la Soc. des Sc. de Strasbourg, 1811, Vol. I. p. 327. - Stalpart van der Wiel describes a similar disease in Obs. rar. Cent. II. Obs. 35.- Martin, in Medic. chir. Trans. Vol. IX. Part I. p. 52. v. Cerutti Pathol. anat. Museum. Part II. pl. 7. 8vo. Leipz. 1822, hereditary. - Mansfeldt Beschreibung einer Ichthyosis cornea spinosa partialis am Bauche eines Kindes, in Archiv f. medic. Erfahrung yon Horn, Nasse, Hencke and Wagner, July and Aug. 1823, p. 1, with engravings. - Loustein Compte rendu, etc. Part CXXXIX. No. 1071 , describes, from the Strasburg Museum, a child entirely covered with warts. The case described by Ernst, although more confined, also belongs here. - Haskel's Ichthyosis cornea, v. New-England Journ. of Med. and Surg, Vol. VIII. No. 1, p. 1, Boston, 1819, v. Salzburger medic.-chir. Zeitung, 1820, Vol. II. No. 38, p. 178, appears to belong rather to Leontiasis.

(8) To wit, Schubert Ahndungen einer allgemeinen Geschichte des Lebens. Vol. II. Part I. p. 63. Leipz. 1806-7.-Carus Versuch einer Darstellung des Nervensystems, p. 39. 4to. Leipz. 1814.

\section{$\S 95$.}

On account of the simplicity and similarity of the horny tissue, it is not surprising THAT IT IS SUBJECT TO BUT FEW DISEASES. Among these must be enumerated the CHANGE of COLOUR in deficient nutrition and in actual death; the DISCOLORATION which is sometimes only seeming, as parts composed of horn, if they be thickened, become dusky; sometimes there is an actual discoloration, as the morbid pigment produced in bodies is deposited in it; or colouring matter applied accidentally or purposely to the skin, hair, nails, \&c., easily colours the horny substance in various ways. Further, 
the vices of consistence, in which the horny tissue sometimes, in a manner recalling the inflammation of the other tissues of animal bodies, ${ }^{1}$ is very materially sOFTENED, swollen, and full of moisture; sometimes is irregularly dry, rough, and broken, whence are frequently produced vicES OF CONTINUITY, which show themselves as clefts, exfoliations, \&c.

(1) Compare above, $\S 53$, note 1 .

\section{First Chapter.}

\section{Of the External and Internal Cuticle. ${ }^{1}$}

\section{$\S 96$.}

The cuticle exhibits very great variation from its natural THICKNess, ${ }^{2}$ either original or acquired, in the development of the body; thus it is sometimes unusually DELICATE and THIN, but more frequently too THICK; the latter sometimes occurs simultaneously throughout the whole skin in barren and masculine-made women. Such irregularities are more usually the consequence of diseases; many scars, the healing edges of cancerous swellings, \&c. are indeed overspread with a thin external skin, which is usually so fine, that a smarting sensation of the skin is the consequence. ${ }^{3}$ Very frequently we observe, in consequence of diseases of the skin, especially of the inflammatory kind, an increased deposition of layers on the inner surface of the cuticle, ${ }^{4}$ whereby it sometimes acquires a very considerable thickness, even that of an inch, ${ }^{5}$ as well as growths of many kinds; most frequently the thickening occurs on particular spots in consequence of friction, pressure, \&c., and is then named CALLOSITY, callus, tyloma; ${ }^{\circ}$ and on the feet, especially on the toes, where like a pointed nail it buries itself deeply in the subjacent skin, whilst its upper surface is broad and projecting, and is then called a cORN, a HORNY substaNCE, clavus, gemursa, helos. ${ }^{7}$ Vices of thickness are usually connected with vICE of CONSISTENCE; thus, for instance, we observe the skin on parts which are moist, in the neighbourhood of ulcers, beneath plasters, at parts where there is habitual perspiration, \&c. irregularly soft, and on the contrary, also under many conditions, especially at the same time with thickening, TOO HARD, DRY, ROUGH, so that it presents, CLEFTS, rhagades, INERUALITIES and GROWTHS of various kinds, and 
both looks and feels like the bark of a tree; ${ }^{8}$ this is especially the case in syphilis, icthyosis, elephantiasis, \&c. The COLOUR of the cuticle is sometimes irregular, inasmuch as generally it not merely participates in the discoloration of the cutis, but also of itself assumes an unnatural colour, ${ }^{9}$ and can very frequently be coloured in different ways, by the introduction of colouring matter, accidentally or purposely; ${ }^{10}$ lastly, the cuticle commonly exhibits vices of CONTINUITY, thus it is either separated from the subjacent cutis by contusions, by the operation of blisters, and by many diseases, especially pemphigus, and is elevated in form of larger or smaller bladders filled with blood, lymph, and pus, or it is separated without forming any such bladders, in shape of bran, scales, even of entire sleeves, stockings, \&c. This commonly occurs after eruptixe diseases, for instance, erysipelas, small-pox, scarletfever, icthyosis ${ }^{11}$ is even periodical; the consequence of poison, ${ }^{12}$ and the like. In animals we also observe this desquamation $;^{13}$ and such of them as are naturally subjected to a change of skin at certain periods, as snakes, lizards, insects, viz. silkworms, ${ }^{14}$ exhibit indeed many irregularities with reference to these changes. In rare cases the internal cuticle or epithelium, has been observed to scale off, to wit, in the intestinal canal of a badger ${ }^{15}$ and of a mangy $\operatorname{dog}^{16}$

(1) Leidenfrost D. de epidermidis lumanæ natura et morbis. Duisburg. 1785. v. Opusc. Vol. IV. No. III. Compare the writers on diseases of the skin. Concerning diseases of the epithelium, v. Lelut, in Repert. gen. d'Anat. et de Physiol. pathol. Vol. III. Part II. p. 161. 1827.

(2) This appears also to be the case with the epithelium.

(3) Osthoff in v. Siebold's Cliron. Vol. II. p. 505.

(4) I have seen this also occur in the epithelium of the mouth and gullet after scalding with boiling water and sulphuric acid. Probably also, in $A s i^{\circ} s$ case, the air-tube was thickened by external horny growth of the epithelium, as $W$. Soemmerring rightly imagines, p. 10 .

(5) In one instance was the skin of the foot and hand so thick, v. Gardane, in Gazette de Santé, 1773, p. 23.

(6) Leeuwenhoek in Philos. Transactions, 1722, p. 156.-Lordat in Sedillot Recueil périod de la Soc. de Médec. de Paris. Vol. XXII. p. 427.-Nürnberger D. de cuticula e frictione comprimente callosa. Viteb. 1789. In animals, not unfrequently from the pressure of the harness ; for instance, on the neck of oxen. Clavus boum Columella. Vol. VI. p. 14.

(7) Wedel D. de clavo pedis. Jenæ, 1675. - Camerarius D. de Gemursa Pliniana, clavi pedis maligniori specie. Tub. 1722.--Lnchner De clavi in pedibus maligna specie, etc. in Ephem. A. N. C. Cent. I and II. p. 419.- van der Haar Berigt om exter-öogen in Verhandl. van het Maatsch. te Haarlem. D. XIII. Part T. p. 605.-J. Wardrop, in Med.-chir. Trans. Vol. V. p. 129.-Lion, Complete Treatise upon spinæ pedum. 8vo. London, 1802, with engravings.-[D. Low, Chiropodologia, or a scientific inquiry into the causes of corns, warts, \&c. 8vo. London, 1785.-A. Carlisle, Observations on the nature of corns, and the means of removing them, in Med. Facts and Observations, Vol. V.II. p. 29. T.]

(8) Vater Pr. de cuticula pueri 15 annorum, cutis rhinocerotis aut corticis arboris instar incrassata, quotannis decidua. Viteb. 1735. In a calf without 
hair, all the skin was covered with scales. v. Fresier in den Mém. de l'Acad. $1722, \mathrm{p} .21$. In negroes, the cuticle on the sole of the foot is often thickened and burst from the heat of the soil. v. Mercurialis De decoriatione, p. m. 103.Blumenbach De generis hum. varietate nativa. p. 246, note 6 .

(9) To wit, the blackish tinge in a new-born child, which, after three weeks, is lost in the black colour of the cuticle. Bernstein in der Salzb. medic. chir. Zeitung, 1813, No. 87, p. 143.

(10) We observe the hands of dyers, the colouring of the cuticle from poultices, plasters, from steeping in a solution of lapis infernalis, the accidental colouring of the skin of many nations with carthamus tinctorius, bixa orellana, \&c.

(11) In my younger days, I had once to treat a person with this disease, in whose bed I found, every morning, three pints of such scales.

(12) For instance, arsenic.-de Haen Rat. Med. Part X. p. 2. § 7.

(13) In many diseases. Camels sometimes lose the whole sole of the foot in wet ground.-Pallas Neue Nordische Beiträge. Vol. II. p. 160. [It has also occurred, that after the operation of nerving horses, proposed by MIr. Sewell, and often attended with success, the hoof has been thrown off. T.]

(14) Bergmann Primæ lineæ anat. comparat. p. 27.

(15) Rudolphi Anat. physiol. Abhandl. p. 46.

(16) Hedwig in Isenflam's and Rosenmiiller's Beiträgen, Vol. II. p. 54.

\section{Second Chapter.}

\section{Of the Nails and Hoofs. ${ }^{1}$}

\section{$\S 97$.}

In rare cases the nails are WANTING originally; ${ }^{2}$ this especially occurs in the imperfect development of supernumerary fingers and toes. Sometimes also a GREATER NUMBER of nails is seen, so that one finger or toe exhibits, with other traces of duplication, even two nails; it is said that many Chinese have two nails on the little toe. ${ }^{3}$ Their sIze, THICKNESS, and Form, is often irregular ; ${ }^{4}$ thus are they found congenitally TOO SMALL and TOo THIN, or become so in later years, as the consequence of deficient nutrition, as in paralytic persons; in horses a hoof may be too narrow, the so-called NARROW-HEELED HOOF, so also is the SHRINKING and conTRACTION of the hoof, not an unfrequent vice. Often we find the contrary, viz. the increase of the nail with thickening, very great elongation, claw-like curving, ${ }^{5} \& \mathrm{c}$. This sometimes occurs simultaneously with the increase of other horny organs, ${ }^{6}$ although it may also occur alone; it is often caused by incessant cutting and rubbing; and is not unfrequently seen in animals. ${ }^{7}$ Irregular enlargement of the nail, and pressure causes its cONVERSION INTO FLESH. ${ }^{8}$ Frequently also are nails con- 
genitally malformed; to this especially belongs the consoliDATION of two, three, and four nails on connected fingers and toes. ${ }^{9} \quad$ In many diseases, the form of the nail also is changed; thus, for instance, in the blue disease, the entire tips of the fingers and toes become unusually large, broad, and curved $;^{10}$ in consumption they become curved and arched in a peculiar way, either in the early or very last stage of the disease ${ }^{11}$ in lepra, mishapen, ${ }^{12} \& c$. Newly produced nails are also frequently very much malformed.

(1) Plempius De affectibus capilloruin et unguium. 4to. Sorau. 1662.-Werner D. de unguibus humanis, varioque modo, quo possunt corrumpi. Lips. 1773. - Nürnberger Meletemata super digitorum unguibus. 4to. Wittenb. 1786. - Blech Tractatio de mutationibus unguium morbosis. 4to. Berol. 1816, with engravings. -- Ozanan in Annales cliniques de Montpellier, Juillet, 1822. - Royer Collard in Repert. général d'Anatom. et de Physiol. pathol. Vol. II. p. 199, pl. 6 and 7.-Bergmann Die Krankheiten der Haut, der Haare, und Nägel. 8vo. Leipz. 1824.-Coleman, Observations on the structure, economy, and diseases of the foot of the horse, Vol. I. and II. 4to. London, 1801 and 1802. Compare also Camper, on the best form of the shoe, and Wardrop, an account of some diseases of the toes and fingers, \&c. in Med. chir. Transact. Vol. V. p. 129, and the writings of the Chiropedists. - A. Cooper, in Lond. med. and phys. Journ. April, 1827. [M. Hall, Commentaries on some of the more important diseases of fernales. 8 vo. London, 1827 . T. $]$

(2) For instance, in a monster in the Museum at Berlin; on all the toes in a monster in the Bresl. Mus. v. Otto Verzeichniss der anat. Präparatensammlung, No. 2888.

(3) Neuhoff Gesandtschaft an den tartarischen Chan, u. s. w. p. 263.

(4) Franck de Franckenau D. de unguibus monstrosis, etc. Hafniæ, 1716.Rouhault Observation anatomique sur des ongles monstrueux in Mém. de Paris. A. 1719. Hist. p. 38 .

(5) Old examples in de Plouquet Repertorium Art. Unguis; Haller Elem. Physiol. Vol. V. p. 30.-in Blech.-A case, Henning, in Horn's Archiv f. med. Erfahrung, 1823, Septbr. u. Octbr. p. 205. fig. 2 and 3.-Lion gives several plates of very ill-formed nails, pl. 1 and 2 ; I have also seen several very large. In the Bresl. Mus. in a monster, No. 2888, is a part of the left hand very long and clawlike. In the Museum at Freyburg, I saw all the nails of one hand remarkably large. [Lncke in Phil. Trans. Vol. XIX. p. 594. Nails on most of the fingers and toes four inches long, and other horny growths on the back of the hands, in a boy of twenty years old.-R. Wroe. Case of a boy in which, within a twelvemonth, the nails of the left hand grew to the length of two inches, " with great quicks or roots under the nails," which were painful when cut, but not otherwise; subsequently they grew on the fingers of the right hand; on both hands they seemed to acquire their full growth in twelve months, then fell off without pain, and were reproduced. It is further mentioned that "he was miserably overspread with leprosy," probably ichthyosis. v. Phil. Trans. Vol. XXIV. p. 1899. In the Museum at St. Thomas's Hospital there are two nails about two inches in length, very much curved, and extending far beyond the ends of the fingers, and I remember it used to be mentioned at the lecture that they were so extremely sensitive, that any attempt at cutting them was attended with severe pain, but I have no further history of them. In Cruvelhier, Anatomie Pathologique, fol. Part VII. plate 6, Maladies de la peau (productions cornées), fig. 2 and $2^{1}$, have a very near resemblance to those just mentioned, but at present no account is given of them. T.]

(6) Musceus D. de unguibus monstrosis. Hafn. 1716, with fig.-Locke in Philos. Transact. No. 230.-Haskell.in New England Journ. of Medicine and Surgery, Vol. VIII. No. 1. Boston, 1819.-Ash Phil. Transact. No. 176.-Behrends and W. Soemmerring, pl. 2-4. 
(7) In wild animals which are confined, I have several times observed elongation and deformity of the claws-in dogs it is sometimes the cause of lameness. v. Blaine On the Diseases of Dogs.-In oxen I have seen it several times; a short time since I possessed two ox feet, in which the hooflets were four inches long, and completely cylindrical;-in the horse there is very frequently malformation of the hoof, as flat-hoof, bound-hoof, brittle-hoof, pomet-foot, ass-hoof, \&r. ; in domestic birds the monstrous elongation of the claws is very common.

(8) Compare especially Roger Collard.

(9) The monsters, No. 2906 and 2917, of the Bresl. Mus. exhibit such nails, the Iatter a common nail for the fingers of the right hand; cases of this kind were also noticed by $v$. Walther Ueber die angebornen Fetthautgeschwiil-ste und andre Bildungsfehler, p. 31. fol. Landshut, 1814. I saw a consolidation of the four outer nails of both hands of a remarkable thief in the Anatomical Museum at Freyburg. Something similar occurs in the undivided hoofs of pigs, v. Otto Selt. Beob. Part II. p. 83. I have since procured the skeleton of a pig of this kind for the Museum, No. 4652, and saw in the Veterinary School at Stockholm, three full-grown swine with the same deformity.

(10) Blech, fig. 5 and 6.

(11) Ib. fig. I and 2.

(12) Schmidt Diss. de leprosa, unguibus monstrosis prædita. Ultraj. 1696.

\section{$\$ 98$.}

The colour of the nails is not unfrequently irregular, thus in many diseases they lose their gloss, reddish colour, and natural transparency; or WHITE STREAKs, seline, are produced in consequence of partial or deficient nourishment; they even become entirely white, which has been once observed in a paralytic person ; ${ }^{1}$ sometimes the normal white streak, lunula, is deficient; in jaundice they assume a YELLOW colour; sometimes yellow and red streaks are produced, as in the hoof of a horse affected with the so-called CORNs; they appear DUSKY and BLursh in the blue disease, in suffocation, after bruises, in which blood is collected beneath them; they have been seen BLACKISH in some diseases. ${ }^{2}$ The nails are also easily coloured either accidentally or purposely in various ways, for instance, yellow, brown, and even black, in baths containing iron and sulphur, ${ }^{3}$ reddish in baths of red madder; in dyers, tanners, hat-makers, they are often deeply coloured, and many nations have the custom of colouring their nails. ${ }^{4}$

(1) Loder Medic. chir. Beobactungen, Vol. I. Svo. Weimer, 1794.

(2) Bartholinus Acta Hafn. I. Obs. 32.-Jackson. - d'Outrepont in Reil's Archiv f. d. Physiol. Vol. IV. p. 472.-I have also seen it so twice in typhus fever.

(3) Waitz in Itufelund's Journ. d. prakt. Heilk. Vol. XVI. Part II. p. 22.

(4) For instance, in the east, red with the Lawsonia inermis.

$$
\S 99 \text {. }
$$

We frequently find the consistence and TExture of the nails morbidly changed, either alone or generally together with similar changes in the cuticle. Spots, lepra, syphilis, gout, 
polish plait, tabes, as well as the handling of sharp instruments by handicraft men, operate on them most frequently and prejudicially; we also observe them diseased in insane people. ${ }^{1}$ The substance of the nail itself is sometimes sofTENED, LOOSENED, SOAKED IN BLOOD, ${ }^{2}$ more frequently it is very DRY, ROUGH, and HARSH, splits, ${ }^{3}$ and scales off in plates. The nails not unfrequently dry up, and are thrown off either alone, or together with the skin. Often also are they changed more or less by ulceration of the soft substance lying beneath and around them, are covered with proud flesh, pterygium unguium, and are partially separated or completely thrown off; this is especially the case in WHITLOE or FELON, panaritium, ${ }^{4}$ in the so-called CANKER OF THE sOLE in horses, ${ }^{5}$ and in the sporadic and epizootic diseases of THE CLAws. Finally, we observe many variations in reference to the FAvourabLE REPRODUCTIVE POWER of the nails; thus it produces in sharp wounds, divisions of the hoof, \&c. puffy SCARs projecting much externally or even internally; or if the nails have entirely been shed, they are either not reproduced or indeed only on foreign parts ; for instance, after partial or complete loss of the finger, they are reproduced on the second or first joint, and even on the fore extremity of the metacarpus $;^{6}$ on the latter part they have been observed also as vices of structure in imperfect fingers, ${ }^{7}$ as well also as congenital on the inside of the forefinger. ${ }^{8}$

(1) Blech gives an engraving of it, fig. 3 and 4.

(2) This at least is the case with the hoof of the horse in corns; perhaps also the case in the human subject given by Nees in Hufeland's Journ. d. prakt. Heilk. Vol. XVI. Part II. p. 183, belongs here.

(3) Not very unfrequent on the hoofs of horses and oxen, and in the former known by the name of cracked hoof, sandcrack, cleft hoof, broken hoof, \&c. Compare Schwab Materialien zu einer pathologischen Anatomie der Hausthiere. 1 st Part, p. 26. 8vo. München, 1815. The sanderack arises usually mechanically from false quittor, whereby the hoof is entirely thrown off at the coronet.

(4) Called also Panaris, Onychia, Paronychia. Acrel in Svenska Vetensk. Acad. Handl. A. 1754, p. 271.- van Amstel D. de paronychia. Lugd. Bat. 1758.-Sue D. de panaritio. Paris, 1772 ; and in Mémoir. de la Soc. médicale d'émulation, Vol. II. p. 284. - Focke D. de paronychia. Gött. 1786.-Melchior D. de panaritio. Duisb. 1789.-Flajani Osservazioni pratiche sopra-il panereccio. Roma, 1791. - Eggel D. de panaritio. Erfurt, 1792._Barfoth D. de panaritio. Lund. 1800. - Vogt D. de paronychia. Viteb. 1803.-Cyvoet D. sur le Panaris. Paris, 1807. -Wardrop.

(5) To abscesses of the nails belong also the quittor and thrush of veterinary physicians.

(6) Pechlin Observat. L. II. Obs. 42. - Tulpius Observat. medic. L. IV. c. LVI. p. 370. - Voigtel Handb. der pathol. Anatomie, Vol. I. p. 86. - Marechal de Rougeres in Journ. de Médec. Vol. XXVII. p. 177.-Ormancey in Journ. de Médec. continué, Vol. XVII. p. 218.

(7) Bartholinus Hist. anat. Vol. I. p. 241.

(8) $I b .240$. 


\title{
Third Chapter.
}

\section{Of Hair ${ }^{1}$ and Feathers.}

\author{
$\S 100$.
}

The formation of hair and feathers is not unfrequently seen DEFICIENT, in consequence of general weakness of the body, or of a certain peculiarity of race; here belong ENTIRE DEFICIENCY of these parts, which has been observed as a congenital formation in man, ${ }^{2}$ and animals $;^{3}$ mere LOCAL DEFICIENCY, ${ }^{4}$ RETARDED PUTTING FORTH OF THE HAIR, either generally or locally, and finally, the TOO SPARING GROWTH OF THE HAIR. ${ }^{5}$ More commonly are the hairs deficient generally or locally, when, as is the fashion with many people, they have been carefully pulled out and removed by aquafortis, or have fallen out from disease ${ }^{6}$ the latter is very common on the head, and is even hereditary ${ }^{7}$ and endemic. ${ }^{8}$ The opposite vice also, viz. EXCESS IN THE FORMATION OF HAIR AND FEATHERS, not unfrequently occurs, in so far as the growth of hair on the whole body, or only on certain parts ${ }^{9}$ is too great; it is also observed on very unusual situations, ${ }^{10}$ or uncommonly early, ${ }^{11}$ and even in advanced age. ${ }^{12}$

(1) Joubert De affectibus pilorum et cutis, præsertim capitis. 8 vo. Lyon, 1577. - Ampsing Hortus adfectionum capillos et pilos corp. hum. infestantium. 4to. Rostock, 1623.-Fort. Plempius De affectibus capillorum et unguium. Lovan. 1661.-Meibom D. de pilis eorumque morbis. Helmst. 1704.-Salwick D. de morbis pilorum. Frib. 1777.-Pfaff D. de varietatibus pilorum naturalibus et præternaturalibus. 4to. Halæ. 1799.-Wolfart Bemerk. iiber die krankhafte Veränlerung der Haare, in Asklepieion, 1811, No. 41, p. 674.- Wedemeyer Com. historiam pathologicam pilorum corporis humani sistens. 4to. Götting. 1812. - van der Burch D. de integumentis conınunibus, pilis ac pilorum varietatibus. L. B. 1814.-Meckel Ueber regelwidrige Haar-und Zahnbildungen, in Archiv für die Physiologie, Vol. I. p. 519. - Agilli D. de pilorum anatomia, physiologia, pathologia et therapia. 8vo. Berol. 1819. - Buck D. de pilis eorumque morbis. 8vo. Halæ, 1819.-Bersmann die Krankheiten der Haut, der Haare und Nägel. 8vo. Leipz. 1824.-Benvenuti De naturali et morbosa pilorum œeconomia. 8vo. Patav. 1825.-Vogel Von der diagnostischen Würde der Haare, in Hecker's literar. Annalen der ges Heilkunde, 1825, Novbr. u. Decbr.-Blümmener Adhandlung über das menschliche Haupthaar, in listor. anatom. physiol. pathologisch und therapeut. Hinsicht. Svo. Berlin, 1826.

(2) Heister in Ephem. Acad. N. Cur. Cent. I. and II. p. 431.-Danz in Stark's Archiv f. d. Geburtshïlfe, Vol. IV. p. 684, in two adult Jews who never had teeth. - Augustin in Wolfart's Asklepieion, 1812, März, p. 281. - Wells in Transact. of the Soc. mell. and chir. knowledge, Vol. 1I. p. 264. [In 1811 there was a man, aged twenty years, employed at the Courier newspaper office, London, who had not any hair upon the head, eyebrows, eyelids, nor chin, and was said to have had none on the pubes. 'T'.]

(3) For instance, the known races of horses and dogs without hair ; a rabbit, v. Allg. Hist der Natur. Part VII. Vol. II. 1). 238. No. 1415 ; a cat, Guettard Mémoires. Vol. I1. 1. 17.-I also once possessed a full grown goat, entirely bare 
from birth; it also occurs in birds. I knew, for instance, a kind of doves entirely featherless, which so continued to be produced through many generations. - Otto Verzeichn. d. anat. Präparatensammlung, No. 2132. - Schleep describes an unfledged canary bird in the N. Annalen der Wetterauischen Gesellschaft, Vol. I. Part I. p. 180.

(4) For example, bare spots in the beard; in one case also on the head in the region of the fontanel. v. Misc. N. Cur. Dec. I. Ann. VI. Obs. 74.

(5) For example, in weakly persons, in eunuchs.

(6) Pilorum defluvium, Alopecia, Madarosis, Calvities, upon the head also called Area, Ovum and Ophiasis, is the consequence of great weakness, therefore also of many acute and chronic diseases, of lying-in, of grief, of fear, of many exanthematous diseases, especially the itch, of poisoning by arsenic, \&c.; in animals also, falling off of the hair occurs; viz. among domestic animals, especially in horses, sheep, and swine. I observed it also in a stag which I still possess; it is common in parrots, and other domesticated birds.

(7) Mangili sulla calvezza ereditaria, in Giorn. della Soc. med. chir. di Parma. Vol. VIII. p. 57.

(8) In Barbary, according to Leo Africanus Descriptio Africæ, Lib. I. p. 85.

(9) For example, in the beard of sterile women; compare Hippocrates E $\pi \iota \delta \eta \iota \omega \nu$, Lib. VI. Sect. VIII. - Haller Elem. Physiol. Vol. V. p. 32.-de Plouquet Repertor. Barba mulierum.-Reuss Repert. Comment. Vol. X. p. 205. -Curiositäten der phys. liter. artist. histor. Vor-und Mitwelt. Vol. I. Part I. Weimar, 1811. - I have myself seen many, both alive and in engravings. Too great length of hair of the head, so that it reaches the ground, Briickmann in Horn's Archiv für medic. Erfahrung, 1811, Vol. II. p. 69 ; the pubic hair in a woman an ell and a half long; v. Collect. Acad. Vol. III. p. 168; a monstrously long tail in a horse in the Royal Cabinet of Natural History at Dresden ; frequently very long manes in horses; monstrous strange feathers in many kinds of domestic birds; individual very long feathers in birds, \&c.

(10) In anencephalous monsters, the hair of the head descends to the eyebrows and root of the nose, and if the spine be, at the same time, cleft, also along its edges; stiff hairs on the upper end of acephalous monsters; upon the navel, Osiander Denkwürdigkeiten a. d. Geburtshülfe, Vol. II. Part II. p. 406 ; a hairy stripe upon the back, Gilibert Samml. prakt. Beobact. übers. v. Hebenstreit, Leipz. 1772 , p. 56 ; especially on warts and mothers' marks, viz. Rosenmüller in his and Isenflanm's Beitr. f. d. Zergliederungskunst, Vol. II. No. 1. p. 106 , pl. 2, fig. 2, upon almost the whole back, besides many other examples; from the breast and shoulders down to the knees, Ruggieri Storia ragionata di una Donna, avente gran parte del corpo coperta di pile et pelle nero. 8vo. Venez. 1815 ; with which are also several other instances; $v$. Walther Ueber die angebornen Fettlıautgeschwülste, u. s. w. fol. Landshut, 1814, pl. 1 and 2 ; upon hair in encysted tumours, compare $\$ 64$, note 9 ; upon hair in the other internal parts, the same.

(11) Compare $\$ 20$, note 4 ; in a girl four years and nine months old, there were strong pubic hairs, Cookson in Medic. and Phys. Journ. Sédillot Journ. géner. de Médec. Vol. XLVII. p. 101.

(12) Schurich De calvo post triginta annorum decursum comato. Misc. Acad. N. Cur. Dec. III. Ann. 7 and 8, p. 191.-Observations sur des cheveux et deux dents revenus à un homme de 70 ans, in Mém. de Paris. An. 1703. Hist. p. 37.

\section{$\S 101$.}

Sometimes also the Form of the hair varies; thus we notice it irregularly thin and fine, for instance, as a kind of lanugo on the skin in adult albinoes; but it is more frequently too thick and stiff; it is often found unequally thick, thus in different places thinner and thicker, here and there knotted, when broken, for instance on the hands, on the parts of hernia, 
\&c.; human hairs are sometimes cleft at the end like bristles, dicophyia. Animals which have the hair otherwise smooth, present it, as an exception, curled $;^{1}$ we also find the direction of the hair and feathers irregular in other respects, for instance, in trichiasis of the eye-lashes, on the head taking unusual turns; certain feathers twisted, \&c. Feathers are produced without barbs, especially in one variety of fowls; on the contrary, there are also double hairs and feathers, sometimes two or several spring out of a single root $;^{2}$ the feathers of very old female birds even assume the form of those of the male, \&c. ${ }^{3}$

(1) A horse with curly hair is engraved in Geoffroy and F. Cuvier's Mammifères, Liv. 32. I saw three horses in the Cabinet of Natural History, in the University and in the Veterinary School at Vienna, with all the liair curly; in a peculiar kind of fowl, the featliers are not unfrequently secn crisped and bent up; I knew a lady, who lost her long smooth hair, which became short and curly; the hair sometimes crisps only during disease, viz. under an attack of gout in the head. v. American Medical Recorder, p. 277.

(2) I have myself noticed such hair; I have also seen a double feather from a goose and from a partridge. v. Otto Verzeichniss d. anat. Präparatensamml. No. 6069.- - Hanow also saw a double wing feather in a goose. v. his Seltenheiten der Natur. Vol. III. p. 114; in many birds remarkable double feathers belong to their natural structure.

(3) For instance, the long band-like feathers of the cock; old hens of the Meleagris Gallopavo sometimes have a hairy tuft on the breast like the males. v. Bechstein Naturgeschichte Deutschl. Vol. III. p. 116.

\section{$\S 102$.}

The COLOuR of the hair and feathers is still more frequently irregular; this is not uncommonly observed as a CONGENITAL or ORIGINAL, and even as an HEREDITARY STATE; to it belongs the unusually LIGHT or ENTIRE WHITE COLOUR of hair and feathers which we observe, especially, in albinoes among men and animals, although also without this known vice in the eyes. $^{1}$ Sometimes the colour of hair and feathers is only white at certain parts, and the body merely spotted. ${ }^{2}$ We also notice other various colours, ${ }^{3}$ as well as the remarkable variation of the colour of the hair in man on various parts of the body. The change of colour in hair and feathers is more frequently ACQUIRED and produced in later years from disease, food, old age; here is to be observed the bleaching of the hair, and its greyness, canities, which occurs in later age, and also earlier under weakening influences, even in rare cases is sudden, sometimes also only local ; ${ }^{4}$ we see besides, though rarely, the outer half of the hair become white, whilst that nearest the root remains black. ${ }^{5}$ Much more seldom is the deepening of the colour of the hair and feathers which we have however seen in $\operatorname{man}^{6}$ and animals. ${ }^{7}$ We observe also other colours; thus, for example, in a woman with blond hair, so often as she 
had fever it became reddish. ${ }^{8}$ Parrots, it is said, in a diseased state, become not white but yellow; also the same colour still remaining, different shades in it are produced. ${ }^{9}$ We have frequently seen hen birds assume in old age the colour and form of the plumage of the male..$^{10}$ Finally, it is known, that the hair can either accidentally or purposely ${ }^{11}$ be rendered black, violet, blue, and green, by various pigments.

(1) Several instances are mentioned of men born with grey hairs; I myself knew a young man, who from his birth had so much white beneath his black hair, that it appeared grey; among mammalia the white colour has been seen as an irregularity in the ape, shrew, mole, marten, (of both the latter there are instances in the Bresl. Mus. of Natural History,) polecat, seal, fox, rat, the several kinds of mice, the squirrel, hare, elephant, horse, camel, stag, fallow deer, and buffalo; among birds we often see white ravens and crows, (one such I possessed alive for a long time,) sparrows, larks, finches, linnets, buntings, swallows, \&c. ; a white Corvus Cornix and Monedula, Garrulus glandarius, Ampelis garrulus, Turdus iliacus, pilaris and musicus, Hirundo rustica, three examples, Alauda arvensis, Motacilla flava, Fringilla domestica and montana, exist in Bresl. Zoological Museum; many instances have been collected by Tiedemann in his Zoologie, Vol. III. p. 304. Compare Günther's Gedanken über die ganz weissen Vögel, welche von anders gefärbten Eltern anatomisch erzeugt werden, im Naturforscher, Part I. p. 54.-Zorn Einwendungen gegen Günther's Hypothese, und Walch von der anomalischen weissen Farbe der Vögel, ib. Part IV. p. 128 and 135.-A white song-thrush and a similar cross-bill are described in Meyer's Zeitsclirift für das Forst-und Jagdwesen in Baiern. 2ter Jahrg. München, 1814.

(2) For instance, stags with a white spot, v. Wildungen Taschenbuch f. Forstund Jagdfreunde f. die Jahre, 1809-1812, Marburg, with an engraving. I saw a similar stag, and one with a much larger white spot on the neck, in the Royal Saxon Zoological Garden at Moritzburgh; a white-thighed roebuck, v. Gatterer and Laurop, Annalen der Forst-und Jagdwissenchaft, Darmstadt, 1811. 1st vol. White spots on birds are not uncommon; in Bresl. Mus. a crow and a song-thrush exhibit them.

(3) Red hair in dark nations, fox-red elephants, a light bay-coloured marten, and an iron-grey roebuck, in Bresl. Mus.

(4) For instance, only on one side of the head. I knew a young officer, in the midst of whose black hair was one completely white lock; in horses, several white spots, from pressure of the harness, are very common; black fowls, when very old, have often white spots. v. Schröter in den Berlin, Mannigfaltigkeiten, Jahrg. II. p. 168.

(5) Destrés in Journ. génér. de Médec. Vol. LXIX. p. 213, Nov. 1819. - de Plouquet Repertor. Art. Capillorum Denigratio.

(6) Bruley in Sédilot Rec. périod. de la Soc. de Santé de Paris, Vol. IV. p. 290.-J. Sinclair, The code of health and longevity, 4 vols. 8 vo. Edinb. 1807. Instead of falling out, light hair will become dark, as I have myself noticed. v. Dict. des Sciences Médicales, Vol. IV. p. 17.

(7) For instance, stags becoming black, v. Sylvan, etc. von Laurop and Fischer. No. 5. Marburg, 1813. - I saw a completely black mus arvalis, in the museum of Professor Schinz, at Zurich. Birds which are confined, as bulfinches, crossbills, goldfinches, often become darker. Compare Günther, Gedanken über die Entstehung der anomalischen schwarzen Farbe verschiedner sonst anders gefärbter Vögel im Naturforscher, Vol. II. p. 1. [Larks in confinement, fed upon hempseed, will become black, as also other birds. T.]

(8) Isouard in Journ. compl. du Dict. des Sc. médic. Vol. V. p. 39 ; in one other instance, instead of blond-hair falling off, it became red. v. Dict. des Sc. Médic. Vol. IV. p. 7.

(9) Le Vaillant v. Rudolphi's Bemerkungen auf einer Reise u. s.w. Part I. 
p. 235 ; it is however said, that the little green parrot, from Surat, becomes quite white in old age. v. Turpin, Hist. de Siam, Vol. I. p. 321. I possess one, probably very old, Psittacus dominicensis, which was first bright red, then marked with dark red spots, and at last almost entirely of a deep purple colour; but the tips of the wings remained bluish-green. In Bresl. Mus. there is a wild Anas boschus, of which the whole under parts have a beautiful purple-coloured plumage.

(10) J. Hunter, in Phil. Trans. Vol. LXX. p. 527; and in his Obs. on certain parts of the Animal Economy, p. 75. 4to. 2d edit. London, 1792.-Blumenbach, in his Institut. Physiol. p. 550 ; and in De anomalis et vitiosis quibusdam nisus formativi aberrationibus Commentatio. 4to. Gött. 1813.-Tiedemann Zoologie, Vol. III. p. 306. - Kob D. de mutatione sexus. p. 11. Svo. Berol. 1823.Butler, in Memoirs of the Wernerian Nat. Hist. Soc. Vol. III. p. 188. - Isid. Geoffroy-Saint-Hillaire in Mémoires du Museum, Vol. XII. p. 220, and in Annales des Sc. Naturelles, Vol. VII. p. 336, March, 1826. This has been also observed in the Phasianus colchicus, nycthemerus, pictus and gallus, in the Meleagris Gallopavo, Tetrao Perdrix, Columba, Otis tarda, Platalea, Anas, in the Ampelides, in some species of Fringilla, Motacilla erythacus, and in Sturnus vulgaris.

(11) In persons of light hair, who work in metal, it is found green and blue.

$\S 103$.

The vices of CONSISTENCE and STRUCTURE are, as might be expected from the simple structure of the hair, but few. To these belong first, the irregular DRYNESS and STIFFNESS of the hair, which arise indeed from a diminution in the quantity of the fatty and lymph-like moisture contained in it, and run on either to the dryness and shedding of the hair already mentioned, or to splitting and breaking; ${ }^{1}$ then the opposite vice, or sofTENING, LOOSENING, VERY GREAT MOISTURE, and ACTIVITY OF SECRETrov in the hairs and feathers. ${ }^{2}$ We observe these frequently in scald head, tinea, in the rot in pigs, and especially in POLISH Plait, plica polonica, trichoma, cirrhagra, ${ }^{3} \& c$. The latter disease occurs spontaneously, but is endemic and even hereditary in Poland, and consists of a peculiar entangling and matting of the hairs, which are swollen at their roots and are more or less soft, and secrete a kind of viscous lymph, by which the hair of the head, the beard, or hair of the pubes, forms various cap-like or plaited masses. The same disease occurs also in animals. ${ }^{4}$

(1) E. H. Weber in Meekel's Archiv f. Anat. und Phys. 1827, No. 11, p. 222.

(2) In many diseases of the horse, oxen, and sheep, we find the hair too soft. v. Vollst. Handb. der Vieharzneikunst von Chabert, Flandrin, and Huzard. Vol. II. p. 186 . Berlin, 1801.

(3) v. the writers in de Plouquet Repertor. and Reuss Repert. Comment. Art. Plica polonica; the most important and recent cases, in Haller Disp. med. pract. Vol. I._Vicat Mém. sur la Plique polonaise. Lausall. 1775.-de la Fontaine Chir. med. Ablandl. 8vo. Breslau, 1792, with seven plates.-Bercnds D. de dubio plicæ polonica inter morbos loco. Francof. 1801.-Wolfram Versuch über die hüchst wahrscheinl. Ursachen des Weichselzopfes. 8vo. Breslau, 1S0\%. J. F. A. Schlegel Ueber die Ursachen des Weichselzopfes der Menschen und Thiere. 8vo. Jena, 1806, with engravings; and in Materialien f. die Staatsarzneiwissenschaft, Vol. VI.; and in Neuen Materialien u.s.w. Vol. I1. No. 22, with drawings. - Walter D. de pl. 1). Marb. 1808.-Gembitzki D. de singulari pilorum vegetatione morbosa, etc. Erlurt, 1808.-Chromy Neuste Wahrnch- 
mungen über die Krankheit des Weichselzopfes u.s.w. 8vo. Krakau, 1809.v. Ruhmfeld Neuste Geschichte des Weichselzopfes. 8vo. Freiberg, 1813.J. Frank, Mémoirs sur l'origine et la nature de la plique polonaise. Vilna, 1814.--Hecker Gedanken über die Natur u. Ursachen des Weichselzopfes. 8vo. Gotha, 1819.-Szklarski D. de trichomate. 8vo. Berol. 1823. - Goullon D. de plica polonica. 8vo. Berol. 1824.-v. Steinköhl der Weichselzopf in Deutschland. 4to. Hadamar, 1824, with one plate.-J. Schlesinger D. de trichomate. Svo. Berol. 1827. - Compare also Larrey's Med. chir. Denkwürdigkeiten, and Alibert Maladies de la Peau, p. 25-48, pl. 6-10.-Leschenault de la Tour on the Polish plait in India, in Mémoires du Muséum d'hist. nat. Vol. IX. p. 245.- - A Artiele Trichoma in Dict. des Sciences Médic.-de Carro on Plica polonica in Med. cliir. Rev. Vol. XIII. p. xxx.-Defour, Case of plica polonica, in Lond. Med and Phys. Journ. Vol. XVI. p. 235. T.] The opinions held by the ancients concerning the blood contained in the hair, in plica polonica, has been treated of lately by Henning, v. Horn's Archiv f. medic. Erfahr. Sept. and Oct. 1823, p. 201. Many cases of plica are found in Bresl. Mus. v. Otto Verzeichn. No. 3998-4013. Even the cliemical composition of the hair is so changed in this disease, that it dissolves in boiling.

(4) For instance, in horses in North Germany. Greve Erfahr. u. Beobachtungen über die Krankheiten der Hausthiere u.s.w. p. 112. Oldenberg, 1818; in oxen, dogs, and foxes.

\section{FIFTEENTH SECTION.}

\section{Of the Bony System.}

\section{First Chapter.}

\section{Of Bones in General. ${ }^{1}$}

\section{$\S 104$.}

The Formation and PERfECTION OF THE BONY SYSTEM, in man and animals, is subject to various INTERRUPTIONs both as to time and degree, sometimes accompanied with imperfect development of the whole organism, sometimes merely with that of the skeleton alone. In rare cases, not the least trace of bone ${ }^{2}$ has been found in monsters; more commonly the deposition of lime in the cartilaginous nidus of the skeleton is, alone, either entirely or partially deficient, and the latter therefore in a high degree imperfect; this is most generally the case in congenital rickets ${ }^{3}$ although also after birth the perfection of the bones is sometimes very much disturbed by debility, disease and pressure $;^{4}$ so that for instance, at the period of manhood, the skeleton is still that of a child, and the epiphyses still remain unattached to the bodies of the bones; ${ }^{5}$ the sessamoid bones continue cartilaginous, \&c. 
(1) Compare de Plouquet Repertor. Art. Os. - Courtial et Petit Description exacte des Os. etc. $12 \mathrm{mo}$. Paris, Leyde, 1709.-Herissant in Mém. de Paris. A. 1758. Mém. p. 419. - Boerhaave A bhandl. vom Krebs und Krankheiten der Knochen. Fr. 1765. - Schaarschmidt's Kurzur Unterricht von den Krankheiten der Knochen. 8vo. Berlin, 1768. - Vicq-d'Azyr in Hist. et Mém. de la Soc. R. de Médec. A. 1779. Hist. p. 224.-Böttcher Abhand. von den Krankheiten der Knochen, Knorpel und Sehnen. 8vo. Dessau u. Könings. 1781-93. 3 parts, and Königs. 1795. - A. Bonn Descriptio thesauri ossium morbosorum Hoviani. 4to. Amstel. 1783.-Bertrandi Ueber die Kuochenkrankheiten, a. d. Ital. von Spohr. Svo. Leips. u. Dresd. 1792. - Clossius Ueber die Krankheiten der Knochen. Svo. Tubingen, 1798.-V. Malacarne Auctuar. observationum et iconum ad osteologiam et osteopathologiam Ludvigii et Scarpc. Patavii, 1801.(van Heckerens und Dyl's) Vermischte Beiträge zur Beförderung der Kenntniss und Behandlung der Knochenkrankheiten. Part II. 8vo. Bresl. 1803.Boyer Leçous sur les maladies des os. 2 vols. Svo. Paris, 1803, translated by M. Farrel, 2 vols. 8vo. London, 1807.-Vidler in Wolfart's Asklepieion, June, 1812. - J. Howship, in Medio-chirurgical Tranactions, 1817, Vol. VIII. Part I. p. 57-107. - Rodati in Præparationes osseas musei pathologici animadversiones in Opuscul. scientif. Fasc. XII. p. 362. Bologna, 1818.Ribes in Bull. de la Facul. de Médec. Vol.VI. p. 299. Compare Meckel's D. Archiv f. d. Physiol. Vol. VI. p. 446.-Jam. Wilson, Lectures on the Struct. and Physiol. of the parts composing the Skeleton, and on the Diseases of the Bones and Joints. 8vo. London, 1820. - Caspari Physiol. pathol. Abhandl. über die Entstehung der Knockenkrankheiten in $v$. Graefe's and $v$. Walther's Journ. f. Chir. u. Augenhk. Vol. V. Part I. p. 44. - v. Walther Ueber Krankheiten fossiler Thierknochen, Vol. VIII. Part I. p. 1-16.-Cumin, in Edinb. med. and surgic. Journ. No. 82, Jan. 1825.-Good plates of diseased bones are given by Cheselden, Osteographia, or anatomy of the bones. fol. London, 1733.-Bonn Tabulæ ossium morbosorum. fol. Fasc. I-III. A mstel. 1785-88.-Ed. Sandifort, Museum anat. Vol. II. tab. 1-103. - Ludwigii Icones anatom. pathol. Lips. 1798, tab. 3-14, \&c. [C. Havers, Osteologia Nova, or some new observations of the bones and the parts belonging to them. 8vo. London, 1691.-Hernauld, Dissertation sur les maladies des os. 12mo. Paris, 1726.-G. Bribosia, De morbis ossium. Givot. 1777. - Walker, Cases and remarks relative to diseases of the bones, in Med. Trans. of Coll. of Phys. Vol. III. p. 25.-A Fasciculus, containing nine lithographic anatomical drawings, from preparations in the Museum of the Medical Department at Chatham. fol. London, 1824. T.]

(2) In a monstrous calf, Camper Abhandl. von den Krankheiten, die sowohl den Menschen als Thicren eigen sind u.s. w. 2d edit. p. 23, note.-Blandin Philos. Transact. 1787, Vol. LXXİ. Part I. p. 363.-G. Vrolick Verhandeling over de zonderlige Misvorming eener Vrucht, u. s. w.; and Mémoires sur quélques interessants d'Anatomie et de Physiologie. trad. par Fallot. 4to. Amsterd. 1822.

(3) Glisson, De rhachitide, etc. London, 1650.-Bidloo Opera omnia, p. 191.Klein D. s. casum rhachitidis congenitæ, etc. 4to. Strasb. 1763; and in Nov. Actis N. Cur. Vol. I. p. 146.-Pinel in la Medecine éclairée par les Sc. physiques, Vod. I. p. 111. - Bordenave in Mém de Mathem. et de Phys. Vol. IV. p. 545.ẅnemmerring Abbildungen und Beschreilb. einiger Missgeburten. p. 30, plate 11.Henke Neue medic. chir. Anmerkungen. Part II. p. 58. Berlin, 1772.-Otto Selt. Beob. Part I. p. 1, pl. 1, fig. 1.-Verzeichniss der anat. Präparatensammlung, No. 2905 and 3012.-Romberg D. de rhachitide congenita. Berol. 1817, with engravings.-J. F. Meckel Anat. physiol. Beobacht. u. Untersuchungen. p. 1. Halle, 1822.-Rathke in Meckel's D. A rchiv, Vol. VI1. p. 484.-Sartorius Rhachitidis congenitæ Observationcs. 4.to. Lips. 1826, with three engravings. - v. Loder Inclex Præparatorum, ctc. Mosqux, 1823. 8vo. Sect. II. D.-I saw a similar foetus in the Anat. Museum at Strasburg, at Naegele's in Heidelberg and at ข. Soemmerring's; 1 have also scen this disense several times in new-born calves; v. Herzberg D. Monstri vitulini descriptio anatomica. 4to. Berol. 1825, with engravings.

(4) Especially in dropsy of the head.

(5) In a man of twenty-five years old. See Rudolphi Bemerkungen auf einer 
reise, u.s.w. Part I. p. 140, which case I also saw with Dr. de Reimer at the Hague. I have also observed in some men of twenty-two, and in one of twentythree years, the separation of all the epiphyses, and the same also in the skeleton of a man of twenty-seven years, in the hospital St. Francisci at Naples.

\section{$\S 105$.}

The opposite vice also, viz. the Too GREAT ACTIVITY IN REFERENCE TO THE FORMATION OF BONE, hyperostosis, occurs, though much more rarely, and in like manner sometimes as to time alone, sometimes as to degree. To the former kind belongs the premature perfection and hardening of all or only of some bones, so that, for example, the bones of a newly born child are too full of lime, and therefore very frangible; further, the very early closing of the fontanels, the consolidation of the bones of the skull, of the two halves of the lower jaw and of the epiphyses, at a much too early, period; the very early cutting of the teeth, \&c. In the latter kind we must include the possible excessive production of bony matter which may occur at any period of life, and in rare cases is exhibited throughout almost the whole skeleton, but more frequently is only local, and consists in the morbid thickening, enlargement or growth of the bones. We also often observe, that the earth of the bones taken up from some diseased parts of the skeleton, is deposited more freely on other parts.

\section{$\S 106$.}

The Number of the bones forming the skeleton is not unfrequently subject to variation, which, if we exclude the mechanical or morbid separation of individual bones, is always naturally oRIGINAL. It is to be recollected that in deficient or excessive formation of single parts, their bones are deficient or supernumerary; but even in the external apparently normal formation of a part, the number of bones sometimes varies, thus some are DEFICIENT or SUPERFLUOUS $;^{1}$ this most frequently appears to be the case with reference to the teeth, the vertebræ, and the ribs; the number of the sesamoid bones ${ }^{2}$ also varies uncommonly, as they are often entirely or partially wanting; in rare cases there are two or three to one joint, or they are also found in entirely unusual situations. ${ }^{3}$ The number of the bones is apparently not less increased by the permanent separation of the single pieces of a bone, and by the sutural and interstitial bones. ${ }^{4}$

(1) Compare further below the separate bones.

(2) J. Fr. Crell de ossibus sesamoideis. Helmst. 1746.-Bertin Traité d'ostéologie, Vol. IV. p. 231.-Haller Element. Physiol. Vol. IV. p. 500.-Blumenbach Osteologie. 
(3) For instance, on the outer four fingers and toes, on the front joints of the fingers and toes, on the articular processes of the thigh bone, on the wrist, the spine, the forehead. v. Burchard D. de peculiari osse sesamoideo ad os frontale reperto, 4to. Rostock, 1742, on the elbow joint. v. Chenal Observ. botanicæ, \$2S. 4to. Basil, 1766; and Soemmerring Vom Bau des menschl. Körpers. Vol. I. p. 425 , Sc.

(4) See further on.

\section{$\S 107$.}

The SIZE of bones is subject to various deviations from the general law. Only in DWARFS ${ }^{1}$ and GIANTS, ${ }^{2}$ is the NORMAL MASS OF THE WHOLE SKELETON changed: a vice which otherwise occurs merely in reference to SINGLE BONES Or INDIVIDUAL REGIONS OF THE SKELETON, may be CONGENITAL as well as ACQUIRED, and not unfrequently produces great disproportion and want of symmetry in the skeleton. The frequency of such vices is not to be wondered at, as the bones, in spite of their hardness, are of all organs the most changeable. The тоo SMALL SIZE of single bones is frequently CONGENITAL; thus, for instance, we find in malformed children, the skull, the face, the chest, the limbs too small, and the latter even only on one side, ${ }^{3}$ \&c. Individual parts of the skeleton frequently remain undeveloped ${ }^{4}$ from different causes DURING YouTH; lastly, well-formed bones may in LATER LIFE distinctly diminish in size, which is called consumption of BONE, tabes ossium; ${ }^{5}$ a phenomenon produced by distúrbed nutrition, and the contractile power which belongs to bones. Sometimes we observe this consumption in the bones of whole limbs after lameness, dislocations, \&c.; it is more commonly local, especially from long continued pressure $;^{6}$ so that in the latter case, without any erosion $^{7}$ of the bone, it diminishes at a particular spot, a pit is formed, and indeed in flat bones, it wastes even to the periosteum, and holes are produced. Here also belong the narrowing and diminution of the cavities and canals of bones which occur every where, and often in a very high degree, if the expansile power be lost or entirely consumed. ${ }^{8}$ The opposite vice, or the IRREgULAR SIZE of CERTAIN bONES OR REGIONS OF THE SKELETON, is, in monsters with disproportion of parts, sometimes CONGENITAL, so also when in original deficiency of individual bones, the neighbouring bones occupy their place; ${ }^{9}$ more frequently it is ACQUIRED, and is then the consequence of hypertrophy in certain parts of the skeleton, of mechanical extension, ${ }^{10}$ or lastly and most frequently of vice of texture, which increases either many bones at the same time or only single ones, and thus produces BONY TUMours, tumores ossium. " This morbid enlargement has generally reference only to the breadth and thickness of a bone, but very rarely to 
its longitudinal proportions. ${ }^{12}$ On account of the strength of the bony tissue, it is very natural that morbid swellings in bones should be more permanent than in soft parts, and if they acquire a certain size, they are never again entirely lost.

(1) Skeletons of dwarfs are found in many collections.

(2) Schoenberg Ueber das Skelet des grossen Anton (now at Marburg) im Magazin der naturf. Freunde zu Berlin, 1810, Jahrg. IV. p. 236. - Degg in Phil. Transact. 1727, p. 363.-Zitterland D. de duorum sceletorum prægrandium rationibus. 8vo. Berol. 1815.-The skeleton of the Irishman, Patrick O'Brien, in the Hunterian Museum at London, is seven feet eight inches and a half high, and his thigh bone is about as tall as the Polish dwarf Borulawski. Gigantic and dwarfish skeletons exhibit frequent disproportions of the several regions; this occurs also in animals, for example, in a dwarf horse. Neergard Beitr. zur vergl. Anat., Thierarzneikunde und Naturgeschichte, p. 28, pl. 1. Gött. 1807.

(3) I have observed this several times. Compare Breschet in Med. Trans.

Vol. IX. 1818, p. 433.

(4) Compare several instances in the upper extremities: Otto Seltene Beobacht, Vol. II. p. 32, No. 11, on the lower extremities: Lobstein Compte rendu sur les travaux anatomiques pendant 1822-23, p. 30, 8vo. Strasb. 1824; the feet of the Chinese women, from long continued pressure, \&c.

(5) Lehmann D. de Tabe ossium. 4to. Lips. 1821, with engravings.-Sebastian Ueber die Knochenscwindsucht, in Hufeland's Journ. p. 3, July, 1821.

(6) For instance, from tumours of all kinds, from the head of a dislocated bone, from water and hydatids in the skull, from external inechanical causes, \&c.

(7) Of this further on.

(8) Thus, for instance, do the orbits, the alveolar cavities, the openings in the base of the skull, the articular cavities, and even the chest, become narrowed.

(9) For instance, the upper jaw, when the nasal and lachrymal bones are deficient; the parietal in deficient frontal bone.

(10) To wit, the bones of the skull from dropsy of the brain, the acetabulum, from enlargement of the head of the thigh bone, \&c.

(11) Roberg D. de ossibus tuberosis. Upsal. 1717. v. Haller Coll. Disp. chir. IV. No. 122.-Heister D. de ossium tumoribus. Helmst. 1740.-Matani de osseis tumoribus. 8vo. Pisa, 1763.

(12) An instance of this kind occurring on the shin bone of a boy is known to me ; compare Trendelenburg præs. Florman D. de longitudine femoris ancta, sine prævia luxatione. 4to. Lund. 1812, on the last joint of the finger. - Portal Cours d'Anatomie médicale, Vol. I. p. 14.

\section{$\S 108$.}

Not less common are the vices of Form in bones, ${ }^{1}$ which may be CONGENITAL as well as ACQUIRED. To these belong the various forms corresponding to the external contour of mishapen bodies which the bones so often present, for instance, in the anencephala, the cyclops, the monsters with clefts of the face, chest, and spine, with deformed extremities, with deficiency, excess, and consolidation of parts; then a great number of more minute variations of form in certain bones, not indicated by the general form of the body, which not unfrequently, like many of the foregoing, are RETARDED FORMATIONS; further, such deformities as arise from pernicious fashions and customs, for instance, pressure of the head, pressure from stays, small shoes, certain positions of the body; the vices of form caused 
by tumours, dislocations, and badly united fractures ; and lastly, especially the obliquity, contortion, and curvature of the skeleton, sometimes congenital, but more frequently produced by disease, which are remarkably frequent in the spine and extremities, ${ }^{2}$ and are sometimes followed by very decided and general malformation of the body. ${ }^{3}$

(1) E. Sandifort De ossibus, diverso modo a solita conformatione abludentibus in Observ. anat. pathol. L. III. cap. 10, and L. IV. cap. 10. - van Doeveren observationes osteologicæ, varios naturæ lusus in ossibus humanor. corpor. exhib. in Observ. acad. specim. Lug. Bat. 1765.-Rosenmiiller D. de singularibus et nativis ossium corp. hum. varietatibus. 4to. Lips. 1804, with engravings.Fesiner præs. Rudolphi D. anat. seu Observationes osteologicæ. Berol. 1812, with two engravings.

(2) On the upper extremities however much more rare than on the lower.

(3) Grood plates of such skeletons are given in Sandifort Museum anat. Vol. II. pl. 1-5. - Rodati in Opusc. scientif. Bologna. 1817. Fasc. V. pl. 11, 12.Copeland, On the symptoms and treatment of diseased spine. 8 vo. Lond. 1815. Striking examples are given by $V$ rolick Mémoires sur quelques sujets intéressants d'anatomie et de physiologie. trad. du Hollandais par Fallot. 4to. Amsterd. 1822. -Compare Otto Verzeichniss der anat. Präparatensammlung, No. 3019-3025.

\section{$\S 109$.}

The irregular connexion of bones with each other, and often their position ${ }^{1}$ also, is tolerably frequent; their connexion may be either in a slight degree or entirely destroyed, or it may be too firm; both occur in bones which are immovably and movably connected, and may be observed both as congenital and occurring at a later period of life. To the DIMINISHED CONNEXION belong the not unfrequent CONGENITAL CLEFTS of the face, spine, chest, and pelvis; the separation in youth, osteodiastasis, ${ }^{2}$ of immovably connected bones, still, however continuing in adults, which is produced in the skull by water, effusion of blood, tumours, \&c., in the face, especially by polyps, and sometimes in the pelvis by relaxation of the ligaments and extension from within; and lastly, the naturally more common dislocation, luxatio, ${ }^{3}$. in which the normally connected articular ends of two or more bones are, by mechanical extension or tearing of the ligaments, separated from each other, partially, luxatio incompleta, subluxatio, or entirely, luxatio completa. If dislocation arise from internal causes, as from swelling of the articular end of a bone or from other diseases of joints, this we call spontaneous DisLocation, luxatio spontanea ${ }^{4}$ in animals it does not appear to take place. If the dislocated bones be not replaced, they acquire, whilst their original articular cavity in the other bone is gradually wasting away, a NEW CONNEXION, either with the edge, or with more distant parts of the same bone, or with another distinct bone: which partly by absorption, partly by cleposition of bone, 
and the adaptation thus effected by opposite means as well as by the production of articular ligaments, often becomes, in time, a tolerably good NEW JOINT, ${ }^{5}$ which in a certain degree restores the use of the limb. The IRREGULAR CLOSE CONNEXION may partly affect such bones as are immovably connected with each other, this is called consolidition of BONEs, concretio ossium, ${ }^{6}$ or it may, as a more distinct and important vice, affect two bones movably connected, the CONSOLIDATION of JoINTs, anchylosis, ankylosis. ${ }^{7}$ This vice is very common in man and animals, ${ }^{8}$ and if it have attained only a trifling extent, and there still remain some motion in the joint, it is called STIFFNESS OF THE JOINT, Or FALSE, IMPERFECT ANCHYLOsIS, rigiditas articulorum, anchylosis spuria, incompleta; but if it be complete, then it is anchylosis vera; consolidation of the articular surfaces with each other, ossification of the articular ligaments, and the irregular deposition of bone in and about the joint, are the next causes of anchylosis. ${ }^{9}$ Sometimes this is a congenital vice $;^{10}$ it rarely occurs in youth, more frequently in more advanced age; in rare instances it occurs in almost all the joints of the body at once. ${ }^{11}$ Some instances are also given, in which anchylosed joints having been separated by violence, have again become movable. ${ }^{12}$

(1) Dislocatio, especially in dislocations; the most remarkable instance I have seen was in the Anatomical Museum at Vienna, No. 297; the dislocated head of the right upper arm bone is thrust between the second and third ribs almost two inches into the chest, and remained there many years, until it had become soft.

(2) Many examples in Plouquet's Repertor. Art. Ossis Diastasis.-Ludwig's Program. de diastasi, Leipzig, 1620, includes several dissertations.-If the diastasis occur in youth and be long continued, the intermass of the bones expand; if this be not the case it is usually torn.

(3) Hamberger D. de luxationibus et subluxationibus. Jen. 1746. - Henkel Abliandlung von Beinbriichen und Verrenkungen. 8vo. Berlin, 1759.-Bordenave D. de luxationibus. Paris, 1764.-Pott, Remarks on Fractures and Dislocations. 8vo. Lond. 1768.-Aitken Ueber Beinbrüche und Verrenkungen mit Anmerk. von Reich. Svo. Nürnb. 1793.-Bernstein Ueber Verrenkungen und Beinbrüche. 8 vo. Jena, 1802. 2d edit. Jena, 1818. - Laemmerhirt Taschenbuch über Beinbrüche und Verrenkungen. Berlin, 1806. - Caspari Anat. chir. Darstellung der Verrenkungen, u. s. w. 8vo. Leipz. 1821.-A. Cooper, A treatise on Dislocations and on fractures of the joints. 4to. Lond. 1822, with plates.-J. M. Cunningham, A synoptical chart of the various Dislocations to which the human frame is subjected. Lond. 1827.

(4) Juncker D. de causis luxationum internis. Halæ, 1761.-Rust Arthrokakologie, oder über die Verrenkungen durch innere Bedingung und ïber die Anwendung des Glüheisens. 4to. Wien, 1817, with plates.

(5) Howship in Medico-chir. Transact. Vol. III. Part II. 1817 : und praktische Beobachtungen aus der Wundarzneikunst und Krankheitszergliederungskunde; übers. v. Schulze, p. 435,8 vo. Halberstadt, 1819 , plate 6 , fig. 5 , plate 7 and 8.-A. Cooper and Travers, Surgical Essays, Part I.-Warren in New England Journ. of Medicine and Surgery, Boston, 1814, April, with drawings. - Todd in Dublin Hospital Reports and Communications in Medicine and Surgery, Vol. III. Dublin, 1822. - Hesselbach Beschreibung der pathol. Präparate zu Wuirzburg, No. 85-91, and 684. Otto Verzeichniss der anat. Präparatensammк 2 
lung, No. $3440,3442,3443,3492$, and several others. - C. M. Geisler D. de Pseudarthrosi a luxatione proficiscente in genere. 8vo. Berol, 1827.

(6) Here belong, for instance, the early, or even congenital consolidation of the bones of the skull, of the nose, of the two halves of the lower jaw, of the epiphyses with the diaphyses, the teeth with their sockets, \&c.

(7) Müller D. de Ancylosi L. B. 1707. v. Haller Coll. Disp. chir. Vol. IV. No. 120. - de Büchner D. de Ancylosi. Erford. 1743. - Paul D. de Ancylosi. Argentor. 1774.-van de Wynsperse Dissertationes med. chir. de Ancylosi. L. B. 1785, with figures. - van Doeveren D. de Ancylosi. L. B. 1783.-Murray, resp. Leffler D. de Ancylosi. Upsal. 1797. - Rudolphi Schwed. Annalen. Part I. p. 132. - Jamain Diss. sur l'ancylose. 4to. Paris, 1806.-Carmichael, in Edinb. med. and surg. Journ. Vol. V. p. 185.

(8) For instance, on the spine of horses, mules, asses, and oxen; in spavin and grease of horses; on the knee of a monkey; and not rarely on the joints of

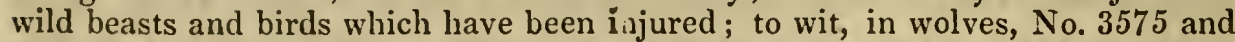
3576 , in a bird, No. 3594 of Bresl. Mus. I also saw one on the heel-joint of a young kangaroo.

(9) Gout, osteomalacy, caries, fracture and injuries in the neighbourhood of a joint, most commonly produce anchylosis; also the long-continued rest of a limb; for instance, the Indian Fakirs, who, for penance, do not move a joint for a whole year, often suffer anchylosis.

(10) I have seen this several times in monsters of men, sheep and oxen, especially on the spine and ribs; on the knee of a new-born child, Yeatman in Lond. med. and phys. Journ. Nov. 1824; on the spine of calves and lambs, No. 3032 , 3034, 3324, of Bresl. Mus.; in a calf, H. Jaeger in Meckel's Archiv f. Anatomie und Physiol. 1826, No. 1, p. 79.

(11) Columbus de re anatomica L. XV. p. 485. - B. Connor, de Stupendo ossium coalitu. Oxon. 1695; and in Philos. Transact. 1695, p. 21.-Deslandes in Mém. de l'Academie des Sc. 1716, in a child. - Smith, Naturalis historia Hiberniæ comitatuum. Dublin, 1744. - Baader Observationes medic incisione cadaverum illustratæ, 1763, p. 80. - Gentleman's Magazine, Sept. 1787.Ramsay Philos. Transact. abridg. Vol. IX. p. 24, with an engraving of the skeleton which is in the museum at Trinity College, Dublin. The skeleton of $\mathrm{Jeffs}$, in the Hunterian Museum, at London, is similar; and there are two skeletons in the Cabinet d'Ecole de Médecine of Paris; compare hercon Percy, Bulletin de la Soc. philomath. Ann. X. p. 93; and in Sédillot Rec. périod. de la Soc. de Médec. de Paris, Vol. XIII. p. 352. - Gastellier, ib. Vol. LIV. p. 380, and Frank Reise nach Paris, London, u.s.w. p. 127 ; - Grabner: Muraschin in Omodei's Annali universali di Medicina, Vol. XXXII. Oct. 1824; almost complete anchylosis in a skeleton in the Anatomical Museum at Berlin. v. Walter Anat. Mus. Vol. II. No. 463, p. 77.

(12) Job. von Meekren Observat. Cap. J.XIV. p. 297 ; in such the consolidation was probably only slight.

\section{$\S 110$.}

The natural COLOUR ${ }^{1}$ of bones deviates variously, in the altered component proportions of the jelly, fat, blood, and lime found in them; if the latter be in excess and the former diminished, the bone appears too whrTe, thus in certain forms of gout it is IVORY-LIKE, ${ }^{2}$ in necrosis often WHITE AS CHALK ; should the bones be very fat and deficient in lime, they are sometimes completely TRANSPARENT ${ }^{3}$ more frequently very YELLow; inflamed, scorbutic, and rickety bones when examined recently are more or less RED, but after some time mostly GREYISII ; in the not rare morbid effusion of blood into the diploe of bones, they are spotted of a DEEP RED OR BLUISII 
COLOUR $;{ }^{4}$ carious and necrotic bones are often DISCOLOURED BROWNISH and even BLACK: the bones are irregularly coloured in rare cases, by pigments morbidly produced in the body; for instance, YELLOW IN JAUNDICE, ${ }^{5}$ and BLACKISH IN MELANOSE $;^{6}$ in one instance, BLUE on the upper surface of exfoliated portions of bone $;^{7}$ but this is more frequently produced by extraneous colouring matter, thus YELLOW from carrots, ${ }^{8}$ RED from madder ${ }^{8 *}$ and galium aparine, DUSKY or BLACKISH, if preparations of peruvian bark, oak bark, rhatany, nitrate of silver, ${ }^{9}$ be applied on bare bones, \&c.; also after death the bones easily assume an extraneous colour, as a DARK BROWN or BLACKISH colour from putrefaction and lying in black earth, a REDDISH from ochrous earth, and a GREENISH colour from that impregnated with oxyds of copper. ${ }^{10}$

(1) H. F. Isenflamm Ueber die Verschiedenheit der Knochenfarbe als Diss. Dorpat, 1809, enlarged on in his Anatomischen Untersuchungen. 8vo. Erlang. 1822 p. $3-45$.

(2) I have several times found this. Compare also v. Sommerring Ueber die Gichtknochen in Blumenbach's medicin. Bibliothek, Vol. III. Part III. p. 508.

(3) Otto Verzeichniss der anat. Präparatensammlung, No. 3020.

(4) I have several times found such spots on the bones of the skull and of the pelvis; on others also, however, which have a thinner shell. Compare Verzeichniss der anat. Präparatensammlung, No. 3119 and 3120.

(5) Lieutaud Hist, anat. medica, Vol. J. L. I. Observ. 817.-J. Andree, Considerations on bilious diseases, \&c. London, 1790.-Stoerck Ann. medic. I. p. 150.- Stoll Ratio medendi, übers. von Fabri. Vol. III. Part II. p. 148. Wrisberg Descript. Embryon, p. 6.-v. Soemmerring Vom Bau des menschlichen Körpers. 2 d edit. Part I. p. 7.- Isenflamm, p. 29.-I have also seen this several times, especially in icterus neonatorum.

(6) Howe and Alison in Transact. of the med. chir. Soc. Edinburgh, Vol. I.

1824, No. 13.

(7) Menegazzi in Brera's Giornale di Medic. prat. Part I. p. 1.

(8) In Geese. Fränkische Sammlungen, u. s. w. Part II. p. 11.

(8*) [De coloratis Animalium quorundam vivorum ossibus, in Comm. Bonoens, Vol. II. p. 129. - M. Bazani De ossium colorandorum artificio per radicem rubiæ, $i b$. Part II. p. 124. T.]

(9) As to the intentional or accidental colouring of the teeth, see further, on the teeth.

(10) v. No. 817 and 818 in Bresl. Mus.

\section{$\S 111$.}

As to vices of CONSISTENCE of bone, these are regularly the consequence of vices of texture and indeed of inflammatory loosening or thickening; this however is not always distinguishable, and in other cases also the vices of consistence, in reality, appear only to depend on the change of nutrition or the proportions of mixture of the fluid with the earthy parts; here, therefore, we must speak of them generally. The Diminished CONSISTENCE of bones appears in a double form, viz. as SOFTENING and as BRITTLENESS. The former, mollities or rachitis ossium, in a greater degree also called osteomalacia, malacosteon, osteosarcosis, ${ }^{1}$ is produced to a less extent in bones, 
by the long-continued rest of a joint; but more commonly is it a symptom of rickets and scrofula, in which, besides the disproportion of the phosphoric acid to the lime sometimes observed, the latter especially is very much diminished, and contrariwise the quantity of jelly very much increased; such bones are therefore more or less flexible, and are easily bent and mishapen, partly by the actual weight of the body, and partly by the operation of the muscles. Rickety bones especially, according to the increase of their vessels and the expansion of their cells with jelly, become swollen, of a bloody-red colour, and therefore in different degrees too deeply reddened. This rickety softening is sometimes CONGENITAL ${ }^{2}$ but it usually only occurs in the early period of youth, in man and animals. ${ }^{3}$ The softening of bone which occurs in adults and old people ${ }^{4}$ is more malignant and greater, and is found in the whole skeleton, or only in certain parts; this is especially called osteomalacia, rachitis adultorum and senitis; it is much more common in the female than in the male sex, and often occurs from scrofula, in animals from the kindred diseases, tubercles, glanders, farcy, ${ }^{5} \& c$. ; further, from rheumatism, gout, syphilis, scurvy, mercurial disease, and in rare cases from onanism, ${ }^{6}$ diabetes, ${ }^{7}$ and lepra $;{ }^{8}$ not less does almost every inflammation of the bony tissue produce this softening at its commencement. The other kind of diminished consistence of bone is that BRITTLENESS, marcor, and GLASSLIKE FRANGIBILITY, fragilitas vitrea, fractura spontanea, ${ }^{9}$ arising therefrom, which in rare cases is merely the result of diminished elasticity, and increased deposition of lime, but on the contrary, is more frequently produced by loss of the lime and jelly of the bone, and not unusually to such extent, that the mere weight of the body, and slight muscular exertion break the bone..$^{* *}$ In rare instances this vice is congenital, or occurring very early in youth, generally it takes place only in advanced age; it also occurs sometimes in animals. ${ }^{10}$. The irregular INCREASED CONSISTENCE of bones, which in and of itself is no vice, depends always on thickening of the tissue, and had therefore better be treated of among changes of structure.

(1) Reuss Repertor. Comment. Vol. XIV.p. 255.-de Plonquet Repertor. Art. Ossis Mollities; almost all the writers on Rachitis.-J. C. Plank D. s. morbum ostensarcoseos singulari casu illustratum. 4to. Tubing. 1741, with figs.-Navier Olservations sur le ramollissement des os. Paris, 1755. - Luthig Pr. Observat. in cadavere, cujus ossa emollita erant. Lips. 1757.-Boehmer D. de ossium mollitie ex læsione viscerum. Hala, 1763.-Fries D. de emollitione ossium. Argentor. 1775.-A. C. Plank De osteosarcosi commentat. 8vo. Tubing. 1782, with plates.-Eckmamn (pras. Acrell) D. descriptionem et casus aliquot osteomalacia s. Upsal. 1788. - Conradi D. cle ostcomalacia. 4to. Gött. 1796.-Metzger D. de osteomalacia. Regiomont. 1797.-Renurd Ramollissement remarquable des 
os du tronc d'une femme. 8vo. Majence, 1804, with fig.-Fleichmann in den Abhandl. der phys. medic. Societät zu Erlangen, Vol. I. No. 1.-Monteggia in Sédillot Rec. périod. de la Soc. de Méd. de Paris, Vol. LXI. p. 75.-Jurine in Journ. de Médec. 1810 , Dec. p. 499.-Keller D. de ossium emollitione morbosa, \&c. L. B. 1816.--Some remarkable cases of general osteomalacy are described by Morand Histoire de la maladie singuliere et de l'Examen du cadavre d'une femme (Supiot) devenue tout a fait contrefaite par un ramollissement général des os. Paris, 1752.-Hosty, An account on the case of A. E. Queriot, \&c. Philos. Transact. 1753, Vol. XLVIII. p. 26.-H. Thomson in Med. Observat. and Inquiris. Vol. V. p. 259. - Gooch's Chir. Works. Vol. II. 1792. p. 395-399. - Vrolick Mémoires sur quelques sujets intéressans d'Anatomie et de Physiologie trad. du Hollandais par Fallot. 4to. Amsterd. 1822.-J. Howship in Transact. of the med. chir. Society of Edinburgh, 1826. Vol. II.-[Astruc de Morbis venereis. Lib. IV. c. 4. -- Tauvry in Mém. de l'Acad. Roy. Paris, 1700, a case of a girl whose bones were as soft as wax, and bent every time she was moved; the teeth, however, still retained their original hardness. - I recollect a boy of seven or eight years old, who was brought into St. Thomas's Hospital, some years ago, having fallen down and bent the fore arm, about its middle, nearly to a right angle; slight extension straitened it, and he did well. T.]

(2) Compare above, $\$ 104$, note 2.

(3) To wit, I have observed it in puppies, calves, lambs, and young monkeys ; examples of the monkey, dog, and porcupine are given by Sandifort, Mus. Anat. Vol. III. p. 275, No. 908, 909.-J. Amesbury, Observations on the nature and treatment of fractures of the upper third of the thighbone, and of fractures of long standing, \&c., with engravings. London, 1828.-Many instances of spontalleously cured fractures and wounds of bone are given by Sandifort, Mus. Anat. Vol. III. p. 202, and in the Recueil périod. de la Soc. de Médec. de Paris, Vol. LXVI. p. 249. I have also observed them more rarely on the mycetes fuscus, didelphis Azaræ, bradypus didactylus, herpestes ichneumon, and on a frog.

(4) J. P. Frank Delect. opusculor. Vol. II. p. 304.-Biermayer Musæum anat. pathol. No. 440. p. 74. I saw an instance of osteomalacia in a woman of eighty years old, in the Anatomical Museum at Bonn. Imperfect fractures have been observed by Lisfranc. v. Revue méd. franç. et étrang. 1827. Vol. X. Miscellen.

(5) I found it in the horse, ox, sheep, dog, cat, rat, in very many monkeys, and in one polar bear; in birds this disease appears to me more rare. Compare Dupuy De l'affection tuberculeuse. 8vo. Paris, 1817. p. 50 and 265-268.Laubender Theoret. prakt. Handbuch der Thierheilk, Vol. IV. p. 112. Erfurt, 1812.--- In the mule and sheep, Robertson Vollst. Werk über die Pferdewis senschaft, herausg. von Mogalla. Vol. II. p. 235. Breslau, 1800.-In a lioness. Ephem. N. C. Ann. 1671 . Obs. 5, p. 6.

(6) I have seen one case of this kind in the Anat. pathol. Mus. at Vienna.

(7) Pott in Phil. Trans. 1753, No. 459.-Lisfranc.

(8) I saw one example on the hand in the anatomical collection of Dr. Pattison, at Glasgow.

(9) Fragility of bones may also be produced by the above-mentioned diseases operating very injuriously upon the bony system. - I Waldschmidt $\mathrm{D}$. de fracturis ossium sine violenta causa externa. Kilon. 1721. - Nicod D. sur la fragilité des os. Paris, 1807.-Viliermé in Journ. de Médec. de Leroux, Vol. XXXVII. p. 331.Many instances in Reuss Repert. Comment. Vol. XIV. p. 254.--de Plouquet Repertor. Art. Ossis Fragilitas; also Medic. Observ. and Inquiries, Vol. V. -Smith, in Lond. Medic. Repository, Vol. IV. Sept.-Chevalier in Journ. de Médec. 1810, Oct. p. 276.-The Medical Repository by Mitchill, Pascalis, and Alerly, new series, Vol. I. New-York, 1812 and 1813.-Hutchinson in Lond. Med. Reposit. April, 1815.-Gastellier in Leroux Journ. de Médec. Chir. et Pharm. Vol. XXXIII. Juill. 1815. - Haime in Journ. gén. de Médec. 1819. Vol. LXV. No. 272, p. 90. - Nicod in Annuaire médic. chir. des Hôpitaux et Hospices civiles de Paris, p. 494. Paris, 1819.-Krïger-Hausen in v. Graefe's and $v$. Walther's Journ. f. Chir. Vol. III. Part IV. p. 647.-Bergmann in Nasse's Zeitschrift für die Anthropologie, 1823. Part II. p. 413. - Whitelaw Ainslie on Flephantiasis, 
in Trans. of Roy. Asiat. Soc. Vol. I. Part II. p. 282. London, 1826.-Otto Selt. Beobacht. Vol. I. No. 40, p. 81, and Verzeichniss der anat. Präparatensammlung, No. 3019. At Breslau the disease is very common in consequence of scrofula, syphilis, and cancer; Ekström observed it following Radesyge. v. Ars. Berättelse om Svenska Läkare-Sällskapets Arbeten. Stockh. 1825.

(9*) [J. Pringle in Phil. Trans. Vol. XLVIII. p. 406, mentions a woman of thirty-one, whose leg was broken merely in walking; no callus (it is said, perhaps more properly, no lime,) was generated, and soon after the lime was removed from all the bones, which, after death, could be cut without turning the edge of a knife. T.]

(10) Dupny._-Gleditsch Abhandlung iiber eine seltene Art des Knockenbruchs bei dem Rindviche u.s.w. Berlin, 1737. I have observed a great degree of brittleness in several monkeys, in a hyæna, a two-year old lioness, in some dogs, stags, and roes.

\section{$\S 112$.}

To the above described vices, those of continurty in a single bone naturally follow. These are produced partly by the more or less deep penetration of sharp instruments, and are therefore called woUNDS OF BONE, vulnera ossium ; ${ }^{1}$ partly they arise from various other mechanical causes operating either externally or within the body itself, ${ }^{2}$ and are then called FRACTURES OF BONES, fructure ossium. ${ }^{3}$ The latter are IMPERFECT, fractura incompleter, ${ }^{4}$ if the natural connexion of a bone is only partially broken, as in FISSURE OF BONE, fissura, and the cracking of bones which are not very brittle; or as usual, COMPLETE FRACTURE, fracturce complela, in which the bone is completely divided into two or more pieces. Such fracture is either SIMPLE, simplex, ${ }^{5}$ or compound, to which also belongs the splitTing, or crushing of the bone, fractura comminuta; further, according to its direction, it is OBLIQUe, fr. obliqua, which is the most common, TRANSVERSE, fr. transversa, ${ }^{6}$ LONGItUdinal, $f r$. longitudinalis, ${ }^{7}$ or lastly, IRrEgular, $f r$. irregularis.

(1) Heister D. de vulneribus ossium rite curandis. Helmst. 1753. in Haller's Diss. chir. IV. No. 123.-P. G. van Hoorn D. de iis, quæ in partibus membri, præesertim osseis, amputatione vulneratis, notanda sunt. L. B. 1803.-Hennen, Principles of Military Surgery. 8vo. Edinb. 1829.-Dict. d. Sc. médic. Art. Plaic. p. 83. Here belong piercing and perforating stab, cut, and gunshot wounds, amputations, trepannings, sawings off, chisellings, \&c.; sometimes also in adults a piece of bone is cut off smooth without splintering.

(2) From violent muscular exertion; this is especially the case with the olech. ranon, the knee-cap, and the heelbone, although also with long and other bones; horses break even the lower jaw in biting, the dorsal vertebræ in drawing, \&c. Compare Nicod Diss. Essai sur la contraction musculaire comme cause de la fracture. Paris, 1807.

(3) Pott, Remarks on fractures and dislocations. 8vo. Iond. 176S.-Aitken. On fractures and luxations. 8vo. Lond. 1790.-Bernstein Ueher Verrenkungen und Beinbrüclee. 8vo. Jena, 1819.- $A$. Cooper, 'Treatise on dislocations and on fractures of the joints. 4to. Lond. 1823, with engraving._J. imesbury, On the nature and treatment of Fractures, $8 \mathrm{ce}$. 8 vo. Lond. 1828. - Richter Handbuch der Lehre von den Brïchen und Verrenkungen der Ḱnochen, 8vo. Berlin, 1827, with many litlographic plates.-Pautaleon Binz Ueber dic verschiedenen 
Knochenbriiche der Hausthiere, besonders der Pferde, u.s.w. 8vo. Tubing. 1824. - J. Peterka Gründliche und kurzgefasste Darstellung von verschiedenen Arten Knochenbrïchen und Hufkrankheiten unserer Haus-und Nutzthiere. 8vo. Prag. 1827, with four lithographic plates.

(4) Boyer, in his Traité des maladies chirurgicales, Vol. III. p. 19, very incorrectly disclaims incomplete fractures; they occur not merely in morbid and in young bones, which have little lime, but also in the healthy bones of adults. In a boy, six years old, affected with the blue disease, I found, after a fall, both fore-arms imperfectly broken; so also the radius of a lion, No. 3577 , a fibula, No. 3890, in Bresl. Mus., the breast-bone of an adult, several skull-bones of newly born children, and of the stag and roe kinds; also in adults, the internal table will snap off whilst the external remains uninjured. Other instances are in Regnault in Journ. de Médec. Vol. XXVI. p. 159.-Cheselden, Anatomy of the human body, observed an imperfect fracture in the ribs of children; and on the ribs and cubit of grown up persons it was seen by Chaussier Recueil de Mémoires, etc. 8 vo. Paris, 1824 , p. 447 , note; on the fibula by Campaignac, v. von Froriep's Notizen, 1826, No. 321, p. 207. Compare also Barton in American medical Recorder, Vol. IV. p. 1, Philadelphia, Jan. 1821; on the ribs by Marjolin, v. Archives général, Mai, 1827.

(5) J. Dunlap D. de fracturis simplicibus. Edinb. 1823.

(6) Transverse fracture of the knee-cap is not rare, (see below); next of the shoulder-blade, which I have seen in several collections. Compare also Allan, System of pathological and operative Surgery, Vol. II. p. 61 ; on the breast-bone, Otto Verzeichniss, No.3474, and Haugk D. s. observat. de fractura sterni et vertebrarum. 4to. Lips. 1816, with plates.-Chaussier exhibited such a breast-bone to the Academy at Paris, on the 8 th of May, 1826; Bonn and Camper have also noticed it in the body of cylindrical bones; to transverse fracture belongs also the breaking off of the epiphyses; v. G. Ch. Reichel D. de epiphysium ab ossium diaphysi deductione. Lips. 1759, with figs.-Instances are given by Champion and J. Cloquet, v.Laurent in Journ. compl. au Dict. des Sc. méd. Paris, 1818. Vol. I. p. 317-226.-Julia Fontenelle in Archiv. génér. de Médec. Vol. IX. Octobr. 1825.-Baumetz, v. von Froriep's Notizen, Vol. VI. No. 6, p. 96.

(7) Improperly do Petit, Boyer and others disallow this; it has been several times observed, especially after shot wounds. Compare Hoffmann D. de ossium cylindricorum fissura. 4to. Lips. 1764, with figs.-Eccard Epistola de ossium cylindricorum fissura longitudinali. Lips. 1784.-Duverney Traité des maladies des os. Vol. I. p. 167.-Leveillé Nouvelle doctrine chirurgicale. Vol. II. p. 158. - S. Cooper, Surgical Dictionary, Art. Amputation.-I have seen such fracture of the knee-cap, No. 3908, in Bresl. Mus., and of the hip-bone of a horse in the Veterinary School of Copenhagen.-Lisfranc.

\section{$\S 113$.}

To the consideration of the broken connexion of a single bone is very naturally consequent, that of its REUNION, reunio, ${ }^{1}$ as well as the REPRODUCTION, regeneratio seu reproductio, ${ }^{2}$ of such bony parts as have been lost by injuries or diseases, for instance, caries and mortification. Both have alike many resemblances with the similar processes in soft parts, and with the original production of bone. The REunion of the divided bony parts is effected by the effusion of a mass which glues the edges of the wound together, gradually becomes organized and ossified, that is, by adhesion or per primam intentionem, which is effected in somewhat longer period than in the soft parts, on account of the peculiarities of the bones; thus, then, in part, pieces of bone which have been completely divided by 
sharp instruments are very commonly healed $;^{3}$ in part, fractures of bone are easily united by callus. ${ }^{4}$ In the latter instance the following is the process: soon after the fracture has occurred, blood and coagulated lymph is poured out in greater or less quantity from the ends of the broken bone, from its periosteal and medullary membrane, as well as from the neighbouring somewhat injured soft parts, which glue all the affected parts together and produce the so-called callous swelling, which at first is jelly-like, soft, and reddish, gradually becomes harder, and as it were cartilaginous and paler. Whilst the torn original periosteum is absorbed, there is formed a new one around the callous swelling, which is connected with the healthy periosteum on the ends of the bone as well as with the other surrounding soft parts, and, together with the whole callus, contains blood-vessels on all sides, whence lime is deposited, and the callus gradually converted into several hard bones. The ossification usually takes place first externally, although sometimes also earlier on other parts, and as the mass interposed between the two ends of the bone becomes ossified, if it be a tubular bone, the medullary cavity is at the same time divided into two parts, which division, however, is at a later period again done away with by absorption. As the broken ends of the bone are usually at the same time rather soft, and have been deprived of their angles and points by absorption, and not unfrequently the primary splinters of the bone surrounded by callus during the cure, and again become living, ${ }^{5}$ so at last do the old and new bone assimilate, and the original form is again tolerably reproduced. In a similar way, is a bone from which the middle portion has been removed, as also two distinct bones from which the articular ends have been artificially cut off, united. ${ }^{6}$ This natural process of uniting broken bones may, however, be DISTURBED in various ways $;^{7}$ for instance, by suppuration and mortification in complicated fractures, by great debility, by syphilis, scurvy, rickets, osteomalacia, pregnancy, suckling, improper position of the broken bones, and their frequent motion. ${ }^{{ }^{*}}$ In such cases either a too large and mishapen mass of callus, callus luxurians, is thrown out, ${ }^{8}$ or the callus is formed in too small quantity, and does not become hard, so that one PART OF THF bONE REMAINS MOVABLE UPON THE oTHER, or the ends of the bones become cicatrized, and a NEW Jorst is produced between them, ${ }^{9}$ in which we sometimes find plates of cartilage, articular ligaments, and synovial membrane, as in the normal joints. The processes of bone also which are broken within the capsular ligament, do not appear to heal by bony substance but only by ligamentous bands. ${ }^{10}$ 
(1) Compare-above, $\S 56$, and the writings of the surgeons. A good plate is given by Bonn, Tabulæ ossium morbosorum, II. fig. 1. - van der Leeuw D. de ossium vulneratorum et fractorum consolidatione. Groening, 1785.-Howship, on the morbid appearances and structure of bones, in Med. Chir. Trans. Vol. X. p. 176. - M. J. Weber in Nov. Actis Acad. W. Cur. Vol. II. Part II. p. 709, pl. $60-64$.

(2) Compare \$56. - Reuss Repert. Comment. Vol. X. p. 41. Vol. XIV. p. 260.- de Plouquet Repert. Art. Ossis. Regeneratio.-M. Troja De Novorum ossium in integris aut maximis ob morbos deperditionibus regeneratione experimenta, Lutet. 1775 ; and Osservazioni ed esperimenti sulle ossa, in supplemento ad un opera sulla regenerazione delle ossa, etc. 4to. Napoli, 1814, with engravings.-Koeler Experimenta circa regenerationem ossium. Goett. 1786.Blumenbach in Richter's Chir. Bibliothek. Vol. VI. p. 107. - Maret in Mémoirs de Dijon, Vol. II. p. 85. - Baronio Della regenerazione delle ossa in Memor. della Soc. Italiana, Vol. IV. p. 430. - Leveillé in Mémoire de Physiologie et de Chirurgie pratique par Scarpa et Leveille. Mém. 4. Paris, 1804.-Osthoff in v. Siebold's Chiron. II. p. 539. - Bouillancy in Journ. Général de Médec. Août, 1807.-- Eggers Von der Wiedervereinigung. Würz. 1821. - Charmeil Récherches sur les Metastases, suivies de nouvelles experiences sur la regéneration des os. Metz. 1821, with engravings. - Eschholz D. de ossium genesi et regeneratione. 8vo. Berol. 1823, with engravings.-Meding D. de regeneratione ossium per experimenta illustrata. 4to. Lips. 1825, with engravings; and in the Dresdner Zeitsclirift f. Natur-und Heilkunde, Vol. III. Part III. p. 305.-Knox in Edimb. Med. and Surg. Journ. June, 1822, and Vol. XVIII. p. 62, April, 1823. - Kortum D. prop. experimenta et observationes circa regenerationem ossium. 4to. Berol. 1824, with lithographic plates. - Ernst D. de regeneratione ossium in genere, etc. 8vo. Bonnæ, 1824.-M. Troja Neue Beobachtungen über die Knochen, translated by $v$. Schoenberg. 4to. Erlangen,1828.-- [A good example of adhesion by the first intention in bones, is given in the Lancet, 1828-29, p. 401 , in a case of vertical division of the whole finger by a chaff-knife, which was perfectly cured in twenty-eight days. T.]

(3) For instance, the phalanges removed from the fingers, and large pieces of bone from the skull, No. 8250 of Bresl. Mus.; further, the pieces sawn off by the trepan, v. No. 3195 , in my Verzeichniss, u. s. w.

(4) Reuss Repertor. Comment. Vol. X. p. 363. - de Plouquet Repertor. Art. Callus.-Dict. des Sc. médicales, Vol. XXXVIII. p. 416. - Müller D. m. chir. de callo ossium. 4to. Norimb. 1707. - Bajer D. de callo ossium. Norimb. 1807.-Boehmer Pr. de callo ossium e rubiæ tinctorum radicis pastu infectorum. Lips. 1752, and Pr. de ossium callo. Lips. 1758.-Detlef D. ossium calli generationem, etc. Götting. 1753.-Delins D. Cicatrix et callus idea nutritionis. Erlang. 1755. - Bordenave in Fougeroux Mém sur les os. Paris, 1760. - Haller Op. minor, II. p. 460 and 478. - Marigues D. phys. et chir. sur la formation du cal dans les fractures. Paris, 1783.-Bonn and Marigues phys. und chir. Abhandlung über die Natur und Erzeugung des Callus überhaupt und insbesondere von den Fehlern und Unförmlichkeiten desselben bei Beinbrüchen. 8vo. Leipz. 1786. - Macdonald D. de necrosi ac callo. Edinb. 1799. - Wood in Memoirs of the Literary and philos. Soc. of Manchester, Series II. Vol. III. 1819.-Breschet These. Récherches historiques et experimentales sur la formation du Cal. 4to. Paris, 1819. - Exposé de la doctrine de Dupuytren sur le Cal, par Sanson in Journ. univ. des Sc. médic. Vol. XX. p. 131. Paris, 1820. - J. H. Reypens Commentatio ad quæstionem ab ordine medicorum propositam: Quæritur ut exponantur variæ doctorum virorum sententiæ de origine et natura Calli ossium; dein observatis in homine, nec minus experimentis in animalibus institutis, probabilior inferatur theoria ossium fractorum coalitus; quæ præmio ornata est. 4to. Lovani 1823, with twenty experiments.-Scarpa Abhandlung über die Knochenexpansion und über die callus nach Frakturen a. d. Lat. 4to. Weimar, 1828.-- [P. Camper, Observationes circa callum ossium fractorum. T. $]$

(5) Breschet and Villerme in Magendie's Journ. de Physiol. experim. Vol. I. No. 2, April, 1821, p. 116.-Howship, p, 89 and 97, pl. 10, fig. 6 .

(6) H. Park, Account of a new metlood of treating diseases of the joints of the 
knee and elbow. Lond. 1783; Cases of the excision of carious juints, by H. Park and P. F. Moreau, with Observations by Jiffray. Glasgow, 1806.Wachter D. de articul. exstiratione. Gröningæ, 1810.-Denové D. sur l'utilité de la resection des os dans les membres. Paris, 1812.-Roux De la resection de portions d'os malades, etc. Paris, 1812. - Kowland, A case of an ununited fracture of the thigh, cured by sawing off the ends of the bone, in New. chir. Transact. Vol. II. No. 5.-Crampton, in the Dublin Hospital Reports, \&c. 1827, Vol. IV.-- Roux, on removal of diseased joints, in Revue Médic.--J. Syme, Cases of excision of elbow and knee joints. v. Edinb. Med. and Surg. Journ. April, 1830. T.]

(7) Callisen De variis formationis calli impedimentis in Collect. Soc. med. Havn. Vol. II. No. 21, p. 189.

$\left(7^{*}\right)$ [A good instance of unumited fracture of the thigh bone from this cause, is related by Sommé, in Med. Chir. Trans. Vol. XVI. p. 36. T.]

(8) Melzger D. de callo luxuriante. Regiom. 1793. Good plates are given in Ludwig de quarundam rgriter. c. h. sed. et caus. tab. 10, fig. 1 and 2. Heckeren D. de osteogenesi præternaturali. L. B. 1797, fig. 1 and 2. It must be remembered that we are not now talking of callus in the same sense as the older writers.

(9) de Plouquet Repertor. Articulatio succedanea. - Salzmann D. de articulationibus quæ fracturis ossium superveniunt. 4to. Argent. 1718. - Gras in Journ. génér. de Méd. chir. et Pharm. August. Paris, 1800.-Reisseisen and Langenbeck, in the Neuen Bibliothek f. Chir. Part I. p. 81, ff -Home, in Transact. of a Society for the impr. of med. and chir. Knowl. Vol. I. p. 233, gives several instances. - Palletta Exercit. pathologicæ, Vol. I. p. 58.-Flormann resp. Nerman D. de articulationibus sic dictis accidentalibus, fracturas ossium interdum subsequentibus. 8vo. Lundæ, 1821. - Schwoerer D. de caus. et structura Pscudarthrosium, etc. 8vo. Friburg. 1822. - Mitsching D. de articulatione spuria et nova eam curandi metlodo. 8vo. Halæ, 1822. - Schuster D. de articulatione præternaturali. 8vo. Landshut. 1822. - M. Troschel D. pseudarthrosi. 8 vo. Berol. 1826, with a plate. They are not unfrequent in animals. I have seen them in dogs, cats, a fox, and several birds.-Greve, Erfahr. und Beobacht. über die Krankheiten der Hausthiere, Vol. II. p. 3, found an umnatural joint in a hare. Compare my Verseichniss der 13reslauer Präparatensammlung, No. 2149, 2150, 2321, 2322, 3589, 3590. - J. Tenon, Observation Aratomique sur une articulation singuliere dans un cliat formée par la nature, in Mém. de Paris, 1760 , Hist. p. 50.

(10) Callisen Annot. circa callum ossium in Act. Soc. med. Hafn. Vol. I. No. 26, p. 312.-A. Cooper, On Dislucations and Fractures, \&c. Lond. 1822, and his Observations on fractures of the Neck of the Thigh-bone, \&c. Lond. 1823. Compare below, the thigh-bone and knee-cap.

\section{$\S 114$.}

Partly in a similar manner occurs also the REPRoduction, regeneratio, of a bone. If part of it be destroyed by wounds or mortification, the reproduction occurs as in soft parts by granulation, ${ }^{1}$ whilst in the newly produced tissue lime is also gradually and freely deposited..$^{{ }^{\circ}}$ The bone usually forms at such part a more or less thick and deep cicatrix ; in rare cases this rises even above the surface of the bone. 'The unattached ends of bone produced by amputation become smooth, rounded, and narrowed by absorption and contraction, and are always closed by a new mass of bone. ${ }^{2}$ Should the bony parts have been destroyed by necrosis, there is poured out a mass very similar to callus, which, by expelling the hard dead piece, 
becomes homogeneous with the healthy bone, and thus the lost bone is completely replaced. ${ }^{3}$ In such manner large pieces of bone, and even whole bones, have been seen to be reproduced; ${ }^{4}$ this, however, especially applies to hard and thick bones, as the spongy bones cannot be thus restored, but are cured by granulation and cicatrization with large deposit of lime in the bony tissue. ${ }^{5}$

(1) Compare above, $\S 56$. The reason why holes in the skull, made by the trepan, are closed with greater difficulty, is the want of blood vessels, both as the outer and inner membranes of the bone are removed.- [Craigie seems to doubt whether these apertures are ever filled up. He admits, with reservation, Weidmann's case, pl. 12 ; but thinks that the cases seen by Russell, who states that the solid matter "possessed all the qualities of solid bone," rather resemble the reproduction after fracture than that after necrosis. v. his Elements, p. 568. T.]

(1*) [These granulations, often, however, have so strong a tendency to ossify, that it becomes a considerable inconvenience, $i$. $e$. they form higher than the surface of the bone in general, which prominence prevents the process of cicatrization. John Hunter, MSS. Lectures on Surgery. T.]

(2) Van Hoorn D. de iis, quæ in partibus membri præsertim osseis, amputatione vulneratis, notanda sunt, p. 36. L. B. 1803. - In rare instances, the uniting bony mass is poured out in too large quantity, and forms mishapen projections. In a hare, the foot of which had been shot off, a paw-like bony mass served as a foot. C'étoit une espece de jambe de bois, dont la nature seule avait fait les frais; Morand in l'Histoir. de l'Acad. des Sc. de Paris, 1770, p. 30.

(3) Compare the particular observations on necrosis.

(4) v. the writings of surgeons. - Voigtel Hanb. der pathol. Anatomie, Vol. I. p. 199-209.--de Plouquet Repertor. Ossis regeneratio, \&c.

(5) Compare Bauer Ueber das geringe Wiedererzeugungsvermögen der schwammigen Knocken, in Heidelberger klinischen Annalen, Vol III. Part I.

\section{$\$ 115$.}

On account of their peculiar structure and composition, the viCES OF TEXTURE of bones differ very remarkably from those of soft parts, but, like them, are they also specially produced by the inflammatory state. The PERIOSTEum, as an essential part of living bone, not only participates in these vices of texture, if at all important, but is, when primarily affected, also often the cause of them. InfLAMMATION OF BONE, ostitis, inflammatio ossium, ${ }^{1}$ attacks, indeed, all bones, but especially those which are very vascular, as young bones, the bodies of the vertebræ, the articular extremities of long bones, the bones of the hands and feet, \&c., ${ }^{1 *}$ and arises partly from external, ${ }^{2}$ partly from internal causes, especially from scrofula, syphilis, rheumatism, gout, and metastasis in fevers and eruptive diseases. Inflammation can exist at the same time in the whole bone, or locally, only in the periosteum, ${ }^{3}$ periostitis, or in the so-called medullary membrane; and in the latter case, according to the strength of the bony tissue, it is confined for a long time to the external or internal layers of the bone, although it occasionally attacks more or less the 
whole tissue, especially in the spongy bones. Should this be the case, the bone becomes swollen, ${ }^{4}$ and exhibits in its substance, as well as in the periosteum and medullary membrane, a great quantity of blood-vessels, and thereby becomes somewhat and in rare cases remarkably red. The cells and canals in the bony tissue increase in size, are irregular, run together in part by the absorption of their walls, and are filled with blood and jelly, so that the fine membranes by which they are lined are found distinctly thickened. The proportion of lime in the bone is more or less diminished according to the intensity and duration of the inflammation. We find the periosteum thickened and relaxed $;^{5}$ this is especially the case, if the inflammation of the bone arises from it, and if it have been long provoked by disease of the neighbouring soft parts. In such cases the surface of the bone generally exhibits an oftentimes very material roughness and porousness. ${ }^{5 *}$

(1) Glass D. de ossium inflammationibus. L. B. 1728. v. Haller's Bibl. chir. Vol. II. p. 198.-Fr. Hoffmann de infl. oss. Halæ, 1737. - Scrinci D. de ossium natura, horumque inflammatione in genere, etc. Pragæ, 1743. - Wallerian Lectiones curiosæ de morbis ex ossium inflammatione ortis. Regiom. 1764. Nebel Pr. de oss. inflammationibus. Giessæ, 1778. - Flormann D. de infl. ossium. Lund. 1799. - Soeminerring de morbis vasorum absorbentibus, p. 164.-Tornero in Mémor. Acad. de la R. Soc. de Sevilla, Vol. III. p. 131. - Victorino, ib. Vol. V. p. 62.-Schramm D. de oss. inflam. Altdorf. 1805. - Naumann D. de ostitide. 4to. Lips. 1818. - Hake Comm. de oss. inflam. 8vo. Goett. 1821.-Howship, On the morbid appearances and structure of bone, in the Med. chir. Trans. Vol. X. p. 176.-Goetz D. de ostitide. Svo. Landshuti, 1822 .

(1*) [Soft bones, and the soft parts of hard bones, are more subject to inflammation than others. J. Iunter, MSS. T.]

(2) Cold, but especially mechanical influences on the bone itself, or upon the neighbouring soft parts, as muscles, synovial membranes, \&c. from which the inflammation extends itself further.

(3) With reference to idiopathic inflammation of the periosteum, compare especially, $P h$. Cramptone, in Dublin hospital reports and communications, \&c. Vol. I. p. 337-397. - Bradley Tylor mentions a remarkable instance of fatal periostitis in the American Medic. Recorder. Vol. II. No. 1. Philadelphia, 1819.-Meiselbach D. de periostei inflammatione. 8vo. Halæ, 1824.

(4) All the bony tumours, which are indeed sometimes very obscure, may be produced by an inflammatory state; the kind of loosening and swelling varies considerably. Compare the following $\S \S$.

(5) It has been once seen half an inch thick, upon the skull, after an injury, v. Trye in Med. Communic. Vol. II. London, 1790. I have seen it in tumours, with growth of bone even an inch thick.-['Tlie periosteum becomes very easy of separation after inflammation, if the ossifying disposition does not take place. J. Hunter, MSS. T.]

(5*) [Ossific inflammation is distinguishable after death by the loss of shape. J. IIunter, MSS. T.]

\section{$\S 116$.}

To the terminations of inflammation of bones, which when found in a distinct degree, is rarely cured by resolution, belong especially sUPPURATION OF BONE, ULCERATION and 
MORTIFICATION, curies. $^{1}$ This disease is very similar to the ulceration of soft parts, and, like it, varies much according to the causes giving rise to it, ${ }^{2}$ of age, of the parts attacked, \&c.; but it always consists in a greater or less destruction and discolouring of the bone, with secretion of pus. ${ }^{3}$ Young and spongy bones largely supplied with vessels most commonly become carious. ${ }^{3 *}$ In many cases, in consequence of the destruction of the neighbouring fleshy parts, and of the parts surrounding the articular extremities, ${ }^{4}$ the periosteum and the upper surface of the bone become first destroyed, caries externa; more commonly the disease commences in the interior of the bone, caries centralis, ${ }^{5}$ then sometimes forms a circumscribed abscess, osteoapostema, and frequently one or several sinuses, osseous fistulas, make their way to the surface of the bone..$^{5 *}$ A peculiar and very malignant form of bony mortification is the so-called PÆDARTHROCACY, spina ventosa ${ }^{6}{ }^{6}$ pedarthrocace. ${ }^{7}$ The characteristic of this disease is a malignant bony tumour originating from within, with very great swelling of the diseased bone, and often accompanied with a disposition to deposit lime in the neighbourhood of the tumour, in form of points or spines. The latter, however, is not always the case, and the bone forms not unfrequently, in spina ventosa, a large bladder-like, tolerably smooth enlargement, without any bony increment. In the interior of this spina ventosa we find a very loose bony tissue with spongy cellular tissue, abscesses, and sinuses, and not rarely also cavities filled with lymph and blood. The spina ventosa attacks hard and thick as well as spongy bones $; 7^{7 *}$ it affects, in children, the articular ends of bones which are swollen by rickets, the so-called double joints, and thus we are led to call it especially pædarthrocacy.

(1) Compare de Plouquet Repertor. Ossis Caries. - Reuss Repert. Comm. Vol. XII. p. 236.-Heinze D. de carie ossium. Gryph. 1751.-Fitzgerald D. de carr. oss. Monspel. 1752. - Rauschert D. de c. o. L. B. 1706 ; in Haller's Bibl. chir. Vol. II. p. 422. - Nicolai D. de c. o. in genere. Jen. 1762.-[C. Barberis De ossium carie. 4to. Monsp. 1775. T.]-Ferrand D. de c. o. Paris, 1765. Piderit Geschichte eines sehr merkwürdigen Beinfrasses. 8vo. Kassel, 1781. -Ulmann D. s. ossium cariem. Marb. 1795.-Delzeules D. sur la necrose et la carie. 8vo. Paris, 1802.-Levret D. sur la carie. 4to. Paris, 1805. - Juan D. sur la carie. 4to. Paris, 1806. - Walter, D: de carie. Helmst. 1807. Louis D. de carie vera. Erlang. 1807. - Mariglier D. de carie. 4to. Paris, 1811. - Wissmann Observationes de rite cognoscendis et curandis nudatione, carie et necrosi ossium. 8vo. Halæ, 1820. - Schmoelzl D. de ossium carie. Landshut. 1823.-Wehmeyer D. de ossium carie. 8vo. Rostock, 1826.In animals, caries is much more rare than in man; the scrofulous, however, occurs in confined animals, and caries in the spine of horses, from poll evil, saddle-gall, ulcer on the croup. Compare No. 3246, 3351, 3520, 3521, 3788, 3789, of the Breslau Museum.--A cured caries on the skull of a monkey, v. Sandifort, Mus. Anat. Vol. III. p. 276, No. 919 . 
(2) For instance, the caries from mechanical causes, the malignant caries from internal causes, the scorbutic, scrofulous, syphilitic, the corroding from pox, the cancerous, \&c.

(3) This is usually at first, though not alwavs, thin, ichorous, very stinking, mingled with broken up bony fragments, and, according to the greater quantity of salts, especially phosphates, which it contains, blackening a silver sound.

(3*) [Suppuration does not so often take place in bone as in soft parts, because when it does take place the effects are so very serious. Although suppuration sometimes takes place in the substance of bones, yet the periosteum of bones being more liable to inflammation, more frequently suppurates, and the bone becomes affected in this way. J. Hunter, MSS. T.]

(4) Compare Eck D. de carie articulorum externa cum interna comparata. 8 vo. Berol. 1818, with engravings.

(5) Compare especially, Rust Arthrokakologie, oder über die Verrenkungen durch innere Bedingung und über die Anwendung des Glüheisens. 4to. Wien, 1817, witl eight engravings.

(5*) [Bones are not very liable to suppuration, performing many operations without this process. J. Hunter, MSS. T.]

(6) Also Ventositas spince, Arthrocace, Teredo, and falsely Bony Cancer. Much confusion occurs in writers, with reference to spina ventosa. Many cases of morbus coxarius, of tumor albus, \&c., belong here. - N. Massa, Epist. medic. 4to. p. 108, Venet. 1550, first used the name spina ventosa.-The older writers, de Plouquet Repert. Art. Pædarthrocace, and Reuss Repert. Comment. Vol. XIV. p. 261-263. -- Hemmer D. de spina ventosa. Hafniæ, 1595. - Augustin D. de Spina ventosa ossium. 4to. Halæ, 1794, with four plates.-G. Ghioni Memoria sopra la detta Spina ventosa. 8vo. Parma, 1798.-Lagresie Observations sur l'amputation de la cuisse, necessitée par le spina ventosa du tibia et du peroné, etc. 8vo. Paris, Ann. VII. - Houzelot D. sur les maladies du systeme lymphatico-sanguins des os, connues sous les differens noms de Pædarthrocace, de spina ventosa, d'osteosarcome, ou de carnifications des os. 4to. Paris, 1804.-Vandenzaude D. sur le spina ventosa. 4to. Paris, 1805. - Suchchardt Annotata quædam de spina ventosa, etc. 8vo. Marburgi, 1817. - - Haenel D. de spina ventosa. 4 to. Lips. 1823, with plates.-Stark, Prog. Historia morbi ossium faciei memoratu digna, cum nonnullis adnotationibus in spinum ventosam et exostosin Contin. I. 4to. Jenæ, 1827. - Good engravings in Sandifort's Mus. anat. tab. 89 , fig. $1-3$; tab. $320,321,424-474$. In animals, spina ventosa occurs not very rarely, especially in the jaws of oxen and horses, and in their fect. v. No. 3166, 3168, 3868, of the Bresl. Mus. in the tip of the tail of monkeys, of the coati mondi, of a camelion, No. 4859, \&c.-Stark, \&c. Continuatio, II. Prog.f. Kraner D. de pancreatitide. 4to. Jenæ, 1828. - [J. Pandolphinus De ventositatis spinæ sævissimo morbo. $12 \mathrm{mo}$. Norimb، 1674.-II. Meer De spina ventosa. 4 to. Duisb. ad Rhen. 1729. T.]

(7) Severinus Tractatus de pædarthrocace, etc. in de recondita abscessuum natura, p. 335. L. B. 1724.--Fausius D. de pæedarthrocace. Heidelberg. 1657.Chun 1). de pædarthrocace. Marburg. 1697. - Schmidt D. de pædarthrocace. L. B. 1721.--Nebel D. de P. Heidelb. 1745.-Rosenblad D. s. casum pæedarthrocaces. Lund. 1777.- [More recently, F. Freind, who placed the primary action in the marrow, which becoming diseased and enlarged, scparates the outer lamella, and distends the periosteum with pain and swelling. - Monro primus Cheselden, and others, held the same opinion. - Bromficld thought it an alscess in the narrow; v. his Surgical Observations and Cases, Vol. II. p. 20-22. Svo. London, 1737 ; and Warner, that it originated in the marrow and vessels; v. his Cases in Surgery, p. 322. Svo. London, 1760.-Richerand considers spina ventosa as a variety of osteosarcoma, and that it is the simple scrofulous swelling of the articular extremities of the phalanges, the membrane lining the spongy cells of which beconing thick, inflamed, ulcerated, and putting forth more or less abundant vegetations. Further, that it does not differ from suppurating exostosis or caries, except in the excessive swelling of the bony substance and the enormous size which the articular extremities of bones acquire; v. his Nosngraphlic Chirurgicale, Vol. 111. 
p. 120. 8vo. Paris, 1815. - Scarpa holds the same opinion; v. his work De Anatome et Pathologia Ossium, p. 76-78. T.]

(7*) [This is denied by Craigie; he says, that "Spina ventosa never occurs in a bone with a distinct medullary canal, unless at the epiphyses where the structure is cancellated." And that the true agent of the process is the vascular medullary web, especially of the epiphyses; v. his Elements, p. 568-572. T.]

\section{$\S 11 \%$}

Another common consequence of inflammation is MORTIFICATION OF BONE, necrosis, osteonecrosis, osteogangrena, ${ }^{1}$ answering to the gangrene of soft parts, but proportionally more frequent and of a more favourable kind than that. Mortification of bone may indeed occur in all parts of the skeleton, although it especially attacks the hard bones, ${ }^{2}$ and is always succeeded by a SEPARATION, exfoliatio ${ }^{3}$ of the dead portions of bone from the living. ${ }^{3 *}$ According to the state of the bone attacked as well as the causal proportions, mortification of bone exhibits various differences. If a part of the body be completely affected by gangrene, the bones found therein become dead, spongy, light, frangible, and of a blackish brown colour. ${ }^{4}$ In other cases, when scorbutic ulceration and hospital gangrene render the bones in the neighbourhood necrotic, so with similar discoloration they become softer and more soluble; in the common cases of necrosis, on the contrary, the dead bone is dry, rough, very deficient in jelly, frequently porous, or as it were, externally corroded, and mostly snow white, but more rarely coloured by a blackish or brown pigment evolved in the body itself. Often is the necrosis connected with caries, or it is the consequence as well as the cause of the latter; in fracture also single portions of bone not unfrequently become necrotic, and are separated and thrown off by exfoliation. ${ }^{5}$ Mortification sometimes occurs only in certain layers of bone, for instance, the external, necrosis externa, superficialis, or the internal, necrosis interna, centralis; sometimes the whole mass, necrosis totalis. The first usually arises from the EXPosure, denudatio, of bone, in consequence of the morbid destruction of the neighbouring fleshy parts, \&c., and attacks a greater or less portion of the outer table of the bone, which, when it is separated, is thrown off by ulceration, and replaced by granulation..$^{*}$ The necrosis interna occurs almost only in tubular and round bones, ${ }^{6}$ the necrosis totalis, on the contrary, in all solid bones. The latter kind of bony mortification, especially in tubular bones, ${ }^{7}$ exhibits the remarkable phenomenon, that before the dead piece of bone has been separated from the living part, there is poured out between the inflamed periosteum and deild bone a jelly-like mass, which 
gradually hardens and becomes ossified, surrounds, like a sheath, vagina seu capsula sequestralis, the necrotic bone, which is then called a SEQUESTER, sequestrum; ${ }^{8}$ at first is connected with it, subsequently separates from it, and is then lined internally by a delicate medullary membrane. In the midst of these bony sheaths are one or several holes, foramina grandia of Troja, cloaca ${ }^{9}$ of Weidmann, which running into the already existing sinuses of the soft parts, produce an outlet for the continually absorbed and diminished sequestrum, as well as for the secreted lymph and pus, and when this is effected, they become gradually closed up. In the necrosis interna, the process is exactly the same; but in this case, the jelly-like substance poured out beneath the periosteum is only connected with the remaining living circumference of the bone, which, in many cases, swells simultaneously, and becomes softish. Both in necrosis totalis and interna, as well as in the externa, if the dead piece of bone be of some thickness, the medullary cavity in tubular bones is usually closed up, ${ }^{10}$ at least for a time, by the deposition of bony matter.

(1) By the ancients in part, Caries sicca; Louis, in Mém. de l'Acad. de Chir. Vol. V. first distinguished this disease by the name Necrosis. - de Plouquet Repert. Art. Ossis Necrosis.-Reuss Repert. Comm. Vol. XII. p. 246, and the above-mentioned writers, $\$ 113$, note 2 ; especially Troja, Knox, Meding and Cortum;-Robert, præs. Chopart De necrosi ossium Theses. Paris, 1776.-David Observations sur une maladie, connue sous le nom de Necrosis. Paris, 1782. - Hirsch, præs. Metzger D. de necrosi ossium. Regiomonti, 1791.-Weidmann De Necrosi ossium. fol. Francof. a. M. 1793, with engravings; and $i b$. Ueber den Missbrauch des glühenden Eisens um brandige Knochenstücke abzusondern, a. d. Lat. von Jos. und K. Wenzel, 4to. Frankf. a. M. 1801, with eight plates.Russel, A practical Essay on a certain disease of the bones, termed Necrosis, Edinb. and London, 1794, with six plates.-Macdonald D. de Necrosi ac Callo. Edinb. 1799. - Himly Abhandlung über den Brand der harten und weichen Theile. 8vo. Gotting. 1800.-Deleuze D. sur la nécrose et la carie. 8vo. Paris, 1802. - Birgelmann De necrosi ossium. Rudolst. 1804.-Béclard in Bullet. de la Fac. de Médec. de Paris, 1815, p. 427.-Whately, Practical observations on necrosis of the tibia. London, 1815.-Blaise Essai sur la nécrose. 4to. Paris, 1815. - Lannes D. sur la nécrose en générat. 4to. Paris, 1815. - Cullevier Observations sur des nécroses lu crane, etc. in Annuaire méd. chir. des Hôpit. et Hosp. Paris, 1819, p. 437.-Wissmann D. s. observationes de rite cognoscendis et curandis nudatione, caric et necrosi ossium. Halæ, 1820.Hennen D. de ossium necrosi. Edinb. 1821.--Kleemam D. de ossium necrosi. 8 vo. Berol. 1S21. - Flecchia Sulla necrosi e sopra un raro osseo processo, in Omodei's Annali univers. di Medic. 1821, Vol. XVII.-Borgh 1te Verhandling over de necrosis gevolget van ecnige Waarnemingen. 8vo. Groeningen, 1822, with plates.-Weiglein D. de nccrosi. 8vo. Wien. 1824.-J. Russel in Trans. of the med. chir. Soc. of Edinb. 1821. No. 3.-liichter Die necrose, pathol. und therapeut. gewiirdigt. 8vo. Berlin, 1826, and in $v$. Grafe's and $v$. Walther's Journ. f. Chir. Vol. VII. and VIII.-Rudolph 1). de necrosi. 8vo. Berol. 1827.-P. Hindernaclit Ueber die Erkentuiss und die Belıandl. des Knockenbrandes. 8vo. Wïrzb. 1827.

(2) lispecially the shin, upper arm, and thigh-bones, the extremities of which it however spares; the lower jaw, and in syphilitic persons, the flat skull-hones. [Hard bones and hard parts of soft bones are found to exfoliate most readily, 
this depending on the hard becoming dead most readily, from the fewer vessels in them; so that it is almost impossible to lay a hard bone bare without exfoliation being the consequence. J. Hunter, MSS. T.]

(3) Scaling, when sometimes the separate layers of the bones are thrown off like leaves.-Exfoliatio sensibilis and insensibilis, if the smaller pieces of bone thrown off are entirely absorbed or evacuated with the pus.-Reuss Repert. Comment. Vol. XIV. p. 251. - Boulay D. sur l'exfoliation des os. 4to. Paris, 1814. - Menegazzi, in Brera's Giorn. di Med. prat. Vol. I. Part I. gives a very remarkable instance of exfoliation on several parts.

$\left(3^{*}\right)$ [When a piece of bone becomes dead, it nevertheless adheres to the living part by attraction of cohesion, but it acts as an extraneous body would do, by stimulating it. In consequence of this stimulus, the surrounding living bone becomes inflamed and more vascular than before, the surrounding parts also inflame, and often take on the ossific disposition to a great extent; the earthy part of the bone is next absorbed, but the dead bone still adheres to the living by the animal substance of the bone; the next process then is the absorption of this animal substance; the absorption begins at the circumference and is continued to the centre; next the granulations arise (beginning at the circumference before it is entirely absorbed at the centre) from the living surface between the living and the dead bone, and the latter is pushed off. J. Hunter. MSS. T.]

(4) So that the whole limb may be separated. Compare $\S 62$, note 2 . A rare instance of loss of the thigh-bone is given by Desessartz in Mém. de l'Instit. nat. Ann. IV. Vol. I.- In the Anatomical Museum of the Joseph Academy at Vienna, I saw four such feet, and a fifth in the Anat. Mus. of the University there.

(5) The so-called secondary splinters.

$\left(5^{*}\right)$ [The dead bone is sometimes confined by the granulations extending over the edges of it and becoming ossified; if the parts so circumstanced are left to themselves, the same process will happen as in cases of other extraneous bodies, \&c. the pressure producing ulceration. J. Hunter, MSS. T.]

(6) Weidmann, De necrosi ossium, p. 94, however, gives an instance of it on the hip-bone.

(7) Among the flat bones this kind of regeneration has been only observed in the blade-bone. v. further, $\oint 140$; the necrotic bones of the skull, as they are generally reproduced, effect this by granulations from the edges and from the dura mater. No instance of the round bones is known, except the heelbone belonging to the Museum at Kiel, in which, however, the containing vagina sequestralis appears to be the shell of the old bone. Compare Seidel Index Musei anatomici Kiliensis. 4to. Kiliæ, 1818. No. 27, p. 22.

(8) Sc. Os.-The size and form of such sequestra vary exceedingly; sometimes they form a complete tube, sometimes merely a part; in internal necrosis both their surfaces are rough, but in complete necrosis the external is usually smooth.

(9) Usually we find only single cloacæ, but Köhler saw sixteen; v. Experimenta circa regenerationem ossium, No. 146, p. 45 ; on a tibia in the Anatomical Museum at Griefswald, I counted as many as thirty cloacæ. Disputes upon the cause of their origin. According to Meding and Cortum, birds seem to form no cloacæ.

(10) Here belongs also the case described by Munk af Rosenschöld, which is not very well known to me; v. D. resp. Rabben, de formatione novi ossis in cavamine tibiæ, exemplo comprobata. 4to. Lund. 1814.

\section{$\S 118$.}

Besides caries and mortification of bone which are the most common consequences of bony inflammation, the latter particularly, if it take on the chronic form and depend upon certain dyscracies and general diseases, produces some very striking

$$
\text { L } \mathscr{2}
$$


vices of texture. To these belong ERosion, INCREASED DEPOSITION OF LIME, AND THE CANCEROUS KIND OF BONY DISEASES.

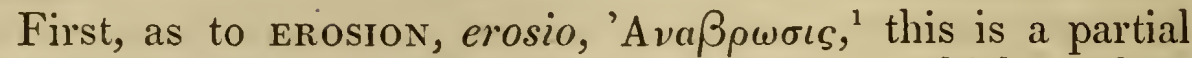
destruction of a bone by increased absorption, which is of an inflammatory nature, and is often very distinctly produced by the increased activity of the numerous veins of the bone. It differs from caries, to which it often otherwise is very similar, in being unaccompanied by suppuration, and usually also without discoloration; from tabes ossium, on the contrary, by its inflammatory nature, and inasmuch as it not merely attacks the diploe, but also the external table of the bone. The erosion then is sometimes INTERNAL, sometimes EXTERNAL; the former is commonly the consequence of scrofula protracta, syphilis, cancer, and other general cachexiæ, in which oftentimes a morbid irritation and inflammatory condition of the bone is produced; the lime is then gradually removed, the diploe more or less destroyed, ${ }^{2}$ and the bones, often quite soft, are mostly in the commencement filled with hard marrow, in which, as in the remaining bony substance, are seen many expanded tortuous veins. If the weakness of the organism increase, so that at last the jelly and hard fat of the bone are consumed, in their place is deposited lymph, which is often bloody, or a thinnish fluid-like marrow, and thus the brittleness of the bone, fragilitas vitrea, is produced. In rare cases this internal erosion arises from the morbid activity of the blood-vessels, and there is found, instead of the absorbed bony tissue, a greater or less collection of blood, mostly coagulated, but sometimes also fluid, which partially destroys, but always very much expands, the outer walls of the bone, and thus produces true BLOODY TUMOURs, tumores sanguinei, of bones. In most instances this disease is, as it were, a VARICOSITY OF THE BONE, and we then find at death, a thin half-coagulated blood collected in the cells of the bony tumour and in the veins, which are here and there enlarged and knotty. ${ }^{3}$ More rarely are these bloody swellings of bone of an anEURYSMal NaTURE, present during life some pulsation, and in their interior, the coagulated fibrous part of the blood partially mingled with cruor in large cells and cavities, and the distinct termination of a quantity of fine arterial branches in the cells. ${ }^{4}$ Just as common as the internal is the EXTERNAL EROSION, which originates in a certain inflammatory irritation of the surface of the bone from disease of the soft parts and periosteum lying upon it, but especially from continued pressure, from effused blood, ${ }^{5}$ and tumours of various kinds, more particularly aneurysmal, fungous, and scrofulous 
tumours, which run into softening on the surface of the bone. At first the bone is more or less rough, often marked with deep lines, the indentations of the expanded blood-vessels, or perforated at several points, as if it were absorbed; the outer walls of the bone are gradually destroyed, together with more or less of the diploe; and flat bones, for instance, the bones of the skull, and the breast bone, are not unfrequently completely perforated.

(1) It is commonly held by some persons to be the same as consumption of bone, tabes ossium, (compare $\$ 107$,) and is besides often very similar to, and even connected with it, although I think it may be distinguished not improperly from that disease. In reference to its literature, v. above, $\S 107$, note 5 ; Scarpa in D. Mémoir. de la Soc. Roy. de Méd. 1780 and 81, Vol. IV. first distinguishe.l the erosion in aneurysm from caries; Cumin first employed the word anabrosis in the Edinb. med. and surgical Journ. 1825.

(2) In the long tubular bones, the shell only remains, hardly a line thick; Saillant in Histoire de la Soc. Roy. de Médecine, 1786, p. 98, calls this goutte medullaire. Compare Lobstein Compte rendu, \&c. p. 26 ; many such preparations are found in the Bresl. Anat. Mus. I have several times seen on the flat bones of the skull, pelvis, and shoulder-blades roundish pits, closed on both sides merely with periosteum, and containing a thin jelly; v. my Verzeichniss, u. s. w. No. 3522, 3649, 3925.-Selt. Beob. Part II. p. 11, No. 4; a good engraving is given by Copeland in his Observations on the symptoms and treatment of diseased Spine. 8vo. London, 1815.

(3) To these belong in part Boyer's tumeurs fongueuses sanguines accidentelles. v. Traité des maladies chirurgicales. 2d edit. Paris, 1818. Vol. II. p. 318.Fabriz Hildanus Observat. Cent. II. Obs. 35, p. 110.-Else, Medic. Observat. and Enquiries. Vol. I I. p. 169. Lond. 1769._Perc. Pott, Chirurgical Works.-Lassus Pathol. chirurg. Vol. I. p. 489. - Pelletan Clinique chirurg. Vol. II. p. 14, Obs. 3. - Breschet Sur des tumeurs sanguines, etc. in Répert. gén. d'Anatom. et de Phys. pathol. 1826. Vol. II. No. 4, p. 263. Several of the preceding observations, however, describe cases of osteosarcom, in which much blood is found in the tumour. I have seen two cases of this kind in the lower jaw and on the shin-bone.

(4) Pearson Medic. Communicat. Vol. XI. p. 95. Lond. 1790.-Scarpa Sull, Aneurysma. Obs. 10.-Lallemand in Répert. gén. d'Anat. et de Phys. patiologiques, 1826, Vol. II. No. 4, p. 253.-Breschet, p. 2s0, in which are described three cases from Dupuytren's practice. Simultaneously also with osteosarcom we find small aneurysms; v. my Selt. Beob. Part II. p. 30.-Scarpa, p. 103.

(5) Hunter in Med. and Surg. Observations and Inquiries, Sc. Vol. I.Thomas in Edinb. med. Comment. Vol. VI. p. 75.

\section{$\S 119$.}

The INCREASED DEPOSITION OF BONY MATTER, hyperostosis, ${ }^{1}$ consequent on the inflamed state of bones, appears under a twofold form, viz. as INTERNAL and ExTERNAL. The former indeed, in a milder degree, is the usual and best consequence even of the least important inflammation of bone, which on account of its hardness, does not appear capable of being resolved in a similar manner to inflammation of soft parts. The necessary consequence of this deposition of bony matter in the diploe is naturally, INCREASED WEIGHT AND SOLIDITY of the bones. The more frequently the inflammatory 
condition recurs, or in other cases the longer the morbid irritation favours the deposition of lime, the more is the weight and solidity increased; so that such bones not unfiequently assume an ivorylike state, and if they be tubular, their medullary cavities are also filled with bony substance. ${ }^{2}$ This bony deposition, however, is always favourable, and is not, as to its consequences, to be compared with the induration of soft parts; it is on the contrary a kind of cure for many diseases of bone, or at least an attempt thereat. We therefore often find a bone consolidated in the neighbourhood of caries and spina ventosa; frequently the venereal disease, ${ }^{3}$ and malignant gout, produce great weight and solidity of the bones; sometimes also the looseness of bone from rickets, or other ill-defined and mixed morbid causes, are as it were cured by the increased deposition of lime, and thus distinct bony tumours, with accompanying unnatural solidity, density, and weight, are produced. We most commonly observe this latter disease, which in a more restricted sense we call hyperostosis, on the head, ${ }^{4}$ although sometimes also on other bones, and even on several parts of the skeleton at the same time. ${ }^{5}$ More frequent than on the interior, is the deposition of lime On THE SURFACE OF THE BONE, Or the EXTERNAL hyperostosis; for the most part also, as is natural, is it more injurious in its consequences than the former. The inflammatory states of the periosteum, and the outer table of the bone, produced partly by mechanical, and partly by internal causes, ${ }^{6}$ are the usual origins of this disease. Sometimes the lime is deposited in the loosened periosteum, which then becomes cartilaginous and bony, in leaf-like patches, ${ }^{7}$ or it assumes the form of flattened rounded tumours of cartilage, gummata, ${ }^{8}$ or of nodes, nodi. If the superfluous bony mass be situated on the bone itself, we call it, when it forms a local and defined prominence, a BONY TUMOUR, exostosis, ${ }^{9}$ but if it be very large and less distinctly defined, а BONY GRowTH, luxuratio ossium; the bony tumours which occur in cavities, for instance, in the skull, the orbit, the pelvis, the joints, we distinguish by the name enostosis; sometimes in the skull an exostosis is produced simultaneously on the external and internal surface. The bones of the skull, as well as the tubular bones, and of these, the thigh and shin bone, most commonly present exostosis; next them perhaps, the vertebra and the pelvis; still however they can be produced on any bone, ${ }^{10}$ and in rare cases on many parts of the skeleton simultaneously. ${ }^{11}$ They are also fiequently found in great number in the neighbourhood of bony parts which have been affected with long-continued caries ${ }^{12}$ and spina ventosa. ${ }^{13}$ 'Their form and size assume an endless 
variety; we observe them flat, globular, gibbous, tooth-like, styliform, broken as it were at both ends and arched in the middle, ${ }^{14}$ sometimes they attain the size of a child's head, and even that of man. But even more considerably does the texture of these bony tumours vary; frequently are they of a mixed structure; they assume, however, three principal forms: they consist indeed often of a more or less close, even ivory-like healthy bony mass, which as it were exudes from the surface of the bone, and there coagulates $;^{15}$ in this case the outer layer of the bone only appears slightly changed in its structure; the spiny and tooth-like exostoses also, as in spina ventosa, appear to be very hard and close. In other instances, from the loosened surface of the bone, innumerable delicate bony fibres, standing close to each other in a perpendicular or oblique direction, shoot up in the inflamed and spongy-like loosened periosteum; these bony fibres are of the length of an inch or thereabout, are harder and closer at their base, and at their further end soft and cartilaginous, and penetrate into the cellular tissue of the loosened periosteum, which still remaining externally unbroken, dips deeply inwards between the bony fibres, surrounding them like sheaths. Lastly, in other cases, by the partial expansion of the bone from within, the contained exostosis has its interior loose, cellular, very vascular, and its cavities filled with very different substances, which vary in consistence from lymph to soft cartilage; large tumours of this kind are particularly common in the lower jaw, ${ }^{16}$ and still more in the bones of the hand, ${ }^{17}$ containing a light coloured jelly in mixed cells of bony fibres and cartilaginous membranes. These cellular exostoses become larger than the other kinds, easily inflame, and run into suppuration, or are converted, by increase of the cellular tissue of their cells and loosening of the periosteum, into large tumours, the base of which consists of thread-like, tooth-like, or leaf-like bony masses. Very hard and close exostoses are in rare instances separated by necrosis. ${ }^{18}$

(1) Nesse-Hill Sur les maladies des os par secretion superflué, \&c. in Journ. de Médec. continué. Vol. VI. p. 122.

(2) van der Haar in Verhandelingen van het Maatsch. te Haarlem. Decl. XV. Boyer, Traite de malad. chir. Vol. III. p. 547, properly considers this to occur but rarely. Compare Pitet in Bulletin de la Société de Médec. An. XIII. and XIV. Several instances occur in the Bresl. Mus; v. my Verzeichniss, u.s.w. No. 3510, 3514.-Lobsiein Compte rendu, \&c. p. 25.

(3) Brugmanns in van Maanen D. de absorptione solidorum, etc. p. 93 . My Verzeichniss, No. 167, 3091, 3092.

(4) Malpighi Op. posth. ed. Lond. 1697, p. 49, from the collection of the Duke of Modena.-Ribelt in Mém. présent, Vol. II. p. 336, (it weighed eight pounds and half an ounce;) a skull which Jussieu possessed at Paris, described and engraved in the Oryctologie par MM. les Sav. de Londres et Montpellier, 
1755, by Jadelct Description anatom. d'une tête humaine extraordinaire, etc. 8vo. Paris, 1799, with engravings.-Jourdain Traité des depôts dans le sinus; IIaxillaire et des Caries, etc. $12 \mathrm{mo}$. Paris, 1761. - Selt. Beob. u.s.w. Vol.II. p. 1, No. 1.-Ilg Einige anatomische Beob. u.s.w. p. 10, Prag. 1821, pl. 2 and 3.-von Soemmerring in Ballenstedt's and Kriiger's Archiv für die neuesten Entdeckungen aus der Urwelt. Vol. III. Part I. p. 25.- Spurzheim possessed a similar skull; v. Kilian Anat. Untersuchungen iiber das neunte Nervenpaar. p. 133, note 10. I saw a similar skull in the Cabinet of Natural History at Darmstadt, (Bojanus has described it in $v$. Froriep's Notizen, Sept. 1826, Vol. XV. No. 9, p. 129.) in Brookes's collection in London, in Vrolick's at Amsterdam, at Copenhagen in the Surgical Academy, in the Anat. Pathol. Mus. at Vienna (when fresh almost seven pounds in weight, ) and the commencement of this disease on a skull in Prof. Huth's at Frankfort, afterwards at Charkow (v. Soemmerring's mention of this case was probably derived from my verbal explanation,) and died at Dorpat. Sometimes it occurs only on certain parts of the skull, v. Sandifort's Mus. Anat. Vol. II. plate 13, fig 3, 4, 5,-v. Soemmerring mentions such a case in his collection. - v. Loder of a parietal bone; v. Index præparator. Part II. p. 9. I also saw this disease on the forehead of a child with a large tumour on the upper jaw, of an osteosarcomatous nature, in the Museum at Freyburg in Brisgow.

(5) Oin almost all the bones of one man; Noel in Roux Journ. de Médec. 1779. Maerz. p. 225.-Sauccrotte in Mémor. de l'Institut nat. Scienc. physic. Vol. II. p. 114. In Soemmerring's collection I saw this disease on two fowls, and also in the Anat. Mus. at Bonn, in the skeleton of a hen; perhaps also here belong the fowls' bones described by Sandifort, Mus. Anat. Vol. 1II. p. 275, No 911-915.

(6) Especially syphilis, gout, and mixed cachexiæ, which are distinguished with difficulty.

(7) Ossification of the Periosteum is indecd a rare disease, though I have seen it several times on the bony stump after amputation, and also on other parts; sometimes the outer layer only is ossified, and then forms a rough thin bony plate, running parallel to, but at about half a line's distance from, the bone itself, and which is only attached to it at certain parts by bony fibres; I once saw this on the outer surface of the hip-bone. Upon ossification of the periosteum, v. J. Howship, in Med. Chir. 'Trans. Vol. VIII. p. 70.-Boyer in Archives générales de Médecine, Nov. 1823.

(8) Boyer, Traité des maladies chirug. 2 d edit. Vol. III. p. 564, calls it Periostosis.

(9) Bidloo De exostosi in Op. omn. p. 202, tab. 2. Lug. Bat. 1715. -Juncker præs. Ludhuig D. de exostosibus. 4to. Halæ, 1756.-Houstet in Mém de l'Acad. de Chir. Vol. III. No. 7, p. 130.—Saldana D. de Exostosi. Traj. ad Rh. 1762._Allan præs. Dumont De exostosi. Theses anat. chir. 4to. Paris, 1770.-Delort præs. Suë De exostosi. 4to. Paris, 1774.-Fayolle De exostosi Monspel. 1774.Sigwart D. exostosis exemplo rariori illustrata. Tübing. 1781.-Morgagni De sed. et caus. morbor. Ep. L. Art. 56, et seq.-Ramonet D. sur les exostoses. Svo. Paris. An. XI.-Millière D. sur les exostoses. 4to. Paris, 1814.-Cullerier in Dict. des Sc. médic. Art. Exostose, Vol. XIV. p. 218.-Howship, p. 55.-A. Cooper on exostosis in his and 'Iravers's Surgic. Essays, Vol. I. 2d edit. 1818.-Bnil D. de ossium luxuriatione. 4to. Berol. 1820, with lithographic engravings.-Busch in Petersb. vermischten Abhandl. u.s.w. Part I. p. 61, pl. 2. Petersb. 1821.Westberg in Svenska Läkare-Sällskapets Handlingar. Vol. IX. 1823._Gibson in l'hiladelphia Journ. of the medical and physical Sciences, ed. by Chapman. Vol. II. No. 1, p. 121.-Starck; v. $\$ 116$, note 6.-Sandifort gives good engravings of exostosis in his Mus. Anat. tab). 87, 88, 102.-In brutes exostoses are not uncommon; to wit, on the spine in horses, on the foot in spavin and ringbone: the latter disease is sometimes hereditary and congenital; - all the progeny of a bull with an exostosis on the head had this vice. Sec Rudolphi Bemerliungen auf einer Reise, n. s. w. Vol. I. p. 75 ;-Boyer describes, at p. 600, a case of hereditary exostosis in the human subject.

(10) Gibson thought it did not occur on the hand and finger bones; this however is incorrect, for many such instances have been seen; note 17.- In Bresl. 
Mus. there is (No. 8090) an exostosis on the first phalanx of a finger, as big as a walnut, liard and close-I have seen a somewhat smaller one on a phalanx of a finger in the Anat. Mus. at Freyburg.

(11) Compare, for instance, several of the above clescribed cases, $\S 109$, note 11, in general anchylosis; further Trafvenfeldt, in Ars. Berättelsa om Svenska Läkare Sällskapets Arbeten. p. 14. Stockh. 1815.-Ekström, ib. 1826.I saw two very striking instances in the Anat. Pathol. Mus. at Vienna, and in the Anat. Mus. at Strasburg. Meckel, in his Pathol. Anat. Vol. II. Part I. p. 274, has described large fibrous exostoses on the skull and pelvis of an individual.

(12) In the Anat. Mus. at Zurich I saw several exostoses as big as one's fist, on the thigh and shin bone in the neighbourhood of caries.

(13) Cumin calls it caries ossificans.

(14) For instance, my Verzeichn. No. 3854.

(15) Cooper's periosteal and cartilaginous exostosis, as it is between the periosteum and bone, is at first formed of a cartilaginous mass.

(16) A case of this kind has, without any reason, been named Hydrexostosis ; see Noack D. de hydrexostosi et hæmatexostosi. 8vo. Vratisl. 1824.

(17) They usually occur in children, especially in those of a rickety disposition, sometimes however also in adults; in both cases, often from mechanical influence, they often exist for ten or twenty years without actual inconvenience beyond their size and weight. - Bidloo Op. omnia, p. 205, with engravings. Plate I.-Mery in Mém. de l'Acad. des Sc. 1720, p. 447, tab. 12-15.-Lentin in Loder's Journ. f. Chir. Vol. I. p. 60.-Meckel Pathol. Anat. Vol. II. Part I. p. 272.-Dupuytren in Dict. des Sc. medic. Vol. XXXIII. p. 8.-von Klein in v. Graefe's and $v$ Walther's Journ. f. Chir. Vol. III. Part III. p. 403, pl. 3, fig. 4. - Souvestre in Journ compl. du Dict. des Sc. médic. Vol. VI. p. 276. -Thurn in Harless Rhein. Jahrb. für Med. u. Chir. Vol. VI. Part I. p. 199.-Edholm and Gadelius in Svenska Läkare-Sällsk. Handl. Vol. I. Part II. p. 100 ff. and p. 109 (the latter case on the foot);-Wahlberg, ib. Vol. III. p. 127, pl. 2.-Bail, p. 16, fig. 4. - Hesselbach Beschreib. der pathol. Präparate zu Würzburg. p. 307, No. 127, 128, 481. - Myself in Selt. Beob. Part II. p. 22, No. 10, tab. 1, fig. 1. - I lately saw a boy, about ten years old, on whose left hand and foot there were many and large gibbous swellings of this kind.

(18) Boyer, Vol. III. p. 554. In the Anat. Mus. of Meckel, at Halle, I saw an ivory-like exostosis, as large as one's fist, which had spontaneously dropped from the nostrils of a horse.

\section{$\S 120$.}

The last and most malignant kind of vice of texture in bones, is the BONE FLESHY SWELLING, Or BONY CANCER, osteosarcoma, osteosteatoma, fungus, and cancer ossium. ${ }^{1}$ as it is called. This disease, so far as the structure of bone permits, resembles the sarcomatous and carsinomatous diseases of soft parts in their various and varying forms, together with their distinct morbid disposition, ${ }^{2}$ their easy recurrence, their existence in the middle and later periods of life, and their common malignity. Sometimes external mechanical influences operate as occasional causes for the production of osteosarcom. This disease most usually occurs on the bones of the head, of the pelvis, and in the long tubular bones: but in animals it is as rarely seen as cancer in the soft parts. The original seat of the disease is usually the internal bony tissue, and the periosteum at first extends unchanged over the bony tumour; 
although in rare cases, tumours and fungosities of similar character are primarily produced in the periosteum. ${ }^{3}$ With regard to the structure of the osteosarcom, this is somewhat different, according as the bone is more delicate and spongy, ${ }^{4}$ and as the disease assumes more the form of sarcom, medullary sarcom, or cancer ; in general however, the tumour at first consists (although afterwards the bone be more or less softened and swollen) of a tolerably homogeneous, greyish-white, unvascular mass, intermixed with bony points, which almost resembles cartilage, and consists of a quantity of sinewy fibres, more or less firmly consolidated with albumen. The tissue gradually becomes loosened, and forms cells of a greater or less size, which are filled with a light-coloured jelly; an inflammatory excitement now takes place in the swelling, the thin cellular tissue which lines the cells becomes thickened, and secretes a mishapen mass consisting of albumen, which is sometimes hard, sometimes soft and resembles brain, or there is produced within them a cellular tissue richly loaded with albumen; the blood-vessels also gradually enlarge in the periosteum, as well also as in the interior of the swelling, and small or large cavities are commonly formed, which in rare cases are filled with arterial, but more usually with venous blood, ${ }^{5}$ and into the brain-like substance blood is also effused. At the same time innumerable bony fibres or plates commonly project from the interior of the bone outwards, and perforate the tumour in various directions, which becoming softer and larger, is finally united at certain spots with the much expanded fleshy and membranous parts lying upon it, perforates these, and allows the escape of a more or less growing fungus.

(1) Also exostosis fungosa, carnosa, carcinomatosa, \&c. There is a great confusion among authors, especially about this disease, as spina ventosa, and particularly cellular exostosis, is often confounded with ostcosarcom. With reference to single cases, v. du Plouquet Repertor. Art. Osteostéatoma; also the old observations of Severinus de Abscondita abscessuum natura, L. 13. 1724, p. 207, with engravings.-Duverney in $\Lambda$ bhandl. iber Knochenkrankheiten.-Amyaud in Phil. Transact. 1708, 1. 170, Sc. -- Hundertmark pras. Tillmann D. s. osteosteatomatis casum rariorem. Lips. 1757.-Hermann D. de ostcosteatonate. 4to. Lips. 1767, with coloured plates.--A. Murray, D. de osteosteatomate. Ujsal, 1780. - Gruner D. Historia osteosteatomatis feliciter curati. Jenx, 1781. -- Ludwig Icones anat. pathol. tab. 1, fig. 1. tab. 2, f. on the pelvis.-Howship, p. 64.-Rust Magazin f. die gesammte Heilk. Vol. I. Part I. P. 60, tab. 1, on the upper arm.-Myself in Selt. Beob. Vol. I. p. 83, No. 41, tab. 2, on the upper arm, and ib. Vol. 1I. p. 23, I. - Bang in $\Lambda$ ctis nov. reg. Soc. med. Vol. I. No. 8. Havniens. 1818, on the pelvis. -- Behr in Recucil de Mém. de Méd. Chir. et Plıarm. milit. par Fournier-Bescay. Vol. XII. No. 10, on the arm. - - v. Walther in his and v. Graefe's Journ. der Chir. \&c. Vol. V. Part 11. p. 2S3, on the land and shin-lone.- Westring in Svenska LäkareSiillskap. Handlingar. Vol. IX.p. 136, on the pelvis and shin-bone. - Cutting 
in Med. Chir. Transact. Vol. II. No. 24, on the upper arm.--Gibson in Chapman's Philad. Journ. of med. and physical Science, Vol. III. No. 1. -- Boyer Traité des Malad. chir. 2d edit. Vol. III. p. 600, on the thigh and pelvis. -- Baldy in Fothergill's Lond. med. phys. Journ. Vol. XL. Nov. 1818, on the upper arm bone.Cerutti Beschreib. der pathol. Präparate des anat. Theat. zu Leips. No. 332, p. 68 , on the upper arm bone.-Pech Osteosarcoma, ejusque speciei insignis descriptio, etc. 4to. Wirceb. 1819, with three engravings, on the face.-Carmichael in Irish Transact. of the Association, \&c. Vol. III. Dublin, 1820, with engravings, on the thigh. - Williams in Lond. med. Repository, Vol. XVII. No. 99, p. 204, March, 1822, on the shin bone. - Dietel D. de osteosteatomate. 4to. Lips. 1822, with three engravings, on the thigh. - Lobstcin Compte rendu, etc. p. 32, Strasb. 1824, on the splint and shin bone, also the chemical analysis of the tumour.-Crampton in Dublin Hospital Reports, Vol. IV. p. 537. Kolsch Ein Fall vom Knochenkrebs, nebst einigen Bemerkungen. Inaugural dissertation. 8vo. Würzb. 1826, with one engraving. -- Graff in v. Graefe's and v. Walther's Journ. d. Chir. Vol. X. Part I.p. 76, pl. 2, fig 4 and 5, on the skull.--On osteosarcom of the jaws and their joints, see those parts.-Koschate Observationes nonnullæ circa Osteosarcoseos naturam et indolem adnexis tribus hujus morbi historiis. 8vo. Vratisl. 1826.-J. F. Bonfils Description succinte d'une Maladie grave et rare de la partie superieur de l'humerus, etc. Nancy, 1817 , with engravings. $-K$. $E$. Donat D. de fractura cum Osteomalacia fungoque carnosa complicata, ex medulla tibiæ exeunte. Halæ, 1828.

(2) Compare my Selt. Beob. Vol. II. p. 23.-Gibson, in which on several parts at the same time, or recurring and connected with a cancerous state of other parts; Pott in Phil. Transact. No. 459. - Voigtel Pathol. Anat. Vol. I. p. 127.-Meckel Pathol. Anat. Vol. II. Part I. p. 274, ff.-Heymann in Harless Rhein. Jahrb. Vol. II. Part I. p. 74. - $M^{`}$ Clellan in Americ. medic. Recorder. Vol. V. No. 4. New-York, Oct. 1822.--v. Walther.--Salomon in Verm. Abhandl. a. d. Gebiete der Heilk. 3d edit. p. 237. Petersb. 1825._-Bonfils in Journ. gén. de Médec. 8vo. 1826.

(3) Sometimes as large roundish loosely attached swellings, more rarely as fungous growths, \&c. v. Walther in der Salzb. med. chir. Zeitung, p. 185. Feb. 1813 , on the collar bone of a woman with fungus of the dura mater; sometimes large sarcoms in the soft structures adhere to the neighbouring periosteum of a bone, and seem then to spring from it.-Voigtel, p. 124, improperly considers the periosteum as the usual seat of osteosarcom.

(4) In this the structure of the tumour is, from the commencement, more loose and cellular.

(5) From these large varicose cavities, the blood starts sometimes in great quantity during operations. v. Rust and myself.

\section{$\S 121$.}

Finally, we observe also vices of the contents of bones. To these first belong the morbid changes of the Marrow ; this in cachetic men and animals is even entirely deficient, or at least it exists only in small quantity; in other instances, on the contrary, it is too abundant, and pervades the usually dry bony parts. Its consistence varies not less from its natural condition, it is sometimes too hard, tallow-like, and even resembling waxy fat; but more commonly it is too thin and too much mingled with lymph. The latter is especially the case in rickets, scurvy, dropsy, and other cachexiæ. The marrow also exhibits numerous deviations in respect to colour, so that it may be too pale and completely white, or too deep yellow. 
reddened by a large admixture of blood; and in carious and mortified bones, sometimes grey and discoloured.

Dropsy, of such kind as is met with in soft parts, cannot occur on account of the firm texture of the bone $;^{2}$ however, we sometimes find in dropsical persons, that the bony cells, instead of containing fat, are filled throughout with lymph-like fluid, and in rare cases, in dropsical children newly born, we observe a turbid serum effused between the bones and their investing periosteum $;^{3}$ there have been also observed in some instances in the cavities of the tubular bones, WATERY BLADDERS, Or HYDATIDS ; ${ }^{4}$ PUS and ICHOR often fill the spongy tissue of inflamed and carious bones; more rarely we find that blood is poured out in their cellular tissue, ${ }^{5}$ without any distinct change of structure in the bones; we more frequently observe, in the swellings of the heads of new-born children, or after contusions, \&c., if the periosteum be partially separated from the bone, blood effused between them. Lastly, in the bones we sometimes meet with entirely extraneous bodies, which have entered from the surface, for instance, MERcury ${ }^{6}$ which in various forms has been taken up by the skin or by the mouth, and received into the body; sULPHUR in labourers in sulphur mines $;^{7}$ and especially sнот, which are generally thrown out by caries or mortification, but sometimes remain, and are firmly connected to the bone for a long time, and even throughout life. ${ }^{8}$

(1) Moignon Tentamen de medullæ morbis. Svo. Paris Ann. III.

(2) The disease described by $v . W_{y}$ in Heelkundig. Mengelstoff, Vol. II. Part I. 1785, under the name IIydrosteon, does not appear to belong to this, but to rickety loosening.

(3) I have seen three or four dead born, though never putrid dropsical children.-A similar instance, with loss of the epiphyses, was seen by Clouquet, v. Leroux Journ. d. Méd. chir. et Pharm. Vol. XXX̃X. Aug.

(4) In a bony swelling, Keate, in Lond. med. chir. Transact. Vol. V. ; and A. Cooper, which latter preparation I saw in the Museum at St. Thomas's Hospital, London; in the cavity of the tibia, Cullerier in Corvisart's Journ. de Médec. Vol. XII. p. 125, Aoút, 1806.-Webster in New-England Journ. of Med. and Surgery, Vol. VIII. Boston, 1809.-A preparation of this kind is in the Hunterian Museum at Glasgow; and another, viz. a long watery cyst in the thighbone of an ox, in the Hunterian Museum in London, No. 521 of the patholog. series. - Many hydatids were found in the tibia, by Wickham, in London med. and physic. Journ. Jan. 1827, p. 530. [There is a preparation in the Mus. at St. 'Illomas's Hospital of liydatids in the spinal column; they are situated in the bodies of the eleventlı and twelfth dorsal vertebra, the greater part of which, together with the intervertebral substance, are absorbed; and the cavity thus formed communicates on the left side with a large bag full of hydatids, which resembles an incipient psoas abscess, and the spine is at this point curved forwards, as in scrofulous caries. It seems impossible to determine whether the hydatids were first formed in the bony, or in the ligancnto-cartilaginous intervertebral substance; of that, however, between the two vertebra, there is not the least trace, but the remainder of the bodies are filled with the little watery cysts. 'I'.] 
(5) I have seen this a few times on the skull bones of an adult, accompanying organic vice of the brain. v. Selt. Beobacht. Vol. II. p. 92, No.3119, of Bresl. Mus.; in the skulls of birds which have been poisoned with opium, belladonna, and spirits, v. Cuvier s. Annales des Sc. naturelles, Vol. II. p. 428.

(6) v. Fricke Annalen des Hamburger Krankenhauses, u. s. w. Vol. I. p. 106. -- de Plouquet Art. Mercurius, also Lieutaud Hist. anat. med. L. III. Sect. VIII. Obs. 558-562. - Boneti Sepulchret. anat. Vol. I. Obs. 114, p. 64.Hufeland's Journ. f. pr. Heilk. 1821.-Isenflamm in Augustin's Neueste Entdeckungen, u. s.w. 1800 , p. 375. - Lobstein Compte rendu, etc. p. 27.-Myself in Selt. Beob. Part IY. No. 13, p. 36.-I also have observed a third instance. v. Verzeich. der anat. Präparatensammlung, u.s. w. No. 3019.

(7) Reil in van Mons Journ. de Chim. Vol. II. p. 105; compare John's Chem. Tabellen des Thierreichs, p. 44.

(8) Compare surgical writers, and de Plouquet Repertor. Art. Peregrina.-Gött. gel. Anzeiger, 1269 , p. 202 , a bullet 59 years in the skull. There are several instances in Isenflamm Anatom. Untersuchungen. 8vo. p. 36. Erlang. 1822-Eck D. de carie articulor. externa. p. 82. Berol. 1818.-Grossheim in v. Graefe's and $v$. Walther's Journ. f. Chir. Vol. X. Part I. p. 142, pl. 3, fig. 123. - Sandifort Mus. anat. Vol. III. p. 201, No. 336, a piece of lead in the collar-bone. On balls in elephant's teeth, v. the Teeth. In animals, enclosed balls and gunshots are not uncommon. I have found them in wolves, No. 3576 of Bresl. Mus.; in foxes, hares, and in the wing-bones of birds.

\section{Second Chapter.}

\section{Of the Bones in Particular.}

\section{A.- OF THE BONES OF THE HEAD. ${ }^{1}$}

\section{$\S 122$.}

In human monsters and in those of animals, the skull is frequently very deficient; this especially occurs in the anencephalous, of which the entire upper part of the skull is apt to be wanting. ${ }^{2}$ But even in a well-formed skull, the number of bony pieces composing it often varies remarkably, inasmuch as, either certain bones, as a vice of formation, are deficient, and their place supplied by others which have become enlarged, or on the contrary, supernumerary bones exist in the different kinds of duplicature of the head. The number of bony pieces in the skull are most usually increased by the CONGENITAL SEPARATION of many bones into several pieces, ${ }^{3}$ and by the SUTURAL BONES, ossa suturarum. ${ }^{4}$ The latter most commonly in the lambdoidal, next in the coronal and squamous suture, vary in number from one to some hundreds; sometimes they are very symmetrical ; and in more rare cases, are produced only on the outer or inner table of the bone. A single large bone of 
this kind occupying the place of the great fontanel, is called a FONTANEL BONE. ${ }^{5}$ Dropsy of the brain, rickets, and cretinism, ${ }^{6}$ are the most usual causes of sutural bones. 'The skull frequently varies in reference to its SIZE; thus we sometimes find it remarkably SMALL, in monsters with imperfectly formed heads, ${ }^{7}$ as well also as in congenital hernia cerebri; also in idiots, ${ }^{8}$ and epileptic persons ${ }^{9}$ it is frequently too small in consequence of imperfect development of the brain, or of the too early closing of the sutures. The opposite vice, or the IRREGULAR ENLARGEMENT of the skull, is more common; we observe this both in man and animals, in a less degree, as a peculiar and often hereditary disposition, but in a greater degree, as consequent on the hypertrophy of the brain often accompanying rickets, and particularly as the effect of the internal dropsy of the head; in the latter case the skull often attains a most enormous size. ${ }^{10}$ The SHAPE of the skull also frequently differs from the normal form, being found irregularly long, broad, flat, even angular, round, and particularly unsymmetrical. ${ }^{11}$ Such DEFormities are sometimes congenital, in consequence of the irregularly formed pelvis of the mother, or of early diseases of the embryon, which have acted on the head; more frequently they occur after birth from deficient and irregular development of the brain, ${ }^{12}$ from the early closing of some of the sutures, whereby the widening of the skull is prevented at this, and on the other hand, increased at other parts ; in rickets, by which especially the front and back of the head are apt to be projected; by dropsy of the brain, which at the same time unequally expands the skull and depresses its base; by softening of the bones, in which that part of the base of the skull which is supported on the spinal column, is gradually thrust into the cavity; ${ }^{13}$ by palsy of one half of the head, hemicrany, the facial pain of Fothergill, and tinea, in consequence of which the skull frequently becomes atrophic, and awry, \&c. ${ }^{14}$ The skulls of epileptic, idiotic, ${ }^{15}$ insane ${ }^{16}$ persons and cretins, ${ }^{17}$ are frequently very much malformed. Sometimes the irregular shape of the skull depends upon mechanical causes, either indeed purposed or accidental, ${ }^{18}$ as by indentation of the skull during labour, by falls, blows, \&c., various and often very distinct impressions and irregularities ${ }^{19}$ are produced. The skull is frequently irregular in its THICKNESS, thus it may sometimes be found too thin, sometimes too thick; the former generally occurs especially in dropsy of the head in man and animals, and sometimes to such a degree, that the bones of the skull are as thin as paper and transparent; this general thimning of the skull also occurs in 
consequence of wasting of the diploe in very old persons, and more rarely also in young people without any assignable cause. ${ }^{20}$ Oftentimes certain spots only are so thin, ${ }^{21}$ particularly when pressure has been continued on them for a long time. Very naturally connected with the irregular thinness of the skull, is that state in which it is not only very thin, but even partially UNOSSIFIED and MERELY MEMBRANOUS; in some cases this occurs to a great extent, more commonly only at certain spots, especially in dropsy of the head, rickets, and cretins. ${ }^{22}$ The opposite vice, the abnormal THICKNess of the skull, ${ }^{23}$ is still more common, especially in persons who are much subject to congestion in the head, also for instance, in insane people, ${ }^{24}$ and often attains such extent, that the bones of the skull become half an inch, or a whole inch thick; in this state, the structure of the bones is sometimes perfectly healthy, in other cases, especially in ricketty people, spongy, and light; in some instances, however, thick and heavy, almost like ivory. ${ }^{25}$ Sometimes the skull is only so thick and tubercular at certain places. ${ }^{26}$ This leads us to the BONY GROWTHs, ${ }^{27}$ which we observe produced not merely on the outer or inner surface of the skull, but sometimes on both sides, and occasionally acquiring a very great size ; in animals, such exostoses are frequently observed. ${ }^{8}$ In epileptic and insane, and even in other persons not unfrequently, processes are found on the interior of the skull which are very prominent and sharp. ${ }^{29}$ As to the conNexion of the separate bones of the skull, there is great deviation from the general rule, arising from diminution, increased strength, and irregular mass of their composition. The first vice exhibits itself in the long continued or permanent existence of such sutures which, as the frontal suture, and some sutures in animals, are naturally consolidated at an early period, and in the unusual congenital separation of certain bones of the skull into many pieces; $;^{30}$ further, it is very common in dropsy of the head, in which congenitally or sometimes soon after birth, the bones of the head are more or less further apart from each other; this happens in more rare cases only in a single suture. Such broad membranous interspaces, sometimes in later years, become so filled up with a quantity of little sutural bones, that some and even all the sutures appear at once double. ${ }^{31}$ Oftentimes we observe bones which have been for a long while united, separated from each other at their sutures ${ }^{32}$ by violent flow of blood to the brain, as well also as by collections of water, and tumours, \&c. The other vice, the too firm connexion or anchylosis of the bones of the skull, is much more common, it occurs especially in the sagittal suture, 
although also not rarely on other, and even on all the sutures of the skull at the same time; sometimes it exists only on the outer or inner surface, whilst on the opposite side the suture is still distinct, and can then only be properly considered as morbid, if it be observed previous to birth ${ }^{33}$ or before the perfect development of the head. ${ }^{34}$ Finally, the sutures of the head often appear so far irregular, as that they run obliquely or tortuously, have too few or too many, too small or too large teeth ${ }^{35}$ in some places are widened, ${ }^{36}$ or become seam-like. ${ }^{37}$ The continuity of the bones of the skull is frequently destroyed by mechanical influences; to these belong, the incised, penetrating, ${ }^{38}$ and shot wounds, the splitting of the external and internal tables of the skull, the clefts or fissures, fissura, ${ }^{39}$ which in consequence of the brittleness of the bones of the head often are very extensive and very numerous, sometimes run into the sutures and divide them, although not unfrequently their course is stopped by them; fissures occur either at the spot on which the blow is received or at some distance from it, producing contrafissura; fractures of bone with the loss of one or several pieces; the more or less deep indentations, impressiones, or depressions, depressiones, of the bony pieces connected with fracture, and the openings artificially made by the trephine, which are but rarely again filled up with bone. Similar apertures in the skull to those purposely made by the trephine, occur also not rarely from other causes, ${ }^{40}$ viz. those which are congenital in hernia cerebri and dropsy of the brain, further, such as occur in caries, necrosis, ${ }^{41}$ and by the erosion of encysted and scrofulous tumours ${ }^{42}$ fungus of the dura mater, aneurysm, ${ }^{43} \& c$. Lastly, we must here mention the so-called fungus cranii; ; this is a sarcom or medullary sarcom of the bones of the skull, in which a distinct tumour is produced often only on the external surface, or also at the same time on the internal surface, and sometimes becomes pretty large; it may run at last into a spongy growth. It usually occurs on the top of the skull, although also sometimes on its base, and then protrudes outwards through the usual openings at this part. ${ }^{45}$

(1) Krebel D. de anatomia pathologica ossium capitis. 8vo. IIalæ, 1823.Betrachtungen über die Ursachen und Verschiedenheiten der Missbildungen des Schädels und des Riiekgıathes beim Foetus von Dugés in Revue médicale francaise et étrangère. Vol. X. p. 358 .

(2) Good engravings in E. Eandifort Anatome infantis cerebro destituti. L. B. 1784, and in Mus. anat. Vol. II. tab. 35, fig. 2-5.-Geoffroy Anat. philosophique. Vol. I. Paris. 1822, pl. 1-3.-J. F. Neckel Descript. monstror. nonnullor. 4to. Lips. 1826 , tab. 1 .

(3) Genernlly the bony germs do not grow; sometimes also there is an anomalous growth. 
(4) Intermedial bones, Ossa Wormiara, O. triquetra, \&c. ; v. Bertin Traité d'Ostéologie, Vol. II. p. 470 ; Monro in Edinb. med. Essays. Vol. V. No. 16, pl. 2.-Sandifort in Observ. anat. pathol. Lib. III. cap. 9, tab. 9, and Lib. IV. cap. 10, p. 136.-Blumenbach's Geschichte der Knochen.-Meckcl Pathol. Anat. Vol. I. p. 313.-Rottböll in Skrif. det kiöbenhavnske Selsk. Nye Samml. Deel I. p. 249. - Jung Animadversiones quædam de ossibus generatim et in specie de ossibus raphogeminantibus, quæ vulgo ossa suturarum dicuntur. 4to. Basil. 1827, with figs.-My Verzeichniss, \&c. No. 183-225; in animals, intermedial bones are very rare, even in extensive water in the head.-Loder, Anat. Handb. Part I. p. 46, in note, mentions two instances of intermedial bones in monkeys. -Wiedemann Archiv, u. s. w. Vol. III. Part II. in an ant-eater.-Greve Bruchstïcke vergl. Anat. und Physiol. p. 10, Oldenb. 1818, in hares, rabbits, and dogs; ;-in lambs, my Selt. Beob. Vol. I. p. 39.-G. Jäger in Meckel's Archiv f. Anat. und Phys. 1826, p. 72.

(5) Lachmund in Misc. Nat. Cur. 1675 and 1676, p. 241.-Wtähelin Obs. botan. anat. in Haller's Coll. disp. anat. Vol. VI. p. 671, with figs.-van Doeveren Spec. observat. acad. p. 189, pl. 7, fig. 1-3, two cases. - Sandifort Observ. anat. pathol. Vol. III. tab. 9, fig. 3-7.-Hebenstreit De rarior. quibusdam ossium momentis, p. 5. Lips. 1740. My Verzeichniss der anat. Präparatensammlung, No. 184-186, 8034. There is also (No. 4566, ) in the skull of an ateles paniscus a fontanel bone, of which I have also seen a beautiful instance in the Anat. Mus. of the Joseph Academy at Vienna, a similar instance in the Anat. Mus. at Zurich, and at Strasburg, and two examples in the Anat. Mus. at Heidelberg.

(6) A very remarkable instance is mentioned by Prochaska Disq. anat. phys. organismi c. h. 4to. Viennæ, 1822, tab. 8-10. p. 177.

(7) Curtius De monstro lumano. L. B. 1762.-Gilibert Advers. med. pract. Lucubratio anat. de foetu acephalo, p. 122. My Verzeichniss, \&c. No. 3044.

(8) Hippocrates early considered microcephalia as the cause of idiotcy.$J$. E. Greding Sänmtliche medicinische Schriften, herausgegeben von $C$. $W$. Greding. Greiz, 1790.-Georget de la Folie. Paris, 1820, p. 478.-Spurzheim, Observations on the deranged manifestations of the mind, or insanity. 8 vo. London, 1817.-Esquirol in Dict. des Sc. médicales. Vol. XXIII. p. 521, and in Pathologie und Therapie der Seelenstörungen, deutsch von Hille, p. 515. 8vo. Leipz. 1827.-A very remarkable instance is given by Blumenbach De anomalis et vitiosis quibusdam nisus formativi aberrationibus Comment. 4to. Gött. 1813. tab. 2, p. 17.- Smallness, depression, and obliquity of the forehead in an idiotic child of two years old.-My Verzeichniss, \&c. No. 3016.

(9) My Selt. Beob. Part I. p. 72.

(10) Good engravings are given by Gall Anat. et Physiol. du Système nerveux en général, etc. Pl, 21-24._Sandifort Mus. anat. Vol. II, tab. 6-12.Rudolphi in Abhandl. der Akademie der Wiss. zu Berlin, 1827, pl. 3-5. - Baillie, Engravings of morbid Anat. Fasc. X. pl. 3, fig. 1._Monro's Outlines of the Anatomy, \&c. pl. 21.-Klein Kurze Beschreibung einiger seltenen Wasserköpfe. 4to. Stuttg. 1819, tab. 1 and 2.-Great increase of the size of the skull is described in the Gazette de Santé, 1817. v, Rust's Magazin f. d. ges. Heilk. Vol. IV. Part I. p. 187, (2 feet 3 inches in circumference; I saw this person in the Charité at Lyons.) - Valentin in Journ. de Médec. Chir. et Pharm.

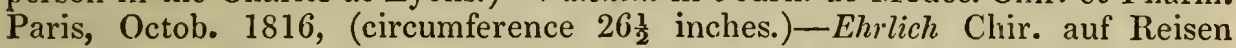
gemachte Beobacht. Leipz. 1795. Vol. I. (in Cruikshank's collection 2 feet 5 inches in circumference.) - In New England Journ. of Med. and Surgery,

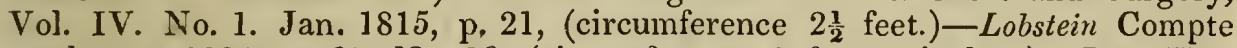
rendu, etc. 1824 , p. 62 , No. 36 , (circumference 2 feet 3 inches.) -J. P. Horn Bemerk. und Erfahr. über einige Gegenstände der prakt. Geburtshülfe. 8vo. Wien, 1826, tab. 1, (circumference in a new-born child 21 inches.)-Himly in

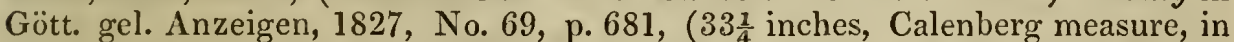
circumference.)-My Verzeichniss, No. 3089 and 3090.-Kohler Beschreibung der physiol. u. pathol. Präparate. - Loder, p. 103, No. 365, described by Kaltschmied Pr. de hydrocephalo interno raræ magnitudinis in Mettelhaüser $D$. de via chyle ab intestinis ad sanguinem. Jenæ, 1752 , with plates, ( 33 inches in circumference.) - A drawing of Himly's case is given by $E$. A.W. Himly 
Darstellung des Dualismus am normalen und abnormen menschl. Körper. Hanover, 1829, p. 21, pl. 5 and 6.-Among animals the skull is frequently very much expanded by dropsy, in the horse, ox, (of which there are two very large, No. 8059 and 8060 , besides three less large in the Bresl. Mus.) and sheep, rarely in other mammalia, and never in birds.- [There is in the Mus. at Guy's Hospital, the skull of a hydrocephalic man, who lived to the age of twenty-nine years, whose skull measured $33 \frac{1}{2}$ inches in circumference.--Also at St. Thomas's Muss., the skull of a child of about two years, which measured 29 inches. T.]

(11) Compare my Verzeichniss, Sc. No. 163, 164, 210, 3057-3063, 3068, and s046.-Hesselbach Beschreibung der pathol. Präparate zu Würzburg. p. 3. -On obliquity of the skull compare Loschge de scelete hom. symmetrico, p. 41 . - Mechel anat. phys. Beobacht. und Untersuch. p. 247. 8vo. Halæ, 1S22Sandifort, Vol. II. pl. 8 and 9.-Köhler Beschreib. der anat. und physiol. Präparate, etc. p. 134. - The obliquity of the skull, in many cetaceous animals, is natural to them. A peculiar deformity of the skull, viz. a very large bony cyst with a large cavity on the temple, occurs in fowls, geese, ducks, pigeons, and canary birds; v. Borellus Hist. et observat. rarior. ed. 1656, p. 154.-Stobaeus in Act. literar. Speciæ 7730, Vol. III. p. 53.-Pallas Spicil. IV. p. 22.-Sandifort Mus. anat. Vol. I. p. 806. - Blumenbach, p. 19, tab. 1. fig. 2 and 3.- [Dupre, Phil. Trans. 1699, p. 372. - In the skull of a female child, a native of Van Dieman's Land, No. 99, Mus. Roy. Coll. Surg., there is great projection in the central part of the parietal bone, giving an angular form to the head. T.]

(12) In the Anat. MIus. at Bomn, I saw a skull, on account of the imperfect formation of which, the left half of the cerebellum was very flat in that region.M. J. Weber, Specimen malæ conformationis encephali capitis et pelvis viri. 4to. Bonnæ, 1828, with lithog. tab.

(13) I have seen this not unfrequently. Compare Verzeichniss der Breslauer anat. Präparatensammlung, No. 163-165. I have also seen it in some cretin skulls.

(14) My Selt. Beob. Part I. p. 74, No. 32. An instance from face-ache in Blumenbach's Geschichte u. Beschreibung der Knochen. $2 d$ edit. p. 29, note f.Gall Anat. et Physiol. du Système nerveux, etc. with figures, pl. 53, a skull, the left half of which had become atrophic from abscesses in the optic beds.

(15) Frequently is the skull not merely too small, but also otherwise abnormally formed, thus the forehead too small and too inclined, \&c. v. Gall, pl. 18-2029. - Reil in his and Hoffbauer's Beitr zur Beforderung der psychischen Curmethode, Vol. II. Part I.-Esquirol in Dict. des Sc. médic. Art. Démonomanie, Vol. VIII. p. 294, tab. 1-4. and Pathol. und Therapie der Seelenstörungen, p. 315.-Georget De la Folie. p. 478. Paris, 1820.-Wittwerck D. de varia hum. cranii forma. 4to. Berol, 1825, with two engravings. But especially Blumenbach De anomalis et vitiosis quibusdam nisus formativi aberrationibus Comment. p. 17, pl. 2.

(16) For instance, unsymmetrical, compressed laterally, with a high vertex ; internally with strong development, \&c.-Pinel 'Récherches anatomiques sur les vices de conformation du crane des aliénés in Bull. de la Soc. philomatl. Ann. IV. Vol. II. p. 103, 109. - Gcorget, p. 480. - My Selt. Beob. p. 72, No. 31.-Romberg Untersuchung irrer Personen, in the Zeitschrift für psychische A crtze, 1822. Part I. p. 124, and in the Zeitschrift für die Anthropologie von Nassc, 1828, Part III. p. 195. - Esquirol Pathologie und Therapie der Seelenstörungen, u.s.w. p. 483.

(17) Gencrally very broad, often as broad as long, shallow from above to below, the base of the skull often uplifted in the middle, Sic. Compare Ackermann Ueber die Cretinen, \&c. 8vo. Gotha, 1790.-Foderé Essai sur le goitre et le crétinisme. 8vo. Turin, 1792, 2 d edit. Paris, Ann. VIII.-Michaelis in Blumenbach's medic. Biblioth. Ricordi della anatomia chirurgica, etc. Padova, 1801. - Wenzel Ueber den Cretinismus. Wien, 1802. - Iphoff D. de Cretinismo. Viteberg. 1804.-Rceve in Philos. Transact. 1808. Part I. No. 7, p. 111, pl. 2 and 3. - Prochaska Disquis, anat. pliys. organismi, etc. p. 177, tab. 8-10. Viennæ, 1812, and in Physiologie. 2d edit. 1820. Abschnitt VI.-Andree D. quxdam de Cretinismo. 4to. Berol. 1814, with engravings.-Osiander in 
Gött. gel. Anzeig. 1817, Part CXXXII.-Iphofen der Cretinismus, philosophisch und medicinisch iintersucht. 2 Theile. 8vo. Dresd. 1817, tab. 5.-Sensburg Der Cretinismus, mit besonderer Rücksicht auf dessen Erscheinung in Untermainund Rezatkreise. Würzb. 1825. - T. H. Wilke D. de Cretinismo. 4to. Berol. 1828 , with two engravings.

(18) For instance, of a very elongated form in a Scythian people on the Mæotic lake. v. Hippocrates Op. omnia, ed. Kühn, Vol. I. Lips. 1825. L. de aëre, locis et aquis, p. 551.- Pressing back of the forehead in the Caribbees and Americans from Colombia river, v. Blumenbach decas cranior. divers. gent. Dec. I. tab. 10, and Dec. II. tab. 20. - Lawrence, Lectures on Physiology, Zoology, and the natural History of Man. London, 1822, pl. 11. - Mitchill in New-York Repository, April, 1821.-Pressure from above, as in the Chocktaws and old Peruvians. v. Blumenbach, Dec. I, tab. 9.-- $[$ A deep broad transverse groove from pressure, passing over the vertex, as in the skulls of the people of Nootka Sound, in the Anat. Mus. at Christchurch, Oxford.-Three Peruvian skulls in the Mus. Roy. Coll. Surg. No. $63,64,65$; but especially the former, resemble the skulls of the Caribs, in the great depression of the forehead, but in these it is considered a natural formation. T.]

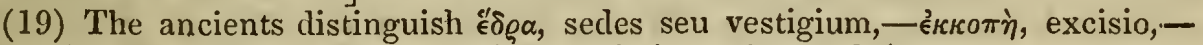

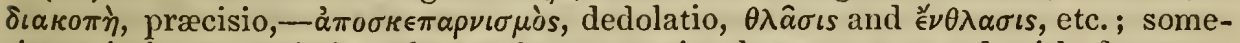
times it is congenital; when subsequent, is always connected with fracture; sometimes only the outer table and diploe are depressed; in other cases, the whole bone deeply so, without great injury. v. de Plouquet Repertor. Art. Cranii Depressio.-Crull D. de depressione cranii. Jenæ, 1808. -- Stalp. van der Wiel Observat. rarior. p. 27. Leidæ, 1727. - Isenflamm's Anat. Untersuchungen, p. 123.-Klein in Graefe's Journ. f. die Chir. Vol. III. p. 226. - My Seltene Beobachtungen. I. p. 75, No. 33. - Home in Philos. Transact. 1814, Part II. p. 469.-Congenital indentation observed by Sandifort, Vol. II. tab. 34.-Frank in Textor's Neuem Chiron. Vol. I. Part II. p. 261.-- [A few years since, a child, about three years old, was admitted into St. Thomas's Hospital, with a depression on the upper and back part of the parietal bone, caused by a fall, which was nearly large enough to hold a dessert spoon. No symptoms occurred, and as there was no external wound, it could not be perfectly decided, but it was believed to be a mere indentation without fracture. $\mathrm{T}]$

(20) My Verzeichniss der Breslauer Präparatensammlung, No. 3065, 3076, and 3169 .

(21) To wit, from external encysted tumours, from internally enlarged pacchionic glands, very expanded blood-vessels, watery bags, as in the gid of sheep, \&c.

(22) I have indeed seen this in twenty monsters, of men, horses, oxen, and sheep, mostly accompanied with traces of dropsy of the head and general dropsy, although sometimes also without.-For instance, in two children, v. Verzeichniss, \&c. No. 3079, 3080; and in a third, which was born without eyes, and with monstrosity of the extremities; in an almost full-grown man, No. 3081; in a child with sarcom on the head, v. Seltene Beobachtungen, II. p. 1661. As such openings, however, sometimes become ossified at a later period, so also on the contrary, may membranous parts of the skull be produced at a late period, especially in dropsy of the head, in the gid in sheep, from absorption, \&c. A woman who had exostosis in the pelvis, was delivered of four children, in which there was an unossified indentation on the forehead. v. Frank.-In Osiander's collection at Göttingen, I saw the skull of a bitch membranous in several spots, and she had produced similar puppies. Instances of such membranous patches on the skull are given by Veirac and Portal sur Rhachitisme; Bidloo Opera omnia. p. 191, tab. 3. L. B. 1715. - Sandifort Obs. anat. pathol. L. III. cap. 10, p. 132 and 137, and Mus. anat. Vol. II. p. 16, tab. 34. - Stark Neues Archiv f. die Geburtshülfe, Vol. I. p. 422. - Löfler, ib. p. 428, note. -- Osiander Beobacht. und Abhandl. u. s.w. p. 223. 1787. - Baillie, Engravings, Fasc. VIII. pl. 3, fig. 2. -- Howship, Practical Observations in Surgery, p. 33, from a fall. - Palletta Exercit. patholog. I. p. 127. Hesselbach Beschreibung der patholog. Präparaten zu Würzburgh. p. 8. No. 652. 
Gall, pl.49. - Cerutti Beschreibung der pathol. Präparate des anat. Mus, zu Leipzig, No.761. In a Cretin, v. Prochaska, \&c.-Sometimes the fontanels remain open for a long time, even throughout life. v. Casp. Bauhini Theatr. p. 280.-Lachmund in Miscell. Acad. Nat. Cur. 1675--1676, p. 240, in a man twenty-three years old.-Nil Rosen resp. Sidren de Ossibus calvariæ. Upsal, 1746. - Mayer Beschreibung des ganzen mencshl. Körpers. Vol. II. p. 63 ; in a woman of some twenty years old I have also seen this, as also an open fontanel in a monstrous sheep. v. Selt Beob. I. No. 9, p. 30, the great fontanel remains long open as a peculiarity in some kinds of sheep, which are called lieath sheep. We also sometimes see it in pug dogs. v. Greve Bruchstuicke zur vergl. Anatomie und Physiologie, p. 1. Oldenburgh, 1S28, in the various kinds of birds with large cells; the bony cell is frequently ossified imperfectly.

(23) Morgagni De sedib. et caus. morbor. Ep. III. p. 2, IV. p. 15, XIV. p. 35, XXVII. p. 2, LX. p. 12. - Albimus Index suppellect. anat. Raviani. No. 27, 29, p. 4. - Sandifort Mus. anat. Vul. II. tab. 13.-Voigtel Pathol. anat. Vol. I. p. 272.-Monro, Outlines of Anatomy, pl. 12.-Biermayer Museum anat. pathol. No. 221, 317, 563.-Hollberg in Ars-Berättelse om Svenska Sällskapets Arbeten, of Carlander, Stockh. 1818, in a child twenty months old. - Wendt in v. Froriep's Notizen, No. 65 , p. 327 , on the back of the head, probably from muscular exertion. - My Verzeichniss, \&c. No. 3093-3097, 3115. - In animals, a morbid thickening of the skull is very rare, excepting such as are scrofulous, in which $\mathrm{I}$ have seen it several times.

(24) Thickening of the skull occurs in insane persons, and it is so much greater as it is fartler back.--Greding found the skull too thick in 151 out of 196 individuals.-Georget, p. 480, found it 1-20th too thick in 480 out of 500 such skulls. v. also Esquirol.--Gall thought the skull was too thick and ivory like in all suicides, which however is by no means generally the case.

(25) Compare above $\$ 119$, note 4 .

(26) I saw a skull of this kind in the Surgical Academy at Copenhagen, and there is a similar one in Bresl. Mus.

(27) Caspart D. de exostosi cranii rariore. Argentor. 1730 ; and in Haller's Coll. Diss. chir. I. No. 4. - Mögling in Eph. Acad. N. C. Cent. V. and VI. p. 221.-Müller D. de febre biliosa, subjuncta observatione exostoseos in cranio repertx. Argentor. 1782.-Tarin in Act. Nat. Cur. Vol. VII1. p. 251.-Baillie, Engravings, Fasc. X. pl. 1, fig. 2.-Köhler, p. 29, No. 100, a very large internal one.--liömhild D. continens nonnulla de exostosibus in olla capitis. Svo. Goett. 1808 , with engravings, from Blumenbach's Collection, engraved and described in J. P. Frank's Opuscula posthuma. p. 102, tab. 4-6. Svo. Viennæ, 1824. Prochaska Disquisitio anat. physiol. organismi, etc. tab. 6 and 7. 1822.-I saw a remarkable case in the Cabinet d'ecole cle Médecine at Paris, it is engraved in the Dict. des Sc. medic. Vol. XXXV. p. 26, pl. 3. - Hartmann in Rust's Magazin f. die ges. Heilk. Vol. III. Part I. p. 19. - Hesselbach, No. 371.Wittwerck. - My Verzeichniss, \&c. No. 3100-3147. - Injuries of the skull are sometimes cured by exostosis, to wit, Sandifort Mus. anat. Vol. II. tab. 19.-Mysclf, No. 3106, 3108.

(28) Especially in the cavity of the skull of oxen. v. Vallisneri De Animalium cerebris ut vulgo creditum est, lapidescentibus in Op. I. p. 80.--Soenmerring Auhang zu Baillie, p. 180, engraved in Rheineck Medic. u. chir. Beobacht. über die einfache Methode, des Serten-Blasensteinsclınittes, pl. 3, fig. 21. Svo. Berl. 1S15.-- G. Moreschi, v. Zscholike's Miscellen f. die Neueste Weltkunde, No. 92. 1809.--Ephem. N. C. Dec. I. Ann. I. Obs. 26, p. 92. - Th. Bartholini, Epist. VIII. Cent. III. and VI.; and Histor. med. Obs. XCI. p. 357.-Giro in Annuare de la Soc. de Médic. du Depart. de l'Eure, 1810, p. 90.-Dobrzensky de Negroponte in Miss. $\Lambda$ cad. N. C. Dec. I. Ann. I. 1670, p. 289. Ann. Iİ. A pp. p. 8. - Duverney in Mém. de Paris, 1703. Hist. p. 26. Mém. p. 261.Barnn in Mémoir. de Paris, 1753. Hist. p. 134. - Pitsclel Anat. chir. Anmerkungen, Dresden, 1784, now in the Anat. Mus. of the $\Lambda$ cademy of Surgery at Dresden. My Selt. Beob. I. p. 79, tab. 1, fig. 3.-Simson, $\Lambda_{n}$ Inquiry how far the vital and animal actions, Sc. p. 259. 8vo. Edinh. 1752, with engravings.Samdifort Mus. anatom. Vol. III. No. 650, p. 392. -I saw a similar exostosis in 
the Imperial Museum of Florence; and another in the collection of Sommerring.-I saw a large exostosis on the skull of a roe, in the collection of Schinz, at Zurich; on the skull of a fowl, v. Nat. Cur. Observ. med. phys. Cent. III. and IV. Obs. 96 , p. 257 ; on the skull of an epileptic canary-bird.-Goldfuss.

(29) Boerhavii Præl. de morbor. nervor I. p. 141.-Fordyce De Hemicrania \$33.-Platner De vi corporis in memor. I. p. 31.-Greding, p. 32.-The London medic. Repository by Burrows and Thomson, Jan. 1817.-My Selt. Beob. I. p. 72. No. 31, Verzeichniss, \&c. No. 233, 234, 236, 238, 240, 242, 243, 3064, 3067, 3109 , and 3110 .

(30) Of which, in the several bones.

(31) Several examples in Sandifort. Voigtel, Pathol. Anat. Vol. I. p. 286.My Verzeichuiss, \&c. No. 187-190.

(32) Many instances in de Plouquet Repertor. Art. Cranii suturæ, Cephalæa, Hydrops capitis, Sutura, \&c. Such a case of diastasis from dropsy of the head, in a boy of seven years, is found in the works of $M$. Baillie ed. Wardrop. Lond. 1825. Vol. I. first described in Medical Transact. Vol. IV. 1813.-My Selt.

Beob. II. p. 95, No. 42; Verzeichniss der anat. Präparatensammlung, No. 3120.

(33) A too perfect state of the sutures and the fontanels, for the most part, or completely closed, is not very unfrequent in newly born children; v. Osiander Annalen der Entbindungslehranstalt zu Gött. 1800, p. 27.-Busch in Stark's N. Archiv für Geburtshülfe. II. p. 96.-Jörg Handb. der Kinderkrankheiten. Leipz. 1826, p. $315, \S 316$. I have seen several such instances, also complete ossification of single sutures in human and brute monsters, to wit, No.3012, $3047,3052,8056,8226,8227$.

(34) Lentin in Blumenbach's Medic. Biblioth. Vol. III. p. 525, (all the sutures in a boy six years old.) -Desessarz in Mém. de l'Instit. nation. des Sc. Vol. I. p. 234, (all the sutures in a boy twelve years old,) individual sutures are pretty frequently scen closed.

(35) v. my Verzeichniss der anat. Präparatensammlung, p. 4-6, in which such varieties exist, for instance, No. 179-182, 209, 214, $226-229$.

(36) To wit, a kind of middle fontanel in the sagittal suture. v. Stein's geburtshiilf. Wahrnelimungen I. p. 345.-Meckel Anat. physiol. Beobacht. und Untersuchungen, p. 3 and 50. Halæ, 1822. I have also found it twice.

(37) In Loder's Cabinet, v. Köhler, p. 50, No. 171.

(38) A good engraving of a large half-united incised wound, in Sandifort Mus. anat. Vol. II. pl. 19.-A remarkable injury of the skull, which a suicide effected on his forehead with an axe, I have described in my Selt. Beob. II. p. 14. v. Verzeichniss des Museums, No. 3183, in which occur, from No. 3169 to 3195 , many instances of iujuries of the skull; of the congenital, v. below, in the foctus. Pieces of the skull which have been cut off obliquely are sometimes bealed with some loss of substance; for instance, Sandifort, Vol. II. tab. 20. fig. 1 ; a case in Bresl. Mus. No. 8250, and some cases in the Anat. Mus. of the Joseph Acad. at Vienna. [There is in the Museum at St. Thomas's Hospital, a fine instance of union of a portion of the parietal bone about the size of a half-crown, which had been struck off by a sabre. T.]

(39) Fissures of the skull sometimes do not heal for a very long time; such cases are described by Duverney in Mém. de l'Académie de Chirurgie. Vol. I.Stanley in Medic. chir. Transact. Vol. VIII. p. 24, pl. 1.-Eltze D. de fracturis baseos cranii cognoscendis quædam. 8vo. Berol. 1826.-Good engravings of fissures are given by Sandifort, Mus. anat. II. pl. 17 and 18 .

(4.0) v. my Verzeichniss, \&c. No. 3122, 3124, 3128-3131, 3164.-Sandifort gives good engravings of such holes in his Mus. anat. II. pl. 20-24, 26, 27.

(41) James Russel, Some observations of a peculiar affection, to which the bones of the cranium are liable, in Transact. of the medico-chir. Soc. of Edinb. 1824, No. 3.-Cullerier Observations des nécroses du crane produites par la syphilis in Annuaire méd. chir. sur des Hôpitaux et Hospices civiles de Paris, 1819, p. 437. [A Fasciculus containing nine lithographic anatomical drawings, \&c. pl. 7. fig. 1. T.]

(42) Palletta De tuberculis ossivoris in Exercit. pathol. I. p. 93-104.

(43) Le Clerc Maladies des Os, etc. v. IIaller's Biblioth. chir. I. p. 469:- 
Pelletan Clinique chirurgicale, Vol. II. fig. 1.-Richter in 2 . Froriep's Notizen, Feb. 1822, No. 24, p. 29.-Krimer in v. Gräfe's and v. Walther's Journ. f. d. Chir. 1827. Vol. X. Part IV. p. 587.- In a case related by Flint in NewEngland Journ. of Medic. and Surgery, new series, Vol. IV. April, 1820, a bloody tumour sprung through an opening on the occiput connected with the sinus transversus. I have also before me a similar case in a boy of five years old.

(44) Crell resp. Kaufmann D. de Tumore capitis fungoso post cariem cranii exorto. Helmst. 1743, cum icone, in Haller's Coll. Diss. chir. I. No. 3.-Sandifort Exercit. academ. Lib. II. p. 40, tab. 3.-Museum anat. Vol. I. p. 152. Vol. II. p. 142, tab. 13, fig. 6-9.-v. Siebold in Arnemam's Magazin fuir die Wundarzneiwiss. Gott. 1797, Vol. I. Part IV. p. 389, with engravings.-Cheston Browne in Philos. Transact. 1780, Vol. LXX. p. 323, with engravings.-Baillie Engravings, Fasc. X. pl. 5. fig. 1.-Home, Transact. for the improvement of Med. and Surg. Knowledge. Lond. 1812, Vol. III. tab. 2.-v. Walther in his and v. Gräfe's Journ. f. Chir. Vol. I. Part I. p. 55._Ficker, ib. Vol. II. Part II. p. 219.-Calliot Diss. sur l'encephaloides ou fongus medullaire. Strasb. p. 25, Obs. vi.-Wishart in Edinb. Med. and Surgical Journ. July, 1822, p. 393. Schneider Diss. de fungo hæmatode. 4to Berol. 1821, with engravings. - Eck in v. Gräfe's and v. Walther's Journ. f. Chir. Vol. V. Part I. p. 105.-My Selt. Beob. II. p. 82; No. 2133, of Bresl. Mus. - Seerig Comm. nonnulla de fungi duræ matris origine et diagnosi, tab. 1. Vratisl. 1825.-Hesselbach Beschreib. der pathol. Präparate zu Würzburg, p. 63, No. 642.-Schwarzschild D. de fungis, capitis et duræ matris. 4to. Heidelb. 1825, with four lithographs. - Salomon in Petersb. vermischt. Abhandl. III. 1825, p. 237.-Schindler in Rust's Magazin f. d. ges. Heilk. 1827, Vol. XXV. Part II. p. 267.-G. Sandifort Mus. Anat. Vol. III. p. 158, No. 127. - C. Graff in v. Grä̈fe and v. Walther's Journal der chir. Vol.X. Part I. No. 4.-Weffer-Abercrombie Pathological and practical researches on diseases of the brain and spinal cord. 8 vo. Edinb. 1828.-A. G. Rhodius D. casum singularem de amaurosi cranii osteosarcomate effecta. 4to Berol. 1829, with engravings, (on the right side of the sphenoid bone;) Ebermaier Ueber den Schwamm der schedel knocken und dic schwammartigen Auswüchse der harten Hirnhaut. 4to. Dusseld 1829, with 10 lithographic plates.

(45) Landmann Comm. pathol. anat. exh. morbum cerebri oculique singularem, 4.to. Lips. 1820, with three engravings.-Myself, p. 86, No. 2356, of the Bresl. Mus.

\section{$\S 123$.}

Sometimes the FrONTAL BONE is entirely deficient, and its place supplied by the elongated parietal bones, ${ }^{1}$ the frontal portion of this bone is very commonly deficient in anencephalous monsters, and its orbitar portion, as in dropsy of the head, is short and depressed backwards. In hydrencephalous children and insane persons, the firontal portion is oftentimes very much inclined backwards, whilst in dropsy of the head and rickets it is usually very prominent and much expanded. The frontal suture remains, in men, especially with broad foreheads, partially or entirely, often for a long time, or even permanently, unconsolidated, ${ }^{* *}$ whilst on the contrary in those animals, in which it regularly remains open, its consolidation is sometimes observed. ${ }^{2}$ In rare cases the frontal suture does not proceed straight to the sagittal. ${ }^{3}$ 'The crista frontalis has been seen remarkably prominent, ${ }^{4}$ and the 
nasal spine abnormally enlarged. ${ }^{5}$ The FRONTAL SINUSES frequently present variations $;^{6}$ in rare cases indeed both are wanting, ${ }^{7}$ or there is but one, or they are unusually small; they become contracted by disease, or are completely filled by bony substance. ${ }^{8}$ On the contrary, we sometimes find them unusually large, both as congenital formations, ${ }^{9}$ and as consequent on morbid extension. ${ }^{10}$ They are often much destroyed by caries, particularly in syphilis, and glanders in horses, \&c. Not unfrequently there arise from the frontal bone, HorNs and ANTLERs, which are irregular. Sometimes these are entirely deficient, and such deficiency becomes hereditary and characteristic of a peculiar race $;^{11}$ more rarely but one horn or antler is deficient; $;^{12}$ or in cattle, there is only the tip of the corniferous process, so that the distorted horn is merely attached to the skin. On the contrary, we observe also too many horns, for instance, in sheep, ${ }^{13}$ goats, ${ }^{14}$ in the antilope saiga ${ }^{15}$ the deer-kind, ${ }^{16}$ and oxen $;^{17}$ also the females of the deer and roe kind which are naturally hornless, possess antlers, especially in old age; these, however, always remain smaller than the normal horns of the male. ${ }^{18}$ Frequently do the form of the horns and antlers ${ }^{19}$ vary, inasmuch as they are observed in sickly deer and roes too small, ${ }^{20}$ become curved in animals which are otherwise healthy, or are merely malformed in various ways. ${ }^{20 *}$ Vices of texture, similar to those of other bones, also attack the bony core of horns and antlers; we observe them deficient of lime, and therefore spongy, light, and frangible; ${ }^{21}$ too full of lime, and therefore too solid and heavy, and studded on their surface with increasing exostoses. ${ }^{22}$ The bony core inflames, is more or less destroyed by caries ${ }^{23}$ and even separated from the horny covering. In rarer instances we observe in deer and roes, instead of the deficient antler, or upon it, a large or small quantity of soft movable swellings, often attached to a neck, which for the most part consist externally of fine hairs, but within of a cartilaginous substance. In sporting language, such roe is called a ROE-KING. ${ }^{24}$ When great violence is applied to the horns, they break, sometimes only one of them, or they even actually break off, which in oxen usually occurs close to the head.

(1) Bonnet, Medic. septentr. collat. Vol. I. p. 19.

(1*) [It was remarked by Dr. Leach and others, who have seen the collection of crania in the catacombs at Paris, that the frontal suture remained unobliterated in at leasi one of eleven skulls.-Clift in catal. of Mus. Roy. Coll. Surg. Part III. p. 7. T.]

(2) For instance, in sheep; v. my Selt. Beob. I. No. 10, p. 31. No. 11, p. 34, and No. 12, p. 39. Congenital consolidation of the frontal suture has also been noticed in the human subject; v. my Selt. Beob. I. p. 5 ;-Sandifort Mus. Anat. Vol. I II. p. 99. No. 687. 
(3) My Verzeichniss, No. 179.

(4) In one instance as a long sickle-shaped bony plate, about a third of an inch broad. Blumenbach Geschichte und Beschriebung der knocken. 2d edit. p. 114, note 1 .

(5) Siebergundi in Harless Rhein. Westphäl. Jahrb. Vol. II. Part II. No. 2.

(6) Runge præs. Zieg!er D. de morbis præcipuis sinuum ossis frontis, etc.

4to. Rintel. 1750.-Welge D. de morbis sinuum frontalium, etc. 4to. Gött. 1786.

(7) Morgagni De sed. et caus. morb. Lib. V. Epis. LXIII. Art. 13. Blumenbach, p. 111, note 1, says that their development is prevented by water in the head, and rickets, which I have also seen several times. Prochaska, Disquis. anat. phys. organismi corp. hum. tab. 8 , also mentions the same from cretinism.

(8) Horn in his Archiv für die medic. Erfahrung. 1815. Part III. p. 552.

(9) My Verzeichniss, Sc. No. 170 and 3226.

(10) Not merely is its anterior wall then protruded, like a bladder, but sometimes the internal also very remarkably, so that the brain is compressed; for instance, Horn, 1815, Part V. p. 854 . I once saw the right frontal sinus in a young roe much expanded by a scrofulous swelling. Selt. Beob. Part I. p. 78. No. 35, Museum, No. 2361.

(11) It is well known that there are unhorned varieties of oxen, sheep, and goats. A bull, which was accidentally without horns, implanted this vice upon all its male progeny, and thus gave rise to the now common race of oxen in Paraguay. v. Azara's Reise nach Südamerika, p. 161. Berl. 1810.-A cow, which had lost the left horn by suppuration, subsequently produced three calves, which had merely a claw-like horny scale on that side instead of a horn. See Thacr in the Moegliner Annalen, 1822, Vol. X. p. 154. - In the forests of Erbach were observed, for several years, stags which in the first year had no antlers, and subsequently merely prickers; see Wildungen Taschenbuch, 1802, p.73. In rare cases also the horns are wanting in buffaloes; v. Cuvier Ossemens fossiles, Vol. IV. p. 123. Plate 10. fig. $7-9$.

(12) Anaxagoras dissected, in the time of Pericles, the head of a ram with but a single horn, Plutarch; in the antilope saiga sometimes there is only a single horn. Linné System. anat. ed. Gmelin, Vol. I. p. 185.-At Mr. Klinkenberg's, apothecary at Utretcht, I saw the skull of a roe with but one antler, and that on the right side. If a stag or roebuck be castrated only on one side, on that side no antler is reproduced.

(13) Such a ram is sketched in the Ecarts de la Nature, tab. 18. Sturm in Viehrassen, Jena, 1819, Part II. pl. 6.-A similar one exists in Bresl. Mus. No. 3223. In Iceland sheep we find as many as cight horns, also in other sheep five horns; for instance, Radzcynski Historia Poloniæ animalium, Vol. II. p. 464, upon Ovis polycerata. v. Linné Ammoen. acad. Vol. IV. p. 174.

(14) Skulls of goats with four horns are not very uncommon; there are three of them in Bresl. Mus. No. 3222, 4672, 8217.

(15) Linné.

(16) Double antlers and supernumerary shoots are not uncommon in stags and roes. Nov. $\Lambda$ cta N. Cur. Vol. I. Obs. 39. p. 148.-Aelian Animal, Lib. XI. cap. 36. In 13resl. Mus. there are the double antlers of two roes, No. 3211, 3212. I saw, in the Aslımolean Museum, at Oxford, the skull of a roe with a third horn in the midclle and in front of the other two; and in the Muscum of Natural History at Copenhagen a skull of an elk, in which the left antler is double. [No. 272, Mus. IRoy. Coll. Surg. a double horn in a goat. T.]

(17) An instance of thrce horns is given by Radzcynsli; a similar one may be seen at Madrid. [No. 2.71, Mus. Roy. Coll. Surg. is a remarkable instance of a third horn in a cow, growing from the centre of the forehead, between the eyes; it arises by a broad base, the greatest diameter of which is $9 \frac{1}{4}$ inches ; it forms an elevated crest, extending forwards as far as the extremity of the nose, is hollow or concave on its inferior surface, and composed of a loose fibrous structure. 'I'.]

(18) Of hinds with horns there are many examples in Anglica Normannica a veteribus scripta ex bibliotheca G. Cameleni, Itinerarium, Cambrix. Francof. 1603, p. 821. - Ephem. N. Cur. Ann. IX and X. Obs. 88, p. 225, and Dec. II. 
Ann. II. Obs. 98, p. 247.-G. E. Stahl De cornu cervi deciduo. Halæ, 1699.Scheuchzer in Leopoldi D. de alce. Basil. 1700.-Valmont de Bomaine in Journ. de Physique, Vol. VI. p. 501.—Ridinger Abbild. seltener Thiere Tab. 79.-Jam. Hoy in Transact. of the Linnean Society, Vol. II. p. 356-v. Wildungen Taschenbuch für Furst-und Jagdfreunde. 1800, p. 14.-Gr. Mellin, ib. 1805, p. 13. -In roes this is noticed in Eph. N. Cur. Dec. II. Ann. VI. Obs. 192, p. 367.v. Wildungen, 1801, p. 178. - I saw an antler of this kind in the Zootomical Cabinet at Paris, and three examples are to be found in Bresl. Mus. No. 32173219 ; in a fourth instance, No. 4668, the animal was even with young. Compare Selt. Beob. Part I. No. 30, p. 71. [No. 16, Mus. Roy. Coll. Surg. is an instance of an old roe hind, which had horns, the longer of which did not exceed three inches. And in the note accompanying this, Lord Egremont states that it is not uncommon to see imperfectly formed horns in the roebuck, stag, and fallow deer which are old and past their prime. 'T.]

(19) There is a rich collection of malformed antlers in the hunting castle of Moritzburg, at Dresden. Compare Allgem. Historie der Natur. Vol. II.

Part III. p. 88, 109, 134. Vol. I. Part VIII. p. 127.- Of a reindecr, Vol. II. Part VI. p. 80.-Ridinger, pl. 81, and in Blätter rarer monströser Hirsche. fol. Augsb. 1740.-v. Wildungen Jagdkalender 1799, pl. 3, and Taschenbuch für Forst-und Jagdfreunde, 1809-1812.-My Verzeichniss, No. 3202-3221.

(20) Such distorted roe horns have given rise to the fable of hares with horns.

(20*) [Horns sometimes grow parallel to each other, become firmly united throughout their whole length, producing the appearance of a single horn; a good example of which is seen in the Ovis Ammon, No. 1043. in Mus. Roy. Coll. Surg. T ]

(21) I kept a stag for twelve years, which at two years old I had castrated, it put up yearly, when it shed its coat, new long prickers, which were mostly covered with velvet, and were so brittle that the stag never attempted to but with them, but if angered, used his fore feet as weapons. [This is a remarkable exception to the fact usually noted, that animals which have deciduous horns, never shed them after castration; there are several instances of such permanent horns in stags, in the Mus. Roy. Coll. Surg. And further to shew the intimate connexion between the growth of horns and the generative functions, it has been observed that if a stag have its horn broken during its growth, the animal is for that year impotent. T.]

(22) Allgem. Historie der Natur. Vol. II. Part III. p. 87, No. 587.-My Verzeichniss, No. 3202.

(23) Cotton Tufts in the Memoirs of the American Academy of Arts and Sciences, Vol. I. Boston, 1785, and in the London Med. Journ. Vol. VII. Part III. p. 305, 1786.

(24) Schmucker Fasciculus admirandorum naturæ. Strasb. 1697, p. 5, No.4. -Rudolphi, Bemerkungen-auf einer Reise, u.s.w. Part I. p. 71. Part II. p. 200, describes one such from the Cabinet of Natural History at Vienna, and another at Brunswick.--Osiander Epigrammata in diversas res musei sui anatomici. 2d edit. Gütt. 1814, p. 155, pl. 6.-My Selt. Beob. II. p. 10, of a female roe; I however possessed for a short time the head of a male roe, of which one of the horns sent off a somewhat longish bottle-like process; the head of the so called roe-king is found also in the Anat. Mus. at Berlin.

\section{$\S 124$.}

The PARIETAL BONEs are very frequently deficient, either entirely or partially in anencephalous monsters; they are, however, occasionally missed in natural foetuses. ${ }^{1}$ In rare cases they are divided by an irregular transverse suture into an upper and lower-half $;^{2}$ we have, however, seen the suture in one instance run partially vertical ${ }^{3}$ and diagonal. ${ }^{4}$ Its form 
participates in almost all the changes of the skull, so that it is sometimes found unequal, oblique, remarkably large in watery head, \&c. We sometimes observe the groove for the longitudinal sinus, not in the middle beneath the sagittal suture, but running along only one of the parietal bones; the edges of this groove are also seen very prominent, like a kind of bony sickle. Frequently very deep pits are found, indeed even bladder-like depressions from the so-called pacchionic glands $;^{5}$ sometimes the parietal holes, foramina parietalia, are very large. ${ }^{6}$ If in the bloody tumours of the heads of new-born infants, the effused blood remain for any length of time upon the parietal bones, on that spot is the external table easily destroyed." Finally, the parietal bones, on account of their position, are especially subjected to injuries ${ }^{8}$ this applies to animals with the prominent crista longitudinalis, also especially in that part, which therefore very frequently exhibits bendings and fractures. ${ }^{9}$

(1) Löfler in Stark's Neuem Archiv für die Geburtshülfe, Vol. I. p. 422; and Stark, ib. p. 423, note.

(2) Winslow in Tarin Osteographie, p. 16, pl. 5.-van Doeveren Observ. academ. p. 195.-Murray resp. Schulzen Descriptio foetus hydrocephalo interno correpti. Upsal. 1797. Compare Rudolphi's Schwed. Annalen, Vol. I. Part I. p. 119.Meckel relates one case from the collection of Gotthard, and two of his own. Handbuch der pathol. Anatomie, Vol. I. p. 337.-Hesselbach Beschreibung der pathol. Präparate eu Würzburg, p. 3. No. 43.-von Sömmerring in Tiedemann's and G. R. and Chr. L. Treviranus Zeitschrift für Physiologie, Vol. II. Part I. p. 1, pl. 1 and 2. The suture sometimes does not pass completely through. v. Aurivillius resp. Ekmark de hydrocephalo 45 annorum. Upsal. 1763. In Sandifort Thes. diss. Vol. II.

(3) Aurivillius.

(4) Hesselbach.

(5) My Verzeichniss, No. 3082.

(6) Jancke De foraminibus calvariæ eorumque usu. Lips. 1762.-Lobstein D. de nervis duræ matris. Argentor. 1772, Tab. 1, fig. 6.-My Verzeichniss, No. 3083,3084 .

(7) Michaelis in Loder's Journ. f. d. Chir. Vol. II. Part IV. p. 657, improperly considered the bloody swelling as an original disease of the bone; v. below, on the Head. Cases of such bony erosions are found in Palletia Exercit. pathol. 4to. Milan. 1820, p. 123. - ILesselbach, p. 145, No. 289. - My Verzeichniss, No. 3122. - Schwarz in v. Siebold's Journ. f. Geburtshülfe, 1828, Vol. VI. Part II. p. 439.

(8) Schneider D. de vulneribus sincipitis. Viteb. 1653.-Kahl D. de fracturis ossis bregmatis. Lips. 1776.

(9) I saw a fossil hyæna's skull in Soemmerring's Museum, in which the longitudinal crest had been almost entirely broken off and reunited. On the skull of a hyæena striata, No. 4608, in Bresl. Mus. it is very much curved; in dogs I have several times seen it indented, and with united fractures; also curved, in the nasua rufa.

\section{$\S 125$.}

The OCCIPITAL BONE, ${ }^{1}$ in anencephalous and hydrencephalous monsters is often very deficient at its upper part; in the latter case we frequently find in it only one single hole of greater or 
less size; in both kinds of monsters we find the occipital bone pressed much backwards and downwards; still, however, after birth the squamous part of the bone is very much driven out by dropsy of the brain; as well also in persons with heavy heads, especially if connected with softening of the bones, the under part of the bones is very much thrust up into the cavity of the skull ${ }^{2}$ sometimes the pressure is so great that we find on the occipital bone a deep impression answering to the first cervical vertebra. ${ }^{3}$ We very frequently find the separate bony pieces, of which in the foetus the squamous part of the occipital bone is composed, ununited at a later period, and therefore large distinct pieces lie in and upon the lambdoidal suture,$^{4}$ or the bone is divided by a transverse ${ }^{5}$ or more rarely by a perpendicular ${ }^{6}$ suture. The occipital spine is sometimes unusually large; the articular processes jut out too much and are too deeply articulated, or are too flat, and at the same time sunk in, oblique, 7 unequal, divided into two surfaces, \&c.; in rare cases we find near the articular processes on one or both sides, some which are accessory, that is, processes which are articulated with the atlas. ${ }^{8}$ Oftentimes we find the occipital hole malformed, viz. too narrow, too wide, oblique, ${ }^{9}$ or in idiots unusually wide and directed backwards, \&c. In horses and cattle we find caries of the occipital bone from pressure of tumours in the neck, poll evil, talpa. ${ }^{10}$

(1) Schneider D. de osse occipitis, ejusdem vitiis et vulneribus. Viteb. 1653.

(2) I have seen this several times in osteomalacy and in rickets; it also often occurs in the skulls of cretins.

(3) For instance, my Verzeichniss, No. 165, 168.

(4) Compare the Catalogue of Bresl. Mus. No. 194, 208, 211, 217, 225, \&c.

(5) Eustachius, tab. 46, fig. 8.-Albinus De sceleto, p. 131.-Albrecht in Nov. Act. Nat. Cur. Vol. IV. Obs. 13, p. 70. Vol I. fig. 7.-Bruns Observat. anat. et chir. med. Götting. 1760. rev. in Sandifort's Thesaurus Diss. Vol. III. p. 65.Schreiber in Nov. Comm. Acad. Petropol. Vol. III. p. 395, pl. 9.-Blumenbach Geschichte der Knochen. Part II. p. 186, note c. - Rudolphi Schwed. Annalen. Vol. I. Part I. p. 119, note. - Meckel Handb. d. pathol. Anatomie. I. p. 320.-Kelch, Beitr. z. pathol. Anat. p. 2. No. 2.-Bleuland Descript. Mus. anat. p. 226. No. 1177 ; one instance in Bresl. Mus. No. 202; in the anat. pathol. Museum at Vienna, and in the anat. Museum at Heidelberg. Deep notches on either side are common.

(6) Vesalius De corp. hum. fabrica. Lib. I. cap. 6, p. 26, the edition by Albin; Reisel in Eph. Nat. Cur. Dec. II. Ann. II. p. 274. A notch often remains for a long while above in the lambdoidal angle.

(7) In long-continued wry neck the whole base of the occipital bone is often awry. v. Bleuland, p. 238 . No. 1241 .

(8) Sandifort Exercit. acad. Vol. I. p. 10. - Mus. anat. Vol. II. plate 14, fig. 31. - Leveling Observat. anat. rarior. p. 134, tab. 5, fig. 2 (hardly more than facettes on the occipital bone, and the tubercles on the Atlas;-Meckel De duplicitate monstrosa, p. 24, in D. Archiv f. d. Physiol. Vol. I. p. 644, pl. 6, fig. 37 ; and in Anat. physiol. Beobacht. und Untersuchungen, p. 178. - T'esmer præs. Rudolphi D. Observat. osteol. Berol. 1812, with plates; three cases, in Bresl. Mus. No. $166,167,8292$. - G. Sandifort Mus. anat. Vol. III. p. 289, No. 987.- 
Knape also possesses such a skull. v. Schupke De luxatione spontanea atlantis et epistrophei. p. 21, in note. 4to. Berol. 1816.

(9) I have seen several instances of this, also some in brutes; to wit, Selt. Beob. I. No. 10 and 11 ; since that time several more; five instances are related by Meckel in his Anat. phys. Beobact. p. 173.

(10) I have seen instances of this at Alfort, and large exostoses, from similar causes, on the skull of a horse in the veterinary school at Stockholm.

\section{$\S 126$.}

The TEMPORAL BONES also exhibit many vices of formation; to these beiong the partial deficiency of the squamous portion in anencephalous monsters, their exceeding smallness, approximation to each other, consolidation and deficient formation in monsters with imperfect face, particularly with cyclopy and want of the lower jaw $;^{1}$ further, the division of the squamous portion into many pieces $;^{2}$ its lengthening forwards, so that it joins itself with the frontal bone $;^{3}$ deficient formation of the zygomatic process, ${ }^{4}$ \&c. In anencephalous monsters, and in watery heads, owing to the lateral extension of the head, the petrous bones, instead of being sloped, are completely transverse, and in the latter disease the petrous bone and squamous portion are more or less pressed upon each other. ${ }^{5}$ In rarer cases the groove for the transverse sinus in the temporal bone is deficient $;^{6}$ the edge of the petrous bone sometimes in insane persons projects as a cutting bony plate $;^{7}$ the carotid canal becomes narrowed, in consequence of the smallness and obliteration of the carotid artery, and is even found completely closed $;^{8}$ the styloid process is remarkably large and becomes bony ${ }^{\circ}$ the glenoid cavity is naturally wanting at the same time with absence of the lower jaw, and in gouty persons is entirely bereft of its cartilage; frequently surrounded with tophus; a new articular cavity has been once found produced after dislocation of the lower jaw. ${ }^{10}$ In rare cases we find in man, unusual openings and canals in the temporal bone for veins, which run out from the transverse sinus. ${ }^{11}$ The temporal bones are frequently found carious ${ }^{12}$ in consequence of primary diseases of the ear, of abscesses of the brain, which burst here, from metastasis, from superjacent tumours, \&c.; we have also once seen a very large exostosis on each temporal bone. ${ }^{13}$ As to those parts of the temporal bone which belong to the ORGANS OF HEARING, we find them as a rare congenital condition malformed in various ways, that is, as in the small foetal state, deficient in certain parts, consolidated together, \&c. We observe the bony passage of the ear, in congenital closure and deficient development, sometimes very short and narrow, and it is also said to be compressed in later years, in such persons as have lost their back teeth. ${ }^{14}$ The drum is in rare 
cases too small, ${ }^{13}$ malformed, with consolidation of both auditory organs, also in deaf and dumb persons $;^{16}$ on the contrary, too large and very frequently rough and broken down by caries. The auditory bones, in rare cases, are all ${ }^{17}$ congenitally wanting, occasionally only some of them, viz. the hammer and the anvil, ${ }^{18}$ or merely, the hammer ${ }^{19}$ or the anvil $;^{20}$ sometimes we notice supernumerary auditory bones in man and animals $;{ }^{21}$ in other cases they are too small, ${ }^{22}$ too large ${ }^{23}$ malformed in various ways ${ }^{24}$ united with each other and with the neighbouring parts, ${ }^{25}$ lost from suppuration, separated by dropsy of the head, \&c. ${ }^{26}$ The parts of the bony labyrinth also are, in rare cases, very much malformed, particularly in deaf and dumb persons $;{ }^{27}$ we have also seen the round and oval holes wanting at the same time, ${ }^{28}$ or merely the round ${ }^{29}$ hole, or the oval hole ${ }^{30}$ or the latter too narrow ; ${ }^{31}$ the cochlea has a turn too little, ${ }^{32}$ or it is too small, so that the promontory in the drum is deficient ${ }^{33}$ in one deaf and dumb person the semicircular canals, ${ }_{2}^{34}$ merely, were wanting, in an otherwise perfect ear, \&c.

(i) I have noticed this in a great number of human and other animal monsters. Compare further down on the Ear.-E. H. Weber has lately described a few instances of consolidation of the organ of hearing, in the Zeitchrift $\mathrm{f}$. Physiologie by Tiedemann, H. R. and L. C. Treviranus, Vol. II. Part II. p. 305, pl. 15.-A skull of this kind is described in Sandifort's Mus. Anat. Vol. III. p. 293, No. 1004 .

(2) Meckel Handb. der pathol. Anatomie, Vol. I. p. 339.-I have similar instances before me.-Kelch, Beitrage zur pathol. Anat. No. 4, saw the mamillary parts divided from the squamous by a suture.

(3) Chizeau in Roux Journ de Médec. Dec. 1772.

(4) In a cretin it was so short as to form no zygomatic arch. v. Prochaska Disquis. Anat. phys. organismi c. h. tab. 8.-Deficiency of the zygomatic arch, in consequence of congenital tumour in this region. My Selt. Beobacht. II. p. 162.

(5) Blumenbach, p. 151, note 1.

(6) The Review of Rosenmüller De singularibus et nativis ossium c. h. varietatibus, in the Ergängungsblättern zur Hall. allg. Litt. Zeitung, 1813. No. 101.

(7) J. E. Greding Sämmtliche medic. Schriften, u s.w. p. 293.-My Selt. Beob. I. p. 73. No. 3-74. No. 7 .

(8) So narrow, that it would hardly admit a pig's bristle. v. Tode Medic. chirur. Biblioth. Vol. X. p. 407 ; entirely closed in a preparation in the Anat. Mus. at Dresden.

(9) So that it could easily be broken.-Blumenbach, p. 139, Note n, had one which was an inch and a half Paris measure; in No.144, 8c. almost two inches; in No. 245, even three inches long; two inches, and two inches and a half long, v. Sandifort's Mus. Anat. Vol. III. p. 289, No. 988 and 989. [There is a very remarkable skull in the Mus. at St. Thomas's Hospital, in which the styloid processes are of great length, and each has articulated on its point a bone which occupies the place of the stylohyoideal ligament, and joins the tonguebone, which is thus connected by bone to the skull, as in many animals. T.]

(10) a Loder Index Præparator. Absch. XI.-Sandifort, No. 594, p. 283.-[There is another instance in the skull of a New Zealander, No. 78, Mus. Roy. Coll. Surg. T.]

(11) My Selt. Beob. II. p. 69, No. 31.b. - There can be no question that this variation of structure, so important to practical surgery, is, in most mam- 
malia, connected with the existence of the canalis venosus. v. De Animalium quorundam, per hyemem dormientium, vasis cephalicis et aure interna in Nov. Actis phys. med. Acad. N. C. Vol. XIII. F. I.

(12) Morgagni Epist. anat. XIV. - Mohrenheim Beobacht. verschied. chir. Vorfälle, I. p. 98. - Mémoir de l'Acad. de Paris, 1754, p. 63. - A. Duncan, in Medic. Commentaries, II. p. 286. - Schuhmacher Medic. chir. Bemerkungen, I. p. 301.-Weidmann Ueber den Missbrauch des glühenden Eisens, pl. 5 and 6.Palletta Exerc. pathol. p. 2. - Brodie, in Transact. of a Soc. for the Improv. of med. and chir. Knowledge, Vol. III. p. 106. - Parkinson in London medic. Repository, Jan. 1817.-O'Brien, in Transact. of the Association, \&c. Dublin, 1818. Vol. II. - Thiele in Rust's Magazin f. d. ges. Heilkunde, Vol. II. Part I. p. 164.-Starke, ib. Vol. II. Part II. p. 311, the pus escaped through the foramen mastoideum. - Rust, Vol. IV. Part I. p. 197. - Neumann in Hufeland's Journ. No. 2, p. 6. July, 1824, the pus escaped through the glasserian fissure in the articular cavity for the lower jaw ; and $I b$. No. 12, p. 14, from an adjacent steatom.-Duncan, jun. in Edinb. med. and surg. Journ. July, 1821, Vol. XVII. in three instances. - Itard Traité des malad. de l'orielle, etc. p. 70.-Dorn in Irufeland's Journ. 1822, Part II. p. 76. - Lallemand Recherches anatomico pathologiques sur l'Encephale et ses dependance. 8vo. Paris, 1824-1829.Raikem in Répert. génér. d'Anatomie et de Phys. pathol. Vol. I. No. II. p. 295.-My Selt. Beob. II. p. 96.-Verzeichniss, No. 3225-3231. - Kimmel præs. Birkholz D. observatio anat. pathol. de canali carotico carie syphilitica exeso. 4to. Lips. 1805, with engravings.-Holst in Magazin for Naturvidenskabere. Part I. Christiania, 1825. - Martin, in Journ. de Médec. Vol. XXX. p. 453.-G. Sandifort Mus. anat. Vol. III. No. 927, p. 278.

(13) Petit found one hard and like ivory, of the size of a melon.

(14) Larrey in the Journ. Compl. du Dict. des Sc. Médic. Vol. XIII. p. 308.

(15) Rudolphi found it very much diminished, and the pyramid especially wasted in a man. Physiologie II. p. 148, note 2.--I have found it very small in several cyclopic monsters. v. my Selt. Bcob. I. No. 12.

(16) Rudolphi.

(17) I have also found this simultaneous with deficient face; since then, in some imperfect auditory organs in animal monsters.

(18) Caldani Ep. ad Hallerum, Vol. VI. p. 142. -Scarpa De structura fenestræ rotundæ auris, etc. p. 84. Mutin, 1772.

(19) My Selt. Bcob. I. No. 10 and 11.

(20) Boneti Sepulchretum anat. Lib. I. p. 19. Obs. 4.-Marin. Mersennus Epist. ad Beverwyk De calculo, p. 80.

(21) Cassebohm Tractat. VI. de aure humana. Halæ, 1734, p. 55. T'eichmeyer Vindiciæ quorundam inventor. meorum anat. Jenæ, 1727. rev. in Haller's Disp. Anat. Vol. IV.-Eustach tab. 7, fig. 3, (in a dog.)-Adair in Cowper Myotomia reformata. fol. London, 1694, p. 70, fig. 9.-In a preparation belonging to Professor Römer, at Vienna, there is a long cylindrical intermediate bone between the mallcus and incus, which are separated from each other.

(22) In a deaf and dumb child, three times too small, Bailly v. Boneti Sepulchretum, Vol. I. p. 19, Obs. $4, \S 3$.

(23) Cotunni De aquæductibus auris humani. Neap. 1760. \$72, concomitant with a closed fenestra rotunda.

(24) Haller Elem. Physiol. Vol. V. p. 209, 213._Rudolphi, p. 128, note.The stapes has been seen with only one leg, or without any opening in it.Comparetti Obs. anat. de aure interna comparata. 1. 24, Obs. 13. 4to. Patav. 1789, in two cases. - Cassebohm Tractat. sextus de aure monst. hum. tab. 6, fig. 18. Halæ, 1735.-Tiedemamn in Meckel's D. Archiv für d. Physiologie, Vol. V. Part III. 1). 349. - In other instances one leg of the stapes does not reach its base. Lösccke Obs. anat. chir. p. 15. 4to. Berol. 1754.-Rudolphi in T'esmer D. s. Observat. osteologicas. tab 1, fig. 15. 4to. Berol. 1812. - An exostosis on an incus, v. Hesselbach Beschreib. der pathol. Präparate zu Wïrsburg. No. 370 .

(25) Valsalva De aure humana. Cap. II. $\$ 10$, p. 52.-In consolidation of both organs of hearing, several of the small bones are also at the same time, in 
many instances, anchylosed together. v. My Selt. Beob. I. No. 10 and 11, and since then in several more cases.

(26) Blumenbach Geschichte und Beschreibung der Knochen. 2d edit. p. 151, note 1.

(27) Mundini Comment. Bonon. Vol. VI. Anatomia surdi nati. p. 422

(28) Roederer Descr. fcetus par. in Comm. Soc. Götting. IV.

(29) Roederer.

(30) Cotunni.-I also saw the same at Römer's, in a preparation from a deaf and dumb boy.

(31) My Selt. Beob. I. No. 12.

(32) Mundini.

(33) In the case of Römer's at Vienna.

(34) Mürer Comm. de causis cophoseos surdomutorum indagatu difficilibus. Haffn. 1825.

\section{$\S 127$.}

The SPHENOID BONE presents numerous varieties in reference to its form, which partly depend on the size of the fossa basilaris; in cyclopic, anencephalous, and dropsical-headed embryons, it is commonly not only very much malformed, but also perforated and divided in its body, perhaps in consequence of the water bursting out ${ }^{1}$ from the cavity of the head at this part. The depth and width of the Turkish saddle varies very considerably, and often becomes very much enlarged by swelling of the cerebral appendage, (pituitory gland) as well as by dropsy of the head. ${ }^{2}$ We frequently find the body of the sphenoid bone, as well also as other parts of it, softened, rough, and broken up. ${ }^{3}$ The sphenoidal sinus in rare cases is indeed completely deficient, or it is very small and undeveloped; to this belongs that state, in which it is filled by a kind of diploe ; ${ }^{4}$ often it varies in having a partition; sometimes we observe it communicating by openings with the skull $;^{5}$ at other times it is unusually distended by diseases, and its roof raised like a bladder towards the cavity of the skull. ${ }^{6}$ If the optic nerve waste in man and animals, the optic hole in the sphenoid bone becomes distinctly narrowed. ${ }^{7}$

(1) My Selt. Beob. I. p. 41, ff.-Klinkosch Pr. quo anatomen partus capite monstroso proponit. 4to. Prag. 1766, rec. in Diss. med. select. Pragens. Vol. I. No. 12, p. 199.-Béclard in Bulletin de la Facult. de Médec. Vol. III. p. 292, note 9 .

(2) I have myself observed this several times. I also saw in the Pathological Mus. at Vienna, a large bladder-like elevation of the Turkish saddle, from induration and hydatids in the pituitary gland.

(3) Especially in epileptic persons; v. Jos. Wenzel Beobacht. über den Hirnanhang fallsüchtiger Personen. 4to Mainz, 1810. - My Selt. Beob. I. No. 31, p. 72; at the same time in several individuals; I also once found the sphenoid bone excessively soft in a syphilitic person. It is often very much destroyed by tumours in the skull and orbit, by large nasal polyps, \&c.; also at the same time with part of the petrous bone.-Monro's Morbid anatomy of the human gullet, stomach, and intestines, \&c. Cap. III. sec. 7.-Klein in $v$. Griife and $v$. Walther's Journ. f. die Chir. Vol. III. Part IV. p. 621. - My Selt. Beob. II. p. 92, No. 39.-A syphilitic caries of the body of the sphenoid bone 
is engraved in Sandifort's Mus. Anat. II. tab. 20, fig. 2.-A necrotic destruction in Weidmann Ueber den Missbrauch des glühenden Eisens. pl. 3 and 4.

(4) Compare Blumenbach, $\$ 69$, p. 170 ; I have sometimes seen it deficient.

(5) Haller Icones Fasc. IV. Tab. narium intern. Vol. II.-Kelch Beiträge zur pathol. Anatomie, No. 7.

(6) In a syphilitic person I once saw it expanded to the size of a walnut, in consequence of the purulent fluid contained in it.-Horn saw it very much expanded towards the cavity of the skull in an epileptic person. v. Archiv f. d. Medic. Erfahr. 1815, Part V. p. 854. In professor Vithusen's Collection at Copenhagen, I saw the skull of a person forty years old, deformed since childhood by the uncommon expansion of the occiput; between the inner and outer tables of the occipital bone is a hollow space an inch and a half deep, which is connected by the pars basilaris with the sphenoidal sinus; the clivus and Turkish saddle are by the expansion of the sinus very much elevated.

(7) v. Sömmerring saw this in a horse and in a squirrel. v. Blumenbach, p. 38, note $z$.

\section{$\S 128$.}

The ETHMoID Bone is not unfrequently very defective in monsters with imperfect or entirely deficient face, and merely consists of the crybriform plate, which is found membranous, cartilaginous, and imperforate. ${ }^{1}$ In other cases, and indeed commonly in anencephalous monsters, we find large holes instead of the crybriform plate, through which probably the water has burst out from the cavity of the skull; ${ }^{2}$ also at a later period the crybriform plate appears sometimes to be partially destroyed, in which case, water, pus, or blood, percolate from the skull through the nose. ${ }^{3}$ In congenital rupture of the brain into the nose, the ethmoid bone must be very imperfectly formed; sometimes the crybriform plate lies unusually deep." 'The ethmoid bone also exhibits various irregularities in other respects, viz. an oblique partition, too few and small, or morbidly large cells, the paper-like bones entirely or for the most deficient, ${ }^{5}$ or divided by a suture into two portions, ${ }^{6}$ \&c. Finally, the ethmoid bone is very often completely or partially destroyed by nasal polyps, by scrofulous tumours, syphilitic caries, and mechanical injuries.

(1) My Selt. Beob. I. p. 31 and 34.

(2) Osiunder Series observat. de homine quomodo fiat et formetur, read on the 3d of September, 1814, in the Göttinger Socieät der Wissenschaft; my Selt. Beob. p. 44:

(3) Burdach Beiträge zur nähern Kenntniss des Gehirns, u. s. w. Leipz. Vol. I. p. 288, and Vom Baue und Leben des Gehirns, Vol. III. p. 80.-Abercrombie Pathol. and pract. researches on the diseases of the brain and spinal cord. $2 d$ edit. 8 vo. Edinb. 1829.

(4) I have seen this in several persons with watery heads, and in epileptic patients, probably produced by the pressure of the water.

(5) Kelch, No. 6.-Meckel Pathol. Auatomie, Vol. I. p. 345.

(6) IIunauld Mém. de l'Acad. des Sc. 1740, p. 527.-Meckel. I have also some such instances before me. 


\section{$\S 129$.}

The Bones of THE FACE taken collectively, present not unfrequently the most manifold variation in reference to number, form, connexion, \&c. as they naturally take the most remarkable part in the different malformations of the face. Sometimes in monsters, NO TRACE OF BONES OF THE FACE is observed in the bony capsule enveloping the brain ; ${ }^{1}$ next there is formed in certain cyclops only an imperfect orbit, as a rudiment of the face, beneath which it develops itself always more and more gradually, from the frame-work of the upper jaw, with or without a lower jaw. The entire deficiency or unusual smallness of the orbits and of the bony nostrils, the partial consolidation of both lateral halves of the face in cyclopy, the mostly very remarkable smallness of the frame-work of the upper jaw in monsters with deficient lower jaw and similar vices, produce very naturally a great deformity in the bones of the face. Sometimes the upper jaw is monstrously short, although perfect in its particular parts ; to this belongs, for instance, the deformity occurring in the so-called pug-nosed carp. ${ }^{2}$ In rare cases the upper jaw is thus short in animals on account of deficiency of the intermaxillary bones. ${ }^{3}$ To these imperfect formations of the bony face, is opposed the Excess of FORMATron in these parts, which we observe in double monsters, with two more or less perfectly formed faces on one head, ${ }^{4}$ as also in malformed embryons with monstrously large frame-work of the jaws. ${ }^{5}$ Great deformity of the bony face occurs also in congenital CLEFTS, which, as in hare-lip and wolf's-mouth, affect only the upper jaw and palate bones, which parts are more or less separated from each other; but in rare cases the cleft also extends from the margin of the jaw into the cavity of the orbits, ears, and skull. ${ }^{6}$ Frequently the symmetry of the two halves of the bony face is disturbed, and the FACE BECOMES MORE OR LESS AWRY $;^{7}$ this malformation is sometimes original ${ }^{8}$ more frequently it is produced by mechanical injuries, and by palsy, eruptions, face-ache, \&c. on one side, also by the early loss of the teeth on one side, or unusual increase of the incisive teeth of gnawing animals. In such cases the upper and lower jaws are commonly found bent back on different sides, and more or less crooked. ${ }^{9}$ Great malformations and destruction of the bones of the face arise fiom various diseases of the face, especially from tumours in the orbits, nostrils, and mouth, which easily force asunder or destroy the bones. Finally, we observe not very seldom the various fractures of the bones of the face, even although the injury has not operated immediately on them, but 
on the skull. ${ }^{10}$ We must not confound small fissures with irregular sutures or with sutural bones, ${ }^{11}$ which although more rarely than in the skull, occur also in the bones of the face.

(1) For instance, No. 2949-2951, 3044, 8021, of Bresl. Mus.

(2) Mayer's Vorstellungen allerhand Thiere, Vol. I. pl. 8.-Voigt in Magazin für die Naturkunde, Vol. III. p. 515.- In Silesia they are not rare; v. my Selt. Beob. I. p. 51, tab. 1, fig. 2, and Verzeichniss der Breslauer Sammlung. No. 3009, 3048-50. In the collection formerly belonging to Minkwitz (now at Warsaw) I saw two pug-nosed carp and three skulls of the same; sometimes are the parts of the mouth extended into a kind of proboscis ; v. de Reaumur in Mémoir. de l'Academ. des Sc. 1747, p. 58.-Hamberger de cyprino monstroso rostrato. Jenæ, 1748.

(3) In two sheep, v. my Selt. Beob. I. p. 31. No. 10, p. 34. No. 11.-In a dog, in Sandifort's Mus. Anat. Vol. III. p. 375 , No. 533.

(4) The least extensive degree of duplication is seen in a calf's skull, of which the snout is too broad; and above, betwcen the intermaxillary bones, are two other accessory bones; as also in the lower jaw, a middle piece, which supports three incisive teeth. Sandifort Mus. Anat. Vol. III. p. 295, No. 1012.

(5) At Alfort and Paris, I saw the skull of a horse, the front jaw of which projected far before the hinder.

(6) Klein Monstror. quorundam descript. p. 5. Stuttg. 1793. - van Doeveren Obs. acad. Cap. II. p. 46, tab. 5. - Meckel Handb. der pathol. Anatomie, I. p. 523 , in a calf, even into the ear.--Nicati, Spec. de labii leporini congeniti natura et origine, Utrecht, 1822, gives an instance of a cleft which passed from the mouth to the eye, from $V$ rolik's collection.-I have seen a similar case, v. my Selt. Beob. I. p. 19.

(7) In the Veterinary School at Stockholm, I saw in the skull of a young horse, the whole upper jaw remarkably bent to one side. I have the same before me, in the skull of a doe, No. 8225. In both instances the cause is unknown. There is also one example from the duck, in Bresl. Mus. No. 3238. There is a remarkable variety of the duck, the anas adunca, or curvirostra, in which the whole bill is strongly bent downwards. An instance of a goose is to be found in the Eph. Nat. Cur. Dec. I. Ann. IV. and V. Obs. 181, p. 226 ; and in Bresl. Mus. No. 2319.

(8) Especially in double monsters. v. my Selt. Beob. Part I. No. 10-13; in a double-headed calf, No. 3032, in Bresl. Mus. -- Wirtensohn D. duorum monstrorum duplicium humanor. descriptio anat. p. 6, tab. 1. 4to. Berol. 1825. However, also, in single monsters, v. Ullersperger Pathol. anat. Beschreib. sweier Missgeburten. p. 44. and 45, fig. 2. Svo. Würzburg, 1822.

(9) This especially occurs in birds; for instance, in the crow and lark. v. Rudolphi Bemerkungen auf einer Reise, Vol. İ. p. 94. - I have also found it in fowls, and in a crow, v. No. 2320,3240, and 8066.--And I saw it on both heads of a monstrous dove, in the Zootomical Museum at Paris.-In a young turkey. v. Sandifort's Mus. Anat. I. p. 306, No. 36. - [In Mus. Roy. Coll. Surg. No. 2, the mandibles decussate in a fetal chick, like those of the crossbill. T.]

(10) J. Clocquet Mémoire sur les fractures par contrecoup de la machoire supéricure. 8 vo. Paris, 1820, with an engraving.- $[J$. Abernethy, in his Lectures on Anatomy, \&c. mentions a case in which the bones of the face were torn off from the skull, at the transverse suture, and left hanging merely by the optic nerves. T.]

(11) For instance, between the frontal and nasal bones. v. Meckel Pathol. Anat. Vol. I. p. 346.-Béclard in the Bulletin de la Facult. de Médec. Vol. III. Ann. IX. p. 292.-- I have some instances before me; viz. No. 165, 177, 191, 203, and 244, of Bresl. Mus.; between the nasal bones, Meckel D. Archiv. f. d. Physiol. Vol. VII. p. 107 ; between the palate bones, Ib. p. 154; between the lower end of the lachrymal bone and the upper jaw, viz. No. 204, in Bresl. Mus. 
$\S 130$.

The UPPER JAW BONES are either entirely or merely partially deficient in monsters with imperfect development of the face, or finally, they are but unusually small and malformed. Among their malformations, the most common is the cleft ${ }^{1}$ present in hare-lip and wolf's-mouth, which runs through the edge of the jaw either on one or both sides, where the intermaxillary are naturally connected with the upper jaw bones, and in the palate prevents, either only on one or on both sides, the junction of the palatine process with the nasal partition. Should the cleft be large, the palatine portion of the upper jaw-bone is sometimes entirely deficient. In rare cases the palatine processes are so long, that they form the palatine spur. The nasal processes, with deficient nasal bones, are so large that they supply their place; the front part of the same forms externally even a deep fork ${ }^{2}$ that part also of the nasal process which surrounds the lachrymal sac, forms in many skulls a particular piece of bone. $^{3}$ The alveolar process differs unusually in form, according as the teeth are absent or present, is large or small, straight or oblique. Sometimes instead of one infraorbitar hole, there are two, three, and even four. ${ }^{4}$ The maxillary sinus is either entirely wanting or very small, according to the imperfect development of the bones; still, however, although these are perfect, the cavities may be very much diminished or even entirely destroyed by great contraction of the bones $;^{5}$ in one syphilitic patient, both cavities were at the same time filled up with a loose bony cellular tissue, very plentifully supplied with fat ${ }^{6}$ more frequently we see it very much enlarged and expanded like a bladder, with pus ${ }^{6 *}$ and water, with polyps, \&c. 'The upper jaw bones are most frequently, of all the bones of the face, subject to diseases which more or less destroy them; for instance, to erosion and breaking up by polyps in the nasal and maxillary cavities, ${ }^{7}$ to caries ${ }^{8}{ }^{8}$ to spina ventosa, ${ }^{9}$ to exostosis, ${ }^{10}$ to osteosarcom $;{ }^{11}$ more rarely to necrosis. ${ }^{12}$ In the animals which have the upper jaw covered with a horny skin, that sometimes presents a mor. bid appearance, viz. irregular enlargement, ${ }^{13}$ clefts, swellings, ${ }^{14} \& \mathrm{c}$.

(1) A good engraving of a skull, with a wolf's-jaw, is given in Sandifort's Mus. Anat. tab. 35, fig. 1. - Paletta Exercit. Pathol. I. fig. 3. - In the double hare-lip, the middle of the edge of the jaw often projects very much, is oblique, \&c.-[J. Rand, Observations on the double hare-lip in Trans. of Lond. Med. Soc. Vol. I. p. 159 . T.]

(2) This may give rise to a peculiarity in the operation for fistula lachrymalis. v. Bromfield, Chirurgical Oloservat. and Cases, Vol. I. p. 341.

(3) Rosenmüller Partium externar. occuli hum. inprimis organor. lacrym. descriptio Anat. p. 57. 4to. Lips. 1797. 
(4) Important from the division of the infra-orbitar nerve in face-ache.

(5) I, at least, have seen it in several cases.

(6) I hare observed this.

$\left(6^{*}\right)$ [Sometimes abscess of the antrum causes absorption of the front of the superior maxillary bone, producing a tumour on the face, v. T. Bell Anatomy, Physiology, and Diseases of the Teeth. T.]

(7) For instance, No. 3236 and 3237, of Bresl. Mus. - A good engraving is given in Sandifort Mus. Anat. No. 2, tab. 30-33. [Some examples also in the Mus. at St. Thomas's Hospital. T.]

(8) Especially on the palate, in syphilitic ozaena, on the edges of the alveolar cavities, in dental fistulas ; more rarely from noma, of which, however, I have seen two instances in the Pathological Museum at Vienna. v. Sandifort Mus. Anat. Vol. III. p. 266, No. 855.--A case of carious destruction of the upper jaw, with restoration, is given by Krimer in $v$. Graefe and $v$. Walther's Journ. f. Chir. 1827, Vol. X. Part IV. p. 606.-Several instances from caries, in Bresl. Mus. No. 3252, 3253, 3256, 3258. - Carious destruction of the upper mandible of a lark, is described by Rathke, in Meckel's Archiv f. die Pliysiol. Vol. VII. p. 497.-A good engraving of caries is given in Sandifort's Mus. Anat. Vol. II. tab. 28 , fig. 1 and 2 .

(9) Hardly more rare in man than in animals, and especially in oxen, v. No. $316 \mathrm{~S}$ in Bresl. Mus.; also in horses and swine, of which $I$ have seen an instance in the Anatom. Mus. at Utrecht.

(10) Böttcher Abhandlung von den Krankheiten der Knochen, u.s.w. Vol. III. p. 170.-Büttner in Nov. Act. Acad. Nat. Cur. Vol. V. p. 71 . Vol. VI. p. 27.-Weber in Museum der Heilkunde, Vol. II. p. 192. - Mosque Chirurgische Novellen, u.s. w. No. 7.-Vialet in Bulletin de l'Ecole de Médec. etc. Ann. XIII. p. 27. - Breschet in Bulletin de la Fac. de Médec. de Paris, 1815, p. 332.- Howship, Pract. Observat. in Surgery and morbid Anatomy, 1816.Rust in his Magazin. Vol. I. Part I. p. 71, tab. 2.-Fox, Natural History and Diseases of the human Teeth. Lond. 1814. - My Verzeichniss, Stc. No. 3254 and 3255.-Dict. des Sc. médicales, Vol. XXXV. p. 25, tab. 1 and 2. - [T. Bell, Anatomy, Physiology, and Diseases of the Teeth, p. 173. T.] - In a bullock, v. Rudolphi Bemerkungen auf einer Reise, u.s. w. Vol I. p. 75. - On the skull of a hippopotamus, in Bresl. Mus., there is one large cellular exostosis on the upper maxillary, lachrymal, and zygomatic bones; a second smaller on the intermaxillary bones, and a third, on the zygomatic process of the temporal bone. [There is in the Mus. at St. Thomas's Hospital, a remarkably fine specimen of exostosis on the right side of the upper jaw, as large as an orange, on the front of the face, filling up the maxillary and part of the sphenoidal sinus, the latter of which is much enlarged by its pressure; the tumour extends into the riglit orbit, backward into the temporal pit, and including the right alveolar process posterior to the second bicuspid tooth, and the right half of the bony palate.--In another instance, an exostosis, as large as a hen's egg, projects from the infra orbitar pit on each side, they fill up the maxillary sinuses and nostrils, and protrude backwards into the temporal pits, and upwards into the orbits. In the left orbit there is also a second exostosis, as large as a walnut, which arises from the orbitar plate of the frontal bone. In consequence of the necessary diminution of the cavity of the orbit, the eye-ball had been thrust upwards and outwards, and by its pressure, expanded and thinned the superciliary ridge and outer angular process of the frontal bone very considerably. The subject of the latter case was a fishwoman, who dropped in a fit of apoplexy at the hospital gate. T.]

(11) Becker præs. Siebold D. de insolito maxillæ superioris tumore aliisque ejusdem morbis. Herbipol. 1776.-Howship, pl. 1, fig. 3.-Klein in Rhein. Jahrb. von Harless, Vol. V. Part II. p. 42, with engravings.-Terwey in Rust's Magazin, Vol. III. Part II. p. 221, tab. 2. - Becker in Rust, Vol. XXI. Part II. p. 218. - Pech Ostcosarcoma ejusque speciei insignis descriptio, etc. Wirccb. 1819, with three engravings. - Giorgi in Omedeis Annali universali di Medicina. Jan. 1827.-My Selt. Beob. I1. p. 6, No. 2; p. 11, No. 10.-Verzeichniss, No. $3164,3165,2134$. - In the Anat. Mus. at Freyburgh, I saw on the upper jaw of a child, a large sarcomatous swelling, as big as its head. v. on the nose. 
(12) Also in animals. - I saw, for instance, in the Zoolog. Mus. at Lund, a walrus, with a large necrosis and exfoliation of the alveolar cavity of one tusk.

(13) At Paris and Alfort, I saw the upper mandible of a hen and of a jay, extremely long, curved, and cleft at the point. In rapacious birds and parrots, which are confined, it easily becomes monstrously long.- Schiöter found the upper mandible very much enlarged, elongated, and warty, in one partridge; and in another, the upper mandible converted into a large horn-like knob, curved upwards, besides having horny warts on it. v. Archiv f. Zoologie and Zootomie, Vol. V. No. 7.

(14) v. Bemerkungen über einen monströsen Canarienvogl, u.s.w. 4to. Hamb. 1780, with engravings. - In the Zool. Mus. at Paris, I saw two large ones on a partridge. - A sparrow witl a spiral horn on the bill, v. Sandifort Mus. Anat. Vol. III. p. 372 , No. 511.

\section{$\S 131$.}

The small bones of the face connected with the upper jaw participate with it in its variations from the normal form. Thus we find, for instance, the PALATE BONES, in wolf'smouth, not connected with each other, and more or less deficient in reference to their palatine portion. In rare cases the palate bones do not touch if the palatine point be formed of the elongated upper jaw bones. In congenital closure of the hinder opening of the nostrils, the palatine bones are very much deformed. They are frequently destroyed by polyps of the nose and throat as well as by syphilitic ulcers. In monsters, with deficient formation of the face, the MALAR BONE is sometimes consolidated, ${ }^{1}$ sometimes also it has been found divided into two halves by an irregular suture. ${ }^{2}$ The NASAL BONES are sometimes, as a congenital formation, entirely wanting, ${ }^{3}$ and are then replaced by the enlarged nasal processes of the upper jaw bones. ${ }^{4}$ In many cases there is originally but one nasal bone, ${ }^{5}$ in other cases there are two, remarkably small, unequal, oblique, arched, consolidated together, ${ }^{6}$ divided into two or more pieces, \&c. ; in horses, we observe them not rarely pressed in from pressure of the cavesson, even absorbed, so that the openings are merely closed with skin. ${ }^{7} \quad$ Frequently are they more or less destroyed by syphilitic caries, polypous and scrofulous tumours in the nostrils, and more rarely in animals, by glanders and farcy. ${ }^{8}$ The LACHRYMaL BONES are sometimes entirely deficient, and their place is then supplied by the nasal process of the upper jaw-bone. ${ }^{9}$ They are frequently very small, or lie so far backwards, as not to assist in forming the lachrymal canal, ${ }^{10}$ the groove in them for which presents also many differences. In diseases of the lachrymal sac, in nasal polyps, \&c. the lachrymal bones are easily destroyed.

(1) Viz. in No. 3045 and 8226 in Bresl. Mus.

(2) Sandifort Observ. anat. pathol. L. III. p. 9, fig. 7. - v. Sömmerring Lehre von den Knochen und Knoryeln. 2d edit. p. 218. 
(3) Roloff in Mém. de l'Academie des Sc. de Berlin, 1761.-Marrigues in Mém. de Mathén. pres. a l'Acad. des Sc. IV.

(4) Sandifort, L. III. Cap. X. p. 130. L. IV. Cap. X. p. 136.-Mus. anat. Vol. I. p. 167, No. 101.-Köhler Beschreibung der phys. und pathol. Präparate. No. 417 , p. 124 ; No. 540 , p. 140 . - I have seen an instance of it on the skull of a man from Nootka Sound, in Prof. Mayer's Collection at Bonn. In two instances, No. 7080 and 8039, of Bresl. Mus. the left nasal bone does not reach the frontal, but its place is supplied by the broad nasal process of the upper maxillary bone. In cyclopic monsters, which have a proboscis instead of a nose, the upper maxillary bones often lie close to each other, and the distorted nasal bones at the root of the trunk, over the orbits.

(5) As a little loose roundish bony germ, in No. 3047 and 8226, in Bresl. Mus.

(6) Entirely or partially, not unfrequently both; for instance, No.67, 70, 100, $115,144,151,164,169,170,188,195,215,237,689,3175,3251,3360,7068$, 7075 and 7130 , Bresl. Mus.

(7) In a dog, No. 3245 , in same.

(8) Licht D. de præcipuis viarum lacrymalium morbis. fig. 1. Argentor. 1776. - Sandifort Obs. anat. pathol. L. III. C. X. p. 128. L. IV. C. X. p. 137.-Meckel Handb. d. pathol. Anat. Vol. I. p. 34.5.-On a skull, No. 171, in Bresl. Mus. the left lachrymal bone is entirely wanting, and the right so small, that it does not contribute to the formation of the lachrymal pit.

(9) Metzger Curat. chirurg. quæ ad fistulam lacrymal. hucusque fuere adhibita, historia critica. p. 66 . Monast. 1772.

(10) On No. 8062, the crista longitudinalis is very strongly developed.

\section{$\S 132$.}

The LOWER JAw is not unfrequently, as a congenital formation, entirely deficient, even although the upper jaw exists. ${ }^{1}$ In other similar cases there is only found a shapeless rudiment, ${ }^{2}$ this sometimes lies on the neck without any connexion to the skull. ${ }^{3}$ Oftentimes is the lower jaw normally formed, but varies in reference to its size and figure; thus, for instance, we find it too small, and indeed too short as well as too small ; ${ }^{4}$ on the other hand also unnaturally large, and this is sometimes in proportion to a short upper jaw, sometimes in reference to its own proportions only ; finally, it is often bent, and indeed particularly upwards, when the upper jaw is monstrously small, or in deformity of the whole face to one and the same side with the upper jaw, or to the opposite side to that with which it is then curved. In rare cases we notice also irregular divisions of the lower jaw, ${ }^{6}$ in which, as is well known, there occurs one or two little bony germs in the suture between the two halves of the lower jaw-bone. ${ }^{7}$ The form of the lower jaw of man and animals, is often very remarkably changed by the loss of some or all of the teeth; the condyle varies very much in reference to its size, direction, and arching; not unfrequently is its cartilaginous covering destroyed and rubbed off $;{ }^{8}$ we find it also covered with gouty tophus $;^{9}$ the internal mental spine is in rare cases unusually long ${ }^{10}$ in the skull of a Botocudan there was found a deep pit before and above the chin, in consequence of the pressure of the wood worn in the lip, ${ }^{11} \& \mathrm{c}$. 
Vices of CONNExion also occur in the lower jaw, as we find it dislocated, completely or incompletely on one or both sides; but even in man before birth, and in animals in which the two halves of the lower jaw remain usually separate, we observe their uncommonly late consolidation with each other, ${ }^{12}$ with the temporal bones, ${ }^{13}$ and even with the edge of the upper jawbone. ${ }^{14}$ The continuity of this bone is easily broken, on account of its peculiar form, by external violence, especially by drawing teeth, indeed even by violent biting. ${ }^{15}$ Among the diseases which frequently attack the lower jaw, are especially to be mentioned, caries, ${ }^{16}$ and necrosis, to which easily follow the reproduction of the lost parts; further, loosening, spina ventosa,${ }^{17}$ bony tumours, ${ }^{18}$ and especially osteosarcom. ${ }^{19}$

(1) Schubarlh, Comment. de maxillæ inferioris monstrosa parvitate et defectu, Francof. ad Viadr. 4to. 1819, with two engravings, describes several instances in man and animals. - Kerkringius Opera omnia anatomica, Obs. 60, p. 122. L. B. 1717. - Themelius Comm. med. qua nutritioue foetus, etc. Lips, 1751, and in Fasc. Diss. anat. medic. recus. Amstel. 1764, p. 125, in a sheep. - Halleri Opusc. pathol. Venet. 1775, Obs. 58, p. 145, in a sheep.-Speer D. de Cyclopia. Halæ, 1819.-My Selt. Beob. II. p. 168.-G. Jäger in Meckel's Archiv f. Anat. und Physiol. 1826, p. 64, in a foetus of cervus axis and in a lamb.-Ib. 1828, No. 1, p. 71 , in a lamb. - Ullersperger Pathol. anat. Beschreibung zweier Missgeburten. 8vo. Würzburg, 1822, p. 39, fig. 2.-Weber Ueber die Verschmelzung der beiden Gehörorgane in d. Zeitschrift f. Physiologie von Tiedemann and G. R. and L. C. Treviranus, Vol. II. Part II. p. 309, in a calf. - My Verzeichniss, \&c. No. 2953-2956, 3013, 3047 ; also No.8022, 8069, 8226, of Bresl. Mus., all three from sheep.

(2) Meckel Handb. der pathol. Anatomie, Vol. I. p. 523, in a calf.-Schubarth, Jager, in a lamb.

(3) My Selt. Beob. I. No. 12, p. 38.

(4) I have seen several men and animals with this vice--Also, in the Anat. Mus. of the University at Vienna, a child, with hare-lip, very small eyes, and very short lower jaw.- In the Anat. Mus. at Heidellerg, a dog, with a short lower jaw, and a monstrous short foot.-A child, on account of the shortness of the lower jaw, could not suck. v. Moschner Couspectus partuum in lechodochio Pragensi, etc. Pragæe, 1826, p. 109.-I saw it shorter than the tongue, in a hen in the Zootom. Cabin. at Paris.-[In the Mus. Roy. Coll. Surg. No. 304, a preternaturally short lower jaw, in a young red deer (cervus dama), in consequence of which, the animal was starved, from not being able to press the udder in itś attemipts to suck.-A short account is given by Lord Egremont, who presented the animal to the College, in which it is mentioned, that this malformation was always found in the white varieties of his red cleer, and that they never lived more than a day or two, for the reason assigned above. T.]

(5) By the French, called Menton de Galoche, in the Milanese Geppa, in England Underhung; is often connected with stammering and weakness of intellect. v. Palletta Exercit. pathol. I. p. 142. - Catalan Mémoire Rapport, et Obs. sur l'appareil propre à corriger la difformité, qui consiste dans le chevauchement de la machoire inférieure en avant de la supérieure, difformité vulgairement nommée Menton de Galoche. 8vo. Paris, 1826, with drawings.--Köhler, Beschreibung der anat. Präparate, u.s.w. No. 171 , p. 50, mentions a human lower jaw, three inches broad. - Some remarkably large and heavy skulls, I saw in the Anat. Mus. at Florence and Bologna. $-\Lambda$ very long hinder jaw in a mule at Alfort.-In birds in confinement which cannot wear out the beak, viz. the parrot, I have often secn the horny covering of the lower mandible uncommonly long; in a 
lark, with injured upper mandible, the lower grew uncommonly. v. Rathke in Meckel's D. Archiv f. d. Physolog. Vol. VII. p. 497.

(6) Eyssonius, De ossibus infantis, p. 49, observed a division of the lateral parts of the horizontal branch; - - divided in a fowl, v. note 4.-The whole length divided in a full grown sparrow, in the Anat. Mus. of the Surgical Academy at Dresden.

( ) Ruysch Thesaur. anat. V. No. 4, p. 45. - Meckel Anat. phys. Beobachtungen und Untersuchungen, p. 21. Halle, 1822.- His Deutsches Archiv f. die Physiol. Vol. VII. p. 107. - I found a similar intermediate bone in No. 3012, and some of the same in No. 8031 in Bresl. Mus.

(8) Leidenfrost in Wesener D. de susurru aurium. 4to. Duisb.1785.

(9) My Verseichniss, \&c. No. 3270, 3271.

(10) In No. 788 , Bresl. Mus., is the spina mentalis interna, almost half an inch long, thick, and cylindrical.-Compare Howship.

(11) In the Anat. Mus, at the university of Vienna; I did not, however, see it in other Botocudan skulls.

(12) Kerkring Spicil. anat. p. 55, tab. 8.-Ruysch Catalogus Musei. p. 187.Morgagni De sed. et caus. morbor. Epist. XLVIII. Art. 50.-Meckel Anat. phys. Beobacht. und Unters. p. 69.-My Selt. Beob. I. p. 6, partially united; in dogs I have found the lower jaw sometimes united.

(13) Eustarhius De dentibus C. XXVIII. p. 92.-Columbus De re anatomica. Lib. XV. p. 484.-Schenk Observat. medic. Basil. 1584. Obs. 405, p. 441. - O'Connor De stupendo ossium coalitu, p. 4, Oxon. 1695.-Palfyn Beschryving der Beenderen. p. 218. - Banks and Solander saw such a skull at Madeira. v. Hawkesworth, An account of Voyages, \&c. Vol. III.-Sandifort Exerc. academ. Vol. II. C. 5, tab. 5 and 6.-Observat. anat. pathol. Lib. I. C. 7, p. 102.Mus. anat. Vol. I. p. 149; Vol. II. tab. 16, p. 384, 603; Vol. III. p. 234, No. 615,616 . v. a Loder, Index.-Köhler, No. 1, p. 3.-Rénard of Mayence possessed such a skull, which has been described by Gulette.-Jam. Snell, in Medic. Repository, Feb. 1825, new series, Vol. III. in a child; one case in Bresl. Mus. No 3262.-Howship._-Tartra in Journ. de Médec. contin. Vol. XI. p. 182.-Rudtorffer Anhang zur Abhandl. über die Operation der Brïche. No. 9. - Holscher in his translation of Brodie's Diseases of joints, p. 334, note.

(14) Rust in his Magazin f. d. ges. Heilk. Vol. I. Part II. p. 226. In a carp. - Hamberger De cyprino monstroso rostrato. Jenæ, 1748.

(15) In a rabid horse in the Museun at Alfort; the possibility of fracture at the symphysis is doubtful, according to Boyer, Delpech, and others; it has, however, been once seen, v. Challet in Journ. gén. de Médecine. Vol. LXVI. No. 266, Jan. 1819, p. 80. - Two instances of fracture in Bresl. Mus. No. 3275 and $3276 .-\mathrm{A}$ false joint after fracture, v. Horeau in Journ. de Médec. contin. Vol. X. p. 195.-Dubois-Faucon in Journ. gén. de Médec. Vol. XXXIII. p. 86.

(16) In man and animals it is very common from cliseases of the teeth, scrofulous and carsinomatous destruction of the neighbouring glands, of the lower lip, \&c. v. No. 3264, 3265, 3268, 3274, of Bresl. Mus.-In a child fatal liemorrhage occurred from caries of the lower jaw, and ulceration of the arteria maxillaris inferior. Edinb. Med. and Surg. Journ. Jan. 1824; v. also Fenner Ueber caries des unterkiefers in the Bibliothek for Laeger, \&c. Kjöbenhavn, Vol. IV. 1813. - Sandifort Mus. Anat. II. tab. 23, fig. 2 ; tab. 28, fig. 3-5, gives some good plates; he also describes carics of the lower jaw, in consequence of cancer of the lip, v. Vol. III. p. 24.6, No. 714-717, and in consequence of noma, p. 266, No. 852 and 853 ; there is also a remarkable case of caries on account of development of hair in the lower jaw, p. 280, No. 933.-Caries in the lower jaw of a dog. v. Sandlifort, 11 I. p. 185, No. 242.

(17) Particularly common in horses; I have seen several examples of it in the collections of different veterinary schools, viz. Alfort, Berlin, Munich; one cise in Bresl. Mus. No. 3166; a similar one from an ox, No. 3167. v. Rudolphi Bemerliungen auf einer Reise, II. S. w. I. 1) 75.-Greve Lirfahr. und Beobacht. iiber die. Krankheitender llatsthiere. II. 1). 3.-Of a pig at Utrecht.-Bleuland resp. Reimam Spicileg. observat. anatom. de Hyäna. 1. 12. 4to. Berol. 1811.In a marmot in v. Sömmerring's Museum. 
(18) Mosque Chirurgische Novellen, u. s. w. No. 10.-My Verzeichniss, \&c. No. 3266, 3269.- - In the veterinary school at Stockholm, I saw an exostosis, as big as a walnut, with a neck, from a horse.

(19) Crennoux in Mém. de l'Académ. de chir. Vol. V. Mém. p. 350.-Bordenave, ib. p. 338.-Morelot, ib. p. 352.-Quittenbaum D. de memorabili quodam maxillæ inferioris fungo scrofuloso. fol. Haunov. 1818, with two engravings. Crowfoot in Edinburgh Med and Surg. Journ. 1825, Oct.-Cusack and Crampton An account of such tumours removed from parts of the lower jaw in several cases; v. Dublin Hospital Reports and Communications in Medicine and Surgery, Vol. IV. 1827.-Oudet in Archives général. de Médec. Jan. 1826, three instances by Mott, and one communicated by Clellan, $v$. d. Busch in Langenbeck's N. Bibliotl. f. d. Chir. und Ophthalm, 1827, Vol. IV. Part III. p. 417, ib. p. 532, with the editor's additions.-G. Sandifort Mus. anat. Vol. III. p. 285, No. 971, p. 348, No. 300 .

\section{$\S 133$.}

The TEETH ${ }^{1}$ are subject to very many irregular formations and diseases, as they are not merely affected alone, but participate also more or less readily in the diseases affecting the organization of the face. ${ }^{2}$ The number of the teeth does not unfrequently vary from that which is normal, inasmuch as in man and in animals, sometimes several, ${ }^{3}$ at other times all $^{4}$ are deficient, as a vice of formation, sometimes also on the contrary there are supernumerary ${ }^{5}$ teeth, two and even three rows ${ }^{6}$ the additional number depends most commonly on the continuance of the milk teeth. ${ }^{7}$ We observe many irregularities with respect to the PERIOD OF CUTTING AND CHANGING THE TEETH; in weakly and especially rickety children, the teeth are sometimes either all or some of them cut very late, ${ }^{8}$ or in irregular order, ${ }^{9}$ and even their change is very much retarded; in rare cases we observe, even in old people, several teeth still to be produced $;^{10}$ on the contrary, we notice the too great activity in reference to the formation of the teeth, as they may have been cut before birth, ${ }^{11}$ or very soon after, ${ }^{12}$ may be changed too early and too frequently $;^{13}$ also in very rare cases, when parts of the jaw have been destroyed by caries, necrosis, \&c. new teeth are produced in the newly formed bone $;^{14}$ so also in a false direction of the formative power, the teeth present themselves not unfrequently in other places than the jaws, ${ }^{14 *}$ indeed even in encysted tumours. ${ }^{15}$ The teeth frequently vary from what is natural in reference to SIZE AND FORM; we thus find not merely the supernumerary, but even some other or all the teeth remarkably undeveloped and small, in consequence of early pressure, rickets, \&c.; the normal teeth are also distinctly diminished in consequence of the wearing away ${ }^{16}$ and rubbing down ${ }^{17}$ of their crowns. Just as frequent is the original irregular size of certain teeth, in consequence of which deformity, displacement and retarded cutting of other teeth is easily produced, as well as the later increase of such teeth as 
have not been retarded in their growth by counter-pressure and rubbing down; such teeth often attain an uncommon length, often curve up and penetrate into the neighbouring parts, for instance, into the palate, nose, orbit, and even into the brain. ${ }^{18}$ Often also without any increase, the form of the teeth varies in numerous ways, in which case the crown is deformed, ${ }^{19}$ the number, length, direction, and curving of the roots varies much, ${ }^{20}$ the whole teeth are curved, ${ }^{21}$ they present congenital tumours covered with ename! ${ }^{22}$ (dentes proliferi), and the surface of the teeth is uneven, owing to congenital unequal deposition of the enamel. ${ }^{23}$ We very frequently observe in rickety persons, and such as have small jaws, the Position and DIRECTION of the teeth irregular $;^{24}$ they stand obliquely, ${ }^{25}$ are more or less turned round on their axis, ${ }^{26}$ horizontal, ${ }^{27}$ and even completely turned round ${ }^{28}$ in all these cases the teeth remain frequently for a long time or throughout life hidden in the jaws, ${ }^{29}$ they stand unevenly in the edge of the jaw, and are huddled together, and in irregular rows, ${ }^{30}$ or they protrude inwards and outwards on the alveolar edges of the jaws, ${ }^{31}$ in the upper maxillary sinus, ${ }^{32}$ in the nostrils ${ }^{33}$ externally on the upper jaw ${ }^{34}$ on the coronoid process ${ }^{35}$ on the outside, ${ }^{36}$ and on the $\operatorname{chin}^{37}$ of the lower jaw, \&c. Not fewer are the variations respecting the Connexion of the teeth; thus, in rare cases, we find some of the teeth sticking ${ }^{38}$ only in the gums, and without roots or alveolar cavities, or in monsters with deficient formation of the jaws or duplicity of the mouth, some teeth entirely loose or covered by a thin membrane and hanging to the skinny parts of the opening of the mouth $;^{39}$ many teeth have uncommonly small roots and alveoli, and easily fall out; ${ }^{40}$ this we especially see in the teeth shed by old persons. But perfectly formed teeth are sometimes also, some or all of them, lost and shed unusually early, ${ }^{41}$ partly owing to imperfect nourishment, ${ }^{42}$ and rapid absorption of their roots ${ }^{43}$ and alveoli, partly in consequence of a morbid state of the jaw, whereby their connexion with each other is dissolved. ${ }^{44}$ The opposite state, viz. the too close connexion of the tecth with the jaws arises partly from swelling of their roots, but often from their consolidation with the alveoli; we also find in not very rare cases, two ${ }^{43}$ or even more teeth, ${ }^{46}$ more or less consolidated at their crowns, roots, or completely grown together throughout. ${ }^{46^{*}}$ The colour of the teeth also presents many vices; to these belong the different shades of the white colour and lustre which is produced by disease and disposition to it; thus we find the tceth bluish white in the disposition to consumption and rickets; like transparent horn in the hereditary disposition to 
herpes ${ }^{47}$ \&c. Meat, drink, medicines, and the like, often colour the teeth more or less brownish and blackish $;{ }^{48}$ diseased teeth usually become discoloured, yellowish, greyish, even black, brown, as in caries. Very frequently the discolouration of the teeth arises from TARTAR, commonly so called, that is, a mass composed of phosphate of lime and a small quantity of animal matter, which envelopes the teeth more or less completely, attaches itself more or less firmly, assumes a greyish, greenish, brownish, blackish, and even metallic shining colour, ${ }^{49}$ and is often deposited in great quantity on the teeth..$^{50}$ As to vices of CONSISTENCE, we find the teeth naturally either too soft and friable, or they become morbidly so; the latter vice occurs commonly in a greater or less degree on the roots, ${ }^{51}$ and internally carious teeth, but seldom it is found in the whole tooth $;^{52}$ in other cases the substance of the tooth is too hard, and brittle like glass, and therefore in consequence of sudden changes of cold and heat, as well as in biting, \&c. fissures, clefts, and actual fractures, easily occur, which can only again be united at the lower part of the tooth..$^{53}$ Not less are the teeth subject to many VICES OF TEXTURE, notwithstanding the hardness and similarity of their substance; to these belong inflammation ${ }^{54}$ and its consequences, as sofTENING and absorption $^{55}$ of the fangs, the swelling, ${ }^{56}$ which rarely attacks the whole tooth, but usually only the roots, Exostosis, ${ }^{57}$ and lastly, especially CARIEs, ${ }^{58}$ which is so usual in man, and also in animals, viz. horses, cattle, house-dogs, \&c. Lastly, in very rare instances we meet with ExTRAneous Bodies in the teeth, for instance, HYDATIDS in the cavity of a carious tooth, ${ }^{59}$ worms commonly so called, that is, the larvæ of insects and infusory animals,$^{60}$ and in the tusks of elephants, especially bullets, ${ }^{61}$ and in one instance the point of a spear ${ }_{5}^{62}$ both of which had perforated the tooth in its young and soft state.

(1) v. de Plouquet Repertor. Art. Dens. and Dict. des Sc. médicales, Vol. VIII. Art. Dent.-Fr. Hoffmann D. de dentibus eorumque morbis. 4to Halæ, 1698, in Operib. VI._Pfaff Abhandl. von den Zähnen und deren Krankheiten, Berlin, 1756.-Berdmore, A Treatise on the disorders and deformities of the Teeth and Gums. Lond. 1770.-Plenk De morbis dentium ac gingivarum. Vindob. 1778. - Jackson D. de physiologia et pathologia dentium. Edinb. 1778. Jourdan Traité des maladies et des operations chirurgicales de la bouche. 2 Vols. Paris, 1778.-J. Hunter, The natural history of the Teeth, their structure and various diseases. 4to. London, 1771.-Walkey, On the diseases of the Teeth, \&c. 1793.-Bring Observationes in hodiernam de dentibus præcipue doctrinam. Lundæ, 1793.-Hirsch Prakt. Bemerkungen über die Zähne und einige Krankheiten derselben. Jena, 1796.-Ettmüller Medic. chir. Abhandl. ïb. die Krankh. der Zähne, u. s. w. Leipz. 1798.-Paldamus D. de dentium morbis. 4to. Halæ, 1799. - Hirschfeld Prakt. Bemerkungen über die Zähne, u. s. w. Gotha, 1801.Skinner, A treatise on the human Teeth, concisely explaining their structure and cause of disease and decay. New York, 1801.-Fox, the history and treatment 
of the diseases of the Teeth, Gums, \&c. Lond. 1806; and the natural history and diseases of the human Teeth. Lond. 1814.-Gariot Traité des maladies de la bouche, etc. Paris, 1805. - Jourdan et Maggiolo Manuel de l'art du Dentiste, ete. Nancy, 1807.-Laforgue Théorie et pratique de l'art du dentiste, etc. $2 \mathrm{~d}$ edit. Paris, 1810.-Duval, many single treatises in French Medical Annuals, and on the diseases of the teeth in animals, in Bulletin de l'école de Médec. et de la Société de Paris, 1811, p. 118.-Gallette Anat. phys. und chir. Beobachtungen über die Krankheiten der Zähne. Mainz, 1813.--König Ueber die Zü̈hne der Thiere und die Krankheiten derselben, u.s.w. Wien, 1820._Ringelmann Der Organismus des Mundes, besonders der Zaline, deren Krankheiten, u.s.w. Nürnberg, 1823.-On the variations of the teeth, v. Sömmerring vom Baue des menschl. Körpers. 2d edit. Vol. I. p. 268, $\$ 236$, and Rudolphi resp. Tesmer D. s. Observat. osteologicas. 4to. Berol. 1812, with two engravings. - [K. Blake, An Essay on the structure and formation of the teeth in man, and various animals. Svo. Dublin, 1801.-T. Bell, On the Anatomy, Physiology, and Diseases of the Teeth. 8vo. with plates. London, 1829. T.]

(2) Rickets, scrofula, scurvy, syphilis, herpes, and gout operate very prejudicially on the development and state of the teeth.

(3) Pretty frequently are two of the upper incisives wanting; I have seen this in two living persons; and in No. 3301, 8044, and 804.5 of the Bresl. Mus. the wise teeth are frequently deficient; once the incisive and cuspid, v. Misc. Nat. Cur. Dec. II. Ann. VI. Obs. 122 ; an incisive tooth in a horse, v. Rudolphi Anat. Physiol. Abhandl. Berlin, 1802, p. 148; several back teeth in a dog, Allg. Hist. der Natur. Vol. VII. Part II.p. 235, No. 1396 ; in sheep sometimes one or other of the back teeth is wanting; so also in stallions and geldings, and in one instance even the tushes. [In the skull of a New Hollander, No. 100 Cat. Mus. Roy. Coll. Surg. the second temporary grinders were formed as permanent grinders, and therefore there are only two bicuspids.-Two skulls from Van Dieman's Land, No. 97 and 98, Cat. Mus. Roy. Coll. Surg. have but three lower incisives, which are so close as to preclude the probability of the deficient tooth having been previously extracted. It is also further remarkable that in both the sympliysis divicles the middle alveolar cavity. T.]

(4) Borelli Hist. et Observ. med. phys. rar. Cent. II. Obs. 41. - Danz in Siark's Archiv f. d. Geburtshïlfe, Vol. IV. p. 684, in two brothers.

(5) G. Thomson, Observations on supernumerary teeth, in Edinb. Med. Lissays. Vol. V. Part I. p. 222.-Dubois-Fíncon in Jourı. gén de Méd. de Chir. et de Pharm. par Sédillot, Mai, Vol. XXXII. p. 73.-Eph. Nat. Cur. Cent. I. and II. Obs. 107.-Five incisive teeth, Plouquet D. ætates human. earumque jura, p. 8, Tubing. 1778. - Two instances in the Berlin Museum. v. Tesmer Præs. Rudolphi D. Observat. osteol. p. 6.-Two instances are mentioned by Sömmerring, p. 269 ; I have also recently seen it in a girl of twelve years old, and on the skull of an adult; six incisive teeth above. v. G. Sandifort Mus. Anat. Vol. III. p. 288, No.983.-[Five incisive teeth in the lower jaw. v. T. Bell, Anatomy, Physiology, and Diseases of the 'Tecth, p. 102. 8vo. London, 1829. T.] - Supernumerary teeth are mentioned in Courtois Grundl. u. auf Erfalhrung gestiitzte Untersuchung der Beschaffenheit und Krankheiten der Zähne, a. d. Franz. p. 163. Gotha, 1778. - It is interesting that the negro has mostly six back teeth. v. Gavard Osteologie, p. 354.-Sömmerring.-Concerning the difference in bodily form of the negro from the European, $\S 30$, (now at Vienna;) I also lately saw a second skull in the Museum of v. Sommerring.'The supernumerary teeth are sometimes imperfect and small. v. Albinus Annot. acad. I. p. 52 and 53, tab. 4, fig. 2 and 3.-Cerulti Beschreibung der pathologischen Präparate, u. s. w. No. 585.-Rudolphi, 1). 7, tab. 1, fig. 13.-In horses they are not unfrequently in the palate, and called wolf's-teeth, dentes lupini.Rudolphi $\Lambda$ nat. pliys. $\Lambda$ bhandl. 1.14 .7 , found them also in the walrus; in mares the tushes sometimes exist; at Alfort I saw the front jaw of a horse with nine cutting teeth; Rudolphi found five of these in the simia paniscus. v. Anat. phys. A hhandl. p. 145. - In the narwlial two tusks. v. Blumenbech Handbuch der naturgeschichte, on the monodon narwhal.-Albers Icones ad illust. A nat. comp. Vol. I. p. 9, where are given nine plates of such skull, and also a tenth from a 
similar skull, which he gives from \%. Froreip's Sammlung ; I saw a skull of this kind in $J$. Brookes's Museum, London; and also in the Veterinary School and Museum of natural history at Copenhagen.

(6) Several instances in Haller Elem. phys. Vol. VI. p. 29.-Columbus De re anatomica. L. XV.-Courtois. - In my youth, I knew a young man who had two rows of teeth in botll jaws.

(7) In a dog, the cuspid teeth. v. No. 3311 of the Verzeich. des Bresl. Mus. In an adult, I found a molar of the first set still remaining.-Here also belongs the milk tooth of a man of thirty-seven years of age, described by Bloch Med. Bemerk. p. 19.-Cerutti Bescreib. der pathol. Präparate, No. 567.

(8) I have known several instances of clildren, from two to three years of age, who had not cut a tooth. In one case they were first cut at thirteen years, v. Misc. Nat. Cur. Dec. III. Ann. VI. and VII. Obs. 183.-A very rickety girl, nine years old, at Neurode, had but one tooth in both jaws. - Three instances of want of one cuspid tooth, at the seventl year, are related in Wichmann Ideen zur Diagnostik, p. 82. -.. A rickety child, of ten years of age, in the Bresl. Mus. had only the first eleven teeth, viz. seven incisive and four back teeth.

(9) For instance, the back earlier than the front teeth, v. Fischer's Beiträge zur Arzneiwissenchaft, 1776. Part I. p. 80.

(10) Several instances in Reuss Repertor. Comment. Vol. X. p. 54. - Sera dentium eruptio.-Doubois-Faucon Sur les dents tardives in Sédillot's Rec. périod. de la Soc. de Médec. de Paris, Vol. XIII. May, p. 73, such teeth have always small sockets. - Ysabeau in Journ. de Médec. Vol. XXV. 1766, gives instances in persons of eighty, ninety-two, and even one hundred and twenty years of age.--v. Sömmerring, p. 270.-Pentzius in Rust's Magazin f. d. ges. Heilk. Vol. XXII. Part III. p. 596 , in a man of seventy-five years of age--Deficiency of room, or irregular position, is often the cause of this. In many cases also there is a second change.

(11) Haller Elem. Pliysiol. Vol. VI. p. 19. - Girardi Oratio de re anatom. p. 27, note c. 8vo. Parmæ, 1781. - Baudelocque Entbindungskunst. 2d edit. Vol. I. p. 222.-v. Sömmerring, p. 269. - Louis XIV. was known to have been born with teeth. v. de Plouquet Repertor. Dentes præcoces.

(12) A boy with premature puberty, had, in the first year, nine teeth in the upper, but none in the lower jaw. - South, in Lond. Med. Chir. Trans. 1822. Vol. XII. p. 1.

(13) Gehler Progr. de dentitione tertia. 4to. Lips. 1786.-v. Haller, Vol. VIII. p. 22. - Albinus Annot. Acad. L. I. tab. 4, fig.3.-Hunter, p.85.-Gavard Osteologie, p. 354.-Med. and Phil. Comment. Vol. III. and VIII.-Simmons, in Med. Obs. and Inq. Vol. III. p. 118. - Dachs in Verhandelingen te Haarlem, Vol. XVI. D. II. p. 327.-Hinze Kleine Aufsätze aus dem Gebiete der Medicin, Chirurgie und Geburtshülfe. Breslau, 1826. - v. Froriep's Notizen, Vol. VIII. No. IX. p. 138. - The Armenian, Saas Oglou, had two new back teeth at the age of a hundred, a third in his hundred and twenty-first year.

(14) Fardeau v. Gerson and Julius Magaz. f. d. ausländ Litt. Vol. II. p. 486. Harder, in Petersb. verm. Abhandl. a. d. Geb. d. Heilk. 1S23. Vol. II. p. 207.Krimer in v. G;äfe and $v$. Walther's Journ. f. Chirurg. 1827. Vol. X. Part IV. p. 606 .

(14*) [In Mus. Roy. Coll. Surg., No. 269, a lamb, in which two well formed incisive teeth project between the angle of the jaw and the external auditory passage on one side of the neck, and on the other side a single incisive tooth only. T.]

(15) Mecicel Ueber regelwidrige Haar und Zahnbildung in his Archiv. f. d. Physiol. Vol. I. Part IV. p. 519.-Compare the several parts below.

(16) Not merely may the roots of the teeth become atroplic, but even the crowns may waste.--I saw this very distinctly in the Anat. Mus. at Lund, in the incisive teeth of a very old horse, which had become exceedingly small. $v$. Duval Mémoirs sur l'atrophie des dents. v. Bulletin de la Facult. de Médec, etc. p. 7.1812.

(17) The crown is sometimes almost worn down to the neck, without the cavity of the tooth being -opened, as a peculiar kind of bony deposit takes place in it $v$. 
Dural Mémoire sur l'usure des dents, p. 6, 1810; and Prochaska De decremento dentium in Annot. Academ. Fasc. I. p. 5, tab. 1. [T. Bell, p. 1S8, mentions a case in which the incisive teeth were so worn down, that when the jaws were shut there was an interspace of near a quarter of an inch; the cavities, however, were saved from exposure by the deposit of now bony matter, solid and hard, but so transparent, that nothing but examination by actual contact could convince an observer that they were closed. T.]

(18) I have seen this several times, in the hare, rabbit, catsquirrel, hamster, rat, and mouse, v. No. 3297-3300, of Bresl. Mus. - I lately had two similar hares.-Moreau de la Sarthe gives, in his fourteenth plate, an engraving of a rat with a very long and curved incisive tooth. - Thunberg, a hare's skull, in the Müncher Akadem. Denkchriften, Vol. IX.-Cheselden, a similar case in a wild boar.-The upper tusk of a babyronssa penetrated by its point into the brain. v. Lobstein Compte rendu, etc. No. 265, p. 74. Strasburg, 1824.-Two instances of rats. v. von Froriep's Notizen, Vol. IV. No. 76, p. 8, and Vol. XI. No. 2, p. 20.- In the last case noticed by Devergie, the tooth had passed through the posterior opening of the nostril into the nose, then again through the upper jaw into the mouth, and again up to the orbit.--I saw in the Anat. Mus. at Lund, a horse's mouth, in which a tooth of the lower jaw had grown high up into a hole in the upper.-In elephants, not unfrequently are the tusks curved and spiralshaped. [In Mus. Roy. Coll. Surg. is an example, No. 12, of perforation of the palate of a dog, in consequence of unnatural situation and length of a lower cuspid tuoth on the right side. No. 516, an upper incisive tooth of a rat, which, from want of apposition, has formed one perfect circle and the segment of another.-Similar elongation, and from the same cause, in rabbits, No. 547 - 549, \&c.; in the latter the secondary incisive teeth are also much elongated. T.]

(19) Compressed, awry, \&c.-An incisive tooth in the Bresl. Mus. No. 3279 , has a roundish and flat crown. - The crowns of the back teeth in dogs, which, for several generations back, have fed principally on vegetable food, lose the points, and produce the flat crown as an hereditary deformity. The palate teeth often vary very much in form; for instance, thcir crowns are pointed and conical.-Cerutti, No. 582, 3282, and 3283, Bresl. Mus.; cauliflower-shaped, v. Soemmerring, p. 272; tulip-shaped, Cerutti, No. 581; the front molar teeth in adults have four, the hinder five and six tubercles, Src.

(20) Incisive tecth with two fangs, Rudolphi, tab. 1, fig. 1 and 3 ; and No. 3285, 8130, Bresl. Mus.-Cuspid teeth with two fangs, Rudolphi, tab. 1, fig. 4 and 5.-Cerutti, No. 573, 574.-No. 3285, with three fangs. v. Fauchart Der Zahnarzt, tab. 27, fig. 13; the third and fourth molar, with but one fang, (one instance in Bresl. Mus.) or with five or six fangs, v. Rudolphi, tab. 1, fig. 6.Frequently we find them hooked, curved, much diverging, connected at the points, and enclosing a portion of the jaw, the roots very long, Sc. No. 3278, $3288,3292,3302,8127,8133$, of my Verzeichniss.

(21) For instance, an incisive tooth bent at an acute angle, and its point directed outwards, No. 3307, of my Verzeichniss.-The tusks of the elephant are often curved and spiral.-Incisive teeth, which are very projecting and curved; as also the persons so provided and called Bronci, v. Mercurialis Variorum lect. L. VI. C. XIII. [An instance of this kind is No. 615, Mus. Roy. Coll. Surg., in which an elephant's tusk is spirally wreathed, or twisted from the bottom to the top with three circumvolutions, standing between two straight lines; it is also furrowed longitudinally, and parallel to the axis of the tooth. v. Grew's Mus. Reg. Soc. p. 31. London, 1681. No. 712, Mus. Roy. Coll. Surg. exhibits the cuspid tooth of a hippopotamus unusually curved. 'T.]

(22) They usually occur singly, on the neck or crown of the back teeth, rarely several at once, and on the front teeth, for instance, three on one cuspid tootl. v. Lemaire in Journ. de Mélec. par Leroux Vol. XXXVI. p. 254. - Dentes proliferi, are described by Albinus Annot. Acad. Vol. I. pl. 4, fig. 3 and 4.-v. Sömmerring, p. 275. - Fox, Natural history and diseases of human teeth, tab. 13, fig. 1-8. -- Rudolphi resp. Tesmer, p. 10, tab. 1, fig. 7-9. -- Meckel Taluulæ anat. pathol. Fase. III. p. 1, tab. 17, fig. 1. - Several instances are found in the Leipzig. anatom. Mus. - I have found several such teetl, v. No. 3287, 
8131, 8132, with two excrescences, and 8250.--Cerutti Beschreib. der pathol. präparate, No. 565 .

(23) Erosion of the teeth, in Bunon Expériences et demonstrations, etc. Paris, 1746; and in Mahon Le Dentiste observateur. Paris. Ann. VI.-Atrophie in Duval, p. $7,1812$.

(24) Dubois-Faucon De dentium vitiose positorum curatione; Theses anatomico-chirurgicæ. 4to. Paris, 1775.

(25) As resemblances to animals, the teeth very sloping as in cretins; also in pug dogs, uncommonly sloping ; further, from the protrusion of the tongue.

(26) In Bresl. Mus. v. my Verzeichniss, \&c. No. 3308.

(27) v. Sömmciring, p. 272 and 278.-Dubois-Faucon in Sédillot's Jour. gén. de Médec. Vol. XXXII. May.-- Powell-Blackett, in London medical Repository, June, 1821. Vol. XV. No. 90, p. 456, with engravings. v. my Verzeichniss, No. 3305,3308 , and 8249 .

(28) Albinus Annot. Academ. L. I. C. XIII. tab. 4. fig. 1, the cuspid teeth in the nasal process of the upper jaw.-Sandifort Observat. anat. pathol. L. III. tab. 10, fig. 1.--Meckel, tab. 17, fig. 7 .

(29) v. my Verzeichniss, No. 3302, 3303, 3306, 8062.- Such teeth not umfrequently give rise to bony fistulas. [No. 144 and 145, Mus. Roy. Coll. Surg.; in these the right upper cuspid tooth is formed so high in the jaw, that it cannot reach the gum. T.]

(30) For instance, the first molar before the cuspid, Miel in Leroux Journ. de Médec. Vol. XL. p. 88.-Meckel, tab. 17, fig. 2--The first molar in the place of the outer incisive tooth, and that in its place, Miel.--In a wild boar, the first right incisive tooth of the lower jaw in its middle, and the tusk opposite, $v$. Allg. Historie der Natur. Vol. VII. Part II. p. 232, No. 1384.

(31) Borellus, Cent. II. Obs. 81. - Erndtel in Actis N. C. Vol. II. Obs. 113, p. 262.-Schenk Observat. L. I. No. 411.-v. Sömmerring, p. 272.--Meckel, tab.17, fig. 6.-Hirsch p. 74. - Tode Medic. Journal. Vol. II. Part IV. p. 21.--Schmidt in v. Siebold's Samml. selt. und auserl. chir. Abhandl. Vol. III. 1812. Part XXII. My Verzeichniss, No. 3282, 3283, 3304.--Albinus, p. 53, tab. 4, fig. 3.--Cerutti, No. 580--582.--In the horse, not unfrequently wolt's-teeth, dentes lupini.

(32) Fauchard in Mém. de l'Acad. de Chir. Vol. V. Mém. 257. - In Anat. Mus. of University at Copenhagen, I saw caries of the bones of the face produced by a molar tooth, which, with its crown outwards, had penetrated the left maxillary antrum; also the fangs of the bicuspid and front molars, sometimes penetrate the maxillary sinus. v. Bertin Osteologie, Vol. II. p. 309.-Portal Comp. d'Anatomie médical. Vol. I. p. 210, note 2.-My Verzeichniss, No. 3278 ; there are, in the Bresl. Mus. No. 8128, two teeth, as it were absorbed, which had been drawn out of the maxillary cavity.

(33) In the Anat. Mus. at Lund, I saw an upper jaw, in which an incisive tooth was breaking into the nostril.-Compare Cerutti. [No. 143, Mus. Roy. Coll. Surg. the crown of the right upper bicuspis projecting upwards and inwards into the right nostril. T.]

(34) Albinus, p. 53.

(35) Sandifort, p. 138 , tab. X. fig. 5 .

(36) Tesmer, præs. Rudolphi, tab. 1, fig. 14.

(37) Sandifort.

(38) Hunter, p. 8. [In Mus. Roy. Coll. Surg. No. 1059, is a lower molar tooth, formed only in the gum, and unconnected with the jaw. T.]

(39) I found this several times in monstrous sheep and calves, v. my Verzeichniss, No. 2322, 2323, 2949 ; further, No.8021, Ib. Mus.-Schläpfer, in a calf, in Schweitz. naturwissenchaftl. Anzeiger. No. 1. July, 1819.

(40) Dubois-Faucon in Sêdillot's Journ. gén. de Méd. de Chír. et Pharm. Vol. XXXII. May.

(41) In diseases of cattle the teeth not unfrequently become loose, especially in oxen and sheep; in an epidemic scabious exanthematous disease which affected the cats in Holland in the year 1796, their teeth fell out.

(42) This appears to be the case, as when the second or permanent teeth are shed by a process similar to that which causes the shedding of the horns of stags, 
viz. the closing of the nutritive canals in their roots which secrete the bony substance, the destructiou of the vessels and nerves, and thus also of the life of the tooth. I have seen this in several teeth; v. Pearsons in New-England Journ. of Medic. and Surg. new series, Vol. IV. Jan. 1820.

(43) Duval in Bulletin de la Faculté de Médec. 1811, No. 7-12.

(44) From inflammation, swelling, and suppuration of the internal membrane of the socket, by which the tooth is more or less pushed out and loosened; from destruction of the gums, gumboil, caries, osteosarcom of the jaw, from glossocele, Sc. It is self-evident that they may be loosened by mechanical influence of various kinds; an imperfect loosening of this kind, we call, though improperly, dislacation of the teeth.

(45) v. Haller Elem. Physiol. Vol. VI. p. 29.-de Plouquet Art. Dentis Continuitas.-Gavard Osteologie. p. 338.-Laveran in Sédillot Journ. de Médec. Vol. XXIX. p. 192.-Courtois, p. 156.-v. Sömmerring, p. 273.-Hirsch, p. 77.Serre Praktische Darstellung aller Operationen der Zahnarzneikunst. Berlin, 1804, p. 208, tab. 21. fig 1 and 2.-Fleisclimamn in Abhandlungen der physik. medic. Societät zu Erlangen. Vol. I. p. 31, tab. 1. fig. 3 and 4.-Tesmer Præs. Rudolphi, p. 9, tab. 1. fig. 11 and 12.-I saw in a student here two incisive teeth grown together by their crowns; two back teeth with their roots united; v. my Verzeichniss, No. 3280, 3281, 3284.-From a cow, v. Cerutti Beschreibung der pathol. Präparate d. anat. Theat. zu Leipzig, No. 586, from man, No. 575, 578.

(46) v. Haller, who as well as Rhodigius Lection. antiqu. Basil. 1517, L. II. C. XXXIII. p. 78, gives doubtful instances of union of all the teeth. I lately had three incisive teeth of a child united at their roots, No. 8129 of the collection.Oudet found on each side of the lower jaw a large unequal tumour, covered here and there with enamel, which seemed to arise fiom consolidation of the incisive and cuspid teeth; v. N. Journ. de Médec. Feb. 1821, p. 245. [No. 146, Mus. Roy. Coll. Surg. a molar tooth of the upper jaw anchylosed to that adjoining, which is inverted. T.]

(46*) In the Mus. Roy. Coll. Surg. No. 265, a double human incisor.No. 266, two tusks of a young elephant growing from the same side of the jaw, closely united throughout, and the cavities cuntaining the pulps communicating laterally. T.]

(47) Duval in Leroux Journ. de Méd. Chir. et Pharm. Vol. XXXIII. July and August.

(48) To wit, smoking tobacco, chewing betel, the use of sugar of lead. v. Saxtorpl in Act. R. Soc. Med. Havn. Vol. III. p. 96.-From sulphur baths, Waiz in IIufeland's Journ. d. prakt. Heill. Vol. XVI. Part II. p. 33. It is well known that many nations colour their teeth artificially; tooth tinctures containing mineral acids easily colour the teeth dusky.

(49) The black glazing of the hind teeth of oxen, sheep, and goats takes place especially in such animals as feed on dry and rooty fodder; the metallic glazing, like bronze, gold, \&c. is often produced from the use of water containing iron. In coppersmiths the teeth are sometimes coloured green, and little particles of metal mingle with the tartar.

(50) Especially in persons with weak digestion, in rickety people, in those which are generally affected by lithiasis; sometimes in uncleanly persons several or all the teeth are united together with tartar, or it surrounds tle whole tooth and forms a large tumour. v. Duval Le dentiste de la jeunesse. Paris, 1804. I have found many such instances, for example, one as large as a walnut, v. my Verzeichniss, No. 3294, 3295.-Cerutti, No. 566, 571.-Sandifort Mus. Anat. Vol. III. p. 297, No. 1031.- [There is in the Mus. at St. Thomas's Hospital, a piece of tartar as large as a hen's egg. 'T.]

(51) Blumenbach's Horny substance of the teeth.

(52) In general osteomalacy the teeth usually remain hard, although there are exceptions to this rule; for instance, the case by Veirac $\Lambda$ bhandlung über die Rhachitis, u. s. w. p. 54 and 83, Stendal, 1794--Isenflanm Versuch einger prakt. Anmerkungen uiber dic Knochen, p. 4.2\%, $-\boldsymbol{\Lambda}$ tooth resembling cartilage was found by Kranss in Mis. Acad. N. Cur. 1697, p. 619.-le Blanc Précis des Opérations. Vol. I. p. 18. 
(53) Jourdain Essai sur la formation des dents. Paris, 1766.-Duval in Recueil périodique, etc. Vol. XIII. p. 275, and in Bulletin de la Faculté de Médec. 1811, July, p. 115 ; Sept. p. 161.

(54) Plouquet D. Primæ lineæ Odontiticlis, s. inflammationis ipsorum dentium. 4to. 'Tübin. 1794.- It easily arises out of scrofulous, syphilitic, and gouty causes.- - A very excellent instance of abscess in the bony body of a molar tooth is given by $T$. Bell, in Med. Chir. Trans. Vol. X. p. 38.-Chuny, the elephant, which, a few years ago, was destroyed at Exeter Change, in consequence of his ungovernable violence, arising as was then supposed from sexual excitement, was found, when the bones were macerated, to have been labouring under inflammation of the tusk, probably its pulp, as in the socket was found a quart or two of pus, and on the tusk itself some bony deposit, and an indentation, perhaps produced when the tusk was recently formed, by a blow with a shovel, which had been given him a year or two before, when very unruly. T.]

(55) Duval in Bulletin de la Faculté de Médecine, 1811, p. 204.

(56) v. Duval, 1811, No. 7-12. - Many instances in Bresl. Mus. viz. No. 3290, 3291, 8126. - Cerutti, No. 550-553, 559. - in Blumenbach's collection I saw the back tooth of an animal, which, excepting the root, was completely expanded into a large bony tumour.--Meckel has figured a similar case of a human tooth; v. tab. 17, fig. 8-10.-Howship, Pract. Observat. \&c.-Ouclet in N. Journ. de Médecine, 1821, Févr. p. 245.

(57) Small exostoses on the fangs are not uncommon; v. above, note 22.

(58) Küchler D. de ulceribus dentium fistulosis. 4.to. Lips. 1733.-Rengelmann De ossium morbis, eorumque, in specie dentium, carie. Arnstadt, 1805. Duval in Bulletin de la Faculté de Médec. 1809, p. 104, and 1810, No. 6, p. 86 . - Lavagna Esperienze e Riflessioni sopra la cari de denti umani. 8vo. Genua, 1812. - Caries also occurs in rare cases in teeth which have not been cut, as well also as in that part of the tooth covered by the gum.- [Perhaps here belongs the case of a large tumour of the lower jaw, with an abscess in the neck, occasioned by supernumerary teeth, related by Whately, in Medical Facts, Vol. VIII. p. 173.-The term caries is objected to by $T$. Bell, in his Anatomy, \&c. of the Teeth, p. 118 ; and he prefers calling it gangrene, as it "has not the slightest analogy to true caries of bone."-J. Hunter also, in his Natural History of the Teeth, had previously stated that it was "such a decay as would appear to deserve the name of mortification ;" though lie considers that there is something more than this. T.]

(59) IIeuermann Bemerkungen, u. s. w. I. p. 302.

(60) v. de Plouquet Repert. Art. Dens. Vermiculi.-Cerutti, No. 563.Kremser in Horn's Archiv f. medic. Erfahrung. July and Aug. 1821.

(61) Daubenion in Buffon, Vol. XI. p. 161.-Gallandat Over de Olyphants Tanden im Verhandelingen der Genootsh. te Vliessingen, Vol. IX. p. 352.Bonn in Descr. Thesauri Hoviani. p. 146._-Blumenbach Handb. der vergl. Anatomie. 2 d edit. p. 44, in notes.-G. Cuvier in Dict. des Sc. médic. Vol. VIII. p. 328.-Isenflamm Anat. Untersuchungen, u. s. w. p. 37.- Several examples are given by von Gothe zur Naturwissenschaft, Vol. II. Part I. p. 7.-One example from v. Gräfe's Sammlung.-Dr. Grosshein in v. Gräfe and v. Walther's Journ. f. d. Chir. Vol. X. Part I. p. 152, pl, 3, fig. 4, and one example of a small bullet in Bresl. Mus. v. my Verzeichniss, No. 3296.

(62) Combe in Philos. Trans. 1811, Part I. p. 165.

\section{$\S 134$.}

The TONGUE-BONE, as being an appendage to the skull, must also be mentioned here. In monsters with deficient or very small tongues, this bone is sometimes completely wanting, or in the imperfect development of the neighbouring parts it exists only as a rudiment, and at the time of birth remains entirely cartilaginous. Sometimes in otherwise well-formed tongue- 
bones certain parts are wanting, viz. once, one of the horns. ${ }^{1}$ On the contrary, we also see the tongue-bone ossified too early $;^{2}$ in double monsters we find one made up of two tonguebones consolidated together. ${ }^{3}$ The size and form of this bone varies remarkably; in many cases we find it proportionally too small; in other cases very large and broad; the direction, curving, and length of the great horns, is not rarely unequal on the two sides, ${ }^{4}$ the small horns also are unequal. The connexion of the several pieces is sometimes irregular, thus the large and small horns are anchylosed to the middle piece; ${ }^{5}$ the fastening of the tongue-bone to the skull is sometimes found too firm. ${ }^{6}$ We observe dislocations ${ }^{7}$ and fractures ${ }^{8}$ of this bone in consequence of external violence, as well also as greater or less destruction from caries, ${ }^{9}$ as a primary and secondary affection.

(1) Leveling Anat. des Menschen, 1794, p. 167.

(2) Loschge Progr. de symmetria corp. human. Erlangen, 1793, p. 65.

(3) For example, my Selt. Beob. I. p. 14.

(4) v. Soemmerring Vom Baue des menschl. Körpers, 2d edit. Vol. I. p. 281. - Several instances are also found in Bresl. Mus.-In a few cases of stuttering persons, the tongue-bone was developed more on one side than the other. $-v$. Serres Anat. du Cerveau, Vol. II. chap. 4, p. 233.

(5) Loschge, already in a child a fortnight old.

(6) Inasmuch as the connecting ligament becomes more or less bony; I have some instances of its almost complete ossification before me; in a horse the tongue-bone was in one instance completely anchylosed with the styloid process.

(7) Valsalva De aure humana in Oper. Venet. Ausg. p. 35. - Molinelli in Comment. Bonon. Vol. V. Part I. p. 90; Part II. p. 1.-Cederschjöld in ArsBerättelse om Svenska Läkare-Sällskapets Arbeten. Stockh. 1818.

(8) For instance, in persons who have been hanged.-Cerutti, No. 804.

(9) Tode Med. Journ. Vol. III. Part II. p. 43.-Biermayer Mus, anat. path. No. 545 .

\section{B. - OF THE BONES OF THE TRUNK.}

\section{$\S 135$.}

The spine, ${ }^{1}$ being the first and most important part of the skeleton, is entirely WANTING only in rare cases, and in the most imperfect monsters $;^{2}$ its formation is more commonly deficient only at certain parts; thus in the acephalous monsters, there is usually wanting, together with the head, more or less of the spine, according as the neck, breast, and even part of the belly are deficient in these monsters. Very generally we find in monsters with anencephaly, the vertebræ of the neck in part imperfectly formed, in part onc or many of them wanting $;^{3}$ in 
very rare cases also, of otherwise well-formed persons, we miss one of the cervical vertebræ. ${ }^{4}$ In monsters with cleft and curvature of the spine, ${ }^{5}$ although with bodies otherwise well formed, several of the dorsal and lumbar vertebra are deficient $;{ }^{6}$ sometimes the hinder extremity of the spine is imperfectly developed, so that it is either entirely or partially wanting, or the number of the sacral and coccygeal bones is diminished. ${ }^{7}$ Very much more rare is the actual INCREASED NUMBER of the pieces of the spine; it is but trifling, however, as we never notice more than one superfluous vertebra; thus, we observe in very rare instances eight cervical vertebræ, ${ }^{8}$ more commonly thirteen dorsal, ${ }^{9}$ and six lumbar ${ }^{10}$ vertebræ in man; sometimes also the sacrum ${ }^{11}$ and the $\operatorname{coccyx} \mathrm{x}^{12}$ have a vertebra too many. In very many instances we observe VICES OF SIZE AND FORM in the vertebræ; in monsters with anencephaly, hydrencephalocele, dropsy of the head, as well as with curvature and cleft of the spine, the vertebræ are sometimes very imperfectly formed, consolidated, but half, unusually narrow, \&c. $;{ }^{13}$ not unfrequently the spine is in them, as also in adults, remarkably short in proportion to the other parts of the body; there has been once observed, in an otherwise well-made child, one dorsal vertebra only half formed, ${ }^{14}$ and on the lumbar vertebra of an adult, an articular process with half of the arch deficient; $;^{15}$ in an adult cow the eleventh and twelfth dorsal vertebræ were partially double, each having two spinous processes $;^{16}$ the sixth cervical vertebra of a man was found spiral-shaped $;^{17}$ in rare cases there occur productions on the first vertebra, which are articulated with the occipital bone $;^{18}$ the form of the first vertebra is, however, besides, frequently very variable ${ }^{19}$ the lowest cervical vertebra has also a second hole in its transverse process for an accessory vertebral artery; the last dorsal vertebra assumes the form of a lumbar $;^{20}$ the spinous processes especially of the dorsal vertebræ, are frequently very much arched; on the lumbar vertebræ sometimes occur very long transverse processes, ${ }^{21}$ also not uncommonly there are on them, in man, large processus accessorii; the sacrum exhibits very many varieties in reference to its length, breadth, and curvature, not unusually is its upper false vertebra, even in adults, completely separate from the following, either on one or both surfaces, or it assumes on one side more or less completely the form of a lumbar vertebra $;{ }^{22}$ the vertebræ in the reproduced tails of lizards are never normally formed, and the processes are mostly deficient; ${ }^{23}$ sometimes the form of the spinal canal is irregular, ${ }^{24}$ and the size of the holes in the vertebræ varying. A malformation of the spine of man and animals, as common o 2 
as it is great, is the CLEFT sPINE, spina bifida, hydrorrhachia, or hydrorrhachis, ${ }^{25}$ in which, as an original vice, on account of the collection of water in the spinal canal, at a very early period, the vertebræ are more or less cleft, and stayed in their development. In rare instances we see only a single little irregular opening on the hinder surface of the spine,$^{26}$ or more commonly the arched part of the vertebra is not closed, more or less open, pressed forwards, and entirely wanting, or in the highest degree even the bodies of the vertebræ are cleft ${ }^{27}$ sometimes also the transverse and articular processes, as well as part of the body of the vertebra, are deficient. ${ }^{28}$ The cleaving of the spine usually occurs at one part of the column, and most commonly in the lumbar and dorsal regions, if it be not at the same time connected with anencephaly and hydrencephaly, with which commonly the cervical region is simultaneously cleft; it is least frequent in the neck. In many instances is the whole spine cleft and open from top to bottom, ${ }^{29}$ it has also been seen cleft in two places at the same time $;^{30}$ and in one instance it still remained in an adult male. ${ }^{31}$ But even without any dropsy in the spinal canal, we sometimes observe in the atlas and in the sacrum, that the hinder arched part has not closed, but that a gap is formed; indeed in an adult cretin, the spinous processes of all the dorsal vertebræe still remained thus cleft. ${ }^{32}$ Some also have thought they found an imperfect union of the original bony pieces in other parts of the vertebræ. ${ }^{33}$ The spine frequently presents as a congenital state, ${ }^{34}$ but more commonly as the consequence of diseases and injurious practices, ${ }^{35}$ irregular BENDINGS and CURVatures, spina dorsalis distortio, curvatura, ${ }^{36}$ of which there are given four principal kinds, viz. the posterior curvature, the HUMP-BACK, gibbositas, kyphosis, ${ }^{37}$ the lateral curvature, skoliosis seu obstipitas, ${ }^{38}$ the curvature forwards, or in animals, downwards, sinking BACK, lordosis, ${ }^{39}$ and lastly, the IREVOLVING SPINE, rotatio spina. ${ }^{40}$ In many instances several of these kinds occur in the same spine at once. In animals also curvatures of the spine are not infrequent. ${ }^{41}$

Concerning vices of CONNEXion of the spinal column, to these belong, Dislocations of the vertebre, ${ }^{42}$ which on account of the firm connexion of these bones with each other, is, proportionally, rarely produced by mechanical, more frequently from internal causes, especially between the first two vertebræ; ${ }^{43}$ as also the opposite vice, viz. the ToO FIRM $A$ ND CONSTRAINED CONNEXION OF THE VERTEBRE, and the actual CONSOLIDATION of THEIr joInts, ankylosis. ${ }^{44}$ The latter vice is not rarely congenital, ${ }^{45}$ especially in connexion with cleft 
and curved spine, but it more frequently occurs at a subsequent period, particularly in the curvature of the back in old persons, and as a most fortunate occurrence after spondylarthrocacy and caries; in animals also, especially in such as often have the back much strained, as in horses and asses, anchylosis of the vertebræ is by no means rare. ${ }^{46}$ The consolidation is produced sometimes by ossification of the joint ligaments, and sometimes by true soldering together of the articular surfaces, sometimes by irregular bony growths; it commonly affects only individual joints, or few vertebræ, more seldom almost the whole spine. ${ }^{47}$ Fractures of THE Vertebre, ${ }^{48}$ on account of the simultaneous strength and suppleness of the spine, are proportionally rare, and mostly fatal at an earlier or later period; they are, however, in individual cases, cured by callus, ${ }^{49}$ or the formation of a new joint. ${ }^{50}$

Finally, of the vices of TEXTURe which occur in the bones of the spine, we must especially mention, on account of its frequency and malignity, the SCrofulous INFLAMMATION OF THE VERTEBRIE, spondylarthrocace, ${ }^{51}$ which very often gives rise to hump-back and to CARIES ${ }^{52}$ especially of the bodies of the vertebræ; this latter disease, as well as ERosion of the vertebræ, which is not to be confounded with it, often arises from other causes, viz. mechanical influence on the sacrum from decubitus, often from scrofulous tumours running into suppuration, from melanosis, and from lymphatic swellings ${ }^{53}$ lumbar abscesses ${ }^{54}$ aneurysms, ${ }^{55} \&$ c. $^{5}{ }^{55^{*}}$ in animals also caries is not rare. ${ }^{56}$ Finally, inflammation of the spine and its periosteum give rise in many cases to SPINA VENTOSA, and to large ExostosEs. ${ }^{57}$

(1) Franck Oratio de vertebralis columnæ in morbis dignitate in Delect. Opuscul. Vol. IX. No. 1. Paviæ, 1791._van Gesscher Ueber Entstellungen des Rückgrathes und Schenkelbeines, a. d. Holländ. 8vo. Götting. 1793. _- Guyenet D. sur quelques maladies, qui affectent la colonne vertebrale. Montpell. 1809. Demussy Histoire de quelques affections de la colonne vertebrale. 8vo. Paris, 1812. - J. Gordon D. de morbo vertebrarum. Edinb. 1813. - Copeland, Observations on the diseased Spine. 8vo. London, 1815. - T. Sheldrake, A treatise on diseased Spine and distorted Spine, with cases to illustrate the success of a new method of cure. London, 1816. - Simpson, C. de Spina dorsi vitiosa. Edinb. 1821.--Lloyd, A treatise on the nature and treatment of Scrofula, describing its connexion with the diseases of the Spine, Joints, Eyes, Glands, \&c. London, 1821.- Ch. Bell, Observations on the Injuries of the Spine, and of the Thighbone, Sc. London, 1824, with nine plates. - Cunow D. de morbis columnæ vertebralis. 8vo. Halæ, 1825. - C. Wenzel Ueber die Krankheiten am Rückgrathe. gr. fol. Bamberg, 1825, with eight engravings.-Dugés in Revue médicale francaise et étrangère. Vol. X. p. 353. -- Harrison in Fothergill's medical and physic. Journ. Vol. XLV. Feb. and Pathological and Practical Observations on Spinal Diseases, illustrated with cases and engravings; also an Inquiry into the origin and cure of distorted limbs. 8vo. London, 1827, with fifteen plates.

(2) Compare above $\$ 104$, note 2. -- In an acephalous monster, which merely consisted of pelvis and lower extremities, the sacral and coccygeal bones, together 
with all tiace of the spine, were deficient. v. Bomn in Verhand. van et Genootschap ter bevordering der Heelkunde. Amsterd. D. III. p. 124.-A similar case of its total deficiency in another acephalous monster. v. Clark in Phil. Transact. 1793, p. 154.

(3) Haller Opera minora. Vol. III. p. 14, v. the Vertebræ.-My Monstror. sex humanor. anat. et phys. disquisitio, Francof. ad V. p. 7, 13, 14, twice but four, once only three vertebræ; and Selt. Beob. Part I. No.9, in a double monster from a sheep, in the neck but six vertebræ.-I have, however, since seen it in many anencephalous monsters. - In the Cabinet of Nat. Hist. at Stuttgart, I saw only two cervical vertebræ in one such monster:--Several instances of deficient individual vertebræ are given in Meckel Descriptio monstror. nonnullor, etc. p. 10, 19, 26. Lips. 1S26. -- Rathke in Meckel D. Archiv f. d. Phys. Vol. VII. p. 490, only six cervical vertebræ.--Detharding in Nov. Act. Phys. med. Vol. X. Part II. p. 706, merely the rudiment of an atlas and epistropheus; also in hydrencephalocele. v. Burkart D. de monstro luumano notabili, Friburgi Brisg. 1825 , p. 15, but five cervical vertebra.

(4) Columbus De re anat. p. 263.-Cullen, Practice of Physic, Vol. III. \$1107, saw this in a family disposed to apoplexy, even hereditarily.-I have lately seen a case of this very kind in an adult man. v. No. 8852 of Bresl. Mus.

(5) Malacarne in Mém. della Soc. Ital. XI1. p. 164. - Meckel Handb. d. pathol. Anat. Vol. I. p. 201.

(6) For instance, two skeletons, with eleven dorsal, but six lumbar vertebræ, in the Anat. Mus. at Kiel.- In oxen, only twelve dorsal vertebræ. v. Pilger Handb. der Veterinär-Wissensch. Vol. I. p. 502. - In the horse, but five lumbar vertebræ. v. Pilger, p. 494, note. - Allg. Hist. der Natur. Vol. II. Part II. p. 189. Rudolphi Bemerk. auf einer Reisc. Part I. p. 37.

(7) In a calf, most of the lumbar, and all the sacral, and coccygeal vertebræe were wanting, and the lower extremities were attached by ligament to the first lumbar vertebra. v. Samlifort MIus. anat. Vol. III. No. 1009, p. 294. - In another calf, No. 1060, $i b$. only the hind part of the sacrum, and all the coccygeal vertebræ; instead of the sacrum and coccyx, there has been scen merely a single small bony germ. v. Friedlieb Monstrosi foetus descriptio atque delineatio. 4to. Altonæ, 1803 , p. 33, tab. 4 and 6 , on children, with congenital large encysted tumours on the back.-The evolution of the lower part of the spine is sometimes retarded. v. my Selt. Beob. Vol. II. p. 165.-In No. 2903, Bresl. Mus. the coccyx is wanting entirely.-The pelvis in man has rarely but four, and the coccyx frequently but three pieces.--Often in arimal monsters, the whole tail is either deficient, or uncommonly short.-This is seen hereditary in the horse, dog, and the peculiar race of tailless fowls.-In domestic animals, however, the normal number of pieces in the tail varies; thus, in the horse, from thirteen to twenty-four; in oxen, from sixteen to eighteen; in sheep, from sixteen to twenty, \&c.

(8) Eustachius Ossium examen, p. 210.-Columbus, p. 484.-Palfyn Anat. Vol. II. p. 100.-Leveling Observ. anat. rarior. Fasc. I. C. III. - Ackermam Ueber die körperliche Verschiedenheit des Mannes vom Weibe, p. 49, note k. v. Meckel De duplicitate monstrosa, p. 27. To a certain degree also belongs here the case quoted under note 16 below.

(9) Morgagni De sed. et caus. morb. I. I. Epist. V. note 6.-Böhmer Observat. anat. Fasc. I. præf. p. 5. - Fabricius Animadv. var. argumenti. Helnst. 1783, p. 9. - van Doeveren Spec. observ. acad, p. 201. - Meckel, p. 25 and 28. - One case in my Sclt. Beob. I. p. 70 ; and Verzeichniss, No. 3312, in which there is a mistake, there not being six lumbar, but thirteen dorsal vertebræ.- In $\Lambda$ nat. Mus. zu Kiel, there is also a skeleton, with thirteen dorsal vertebræ. - In animals, a dorsal vertebra too many.--In a horse at Hanover, there are nineteen dorsal vertebrx.-Rudolphi, I. p. 74.--In an ox. v. Pilger, p. 502.

(10) v. Blumenbach Geschichte und Beschreib. d. Knochen, 2d. edit. p. 309.Hesselbach Beschreib. d. pathol. Präparate zin Wiirzburg, No.651, p. 12. In two sheep, a supernumerary lumbar vertebra. v. Rudolphi, I. p. 37.

(11) van Doeveren, p. 206. - Albimus Amnot. acad. lib. IV. C. XI. de osse sacro. - Sandifort Mus. mat. Vol. 1. p. 87, No. 352; p. 176, No. 162 and 
177 ; No. 163; compare Blumenbach, 1. 316.--Some instances also in Bresl. Mus.

(12) As it appears more frequently in women. v. von Sommerring, Vom Baue des menschl. Körpers. 2 d edit. I. p. 360. - I have also some instances before me. If the observations about men with tails are to be believed, the coccygeal vertebræ must have been much increased or very long.

(13) I have seen this in a great number of monsters, especially in the Anencephalous. v. D. Monstror. sex humanor. anat. et phys. disquisitio; Selt. Beob. I. p. 20, and since in several more.-Meckel Handb. der pathol. Anatomie, Vol. I. p. 382, and Descript. monstror. nonnullor, p. 10, 19, 26, 36.-Seerig D. de hydroencephaloceles specimine eximio, p. 12. 4to. Vratisl. 1822.

(14) On No. 3018 in Bresl. Mus. v. my Selt. Beob. II. p. 15.

(15) Rosenmüller D. de singularibus et nativis ossium c. h varietatibus, p. 58.

(16) I saw this in the Veterinary School at Munich, the cow had supernumerary feet on this part, and, according to the account, she had also an udder here; the lumbar vertebræ exhibited a spina bifida; the spinous processes of the dorsal vertebræ were not at all cleft, but actually double.

(17) It formed two turns with two spinous processes, and on each side two transverse processes. I saw this very remarkable piece in the Anat. Mus. of the Joseph Academy, at Vienna.

(18) Leveling Observat. anat. rar. p. 134, tab. 5, fig. 1.-Sandifort Mus. anat. Vol. II. tab. 14, fig. 3 , v. $\$ 125$, note 7 .

(19) Compare $v$. Söinmerring, p. $312, \$ 284$.-I have frequently found it, as it were, squeezed flat, in water of the head, and rickets.-A similar atlas is described by Kelch Beiträge zur pathol. Anatomie, No. VIII.

(20) Only on one side in an ass. v. Allgem. Historie der Natur. Vol. II. Part II. p. 219.

(21) I have seen this several times; -in many cases they are so large on the fifth lumbar vertebra, that the vertebra is locked between the hip bones, and indeed resembles the first false vertebra of the sacrum. v. Kelch, No. X.-On the first lumbar vertebra of two horses, in the Veterinary School, at Stockholm, I saw the transverse processes almost as long as the last rib, formed also like it, with a cartilage at the extremity, not however movable.

(22) This seems to occur only in men.

(23) I have this in No. 8160 of Bresl. Mus. before me.-In the Anat. Mus. at Prague, I also saw the skeleton of a lizard, which had lived for three years after breaking off the tail, without the new vertebræ becoming ossified, or having processes.

(24) To wit, too narrow or too wide, compressed, completed at an early period, so that there is no hole in the sacrum.--I have seen the latter in children with cleft spine. - Stoll Ratio medendi. - Mohrenheim's Beobactungen, u.s.w. Vol. I. p. 174 .

(25) Reuss Repertor. Comment. Vol. XIII. p. 570.-de Plouquet Repertor. Art. Hydrops spinæ.-Hochstetter D. de Spina bifida. Altdorf. 1703. - Titsingh Heelkundige Verhandeling over de tegen-natuurlyke Splytinge de Rugge-graat. 8vo. Amsterd. 1782, with four engravings. -- Vyllhoorn Noodig Denkbeeld van Spin. bif. 8vo. Amsterd. 1732, with an engraving; and Tweede Vertoog over het ongemak van de Spin. bif. u. s. w. Amsterd. 1733.-- Platner Progr. de Sp. bif. Lijus. 1734.-Gild D. de Sp. bif. Viennæ, 1754. v. Haller's Diss. pract. VII. note 253. - Murray D. Sp. bif. ex mala ossium conformatione initia. Goetting. 1779. v. Opusc. II. note 5.-Cappel D. de Sp. bif. Helmst. 1793.-Meckel D. de hydrorrhachia. Halæ, 1795. - Bauer D. de hydrorrhachitide. Erford. 1798. Bodin D. de Sp. bif. v. Journ. de Médec. continué. Vol. III. p. 148.-Fleischmann De vitiis congenitis circa thoracem et abdomen, p. 9. Erlangæ, 1810._J. F. Meckel Handb. der Pathol. Anat. Vol. I. p. 356. - Forster D. de Sp. bif. 8vo. Berol. 1820. - A. F. Moeckel Comm. de Hydrorrhachitide. 8vo. Lips, 1822, with engravings. - Compare No. 3313-3319.

(26) Ruysch Observ, anat. chir. Obs. 36.-Acrell in Schwed. Abhandlung. Vol. X. p. 291.

(27) T'ulpius Observ. med. p. 230.-Wepfer in Ephem. Nat. Cur. Dec. I. Ann. 
III. Obs. 129, p. 222.-Bugden in Philos. Transact. Vol. XXXVI. No.410.-Salzmann in Orthii D. de quibusdam tumor. tunicat. ext. recus. in Haller's Coll. Diss. med. chir. Vol. V. \$3, p. 411.-Camerarius, ib. §4.-Fleischmann.-Lallemand Observat. patholog. p. 32. Paris, 1818. - Meckel Anat. phys. Beobacht. und Untersuchungen. p. 90, 96. - v. Loder Index præparator. Abschn. Part II. No. 3313 of Bresl. Mus. seem to belong here; also No. 3318.

(28) In a calf, I saw the cleft entirely on the right side of the spine, so that the right half of the vertebræ was entirely wanting, while the left half, both of the bodies and arches, were perfect. v. my Verzeichniss, No. 3318.

(29) Several examples in Bresl. Mus. v. Fielitz in Richter's Chir. Bibliotl. Vol. IX. p. 185. - IIoin in Mémoir de Dijon, Vol. II. p. 105. - Bidloo Opera omnia. L. B. 1715 , pl. 4, fig. 1 and 2, from the first vertebra even into the sacrum.-Palletta Exercit. pathol. I. fig. 11.--Potthof D. Descriptio casus rarissimi spinæ bifidæ totalis. Berol. 1828.

(30) Camper Ueber die Natur und Ursachen der versch. Wassersuchten. v. Samml. auserl. Abhandl. f. prakt. Aerzte. Vol. X. p. 448.

(31) J. P. Frank Delectus opusculor. medicor. Vol. II. p. 33, in the note.Perhaps here belongs, as a less degree, the case engraved by Sandifort Mus. Anat. Vol. II. tab. 45, fig. $1-3$, in which the cavity of the sacrum of an adult man was, at one spot, remarkably enlarged, and its sides expanded.

(32) Prochaska Disquis. anat. phys. organ. c. h. tab. 9, fig. 2.

(33) Bichat Anatomie descriptive, Vol. I. p. 133; the arch of a lumbar vertebra movably connected with its body, was seen by Heiland, in Ephem. Nat. Cur. Dec. III. Ann. VII. p. 278 , and Rosenmuiller, p. 57 ;--a transverse process joined to its vertebra.-- Ungebauer Epistola osteologica de ossium trunci genesi, p. 257, Lips. 1739, and twice in Rosenmiiller, p. 58. - A movable spinous process on the sacrum, in Ilebenstreit de rarior. quibusdam ossium momentis, p. 7. Lips. 1740.- On the point of the spinous process of the seventh cervical vertebra, there was a roundish bone articulated, almost as large as a hazel nut, v. Kelch, No. 9; and a similar bone on one lumbar vertebra. v. Schulze in Commercio Noric. 1731, No. V. p. 33. Perhaps, in both cases, there were sessamoid bones. Compare below, note 48 .

(34) For instance, in monsters with anencephaly, and hydrencephaly, very often in the neck; in man and animals with cleft spine, with lateral excentration: in many double monsters, very common in calves, \&c.

(35) Especially in softening of bone, erosion, inflammation, and ulceration of the vertebræ, and the intervertebral substance, from muscular weakness, negligent carriage, and various mechanical causes, as tight lacing.

(36) Compare above, note 1. - Jones, Essay on Crookedness or distortions of the Spine. 8vo. Lond. 1788. - Palletta Beobachtungen iiber die mit Lähmung verbundene Krümmung des Rückgraths, a. d. Ital. Svo. Tubing. 1795. - Portal Observations sur la nature et le traitement du Rhachitisme, ou des courbures de la colonne vertebrale et de celles des extremités. 8vo. Paris, 1798. - Wilkinson, Physinl. and philosophical Essays on the distortions of the Spine. 8vo. Lond. 1798. - Earle, Observations on the cure of curved Spine, \&c. 8 vo. Lond. 1803.Frolich resp. Meyer D. de curvatura spinæ dorsi cum paralysi extremitatum inferiorum. 4to. Upsal. 1804. - Feiler De spinæ dorsi incurvationibus, etc. 8vo. Norimb. 1807, with figures.--Jörg Ueber dic Verkrümmungen des menschlichen Körpers und die Heilart derselben. 4to. Leipz. 1816, with engravings. Macartney, Observations on the Curvatures of the Spine. 4to. Dublin, 1817.Penneld D. de spina incurva. Edlinb. 1818. - Malsch D. de noval machina Græfiana, etc. nec non disquisitio deformitatum istirum. 4to. Berol. 1818.Choulant Decas pelvium spinarumque deformatarum. 4to. Lips. 1818. - Decas secund. Lips. 1820. - Hasbach D. de distortionibus columnæ vertebralis in genere. Svo. Marburg. 1820.-Ward, Practical Observations on Distortions of the Spinc, Chest, and Limbs, Sc. 8vo. London, 1822.-J. Shaw, On the Nature and Treatment of the Distortions to which the Spine and the Bones of the Chest are subject, \&c. 8 vo. London, 1823, illustrated hy plates in folio; and further, Olsservations on the lateral or serpentine Curviture of the Spine, \&c. 8vo. London, 1825. - Dods, Pathological Observations on the rotated or contorted 
Spine, commonly called lateral Curvature, \&c. 8vo. London, 1824.-Jarrold, An inquiry into the causes of the Curvatures of the Spine, \&c. 8vo. London, 1824, with engravings. - Strauss D. de Spinæ vertebralis curvaturis cum statu paralytico junctis. 8vo. Marburg. 1824. - Bampfield, An Essay on Curvatures and diseases of the Spine, including all the forms of spinal distortions, \&c. 8vo. London, 1824. 2d edit. 1826. - Maisonable Récueil d'observations sur les difformités dont le corps humain est susceptible, etc. Paris, 1825.--Good plates in Walter's Museum anatomicum. - Sandifort Mus. anat. Vol. II. tab. 36, 37, 41-43, 50-61, and Wenzel.-Many beautiful examples in Bresl. Mus. No. 3017 -3025, 3329-3348.

(37) Gibber, Gibbus, Cyrtoma, \&c.--Reuss Repertor. Comm. Vol. XIII. p. 3S3. - de Plouquet Repertor. Art. Gibbus, etc. - Wedel D. de gibbere. Jenæ, 1684. - Crell Pr. sectio puellæ gibbosæ. Helmst. 1745; and in Act. Acad. Nat. Cur. Vol. IX. p. 229. - de Haller Pr. Gibbi descriptio. Groett. 1749.Coopinann D. de Cyphosi. Franequer. 1770. - Donner D. de gibbositate. Goett. 1785.

(38) a Roy Com. de Scoliosi. 4to. L. B. 1774. - Reynders D. de scoliosi ejusque causis et sanatione observatione et propriis experimentis confirmata. Groening. 1787. - Pape D. de Scoliosi ejusque casu rariore. 4to. Regiomont. 1808.-Here also belongs wry-neck, which, if it occur in early youth, often pro. duces consequent obliquity of the vertebræ.

(39) G. W. Wedel De Lordosi in Misc. Acad. Nat. Cur. Dec. II. Ann. V. p. 445 .

(40) This kind rarely occurs as a congenital disposition in man, and only in a minor degree.-More frequently in animals, especially in calves, and is then sometimes so great, that the spine can be twisted round once or twice on its axis.--I have seen this several times, v. my Verzeichniss, No. 3034.-Blumenthal D. de monstroso vituli sceleto. 8vo. Regiom. 1826, with lithographic tables.

(41) Much more rarely lowever than in man ; and this, besides other causes, on account of the horizontal position of the spine.-On distortions in animals, $v$. Camper Von den Krankheiten, die sowohl den Menschen als Thieren eigin sind. p. 28. $2 \mathrm{~d}$ edit.-It has been found in monkeys, dogs, \&c. v. Voigtel Handb. der pathol. Anat. B. I. p. 316 ; in the hare, pig, horse, and ass, especially the sinking back; although also other kinds, for instance, great lateral curving. - Rudolphi Bemerkungen, u.s.w. Vol. I. p. 74. -- A humpback, v. Neergaard Beiträge zur vergl. Anatomie, u.s.w. p. 37, tab. 1. Gött. 1807.-In oxen, v. my Verzeichniss, No. 3032, 3034, 3317, 3318. - In lambs, of which I have several examples, v. No. 3323 and 3324 .- In birds, viz. fowls and geese; of the latter, there are two instances in Bresl. Mus. - Examples in Bresl. Mus. No. 3038 and 3039. Even in fishes, v. Camper.--Bergmann Primæ lineæ pathologiæ comparatæ, p. 30, (in Perca fluviatilis).-Bleuland Descriptio Musei anat. No. 2569, p. 407, (in Pleuronnectes Flesus).-G. Sandifort Mus. anat. Vol. III. p. 276, No. 916 and 917.

(42) v. Reuss Repertorium. Comment. Vol. XIV. p. 113.-de Plouquet Art. Vertebrarum Luxatio.-Columbus, Valsalva, Morgagni, Heister, Mauchart, Tabarranus, Palletta, Schack, Cooper, \&c. maintain that dislocation from external causes can never occur without simultaneous fracture; others properly admit them, at least subluxations; viz. Rust in Arthrokakologie, and Boyer, (between the atlas and epistropheus.) - $C h$. Bell describes and engraves several dislocations; a dislocation of the fifth cervical vertebra is described by Thillaye in Leroux Journ. de Médec. 1816, p. 35. Bulletin de la Faculté, p. 26.-Of the seventh cervical by Gaitskell in the London medical Repository, April, 1821, Vol. XV. p. 282.-Edinburgh Med. and Surg. Journ. July, 1819.-Of the fourth cervical, by Lawrence in the Lancet, Vol. XI. p. 749.-v. Deggeller Diss. de luxatione vertebrarum. Altdorf. 1707.-Mauchart $\mathrm{Pr}$. de luxatione nuchæ. Tubing. 1747 . Cuenotte D. s. casum subluxationis vertebræ dorsi cum fractura complicatæ, etc. 8vo. Argentor, 1761.-Murray D. de spinæ dorsi luxationibus. Upsal. 1780.Ludwig De luxatione vertebrarum colli a medico forensi circumspecte disquirenda. Lips. 1787.- Sömmerring Bemerkungen über Verrenkung und Bruch des Ruckgraths. 8vo. Berlin, 1793. - A good collection of cases are given by 
Casper in Rust's Magazin f. d. gesammte Heilk, Vol. XIV. p. 433.--Several also are found in $v$. Gräfe and $v$. Walther's Journ. f. Chir. Vol. III. Part II. p. 197.-J. F. L. Rauch D. de vertebrarum cervicalium luxatione. Svo. Berol. 182S, (of the fifth and sixth.)-[Dislocation between the last dorsal and first lumbar vertebra. v. Med. Gazette, Vol. III. p. 651.-Dislocations of the vertebræ from each other without fracture, are, as far as I am aware, extremely uncommon. T.] Imperfect dislocations in the horse, of which Havemann has spoken, are observed by Lebel.-v. Recueil de Médec. veterinaire. Vol. II. Sept. 1825.

(43) Especially from inflammatory swelling of the vertebræ, caries, destruction of the ligaments, exostosis, Sc. it is most common on the first two vertebræ; it has been also observed by Daubenton v. Allg. Historie der Natur. Vol. II. Part I. p. 68, No. 200.-Duverney Maladies des Os. II. p. 131.-Sandifort Mus. anat. Vol. I. p. 143 ; Vol. II. tab. 14 and 15; Vol. III. p. 384, No.603.-Rust's Magazin f. d. gesammte Heilk. Vol. XII. Part II. p. 413.-Bauer in Tübinger Blättern, Vol. I. No. 2, p. 154.-Sclupke De luxatione spontanea atlantis et epistrophei. 4to. Berol. 1816, with one engraving.-Scluag D. de luxatione vertebrarum spontanea. 4to. Lips. 1817. - de Wagner D. de luxatione capitis spontanca. Svo. Dorpati, 1822, with engravings. - Shaw.-Rosenthal Abhandl. aus dem Gebiete der Anat. Physiol. und Pathologie. Svo. Berlin, 1824, p. 141, pl. 9.-J. Cloquet in Árchives générales de Médec. Jan. 1824, p. 143.-I myself have seen this three times; v. Selt. Beob. I. p. 80, and Verzcichniss, No. 3361 -3363._Bertin Traité d'osteologie, Vol. III. p. 61._Ollivier Traité de la moelle epinière et de ses maladies, Sc. 2 vols. 8 vo. 2 d edit. Paris, 1827. - C. A. Parry.

(44) Compare above \$ 109, note 7.- de Plouquet Repertor Vertebrar. Ancylosis, and Voiglel Handb. der pathol. Anat. p. 227, ff.-It frequently oceurs on all the vertebral regions, viz. between the atlas and occipital bone, between that and the second vertebra, or between all three; hereto belong almost all the cases mentioned in the last note ; further, Göt $\approx$ Diss. de morbor. ligamentor. Halæ, 1798, p. 32.-Kelch No. 8. - I lave twice found it, viz. No. 3360 ; I saw several instances in the Mus. of Brookes at London; in Sandifort's at Leyden; two cases in the Mus. pathologicum at Vienna; three cases in the Anatom. Museum at Heidelberg; an anchylosis of the second vertelura with the occipital bone in destruction of the front areh of the atlas was seen by $J$. Cloquet.-In a horse, Viborg in VeterinairSelsk Skrifter. Vol. III. p. 479, Sc.-Anchylosis of several or all the cervical vertebræ, v. Bacheracht D. sur le Scorbut, $\$ 40 .-$ Albrecht in Act. phys. med. Vol. VIII. Obs. 124, p. 452.-My Verzeichniss, No. 3363, and a similar case in Brookes's Mus.-Sometimes the cervical vertebræe are anchylosed also in very early existing collum obstipum.-Anchylosis of the dorsal and lumbar portions of the spine are very common; also the consolidation of the sacrum with the last lumbar vertebra, and with the coccyx; so also are ancliyloses of the false vertebræ not rare. v. Sandifort Mus. anat. Vol. II. pl. 38-44, and my Verzeichniss, No. $3365-3373$.

(45) I have found this in several human monsters, also in calves and sheep. v. Verzoichniss, No. 3032, 3034, 332\%, S016.-In a calf, G. Sundifort Mus. anat. Vol. III. p. 294, No. 1009, 1010.-In a monstrous stag, G. Jïger in Meclel's Arcliv f. Anat. und Physiol. 1826, No. 1. p. 65 and 66 .

(46) On anchylosis of the vertebre in the horse, v. Albrecht in Nov. Actis Acad. N. C. Vol. VIII. p. 452.-Complete anchylosis of all the dorsal and lumbar vertebra in two horses was found by Greve Erfahr. und Beobachtungen über die Krankheiten der Hausthiere, Vol. I I. p. 3.- Instances of anchylosis in Irorses, v. Sandifort Vol. II . 1). 21.3, No. 68.9-701.-My Verzeiclmiss, No. 3374 -3381. - In an ass, Pilger Handbueh der Veter. Wiss. Vol. II. 1) 1824.-Allg. II istorie der Natur. Vol. II. Part II. p. 22:3, No. 436.-In a sheep, of which I saw an example at $\Lambda$ ffort. - In a boa constrictor.-Sandifort, 1). 213, No. 703.

(4.7) Compare \$ 109, note. 11.-G. Sandifort Mus. anat. Vol. III. 1. 236, No. 639. - $\Lambda \mathrm{n}$ anchylosis of all the vertebra, but only on the right side, after rheumatism, was seen by J. Cloquet, v. Archives générales de Médec. $\Lambda$ pril, 1823. [R. Comnor, in Phil. 'Truns. Vol. XIX. p. 21, gives an account of a spine, "the ligaments of which were so perfectly bony, and their articulations so 
effaced, that they really made but one uniform continuous bone. On sawing through them it was found that the ossification extended two lines deep, and the rest of the surfaces of the bodies were ununited as usual." There is in the Mus. Roy. Coll. Surg. No. 310, one example; and in the Mus. at St. Thomas's Hospital, another of anchylosis of the first vertebra with the occipital bone; and in the latter collection another of the first and second cervical vertebræ, both of which are, I believe, extremely rare. T.]

(48) Ludwig Pr. de Paraplegia e fractura vertebrarum colli. Lipsiæ, 1767.$v$. S̈̈mmerring Bemerkungen über Verrenkung und Bruch des Rückgraths. Berlin, 1793.-Haugk D. de fractura sterni et vertebrarum. 4to. Lips. 1816. Casper in Rust's Magazin f. d. ges. Heilk. Vol. XIV. p. 433.-A. Cooper Lectures by 'Tyrrel, Vol. II. p. 6. [Among the cases related in which, is a most remarkable one of transverse fracture of the atlas, without displacement, which occurred to Mr. Cline, sen. in which, when the head was depressed or elevated, the atlas was displaced from the epistrophea, the dentiform process of which, together with the broken piece of the atlas connected with it, was then thrust against the spinal marrow; the child lived twelve months after the accident. $T$.

(4.9) Ephem. Nat. Cur. Dec. II. Ann. VI. Obs. 142; and ib. Cent. I. Obs. 1; van de Wynperse D. de Ancylosi, p. 21, tab. 1, fig. 4.-Sandifort Mus. anat. Vol. II. tab. 40. fig. 6 and 7, (after a gun-shot, the bullet grew in,) and Vol. III. p. 201, No. 340.- [In Mus. Roy. Coll. Surg. there is a very fine instance of a ball lodged in the vertebral canal; it rests in the front of the arch of the eleventh dorsal on the right side, and has become slightly embedded; its surface is rough, as if corroded. v. further for this in the Spinal Marrow. T.]-One case of united fracture of the spine I saw in Museum of Brookes, and in Hunterian Museum at London. [The preparation here alluded to, is a beautiful example of united fracture of the twelfth dorsal vertebra through the body and arch, in consequence of the man having been bent double by the falling in of a gravel pit. There is not very much displacement, and a broad band of bony deposit passes across the injured vertebra, connecting it with the lower edge of the superjacent vertebra on the left, and with the subjacent one on the right side, to which it is more firmly connected than to the upper. The man lived for twelve months after the accident. 'There is a specimen at St. Thomas's, in which there is a ligamentous union in one of the common cases, in which the fractured upper edge of the body of the lower vertebra had been carried forward with the displaced upper vertebra. T.] - Two instances are mentioned by Richerand Nosographie chirurgicale, and a case by $J$. Cloquet in von Froriep's Notizen. Octob. 1826, No. 322, p. 221.-A case of united fracture of the sacrum is engraved in Sandifort, Vol. I I. tab. 45 , fig. $5-7$.

(50) Compare my Selt. Beob. II. p. 15, No. 7, and Verzeichniss, No. 6, 3321 , and 3322, all three cases on the lumbar vertebræ; the arches were articulated on the bodies.-Howship, Practical Observations in Surgery and morbid Anatomy. Lond. 1816, 101st case.-Shaw, On the Nature and Treatment of Distortions, also relates one instance. The cases related above, at note 33 , by Heiland, Rosenmüller, Ungebauer, and Hebenstreit belong, in my opinion, here, and not to vices of formation.-Lisfranc in Journ. gén. de Médec. Vol. XCVIII. March, 1827.-Jefferys in Lond. Med. and. Phys. Journ. July, 1826.

(51) Here belongs also the so-called Morbus Pottii, in which, at the same time, swelling of some vertebra, distortion, and mostly lameness of the lower extremities, are connected with inflammation; the spondylarthrocacy especially affects the bodies of the vertebræ, particularly in the cervical and dorsal portions of the spine. Compare, on this disease especially, Pott, Remarks on that kind of palsy of the lower limbs which is frequently found to accompany a curvature of the spine, in Chir. Works, Vol. III. p. 349. Lond. 1779.-Palletta Anatom. pathol. Beobachtungen über die mit Lähmung verbundene Krümmung des Rückgraths. Tübin. 1794. - Rust Arthrokakologie, u. s. w. - Schröder D. de Spondylarthrocace. 8vo. Halæ, 1827.- I saw a case of morbus pottii in an old man. v. Selt. Beob. II. p. 17, and Verzeichniss, No. 3363.

(52) Hunculd D. an ab ictu, lapsu, nisuque quandoque vertebrarum caries. Paris, 1742.-Balk jun. Beobachtung über Beinfrass der Riickenwirbel in Mur- 
simnas Journal. Vol. I. p. 49.-Joffion D. sur la caric des vertébres et les abcès par congestion, qui en sont frequemment un effet. Svo. Paris, 1S01. - Fievet D. sur la carie de la colonne vertébrale. Strasb. 1802._Ducasse D. sur la carie du corps des vertébres. Paris, 1S07.-Blackburn D. de spinæ carie. Edinb. 1S22. - Caries on the first two vertebræ after spondylarthrocacy is not rare; instances are given in Reil Fieberlehre, Vol. II. $\$ 102 .-R u s t$ in the Salzb. med. chir. Zeitung. 1813, Vol. III. p. 10S; and in his Magaz. f. d. ges. Heilk. Vol. I. Part II. p. 213; and an engraving of it in the Arthrokakologie, pl. 5 and $6 .-$ Biermayer Museum anat. pathol. No. 227 and 382.-Raimam in Medic. Jahrb. der östreich. Monarchie. Vol. IIJ. No. 1, p. 43.-Schallgruber in der Wiener Literatur-Zeit. 1813, Part III.-Schupke, with engravings.-Carious destruction of the first two cervical vertebræ from vencreal ulceration of the spine, so that the spinal marrow, with its membranes, was exposed from the moutl. v. Tübinger Blätter, Vol. II. Part II. p. 135.-Carious exfoliation of the greater part of the body of the sccond cervical vertebra cured, was seen by J. Syme, v. Edinb. med. and surg. Journ. April, 1826.-Caries of the sacrum, Biermayer No. 107, 234, and 544.-Sandifort, Vol. II. tab. 44, fig. 4.-My Verzeicliniss, No. 3406, 3408. - Caries and erosion of the sacrum consequent on concubitus analis, v. my Verzeichniss, No. 3404.-Ib. No. 3351-335s several instances of caries on the vertebral column.- [An instance of syphylitic caries of the dentiform process of the second vertebra occurred several years since in St. Thomas's Hospital, which so much destroyed it that the mere weight of the head broke it, and the woman was killed by pressure upon the spinal cord. T.]

(53) On the transverse processes of the four lower cervical vertebræ.Palletta Exercit. pathol. Vol. I. p. 62.-On the lumbar vertebræ Biermayer, No. 370.- I lave described several instances of this kind in my Selt. Beob. Part II. No. 33.-A case of caries in consequence of scrofulous suppuration of the throat, v. my Verzeichniss, No. 3352.

(5ł) Knackstedt Medic. chir. Beob. No. 54.-Sclle N. Beiträge II. p. 102.Howship, 100 and 101st cases.- Several instances in the Strasburgh Muscum. Compare Kilian Anat. Untersuchungen iber das 9th Hirnnervenpaar, p. 121.A psoas abscess connected with the vertebral canal. v. J. Jackson in NewEngland Journ. of Med. and Surg. Vol. V. No. 1, Jan. 1816.-Two psoas abscesses connected with each other through the spine, observed by Milroy, communicated by Lizars in Edinb. Medical and Surg. Journ. July, 1825. In such lumbar abscesses, with caries of the spine, ascarides in very rare cases have been found; v. my Selt. Beob. II. p. 41, and Velpeau in Archives gén. de Médecine, Vol. VII. March._-Sandifort, Vol. III. p. 262, No. 839-844.

(55) The destruction of the vertebræ seems to take place, as Scarpa has very admirably shewn, usually from increased absorption, although in rare cases, if the morbid irritation produce inflammation in the bones; also from caries, of which I have an instance. Scarpa himself describes such cases; v. his Sull' Aneurisma reflessioni ed osservazioni anatomico chirurgiche. fol. Pav. 1804, translated by Wishart, 8vo. Ediub. 1805.-Ayrer Ueber Pulsatergeschwiilste, u. s. w. Göttingen, 1800 , p. 16.-Eck De carie articulorum exterıa. 8vo. Berol, 1818, p. 47.-Cerutti Beschreibung der pathol. Präparate zu Leipzig, No. $743,8 \mathrm{c}$.

(55*) [In the Mus. at St. Thomas's Hospital, there are two fine instances of cancerous affection of the spine, which were concomitant witl cancer of the breast. In one instance, the cellular structure of the bodies of the vertchra is so completely destroyed, that they have been crushed by their own weight. In the other, there are distinet scirrlıous tubercles, and the disease does not seem to have proceeded so far as in the former case. 'I'.]

(56) For instance, in oxen and horses on the first cervical vertebra from poll-evil; v. my Verzeichniss, No. 3351. I saw similar instances on the atlas of two horses in the Veterinary College, Jondon, and at Stockholm.-On the spinous processes of the withers of horses, from neglected saddle-gall, on the caudal vertebra from tail-evil, of which I have seen instances in the veterinary schools at Berlin, Viemua, and Alfort, and not unfrequently on the tip of the tail in monkeys, makis, coatimondis, marsupial animals, Sc. in confincment. 
(57) I saw, in the Collection of the Joseph Academy at Vienna, a remarkable fungous exostosis of the spine, in consequence of a blow, projecting into the chest; a lesser one on the lumbar vertebræ, (called osteosteatoma, is found in Sandifort Mus. Anat. Vol. I. p. 188; Vol. II. tab. 59 and 60.-I have a smaller one on the last lumbar vertebra. v. Verzeichniss, No. 3386.-A bony growth on the neck of a dog. v. Viborg in Veterinair-Selsk. Skrifter. Vol. III. p. 493.Spina ventosa on the lumbar vertebræ of a pig, at Alfort.-Spina ventosa and exostosis are frequent on the tip of the tail in long-tailed monkeys, marsupial animals, coatis, \&c. - I found a spina ventosa on some caudal vertebræ of a camelion; v. Verzeichniss, No. 4859.-Also large exostoses on some spinous processes in Lepidopus Peronii and Sparus erythrinus, v. No. 4899 and 4905.An exostosis as large as a hen's egg on the spine of Gadus Eglefinus at Kiel. v. Seidel Index Musei anat. Kiliens. p. 28, No. 21.-A large exostosis on the side of the tail of a fish, v. Sandifort, Vol. III. p. 243, No. 702 ; and on two vertebræ of a boa constrictor, No. 703 .

\section{$\S 136$.}

The RIBS exhibit many variations in reference to their usual NUMBER $;^{1}$ thus they are WANTING, for instance, in human and animal monsters with imperfect development of the upper half of the body, with deficient skull, with cleft breast and spine, congenital curvings, \&c. usually also at the same time with deficient, imperfect, and consolidated dorsal vertebræ, or of themselves several ribs are alone absent $;^{2}$ the absence of one or other ribs, however, occurs also in otherwise well-formed men and animals, without absence of one vertebra. ${ }^{3}$ On the contrary, we find also on one or both sides, ONE RIB TOO MANY, and sometimes indeed when there is a dorsal vertebra too many, or the first lumbar supports a rib $;^{5}$ sometimes, in rare cases, from the seventh cervical vertebra springs a rib, either terminating loosely or connected with the breast-bone, or with the first normal rib. ${ }^{6}$

The SIZE and FORM of the ribs also deviate in various ways; we find them, either as a congenital or acquired state, irregularly SHORT, ${ }^{7}$ of DIFFERENT LENGTHS ${ }^{8}$ on the two sides; next, as it were, the commencement of duplicity, unusually THICK, ${ }^{9}$ BROAD, ${ }^{10}$ and MORE OR LESS DIVIDED at their front ends $;^{11}$ lastly, frequently ARCHED in a greater or less degree. ${ }^{12}$ If the dislocated head of the upper arm-bone remain long upon the ribs, then a PIT is formed upon them. We also sometimes observe irregularities with respect to conNexion; thus on account of cleft spine, we observe the heads of the ribs lying in front of the bodies of the vertebræ, and touching those of the opposite side ${ }^{13}$ frequently is the attachment of the front ends of the true ribs deficient, inasmuch as, they are either not connected with their cartilages, or they are not connected by them to the breast-bone, or the cartilages are entirely deficient $;^{14}$ the first rib is even connected by a true capsular joint with its cartilage ${ }^{15}$ two ribs liave, in rare cases, but one com- 
mon cartilage ${ }^{16}$ sometimes instead of seven, only six, or even eight ribs are joined to the breast-bone ; $^{17}$ we have also seen in one disease the costal cartilages separated from the ribs, ${ }^{18}$ and in one instance, a costal cartilage Dislocated. ${ }^{19}$ The ribs are not unfrequently anchylosed at their hinder ends, partly with the vertebræ, ${ }^{20}$ partly irregularly connected with each other, in so far as that, as an original or acquired formation, they have as it were been consolidated,,$^{21}$ or by particular processes ${ }^{22}$ or wing-like projections from their edges, jointed with the neighbouring ribs, or grown together. ${ }^{23}$

VICES OF CONSISTENCE in the ribs are also to be mentioned here; we find not merely in rickets, but also often in epilepsy, and idiots, that they are very soft, and bending like fishbones. $^{2+}$ The opposite vices are also found, that is, the too great brittleness and frangibility of the ribs, especially in longcontinued disease of the lungs, in cancer of the breast, \&c. ; in which the cartilages of the ribs frequently participate, as, on account of the increased deposit of lime, they lose their elasticity and flexibility, sometimes on their interior, but more frequently on their external surface. ${ }^{25}$ In consequence of this brittleness of the ribs, their otherwise great disposition to FRACTURE ${ }^{26}$ is very much increased, which, if the motion of the broken parts be not entirely prevented, easily unite out of shape, or with UNNATURAL JOINTS ${ }^{27}$ the latter has many times been found congenital. ${ }^{28}$

Of the vices of Texture of the ribs, we must here notice their frequent ERosion and DEsTruction by aneurysms in the cavity of the chest, ${ }^{29}$ from CARIES in consequence of carsinoma of the chest, from consumption ${ }^{30}$ and empyema; and lastly, Exostoses, ${ }^{31}$ which are observed in rare instances on the ribs.

(1) F. J. Munauld in Mém. de Paris, 1740, p. 377,-v. Sömmerring Vom Baue des menschl. Körpers. 2 d edit. Vol. I. p. 339, \$384. Variations of the ribs.

(2) In anencephalous monsters the upper vertebrx which exist do not support any rib; in many children with anencephaly, hydrencephaly, spina bificla, \&c. I saw, simultaneously with deficiency or consolidation of the vertebrx, deficient ribs on one or both sides; for instance, the five lower on the left side, in No. 2929.-v. Seerig D. de hydrencephaloceles specimine eximio, p. 12. 4to. Vratisl. 1824,-Meclel, Handb. der pathol. Anat. Vol. I. p. 201, found in an anencephalous monster only eight dorsal vertebræ and pairs of ribs. -Morgagni, Ep. an. med. XLVIII. note 50, saw in a monster without a skull, on the right side only eleven ribs; in a monstrous calf, on each side only four ribs; v. G. Sandifort Mus. anat. Vol. III. p. 295, No. 1010. - In a cliild with spina bifida, only ten ribs; v. Seidel Index Musei anat. Kiliensis, p. 2, No. 12.

(3) The twelfth rib is frequently wanting on one or both sides; for instance, Bölımer Obs. anat. rar. Fasc. I. Praf. p). vi. No. 2.-In two sleletous in Kiel Mus. v. Seidel, No. 3 and 6.-In one case I saw the eleventh rib wanting, with the left half of the spine. v. Selt Beol. I. p. 15, Verzeichniss, No. 3018. - In an adult man, the third, fourth, and fifth ribs were wanting on the left side, as a 
vice of formation. v. Lallemand in Ephémérides médicales de Montpellier, Vol. I. Févr. 1826. - Several instances in Voigtel Handb. der pathol. Anat. Vol. I. p. 324 .

(4) Compare Meckel De duplicitate monstrosa, p. 28.-Voigtel.

(5) Bertin Osteologie, Vol. III. p. 142.-Böhmer, Fasc. I. Præf. p. vi. No. 3.van Doeveren Spec. Obs. academ. p. 199 and 201.-Hunauld, p. 536.-Ruysch Diluc. velc obs., Cap. 4, Obs. 1.-v. Haller in Boerhaave's Prælect. ac. Vol. V. Part I. p. 74.-Morgagni Epist. V. p. 6, 10.-Gemmil Medic. Essays and Obs. Vol. V. Part I. p. 336.-Acta med. Berolin. Dec. I. Vol. IX. p. 58. N.-Five instances in Meckel, p. 30.-A case at Moscow, v. Loder Index Præparatorum.A case in Bresl. Mus.-Nineteen pairs of ribs in a horse at Hanover. v. Rudolphi Bemerkungen, u.s. w. Vol. I. p. 74.-In the Veterinary School at Stockholm I saw in an ass, on one side of the first lumbar vertebra, a supernumerary rib full seven inches long.

(6) Bertin.-Böhmer, No. 2.-Leveling Observ. anat. rar. p. 145, tab. 5, fig. 3-5. - Meckel found this only on one side in an adult. v. his Archiv. f. d. Physiol. Vol. I. p. 6.-I have seen two instances. v. my Verzeichniss, No. 14 and 3011.- I saw a third in the Anat. Mus. at Christiana, in an adult; the ribs go one side as far as the middle in the one, but on the other to the breastbone; and a fourth, at the Joseph Academy at Vienna, from an adult woman; the supernumerary ribs do not reach the breast-bone, Polthoff D. s. descriptionem casus rarissimi spinam bifidam totalem exhibentes. Berol. 1827, p. 11.

(7) And therefore the chest either completely or partially too narrow; I have several times found this congenital, especially in children with abdominal cleft and undeveloped lungs, also in some monstrous calves. v. my Selt. Bcob. I. p. 6, and Verzeichniss, No. 3012.-Fleischmann De vitiis congenitis circa thoracem et abdomen, p. 7.-Also in later years we find the malproportion of the chest to the other parts of the body frequent, especially in consumptive persons.-Frequently the last rib is very short.

(8) I saw this most remarkably in a lateral cleft of the chest. v. Fleischmann, p. $6, \S 5$, tab. 1, fig. 2.-I also have seen it several times as a vice subsequently originating in diseases of the chest, as the chest conforms itself to the form of the viscera it contains; if therefore one lung have not its proper bulk on account of tubercles, hepatization, compression, \&c., so is the chest not properly developed on that side. In a child which had for a long while laboured under empyema of the left side, I saw the chest distinctly compressed on that side.--Similar cases are described by Malmstrom Præs. Florman De insolita costarum depressione, etc. 4to. Lundæ, 1807.-Sommer in v. Gräfe and v. Walther's Journ. f. d. Chir. Vol. VII. Part IV. p. 605.-Celloez in Journ. de Médecine, Vol. XVIII. p. 161.-Laennec Sur l'auscultation immédiate, etc.-In other cases is the one half of the chest very much enlarged by prominence and expansion of the ribs, as well as distortion of the spine, from the collection of water or pus in one of the pleura; here also I have some examples.-Pitcairn in Med. chir. Trans. of Edinb. Vol. II. 1826, describes a case of this kind in progress.

(9) For example, in a case which I have described in my Selt. Beob. I. p. 6. - Sometimes there are only single ribs so thick; to wit, the seventh, in No.2929, of Bresl. Mus. v. Seerig.-Or with other thinness merely the anterior end of the rib very thick. v. Fleischmann, $\$ 6$.

(10) Sometimes we find this only on one, sometimes on several at once, especially if the fore extremity of the rib be cleft.-In $v$. Soemmering's Museum there is a rib an inch and a half broad. v. his work Vom Baue des menschlichen körpers. 2 d edit. Vol. I. p. 340.

(11) Albinus Adnot. acad. L. II. c. 13, tab. 7, fig. 8.- Histoire royale de Médec. à Paris, 1779, pl. 3, fig. 5.-van Doeveren Spec. Observ. acad. No. 13, p. 203.-Sandifort Mus. anat. Vol. II. tab. 49, fig 3; Vol. III. p. 289, No. 991. -Walter's Anat. Mus. p. 185, No. 681-684.-Meckel, p. 29, mentions several such in his collection.-I have also found this formation seven times. v. Selt. Beob. I. p. 71, and Verzeichniss, No. 3445-3451.-Kelch describes a case in Beitr. zu pathol. Anatomie, No. 12. This cleft occurs, as it appears, only on the true ribs; also in animals, for instance, in cattle. v. Sandifort, Vol. III. 
p. 2S9, No. 995 , and p. 295 , No. 1010 ; in the latter case another rib expanded into three extremities, as Bertin also observed in the human rib in the last described case.

(12) Very common, and in very different kinds, especially with distortion of the spine; in consequence of pressure from bandaging and lacing. v. von Sömmerring Ueber die Wirkungen der Schnürbriiste, 8vo. 2d edit. Berlin, 1793. - In monstrous sheep and calves, I have seen not merely the ribs unnaturally straight, but even bent inwards; to wit, in No. 3028 of my Verzeichniss. The distorticn of the ribs, with that of the back and left chest, is peculiar to some races of cattle.I have met with such an instance, v. my Verzeichniss, No. 3034. -- Sandifort, Vol. III. p. 295. No. 1011. - Cerutti s. Weese De cordiscetonia, p. 40. Berol. 1S18. - I have seen this in two calves in the Veterinary School at Berlin.

(13) I saw this in the Anat. Mus. at Zuricl.

(14) Especially in monsters with prolapse of the thoracic and abdominal viscera, thongh also in others; compare Meckel Handb. der pathol. anat. Vol. I. p. 93, ff. - Sandifort in Obs. anat. pathol. L. III. C. I. p. 16, describes a case, in which the greater number of ribs, of both sides, were not connected with the breast-bone; only the upper four ribs of the left side were joined to the breastbone, Kelch, No. 18.-In a child with frenic hernia, I found the cartilages of the first three ribs not connected with the breast-bone. v. No. 2899 of my Verzeichniss. - In an adult there is another similar case, v. Vallot in the Journ. de Med. chir. et pharm. Nov. 1813. Vol. XXVIII.

(15) I found such a case on the right side in an old man. It was found on both sides by Hensinger. v. Meckel's deutsch. Archiv. f. d. Physiol. Vol. VI. p. 541, pl. 5 , fig. 4 and 5 .

(16) Cheselden, Osteographia, pl. 17, fig. 2. - Albinus Annot. acad. Vol. VII. I. II. p. 8.-G. Sandifort Mus. anat. Vol. III. p. 352, No. 312.

(17) I have found some examples of both vices.

(18) Stoll Ratio Medendi, Vol. VII. p. 1052.-I have found the cartilage of the second rib separated from the breast-bone by abscess. v. No. 3472 of my Verzeichniss.

(19) Martin, in Journ. d. Médec. Vol. LIV. p. 328.

(20) Engravings of it are to be found in Sandifort, Mus. Anat. Vol. II. pl. $41-43,47$. - Several examples are in Bresl. Mus.; it is very frequent in distortion of the back.--In a horse, Sandifort, Vol. III. p. 243, No. 700.

(21) Compare Voigtel, p. 230.-Kaltschmidt Progr. de costis duabus primis veris in dextro pucllæ latere per interpositam substantiam osseam colırentibus. Jenæ, 1767.-Many instances in de Plouquet Repertor. Art. Costar. symphisis. Sandifort has many cxamples, and one very remarkable case, in which four ribs are completely united from behind to before, Vol. III. p. 289. No. 993. The same in two calves, No. 1000 and 1011.-- Meckel noticed congenital consolidation in several cases; Handb. der pathol. anat. Vol. I. p. 201, 211.-Rathke, in Meckel's D. Archiv f. d. Physiol. Vol. VIII. p. 489, describes a congenital consolidation of almost all the ribs on one side.-In Saxtorph's Collection, at Copenhagen, I 'saw a skeleton of a child with deficiency of skull and cleft spine, in which all the ribs of both sides were consolidated in the middle.-I found this consolidation on three ribs, in No.2929. v. Seerig D. de hydrencephalocelis specimine eximio, p. 12. 4to. Vratisl. 1824. - Further, in my Verzeichniss, No. 3153.

(22) Morgagni De sed. et caus. morb. Ep. XLVIII. note 50.-Leveling Observ. anat. rar. p. 153, tab. 5, fig. 6.-Sandifort Mus. anat. Vol. I. p. 1S0, 197, 198; Vol. II. p. 48, tab. 47, fig. 6 and 7.-Rosenmiiller De singul. et nativ. ossium c. h. varietatilus, p. 55. - Kelch, No. XIII. - In a pig, Blumenbach Geschichte und Beschreibung der Kinochen. 2d edit. p. 352.

(23) Of this I have several examples; and probably No. 34.52 of my Verzeichniss belongs here.-In one case these leaf-like processes were joined by a suture. v. Sandifort, Vol. 11I. p. 289, No. 992.

(24) Greding's Säinıntl. medic. Sclıriften, I. p. 333.

(25) Extensive ossification of the cartilages of the ribs, especially in the form of little bony plates and scales in the membrane of the cartilinges, I found 
common, particularly in consumption, and also in tubercular lisease. It has also been seen in animals; for example, in a horse. v. G. Sandifort Mus. anat. Vol. JII. p. 288 , No. 982.

(26) Viole Diss. de costarum fractura. Paris, 1788. - Vacca Berlinghieri Mémoire sur les fractures des côtes, in Mém. de la Soc. médic. d'émulation. Ann. III. p. 151.

(27) Sandifort Obs. anat. pathol. L. III. C. X. p. 135.-van Doeveren Specim. obs. acad. Cap. XIII. p. 204.- Some of the fractures of the ribs of horses, oxen, and sheep, related by $G$. Sandifort, Mus. anat. Vol. III. p. 185, ff. No. 243-246, 249-252. p. 381, No. 580, belong here. One example in an ox, in the Strasburg Mus. v. Kilian A natom. Untersucliungen über das neunte Hirnnervenpaar, p. 136 .

(28) Meckel Beiträge zur vergl. Anatomie, Vol. I. Part II. p. 138.-I once found this in some ribs of a monstrous calf, and of a monstrous sheep, No. 3028 of my Verzeichniss.

(29) Ruysch Observat. XXXVII. - Morgagni De sed, et caus. morbor. Epist. XVII. p. 25 ; Epist. XXIII. p. 25 ; Epist. XXVI. p. 5. - Walter Anatom. Mus. Vol. II. p. 103 , No. 560 ; p. 114 , No. 561 ; p. 121, No.563. - Baillie, Morbid Anatomy.-I have found it thrice. v. below, on Aneurysm. - Janin in Bulletin de la Soc. médic. d'émulat. July, 1817. - Salomon in Petersburg. vermischt. Abhandl. 1825, p. 164 .

(30) Bleuland Icones anat. pathol. Fasc. II. pl. 8.

(31 A remarkable exostosis attached to the ribs and breast-bone of a lorse, measuring seven inches in every diameter, I saw at Alfort; it is, probably, the same which Grognier, in Journ. de Médec. contin. Dec. 1810, p. 505, described. - Ekström found a cartilaginous exostosis, weighing several pounds, which included six ribs. v. Ars. Berättelse om Svenska Läkare-Sällskapets Árbeten. Stockliolm, 1826.

\section{$\S 13 \%$.}

The BREAST-BONE is sometimes entirely waNTING, or is often very imperfectly formed in monsters with acephaly and prolapse of the viscera of the chest and belly. In the latter it is also frequently cleft throughout its whole length, or only at the upper, middle, or lower part. ${ }^{1}$ We, however, miss in rare cases, without prolapse of the viscera of the chest, and when the common integuments are undivided, the whole or part of the breast-bone; or it is found cleft. ${ }^{2}$ The lowest degree of this formation is in the common perfect division of the point of the breast-bone $;^{3}$ not unfrequently there is a hole in the lower part of the breast-bone $;^{4}$ the bony kernels lying together in pairs, and their often long-continued existence in that state, ${ }^{5}$ and the too late and too incomplete ossification of the breast-bone.

Variations as to SIZE and FORM occur very frequently in the breast-bone, ${ }^{\circ}$ sometimes to a remarkable degree; thus, for instance, we see it remarkably short, ${ }^{7}$ small, or on the contrary, very long, ${ }^{8}$ broad, ${ }^{9}$ bent inwards, unusually arched and projecting, or arched and malformed in other directions. ${ }^{10}$

As to vices of ConNexion, we observe in the later period of youth, and even in manhood, that the original bony kernels remain unconsolidated. There is a kind of articular motion 
between the handle and the body of the breast-bone, which has been observed not merely in very narrow-chested children, ${ }^{11}$ but sometimes even in adults. ${ }^{12}$ Frequent is the opposite vice, the complete immobility of the breast-bone, in consequence of anchylosis of its pieces. ${ }^{13}$ Once there was found an unnatural ligament on the breast-bone. ${ }^{14}$

We must mention among the vices of CONSISTENCE, imperfect fractures or cracking of the breast-bone, and its complete fractures,$^{15}$ which appear not rarely as distinct longitudinal and transverse fractures. One longitudinal fracture of this bone remained ununited through life. ${ }^{16}$

Lastly, as to vices of TEXTURE in the breast-bone; here especially must be mentioned the not unfrequent RICKETY and INFLAMMATORY POROUSNESS, and LOOSENESS, ${ }^{17}$ the frequent EROSION and PERFORATION, of the breast-bone by aneurysms of the arch of the aorta, ${ }^{18}$ CARIEs, ${ }^{19}$ which not unfrequently arises from scrofulous glands and from abscesses within the anterior mediastinum, and as a more rare condition, SPINA VENTOSA, ${ }^{20}$ EXOSTOSES, ${ }^{21}$ and OSTEOSARCOM. ${ }^{22}$

(1) v. Wiedemann Ueber das fehlende Brustbein. Braunschw. 1794.-Mcckel. Ueber Spaltungen der vorderen Körperflache, v. Handb. der pathol. Anat. Vol. I. Sect. II. P. 93.-Fleischmann De vitiis congenitis circa thoracem et abdomen. p. 1, tab. 1.-My Selt. Beob. I. p. 64.-In a child with a large umbilical rupture; I have however since seen cleft of the breast-bone in three human monsters, and in one monstrous calf ; in another calf both halves of the breastbone with their ribs were curved back on the spine. v. Sandifort Mus. Anat. Vol. III. p. 295, No. 1011.-No. 3034 of Bresl. Mus. is similar.-An instance of deficient formation of the breast-bone, with prolapse of the heart, is described by Chaussier in the Bullet. de la fac. de Méd. de Paris.

(2) Ficker Beiträge zur Arzneiwiss, Part I. p. 76.-Wiedemann.-v. Sömmerring Vom Baue des menschlichen Körpers. 2d edit. Vol. I. p. 347, note 5.Chaussier. in a man of twenty-seven years, there was only the manubrium present.-Deficiency of the lower part of the breast-bone in a young person. v. G. Sandifort, Vol. III. p. 393, No. 662.-C'ullerier in Journ. gén. de Mrédec. No. 292, saw it divided to the lowest extremity in a woman of thirty-one ytu... In a calf with two supernumerary fect on the breast, the sternum is completely divided or remarkably doubled, without any ribs between. v. No. 3031 of my Verzeichniss.

(3) I have found these clefts very wide in several children with umbilical or ventral ruptures; in many instances, instead of a cleft there have been one, more rarely two holes in the ensiform cartilage.

(4) I have four examples before me; in one case, where the lower part of the breast-bone was wanting, I found in the middle very broad part, consisting of several pieces, a hole covered with menıbrane. v. Sandifort Mus. Anat. Vol. III. p. 898 , note 662 .

(5) Two symmetrical bony germs, close to each other, in the handle of the breast-bone. v. Meckel in Beiträgen zur vergl. Anat. Vol. II. Part I. p. 145, pl. 1, fig. 8. II andb. der pathol. Anat. Vol. I. p. 115; and myself in one case. v. Selt. Beob. I. p. 7. -I have seen these bony germs lying symmetrically in pairs in the middle pieces in four young skeletons, and indeed even in two boys nearly sixteen years. v. No. 7 and 8 of my Verzeichniss.

(6) Eustachius in Ossium examen, p. 197 and 'Tab. anatom. tab. 47, fig. 18-21. 
-Allinus Icon. ossium Fœtus, p. 75-95.--Sandifort Mus. anat. Vol. I. p. 179, No. 191-193, 196; Vol. II. tab. 46. -The cartilaginous tip of the breast-bone particularly also varies in respect to size and form.

(7) In children with cleft of the belly, large umbilical rupture, and in other cases in which the chest, in proportion to the belly, is not properly formed; I saw the latter once, as it were, with remarkable breadth, in a child with rachitis congenita. v. my Selt. Beob. I. p. 6. It sometimes appears very short, if the point of the cartilage be either deficient or very small.

(8) In one monster it reached to the symphysis pubis, with which it was connected by cartilage. v. Marrigues in the Mém. de Mathém. prés. à l'Acad. des Sc. Vol. IV.-Sometimes the ensiform cartilage alone is remarkably long, reaching down to the navel.

(9) Blumenbach, Geschichte und Beschreib. d. Knochen. 2d edit. p. 365, note 1 , mentions a breast-bone in his collection nearly as broad as the hand; several are before me almost as broad at the lower part.- In a double monster with two spines, but only one chest and breast-bone, the latter as a trace of duplication is very broad, and consists of a double row of bony kernels. v. No. 3028 of my Verzeichniss.

(10) It is often very much curved, especially outwards, as consequent on deficient development of the chest, of rachitis, distortion of the spine, and mechanical influence. Compare van dem Bosch Anatomia systematis respirationi inservientis pathologica, p. 65. 4to. Haarlem, 1801. - Biernayer Museum anat. pathol. No. 99 and 457.-My Verzeichniss, No. 3022, 3331, 3332, 3335, 3465 , and 3466.-To these belong the projecting or hawk breast of horses; the chest of birds is frequently distorted. I have seen this in fowls, pigeons, geese, ducks, guinea-hens, heath-cocks, and a buzzard. Sometimes the ensiform cartilage is strongly bent from internal or external disease. v. Codronchius De morbo novo s. prolapsu cartilaginis mucronatæ, in his work De morbis, qui Imolæ vulgati sunt. 4to. Bonon. 1603.- Septalius De morbis ex mucronata cartilagine evenientibus. 8vo. Mediol. 1632.-Pico Histor. natur. Brasil. p. 36. -Troschel De morbis ex alieno situ partium abdominis. Francof. $\S 28$. a. V. 1754. - The breast-bone was uncommonly twisted and deformed, as a vice of formation, in an adult. v. Vallot in Journ. de Méd. Chir. et Pharm. Nov. 1813, Vol. XXVIII.

(11) Blumenbach, p. 367, note m.

(12) Beauehène Observation sur une sorte d'articulation contre-nature, entre les deux premières pièces du Sternum in Sédillot Rec. périod. de la Soc. de Médec. de Paris, Vol. XXXI1I. p. 287.-Heusinger in Meckel's D. Archiv für die Physiologie, Vol. VI. p. 541, tab. 5, fig. 4 and 5.-In diseases of respiration;-I have also once found it in a man who died of asthma.

(13) I have found this several times.-Many such instances are given by Sandifort Mus. anat. Vol. I. No. 186-189; Vol. II. tab. 46; Vol. III. p. 237, No. 640-642, 646-650.

(14) Kelch, No. 11, p. 8 ; it lay loosely on the external surface of the breastbone, and descended from a transverse ridge between the insertion of the third pair of costal cartilages, down to the ensiform cartilage, and to the sixth pair.

(15) Busnel D. de fractura sterni. Paris, 1761.-Sabatier Mémoire sur la fracture du sternum in Mém. de l'Institut. nation. de Paris. Sc. Mathém. et Phys. Vol. II. Mém. p. 115. - Fr. Haugk D. de fractura sterni et vertebrarum. 4to. Lips.1816. - Compare several cases in de Plouquet Repertor.-A case of longitudinal fracture in Dict. des Sc. médical. Vol. LII. p. 576. - Two cases of transverse fracture from muscular action were observed by Chaussier. v. Revue medicale, 1827. Vol. 1V. p. 260.-A third in Cruveilhier. - I have found one case. v. No. 3474 of my Verzeichniss. - A remarkable union of a fracture in a fowl, described by 'Tilesius in Mém. de l'Academ. des Sc. de Petersburg. Vol. VI. p. 44.-A transverse fracture from violent exertion in labour. v. Compte et Martin in Revue Medic. franc. et étrang. Nov. 1827. Vol. IV. with engravings.

(16) Mcyer Samml. medic. Beobachtungen, p. 714.

(17) I have seen several instances of both.-Cases of inflammatory swelling P 2 
are described by Howship, Pract. Observat. in Surgery and morbid Anatomy, case $51-53$.

(18) Verbrïgge D. de aneurysmate, etc. L. B. 1773, tab. 1 and 4.--Frank De cur. hom. morb. L. V. 2. p. 40.-Baillie, Morbid Anatomy.-Breschet in Journ. de Méd. Chir. et Pharm. 1813. Vol. XXVI. p. 365.-_I have found it four times. v. Selt. Beob. II. p. 64. - Verzeichniss, No. 2257 and 2258 ; and since two cases. - Heisler $\mathrm{D}$. rariorem atque memoratu dignissimam aneurysmatis aortæ sternum perforantis historiam exhibens. Landshut. 1817. -- Sandifort Mus. anat. Vol. III. p. 347 , No. 288.

(19) v. Reuss Repertor. Comment. Vol. XII. p. 243.--de Plonquet Repertor. Sterni A postema. - Biermayer Mus. anat. pathol. No. 143, from Syphilis. -Lobstein Compte rendu, etc. Strasb. 1824, p. 63, No. 51 and 52. - Sandifort Mus. anat. Vol. I. p. 178, No. 184, 185; Vol. III. p. 207 , No. 381 ; p. 347 , No. 2SS.--I have found three cases, v. my Verzeichniss, No. 3471-3473. -- In rare instances, the breast-bone is entirely destroyed, and the opening in the chest filled up by adherence of the opposite ribs. v. Schenk Obs. med. L. II. Obs. 171 and 172, p. 367.--Gazette salutaire de Bonillon. 1789. v. Hufeland's Neuste Annalen der franz. A. Wiss. Vol. I. p. 420.

(20) An instance from the Strasburgh Mus. is mentioned by Kilian Anat. Untersuchungen über das neunte Hirnnervenpaar, p. 136. - A very striking instance in a hen in the Anat. Mus. of the University at Vienna.

(21) Lobstein, No. 53; and a case in a horse at Alfort. v. above, $\S 136$, note 31 .

(22) Sandifort, p. 349, No. 301. - v. Gräfe, 11 ter Jahresbericht über das klinische chir. und augenärztl. Institut. Berlin, 1827, p. 18. [In the Mus. St. Thomas's Hospital there is a preparation of scirrhous tubercles in the sternum; and from the same person tubercles of the like kind in the thigh bone, which was fractured merely in rising in bed, consequent on the absorption of the shell of the bone. T.]

\section{$\S 138$.}

The PELVIS ${ }^{1}$ is, in rare cases of different kinds of monsters, found partially DEFICIENT; thus we miss the sacrum together with the coccyx, ${ }^{2}$ or a part of the lateral pelvic bones in absence of one lower extremity, ${ }^{3}$ in the cleft pelvis, ${ }^{4}$ and in the syren formation; in the latter case we frequently observe the lateral parts of the pelvis consoliclated, whereby the pelvis itself is closed at its lower part, unossified, and more or less malformed. ${ }^{5}$ On the contrary, in monsters, we frequently notice the pelvis in various ways either completely or partially DOUBLE, and as it were, two united into one.

The SIZE and ForM ${ }^{6}$ of the pelvis is very often, as an original or acquired vice, irregular; thus it varies in reference to its breadth in both directions from the normal mass; it may be too narrow ${ }^{7}$ or too wide $;^{8}$ it is variously formed as to its particular diameter's, its cavity, direction, and inclination; and sometimes in consequence of softening of the bones, it is found awry and crooked in very many ways. ${ }^{9}$ Even in adults the form of the pelvis is sometimes very distinctly altered by osteomalacy, ${ }^{10}$ fractures, dislocations, \&c. The pelvis is also frequently irregular as to its ARTICULAR CAVITIES; not merely, as might be supposed, in deficiency of the lower extremities, but even 
when they exist, these cavities are entirely wanting $;^{11}$ or in monsters with consolidated lower extremities, they are not double, but form only a single cavity, placed at the under and fore part of the pelvis, and may be too flat, too narrow, too deep and wide, oval, triangular, and malformed in other ways $;^{12}$ the acetabula indeed are often very much altered and even much widened in later life by various diseases $;{ }^{13}$ should the dislocated head of a thigh bone remain unreduced, the original socket becomes narrowed and flattened by absorption and contraction, or by being filled up with cartilaginous and bony substance, and in its stead a pit and a more or less perfect new socket is formed, where the head of the bone rests. ${ }^{14}$

The connexion of the bones of the pelvis with each other also sometimes exhibits certain irregularities; to these belong, the late consolidation of the hip, haunch, and share-bones with each other in weakly persons $;^{15}$ the crest of the hip-bone with itself; ${ }^{16}$ the want of junction of the share-bones in congenital protrusion of the bladder ${ }^{17}$ sometimes also great mobility on the sacro-iliac joint; the rare complete relaxation, ${ }^{18}$ or rupture of the pelvic ligaments, whence dislocation of the lateral bones arise $;^{19}$ and lastly, the ossification of these ligaments ; consequent to which is the true anchylosis of the ilium with the sacrum,$^{20}$ or more rarely of both the pubic bones. ${ }^{21}$

VICES OF CONTINUITY OR FRACTURES OF THE PELVIC BONES ${ }^{22}$ naturally and very easily occur, not merely in consequence of external violence, but also from difficult labour, and even from violent muscular exertion, and are not unusually united pretty much out of shape, on account of the difficulty of fixing them with bandages.

Among the vices of Texture which affect the pelvis, deserve to be particularly mentioned, partly on account of their frequency, partly on account of their connexion with midwifery, the SOFTENING, swELLING, AND FRANGIBILITY of the bones of the pelvis produced by rickets, scrofula, gout, syphilis, \&c.; next, CARIES and SPINA VENTOSA, which here not only easily arise from the same causes as in other bones, but frequently also from lumbar abscess, decubitus, cancer of the rectum, and especially from diseases of the hip-joint, and also coxarthrocacy; and lastly, ExosTosis ${ }^{23}$ and OSTEOSARCOM, ${ }^{2+}$ both of which are here as frequent as they are large.

(1) Jördens De vitiis pelvis muliebr. rat. partus. 4to. Erlang. 1787.-Creve Von den Krankheiten des weiblichen Beckens. 4to. Berlin, 1795, with eleven engravings.

(2) G. Sandifort Mus. anat. Vol. III. p. 294, No. 1009, in a calf; the hind legs with the ossa innominata attached to the last lumbar vertebra. In another case, only the posterior part of the sacrum with the tail, ib. No. 1010. - Bonn in 
Verlandel. van het Genootschap ter bevordering der Heelkunde. Amsterd. D. III. p. 124, in an acephalous monster.-Myself in a syren monster, No. 3015 in Bresl. Mus.

(3) I have found this a few times in men and animals; viz. in No. 2902 of my Verzeichniss.-In a full-grown pig, with deficient right hind leg, I found the right half of the pelvis very small, and the ischium entirely wanting. v. No. 3027.-Saxtorph, Gesammte Schriften von Scheel, I. p. 314, Copenhagen, 1823, missed the hip-bone at the same time with a lower extremity.-Vrolick Memoires sur quelques sujets intéressans d'Anatom. et de Physiol. trad. par Fallot. 4to. Amsterd. 1822, pl. 3, fig. 1 and 2.-Heusinger in his Zeitchrift f. die organische. Physik. Feb. 1828. Vol. II. Part II. p. 208.

(4) Warwick in Philos. Transact. Vol. XLII. No. 464, p. 152, ff.; and le Sage, in Roux Journ. de Médec. Vol. XXXV. 1788, p. 221, ff. missed the pubic bone.

(5) See below, in the extremities, the observations on the syren formation; in No. 2903 Bresl. Mus., the coccyx is deficient, and the outlet of the pelvis almost closed.

(6) Büchner resp. Schiffert D. de difficultate pariendi ex mala conformatione pelvis. Halæ, 1756. - Thierry D. de partu difficili a mala conformatione pelvis. Argentor. 1764. - Choulant Decas pelvium spinarumque deformatarum. 4to. Lips. 1818 ; and Decas secunda, adjectis nonnullis adnotationibus. 4to. Lips. 1820. - K. W. Schwabe D. de pelvi ejusque deformationibus. 4to. Jenæ, 1828.According to $J$. M. Weber, the form of the pelvis is always in reference to that of the head in malformed skeletons, which 1 have, however, not found constant. v. Nov. Act. Phys. Med. Acad. Nat. Cur. Vol. XI. Part II. p. 411, pl. 1; and Specimen malæ conformationis encephali, capitis et pelvis viri. 4to. Bonnæ, 1828.

(7) It seems to me that the size of the pelvis, equally with the skull, the chest, 8 c. generally depends on the viscera it contains; in the higher degree especially, which originates in deficient development of the generative organs. I have thus found in two adult women the generative organs of the size of those of a child of ten years old, and the pelvis at the same time remarkably small. A similar case was recently shown to me by Professor Lauth, of Strasburg. Also in monsters with deficiency of the rectum, or of various kinds of retarded formations in the generative organs and lower extremities, I have seen the pelvis very small. I have also found the ilium and ischium sometimes in anchylosis, unreduced dislocations, and lameness of one lower extremity, very much wasted.

(8) Ebermaier D. de nimia pelvis muliebris amplitudine, ejusque in graviditatem et partum influxu. 8vo. Goett. 1797.- In congenital prolapse of the bladder the pelvis is usually very spacious, especially too broad.

(9) Compare my Verzeichniss, No. $3019-3025,3383-3425$; -in No. 3020 and 3025 are the pubic bones compressed laterally and closely, and project like a fold; - in No. 3023 the projection of the junction of the left ilium and os pubis is so great, that therc seems to be formed two upper apertures to the pelvis. Descriptions and engravings of very mishapen pelves are given by Sandifort in Museum anat. - Walter in Mus. anat., Köhler, Voigtel, \&c.-In distortion of the spine the form of the pelvis is usually affected, especially in scoliosis.-[ In the Mus. Roy. Coll. Surg. No. 623, is a cast of a female pelvis, in which the upper aperture of the pelvis is only an inch wide between the pubes and sacrum. T.]

(10) de Fremery De mutationibus figure pelvis, prasertim iis, qux ex emollitione ossium oriuntur. Lugd. Batav. 1793. - Wood in Bralley's med. and phys. Journ. 1801, No. 32.—von Sicbold's Journ. f. Geburtshülfe, Vol. III. Part II. 1821. - 'Those cases are more rare in which a too narrow pelvis expands. v. Rust's Magaz. f. d. gesammte Heilkunde. 1825.-[No. 624, Mus. Roy. Coll. Surg. is a cast of a female pelvis distorted in consequence of mollitus ossium, in which the pubic bones are compressed and project forwards, and the acetabula are on the front of the pelvis. 'T.]

(11) They are wanting on one side, as causes of congenital lameness. v. Schreger chir. Versuche, Vol. II ; their entire absence, or mere rudimentary state, was noticed by Dupuytren in liepert. gén. d'A nat. et de Physiol. pathol. Vol. II. seet. ह̈, ]. 150 . 
(12) Palletta Exercit. de claudicatione congenita, L. B. 1787, and Exercit. pathol. Vol. I. p. 64-92.-Prochaska found the acetabula in a cretin very wide, flat and mishapen. v. Disquis. A nat. phys. organ. c. h. tab. 11, fig. 1. Sometimes we find, without disease, a hole in the bottom of the acetabulum merely filled by membrane.

(13) I have described in my Selt. Beob. II. p. 9, No. 9, a remarkable case, viz. a great projection of the bottom of the acetabula on both sides, like a bladder, into the pelvis. v. Verzeichn. No. 34.25. Not unfrequently the acetabulum appears deeper than it should be, in which case its fibro-cartilaginous edge is ossified, or bony matter of some kind is deposited around the edge of the cavity.-[No. 198, Mus. Roy. Coll. Surg. is a fine example of ulceration of the acetabulum, by which an aperture was made through its centre into the pelvis. T.]

(14) Sandifort Mus. Anat. Vol. II. tab. 64-68. - Palletta Exercit. path. I fig. 11, engraves an os innominatum, with three pits, on which at different times the head of the thigh-bone was seell.-Loder Index præparat. II. sect. A, describes a new acetabulum above the crest of the right pubic bone; and the reviewer in Rust and Caspar's Krit. Repert. Vol. XV. Part III. p. 432, mentions a similar case in the midwifery school at Bamberg.-Good engravings of such new acetabula are given in Cooper and Travers's Surgical Essays, Part I. Three cases are found in Bresl. Mus. v. my Verzeichn. No. 3440-3442 and 3443.Tenon, in Mem. de Paris, 1770, Hist., p. 54, describes a rare similar instance in a liorse.

(15) Not even in the seventeenth year; de Fremery, p. 14.

(16) I have seen this a few times in rickety persons, some twenty years old.

(17) Compare the writers on congenital prolapse of the bladder, below, on the Bladder. The pubic bones are often distinctly separated from each other, in adults, to one-third of an inch; they are generally connected by a small tendinous band. At present we have only Walter's observations on the non-union of the pubes without prolapse of the bladder. v. De dissectione Synchondroseos ossium pubis in partu difficili, p. 22. Berol. 1782.

(18) We find the old disputes and opinions about the existence of such laxity of the pelvic ligaments, especially in Michel De utilitate Synchondrotomiæ pubis in partu difficili, p. 4 and 5. Lug. Bat. 1781; and de Plouquet Repert. Art. Pelvis Discessus.-Instances of separation of the pubic joint in natural labour are noted by Eichelberg in Rust's Magazin. f. d. ges. Heilk. Vol. XVII. Part III. p. 550, and Nicholson in the Transact. of Physicians in Ireland. Vol. IV. 1824.-More remarkable are the instances in which in children the bones of the pelvis were very movable; such were observed by Deventer.-Alix Observat. chirurgica, Fasc. III. p. 60.-Palletta, p. 89.- In a woman the pelvis was so movable every time she became pregnant, that she was unable to stand. v. Frank in Textor's Neuem Chiron. Vol. I. Part II. p. 261.

(19) Enaux in Nouv. Mémoires de l'Académie de Dijon, Vol. VIII. No. 6, 1784, sect. I.-Louis in Mémoires de l'Acad. de Chir. Vol. IV.-Creve, p. 137. -I have seen one instance of subluxation. v. my Verzeichniss, No. 3417.- The so-called dislocation of the os coccygis is more probably fracture.

(20) Many such cases are collected by Creve, p. 164.-Individual cases described by Desgranges in Anc. Journ. de Médec. Vol. LXVIII. p. 85.--Lamorier in Mémoires de Montpellier, Vol. II. Mém. p. 243.-Sandifort, Mus. anat. Vol. I. No. 217-232, 242, 246; Vol. II. tab. 61-63; Vol. III. p. 219, No. 459; p. 223 , No. 492 ; p. 237 , No. $651-656$; p. 385 , No. 605 .- Seven instances are described by Bleuland Descr. Mus. anat. p. 257, No. 1390-1396.-Engravings are also given by Sandifort from $C$. $O$. Wagner D. de ancylosi ossium pelvis. 4to Heidelb. 1818 ; and Weidmann D. de comparatione inter sectionem cæsaream et dissectionem cartilaginis et ligamentorum pubis. Wirceburgi, 1779, tab. 2, fig. 1.-I have found sacro-iliac anchylosis six times. v. No. 3387, 3410, 3414 . [No 308, and 309, Mus. Roy. Coll. Surg. are examples of anchylosis at the sacro-iliac joint.-There are also some examples in the Mus. at St. Thomas's Hospital. T.] - It also occurs unnaturally in mammalia, especially in loorses, asses, and oxen.

(21) This is often doubted, though improperly. Instances are given in 
Sandifort, Vol. I. p. 190, No. 216 ; Vol. II. tab. 63 ; Vol. III. p. 238, No. 657 -659; p. 385, No. 607 and 608. - Walther, p. 14.-Köhler Beschreib. der Präparate des Hrn. Loder, p. 11, and Loder's Index Præparator.-I saw one case in Anat. Museum at Heidelberg, and another in Meckel's Museum.-Older cases in Creve, p. 168, and pl. 11.-Also in those animals in which anchylosis of the pubis is not normal, it occurs as an exception, viz. in monkeys, many kinds of dogs, \&c.

(22) Maret Sur les fractures des os du bassin in Mémoires de Dijon, Vol. II. p. 85.-Creve D. de fractura ossium pubis. Mogunt. 1792 ; and on fracture of the pelvic bones, in his treatise Von den Krankheiten des weibl. Beckens, p. 13-18.-Sandifort, Vol. I. p. 17S, No. 1S2; Vol. II. tab. 45, fig. 5-7, (a fracture of the sacrum united at an angle,) tab. 63, Vol. III. p. 199, No. 331 ; p. 204, No. 358. Compare No. 3416 , 3430, 3431, my Verzeichniss.In horses, fractures of the pelvis occur from nuscular exertion. v. Albers in Salzburg. medic. chir. Zeitung, 1808, I. p. 233.-I saw a similar case in the veterinary school at Copenhagen; a fractured pelvis of a loorse, united, in the veterinary school at Dresden; and a human pelvis, fractured in difficult labour, at the Hospital of St. Anna, at Brïn.-In rare cases fractures of the pelvis occur, in which the head of the thigh-bone passes through the acetabulum. v. Lawson in Edinb. Med. Com. II. Dec. III. p. 28.

(23) van Doeveren Specim. observ. acad. Cap. XII. p. 177. - Stark in Baldinger's Neuem Magazin. Vol. V1. p. 73.-van Heekeeren De osteogenesi præternaturali. L. B. 1797, fig. 4.-Murray in neue Samml. der auserless und neuesten Abhandl. für Wundärzte, Vol. II. p. 79.-Wichert D. de excrescentiis præternaturalibus ex interiori pelvis muliebris superficie, etc. 4to. Gött. 1797. - Autenrieth resp. Silber D. de viribus naturæ medicatricibus in situm fotuum iniquum. Tübing. 1799 , p. 31.-Sandifort Mus. anat. Vol. II. tab. 62. - Duret in Bulletin de l'Ecole de Médecine et de la Soc. de Paris, 1810, p. 148.-Bail D. de ossium luxuriatione. 4to. Berol. 1820, fig. 1.-von Persyn D. de exostosium atque osteosteatomatum pelvis muliebris influxu in partum. 8vo. Berol. 1821. - Frank.-I have found several. v. No.3386, 3387, 3393, 3403, 3405, 3428, 3429, my Verzeichniss, and one as big as the fist, and hard, deep in the pelvis of a very rickety boy.Exostosis on the pelvis in the region of acetabulum is very common in coxarthrocacy, dislocations, fractures of the neck of the thigh-bone, and gouty aflections of these parts. v. engravings of them in Sandifort Mus. anat. Vol. II. tab. $67-74,79$. - Also in animals exostoses occur on the pelvis.-I have seen several on the ilium in horses.-One weighing three pounds on the pelvis of an ox. v. Pilger's Handbuch der Veterin. Wissensch. Vol. II. p. 1819.-Exostosis around the carious acetabulum of a pig. v. Sandifort, Vol. III. p. 241, No. 681.- In the same animal I have found exostosis on the spine of the ischium, and many small ones on the pubic bone and acetabulum in a kangaroo.

(24) Herrmann D. de osteosteatomate. Lips. 1767, p. 23.-Boyer Traité des maladies chirurgicales, Vol. III. p. 594.-Pascal in Graperon's Bulletin des Scienc. médical. Vol. II. p. 265.-Bang in Actis Regiæ Societ. med. Havniensis. Vol. V. No. 8, 1818, (above twenty pounds weight.) - Biermayer Mus. anat. pathol. No. 153, (four pounds, in a child.) - Sandifort Mus. anat. Vol. III. p. 286, No. 972 ; p. 349 , No. $302-305$; p. 391 , No. 641.-At Sartorpl's, in Copenliagen, I saw one so large that it almost filled the whole pelvis.

\section{C.-OF THE BONES OF THE UPPER EXTREMITIES.}

$\S 139$.

'The COLLAR-BONES are occasionally wanting together with the blade-bones in monsters which have no upper extremities; they are, however, missed in rare instances, entirely ${ }^{1}$ or partially, ${ }^{2}$ 
although the latter exist. They vary exceedingly in length, thickness, flexibility, \&c.; thus in imperfect evolution of the chest, they are often very short, very thick and broad, too thin in atrophy of the arms ${ }^{3}$ too straight in deficiency of the upper extremities, and in women who have worn stays from their youth, ${ }^{4}$ and the like. Dislocations ${ }^{4 *}$ of the collar-bone even on the blade-bone are rare, still more so on the breast-bone; as also are ANCHYLOSES ${ }^{5}$ but FRACTURES ${ }^{6}$ are very common even merely from muscular exertion. ${ }^{7}$

VICES OF TEXTURE occur proportionally but rarely on the collar-bones; however, rickety expansion, erosion from aneurysm, caries, necrosis, and osteosarcom, ${ }^{8}$ have been observed.

(1) In Acephala. v. Henkel Neuc Bemerk. 1st. Samml. p. 60. - Meckel Abhandl. aus der mensch. und vergl. Anat. p. 165 and 173.-In children with cleft breast. v. Mém. de Paris, 1760, p. 58.

(2) I have a few times scen the inner extremity wanting in cleft chest, as also the outer, in absence of the upper extremities.-In an adult the outer fourth of it was hereditarily wanting, and was attached by a little thin process to the coracoid process. v. Martin in Roux Journ. de Méd. Vol. XXIII. p. 458.In a cretin the outer half of both were deficient, and their place supplicd by ligament. v. Prochaska Disquis. anatom. phys. organ. c. h. expl. tab. 8.

(3) v. Selt. Beob. II. p. 32.

(4) Sabatier Tr. d'Anat. Vol. I. p. 172.

(4*) [In the course of the last spring, I saw a dislocation of the sternal end of the clavicle behind the sternum, in a man, which did well. T.]

(5) I know no instance of its occurrence at the sternal extremity; at the scapula many are related. v. Köhler Beschreibung der phys. und pathol. Präparate, u.s.w., p. 11, No. 39. - Sandifort Mus. anat. Vol. III. p. 239, No. 660.

(6) Ph. Wilhelm Ueber den Bruch des Schlüsselbeins. 8vo. Würzburg, 1827, with engravings.

(7) Churchill in the Lond. medic. Repository, April, 1822, p. 289.

(8) Kulmus resp. Möhring D. de exostosi steatomatode claviculæ ejusque felici sectione. 4to. Gedan. 1732. - von Gräfe in 11 ten Jahresbericht des klin. chir. Instituts. Berlin, 1827, p. 18.-- [A very excellent case of osteosarcoma of the clavicle, in which this bone was removed by Mott, of New-York, is given in Med. Gazette, Vol. III. p. 405 . T.]

\section{$\S 140$.}

In imperfect development of the upper extremities we notice, in rare cases, the BLADE-BONE DEFICIENTLY FORMED, sometimes it is too small, too narrow, or cartilaginous, and terminating in a round tubercle instead of an articular cavity, \&c. In imperfectly formed upper extremities its form is also sometimes irregular; thus we find it cleft, as a congenital formation ${ }^{1}$ imperfectly ossified $;^{2}$ its hinder edge sometimes straight, sometimes more rounded; and especially in rickety softening, more or less curved. ${ }^{3}$ The point of the spinous process (acromion) is sometimes a distinct and even movable piece. ${ }^{4}$ If the posterior ligament be ossified, we find a hole instead of the semilunar notch in the upper edge of the blade-bone. 
If the dislocated upper-arm-bone be not replaced, the form of the original socket is changed, and at that part of the bone on which the dislocated head rests, a kind of new socket is produced. ${ }^{5}$ Anchylosis of the blade-bone with the upper-arm is very rare ${ }^{6}$ Fractures, ${ }^{7}$ on account of the exposed position of the bladebone, are not very unfiequent, and especially the complete transverse fracture $;^{8}$ such fractures generally unite perfectly well; shot and other wounds however remain open for a long while, ${ }^{9}$ or if there be a fracture and it do not unite, an unnatural joint is produced. ${ }^{10}$

Among the vices of TEXTURE, which occur in proportion but rarely, in the blade-bones, we must particularly mention scrofulous enlargement, and caries $;^{11}$ still more rare is the partial destruction by aneurysm ${ }^{12}$ and superjacent encysted tumours; necrosis with reproduction, ${ }^{13}$ exostosis, ${ }^{14}$ and osteosarcom. ${ }^{15}$

(1) Hochstïdter D. de spina bifida. Altdorf, 1703.

(2) Thilow Beschreib. anat. pathol. Gegenstände. Vol. I. No. 6. - Cerutti Besclureibung der pathol. Präparate zu Leipzig, No. 4.84 and 485.

(3) I have also seen this in a lioness. v. Verzeichniss, No. 3482 and 3483.

(4) $v$. Sömmerring Vom Baue des menschl. Körpers. 2d edit. Vol. I. p. 414.I have found this also, v. Verzeichniss, No. 2150.-Sandifort Mus. anat. Vol. I. p. 222 , No. 541 .

(5) Sandifort Mus. anat. Vol. II. pl. 99 ; Vol. III. p. 212, No. 419-424; p. 383 , No. 593 ; p. 384, No. 598 and 599. vo my Verzeichniss, No. 3492. Löseke Observ. anat. chir. p. 11.-[Mus, Roy. Coll. Surg. No.436. T.]

(6) Allg. Historie der Natur. Vol. II. p. 68, No. 201. - Ratier in Hist. de la Société de Médec. 1779.-Köhler, p. 11, No. 40.-Walter Mus. anat. II. p. 70, No. 445.-G. Sandifort Mus. anat. Vol. III. p. 239, No. 661 and 662 . - I have seen a similar case in a living person.-[No. 296 and 297 Mus. Roy. Coll. Surg. in both of which the humerus has become anchylosed to the scapula, by ossification of the capsular ligament; but the articular surfaces have not taken on the ossific inflammation. Both specimens are from a feline animal, but of what genus is not known. $\mathrm{T}$.]

(7) Adoue D. de fractura Scapulæ. 4to. Paris, 1787. - Vogt Anat. physiol. chirur. Abhandlung eines sehr seltenen Bruches zweier Schulterblätter und des rechten Schlüsselbeins. 4to. Leipzig, 1800.

(8) I saw a recent instance of this discase in a man, in consequence of a blow, and a united transverse fracture in the Mus. Pathol. at Vienna.-A united fracture of the shoulder-blade is described by Lobstein Compte rendu, etc. Strasb. 1824, p. 64 , No. 78. - I found a similar instance of this kind in a wolf. v. No. 3490 of my Verzeichniss.

(9) Sundifort Mus. anat. Vol. III. p. 186, No. 247 and 248 ; p. 101, No. 338.$\Lambda$ hole made by trepanning in a horse at Alfort, is not entircly closed. v. Rudolphi Bemerkungen auf einer reise, Part II. p. 56.

(10) Flormannn resp. Nerman D. de articulationibus sic dictis accidentalibus. Svo. Itund. 1821 , p. 8 .

(11) In scrofulous and syphilitic persons, in diseases of joints, \&c. No. 3484-3487, 3489; Sandifort Mus. anat. Vol. II. tab. 99, fig. 5 and 6.

(12) l'rom an ancurysm of the art. subscapularis, v. Liston, in Edinb. med. and surg. Journ. Jan. 1820.

(13) Chopart resp. Robert De necrosi ossium theses. Paris, 1776, p. 7. - An instance in a horse at Alfort. v. Rudolphi, p. 55 ; the engraving of it in Edinb. ined. and surg. Journ. April, 1823, 1.217, ficr. 1 and $3 .--\Lambda$ similar case in the Veterinary School at Berlin. v. Kortum D. experinenta et observationes circa regenerationem ussium. tto. Berol. 18\% f, j. 8, fig. 1 and 2. 
(14) A fungous exostosis. Bondin in Lond. med. and phys. Journ. Vol. XLVI. August, 1821. - A large one on the shoulder-blade and collar-bone, Köhler, p. 11, No. 39.-A cauliflower-like one, Lobstein, No. 79. Compare No. 3488 and 3489 of my Verzeichn. - In a horse, around a trephine aperture, at Alfort. v. Rudolphi, p. 56.

(15) Heymann in Rust's Magazin f. die ges. Heilkunde. Vol. XIX. Part III. p. 505.

\section{$\S 141$.}

As to the other bones of THE UPPER EXTRemities, they as well as the last mentioned are often DEFICIENTLY formed in very different degrees; in many cases, in the little rudiment of the upper limb, we find only a more or less imperfect piece of the upper-arm-bone, or this may be wanting at the same time with the fore-arm, and the hand articulated with the blade-bone, ${ }^{1}$ or if only the fore-arm be deficient, with the extremity of the upper arm $;{ }^{2}$ frequently also are the bones of the fore-arm deficient, inasmuch as there is only one of them present, to which the imperfect hand is attached; or if that be deficient, it terminates short and pointed $:^{3}$ the bones of the hand are frequently deficiently formed, and owing to the want of all or individual fingers, they are consolidated or shortened. Without, however, any external deformity of the hand, one of the bones in the metacarpus may be missed. ${ }^{4}$ We find also, on the contrary, SUPERNUMERARY BONES on the fore extremities, and then not merely with excessive number of the fingers, but also with otherwise well-formed joints ; for instance, in the metacarpus, ${ }^{5}$ a phalanx too many on the fingers(?), ${ }^{6}$ unusual sessamoid bones at the elbow joint, ${ }^{7} \& \mathrm{c}$.

The FORM of the bones of the upper extremities varies not merely as to their different formal vices, in numerous ways, from what is regular, ${ }^{8}$ but is also frequently changed by diseases; for instance, in imperfect growth of certain regions, ${ }^{9}$ in arms lamed ${ }^{10}$ and curved by rickets, in club-hands, from DISLOCATION, ${ }^{11} \& \mathrm{c}$.

ViCES OF CONNEXION, both Dislocations and ANCHYLOSIS, ${ }^{12}$ as well as FRACTURES ${ }^{13}$ and wounDS, are naturally very common in the bones of the upper extremities of man; in animals also similar vices are not unfrequent. ${ }^{14}$

Vices of TEXTURE, of the most different kinds, very frequently occur in the fore extremities both of man and animals, as Rickety ENLARgeMent, CARIES, SPINA VENTOSA, ${ }^{15}$ NECRosis, Exostosis, and osteosarcom.

(1) Dumeril in Bulletin de la Soc. philom. Vol. III. p. 122.-I have seen a similar case. v. No. 2894, my Verz.

(2) Flachsland Obs. anat. pathol. Rastad. 1800, p. 44. - Palletta Exercit. pathol. 1. p. 139, tig. 9.-Hesselbach Beschreib. der pathol. Präparate za Würzlurg, p. 13, No. 71 and 72. 
(3) Of all these vices I have instances before me-Absence of the radius is not rare when there is no thumb, and in bending inward of the hand. I have seen this four times. - Similar cases are given by Wiedemann in Isenflamm's and Rosenmüller's Beitragen zur Zergliederungskunst. Vol. I. Part I. 1).42; and Fleischmamn in Leichenöffiungen, p. 259, No. 92. - Compare the different malformations further on, and the observations on the extremities in particular.

(4) Sandifort Observat. anat. pathol. L. III. C. X. p. 136.

(5) Sulzmann Decas Observat. anat. Argentor. 1725, p. 3, rev. in Halleri Coll. Diss. anat.--Nine carpal bones in man. v. Vol. VI. p. 69. - Sandifort.In the horse, ten bunes instead of seven in the carpus. v. Pilger Handbuch der Veterin-IViss. Vol. II. p. 527.-On a rana temporaria, a supernumerary carpal bone, v. Carus Von den Urtheilen des Knochen-und Schalengeriistes. fol. Leipzig;, 1828, p. 133, §590.

(6) Columbus De re anatomica, p. 4.55.

(7) A large one on the olecranon. Chenal Observ. botan. 4to. Basil. 1766, $\$ 28$; and Rosermiiller D. de sing. et rar. oss. c. h. variet. p. 62.-One on the point of the coronoid process. v. son Sömmerring Vom Baue des Menschl. Körpers. 2 d edit. Vol. I. p. 425.

(\$) As a rare cxample, I have once seen the bicipital groove wanting on the upper-arm-bone, with deficiency of the long head of the M. biceps cubiti.Less rare is the communication between the anterior and posterior pits at the lower part of the bone.

(9) For instance, the fore-arm, on account of disease in youtl. v. No. 3503 and 3504 of my Verzeichn.

(10) I have described a good instance in my Selt. Beob. II. p. 32, and Verzeich. No. 3502.

(11) The form of the head of the upper arm varies much, especially if it be dislocated; in which case it is, as it were, compressed and flattened.

(12) Many instances of it in Bresl. Mus. No. 3572-3574.

(13) The lesser fractures are easily overlooked; to wit, that of the olecranon. On this fracture, v. de Plonquet's Repcrtor. Art. Olecranon; also Camper and Alcock, Sc. \$142, note 8. - Bizion D. de fractura olecrani. 4to. Paris, 1786 ; and Feiler Ueber den Bruch des Olecranums, nebst einer neuen Methode denselben zu heilen. Svo. Sulzbach, 1811.-On fracture of the processus coronoidcus, v. Schrebelins D. de fracturis in genere et de fracturæ cubiti natura et curatione. Basil. 1602.-Combes Brassard Sulla frattura del' apofisi coronoide del cubito. Montauban. 1811.-Kü̈nholz in Ephémérides médicales de Montpellier. March, 1826.-Several instances of united fracture of the bones of the arm, in Bresl. Mus. No. 3577--3593.

(14) Especially anchyloses in the horse.-On the skeleton of a monkey, in the Zuot. Mus. at Paris, between the fore-arm and carpus. -- In a wolf, v. my Verzeichn. No. 3575 and 3576.-In a bird, No.3594.-At Alfort, I saw, in a dog, in dislocation, a new articular pit formed on the olecranon, for the humerus.

(15) I have recently seen some remarkable cases in the MIus. Anat. Pathol. at Vienna; viz. on the lower end of the ulna, a spina ventosa, as big as an ostrich egg; and two cases on the cnd of the radius, as big as the head of a child two years old.--It also occur's in animals; thus $I$ found it on the uhna of a liorse, on the metacarpal and pastern bones of an ox, at Alfort.-On the great wing-bone of a parrot, in the NIus. of Sandifort. v. Rudolphi, Part I. p. 131.

\section{D. - OF THE BONES OF THE LOWER EXTREMITIES.}

$\$ 142$.

The bones of the lower extremity, like those of the upper, are found congenitally DEFICIENT, inasmuch as they may be 
altogether wanting, or only imperfectly developed in certain regions. ${ }^{1}$ But they have this peculiarity, that, in the syrenlike monsters, there exists a greater or less degree of CONSOLIDATION; the frame-work of two extremities indeed is found, which are merely connected below at the feet alone, or at the knees, or there may be only the frame-work of one lower extremity, in which case, however, by the greater breadth and duplicity of the articular surfaces we can distinguish the consolidation of the two; at the same time all the bones may be so turned round upon their axis, that the parts usually in front are situated behind. ${ }^{2}$

The opposite vice, or the EXCESSIVE NUMBER of bones in a more or less double lower extremity is at once shown by its external form.

The SIZE and FORM of the bones in the lower extremities frequently appear irregular; to these belong especially, the disproportionate shortness or length of the bones of the thigh and leg, or only in one of these regions; their occasional unequal length in the two extremities; the articular extremities very often rendered too broad in rickets, and as it were dislocated; the crookedness of the long bones, which is no where else so common and so great, partly congenital, partly produced especially by rickets; the malformation of the bones of the foot, in club-foot, ${ }^{3}$ and from wearing too small shoes; and the partially congenital, ${ }^{4}$ partially acquired ${ }^{5}$ varying forms of the upper end of the thigh-bone.

VICES OF CONNEXION AND CONTINUITY which originate in the form and use of the bones of the lower extremity are very common. To the former belong the displacement of the metatarsal bones in club-foot, DISLOCATIONS ${ }^{6}$ from external and internal causes, and ANCHYLOSIS ${ }^{7}$ to the latter, the various FRACTURES, of which those of the NECK OF THE THIGH-BONE ${ }^{8}$ and the KNEE-CAP, ${ }^{9}$ usually exhibit much difficulty of union by callus..$^{9^{*}}$

Vices OF TEXTURE occur in the bones of the lower extremities in man still more frequently than in those of the upper, which may indeed arise from their more active employment, and the more ready influence of injurious causes upon them; to these especially belong, the RICKETY INFLAMMATORY SWELLING of the small bones, as the knee-cap and the bones of the feet, as well as the articular ends of the tubular bones; CARIES, which especially in morbus coxarius, ${ }^{10}$ and in the bones of the knee joint, ${ }^{11}$ is as common as it is dangerous; sPINA VENTOSA, which often produces very large swellings, especially on the thigh and shin-bones $;{ }^{12}$ NECRosis which occurs particu- 


\section{larly on the shin-bone and often on the thigh ${ }^{13}$ the common BONY GROWTHS, ${ }^{14}$ and DEPOSITION OF GOUTY TOPHUS, OSTEO- SARCOM, ${ }^{15} \& \mathrm{c}$.}

(1) v. below in the extremities; a mere rudiment of the thigh-bone has been seen several times-in the case described by Dumeril; although there was on each side a rudiment of the thigh-bone, consisting merely of the head and trocanters, the single bone which formed the leg was not attaclied to it, but articulated with the inferior anterior spinous process of the ilium. In another case there was merely a single bone between the pelvis and the foot. v. Dumas Principes de Physiologie, Vol. III. p. 163.- Sometimes the foot is directly attached to the pelvis, v. Bouchard, Eph. Nat. Cur. Dec. I. Ann. III. c. 12 ; or to the lower extremity of the thigh-bone, v. Flacksland, \&c.; at the same time with the outer toe in one instance was the fibula wanting, except a small portion of its lower end, v. Meckel, Handb. der pathol. Anat. Vol. I. p. 750.- In another case of the foot there were only the hinder three tarsal bones present. v. ib. p. 751, \&c.In a syren monster I missed the knee-cap at the knee-joint. v. Monstror. sex humanor. anat. et phys. disquisitio, p. 40. [In the Mus. Roy. Coll. Surg., No. 105, a foetus, in which both the lower extremities are deficient, and the trunk terminated in a rounded stump about two inches long, with a depression in it resembling an anus. - No. 106 of the same collection, a foetus, in which there is a slight projection from the back of the sacrum, like a rudiment of an extremity. Unfortunately neither of these preparations are dissected, so that no further account can be given. T.]

(2) Compare below in the extremities.

(3) $I b$.

(4) In the syren monsters with but a single thigh-bone, the neck is wanting, and the head is attached on the extreme end of the bone. In a cretin, the neck was wanting, and the malformed head was attached much lower down. v. Prochaska Disquis. anat. physiol. organ. c. h. explicatio. tab. 8, and engraving, tab. 11, fig. 2.-We observe the head of the thigh-bone variously malformed, sumetimes in congenital lameness; otherwise also, however. v. Palletta Exercit. de claudicatione congenita. L. B. 1787, § 82, and Exercit. pathol. Vol. I. In rare instances the pit on the head of the thigh-bone for the round ligament is deficient. v. Genga Anatomia chirurgica, 8vo. Rom. 1687, p. 124.-Nicolai præs. Salzmann Decas Observat. anatom. Argent. 1725, p. 10., abbreviated in Haller's Select. Diss. Vol. VI. p. 694._Caldani Institut. anat. Vol. I. p. 14.5, and Palletta Exercit. pathol. Vol. I. p. 65.-Bonn Thesaurus ossium morbos. No. 22, 43, 47.-Sandifort Observat. anat. pathol. L. III. c. 10, and Mus. anat. Vol. I. p. 203, No. 271; Vol. II. tab. 77, fig. 1 and 2.-Prochaska.-The pit and ligament are, however, sometimes destroyed also by disease, viz. gout. v. Sömmerring Vom Baue des menschl. Körpers. 2d edit. Vol. I. p. 482 , and in Blumenbach's medic. Bibliothek. Vol. III.

(5) For instance, after dislocation, in which the head and neck of the thighbone are often very much changed; thus the former becomes flattened, the latter often shortened and distorted; after gouty affections, and other inflammatory forms of disease, both sometimes become much swollen and mishapen; beautiful delineations of both vices are given in Sandifort's Museum anat. Vol. II. tab. 65-74.-Compare 13. Bell, Remarks on interstitial $\Lambda$ bsorption of the Neck of the Thigh-bone. Lond. 1824.

(6) Among dislocations from mechanical causes, that of the foot is the most frequent; among the spontaneous, that of the hip in coxarthrocacy; upon congenital dislocation of the hip-joint. v. Dupuytren in Repertoire général d'Anatomie, etc. Vol. II. p. 151, pl. 4.- -Sometimes also merely the knee-cap is dislocated. v. le Vacher 'Theses de variis patellæe luxationibus. Paris, 1761; it then ruls for itself a chase at some other part of the thigh-bone. v. Ver\%eichmiss, No. 3882,-Morean in Sédillol's Rec. périod de la Soc. de Médec. Vol. LXIV. p. 79 ; the so-called strain in the whirlbone, or stiffle strain in the thigh of the horse, is a true dislocation of the patella. 
(7) Imperfect anchylosis of the hip-joint is not rare; there are several instances in the Bresl. Mus. viz. No. 3425, 3436-3439; Allg. Historie der Natur. 2ter Theil, p. 72. No. 222-225.-Sandifort Mus. anat. Vol. II. tab. 69, fig. 1 and 2, tab. 72-74.-More rare is perfect anchylosis. v. Hildanus in Op. p. 882. - de Haen Rat. medend. Vol. I. p. 360.-Allgem. Historie der Natur. Part II. p. 24, No. 226, 230, tab. 3. - van der Wynpersse D. de ancylosi, p. 41, § 38.-Kohler, p. 14, No. 56-62. - Walter, Mus. anatom. Vol. II. p. 71, No. 446 ; and Sandifort, Vol. II. tab. 75 and 76 ; Vol. III. p. 240, No. 671, iristances are mentioned.-It has also been found in a horse at Hanover. v. Rudolphi Bemerkungen auf einer Reise, u. s. w. Vol. I. p. 77. - The anchylosis of the thigh-bone, with the shin-bone, the splint-bone, and knee-cap, altogether, or singly, is not uncommon. v. No. 3440,3883-3885 of my Verzeichn. - Still more frequently does it occur between the shin and splint bones, at the ankle joint, and between the bones of the foot. v. No. 3886-3889 of Bresl. Mus.[Among the preparations of anchylosis, in the Mus. St. Thomas's Hospital, there are several fine specimens of this disease in almost every joint; among them is one very interesting case of fibro-cartilaginous anchylosis in the kneejoint of a child; and a bony anchylosis of the knee-joint, by which all the three bones are connected, but in a very remarkable manner, the leg being bent forwards at a right angle upon the thigh. T.]-On the foot of the horse, it is especially in ring-bone and spavin not unfrequent.- [In Mus. St. Thomas's Hospital, there is a cast of a simple dislocation of the head of the tibia upon the thigh-bone, in which the tibia is thrown backwards : a very rare accident. T.]

(8) Salzmann D. de curatione ossis femoris rariore, frequentiore colli fractura. Argentor, 1723, rev. in Haller's Coll. Diss. chir. IV. No. 145.-Bordenave D. de fractura colli femoris. Paris, 1771._Ludwig Pr. de fractura colli femoris. Lips. 1755, in Haller, No. 146. - Haase Pr.de fractura colli ossis femoris cum luxatione capitis ejusdem ossis conjuncta. Lips. 1801.-Richerand Dissert. sur les fractures du col de femur, etc. Paris, Ann. VII.-Gerard, Mémoires sur les fractures du col de femur. Gand. 1805. - Hagedorn, Abhandl. über den Bruch des Schenkelbeinhalses. 8vo. Leipz. 1808. - Meyer D. observationes circa fracturam colli ossis femoris. Gryphisw. 1810. - The fracture usually heals only by a mass of ligament, not by bony substance.-A. Cooper, in his and B. Travers's Surgical Essays, Vol. II. 2d edit. Lond. 1820, pl. 1-3; and in his treatise on Dislocations and on Fractures of the Joints, Lond. 1823, and in Observations on the Fracture of the Neck of the Thigh-bone, \&c. 4to. Lond.1823, with plates, first held that this fracture was not united by callus, but by a ligamentous mass.-Colles, in Dublin Hospital Reports, \&c. Vol. II. Dublin, 1818, found this confirmed in nine cases. Similar is the opinion of $C$. Bell, in Observations on the Injuries of the Spine and of the Thighbone, \&c. 4to. Lond. 1824, with plates; J. Wilson, On the Structure and Physiology of the Skeleton, Lond. 1820, p. 243, and H. Mayo in London med. and phys. Journ. Decbr. 1826. -The opposite opinion is held by Earle in Practical Observations in Surgery, Lond. 1823; London med. and surg. Journ. by Macleod and Bacot, Vol. L. October, 1823, though without mentioning cases of union. A rare notice of such cure is given by Liston in Edinb. med. and surg. Journ. A pril, 1820.van Houte $\mathrm{D}$. de collo femoris intra ligamentum capsulare fracto et rite sanato. 8 vo. Amstelod. 1824, with engravings. - Dzondi, De colligendo, conservando, disponendo et inspiciendo Museo anat. pathol. 8vo. Halæ, 1825, p. 13, had seen cases of this kind in Leyden and Brunswick; an instance is described by Begbie in Edinb. Journ. of med. Sciences, Jan. 1826 ; several instances by G. Sandifort, Mus. anat. Vol. III. p. 206, No. 379 and 380, p. 346, No. 273; incipient cure, p. 204, No. 359. I saw a case of this kind in the Anat. Mus. at Dresden, and if I be not mistaken also in Soemmerring's Museum; the cases I have observed, No. 2147, 2148, 3892-3895, and 3925, in Bresl. Mus., exhibit no callous union. I have, however, once seen the neck of the thigh-bone penetrating, as it were, and driven into the cavity of the bone itself, as was observed by Dessault several times, and engraved by Sandifort, Vol. II. tab. 78, fig. 4-7.- [This is by no means an uncommon accident; there are several specimens of it in the Mus. at St. 'Thomas's ; and among others, one sent by Roux, as an instance of fracturcd neck of the thigh-bone united by bone from which it is quite distinct.-The 
fractured neck of the thigh-bone of English surgeons being always within the capsular ligament. T.] - An ununited fracture of the neck of the thigh-bone in a young stag is mentioned by Sandifort, Vol. III. p. 346, No. 272.-J. Amesbury, Observations on the nature and treatment of fractures of the upper third of the thigh-bone, and of fractures of long standing. Svo. London, 1828, with plates. -Instances of cure of fractured neck of the thigh-bone by callus are related by Langstaffe in Med. Chir. Trans. Vol. XIII. Part II. p. 487, London, 1827.G. Sandifort in Niewe Verhandelingen dereeste Klasse vanhet K. Neederlandsche Institut van Vetenschappen. Amsterd. 1827, Vol. I. No. 1, two instances; and Brulatour, in Revue méd. franc. et étrang. Dec. 1827, Vol. IV. p. 398. - [A case of fracture of the neck of the thigh-bone united by bone occurred to Swan, and is to be seen at the Mus. Roy. Coll. Surg.-Another case occurred to Stanley, and is, I believe, in the Mus. at St. Bartholomew's Hospital. -A third to Chorley, of Leeds. T.]

(9) v. de Plouquet Repertor. Art. Patella.-Meibomius de patellæ osse, ejusque læsionibus et curatione. Frank. 1697 ; Langguth D. de fractura patellæ genu. Viteb. 1745.-Koole D. de patellæ fractura. Franequer, 1761.-Allough D. de patellæ transversa fractura. Paris, 1775.-Deidier De patellæ transversa fractura. Paris, 1775.-P. Camper D. de fractura patellæ et olecrani. 4to. Franequ. 1754, and Hagæ Comit. 1789. - Sheldon, An essay on the fracture of the Patella or Kneepan. Lond. 1789.-Hierbuur D. de fractura patellæ. Franequer, 1790.-Buirer in v. Siebold's Chiron. Vol. III. Part I. p. 64._Keller De ossium emollitione morbosa, de perfracti genuum orbis sanationis rarioris causa, etc. L. B. 1816.-Linon D. de fractura rotulæ. L. B. 1816.-Fielding, A case of transverse Fracture of the Patella, in which perfect osseous union was procured. 8vo. Lond. 1822. - de Zutter D. de rotulæ fractura et curativa methodo. 4to. Gandæ, 1823.-Alcock, Practical Observations on fracture of the Patella and of the Olecranon. 8vo. Lond. 1823. Fest D. de fractura patellæ. 4to. Berol. 1827. - Ortalli D. de fr. pat. 8 vo. Berol. 1827. - Callisen, in Actis reg. Soc. med. Havn. Vol. I. p. 307 ; and $A$. Cooper, are of opinion that the transverse fracture of the knee-cap, which usually originates in muscular exertion, is never cured by callus, although many instances are given, besides the several cases of the above authors, by Lallement. v. in Boyer Traité des malad. chir. Vol. III. p. 355, pl. 3 and 5. - Wilson, p. 240.-Langenbeck in D. N. Bibliothek f. d. Chir. und Ophthalm. Vol. III. Part I. - Rodati in Opusc. scientif. Fasc. XII. p. 377, after comminuted fracture.-Bleuland Descriptio. Mus. anat. p. 275, No. 1519.-I have also seen one instance in W. IHunter's Mus., and another in the Anat. Mus. at Prague.I once found a piece of the outer edge of the knee-cap well united, after a perpendicular fracture. v. No. 3908 of my Verzeichniss.

(9*) [Some few years back there was, in the Mus. at Thomas's, a very remarkable instance of fracture of the tibia ununited, in which the fibula, which had remained perfect, increased exceedingly in size, and performed the office of the tibia in supporting the body. It has unfortunately disappeared. T'.]

(10) Compare bclow, § 150 .

(11) J. Russell, upon Diseases of the Knee-joint.

(12) Compare above, $\S 116$.

(13) T. Whately, Practical Observations on Necrosis of the Tibia, \&c. Svo. Lond. 1815, with an engraving.

(14) Compare above, § 119.

(15) Rare on the smaller bones. For instance, on the inside of a knce-cap.-G. Sandifort Mus. anat. Vol. III. p. 141, No. 4, on the first phalanx of the thumb.-Ehrmann Compte rendu, etc. Strasburg. 1827. p. 60, No. 418, b. 


\section{SIXTEENTH SECTION.}

\section{Of the Cartilaginous System. ${ }^{1}$}

\section{$\S 143$.}

Although the cartilages in different parts of the body, especially as they have greater or less commixture of tendinous fibres, (fibro-cartilage, ) exhibit very important differences of structure; they however all agree in this, that they exhibit vices of formation as rarely as morbid destruction, and that they possess also the consequent power to withstand, for a long while, those morbid influences which oftentimes completely destroy the neighbouring parts. As cartilage is formed very early in the embryon, so do we easily comprehend why its actual congenital DEFICIENCY is not otherwise observed than when the parts of which it forms the base, are entirely deficient or are very imperfectly developed ${ }^{2}$ in the latter case the cartilage is not properly formed, but is soft and like membrane, as in the young embryon. $^{3}$

Just as rarely do we observe sUPERnUMERARY cartilages; to these belong certain little cartilaginous pieces, which we observe now and then in the external ear, the nose, the larynx, besides those which are usual; the fibro-cartilaginous mass sometimes formed in dislocations, as well as the thin cartilaginous plates which often show themselves in the new joints on the ends of broken bones; and lastly, the various extraneous isolated bodies which are composed of cartilage or fibro-cartilage, which we meet with as a congenital, ${ }^{4}$ or more frequently as a morbid condition in various organs. ${ }^{5}$

The sIzE and FORM of cartilage rarely deviates, except when the whole organ, in which it is found, appears malformed; still we find now and then even one of the costal cartilages irregularly formed; the cartilaginous rings on the air tube vary uncommonly in their form, are crooked; the menisci in disease are diminished, rubbed through, \&c. The latter also sometimes vary as to their natural position, if from mechanical violence their CONNEXION with the neighbouring parts be disturbed. ${ }^{\circ}$

Not less permanent is their colour, so that often they retain their whiteness and gloss in the midst of ulcerated and mortified parts; we however find them, as exceptions, in certain cases of greater destruction, opake, dull, and yellowish grey; also in the morbid deposition of lime, they lose their bluish, transparent colour; in the severer degrees of jaundice, they 
have been in one instance seen yellow $;^{7}$ lastly, in diseases of young persons, although never red, still, on account of their somewhat increased vascularity, they appear at times paleyellow. ${ }^{8}$

Vices of Continuity naturally do not often occur in cartilages, on account of their great elasticity; we observe, however, in the firmest of them, viz. the cartilages of the larynx and ribs, even in the cartilages of the ear, the nose, and the airtube, especially if by morbid increase of the lime contained in them, their frangibility is increased, very often FRACTURES, which have been observed to unite in the costal cartilages only by a bony callus in form of scales or rings; ${ }^{9}$ those however which are ever so small, as incised wounds of cartilages, unite indeed, but are merely joined by cellular tissue; loss of substance appears to be replaced no otherwise than by cellular tissue. ${ }^{10}$

(1) Böttcher Abhandlung von den Krankheiten der Knochen, Knorpel und Sehnen. 3 Theile. Svo. Königsb. 1796. - Autenrieth resp. Dörner D. de gravioribus quibusdam cartilaginum mutationibus. 8vo. Tubing. 1798.--Cruveilhier Observations sur les cartilages diarthrodiaux et les maladies des articulations diarthrodiales; in Archives générales de Médecine, Vol. IV. p. 161.

(2) The fibrous cartilages in the joints are, however, in very rare instances, deficient. At least $\mathrm{I}$ once could not find, in a perfect syren monster, the semilunar cartilages in the knee-joint; once in a monster with imperfect formation of the face, the meniscus of the maxillary joint; and a few times in new-born children with club hands, the cartilago intermedia triangularis in the wristjoint. - That single or several cartilages of the ribs are deficient, has been alrcady observed above. v. $\$ 136$, note 14 .

(3) For example, in the ears, the eye-lids, the nose, the air-tube, Sc.

- (4) Once in a new-born child, I found an irregular-shaped, angular, tolerably large piece of cartilage, situated beneath the skin of the neck, upon the sternomastoid muscle.-Another child had, in the inside of the upper eyelid, a tolerably large swelling, which consisted of firm cartilage, and was closely attached by a neck to the interior of the orbit. - In a sheep, I have found a few times, between the ear and the jaw, as a rudiment of a second mouth, a process principally composed of cartilage, with a canal leading inwards. v. No. 2322 and 2323.

(5) For instance, in the synovial cavities and the serous membranes, in the womb, the ovaries, in encysted tumours, \&c.

(6) Hesselbach once found a triangular meniscus in the wrist-joint, torn from the ulna, and perforated in consequence of the friction at its base. v. Vollst. Anleitung zur Zergliederungskunde. Vol. I. Part II. p. 37, note. 4to. Arnstadt, 1806. - I once found in a strong man, after a severe strain, the external semilunar cartilage of the knee-joint situated in a cyst-like extension of the capsule, and torn through at its anterior extremity.

(7) Stoll Ratio Medendi.-Störck's Annus medicus, I. p. 150.

(8) This must not be confouuded with the great redness exhibited in the cartilages of young people and animals, from maceration or soaking in water, which Berzelius states to arise from the oxide of iron contained in them.

(9) Lobstein Rapports sur les travaux exécutés à l'amphithéatre d'Anatomie. Strasb. 1805 , p. 11.-Magendie and Desöer have also observed this. v. Cruveilhier Essai sur l'Anat. pathol. Part I1. p.9.-Greve saw it in the cartilages of threc of the false ribs of a horse.

(10) On account of the small number of blood-vessels in cartilage, this is not to be wondered at. - In such injuries also, the membrane of the cartilage, from 
which it especially seems to derive its support, is commonly destroyed, and thus the first step to regeneration is removed. If Laennec, in the Dict. des Scienc. Médic. Vol. IV. p. 129, consider the several thin spots of cartilage on the articular ends of bones to be newly produced cartilage, he is certainly mistaken ; it is much rather the destruction of the cartilage.

\section{$\S 144$.}

Lastly, concerning VICES OF TEXTURE in cartilage, INFLAMMATION in this tissue is so indistinct, that it has been entirely denied. ${ }^{1}$ We must not however exclude them from several vices of texture which are known as the usual consequences of inflammation, and occur also in cartilage; sometimes even slight traces of inflammation itself have been observed. To the latter belong, for instance, swelling of cartilage, inflammatory injection of the vessels in cartilaginous membranes, viz. of the larynx and costal cartilages, as well as in the interior of the cartilage, and particularly of fibro-cartilage, and the pale-reddish and even rosy-red colour which cartilage, and especially fibro-cartilage, sometimes exhibits; although compared with other organs, these signs of inflammation are always very indistinct and their course very tedious. ${ }^{2}$ Inflammation of cartilage hardly ever runs into true ULCERATION with formation of pus; it only occurs when a previous conversion of the cartilage into bone has taken place. The usual consequence of inflammation is the SOFTENING AND DESTRUCTION OF THE CARTILAGE BY MORBID ABSORPTION; it is then found not merely porous and crumbling, but even converted into a greasy or jelly-like fluid, usually greyish, but sometimes also coloured; ${ }^{3}$ or partially and generally withered, or finally more or less eroded; so that it is sometimes seen having many small pits and holes, sometimes lost in many single fibres, separated from each other and standing perpendicularly upon the articular ends of the bones. In such way is not unfrequently a meniscus, and the cartilaginous plate which overspreads a bone, entirely destroyed; in which case the ends of the bones, if anchylosis do not ensue, assume a thick and very rough bony covering, in consequence of the existing inflammation, which, in the motions of the joint, is gradually rubbed down, polished, and assumes a very similar appearance to ivory; ${ }^{4}$ this is sometimes observed in gouty persons. More rarely, after destruction of the cartilaginous covering of the articular surfaces, is the bony matter deposited more largely and unequally, and thus a hilly surface is produced. ${ }^{5}$

As inflammation of cartilage is of so indistinct and chronic a nature, MORTIFICATION and NECROSIS are also very rare in this system; it has, however, been many times observed, that large or small pieces of cartilage, separated from the surface or lying in mortified soft parts, have exfoliated, that the cartilaginous Q 2 
coverings of the articular ends of bones have been lost, indeed that even the whole of large cartilages, for instance, of the ribs and larynx, have been thrown off in malignant ulceration.

The last, and indeed not uncommon consequence of inflammation is ossification, to which, however, all the cartilages have not a similar disposition; thus, for instance, in the cartilaginous tip of the breast-bone, the cartilages of the ribs and larynx, it is very common and extensive; more rarely, however, and imperfectly, the fibro-cartilages of the wind-pipe, the edgings of articular cavities, and the interarticular cartilages; still less in frequency and extent, those of the eyelids, ears, and nose; and the cartilaginous covering of the articular ends of bone, and the pulleys for tendons are perhaps never ossified. This ossification of the cartilaginous system, is distinctly preceded by an increased absorption of the jelly, and a greater vascular development, somewhat similar to the normal ossification of cartilage, so that the genuine cartilage then assumes a more fibrous appearance; and about the cornlike deposition of lime, little arterial nets are observed. In rare cases, especially in the cartilages of the ribs, the lime is deposited only in the membrane of the cartilage, whence these are merely surrounded by a kind of bony shell or rind. Cartilages morbidly converted into bone are equally subject to all the diseases which can affect normal bone.

(1) Autenrieth reviewed by Dörner. - Russell, A treatise on the Morbid affections of the Knee-joint. 8vo. Lond. 1802. - Scott, On diseases of the Joints. Lond. 1828.

(2) H. Mayo, in Lond. Medic. Chir. Trans. Vol. IX. Part I. speaks indleed of a transient inflammation and ulceration of the cartilages of the kuee-joint, which commonly terminate in anchylosis of the joint. We, however, readily see that this is not properly expressed.

(3) We see this as a primary state, particularly common on the fibrous cartilage between the vertebræ, of which especially mention is made by Palletta, in his Exercit. pathol. Vol. I. p. 104-108; and by Brodie, in his Diseases of Joints.--I have also, several times, satisfied myself, that the destruction of the spine may originally spring from the intervertebral substance; but I have never found suppuration, except at the same time the bones and the neighbouring cellular tissue were inflamed. Sometimes in the intervertebral mass, and once also in the cartilage of a rib, more or less large roundish cavities, closed by membrane, which were filled with a brown redelish ichor, containing albumen.

(4) Herzius D. de crepitu ossium. Giessa, 170\% - Leillenfrost in Wesener D. de susurru aurium. 4to. Duisb. 1755.-v. Sömmerring's Abhandlung iber Giclitknochen in Blumenbach's Medic. Bibliothek. Vol. III. Part III. p. 493; and De morbis vasor. absorbent, p. 30. - J. Wenzel D. de ossium arthriticorum indole. 8vo. Mogunt. 1791. - Cruveilhier; and in Nouv. Biblioth. médicale. Jan. 1827 , p. 79.-The latter observer this vice in the jaws, shoulder, and hipjoint; also in the horse.-I have found it not merely on the same spots, but also in the elbow-joint, between the radius and ulna, and especially in the knee joint, of which proofs may be found in the Bresl. Mus.

(5) I have instances of this before me; whether it is of a similar nature with the gouty tophus to be subsequently treated of, I know not; however, in rare cases, it becomes so great as to give rise to dislocations. 


\section{SEVENTEENTH SECTION.}

\section{Of the Fibrous System in General, and of the Joints in Particular. ${ }^{1}$}

\section{$\S 145$.}

The various membranous and ligamentous parts which we include in the fibrous system, exhibit numerous peculiarities, dependent on their position, connexion, and more minute variety of texture; in reference to the frequency and kind of their organic vices, however, they naturally agree with each other in many morbid phenomena, and especially in this, that, with the exception of the periosteum, perhaps, which is very vascular, and by its connexion with the bones more thereto disposed, these parts exhibit proportionally less disorganization, and this only after a long time and very indistinctly, on account of their lower vitality.

(1) Rhases Liber de morbis articulorum in Op. Widmann D. de genuum structura, eorumque morbis. Helmst. 1744. - Curtmann D. morborum articulationis ac symphysis brevis ætiologia ac diagnosis. Giessæ, 1797.-Bacheracht D. de morbis ligamentorum. L. B. 1750.-Park, On the Diseases of the Joints, etc. Lond. 1783.-Götz D. de morbis ligamentorum ex materiæ animalis mixtura et structura mutata cognoscendis. Halæ, 1798, with two engravings.-J. Russel, On the morbid affection of the Knee-joint. Svo. Lond. 1802.-B. N. Schreger Chirurgische Versuche, Vol. II. No. 4. Nürnberg, 1818.-Brodie Pathological and surgical observations on diseases of the Joints. 8vo. Lond. 1818, witl engravings. - Wilson, Lectures on the Structure and Physiol. of the parts comp. the Skeleton, and on the Diseases of the Bones and Joints. 8vo. Lond. 1820. - Lloyd, A treatise on the nature and treatment of Scrofula, describing its connexion with diseases of the Spine, Joints, \&c. London, 1821. W. F. Gniest D. de morbis articulorum. Halæ, 1826. - F. A. G. Geiss D. de morbis articulorum accuratius distinguendis et aptius curandis. 8vo. Halæ, 1826.

\section{$\S 146$.}

First, concerning the vices of NUMBER, SIZE, and Form in this system; these are in general but seldom observed, and especially as congenital. Thus, for instance, the fibrous membranes investing the different viscera, the muscles, synovial membranes, \&c. are only deficient when those parts are wanting; the ligament-fibrous parts are also very constant in their formation, although a fibrous band has been occasionally missed at a joint, or a whole ligament, ${ }^{1}$ and particularly a tendon from a muscle. Sometimes indeed the capsules of joints, viz. those of the shoulder, the hip and knee, are so far imperfectly formed, that there are more or less large gaps in them, by which they are connected with the neighbouring mucous bags. Rarely also is INCREASED NUMBER of fibrous parts observed without duplicature of such organs 
as they belong to, and then almost only in reference to tendons and individual bundles of fibres of joints; here, however, also belong the capsular ligaments constantly existing in irregular joints, which are sometimes formed after dislocations and fractures. ${ }^{2}$

The fibrous parts frequently vary in respect to their THICKNESS and SIZE : thus we find them, in some instances, congenitally, remarkably THIN, and as in the early state of foetal existence, but little tendinous ${ }^{3}$ in other cases wasted and relaxed on account of disease, for instance, in lamed joints. Irregular THICKNESS is mostly a morbid state. Frequently also are certain parts of this system TOO SHORT Or NARROw; to these belong the CONGENITAL STRICTUREs which occur in the aponeuroses of the upper and lower extremities, to such extent, that the subjacent soft parts are retarded in their development; the relative narrowness, and consequent tension which arise in such aponeuroses, when pus, blood, \&c. is effused in them, or the muscles are swollen by inflammation; the ligaments very short on one side in contortions of the limbs and spine, both congenital, and when acquired during youth, ${ }^{4}$ and finally, the MORBID conTrACTIONs, contracture, of certain fibrous parts, viz. tendons and ligaments, which mostly arise from inflammatory irritation after too great extension, cramp, \&c. Just as frequently does the opposite vice, or IRREGULAR SIZE AND WIDTH, occur in such fibrous parts as surround other organs or cavities, and to as great extent, as they are capable of expanding in consequence of a power long operating on them; we find this not merely in swellings of the bones, of the spleen, the kidneys, \&c. of which the fibrous membranes increase in equal proportion; but also the sclerotic coat of the eye, the dura-mater of the brain, the articular capsules, \&c. are often very much expanded by collections of fluid, and then usually at the same time attenuated. Such expansion is frequently seen only at one spot, so that bag-like elongations are then formed. ${ }^{5}$ The bundle-like articular ligaments nearest the articular capsules are also sometimes, in diminished tone, distinctly elongated, and give rise to dislocations. ${ }^{6}$

Mere vices of form very rarely occur in the fibrous system itself; to these belong, now and then, certain varying forms of isolated ligaments, unusual expansion in the articular ligaments, in the broad tendons of the abdominal muscles, in other tendons, and the like.

(1) This especially applies to the ligamentum teres at the hip-joint, which, in some cases as an original formation, but more frequently in consequence of rupture, suppuration and ahsorption, does not exist. Compare above, $\$ 142$, rote 4, and Tioch, in Mém. de Montpellier, Vol. II. p. 354.- I myself have 
twice missed it in syren monsters, and oftener in diseased hip-joints, especially those affected with gout; if the semilunar cartilage in the knee-joint, or the meniscus in the wrist be wanting, their ligaments also naturally do not exist. v. $\S 143$, note 2 .

(2) Compare $\S 109$, note 5 , and $\S 113$, note $9 .-$ Howship imagines that the formation of a new joint takes place only in those dislocations in whicl the capsular membrane, wherein the new bony matter is deposited, is not torn ; this, however, is by no means the case, for after lacerations, tolerably perfect new joints are formed, as I have sometimes seen, and as the case described by Warren proves, in which the slit in the old capsule of the shoulder-joint remained, although at the same time there existed a new capsule with synovial membrane. It however requires a long time before the new capsule, which was at first cellular, becoines of a fibrous nature, which in false joints arising after fractures is very much furthered by motion, as Villerme's experiments on dogs have proved. v. Revue médicale, historique et philosophique. Paris, 182l, Vol. V. p. $68-75$. - In a rabbit the new capsule was formed from the untorn but thickened periosteum of the thigh-bone. v. Howship.-An engraving of a false joint in the upper-arm is given by Delpech in his Chirurgie clinique de Montpellier, Vol. I.-Observations and engravings of similar joints in the thigh-bone and fore-arm are given by Kuhnholtz in the Journ. compl. du Dict des Scienc. med. Vol. III. p. 289. - An Indian at New-York was obliged to move himself forward by means of a large wooden ball, as he had double joints in both the upper and lower extremities. v. Tilloch Philos. Magaz. and Journ. No. 278, June, 1821.

(3) As it were, merely cellular, membranous-like.-I have seen this a few times in malformed eye-balls, and in the aponeuroses and articular ligaments of imperfect extremities.

(4) Very common in club-hands and feet, wry-neck, and other distortions, in which cases I have found it common in man, and often also in calves and lambs. Compare further the writers on club-feet.-Murray Fœtus hydrocephalo interno corrupti descriptio. Upsal, 1797.-Rudolphi, Swedische Annalen, Vol. I. p. 123, found it on a foot.-Morgagni, De sed. et caus. morbor. Epist. LXIII. p. 19, found in an old woman one lateral ligament of the dentiform process of the second vertebra much longer and thicker than the other.

(5) For instance, on the dura-mater in hernia cerebri and hydrencephalocele. -We sometimes find in horses, on the hock and pastern joints, tumours full of synovia, which originate in a partial extension of the articular capsule. v. Rohlwes Magaz. f. die Thierarzneikunde, Vol. I. Abhandlung von den Gallen.[They are named by farriers, according to their situation, windgall, when about the fetlock; bogspavin, on the inside of the hock; thoroughpin, on the upper and back part of the hock ; capulet, or capped-hock, on the point of the hock; and capped-elbow, on the point of the elbow. T.] - I have once noticed on the outside of the knee-joint in a man a bag-like expansion, in which, after a severe strain, probably, the external semilunar cartilage, partially torn through, was thrown.-Aneurysmal and varicose expansions of some parts of their fibrous membrane occur on the cellular bodies of the spine, \&c.

(6) There are some persons whose ligaments are naturally so loose and long that they can bend some of their limbs in a contrary direction; thus, for instance, the finger and the thumb especially can be bent so much backwards as to touch the back of the hand. In a case of lameness and great atrophy of the left arm, I found the capsule of the shoulder joint very loose and long, so that the head of the upper-arm-bone hung very low and loose. v. Selt. Beob. II. p. 32, No. 11.-An interesting example of such looseness of several ligaments, giving rise to dislocations, is mentioned by $G \ddot{t} t z$, p. 32 .

\section{$\S 147$.}

The normal colouring of fibrous parts is rarely entirely, although in different vices of texture variously changed; this occurs also sometimes without any other distinct morbid 
change, and indeed from the deposit of animal pigment; to these belong, that in jaundice, as well as the colour but seldom occurring, and more or less yellow, and still more seldom brown or blackish, in melanosis.' In the negro fowls, all the fibrous membranes and ligaments are hereditarily of a blackish colour. ${ }^{2}$

(1) I once found several single black spots on the fibrous membrane of the air-tube; also a few times brownish or blackish spots upon the dura-mater, without distinct vice of texture.

(2) Chapotin Topographie medicale de l'Isle de France, p. 31.-Pallas Zoographia Rosso-Asiatica. Vol. II. p. 90. 4to. Petrop. 1S11.-Temminck Histoire naturelle des Pigeons et des Gallinaces. 8vo. Vol. II. p. 253 and 256. Amsterd. 1813.--Rudolphi Grundriss der Physiologie, Vol. I. $\$ 77$, note 1.

\section{$\S 148$.}

Vices of Continuity in this system are sometimes produced by preceding atrophy or marcor, and by extension gradually increased to bursting, but more frequently by sudden and actual violence. To the latter belong, various wounds with and without loss of substance, the perfect and imperfect rupture of tendons ${ }^{1}$ and tendinous sheaths, which originate not unfrequently in violent muscular exertion, and the rupture of ligaments arising mostly from external violence, which occurs as a usual condition in dislocations from external causes ${ }^{2}$ whilst in dislocations from internal causes, as arthrocacy, collections of water and pus in joints, swelling of the ligaments, cartilage, and the fatty masses in joints, exostosis, ${ }^{3} \& \mathrm{c}$. the ligaments are only more or less expanded; although the latter occur as an exception also in dislocation from external causes, especially in imperfect dislocation without any rupture.

Although simple incised wounds of fibrous organs seem to heal easily and quickly, this, however, is by no means the case with other of their injuries, especially in those with loss of substance, as almost all fibrous parts possess but very confined or even no reproductive power; and commonly wounds and loss of substance in them are only healed and replaced by cellular tissue, which gradually becomes tougher, but seldom actually tendinous. Hence, for instance, ruptured ligaments heal but slowly and imperfectly, so that consequently the reproduced synovial membrane and the new cellular tissue are ruptured by less violence, and the head of the bone is again protruded through the old aperture." The difficulty of reproduction is not, however, equally great in all parts of the fibrous system, as when tendons have been destroyed by suppuration or mechanical violence, they sometimes appear to be not only actually reproduced, ${ }^{5}$ but even the periosteum itself is also easily and quickly restored. 
(1) Compare Reuss Repertor. Comment. Vol. X. p. 63, de ruptura tendinum.de Plouquet Repertor. Art. Tendo.-Very frequently the tendo Áchillis. v. Kulmus D. de tendine Achillis disrupto, etc. Gendan. 1760.-Delauriere D. sur la solution de continuité du tendon d'Achille, produite par la contraction musculaire. Paris, 1809.-Oehlers D. tendinis Achillis disrupti felicissimæ sanationis, etc. 8vo. Kiliæ, 1819.- - A case of imperfect rupture of the tendo Achillis is given by Ehrmann Compte rendu des travaux anatomiques. Strasb. 1827, p. 22. Kelch, Beiträge zur pathol. Anatom. No. 16, found, in a very old dislocation of the upper-arm-bone, the long tendon of the $\mathrm{M}$. biceps torn; an instance of rupture of the ligament of the patella is given in the Lond. Med. Repos. Sept. 1825.Ruptures of tendons also occur in animals, viz. the perforating flexor tendon of the foot in a horse. v. Greve Erfahr. und Beob. über die Krankheiten der Hausthiere, Vol. II. p. 5.-C. Fr. Hoffendahl D. de tendinis Achillis ruptura et conglutinatione. 4.to. Berol. 1826, with plates.

(2) Compare the observations above quoted, $\S 109$, note 3 and 4 ; also A. Bonn, Comment. de humero luxato. 4to. L. B. and Amstel. 1782, with engravings. - Todd's account of a recent dislocation of the hip-joint, in Dublin Hosp. Rep. and Commun. in Med. and Surg. Vol. III. Dublin, 1822. Warren. - Sometimes merely one lateral, or only an internal ligament, as the round ligament of the hip is torn, whilst the capsule of the joint remains uninjured; the latter was observed by Hesselbach, Vollst. Anleitung zur Zergliederungskunde, Vol. I. Part II. p. 57.-W. Wallace in Dublin Transactions of the Association of Physicians, Vol. V. 1826.

(3) Spangenberg relates an instance in the translation of Boyer's work on the diseases of bones. Vol. II. p. 197. Leipz. 1804.-Nees observed a spontaneous dislocation from the deposition of gouty tophus in a joint. v. Hufeland's Journ. der prakt. Heilk. Vol. XVI. Part II. p. 180.

(4) I have seen dislocations several months and even years old, in which the original rupture of the articular capsule was still very distinct, and merely closed within by synovial membrane, and without by a little and soft cellular tissue. In a lady of my acquaintance, who some twenty years since dislocated the humerus, the bone was readily dislocated at every violent elevation, but was as easily reduced. Hence also old dislocations are sometimes perfectly replaced; for instance, the head of the thigh-bone, even after five years. v. Cornish in Lond. Med. Repos. p. 200. Marcli, 1822.

(5) A most remarkable instance of this is related by Baronio, in which the whole tendo Achillis was reproduced. v. Weigel's I talien. medic. chir. Bibliothek. Vol. IV. Part I. p. 47. - Experiments on the reproduction of this tendon are related by Lee Fearn in Medical Recorder, quarterly series, No. 39, Vol. XII. No. 1.

\section{$\S 149$.}

INFLAMMATION, ${ }^{1}$ as the common cause of VICE OF TEXTURE in fibrous parts, deserves first to be noticed. This is in general not very frequent; but in parts of this system which are very vascular, as the periosteum, the articular ligaments, and the dura-mater, it is by no means unfrequent, and is sometimes produced by mechanical causes, as contusions, ruptures, ${ }^{2}$ wounds, occasionally by stabs, \&c., sometimes by general diseases communicated to them, and among these especially, gout, rheumatism, syphilis, and scrofula. The inflammation of fibrous parts rarely assumes an acute character, as is, however, sometimes the case in gout and rheumatism; its course is usually nore tedious, and all the phenomena so indistinct, that they are often overlooked. According as the degree of 
the inflammation and the state of the fibrous parts varies, so do we find the REDNESS and swelling in a greater or less degree; sometimes indeed we observe the parts, as it were, merely injected, or with more or less large and numerous red streaks or undefined spots; in other cases they are more generally reddened, and not uncommonly of a rose-red colour; the latter is especially the case, if they come in contact with the air, as may be best seen in trepanning and in amputation through joints; in many cases also the colour of the inflamed parts is more or less yellowish, and if they have naturally a tendinous glistening, that is also in general completely lost, and in chronic or often repeated inflammation and their consequences, the fibrous organs are sometimes also found discoloured in various ways, viz. grey, brownish, and even blackish.

The sweLLiNG is commonly but trifling; if the inflammation continue longer, or it recur often without complete resolution, the fibrous organs also swell very much, and we then find the fibrous structure more or less wasted, their boundaries with the neighbouring as well as with the inflammatory parts, not distinct, and either a jelly-like fluid poured out into the swollen cellular tissue, or the latter converted rather into a soft, reddish kind of substance.

Should the degree of inflammation be very high, it runs, although tediously and moderately, into suppuration, in which the fibrous parts are eaten through, and more or less destroyed.

(1) Huhn D. de rite cognoscenda et curanda systematis fibrosi inflammatione. 8vo. Halæ, 1820. - Rayer, in Archives générales de Médecine, March and A pril, 1823.

(2) For example, in sprains and dislocations of joints, distortio.

\section{$\S 150$.}

Concerning the INFLAMED STATE of JoINTS in particular, this indeed in many cases has its original seat in their fibrous and fibro-cartilaginous parts, ${ }^{1}$ however more frequently in their lining membrane, the SYNoviaL, ${ }^{2}$ which like all serous membranes easily inflames; it is just as easily affected by mechanical causes as by gout, rheumatism, syphilis, metastasis, \&c., and is then found more or less swollen, reddened, and softened. ${ }^{3}$ If the inflammation be not resolved, then there is consequent either increased secretion into the joint especially of fibrous matter, which not rarely produces anchylosis, or there is more usually suppuration. Not less frequently does articular inflammation and destruction originate in the bones, of which the articular extremities, partly from injuries; partly 
in an especial manner from scrofulous diseases, and other internal causes, inflame; and internal caries, caries articulorum interna seu centralis, ${ }^{4}$ a kind of pædarthrocacy, is produced. But should the disease have its original seat in the bones or synovial membrane, sometimes also are the fibrous, fibrocartilaginous, and even the bony parts of the joint themselves coaffected; this is also the case where the morbid causes operate so violently upon the joint, that all the parts are simultaneously attacked with inflammation, as we not unfrequently find the case after violent bruises, penetrating wounds, fractures of bones, which extend into joints, \&c. In all these cases there arises either an ACUTE and distinctly progressive general InfLAmmaTION OF THE JOINT, arthrophlegmone, to which articular anchylosis, abscess, caries, caries externa, ${ }^{5} \& c$. are consequent; or a more chronic, and in its origin a more undecided state of inflammation, mostly produced by scrofula and rheumatism, which, according to the variety of its symptoms, seat and consequences, is named morbus coxarius, luxatio spontanea, ciaudicatio congenita, fungus articulorum, arthrocace, HIP Disease, SPONTANEOUS LAMENESS, ARTICULAR FUNGUS $;{ }^{6}$ but it is essentially always the same disease, of which the following are the most remarkable symptoms: the joint is, more or less, sometimes very remarkably swollen, less movable than in the healthy state, and always to a certain degree bent; the tumour itself is at certain parts hard, firm, elastic, in other parts as it were doughy, and unsteady; the common integuments, even to the last stage, when sinuses are formed, remain unchanged, though occasionally somewhat varicose and underlaid with hard fat; the muscles which surround the joint often appear pale, and together with the neighbouring cellular tissue, infiltrated with lymph; the articular ligaments more or less swollen, hardened, although loosened in some spots, dull, often without any distinct fibres, and often consolidated with the neighbouring cellular tissue; whitish, here and there discoloured, generally converted into an unvascular mass, in which are observed at different parts several little cavities filled with lymph, jelly-like fluid, or ichorous pus; the internal articular ligaments, the menisci, the cartilaginous layers on the articular extremities, and the synovial membrane are entirely or partially destroyed; the bone becomes affected primarily or secondarily in a greater or less degree, is either swollen, softened, inflamed, and becoming carious from within, or it is but little swollen and tolerably hard, but superficially eroded or destroyed by caries, by which in general, especially if the heads of the joint are swollen, and even without that, dislo- 
cated; we find also in young individuals the epiphyses sometimes lost at their diaphyses; in the articular cavity itself, we observe at first a large quantity of thickish, albuminous-like, often pale-reddish-coloured synovia, and in later stages of the disease, if the suppuration have more or less destroyed the joint, a thinnish, often very foul-smelling pus mixed with blood, cartilage, and cartilaginous fragments, and the so-called articular mass of fat sometimes increased, filling up entirely or partially the cavity of the joint. ${ }^{7}$ In animals, fungus of the joint and spontaneous lameness occur but rarely. ${ }^{8}$

(1) I think I have also observed this very satisfactorily in several cases.

(2) L. Moffait Recherches sur les Phlegmasies des membranes synovial des articulations. Paris, 1810. - Sauveur de la Villeraye Thèse sur les inflammations du système sereux et du système synovial. 4to. Paris, 1812.-Chomel D. sur le Rheumatisme. Paris, 1813.-Valleraud de la Fosse, D. sur le Rheumatisme. Paris, 1815. - Roche Sur les Phlegmasies du système fibro-sereux des articulations. 4to. Paris, 1819.

(3) Brodie, c. 3, has found the synovial membrane frequently converted into a light brownish pultaceous mass, from $\frac{1}{4}$ to $\frac{1}{2}$ an inch thick. I have also found this several times; but it seems to me that this extraneous mass is rather putrid bloody sediment mingled with fibrous matter, than a conversion of the mucous membrane, of which however I find at the same time, here and there, distinct traces.

(4) According to Rust.

(5) Eck D. de carie articulorum externa cum interna comparata. 8vo. Berol. $1 \mathrm{S18}$, with engravings.

(6) By the English, according to Wisemann's Chirurg. L. IV. c. 4, White Swelling; from the difference of its seat, also Coxarthrocace, Gonarthrocace, Omarthrocace, Olecranarthrocace, Spondylarthrocace, \&c.-Here also belong the cases described by the ancients under the names Pcedarthrocace, Abscessus articularis.-J.11. Slevogt resp. Wucherer D. de tumoribus artuum fungosis. Jenæ, 1715.-A. Monro primus, On the White Swellings of the joints, in Edinb. Med. Essays and Observat. Vol. IV.p. 242.-Th. Simpson, History of a White Swelling of the knce, ib. p. 246. - Detharding resp. Becker D. de fungo articulorum. Rostock, 1743. - Encleelmann D. de fungo articulor. 4to. Argent. 1749.-Reimarus D. de tumore ligamentorum circa articulos, fungo articulorum dicto. Leid. 1757. - Cartheuser D. de fungo articulor. Francof. 1769. - Sidrén resp. Bockler D. de tumore articulor. fungoso. Upsal. 1769.-B. Bcll, A treatise on the theory and management of ulcers, with a dissertation on White Swellings of the joints, Sc. Edinb. 1778. - Müller D. de fungo articulor. Gött. 1780.-P. Camper Over het mankgaan in Iraarlem. Verhandelingen, Vol. VII. Part I. p. 452, and in Kleinern Schriften, deutsch von Herbell, Vol. I. Part II. p. 108.-Palletta Exercitatio de clandicatione congenita. L. B. 1787, and Exercit. pathol. I. p. 30 -58.- Jäger Beiträge zur Erläuterung der Entstehungsursacherı und der Heilarten des Gliedschwammes. Frankf. 17S9. - Storr D. de fungo articulari. T'übing. 1792. - Fuhsel D. de fungo articulor. Gött. 1792. - Ford, Observations on the disease on the Hip-joint, to which are added some remarks on White Swclling of the knee, Sc. London, 1794; second edit. by Copeland. Svo. London, 1810.-Oemler D. de fungo articuli, etc. Jenx, 1797.-Dylins D. de claudicatione. 4to. L. B. 1798. - J. Ilewson D. de morbo coxario. Edinb. 1798.-Kleffel D. de fungo articulor. Halæ, 1798. - Kreysig D. de fungo articulari. Viteb. 1799. - Munck af Rosenschöld D. de morbo articuli coxx. 4to. Lund. 1799; and in K. Svenslaa Vetensk. Akademicns nya. Handlingar, 1802, Part I. p. 57.Bernstein D. de fungo articulor. Jenix, 1801.-J. Herdman, on White Swelling of the joints, Sc. Sro. Edinb. 1S02.-J. Russel, 'Treatise on the morbid affections of the Knec-Joint. Edinb. 1S02. - P'alous Observations et Ilées relatives 
aux tumeurs blanches des articulations. 8vo. Paris, 1802.-Berends D. de fungo articulor. Francof. 1804. - Franck D. de morbo coxario. Marburg. 1804. Veerbek De morbo coxario seu de tumore albo articuli coxo-femoralis. 4to. Paris, 1806.-J. A. Albers and Ficker Grekrönte Preisschrift über das sogenannte freiwillige Hinken der Kinder. 4to. Wien, 1807.-Crowther, Practical observations on the disease of the joints, commonly called White Swelling, \&c. London, 1808. - Wirth D. de coxalgia. Wirceb. 1809. - Krause De claudicatione Comm. med. chir. 4to. Lips. 1809. - Pundt D. de fungo articuli. Gött. 1809. - J. Watts D. de morbo coxario. Edinb. 1809. - Browne D. de morbo coxario. Edinb. 1813. - Gordon D. de tumore albido. Edinb. 1815. - Baier D. de fungo articulor. 8vo. Wirceburg. 1816. - Volpi Saggio di osservazioni medico-chirurgiche, Vol. III. No. 4. Pavia, 1816.-R. M. Davis D. de morbo coxario. Edinb. 1816.-Rust Arthrokakologie, oder über die Verrenkung durch innere Bedingung und über die Anwendung des Glüheisens. 4to. Wien, 1817, with eight engravings.-P. Fairbairn D. de mordo coxario. Edinb. 1819.-Leube Adnotationes ad coxarthrocacen. 8vo. Tubing. 1821.-C. L. Lehmann D. de coxarthrocace. 8vo. Berol. 1821.-Jungnickel D. de tumore albo. 8vo. Berol. 1824.-Zeisick Abhandlung über die Coxalgie. 8vo. Prag. 1824.-Margot Mém. sur les tumeurs blanches des articulations, in Archives génerales de Médecine, May, 1826.-Lehmann Tumoris genu albi et Gonarthrocaces adumbratio pathologica. 8vo. Rostock. 1826.- Ruhstrat Abhandlung über die weisse Kniegeschwulst. 8vo. Gött. 1826.-H. F. Zöhrer Monographie der weissen Geschwulstam Kniegelenke, u. s.w. Wien, 1828. - Sprengel in Rust's Magaz. f. d. ges. Heilk. Vol. IX. Part II. p. 302, has well described a few cases of White Swelling in the knee; and Nicolai also in the same work, Vol. XXII. Part I. p. 3.-Compare above, $\S 135,138$, and 142.-In very rare instances, congenital spontaneous disease of the hip-joint has been observed. v. Hippocrates De articulis, Sect. VI. p. 819.-Albers relates three instances of it; perhaps also the cases of congenital dislocation of the head of the thigh-bone mentioned by Dupuytren may be referred here, at least that in which the round ligament was very much elongated. v. Repertorie général d'Anatomie et de Physiologie pathologiques, etc. Vol. II. Part III. p. 150.

(7) I have made use of this description; after numerous observations on individual cases, and the proofs of it are partly to be found in Bresl. Mus. v. No. 2152-2154, 3407, 3408, 3432-3435, 3440, 3442, 3443, 3489, 3684$3693,8 \mathrm{c}$.

(8) I have found examples in the hip-joint in two monkeys, one nasua rufa, and one adult female kangaroo. Perhaps also here belongs the diseased hipjoint, of a pig, mentioned by Sandifort Mus. Anat. III. p. 241, No. 681, 682.

\section{$\S 151$.}

Another termination of inflammation in the fibrous system is ossification, ${ }^{1}$ which is especially very common in many parts of this system, viz. the ligaments and the dura-mater; less frequently in the periosteum, ${ }^{2}$ the tendons, ${ }^{3}$ the fibrous membrane of the spleen, and but seldom in the other fibrous structures; it shows also a very different degree of production, as sometimes only the fibro-cartilaginous base of bone is deposited in form of plates or flat roundish swellings, ${ }^{4}$ more frequently true phosphate of lime is deposited, sometimes as distinct spots and kernels of bone surrounded with vascular circlets, sometimes in form of splinters, sometimes, lastly, throughout and equally in the fibrous tissue. Should the articular ligaments, which are then usually shortened, be found in this state, there ensues either STIFFNESS OF THE JOINT, rigiditas articulorum, 
anchylosis incompleta seu spuria, or ACTUAL ANCHYLosis, anchylosis vera. ${ }^{5}$ Both vices occur commonly in man and even in animals, when an earthy mass, less resembling bone than gypsum or chalk, GOUTY TopHus, ${ }^{6}$ as it is called, consisting especially of urate of soda, is, in gouty persons, deposited in the ligaments, in the neighbouring aponeuroses, and periosteum of one or several joints, at first in a soft, but subsequently in a hard state, and often in great quantity.

(1) Compare especially Boyer in Archiv. génér. de Médec. March and April, 1823.

(2) v. above, $\$ 119$.

(3) I have seen only a few instances in man.-A good example on almost all the tendons of the lower extrcmities is described by Veslingius Observ. Anat. Epist. posth. XV.-Other instances in Bartholinus De diaphragmatis structura nov. Paris, 1676.-Booerhaave Prælect. ad instit. Medic. edit. Halleri. Goett. $1739, \S 478$. - Heuermann Physiologie, Vol. III. p. 162. - Whether the disease described by Sauvages in his Nosol. Method. Vol. I. p. 530, under the name Catochus, and by Macbride in his Introd. med. theor. et pract. med. Traj. 1774 , as sarcostosis, in which the entire limb was said to be converted into bone, belongs here, or whether it was ossification of the aponeurosis, it is very difficult to determine, as they, and indeed that related by Henry, in Philos. Trans. 1759 , Vol. LI. p. 89 ; Vol. LII. Part I. p. 143, are very doubtful.Walter also found lime deposited between the tendons of the fore-arm, in a gouty person. v. his Mus. Anat. Vol. I. p. 144, No. 289.-In animals, ossification of the tendons is more frequently observed; for instance, in the horse. v. Schwab Materialen zur pathol. Anat. der Hausthiere, Iste Liefer, p. 49. - In the Cape jerboa, and other quadrupeds, which always spring from their hind limbs. v. Cuvier Leçons d'Anat. Comp. Vol. I. p. 115.-I found the tendo Achillis ossified in a dipus; very frequently in birds, especially of the gallinaceous kind, in the legs; and, before all others, in cranes. v. Rudolphi Physiol. Vol. I. p. 85, $\$ 88$, note. - I have observed the same in the peacock, guinea-fowl, partridge, crax pauxi, No. 3931 of Bresl. Mus. and in an ossifrage eagle.

(4) Here partly belong the gummata in the periosteum, the fibro-cartilaginous spots on capsular membranes especially in the hip-joint, the frequent cartilaginous plates in the fibrous membrane of the spleen, in the tendons of the smaller muscles, \&c.

(5) Compare above, § 109.-Also without anchylosis, those ligaments which connect two immovable bones naturally become ossified; for instance, the proper ligaments of the blade-bone, the lig. tuberoso and spinoso-sacrum, \&c. Greve saw a large lime-like deposit in the nuchal ligament of a horse. v. his Erfahr. und Beob. über die Krankheiten der Hausthiere, Vol. II. p. 4.

(6) Gouty deposits occur not merely on the joints of the extremities, but even in the jaw. v. No. 3270,3271 , and 8360 , of Bresl. MIus.-On the joints of the spine, S.c.-Sometimes they become very large; I have seen them as large and larger than a walnut. In many instances they give rise to spontaneous dislocation.- - Lieutaud Historia anat. medica. Vol. 1 II. p. 90, Obs. 230 and 232. - Nees in IIufeland's Journ. der prakt. Heilk. Vol. XV I. Part II. p. 180.On gouty deposits, compare $\$ 72$, note $3 .-A$ lso Contuli De lapidibus podagræe et chiragræe in corp. hum. productis. Rom, 1679. - Born De arthritide nodosa. Leid. 1699. - van Priesteren D. calculorum genesis et convenientia cum tophis podagricis. L. B. 1788.-Jäger D. acichm phosphoricum morbor. quorundam caussam proponens. Stuttgart, 1793. - A remarkable instance of tophus in the ligaments, tendons, and aponeurosis about a joint, is described by Lobstein in Compte rendu sur les travaux anatomiques, etc. Strasb. 1824, p. 16.-Another by van der Boon Mesch Ecne scheidkundige outleding van den Jichtkalk in Bydragen tot de naturkundige Wetenschappen. Amsterd. 1826, D. I. No. 2, p. 127.Tennant's and Wollaston's opinion that it is not phosphate of lime, but phosphate 
of soda, is confirmed by Fourcroy and Vauquelin in Anal. du Mus. d'hist. nat. Vol. I. p. 93 ; Vol. II. p. 201 ; Vol. IV. p. 329, and in Fourcroy's Syst. de conn. chym. Vol. X. p. 265.- Vogel in Bulletin de Pharm. No. 12, p. 568, \&c.-In many instances gouty concretions contain no urate of soda, but phosphate of lime.-John in Meckel's Archiv für die Physiol. Vol. I. Part IV. p. 513. -Gouty tophus also occurs in animals, though much more rarely; viz. in fowls and hawks, on the joints of the toes. v. Aldrovandi Ornithol. Vol. I. p. 456.Tiedemann Zoologie, Vol. II. p. 165.

\section{$\S 152$.}

A very rare termination of the inflammation of fibrous parts is MORTIFICATION ; ${ }^{1}$ it occurs primarily and distinctly, but is always rare, perhaps only in such parts of the system as are proportionally tolerably supplied with blood-vessels, viz. the periosteum and the dura-mater; in the other fibrous organs, for instance, the tendons, articular ligaments, aponeuroses, \&c., it has generally only been primarily observed, when they have been completely laid bare by wounds and ulcers, and exposed to the air, in which case they are destroyed and exfoliate, together with the surface of the bones and cartilages. ${ }^{2}$ In connexion with other parts, the fibrous system, as is understood, is often attacked with mortification; so that, for instance, in a mortified foot, the tendons, aponeuroses, \&c. together with the other soft parts, become gangrenous; anthrax also easily extends itself from the neighbouring to fibrous parts. ${ }^{3}$ In mortified limbs, the articular ligaments are also attacked, so that hence sometimes arises the spontaneous loss of a limb. ${ }^{4}$

(1) Neither brownish nor blackish coloured fibrous parts are, for that reason, gangrenous; because sometimes from morbid irritation alone there is a deposit of black pigment. Compare $\S 147$.

(2) Remarkable instances of exfoliation of the tendo Achillis are described by Baronio, and by Acrel, v. Chirurg. Vorfälle, Vol. II. p. 380. This is not unfrequently the case in the finger in whitloe.-- [ In the Mus. at St. Thomas's Hospital, there is a tendon on one of the flexors, which had sloughed out, in consequence of injury to the finger. T.]

(3) Lavernet in Journ. de Médec. contin. Vol. II. p. 248, describes a case of destruction of several tendons by an anthrax.

(4) Compare $\S 62$.

\section{$\S 153$.}

As to SPURIOUS FORMATIONS, these are but rarely observed in the fibrous system. There exist, for instance, but few examples of ENCYSTED TUMOURs ${ }^{1}$ in this tissue, if we do not reckon those bursal tumours which occur on the articular capsules, and partly between the tendinous fibres of the aponeuroses, and especially on the elbow-joint, and knee-cap, which have their origin in the mucous bags there placed. Just as rare are the TUBERCULAR FORMATIONS in and on fibrous parts; deposits of scrofulous matter, however, occur here and there in the 
tissue of the dura-mater and the periosteum. ${ }^{2}$ We more frequently find FUNGOUS AND SARCOMATOUS SWELLINGS in the fibrous organs, to which belong the already described sarcom of the periosteum, ${ }^{3}$ the fungus of the dura-mater hereafter to be mentioned, the very rare fungous growths on the tendons, ${ }^{4}$ and the sarcom observed sometimes in and upon the articular ligaments, which indeed occasionally approaches the character of medullary sarcom. ${ }^{5}$ CANCER does not occur primarily in the fibrous system, but it equally attacks it secondarily. ${ }^{6}$

(1) In the Strasburg Mus. there is an encysted tumour on the tendon of the flexor muscle of the finger. v. Ehrmann Compte rendu des travaux anatomiques, etc. Strasburg, 1827, p. 22, No. 428, des Musei.

(2) I have myself found them on these parts.

(3) Compare $\$ 120$.

(4) Dzondi observed them on the extensor muscles of eight fingers. v. Beiträge zur Vervollkommung der Heilkunde. 1ster Theil. Halle, 1816.

(5) I have three or four times found in very old and large white swellings, so called, between the layers of the much-thickened articular ligaments, and the aponeurosis of the knee, several roundish tumours, which, in their nature, very nearly approximate to medullary sarcom.-Burns, Dissertation on inflammation, Vol. II. p. 311, describes an instance of fungus hæmatodes in the hip-joint; and Langenbeck, one of medullary sarcom in the knee-joint. v. Neue Bibliothek f. Chir. und Augenheilkunde.

(6) In a carcinoma of an inguinal gland, I have found the ligamentum fallopii, and the neighbouring tendons of the abdominal muscles, partly destroyed.

\section{$\S 154$.}

Lastly, we observe the contents of the cavities formed by fibrous membranes not unfrequently irregular. To these belong partly, the morbid collections of water, jelly-like fluid, pus, blood, \&c. in the aponeurotic sheaths surrounding and separating the muscles, as, not merely does the JorNT-FLUID, synovia, ${ }^{2}$ vary exceedingly, but even extraneous substances occur in the articular cavities. Thus we find the synovia deficient in respect to quantity, inasmuch as it is sometimes in so small quantity, that hence ensues a kind of stiffness, friction, and even a creaking of the joint; or it is much more commonly found in too great quantity. The latter is most generally the case in all inflammatory states of the synovial membrane, but it occurs without any distinct inflammation, especially in the knee-joint in rheumatic, rickety, and syphilitic patients, \&c., sometimes to such degree that the joint is occasionally more or less swollen at the weaker parts, its use prevented, and itself even dislocated; this always local disease we distinguish by the name DROPSY OF A JOINT, hydrops articulorum, hydrarthus, meliceria. ${ }^{3}$ The colour and consistence of the synovia are also often abnormal, and we observe it then muddy, reddish, too watery or too albuminous, similar to half-coagulated jelly, \&c. 
To the extraneous substances which we sometimes observe in joints, belongs QUICKSILVER, ${ }^{4}$ which is however very rare; rarely also BLOOD, which is effused into joints in injuries of various kinds $;^{5}$ more frequently pus, which is produced either from a high inflammatory state of the synovial membrane, and of the bony cartilages and ligaments forming the joint in the articular cavity itself, or it may have made its way into the joint from without $;^{6}$ and lastly, unUsUal LOose CARTILAGINOUS CONCRETIONS, which have not unfrequently been observed to grow on the inner or expanded surface of the synovial membrane, into CLUB-LIKE OR NECKED APPENDAGEs; $;$ these at first are attached by thin threads, but when these are broken, they lie loosely in the joint, are at first soft, then mostly cartilaginous, sometimes however merely cartilaginous within, or are entirely bony; are usually round, but in some cases also flattened and angular, and very variable in size and number. ${ }^{8}$

(1) Very commonly in acute rheumatism.

(2) J.A. Cämmerer pros. Haase D. de unguine articulari ejusque vitiis. 4to. Lips. 1774.

(3) Fabricius Hildanus De ichore et meliceria acri Celsi, sive Hydarthro, v. Op. p. 831. - M. Hoffmann D. de meliceria s. articulorum læsorum inundatione. Altd. 1650.--Charisius D. de meliceria Celsi. Regiom. 1726. - Haffner Von der Gelenkwassersucht. Freiburg. v. Weiz N. Auszüge. Vol. V. p. 129.-Brown D. de hydarthro. Edinb. 1798. - Savarin-Marestan D. sur les hydropisies articulaires, etc. 8vo. Paris, 1803. - Sanders D. de liydarthro. Edinb. 1809.Taaks D. de hydrope articulationum. 8vo. Berlin, 1815.-Russel, Chap. VI.An instance of water in the knee-joint is described by Bobillier in Recueil de Mémoires de Méd. Chir. et Plıarm. militaire par Fournier, Vol. XI. p. 300.In a rickety boy, four years old, I once saw dropsy of the joints, both of the foot and hand, as also of the menbrana capsularis carpi communis. - In the horse, hydrarthus is not rare. v. Rohlwes Magaz. f. d. Thier arz neikunde, Vol. I. - Of windgalls, v. Greve Erfahr und Beob. über die Krankheiten der Hausthiere, Vol. I. p. 85 .

(4) Several instances in Lieutaud Historia anatomico medica, Vol. III. p. 93.

(5) Compare Russel, Chap. V. - Hey, Practical Observations in Surgery, p. 354 .

(6) Abscesses in the neighbouring soft parts easily penetrate into the cavities of the hip and knee, when the mucous bags there situated are connected by an aperture with the joint, either from being rubbed through, or as an original vice of formation. I have seen some such instances in both the above-mentioned joints. In one ease, v. my Selt. Beob. Part II. No. 17, p. 42, a lumbar abscess had burst into the hip-joint. I have also since seen another such case. Rusi, too, describes a similar instance, in his Magaz. f. d. ges. Heilkunde. Vol. I. Part I. p. 46.

(7) Compare above, $\$ 81$.-Cases in which these processes with necks were very numerous are described by $A$. Bonn, in Thesauro ossium morbosor. Hoviano, No. 75 ; and by Götz D. de morbis ligamentorum, tab. 1.-Bobillier in Recueil de Méd. Chir. et Pharm. milit. par Fournier, Vol. XI. p. 300 ; all three in the knee-joint. I have lately observed a very great quantity of them in the diseased hip-joint of a gouty person; we usually find at the same time much viscous synovia in the joint.

(8) The disease is also called mures in genu; by Swediaur, arthroncus tuberculosus. Such cartilages are not to be confounded with little exostoses and 
gouty tophus, which have been broken off. They most commonly occur in the knee, although also in other joints.-Ambr. Paré QEuvres, Livr. XXI. Chap. 15, p. 772.-Marcellus Donatus De histor. med. mirab. L. IV. c. 30 (in the hip).Pechlin Observat. physico-med. Obs. 38, p. 306.-Henkel Med. und chirur. Anmerk. Part III. p. 7 ; Part V. p. 26 (several). - Monro prim. in Edinb. med. Essays, Vol. IV. No. 19, p. 244.-Simson, ib. No. 20, p. 246.-Reimarus D. de tumore ligamentorum circa articulos, etc. Leyd. 1757.- Morgagni De sedibus et caus. morbor. Epist. L. LVII. 14 (some twenty in the knee; in other instances he also observed them in the knuckles). - v. Haller Progr. de induratione in c. h. partibus, $\$ 5$, and in Elem. Physiol. Vol. VI. p. 9 (above twenty in the maxillary joint).-Bromfield, Observations, I. p. 330; II. p. 76.-7'heden Neue Bemerk. und Erfahrungen zur Bereicherung der Wundarzneikunst, 17S2, Vol. I. Sect. 17, p. 99.-Cheston Pathological Inquiries and Observations in Surgery, Se. - Cruikshank in Edinb. medic. Comment. Vol. IV. p. 342.Ford, in Medical Observations and Inquiries, Vol. V. No. 30, p. 329 (of the size of a chestnut). - Löfler Beiträge zur Wundarzneikunde, Part I. (in the elbowjoint).-Warner in Philosoph. Transact. 1756, p. 452.-Coley in Medico-chir. Transact. Vol.V. p. 76 (in the elbow-joint as large as a nux vomica).-Mohrenheim Beobachtungen verschiedener chir. Vorfälle, Vol. II.-Home, in Transact. of a Society for the Improv. of medic. and chir. Knowledge, p. 229 (one instance of three pieces; another, in which the cartilage was nearly as large as the patella; and a third, in which thirty or forty of such little cartilaginous bodies were produced in a false joint). - Sulzer in Richter's Chir. Bibliothek. Vol. VIII. p. 492.-Desault in Journ. de Chir. Vol. II. No. 45. Similar instances observed by Hewit, Middleton, Gooch, Sabatier; and B. Bell found them in the joints of the foot; they were found also in those of the hand. v. Boyer Traité des Maladies chirurgicales, Vol. IV. p. 434.-Heilmønn D. de corporibus juxta articulos mobilibus. Würceb. 1796.-Munro, a Description of all the Bursæ, \&c. fol. Edinb. 1788.-Bichat Anat. Gén. (in the capsular membrane of the pisiform-bone).-Champigny D. sur les corps étrangers, qui se forment dans les articulations. 8vo. Paris, 1803. Abernethy, Surgical Observations, \&re. Lond. 1S04, p. 253, found one humdred in one joint as large as shot.-Laennec, in Dict. des. Sc. médical. Vol. IV. p. 123, Art. Cartilares accidentelles, found them also in the joint between the head of the tibia and fibula, and mentions, on the authority of Bichat, that they were observed in the thumb. - Sauter in v. Siebold's Chiron. Vol. II. p. 359, with plates.-Larrey in Nouv. Bulletin de la Soc. philomath. 1810, Vol. II. p. 182; and in Mémoir. de Chir. militair. Vol. II. p. 421.-Lazzari in Giornale della Soc. med. chir. di Parma. Vol. I. p. 198. - Wardrop in Edinb. med. and surgic. Journ. Vol. IX. p. 14.-Clark in Med. chir. Transact. of Lond. Vol. V. No. 4, p. 67 (in one case three).- Hey, Practical Observations in Surgery. Lond. 1814, Cap. VII. (an instance in the elbow-joint). - Williams, in London medical Repository, March, 1815. (The mother and grandmother of the boy had had the same disease).- B. G. Schreger Beobachtungen-und Bemerk. ïber die beweglichen Coneremente in den Gelenken und ihre Exstirpation. 4to. Erlangen, 1815. - Blacliett, in London medical Repository, May, 1816.-Russel, On the Morbid affections of the Knec-joint. ('They were sometimes covered with a delicate membrane, which, in rare instances, was freely supplied with bloodvessels).-Cerutti Beschreibung der pathol. Präjparate des anat. Mus. zu Leipzig 1819, No. 616.-Buhle D. de arthroncis tubereulosis. Svo. Halx, 1823 (two instances in the knee, a third in the shoulder).-Bleuland Deseriptio Musei anat. 1826, p. 293, No. 1663 (attached in the elbow-joint.)-Wedemeyer in v. Gräfe's and v. Walther's Journ. der Chir. 1826, Vol. IX. Part I.-Cassan Note sur les concretions dites albumineuses, in Archives générales de Méclecine, Mai, 1826.-Elström in Ars. Berättelse om Svenska Lakare-Sällskapets Arbeten Lemnad af Ekström. Stockh. 1826 (as large as a bitter almond, after some time a still larger must have been removed).-Cruveilhier in Nouv. Biblioth. médic. Janv. 1827, p. 79.—G. Saudifort Museum anatomicum. Vol. III. p. 298, No. 10.10 and 104.1 (partly porous).- H. A. Kïhler 1). de colporibus alienis in articulis obviis. 8vo. Berol. 1827. - In the Hunterian Muscum, London, I siaw several such cartilages, among which, one almost as large as the knee-eap 
(v. Home), and a diseased knee-joint, which was internally covered with cartilaginous growths, and with several large cartilages suspended by necks. Further, in the Anat. Mus. of the Surgical Academy at Copenhagen, a few large cartilages, removed from the knee-joint by operation; and a large irregular cartilaginous concretion from the knee, in the Anat. Mus. at Rostock. I have described three such instances in my Selt. Beob. Part II. p. 37, No. 14, the first of which consists of a large loose flat bone from the knee; the second, of a little cartilage from the elbow; and the third, of two bones hanging by threads to the knee. I have since twice found in the elbow-joint a little loose cartilage. v. my Verzeichn. No. 2159, 2161-2163, and 8446, of the Bresl. Mus.

\section{EIGHTEENTH SECTION.}

\section{Of the Muscular System.}

\section{$\S 155$.}

Among the different vices of the muscular system $^{1}$ are its so-called VARIETIEs, ${ }^{2}$ and especially such as refer to NUMBER, which are the most common; rarely, however, is there a true morbid condition, that is, the cause of impeded or disturbed muscular activity. The latter, however, is the case, if in monsters the muscles of the whole body, or of certain regions, have not been developed from their original jelly-like cellular base into true muscles, or are entirely deficient; this has been observed in some instances throughout the whole body ${ }^{3}$ more frequently at certain parts. ${ }^{4}$ The congenital deficiency of certain muscles, or parts of them, without actual hindrance of the power of motion, is very common; thus the zygomaticus minor, one sternothyreoideus, stylohyoideus, styloglossus, one scalenus, the sternocostalis, one or both pyramidales abdominis, the interspinales cervicis, the palmaris longus, one lumbricalis, the extensor proprius, and the flexor of the little finger, one or other tendon of the flexor and extensor of the fingers, the psoas minor, the upper gemellus, the plantaris, the peroneus tertius, and single heads of the flexor and extensor of the toes are deficient. ${ }^{5}$ More rarely is there deficiency of all or some of the muscles of the eyes, ${ }^{6}$ of the levator labii superioris proprius, the zygomaticus major, the geniohyoideus, both siylopharyngei, the omohyoideus, the long head of the biceps brachii, ${ }^{7}$ the whole anterior half of the deltoideus, ${ }^{8}$ the pronator quadratus, the middle portion of the serratus anticus major, of the lower gemellus, the pyriformis, ${ }^{9}$ the quadratus femoris, the short head of the biceps femoris, \&c.

The opposite vice, or excess of Number in the muscles, is not less fiequent, and occurs sometimes in many parts of the 
body at once. ${ }^{10}$ The increased number commonly arises from the stronger development and division of the normal muscles; thus, for instance, we observe the obliquus oculi superior, and the abducens, ${ }^{11}$ the retrahentes auris, the risorius santorini, depressor alce narium, stylohyoideus, stylopharyngeus, geniohyoideus, omohyoideus, stcrnohyoideus, the sternocleidomastoideus, splenius capitis, rectus capitis posticus major, rectus capitis lateralis, the scaleni, interspinales, intercostales, cucullares, pectorales, the subclavius, biceps brachii, brachialis intermus, pronator teres and quadratus, supinator brevis, extensor radialis brevis, the flexores and extensores of the fingers, the lumbricales, the pyramidales and recti abdominis, the glutai, the pyramidalis, the adductores femoris, the sartorius, biceps femoris, popliteus, peroneus brevis, the extensores and flexores of the toes, \&c. double or even manifold. The normal number is also increased, although much more rarely, by entirely unusual muscles; to these belong, viz. the anomalus faciei, cephalopharyngeus, a muscle between the occipital bone and the transverse process of the second cervical vertebra, another between the transverse process of the sixth, and the collar-bone, a capsularis humeri, the sternalis brutorum, the extensores breves of the fingers, a very remarkable muscle on the under and outer part of the hinder surface of the tibia, \&c. In many instances normally formed muscles send off unusual heads or tendons, for example, the omolhyoideus, a head to the sternothyreoideus; the digastrici maxilla, a head which connects them with each other and binds them to the transversus menti; the sternocleidomastoidens, a slip to the angle of the lower jaw ; a long process from the levator anguli scapula, which loses itself between the shoulder-blade and the spine; from the serratus posticus superior, a portion to the transverse process of the first vertebra; from the pectoralis major, a fleshy or tendinous portion to the latissimus dorsi, which can easily compress the axillary vessels and nerves, or processes to the skin of the arm-pit, to the tendon of the coraco brachialis, to the biceps brachii, \&c.; a slip to the latissimus dorsi, to the processus coracoideus, or to the occipital bone; a slip of the deltoideus, to the infraspinatus, or inner edge of the shoulder-blade; the ulnaris extermus, a tendon to the fifth finger, the flexor digitorum communis profundus, a head to the condylus flexorius; the bioeps femoris, a slip to the tendo Achillis, \&c.

(1) Isenfamm D. de musculorum pathologia. 4to. Erlang. 1774.-de Schallhammer $\mathrm{D}$. de morbis fibrix muscularis ex materiei animalis mixtura mutata eognoscendis. Hto. Halx, 1799, with engravings; and in Reil's Archiv f. d. 
Physiol. Vol. IV. p. 222. - Rodati in præparationes myo-pathologicas Musei Bononiensis animadversiones in Opusc. scientific. Fasc. XVIII. p. 397.

(2) G. de la Faye Observat. anat. sur des muscles surnuméraires in Mém. de Paris, 1736 , Hist. p. 59 ; B. S. Albini Annot. acad. Lib. IV.-VI.-A. K. Boerhaave Observatio anatomica musculi in pectore præternaturalis et varii in diversis corporibus inventi in N. Comment. Acad. Petropol. Vol. II. Hist. p. 23, Mém. p. 257.--Böhmer Observat. anat. rarior. Fasc. I. in Præfat. p. 6, Fasc. II. in Præfat. p. 5.-Sandifort Exercit. academ. L. I. c. 6, L. II. c. 6.-Hildebrand Bemerkung einer merkwürdigen Varietät am Nervo musculo-cutaneo und einiger Muskelvarietäten in Blumenbach's Medic. Biblioth. Vol. III. Part I. p. 176.-Heymann Varietates præc. c. hum. muscul. Traj. ad Viadr. 1784.--Brugnone, Observations myologiques in Mémoires de Turin. Sc. Phys. et Mathem. Vol. VII. p. 157.-Rosenmiïller D. de nonnullis musc. c. h. variet. Lips. 1804.-Zagorsky in Mém. de l'Acad. de Petersb. Vol. I. 1809.-Fleischmann in d. Abliandl. der physical. medic. Societät zu Erlangen. Vol. I. No. I. 1810.-Duille præs. Tiedemann D. anat. nonnullas musculor. varietates exhibens. 8vo. Landshuti, 1813.--Kelch Beiträge zur pathol. Anatom. No. 20-36.-Gant 2 er præs. Rudolplii D. anat. musculor. varietat. sistens. 8vo. Berol. 1813. - Sels præs. Rudolphi D. anat. musculor. varietat. 8vo. Berol. 1815. -Moser in Meckel's Archiv f. Physiol. Vol. VII. p. 224.-My Selt. Beob. Part I. p. 89, Part II. p. 39.-J. F. Meckel in Liman D. de ano contra naturam. Halæ, 1822, p. 34, and in his Archiv f. d. Physiol. Vol. VIII. p. 585.Compare also the anatomical Manuals of Mayer, Sömmerring and Meckel.

(3) In an acephalous monster in Meckel's collection. v. de Schallhammer, p. 27.$v$. Lenhosseck, in the Medic. Jahrbuch d. K. K. öesterr. Staates, Vol. V. Part IV. instead of muscles, a fatty mass in a malformed child. Hardly any trace of muscle in a very mishapen monster was observed by Peschier, as mentioned by Locker-Balber, in Hecker's litter. annal. d. g. Heilk. 1828, Aug. p. 406 ; I also found jelly instead of muscle in a human monster.

(4) J. G. Salzmann D. s. plurium pedis musculor. defectum. Argent. 1754.von Bergen D. de plurium musculorum femoris defectu. Franc. ad Viadr. 1734.Commerc. liter. Nor. 1739, p. 22 (on the right lower extremity).-v. Haller. Op. minor, Vol. III. p. 33, remarks, from the observations of Winslow and Ruysch, that in supernumerary limbs, fat is sometimes found instead of muscle; this was also seen by C.C.F. Jäger, Ueber die Natur und Behandlung der krankhaften Schwäche des menschl. Organismus. Stuttg. 1807, p. 227. I have also noticed it four or five times in birds and calves; in a foetus in Meckel's collection all the muscles of the thigh are deficient. v. Thamm D. de genitalium sexus sequioris varietatibus. Halæ, 1799, p. 24, fig. 1 (all the muscles of the right lower extremity wanting) Breschet in Medic. chir. Transact. Vol. IX. 1818, p. 433.Palletta saw, in two cases, lameness produced by deficiency of the $\mathrm{m}$. gastrocnemii and tendo Achilles. v. Exercit. pathol. I. p. 151.-G. Jüger saw several muscles very imperfectly formed in a monstrous calf. v. in Meckel's Archiv f. Anat. and Physiol. 1826, No. 1, p. 79. - Similar cases are described by Clarke in Philos. Transact. 1793, Part II. - Vrolik in Verhandel. van het k. Instit. 2. aflev. p. 29, and in a lamb on the hind legs. - Schröder van der Kolk Observ. anat. pathol. et pract. argumenti. Fasc. I. Amsterd. 1826 , p. 9.-It is self evident that in imperfect formation of individual parts of the body their muscles must be deficient; thus in extensive spina bifida almost all the muscles of the back; in thoracic and abdominal clefts, as well also as in large umbilical ruptures, the muscles are often deficient. In four monsters, with deficiency of the radius and thumb, all the muscles naturally situated on the radius were absent. If an entire part of an extremity be wanting, the muscles lying on the superjacent limb, which would have moved it, are generally very imperfect.

(5) I have missed the just-named muscles several times.

(6) Klinkosch, Progr. quo sect. et demonstrat. indicit, \&c. 4to. Pragæ, 1766, missed all of them. Several in squinting persons. v. Wrisberg, Götting. gel. Anz. 1781. p. 683.

(7) My Selt. Beob. Part I. p. 89, Part II. p. 39.

(8) I have lately seen this in a subject which exhibited many other varieties in the muscles. 
(9) I have missed this once, in which case the m. gemellus superior was very large.

(10) Instances of this kind are described by Tiedemann in Meckel's Archiv fur Physiol. Vol. IV. p. 412 ; Meckel, ib. Vol. V. p. 115. I once saw in a subject seven supernumerary muscles, viz. on the arm, an additional head to the biceps, an anomalus faciei on each side, a double styloglossus, a sternalis brutorum, and on the thigh an anomalous muscle from the heel to the gastrocnemius.

(11) Albinus Histor. musculor. hom. p. 167.-Zagorsky.

\section{$\$ 156$.}

The size and Form of the muscles depend in general on that of the skeleton, so that in its vices of form the muscles are found to vary very much. ${ }^{1}$ Still, however, we observe these circumstances alone without the bones being malformed; thus we find them, congenitally, too long or too short, too broad or too narrow, too thick or too thin, unsymmetrical, \&c. ${ }^{2}$ More frequently their form varies as an acquired vice; to these belong the MORBID CONTRACTIONs, contracturce, ${ }^{3}$ arising especially in consequence of inflammatory and convulsive conditions, the SHRINKING of muscles ${ }^{4}$ in consequence of diminished nourishment in cachetic patients, general or local in lame people, or in limbs which have been long unused from other causes, or if long-continued pressure have acted on the muscles, as in wens, abdominal dropsy, and swellings of various kinds; in such instances, thick muscles become, generally when they are simultaneously expanded, often as thin as membrane: further, the opposite vice or morbid increase from hypertrophy, ${ }^{5}$ and the various kinds of swellings connected with vice of texture, as well as extension of length and breadth occurring in relaxation, which, when also the extensile causes, as tumours, collections of water, dislocations of bone, \&c. cease to operate, often distinctly remain for a long time.

(1) For instance, on imperfectly developed limbs, very small. In crookedly united fractures of bone, in distortions. - $A$ description and engraving of some cases of the latter kind, in rickety persons, is given by Rodati, p. 397, pl. 18 .

(2) The platysma myoicles, instead of being flat, has been seen thick and roundish, and extending up to the occipital bone. v. Zagorsky, p. 357.-I have scveral times found, in new-born children and animals, some of the limbs too much arched or distorted, in consequence of the unnatural shortness of certain muscles. - In congenital wry-neck, as well as in club-hand and foot, this is generally the case.

(3) Reuss Repertorium Comment. Vol. XII. p. 284.-Crausins D. de contractura. Jenæ, 1687.-Vater D. de contracturis. Witeb. 1696. - Schwab D. de contractura. Leyd. 1701.-P'rietto D. de contractura. Budæ, 1703.-Matthias præs. Reil D. de diversis morborum localium formis ad contracturæ genus revocandis. 8vo. Berol. 1811. Compare § 24, note 1 .

(4) $\mathrm{After}$ the bite of the Ccylon leech, malignant ulceration and great wasting of the inuscles are said to arise. v. T'ytles in 'Transact. of the Med. and P'hys. Soc. of Calcutta. 8vo. Vol. I. 1828.

(5) Compare above, $\$ 21$, note 4 . 


\section{$\S 15 \%$.}

The Position and CONNEXION of muscles vary in rare cases from what is regular; this may be as well a congenital as an acquired vice. The former is the case when certain muscles have unusual points of origin and attachment; thus we find, for instance, the flexing muscles on the limbs sometimes irregularly deeply attached, and the extension of the part consequently very confined $;^{1}$ in deficient formation of the extremities, the tendons of the muscles of the terminal pieces are frequently connected with each other; in deficiency of the lower jaw, we find the masseter and maxillary muscles of the cheeks of both sides running into each other ${ }^{2}$ in the complete and sometimes also in the incomplete cleft belly, the tendinous membranes of the abdominal muscles are not connected at the white line; the biventer maxilla has been seen attached not to the chin, but to the lateral part of the jaw $;^{3}$ the omohyoideus not arising from the tongue-bone, but from the second vertebra, ${ }^{4}$ and the stylo glossus from the pterygoideus internus $;{ }^{5}$ the sternocleidomasioideus, by means of the sternalis brutorum running into the rectus abdominis ${ }^{6}$ all the scaleni attached to the first and none to the second rib; the biceps brachii not fixed to the fore-arm, but only belonging to the upper-arm, \&c. To the acquired vices of situation and form, belong the various DISLOCATIONS of individual or several muscles which may be produced by tumours of different kinds, but especially by bony tumours and dislocations of bones; and without these in consequence of unnatural motions, and the rupture of their retaining ligaments and the aponeuroses surrounding them. ${ }^{8}$

(1) I have occasionally seen this in human, but more frequently in animal monsters, especially in calves and sheep.

(2) I have seen this formation in two human monsters, and in six monstrous slieep.

(3) Platner D. de musculo digastrico maxillæ inferioris. Lips. 1737, p. 14, tab. 1.

(4) Rudolphi resp. Sels, p. 4.

(5) Moser, p. 226.

(6) I have also once seen this.

(7) Petit in Mém. de l'Acad. des Sciences. 1733, p. 21.

(8) Compare de Plouquet Repertor. Art. Musculor. Dislocatio. - Pouteau Vermischte Schriften. Dresden, 1764. - De la luxation des Muscles in Villers et Capelle Journal de la Societé de Santé et d'histor. natur. de Bordeaux. Vol. I. p. 120; and Coffinière Observations sur la luxation des muscles, $i b$. p. 138. - Ximenes in Memor. Acad. de la R. Soc. de Sevilla, Vol. VI. p. 108.Richter's Chir. Bibliothek, Vol. VII. p. 344.-C. F. Ludwig De Diastasi, No. III. Myodiastasis. Lips. 1821.

\section{$\S 158$.}

The usual red colour of the muscles not unfrequently varies from the normal in both ways, and is naturally, though 
not always, proportioned to the quantity and state of the cruor contained in the blood. The muscles are therefore, in all those diseases in which the quantity of blood and its contained cruor are greatly diminished, much paler than usual; thus in almost all cachexiæ of man and animals, as lameness, dropsy, wasting, in rickets, tubercular disease, \&c. ; further, in individual parts more or less used, as in wry-neck, club-foot, and anchylosis, in which the muscles are in a state of inactivity, they often become very pale and white, appear almost similar to the breast muscles of fowls; and on the contrary, muscles which are more used are often very pale from bleeding; also in several changes of texture, as in their conversion into fat, in induration from inflammation, and in scirrhus, the colour of the muscles becomes unnaturally light. The opposite vice, or the too great redness and colour of the muscles, is not less common; thus, for instance, they are very red naturally in all persons who are hanged, drunk, stiffled, destroyed by narcotic poisons, \&c. on account of the great congestion of blood; further, in all inflammatory diseases of men and animals, in consumption, \&c., dark or purple-red; also bluish-red in typhus and many plague-like diseases of man and animals, especially in yellow fever ${ }^{1}$ and mortification of the spleen; also in the blue disease, they are sometimes dusky-red, ${ }^{2}$ and in scorbutic persons, of a soot-like dark colour. In other cases, we find them coloured yellow or brownish-red, and if depositions of blood or destruction from mortification occur, they then become dark-brown and blackish.

(1) Laso Colleccion de inspecciones anatomicas relativas a la fiebre amarilla. 4to. Cadiz, 1824.

(2) I have seen this in two instances.

\section{$\S 159$.}

The consistence of muscles also varies exceedingly. We find it diminished in many cachetic diseases, particularly in long continued and general dropsies; in the continued rest of a part, especially in paralytic limbs, in cholera morbus, ${ }^{1}$ in putrid fever, plague of every kind, mortification of the spleen, $\& \mathrm{c} . ;^{1^{*}}$ also in the glanders of horses and in tubercular diseases, the muscles are often very flabby, withered, and soft; so again in hunted animals, and such as are killed by lightning; finally, it must be understood that they often exhibit much diminished consistence together with the changes of texture. The opposite vice, or too great solidity, firmness, and dryness of the muscles, is not merely the consequence of vice of texture, but occurs also without it, in rare cases, in a high degree, sometimes locally, in muscles which have been contracted 
and compressed for a long time, and sometimes generally; they have been thus found extremely dry, ${ }^{2}$ once in a hydrophobic patient, and once in an idiot, dark, bloodless, very hard and as dry as cured flesh. ${ }^{3}$

Vices of consistence occasionally give rise to vicEs of contrnuity, ${ }^{4}$ which, however, are more commonly the consequence of mechanical violence. To the latter belong, not merely the various flesh-wounds, the violent rupture of muscles, ${ }^{5}$ the separation of their connexion by suppuration, \&c. ; but also the more rare separation of the fleshy fibres by substances penetrating them, ${ }^{6}$ and the spontaneous rupture of individual muscles by violent exertion. ${ }^{7}$

In all these cases is the perfect or imperfect division of connexion, and the consequent loss of substance repaired by a reddish jelly-like substance being poured out, which at first is converted into a vascular and reddish cellular tissue, subsequently becomes compressed, lighter in colour, solid and devoid of vessels, produces the union of the two divided portions, and thus the use of the muscle is perfectly restored; in man and animals, ${ }^{8}$ however, this structure does not consist of true muscular substance. ${ }^{9}$

(1) Davy s. Neue Sammlung auserl. Abhandl. zum Gebrauche prakt. Aerzte Vol. VI. Part II. p. 302.

(1*) [A remarkable instance of the softening of the muscles in a person who had painters' colic, is mentioned by Dehaen, Ratio medendi ; and another person, similarly circumstanced, is stated by Barthez, to have had the firmness of the muscles restored, when the paralysis subsided. v. Andral Précis. d'Anat. Patl. Vol. I. p. 220. T.]

(2) Morgagni De sedib. et caus. morbor. Epist. VIII. Art. 30.

(3) My Selt. Beob. I. p. 92.-An interesting case of hardening, without vice of texture, is noticed by Isenflamm. v. Versuch über die Muskeln, $§ 159$.

(4) For instance, rupture of the heart, the womb, the bladder, \&c. from softening of their fleshy parts.

(5) I have in a few cases, of persons who have been run over, or who have fallen down dead, observed some of the muscles torn. This occurs also in violent pressure of the air from explosion of gunpowder, \&c. If parts of the extremities be lacerated by mills, or other machinery, the tendons are sometimes torn out above the common point of separation, even up to the heads of the muscles, as I have seen in one instance.- [ In one instance, I saw the upper portion of the rectus abdominis ruptured by the shaft of a cart, without injury to the common integuments: a ventral rupture was the consequence. T.]

(6) In the alimentary canal, the urinary bladder, and the arteries, the internal membrane protrudes between the divided muscular fibres. The same also occurs in the abdominal muscles in ruptures, and in very fat persons.

(7) Compare de Plouquet Repertor. Art. Musculor. Ruptura et Dislocatio fibrarum; and Reuss Repertor. Comment. Vol. XIV. p. 387 ; also Janson D. sur les ruptures des tissus et des organes du corps humain. 4to. Paris, 1813.Fleischmann Leichenöffnungen. Erlangen, 1815 , p. 211.- In a person struck by lightning, v. Ouvrard in Nouv. Journ. de Médec. Chir. et Pharm. Paris, Dec. 1822. - Larrey Mém. de Chir. milit. Vol. III., the rectus abdominis in tetanus.II. F. Isenflamm Anatom. Untersuchungen, 1822, p. 173.-Roulin Du mécanisme des ruptures inusculaires in Magendie Journ. de Physiol. expérim. Vol. I. No. 3, p. 295.-Chaussier Recueil de Mémoires, Consultations et Rapports sur divers 
objets de Médecine légale, p. 402. Svo. Paris, 1824. - Richerand Grundriss der neuern Wundarzneikunst, a. d. Fr. vo Rohbi. Vol. VIII. Leipz. 1824. Martin in Rust's Magaz. f. d. ges. Heilk. Vol. X1X. p. 590. - Boyer Traité des Maladies chirurgicales. 8ro. Paris, 1822-1826, Vol. XI. Chap. 3, the right M. rectus after vomiting. - Flaubert in Répertoire génér. d'Anat. et de Physiologie pathologiques, 1827, Vol. III. Part I. p. 121, rupture of the pyriformis, of the gemelli, and of the quadratus femoris, caused by dislocation of the hip outwards or inwards. - I consider the case of Kelch, No. 37, which has been often observed, to have takeu place after death, as in it all the marks which accompany rupture during life, viz. effusion of blood and inflammation, were absent.I have once seer after spasm, the omohyoideus torn; and a few times also, other muscles. v. Selt. Beob. I. p. 92. Verz. No. 2175.

(8) It is well known, that in the lower animals, muscular fibres also are reproduced in regenerated parts. However, I find that in the reproduced tails of lizards, the muscles still remain, for many years, more imperfect than the original.

(9) Compare the notices given above, $\$ 56$, note 1; also Kleemann D. s. quædam circa productionem partium corp. hum. Halæ, 1786. - Schnell præs. Autenrieth D. de natura reunionis musculorum vulneratorum. Tubing. 1804.F. Paul Comm. physiol. chir. de vulneribus sanandis, in certam. lit. præm. ornata. 4to. Gött. 1825, with two engravings.

$\S 160$.

Among the vices of Texture of the muscular system, INFLAMMATION, myositis, ${ }^{1}$ arises very generally both from internal and external causes; so also its usual consequence, SUPPURATION, which, according to the difference of its causal proportions, its seat and extent, assumes the most varying forms ; $;^{2}$ and GANGRENE, which often destroys very large masses of flesh. Softening of the muscles, in consequence of inflammation or uncertain proportions of mixture, is much less common; it occurs in the muscular coats of the alimentary canal and urinary bladder at the same time, with softening of the other coats of the aforesaid parts, and in softening of the stomach secondarily in the diaphragm; it occurs in the muscles of the lips and cheeks in watery cancer, and even in the large muscles, and sometimes attains such an extent, that a muscle is converted either entirely or partially into a slimy, purulent, bloody, jelly-like, pappy, or fungous mass. The converSION OF MUSCLES into TRUE $\mathrm{FAT}^{3}$ is more frequent, by which ultimately the fibrous structure of the part is entirely destroyed; this vice occurs especially on the lower extremities, ${ }^{4}$ particulary in the gastrocnemii, in anchylosis and other diseases of the knee-joint; so also in fat people, there is frequent paleness of the muscular fibres by the simultaneous deposition of fat in the muscular tissue. The consistence of the muscles in this disease, as naturally as frequently, though not always, diminishes their size. HARDENING of the muscles, with change of their tissue, is always the consequence of inflammation, and the exudations thereby produced into their interior, and often occurs as well in the voluntary as in the 
involuntary muscles, and in very different degrees; usually also with some swelling. Should this state be longer continued, and the hardening become more distinct, then the muscles become whitish, entirely lose their usual texture, and assume a leathery and even tendinous or cartilaginous appearance. $^{5}$ The ossification of muscles, that is, the actual conversion of muscular fibre into bony substance, does not appear to occur $;^{5 *}$ although frequently, and especially in old and gouty persons, we observe BONY AND STONY CONCREMENTS, which, however, are always seated merely in the cellular tissue between the muscles, and appear in very different number, size, and form. ${ }^{6}$ Spurious Productions are extremely uncommon in the muscular system; to these belong, TUBERCLES, which sometimes occur in the involuntary and more rarely in the voluntary muscles $;{ }^{7}$ further, LIPOMA, ${ }^{8}$ and other Tumours, ${ }^{9}$ for example, MEDULLARY sARCom, which usually render the neighbouring parts gangrenous, ${ }^{10}$ and scirRHus, which attacks the muscular system but only secondarily, and changes it into a solid, whitish fibrous substance, which subsequently runs into malignant ulceration.

(1) de Plouquet $\mathrm{D}$. de myositide et nevritide. Tübing. 1790. - A very confined motion may easily occur, in consequence of inflammation of muscles, their adhesion with each other, with the aponeurosis and with the skin.

(2) I have described two cases of a peculiar kind of suppuration in muscles, in my Selt. Beob. Part II. p. 40. The most important kind is psoitis, on account of its frequency and consequences, of which we must speak further, when on the abdominal and pelvic cavities.

(3) Myodemia of Lobstein. v. Compte rendu, etc. Strasb. 1820, p. 32.-[Steatosis of Cragie. v. his Elements, p.498. T.]

(4) I have never seen the true conversion of muscle into fat, as has Lobstein, in any other parts than on the extremities. It is, however, said to occur in other parts, and even to take place in all the muscles at once. v. Saillant Mémoire sur la Maladie de veuve Melin. Paris, 1776.-Several instances of this disease have been collected by de Plouquet, in his Repertorium, and by Reuss, in his Repert. Comment. Vol. XIV. p. 170.

(5) I have seen the latter in the foot of a man, who was destroyed by elephantiasis. v. No. 2168 of my Verzeich.--In a child, of which the skin had become remarkably hard, the muscles also participated in the hardness. v. Baillie's Works, edited by Wardrop. 2 vols. 8vo. London, 1825. Vol. I. - [Andral saw, in one instance, the sterno mastoid muscle converted, throughout its whole extent, into a fibrous structure, exactly similar to its own lower tendon, Vol. I. p. 275 . T. $]$

$\left(5^{*}\right)$ [Tavernier in Andral Préc. d. Anat. Vol. II. Part II. p. 571, gives an account of ossification of the diaphragm to the extent of three inches by three inches and a half, in which he states, that no trace either of muscular or fibrous structure existed at that part; and concludes, "Dans ce cas il semble evident que le diaphragme lui même était le siège de la transformation cartilagineuse et osseuse. T.]

(6) Sometimes they are remarkably large; to wit, as long as the finger. v. Phil. Trans. 1741, No. 461.-I saw a similar concretion at Rudolphi's, on the thigh. I once found a large one, two inches long, and above an inch broad, upon the diaphragm. v. my Selt. Beob. Part I. p. 93. - I have frequently found smaller ones.-Cerutti, in his Beschreib. der pathol. präparate zu Leipzig, relates 
several, No. 639-644.-Tiedemann found in the body of a gouty person, white, stone-like, roundish concretions, principally consisting of phosphate of lime, in most of the muscles, especially in those of the extremities. v. von Froriep's Notizen, No. 4, p. 64. Aug. 1821. - Mechel found in a newly-born rickety child, a little hard bony concretion in the left M. levator scapulæ. v. Anat. Physiol. Beob. und Untersuch. p. 22. Halle, 1822. - I once saw a congenital large angular piece of cartilage, in the M. sternomastoideus of a boy. The case related by $W$. Henry, in which the muscles and tendons of a young man were said to be converted into bone, is certainly improperly related. - [In Mus. Roy. Coll. Surg. No. 534, is a remarkable case of extensive ossification, some of which certainly appear to be conversion of the muscles into bone; thus, one large mass occupies the place of the deltoid, joins the clavicle, scapula, and humerus together ; another, that of the supra spinatus; a third, attaches the scapulæ of both sides to the spine, and the angle of the scapula on the right side to the humerus, taking the course of the teres major and latissinus, and many others below; but one especially joins the pelvis to the right thigh, in the exact situation of the long-head of the triceps adductor femoris. T.]

(7) In scrofulous monkeys, I have seen a few times tubercles in the muscles of the neck, also in those of the thigh. I once also found a large tubercle on the sternonastoid muscle of a girl. - Laennec also found tubercles. v. his work, De l'auscultation médiate.

(S) de Schallhammer, fig. 11.

(9) Haller Opera Minora, Vol. III. p. 286, of an undefined character in the M. masseter.

(10) Will. Chevalier, General observations of morbid tumours, in which the muscular structure is attacked, \&c. in London Med. and Phys. Journ. Vol. LV. p. 95 , with engravings.

\section{$\S 161$.}

Lastly, we find also extraneous and unNatural subSTANCES in the muscles, and especially FLUIDS, as WATER in dropsy, by which the fibres are sometimes widely separated from each other, and the muscle similar to a sponge filled with water; JELLY-LIKE FLUID, which seems to be poured out in and upon the muscles in acute rheumatism; a YELLOwISH LYMPH-LIKE FLUID, which, in mortification of the spleen in animals, is often poured out between the skin and the flesh, sometimes also between and in the muscles; not unfrequently BLOOD and PUs, in manifold different proportions; further, PARASITIC ANIMALS, ${ }^{1}$ as the lernea, which in fishes penetrate through the skin, sometimes into the muscles; FLY-MAGGots, which occur in foul sores, and their surrounding fleshy parts in man and animals; the hydrachna concharum, in the flesh of freshwater muscles; the gamasus marginatus and pulex penetrans which sometimes insinuate themselves through the skin into the adjacent muscles; and lastly, the several kinds of intestinal worms, filaria, distoma ${ }^{2}$ ligula and cysticercus, or MEASLES in pigs. ${ }^{3}$ Finally, we must here also mention, DEAD EXTrANeOUs Bodies, as needles, fish bones, balls, \&c. which may remain sometimes for a longer or shorter period in the muscles. ${ }^{4}$

(1) Compare above, $\$ 70$. 
(2) For instance, Distoma isostomum and cirrigerum in the flesh of crabs, even in the claws, and D. duplicatum in the foot of the anodonta. v. von Bär in Nov. Act. Nat. Cur. Vol. XIII. Part II. p. 553 and 559.

(3) I found the cysticercus cellulosæ throughout almost every winter in one or several subjects, sometimes numerous, at other times but few ; but I never saw cysticerci in the muscles of the head. Perhaps these animals give rise to the formation of the very rare, little, thick-coated, tough cysts filled with fluid. v. my Selt. Beob. Part I. p. 93.

(4) Compare above, $\$ 73$.

\section{NINETEENTH SECTION.}

\section{Of the Vascular System.}

\section{First Chapter.}

\section{Of the Pericardium.}

\$162.

The vices of formation which the PERICARDIUM but rarely presents, ${ }^{1}$ are mostly in close connexion with those of the heart itself, to which it merely serves as an investing membrane, and a mean of attachment. The pericardium, therefore, is not only always completely deficient if the heart be wanting, but commonly also if the heart be exterior to the chest $;^{2}$ yet sometimes it is either wholly ${ }^{3}$ or partially ${ }^{4}$ wanting, although the heart exists and is situated within the chest.

The sIzE and FORM of the pericardium depends partly on that of the heart, partly on that of the chest, and of the neighbouring soft parts. Sometimes it is found VERY LARGE, if in monsters it contain two hearts, or more commonly if it be MORBIDLY DISTENDED, as in swellings of the heart and of the origin of the aorta, as well as in collections of fluid or of air in it. Very rarely the extension is so great at a particular spot, that a diverticulum is produced. ${ }^{5}$ In many instances, especially in monsters, it is found, at the time of birth, as imperfectly developed and THIN as in the early stage of foetal existence; in other cases, it is observed unnaturally thin at a later period, in consequence of atrophy. The opposite vice, viz. the TOO GREAT THICKNESS, is much more frequent, which, however, seems to occur only in disease.

(1) M. Hoffmann D. de pericardio. Altd. 1690.-Luther D. de pericardii, pulmonum et partium genitalium anomaliis. Kil. 1704,-A. B. Heimann D. de 
pericardio sano et morboso. Leid. 1729.-Compare the treatises on the diseases of the heart.

(2) To this rule I have seen a few exceptions. - In the Anat. Mus. at Berlin, a case of protruding heart appears to possess a pericardium.-The same was observed by Bock. v. Cerutti's Pathol. anat. Museum, Vol. I. Part III. p. 45.Cerutti in Meckel's Archiv für Anat. und Physiol. 1828. No. II. p. 194.-When the heart rests in the belly, sometimes the under part of the pericardium is wanting, as I have seen several times.-Observed also by Rosenthal Abhandl. a. d. Gebiete d. A nat. Physiol. und Patholog. p. 148. 8vo. Berlin, 1824.

(3) On removal of the breast-bone, the heart lies quite exposed, with the left lung in a common cavity, and derives its serous covering from the left pleura. For the most numerous observations of deficient pericardium, compare de Plouquet Repertor. Art. Pericardium deficiens: though not all, as Haller, De corp. hum. fabr. L. IV. Sect. $1, \S 23$, erroneously maintains, were real adhesions of the pericardium with the heart, although in the following cases there appears to have been an actual deficiency: Columbus De re anat. L. XV. p. 489.-Bartholinus Hist. anat. Cent. IV. No. 20; Epist. p. 406.-Baillie in Philos. Transact. 1740 and 1741, No. 46; and in another case, in Transact. of a Society for the improvement of med. and chir. knowledge. London, 1793, Art. 6, with an engraving, Appendix, p. 2. - Dinkler in Sandifort's Natuur-en geneeskundige Bibliothek. Vol. I. p. 661. - Joh. G. Walter Museum anatom. No. 668. Compare Henkel D. de pericardio deficiente. Berol. 1818.-My Monstros. sex humanor. anat. et physiol. disquisitio. 4to. Francof. ad Viadr. 1811, p. 16; and since then in another case.-Petersb. vermischte Abhandl. aus dem Gebiete der Heilkunde. 1st Part, 1821, p. 230.-Wolf in Rust's Magazin für die gesammte Heilk. Vol. XXIII. Part II. p. 333.-Gotthoff D. s. descriptionem casus rarissimi spinam bifidam totalem-exhibentis. 4to. Berol. 1827, p. 7 .

(4) This, on account of the oblique situation of the heart, seems to occur only on the left side; a portion of the heart then lies sometimes in the left pleura, sometimes, on the contrary, une lobe of the lung in the cavity of the pericardium. Similar cases are described in my Selt. Beob. Part II. No. 18, p. 44. - Since then a second similar case occurred in the Bresl. Mus. No. 2874.-Breschet in Répertoire gén. d'Anat. et de Pliysiol. pathol. 1826, Vol. I. Part I. p. 212.J. F. Meckel Descriptio monstror. nonnullor. 4to. Lips. 1S26, p. 12.

(5) I saw a similar instance in the Anat. pathol. Mus. at Vienna, which is large, and only connected with the pericardium by a narrow aperture.

\section{$\S 163$.}

The pericardium sometimes also presents numerous varieties in reference to POSITION and ATTACHMENT, inasmuch as, in rare instances, it is not only placed with the heart too high or too low, even in the belly, ${ }^{1}$ or exterior to the chest, ${ }^{2}$ whilst the heart still retains its perpendicular position in the middle; so in the congenital situation of that organ to the right side, it also lies too much to the right; but it further deviates in a peculiar manner as concerns the common degree of its attachment to the diaphragm. ${ }^{3}$

The colour of the pericardium is but seldom irregular, and it may be either too pale, dull, or slightly reddened in many diseases; also in suppuration, mortification, \&c. in the cavities of the mediastina it is variously discoloured, even black, ${ }^{4}$ and, in the severer forms of jaundice, yellow. ${ }^{5}$ Sometimes its internal surface is marked with large red-brown spots from the blood transuding through the right auricle. 
(1) I remarked this several times, particularly in large umbilical hernia.

(2) Compare $\$ 162$, note 2.

(3) Compare my Selt. Beob. Part I. p. 94.- Sometimes in equal size of the heart the diameter of the point of attachment is only one and a half, often also four inches. The first vice forms the transition to the more unattached position of the pericardium in mammalia.

(4) Stoerck Annus I. p. 108.

(5) Stoll Ratio medendi.

\section{$\S 164$.}

The Consistence of the pericardium, which is sometimes considerably lessened by disease, and may also be increased, falls but very seldom under consideration, on account of its protected position and its pliancy. In a few instances it has been seen torn by external violence, not by any thing piercing it, but merely by concussion ; ${ }^{1}$ more frequently however, it is INJURED by bullets, pointed instruments, broken ribs, and pointed substances which have been SWALLOWED; and it has been marked by CICATRICES, ${ }^{2}$ the consequence of such wounds as have not been mortal. It is very remarkable, that in some few instances the pericardium is found as dry as if it had been long exposed to the air $;^{3}$ and this has even sometimes been observed in cases of hydrophobia, both in man and animals. ${ }^{4}$

(1) Boneti Sepulchret. Lib. IV. Sect. 3, Obs. 27.--Danz in Starli's Archiv. Vol. III. Part III. No. 2. - In a healthy young man, the heart completely burst the pericardium, without any injury to the chest, in consequence of a blow on the breast from the wadding of a small cannon; in a morbid examination at the Med. Coll. of Silesia.

(2) de Hautesierk Recueil d'Observations de Médecine. Paris, 1772, Vol. II. p. 600.-Bongon v. Rust and Casper Krit. Repert. f. d. ges. Heilkunde, Vol. VI. Part III. p. 474.-Compare the cases of cured wounds of the heart, related by surgeons.

(3) Boerhaave's Pathological treatises on the Heart, in the Sammlung auserles. Abhandl. prakt. Aerzte, Vol. IX. p. 495.-Hunter, Sömmerring, and Baillie's Morbid Anatomy.-I once found it in an asthmatic person as dry as parcliment, only on the left side.

(4) Capivacci Practic. L. VII. c. 12, p. 1085.-Brechtford v. Acta med. Havn. Vol. V. Obs. 144, 1677. - Taury in Mém. de l'Acad. de Paris, 1699, p. 55.Gherardini Samml. für prakt. Aerzte, Yol. XV. p. 96.-Andry Untersuchungen über die Wuth nach dem Bisse tolier Thiere. Leipz. 1785.--Ferriar Medical Facts and Experiments. Vol. I. London, 1791.

\section{$\S 165$.}

Among the vices of Texture of the pericardium, its inFLAMMATION, pericarditis, ${ }^{1}$ is the most important. This disease, according to the diversity of its causes, ${ }^{2}$ its acute or chronic course, its degree and extent, exhibits many varieties; it, however, always shows itself by tumefaction, loosening, and more or less redness. A morbid exudation of lymph-like fluid and fibrous substance on the inner surface of the pericardium is the usual consequence of inflammation of that membrane. From the fibrous substance are produced false 
membranes, bands, flakes, fibres, \&c., which are either simple, more or less thick, even double, and in time become organized; they are situated either merely upon the inner surface of the pericardium or upon the surface of the heart also, and then cause either a general or local, a close or loose CONNEXION $^{3}$ of the pericardium with the heart. Less frequently such effusion occurs on the external surface of the pericardium, and then produces its adhesion with the breastbone, the mediastina, the gullet, \&c. Pericarditis seldom runs on to suppuration; but when this happens, one or more ULCERATED SPOTS ${ }^{4}$ are found, sometimes externally, but more usually internally. Inflammation of the pericardium probably never terminates of itself and without gangrenous destruction of the neighbouring parts, in MORTIFICATION. After chronic pericarditis the pericardium more commonly becomes thickened, either generally or in particular spots; ${ }^{5}$ becomes hard, leathery, and even cartilaginous $;{ }^{6}$ and more rarely ossified in patches.

(1) Lemazurier D. sur la pericardite. 4to. Paris, 1810.-Petrenz D. de pericarditidis pathologia. 4to. Lipsiensis, 1822. - Tacheron Recherches anat. pathol. Vol. III. p. 226. Paris, 1823.-J. Abercrombie in Transactions of the medic. chirurg. Soc. of Edinb. 1824, No. 1. - Andral jun. in Mémoires de la Soc. médicale d'Emulation de Paris, Vol. IX. No. 14, 1826.-Louis in Revue médicale française et étrangère, Paris, 1824, Jan. to March; and in Mémoires, ou Recherches anat. pathol. p. 253. 8vo Paris, 1826. - Adams in Dublin Hospital Reports and Communications, Sc. 1827, Vol. IV. No. 19. - Good engravings, by J. G. Walter Sur les maladies du Cœur in Nouv. Mémoir. de l'Academ. des Sc. à Berlin, 1785, tab. 4; and Bleuland Icones anat. pathol. 4to. Traj. ad Rhen. 1826, tab. 1 and 2. - Stiebel Monographixe carditidis et pericarditidis acutæ, epistola dedicatoria et præfatio. 4to. Francof. ad Mœn. 1828.

(2) For instance, from mechanical causes, from catching cold, metastasis of gout, rheumatism, hydrophobia, \&c.

(3) It is not unfrequently so general and so firm, that the pericardium seems to be entirely wanting; often it resembles cellular tissue, ligaments, threads, $\mathcal{S} \mathrm{c}$, - Pohl Progr. de pericardio cordi adhærente ejusque motum turbante. Lips. 1775. - Nebel Progr. de pericardio cum corde concreto. Giess. 1778. - 「In the Mus. at St. Thomas's Hospital, there is a fine specimen of complete adhesion of the close and investing portions of the pericardium, which, from its appearance, has evidently existed for a considerable time. 'T.]

(4) Hilscher et Schmierlel D. de exulceratione pericardii et cord. exemplo illustrata. Jenæ, 1742 :-Lientaud Histor. anat. med. 4to. p. 210.-Meckel Mém. de Berlin, 1756, Vol. XII. p. 31. - Stoll Rat. med. VII. p. 172.-ran Doeveren Specim. observat. acad. Cap. V.-Senac de Corde, L. V I. cap. 2.-Siörck Amus medicus secundus, p. 92. - Chambon de Montanx Merkw. Krankengeschichten und Leichenberichte. Lejpz. 1791. - Biermayer Mus, anat. pathol. No. 434.I have myself once scen scrofulous suppuration of the anterior wall of the heart. ['The assertion of the author, that suppuration of the pericardium never occurs without ulceration, is not correct.-Baillie once found the pericardium lighly inflamed, and containing a quart of pus, but without ulceration.-In the Mus. at St. 'Thomas's Hospital, there is a case of suppuration of the pericardium, which protruded at the pit of the stomach, and being mistaken for abscess of the liver, was tapped; what was the immediate result I do not know. 'I.]

(5) I have found this several times fiom two-twelfths to thrce-twelfths of an 
inch thick, and in one here and there half an incl. Good instances of thickening are given by Boerhaave, Vol. IX. p. 498.-Senac, p. 72.-Morgagni De sed. et causs. morbor. Ep. XVIII. p. 34 ; XX. 20, 35 ; XXII. 10 ; XLIII. 17; XLV. 16 ; LIII. 29.-Portal Cours d'Anat. méd. III. p. 24.-It was found nine lines thick, and with two suppurating, and one gypsum-like tumour, by Rochoux v. Journ. gén. de Méd. et chir. Vol. XXIX. Feb. 1814, Bulletin, p. 33.-Fibrous degeneration of the pericardium, many lines thick, \&c. v. Bidois fils, in Archiv. génér. de Médec. Decbr. 1823.-Elliotson, Diseases of the héart, fig.

(6) Morgagni, Ep. XXII. p. 10.-Boerhaave. - Riolanus Anthropographia, L. III. c. 12.-Hautesierk Recueil d'Observations, Vol. JI. p. 583.-Saviard in Journ. des Savans, 1691. - Testa ;-very thick and cartilaginous. v. Peterb. vermischte Abhandl. a. d. Gebiete der Heilk. 1ste Samml. p. 232, 1821. - I have observed several remarkable cases.

(7) Ossification occurs, sometimes in the fibrous, sometimes in the serous, layer. - Instances are related by Haller Addenda ad Elem. Physiol. p. 128. -Senac Traité des Maladies du Cœur. I. VI. c. 2. - Saviard Observat. chir. I. LV. p. 25.-Aurivillius in Nov. Art. Upsal. Vol. I. p. 101.--Walter Observ. anat. p. 63, and Anat. Mus. Vol. I. p. 148, 149, 297. - P'asia Ep. de cordis polypo. p. 75,-Prost Médecine eclairée par l'overture des corps. I. p. 140.-Rayer in Archiv. général. de Médec. March and April, 1823. - Abercrombie, in Trans. of Med. Chir. Soc. of Edinb. No. 1.-Adlams. - $\Lambda$ large piece of bone was once found in the pericardium, which had been driven in from the breast-bone by a shot a long while before. v. Rust's Magazin f. d. ges. Heilk. Vol. XVI. Part I. p. 185.

\section{$\S 166$.}

To the other vices of texture, which either are not, or at least not distinctly, consequences of inflammation of the pericardium, belong the too great deposition of FAT on the external surface and between the layers of the pericardium, which produces sometimes a narrowing of the cavity of the chest, and especially an injurious pressure upon the heart and great vessels ${ }^{1}$ next HYDATIDS, ${ }^{2}$ which are occasionally observed situate both on the inside and outside of the pericardium both in man and beasts; then a peculiar kind of PEDUNCULAR GRowTHS, peculiar to serous membranes, is found on its inner surface, ${ }^{3}$ in which, although very rarely in this membrane, cartilaginous or osseous masses present themselves, which, if the connecting pedicle be ruptured, are found loose in the pericardium; true ENCYSTED TUMOURS, ${ }^{4}$ and, finally, TUBERCULAR $^{5}$ and SARCOMATOUS ${ }^{6}$ SWELLINGS, which are all merely spurious formations, are here very seldom met with.

(1) Boneti Sepulchret. anat. Lib. II. sect. 11, obs. 16.-Senac, p. 69.-Godart, in Journ. de Médec., 1761, May, Vol. XIV. p. 401.-Morgagni, Epist. XIX. § 7.Mectiel Mém. de l'Acad. de Berlin, 1756, p. 79.-J. v. Bergen, in Act. soc. med. Havn. Vol. I. p. 247.-Testa.-Parry, Inquiry into the symptoms and causes of the syncope anginosa. Lond. 1801.-Black, in Mem. of the Med. Soc. of London, Vol. V1. p. 45. -Kreysig Von den Krankheiten des Herzens, Vol. III. p. 124.Horn, in Archiv f. d. Med. Erfahr. Vol. III. Part I. p. 58, found a steatomatus pericardium three inches thick. Such fatty deposits on the pericardium have been improperly considered as possible causes of angina pectoris. v. Fothergill, Med. obs. and Inq. Vol. V. p. 246. - Wall, in Med. Mem. Vol. III. p. 13.Schramm Comm. pathol. de angina pectoris, p. 17, \&c.-In many of the above rlescribed cases the disease killed suddenly. I have scen a few such cases, in one 
of which the pericardium had become remarkably narrow, and in meagreness of other parts of the body I have found very much fat in the pericardium.

(2) Rolfinck, Epitome method. cognosc. c. h. affect. p. 164.-Boneti Sepulchret. L. II. Sect. VIII. Obs. 6, L. III. Sect. XXI. Obs. 21, § 14. Sect. XXXVII. Obs. 3, § 12.-Heuermann Pliysiologie, Vol. I. p. 202.-Richter Deutsche Biblioth. Vol. IV. p. 239. - Steinbuch De tænia hydatigena, 1802, p. 5.-Bernhardi Observat. circa ingentem cordis tumorem. Svo. Regiomonti, 1826, p. 22.--Here also perhaps belongs the case of a cyst filled with lymph in a monkey. v. Galenus De loc. affect. L. V. c. 2.

(3) Compare $\$ 81$. I have found this twice, and in the one case, at the same time with loose cartilages. v. my Verzeichn. No. $21 S 3$ and 2184.

(4) The case related by Lancisius de Ancurysm. L. I. propos. 5, seems to belong here.-Senac, Vol. II. p. 340, found a meliceris.-Portal Cours d'Anatomie médicale, Vol. III. p. 23.

(5) I have twice found this, once in a child and once in a monkey.-Luchtmann's Samml. auserles. Abhandl. Vol. XVII. p. 210.-Baillie found two or three such tubercles, one of which was as large as a walnut; he also found two tubercles as big as hazelnuts on the side of the heart. v. his works, edited by Wardrop, Vol. I. London. - Macmichael in London med. and phys. Journ. Aug. 1826.Perhaps we may here include the cases mentioned by Zacutus Prax. adin. L. II. Observ. 137.-Galenus, in a fowl.-Dionis, v. Lieutaud hist. anat. med. Vol. II. p. 271.-Bourru in Hist. de l'Acad. de Paris, 1763, p. 35. - Haller Op. minor. Vol. III. p. 365.-Nov. Comm. Petropol. v. Voigtel Path. Anat. L. II. p. 220. C. Bell, System of Dissection, Sc. Edinb. fol. 1798. - Laennec De l'auscultation médiate. Vol. II. p. 397. Paris, 1819 ; also in an ox.--Musgrave, in Phil. Transact. 1685. p. 860.

(6) In a case of medullary sarcoma in the posterior mediastinum not only was the posterior part of the pericardium affected, but even perforated by it. In an old woman, whose arm was amputated on account of fungus hæmatodes, medullary sarcom was found on the pericardium and heart. v. Gerson and Julius Magaz. der ausländ. Literatur d. g. Heilk. 1823, Sept. Oct. p. 199.

\section{$\S 16 \%$}

Finally, as to the vices of contents, we must first notice the collections of gaseous and lymph-like fluids which are mostly the product of morbid irritation or of an inflammatory condition; the collection of $\mathrm{AIR}^{1}$ in the pericardium is not often observed without existing decomposition; but sometimes, however, it is observed in such degree that the membrane appears inflated. The collection of WATER or DROPSY of the PERICARDIUM, hydrops pericardii, hydropericardion, ${ }^{2}$ is much more common. It is generally found accompanying dropsy in other parts, but rarely alone, and varies considerably with respect to the quantity, colour, and consistence of the collected fluid. ${ }^{3}$ In inflammation of the pericardium and its consequences, distinct extravasations of PLASTIC LYMPH or FIBRINE are frequently seen on the heart, which float in the greater or less quantity of water in the form of flakes and lumps; or, on the contrary, if it be coagulated into cells, the water is contained in them; or, finally, becomes thicker, and assumes the appearance of a pus-like substance. ${ }^{4}$ If ulcers are found on the pericardium or heart, true Pus is scen on the former, which, however, in rare cases makes its way from the neighbouring. 
parts $^{6}$ into the pericardium, ${ }^{7}$ as it can in like manner make its way out of the pericardium. When the heart or the blood-vessels are injured, or burst within the pericardium, that membrane is naturally found more or less filled with fluid or coagulated BLOOD $; 8$ still we sometimes find in the pericardium bloody water or actual blood, without any other cause than mere transudation. ${ }^{9} \quad$ Sometimes blood is poured out between the layers of the pericardium, and forms larger bladders of blood, ${ }^{10}$ or smaller petechial spots. ${ }^{11} \quad$ Fibro $_{\text {CARTILAginous }}{ }^{12}$ and STONY ${ }^{13}$ CONCRETIONs are very rarely observed loose in the cavity of the pericardium; these very probably have had their origin in peduncular tumours, which had been subsequently broken off. ${ }^{14}$ Lastly, in the pericardium of beasts, ENTOZOA have been found. ${ }^{15}$

(1) Compare $\S 51 .-$ Hollerius de morb. int. L. I. c. 29, p. 129.-Hercules a Saxonia Præl. pract. C. 1, p. 2.-Bartholin. v. Lieutand Hist. anat. méd. sect. 1, Obs. 1672.-Ballonius paradigmata, No. 96.--Senac, L. VI. c. 3.--One case in Med. Chir. Rev. 1825. - Brière in Nouv. Bibliotl. Febr. and March, 1826._-In my Selt. Beob. some good instances.

(2) See for single cases in de Plouquet Repert. Art. Hydrops pericardii, and Reuss Repertor. Comment. Vol. XIII. p. 561.-Schellhammer D. de aqua pericardii. 1694.-Fr.Hoffmann resp. Giatz D. de hydrope pericardii rarissimo. Halæ, 1697.Mercker D. de hydrocardia. Ultraj. 1711.-Westring in K. Svenska Vetensk. Acad. Nya Handl. 1790, Vol. XI. p. 292.-Landvoigt D. de hydrope pericardii dignoscendo. Halæ, 1798.-Heinecke D. de hydrope pericardii. Erford, 1799.Modes D. Essai sur l'lydropisie du péricarde. Paris, 1808. - - In rare cases we find the water between the layers of the pericardium itself. v. Portal, Vol. III. p. 11, note 2.-Morgagni, Epist. XV I. p. 44; XXV.p. 16 ; and Portal, p. 28, have improperly asserted that dropsy of the pericardium may arise from ruptured hydatids.

(3) The quantity varies from some spoonfuls to two or three pints. v. Frank, p. 243. - Corvisart Sur les Maladies et les lésions organiques de cœur. 8vo. Paris, 1806 ; translated by Hebb, London, 1813. - [ In a case of hydrops pericardii, related by $W_{o o d}$, in London Med. and phys. Journ. Vol. LXI. p. 406, two quarts of lympll were effused. T.] The coLouk is sometimes light and clear, more frequently yellow or brownish, even reddish, viz. commonly in bilious and putrid fevers; milky in metastasis of the milk in lying-in women, \&c. The consistence is often very mucous, albuminous-like, \&c. A moderate quantity of water in the pericardium does not necessarily lead to the conclusion, that disease existed during life, since here, as in other serous cavities, it is often first effused in the very moment of death.

(4) Compare $\S 55$. The coagulum lying loosely in the pericardium, improperly called polypus by Hohnbaum, v. Heidelberger klinische Annalen, Vol. I. Part III. p. 414, undoubtedly belongs here. [According to Elliotson, On Diseases of the Heart, p. 8, the quantity of serum effused in acute pericarditis is far less in proportion to the fibrine than in pleurisy, rarely amounting to a pint: on the contrary, in chronic disease the fibrine, if any, is thin and soft. T.]

(5) The older and even more modern authors often confound pus with puriform coagulable lymph, therefore their observations are not to be relied on. Compare the cases described at $\S 165$, note $4 .-A$. Monro, in his description of all the bursæ mucosæ, \&c. Edinburgh, 1788, p. 41, states, that after an injury with a red-hot iron, lie found five ounces of pus in the pericardium.

(6) For instance, from abscess of the liver, through the diaphragm ; Nov. Acta, Nat. Cur. Vol. VIII. Obs. 9, and v. Siebold Samml. chir. Bcobachtungen Vol. I. 1). 248. - Chaussier in Bulletin de la Faculté de Médecine, 1811, No.5, p. 98. 
In Philadelphia medical Journal.-I once found in an abscess in the anterior mediastinum some pus penetrating through a delicate fistulous orifice into the pericardium.

(7) From abscess between the ribs. v. Sabatier in Mémoires de l'Institut de France, Sciences mathém. et physiques, 1807, p. 104.- Fabricius in Harless Rhein. Jahrb. der Med. und Chir. Vol. I. Part I. p. 156.

(8) Tolerably frequent in rupture of the heart, and of aneurysmal bags in the aorta ; more rarely in bursting of the arteria innominata.-Meyer in Oesterr. medic. Jahrbücher, Vol. V. Part III. p. 61, the coronary veins. v. Commercium Litt. A. 1732, Hebd. 41, No. 4. - Acta Nat. Cur. Vol. II. Obs. 107, Vol. V. Obs. 37.-Viridet, v. Haller Bibl. chir. II. p. 103.-Hedlund in Svenska Läkare-Sällskapets Handlingar, Vol. III. p. 181, on the v. cavæ and pulmonal. v. Morgagni, Epist. XXV I. 27, 28. - Syl Aufsätze und Beobachtungen, Vol. IV. p. 34.-Portal, v. Auserlesene Abhandlungen, Vol. XII. p. 724.-Doubleday in Medical Observat. and Inquir. Vol. V. p. 144.-Wright in ibid, Vol. VII. No. 1, on one side of the vena cava. v. Salzmann D. de morte subita ex sanguine in pericardiun effuso. Argentor. 1731.-Sometimes the openings from the bloodvessels into the heart are very small, viz. in two instances before noted in ny Selt. Beob. Vol. II. p. 60 and 66. - Villesavoye, v. Fränkische Sammlungen, Vol. II. Part II. p. 31\%.-Arnott in London med. and phys. Journ.-Abercrombie in Transact. of the med. chir. Society of Edinb. Vol. I., \&c.

(9) Compare $\$ 51$. - Lieutaud, Vol. II. Obs. 659. - Vater in Miscell. Nat. Cur. Dec. 1II. Ann. IX. p. 293. - Bader Observ. med. incisionibus illustratæ, 1762. Observat. 1. in Sandifort Thesaur. Diss. Vol. III.; de Haen Ratio Medendi, Vol. IX. cap. $1, \S 6 .-$ Thomson in Medical Observat. and Inquiries. Lond. 1771, Vol. IV.-Hooper in Mem. of the med. Societ. of London, Vol. I. No. 18. - Alston in Med. Essays and Observat. by a Soc. in Edinb. Vol. V. Part II. p. 609.-Testa, p. 294.-My Selt. Beob. Vol. I. p. 95, and a few times since, among others also in a stag. - Hufeland and Harless Journ. d. prakt. Heilk. 1815, Part I. Jan. p. 85. - Fitzpatrick in London Med. Repos. 1822, A pril, p. 295.-Copland, ib. p. 298.

(10) Morgasni Epist. XXIII. 23.- de la Faye in Hist. de l'Acad. de Paris, 1735 , p. 20,21 .

(11) Stoll, Ratio medendi. In a man who died of asthma I observed some little effusions of blood between the layers of the pericardium. Do the cysts observed by Wrisberg in his Comment. med. physiol. anat. et obstet. arg. Vol. I. No. 4, belong liere?

(12) My Selt. Beob. Part II. No. 19, p. 45, and Verzeichn. No. 2184.

(13) Lanzoni in Miscell. Nat. Cur. Dec. III. Ann. VII. and VIII. 1699 and 1700 , Obs. 75 , p. 129 , three stones.

(14) Compare above, $\S 82$.

(15) Especially in pigs, the echinococcus veterinorum Rud.-In the pericardium of the mya pictorum, and various kinds of anodonta, the aspidogaster conchicola. v. Baer in Nov. Act. Cur. Vol. XIII. Part II. p. 527.

\section{Second Chapter.}

\section{Of the Heart.}

$\S 168$.

The DISEASES of the HEART, ${ }^{1}$ both those which are congenital and those which are acquired, are not of rare occurrence. 'The former, or vices of formation, depend partly on the earliest 
form and structure of the heart itself, and are true retarded formations; the latter are oftentimes the consequence of recurring sympathetic irritation, which, in passionate men, arises from the brain, in others, often also from the respiratory or the digestive organs. Therefore, diseases of the heart are more common in the male sex, in elderly persons, and perhaps also in criminals, and in diseases of the mind $;^{2}$ sometimes mechanical causes, and among these, especially in the malformation of the chest and of the spine, and even hereditary disposition also, ${ }^{3}$ give rise to them.

(1) C. a Vega De cordis et thoracis affectibus in de arte medendi. fol. Lugd. B. 1564.-C. Bruno De corde et ejus vitiis. 4.to. Basil. $1580 .-\boldsymbol{R}$ yff D. de affectibus cordis. Basil. 1584.--Rudius De naturali et morbosa cordis constitutione. 4to. Venet. 1600. - Montaguana Consilia de ægritudinibus cordis i. Op. select. fol. Francof. 1604. - Alberini De affectibus cordis. L. III. 4to. Cesena, 1648.A. Bulgetius De affectionibus cordis. 4.to. Patav. 1657.-ab Hartenfels Pr. de corde, ejusque affectibus. Erford. 1697.-Barbeyrac D. nouvelles sur les maladies de la poitrine, du cœur, etc. 8vo. Amstel. 1731._J. F. Meckel Sur les maladies du cœur in Mém. de l'Acad. des Sc. de Berlin. 1775, p. 56; 1776, p. 31. - Juncker and Bockmann D. cordis morbos proprios in tabula exhibens. 4to. Halæ, 1763. - Spaventi D. de frequentioribus cordis, majorumque vasorum morbis internis. Vienn. 1772.-Senac Traité de la structure du cœur et de ses malad. Par. 1749; ed. Portal. 4to. Vol. II. Par. 1778.-H. Boerhaave in Genees-Natuur-en Huishoudkundig Kabinet. door J. Vocgen van Enge!en. Leid. 1779. Deel. I. p. 562._de Petraglia De cordis affectionibus syntagma. 8vo. Romæ, 1779.-J. G. Walter Sur les maladies du Cœur in Nouv. Mém. de Berlin. 1785, Mém. p. 57.- Reil Analecta ad historiam corảis pathologicam. 4to. Halæ, 1790.-J.F. Meckel De cordis conditionibus abnormibus. 4to. Halæ, 1802 ; and in Reil's Archiv für Physiologie, Vol. VI. p. 549.-Cabirau-Cabannes A perçu sur quelques affections organiques du cœur, etc. 8vo. Paris, 1805.-F. Zuliani De quibusdam cordis affectionibus. 4to. Brix. 1805.-le Herissé Propositions sur les affections organiques du cœur. 4to. Paris, 1806.-Corvisart Essai sur les maladies et les lésions du cour et des gros vaisseaux. Paris, 1806, 1812, and 1818.-C'ontelle D. Essais sur quelques causes de maladies du cœur. Paris, 1808. - Harnier D. de morborum cordis diagnosi. Gött. 1809.-Warren, Cases of organic Diseases of the Heart, with Dissections, and some remarks intended to point out the distinctive symptoms of these diseases. Boston, 1809.-Allan Burns, Observations on some of the most frequent and important Diseases of the Heart, \&c. Edinb. 1809. - Testa Delle malattie del cuore, loro cagioni, specie, segni e cura. Vol. III. Bologna, 1810, 1811.-Pelletan Mém. sur quelques maladies et vices de conformation du cœur in Clinique chirurgicale, Paris, 1810, Vol. III.-Grassal D. sur quelques affections organiques du cour. 4to. Paris, 1810.-Sandberg D. de vitiis cordis. Edinb. 1813.-Farre, Pathological Researches in Medecine, Essay I, on malformations of the human heart, illustrated by numerous cases and 5 plates, containing 14 figures. 8vo. Lond. 1814.-J. Gorgham, On organic Diseases of the Heart, with Dissections, in New England Journ. of Medic. and Surgery. Boston, 1814. Vol. III. Jan.F. L. Kreysig Die Krankheiten des Herzens, systematisch bearbeitet, u.s.w. Vol. I1I. Berlin, 1814.-1816.-J. F. Meckel Tab. anat. pathol. Fasc. I. Cor. fol. Lips. 1817.-G. Foster D. de organicis vitiis cordis. Edinb. 1819.--Lueck D. Adumbratio morborum cordis generalis. 8vo. Berol. 1819.-Mayer Berichte über organische Fehler des Herzens under grösseren Blutgefässe in d. Oestreich. medic. Jahrb. Vol. V. Part III. 1819, p. 59.-Laenncc De l'auscultation médiate, ou traité de diagnostic des maladies des Poumons et du Cour. Vol. II. Par. 1819 and 1826. - - Wetzler Ueber Krankheiten des Herzens und der Arterien in his Beiträßgen zur theoret. u. prakt. Medicin. Vol. I. Part I. and II. Mainz, 1820. 
J. A. Walter D. de variis cordis affectibus. Halæ, 1821.-Re'eder, Practical treatise on the inflammatory, organic, and sympathetic Diseases of the Heart. Lond. 1821.-J. Whitsed D. de tabrica cordis vitiosa. Edinb. 1823.-TVedemeyer in Rust's Magazin f.d. ges Heilk. Vol. XIII. Part II. p. 177.-Abercrombie, Contributions to the pathology of the heart, in Transact. of the medico-chir. So. of Edinb. 1824, Vol. I. p. 1.-M. A. Petit Essai sur la Médecine du Ccur, etc. second edit. Lyon, 1824.-Bertin Traité des maladies du cceur et des gros vaisseaux, rédigé par Boullaud. Paris, 1824, with six engravings. - Bürger Diagnostik der Herzkrankheiten. Berlin, 1S25.-C. H. Parry, Collections from the unpublished medical writings, Vol. II. p. 129. Lond. 1825.-R. Adams in Dublin hospital Reports and Communicat. 1827. Vol. IV. No. 19.-Faber in Hufeland's Journ. d. prakt. Heilk. Aug. 1827, p. 3.-Stadelmeyer D. de morbis cordis organicis observationes quædam. 8ro. Wirceb. 1827.-J. Brown, Med. Essays on fever, inflammation, rheumatism, diseases of the heart, Sc. 8vo. London, 1828.- Many single cases in de Plouquet Repertor. Art. Cordis morbi; in Reuss Repertor. Comment. Vol. X. p. 87, Vol. XII. p. 304, and in the periodicals. [Andral in Précis d'Anat. Pathol. Vol. II. p. 275, Maladics du Cœur.$J$. Elliotson, On the recent improvements in the art of distinguishing the various Diseases of the Heart. fol. plates. London, 1830. T.]

(2) Compare J. E. Greding's Sämmtl. medic. Schriften, edited by $C$. W. Greding. Graiz. 1790. Vol. II.-Nasse in Archiv f. medic. Erfahr. von Horn, N'asse, and Henke, 1817, July and August. - Weber in Nasse's Zeitschrift f. Psychische Aerzte, 1820. Vol. II. p. 396. - Diseases of the heart, however, according to Georget Sur la folie, p. 496, Paris, 1S20, are rare in insane persons, which is confirmed by my experience.

(3) Several instances are given by Lancisi De aneurysm. L. II. Prop. 47, p. 74 ; and by Testa, p. 45, Frank, Abernethy, \&c.-I knew a woman who died of disease of the heart, in the prime of life, having had two daughters affected with disease of the heart, one grand-child the subject of the blue disease, and another, which from youth, had a violently pulsating heart.

\section{$\S 169$.}

The DEFICIENCY of THE HEART, alardia, is observed, although not as a constant, yet as a common and regular phenomenon in headless monsters, even when they possess the chest and neck of the trunk.' In other embryons with heads there exist but few instances of deficiency of the heart. ${ }^{2}$ The opposite vice, or Double HEART, is, in double monsters with a single chest, naturally not uncommon, particularly if the upper part of the body be double. The degree of duplication is therefore very different, since the heart common to two bodies is very large, or sends off double vessels, or is even itself double $;^{3}$ or in the higher grades, two distinct hearts may be contained in one pericardium, or each may be enclosed in its own proper membrane, and more or less removed from each other. Cases very rarely occur in which, in a single body, the heart has been found double, either in certain parts, ${ }^{4}$ or entirely. ${ }^{5} \quad$ The latter has been several times noticed in birds. ${ }^{6}$

(1) J. F. Meckel Handbuch der pathol. Anatomie, Vol. I. p. 162.-F. Tiedemann Anatomie der kopflosen Missgeburten. fol. Landshut, 1813, p. 69, § 75.Béclard Mémoire sur les foetus acephales. Svo. Paris, 1818; and in Leroux Journ. de Médec. 1815 and 1816. - E. Elben D. de acephalis s. monstris corde carentilus, p. 84. 4to. Berol. 1821, with 22 lithogr. tab. - 'I'he two last authors believe that the heart is always wanting in acephala. - Jagorsky, however, 
found a rudiment of it. v. Nov. Acta. Petropol. Vol. XV. 1806, p. 45, ff.; and Yallisneri in Malpighi Op. posthuma. fol. Lond. 1697, p. 87. - Katzky in Act. Medicor. Berol. Vol. 1X. p. 61. Svo. Berol. 1721; and Gilibert Adversaria med. pract. I،udg. 1791, p. 132, a true heart. There is also in the Anat. Mus. at Berlin, according to an excellent communication of Rudolphi's, an acephalous monster with a heart.

(2) Marriøues in Mém. de Mathém. prés. à l'Acad. des Sc. Vol. IV. p. 123. Daniel Samml. med. Gutachten. Leipz. 1776, p. 276.-Brodie in Phil. 'Transact. 1809 , p. 161 ; and in Edinb. med. and surg. Journ. Vol. VI. p. 191.-Lawrence in Med. chir. Transact. Vol. V.

(3) A heart with four auricles, and four ventricles, v. Vetter's Aphorismen aus der pathol. Anat. p. 108.- In a calf, there was a third smaller one near the left ventricle. Lictzan Hist. trium monstrorum. Regiomonti, 1825, p. 9.-In a goose, three ventricles. v. Ephem. N. C. Dec. I. Ann. IX. and X. Obs. 108 ; Dec. II. Ann. VIII. Obs. 114, Schol. p. 251.-- J. F. Mecliel Tab. anat. path. Fasc. I. Vol. II. fig. 1, describes a heart, from the right ventricle of which two aortæ arose. Similar cases are described by Haller, Opera minor. Vol. III. tab. 16.Walter Observat. anat. tab. 4, fig 3 and 4.-I have also seen a similar case.

(4) Kerlining Spicil. anat. Obs. 69, p. 139, 64.2, the right ventricle double, with two pulmonary arteries.

(5) Compare several doubtful cases in de Plouquet Repertor. Art. Cor. duplex.Winslow in Mém. de l'Acad. de Paris, 1743, p. 462.-Coulomb CEuvr. méd. chir. Lyon, 1798. s. Reil's Archiv, Vol. IV. p. 213.-Chaussier in Bulletin de la Facult. de Médec. de Paris, 1816 ; in J. F. Meckel's D. Archiv, Vol. II. p. 137. - In a dog. v. Paullini Cynograph. cur. p. 43.--In a rat. v. Boerlaave, p. 491.

(6) For instance, in fowls. v. Ephem. Nat. Cur. Cent. VIII. Obs. 8 ; and Litlre in Mém. de Paris, 1700 , p. 32.-In partridges. v. d'Aboville in American Philos. Transact. Vol. II. p. 330.-In pigeons. v. Barzellotti in Nuovo Gionnale de' Letterati. Vol. I. No. 1. Pisa, 1822. - In geese. v. Sömmerring addenda to Baillie, p. 27, note 51 ; and $J . I^{\prime}$. Meckel Comm. de duplicit. monstrosa, p. 54. fol. 1815.-Ephem. Acad. Nat. Cur. Dec. I. Ann. IX and X. Obs. 108, p. 267.

\section{$\S 170$.}

The heart varies, not unfrequently, considerably from its usual and proportionate SIZE in both directions, not only as consequent on original formation, but also more frequently from disease; such disproportionate size of the heart to the whole body appears even to be hereditary. The irregular SMALLNESS of the heart is sometimes congenital, and is then pro- . bably connected in some cases with other vicious formations of that organ. ${ }^{1} \quad$ Sometimes this smallness is connected with general weakness and imperfect development $;^{2}$ although, indeed, often not distinctly marked. ${ }^{3}$ The acquired smallness of the heart, the consequence of disease, consumption, or ATrophy, ${ }^{4}$ is very different from the state just described. This vice is rarely produced by external pressure or narrowed space, stenocardia $;^{5}$ but is more usually caused by defective nourishment of the whole body, ${ }^{6}$ or of the heart alone, especially after inflammation, softening, \&c., and is, since the consumption takes place principally in the muscular substance of the heart, connected naturally with the more or less considerable ThinNing of THE walls of the heart. ${ }^{7}$ Sometimes this smallness of the heart is only a seeming diminution, in 


\section{consequence of the violent contraction of the muscle itself, con-} tinued even after death. ${ }^{8}$

(1) I have found it exceedingly small in a dozen instances, in monsters, or newly-born clildren otherwise well-formed, together with other vices, as holes in the partition of the ventricles, closure of the venous aperture of the right ventricle, but especially in unnatural position of the heart, and in frenic ruptures; in the latter, indeed, there has been irregular pressurc upon the heart. Other observers have also frequently noticed the same. Also in duuble monsters, in which two hearts are placed in one chest, it is not unfrequent for one of them to be remarkably small.

(2) Kerkring Spicil. anat. p. 43. - Mém. de l'Acad. des Sciences de Paris, 1712. - Lieulaud, Vol. II. p. 147, Obs. 453.-Morgagni, Epist. XVII. p. 12.Chavasse in Lond. Med. Journ. 1786, p. 409. - Kreysig, Vol. II. Part II. p. 468, \&c.-I have twice found in grown-up persons, and in a weakly girl, whose generative organs were almost those of a child, the heart remarkably small. v. No. 2186 and 2187 of my Verzeich.; in which, under No. 2188 and 2189 , other cases of still further diminution are related.- In tame birds, the heart is proportionally less large and muscular than in wild ones of the same species. v. Tiedemann's Zoologie, Vol. II. p. 571.

(3) Many cases of very small hearts, in grown up persons, are loosely mentioned by Lieutaud, p. 146; and in de Plouquet Art. Cor. parvum. - In a man of fifty years it was not larger than in a child of four years. v. Wedemeyer in Rust's Magaz. f. d. ges. Heilk. Vol. XIII. p. 190.-Biermayer Mus. Anat. Pathol. No. 381 .

(4) Compare Testa, §4, No. 15.--Kreysig, Vol. II. Part I. p. 326. - Vetter, in his Aphorismen aus der pathol. Anatomie, p. 101, note, seems to consider, improperly, the small size of the heart as a congenital vice.

(5) Brera Della stenocardia, malattica volgarmente conosciuta sotte il nome di Angina pecturis. Verona, 1810. - I have occasionally found the heart, when it has been mucl confined by collection of fat in the pericardium, by liardened lungs, tumours in the mediastina, and by elevation of the diaphragm, not merely very small, but compressed as it were into an angular shape. Compare note 1.A heart which had been diminished in size by a fatty swelling, is described by Meckel Mém. de l'Acad. des Sc. Berlin, 1755, p. 82.-In an uncommon collection of water in the belly, which very much compressed the heart, Testa, p. 255, found it extremely small. -- Kreysig, Vol. III. p. 124, found it small in a case of lardaceous growth in the mediastina.

(6) Hence not unfrequently arises the diminution of the heart, in a small degree, in wasting diseases, although by no means so common and rapid as in other muscles, as Morgagni, Epist. LXX. p. 5, has observed. This arises from 2 the want of cellular tissue between the inuscular bumdles.

(7) The walls of the heart are so thin, that they are merely membranous, especially when the muscular fibres are very pale. Here belong also the case of a person who died of a long-continued sickness, in whom no heart was found, but in its stead merely a membrane. v. Telesius De rer. nat. L. V. c. 28. - Schenck Observat. L.. II. p. 272. -- If a really small heart be fleshy, hard and red, I consider it as a vice of formation; if it be, notwithstanding, at the same time, thin and dried up, pale or hardened, 1 then consider it as a wasting atrophia.

(8) I have seen this repeatedly, particularly in cleaths from accident, and in those who have died of tetanus; also once in a person who died suddenly from a stab in the heart.-Tesia, 1). 148, cites an interesting case, in which a man struggled uncommonly when execnted, and on dissection, the heart was discovered very small, from its being most strongly contracted; therefore Porlal, Vol. III. p. 88, and Kreysig, Vol. II. Part 11. p. 469, very properly warn us against thẹse easily to be avoided errors.

$$
\$ 171 .
$$

The opposite vice, or IRREGULAR ENLARGEMENT of the heart, is but rarely a congenital disease, ${ }^{1}$ usually it is acquired, 
in consequence of the mode of living, or of certain diseases, in which the heart can attain very considerably more than its usual size. ${ }^{2}$ This enlargement appears, first, in the otherwise normal state of the heart, as the mere thickening of its walls, that is, as an increase of bulk, or HYPERTROPHY of the fleshy substance, which arises from increased excitement, in a manner analogous to other muscles $;^{3}$ and, secondly, as the MORBID EXPANSION OF THE CAVITIES OF THE HEART, aneurysma cordis, cardieurysma, cardiectasis, \&c. ${ }^{4}$ This latter is usually divided into the ACTIVE and the PAssive, the former of which consists in the expansion of the cavities of the heart, with simultaneous thickening and increased hardness of its walls; the latter in expansion of the cavities, with thinning, relaxation, and extension of the walls of the heart. The active aneurysm, which properly does not deserve the title aneurysm, if compared with the so-named disease of arteries, occurs most commonly on the left side, especially in the ventricle, but more rarely on the right side; the passive, on the contrary, is usually seated on the right side of the heart, and particularly in the right auricle. Both forms of aneurysm are frequently met with in the same individual, and but rarely is the whole heart affected with one or other species of the disease alone. The expansion of the cavities is naturally greater in the passive than in the active aneurysm, and the whole cavity generally participates equally in it; more rarely is one single circumscribed spot affected, which is then distended in a bag-like form, and connected with the cavity of the heart by an aperture between the ruptured or separated muscular fibres. ${ }^{5}$

(1) In new-born children of similar size, we sometimes find a striking difference in the size of the heart, and the whole of its blood-vessels, as it is usually larger in wide, than in narrow-chested children; often also are the hearts of new-born children affected with the blue disease, proportionably very large.

(2) Even double and more of the usual size and weight. Compare Lieutaud, Vol. II. p. 129-146. - de Plouquet Repertor. Art. Cor. magnum. - Reuss Repertor. Comment. Vol. X. p. 92 ; Vol. XII. p. 304; for instance, as large as the heart of an ox.--Lancisius Von den verschiedenen plötzl. Todesarten. Vol. II. p. 130.-Morgagni Ep. XVII. p. 21; XVIII. 28; LIII. 9. -Wildberg in the A bhandl. der Erlanger phys. med. Soc. I. No. 16.-Gustavus Adolphus's heart weighed 25 ounces.- Hearts of two or three pounds were found by Chambert, in Journ. de Méd. cont. July, 1810, p. 5.-Fritze in Horn's Archiv f. prakt. Medic. Vol. III. p. 298. - I once found a heart which weighed two pounds and ten ounces. - Boeck D. de statu quodam cordis abnormi. 8vo. Berol. 1818, with plates, \&rc.

(3) Vetter Aphorismen aus der pathol. Anatomie, p. 99. - Bertin. - Legallois Observation sur une maladie du cœur par hypersarcose, ou par excés de la substance musculaire, etc. in Bulletin de la Faculté de Méd. de Paris. Ann. XIII. p. 69. - Several cases of hypersarcosis of the heart are given by Lallemand in Archiv. générales de Médec. Aug. 1824. - Rousseau compares the hypertrophy of the heart in active aneurysm, with the development of the muscular substance of the uterus in pregnancy. v. Recueil de Mémoir. de Méd. Chir. et Pharm. 
milit. par Foumier, Vol. X. p. 366.-[Hypertiophy, when partial, is more common in the left ventricle than elsewhere, and in the ventricular partition more frequently than in the other parts.-Hypertrophy of the auricles are rare. v. Andral, Vol. II. p. 284, 285. T.]

(4) Compare Reuss Repertor. Comment. Vol. X. p. 92 ; Vol. XV. p. 200.de Plouquet Repertor. Art. Cordis Aneurysma.-Lientaud.-Morgagni De sed. et caus. morb. in several parts. - Lancisins De motu cordis et aneurysmatibus. fol. Rom.1728.-Matani De aneurysmaticis præcordiorum morbis. Francof. 1766; and in Lauth Scriptor. latinor. de aneurysmat. collatio. - Hiefinger D. s. histor. hydropis pectoris cum aneurysmate cordis. Viennæ, 1770. - Michaelis D. aneurysmatum cordis disquisitio anatom. med., observatione quadam illustrata. Halæ, 1785.-A. Ramsay, Anatomy of the Heart, Cranium, and Brain. $2 \mathrm{~d}$ edit. Edinb. 1803, remarks, that enlargement of the aortic chamber is very common in warm climates.-Lesage $\mathrm{D}$. sur les aneurysmes du Cœur et des gros vaisseaux. 4to. Paris, 1803, with five plates. - Corvisart first employed the terms Aneurysma activum and passivum; Matani, Morgagni, and Bertin, had however previously remarked on their distinctions. - Flormann De aneurysmate cordis. P. I. resp. Hjerstedt, P. II. resp. Engeström, P. III. resp. Pramberg. 4to. Lond. 1812. - Mém. du Mus. d'hist. natur. 1818. Vol. IV. p. 62. - Rostan very frequently found aneurysms of the heart in asthmatic persons. v. L'Asthma des vieillards est-il une affection nerveuse? 8vo. Par. 1818.-Foderé in Journ. compl. du Dict. des Sc. médic. Vol. VIII. p. 309; Vol. IX. p. 97. - Portal in Journ. universel des Sc. médic. Vol. VIII. p. 5. - Everest D. de cordis aneurysmate, Edinb. 1822.-I have described several instances in my Selt. Beobacht. Part I. p. 86.-Verzeichniss, No. 2190-2200. - Engravings of aneurysms of the heart are given by J. F. Meckel Tab. anat. pathol. Fasc. I. tab. 3, 4, and 6.--Dundas v. Allgem. Medic. Annalen, 1811, p. 702.-Portal Sur les aneurysmes du cœur, etc. in Mém. du Mus. d'histoire nat, 1818, Vol. IV. p. 62. - H. B. Simitz D. de ancurysmate cordis. 4to Gandavi, 1827.- Aneurysmal hearts have also been observed in animals; viz. in horses affected with palpitation of the heart.-[The term, Ancurysm of the heart, is objected to by Andral, Vol. II. p. 282, as not inclicating the real circumstances of the disease. T.]

(5) J. G. Walter, Mém. de l'Acad. des Sc. de Berl. 1785, p. 55, tab. 4, fig. 1; and Mus., No. 675 , as steatoma cordis; although M. Boas D. de cordis ancurysmate rarissimo, $8 \mathrm{vo}$. Berol. 1826, with engravings, has shown it to be an aneurysm of this kind.-Baillie, Morbid anatomy, and Series of Engravings, p. 15, pl. 3, fig. 1.-Jannini Anatomia pathologica di M. Ballie. Vol. I. p. 27, No. 17 and 18. Venezia, 1819. - Corvisart, p. 269, Obs. 42. - Berard D. sur plusieurs points d'anatomie pathologique et de pathologie, Paris, 1826 ; and in Archiv. général. de Médec. Vol. XI. March, 1826, two cases. - Cruveilhier in Nouv. Bibliotl. méd. April, 1827. - Biett Histoire de la maladie de Talma, in Répertoire genéral d'Anatom. et de Physiol. pathol, etc. Vol. III. Part I. p. 214.-Breschet Sur l'aneurysme faux consécutif du Cœur, etc. - Ib. Vol. III. Part II. p. 183, contains one case from Dance, and another, and pl. 6 and 7, engravings of such hearts; all these cases occurred in the left ventricle, and answer, in a certain degree, to aneurysma spurium of the arteries. An eleventh case, in the right auricle, is mentioned by $C$. $\boldsymbol{R}$. Bernhardi, D. observatio circa ingentem cordis tumorem. 8vo. Regiomonti, 1826, with a wood-cut. - [Johnson's Med. chir. Review, for July, 1829, gives a case of aneurysm of the left ventricle protruding into the auricle.-In the Mus. St. Thomas's Hosp. there are three specimens of aneurysm of the heart, two of which are in the posterior part of the left ventricle; one of them is nearly as large as the heart itself, and its walls are principally formed of the thickened pericardium, containing thick layers of coagulable lymph; the other is the case related by Dr. Elliotson, p. 29, in which there is also a tumour as large as a pigeon's egg, with several smaller in the right ventricle; the third is an aneurysm of the sinus of the left auricle, also mentioned by Dr. E., p. 29. He gives engravings of both the latter in his work. - According to a memoir of Reynuad, in Journ. heblom. de Médec. Vol. XI. the lining membrane of the heart, said by Breschet to be ruptured, merely distended, as in true primitive aneurysm. ' $\mathrm{T}$.] 


\section{$\S 172$.}

The just-mentioned partial enlargements of the heart naturally lead us to consider the vices of FORM in this organ. These are usually congenital, and may affect both the ExTERNAL and INTERNAL form. The former are frequently connected with the latter, and are often necessarily consequent upon them $;^{1}$ still, however, vices of the external form alone are not infrequent, ${ }^{2}$ since, both in infants and adults, the heart has been noticed, for instance, too globular, ${ }^{3}$ flattened, ${ }^{4}$ very long and pointed, ${ }^{5}$ very broad and blunt, ${ }^{6}$ deeply indented at the tip, ${ }^{7}$ unsymmetrical, ${ }^{8}$ crooked, ${ }^{9}$ with processes and deep indentations of the auricles, ${ }^{10} \& \mathrm{c}$. The irregular internal form and arrangement of the heart, as it depends partly on the development of the organ itself, and is merely a retardation of it, is not merely more common, but more important, ${ }^{11}$ as the circulation of the blood is usually so irregular that the continuance of life for any length of time after birth is prevented, or at least rendered very difficult; and in both cases a morbid condition is presented by the mingling together of the arterial with the venous blood, which has been named, from its most remarkable symptom, the BLUE DISEASE, morbus carulens, cyanosis, cyanopathia. ${ }^{12}$

(1) In the greater number of instances, the hearts of persons affected with the blue disease are also externally malformed, not to mention examples of still more imperfect formations of the heart. I have found the heart also, in a great number of such cases, most commonly too broad and blunt; for example, No. 2896, 2929, 2930, 2899, 8011, 8012, in Bresl. Mus. and in many others.-Also in many animal monsters.

(2) Sometimes the fault appears tolie in an irregular position, or narrowed space.

(3) K. Blegny Zodiacus Ann. II. Jan. Obs. 4.-Köhler Beshreib. der Loderschen Samml. No. 1037. - I found it once in a child with anencephaly and abdominal cleft, almost spheroidal, No. 8016, of the Museum.

(4) Stalpart van der Wiel Observat. rar. med. anat. L. B. 1687. Cent. I. Obs. 37.-Kulmus in Actis Lips. Ann. 1727.-I have found it likewise occasionally in dropsical people, also in a monster. v. Selt. Beob. Part I. p. 8.

(5) For instance, if the pericardium be deficient at its base, the point of the heart lies between the lobes of the liver. v. Selt. Beob. Part I. p. 64; and frequently since.-Very much elongated, in which case its apex adhered to the head.-Cerutti Rar. monstr. descript. anat. 4to. Lips. 1827.- Very pointed when one of the ventricles does not reach the point, \&c.

(6) Not unfrequently.

(7) Bartholinus Histor. anat. Cent. I. Hist. 67 ; Vol. I. p. 117.-J. F. Meckel Pathol. Anat. Vol. I. p. 469.-Kelch Beiträge zur pathol. Anat. p. 81, No 57.Burkhardt D. de monstro humano notabili. 8vo. Frib. 1825.-My Verzeichniss, No. 2201. - A. Meckel in J. F. Meckel's Archiv f. Anat. u. Physiol, 1828. No. 2, p. 153.

(8) In which case one or other ventricle is too small.

(9) Morgagni Epist. LX. p. 8.

(10) de Haen Ratio medendi. Vol. IX. p. 39. Viennæ, 1764,-E. d'Alton D. cyanopathiæ specie, p. 15, Bonn, 1824.

(11) The resemblance which such malformed human hearts are said to have to those of the lower animals, for example, insects, crabs, molusca, fish, and 
amphibious animals, is to me not conclusive. Setting aside the number of cavities and holes in the partitions of the heart, I have never been able to discover the smallest or most remote similarity with any one heart of an animal. How different, for example, is the heart of a child affected with the blue disease with the opening insepto of the heart of a tortoise with the other form, the several auricles, the loose but at the same time spongy structure of the walls of the heart; the other valves, the pale and soft muscles, \&c.? It is remarkable that this kind of vice of structure is, against all rule, more common in the male than in the female sex.

(12) Seiler Pr. de morbo cœruleo. Viteb. 1805. - Schuler D. de morbo cœruleo. 8 ro. Enipont, 1810. - Nasse in Reil's Archiv f. d. Physiol. Vol. X. p. 213.-In a supplcment to the translation of Burns on Diseases of the heart, and a collection of twelve cases, in Horn's, Nasse's, and Henke's Archiv für medic. Erfahrung. Nov. and Dec. 1817.-Kämmerer D. de morb. corul. Halæ, 1811.$J$. F. Meckel Handbuch der pathol. Anat. Vol. I. p. 419, ff.; and in D. Archiv f. d. Physiol. Vol. I. p. 221, with a table of seventy-seven separate observations. - Tobler D. de morbor. cœrul. Gött. 1812. - Haase D. de morb. cœrul. 4to. Lips. 1813, with engravings. - Kwiatkowski D. ætiologiam morbi cœrulei amplificans. 8vo. Vilnæ, 1815.-Hein D. de istis cordis deformation. quæ sanguinem venosum cum arterioso misceri permittunt, 4to. Gött. 1816, with a table of more than seventy-one cases.-C. de Harimannn D. de cyanosi ejusque cura. Viennæ, 1817. - Cherrier D. sur la maladie bleue, etc. Paris, 1820.-Marx D. morbi corul. exemplum memorabile. 8vo. Berol. 1820._Zimmermunn D. de morb. cœruleo. $\$$ vo. Berol, 1822, (without a case of his own.)-Peters D. s. relationem de puero, morbo cœruleo laborante. 4to. Kiliæ, 1822. - Horner D. de Cyanosi. 4.to. Monachii, 1823.-Louis Observations suivies de quelques considerations sur la communication des cavités droites avec les cavités gauches du Cœur in Arcliv. génér. de Médec. Nov. 1S23, and in Mémoires ou Recherches anat. pathol. p. 301, Paris, 1826. (with some of his own cases.)-Gintrac Observations et Recherches sur la Cyanose ou maladie bleue. Paris, first as a Diss. 1814, subsequently enlarged. Svo. 1S21. (three cases of his own, and a collection of fiftythree others.) - Ramberg $\mathrm{D}$. de corde vasisque majoribus eorundem ratione normali in animantibus et abnormi in homine, 8vo. Berol. 1824, with engravings. $-E$. d'Alton D. de cyanopathiæ specie ex invicem permutata arterix pulmonalis atque aortæ origine, 4.to. Bonnæ, 1824, with engravings. - Mcinecke D. de cyanosi. 8vo. Berol. 1825. - Lewes D. de morbo cœruleo. 8vo. Berol. 1826.Fr. Ermel D. de cyanosi. 4to. Lips. 1827. - As to individual cases, v. the tables of Meckel, IIain, and Gintrac, the latter of which I have not unfortunately at hand. - Gallois Bulletin de la Faculté de Médecine de Paris, 1809, p. 133. -Pelletan Clinique chirurgicale, Vol. III. Paris, 1810.-Tupper in London Medical and Physical Journal, Vol. III. p. 497. - Jackson, ib. No. 19S, p. 100, Aug. 1815; and in New-England Journ. of Med. and Surg. Vol. III. p. 161, 1814. - Ribes in Corvisurt and Leroux Journ. de Médec. Voì. XXXIV. p. 421, 1815. - Thomson in Ebinb. Med. and Surg. Journ. Vol. XII. p. 3.Dorsey in New-England Journ. of Med. and Surg. Vol. I. p. 69, 1812.-Young in Journal of Science and Arts of the Royal Institution, London, 1816, Vol. I. Art. 3, with engravings. - Howship, Practical Observations in Surgery and murbid Anatomy, Cases 57-59, 1816. - Kreysig Die Krankheiten des Herzens. Part III. p. 10\%, with engravings. $-R$. Thoxter in New-Eugland Journal of Medicine and Surg: Vol. V. Boston, 1816. - Creveld in IIufeland's Journal d. pr. Heilk. p. 74. Decemb. 1816. - Delondre in Sédillot's Journ. de Médec. Vol. LX. p. 38.-Wistar s. Gö:t. gelehrte Auzcigen, p. 1767, 1818.-Nordblad in Ars-Berättelse om Svenska Laikare-Sïllskapets $\Lambda$ rbeten of Carlander. Stockl. 1816. - Seidel Index Musei anatom. Kiliensis. p) 61, Kilia, 1818.-Marechal in Journ. gén. de Médec. Vol. LXIX. p. 354, Dec. 1819.-Thibert and Fouquier in Bulletin de la l'aculté de Médec. Vol. VI. p. 355 - Olivry in Journ. gén. de Medec. Vol. J.XXIJI. p. 145.-Hesselbuch Bericht von der liönigl. anat. Anstalt zu Wiirzburg, 1820, and Beschrcib. der pathol. 1'riiparate z.u Wiirzburg. p. 201. No. 541 ; p. 202, No. 610. Giessen, 1821. - Nasse Lcichenöfnumgen, 1) 166, 1ste lieihe. 1821.-Gregory in Med. chir. Transict. Vol. XI. 1. 296, 1821.- 
Olory in Repertorio Med. chir. per l'anno 1821, Turino.-Bock in Cerutti's Pathol. anat. Museum, Vol. I. Part III. p. 37. - Holmsted in London med. Repository, Vol. XVII. p. 455, June, 1822. - Schallgruber Abhandl. im Fache der Gerichtsarzneikunde, p. 55-76. Grätz, 1823.-Rust's Magazin f. d. ges. Heilk. Vol. XVIII. p. 346.-Hesse D. Monstri bicipitis descriptio anat. p. 20. Berol. 1823.-C. Perkins in New-York Med. and Phys. Journ. Vol. II. p. 444.Holmers in Transact. of Med. chir. Soc. of Edinb. Vol. I. No. 11. 1824.Tiedemann in d. Zeitschrift f. Physiologie, Vol. I. Part I. p. 111, pl. 7, fig. g.Coates in Chapmann's Philadelphia Journal of the Med. and Physic. Sc. Vol. IX. No. 17, Nov. 1824. - Rosenstiel D. monstri duplicis rarissimi descriptio anatomica. p. 12. Berol. 1824.-Wirtensolin Duor. monstror. duplic. humanor. descr. anat. p. 13, tab. 2. Berol. 1825.-Hall and Vrolik in Praktisch Tijdschrift voor de Geneeskonde. Part II. 1825.-Burkart D. de monstro humano notabili. Svo. Friburg, 1825. - Abercrombie in Trans. of Med. Chir. Soc. of Fdinb. Vol. I. p. 1. - J. F. Meckel Descript. monstr. nonnull. p. 11, 21, 31, 59. 4to. Lips. 1826. - Breschet in Répert. gén. d'Anat. etc. Vol. II. p. 12, 17.-Hufeland's Journ. d. prakt. Heilk. p. 133. Feb. 1826. - Delmas in Ephémér. méd. de Montpell, Vol. I. Jan. 1826.- Ullrich in Rust's Magaz. Vol. XXII. p. 502.Mauran in Philadelphia Journ. Vol. XIV. p. 253. - Dujes in Journ. gén. de Méd. Vol. CI. p. 88.-Mayer in v. Gräfe's and v. Walther's Journ. der Chir. Vol. X. p. 44, pl. 2, fig. 1.-Knup in Harless Rhein-Westphäl. Jahrb. d. Med. und Chir. Vol. IV. Part I. No. 8.-One case in Archives gén. de Médecine, Sept. 1827.-Cerutti Rarior. monstri. descript. anat. 4to. Lips. 1827, with engravings.-Staupa Anweisung zu gerichtl. und pathol. Untersuchungen menschl. Leichname. p. 164, note xx. Wien, 1827. - Cogoreux in Revue médic. franc. et étrang. Vol. I. and II. 1827.-Wittcke in Hufeland's and Osam's Journ. d. prakt. Heilk, April, 1828-R. K. Hoffmann in New-York Med. and Phys. Journ. Vol. VI. p. 250. - Basedow in Hufeland's Journ. p. 78, July, 1828.-My Selt. Beob. Vol. I. p. 16, 64; Vol. II. No. 21, p. 49, 102 ; since in No. 2203-2207, 2896, 2899, 2929, 2944, my Verzeichniss, and in No. 8011-8014, 8020, besides in several monstrous cattle and sheep.-Legallois observed one case in a rabbit, Vol. XII. p. 122. v. Bulletin de la Soc. de Médec. 1809, p. 99.-Compare Reil's Archiv. B. and Meckel's Descript. monstror. nonnullor. p. 50, in a pig. $-R$. Knox, in Edinb. med. and surg. Journ. 1815, Vol. II. p. 57.- Alibert Nosologie Naturelle, 1817, Vol. I. p. 344.-Bonnissent, Obet, and Pinel, in Revue Médic. Vol. VI. p. 175, Oct. 1821.-Lallemand in Rech. anat. pathol. sur l'Encephale, Vol. II. p. 7, Paris, 1823.-Cruveilhier Anat. Pathol. Fart I. pl. 6.

\section{$\S 173$.}

These MALFORMATIONS of the heart vary considerably in degree. As the lowest kind we must notice that rudimentary formation of the heart in which it appears as a mere fleshy mass without any cavity; ${ }^{1}$ as a longish solid mass, from which the vessels arise ${ }^{2}$ or as a mere expanded vascular trunk. ${ }^{3}$ To these, follow the heart with a very imperfect muscular structure, containing a single valveless cavity, with a very imperfect trace of an auricle; ${ }^{4}$ then such hearts as are occasionally formed with but a single ventricle and auricle, with a corresponding vascular trunk, ${ }^{5}$ succeeded by those which, having merely a single ventricle, are furnished with an auricle, more or less perfectly divided by a partition into two cavities, whence the venous and arterial trunks simultaneously arise, either confounded together or distinctly divided. ${ }^{6}$ More perfect and.more common are those formations of the heart, in 
which, either by the increased capacity of the ventricle, or by the gradual development of the partition, merely open at a single point, ${ }^{7}$ the division into two ventricles is completed, ${ }^{8}$ of which, sometimes the right, ${ }^{9}$ at other times the left alone, ${ }^{10}$ is small and imperfect. Lastly, we frequently meet with those hearts which are irregular in their normal structure, merely so far as that the peculiar foetal blood-passages remain morbidly open, so that either both the oval hole, and the arterious duct, ${ }^{11}$ or only the former, ${ }^{12}$ or the latter alone, ${ }^{13}$ are found unclosed. In diving mammalia, viz. the otter, the seal-kind, the beaver, the desman, and the cetaceous animals, we find the oval hole or the arterious duct generally, though not always open, but still much more frequently than in other beasts. ${ }^{14}$ We also occasionally meet with, in the human subject, one or more tolerably distinct apertures in the oval pit, continuing to a later period of life without any consequent diseased condition $;^{15}$ it however appears that, by no means infrequently, is the already closed oval hole again morbidly opened, and with it, as it were, a recurrence to the foetal state. ${ }^{16}$

(1) Misc. Nat. Cur. Dec. II. Ann. II. Sect. 143; Dec. III. Ann. II. Sect. 9. -Veslingii Syntagma Anatomicum, p. 150.-In a large fat pig, with accompanying small size of the liver and spleen, the heart was found not bigger than a small cherry, attached by a thin neck in the pericardium, and withoutauricles and blood-vessels. v. Fahnestock in American Medical Recorder, Vol. VI. April, 1823.

(2) Zagorsky Nov. Act. Petropol, Vol. XV. p. 478. 1806.

(3) In many headless monsters.

(4) Roederer Fœtus parasitici descriptio in Comment. Soc. Götting. Vol. IV. p. 125.

(5) Wilson in Phil. Trans. 1798, Part II. p. 346.-Furre, p. 2.-Mauran and Breschet, p. 17.

(6) Standert in Phil. Trans. 1805.-Tiedemamn's Zoologie, Vol. I. p. 177.Chemineau in Mém. de l'Acad. des Sc. 1699, Hist. p. 43. - Luwrence in Farre, p. 31.-Fleischmann, p. 193.-Pozzis in Senac.-Hartmann and Staupa.-Mauran. -My Selt. Beob. Part I. p. 16. -Wolf in Kreysig, Vol. III. p. 200.-Rosensticl, p. 12.-Breschet, p. 12.

(7) Usually we find an opening more or less large in the upper part of the partition; and over it the aorta springing out of both ventricles. In rare cases, however, is this hole further downwards towards the apex, or it is even manifold. The first instance was found by Meckcl, v. Reil's Archiv. Vol. IX. p. 44:2, and Tab. anat. Fasc. I. tab. 1, fig. 2; Gregory;-and myself in a monstrous calf-the latter, J. F. Meckel Descriptio monstror. nonnullor, p. 11.-Kreysir, Vol. III. p. 104; and myself, No. 2899; in all three cases two openings; in one case even three. v. Hodgson in Farre, p. 19.

(8) Such holes in the upper part of the partition were observed by Stenson, Mery, Sandifort, Hunter, J. F. Meckel in three cases, F'arre in three cases, Langstaff, Ring, Abernethy, Obet, Prochaskia, Meyer, Cooper, Tiedemann, Richerand, Nevin, Pultcney, Cruilshiank, Corvisart, Cailliot, Duret, Huet, Lawrence and Haase. v. J. F. Meclicl's and Hayn's tahles.-Further, Pelletan, Tupper, Jackson, Ribes, Creveli, Thoxter, Dorsey, Delondre, Seidel, Marechal, Oliviy, Hesselbach, Nasse, Gregory, Olory, Bocl, Holmsted, Horner, Schallgrulber, Perkins, Holmers, Burliarl, Meckel in six cases, Hufcland, Gallois, Howship, Abercrombie, Lonis, Obs. 10, IIolfimann, Busclow, Knox, Gintrac, p. 164, and myself in twelve cases, viz. Selt. 
Beob. Vol. I. p. 64 ; Vol. II. p. 50, 102.-In No. 2203-2207, 2896 (with a valve,) $2899,2929,8011,8013,8014,8020$. In an anencephalic as well as in a calf and sheep monster.-In very rare cases such holes appear also capable of arising later throngh disease, for instance, in abscess, lacerations, \&c.-Hereto belongs a case which $I$ saw in the Anat. Mus. at Strasburg, and the case of Thibert and Fouquier.

(9) For example, Marechal, Holmers, Bechhaus, Schuler, Kreysig, Vol. III. p. 104. -My Selt. Beob. Part I. p. 64; Part II. p. 50 ; and in No. 8020 of the Bresl. Mus.-Hereto belongs, in a certain degree, also the case observed by Abercrombie, in which the upper part of the right ventricle of the heart by adhesion of its walls was separated, and produced a small cavity.

(10) This was found by Mery, Meckel, in two cases, Corvisart, Farre, in two cases, Louis, Obs. 4, Ramberg, Rust, and Hesselbach.

(11) For instance, in the cases by Langstaff, Jurine, Spry, Seiler, Burns, and one by Farre.-Wolf in Kreysig, Vol. III. p. 200.-Marechal.

(12) Hodgson, Hunter, English, Lawrence, Schuler, Nevin, Haase, Jurine, Sandifrrt, Meckel, Tacconi, Morgagni, Nordblad, Farre, in two cases Meyer, Green, Corvisart, Hesselbach, Seiler, Delmas, Ulrich, Hoffmann, Basedow.-Moreau de la Sarthe Fragmens pour servir à l'histoire de la Médecine en France, p. 45. 1812. -Kreysig, Vol. III. p. 104, with an engraving.-Knox, Alibert, Gintrac, p. 164. Cherrier, Bonnissent, Obet, Pinel, and Lallemand.

(13) Fabricius Hildanus Op. omnia. Ep. XLV. p. 992.-Brendel in Ephem. Nat. Cur. Cent. IV. Obs. 166.-Hunter and Jurine found it open but narrow. English, Obet, Richerand, Spry, Seiler, Marechal, Burns, Thoxter and Delmas saw it wider.

(14) J.F. Meckel has cullected such cases in his edition of Cuvier's Comp. Anat. Vol. IV. p. 37, note; in his Beiträgen zur vergl. Anatomie, Vol. II. Part I. p. 15, and in his Patlol. Anat. Vol. I. p. 447.-Blumenbach Handbuch der vergl. Anatomie, p. 543.- - I have hitherto found the oval hole open in three seals, and also in the alca torda in Tiedemann's anat. Mus.-The oval hole open in a young delphinus phocœna. v. Eiclıwald in Mém. de l'Academ. des. Sc. de Petersb. Vol. IX. p. 431.

(15) Compare J. F. Meckel's Pathol. Anat. Vol. I. p. 447.-We usually find the aperture obliquely upwards, sometimes downwards, and in number even as many as a dozen. In the Anat. pathol. Mus. at Vienna I saw the heart of a young man with an open oval hole, and a second also, separated from it by a thick column of flesh. Two oval holes were found by Vieussens Du Cour, p. 53.-Breschet and Hoffmann.-I have very often found in adults, who had never complained of any affection of the heart, openings in the partition of the auricle of the thickness of a finger. Similar cases have been often described; compare Feuss Repertor. Comment. Vol. X. p. 39, and de Plouquet Repert. Art. Cor. and Biel D. de foraminis ovalis et ductus arteriosi mutationibus. 4to. Berol. 1827, with engravings.

(16) Lentilius, Eph. Nat. Cur. Cent. VII. VIII. Obs. 62, was the first who adopted the idea of the reopening of the oval hole. - Tacconi, in Comment. Bonon. leads to this from a case.-Abernethy, in Phil. Transact. 1798, P. I. believed that this was the case in affection of the lungs; also Meckel, p. 465, is not disinclined to adopt this opinion. I myself have endeavoured to ground it upon fourteen cases. v. my Selt. Beob. Part I. p. 97, and Part II. p. 53. And since then I have observed more cases which speak to that point. Also Gintrac and $A$. Retzius, v. Ars. Berättelse om Svenska Läkare-Sällskapets Arbeten leminad af Eliström Stockh. 1826, are of this opinion.-Single obs. which appear to me to countenance it are Schrader Obs. an. med. Dec. I. Obs. 4, p. 65. Brendel, Ephem. N. C. Cent. IV. Obs. 166.--Sandifort, Obs. anat. pathol. L. IV. cap. 6.-Thomson in Edinb. med. and surg. Journal, No. 46, Jan. 1826, No. 2.Thibert, Fouquier, and Young. - Boillaud in Nouv. Journ. de Méd. Vol. VI. p. 23. - Corvisart, 2 d edit. p. 290. - Retzius. - Hesselbach, p. 205, No. 620. Compare Pasqualini Mémorie sulla frequente apertura del foramine ovale rinvenuta nei cadaveri dei tisici. 8vo. Roma, 1827. 
$\S 1 \% 4$.

Though sereral of the just described vices of formation, for instance, the open state of the oval hole, and simultaneously with it, the perforation of the ventricular partition, are often present in the same heart, we also find still other malformations of various kinds associated with them. To these belong, for instance, the IMPERFORATE STATE OF THE VENOUS ORIFICE of the right ${ }^{1}$ or left ${ }^{2}$ ventricle, which is of very rare occurrence ; and no less rare the NARROWED OR CLOSED STATE OF THE ARTERIAL APERTURE of the left ventricle, ${ }^{3}$ and the very comMON NARROWING OF PERFECT CLOSURE OF THE ARTERIAL ORIFICE of the right ventricle, viz. the origin of the pulmonary artery. ${ }^{4}$ Very frequently also we observe, either alone or in connexion with other vicious formations, an irregular arrangement of the ARTERIES AND VEINS arising from the heart, in consequence of which, the arterial and venous blood become mixed, or the change of the latter into the former is prevented. ${ }^{5}$ The VALVES of the heart also not unfrequently present congenital vices ${ }^{6}$ of formation; thus for instance, the VALVE of THE OVAL HOLE is often entirely deficient, and especially, if in persons affected with the blue disease, the aperture be very large $;^{7}$ or it is too small, and not adherent at one or more points of its edge; sometimes it is perforated, sometimes very thin, double, ${ }^{8}$ and differing variously in position and form. ${ }^{9}$ The eustacinan valve commonly, though not always, has a certain relation to the oval hole, so that it appear's to be large, if in the later periods of life that aperture is found open; ${ }^{10}$ frequently it is entirely deficient, and not merely in after life, when it is often very small, thin, perforated, and lost in net-work, and fibres, but even in young persons ;" sometimes it is so large that it occupies the place of the deficient thebesian valve, and covers the orifice of the coronary vein; even its position varies in certain cases. ${ }^{12}$ It has been already observed that the THEBESIAN VALvE is often wanting, ${ }^{13}$ but it also deviates considerably in size, form, and position $;^{14}$ and is also found double and manifold. ${ }^{15}$ The TRICUspid ${ }^{16}$ and BICUSPID ${ }^{17}$ VALVIS are also deficient, simultaneously with other malformations of the heart, or they are imperfectly developed and mishapen. In rare instances the semilunar valves, both of the aorta and of the pulmonary artery, were not found, ${ }^{18}$ or only as a single valve..$^{19}$ And equally rare is the existence in the former ${ }^{20}$ or in the latter ${ }^{21}$ of only two valves; or on the contrary, both in the pulmonary artery, ${ }^{22}$ and the aorta, ${ }^{23}$ four, and even five ${ }^{24}$ semilunar valves; they are also seen cleft, and of unequal sizc. In a single instance an unnatural valve has 


\section{been observed on the orifice of a pulmonary vein, in the left auricle of the heart. ${ }^{25}$}

(1) Kreysig, Vol. III. p. 106.-Myself in a human monster, No. 8012, and in a double lamb, No. 8020 of the Bresl. Mus.

(2) My Selt. Beob. Part I. p. 16. - Respecting the morbid narrowing of this and other openings of the heart, I shall treat when I speak of the vices of texture.

(3) A case in Corvisart, Rust, Ramberg, \&c.

(4) This was found by Stenson, Langstuff, Chemineau, Hodgson, Hunter, Schulcr, Fleischmann, Farre (several times), Howship, Nevin, Ring, Abernethy, Cailliot, Obet, Meyer, Cooper, Haasse, Sandifort, Huet, Pulteney, Tacconi, Morgagni, Seiler, Schallgruber, Hall and Vrolick, Delmas, Meckel, and myself. v. Selt. Beobacht. Part II. p. 102, and in the monsters, No. 8012 and 8020 in Bresl. Mus. This vice consists sometimes in a mere narrowing of the arteries; in other cases the opening is through an oblique partition, but only slightly perforated in the middle, through the adherent or entirely closed semilunar valve; although this is by no means always the case in the blue disease, inasmuch as the arteries of the lungs have commonly their normal width; they are even irregularly wide, as the cases of Farre, Richerand, Lawrence, Corvisart, Meckel, Young, Hufeland, and Lallemand, will show.

(5) See further down in the several blood-vessels.

(6) Of the acquired deformity of the same we shall speak further on.

(7) Plancus, v. Morgagni, Ep. XLVIII. 62._Delmas, Hodgson, English, Lawrence, Ulrich, \&c.

(8) Vieussens Du Cour, p. 53.-There were two foramina ovalia.

(9) Haller Elem. Physiol. Vol. VIII. p. 379.-Kilian Ueber den Kreislauf des Blutes im Kinde, u. s. w. 4to. Karlsruhe, 1826.

(10) Compare J. F. Meckel Pathol. Anat. Vol. I. p. 455 ff.

(11) I have found this myself often, viz. in monsters, No. 8012 and 8014 of the Bresl. Mus.

(12) Kilian, pl. 3 and 4.

(13) Meckel resp. Lindner D. de lymphat. vasor. systemate. Halæ, 1787, p. 2.I have missed the valvula thebesii three times, viz. in an adult and in two monsters, No. 8013 and 8014 in the Bresl. Mus.; also in the case of $D^{\prime}$ Alton it was wanting.-If the left upper vena cava open into the coronary vein, then the valve also is sometimes wanting. This I observed, for instance, in a monster, No. 8020 of Bresl. Mus.

(14) In such rare cases, in which the coronary vein empties itself in the left auricle, the valve very naturally cannot be in the right, but only in the left auricle.

(15) Sömmerring Vom Baue des menschl. Körpers, Vol. IV. p. 427.

(16) It is wanting always when the venous opening of the right ventricle is closed, and sometimes when the aorta springs up very far to the right, by which its development is retarded, and it can only partially exist, as I have myself found several times. In two cases I found it consisting of four pieces, as was also seen by Hesselbach. v. Beschreib. der pathol. Präparate, p. 201, No. 541. .

(17) In closed ostium venosum of the left ventricle, although also without it; for example, $J . F$. Meckel, Descriptio monstror. nonnullor, p. 11. It was very deformed in the case in Rust.

(18) For example, Wichert, Descriptio monstri duplicati. 8vo. Dorpat, 1824, p. 24, 26.-Wirtensohn D. duorum monstror. duplic. humanor. descriptio anat. p. 24, 4to. Berol. 1825.

(19) For example, when it is closed at its origin, or sometimes only very narrow ; so that in the blue disease, in the pulmonary artery commonly, instead of the three valves, there is only a membranous ring, with a narrow opening in the middle, as mentioned above, v. note 4 .

(20) Littre in Mém de Paris, 1713, p. 22 and 29. - Baillie, Engravings of morbid Anat. pl. 2, fig. 5.-J. F. Meckel Handb. der pathol. Anat. Vol. I. p. 436, and Tab. anat. pathol. Fasc. I. tab. 1, fig. 1 ; and myself in three cases. v. Selt. 
Beob. Part II. p. 67 . In a monster, No. 2896 of my Verzeichn, and in a monstrous calf, with cleft palate, monstrously short legs, $\delta \mathrm{c}$.

(21) Walther Observat. anat. p. 9, tab. 4, fig. 3. - Sandifort Observ. anat. pathol. Lib. I. tab. 3, fig. 4 and 5, Lib. III. tab. 4, fig. 3.-J. F. Meckel De corde abnorm. Vol. II. fig. 2 and 3, and Tab. anat. path. Fasc. I. tab. 2, fig. 5 and 6. - Farre, fig. 12.-Palois in Bullet. de la Soc. de Médec. de Paris, 1809, Vol. IV. p. 226. Cailliot, ib. 1807. p. 21.-Hesselbach Beschreib. der pathol. Präparate, p. 201, No. 541, and myself in two monsters, No. 8011 and 8013 of Bresl. Mus.

(22) Petschke, v. Haller Coll. Disp. anat. Vol. VI. p. 774. - Morgagni, Epist. XXXIV. 15.-J. F. Meckel De cord. abnorm. tab. 2, fig. 1, and Tab. anat. path. Fasc. I. tab. 2, fig. 2-4.-Penada Saggio terzo d'osserv. e memor. med. anat. Padova, 1803 , No. 3.

(23) Kelch Beiträge zur pathol. anat. p. 81, No. 58.

(24) In an aorta at first single, but very soon after divided. v. Malacarne Osservazione in Chirurgia, Torino, 1788, Part III. p. 119.

(25) Kelch, No. 59.

\section{$\S 175$.}

The position of the heart is not unfrequently found irregular, ${ }^{1}$ both as a congenital and as an acquired vice. The first kind presents very many variations and gradual transitions into each other, but which may generally be referred to two forms, viz. IRREGULAR POSITION WITHIN and WITHOUT THE CHEST. To the former belong, the very rare position of the heart too much to the left side, ${ }^{2}$ next, the more usual, and in very different degrees, situation of the heart to the right side, which is not merely observed in the transposition of all the viscera of the chest, ${ }^{3}$ but sometimes even of the heart alone $;^{4}$ next follows, the transition thereto in the direct or vertical position of the heart ${ }^{5}$ or its transverse position, ${ }^{6}$ in which the point is turned, now to the right and now to the left side, and often even upwards, and the heart itself also often placed lower; finally, some instances of the too high situation of the heart, especially in connexion with imperfect development of the cavity of the chest, in reference to its longitudinal diameter, are observed. The second kind of irregular position of the heart, in which case it is situated externally to the chest, is either its partial or entire concealment in the belly, ${ }^{7}$ or in its more or less complete prolapse, when the anterior surface of the body is deficient, propendentia, hernia cordis, \&c. ${ }^{8}$ In this prolapse the heart may protrude either alone, ${ }^{9}$ or in connexion with other thoracic and abdominal viscera, ${ }^{10}$ at the neck or in absence of the breastbone and through congenital holes and clefts of that bone, either higher or lower upon the breast, or close under the point of the breast-bone and at the top of the belly. Should the heart in such cases be uncovered by the sacciform expanded walls of the chest or belly, but lying completely free on the exterior, it will in rare instances ADHERE to other parts of the body. ${ }^{11}$ 
(1) Dislocatio seu ectopia cordis; compare de Plouquet Repertor. Dislocatio cordis.-Haller Elen. Physiol. Vol. I. p. 303.-Zedler D. de situ cordis abnormi cum historia morbi singularis huc spectante. 4to. Vratisl. 1817. -- Breschet Mémoire sur l'ectopie de l'appareil de la circulation et particulièrement sur celle du cœur. 4to. Paris, 1826, with three plates; and in Repertoire général d'Anat. et de Physiol. patholog. \&rc. Vol. II. p. 1.

(2) In congenital frenic ruptures on the right side, of which I have found two examples, viz. No. 2874 and 8015 of the Bresl. Mus.

(3) Compare above, $\S 25$, and below, on the cavity of the chest.

(4) Reuss Repertor. Comment. Vol. X. p. 90 and 91 . We here also find different degrees, in so far as sometimes the point or the whole heart is turned towards the right, and sometimes turned completely to the right side. Examples hereof are given by Riolanus Anthropographia, L. III. cap. 12. - Bartholinus Histor. anat. 1747, Cent. II. Hist. 25. - Fr. Hoffmann D. Cardianastrophe admiranda, etc. Lips. 1761.-van Doebeln in Act. Acad. N. C. Vol. IV. Obs. 132, p. 505. - Buxtorf in Act. Helvet. Vol. VII. p. 101. - Mery, v. du Hamel Hist. acad. reg. Scient. L. III. c. 2.-Walter in Nouv. Mémoir. de l'Acad. des Sc. de Berlin, 1775, p. 139. - Abhandl. der Josephsakademie, Vol. I. p. 286.--Delamare in Journ. de Médec. Vol. XXXIII. p. 510.--T'antini Wissenschaftl. Werke. Pisa, 1812.-Barton in American medic. Recorder. Vol. IV. No. 2. Philadelphia, 1S21. -I have found three instances. v. Selt. Beob. Part I. p. 95 ; Part II. p. 47 ; and Verzeichness der anat. Präparatensammlung, No. 2186-Breschet, p. 10. pl. 1, found this four times; the heart, in congenital ruptures of the diaphragm, is commonly forced to the right side by the pressure of the protruded bowels; also, in the blue disease, the heart lies sometimes on the right side. v. Testa, Haase, Seidel, and $\$ 172$, note 11.-Breschet, p. 12.

(5) Sandifort Obs. anat. pathol. L. IV. cap. 6, p. 55. - My Selt. Beob. Part I. p. 16.-d'Alton De de cyanopathiæ specie, etc. 4to. Bonnæ, 1824.--Breschet, p. 17.

(6) Acta Nat. Cur. Vol. X. p. 17. - Abhandlungen der Josephsakademie, Vol. I. p. 265.-Caillot. -J. F'. Meckel Archiv f. Anat. u. Physiol. 1826, No. 1, p. 41.-My Selt. Beob. Part II. p. 48, in a monster, No. 8013 of Bresl. Mus., on account of depression from umbilical rupture.--Torres found the heart with the point turned somewhat upwards. v. Mém. de Mathém. et de Phys. Vol. I. p. 136 ; and in Plil. Transact. 1741, p. 776.

(7) Miscell. Nat. Cur. Dec. II. Ann. VI. Obs. 232 ; Ann. VIII. Obs. 114.Bartholinus Hist. Anat. 1747, Cent. III. Hist. 32.-Boerhaave, v. Samml. auserl. Abhandl. Vol. IX. p.491, in a rat. - Ramel in Journ. de Médec. Vol. XLIX. 1778, May, p. 423. - Deschamp in Journ. gén. de Méd. Vol. XXVI. p. 276, in the region of the left kidney.-Vetter Aphorismen aus der pathol. Anat. p. 108, note.-Voigtel Fragmenta sem. obstetr. Hal. 1792, p. 77, tab. 5. - Lenhosseck in Oestr. medic. Jahırb. Vol. VI. Part II.

(8) Also ectopia cordis in a strict sense; for instance, in Fleischmann De vitiis congenitis circa thoracem et abdomen. 4to. Erlangæ, 1810. - C. Weese D. de cordis ectopia. Berol. 1818, with six engravings.-H. J. Haan D. de ectopia cordis casu illustrata. 4to. Bonnæ, 1825, with two lithogr. plates.-Compare on this kind of false position of the heart, J. F. Meckel Handb. der pathol. Anat. Vol. I. p. 97 , ff.

(9) Acta Hafn. Vol. I. No. 110.-Eph. N. C. Ann. VI. and VII. Obs. 232.Philos. Transact. No. 461. - Martinez Observatio rara de corde in monstroso infantulo, etc. Madriti, 1723. v. Haller Disput. anat. select. Vol. II. p. 973.Morand in Mém. de l'Acad. des. Sc. 1760. Hist. p.47.--Büttner Anat. Anmerk. 4to. Königsberg, 1752, with engravings, in a child born alive, with the heart prolapsed ; and Anat. Wahrnehmungen. Königsb. 1768, p. 36, with plates.Sandifort in Act. Helvet. Vol. VII. p. 59.-Vaubonnais Mém. de l'Acad. des Sc. 1712. Hist. p. 89. - Weber, or especially Mauchart, v. Baldinger's Magazin f. Aerzte, 1776, Part VI. p. 510. - Gilibert Adversaria med. pract. Lugd. 1791, p. 132. - Prochaska Adnot. academ. Fasc. III. p. 172. - Malacarne in Lezioni academiche. II. VIII. p. 12. Fasc. III. V.-Chaussier Note sur une lernie congeniale du Cœur, in Bulletin de la Faculté de méd. de Paris, 1814, p. 93. Herold in Stark's Archiv f. die Geburtshülfe. Vol. I. Part 1. p. 37.-Iaan Medic. 
Jahrb. des östr. Staates. Vol. V. Part II. p. 68. - Cerutti Rarioris monstri, in museo anatomico Lipsiensi adversati descriptio anat. 4to. Lips. 1827, with two engravings. v. Meckel's Archiv f. Anat. und Phys. 1828, No. 2, p. 192. - Mende in Nov. Act. phys. med. Acad. cæs. L. C. Vol. XI. Part II. p. 445, tab. 53, fig. 2, in a fœtus six or seven weeks old; also, though rarely in animals, viz. in dogs and calves. v. Journ. des Savans, 1668, No. 3, 1681 and 166, in two cats. v. Regis Journ. des Savans, 1681, p. 166. Paris.--In a sheep on the neck, v. Weese, p. 8, tab. 1; as a transition to this malformation is to be attributed the very loose position of the heart in deficient breast-bone, with undivided common integument. - Cordis situs patulus, in Fleischmann, p. 15. Compare \$ 137. - Lund Schwedische Abhandl. Vol. XXIV. p. 248.-The same in a dove, de la Chevalleraye. v. Mém. de l'Acad. des Sc. 1740 , p. 586 and 595.

(10) Compare below, on thoracic and abdominal clefts. - In large congenital ventral ruptures, which often include the under part of the chest, we frequently find the heart then situated in the upper part of the sack, in the scrobiculus cordis above the diaphragm; but if the diaphragm be imperfectly developed, and in rare cases, even when it is properly formed, we find the lieart in the belly itself, and mostly in the neighbourhood of the liver. Instances of this kind are found in Chabelard Mém. de l'Acad. des Sc. 1746, Hist. p. 67.-Wahlbom in Abhandl. der k. schwed. Acad. der Wissensch. 1767, Vol. XXVI. p. 82. Sandifort in Act. Helvet. Vol. VII. p. 86.-Büttner Anat.Wahrnelmmungen, p. 121. -Wilson, in Philos.Transact. 1798, Part II. p.346. - Voigtel Fragm. semiol. obstetr. Halæ, 1792, tab. 5, p. 77 ; compare J. F. Mleckel De cord. condit. abnorm. p. 6.Fleischmann, p. 2, 17, 24, tab. 1, fig. 1. - Bock in Cerutti's Pathol. anat. Mus. Vol. I. Part III. p. 37, pl. 16 and 17. Leipz. 1822.-Herrmann in Salzb. med. chir. Zeitung, 1822, Vol. IV. p. 95.-Lenhosseck in Medic. Jahrb. des. k. östr. Staates, Vol. VI. Part II.--My Selt. Beob. Part I. p. 64.-Verzeichn. No. 2883 and 8016 of Bresl. Mus.-Also once in a monstrous calf.-In two instances it was found by Cerutti. v. Weese, p. $40, \$ 60$. - The division of ectopia into pectoralis and ventralis, to which Breschet adds cephalica, appears to me by no means applicable, as all these forms gradtually run into each other; at all events, we must then assume an e. collaris of which a case is described by Lachmund, in Ephem. N. C. Dec. I. Ann. III. Obs. 103, p. 166; that of von Hammer, v. Commerc. lit. Noric. 1737, Hebd. X. p. 74, tab. 1, fig. 1. - One in a sheep. v. Weese, p. 8, pl. 1.-And a case by Breschet, p. 44, in which the heart was raised upon the front of the neck, from the ramus of the lower jaw to the tongue, with which it was connected.

(11) For example, by a thick plastic thread with the navel-string. v. Haan, fig. 1. -With the spine on the palate, \&c. v. Breschet, p. 45, pl. 2.-With the fore part of the face. v. Bonfils and Breschet, p. 48, pl. 3.

\section{$\S 176$.}

So again the heart may be irregularly situated AFTER BIRTH, and at every period of life, from causes originating either in itself or in the parts by which it is surrounded. 'To the former belong an unusual general enlargement or partial swelling of the heart, in consequence of which it is, as it were, dragged down out of its natural place; and the accompanying increased weight, whereby, if at the same time the parts supporting it are weakened, the heart sinks down in a remarkable manner, and carries with it the diaphragm in a bottle-like form; this sinking down of the heart has been called its PROLAPSE, prolapsus. ${ }^{1}$ Large tumours lying on the upper part of the heart, especially aneurysms of the aortic arch, may also depress it. ${ }^{2}$ The heart is also commonly displaced in other vices occurring 
in the chest; to these belong, curvatures of the spine, of the ribs, and breast-bone, large tumours connected with increased consistence of the lungs, ${ }^{3}$ collections of water, ${ }^{4}$ plastic lymph, and pus, ${ }^{5}$ blood, ${ }^{6}$ and even air $^{7}$ in one of the pleuræ, in consequence of which the heart is gradually thrust in the opposite direction; again, all kinds of tumours, as large exostoses, ${ }^{8}$ aneurysms, ${ }^{9}$ adipose and sarcomatous swellings, ${ }^{10} \& \mathrm{c}$. and also from the intestines of the belly rising up into the chest through rupture of the diaphragm. ${ }^{11}$ Finally, also, the heart may be thrust upwards into the neck, and in various other directions, by pressure of the abdominal viscera; large dropsies of the belly, tumours of the liver, spleen, of the stomach and other organs, ${ }^{12}$ sometimes produce the same effect. ${ }^{12 *}$

(1) Lancisi De aneurysmatibus, L. II. Propos. 52, p. 81; and De mortibus subitaneis, p. 136. - Morgagni Epist. anat. XV. note 53; and De sed. et caus. morb. Epist. XVII. p. 25-28. - Leidenfrost Exercit. de hernia et prolapsu cordis humani. Duisb. 1778; and Opusc. phys. chem. et med. Lemgo, 1797, Vol. I. p. 3.-Testa, p. 174. - Single observations in Pachioni Op. Edit. 4to. - Fel. Plater Observat. L. III. p. 636. - Senac Traité du Cœur. L. IV. Ch. VIII. No. 4, p. 178. - Zuliani De quibusdam cordis adfect. Obs. 2-4.

(2) Morgagni De sed. et caus. morbor. Ep. XVII. p. 25. - I have observed this twice.

(3) I have found this several times; -in one case, where a very large hard cartilaginous bag, surrounding a vomica, existed in the left lung, the heart beat for upwards of a year only on the right side, and lay there also, as seen on dissection. Compare my Selt. Beob. I. p. 95; II. p. 18. - Senac, L. IV. Ch. IX. § 7, p. 429.Acta med. Berol. Dec. I. Vol. VII. p. 98. - Schmidt, v. Hufeland's Journ. Vol. XXV. p. 189. - E. Jäger D. de hepatitide et phthisi, etc, -in viro, cui cor in dextro latere pulsabat. Tubing. 1780. - Scliwarz Præs. Mai D. paradoxum asthma cum corde e situ naturali deturbato. 4to. Heidelb. 1803.-Abercrombie, in Transact. of the med. chir. Soc. of Edinb. 1824, Vol. I. two cases.-Also from emphysema of the lungs. v. Laennec De l'auscultation médiate. Vol. II. p. 336, Paris, 1810.

(4) Harless and Ritter's N. Journ. d. ausländ. med. chir. Lit. Vol. VI. p. 148.A watery bag containing fifteen pints. v. Sammlung für pract. Aerzte, B. XXIII. p. 538 .

(5) Most frequently is the heart pressed to the right side by a large collection of puriform plastic lymph in the left pleura.-Klinz in Abhandlungen der Josephsakademie, Vol. I. p. 273. - Sömmerring De morb. vasor. lymphaticor. p. 139. - Friese Archiv der pract. Heilk. f. Schlesien, Vol. III. Part III. No. 6.-Larrey Mém. de Chir. 'Milit. \&c. Paris, 1812.-Rust's Magazin. Vol. V. p. 165.-Zedler.-Howship, Practical observations, Case 64.--Ficker in Harless Rhein. Jahrb. f. Med. und Chir. Vol. IV. p. 34.-I have seen this several times.

(6) From a bag filled with blood. v. Plenciz Acta et Observ. Med. p. 162.

(7) Laennec.

(8) Compare above, $\S 136$, note 31 ; and $\S 137$, note 21 and 22.

(9) Werdermann in Mursinna's N. Journ. f. d. Chir. Vol. I. p. 188. - I observed a similar case in an old woman, with very large aneurysm of the aorta, close to the diaphragm, by which the heart and left lung were thrust upwards and to the right.

(10) For instance, Boerhaave Opera omnia. Hagæ Com. 1738, p. 3.-Meckel in Mém. de l'Acad. de Berlin, 1759, p. 44, 45, and 86. - Ib. De conditione cord. abnorm. p. 6. - Corden, in Mem. of the Med. Soc. of London, Vol. VI. p. 122. Mac in Hufeland's Journ. Vol. XIX. Part I. p. 112.-Horn, N. Archiv f. medicin. Erfahrung, Vol. III. Part I. No. 3.-Corvisart in Leroux Journ. de Médec. cont. Vol. II. p. 14.-Lallemend in Ib. p. 24. 
(11) Very common in congenital frenic hernia, very rare when occurring subsequently; for instance, after a sword wound, through which the stomach was thrust up into the left cavity of the chest. v. Sennert Practica, L. II. Part II. cap. 15, p. 703. Lugd. Bat. 1650.-Möbius Fundam. med. Physiol. C. X.

(12) Even the ovaria. v. Kelch in Hufelund's Journ. d. pr. Heilk. Vol. XXV. I have twice seen it thrust obliquely upwards by large hydatid cysts in the belly. It is well known that Brera believed that angina pectoris arose from the heart being thrust out of its place by swelling of the liver. v. Brera Della Stenocardia, malattia volgarmente conosciuta sotto il nome di angina pectoris. Verona, 1810; and in Giornale di medicina practica, 1\$14, p. 1-26. -Jos. Averandi D. de angina pectoris, ejusque præcipua specie, Stenocardia, ib. January, 1816.

(12*) [ $\mathrm{W}$. Stolies, in Med. Gazette, Vol. VIII. p. 560, mentions a case, in which the heart was thrust (by the blow of a water-wheel) from its natural position on the left, to the right side, between the sixth and seventh ribs, on which side it pulsates. The patient still lives, but the narrator of the case has no doubt of the fact. T.]

\section{$\S 17 \%$.}

Sometimes also the colour of the heart is irregular; this is very commonly the case in cachetic and especially in dropsical persons; and it is not PALE merely on the external surface, but also in the muscular substance itself; a similar lighter or darker YELLOW colour is seen in fat hearts; in hypertrophy as well as in inflammation the heart is coloured too RED; hearts which are affected with softening, suppuration, mortification, or other vice of texture, are spotted sometimes GREY, LIGHT, or DARK-BROWN, and even BLACKISH. One or more white SPECKS of different degrees of size are frequently observed on the heart; they are produced by a trifling degree of inflammation, which causes thickening and opacity of the membrane of the heart, and are more commonly present on the right than on the left ventricle, and on the auricle $;^{1}$ PETECHIx have also been noticed on the heart. ${ }^{2}$ In a very few instances the surface of the heart itself is also reddened throughout, by the transudation of the blood; ${ }^{3}$ and lastly, I have once seen it tinged with GREEN in a case of poison. ${ }^{4}$

(1) Morgagni, Epist. III. p. 26.--Baillie's Morbid Anatomy, p. 20.-I have occasionally seen them also on the auricles, on the left ventricle, and even on the venx cavx, so far as they are in the pericardium.

(2) Stoll's Ratio medendi. - Fairbairn, in Transact. of the med. chir. Soc. of Edinb. Vol. 1I. 1. 157, found, in one case of purpura hæmorrhagica, eflusions of blood under the inner coat of the heart, and in the muscular substance; a similar case I observed in a person who died of the febris petechialis. - I also found it in a person killed by fire-damp; and in a child which died of the whooping-cough; also in one case in violent inflammation of the lieart, on insulated places, under its outer membrane, there were small extravasations of blood.

(3) Compare \$ 36.-Laennec De l'auscultation nrédiate, Vol. II. p. 353.-And I found this often, without suspicion of inflammation. Sometimes also even the coagulated blood transudes from the right auricle through its parietes, and colours them throughout of a lorown red colour.

(4) I found this once in a child poisoned by stramonium seeds. 


\section{$\S 178$.}

No less does the consistence of the heart vary considerably in consequence of vice of texture. But it is also not unfrequently unnaturally relaxed, soft and easily broken down, ${ }^{1}$ without any distinct vice of structure, but merely consequent on atrophy or some unknown proportion of composition; so also very fat hearts are always flabby and soft; violent exertion appears, as in other muscles, to render the heart easily broken down; thus, for instance, it is found very weak in hunted deer. ${ }^{2}$ The opposite vice, or abnormal firmness of the heart, though we do not here include inflammatory hardening, is most common in hypertrophy of the heart; it is also sometimes merely a seeming hardening, in consequence of the muscles of the heart having become unusually contracted in death.

(1) In persons who have died suddenly, and without any distinct cause, we sometimes find the heart very lax and bloodless. v. Chevalier in Med. Chir. Trans. Vol. I. p. 157.

(2) According to Senac. Compare $\$ 159$.

\section{$\S 179$.}

RUPTURE OF THE HEART, ruptura cordis, cardiorrhexis,${ }^{1}$ is usually the consequence of the already described diminished consistence of this organ; as also ulcerative erosion, great aneurysmal expansion with thinning of the walls, and obstruction of the flow of blood through the openings of the heart or of the neighbouring large vessels. Not unfrequently, however, we observe in apparently healthy hearts, bursting in consequence of superabundant influx of blood, ${ }^{2}$ violent emotions and external violence, not penetrating but merely producing concussion. Most frequently the left ventricle is found torn, the right ${ }^{3}$ less so, and the auricles least of all; in some instances also, we observe numerous cracks at the same time or only rupture of the septum, ${ }^{4}$ of some of the fleshy columns and tendons, ${ }^{5}$ but principally of the valves of the heart. ${ }^{6}$ Wounds of the heart which arise not merely from penetrating incisions, stabs, and gunshots, but also from splinters of fractured breast-bone and ribs, ${ }^{7}$ are indeed, if they be considerable and pierce the cavities, usually immediately fatal; still they are sometimes also fatal after a longer time $;^{8}$ they, however, occasionally heal, so that subsequently we observe the scars of the wounds. ${ }^{9}$ That such scars, however, can also be produced by ulcers which have healed, and hydatids ${ }^{10}$ which have been destroyed, is selfevident.

(1) Salzmann D. de subitanea morte a sanguine in pericardium effuso. Argentor. 1731 , in Haller's Coll. Diss. pr. Vol. II. No. 67.-Mummssen D. de corde rupto. Lips. 1764, with engravings.-Murray resp. Tengmalm D. de corde rupto. 4to 
Upsal. 1788.-A. Olmi Memoria di una morte repentina, cagionata della rottura del cuore. Svo. Firenze, 1S03.-Pohl De ruptura cordis. 4to. Lips. 1808, with engravings. - Brera Di una straordinaria rottura di cuore. Verona, 1808.-Rostan Mémoire sur les ruptures du cœur, in Journ. gén. de Médec. p. 72, July 1820. -As to single observations, v. Reuss Repertor. Comment. Vol. XIV. p. 384.de Plouquet Repert. Art. Cor ruptum. Dictionn. des Sc. médical. Vol. XI.IX. ץ. 212.-Charasse in London Med. Journ. 1786, Part III.-Buchholz Beiträge zur gerichtlichen Arzneigelahrtheit, Vol. III. p. 192, (a tear in the right ventricle of an apoplectic person.) - Ferrus, Laennec, Blaud, L. and J. A. Rochoux. v. Breschet in Répertoire général, Vol. III. Part II. p. 203.-Three instances in Testa, p. 391.-Salzburger Med. chir. 'Zeitung, 1814, No. 40, p. 239, (from an ulcer.) -Mott in Transact. of the Phys. Med. Soc. of New-York, Vol. I. 1817, (as a consequence of ulceration.)-Asdrubali in Nuovi commentarj di Med. et di Chir. Padova, 1818, (in one case.)-Akermann in Svenska Läkare-Sällskapets Handlingar, 1818. Vol. V. p. 221, (a gangrenous spot.)-Betulin, ib. p. 225, (after ulceration.) - Petersb. vermischte A bhandl. aus dem Geb. der Heilk 1S21. Erste Samml. p. 231, (the brother of this man died in a similar way.)Rudolphi Physiologie, Vol. I. p. 90.-Ashburner, v. von Froriep's Notizen, 1823, No. 82, p. 253, (both ventricles.)-Nouv. Biblioth. Med. Vol. I. No. 3, p. 1823, (both ventricles.)-Archives générales de Médec. Vol. IV. Part IV. 1824:Bayle in Revue médicale, July, 1824, (the diseased person died after fourteen hours.) - Carrier and Buron in Journ. compl. du Dict. des Sc. med. Oct. 1824. -Edinb. med. chir. Transact. v. Horn's Archiv, Jan. and Feb. 1824, p. 143, (with suppuration.) - Hesselbach Beschreibung der pathol. Präparate, u. s. w. p. 321, No. 369.-Thomas in London Med. and Phys. Journ. Vol. LIII. p. 193, March, 1S25, (the right ventricle in a boy of fourteen years old, with erosion.) - Ziehl in IIarless Rhein. Westp. Jahrb. Vol. III. Part III. p. 9, (on the right ventricle.) Charpentier in Journ. gén. de Méd. May, 1S26.-Berard D. sur plusieurs points d'anatomie pathologique, No. 2, Paris, 1826, (from a fall.) - Abercrombie in Transactions of the Med. Chir. Soc. of Ldinb. 1824, Vol. I. (two cases.) Zechinelli in Omodei Annali universali di Medicina, Vol. XXXVII. Feb. 1826. - Myself in four cases, v. Selt. Beob. Part II. p. 59, and Verzeichniss, No. 2245 and 2216. - More recently, two instances are mentionea in the account of morbid examinations of the Bresl. Med. Coll. in one of which there was a burst aneurysm of the left auricle in a girl of fourteen.- - Bignardi, Rupture of the left ventricle, the substance of the henrt about the aperture soft. v. Annali Univers. di Medic. Jan. 1829. 'T.]

(2) For instance, in the plague. Quesnai des fièvres, Vol. II. p. 44.8, and 'Traité des causes, des accidens et de la cure de la peste. Vol. I. p. 201. - In epileptic cases, v. Johnston Med. Bermerk. und Untersuchungen, Vol. II. p. 201.Several in anger and trouble, viz. Philip V. on hearing of the loss of the battle of Placenza. - Zimmermann von der Erfahrung, Vol. II. p. 449.-Sometimes during coitus. v. Morgagni, Ep. XXVI. p. 13, and Vater De mortis subitanex non vulgaris caussis et remediis, Viteb. 1723, and in Misc. Nat. Cur. Dec. III. Ann. IX. Obs. 164. - In straining on going to stool, Gcorge II. of England. v. Nicholls in Philos. Transact. Vol. I1. Part 1, p. 265.- In hydrophobia in a pig, in the veterinary school at Alfort.-Compare Rudolphi Bcmerk. auf einer reise, u. s. w. Vol. 11. p. 62.

(3) This does not occur in those cases in which the heart is burst from external violence, as the right ventricle is then more commonly torn, on account of its being more exposed and more easily struck.

(4) Breslauer Sammlungen, May, 1723, p. 560.

(5) Marat in Jourı. de Médec. continué, Vol. VI. p. 587.-Corvisart, p. 257. - Ailams in Dublin Hospital Reports and Communications, Vol. IV. 1827, No. 19.- - [Andral, Précis, Sc. Vol. II. p. 305, speals of perforations in the muscular sulstance of the heart, by which the blood is bronght in direct contact with the close portion of the pericardium without rupture of that membrane, and mentions al case at the $\Lambda$ call. Roy. de Mélec. in which the posterior part of the left ventricle exhibits five such perforations without any surrounding noftening. - Bouillaud mentions iupture of the fleshy columus of the tricuspict 
valve in a phthisical girl who had severe attacks of coughing. v. Andral Précis, \&c. Vol. II. p. 307 . T.]

(6) Compare Haller Elem. Physiol. I. p. 339.-Mummssen, p. 37.-Sandifort Obs. anat. pathol. L. I. c. I. p. 24 and 53.-Meckel in Mém. de l'Acad. des Sc. de Berlin, 1755. - Baillie, Morbid Anatomy, p. 32, and an engraving of it at pl. 2, fig. 5. - In an asthmatic person I once saw the tricuspid valve with a hole in it; once also one of the semilunar valves of the pulmonary artery obliquely cleft and jagged in its upper edge. The flask-like expansions which, in some instances, we observe in some of the valves, very much dispose to such tearings. -Morand, Hist. de l'Acad. Roy. des Sc. 1729, Obs. Anat. 7, found one of the mitral valves so distended.- - In Mus. St. Thomas's Hospital there is a case of this flask-like protrusion of the mitral valve into the left auricle, in which there are three small holes.-Rupture of the tricuspid valve in violent exertion is mentioned by $A$. Williams, Med. Gaz. Vol. IV. p. 78. T.]

(7) I have found several cases of this kind in the account of the morbid examinations of the Breslau Medicinal College; but very recently I saw in a man of Ems, who was murdered at Tillendorf, with fracture of the breast-bone and some of the ribs, the right auricle torn by a splinter of the breast-bone.In a horse. v. Rohlwes Magaz. f. d. Thierarzneikunde, Vol. I. p. 311.

(8) Many cases are collected in de Plouquet Repert. Art. Cordis vulnus. Krïgelstein Promptuarium medicinæ forensis. Erfurth and Gotha, 1822, Art. Cordis vulnus.-Alleweireldt $\mathrm{D}$. sur les lésions mécaniques du cœur et des vaisseaux sanguins, Sc. 4to. Paris, 1814.--Alphonse Sanson Thèse: Plaies du cœur. Paris, 1827.- [Gunshot wound of the right ventricle; the boy lived two months and six days ; three shot were found in the cavity of the ventricle, and the right lung nearly destroyed. v. Randall in Western Journal of Med. and Phys. Sc.Left ventricle stabbed with a knife; patient lived ten days. v. Journ. hebdom, 1828. - In Mus. St. Thomas's Hospital, bayonet wound of left ventricle; patient died in forty-nine hours.-Dapuy, in Journal de Méd. Vétérin, 1826, p. 24 , mentions a wound of the right ventricle of the heart of an $\mathrm{ox}$, in which a piece of iron wire it had swallowed ulcerated through the honeycomb stomach, diaphragm, pericardium, and into the substance of the heart itself; it died in fourteen days. T.]

(9) Ido W'olf Observ. Med. Chir. L. I. No. 21. p. 70.-Durande Mém. sur l'abus de l'ensévelissement des morts, p. 28, Strasb. 1780.-Rougnon Considerationes pathologico semioticæ, Sc. p. 7. Vesunt. 1786.-Meier in Baldinger's Neuem Magaz. Vol. IV. p. 109.-Ollenrot in Schmucler's Vermischten Schriften Vol. II. p. 127.-Penada Saggi di Padova, Vol. I1I. Part II. p. 59._Lentin's Beiträge. Suppl. B. Leipzig, 1808.-Manssion v. Dict. des Sc. méd. Vol. IV. p. 216.-Bougon, v. Rust and Casper's Krit. Repertor. f. d. ges. Heilk. Vol. VI. Par. III. p. 474.-Moglin in Revue Méd. franc. et étrang. Vol. XI. p. 133.Two instances in $A$. Sanson.-Suringar D. de Gallorum chirurgia observationum Sylloge, L. B. 1827. - Scars have also been found several times on the hearts of animals.

(10) Morgagni Epist. XXXVIII. 43.-He also saw it in a hare.

\section{$\S 180$.}

Inflammation, with its consequences, must be mentioned first among the vices of TEXTURE in the heart. INFLAMMATION, inflammatio cordis, carditis, ${ }^{1}$ is not at all an unfrequent disease of the heart in men $^{2}$ and animals ${ }^{3}$, as the consequence of mechanical influences, of cold, of metastases, of gout and rheumatism, of eruptive diseases, ${ }^{4}$ of canine madness, ${ }^{5}$ \&c., and occurs sometimes in the heart alone, but more frequently simultaneous with that of the pericardium and pleura, and may be even epidemic. ${ }^{\circ} \quad$ Oftentimes we observe but a single spot of 
the heart inflamed, more frequently the external membrane alone is rose-coloured, or the muscular substance, is more or less similarly affected, ${ }^{7}$ but in rarer cases only the internal membrane lining the cavities of the heart ${ }^{8}$ is affected. Should the inflammation of the heart be merely superficial, there is but an imperfect pouring out of serum and coagulated lymph in a slight degree, and to little extent, beneath the membrane, ${ }^{9}$ hence, consequently, arise the above-mentioned white spots; but in higher degrees of inflammation there is a very decided effusion of a similar substance upon the surface, and even in the cavities of the heart. 'This effused fibrous matter renders the surface of the heart both wrinkled and uneven, ${ }^{10}$ with little projections and knots, more frequently with fibres and net-work of various form, cor villosum, ${ }^{11}$ or it is produced more largely and more smoothly, so that the heart and pericardium are lined with a false membrane, ${ }^{12}$ of a cellular texture filled with serum, the mass occupying the interspace between the heart and the pericardium; or, finally, there is a more or less extensive and firm adhesion between these two parts. ${ }^{13}$ Should the effusion of fibrous matter occur upon the internal surface of the heart, it appears capable of pro. ducing in very rare cases polypous COAGULA, ${ }^{1+}$ also FALSE MEMBRANES, ${ }^{15}$ ADHESIONS OF THE WALLS OF THE HEART ${ }^{16}$ and of the VALVES ${ }^{17}$ to each other, and to themselves.

(1) de Berger D. de inflammatione cordis. Viteb. 1717.-Gloger D. de inflam. cordis vera. Jenæ, 1758. - Nunn D. de carditide spontanea. 4to. Erford, 1788. - Metzger resp. Merzfeldt D. de carditide. Regiomonti, 1789. - Davis, Inquiry into the symptoms and treatment of Carditis. Iondon, 1808.-Reikem in Bulletin de la Fac. de Médec. p. 140. Paris, 1809. - Burrow D. de carditide acuta. Edinb. 1816.-G. L. Ilertzberg De carditide, Parts I. and II. Halæ, 1817.- Heim Von der hitzigen idiopathischen Herzentzündung in Rust's Magaz. f. d. ges. Heilk. Vol. VI. p. 343, with one engraving. - Roux Collectanea quædain de carditide exsudativa. 4to. Lips. 1819, with engravings.-Also under the title Comment. pathol. anat. de card. exsud. 4to. Lips, 1820, with col. engrav.C. U. J. Huber D. de carditide, quæ epidemice grassavit (!) inter milites anno 1814, in obsidione castelli Delfzyl, etc. 8vo. Gröning. 1S19, with engravings.Compare Harless Rhein. Jahrb. f. Med. und Chir. Vol. VI. p. 1.-Puchelt De carditide infantum Comment. 8vo. Lips. 1824. - Glas Ueber Herzentziindung. Inaugural dissertation. 8vo. Wurzburg, 1826.-Krause D. de carditide idiopathical acuta. 8vo. Berol. 1826. $-\mathrm{An}$ interesting case of inflammation of the heart, proved by dissection, is given by Gairdner in 'Transact. of the Med. chir. Soc. of Edinb. Vol. II. p. 237. - Stiebel Monographiae carditidis et pericarditidis acutxe epistola dedicatoria et præfatio. 4to. lirancof. ad Mocn, 1828. - Compare above. $\$ 165$, note 1 .

(2) Marcus Entwurf einer speciellen Therapie, Vol. II. \$ 1273, ff.-I find traces of inflammation of the heart not uncommon here (Breslau) especially among the poorer inhabitants, and in plithisical persons.

(3) Especially in horses and dogs; I lut lately lost a Newfoundland dog with this disease; in monkeys also $I$ have observed inthammation of the heart occurring with peripmeumony.

(4) Tunchou On smallpox. v. Edinb. Journ. of Med. Science, July, 1826. 
Forlani Observat. Dec. No. 5, in repressed itch. I have found it in a child which died of scarlet fever.

(5) Compare Sprengel in Testa, p. 246, note 37.

(6) Trecourt in Recueil périod. d'observations de Méd. de chir. et de Pharm. Paris, 1755, Vol. III. p. 458.-Huxham Op. phys. med. Lips. 1764, Vol. III. p. $50-52$. - Huber.

(7) I have sometimes found the muscular substance inflamed an inch deep in the greater part of both ventricles, and on their outer surface.

(8) I have noticed this a few times; Vetter also saw it. v. Aphorismen aus der pathol. Anat. p. 98, § 109.-Orfila, after poisoning with white oxyd of arsenic, v. Archives générales de Méd. Feb. 1823.-Tanchou in small-pox.

(9) I have sometimes found between the membrane and the muscular part of the heart a considerable quantity of lymph poured out, and the heart as it were œedematous; in other cases this has been found only on one or some parts. - Compare Burns, p. 132.

(10) Hence the ancients called such hearts broken up and suppurating.

(11) Cor pilosum, hirsutum, tomentosum, etc. v. Bose Pr. s. historiam cordis villosi, Lips. 1771. - Good engravings are given by Walter Sur les maladies du cœur, in Mém. de l'Acad. de Berlin, 1785, tab. 4, fig. 1. - Baillie Engravings, Fasc. I. pl. 1, fig. 1-3; and Roux, and Bleuland Icon. anat. pathol. Fasc. I. tab. 1 and 2.-This condition also is not rare in animals; I have seen it in horses, in a cow, and a dog.

(12) Sometimes is the heart so concealed thereby that it almost appears deficient, as it is attached to the diaphragm, but upon its upper surface, smoothly covered with a thick false membrane, between which and the pericardium a large cavity is found filled with serum.

(13) Pohl Pr. de pericardio cordi adhærente ejusque motum turbante. Lips. 1775. - NeVel Pr. de pericardio cum corde concreto. Giess. 1778. - J. C. F. Müller D. de concretione morbosa cordis cum pericardio, casibus aliquot illustrata. 8vo. Bonnæ, 1825.-A partial congenital adhesion has also been found. v. J. F. Mecliel Anat. Phys. Beob. und Untersuch. p. 87.

(14) Burns, On some of the most frequent and important diseases of the heart, \&c. 8vo. Edinb. 1809.-Corvisart, p. 419, Obs. 56.-Although in the cases here recited, the spots where the polyps were situated were said to be diseased, and therefore might have given rise to effusion during life, I do not, however, comprehend why the fibrous matter which is poured out in exudative inflammation in a fluid form, should not have been washed away by the doubly powerful flow of blood in inflammation of the heart, and thus its coagulation prevented. I therefore think, even in opposition to the grounds laid down by Xreysig, Part I. p. 86, that I must for the present firmly hold the doubts I have expressed in my Selt. Beob. Part II. p. 56 .

(15) Baillie, in his Morbid Anatomy, p. 33, once found the venous valves of the heart inflamed and covered with a layer of coagulable lymph; the latter indeed was deposited only at death, as well as the false membrane which Burns, p. 206, found in the right auricle, and Corvisart, Obs. 55, p. 419, in the right ventricle.

(16) J. Abercrombie found, in a man who had at an earlier period been subject to dyspnœa and palpitation of the heart, the walls of the right ventricle increased an inch and a half in thickness at its base. v. Med. chir. Trans. of Edinb. Vol. I. No. 1, 1824.

(17) H九nauld in Mém. de Paris, 1735, Hist. p. 19.-Licutaud Hist. Anat. Med. Vol. II. p. 184. - The review on Corvisart in the Hall. Allgem. L. Zeit. Sept. 1813, No. 219, p. 76. - Kelch Beiträge zur pathol. anat. No. 60.-I have also sometimes found it, especially with otherwise diseased valves.

\section{$\S 181$.}

Another consequence of inflammation of the heart is the frequent formation of ULCERS and ABSCESSES on this organ. ${ }^{1}$ 
The former are found on the external surface of the heart to a greater or less extent ${ }^{2}$ they however occur, but more rarely on the inner surface of the cavities of the heart, ${ }^{3}$ and very fiequently, in form of slight erosions, on the diseased valves. But the latter, ${ }^{4}$ which are seated in the substance of the heart itself, and sometimes attain considerable size, may burst either externally or internally, and as well as ulceration, produce perforation and rupture of the walls of the heart. ${ }^{5} \mathrm{~A}$ high degree of inflammation will very rarely run on to GANGRENE, ${ }^{6}$ which then attacks one part of the heart, and like ulceration, will give rise to perforations and bursting of that organ.

(1) As the opinions of the older writers are for the most part not to be depended on, because their diagnosis between cardielcosis and inflammatio exudativa cordis is so imperfect, I refer to Hielscher and Schmiedel D. de ulceratione pericardii et cordis, exemplo illustrata. 4to. Jenæ, 1742; as also with reference to the several observations in de Plouquet's Repertorium Art. Cordis apostema, arrosio, exulceratio, suppuratio and ulcus; and Lieutaud, Vol. II. p. 16I, Obs. $510-538$.

(2) Malpighi v. Morgagni Epist. XXV. p. 17.-van Doeveren Specimen observ. acad. L. B. 1765 , No. 4 , p. 70 . - Sandifort Observat. anat. pathol. L. IV. s. x. p. 109.-Penada Saggi di Padova, Vol. III. Part II. p. 59._Caldani in Memorie di Fisica della Soc. Ital. di Modena, Vol. XII. p. 11.-Desault Cours de Clinique externe, p. 117. Paris 1804. - 'iesta p. 233, 239, 241. - Bagatta in Brera's Giornale di Medic. pratica, Vol. III. Part IX.-Cerutti Beschreibung der pathol. Präparate, u.s.w. No. 845. [Scrofulous ulcer, No. 307, Mus. Roy. Coll. Surg. T.]

(3) The LAxdart, Part XXXIV. and Auszüge a. d. 'Tagebuche eines prakt. Arztes. Berlin, 1791, Part I. last article; Testa, p. 239; Laennec, De l'auscultation médiate, Vol. II. p. 305, contends, although erroneously, that ulceration of the inner surface is more common than that of the outer.

(4) Benivenius Observ. cap. 42.-Columbus de re anat. L. XV. p. 489.-Morgagni, Epist. XXV. 25. - Cruitishank, The Anatomy of the absorbing vessels of the human body. 4to. London, 1786.-G. Jiger in Harless Rhein. Jahrb. Vol II. p. 146. - Laennec, p. 303. -- Neubert in Hufeland's Journ. 1823, Nov. p. 91. [Andral, Vol. II. p. 324, an abscess as large as a hazel-nut in the parietes of the left ventricle, accompanied by, but not communicating with, suppuration in the pericardium. T.]

(5) Compare § 179, note 1.-Penada.-Walter Mém. de Berlin, 1785.-Morgagni, Epist. XVII. 5, 8; Epist. LXIV. 15. -- Journ. de Médec. Août, 1791.Biermayer Museum anat. pathol. No. 374.-H. Cloquet in Bulletin de la Faculté de Médec. de Paris, 1822 , p. 219. - Sometimes only the partition of the ventricle is eaten through. v. Sönmerring addend. to Baillie, p. 11.-Testa, p. 24t.--Weber in Nasse's Zeitschr. f. pyschische Aerzte, 1820, p. 396.

(6) Lieutaud, Vol. I. p. 476 , Obs. 1618, Vol. II. p. 168, Obs. 539-543 (amongst them three instances in the plague.)-Morand in Mém. de l'Acad. des Sc. de Paris, 1732, p. 59\%.-Stoerck Annus medic. II. p. 262.-Götting. gelehrte Anzeigen, 1786, Part CXXVIII. p. 1284. - Chambon de Montaux Merkwïrd. Krankengeschichten und Beobachtungen, Leipz. 1791, 1. 370. - Johnstone in Mem. of the med. Soc. of Lond. Vol. I. and in Medical Essays. Evesham, 1795, p. 192. - Alenside in Phil. Transact. Vol. LIII. 1. 353. - Vering in den Abhandl. der Josepsakademic, Vol. II. p. 315.-Gauluy Mémoire sur la gangrène du Coeur. Svo. Paris, 1807, and in Journ. de Med. Chir. et Plarm. par Corvisart, Leroux and Boyer, Vol. XIII. p. 7.-Porlal Cours d'Anat. niedic. Vol. III. p. 79.Testa, p. 245.-Corvisurt, p. 253.-J. Kennody, in London medical Repository, April, 182t, Vol. XXI. No. 124;-also in horses, v. Journ. de Méd. continué, Febr. 1812, 1). 151.-Bertin, Tríité des maladies du cour, etc. par Bouillaud, I'aris, 1824, 1. 108, improperly consiclers gangrene of the heart doulntful. 


\section{$\S 182$.}

Lastly, inflammation also frequently produces in the heart many changes of tissue, in consequence of which its normal conSISTENCE is remarkably altered. To this belongs the LOOSENING or sOFTENING, ${ }^{1}$ which, in a minor degree, always accompanies the early stages of inflammation, but, in a higher degree, is so closely connected with the changes of composition and texture consequent on inflammation, that a general disposition of the heart to break and tear to pieces is produced; suppuration and mortification, as might be supposed, are connected with greater softening of the tissue, although we sometimes find, without any distinct mortification, a particular spot on the heart, as it were, rotten, brownish, dryish, and so soft, that it can readily be torn with the finger or the probe. Quite as common is the opposite vice or inflammatory HARDENING of the heart, ${ }^{2}$ of which the extent and degree are not less variable. Sometimes indeed only the external membrane of the heart is thickened and hardened; or on the contrary, only the internal coat and the valves composed of it; or finally, more or less of the muscular substance of the heart itself, in which case, either its outer layer may be entirely hardened, or only certain spots through and through. The degree of this hardening of the heart varies very considerably; the most common form is the red hardening, the less frequent the white, which appears to be confined to certain spots, and sometimes goes so far that the hardened spots assume a TENDINOUS ${ }^{3}$ and CARTILAGINOUS-LIKE ${ }^{4}$ character. The highest degree of hardening occurs in the deposit of EARTH AND BONY MASSES IN THE HEART,${ }^{3}$ which however are, in proportion, very seldom found in the fleshy substance, whereas, ossifications are found, as frequently as extensively, in and beneath the external coat of the heart, ${ }^{6}$ in its fibrous parts, ${ }^{7}$ and in the internal coat, ${ }^{8}$ and at the same time in the valves. ${ }^{2}$ Considerable difference is found to exist with reference to the disposition to ossification in particular parts of the heart, inasmuch as the ventricles, the valves on the left side of the heart and the coronary arteries, ${ }^{10}$ are more frequently ossified than the auricles, the valves on the right side, ${ }^{11}$ and the veins of the heart; ${ }^{12}$ and we also find that the deposit of earthy matter is more rare in the venous than in the arterial valves of the heart. The just-described hardening, thickening, and ossification of the valves of the heart, frequently give rise to narrowing of the venous orifices as well as those of the arteries of the ventricle, especially of the left; to deficient motion and shutting up of the valves at these points, and con- 
sequently to the irregular flow of blood, which in its turn becomes the cause of many other diseases of the heart. ${ }^{13}$

(1) Portal, Vol. III. p. 80. - Lrennec de l'auscultation médiate, Vol. II. p. 286.-According to Dundas, the substance of the heart is too soft and pale in gout and rheumatism.

(2) I found general inflammatory hardening of the heart several times in so high a degree that its substance was quite firm and elastic. I also saw this in a cow which had a needle in her heart, and in a dog destroyed by inflammation of that organ. A few interesting cases of induration of the heart are mentioned by Testa, p. 234, and by Corvisart, p. 176.

(3) Albertini in Comment. Bonon. 1731, Vol. I. - Scharschmidt Medic. and chir. Nachrichten Jahrg. III. p. 245.-Morgagni, Ep. XLV. 23.-Tendinous tumours. v. Guest, Account of an uncommon ossification in the heart in Med. Mus. Lond. 1764, Vol. III. p. 165.

(4) Columbus de re anat. L. XV.—v. Haller Bibl. med. pract. II. p. 125.Veslingius Obs. anat. et Epist. med. XV.-Martenus de Cilano in Act. Acad. Nat. Curios. Vol. IX. p. 357.-Morgagni, Epist. XX VII. 17.-Beauchame in Sédillot's Rec. périod. Vol. V. p. 292.-Burns, p. 146 -Corvisart, p. 184, (the point of the heart.) - Kreysig, Vol. III. p. 173, (the left auricle of the heart.) -I have found often the outer membrane of the heart, and a part of the subjacent tissue, changed into a cartilaginous mass of one or two lines thick. Once I also saw the right auricle of the heart studded externally with small cartilaginous points and spots.-Laennec, p. 301, $\S 783$, found pretty often cartilaginous plates in the inner membrane of the left ventricle.

(5) Compare Haller Elem. Physiol. Vol. VIII. Part II. p. 78. - Lieutaud, Vol. II. Obs. 556-571. - Reuss Repertor. Comment. Vol. X. p. 94 and 95.de Plouquet Repertor. Art. Cordis ossa.- Striking instances related by Boerhaave Prælect. ad Inst. $\$ 478$, (also the septum.)-Garengeot in Mém. de Paris, 1726, Hist. p. 24.-Senac Traité du Ceur, L. IV. c. 9, No. 5.-Crüwel D. de cordis et vasorum osteogenesi, etc. Halæ, 1765, with engravings.-Mohrenheim in Wiener Beiträgen, Vol. II. p. 212.-Simmons and Watson in Medical Communications, Vol. I. Lond. 1784, No. 18, p. 228 and 234, engraved in Baillie's Engravings, Fasc. I. tab. 5.-Michaelis Prakt. Bibl. Vol. I. Part I. p. 116, in the Appendix.Hagstrün in Svenska Läkare-Sällskapets Handlingar. Vol. I. Part I. p. 52.Renauldin in Corvisart's Journ. de Méd. Vol. XI. Jan. 1806, p. 259, (the left ventricle stony internally with stalactic-like chrystals.) Also in animals ossifications of the heart occur, which I saw at Alfort, on the left auricle in a horse; and in the anatomical Museum at Utretcht a considerable ossification on the heart of a sheep; the entirely ossified hearts of ducks, which le Meilleur, v. Roux Journ. de Méd. Vol. XXXII. p. 411 ; V. Malacarne, delle Osservazioni in Chirurgia, Part II. Torino, 1784, p. 190 ; and Michaelis, Medic. prakt. Bibliothel. Vol. I. Gött. 1785, mention, were really the inferior male larynx; here perliaps belongs also the whole ossified heart of a goose, which Cruveilhier, Essai sur l'Anat. Pathol. Vol. II. p. 77, is said to have seen.

(6) Frequently between the adhering pericardium and heart. v. Aurivillius in Nov. Act. Upsal. Vol. I. No. 15, p. 101.- Crowfnot in Edinb. med. and surg. Journ. Vol. V. Part XIX. No. 7. - Kreysig, Vol. III. p. 268.-Cruveilhier, Vol. II. p. 22.-Laennec, Vol. II. p. 402.-Berlin Traité des maladies du cneur, p. 262.Tachéron Recherches anat. patholog. Vol. III. 1. 257 and 261.-Arch. gén. de ined. Vol. I. p. 521.-Louis Mém. ou Recherch. anat. pathol. p. 298.-Abercrombie in Trans. of the med. chir. Soc. of Edinb. Vol. I. 1824, No. 1.-I once found in the cellular tissue between the heart and pericardium many distinct gypsum-like hard corns. In another case large thin points and plates of bone. Ossification and stoniness, which more or less decply penctrate into the tissue of the heart, are often found on the superfices of unalhering hearts, viz. Morgagni Epist. XXV111. 16. - Borlenave in Mém. de l'Acad. des Sc. 17S6, p. 53, (in part two inches broad.) - Prost Médecine éclairée par l'observation et l'ouverture des corps. Vol. I. p. 110, Paris, 1804.-Weber in der. Salzl). med. clin. Zeituner, 1811, Part II. p. 80. (I saw this preparation myself, the two bony plates are almost as 
large as a pair of oyster shells, and like stone.)-Burns, p. 146, (both chambers resembled calcareous boxes.) - Boeck D. de statu quodam cordis abnormi. 8vo. Berol, 1818, p. 25 (in the right ventricle.)-Mayer in d. Oestreich. medic: Jahrb. Vol. V. Part III. p. 80, (almost the whole upper surface); one instance in College of Surgeons in London, v. von Froriep's Notizen, 1823, No. 84, p. 286 (a bony scale on the left ventricle and right auricle.)-Adams in Dublin Hospital Reports and Communications, Vol. IV. 1827, No. 19 (one above an inch broad and three lines thick); an instance in Berlin Mus. v. Rudolphi Grundriss der Physiologie, Vol. II. Part II. p. 290, note 1.-I saw in the Anatomical Museum at Leipzig large ossifications on the right ventricle and auricle.

(7) Most commonly in the fibro-cartilaginous mass which forms the basis of the chamhers of the heart where the bony earth, which is deposited, frequently assumes the shape of rings of the thickness of a finger, which surround the venous openings of the ventricle, especially the left; for example, Bartholinus Hist. Anat. Cent. II. Hist. 45, in Pope Urban VIII. a large triangular bone--Morgagni Epist. XXVII. 2.-Haller Elementa Physiolog. Addenda, p. 129. Soemmerring's additions to Baillie's Morbid Anatomy, p. 26, note 49. - 2 an Heekeren D. de osteogenesi præternaturali, Lug. Bat. 1797, p. 120.-Vetter Apliorismen aus der pathol. Anat. p. 100, § 112.-Corvisart, p. 211.-Howship's Practical Obs.Louis, p. 298. - My Selt. Beob. Part I. p. 99, and Verzeichn. No. 2233-2235, 3937, 3938.-The chordæ tendineæ of the mitral valve are not unfrequently more or less filled with lime, as I have several times observed. - Boerhaave, Prælect. ad Instit. L. V. $\S 478$, found them quasi osseas festucas.

(8) I have several times seen little single earthy deposits on the internal coat of the left ventricle. - Vesling, Obs. Anat. et Epist. med. 15, saw the left ventricle lined witl a cartilaginous crust.-Tilling found one of the carneæ columnæ in the left ventricle ossified. v. Hufeland's Journ. Vol. XV. p. 156.-Köriig in Horn's Archiv f. medic. Erfahr. 1825, March and April, p. 292, a scale of bone in the left auricle; the upper part converted into fibro-cartilage.

(9) Many cases in Morgagni._Lieutaud, Vol. II. obs. $\$ 575-595$.-de Plouquet Repert. Art. Cord. palpitatio et Valvularum vitia.-V. Malacarne Discorso sulla litiasi delle valvule del cuore. 8vo. Torino, 1787. - Lucas De depositionibus cretaceis intra cordis valvularum arteriarumque substantiam. 4to. Marburg, 1815. - Hering D. de osteogenesi valvularum cordis. 4to. Lips. 1819, with coloured engravings. - I often find deposits of lime on the valves of the left side of the heart, not merely in old men, but also in women, and even in persons who lave not attained the adult period, as it appears almost always connected in a certain degree with scrofula, which at Breslau is very frequent and malignant. Aldis also found in a man of eighteen extensive ossification of the valves. v. Edinb. med. and surg. Journ. Vol. V. Part XX. No. 5.-The lime also frequently forms strong points on the valves; or grapelike and roundish processes as big as peas, or thereabouts. Good engravings of such ossifications are given in Sandifort Observat. anat. path. Lib. I. - Baillie's Engravings, Fasc. I. fig. 1, 2, 3, 5.Hodgson, Engravings intended to illustrate some of the diseases of arteries. London, 1815, tab. 1.-Meckel Tab. anat. path. Fasc. I. tab. 5, fig. 1-8.-Hering also mentions ossification of the aortic valves sumetimes occurring in animals. I have seen it, for example, a few times in horses.

(10) Senac, L. IV. c. 10.-Morgagni Epist. XXIV. 16, 17, in which are mentioned the observations of the ancients.-Crell et Rheinhold D. de arteria coronaria instar ossis indurata. Vidob. 1740.--Lentin Beiträge zur ausüb. Arzneiwissench. Vol. III. p. 113.-Parry, On angina pectoris, Lond. 1799; and An Inquiry into the symptoms and causes of the syncope anginosa, Lond. 1801, holds the opinion that ossification of the coronary arteries is the cause of angina pectoris. In favour of this notion are the observations of Sam. Black in Mem. of the med. Soc. of Lond. 1805, Vol. VI. No. 2.-Ring in Edinb. med. and phys. Journ. No. 95, p. 9.-Kreysig in Horn's Archiv f. med. Erf. Vol. III. Part I. No. 4, and Krankh. d. Herz. Vol. II. Part II. p. 532, ff. Vol. III. p. 289; in which several cases are collected.-Ritter in Hufeland's Journ. Vol. XX. p. 117.-Burns, p. 157.Albers in Salzb. med. chir. Zeitung, 1815, No. 25, p. 416.-Louyer-Villermay, v. Bulletin de la Faculté de Méd. de Paris, 1816, No. 1.—urine Mémoire sur 
l' angine de Poitrine, 8vo. Paris, 1815. - Schramm Comment. pathol. de angina pectoris, p. 17. Lips. 1822, with coloured plates. - Faber found this in a man who had died from difficult respiration. v. Hufeland's Journ. 1827, Aug. p. 79.-We do not, however, by any means always find them ossified in this disease. v. Testa, p. 321 ; on the contrary, there is often great ossitication of the coronary arteries without this disease. v. Hodgson, p. 59 ; my Verzeich. No. 2236, 2237, 3938. Howship, p. 64.-Adans.

(11) Bichat, Anatomie générale, maintains that it never occurs, which Adams supports, though wrongly, as the following examples show: Senac, p. 428, (of the semilunar valve in two cases).-Morgagni Epist. XIV. 35 (the tricuspid valve); XVII. 12 (semilunar valve); XLVII. 16 (tricuspid valve); several cases col.. lected by Hodgson, On the discases of arteries and veins, p. 67.-Seiler in Horn's Neuem Archiv f. med. Urfahr. Vol. II. Part II. (semilunar valve)-Nevin in Medical Commentaries by Duncan, Dec. II. Vol. IX. No. 10, p. 325, (semilunar valve.)-Corvisart, p. 210, \$3.-Horn in his Archiv f. prakt. Medicin. Vol. IV. p. 296 (tricuspid valve.) - Burns, p. 34, (tricuspid valve.) - Young, in Journal of Science and the Arts, No. I. p. 49, (tricuspid and semilunar valves.) - Hall Jackson in Corvisart's Journal de Méd. et Chir. Vol. XIX. p. 468, (tricuspid valve.)Cerutti Beschreibung der pathol. Präparate, p. 113, No. 590.-Cherrier D. sur la maladie bleue, etc. Paris, $1820 .-$ Louis, p. 318, (tricuspid valve.)-The reviewer in Gerson and Julius Magazin d. ausl. Litt. d. ges. Heilk. Jan. and Febr. 1828, p. 198.-My Selt. Beob. Part I. p. 98, (semilunar valve); since in another case, on the same place. I also saw at Vienna, in the Pathological Museum, No. 3237, ossification on the tricuspid valve.-[No.311 Mus. Roy. Coll. Surg. ossification of the tricuspid valve. - No. 309, ib. of the bicuspid. - In Mus. St. Thomas's Hospital, a preparation of the mitral valve ossified. T.]

(12) A case by Bonet, which I cannot again find; another in Ephem. Nat. Cur. Dec. II. Ann. X. Obs. 175.

(13) Abernethy, On a diminution of the area of the aperture, by which the left auricle of the heart communicates with the ventricle of the same side in Medic. chir. Transact. Vol. I. p. 27. - Corvisart sur les Maladies, etc. du cœur, p. 204, ff. - Kreysig, Vol. II. Part II. p. 583-615. - Bertin says that he has seen two hundred cases of enlargement, or aneurysm of the heart, with narrowing of the apertures.-[Elliotson, p. 19. T.]

\section{$\S 183$.}

Less distinct are some other textural vices of the substance of the heart consequent on inflammation, although in many such instances they may bear at least some resemblance to those above-mentioned. To these belong the IrREgular FATNESS and SPURIOUS FORMATIONS of the heart; the former appears under two shapes, viz. as a mere enormous deposit of fat upon the surface of the heart, ${ }^{1}$ which is so much increased and so unequal, that the heart itself, especially if there be much fat deposited at the same time in the mediastina, suffers from want of space and from pressure; or secondly, as a real metamorphosis of the muscular substance, which is then changed more or less completely into fat, and is generally at the same time very flabby and thin. ${ }^{2}$ To the SPURIOUS Formations, which are rarely met with in the heart, belong first many kinds of TUMOURs, ${ }^{3}$ especially STEATOMES, ${ }^{4}$ HYDATIDS, and other WATERY CYSTS, ${ }^{5}$ as well as GRITTY tumours; ${ }^{6}$ next, tuBercles, ${ }^{7}$ and lastly, sarcomatous for- 
MATIONS of various kinds, ${ }^{8}$ even MEDULLARY SARCOMA. ${ }^{\circ}$ The existence of true scirrhus and CARCINOMA upon the heart is still doubtful. ${ }^{10}$

(1) Lieutaud, Vol. II. p. 150, Cor adipe obrutum. Morgagni Epist. III. 20, XVI. 36, XXVII. 2, XXXV. 18, XLIII. 17, LII. 34. - Meckel in Mém. de l'Acad. de Berlin, 1756, p. 79.-v. Bergen in Actis Soc. med. Havn. Vol. I. p. 247.-Pyl Aufsätze und Beobachtungen aus der gerichtl. Arzneiwissenschaft: Vol. VII. p. 106, (in a drunkard.) Portal Cours d'Anatomie médicale, Vol. III. p. 74.-Testa, p. 342.-Fothergill in Lond. medic. Observ. and Inquiries, Vol. V. p. 233, considers it as giving rise to angina pectoris. - Corvisart, p. 197. Laennec, Vol. II. p. 295. - Schranm, Comm. pathol. de angina pectoris, Lips. 1822 , p. 17 , thinks that in the disease described by him there was always great deposition of fat on the heart, pericardium and omentum.-Wedemeyer. v. Rust's Magaz. Vol. XIX. p. 246, 269, often observed in drunkards great fatness of the heart, with accompanying ossification of the coronary arteries.-I have sometimes found in old persons the heart so surrounded with fat, although there was otherwise great meagreness, that it became mishapen and gibbous.

(2) Weitbrecht. v. Senac Traité de la structure du cœur, etc. L. IV. Ch. IX. 12. - Edinb. med. and surg. Journ. No. XI. VI. I. Jan. 1806. — Duncan, ibid. Jan. 1816, No. XLVI. I. found the greater part of the heart converted into a homogeneous greyish yellow fatty mass.-Cruveilheir Essai sur l'Anat. pathol. Part I. p. 183. - Chardel Monographie des dégénérations skirrheuses de l'estomac. 8vo. Paris, 1808, (the left ventricle.)-Dublin Hospital Reports and Communications, Vol. II. Part II. (in an apopletic person.) -Laennec, De l'auscultation médiate, Vol. II. p. 298, found it merely on the point of the heart.-N Auserl. Abhandl. zu Gebrauche f. prakt. Aerzte, Vol. IV.p. 4.-Adams, ibid. Vol. X. p. 4.-C. zum Tobel D. seu singularem casum degenerationis adiposæ cordis, cum aliis vicinarum partium mutationibus conjunctæ, 8vo. Tubing. 1825. - The case related by Simeon in the Heidelb. Klin. Annalen, Vol. III. Part II. p. 262, does not belong here, as the narrator mistook the plastic formation on the heart for fat.-I have seen two cases, in which almost the whole of the heart was converted into fat. v. Verzeichn. No. 2226 and 2227.

(3) Where many of the tumours on the heart observed by the ancients belong to, cannot be decided, on account of their deficient anatomico-pathological knowledge at that period, and the not less defective descriptions therefrom arising. To these belong, for instance, the observations which Lieutaud, Vol. II. Obs. $544-553$, has collected; further, those by Columbus De re anatomica, L. XV. p. 489, 492, (hard tumours in the substance of the left ventricle as big as an egg.) -Rhodius Observ. Medic. Cent. III. Obs. 4, (follicle in the right auricle of the heart.) - Srhenk Observ. L. II. No. 203.-Gantius. v. Boneti sepulchretum Anat. L. II. Sect. 1, addit. Obs. 2 (several tumours on the base of the heart, one of them as large as a pigeon's egg); other cases in Bonet, L. II. Sect. VII. Obs. 56,132 , addit. Obs. 9, Sect. 8 , Obs. 34 ; L. III. Sect. 21 , addit. Obs. 60.-Pyl Aufsätze und Beobachtungen, Vol. VI. p. 78 (on the tip, as a gland, as large as a bean.)

(4) Penada Saggio secondo d'osservazioni e memorie medico-anatomiche. 4to. Padua, 1800, (in a duck containing feathers.) Whether the case described by Fleisch in d. Allg. Annalen, 1811, Jul. p. 645, as the conversion of the heart into a fatlike cartilaginous mass, weighing six pounds, belongs here, must remain undecided. In the Hunterian Mus. at London I saw a lardaceous tumour on the tip of the heart of an ox, which contained a bony mass. I also found in a man a large lardaceous tumour on the right ventricle near the aorta, consisting of a firm lard-like mass mingled with hydatids. v. my Selt. Beob. Part II. p. 58.

(5) Compare Lüdersen D. de hydatidibus Gött. 1808, p. 11.-Boneti Sepulchret. anat. L. III. Sect. 37, Obs. 4, L. N. Sect. 12. Obs. 12.-Morgagni Epist XXI. 4, Epist. XXV. 15. - W. Rutty in Philos. Transact. 1728, p. 562. - Heuermann Physiologie, Vol. I. p. 202. - Salzmann in Haller's Disputat. Vol. IV. p. 248.Clossius in Baldinger's Magazin, Vol. X. 1. 543.-Portal Cours d'anat. médic. 
Vol. III. p. 29, 74 (several on the base of the heart, of which one was the size of a small hen's egg.) - Testa, p. 64, 67, 277, 278.-J. F. Mcclel Tab. anat. pathol. Fasc. I. Vol. I. tab. 8, (a large hydatid sac on the left ventricle.)-D. Price in London med. chir. Transact. Vol. XI. Part II. 1821, (in a boy of ten years old, who died suddenly, a large single hydatid in the muscular substance.)-Bernhardi Observatio circa ingentem cordis tumorem, Svo. Regiom, p. 22, 1826 (an hydatid externally on the right ventricle.) v. my Verzeichniss, \&c. No. 2229.-I saw in Museum pathologicum at Vienna, No. 664, little hydatids on the upper surface of the heart, and the engraving of a heart beset witl large hydatids at Allietti's, in Venice.- J. Abercrombie found a bag containing two ounces of an albuminous fluid on the left auricle of a child.-[In the Mus. at St. Thomas's Hospital, there is a heart with a cyst on its apex, as large as a hen's egg, which was filled with hydatids. T.] - Sometimes we find hydatids attached within the cavities of the heart. v. Trotter in Medic. and cliym. Essays. Lond. 1796, (two hydatids in the right ventricle of the heart.) -Dupuytren in Corvisart's Journ. de Médec. Ann. XI. Brumaire, (several large ones in the right auricle.) I saw a large hydatid in the right auricle in the Anat. Nus. at Vienna, No. 4040.- In a man thirty-four years old, who died of struma testis, I saw a large heap of hydatids on the Eustachian valve, hanging by several threads into the right ventricle. v. Selt. Beob. Part II. p. 57, tab. 1, fig. 2. - Hydatids have also been found on the hearts of animals, one as large as an apple on the heart of an ox. v. Bartholimus Hist. XXXII. Cent. II.-Privy Councillor Heim, at Berlin, in an ox, which he was kind enough to communicate to me in a note on Baillie.In a lioness the size of a hazel-nut. v. Eph. Nat. Curios. Dec. I. Ann. II. 1761, Obs. 5, p. 6 .

(6) Walier in Mém. de l'Acad. de Berlin, 1785, p. 65, tab. 4, fig. 2.-Muscum anat. Part I. p. 163, No. 1086, described and engraved in Arndt D. de tumoribus cordis tunicatis. 4to. Berol. 1817, with two engravings, (on the point of the heart of an ox.)-Cruveilheir, Vol. I. p. 301, (a little meliceris of the size of a pea.) I have seen three cases in the Mus. pathol. at Vienna, viz. a flat gritty tumour in the substance of the right ventricle of an old woman, and five or six encysted, the size of hazel-nuts, in the mass of the left ventricle of a young man.

(7) Here perhaps belong Licutaud, Vol. II. Obs. 545, 546.-Heurnius. v. Boneti Sepulchretum, L. IV. Sect. I. Obs. 15, \$13. - Irr. von Hilden Observat. chir. Cent. I. Obs. 51.-Morgagni Epist. LXVIII. 12, (the right auricle of a boy, fifteen years old, was externally quite beset with it.) - Portal, Vol. III. p. 74.Abernethy, Surgical Observations. - Autenrieth in Tübinger Blätter, Vol. I. Part II. p. 191 . - Spens in Edinb. med. and surg. Journ. 1816, Vol. XII. p. 194. - Lawrence in Med. chir. Transact. Vol. III. p. 78.-Laennec, Vol. II. 1). 325, in two cases. - Andral and Bayle, in Revue médicale franç. et étrangère, Février, 1821, found the heart of a child, as it were, enveloped in the tubercular mass. - Macmichael in London med. and phys. Journ. August, 1826.Although I have dissected a great number of scrofulous men and animals, I have never found a tubercle on the heart, and therefore consider them very rare. [Perhaps the preparation in Mus. St. Thomas's Hospital, mentioned by Elliotson, p. 32 , as having little scrofulous deposits in the walls of the left ventricle, surrounded by white and almost cartilaginous induration, belongs here. T.]

(S) They esplecially occur in a threefold form; first, as single little roundish knots deposited between the layers of the valves of the heart; then as white condylomatous growths on the inner surface, and especially on the valves; and, lastly, as more or less spheroidal, smooth, often tolerably large and solid growths, or true sarcoms. The first kind is very common; of the second, instances are given by Lancisi De morbis subitancis, Obs. IV. p. 121.-Rivière. v. Boneti Sepulchretum anat. L. II. Sect. 8, Obs. 24.-Morgagni, Epist. XI. 11.-Sandifort Obs. anat. pathol. L. I. c. 1, p. 31 ; L. III. c. 1, p. 41, tab. 3.-Corvisart, p. 223, ff. which he considers of a syphilitic nature, as also does Scarpa.-Bertin, in Bulletin de la Faculté de Médec. 1812, p. 58, and in Traité des maladies du cour, p. 232, denies Corvisart's opinion that it is syphilitic.-T'csta, p. 314.Laennec de l'Auscultation médiate, Vol. II. p. 334.-Desruelles in Revie médic. histor. et philos. Vol. IV. p. 30.), Paris, 1821.-Wedemeyer in Rust's Magaz. 
Vol. XIX. Part II. p. 239, in both auricles.-I have often found it both in syphilitic as well as in many other persons ; sometimes it is very large, grapelike, in form of a cock's-comb or a cauliflower. I saw a very large grape-like one on the mitral valve of a syphilitic person in the Mus. pathol. at Vienna, No. 1020. The third kind is most rare, to which perhaps belong several of the tumours on the heart described in note 3 above, as well as in the following.Testa, p. 314, found in a person who had been long afflicted with syphilis, the left auricle so beset externally with this structure, that a second auricle seemed to have been produced. Sometimes they are attached on the inner suríace of the heart. v. Blancard Anatomie rar. Cent. I. Obs. 75, p. 158.-Forlani Obs. rar. med. pract. Dec. I. p. 70 ; Dec. II. p. 10 , found a round tumour as large as a hazel-nut on one of the valves of the heart. - Söemmerring, in his additions to Baillie, p. 21, note 2, a similar one.-Myself in Selt. Beob. Part I. p. 98, in the right auricle. -J. F. Meckel Tab. Anat. pathol. Fasc. I. tab. 7, found fifteen such growths, from the size of a pin's head to that of a hazel-nut, partly within, partly without the heart. - Nasse found in the left auricle many pyriform growths with necks. v. his Leichenoffnungen, 1 te Reihe, p. 24. - The swellings which Laennec, p. 346, describes as végétations globuleuses, appear to be quite different from these sarcomatous growths; they are cyst-like projections of the inner coat of the heart, filled with effused blood, which is sometimes black and coagulated, sometimes deprived of red pigment, as there is more or less coagulated fibrous niatter; the smaller are semiglobular, the large more spheroidal, and furnished with necks. I might compare them with the tumours of serous and synovial membrane described alove, $\$ \S 81$ and 154, note 7. - Laennec found them in a phthisical person in the right ventricle. - I have seen them three times in calves, especially a remarkably large one on the mitral valve in the left ventricle. v. Selt. Beob. Part II. p. 53 ; Verzeichniss, 2228. - There is a similar one in the right auricle of a calf, No. 8610 ; and many on different parts in one of the two hearts of a double calf, No. 8611, of Bresl. Mus. [In Mus. St. Thomas's Hospital, on the interior of the right auricle of the heart of a man, who had a sarcomatous growth in the nostrils, there are two similar tubercles, one as large as a bean, the other as a pea.-Rigacci, fleshy polypus in left ventricle, similar to sarcoma, with vascular connexions, which were injected with quicksilver, in Antologia Firenze. T.]

(9) Bartzky Observatio singularis fungi medullaris in corde; præf. Dzondi, 8vo. Halæ, 1821, with plates, (a large tumour on the fore and upper surface of the heart.) - Hodgson, v. engraving in Savenko Tentamen anat. pathol. de Melanosi. 4to. Petropoli, 1825.-Segalas d'Etchepare in Revue Médic. franç. et étrang. 1825, Vol. IV. p. 247 ; and Nouv. Bullet. des Sc. par la Soc. philom. May, 1825, in a boy eleven years old.-In a womarı who had medullary sarcom on the fore-arm, there were several such knots on the heart. v. Gerson and Julius Magaz. d. ausl. Litter. d. ges. Heilk. p. 199, Sept. and Oct. 1823.-Stanpa Anweisung zur gerichtlichen $u$. pathol. Untersuchung menschl. Leichname, p. 164. 8vo. Wien, 1827, in an aged man, who had a similar tumour, as large as one's head, in the pelvis on the right ilium.-Another case I saw in the pathological Museum at Vienna, No. 4116, of a man with medullary sarcom on the thigh-bone. There are many such tumours, externally, in the muscular substance and within the right ventricle.

(10) Carcassone observed a carcinoma on the heart in a girl who had been long affected with syphilis. v. Hist et Mém. de la Soc. roy. de Médec. 1777 and 1778 , Hist. p. 252, Ann. 1786 ; Hist. p. 320, (there was indeed only one ulcer with hardening.) -Duchateau in Journ. de Médec. $p .243$, Oct, 1810, a tumour as large as a pea, in a woman who had many cancerous swellings on the skin and on other parts. - Rullier. v. Bulletin de la Fac. et de la Soc. de Médec. de Paris, No. 5, p. 367, 1813, in Journ. de Médec. chir. et Pharm. Vol. XXVII. 1813, at the same time, with many scirrhi on other parts ; also scirrlius and carcinoma of the heart.-Dupuytren. v. Cruveilhier, Vol. II. p. 87, (many, above six hundred carsinomatous tumours.)-Andral and Bayle in Revue méd. franc. et étrang re, Feb. 1824, (three cases of carcinoma.) - Ib. Nov. 1825, a case is related by Recamier. - Ollivier. De la moelle épinière et de ses maladies, p. 262. 8vo. Paris, 
1824, (a case of eancer.) - Velpeau Exposition d'un cas remarquable de maladie cancereuse, etc. 8vo. Paris, 1825. - Churchill in London Med. and Phys. Journ. March, 1827, together with scirrlus and carcinoma of other parts. - The cases mentioned appear to me to be more properly included in sarcom that in cancer.

\section{$\S 184$.}

Lastly, in the heart numerous remarkable phenomena as respects its contents are frequently observed. To these, for instance, belong the ENTIRE ABSENCE, as well as, contrariwise, the unusual enormous GORGING OF BLOOD, the latter of which indeed appears to be very considerable, especially in the right side of the heart, in suffocation, apoplexy, in paralysis of the heart and lungs, as also in persons destroyed by narcotic poisons: next, we have COAGULA OF BLOOD, which are known by the name of CARDIAC POLYPS $;^{1}$ these are usually only produced at the time of death, but, in some rare instances, they may be formed during life in consequence of the greater plasticity of the blood and the morbid operation of the walls of the heart upon it, and vary as to size, shape, colour, consistence, \&c. without end. ${ }^{2}$ Occasionally the heart is found distended with $\mathrm{AIR},{ }^{3}$ although there is not the slightest trace of putrefaction in the body. In rare instances, we observe PARASITIC ANIMALS, ${ }^{4}$ both on and in the heart, also stones ${ }^{5}$ lying loose in the cavities of the heart, and even different ExTRANEOUS SUBSTANCES, ${ }^{6}$ which, having penetrated by external violence, have remained here for a considerable space of time.

(1) Pissini Epistola de cordis polyp. App. ad Librum de Diabete. 4to. Mediol. 1654. - Malpighi de polypo cordis, 1666, in Op. p. 123. - Scheid D. Quæstionum de polypo cordis $\pi \in \nu$ Tas. Argent. 1689. - Zollikhofer D. de polypo cordis. Witeb. 1689.- - de Berger D. de cordis polypis. Witeb. 1689.-Rossen D. de polypo cordis. Leidæ, 1693. - Albini D. de polypis. Franc. 1695. - - Snell D. de polypo cordis. Giess. 1702. - de Cruystierken D. de polypo cordis. Leid. 1705.-Gohl De cordis polypis ex neglectis hæmorrhoidibus. Berlin, 1710.Beck D. de polypo cordis. Giess. 1718.-Goez D. de polyposis coneretionibus variorum in pectore morborum causis. Altd. 1726. - Ludolff D. de polypo cordis. Erford. 1727. - Teichmeyer D. de polypis, in specie cordis. Jenæ, 1729.-Grateloup D. de polypo cordis. Argent. 1731.-Bochmer D. de pracavenda polyporum generatione. Halæ, 1736.--A. Pasta Epistola de cordis polypo in dubium revocato. Bergamo, 1739.-Alberti D. de polypo cordis. Halx, 17\%1.-Langguth D. de polypo infantis rhachitici. Viteb. 1744.- V'aughun, D. de polypo cordis. Edinb. 1761. - Goetzle Casus medico-practicus de polypo cordis, etc. Spiræ, 1764. - Jos. Pasta De sanguine et sanguineis concretionibus per anatomen indagatis et pro causis morborum habitis quastiones medicæ. Svo. Bergan. 1786. - Maincourt D. de sanguincis lymphaticisque male polypis dictis concretionibus in corde et in vasis per vitam existentibus. Paris, 1789.Tiedemann D. de cordis polypis. Svo. Marb. 180 1. -- Pontin pras. P. Afzelius D. de cordis polypo. 4to. Upsal. 1805. - Gärtner D. path. med. de polypo cordis in specie infantum. Wiirceb. 1810, with eight engravings.-Flormann Bemerkungen über Polypen in Herzen in Svenska Läkare-Säallskapets Handingar. Vol. IV. 1. 165. Stocklı. 1817. - Simon D. de cordis polypo. 8vo. Berol. 1818. - Nusse zur Kenntniss der Her\%polypen in Horn's Archiv f. medic. Iirfalırung, 1818, July and $\Lambda$ ugust, p. 116. - Schmelcher pras. Miinz I). de polypis cordis. 8vo. 
Landishuti, 1819. - Deegen D. de polypis cordis. 8vo. Halæ, 1821. - Ieinrich D. de polyporum cordis genuinorum natura et origine. 4to. Jenæ, 1828.-A. Meckel Beiträg zur Lehre von der Entsteh. ler Herzpolypen in J. F. Meckel's Archiv f. Anat. u. Physiol. 1828, No. 2, p. 166, tab. 6, fig. 4.-- As to single observations, compare the writers on diseases of the heart; de Plouquet Repert. Art. Cordis polypus, and Reuss Repert. Comm. Vol. XIII. p. 117; also in animals, polyps of the heart are not rare.

(2) They occur very frequently on the right side of the heart, on account of the obstruction which the blood meets with in its passage through the lungs, although pretty often also on the left side of the heart; their size is sometimes so considerable, that they become as big as one's fist, and expand the auricle or ventricle, and if they be also firm, compress the muscular fibres flat. Their form is also very various, as they are either like membrane, long and thin, thick at one end and pointed at the other, oval, spheroidal, \&c. Their colour varies from black to pale yellow; their consistence is sometimes that of jelly, or of the buffy coat of the blood, of the clot of blood, or of fibrous matter coagulated in different degrees, so that they feel tough, and may be divided into bundles of fibres or concentric layers, whilst interiorly they are hollow, and contain cruor or lymph, which is wrongly considered as pus. Sometimes they lie quite loosely, like balls, even several of them in the cavities of the heart; but generally they are attached so firnly to its walls, and penetrate by so many processes between the fleshy columns, tendinous fibres, valves, and the openings of the small veins of the heart, that we naturally imagine they arise from the walls of the heart. Kerliring, in part, also Senac, Morgagni, but especially Lieutaud, both Pastas, Baillie, Soemmerring, Bichat, Vetter, and myself, in Selt. Beob. Vol. II. p. 54, satisfied me of the contrary; no one as yet has ascertained cellular tissue and blood-vessels in them. Hence it appears to me, that Meckel's opinion, v. Handb. der pathol. Anat. Vol. II. Part II. p. 336, that at first they are firmly attached, but subsequently are separated, is not probable. - Kreysig thinks that the so-called true polyps of the heart, or plastic coagula in carditis exsudativa, are secreted from the internal membrane of the heart, and that such may subsequently become separated. The former may perhaps be the case in very rare instances. I have, however, at least, a hunclred cases before me, in which the internal membrane of the heart was never diseased; so, on the contrary, it may sometimes be inflamed and thickened, without there being any polyps; also, as far as I am aware, plastic membranes may sometimes be separated from mucous, hut never from serous membranes, to which class the internal nembrane of the licart naturally belongs.

(3) Morgagni, Epist. VIII. p. 23, in a hydrophobic person.-Acta Eruditor. Lips. 1721.-Cheston in Medic. Observat. and Inquiries, Vol. VI. No. 5.-Nystea Recherches de Physiologie et de Chimie pathologique, p. 5 and 167. - Nasseinsat Leichenöffnungen, 1 te Reihe. p. 138.-I have twice observed this phenomenon. [J. Barlow, in Med. Chir. Trans. Vol. XV. p. 28, mentions three cases of air in the right auricle, which had entered through the divided orifices of veins during operations; one of them his own, and another Dupuytren's, and the third Mott's. T.]

(4) Of the many old observations collected in Plouquet's Repertorium, it is hardly possible to make use of a single one. Perhaps, however, those mentioned by Haehne in Actis Nat. Cur. Ann. VII. p. 53, belong here. We very rarely find the cysticercus cellulosæ in the liuman heart. v. Rudolphi Entozoorum Synopsis, p.546, (once three pieces.)--Dubreuil in Ephémérides médicales de Montpellier, Nov. 1826, in the right auricle. Rarely also in swine, viz. at Alfort. v. Rudolphi Bemerkungen auf einer Reise, Vol. II. p. 62; and Dupuy De l'affection tuberculeuse, Paris, 1817, p. 267.-Ascarides have several times been found in the hearts of dogs; for example, Peysson, in Annales de la Soc. de Méd. prat. de Montpellier, Vol. XV. p. 49. v. Journ. de Médcc. continué, Vol. XI. p. 441.-Zeviani in Memor. della Soc. Ital. Vol. XIV. Part II. p. 152, (one in the left ventricle.)-Bobe-Moreau in Sédillot's Journ. général de Médec. Vol. XLVII. p. 4. May, 1813.-O. Fabricins, in Fauna Groenland, p. 272, No. 250 , found ascarides in the heart of a living plioca foetida, which had been wounded by a harpoon; and also ophiostoma dispar, I?ud._I'aullinus, in Observ. 
med. phys. in Eph. Nat. Cur. App. ad. Dec. II. Ann. V. p. 19, found a filaria on the heart of a duck.-Daldorf, s. Dansk. Selsk. Skrift. Vol. II. 2. p. 159, saw an intestinal worm on the heart of a squalus; in anodonta ventricosa in the substance, and in the cavities of the heart, distoma duplicatum; and in paludina vivapara, \&c. in the auricle of the heart, cercariæ. - von Baer in Nov. Act. N. C. Vol. XIII. Part II. p. 559, 616, and 617. [Abercrombie, in Edinburgh Med. Chir. Transact. Vol. I. p. 53, found a cyst in the left auricle, containing others collapsed, in a dark fluid. Andral, Précis, Vol. II. p. 332, frequently found cysticerci in the hearts of measly pigs; also, in a patient at La Charite, he found three vesicles, as large as filberts, in the heart. Elliotson, p. 32 , found in the ventricles of the heart inmumerable thin globular cysts, attached by peduncles. 'T.]

(5) Compare de Plouquet Repertor. Calculus in corde. These observations are almost all inapplicable.-Bartholin Hist. anat. Cent. VI. Hist. 93, p. 364, thought that the stone found in the heart of a stag might have been an encrusted bullet, which is possible, although such stones arise like phlebolithi, or as in the necked processes in serous membranes. 5. $\$ 183$, note 8 , towards the end.

(6) For instance, bullets, which it is probable had penetrated deeper, whilst the parts behind them had healed:-thus, in a man who had received a shot in his breast several years before, a flattened bullet was found in the anterior ventricle. v. Penada in Saggi di Padova, Vol. III. Part II. p. 59. - A similar case described by Maussion, in Dict. des Sciences médic. Vol. IV. p. 216; and Boyer, Traité des maladies chirurgical. Vol. VII. 8vo. Paris. - Edinb. med. and chirurg. Journ. Vol. V. p. 417. - This has been observed several times in animals. v. Vorwaltner in Misc. Acad. N. Cur. Dec. III. Ann. V. and VI. Obs. 3, p. 228, (in a stag).--Eph. Nat. Cur. Dec. II. Ann. VI. Obs. 77, in a dog. - London medical and physical Journal, by Fothergill, Vol. XXXVI. Nov. 1816, (in an abscess of the substance of the heart of an apparently healthy deer.) - More frequently nails in cattle. Ann. X. Obs. 171, Schol. p. 313; and especially needles in cows. v. Hoffmann in Ephem. N. C. Cent. IX. and X. p. 462. -- Peyer Parerga, Salzburger medic. chir. Zeitung, 1812, I. p. 227. -- Gebhard in Teuffel's Magazin f. theoret. und prakt. Thierheilkunde, Vol. I. Part II.-In my Selt. Beob. Part I. p. 99; and Verzeichn. No. 2238. Schwab Materialien zur pathol. Anat. der Hausthiere, 1 te Lief. p. 15, a piece of scissors. - A needle in the heart of a sheep. v. Maret in Mémoir. de Dijon, Part I. Hist. p. 107.--A broken clock-maker's file, which had penetrated through the left into the right ventricle, was extracted after twentyone days.-Ferrus in Répert. gén. d'Anat. et de Plyssiol. pathol. Vol. II. Part II. p. 402, engravings, pl. 8, fig. 1 ; by whom are also mentioned some examples of bullets, needles, and file points which have been found in the heart.

\section{'Third Chapter.}

\section{Of the Arterics. ${ }^{1}$}

\section{$\S 185$.}

As the circulation of the blood is a necessary condition of the existence and formation of the organs ${ }^{2}$ in men and in the higher animals, there cannot be a complete absence of the bloodvessels, especially of the arteries; there may, however, be a partial deficiency in them, but only in proportion to the vices of the parts for which they were destined. ${ }^{3}$ If therefore, the vessels, which according to their proper arrangement supply an organ with blood, are destroyed, the part becomes dry, 
owing to deprivation of its usual supply of blood. ${ }^{4}$ For this reason also, in the most imperfect monsters, to which especially many of those which are headless belong, there is always a vascular system proportioned to their size and extent. ${ }^{5}$ But as the normal mass of blood, which is proportioned to the size and activity of the part, may be conveyed to it in a usual or unusual manner, as well as by a large vessel, or by many small ones, so with reference to the number, size, connexion, ramifcations and position of the arteries, we shall find there are very frequent and diversified VARIETIES, ${ }^{6}$ the most important of which will be here treated of.

(1) Faselius D. s. morbos arteriarum, Jenæ, 1757.-Langsworth Theoria med. de arteriar. et venar. in corpore humano adfectionibus, Vol. I. 4to. Prag: 1763.-Alex. Monro, Remarks on the coats of arteries, their DISEAsEs, \&c. in Edinb. med. Essays and Observations, Vol. II. p. 264. - Malacarne Osserv. sopra alcun. arterie nel corpo umano nello stato preternaturale et nello stato morboso in osserv. in Chirugia, Vol. II. p. 119. Torino, 1784, ff.-Lane D. de arteriarum morbis, etc. L. B. 1787.-H. Watson, Account of a large aneurysm, with some introductory reflections on THE ARTERY IN ITS DISEASED STATE in Medic. Commun. Vol. I. p. 178.-Freer, Observations on Aneurysm and some diseases of the arterial system. Birmingham, 1807.-Hodgson, a Treatise on the diseases of Arteries and Veins, containing the pathology and treatment of aneurysms and wounded arteries, \&c. 8vo. Lond. 1815 ; second edition, Lond. 1822; translated into German by Koberwein, with remarks by Kreysig, Hanover, 1819 ; translated into French by Breschet, with notes. 2 Vols. 8vo. Paris, 1819.Engravings to illustrate some of the diseases of the arteries. fol. 1815.-J. $F$. Mecliel Tabulæ anat. pathol. Fasc. II. Vasa. fol. Lips. 1820.-Engelhardt D. s. succinctam systematis arteriosi pathologiam. 4to. Lips. 1821.-C. H. Ehrmann Recherches sur la structure les fonctions et les alterations organiques des artères, p. 32. 4to. Strasb. 1822. ff.

(2) This appears to me a better mode of expressing it than that of $A$. Serres in Bullet. de la Soc. méd. d'Emulation, Sept. 1821, who finds in malformation of the vessels, the cause of almost all malformations of the fotus, especially the deficiency and excess of parts, though indeed the common origin of deficiency or excess of parts and their blood-vessels is, as is well known, one and the same variation in the formative impulse. It appears rather, however, as if the principle determining the form arose out of the nervous system.

(3) The observations on deficiency of all blood-vessels in monsters, viz. in an acephalous monster, v. Schellhammer in Ephem. Nat. Cur. Dec. II. p. 253, 1690, ff. (in the right lower extremity of a child.) v. Chaussier in Bullet. de la Fac. de Médec. Vol. V. p. 405, are certainly founded in error, since the small and delicate vessels are overlooked.

(4) Hence sometimes spurious formations are produced and nourished by absorption; I have, however, always found small arteries and veins.

(5) In the acephala, of which the heart is notoriously naturally wanting, we find either merely an umbilical vein dividing like an artery, or the umbilical arteries also; sometimes even the aorta and vena cava with several branches; even in the most imperfect monsters, which have been described by Vrolik, Mémoires sur quelques sujets intérressans d'Anat. et de Physiologie par Fallot, p. 25-64, Amst. 1822 ; and G. Lieber D. Monstri Molæ speciem præ se ferentis descriptio anatomica. 4to. Berol. 1821.-As also in a head born alone. v. Rudolphi in the Schriften der Acad. der Wiss. zu Berlin f. d. Jahr. 1816 ; and in a monstrous goat, which consisted merely of a foot, v. Ign. Hayn Monstri unicum pedem referentis descriptio anatomica, 4to. Berol. 1824, arteries and veins were found. 
(6) Compare most of the writers on the vessels, especially Haller, Mayer, Söemmerring, Mecliel, further Timmermann D. de notandis circa naturæ in hum. machina lusus. $\S 50$. Rintel. 1765, ff.-Nicolai $\mathrm{D}$. de directione vasorum in Haller's Coll. Disput. anat. Vol. II.-Ludwigii Progr. observat. angiol. tradens. Lips. 1764.- Sandifort De notabilioribus vasorum observationibus in Obs. anat. pathol. L. IV. and VIII. - Loder D. Nonnullæ arteriarum varietates. Jenæ, 1781.-Penclienati in Mém. de l'Acad. des Sc. de Turin. P. I. 1786.-Wrisberg Varietatum angiologicarum per $\mathbf{X} \mathbf{X} \mathbf{X}$. annor. seriem in corp. hum. observatarum. P. I. Göett. 1791.-Burns, Observations on some of the most frequent and important liseases of the heart, and on the unusual origin and distribution of some of the large arteries of the human body. Edinb. 1809. - Zagorstiy in Mém. de l'Acid. Imp. des Sc. de St. Petersburg, Vol. I. and II; he also read, on the 30th of May, 1S27, in the Academy : Abnormitas quæ ad ortum et numerum quarundam arteriarum observata. - Koberwein D. de vasorum decursu adnormi ejusque vi in omnem valetudinem varia. Viteb. 1810. - Fleischmann in the Abhandl. der physical. med. Societät zu Erlangen, Vol. I. and II.-Ryan D. de quarundam arteriarum in corpore hum. distributione. Edinb. 1812.-My Selt. Beob. Part I. p. 100 ; Part II, p. 60.-J. F. Meckel Tab. anat. pathol. Fasc. II. Lips. 1820. -Fr. Tiedemann Tabulæ arteriarum colp. hum. Fasc. I-IV. gr. fol. Carlsruhæ, 1822.-Schoen D. de nonnullarum arteriarum ortu et decursu abnormi. 8vo. Halæ, 1823.

\section{$\$ 186$.}

The trunk of the PULMONARY ARTERY is not merely wanting, if the organs for which it is destined, viz. the lungs, are deficient, but also not unfrequently when they exist, in cases of unusual form of the heart, in which case the arteries supplying the lungs with blood usually arise either as a distinct but later given off trunk, or else as two vessels from the root of the aorta $;{ }^{1}$ more rarely from their ascending portion ${ }^{2}$ or even from the branches of the aorta. ${ }^{3}$ Sometimes the trunk of the pulmonary artery exists, gives off no pulmonary branches, but runs branchless as the ductus arteriosus into the aorta $;^{4}$ in other instances the pulmonary artery, otherwise normal, forms no connexion with the aorta, so that the ductus arteriosus is entirely wanting. ${ }^{5}$ On the contrary, we observe very rarely a distinct duplicate of the pulmonary artery, in this case, for instance, besides the pulmonary artery, a particular ductus arteriosus arises from the right ventricle, ${ }^{6}$ or a second vessel opens itself into the true pulmonary artery. ${ }^{7}$ This formation is followed by those very rare cases in which the lungs, besides their usual pulmonary artery, are supplied from some other accessory branches. ${ }^{8}$ More frequently we observe an irregular origin of the pulmonary artery from the heart, in which, for instance, it originates not from the upper part, but rather from the middle of the right ventricle, ${ }^{9}$ out of a special little third part of the heart, ${ }^{10}$ out of both ventricles at once, ${ }^{11}$ or from the left ventricle together with the aorta. ${ }^{12}$ In several cases we see, in the normal entrance of the veins into the heart, a transposition of the pulmonary artery and aorta, so that this 
springs from the left and that from the right ventricle. ${ }^{13}$ Another vice, which in the blue disease is not uncommon, is the unnatural narrowing or actual closing up of the pulmonary artery, either at its origin, or still higher up, ${ }^{14}$ in which cases the blood is usually conveyed from the aorta, through the wide ductus arteriosus to the lungs. ${ }^{15}$ The contrary state, the too great capacity of the pulmonary artery, is much more rare. ${ }^{16}$ Finally, the division and subsequent course of the pulmonary artery sometimes varies; so that from its left branch, a twig is sent to the left subclavian, ${ }^{17}$ from its right branch to the truncus anonymus ${ }^{18}$ from its division, the right subclavian $;^{19}$ from the duclus arteriosus, the left subclavian $;^{20}$ at the separation of the pulmonary branches, the left subclavian and descending aorta, or the left carotid, subclavian and descending aorta $;^{21}$ and more frequently besides the pulmonary branches, the descending aorta merely is given off. ${ }^{22}$

(1) Such cases were observed by Farre, Wilson, Standert, J. F. Meckel, Seidel, Beckhaus, Mayer, Cerutti, and myself in three cases, in the abovc-mentioned place, $\S 172$, note 11.-Lietzan Hist. trium Monstror. p. 19, 8vo. Regiom, 1825, in a double sheep.

(2) J. F. Meckel Descriptio monstrorum nonullorum, p. 11.

(3) In a rabbit, from the subclavian. v. Legallois in Bulletin de la Soc. de Médec. p. 99, 1809.-Compare Reil's Archiv. Vol. XII. p. 122.-I also saw in a clouble monster an artery from the truncus anonymus pass to the accessory lung. v. Selt. Beob. Part I. p. 16.

(4) I found it so in a monstrous sheep without lungs. v. my Verzeichniss, 2949.

(5) Such cases were observed by Slenson, Bartholin, Sandifort, Chemineau, Kreysig, Knox. - Compare $\$ 172$, note 11. - Meckel in Reil's Archiv. Vol. IX. p. 437.-My Selt. Beob. Part I. p. 16, in No. 8025 of Bresl. Mus. and in another monster, hereafter to be described, with abdominal cleft and hernia cerebri.Gamage in New-England Journ. of Med. and Surg. Vol. IV. p. 244.

(6) Wrisberg addend. to Haller's Physiologie, p. 77.

(7) Hall and Vrolik in Praktisch Tydschrift voor de Geneeskunde, Part II. 1825 .

(8) For instànce, a large branch from the aorta in the region of the sixth dorsal vertebra for the lobes of the right lung. v. Huber in Act. Helvet. Vol. VIII. p. 85, a similar twig for the under lobe of the left lung. v. $J$. $F$. Meckel in his Archiv f. d. Physiologie. Vol. VI. p. 454. - Branches from the frenic arteries for both lungs. v. Mangers in Sédillot Recueil périodique, Vol. XIII. p. 74; and in Corvisart Journ. de Médec. Ann. X. Pluviose.-Or with very small pulmonary arteries, equally for both lungs from the pericardial arteries. v. Jacobson in Meckel, Vol. II. p. 134, ff

(9) Hodgson and Leadam in Farre.

(10) Lawrence in Farre, p. 26.

(11) This was observed by Cooper, Farre, Bock, Horner.

(12) Mery in Mémoires de Paris, 1700, Hist. p. 54.-Richard K. Hoffmann in Ncw-York medical and physical Journal, Vol. VI. p. 250.-Marechal.

(13) Baillie, Engravings of morbid Anatomy, Fasc. I. pl. 6, fig. 1 and 2.Wistar System of Anatomy, Vol. I. Pennsylvania, 1811.-Langstaff in London Medical Review, Vol. IV. and in Farre, p. 28.-Farre, p. 29, with plates, fig. 14. -J. F. Meckel Tabulæ anat. pathol. Fasc. II. p. 1 and 2, (in a lamb and a calf, ) and Descriptio monstror. nonullor. p. 21, (in a hemicephalic monster.) - Tiedemann in his and G. R. and $L$. Ch. Treviranus Zeitschrift für Physiologie, Vol. I. Part I. p. 111, tab. 7, f. g. - E. d'Alton D. de cyanopathiæ specic ex invicem 
permutata arteriæ pulmonalis atque aortæ origine. 4to. Bonnæ, 1824, with plates.-Jos. Burckart D. de monstro humano notabili. Friburg, 8vo. Brisg. 1825. -Dugés in Journ. génér. de Médec. Vol. CI. p. 88.

(14) Farre had a case of his own, and one from Hodgson. The latter saw the pulmonary artery like a thread.-Narrow only on one side, seen by Pulteney in Medic. Transactions by the Coll. of Physic. of London, Vol. III. p. 339, 1785. And Kreysig Herzkrankheiten, Vol. III. p. 104, with plates. - Basedow, (only a ligamentous rudiment.) - On closure of their orifices, v. $\$ 174$, note 4.-Simple narrowing of the pulmonary artery often occurs in the blue disease.

(15) v. Hodgson in Farre, Perkins, Beckhaus, Delmas, Breschet, p. 12 ; Mauran. Cerutti.-Myself in a few instances, v. above, $\$ 172$, note 11 .

(16) Such cases described by Cooper in Farre, Richerand, Corvisart, Testa, J. F. Meckel, Hufeland, Lawrence, Young, \&rc.

(17) Jackson in Lond. Medic. and Physical Journ. Aug. 1815, p. 100-102.

(18) Breschet in Repert. général d'Ánat. et d. Physiol. pathol. etc. Vol. II. Cah. I. p. 17, Paris, 1826.

(19) J. F. Meckel Tabul. anat. pathol. Fasc. II. p. 2, (in a calf.)

(20) Reinmann in Nov. Act. Acad. Nat. Cur. Vol. I. p. 302.-Klinkosch Progr. de anatome fœtus capite monstroso. Prag. 1766. - J. F. Meckel Handb. der pathol. Anat. Vol. II. p. 105.- In other cases the ductus arteriosus opened in the left subclavia. v. Obet in Bulletin des Scienc. médic. par la Soc. méd. d'Emulation, May, 1808.-Rudolphi in Bernhard D. de arteriarum e corde prodeuntium aberrationibus. 4to. Berol. 1818. - Reinmann in Nov. Act. Acad. Nat. Cur. Part I. p. 802. - Sandifort Mus. anat. Vol. I. p. 273 ; Vol. II. tab. 107, fig. 1 and 2.-Corvisart, 288.

(21) I found the former in a child with frenic rupture, deficiency of a finger, Sc. No. 8025 ; the latter in a double monster of a sheep in one of the hearts, No. 8020, of Bresl. Mus.-One similar case is described by Seidel, Index Musci Anat. Kiliensis, p. 61. Kiliæ, 1818.

(22) For instance, Langstaff and Cooper, in two cases.-Farre.-Steidele Sammlung chirurg. Beobacht. Vol. II. p. 114. Wien, 1778.-Choulunt Épist. gratılat. ad Pezold, p. 13. The preparation is at Dresden, in the collection of the MedicoClirurg. Acad. - Kreysig Krankheiten, Vol. III. p. 104, with engravings. Lietzau, p. 19, the right descending aorta in a double sheep.

\section{$\S 18 \%$.}

The ENTIRE ABSENCE OF THE AORTA when the heart is present, has not yet been satisfactorily observed; but the PARTIAL DEFICIENCY Occurs, as when the pulmonary artery gives off branches of communication to the aortic branches, or forms the descending aorta, it is very small, and merely gives off the branches to the upper half of the body, and even then not completely. In these cases it is sometimes only connected with the lower aorta by a narrow vessel, and frequently not at all. Excess of Formation is exhibited in its too great size, when it and the pulmonary artery originate by a single trunk ${ }^{2}$ from the heart, and from an actual duplicity of the same in the single heart of a double monster. Frequently we find the ORIGIN OF THE AORTA irregular in the blue disease, inasmuch as it is more or less inclined to the right, and then arises, owing to deficient formation of the septum, from both ventricles, ${ }^{3}$ or entirely from the right ventricle ${ }^{4}$ sometimes it is unnaturally NARROW at its commencement, ${ }^{5}$ or even COMPLETELY CLOSED, ${ }^{6}$ 
and the blood then proceeds from the pulmonary artery through the wide ductus arteriosus. ${ }^{7}$ In rare cases also the further course of the aorta is abnormal; to these belong its division, and stretching itself in a ring around the air tube, ${ }^{8}$ its division from the commencement into an upper artery which merely supplies the head and the arms, and a descending, which is the proper artery of the lower half of the body ; ${ }^{9}$ its course to the right instead of the left side, inasmuch as it not merely descends on the right side of the spine, as might naturally be expected in the usual transposition of the viscera, ${ }^{10}$ but also sometimes in the normal position of the intestines, it curves over the right bronchus, and descending along the right side of the spine, soon inclines more or less far down towards the usual orifice in the diaphragm ; ${ }^{11}$ its unconnected and separated course from the spine, so that it perforates the diaphragm not behind but near the right of the gullet, ${ }^{12}$ and in a syren-formed monster, once divided in front of the urinary bladder and uterus into the two iliac arteries; $;^{13}$ and lastly, its unusual early high division. ${ }^{14}$

(1) Compare § 186 , note $17-22$.

(2) Compare $\$ 186$, note $1-3$.

(3) This was observed by Stenson, Sandifort, Howship in three cases, Nevin, Ring, Cuilliot, Obet, Cooper, Hunter, Corvisart, Huet, Pulteney, Lawrence, Farre, Jacobson, Knox, Haase, Meckel, Tupper, Creveld, Palois, Dorsey, Thoxter, Olivry, Gintrac, Gregory, Basedow, in $\S 172$, note 11.-Myself in four cases. v. Selt. Beob. Part I. p. 64; Verzeichn. No. 2203, 2929; and in No. 8011 of Bresl, Mus.

(4) To wit, Abernethy, Farre, p. 37, Fleischmann, Bock, Burkart. - My Selt.

Beob. Part I. p. 16, and Andre, compare $\$ 186$, note 13.

(5) Lemaire in Bulletin des Sciences médic. Vol. V. 1810. - J. F. Meckel Descriptio monstror. nonnullor, p. 11.

(6) Roederer De foetu parasitico in Comm. Soc. Goetting, Vol. IV. p. 121 and 123 ; in this case they were attached to the heart merely by cellular tissue.

(7) Ramberg D. de corde vasisque majoribus eorundem ratione normali in animantibus et abnormi in homine, p. 21. 8vo. Berol. 1824, with engravings.Rust Magazin f. die ges. Heilkunde, Vol. XVIII. Part II. p. 346.

(8) Hommel in Commerc. litter. Vol. II. p. 161, fig. 1 and 2. Norimb. 1737, (the preparation is at present in the Anat. Mus. at Strasburg.)-Malacarne Osservazioni in Chirurgia. Part II. p. 119, fig. 1 and 2. Torino, 1784.-Both cases are again engraved in $\boldsymbol{J} . \boldsymbol{F}$. Meckel Tab. anat. pathol. Fasc. II. tab. 9, fig. 3 and 4, and in Tiedemann Tabul. arteriar. corp. hum. Fasc. I. tab. 4, fig. 6 and 7.-A third instance was observed by Joseph. Exupere Bertin. v. R. J. Bertin Traité des maladies du cœur, p. 433.

(9) Haller Elementa Physiol. Vol. II. p. 162, note f, from the Journ. des Savans, 1668, No.3, (in a child.)-Klinz Abhandl. der Josephin. medic. chir. Akademie, Vol. I. p. 271, pl. 6. Wien, 1787.

(10) Not always, however; for instance, not in the cases related by Douglas Fox, in Lond. Med. and Phys. Journ. July, 1824; it usually descends on the left side of the spine, but the arteria anonyma arose from the left of its arch.

(11) Cases of this kind have been observed by Klinkosch Progr. de anat. fœetus capite monstr. p. 15. Prag. 1766. - Abernethy, in Philos. Transact. 1793, p. 59.Fiorati in Saggi di Padova. Vol. I. p. 69, ff. - Sandifort Mus. anatom. Vol. I. p. 273 ; Vol. II. tab. 107, fig. 1 and 2.-Cailliot, two cases in Bulletin de l'Ecole de Méd. 1807, p. 24.-Obet in Bulletin des Scienc. médical. par Graperon, Vol. II. 
p. 65. 1808.-Legallois in Bulletin de la Soc. de Médec. 1800, p. 99, (in a rabbit) J. F. Meckel Handb. der pathol. Anat. Vol. II. Part I. p. 97. - Rudolphi, v. Bernhard D. de arteriar. e corde prodeunt. aberrationibus. 4to. Berol. 1818, with engravings. - Breschet in Répertoire gén. d'Anat. et de Physiol. pathul. Vol. II. Part I. p. 14.-Mysclf in my Selt. Beob. Part II. p. 60 ; and Verzeich. No. 1922.-More rare is the case which I found in a child with frenic rupture, deficient fingers, \&c. No. 8025 of Bresl. Mus.; viz. that the descending aorta, which arose from the pulmonary artery, after giving off the left art. subclavia, passed to the right between the gullet and the second dorsal vertebra, and turned again downwards and to the left to the hole in the diaphraym.

(12) Potthoff D. s. Descriptionem casus rarissimi spinam bifidam totalem exhibentis, p. 9. 4to. Berol. 1827.

(13) Myself, Monstrorum sex humanor. anat. et physiol. disquisitio, p. 38. Francof. ad Viadr. $1 \$ 11$.

(14) In a few instances, which I have already described in my Selt. Beob. Part II. p. 71 ; and Verzeichn. No. 1988, it divided about the third or fourth lumbar vertebra.-Pelsche also found it divided early, and the two iliac arteries connected with each other by a transverse branch. v. Syllog. Observat. anat. select. $\$ 77$; rec. in Haller Coll. Diss. Anat. Vol. VI. p. $781 .-$ It divided very carly, in a case by Wehrde D. anat. pathol. de monstro rariore humano. 8vo. Halæ, 1826. - This varicty would partly render impracticable compression of the aorta in active hemorrhage after birth.

\section{$\S 188$.}

As to the individual branches of the aorta, these present not a few and somewhat interesting varieties. Thus we find, for instance, instead of two coronary arteries to the heart, only one, ${ }^{1}$ or more frequently three, and even four; or finally, they have unusual origins, viz. higher up from the aorta, ${ }^{2}$ and in one instance from the subclavia dextra, ${ }^{3} \& \mathrm{c}$. Very frequently the number, origin, and course of the great vessels ${ }^{4}$ arising from the arch of the aorta vary, as in rare cases they originate from one common short trunk, or more frequently from two, or finally, still oftener, by a greater number than usual, that is, by four, five, ${ }^{5}$ and even six, ${ }^{6}$ so that instead of from the innominata, the right subclavia and carotis arise separately from the aorta; or the vertebral arteries, one of the thyroid, one of the thymic, or the internal mammary, arise from the arch of the aorta. In operative surgery, the most important are, the origin of a middle inferior thyroid, which arises from the arch of the aorta, the truncus anonymus or the carotis, and ascends directly in front of the air-tube to the thyroid-gland; ${ }^{7}$ the crossing of one carotis upon the air-tube, as for instance, the left arising from the innominati, or the right unusually far on the left side; and the origin of the right subclavia, firom the left side, in which case it usually proceeds between the spine and the gullet $;^{8}$ more rarely between the latter and the air-tube, ${ }^{9}$ or still less frequently before ${ }^{10}$ these to the right arm. In some instances the right sulbclavia did not arise so far to the left, and only lay behind the right ${ }^{11}$ or behind both ${ }^{12}$ carotids at their division. 
(1) I lave once observed this.

(2) Farre, p. 2, ff.

(3) Mayjer in Graefe and $v$. Walther's Journ. f. d. Chir. Vol. X. p. 44.

(4) Huber De arcus aortæ ramis in Actis Helvet. Vol. VIII. p. 68-102. Walter Mém. de l'Académ. des Scienc. de Berlin, 1785, p.57, ff.-Tiedemann resp. J. N. Bayer D. de ramis ex arcu aortæ prodeuntibus. 4to. Salzb. 1817, with lith. plates.-Zagorski, Malacarne, and Fiorati.-Thilow in den Allg. medic. Annalen, March, 1817, p.289. - I have also sometimes observed in animals varieties respecting these branches.

(5) $\mathrm{Ph}$. Ad. Böhmer De quatuor et quinque ramis ex aorta ascendentibus. Halæ, 1741.

(6) Penada Saggio terzo di Osservazioni patologico-anatomiche. Padova, 1801.-F. Müller, v. Meckel's Handbuch der menschl. Anatomie. Vol. IIJ. p. 84, note 21.-Tiedemann Tabulæ arteriar. Fasc. I. tab.4, fig. 5.

(7) This anomaly was first described by Neubauer, Descr. anat. arter. immominatæ et thyreoideæ imæ in Op. Anat. collect. p. 287, note o. - Tiedemann gives a good engraving of it in his Tab. 3, fig. 11.-I have only found this variety once, but the origin of the thyreoidea ima below from the truncus anonymus I have seen twice; both varieties, as well as the following, are very important in tracheotomy.

(8) Böhmer, fig. 1.-Fabricius Proëmticum nonnullas observationes sistens, ad Diss. J. B. Hoffmanni. Helmst. 1751, p. 10.-Mieg Spic. observat. anat. et botanicar. Basil. 1753, Art. 8. - Loesecke Observat. anat. chir. med. Berol. 1754, p. 26. - J.F. Meckel, the grandfather, Ep. ad Hall, Vol. III. p. 132, 141.Ludwig Progr. observat. angiologicas tradens. Lips. 1764, p. 5.-P'ohl Observat. angiol. de arteriis. Lips. 1773, p. 7. - Neubaner, $\$ 13$. - Murray Abhandlungen der Schwed. Akademie. Vol. XXX. p. 92.-Schleitz, ib. p. 98. - Sandifort Mus. anatomicum, Vol. II. tab. 106, fig. 2.-Hulme in Soc. of London, 1789, Vol. II. p. 271 , ff. - Autenrieth resp. Pfeiderer D. de dysphagia lusoria. 8vo. Tubing. 1806.-Obet in Bulletin des Sc. médicales, reviewed by Graperon, 1808, Vol.1I. p. 65, ff. - Koberwein, p. 16. - Herold D. exhib: observationes quasdam ad corp. hum. part. struct. Marburgi, 1812, p.7. - Fleischnıan Leichenöffn. Erlang. 1815, p. 213. - J. F. Mickel Handb. der pathol. Anatomie, Vol. II. Part I. p. 98; also in a hedge-hog. v. Cuvier Anatomie Compar., Vol. IV. p. 699, which has been observed by Tiedemann, and Tabul. arteriar. Fasc. I. tab. 2, fig. 6 ; the engraved case appears to belong here.-G.W. Stedmann, in Edinb. med. and surg. Journ. Oct. 1823, No.77, with plates. - Perhaps also Hart, ib. April, 1826. - Mayer in v. Graefe and $v$. Walther's Journ. der Chir. Vol. X. p. 44. - Cerutti Rarior. monstri descript. anat. Lips. 1827. - I have seen these varieties six times; compare my Selt. Beob. 'Part I. p. 100; Verzeichniss, No. 1923, 2247, 2248, 8683 of Bresl. Mus. and in two cases not preserved. In neither case had difficult swallowing occurred, which had already been missed by Fleischmann and Koberwein, whilst Bayford, Hulme, Monro, Autenrieth, and Murray, have mentioned a peculiar kind of dysphasia (lusoria). This variety is important in the operation of tying the subclavian artery, because its inner part naturally lies deeper, $i . e$. more backwards. It is interesting, that sometimes the left subclavian, which, in altered position of the aorta, mostly arises from the right, passes behind the gullet to the left arm. v. Fiorati Saggi scientifiche di. Padova, Vol. I. p. 69, 70; and myself in Selt. Beob. Vol. II. p.61.

(9) Bayford D. de dysphagia lusoria. v. Memoirs of the med. Soc. of London, Vol. II. 1789, p. 271. - Alex. Monro D. de dysphagia, Edinb. 1797, and in Outlines of the Anatomy of the human Body, Edinb. 1813, Vol. III. p. 277, pl. 43.-Zagorsky, Vol. II. p. 318, tab. 2, fig: 7.-Herold D. exhib. observationes quasdam ad corp. hum. part. struct. Marburgi, 1812.-J. F. Meckel, p. 100.Hesselbach Beschreib. der pathol. Präparate zu Würzb. p. 181, No. 604, and p. 212 , No. 587.

(10) Hunauld in Mém. de l'Acad. des. Sc. 1735, Hist. p. 28, No. 7.-- Walter Mém. de l'Acad. des Scienc. de Berlin, 1785, Vol. III. p. 62, tab. 3, fig. 5.

(11) Huber in Actis Helvet. Vol. VIII. p. 75, fig. 3.

(12) Wralter, tab. 3, fig. 4. 


\section{$\S 189$.}

The further course of the arteries originating from the arch of the aorta is sometimes irregular, in a manner peculiarly interesting to operative surgery; thus, the COMMON ARTERY OF THE HEAD, from which, in rare cases, large unusual branches are given off, divides at once, ${ }^{1}$ very early, ${ }^{2}$ or on the contrary, very late and not distinctly, ${ }^{3}$ into external and internal branches; the CEREBRAL CAROTID was in one instance entirely deficient on one side $;^{*}$ in anencephala, the cerebral carotid as well as the vertebral arteries are mostly very small, thin coated, and even terminate in blind extremities. The superior THYROID ARTERY is sometimes wanting on one side, or is not unfrequently double; the occIPITAL ARTERY in many cases takes its origin from the cerebral carotid. The EXTERNAL MAXILLARY ARTERY is sometimes remarkably small, and its place is then supplied by the so-much larger transverse facial artery. The VERTEBRAL ARTERY is not unfrequently very small on one side and as much larger on the other; sometimes it is more or less double, sometimes indeed only at its origin ${ }^{5}$ sometimes still higher up; it has been seen even three-fold $;^{6}$ not unfrequently it proceeds superficially on the spine, in order to make its first entrance into the fifth, fourth, and even the third or second cervical verteb.a; in one instance its upper part was perforated by the nervus hypoglossus. ${ }^{7}$ The inferior THYroid ARTERY is sometimes wanting on one side, it arises also double, or the left and right spring fiom a common trunk $;^{8}$ sometimes they lie very loosely; are very uncommonly tortuous, \&c. The internal MAMMARY ARTERY was, in one case, formed of three parallel descending vessels, of which the outer two were only connected by a small transverse branch $;^{9}$ in another case it gave off a large external branch, which passed upon the first four ribs. ${ }^{10}$ The ARTERY OF TIIE ARM varies very frequently and differently in respect to its course and division; ${ }^{11}$ in a practical point of view, the most important anomalies are, that the artery gives off a vas aberrans, which descends more or less completely to the elbow-joint, and here terminates either in the principal trunk or in one of the arteries of the fore-arm; the artery divides higher than usual, and not unfrequently even in the arm-pit, into two branches, which lie close by each other; and of the two, the abnormal sometimes very superficial, that is, close beneath the skin, is most frequently the radial, more rarely the ulnar, or lastly, and the most unusual, the interosseal artery; the RADIAL ARTERY in very rare instances is entirely wanting, and then can no pulse be felt on the 
fore-arm $;^{12}$ it divides too high, in which case, its palmar branch, taking the direction of the trunk of the radial, gives rise to mistakes in feeling the pulse, ${ }^{13}$ or its dorsal branch runs down on the fore-arm superficially, and is easily wounded; the ULNAR ARTERY, instead of its usual deep course, descends superficially $;^{14}$ and finally, the INTEROSSEOUS ARTERY sends off an anomalous twig on the inside of the fore-arm, which lying nearer to the skin than itself, runs to the palm of the hand.

(1) A case of this kind in a monster I have described in my Selt. Beob. Part I. p. 16.

(2) Morgagni De sed. et caus. morbor. Epist. XXIX. 20. - Burns, Diseases of the Heart, p. 327.-Ryan, p. 4. I have seen it a few times divided an inch or two deeper than common.

(3) Burns, p. 326 and 327.

(4) T'ode, Medic. chir. Bibliothek. Vol. X. p. 401.

(5) For instance, with one origin from the aorta; with another from the left subclavia. v. Huber in Act. Helvet. Vol. VIII. p. 73.-Henkel's Anmerk. von wiedernatürl. Geburten, Part II. p.10; with both origins from the right subclavian. v. J. F. Meckel Handb. der menschl. Anatomie, Vol. III. p. 135.

(6) Viz. two origins from the right subclavian, and a third from the inferior thyroid; all three united together between the fourth and fifth cervical vertebræ. v. A. Meckel in J. F. Meckel's Archiv für Anat. und Physiol. 1828, No. 2, p. 170, tab. 7, fig. 4 .

(7) The wax model of it is in the Anatomical Museum of the Joseph Academy at Vienna.

(8) Burns, p. 331.

(9) I saw this rare preparation in the Anat. Mus. of the Surgical Academy at Copenhagen.

(10) v. my Selt. Beob. Part II. p. 62, Verzeichn. No. 1931, and once since. It may be easily seen that this anomaly may, in penetrating wounds of the chest, fractured ribs, \&c. give rise to internal hemorrhage.

(11) C. G. Ludwig Progr. de variantibus arteriæ brachialis ramis in aneurysmatis operatione attendendis. Lips. 1767.-J. F. Meckel Ueber den regelwidrigen Verlauf der Armpulsadern; in his D. Archiv f. d. Physiol. Vol. II. p. 117-131, and in Tabul. anat. pathol. Fasc. II. tab. 11. - Fr. Tiedeman Beobachtungen über die hohe Theilung der Armschlagader in die Speichen-und Ellenbogen-Schlagader; in the Denkschriften der Akad. der Wissench. zu München, Vol. VI. p. 3, ff. and in Tabul. arteriar. Fasc. II.

(12) I have observed this during life and after death, on both arms of an aged woman; from the radial artery there is merely the recurrent and a few little muscular branches; the descending trunk is entirely wanting; hence the interosseal is larger, and gives off the branch to the hand, which is naturally sent from the radial. Compare No. 8531, Bresl. Mus.

(13) Burns, p. 343, in which he relates an observation of Dr. Baird, according to which three persons in the same family were subjects of this anomaly.

(14) Tiedemann, Tabula Arteriarum, Tab. XVII. fig. 1.-Burns, p. 341, saw it three times. I have only to the present time seen it once.

\section{$\S 190$.}

Not fewer varieties are exhibited by the ARTERIES ARISING FROM THE DESCENDING AORTA. Thus we sometimes find the BRONCIIAL ARTERIES very much enlarged in persons affected with the blue disease $;^{1}$ the origin and course of the intestinal 
and mesenteric arteries vary uncommonly; in large umbilical ruptures and protrusion of the abdominal viscera, their ARTEIRIES are very deficient ${ }^{2}$ the INFERIOR MESENTERIC ARTERY in an otherwise well-formed child was deficient, ${ }^{3}$ and in one case of high division of the aorta, it arose from the common iliac artery ; ${ }^{*}$ the arteria omphalo mesaraica, not merely in new-born children, but even in adults, still remains distinct; ${ }^{5}$ the RENAL ARTERIES are very commonly irregular in number and origin, sometimes there are five instead of two, and in one instance the arteries of both kidneys arose by a common trunk from the front of the aorta close to the superior mesenteric, ${ }^{6}$ or lastly and more commonly, in congenital abnormal position of the kidneys, their arteries also arise irregularly, riz. lower down from the aorta, from the iliaca communis, the hypogastrica, and even the sacralis media ${ }^{7}$ \&c. The PELvic ARTERIES also vary fiequently; to these first belongs, the UMBILICAL ARTERY, which especially in malformed, although also frequently in well-formed children, is entirely deficient on one side,$^{8}$ or as an approach to such formation, is unusually small, sometimes has an unnatural origin ${ }^{9}$ and in its shrivelled state, in adults, does not lie close to the abdominal parietes, but depends loosely in a tolerably broad fold of the peritoneum..$^{10}$ The irregular course of the pudenda commenis is also important, as its principal trunk, in some instances, does not descend between the inferior pelvic ligaments, but along the urinary bladder and prostate gland, or even through these to the penis, and may therefore, in the operation for the stone, be easily wounded in a dangerous manner. ${ }^{11}$ Not less important in reference to the operation for crural rupture is the varicty of the obturatoria; it arises, in rare cases, beneath the crural arch from the femoral artery itself, or very frequently from the epigastrica, or even by one trunk common to it and the latter from the pelvic artery; ${ }^{12}$ in all these instances it returns upon the share-bone into the pelvis, and then passes usually on the outer side of the femoral rupture, although also in external femoral rupture on the inner side, and sometimes even curves in front of the neck of the sac. Finally, the course of the FEMORAL ARTERY and its branches is subject to numerous varieties, of which the most important are the following: the epigastrica, which normally, in external [oblique] inguinal rupture is on the inner side, and in internal [direct] inguinal rupture, on the contrary, is on the outer side of the neck of the sac, and in femoral rupture also ascends to its outer side, sometimes takes a contrary course, if it arise too low down from the femoral artery, or as is commonly the case with 
the obturatoria, or although arising at its usual place, descends too low; $;^{13}$ the abdominalis is sometimes double, and so large, that in wounds of the belly, injury to it is very dangerous ; ${ }^{14}$ the common FEMORAL ARTERY divides sometimes close to the crural arch, and in rare instances even above the crural arch into superficial and deep femoral arteries; ${ }^{15}$ the latter is sometimes, as to size, the principal trunk, so that the perforating arteries of the thigh are unusually large; the internal conoNARY [CIRCUMFLEX] ARTERY arises sometimes so high, that in the operation for femoral rupture it may be wounded; ${ }^{16}$ the SUPERFICIAL FEMORAL ARTERY in one instance gave off an uncommon branch, which descended on the inside of the lower extremity close beneath the skin to the inner condyle ${ }^{17}$ in other instances it was double to the tendon of the triceps, so that two trunks descended parallel to each other $;^{18}$ this leads to the unnatural high division into tibial and peroneal arteries, ${ }^{19}$ from the POPLITEAL ARTERY a large branch which ascends to the middle of the thigh, and anastomoses with the perforating arteries $;^{20}$ lastly, the ARTERIES OF THE LEG also frequently vary, as the one or the other of them may be either entirely deficient or very small $\dot{;}^{21}$ the division into the posterior, tibial, and peroneal arteries takes place very low down, there is irregular communication between them, or their course is unusual. ${ }^{22}$

(1) I have found this once; also Tiedemann. v. Zeitschrift f. Physiologie. Vol. I. Part I. p. 111, ff.-Jacobson v. Meckel's D. Archiv für Physiol. Vol. II. p. 134, and others, observed this.

(2) Potthoff D. s. descriptionem casus rariss. spinam bifidam, totalem, etc. exlibentis. 4to. Berol, 1827, p. 9, (but one artery instead of the cœliaca, mesenterica superior and inferior.) I have seen a similar case.-Wehrde D. anat. pathol. de monstro rariore humano. 8 vo. Halæ, 1826, (the mesenterica superior, the sacra media, and the umbilicalis were wanting.)

(3) Fleischinann, v. Leichenöffnungen, p. 239, No.81._Vic d'Azyr once missed the communicating branch of the superior mesenteric artery. v. Mém. de Paris. A nu. 1776. Mém. p. 702.

(4) Petscie Syll. Obs. rec. in Halleri Col. Diss. Vol. VI. p. 781.

(5) I have found three times in newly born children that the artery is closed, but totally distinct from the vein. I have also fourd it in animals, viz. in a full grown otter and in a cavia aguti.--Heusinger found it in a full grown foetus. v. Zeitschrift für organ Physik. Vol. I. Part III. p. 335.

(6) Portal Cours d'Anatomie médicale, Vol. III. p. 290.

(7) I have observed this once on the right and once on the left side. I have also seen an artery for the left deep seated kidney taking its origin from the right common iliac.

(8) Only a single umbilical artery, without any account to which side it belongs, is given in Haller Elem. Physiol. Vol. VII. p. 495.-Hebenstreit resp. Lehmann Funiculi umbilic. hum. pathol. Lips. 1747; and in Haller's Collect. anat. Vol. V. p. 682. - Osiander Annalen, Vol. II. p. 80.-Murdoch in Edinb. mecl. and surg. Journ. 1821, p. 315. - Windsor, ib. October, 1821. - Rathke in Meckel's D. Archiv. f. Physiol. Vol. VII. p. 483. - Herrmann in d. Salzburg. med. chir. Zeitung, 1822, Vol. IV. p. 93, ff.; the right inissed by Breschet, v. Répertoire, etc. Vol. II. Cah. I. p. $471 .-J$. F. Meckel in five cases. v. Descript. mon- 
stror. nonnullor. Lips. 1826, p. 13, 22, 31, 43; and in Archiv fiir Anat. und Physiol. 1826, No. 1, p. 37.-Faber D. duor. monstror. humanor. descript. anat. 4to. Berol. 1827, p. 16.-Hesse D. monstri bicipitis descript. anat. 8vo. Berol. 1823, p. 21.-Bock in Cerutti's Pathol. anat. Museum, Vol. I. Part III. p. 39.--Mende in Nov. Act. phys. med. Acad. Nat. Cur. Vol. XIII. Part II. 1827, p. 869; and myself in four cases. v. Selt. Beob. Part I, p. 16, and in No. 2903, 8012, and S013, Bresl. Mus. ; the left missed by Wrisberg Descr. anat. embryon. Obs. 4.Sandiforl Obs, anat. pathol. Lib. III. cap. 1, tab. 3, fig. 3, k.-Carus Zur Lehre voll Schwangerschaft und Geburt. Part II. p. 107. - Fränkel D. de organor. generat. deformitate rariss. p. 14, 4to. Berol. 1825. - Wehrde D. anat. pathol. de monstro rariore humano, p. 12. Halæ, 1\$26.-Mayer in the Zeitsclırift für Physiologie of Tiedemann and G. R. and L. Ch. Treviranus, Vol. II. Part I. p. 37 ; and inyself in five cases, viz. in Monstror. sex humanor. anat. et pliys. disquisitio, p. 15. 4to. Francof. 1S11, and in No. 28\$1, \$011, 8015 , and 8016 , Bresl. Mus. I have also scen a case belonging here in the Anat. Mus. at Freyburgh. There appears also, in reference to the frequency of this phenomenon, nc actual difference between the right and left sides. In rare cases both umbilical arteries are consolidated into one trumk within the cord. v. Henkel Medic. chir. Beobachtungen.-Flcischmann Leichenöffnungen, p. 239, No. 82.

(9) For instance, from the iliaca. v. Breschet.-From the aorta; this is indeed regular in the syren monsters. v. Hottinger in Misc. Nat. Cur. Dec. III. An. 9. Obs. 233.-A. K. Boerhaave Hist. anat. infantis cujus pars corporis inferior monstrosa. Petrop. 1754, p. 74; and Hist. altera Petrop. 1757, p. 73.--Kossi D. s. fotus moustrosi Holmiæ nati descript. et delineat. Jenæ, 1800, p. 16.-Sachse D.s. descriptionem infantis monstrosi. Lips. 1803, p. 14.-Dieckerhnff D. de Monopodia. Halæ, 1819 (in several cases.) - Hesselbach Beschrcibung der pathol. Präparate zu Würzburg, p. 232.-Behn D. de monopodibus, p. 12. 4to. Berol. 1827.-Myself. v. Monstror. sex humanor. anat. et physiol. Disquis. p. 38, and in No. 2903 of my Verzeichniss. -This anomaly, however, also occurs without syren formation. v. Needham De format. fœtu. Cap. IV.-Kerliring Spicil. anat. Obs. 9, p. 27.-My Selt. Beob. Part I. p. 16.-Herrmann in d. Salzb. medic. chir. Zeitumg, 1822, Vol. IV. p. 95.-In a monstrous calf, with deficient hindpart of the body, the umbilical arteries arose from the anterior mesenteric. v. Fingerhuth in Meclel's Archiv für Anat. und Physiol. 1826. No. 1. p. 3.

(10) I have observed this twice; Kelch also has seen it once. v. Beiträge zur pathol. anat. p. 60, No. 47.-There may easily arise from this anomaly an internal contraction of the intestine.

(11) This variety is so common, that Vesalius, and other older writers, have considered it as the usual formation. I have, however, observed it but twice in adult men. Burns, p. 350, first pointed out the danger of wounding it in the operation for the stone in man. -- Tiedemann Tabulæ Arteriar. tab. 30, fig. 2, has engraved it very satisfactorily.-On account of this anomaly, J. Shaw lost a patient by hemorrhage, very shortly after operàting for the stonc. v. Magazin der ausländ litterat. der ges. Heilkunde, Vol. XI. p. 349.--Seldom, and perhaps only in injuries of the penis, is the origin of the arteria dorsalis penis from the deep artery of the thigh important. v. Tiedemann, tab. 3, fig. 1.

(12) I have several times found the varieties just mentioned, and it appears to me, as also to Hesselbach and Tiedemam, that the external origin of the obturatoria in women is more frequent than in men. Good plates of these varieties are given by Monro in his Morbid Anatomy of the human Gullet, Stomach, and Intestines. Elinb. 1811, Tab. 14-Burns in Edinb. med. and surg. Journ. Vol. I1. p. 273, fig. 1. - Wardrop, ib. p. 203. - A. K. Hesselbach Ueber Ilen Ursprung und Verlauf der untern Banchdeckenschlagader und der Hüftbeinlochsschligader. 4to. Bamberg and Würzb. 1S19, with six plates.-Tiedemann Tabula Arteriar. tab. 30 , fig. 3 and 4 ; tab. 33, fig. 2-4.

(13) Such cases are described by $F$. C. Messelbach in der Salzb. merl. chir. Zeitumg, 1811, No. 62, 1). 186; and in Untersuchung ïber den Ursprumg umi das fortschreiten der Leisten-mul Schenlelbriche, 1). 17. Wiiramrg, 1s15.Burns, p. 360.- Beckers 1). med. de hernia inguinali, p. 316. P'aris, 1813.A. K. Messellach, 1. 21, No. 31 . 
(14) Ramsay in Edinb. med. and surg. Journ. Vol. VIII. p. 282, plate 1, fig. 1.-Burns, p. 361 .

(15) The ligature of the superficial femoral artery for aneurysm was without any good result, because the deep artery arose almost immediately below the crural arch; and, therefore, between its origin, and the part at which the ligature was applied, so small a space remained, that the clot could not withstand the flow of the blood. v. Ephém. médic. de Montpellier, Vol. V. p. 61.A few good engravings of high division are given by Tiedemann, tab. 33, fig. 2 and 3.- The division above the crural arch was observed by Burns, p. 362, in four individuals. - Tiedemann once. v. Explicat. Tabular. Arteriar. p. 322, note a.-I have found it twice, and, indeed, on both sides in each case; the high division near the crural arch I have not unfrequently seen.

(16) Burns, p. 362.

(17) Zagorsky, Vol. I. observed this case, interesting plyysiologically, on account of the similarity between the arteries and veins of this region.

(18) C. Bell in London med. and plyysical Journal, August, 1826. - As in this case the man had popliteal aneurysm, the blood, after the ligature had been applied, naturally passed by one femoral artery into the sac.-A similar variety was found by Houston. v. Dublin Hospital Reports and Communications. Vol. IV. p. 314 .

(19) According to Ramsay, p. 283, the division takes place sometimes above the popliteal muscle, so that of these, the anterior tibial artery proceeding from it, inclines towards the tibia; in rare cases the division is found as high as the crural arch. v. Sandifort, Obs. Anat. pathol. Lib. IV. p. 97.-Portal Cours d'Anatomie Medicale, Vol. III. p. 326.

(20) My Selt. Beob. Part II. p. 62.

(21) According to my observations, this most frequently occurs in the peroneal. I have, however, now and then missed the anterior tibial, in which case the dorsal artery of the foot is formed by the anterior peroneal. I have never myself seen the posterior tibial deficient.

(22) In one man the anterior tibial lay so superficially, that its pulsation excited a suspicion of aneurysm; in one of his children an early similar anomaly was observed. v. Pelletan Clinique Chirurgicale, Vol. I. p. 101.

\section{$\S 191$.}

The course of one or several arteries is occasionally so far irregular that they appear unnaturally CURVED and TORTUous. In many instances this seems to be congenital, ${ }^{1}$ more frequently acquired, as in incurvation of the skeleton the neighbouring arteries participate in this change $;^{2}$ or tumours, dislocated bones, \&c. sometimes displace the neighbouring blood-vessels; or the arteries in disease of their coats, and consequent diminished elasticity, become gradually elongated by the stream of blood, and therefore curved. ${ }^{3}$ Great difference also exists in reference to the THICKNESS of the arterial parietes; thus frequently they are throughout the whole body congenitally too THIN, and resemble veins, ${ }^{4}$ or this occurs only in certain parts $;^{5}$ lastly, the arterial membranes are sometimes remarkably thinned at a later period, owing to great extension and atrophy. ${ }^{6}$ Very frequently also, on the contrary, the arteries become THICKENED by disease.

(1) Thus the carotids were once found twisted in the middle like a snail's shell. v. Morgagni, Epist. XLIX. 18 ; perhaps, also the remarkable serpentine course of the iliac artery, which I have described, was congenital.-Compare 
my Selt. Beob. Part II. p. 63 ; that hoth cases are inıportant in operative surgery requires no further discussion.

(2) For example, in rickety distortion of the lower extremities ; the vertebral artery in spondylarthrocacy of the first cervical vertebra; the subclavian in unsymmetry of the shoulders; but especially the aorta in kyphosis and scoliosis of the spine below the fifth dorsal vertebra.- $A$. L. C. Wetzel præs. Hartmann Efficacium gibbositatis in mutandis vasorum directionibus. 4to. Traj. ad Viadr. 1778, with four engravings. - Vrolik D. anat. pathol. de mutato vasorum sanguiferor. cursu in scoliosi et cyphosi. 4to. Amstel. 1823, with two plates. - My Verzeichn. No. 3932-3935. - In hadly united and distorted fractures of the long tubular bones, I have seen the vascular trunk of the extremity very much curved.

(3) I have also seen this several times, once in the greatest degree in the aorta, which was hent at a right angle, and was displaced almost two inches to the left. Compare my Selt. Beob. Part II. p. 64, and my Verzeichniss, No. 3936. -A similar extension of the iliac arteries and aorta was observed by Morgagni. v. Fpist. XIX. p. 58 ; XXXVII. 30 ; also in the carotid and vertebral arteries, XLII, 34; LXVII. 11.

(4) Abernethy thus found the aorta and pulmonary artery in a blue child. v. his Surgical and Physiological Essays. - I have also seen a sinilar state in some monsters.

(5) For instance, the carotids and vertebral arteries within the cavity of the stull in acephaly, hydrencephaly, and congenital water in the head; further, the arteries of many spurious growths, particularly the common and medullary sarcom.

(6) For instance, in limbs which have been paralytic for a long while.

\section{$\S 192$.}

The variation of arteries as to their normal CALIBRE is found in both directions. First, as to their IRREgular NarRowness, or smallness, this may be equally congenital as acquired, general or local, and may lead to the complete closing up and imperviousness of the vessels. We find it indeed occurring throughout the whole arterial system in relation to the heart, or with it in reference to the whole body remarkably narrow, as was once observed in the trunk of the aorta. ${ }^{1}$ In persons affected with the blue disease, the pulmonary artery is often too narrow or even closed. ${ }^{2}$ In limbs which have been long paralytic, the arteries are now and then too narrow, as also usually the other wasted, hardened, or even inactive organs, as well also as the arteries below an aneurysmal tumour. Sometimes we observe only on certain spots a great narrowing and even imperviousness of the arteries, without being able to determine, whether it be vice of formation, or the consequence of disease and mechanical influence; this happens not unfrequently in the smaller arteries ${ }^{3}$ it has been observed several times even in the aorta. ${ }^{4}$ In other cases the cause of the narrowing or closing of certain arteries is foreign to the vessel itself; thus, for instance, when they are compressed by tumours in their neighbourhood, ${ }^{5}$ or their proper coats are rendered less transparent by thickening, ${ }^{6}$ or lastly, when they are cloggred up by cancerous matter, ${ }^{7}$ \&c. 
(1) Morgagni, Epist. XVIII, p. 2; XXI. 36; XXIII. 4; XXX. 12; XXXVIII. 34; XLV. 23; LIV. 37; LV. 10 ; LVI. 10 ; LXVI. 8. - Mechel Mémoires de Berlin, 1750, p. 163-182; 1756, Obs. 17, p. 61. - I have myself found several such cases in lencophlegmatic persons. In a large nan I once saw all the arteries not larger than those of a boy twelve years old, at the same time the heart was very small.

(2) Compare $\S 174$, note, and $\S 186$, note 14 and 15 .

(3) Fleischmann found the aorta with its branches, from the diaphragm downwards, very narrow, v. Leichenöffnungen, p. 226, No.71.-On spontaneous closure of the arteries, compare Chaussier in Bulletin de la Fac. de Méd. et de la Soc. de Paris, 1818, p. 149.-A remarkable case of spontaneous closure of the right art. brachialis, ulnaris, cruralis, poplitea, and tibialis, after severe cold, was observed by Thomson. v. Hodgson, On diseases of Arteries, \&c.-Closure of the carotids, seen by Petit. v..Mém. de l'Acad. des. Sc. 1765, p. 758.-Pelletan Clinique chirurgicale, Vol. I. p. 68.-A. Cooper in Med. chir. Transact. Vol. I. p. 12, tab. 2, fig. 2. - The subclavia and axillaris, Pelletan, p. 77, 80.Beauchene in Journ. de Méd. Vol. XX. p. 209. - Hodgson, p. 156. - The brachial artery from its orgin to its division. v. Ribes in Bullet. de la Faculté de Méd. de Paris, 1817, No. 1-4.-Rostan in Sédlilot's Recueil périod. Vol. I.XIV. p. 24.2. -The external iliac, Bryant in Edinb. Med. and Surg. Journ. Jan. 1823-The popliteal, Ribes.-The anterior tibial in the region of the ankle. v. J. Barclay, A description of the arteries of the Human Body. p. 263. 8vo. Edinb. 1812.

(4) A very narrow part was found by Paris. v. Dessault's Journ. de Chir. Vol. II. p. 107, (close under the arch of the aorta.) - $A$. Cooper, Surgical Essays, Part I. p. 115, (close under the arch of the aorta, death by bursting of the heart.) - My Selt. Beob. Part II. p. 66, tab. 1, fig. 3, (close beneath the arch, death from rupture of the aorta.)-Complete closure of the aorta was noticed by Graham, and communicated by Blane in Med. chir. Trans. Vol. V. p. 287, (in the region of the canalis arteriosus.)-Goodisson's case of obliterated aorta, with some additional remarks by Crampton in Dublin Hospital Reports, \&c. Vol. II. p. 194, (below the inferior mesenteric artery.) - A. Monro. v. Johnson Med. chir. Review, new series, No. 12, p. 481, April, 1827, (the abdominal aorta below an aneurysm.) - A. Meckel in J. F. Meckel's Archiv für Anat. und Physiol. 1827, No. 3, 1. 345, pl. 5, fig. 1 and 2, (on the fourth dorsal vertebra.)-[Left carotid at its origin from the aorta so narrowed by a membrane as scarcely to admit a probe, in a patient of Key's who had aneurysm of the innominata, for which the carotid was tied; she died an hour and a half after the operation. v. Med. Gazette, Vol. VI. p. 702.-The pulmonary artery contracted to the size of the brachial. v. Elliotson, p. 19 . T.]

(5) For example, bronchocele the carotids, aneurysm the neighbouring arteries; compare Pellatan, A. Cooper, Hodgson, note 3. - In one case, two steomatous tumours enclosed the aorta close under its arcl. v. Stenzel D. de Steatomatibus in principio arteriæ aortæ repertis. Viteb. 1723.-I have several times seen individual arteries closely compressed by scrofulous, scirrhous, and encysted tumours. v. Verzeichn. No. 2265.

(6) Compare further below, in vices of texture; and my Verzeichn. No. 2266 and 2267. - In the late Margrave of Baden-Baden, almost the whole aorta was filled with lime. v. J. P. Frank Apit. de cur. lom. morbis, Vol. VIII. L. VI. p. 331.

(7) Velpeau Exposition d'un cas remarquable de la maladie cancerense avec obliteration de l'Aorte, etc. 8vo. Paris, 1825. - In a person with carcinomatous disposition, the aorta was filled from the third lumbar vertebra downwards, and also the iliac arteries partially, with a firm cylinder of a greyish yellow colour. v. Churchill, in Lond. Med. and Phys. Journ. new series, Vol. II. No. 9, March,1827.

\section{$\S 193$.}

The opposite state, that is, a PERMANENT IRREGUlar WIDENING, OR GREAT SIZE OF ARTERIES, is much more coinmon, and exhibits likewise many variations of grade and 
extent. It occurs in individuals in whom the whole arterial system is congenitally very large in proportion to the body; but this enlargement of arteries is commonly more defined and occurring at a later period, in which we distinguish the DILATATION OF ARTERIES, dilatatio, distensio arteriarum, arteriectasis, and ANEURYSM, aneurysma, although without being always able to distinguish them accurately from each other. To the former kind belongs the general enlargement, affecting the diameter of one or several arteries, as it appears sometimes in hypertrophy of certain parts, but especially in many tumours, and most distinctly in neighbouring branches after the closing up or narrowing of the principal trunk $;^{1}$ in these cases the coats of the artery are healthy, and the dilatation of the vessel appears to be spontaneous and active. Another, is the passive or morbid form, in which, according to the more or less abnormal change of its structure, or diminished coherence, the artery loses its necessary elasticity, and so, being incapable of opposing the violent passage of the blood, is often very distinctly expanded, in a greater or less degree; the latter state especially occurs in diseases of the lungs, in the trunk of the pulmonary artery, but more frequently at the origin of the aorta. ${ }^{2}$ A peculiar form of disease, not however yet, according to its nature, fully investigated, but which still must be classed with these, is the extension of the extremities of the ARTERIES, telangiectasis, angiectasis, aneurysma per anastomosin, hamatoncus, tumeurs erectiles, ${ }^{3}$ \&c. This is usually congenital, in form of a mother's mark, more or less large, elevated and reddish, which earlier or later begins to increase and develope itself, and indeed sometimes only after a long period, and even then but slightly; in rarer cases, however, this disease appear's to take place later, spontaneously, or from some mechanical cause. It especially attacks the skin of the head, although also in rare cases it affects other parts of the skin, and perhaps even the interior of the body itself, ${ }^{4}$ and produces tumours of various size and form, which are easily dispersed by pressure, but when that is withdrawn, again become filled; often have a tremulous motion, accompanied with an internal rushing, a bluish-red colour, and an unequal surface; at a later period much blood is repeatedly poured out from the most projecting parts having burst, and from anatomical examination, they are found to consist of a vast quantity of the extreme branches of arteries, collected on all sides, expanded, anastomosing, and disposed in a net-like and coil-like manner, of many veins expanded here and there into cavities, and of a loose cellular tissue. 
(1) Some striking examples of this kind are given in White, Cases in Surgery, p. 139, tab. 7. Lond. 1770, (on the arm.) - Deschamp in Mrém. prés. à l'Institut. des Sciences, 1805, Vol. I. p. 251, (on the foot.)-Pelletan Clinique chirurgicale, Vol. I. p. 127, (on the foot.) - A. Cooper in Medico-chir. Transact. Vol.II. p. 249, and Vol. IV. p. 429. pl.5, (on the feet.)-Jones, On the process employed by nature in suppressing the hemorrhage from divided and punctured arteries, \&c. Svo. London, 1810, (experiments on dogs.) The same occurs after closure of the aorta. - In the Anatom. Mus. at St. Thomas's Hospital, I saw some very rare preparations of collateral circulation.-In one instance, in which the truncus anonymus was closed, the right arm received its blood from the left subclavia, by the much widened communicating inferior thyreoideal arteries. v. William Darrach, in Philadelphia Journal.-Often in varicose aneurysms, the arteries which are narrowed above, become widened below the injured part. v. W. Hunter, Vol. II.-Dorsey and Schottin, \&c. \$ 194, note 6.

(2) On both places I have found it several times very distinctly, and on the aorta also sometimes unequally, that is, slightly bottle-shaped; compare my Verzeiclin. No. $2250-2253$.

(3) In the venereal disease, also cavernous, spongy, bloody fungous tumours, \&c. The disease was first satisfactorily described by John Bcll, under the name of Aneurysma per anastomosin. v. Principles of Surgery, Vol. I. p. 456 ; Vol. III. p. 255.-Grïfe Angiectasie, ein Beiträg. zur rationellen Cur. und Erkenntniss der Gefässausclehnungen. 4to. Leipz. 1808, with plates. - Alibert calls this disease Hematoncus; and distinguishes three kinds:-H. fungoides, H. frambæesia, and H. tuberosus. v. Nosologie naturelle, Vol.1. p. 334. - v. Walther in his and v. Grïfe's Journ. d. Chir. Vol. V. Part II. p. 231, (five instances on the head, a sixtl on the labia pudendi.) - Some interesting cases are described by Desault in Journ. de Chir. Vol. II. p. 73, (on the chin.) - Lamorier in Mém. de la Société de Montpellier, Vol. I. p. 245, (on the arm.)-Scarpa Sull' aneurysma, (in the left arm-pit.) -Pelletan, Vol. I. and Vol. II. p.59, (on the head.)-Travers in Meclico-chir. Transact. Vol. II. p. 1, (in the orbit.) - Dalrymple, ib. Vol. VI. p. 110, (in the orbit.) - Abernethy, Surgical Observations, p. 224, (besides several cases on the head, one also in the orbit.)-Boyer, Traité des maladies chir. Vol. II. p. 269, (in the orbit.) - Tartra s. Harles N. Journ. der ausländ. med. chir. Litt. Vol. V II. Part I. (on the head.) -Wardrop Obs. on one species of novus, in Mecl. chir. Transact. Vol. IX. p. 203, ff, (several of his own cases, also a case by Lawrence, p. 216, on the finger.) - Breschet gives a case of a large telangiectasy on the occiput and neck of a grown-up person, in the Diet. des Sciences médicales, Vol. XX. p. 200. Art. Hæmatoncie. - G. S. Pattison, in American medical Recorder, New-York, Jan. 1822, Art. 11, (on the face, cured by tying the carotid.) - Arendt in Journ. f. Militair-Medicin. 8vo. Vol. I. Part I. p. 75-88. Petersb. 1823, with engravings, (on the right side of the liead, cured by tying the carotid.)-Büchner in Harles Rhein. Westphäl. Jahrb. de Medic. u. Chir. Vol. VIII. Part II. p. 123, with plates, (on the forehead of a child.) Brosse in Rust's Magazin der ges. Heilk. Vol. VII. Part II. p. 161, (on the right ear and the surrounding parts, cured by tying the carotid.)-Hodgson, p. 86, (on the temple.) - $I b$. translated into French by Breschet, with several observations by Dupuytren.-Kreysig observed a case on the point of the fore-finger. v. Hodgson, p. 97, note 13.-Burns, Anatomy of the II ead and Necl, p. 309, 8vo. Edinb. 1811, tab. S, fig. 1, (on the face.) - Weese in Rust's Magazin f. die ges Heilk. Vol. XII. Part II. p. 227, (on the lower eye-lid.)-I once saw a very remarkable case in a stout countryman on the right side of the face and neck.[ neurysm by anastomosis occupying the middle of the upper lip, the whole nose, and lower part of the forehead, cured by ligature. v. Liston in Med. Gaz. Vol. VI. p. 896. - Anastomosing aneurysm extending across the nose from canthus to cantlus, covering the mose to its extremity and reaching on the forehead, in a child three montlis old, the common carotid tied by Mott. Amer. Journ. of Med. Sc. - Anastomosing aneurysm on the head, with a base of five inches diameter, and elevation of nearly two inches, cured by tying loth primitive carotids. v. R. D. Mussey in American Journ. of Med. Se. Feb. 1830. 'I'.]

(4) I have my doubts whether the cases described by Meckel in Handb. der 
pathol. anat. Vol. II. Part I. p. 244, were true telangiectases; the pulsating spleen, indeed, of writers is for the most part inflamed spleen, and the similar diseases occurring in the brain and liver, are, indeed, fungus hæmatodes, that is, a kind of medullary sarcomia; lastly, the pulsating tumour described by Bell, p. 471 , as large as an egg, and situated between the vagina and rectum, is not, from the description, to be received with certainty.

\section{$\S 194$.}

Aneurysm, aneurysma, ${ }^{1}$ is an arterial swelling, proportionally more distinct, more perfectly defined, and especially affecting but one side of the arterial trunk. ${ }^{2}$ We generally speak of the following kinds of aneurysm: first, the TRUE OR GENUINE, aneurysma verum, genuinum, ${ }^{3}$ which consists of a more or less distinctly sac-like extension of all the coats, of an always diseased artery; secondly, the MIXED ANEURYSM, aneurysmu mixtum ${ }^{4}$ in which the genuine and spurious are confounded together, and arises from a mechanical or morbid destruction of the two inner coats of the artery, with sac-like expansion of the outer or cellular coat, as well also as of the adjacent cellular tissue, and sometimes also of the other membranes investing the artery; the third, is the FALSE or spURIous ANEURYSM, aneurysma spurium, ${ }^{5}$ the essence of which is grounded in an aperture in all the membranes of an artery, and the production of a swelling, more or less extensive, from the effusion of blood into the neighbouring cellular tissue, and on the limbs into the tendinous sheaths; lastly, and fourthly, the VARICOSE ANEURYSM, aneurysma varicosum, or varix aneurysmaticus, ${ }^{6}$ in which, in consequence of wound and the production of a communication between the artery and vein, the blood from the former flows into the latter, and produces a swelling in it. We also distinguish them according to their situation, as EXTERNAL and INTERNAL ANEURYSM, aneurysma externum and internum, and thus we commonly designate by the former title those situated on the limbs, which are also the most visible; and by the latter name, those which are mostly occult on the trunk.

(1) J. B. Sylvaliens, Tract. de aneurysmate. 4.to. Vincent. 1595.-v. Haller's Bibl. med. pract. Vol. 1I. p. 245.-van Horne Lipist. de aneurysmate. Svo.

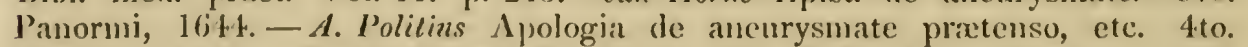

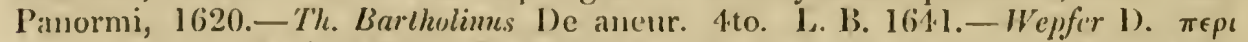

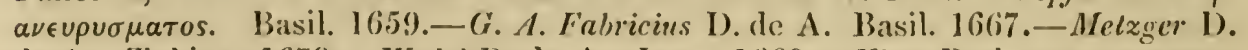
de A. 'Tubing. 1679.-Wedel 1). de A. Jena, 1669.-Klose D. de tumore aneurysmatico. Leips. 1702.-Alberli D. de $\Lambda$. Halae, 1725.-Lancisius De ancurysmatibus. Ronx, 1728, in Laulh's Collect.-Ililscher D. de A. Jenxe, 172S.$1 \%$ Nicholls, Some observations on ancurysms in general, in Philos. Transact. 1728, 1. 410.-J. I. Pelil in Mem. de Paris, 17:36. Mem. p. 24t.-A. I: Walther Pr. de $\Lambda$. Lips. 1738. - van Lienwen 1). de $\Lambda$. vero. Leida, 1742.Gunluni Historice duxe ancurysmatmm, ete. Ronne, 1745, and De cxternis aneurysmat. Roma, 1772. v. Lauth's Collect.-1I. L'tiot de $\Lambda$. in Quxstion. med. XI1. Monsj. 1719.-Wellinus D. de ancur. vero pectoris externo, hemi- 
plegiæ sobole. Basil. 1750. v. Lauth's Collect. - Arnauld, Observations on aneurysms. London, 1750.-Matani Animadversiones de aneurysmat. præcordiorum morbis, etc. Florent. 1756. v. Lauth's Collect.-Foubert in Mémoires de l'Academie de Chir. de Paris. Vol. II. p. 535.-Gibellet D. de A. Argentor. 1757.-Alex. Monro, Remarks on the coats of arteries, their diseases, and particularly on the formation of an aneurysm, in Edinb. Medic. Essays and Observat. Vol. II. p. 264.-Donald Monro, Cases of aneurysms, with remarks, in Edinb. Med. Essays and Observat. Vol. III. 1771. No. XII. p. 187.-Asmann D. de aneurysmatibus. Grœning, 1773. v. Lauth's Collect.-Verbrugge D. anat. chir. de A.; oblata notabile aortæ aneurysma divulgandi occasione. L. B. 1773. v. Lauth's Collect.—J. B. Heraud De aneur. externis. Monsp. 1775.-W. Hunter, The history of an aneurysm of the aorta, with some remarks on aneurysms in general, in London Medic. Observ. and Inquiries. Vol. I. 1776. p. 323. Pl. IV. fig. 1. Vol. II. p. 390.-Stribel D. de A. Viennæ, 1783.-Th. Lauth Scriptor. latinor. de aneurysmatibus Collectio. 4to. Argentor. 1785, with 15 engravings.Penchienati Recherches anat. pathol. sur les aneurysmes, etc., in Mém. de l'Acad. de Turin, 1784-85. Part I. p. 153.-Walter Sur l'aneurysme in N. Mém. de Berl. 1785, p. 48. - C. Lombardini De aneurysmat. præcordior. norbis. 4to. Ticini, 1787.-Witte D. de A. ejusque curatione. Kilon, 1787. - Laue D. de arteriar. morbis et præcipue de aneurysmatibus. L. B. 1787.- Scheid Obs. med. chir. de A. 8vo. Harderovici, 1792. - E. Home, Account of Mr. Hunter's method of performing the operation for the cure of the popliteal aneurysm in Transactions of a Society for the Improvement of medical chir. Knowledge, Vol. I. p. 138, Vol. II. p. 235. 1793 and 1800.-Salmade in Sédillot Recueil périod. de la Société de Santé de Paris. Vol. III. p. 454.P'alletla in Giornale di Venezia, 1796, No.1, p. 24; and in Külnn's and Weigel's Ital. medic. chir. Biblioth. Vol. IV. p. 73.-R. Calliot Essay sur l'Aneurysme. 8vo. Paris. Ann. VIII.-Ayer Ueber die Pulsadergeschwiilste und ilre clirurg: Behandlung. Svo. Gütting. 1800, with plates.-Sarazin Considérations sur les causes générales de l'Aneurysme et de la rupture spontane des vaisseaux sanguins arteriels, etc. Paris, 1800.-Benedix D. A. externum ejusque curatio. Jenæ, 1801.-Briot Essai sur les tumeurs par le sang arteriel. Svo. Paris, 1S02.-Guerin Ménoire sur l'Aneurysme in Rec. des Actes de la Soc. de Santé de Lyon. Vol. II. p. 149, 176.-Maunoir Mémoires physiologiques et pratiques sur l'Aneurysıne et la ligature des artères. Genève, 1802.-Richerand Observiltions sur une nouvelle espèce d'Aneurysme in Bulletin de la Soc. Philomath. Aun. III. Vol. II. p. 48.-Larrey Notice sur l'A neurysme in Bulletin de l'Ecole de Méd. et de la Soc. de Paris, Ann. XIII. p. 116.-Dingeman's Verhandeling over de waare en onwaare Slagaderbreuken. 8vo. Amsterd. 1803.-A. Scarpa Sull' Aneurysma, riflessioni ed osservazioni anatomico-chirurgiche. gr. fol. Pavia, 1804, with plates; with notes and additions, translated into German by Harles. Ziirich, 1808. Text in 4to., with fol. plates, into French, by Delpech. Paris, 1809. -Sammlung einiger Abhandlungen von Scarpa, v. Berlinghieri und Uccelli Ueber die Pulsadergeschwulste, als Nachtrag zu Harles's Uebersetzung von Scarpa's Werke a. d. Ital. mit Zutsätzen von $W$. B. Seiler. 8vo. Zurich, 1822. Akerman resp. Ahlander Observationes in Aneurysmata D. Upsal. 4to. 1804Deguise D. sur l'Aneurysme, etc. Paris, 1804.-Popp D. selectiora capita de Aneurysmatibus. Altdorf, 1805.-Ludwig Progr. Annot. diagnostices chirurgicæ fragmenta, I. de aneurysmate interno. Lips. 1805.-C. Fr. Hübrer D. de Aneurysmatibus. Göett. 1807.-Freer, Observations on Aneurysm and some diseases of the arterial system. 4to. Birmingham, 1807.-Ingelmam præs. Engelhart D. Aneurysma spurium externum, casu hujus morbi illustratum. 4to. Lund, 1814. -Jacob D. de A. Edinb. 1814.-Aitkin D. de. A. Edinb. 1814.-Szwenski D. de aneurysmatis structura. Halæ, 1814, with two engravings.-J. Hübner D. de Aneurysmatibus. Viennæ, 1815._J. Hodgson, Treatise on the diseases of Arteries and Veins, containing the pathology and treatment of Aneurysms and wounded Arteries. 8vo. Lond. 1815, with plates.-G. A. Spangenberg Erfahrungen iiber die Pulsadergeschwülste, in Horn's Archiv f. d. medic. Erfalirung. 1815, j. 209.-C. D. Kühln D. de A. externo. 4to. Jenx, 1816.-Hurst I). de A. Edinb. 1817.--Herrick D. de A. Edinb. 1817.-Framiton D. de A. Edinb. 
1S19.-Huston D. de A. Edinb. 1819..-Manzoni in Memorie della Soc. Ital. di Modena. Vol. XVIII. Mem. di Fisica. No. 12.-A. J. Miinzenthaler pros. Miinz. D. s. Observationes et annotationes quasdam de aneurysmatibus et prac. veris. 4to. Landishut, 1820, with two plates.-Beathy D. de A. Edinb. 1820.Chevallier D. Aneurysmatım adumbratio anat. pathol. Svo. Berol. 1821.-Döring D. quaedam circa Aneurysmatum pathogeniam. 8vo. Berol. 1822. - Townsend D. de A. Edinb. 1S22.-J. Shekelton in Dublin Hospital Reports and Communications, 1822, Vol. III.-Boysen D. de Aneurysmatibus. 4to. Kiliæ, 1822.Gottschalk D. doctrinam hodiernam de aneurysmate exhibente. Trajecti ad Rhen. 1822. - M. S. Levi Saggio teortico-pratico sugli areurismi interni, etc. Svo. Venezia, 1S:2. - Wedemeyer in Rust's Magazin für die gesammte Heilkunde, Vol. XIII. Part II. p. 229. - Pascalis in New-York medical Repository, Vol. VII. No. 1.-Casamayor Reflexions et Observations anat. chir. sur l'aneurysme spontané eu general et sur celui de l'artère femorale en jarticulier. Svo. Paris, 1825.-J. S. Morizio D. cle Aneurysmatibus internis. Svo. Patavii, 1S25.-Fr. Schippang D. de Aneurysmate in genere. Svo. Berol. 1826.-Desmann D. de incerta aneurysmatum internorum diagnosi. 4to. Berol. 1827, with lithogr. plates. - G. Breschet Recherches et Observations sur l'Aneurysme faux consecutif du cour et sur l'Aneurysme vrai des artères in Répertoire génér. d'Anatomie et de Phiysiol. pathol. Paris, 1827, Vol. III. Part II. 1). 183.Dupuytrén Mémoire sur les aneurysmes, qui compliquent les fractures et les plaies d'armes à feu in Arcluives générales de Médecine, Juillet, 1828.

(2) In order to obviate the confusion relating to arteriectasy and ancurysm, it scems to me necessary to confine the partial and bag-like extension to the latter, but the general and simultaneous to the former. The so-called aneurysma verum cylindroides of Sauvages may, however, and with propriety, be called merely an extension of the vessels sensu latiori, in which notion Scarna includes only one particular kind of aneurysm.

(3) The first opinion held by Fernelius, Universa Medicina, de extern. corp. affect. L. VII. cap. 3, that all aneurysins arose from expansion of the whole arterial coats, only holds good in certain cases, which Scarpa denies without sufficicnt grounds. Many cases of true aneurysms have been collected by Marles, in his translation of Scarpa, 1).310, ff.-J.F'. Meckel in 'I'ab. anat. pathol. Fasc. II. p. 10 ; and Hodgson, p. 94, fl. -1 myself have, 1 p to this time, examined five aneurysms, in which all three coats of the artery were uninjured, lut expanded, and 1 have already mentioned them, v. Handbuch der pathol. anat. 1st edit. 1) 105. note 42. Selt Beol. Part I. p. 103 ; Part II. p. 65 . It is self-eviclent, that the true aneurysms, especially on the aorta, seldom become so large as the mixed and spurious aneurysms, and easily run into the latter. In true aneurysm, the extension of the artery, arteriectasis, usually occurs in all parts of the vessel, and subsequently the artery begins to expand at its weakest part, in a bag-like form, so that we may notice a gradual transition, and endless steps, from arteriectasis to true, mixed, and spurious aneurysm.-Anton Nuck, Operat. et experim. chirurg. I. B. 1696, 1.97, appears to have been the first who gave an account of the correct differences between true and spurious ancurysm. [In the Mus. St. 'Thomas's Hospital there are two instances of aneurysm by simple dilatation of the aorta, and two of the caroticl artery. ' $\mathrm{T}$.]

(4) W. Innter first employed this term as synonymous with dueurysma hemiam arteris sistens, and showed the diverticulum, or hellying protrusion of the inner cont throngh an aperture in the outer; as this circumstauce, however, according to the experiments of John Hunter and E. Home, does not always occur in the above state, and the few observations thereon by Dubois and Dupmylren, in the Dict. des Sc. Méd. art. Ancurisme; and Bresche, in his translation of IIodgson, 1. 130; Richerma Aneurysma aortix enorme per herniam membrana internae, in his Nosogr. Chirurg. Vol. I. p. 7t, 180.5; and Asklepieion, 1811, No. 71, do not hold it to be sufficiently made out; this distinction is therefore given up by most persus.-Alex. Monro called a true ancurysm which had burst, mixed or consecutive.-l'erhrngge, p. 15. \$7, malies use of the terms $\Lambda$. varicosmm and $\Lambda$. mixtum incliscriminat:ly. - Morgagni, in his Advers. Anat. II. Animalvepsiones, XXXIX. and lipist. Anat. XVII.27, calls common or mixed ancurysu the succiforme, 
which title, however, suits true aneurysm. - Scarpa includes A. mixtum with the spurium, because he only admits two arterial coats, and has taken great trouble to make out the frequency and true nature of this species especially, although Harvey, Exercit. Anat. de circul. sanguinis, ex editione Albini, L. B. 1736, Preface, p. xiv. and cxxix. \&c. had already defined it. The aneurysmal sac is commonly connected with the artery by means of a round, and, more or less, large aperture; rarely is this aperture a kind of oblique or ragged slit.

(5) It is known that Galen, Aetius, Fabricius, Hildanus, Sennert, Sylvaticus, Diemerbroech, and more recently, especially Palletta, Scarpa, and Burus, derive all ancurysms from rupture of the arterial coats. $-W$. Hunter divides A. spurium into the diffusum and circumscriptum.-Foubert, on the contrary, less correctly, divides them into $A$. primitif, answering to the diffusum; and $A$. consecutif, to the circumscriptum; the latter contains the blood in a bag, not belonging to the artery, formed by coagulation and inflammation; in $A$. diffusum, on the contrary, the blood is poured out loosely into the cellular tissue, and the aponeurotic sleaths; both kinds may occur, as is easily perceived, may go through their stages together, or may run into one another. [In Mus. St. Thomas's Hospital a case of spurious aneurysm of the femoral artery from a bayonet wound. There is no attempt at repairing the wound, but around the orifice a sac as large as a lien's egg, consisting of layers of coagulum; and close to the artery an aperture, through which the blood escaped into the cellular tissue of the thigh, which was enormously swollen. T.]

(6) W. Hunter, who first described the disease, called it aneurysma per anastomosin; subsequent observations upon it may be found in Guattani, Obs. 2 and 4.-Cleghorn, Case of aneurysmal varix in Med. Observat. and Inquiries, Vol. III. No. 13, p. 110.-White, On the varicose aneurysin, $i b$. Vol. IV. No. 34.Armiger, On varicose aneurysm. $i b$. No. 35.-Duval De aneurysmate varicoso, Theses, 8vo. Paris, 1786 .-Garneri, v. Bertrandi Oper. post. delle Operaz. chirurg. Vol. III. p. 208. - A. v. Brambilla Von der blutaderichten Schlagadergeschwulst (A. venosum) in d. Abhandl. der Josephin. med. chir. Akademie, Vol. I. p. 92.Van Wy Samml. einiger Wahrnehmungen, u.s.w., No. 1.--Pott, Vol. I. p. $173 .-$ B. Bell, A System of Surgery, Vol. III. p. 199.-Monteggia Instituzioni chirurgiche, Vol. I. p. 187.-Park in Medical Facts and Observations, Vol. IV. p. 111 Scarpa. - Nouvel in Capelle Journ. de Santé, et d'hist. nat. de Bordeaux, Vol. III. p. 107.-Atkinson. v. S. Cooper's Surgical Dictionary._Chidella in Canella's Giorn. di Chirurgia pratica. Januar. 1827. - In the above cases the disease occurs after badly performed blood-letting in the arm, although it occurs in other parts, and from other causes; for instance, from a stab with a sword in the popliteal artery and vein, noticed by Larrey at Toulouse. v. Larrey Mémoires de Chir. mil. Vol. IV. p. 340. The same case is described by Lassus Médecine opératoire, Vol. II. p. 443. - Subatier Médecine opératoire, Vol. I. p. 417. - Richerand in Dict. des Sc. médic. Art. Aneurysme variqueux, and Boyer T'raité des Maladies chirurgicales, Vol. II. p. 177. - On the aorta and vena subclavia by a sword wound, and on all the veins of the arm by a stab in the armpit. v. Larrey, Vol. IV. p. 431 . - Through a stab in the art. carotis communis, and vena jugularis, observed by Larrey in v. Froriep's Notizen, No. 259, Vol. XII. No. 17, p. 271 ; and Williaume in Journ. compl. du Dict. des Sciences médicales, Vol. XI. p. 91.By small shot in the art. tibialis posterior. v. Dorsey Elements of Surgery, Vol. II. p. 210, Pliladelphia, 1813. - In the thigh by a stab with a red-hot piece of iron; and in the knee by a pistol shot. v. Hodgson, p. 514, ff.-On the arm after injury. v. Richerand Histoire des Progrès récens de la Chirurgie, p. 119, 122.Alter wound by small shot. v. $P$. Adelmann Tractatus anat. chir. de aneurysmate spurio varicoso. 4to. Würceburgi, 1821, with lithographic engravings. After a contusion between the art. radialis and the vena cephalica. v. K. Schottin merkwiirdiger fall von aneurysmatischer Venegeschwulst. 4to. Altenburg, 1822, with plates.-On the crural artery and vein in the middle of the thigh by a wound with a knife. v. J. T\%. Fleischer D. aneurysmatis varicosi complicati historia. Dorpat, 1822.-Besides other cases, one also in the art. and vena iliac externa. v. Brodie in London med. and pliysic. Journ. Feb. 1827. 


\section{$\S 195$.}

The CaUsEs which produce aneurysm are of very different kinds. The most common is a MORBID STATE of THE INNERMost, and frequently also, at THE SAME TIME, of THE FIBRous COAT, by which they lose their elasticity, become soft and easily ruptured, and are even entirely destroyed.' Thus is produced an ANEURYSMAL DISPOSITION, which it is clear may, consequently, produce several aneurysms in the same individual, sometimes at once, and sometimes consecutively. ${ }^{2}$ Old age, the male sex, ${ }^{3}$ and several general diseases, especially syphylis and gout, in which all the internal coats easily lose their elasticity, dispose to aneurysm. Other frequent causes of this disease are MECHANICAL INFLUENCEs, which render the artery diseased, or immediately weaken or break up its connexion, as concussion, rupture, contusion and actual wounds from sharp instruments, splinters of bone in fracture, \&c.; but especially bleeding. ${ }^{4}$ Lastly, aneurysms may now and then be spuriously produced by INFLAMMATION, SUPPURATION, and MORTIFICATION IN THE NEIGHBOURHOOD of an artery. ${ }^{5}$

(1) Compare further on.

(2) Instances given by Morgagni.-Ruysch Opera Obs. anat. chir. Vol. I. p. 4.-Matui in Lauth's Collect. p. 290, (innumera dispersa per totum corpus.) Donald Monro, on the A. mesenterica superior, inferior, renalis, and cruralis. Alex. Monro, on both A. inguinales, crurnles and popliteæ. - Arnaud in Mémoire de chirurg. Vol. I. p. 182. - Guattani, p. 158 and 232. - Stoll Rat. Medendi, Vol. I.-Michaelis. v. Loter's Journ. Vol. II. p. 665, (nine pieces on the arm.) - Sömmerring on Baillie, p. 16, note 31.-Guerin, v. Journ. 1. ausländ. med. chir. Litt. 1802 , October, p. 338, ff: - J. Major Wilson. v. Ib. Vol. IlI. p. 1. - Ev. Home, in two cases. v. Neues Journal der ausl. med. chir. Litt. Vol. I. Part II.-Baillie in Transact. of a Soc. for the improv. of med. Knowl. Vol. I. p. 121.-A. Cooper in Med. chir. Transact. Vol. IV. p. 427.- Warner, Cases in Surgery, p. 139), (the brachial artery was tied three times, on account of recurring aneurysm.) - Pelletan Clinique chirurgicale, Vol. II. p. 1, (sixtythree in one body.) - In two cases of operation for popliteal aneurysm, the paticnt died by hursting of aneurysm of the aorta. v. Iondon medical Review, Vol. II. p. 420; and Burns, Diseases of the Heart, 1. 261:-Five following each other on the descending aorta, were seen by Mayer. v. Jahrb. medic. des Oesterr Staates. Vol. V. Part I1I. p.62. - Several, O'Reardon in Journ. de Medic. continué, Vol. XVI. p. 482. - Beauchene, ib. 1810, Sept. p. 209. - Aneurysm on the aorta, described by Münzenthaler præs. Miinz, five on the same.-Ulrich in Hufeland's Journ. I823, October, 1).122. - 'Two on the aorta, Clocquet in Revue medicale française et étrangère. March, 1823; ancl Elsström in $\Lambda \mathrm{rs}$. Berättelse om Svenska Lakarre-Sällskapcts $\Lambda$ rbeten. Stocklı. 1825. $-\Lambda_{11}$ anenrysm, first in the left, and then in the right ham, described hy Travers, in Lond. medic. and phys. Journ. Vol. LVIII. p. 25. - $\Lambda$ man, who had aneurysm in the ham and thigh, died, after operation for it, of aneurysm of the arch of the aorta, from London medic. Irepository. - In the Mus. at St. Thomas's Hospital I saw seven aneurysmis in one body.

(3) Of sixty-three cases, fifty-six in men and only seven in women. v. Ilorlgsom, 1. 130.

(4) An aneurysma spurium on the arm, in consequence of bleeding, is described, among others, by 'Th. Barlholin, in Hist. anat. rar. 1754. Cent. II. IIst. IX.-Molinelli De aneurysmate a laesal brachii arteria. 4to. Bonon. 1756. 
Macquil and Monro, in Edinb. med. Essays and Observations, Vol. II. and III.Guattani in Lauth, p. 216.-T'eichmcyer resp. Emmrich D. de stupendo aneurysmate in brachio, etc. Jenæ, 1734.-Ludwig Pr. de variantibus arteriæ brachialis ramis in aneurysmatis operatione attendendis. Lips. 1767. - Trew Aneurysmatis spurii post venæ basilicæ sectionem orti histor. et curatio. 4to. Norimb. 1769. - Schmucker, v. Vermisch te chir. Schriften. Vol. I. p. 329. Vol. II. p. 165, Vol. III. p. 318.-Ol. Acrel Chir. Vorfälle, Vol. I.-Loder Pr. historia aneurysmatis spurii arteriæ brachialis feliciter curati. Jenæ, 1795.-Penchienati, Guerin, and Adams, in Journ. der Ausländ. med. cliir. Litt. Vol. II. p. 369 and 443.-Cartier and Vimont s. Neues Journ. d. ausl. med. chir. Litt. Vol. II. Part II. and Vol. VI. Part I.-Gius. Flajani in Osservazioni e Riflessioni di Chirurgia, Vol. II. Osserv. VII.-X. and Riflessioni generali, p. 41-66.B. Travers, in London medical and physical Journ. April and July, 1827, 8 th case.-A. Cooper's Lectures, Vol. II. p. 78.-Many other cases are collected in de Plouquet, Art. aneurysma arteriæ brachii, and A. spurium. In a case which I have before me, the injury was cured by compression, as, the man having died about two months after, I found the hole in the artery still open, but a little plastic bag at first about the size of a pea, and with thick walls, the commencement of an A. spurium circumscriptum, situated on the aperture. [I once saw in a wound by a penknife of the external carotid, close to the origin of the lingual artery, a similar little bag about as large as a pea, into which the artery opened. The patient had lived some weeks after the common carotid artery had been tied for this accident; but adhesion did not occur at the point on which the ligature was applied, and he died of hemorrhage, but no blood escaped from the original wound. 'T.]-A good engraving of false aneurysin on the arm in consequence of blood-letting is given in Tiedemann Tabulæ arteriarum, Fasc. II. tab. 14. fig. 2.

(5) For instance, after shot wounds. I saw an interesting case of this kind in one of the students here (Breslau,) who had received a shot through the right shoulder joint, in consequence of which, half a year after a diffused aneurysm of the axillary artery took place, which, at last, ran into spurious diffuse aneurysm, and caused death by mortification. Cases of aneurysms on the arm, arising from mortification, are described by Peclilin D. seu historiam vulneris thoracici.-Scarpa, Obs. 9.

\section{$\S 196$.}

Aneurysms occur By no MEANS EQUALLy FREQUENT IN ALL ARTERIES, but are much more common in the larger than in the middle-sized and smaller arteries; they are much less frequent in the pulmonary artery than in the aorta, and also more uncommon in the upper than in the lower extremities, where they moreover often appear spontaneously, while in the former they originate almost solely from mechanical causes. Aneurysms, both in men and animals, are observed by far the most frequently on the aorta, ${ }^{1}$ especially on its arch; next on the art. poplitea, ${ }^{2}$ the art. cruralis, the iliaca, ${ }^{3}$ the subclavia and axillaris, ${ }^{4}$ and the carotis $;{ }^{5}$ more rarely are they on the smaller arteries, viz. the coronaria cordis, ${ }^{6}$ the LESSER BRANCHES of the carotis on the head, as the maxillaris, temporalis, auricularis, occipitalis, ${ }^{7}$ \&c., on the vertebralis, ${ }^{8}$ the mammaria interna, ${ }^{9}$ the thyreoidea ${ }^{10}$ on the circumflexa humeri anterior, ${ }^{11}$ the ARTERIES OF THE FORE-ARM and HAND, ${ }^{12}$ on an intercostalis, ${ }^{13}$ bronchialis, ${ }^{14}$ on the celiaca 
and ITs BRANCHes, ${ }^{15}$ the mesenterica superior and inferior ${ }^{16}$ one renalis, ${ }^{17}$ spermatica interna, ${ }^{18}$ gluta ${ }^{19}$ ischiatica, ${ }^{20}$ pudenda, ${ }^{21}$ on the ARTERIES OF THE LEG and FOOT; ${ }^{22}$ and lastly, also on the PULMONARY ARTERY, ${ }^{23}$ and on the ductus arteriosus. ${ }^{24}$

(1) The first observation on aneurysm of the aorta was made by Vesalius. v. Boneti Sepulchretum anat. Lib. IV. sect. 2. Obs. 21.-Alex. Knips Macoppe Epist. de aortæ aneurysmate et polypo cordis. 8vo. Brixiæ. 1731.-1laller Pr. de aneurysmate aortæ. Göett. 1749.-Matani.-Ed. Sandifort Heel en ontleedkondige Verhandeling over eenen Slagader Breuk in de groote Slagader, etc. Gravenhage, 1765 ; Verbrugge, Lombardini, and Burns. - Naegele Epist. ad Th. Fr. Baltz, Qua hist. et descript. aneurysmatis, quod in aorta abdominali observavit, continetur, addita tab. ænea. 4to. Heidelb. 1816.-J. N. Heisler D. rariorem atque memoratu dignissimam ancurysmatis aortæ sternum perforantis historiam exhibens. Landishuti, 1817. - Laennec Des ancurysmes de l'aorte in De l'auscultation médiate, 1819, Vol. II. p. 404.-- Ehrhardt De aneurysmate aortæ Comment. anat. pathol. 4to. Lips. 1820, with five engravings. - G. Noverre D. sur les aneurysmes de l'aorte. 8vo. Paris, 1820.-H. Hartmann D. Observatio ingentis aortæ aneurysmatis. 8vo. Berol. 1828.-Many individual cases are collected by Verbrugge, Eberhardt, Scarpa, and Harles.-Puchelt Ueber aneurysmen der bauchaorta in Heidelb. klin. Annal. Vol. III. Part IV. No. 6 (with a case of his own); and Plouquet Repert.-I have nine times observed aneurysm of the aorta.-Compare my Verz. No. 2254-58, 8498, 8690.-In animals also, aneurysms of the aorta occur, especially on the posterior aorta in horses, of which I have seen many instances in the collections of the veterinary schools; such are described also by Grognier. v. Correspondance sur la conservation et l'amelioration des animaux domestiques par Fromage de Fengré, Vol. II. p. 97.Carrille in Annuaire de la Soc. de Méd. du Depart. de l'Eure, 1806, p. 308.Huzard in Bulletin de la Fac. de Méd. et de la Soc. de Paris, Ann. XIII. p. 45. -In Sus Tajassu. v. Danbenton in Allg. historie der natur, Vol. V. Part II. p. 22. - Edw. Tyson, The anatomy of a pigmy compared with that of a monkey, an ape, and a man, Se. Lond. 1731 (three behind each other).-Viverra Nasua, from a verbal remark of Ducrotay de Blainville.-Good engravings are also given in Littre in the Mémoires de l'Academ. R. de Paris, Ann. 1707.-Ruısch Observ. anat. chir. p. 37.-Haller Opera minor, Vol. III. p. 301, tab. 9.-W. Hunter, in Medic. Obs. and Inquiries, Vol. I. tab. 4 and 5.-Bayford, Ib. Vol. III. pl. 1.Walter, in the Mémoires de l'Acad. de Berlin, Ann. 1785, p. 56, tab. 1 and 2.Sandifort Museum anat. Vol. II.-Scarpa, pl. 8, fig. 1, 2; pl. 9, fig. 1, 2; translated by Harles, pl. 10, fig. 4, 5.-Baillie, Engravings, Fasc. I. pl. 3, fig. 2.Monro, Outlines of the anatomy of the human body, \&c., pl. 33-35.-Hodgson, pl. 2.-Meckel 'Tab. anat. pathol. Fasc. II. pl. 12, 13, 15, \&c.

(2) Sabatier D. de poplitis aneurysmate. Paris, 1772.-Massotti D. sull' Aneurisma del poplite. Firenze. 1772.-La Motte D. de poplitis aneurysmate. Paris, 1773.-Ang. Grima De poplitis aneurysnate. Malta, 1773. - Penchienati Recherches anat. pathol. sur les aneurysines des artères crurale et poplitée. 8vo. 1786 . -Windel D. de ancurysmate, præsertim de illo arteriæ popliteæ. Goett. 1795.Deschamps Observat. et Reflex. sur la ligature des principales arteres, et particul. sur l'A neurysme de l'artère poplitée. 2l edit. Paris, 1797.-Vaccà Berlinghieri Istoria d'un A neurisma del poplite.-Intchinson, Letter on popliteal aneurysm. 8 vo. London, 1811. The disease is very frequent in coaclimen and carriers.

(3) Alefeld D. aneurysmate arterix cruralis in cartilaginem et os mutato. Giessa, 1763. - Ad. Murray resp). Arvillsson D. in ancurysmata femoris observationes. 4to. Upsal. 1781. - Compare Lanth's Collection. - Hosok, Case of aneurysm of the femoral artery. 8vo. New-York, 1812.-Dawidowicz D. exhibens casum ancurysmatis arterix cruralis. 4to. Regiom. 1821, with a lithographic plate. - J. A. L. Casamajor Reflexions et Observations anat. chirurgicales sur l'ancurysme spontané en général et sur celui de l'artère femorale en particulier. 
4to. Paris, 1825, (he relates forty-six cases of spontaneous or artificial closure of the art. iliaca externa and interna.)

(4) A good engraving of an aneurysm in the armpit is given by Dupuytren in Répert. gén. d'Anat. et de Physiol. pathol. etc. Vol. I. No. 2, pl. 2. Paris. 18'26. -Sometimes they arise in this region from violent extension in reducing dislocation. v. Pelletan Clinique chirurgicale, Vol. II. p. 95. - Gibson in Philadelphia Journal by Chapmann, Vol. VII. No. 1, Nov. 1823. - Flaubert in Répertoire général d'Anatom. et Physiol.-pathol. Vol. III. Part I. p. 102, 1827.

(5) Both on the carotis communis, and on the externa and interna, a good engraving of an aneurysm of the carotis is given by Scarpa, pl. 8. fig. 4 and 5.-J. Vose D. de arteriæ carotidis aneurysmate. Edinb. 1809. - P. J. Y anderhagen D. sur l'A neurysme de l'artère carotide. Paris, 1815.

(6) Hedlund in Svenska Läkare-Sällskapets Handlingar, Vol. III. p. 181.In a man of forty years old it was fatal by bursting and effusion of blood into the pericardium.

(7) To wit, on the lingualis. v. Collomb QEuvres méd. chir. p. 451.- On the maxillaris externa. v. Gilibert Adversaria pract. prim. p. 3.-Ant. Petit in Mém. de Paris, 1765, Hist. p. 38, Mem. p. 480.-It also occurs here in horses.-On the art. palatina of a horse. v. Schwab Materialien zu einer pathol. Anatomie der Hausthier. p. 3. Ite Lief. München. 1815,-On the art. nasi externa. v. de Haen Ratio Mendendi. Part IV. p. 11. - On the art. frontalis. v. Acta cruditor. p. 51, Lipsiens. 1699; and Meckel in Journ. de Méd. Vol. XLVIII. p. 239.-On the art. temporalis. v. Palletta.-Scarpa, p. 529; and several instances in de Plouquet Repertor.-On the auricularis. v. Klaunig in Ephem. Nat. Cur. Cent. III. Amn. 1715. Obs. 66. - A. Cooper. v. Burns, p. 266.-On the occipitalis. v. Vidus Vidius Op. omnia. L. VI. - Vareliaud. v. Journ. d. ausländ. med. chir. Litt. 1803, Vol. I. p. 154.-Mejer D. de aneurysm. occipitali. Würceb. 1804.-Pelletan and Tartra; compare $\$ 193$, note 3.-Richter. v. von Froriep's Notiz. No. 24, p. 29, Feb. 1822 (as big as a pigeon's egg.) - Fr. E. Schilbach D. s. casum aneurysm. in capite virginis sexagenariæ rar. 4to Jenæ, 1825, with plates._Dopfer Geschich te eines Pulsaderbruches auf dem Kopfe in Beobacht. und Abhandl. aus dem Gebietc (ler gesammten prakt. Heilk. Vol. V. p. 416. Wien. 1820. I have a case at present in a living boy, who has water on the head and amaurosis; the aneurysm, however, is not on the occipitalis, but the strong pulsating tumour on the back of the head receives its blood distinctly from the skull, by a small hole in the upper part of the occipital bone.-On the meningeis. v. J. N. Holtorf Casus aneurysmatis in capite pueri 11 annorum. Argentorati, 1722.-Röderer De cerebri scirrho. 4to. Gött. 1762. - Stoerck v. Lieutaud Hist. anat. méd. Vol. II. p. 325. Lib. III. Obs. 54. - Malacarne Encefalotomia nuova umiv. p. 68, Torino, 1780 (as large as a pigeon's egg.) - Krimer in v. Gräfe and v. WValther's Journ. d. Chir. Vol. X. Part IV. p. 587, 1S27 (on the meningea media; the skull was perforated.)-On the carotis cerebralis, where it appears in the skull; I have found it twice ; similar cases were seen by Biumi in Sandifort Thesaur. III. p. 373.-Gilb. Blane, in Transact. of a Soc. for the improv. of medic. knowl. Vol. II. p. 193. - Baillie's Morbid anat. \&c. 1). 468. 5th edit. Lond. 1818.-Chevalier in Journ. univ. des Sc. medic. Janv. 1828 (on the cerebral arteries.) v. Bell, Anatomy of the human body, Vol. II.-Hodgson, p. 116, ff. and 177, (in four instances on the basilaris, and on the anterior cerebri.)-Serres Annuaire medico-chirurg. p. 314.-Ollivier Traité de la moelle épinière et de ces maladies, \&c. 8vo. 2 vols. Paris, 1827. Case 23.-Spursin in London medic. Repos. June, 1825 (on the cerebralis arterior.)-On the ophthalmica, v. Desessarz in Auserles. Abhandl. f. prakt. Aerzte. Vol. XVIII. p. 99, ff. The reason why the thin-coated arteries of the brain are proportionally found so rarely aneurysmal, depends on their being soon ruptured at the commencement. [In the Mus. St. Thomas's Hospital there is a beautiful preparation of aneurysm of the cerebralis media, about the size of a sinall pea, which burst and produced apoplexy; it illustrates extremely well the preceding observation. T.] I have, however, seen, a few times little ancurysms of the A. fossæ sylvii, of the $A$. corpus callosum, and once the $A$. cercbelli, but not larger than a vetch or a pea.--Chevalier in London Med. and Phys. Journal, by Macleod, new series, Vol. LVIII. 1827.-Abercrombie Patho- 
logical and practical remarks on diseases of the Brain and Spinal corcl. 8 vo. Edinb. 1828.

(8) Hence pressure on the spinal marrow ; one case in Heaviside's Cabinet. v. Hodgson, p. 116; and Howship, Practical Observations in Surgery and morbid anatomy, p. 59. Lond. 1816, - Malacarne found, in two instances, aneurysms on the arteries of the spinal marrow as large as peas.

(9) Sommer in der Petersburger Sammlung f. Naturwissenschaft und Heilkuust, Vol. II. Part II. p. 1.

(10) Especially in some cases of struma aneurysmatica, in which the arteries of the thyroid gland are rather generally enlarged.

(11) Portal, Cours d'Anatomie médicale, Vol. III. p. 236.

(12) On the radialis. v. Fischer in Mus. der Heilkunde, Vol. II. p. 276.On the arteries of the hand. v. Guattani De extern. Aneurysmat. Hist. XXI.Becket, Chirurgical Observations. - Hildanus Centur. III. Obs. 44. - Tulpins Observ. med. Lib. IV. Obs. 17.-Ranby in Chirurgical Observations.

(13) Ruysch Thesaur. anat. IV. No. 5. - Obs. anat. chir. XXXVIII. - Acta Eruditor. Lips. 1714, Sept. p.420. - Vylhoorn in der Holland Uebers. v. Heisteri Instit. chir.

(14) A.Leprottus in Comment. Bonon. Vol. I. p 345 and 353.

(15) On the cœliaca, v. Guerin, Vol.II. p. 348. - Nenci Observatio de disrupta splenica arteria. Siena. 1786.- [In Museum of St. Thomas's Hospital, aneurysm of the cœliac artery, which, by its motions against the stomach, produced vomiting whenever food was taken, and the patient died of consequent starvation.-T.] - Portal, p. 268.-Nysten in the Journ. de Médec. Chir. et Pharm. Oct. 1815. - Isenflamm Anat. Untersuchungen. Erlangen, 1822, p. 207.--On a twig of the coliaca. v. Lancisi, p. 64.-On the coronaria ventriculi. v. Portal.-Souville in Journ. d. Médec. Vol. L. p. 239._-Delmas in Annales đe la Soc. de Méd. prat. de Montpellier, Vol. VIII. Part I. p. 233, Sept. 1S06.On the splenica, v. Nenci.--Morgagni, Epist. III. p. 2. - Beaussier in Journ. de Médec. Vol. XXXII. p. 157.- Staupa Answeisung zur gerichl. und. pathol. Untersuchungen von menschlichen Leichnamen, p. 186, note. Svo. Wien, 1827. I have scen three times little aneurysmal explansions of the splenic artery, which camnot be confounded with their convolutions.

(16) Donald Monro in Edinburgh Essays, Sc. Vol. III.-They not unfiequently occur in horses and asses in the anterior mesenteric artery, and frequently contain worms, viz. the strongylus armatus minor, Rudolph. which, as they are often situated in tubercles in the arterial coats, and render them diseased, in many instances, are the cause of ancurysm. Compare Rudolphi Entozoor. v. vermium intestinal. historia naturalis. Vol. I. p. 437, Vol. II. p. 204, and Synopsis, p. 259.-Grognier in Journ. de NFédec. cont. 1810, Dec. p. 504.-Hodgson, p. 581, ff. with a good plate, in Engravings intended to illustrate some of the diseases of Arteries, tab. 8, fig. 2. 4to. Lond. 1815. - Greve Erfahrungen und Beobachtungen iiber die Krankheiten der Hausthiere, Vol. I. p. 105; hoth the latter have not always worms as the cause of aneurysm. One instance in Bresl. Mus. v. Verzeichniss, No. 2259.

(17) Ephem. Nat. Curios. Cent. IX. Obs. 59.-Julien in Journ. de Médec. Vol. XIII. p. 359.-Donald Monro.-Nenci.-Titius Pr. aneurysmatis arteria renalis sinistræe exemplum. Viteb. 1798.

(18) Vilhoorn.-Julien. Perhaps also here belongs the case of an aneurysm on the proper coat of the testicle. v. Bird in Mem. of the med. Soc. of London, Vol. IV. p. 406.-The situation of an aneurysin on the organs of generation, which was fatal by bursting, is doubtful. v. Osiander Denkwïrdigkeiten, Vol. I. p. 2. No. 1 .

(19) Joln Bell, Principles of Surgery, Vol. I. p) 421.-W. Stevens in Medic. chir. 'Transact. Vol. V. p. 422. [It has recently appeared, however, from the dissection of this case, v. Owen Med. chir. Trans. Vol. XVI. p. 219, that the diseased artery was the ischiatica, and not the glutea, as supposed. 'I'.] -Atkinson in Medic. and physical Journal, Vol. XXXVIII. p. 267.-White in American Journ. of the med. Seiences. Febr. 1828.

(20) E/hrmam Complte rendu, ctc. 1). 24, Strasburg, 1827. 
(21) B. S. Albinus Adnot. acal. L. III. p. 27, after violent extension of a dislocated limb.

(22) Guattani, p. 162, ff. (on the calf of the leg.) p. 176, Hist. XXII. (on the top of the foot after blood-letting.) - Ehrlich Chir. Beob. p. 104, (on the tibialis.) -van Esch Heelkondige Waarneeminge, etc. Gouda. 1772, (also on the tibialis from mortification.) - Tartra. v. Harles N. Journ. d. ausl. med. chir. Litt. Vol. V1I. Part I. p. 190, ff-Hodgson, p. 438.

(23) Andr. Caesalpin Catoptrices, Lib. VI. cap. 20. -Ambr. Paré. L. I. De tumoribus. Cap. XXVIII. - Blancard Anat. pract. rat. Cent. II. Obs. 74.Fabriz von Hilden Observat. et Cur. chir. Cent. II. Obs. 89. - Eggerdes in Misc. Acad. N. Cur. Dec. II. Ann. VI. 1687, p. 415.-Several instances are collected in Morgagni, Epist. XXIV. 36. - Matani De aneurysmat. præcordior. morbis. p. 145. - Baader Observ. med. incision. cadav. illustr. Frib. 1765.-Bach. v. Richter's Chir. Bibliothek. Vol. VIII. p. 498. - Eisenschmidt in Schmucker's Vermischt. Schriften, Vol. II. p. 241. - J. C. Stark in Abhandlungen der Erlanger physic. medic. Societät. Vol. I. p. 472.-I saw one instance in the Anat. Mus. at Strasburg. Compare Lobstein Compte rendu, etc. p. 35 .

(24) Pathol. anat. Atlas zur Erläut der Geschichte der Kinderkrankh. v. Billard, Taf. VII. fig. 1 .

\section{$\S 197$.}

Lastly, as to the TERMination of aneurism, this, if surgical assistance be not rendered, is necessarily mortal, as the tumour by continued extension at last bursts, and bleeding ensues. Should the consistence of the arterial walls be very much diminished, or the current of blood be very strong, even small aneurysms burst early. If the diseased artery be situated apart in one of the great cavities of the body, it usually at once bursts the surrounding thin serous membrane, and a fatal gush of blood takes place into the cavity of the skull, chest, pericardium or peritoneum $;^{1}$ if, however, the aneurysmal sac be directed towards the harder parts, and consolidated with them, the eflusion of blood does not take place into the great cavities of the body, but by preceding erosion of the neighbouring bones, membranes, \&c., either externally, ${ }^{2}$ or into the air tube ${ }^{3}$ and its branches, ${ }^{4}$ the gullet, ${ }^{5}$ the stomach, ${ }^{6}$ the intestines, ${ }^{7}$ the urinary bladder, ${ }^{8}$ even into the heart and other blood-vessels. ${ }^{9}$ If the aneurysm occur on the external parts of the body, then the blood is effused among the muscles, into the aponeuroses and beneath the skin, all which parts it greatly expands, and becoming more or less coagulated, forms a continually increasing tumour, which at last assumes an inflammatory and gangrenous disposition, and produces a slough of those parts of the common integuments which are most distended, upon the immediate or repeated throwing off of which fatal hemorrhage ensues. It is interesting to observe, how the conservative power of the system strives to prevent this melancholy termination of the disease: the fibrous part of the blood being, in the later stages, naturally deposited in more or less thick and concentric layers within the 
aneurysmal sac, which is thereby remarkably strengthened. ${ }^{10}$ In rare cases a spontaneous cure is thus effected, inasmuch as the aneurysmal sac is entirely filled with fibrous matter, whilst the artery itself remains pervious, or more commonly the fibrous matter fills up the whole artery as far as the last collateral branch. In not less rare cases the spontaneous CURE of the aneurysm is effected by the aneurysmal sac itself, which having become enlarged and hard from being filled with fibrous matter, compresses its artery, and produces adhesion; or the sac is destroyed by the inflammatory shutting up of the artery, with simultaneous suppuration and mortification. ${ }^{11}$

(1) A. Burns, On some of the most important Diseases of the Heart, p. 258, first pointed out that the serous membranes, into the cavities of which internal aneurysms had been effused, were not destroyed like mucous membranes, and the common integuments by suppuration or mortification, but by bursting.Hodgson, p. 86, confirmed this, as also can I from several cases which have come before me.-In rare cases the blood of a burst aneurysm of the thoracic aorta does not empty itself into the chest, but penetrates between the legs of the diapluragm in the cellular tissue behind the peritoneum, and thence first makes its way through the peritoneum into the cavity of the belly. v. Richerand Nosogr. chirurg. $2 \mathrm{~d}$ edit. Vol. IV. p. 82.-Scarpa, Sull' Aneurysma, found, on the contrary, an aneurysm rf the abdominal aorta, which penetrated into the chest.-Morgagni Epist. XL. p. 29. - Aneurysms near the heart burst soonest, and naturally into the pericardium. Effusion of blood from aneurysm into the left pleura is common, but very rarely into the right pleura and mediastinum. v. My Selt Beob. Part 11 . p. 65.-Hodgson, p. 4\$1, mentions two cases in which ancurysm of the aorta burst in the mediastinum and mesentery, and so caused death.

(2) Aneurysms of the arch of the aorta sometimes ascend into the neck, and may be confounded with aneurysm of the carotid and subclavian; most commonly, when they do not burst internally, they perforate the breast-bone, the neiglibouring ribs, or the clavicles, dislocate the latter, and form, inore or less, large tumours on the front of the chest. Instances are mentioned by J.Lefaye in Phil. Trans. 1700, p. 666.-Morgagni De sed. et caus. Morbor. Epist. XXVI. 9. - Morand in Mém. de Paris, 1721, Hist. p. 30. - Weltinus D. de aneurysmate vero pectoris externo, hemiplegia solole. 4to. Basil, 1750. v. Lauth's Collect.-Verbrugge D. de aneurysmate, I. B. 1778, fig. 4. tab. 1-6.--Ephem. Nat. Cur. Cent. V. and VI. Obs. 74:--Ehrlich Chirurg. Beob. p. 93, 95, 96.Schreiber in Nov. Comm. Petrop. Vol. III. Hist. p. 36, Mém. p. 401.-Weikard Vermischte medicinische Schriften, Vol. II. No. 6.--Armane in Sédillot's Recueil périod. de la Soc. de Santé de Paris, Vol. X. p. 390.-Compare above $\$ 136$, note 29 , and $\$ 137$, note 18 ; also Scarpa in IIist. et Mém. de la Société de Méd. 1780 and 1781, Hist. 290.-Rosemuiller in Harles' translation of Scarpa, 1. 364.-Biermeyer Mus. anat. pathol. p. 94, No. 575. Vindob. 1816. - N. Heisler De rariorem atque memoratu dignissmam aneurysmatis aorta stermum perforantis historiam exhibens. Landish. 1827. - Hodgson, p. 105, case 17.--Laennec De l'Auscultation inédiate, Vol. II. p. 431.-Cerulti Beschreibung der pathol. Pr:̈iparate $z$ Leipzig, No. 286, engraved in Ehrhardt Comm. de aneurysmate aorta, tab. 3.-Pfeufer in Horn's Archiv für medic. Erfahrungen, 1824, May and June, p. 4.52.-A. Cooper, Lectures on the principles and practice of Surgery Vol. 11. 1). 31 . -Comprare also Lientand Hist. anat. med. ed. Schlegel, Vol. II. p. 255, Obs. 796 , $805,810,811,814,816,823,824,827,830,831,832$, \& c.-Sometimes such tunours do not burst externally, but sink down again, because the aneurysmal sac is more expanded inwardly. Very rarely such aneurysm, having run into suppuration, actually bursts, but it discharges no blood. v. Delort in Nouvelle Biblioth. médic. May, 1826. - Aneurysus of the descending arta frequently destroy the hinder 
part of the ribs and their vertebrx, and protrude through the ribs as larger or smaller swellings.-Compare de Heyde Observat. med. 8vo. Amstel, 1686, No. 34. -Noortwyck Obs. de gibbo ab aortæ aneurysmate, ad Solani Observ. de pulsu. 8vo. Amstel. 1746.-- Walter Sur les maladies du Cœur in d. Nouv. Mém. de Berlin, 1785. - Lieutaud Hist. anat. med. ed. Schlegel, Vol. II. p. 253, ff. No. 795 and 809.-Horn Archiv f. prakt. Medecin. Vol. IV. p. 290.-Kreysig Herzkrankheiten, Vol. III. p. 176 , ff.--Laennec, p. 429, ff.--Cerutti Beschreibung der pathol. Präparate zu Leipzig. No. 285, engraved in Ehrhardt Comm. de aneurysmate aortæ. Lips. 1820, tab. 4.--Salomon in Petersb. vermischten Abhandlungen aus dem Gebiete der Heilkunde. 3te Samml. 1825, p. 164, pl. 2.--Schión in Hecker's Litter. Annalen d. ges Heilk. Sept. 1828, p. 10, in two cases.--A. Cooper, Vol. II. p. 30-35, in the latter case the aneurysm was mistaken for lumbar abscess. - In the cases of Kreysig and Salomon, the blood penetrated even into the spinal canal. -J. Rainy in London Med. and Phys. Journ. Dec. 1827.

(3) Boneti Sepulchret. anat. L. II, § 5, Obs. 8. - Lieutaud Hist. anat. méd. Vol. II. p. 258. Obs. 802.-Hall, in Medical Observations and Inquiries, 1784, Vol. IV. p. $23 . \quad$ v. Richter's Chir. Biblioth. Vol. 1X. p. 376. - Richerand in Mém. de la Soc. méd. d'Emulat. Ann. IV. p. 345. - Corvisart. - Newbolt in London medical Repository, March, 1826, Vol. V. No. 27.-Biermayer Museum anat. patholog. Vindob. 1816, p. 96, No.96. - Mandruzzato in Memorie scientifiche e letterarie dell' Ateneo di Treviso. Vol. I. 1817. - Hodgson, p. 134, case 17.-Mussey in the New-England Journ. of Medic. and Surgery, Vol. VII. No. 2. Boston, 1818. - Noverre D. sur les Aneurysmes de l'Aorte. Paris, 1820.Andral in Archives général. de Médec. Nov. 1823, p. 466. - Ward in London medical Repository, Vol. XXI. No.131. Nuv. 1824. - Bertin Traité des maladies du Cœur, etc. p. 107.- H sselbach Beschreibung der pathol. Präparatezu Würzburg, p. 279, No.550. - Meriadec Laennec in Revue médic. franç. et étrangère, 1825, Vol. IV. p. 3. - Hensinger Erster Bericht der anthropotom. Anstalt zu Würzburg, 1826, Pref. p. v. - Schön, in two cases. - A. Cooper, Vol. II. p. 32.- I also saw engravings of such cases at Venice, at Allietti's.

(4) In the cells of the lungs. v. Pelletan Clinique chirurgicale, Vol. I. p. 89. J. O'Reardon in Graperon Bulletin des Sc. médicales, Vol. II. p. 411. - Laennec, Vol. II. p. 63 and 427 . - In the bronchus. v. E. Fritz D. s. Observationem de aortæ aneurysmatis in bronchum ruptura. 4to. Gryphiæ, 1817, with engravings; and Richerand. In the left bronchus. v. Fleury in Ephem. médic. de Montpellier, Vol. VI. Nov. 1827.

(5) Sauvages Nosologia methodica, Vol. II. p. 29S.-Matani De ancurysmat. pracordior. morbis. $\$ 62$, p. 120.-Laforgue in Bulletin de la Soc. de Médec. p. 154.-App. zum Journ. de Médecine continué, Vol. XIV.-Armiger in Medico-chir. T'ransact. Vol. II. No.21, p. 244. - O'Reardon in Journ. génér. de Médec. Chir. et Pharm. Dec. 1808; and in Graperon Bulletin des Scienc. médicales, Vol. II. p. 441. - Dupuytren in Corvisart Sur les Maladies et lésions organiques du Cœur et des gros vaisseaux.-Bertin v. Bulletin de la Fac. de Médec. et de la Soc. de Paris, 1812, p. 14.-Raikem and Bouvenot, ib. p. 181.-Bricheteau in Bulletin de l'Athenée de Médecine de Paris, Dec. 1816. - Copeland, Observations on the symptoms, \&c. of diseased spine. 8vo. London, 1815. - Laennec De l'Auscultat. méd. etc. Vol. II. p. 427, (in three cases.)-Cerutti Beschreibung der patholog. Präparate zu Leipzig, 1819, p. 156, No.743. - Becker in Rust's Magazin f. die gesammte Heilkunde, Vol. XX. Part III. p. 447, with plates.-Bertin, p. 110. - Proudfoot, in Edinb. med. and surg. Journ. 1824. - Stanpa Anweisung zur gerichtl. und pathol. Untersuchung menschl. Leichname. Wien. 1827, p. 168.*-A case in the London medical and physic. Journal, by Macleod, Aug. 1827, Vol. LVIII. - Th. Molison, in Transact. of the med. chir. Soc. of Edinburgh, Vol. III. Part I. p. 173. - Also in animals, viz. in a nasua, from the verbal communication of de Blainville.

(6) IIndgson, p. 75.--Staupa.

(7) Hodgson, p. 75. - A. Comstock, in Philadelphia Journal, Vol. XIII. p. 318, with engravings, (an aneurysm of the aorta opened into the flexura iliaca coli.) - A. Cooper's Lectures, Vol. II. p. 35. 
(8) Hodgson, p. 75. - Perhaps also here belongs the case observed by A. Cooper, Vol. II. p. 36.

(9) For instance, aneurysm of the aorta in the right auricle. v. Med. chir. Journ. Vol. VI. p. 617. - Bulletin de la Soc. de Médecine à Paris, 1810, No.3, p. 38 ; or in the pulmonary artery. v. Wells in Transact. of a Soc. for the Improv. of med. and chir. Knowledge, Vol. III. p. 85. - Sue in Bulletin de l'Ecole de Médec. et de la Soc. de Paris, 1S09, p. 128.-Payan and Zeink in Bulletin de la Faculté de Vedecine, 1819, No. 3, (two cases.)-Journ. de Médec. continué, Vol. XXIV. p. 124; and Bulletin de la Faculté, etc. Vol. XVII. p. 16.

(10) Kreysig thinks that the layers of fibrous matter in aneurysmal sacs originates in effusion from the walls of the artery. v. Herzkrankheiten, Vol. II. p.3S8, and note to Hodgson, p. 124; whilst to me he seems to say, that the external layers are the firmest ; the innermost are, on the contrary, the weakest, and that the quantity of fibrous matter collected is by no means proportionate to the vascular weakness of the vessel, which is often indurated, or very much expanded, and thin arterial coats. - $\boldsymbol{A}$ s such coagulum is but rarely found in angiectasy, and as seldom missed in aneurysm, so the ancients improperly distinguished both forms of the disease by the coagula.

(11) Hodgson, p. 100, ff, treats admirably of the spontaneous cure of aneurysm, and many individual cases in de Plouquet's Repertorium Art. Aneurysma, and in surgical writers. - Some new cases are given by Howship, Practical Observat. in Surgery and morbid Anatomy, Case 110, (the art. femoralis.)--R. Archer, in American medical Recorder, by Eberle, Vol. VI. Art. 3. Philadelphia, October, 1823 , (the femoral artery.) - W. Beack, $i b$. Jan. 1824, (the art. femoralis, from cold.) - H. Lyford, in the Lancet, Vol. XII. p. 767, (also the femoral.)$J$. Clocquet in Gazette de Santé, 1825, No. 3, (the right subclavia.)-Many cases of spontaneous cure of the Art. iliaca externa and interna, are collected by Casamajor, Reflexions et Observat. anat. chir. sur l'Aneurysme spontanée, etc. 8vo. Paris, 1825. - An interesting case is described by $W$. Darrach, in Philadelpluia Journal, Vol. XIII. p. 115. Compare Magazin der ausländ. Litt. der ges. Heilk. Sept. and Oct. 1827, p. 338. It was an aneurysm of the arch of the aorta, in which the truncus anonymus was closed, and the blood flowed from the left subclavia through the much enlarged and anastomosing arteriæ thyreoidex inferiores, to the right subclavia. [In Mus. St. Thomas's Hospital, a fine example of spontaneous cure of aneurysm of the femoralis, by the aneurysmal sac compressing the artery between itself and the thigh bone; it is mentioned in Cooper's Lectures on Surgery, Vol. II. p. 47 . 'T.]

\section{$\S 198$.}

The unnatural widening of vessels and aneurysmal tumours, naturally lead to the consideration of VICES OF CONSISTENCE $\Lambda$ ND ConTINUITY in the arterial system. The first arise, perhaps, in many cases without distinct change of the arterial tissue, in diminution of elasticity, and in alteration of nourishment; but usually they are consequent on actual change of texture, as inflammation and its various terminations. 'The DIMINUTion of CONSISTENCE, with which we are alone concerned, is not unfrequently to such extent, that the mere strong current of blood, or slight stretching or concussion of an artery, produce gradual extension, or fine cracks, mostly in the transverse direction of the two internal membranes, whence arises the first disposition to aneurysm. Sometimes the disposition to rupture in the arteries is so great, that SPONTANROUS TEARINGS of all the coats of the artery occur 
independent of any of the just-mentioned causes. ${ }^{1}$ In many cases also arteries burst, if their walls have been weakened by suppuration and mortification. To wounds of arteries belong ruptures from violent extension, ${ }^{2}$ then cut, thrust, and contused wounds. ${ }^{3}$ If in thrust wounds of arteries, which may occur both in fractures of bones by bony splinters, ${ }^{4}$ or swallowing pointed bodies, ${ }^{5}$ the external wound is healed, whilst the blood continues pouring from the still open wound in the vessel into the cellular tissue, then it is called a spurious aneurysm. ${ }^{6}$ If the wounded vessel be not too large, Nature stays the hemorrhage, and cures the wounded artery thus, the vessel itself contracts at its extremity, and often for a considerable distance up, and if, as is usually the case, it lies in the loose cellular tissue, it retracts, ${ }^{7}$ whilst the effused and coagulated blood compresses the end of the artery, and closes it by an internal plug of blood, thrombus, coagulum internum. The latter now becomes firmly adherent to the artery, by subsequent inflammation and pouring out of lymph, which is thus healed by being closed, usually up to the nearest superior branch, and is gradually converted into a kind of tendinous-like band. A similar inflammatory shutting up of arteries occurs after ligature, in which besides, both the inner coats of the vessel are transversely divided, by the indentation of the ligature on the part, and thus easily give rise to the curative effusion of lymph. ${ }^{8}$ As to the collateral vessels by which, after adhesion of an artery, the blood takes its course, it is difficult to decide whether they be merely vessels which had previously existed, increased in size, or whether they be partial new productions. ${ }^{9} \quad$ Small cut and thrust wounds, especially if they be longitudinal, heal in rare instances without closing of the artery by firm cicatrices $;^{10}$ so also such wounds of arteries, in which merely the external coat is destroyed, are rendered tough by the coagulable lymph which is effused. ${ }^{11}$

(1) v. several cases in de Plouquet and Reuss's Repertor. Art. Ruptura Arteriarum. - Morgagni, Epist. LIII. 35, 36, (the aorta.) - Bohn De officio medic. dupl. Cap. IV. p. 390, (a branch of the carotis.)-Pyl Aufsätze und Beobacht. aus der gerichtlich. Arzneiw. Vol. IV. Obs. 7 and 8, (the aorta.) - Vogther and Kausch's Memorabilien der Heilkunde, u.s. w. Vol. III. (the right pulmonary artery.) - Hodgson, p. 391, (the brachial artery from an accident, of which a similar ease is mentioned by Saviard, Observ. Chirurg. 7 th Observation.) - Bonsdorf resp. Wegelius D. anatomicam veneficii arsenico peracti investigationem sistens. Abo. 1817, (the vertebral artery from violent bending backwards of the liead.) - [In Mus. St. Thomas's Hospital, the right vertebral artery ruptured in fracture of the cervical vertebræ. T.] - My Selt. Beob. Part II. p. 66, (the aorta.) - Hamilton in London Med. and Phys. Journ. Vol. LVII. p. 506.-Rose, ib. Vol. LVIII. (the aorta; two other cases of rupture of the aorta are also mentioned.) - Simpson in Trans. of Med. Chir. Soc. of Edinburgh, 1824, No. 22, (the pulmonary artery in a clild.) - J. Adam in the Trans. of the Med. and Phys. Soc. of Calcutta, Vol I. 1827, (in the pulmonary artery.) - It is well known that 
we often find the arteries of the brain burst in apoplexy, also branches of the pulmonary artery in violent coughing. - [A case of rupture of the pulmonary artery. v. W. Gumn in Edinburgh Med. and Surgical Journ. 1829. T.]

(2) For example, in clislocations and the extension employed to replace the bone. v. Petit Traité des maladies des os. Vol. I. p.179, (the brachial artery.) Pelletan Clinique Chirur. Vol. II. p. 95, (the brachial artery.) - P'opinel in Graperon's Bulletin des Sc. Medic. Vol. III. p. 253, (the femoral artery in dislocation at the hip.) - Gibson in Philadelphia Journal, by Chapmann, Vol. VII. No. 1, Nov. 1823, and the Lancet, Vol. III. p. 90, (the brachial artery.) Flaubert in Répertoire gén. d'Anatomie et de physiol. patholog. 1827, Vol. III. Part I. p. 102, (the brachial artery.)-When the whole limb is torn off, the arteries bleed proportionally, but little on account of their great extension; sometimes they are even stopped by the cellular tissue drawn around them. [A beautiful instance in the Mus. St. Thomas's Hospital, shewing the mode employed by nature in sealing up a torn artery, by the drawing over it the surrounding cellular tissue, in a man whose thigh was torn off by a cable. T.]

(3) Shot and other contused wounds of arteries are fatal, because often after eight or more days, when the slough is thrown off, the artery is opened.

(4) White's Cases in Surgery, p. 141.-Bell, Principles of Surgery, Vol. I. p. 337, 368.-Pelletan Clinique Chirurgicale, Vol. I. p. 178.-I have had an opportunity of examining a case in which the coracoid process of the scapula being shot off, had injured the axillary artery and given rise to a false aneurysm on the arm.

(5) The aorta was torn by a piece of bone which had been swallowed sticking in the gullet. v. Luuren in Archives générales de Médec. Oct. 1824.

(6) Compare above, $\$ 194$. They occur most frequently in consequence of bleeding in the arm over the brachial artery; they occur however accidentally in almost all the arteries, even in the aorta from stabs. v. Guattani De externis aneurysmat. Hist., p. 26.-Pelletan, Vol. I. p. 92.

(7) Hence arteries, which do not lie in the loose cellular membrane, but being attached to the bones cannot retract, as the A.meningex, alveolares, nutritix ossium, \&c. bleed even for a long time and very much.

(8) Ligatures sometimes produce the closure of an artery in a very short time, and even if the ligature be again loosened. If the artery be tied at some distance from the wound, or the aneurism, there is often danger from a collateral stream of blood, in which case the artery sometimes is only closed at a small point. The closed wounds of arteries in amputated limbs are often consolidated so closely with the cellular tissue of the surrounding parts, that it is impossible to separate them. The most important works on injuries, spontancous cure, and ligature of arteries, are Petit Mémoire sur la maniere d'irrêter les hemorrhages. I. and II. in Mém. de l'Academic des Sc. de Paris, 1731 and 1732._Morand Sur les changemens, qui arrivent aux artères conpécs, etc., ib. 1726. Hist. p. 58. Mém. p. 321.-Th. Kirkland, Essay on the method of suppressing hemorrhages from divided arteries. Svo. Lond. 1763. - Pouteau Mélanges de Chirurgie, 8vo. Lyon, 1760. - le Comte Resultats de quclques experiences tentées sur plusieurs animaux, pour faire l'essái de la nouvelle methode de traiter les plaies des artères in Hist. et Mém. de lá Soc. Roy. de Médec. 1776, Hist. p. 305.-Callisen D. de vulneriluus arteriarum. Havnix, 1788.-Deschamp Observ. et Reflex. sur la ligature des principales artères blessées et particulièrement sur l'A neurysue de l'artère poplitée. Svo. Parris, 1797. - Mannoir Mémoires pliysiologiques et pratiques sur aneurysme et la ligature. Geneve, 1802.-Jones, $\Lambda$ treatise on the process employed by nature in suppressing the hemorrliage from divided and punctured arteries, and on the use of the ligature. Sro. Lond. $1 \mathrm{~S} 06 ; 2 d$ edit. 1810, with fifteen plates.-B. Travers in Medic. chirurg. 'Transact., Vol. IV. p. 435, and Vol. VI. p. 632.-W. Lawrence, $\Lambda$ new method of tying the arteries, S.e. ib. Vol. VI. p. 155, and further olsservations on the ligature of arteries, $i$. Vol. VIII. Part II. 1. 490.-Béclard Recherches et Experiences sur les Blessures dess Artères in Mém. de la Soce. méd. d'Limulation, 1816, Part 11. 1. 569.A. Scarpue Memoria sulla legatura della principali arterie degli arti, con una appendice all'opera sull' ancurisma. Ato. P'avial, 1S18. -Vacea Berlinghieri Me- 
moria sopra l'allacciatura dell' arterie. Pisa, 1819.-Lettere del $A$. Scarpa al Vaccu Berlinghieri sulla legatura delle grosse arterie degli arti e riposta alla midisima di V'acca Berlinghieri. 8vo. Pisa, 1820.-L. Koch D. de præstantissima amputationis methodo. Landish. 1826, and Ueber die Amputation and die Hinweglassung der Ligatur der Gefässc in von Gräfe and von Walther's Journ. der Chir. 1827, Vol. IX. p. 560,-Theoph. Ebel D. de natura medicatrice sicubi arteriæ vulneratæ ct ligatæ fuerint. 4to. Giessæ, 1826, with six plates.

(9) From my observations, I believe that both occur. Experiments on the reproduction of blood-vessels are found in Cal. Hillier Parry, An experimental inquiry into the nature, cause, and varieties of the pulse, and certain other properties of the larger arteries in animals with warm blood. Illust. by engravings. London, 1816.- Ib., Additional experiments on the arteries of warmblooded animals. London, 1819.-A. E. J. C. Mayer Disquisitio de arteriarum regeneratione. 4to. Bonnæ, 1S23, with engravings.-G. Salemi Sull' uso del premiarterie. Palermo, 1825. - v. Schönberg Memorie sul ristabilimeno della circolazione nella legatura o anche recisione del troncli delle arterie, con le conchiusioni immediate, illustrate da esperimenti e disegni. Napol. 1826.-A. Zhuber Neue Versuche an 'Thieren und deren Resultate über die Wiedererzeugung der A rterien, mit beigefügten Bcmerkungen darüber. 8vo. Wien, 1S27, with three lithographic plates.

(10) Scarpa Sull' ancurisma, p. 230.-Hodgson, p. 455 and 467.-Cruveilhier Essai sul l'anat. patholog. Vol. I. p. 330, (the cicatrization doubtful.) In one case I found the little opening in the artery produced by blecding, still open after two months. v. No. 8797 , Bresl. Mus.

(11) Hunter and Ev. Home in Transact. of a Soc. for Improv. of Med. Knowleclge. Vol. I. 1. 144.

\section{$\S 199$.}

Among the vices of texture of arteries, inflammation, arteriitis, ${ }^{1}$ deserves, from its frequency and importance, the first place. This occurs, not only especially in all the blood-vessels of inflamed parts, but also frequently in the arteries alone, especially in the large ones, as an idiopathic or deuteropathic disease. We observe it frequently in inflammatory fevers, in the neighbourhood of local inflammation, in eruptive diseases, in hydrophobia, gout, rheumatism, syphilis, in mechanical injuries of arteries, ${ }^{2} \& c_{0}$; and in aneurysm and wounds of arteries it is produced by intentional pressure and ligature, in order to effect the usually consequent adhesion of the vessels. The seat and degree of this inflammation is subject to numerous varieties. Most commonly the inner or serous coat of the artery alone is inflamed, in a greater or less degree, which we distinguish by its more or less intense red colour, greater softness and solubility, by its opacity, its loss of lustre, in the larger arteries by a slight thickening, and especially by a large net-work of vessels spread over the external surface of their fibrous coat. This distinct inflammatory state must not be confounded with the often very similar although generally somewhat dull red colour of the inner arterial coat, which is observed not very unfrequently in a peculiar disposition of the blood to impart colour, in arteries which are putrid, which have been frozen and then thawed, as also such as have been dried by the air, 
in asthenic fevers of men and other animals, ${ }^{3}$ and, lastly, as consequent on effusion of blood, ecchymosis between the coats of an artery. ${ }^{4}$ Phlegmonous or general inflammation of all the coats of an artery is more rare, which we can distinguish, not merely by the already described signs of inflammation of the internal coat, but also by swelling, loosening, more easy separability, and by greater injection of both the outer arterial coats.

(1) Morgagni De sed. et caus. morbor. Epist. XXVI. 35 ; Epist. XLIV. 3.J. P. Frank Epist. de cur. hom. morb. I. I. \$118. - Schmuck D. de vasorum sanguiferorum inflammatione. Heidelb. 1793. - Sasse D. de vasor. sanguiferorum inflammatione. Halæ, 1797.-Portal Cours d'anatomie médicale. Vol. III. p. 127 (on the aorta.)-Spangenberg Ueb. die Entzündung der Arterien in IIorn's Archiv für medic. Erfahrung, 1804, Vol. V. p. 269. - Testa On inflammation of the aorta, in his Delle Malattie del Cuori, Sc.-Patissier in Bulletin de la Faculté de Médec. de Paris, No. 10, 1815, (lieart and large vessels.) - Kreysig Herzkrankheiten, Vol. II. p. 86, ff; Vol. III. p. 269.-Hodgson, p. 3.-Laennec De l'auscultation médiate, P. II. p. 353. - W. Sprengel in Rust's Magazin, Vol. VII. p. 475 , (the brachial artery, after injury to the thumb.)-Bard in Revue médicale, Mai, 1820, (almost all the arteries.) -Meli in Annali univers. di Medic. comp. del Omodei, Vol. XVII. and XVIII. Jan._Jun. 1821, (all the arteries and veins.)-Jemina de Mondovi on Aortitis thoracica acuta, ib. 1824. -Montesanto ib. Vol. XXXVI. No. 5, 1825 (in the aorta, A.innominata, carotis, and subclavia.)-Bertin Traité des maladies du Cœur, 8c. par Bouillaud, Liv. I. Paris, 1824._- inanchon v. Edinb. Journ. of medical science, July, 1816 ; and von Froriep's Notizen, No. 320, p.183, October, 1826.-Berard in D. sur plusicurs points d'anatomie pathologique, No. 3, Paris, 1826. - R. Bright, Reports of medical cases, Sc. 4to. London, 1827, (three cases.)-Hinterberger in der Medic. chir. Zeitung, 1828, p. 31, ff, (the aorta in pregnant and lying-in women.) - B. Locatelli $\mathrm{D}$. de Angioitide $\mathrm{s}$. de vascularis sanguiferæ provinciæ inflammationibus. Patav. 1828. - Gendrin Histoire anatom. des inflammations. 2 vols. 8vo. Paris, 1826. - [ Elliotson on Inflammation of the aorta, in his Discases of the Heart, p. 33 . T.]

(2) I consider the inflammation of the artery, especially that of its serous membrane, by no ineans a rare disease; inasmuch as I have not merely often met with it in dead bodies, the previous state of which I could know nothing about, but also several times in diseases which I had previously conducted. In my younger days I thought I was the subject of aortitis, in consequence of very severe cold, in which a very distinct and painful pulsation of the aorta, high fever, and great sensibility of skin were the symptoms exhibited.-Also in animals, I have several times seen inflammation of the internal coat of the aorta, and of the heart, especially in horses, and most severe in a young horse, which had a large alsscess in the thigh. In a few instances, of dogs which had died of hydrophobia, and in one destroyed by inflammation of the heart; and in many foreign animals, which frequently die in menageries, of inflammation of the heart. - In children which have heen destroyed by measles and scarlet fever, I have found arteriitis.-Portal, after measles - Testa, in other eruptive diseases. - Tanchon, in fifty persons who died under small-pox, \&c.- In syphilitic persons who have taken much mercury, and after catching cold have died of inflanmatory diseases, I have twice found inflammation of the inner-coat of the aorta, and of the larger branches springing from it.-Morgagni, and Epist. XVIII. p.27; and Testa, have several examples of arteriitis in persons affected with the venereal disease.-Others also have derived arteritis from syplilis and the use of mercury; viz. Lancisi De aneurysmatibus edit. Lauth, p. 52. - Corvisart, 1).307. - Richerand Nosographie Chirurgicale, Vol. IV. 1). 7\%.-IIodg.son, 1\%.9.-I have even seen, in phthisis, the intermal coat of the pulnonary artery, and of the aorta, inflamed several times; and this once also in a child, in which the greater part of the stin had been scalded with hot water. 
(3) Compare above, $\S 35$ and 36 , on the redness of the inner-coat of the aorta. v. Corvisart, p. 334.-Hodgson, p. 7.-Laennec, Cliap. XVII. p. 353.-Troussean and Rigot, in Archives générales de Médecine, Oct. 1826, and July, 1827.

(4) Compare $\$ 37$. - Good instances are given by Boerhaave Progr. med. Vol. I. p. 242; and Prælect. in Instit. Vol. III. p. 501, No. 827, in a stout ox and in a hunted hare. - van Swieten Comment. in Aphorism. Boerhaavii, p. 171, in a hunted stag. - Morgagni, Epist. XXVI. p. 13; Epist. XXVII. 28, with rupture of the aorta.-Testa, p. 210, after violent coughing.-I have myself found such extravasations on the internal coat of arteries in a child which died of whooping-cough; in some asthmatic persons; in one person killed by choke damp, and in some drunkards and hanged people, on the aorta, and sometimes also on the larger branches.- Sometimes I have also found the larger arteries, in amputation, of a bright violet colour, for an inch or two. - I lave seen, also in high degrees of inflammation of the aorta, in a few instances, some little drops of pale blood between the coats of the arteries.-Laennec found the violet colour produced by ecchymosis, in those persons especially who had died with severe struggles.

\section{$\S 200$.}

A more or less copious EFFUSion of COAGULABLE LYMPH is a frequent consequence of arterial inflammation. If this occur in and between the coats of the artery, there is often consequently distinct thickening, also an intimate adhesion and consolidation of the three coats with each other, as has been observed, for instance, frequently in aneurysmal sacs; if the exudation occur on the external surface, the artery adheres more or less firmly to the neighbouring parts ${ }^{1}$ should it take place on the internal surface of the artery, it gives rise to obstruction, narrowing, and obliteration or closing of the vessels. ${ }^{2}$ The latter is the consequence intended in artificial compression and ligature of arteries, as well as the means whereby Nature herself cures wounds of arteries, and sometimes even aneurysms. ${ }^{3}$

(1) For example, aneurysms with the bones, the air-tube, gullet, \&c.-Amputated arteries in the cicatrix with the neighbouring parts. - In one instance the axillary artery was torn in reducing a dislocation of the. shoulder, in which it was adherent to the capsule of the joint. v. Gibson in Philadelphia Journ. edited by Chapmann, Vol. VII. No. 1, Nov. 1823.

(2) I have already described above, $\S 192$, some examples of the spontaneous obliteration of individual arteries. I have also lately found, in the body of an old man, the left subclavian artery very much narrowed, witliout any distinct cause, but the left carotid completely closed. v. No. 8680 , of Bresl. Mus.; and in another case the cœliac artery thickened and completely closed, No. 2266, of my Verzeichn.-Lardner in Edinb. Med. and Surg. Journ. Vol. VIII. Part XXVII. No. 4 , one carotid artery from pressure of a thickened gullet.

(3) Compare $\S 198$.

\section{§201.}

The less frequent terminations of inflammation are suppuRATION and MORTIFICATION. The former appears to occur most commonly, in consequence of chronic inflammation on the innermost coat of hardened arteries, but without the formation of pus, and is thus rather erosion. In this vice is often the origin of mixed aneurysms, as well as of rupture of 
arteries. Much more uncommon is the true suppuration of arteries $^{1}$ in which the disease is seated, either primarily in the vessels, or more commonly in the parts immediately adjacent to the artery; in both cases the artery is easily perforated by ulceration, and thus gives rise to bleeding, ${ }^{2}$ unless the existing inflammation have previously closed the vessel. MortificaTION does not appear to occur primarily in the arterial system, indeed the tissue of the artery seems to withstand, for a tolerably long time, the sloughing which affects the neighbouring parts. ${ }^{3}$ But if at last the vascular system also runs into sloughing as well as all the other parts, so consequently bleeding would be produced, either by the percolation of the blood towards the softened tissue, even by the incisions often made into mortified parts, finally, by the spontaneous or even artificial amputation of the neighbouring mortified parts; whilst the arteries, by the inflammation preceding gangrene, are sometimes stopped up by a plug of coagulated blood, sometimes are actually adherent and closed. ${ }^{4}$ But only in those cases in which a large artery is destroyed on one side by the mortification of neighbouring ulcers, wounds, \&rc., is dangerous hemorrhage to be dreaded.

(1) Morgagni Epist. VII. 9.-Mcckel primus. in Mém. de Berlin, p.43, 1756.v. Haller Opuscula pathol. Obs. 22, p. 500.-Weilbrecht in Comment. Acad. Petropol, Vol. IV. p. 263.-Scarpa Sull'Aneurisma reflessioni, Sc. translated hy Wishart, 8vo. Edinb. 1808. - Recamier in Journ. de Mél. Chir. et Pharm. Vol. XI. p. 30.-Lobstein Compte rendu à la Faculté de Strash. 1S20, 1\% 11\%, No. 433, 435 and 437.- I have several times scen ulceration of the femoral artery from suppuration of the inguinal glands. v. No. 2269, my Verzeichniss. Compare Gendrin, Vol. II. p. 48.- [In Mus. St. 'Thomas's Hospital, there is one instance of ulceration of the femoral artery from sloughing bubo, and another from discase of the hip-joint.-Luke, wound of carotid? from abscess. v. Med. Gazette, Vol. V. p. 333. T.]

(2) To wit, ulcerous perforation of an aorta not ancurysmal and eflusion of blood into the gullet. v. van Doeveren Observat. anat. pathol. Obs. 1, with engrav. and Sandifort Mus. anat. Vol. II. tab. 105 and 106. - Perforation of the gullet and aortil, in consequence of a piece of money sticking in the former, and effusion of blood into it. v. Martin in La Clinique des Hopitaux et de la Ville, Vol. I. No. 23, p. 30. - The femoral artery. v. Cruikshamks Anatomy of the absorbing vessels, Sc. 4to. 1786 . - The aorta. v. P. Franl De cur. hom. morb. L. V. 2, p. 17. - F'anzago Osservazione di un ulecre nell' aorta. A.to. Padova, 1816, with engraviugs; and in Memorie sopra alcumi perai morbosi, etc. Fasc. I. p. 7, tab 1. - Biermayer Mus. anat. pathol. No. 477, and Eingberg and 1. Retzius in Ars. Beräittelse om Svenska Läkare-Sailskalpets $\Lambda$ rbeten, lemnad of Elistroem, 1825. - 'The coronary artery of the heart. v. J. Traine in London Med. Repository, Feb. 1815.- The coronary artery of the stomach, the splenic, and one pulmonary artery. v. Ilodgson, ). 11.--'The femoral artery. v. B. Truvers in London Med. and Physic. Journ. $\Lambda$ pril and July, 1827, in two instances, and Gibls, ib. Aıg. 1827.

(i) I have examined the arteries, thougl slightly, in several eases of latal mortification of the mpper and lower extremities; and indeed, in one case, in which an aneurysma spuriun diflusum was fatal from mortification of the anm and the adjacent hatf of the thorax, by the closest examination, I could not discover any injury of the artery. 
(4) Compare especially $J$. Thomson's Lectures on Inflammation, \&c. Edinb. 1816, p. 352.

\section{\$202.}

Inflammation of arteries appears to have such consequent vices of texture as answer to the hardening of the other tissues in general, but here exhibits many peculiarities. To these belong the already-mentioned FRANGIBILITY AND DRYNESS of the arterial coats, especially of the innermost, which is then found simultaneously lustreless, often also puckered, discoloured, and easily separable from the other coats; further, there is often very distinct THICKENING and INDURATION of the walls of the artery by the effusion of coagulable lymph into its cellular tissue; next, the conversion of certain spots into a Cartilaginous substance, and, lastly, ossification. ${ }^{1}$ The latter appears under various forms; thus in rare instances, as little distinct specks of bone in the previously formed plate of cartilage, surrounded by a large vascular circle; or more commonly as a pap-like substance, sometimes white, sometimes yellow, consisting of phosphate of lime and albumen, a milky fluid, very similar to fluid lime, ${ }^{2}$ which gradually becomes firmer, leather-like, at last bony; and finally as earthy or gypsum-like small specks and flakes, not unfrequently exhibiting traces of crystallization. These three kinds of ossification'often occur at once in a large artery, for instance the aorta, and then at the same time form more or less numerous isolated or closely approximated irregular bony scales, indeed even actual unbroken bony cylinders, which prevent the approximation of a divided artery, and in the application of a ligature on it, break like a cracked eggshell. ${ }^{3}$ These ossifications have their original seat always between the serous and fibrous coats of the artery, although in their increasing thickness they destroy by pressure and irritation not unfrequently parts of both coats, ${ }^{4}$ so that within they are immediately washed by the blood, and project into the cavity of the artery as irregular plates, generally yellow, or as points and processes, which is often very much narrowed and even filled with them. ${ }^{5}$ Ossification of the arteries is but rarely observed in young persons, ${ }^{6}$ very frequently, though by no means as a natural condition, in more advanced age, ${ }^{7}$ perhaps somewhat more frequently in men than women, and by no means equally common in all parts of the body. Thus we observe, for instance, the smaller much more rarely than the larger arteries, those of the upper less frequently than those of the lower extremities,--very rarely the pulmonary arteries, ${ }^{8}$ the arteries of the walls of the chest and belly, and perhaps those of the 
alimentary canal and liver are never ossified; on the contrary, commonly the aorta, the angle of the carotids, the arteries of the pelvis, of the brain, of the thyroid gland, the heart, the spleen, kidneys, \&c. In beasts also we sometimes find ossification of certain arteries, although less frequently than in man. ${ }^{9}$

(1) W. Cowper, On Ossifications or petrifications in the coats of Arteries, \&c. in Philos. Transact. 1705, p. 1970.-Kulmus D. de tendine Achillis disrupto, et arteriis in osseam naturam conversis. Gedan. 1730. v. Haller's Diss. chir. Vol. V. No. 153.-Crïwel De cordis et vasorum osteogenesi in viro quadragenario observata. Halæ, 1755, with engravings. - Haller Elem. Physiol. Vol. VIII. Part II. p. 80, and Opusc. pathol. Obs. 59-Morgagni De sed. et caus. morbor. o: many parts. v. Index. - Pohl D. de ossificatione vasorum. Lips. 1774.-Malacarne in Osserv. in Chirurgia. Vol. II. Torino, 1784. Art. XII. p. 160, ff. -J. van Heelieren De osteogenesi preternaturali. I. B. 1797, p. 116.-Scarpa, Sull' Aneurisma.Loustein Mémoire sur les ossifications des artères in the Mém. de la Soc. des Sc., Agriculture et Arts de Strasbourg, Vol. I. p. 338, ff.-Lucae De depositionibus cretaceis intra cordis valvularum arteriarumque substantiam. 4to. Marburg, 1815 , and Accelerandæ liter. in universitatibus perfectionis subsidias quasdam commendat et de ossescentia arteriarum senili quædam præfatur. 4to. Marburgi, 1817. - Cruveilhier Essai sur l'Anat. pathol. Vol. II. p. 52, ff. - Hodgson, p. 19. - Meckel Handb. der pathol. Anatomie, Vol. II. 2, p. 183.-Rosenthal in Horn's Archiv, June and July, 1818. - Wedemeyer in Rust's Magazin f. d. ges. Heilk. Vol. XIII. p. 194, ff.-C. H. Ehrmann Recherches sur la structure, les fonctions et les alterations organiques des Artères. 4to. Strasb. 1822, p. 41.-Many instances of complete ossification of the whole aorta, or of almost all the arteries at once, may be found in Morgagni, and in de Plonquet's Repertorium, Art. Aortæ et Arteriarum Ossiticatio.-A few striking instances of ossified aorta are given by J. P. Frank Sclbstbiographie, Wien, 1802, p. 57 and 58; Salzb. medic. chir. Zeitung, 1811, Vol. I1. p. 185.-Hagström in Ars. Berättelse om Svenska LäkareSällskapets Arbeten of Gadelius. Stockh. 1810.-Biermayer MIus. anat. pathol. No. 458. -The Bresl. Mus. also possesses many remarkable cases. Good plates are given in Baillie's Engravings, tab. 4, fig. 2, 3.-Hodgson, tab. 1.-J. F. Meckel, Tal. anat. pathol. Fasc. II. tab. 14, fig. $1-3$, tab. 16. - As these calcareous deposits increase the friability of the arterial coats, so also do they frequently give rise to the bursting of arteries, as well as to aneurysm.

(2) Many writers not quite correctly call this a steatomatous, or atheromatous inass.

(3) The cylindrical ossification of arteries is certainly much more rare than the scattered or scalc-like; it is, however, by no means so rare as many writers have supposed. I have no inconsiderable number of such arteries of a middling and small size, forming bony tubes nearly a foot long, viz. the femoral artery, the anterior and posterior tibial, the radial, ulnar, Sc. I have not found it in the aorta, although it is sometimes so stiff that it prevents flexion of the body.

(4) The distinction between bony concretion and ossification assumed by Cruveitheir and $W^{r}$ edemeyer, and following them also by Spitta, in Die Leichenöffnung in bezug auf Pathologie und Diagnostik, Stendal, 1826, p. 2.22, is, as is generally the case, so also liere, on account of the thimness of the membranes, doubly difficult to make out. It appears to me that the original deposition of lime never takes place in the membrane itself, but in the thin layer of cellular tissuc situated on the outside of the serous coat, in which, as in all similar membranes, there is a very large network of blood-vessels. $\Lambda$ s the bony scales become thicker, the subjacent serous membrane is torn, stretched, and at last is entirely destroyed by erosion. The same also appears to occur on the external surface with reference to the muscular coat, the filbres of which are pressed by the bony mass intruding between them in form of little corns or transverse fibres, are separated from each other, and at last completely wasted; but they never are actually converted into bone any more than other museles. If the bony scales becone still thicker, the cellular coat itself is rendered atrophic. An actual conversion of 
the arterial coats into bone, therefore, according to my opinion, never occurs. Oftentimes there are also produced upon the interior of the bony scales already deposited little deposits, somewhat differing in colour, more transparent and very brittle, almost crystaline, the chemical analysis of which is still to be desired.

(5) This in many instances is the cause of gangræna senilis. Compare $K u l$ mus.-Morgagni, Epist. LV. 26.-Cowper, Vol. XXII. p. 1195, and Vol. XXIV. p. 1970. - Naish, ib. Vol. XXXI. p. 226. - Rossignolly in Journ. de Medec. Vol. IX. p. 307.-Steigerthal in Phil. Transact., No. 367 and 369.-v. Mohrenhein Beiträge zur prakt. Arzneik. Vol. II. p. 214.-Charitius Pr. de arteria crurali ossea, per œdema, gangrænamque siccam letali. Viteb. 1798.-Thomson, Lectures on Inflammation, 1813, p. 537.-Hodgson, p. 41.-Cruveilheir Essai sur l'Anat. pathol. Vol. II. p. 57.-James, Observation, \&c. on Inflammation. Lond. 1821.A. Cooper, Lectures, Vol. I. p. 240.

(6) Cowper, No.299, (in a man of thirty years.)-Böhmer Observ. anat. rarior. Fasc. I. Præf. p. ix. - Penada Saggio di Osservaz. Vol. II. p. 22. Padova, 1800.Portal Cours d'Anat. médic. Vol. III. p. 133, p. 63. - Scarpa.-Young found the temporal artery of a child, fifteen months old, completely converted into a calcareous cylinder. v. Hodgson, p. 23.-I once found incipient ossification of the aorta in a girl of seventeen. v. Selt. Beob. II. p. 66, No. 29.; also a few times ossification of the cerebral arteries in people about thirty years old. On the semilunar valves of the aorta, and in the ductus arteriosus Botalli, ossification occurs not unfrequently in young persons.

(7) As for instance, Cowper, p.1970, supposed. According to Baillie. v.Transact. of a Soc. for the improvement of Med. and Surg. Knowledge, Vol. I. p. 133, it is in persons of sixty years old more frequent than the healthy state; and according to Bichat, Anat. gén. Vol. II. in every ten persons of sixty years it occurs in at least seven of them; according to Lobstein also it is very common in this class of people. The use of wine, cider and other strong liquors, may in England and France render the deposition of lime in the arteries proportionally more frequent, as it is well known that lithiasis is more common in those countries. Here, in Silesia, ossification of the arteries is much less frequent, according to the reports; even in the West Indies it is said to be still more rare. v. Stevens in Med. chir. Trans. Vol. V. p. 34.-In persons who have been subject of syphilis, and are filled with mercury, in gouty people, in those subject to piles, in wine and brandy drinkers, in gourmands, \&c. I find it most common. On the contrary I miss it in a great number of very aged persons entirely free from dyscracies; so also we hardly ever find it in very old animals. - In many instances the disposition seems to be hereditary. v. Testa Delle Malattie del cuoro, \&c. 3 vols. 8vo. Napoli, 1826 ; and Kreysig Die Krankheiten des Herzers, Vol. II. Part I. p. 346. These ossifications do not appear to me to be a mere sign of deficient vital activity in old age. 'Their increase also, as Hodgson, p. 23, has justly observed, is not in proportion to the increase of age; and, as far as we can add, as little in morbid disposition of the body to other ossification. It appears to me much rather the consequence of a peculiar irritation, partly dependent on climate, partly on dyscracy, originating in climate and mode of living, and the so frequent creeping inflammation of the serous coat of the arteries.

(8) Bichat improperly denies the existence of ossification in it; in the blue disease, lowever, the deposition of cartilage and lime in the valves of the pulmonary artery is not unfrequent; other instances also are given by Riolan and Vesling. v. Cruveilhier Essai sur l'A nat. pathol. Vol. II. p. 53.-Chomel in Mem. de Paris, 1707, Hist. p. 26.-Burnet D. de polyposis concretionibus varior. in pectore morbor. causis. Altd. 1729. - Pohl D. de ossificatione vasor præternaturali. Lips. 1774. - Sandifort Observ. anat. pathol. L. I. p. 22. - v. Mohrenheim Beiträge zur prakt. Arzneik. u.s.w. Vol. II. p. 215. - Stoll Ratio Medendi. Vol. I. p. 200.-Lobstein, No. 434, in Strasburg Museum.-An instance of this in a young woman who died of consumption, I saw in the Anat. Museum at Freyburg. - A case in an ox. v. Grimm in Eph. Nat. Cur. Dec. II. Ann. III. Obs. 38, p. 108.

(9) Grimm in Misc. Acad. Nat. Cur. 1684, Dec. II. Ann. III. p.108, (in oxen.) -In the collection of some Veterinary School, I remember having seen slight 
ossification on the aorta of horses; on the creliac and anterior mesenteric arteries however they occur principally in the horse.-I once saw in an old monkey which died of tubercles, yellow earthy spots on the aorta, and in an old otter a large, prominent, hard pointed bony concretion on the same artery. v. my Verzeichniss, No. 3957.

\section{$\S 203$.}

To the most rare vices of texture which have been observed in the arteries, belong the FUNGous LOOSENING OF THEIR INTERNAL COAT, and the various IRREGULARITIES and GROWTHS which project into the cavity of the vessels. ${ }^{1}$ If cancer and medullary sarcom of neighbouring parts approach large arteries, these also as well as other structures are affected, and then exhibit TUMOURs of various sizes, especially in their cellular coat. $^{2}$ The latter is also the especial seat of ENCYSTED TUMOURS, ${ }^{3}$ SCROFUlous SwEllings, ${ }^{4}$ and TUBERCLES CONTAINING WORMS, ${ }^{5}$ which in rare instances have been found in men and brutes. Finally, the arteries also sometimes exhibit anomalies in respect to their contents, as in many diseases they, though naturally found empty, contain a considerable quantity of $\mathrm{BLOOD}^{6}$ even in their larger trunks, or LYMPH in a fluid or coagulated state $;{ }^{7}$ in rare cases even worms, ${ }^{3}$ and loose STONY CONCRETIONS. ${ }^{9}$

(1) It is often very difficult to make out what the ancients meant by excrescences, tubercles, and pustules; they are in reality the deposits of lime already mentioned in the last section; for instance, Morgagni, Epist. XI. 15; XVIII. 8; XXVII. 28; LXIV. 5 ; but in other cases they appear to be true thickenings and growths from the internal coat; to wit, Epist. XXVI. 17 ; XLIV. 3.I have myself found several times the internal coat loose and fungous-like, in other instances thick, fleshy, knotty, and hardisl. v. also Hodgson, Sect. IV. p. 23.-Adelmann found a spot on the interior of the pulmonary artery, thickly studded with some firmly attached growths of a bluish green colour, and the size of peas, consisting of a viscid jelly. v. Harles Rhein Jahrb. der Melic. und Chir. Vol. I. p. 177.-Yelloly found the arteria innominata, the left carotid and subclavian arteries very much narrowed by growths from their internal coat. v. Mell. chir. Trans. Vol. XII. Part II. p. 565, with an engraving. - Hodgson, p. 18, case third, mentions a growth on the femoral artery, and compares it to the growths on the valves of the heart; but it appears to me nothing more than inflammatory exulation. What was the nature of the pedunculated growth which Crnickshank found at the origin of the pulmonary artery, and whether it was situated within or without, I cannot mention, as I cannot find the place.v. Soemmerring's additions to Baillie's Morbid Anat. p. 10, note 35. - liecamier. once found in the subclavian a polypous-like concretion, with a firmly attached extremity. v. Laennec De l'auscultation médiate, Vol. II. p. 353.

(2) I have sometimes observed this on the aorta.- In a case mentioned ly Fabriz Hildanus, the aorta and vena cava were so compressed by a scirrhous tumour that gangrene of the foot took place. v. Saml. Cooper.

(3) For instance, in the coats of the aorta. v. Stenzel D. de steatomatibus in aorta repertis. Viteb. 1723, and in Haller's D. ad morb. hist. et curat. facient. Vol. II.--Donald Monro in Med. Essays and Observ. Vol. II. Art. 16, p. 237.Stemulifort Mus. Anat. Vol. I. No. 11, 1).242.-Beauchene in Bulletin de la Suc. de Méd. $\Lambda$ p. to the Journ. de Médec. contin. Vol. XI. 1) 225. - Corvisart Essai sur les maladlies du Coeur, 1806, p. 314. - 'Two examples of encysted tumours, as hig as walnuts and oranges, 1 saw upon the aorta of a horse in ' $)$. Vete- 
rinary School at Munich.-Sometimes encysted and other tumours lying close upon large arteries are mistaken for aneurysms, by the pulsation which they exhibit. I have seen two such cases, one on the neck and the other on the thigh.-A similar case is described by Tabarrani Observ. Anat. v. Haller's Bibl. chir. Vol. II. p. 249.

(4) I have occasionally seen scrofulous swellings so close to the carotid and aorta, that it was impossible to remove them without injury to the external coat of the vessel. - Perhaps hereto belong the tubercles observed by Sandifort, Observ. anat. J. IV. Cap. X. p. 109; and Mus. anat. Vol. I. No. IX. p. 242.

(5) viz. On the anterior mesenteric artery of the horse and ass; on the aorta of a dog. v. Morgagni Epist. anatom. Epist. IX. Art. 44-46. Patav. 1764.

(6) The notion that the arteries in death are always emptied of their blood is incorrect; it is by no means uncommon to find a large quantity of blood in them. - 1 have most frequently observed this in persons who have been lianged, killed by drinking, by fire-damp, after inflammatory and eruptive diseases, in ossified arteries, and in many corpses, in which I could find no sufficient cause. Also in hydrophobia and epilepsy, I have found a tolerable quantity of blood in the arteries.

(7) On these coagula or false polypus, compare $\$ 184 .-$ Also Palin and Knips Malioppe Epistola de Aortæ polypo. 8vo. Brixæ, 1731.

(8) Compare $\$ 196$, note 16. - Perhaps the bloody mass, in which Rodman found five living ascarides, (?) was a popliteal aneurysm. v. Edinburgh medic. and surg. Journ. 1814, Vol. X. Part XXXVII. No. 6 ; in the pulmonary artery of the delphimus phocæna, the strongylus inflexus, Rud. has been found sometimes singly, at other times in great numbers.-I found the same in the year 1818, in some porpoises which I dissected at Edinburgh.-They have also been found by $W$. Vrolik. v. Bijdragen tot de natuurkundige Wetenschappen, versaineld door van Hall, W. Vrolik en Mulder. 8vo. Deel I. No. 1, p. 77. Amsterd. 1826; and v. Baer, v. Nov. Acta Acad. Nat. Cur. Vol. XIII. Part II. p. 560, note.

(9) In the Anat. Mus. of the Surgical Academy at Copenlagen, I found a round stone, as large as a pea, which, according to the account given, was from the spermatic artery; probably it is a venous stone.-Wight loose stony concretions liave, however, been found in an aneurysmal sac. v. Biermayer Mus. anat. pathol. p. 101, No.360, the largest of which is as big as a plum.

\section{Fourth Chapter.}

\section{Of the Veins.}

\section{$\S 204$.}

The veINS ${ }^{1}$ are said to be completely and entirely wANTING in some monsters ${ }^{2}$ but generally they exist, even when there is neither heart nor arteries, in which case the umbilical vein serving the purpose of an artery divides, and carries the blood directly to all parts of the body, or a kind of vena cava is formed, or finally, it goes at once into the principal artery. ${ }^{3}$ We not unfrequently observe numerous variations in the veins as to their origin and course. ${ }^{4}$ The following are the most important: the CORONARY VEIN of the heart opens in the left instead of the right auricle, either alone, ${ }^{5}$ or together with the 
pulmonary artery ${ }^{6}$ and in one instance into the left subclavian vein $;^{7}$ the lesser coronary vein sometimes at once sinks into the right auricle. ${ }^{8}$ In imperfect formation of the heart, there arises BU'T ONE INDIVIDUAL DISTINCT VEIN FOR THE WHOLE BODY, ${ }^{9}$ or the veins of the body and of the lungs already divided spring from one and the same auricle $;^{10}$ both vence cavae are UNITED INTO A SINGLE VENOUS TRUNK from the right auricle; ${ }^{11}$ the vence cave, with normal position of the great arteries of the heart, sink into the left auricle, whilst the pulmonary veins, on the contrary, proceed to the right. ${ }^{12}$ Several times has the superior venc cava been found double, whilst the left jugular and subclavian veins united into a single left trunk, which commonly proceeded around the base of the heart in the course of the great coronary vein to the right auricle, ${ }^{13}$ or in rare cases to the left auricle, ${ }^{14}$ or still more rarely terminated in some other unusual place. ${ }^{15}$ The single BRANCHES of the superior vena cava, especially the smaller, as the pericardial, the thymic, ${ }^{16}$ bronchial, thyroideal, and superficial veins of the neck, \&c. are subject to very numerous variations in their origin and course. The hemiazygous vein is sometimes wanting $;{ }^{17}$ it and the azygous are double, terminate in the coronary, ${ }^{18}$ in the vena innominata, ${ }^{19}$ and oftener in the jugular and subclavian veins of both sides. ${ }^{20}$ The superficial JUGULAR veIN varies very much, sometimes it is so large that it gives off the greater number of the superficial veins of the face and skull, and forms two or more large trunks on the neck; ${ }^{21}$ the DEEP JUGULAR VEIN sometimes divides itself very early into its two larger branches ${ }^{22}$ the VERTEBRAL VEINS are deficient, ${ }^{23}$ or on the contrary, they are seen double $;^{24}$ the sinuses of the brain also, in rare instances, vary from what is regular. ${ }^{25}$ Of the VEINS OF THE ARM, the subclavian has been once seen double $;^{26}$ the cephalic vein is not unfrequently entirely deficient or terminates at the lower edge of the deltoid muscle ${ }^{27}$ the median vein also varies uncommonly, inasmuch as it is not unfrequently wanting, is double, and variously connected with the cephalic and basilic. ${ }^{28}$ The inferior vena cava has been several times observed very irregular in reference to its origin and course ; it sprung, for example, out of the left auricle, ${ }^{29}$ or from the superior vena cava, whilst it took in its further course, the unusual direction of the azygous and hemiazygous veins $;^{30}$ or it did not receive the hepatic veins, so that these entered as a distinct venous trunk into the heart: ${ }^{31}$ it was also double or divided unusually high up, ${ }^{32}$ its position has also been observed reversed..$^{33}$ Of the BRanchiss of the inferior vena cara, 
the emulgent, the capsular, spermatic and pelvic veins, vary considerably in their origin and number; the DEEP VEINS OF THE LOWER LIMBS are tolerably constant, though the femoral vein, like the artery, divides sometimes higher, sometimes lower, and the veins of the leg vary in a similar manner to the arteries of the same part. The superficial veins of the lower extremities vary much more commonly; thus, for instance, the great saphenous vein perforates the femoral sheath at very different parts, in many instances it is lost in a net-work without forming a trunk, in other instances it forms two distinct parallel trunks, it also supplies the place of the lesser saphenous, when, in rare instances, that vessel forms no peculiar trunk, which sinks into the ham. ${ }^{34}$ The veins on the foot in which we bleed are as little determinate in their position and connexion, as those on the back of the hand, but are subject to many varieties. The pulmonary veins are sometimes branches of the superior vena cava, ${ }^{35}$ or arise from the right auricle, ${ }^{36}$ or vary in number, so that they are all connected to one trunk, ${ }^{37}$ or merely on one or both sides to one common trunk $;^{38}$ also five, six, and even seven pulmonary veins occur. ${ }^{39}$ I once found a semilunar valve at the opening of a pulmonary vein. ${ }^{40}$ In headless monsters the PORTAL VEIN is always entirely wanting, and the veins which it usually forms then arise either from the vena cava, or the umbilical vein; in rare cases the portal vein does not terminate in the liver but in the inferior cava. ${ }^{41}$ The UMEILICAL VEIN also sometimes exhibits varieties, thus, for instance, it is manifold $;^{42}$ or it enters the liver at an unusual part $;{ }^{43}$ or it sinks into the vena cava, ${ }^{44}$ into one of the mesenteric veins or into the splenic ${ }^{45}$ sometimes even directly into the heart. ${ }^{46}$ In one instance it connected itself with a remarkable branch springing out of the right iliac vein. ${ }^{47}$ Sometimes it remains open and carrying blood, for a long time after birth, even in adults. ${ }^{48}$ The ductus venosus arantii is sometimes entirely wanting; ${ }^{49}$ the vena omphalo mesaraica was, in one adult, found open and containing blood..$^{50}$

(1) Compare several of the writers quoted on the arteries at § 185.-de Haller Pr. de aortæ venæque cavæ gravioribus quibusdam morbis observationes. Gœett. 1749.-Delius Pr. de vena cava plena malorum. Erlang. 1751.-Puchelt Das Venensystem in seinen krankhaften Verhältnissen dargestellt. 8vo. Leipz. 1818.Gurlt D. anat. pathol. de venarum deformitatibus adnexo vitii rarioris venæ cavæ inferioris exemplo. 4to. Vratisl. 1819, with lithogr. plates.-Breschet Recherches anat. physiol. et pathologiques sur le systême veineux et specialement sur les canaux des Os. Liv. I. p. 6. fol. Paris, 1828-29, with plates.-Stahl D. de vena portæ, porta malorum hypochondriacorum. Halæ, 1698. - de Bertholdi D. priinæ lineæ morborum venæ portæ. Viennæ, 1777.

(2) Schelhammer in Ephem. Acad. Nat. Cur. Dec. II. Ann. IX. 1690, p. 253, ff.; and Winslow in Mérn. de l'Acad. àes Sc. 1740, p. 817, ff. (both in acephalous monsters.)-Marrigues v. Mém. de Mathen. prés. à l'Acad. des Sc. Vol. IV. 
p. 123, ff. ; and Sammlungen medicin. Gutachten. Leipz. 1776, p. 276, ff, (in children without hearts.)

(3) Compare J. F. Meckel Handb. der pathol. Anatomie, Vol. I. p. 162, ff.Tiedemann Anatomie der kopflosen Missgeburten. fol. Landshut, 1813, § 75, p. 96, ff.-Elben D. de acephalis s. monstris corde carentibus. 4to. Berol. 1821, p. 108, ff.

(4) J.F. Meckel, Ueber den Verlauf der Arterien und Venen, in his Deutschen Archiv f. d. Physiologie, Vol. I. p. 285, ff., endeavours to make out the rarity of venous in comparison with arterial variety; but I cannot agree with this opinion, as the number and difference of the varieties are really much greater than are there mentioned, and the comparison of the variation of the vessels arising from the aorta, No. 4-19, with the single duplication of the superior vena cava, does not appear to me quite correct, as the branches which arise from the venæ innominatæ, and the commencement of the thyroideal and subclavian veins, certainly do not vary less frequently than the arteries which have been named. But as to the middle and smaller veins, especially the cutaneous, these run into an endless varicty, so that I can boldly assert, of the superior thyroideal, the veins at the bend of the elbow, and on the back of the hand, they are never, even in a single person, the same on both sides in the same individual. Two supernumerary venous trunks (which?) are described by Menieres, in Archiv. génér. de Médec. Vol. XI. March, 1826.

(5) J. F. Meckel Handbuch der Menschl. Anat. Vol. III. p. 67.

(6) Lemaire in Bulletin des Sc. med. 1810, Vol.V.; there opened two coronary veins into the pulmonary artery ; in another case, the large coronary vein was entirely deficient, the middle opened in the left superior cava, and a third, coming from the under part of the heart, terminated in the right auricle, by one of the thebesian openings. v. Murray, in Svenska Vetensk. Academiens nya. Handlingar, 1781, Part IV. p. 282.

(7) Le Cat in Mémoires de l'Acad. des Sc. 1738, Hist. p. 62.

(8) I found this twice. Murray once saw, in deficiency of the great coronary vein, a coronary vein open immediately in its stead; v. A. Murray in Svenska Vetensk. Academ. nya. Handl. 1781, p. 282.

(9) For instance, Roederer in Comm. Soc. Gotting. Vol. VI. p. 125.-Mayer in v. Graefe and v. Walther's Journal d. Chir. Vol. X. p.4t, ff. - Cerutti Rarior. monstri, in museo anat. Lipsiensi adservati, descriptio anat. 4to. I Lips. 1827.

(10) Standert in Philos. Transact. 1805, Part II. p. 228.-Meckel Handb. d. pathol. Anatomie, Vol. II. 1, p. 52, (in a double monster.) - Farre Pathol. Researches, Essay I. Malformations of the human heart, p. 2, Lond. 1814.Fleischmann Leichenöffnungen, p. 197.-Mauran in Philadelphia Journal, Vol. XIV. p. 253.

(11) Wichert Descript. monstri duplicati. 8vo. Dorpat, 1824, p. 25 and 27.

(12) I observed this in a double human monster, No. 8014 of Bresl. Mus. yet to be described.

(13) Bartholinus Histor. 84, Cent. II.-Theune præs. Boehmer D. de confluxu trium cavarum in dextro cordis atrio. 4to. Halæ, 1763, with plates; and Boelmer Observat. anat. rarior. Fasc. I. Præf. p. xii.-A. Murray.-J. F. Meckel, four cases. v. Handb. der pathol. Anat. Vol. II. 1. p. 125.-Tabulx anat. pathol. Fasc. II. tab. 10, fig. 6 and 7 ; and Archiv f. d. Physiol. Vol. IV. p. 479. Béclarl in Leroux Journ. de Médecine, Vol. XXXVI. p. 115.-Weese D. de cordis ectopia. Berol. 1819. p. 30. tab. 6.-Küstner in Bereicherungen für d. Geburtshülfe, etc. by Choulant, IIaase, Küstner, and Meissner, Vol. I. p. 50, (this is the same case described by Weese.) - Bock in Cerutti's Pathol. anat. Mus. Vol. I. Part III. p. 50. - M yself in three instances. v. My Selt. Beob. Vol. II. p. 69; and Verzeichniss, No. 2874. - IIesselbach Beschreibung der pathol. Präparate zu Würzburg, p. 229. - Wirtensohn D. duor. monstror. duplicium humanor. descript. anat. p. 22. 4.to. Berol. 1825.-Wehrde D. anat. pathol. de monstro rariore humano. p. 11. 8vo. Halæ, 1826.-Breschet Recherches anat. physiol. et pathol. sur le Systeme veineux, etc. I. I. p. 2. Paris, 1827.

(1+) Breschet in Répertoire général d'anat. et de pliysiol. pathol. Vol. II. 
p. 12 ; in another case, in the left side of the single auricle, p. 17.-Barkow Monstra animalium duplicia, Vol. I. p. 16. 4to. Lipsix, 1828.

(15) For instance, in the right auricle, close to the right upper vena cava.v. Hesse D. Monstri bicipitis descriptio anatomica, p. 21, tab. 2. 8vo. Berol. 1823. In another case, both the superior venæ cavæ joined eacls other very shortly before their entrance into the right auricle, but had there two distinct orifices.-Rosenthal Abhandl. aus dem Gebiete der anatomie, physiologie, und pathologie, Berlin, 1824, p. 150 ; or in the inferior vena cava. v. Niemeyer D. singularis in fœetu puellari recens editio abnormitatis exemplum. p. 7, 4to. Halæ, 1814.

(16) One thymic vein, as large as a writing-quill, sunk at once into the right auricle of a child affected with the blue disease. v. Marechal in Journ. géneral de médecine, Vol. LXIX. p. 354.

(17) Sömmerring Vom Bau des menschlichen Körpers. 2d edition. Vol. IV. p. 470 .

(18) Compare Haller Elem. physiol. Vol. III. sect. I, p. 107; and Wrisberg Observationes anatomicæ de vena azyga duplici aliisque hujus venæ varietatibus. Goett. 1778, rev. in Sylloge Diss. p. 127.-J, as well as many others, have several times found hoth veins entirely or partially double; the latter is also engraved by Mascagni in Vasor. lymphat. c. h. historia et ichnographia, Senis, 1787 , pl. 19.

(19) Sylvius Vesani calumniarum depulsio XVII. in Op. p. 144. - Le Cat in Mémoires de Paris, 1738, Hist. p. 62, (with one branch in the right and the other in the left auricle.)-Sömmerring p. 469; the hemiazyga in a cat, in the left auricle. v. Barkow, Vol. I. p. 115.

(20) The vena azygos in the right subclavian. v. Wrisberg, (by a canal in the upper lobe of the right lung.) - Breschet, p. 12, ff. 16. I once observed a similar case in a man. The vena azygos very rarely terminates in the lower vena cava, within the pericardium, v. Soemmerring, p. 474; or in the upper cava, v. Cheselden, in Phil. Trans. Vol. XXVIII. No. 337; or in the right vena innominata, v. Wrisberg, p. 136, and J.F. Meckel Handbuch der menschl. anat. Vol. III. p. 350. More frequently the vena hemiazyga, instead of going into the vena azygos, empties itself through the left superior intercostal vein, into the left subclavian, which I have seen several times, as also have WVrisberg, Fleischmann Leichenöffnungen, p. $228 ; J . F . M e c k e l$, p. 350 . In some of these instances, the vena hemiazyga has also terminated in the azyga; the hemiazyga sometimes terminates in the thyroideal vein. v. Cerutti Beschreibung der Pathol. präparate zu Leipzig, No. 765 and 766. I have also once seen it terminate in the azygous and the left subclavian, at the same time; in one case, in which the inferior cava extended upwards, the hemiazyga terminated in the left vena innominata. v. Wistar.

(21) Lauth Spicilegium de vena cava superiore, p. 47. 4to. Argentor, 1815.

(22) Columbus De re anat. L.XV. p. 487, found it double; I have seen it a few times divided below the larynx; Cerutti observed the same, No. 764,

(23) At the same time in monsters with deficient brain and cleft spine. v. Rossi in Mémoires de Turin, 1800, Vol. VI. p. 18.

(24) Sandifort in Obs. anat. pathol. L. IV. cap. 8, p. 98.

(25) It is said that in one case, one sinus transversus was deficient. v. Lieutaud Essai anatomique, p. 385, and one sinus cavernosus. v. Santorinus Observat. anat. p. 72 ; more frequently the smaller is deficient, or double, even the sinus falciformis major has been observed in part double. v. Haller Elem. physiol. Vol. IV. p. 147; and Vicq d'Azyr, tab. 32.-A remarkable sinus on each side, from the sinus transversus passing over the petrous bone, and through the middle cavity of the skull into the orbit, was seen by Kelch, Beiträge zur pathol. Anatomie, Berlin, 1813, p. 80, No. 56.-I once found the transverse sinus connected, by an unnatural large hole in the skull, with the external cranial veins, almost as is regularly the case with mammalia. v. My Selt. Beob. Part II. p. 69, No. 31,6 .

(26) Morgagni, Epist. LXIX. 2.

(27) In almost every winter, I have seen once or twice the cephalic vein wanting from the shoulder to the elbow. 
(2S) Sometimes a large venous trunk passes from the median vein between the cephalic and basilic, some way upwards towards the shoulder, in one or other or in both of which it terminates.

(29) Ring in Med. and Physic. Journ. Vol. XIII. p. 120.-Lemaire in Bulletin des Scienc. médic. Vol. V. 1S10.-Breschet, p. 20, (it passed into the belly on the left side of the aorta.)

(30) Cheselden in Philos. transact. Vol. XXVIII. No. 337. - E. Wistar, A system of anatomy, for the use of students of medicine. Philadelphia, 1811-14. Vol. I1. p. 320.-I saw a similar instance at Professor Jeffray's, at Glasgow, and myself found a third case. v. Gurlt. p. 20, with a plate, my Selt. Beob. Part II. p. 67 ; and Verzeichniss, No. 204S. - Herholdt in Abhandlungen der k. Akademie zu Kopenhagen, 1818 ; and in two unpublished plates, very kindly presented to me, the inferior cava passes from the right side, in spite of the convolutions of the intestines, and terminates above in the superior cava, which lies on the left side.-Weber in Rust's Magazin f. d. ges. Heilk. Vol. XIV. p. 536. Here, perhaps, belongs also a case of unusual arrangement in the ascending cava, and the external jugular veins, by $W$. Horner, in Journ. of the Acad. of natural Sciences of Philadelphia. Vol. I. P. II. p. 407, with engravings.

(31) Rothe in Abhandl. der Joseph. Akademie, Vol. I. p. 265, pl. 4, (in the upper part of the right ventricle, in which there were three valves), re-engraved in Meckel, Tab. anat. pathol. Vol. X. fig. 9 and 10.-Breschct, p. 14 and 20 , (in the first case, the hepatic vein terminated in the left, in the second, in the right auricle; an approximation to this formation is, when the hepatic veins perforate the diaphragm, and empty themselves above it into the inferior cava.) v. Morgagni V. 6,9; LX. 6.-Huber Observat. aliquot anat. p. 24, Cassell, 1760 , rev. in Sandifort's Thesaur. Vol. I. p. 306.-In the case mentioned in the preceding note, the hepatic vein passed as a narrow trunk to the right auricle; and in the case mentioned by Wistar, as two trunks; in the cases related by Weber, however, it was connected with the inferior cava by an unusual branch; -in the instances given by Herholdt, it proceeded in spite of the convolutious of the intestines into the right atrium.

(32) Petsche Sylloge observ. anat. rev. in Haller's Diss, anat. Vol. VI. No. 77. I'immermann De rotandis circa naturæ humanæ machinæ lusus, p. 54, Duisb. 1750. - Wilde De vena cava duplici ascendente in Commentar. Acad. Petropol. Vol. XII. p. 262, with an engraving, which is copied in Meckel's Tab. anat. pathol. Fasc. II. tab. 10, fig. 8.-Lobstein Compte rendu, etc. Strasburg, 1820, No. 469. (divided from the kidneys downwards.) - A similar case is described by Zagorsky in Mémoires de l'Acad. imp. des Scienc. de Petersbourg, 1822, Vol. V I I I. p. 2 S9. - Meckel in Anat. physiol. Beobachtungen und Untersuchungen, p. S7, and my Selt. Beob. Part II. p. 70, No. 31.-In a dog. v. Kerckringii Spicilegium anat. Obs. 29, tab. 11. - As a first step to division of the inferior cava, we sometimes observe a thin venous trunk, which passes on the left side of the aorta, springs from the vena iliaca, and usually terminates in the renal, although also in the cava itself. Such cases were seen by Morgagni, Epist. XLVII. 30.-Pohl De venar. variet. 1773.-Meckel often. v. Handb. der menschlichen Anat. Vol. III. p. 358, and myself once.

(33) It passes upwards on the left sidle of the aorta and just close beneath the diaphragm turns to the liver. v. Morgasni Epist. LVI. 31.-II. L. Franke in Der Dresdner Zeitschrift für Natur-und Heilkunde. Vol. V. Part II. (the preparations are to be found in Anat. Mus. of the Chir. Academy of Dresden.)

(34) Which 1 have sometimes seen.

(35) Wilson in Philos. Trans. 1798, Part II. 1. 346.-Meckel Tab. anat. pathol. Fasc. II. tab. 9, fig. 2, (the superior right.)-Breschet, p. 13, (from the double superior cava.) - $\mathbf{A n}$ anastomosis between the superior cava and superior right pulmonary vein was seen by Winslow in Mémoir de l'Academ. R. des Scienc. 1739, p. 113.

(36) W'eese D. de cordis ectopia, J.29. Berol. 1819, (the right superior.)Breschet p. 20, (the right pulmonary vein.)

(37) Lemaire in Bulletin des Sc. médical. Vol. V. 1820. - Wichert Descriptio monstri duplieati, p. 25. 8vo. Dorpati, $182 \%$. 
(38) From each lung only one vein was seen to come, by Haller De corp. hum. part. fabrica. Vol. II. p. 12:31. - Sandifort Observ. anat. pathol. L. IV. cap. 8. p. 97. - Portal in Mém. de l'Acad. de Scienc. 1771. Hist. p. 74. - Schuler D. de morbo cœruleo, p. 12. EEnipont. 1810. - J. F. Meckel Handb. der pathol. Anat. Vol. II. 1, p.133.-Rust's Magazin f. d. gesam. Heilk. Vol.XV III. p. 346. - Bock in Cerutti's Pathol. anat. Museum, Vol. I. Part III. p. 37, ff. -Ramberg D. de corde vasisque majoribus, etc. p. 21. 8vo. Berol. 1824, ff. - Myself in a double monster of a sheep with one heart. v. No. 8020 Bresl. Mus. - Sometimes the pulmonary veins were connected only on one side in a single trunk. v. Löseke Obs. anat. chir. med. p. 26. Berol. 1754, (left.)--Sandifort, Lib. III. cap. 1. p. 18, tab. 6, fig. 4, (left.) - Pohl Observ. angiol. de venis. Lips. p. 11.-J. F. Meckel, (left.) - Nasse Leichenöffnungen, Ite Reihe, p. 1661.-Delnas in Ephem. médicales de Montpellier, Vol. I. Jan. 1826, (only one right.)

(39) I have several times seen five pulmonary veins, and always three on the right side; the same was seen by Meckel in Mém. de Berlin, 1750, p. 167.-Haller De corp. hum. fabr. Vol. II. p. 123. - Portal in Mém. de l'Acad. des Sc. de Paris, 1771, Hist. p. 74.-J. F. Meckel Handb. der menschl. Anatomie, Vol. III. p. 370, (in two cases, three pulmonary veins on the right, and, in one instance, the same on the left.--Six pulmonary veins, of which four were on one side, were found by Sandifort L. III. 41. IV. 97 ; seven described by Müller D. exh. syllogen observation. quarund. anatom. Giessæ, 1760. v. Voigtel Handb. der pathol. Anatom. Vol. I. p. 478.

(40) Kelch Beiträge zur pathol. Anatomie, No. 59, p. 81.

(41) Abernethy in Phil. Transact. 1793, P. I. p. 59; and in W. Saunders, On the Liver, p. 59, London, 1793. - Lawrence in Med. chir. Transact. 1814, Vol. V. p. 174; in one case it perforated the diaphragm, and terminated within the chest, in the inferior cava. v. Huber Observat. anat. p. 34. - [Vena portæ terminating in the vena cava. v. Wilson, in Med. Gazette, Vol. VIII. p. 443. T.]

(42) Sandifort L. III. p. 33.-In human double monsters, with only a single navel-string, two umbilical veins are often found, which, sooner or later, though not always, become united. In double monsters of cattle and sheep, which regularly possess two umbilical veins, I have often found three, and even four, within the navel-string.

(43) I have several times seen, especially in children with cleft abdomen, large umbilical and frenic rupture, with dislocation of the liver, the umbilical vein entering at the edge and even on the upper surface of the liver. The latter has also been observed by Breschet. v. Med. chirur. Transactions, 1818, Vol. IX. p. 433.

(44) Rosenthal Abhandlungen aus dem Gebiete der Anatomie, Physiologie und Pathologie, p. 150, Berlin, 1824, (in a foetus, with umbilical rupture in the. inferior cava.)-Littre in Mém. de l'Acad. des Sc. p. 10, 1709, (it principally formed the inferior cava, perforated the diaphragm distinct from the hepatic veins, and terminated in the superior cava.)-Weese, p. 22, one branch from it into the liver, the other into the superior cava.

(45) By one branch into the liver, by the other into the mesenteric vein. v. Kerkring Spicil. anat. p. 80, Obs. 37. - In the splenic vein. v. Fingerhuth in Meckel's Archiv für Anat. und Physiologie, 1824, No. 1, p. 111, (in a calf with deficient abdominal parietes, pelvis and hinder extremities.)

(46) Above the liver, directly in the right auricle. v. Mende in Nov. Actis phys. med. Acad. N. C. 1821, Vol. XIII. Part II. p. 869, pl. 46.

(47) Serres. v. Archives générales de Médeeine. Dec. 1823.

(48) Kerlkring Spicil. anat. p. 21, Obs. 7. - Haller Elem. Physiol. Vol. VI. p. 483.-M. Hoffmann in Ephem. Acad. N. C. Cent. IX. and X. p. 443. - Powel Treatise on the Bile.-My Selt. Beob. Part II. No. 31, p. 71, and Verzeichniss, No. 2273, (in a man of fifty years, the umbilical artery also was still open.)

(49) Sömmerring Vom Bau des menschlichen Körpers. 2d edit. Vol. IV. p. 485.-Küstner in his and Choulant's, Hase's, and Meissner's Bereicherungen f. die Geburtshülfe, u. s.w. Vol. I. p. 52.-As I have myself examined the justmentioned fotus, I can confirm this observation.-I have three times besides 
seen the ductus venosus deficient in similar cases; in which, however, the umbilical vein entered the liver in unnatural situations.

(50) G. Spangenberg in Mecliel's D. Archiv f. die Physiologie, Vol. I. p. 87.

\section{$\S 205$.}

The SIZE and FORM of the veins, as might be expected from the great pliancy of their walls, are subject to frequent variations. There are some individuals, in which, as a congenital and even hereditary peculiarity, the whole system of bloodvessels, and thus also the veins, is very NARRow. In great deficiency of blood throughout the body, in the diminished circulation of wounded, paralytic, and indurated parts, in continued pressure, ${ }^{1}$ in amputated limbs, \&c. the veins are often very remarkably NARROWED. More frequent, however, the opposite state, or the UNNATURAL ENLARGEMENT of the veins, which is sometimes general, sometimes only local, and especially caused by frequently recurring congestion in a part, by the various obstructions to the circulation of the blood, for instance, vices of the heart and lungs, compression or obliteration of the greater venous trunks, ${ }^{2} \&$ c. as well as by a state of too great laxity and torpor of the venous coats. In telangiectasy, there is a peculiar degeneration of the blood-vessels connected also with widening of the smaller veins. ${ }^{3}$ If the diseased extension of the veins be continued, partial, and considerable, we give it the name of BURST-VEINS, BLOOD-KNOTS, varix, cirsus, phlebeurysma, ${ }^{4}$ \&c. This occurs in women, especially in pregnancy, ${ }^{5}$ and more frequently than in men $;^{6}$ it occurs sometimes throughout the body, ${ }^{7}$ but most conmonly in the superficial veins of the lower extremities ${ }^{8}$ and lower part of the belly, in the female generative organs, in the spermatic cord, in hemorrhoidal disease on the urinary bladder and rectum, and on the venous plexuses of the brain. Sometimes the varices occur simultaneously on several parts in the same individual, thus they often form on the vena saphenu a prominent series of swellings; the form of these vascular swellings, which are often very large, is usually that of knots, although in many cases, if the veins are simultaneously very much elongated, winding like intestines, and large lobulated or grape-like tumours, which at first are soft and easily emptied by pressure, but in time become more solid, whilst their coats are thickened by inflammation, and their cavities either entirely or partially filled with fibrous matter. Varices also occur in brutes, although much more rarely than in man." A peculiar kind of venous swelling is the already described varix ancurysmus, ${ }^{10}$ or ancurysma varicosum, in 


\section{which the extension of the vein is produced by the influx of the blood from the adjacent wounded artery.}

(1) For instance, by aneurysm, which I have a few times seen on the superior vena cava, once on the v. subclavia, and a few times on the v. cruralis and poplitea. - Hunter, v. Med. Obs. and Inquir. Vol. I. p. 333, found the v. cava superior, subclavia, and thyroidea, extensively compressed by an aneurysm.-Similar cases were observed by Corvisart, Sur les Maladies, \&c. du Cœur.-Bertin Traité des Maladies du Cœur, p. 137.-They are not unfrequently compressed by tumours of the lymphatic glands; this was observed by Bleuland on the superior cava, v. De difficili aut impedita alimentorum depulsione, L. B. 1780, and myself twice on the deep thyroid and crural veins; lastly, tumours of other kinds, as I have myself seen, may occasionally compress the venous trunks.

(2) I have several times ohserved this to a great extent in diseases of the lungs and heart, both in the cavæ and their large branches, as well also, as though more rarely, in the pulmonary veins; also, in the blue disease, I have several times noticed great expansion of the veins. v. Pozzis, v. Senac Sur la structure du Cœur. Vol. II. p. 414, ff.-Haase D. de morbo cœruleo. Lips. 1813.The expanded jugular veins in many diseases are seen pulsating strongly. Comp. Morgagni, Epis. XVIII. p. 9.- If the cavæ, or other large veins, are very much narrowed, or completely closed, the circulation can be restored by the expansion of the neighbouring small veins. I have twice found this in great compression of the inferior cava from tumour of the liver; and in a third case, in consequence of closure of the superior cava, the v. azyga, hemiazyga, and mammariæ, remarkably large; the same occurred in the cases of obliteration of the inferior cava, to be mentioned further on. Whether the enlargement of the veins in the neighbourhood of cancerous tumours, medullary sarcoma, osteosarcoma, large aneurysms, \&c., arises from pressure on the veins, or from disease in themselves, I do not venture to decide; I could, however, almost always refer it to pressure.

(3) Compare above, $\S 193$.

(4) Mancinus Tract. duo, alter de varicibus, alter de reficiendo naso. 8 vo. Francof. 1586.-Rolfink D. de articulor. doloribus, varicibus, etc. Jenæ, 1637.Seger D. de aneurysmate venarum s. varicibus. Basil, 1661. - Fehr in Misc. Acad. N. C. 1675 and 1676, p. 55 ; 1699 and 1700, App. p. 162.-Miller D. de varicibus, Altdorf, 1680.-Stammell D. de tumoribus varicosis. Mogunt. 1789. Wedel D. de varice. Jenæ, 1699.-Pohl D. de varice interno, morborum quorundam causa. Lips. 1785 ; and $J$. Coquart D. de varicibus. 4to. Paris, 1786. de Plouquet De phlebeurysmate s. varice. Tubing. 1806.-Graefe's Angiektasie. Leipzig, 1803.-Brodie in Medico-chir. Transact. Vol. VIII. Part I. p. 195.$V$ olpi in Saggio di osservazioni, etc. Vol. II. Phil. 1814.-Delpech Traité des maladies chirurgicales, Vol. III.-Carmichael in Transactions of the Fellows of College of Physicians in Ireland, Vol. II. p. 345.-Briquet in Archives générales de Médecine, Yol. VII. Febr. and March, p. 200 and 396.-J. Csorba D. de Phlebeurysmate, in specie de hæmorrhoidibus. 8vo. Pesth. 1817.-Heisterbergk D. de varicibus. 4to. Lips. 1824.

(5) Haase and Richter D. de gravidarum varicibus. Lipsiæ, 1781.-Birkholz D. de quibusdam gravidarum varicibus. Lipsiæ, 1782.-Lützelberger D. de symptomatibus quibusdam gravidarum præcipue de varicibus atque odemate pedum. Jenæ, 1791. - Brasse D. de varicibus præsertim gravidarum. 4to. Berol. 1819, with engravings.

(6) In a man of forty years old and in poor health I saw almost all the cutaneous veins of one lower extremity exceedingly varicose. I have also several times seen little varices on the vena saphena of men.-Hodgson, p. 542 , case 51 , describes large varices on the vena saphena of a man.

(7) Besides the already mentioned parts, I have also seen it sometimes on the veins of the heart in aneurysm, once in the vena cava, once in the orbit as large as a hazel-nut, and occasionally in the oesophageal veins, although not very large.-von Siebold found a considerable varix in the orbit. v. Salzb. Med. chir. Zeitung, 1813, 
Vol. II. p. 199.-Frank observed it on the lips, the palate and the cheek. v. De cur. hom. morb. L. V. 2. p. 57.-Dzondi Lehrb. der Chir. Halle, 1824, p. 395, saw one as large as a hen's egg in the jugular vein ; they are very rare on the arm, although Petit, in Traite des maladies chirurgicales, Vol. II. p. 49, has described a case.

(8) A very beautiful engraving of varicose veins on the thigh is given by Alibert in his Nosographie Naturelle, Vol. I. pl. 4._Ghidella, in Nuovi Commentarj di Medicina e di Chir. 1819, Vol. III. Part I. gives a very remarkable instance of the whole $v$. saphena varicose, and thicker than one's thumb, with a varicose tumour in the ham: a varicose expansion of the $v$. saphena confounded at its upper extremity with a rupture, is described by J. L. Petit v. Dict. des Sc. Médic. Vol. XLIX. p. 573.

(9) I have seen it only in the horse in the jugular vein and on the prepuce;a varix as large as a hen's egg was observed on the transverse sinus of the brain in a horse. v. Journ. gén. de Médec. p. 285, May, 1821.

(10) Compare $\$ 194$.

\section{$\$ 206$.}

The great extension to which varicose veins are subjected sometimes gives rise to BURSTING of THEIR SwELlings. ${ }^{3}$ Various VICES OF CONSISTEICE, however, a ssuppuration and sloughy softening, and in the healthy state of veins, great congestion of blood, violent muscular exertion, ague, \&c. also give rise to sPONTANEOUS RUPTURE, which, however, is more rare than in arteries. ${ }^{2}$ If it occur in the small and deep-seated veins, spots and bloody swellings arise, which latter may, under some circumstances, be mistaken indeed for aneurysm ; ${ }^{3}$ the bursting of larger veins is naturally sometimes fatal. Sometimes the umbilical vein again opens itself several days and even weeks after birth, and causes dangerous and mortal hemorrhage. ${ }^{4}$ Not very rarely injuries of veins arise from mechanical injuries not penetrating, but rather by concussion. ${ }^{5}$ Wounds of veins, ${ }^{6}$ if they be not 'mortal from effusion of blood, are readily healed, not merely by closing of the vessels, but if the wounds are not large, and especially, if they be longitudinal, even by adhesion and cicatrization, in which they differ remarkably from those of arteries.

(1) Sumetines witl fatal consequences. v. Commerc. Liter. Noric. 1734, p. 116.-Morgagni Epist. XXVI. 29, (the vena azygos.)-Mfichaelis in Richtcr's chir. Bibliothek, Vol. V. p. 123, (the vena jugularis.)-Portal Cours d'Anat. médic. Vol. III. p. 35t, (the subclavia,) p. 373 (the vena azygos.)-Cline v. Hodgson, p. 538, (the vena jugularis interna.) - Amussat and Murat in Revue médic. franç. et étrang. 1527, Vol. IV. (the vena saphena); compare Haller Elem. Physiol. Vol. I. p. 130, note 9; a fatal rupture of a varicose plexus pampiniformis was seen in a young wonan by Fleischmann.

(2) Spontaneous ruptures of the v. cava olsserved by dretaus De caus. et sign. norbor. acut. Lib. II. cap. 8.- Lanrentius II ist. anat. h. c. Lib. IX. १u. 18.-Hacquinet v. Eph. N. C. Dec. I. A. I. Obs. 101.-Puerarizs ad Buruet T'hes. med. Lib. III. 1) 58. - Laucisins De subitan. mort. Obs. pluys. anat. 5.Funtoni ad Morgagnum List. VIII.-Senuc, Licutaud. v. Portal; in which he describes two of his own cases.-Th. Bartholinus. v. Misc. Acal. N. C. A. I. 1670,

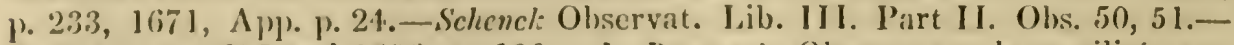
S. Nebel, ib. 1695 and 1696, P. 120.-L. Bourgeois Obscrv. sur la sterilité, etc. 
Lib. I. p. 221, (the inferior.) - de Itaen Ratio Medendi, Vol. IV. Part X. pl. 1, § 3, p. 391.-Salzmann D. morte subita ex sanguine in pericardium effuso. Argentor. 1731.-Doubleday in Med. Observat. by a Soc. of Physic. in London, Vol. V. p. 144.-L. Lovadina Memorie scient. e letter. dell' Ateneo di Treviso, 1817, Vol. I. p. 251 (both cavæ in mortification on account of an extraneous body sticking in the gullet.-Nasse Leichenöffnungen, 1st Reihe, p. 85, (the inferior in the chest.) - J. Kennedy, On Ruptures of the Vena Cava in London medic. Repository, Vol. XX. Octob. 1823 (with copious references and two cases of his own.) - Dommanget in Journ. gén. de Méd. Août. 1824, (the inferior in the chest.)Seymour in Lond. med. and phys. Journ. - Larrey, in the Journ. de la Gironde, in $v$. Froriep's Notizen, 1827, No. 365, p. 206, (the inferior,)-the inferior in a horse. v. Grognier in Correspond. vétérin. Vol. II. p. 97 ; and in Journ.

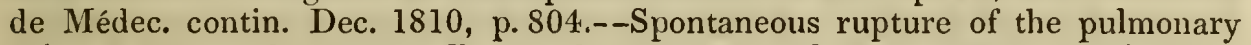
veins was seen by Bellini De morb. pector. and Franc. Queye Disp. de Syncope, C. III. Prop. 2.-Compare Morgagni Epist. XXVI. 27.-Portal Mémoir. de Paris, 1784. - Compare Auserl. Abhandl. f. prakt. Aerzte. Vol. XII. p. 724, (the coronary veins of the heart in aneurysms.) v. Bertin Traite des maladies du Cœur. Paris, 1824, p. 417. - The jugular vein. v. Breslauer Sammlungen, Aug. 1726, p. 254 : and frequently in horses from Moldavia, Wallachia, Tartary, \&c. in summer, as I have several times seen.-On the cheek. v. IIaller, note.-The sinuses of the brain. v. London medic. Repository, Vol. V. Part I. No. 25, (the sinus longitudinalis.) Ib. Vol. X. Dec. 1828, (both transverse sinuses.) - Portal, Olsservat. sur la nature et la traitement de l'Epilepsie. 8vo. Paris, 1827. - Douglas in Edinb. medic. Essays and Observat. Vol. V. Part II. p. 602, an effusion of blood on the occiput caused death, on account of its connexion by a hole in the skull with the sinus. v. Flint, in New-England Journal of Medic. and Surgery, new series. Vol. IV. A pril, 1820.-The veins of the arm. v. Haller, note 1. - The vena azygos, de Haen, Ratio Medendi, Vol. 1V. Part X. cap. 1, §3, p. 391, (in cholic.)-The internal iliac vein in a pregnant woman. v. $W$. Blizard, in London medic. Repository, Vol. I. p. 456. The veins of the lower extremities. v. Haller, note $\mathrm{p}-\mathrm{s}$. - The vena portæ. v. Schenck Observat. L. III. Part II. No. 51.-Rupture of the veins has also been seen in cold and inflammatory fever. v. Portal, p.355. [Andral, Vol. II. p. 399 , rupture of the abdominal cava of an apparently healthy man, in a scuffle, and death in a few seconds. T.]

(3) Else, Of tumours formed by ruptured veins, sometimes mistaken for aneurysms, in Lond. medic. Observat. and Inquiries, Vol. III. p. 169.

(4) Panarolus Iatrolog. Pentecost. I. Obs. 7.-Pont, communicated by A. Cooper, in Lond. med. chir. Transact. Vol. XII. Part I. 1822. - Lerche in Petersb. vermischten Abhandlungen a. d. Gebiete der Heilk. 1823, 2te Samml. p. 208.

(5) Compare Portal. - Some such cases of the superior cava I have known, from the accounts of morbid examinations.-Rupture of the inferior cava, from being run over, was seen by Starke, in Rust's Magaz. f. d. ges Heilk. Vol. V. Part II. p. 323. - One right pulmonary artery, from being run over, without fracture of bones. v. Rust, Vol. XX. p. 188.-The vena portæ, together with the aorta. v. Pyl Aufsätze und Beob. aus der gerichtl. Arzneiwiss, Vol. IV. case 7, and 8. - Many effusions have been observed from rupture of veins.-I once saw a large bloody tumour arise on the calf of the leg, from rupture of a vein in consequence of a false step.-Hodgson, p. 520, on the same part, in two cases, from violent cramp.

(6) Autenrieth De vulneratarun venarum sanatione. Tubingen, 1812.Ristelhuber Mémoires sur les plaies et les ligatures des Veines in Annales de la Soc. Méd. prat. de Montpellier, Vol. XLIII. p. 416; and in Leroux Journ. de Médec. Vol. XXXIX. p. 3, May, 1817.

\section{$\S 20 \%$}

Among the vices of Texture occurring in the veins, INFLAMMATION, phlebitis, ${ }^{1}$ and its consequences are the most 
important; this is by no means a rare disease, it arises not merely from accidental and intentional mechanical injury, as contusions, stabs, bleeding, ${ }^{2}$ amputation, ligature, continued pressure, \&c.; but also from internal causes, for instance, gangrene, erysipelas, ${ }^{3}$ cold, various fevers, ${ }^{4}$ especially the puerperal, scurvy, ${ }^{5}$ and particularly also in consequence of irritation propagated from malignant ulcers in the bones and soft parts; inflammation of the veins occurs in the veins of the pelvis and belly, ${ }^{6}$ more frequently than in those of the chest, the neck, and head. ${ }^{7} \quad$ Inflamed veins appear, according to the variation of the degree of inflammation, more or less red, throughout or in spots, the larger especially on the outer surface of their internal coat, and sometimes also in the cellular tissue, as it were injected, usually also somewhat loosened, opake, shrivelled, and thickened, so that, now and then, when cut through, they exhibit, like the arteries, an orifice which does not collapse ; in this their coats are more easily torn than in the healthy state. The most common termination of venous inflammation, is the EFFUSION OF COAGULABLE LYMPI on their inner surface, in the shape of more or less tough and adhering bands, false membranes and plugs, whereby the veins are in a greater or less degree filled, and often completely stopped up. ${ }^{8}$ Not unfrequently complete obliteratron, obliteratio, of the veins is produced by this adhesive inflammation $;{ }^{9}$ less frequent is the inflammatory effusion on the external surface of veins, whereby they are sometimes closely consolidated with the neighbouring arteries, nerves, and other parts. Inflammation in veins runs on not unfrequently to suppuraTION ${ }^{10}$ in which we see either mere pus of various composition, colour, and consistence, secreted into the canal of the vein, from the loosened and, as it were, villous internal coat, or the walls of the vein are actually broken up, perforated, and even entirely destroyed. Inflamed varices also often produce malignant ulcers. The highest degree of venous inflammation not unfrequently runs into MORTIFICATION, which is rather communicated by the neighbouring parts to the veins, although in mortified limbs, they as well as the arteries are often found tolerably healthy; hemorrhage does not then easily arise, as the preceding inflammation has already stopped up and closed the veins; and merely the large veins are opened in particular cases by the sloughing destruction of the neighbouring parts at one part, and thus fatal hemorrhage ensues. Lastly, there also probably occurs an inflammatory state which gives rise to the very rare conversion of the venous coats into CARTILAGE, or BONE, or to the DEPOSITION OF LIME ${ }^{11}$ in them. 
(1) Although well known to the older writers, it was only first circumstantially treated of by the following authors: John Hunter, in Transactions of a Society for the Improvement of medical and chirurgical Knowledge, Vol. I. p. 18.P. Frank De cur. hom. morb. Lib. V. 2. p. 66. - Abernethy, Surgical and Physiological Essays. - Sasse D. de vasor. sanguiferor. inflammatione. Halæ, 1797.-Osiander, Neue Denkwürdigkeiten, Vol. I. p. 57. Goth. 1799.-Longuct D. sur l'inflammation des veines. 4to. Paris, 1815.-Carmichael, Observations on Varix and venous inflammations. - Palletta De inflammatione venarum in Exercit. pathol. I. p. $20 ;-$ Dumbred D. de inflammatione venar. Edinb. 1822.$B$. Travers in his and A. Cooper's Essays.-Bunny D. de inflammatione venar. Edinb. 1823.-Stan. Czarnowski D. inaug. chir. pract. de Phlebitide. 8vo. Vilna, 1823, (with four of his own cases).-Bresshet in Journ. compl. du Dic. des. Sc. médical. Vol. II. p. 325.-Schwilgué Faits pour servir à l'histoire des inflammations des veines in Biblioth. médic. Vol. XVI. p. 194.-Bouillaud in Revue médicale franç. et étrangère, 1825, Vol. II. p. 71-92 and 418-434.-Ribes Mémoire sur la phlebite, ib. 1825, Vol. III. Part IV. and VI. - Ferd. Guttmann D. de Phlebitide s. inflammatione venarum. 8vo. Berol. 1826.H. G. Mende D. med. chir., nonnulla de venar. inflammatione, præsertim phlebotomiam excipiente, 8vo. Dorpat. 1826, (a fatal case after bleeding.)Gendrin Considérations sur les eauses de la pllebite et observations sur l'inflammation des veines encéphaliques in Revue médic. 1826, April and May.$F$. A. Balling Zur Venenentzïndung. 8vo. Würzb. 1829.-Interesting observations are related by $P$. Dionis Cours d'opérations de chirurgie, p. 680 , (after bleeding.) -Morgagni, Epist. LVI. 10. - van Swieten Comment. in H. Boerhravii Aphorism. II. \$372, p. 628, ff.-Sherwen in Edinb. medic. commentaries, Vol. IV. p. 206, (after bleeding.) - Herissé in Journ. de méd. chir. et pharm. Vol. XII. p. 417. - Testa Della malattie del cuore, \&c. (on the vena cava and azygos.) -Dav. Dundas in Med. chir. Trans. (the vena cava.) - J.'Russel in Edinb. med. and surg. Journ. Jan. 1814, (the vena cava.) - Sprengel in Rust's Magazin f. d. ges. Heik. Vol. VII. p. 475, (after wound of the thumb.)-Erdmann Annales scholæ clinicæ medicæ Dorpatensis. Annor. 1818-20, (after bleeding and after amputation.) - Oldknow in Edinb. med. and surg. Journ. Vol. X. p. 175, (from ligature.)-Hopfengürtner in Hufeland's Journ. d. prakt. Heilk. Oct. 1820.-Meli in Annali univers. di medic. comp. dal Omodei. Vol. XVII. and XVIII. Jan.June, 1821, (general.) - Fallot in Journ. compl. du Dict. des Scien. med. Vol. XXXVII. July, 1821, (general inflammation of the vessels.)-Andr. Duncan in Transact. of the med. chir. Soc. of Edinb. Vol. I. 1824, p. 439-454, and 470-642.-Velpeau in Archives générales de médecine, Oct. 1824.-Forbes in Medic. chir. transact. Vol. VIII. p. 293, (the iliac and femoral veins.) - Guthrie in London med. and phys. journ, July, 1826, (after amputation.)-Cruveilhier in Nouv. Bibliotheque, May, 1826, (of the lower extremities.)-Monod in Journ. univers. des Scien. med. June, 1828, (fatal after bleeding.)-Chapmann in Philadelphia Journal, No. 14, p. 322, (fatal after bleeding.)-Hinterberger in med. chir. Zeitung, 1828, p. 31, (of the inferior cava.) - Fricke Annalen des Hamburger krankenhauses, 1828, with plates. [J.M. Arnott, On the secondary effects of inflammation of the veins, in Med. chir. Trans. Vol. XV. Part I. p. 1. - R. Lec no Phlegmasia Dolens, ib. p. 132.-Ibid. On inflammation of the veins of the uterus, Vol. XV. Part II. p. 369. Three excellent papers, containing an immense number of original and selected cases. Of late, the French have named inflammation of veins PhLEBectasie. v. Briquet Essai sur la phlebectasie. T.]

(2) I have twice seen, after blood-letting, fatal inflammation of the veins of the arm, extending up to the superior vena cava; this is also not unfrequently the case in the neck of the horse; in which there is formed, at the part where the vein has been opened, a hard, roundish swelling, sometimes secreting lymph, from which a painful, hard cord may be felt, taking the course of the vein downwards. [Arnott, in Medico-chirurgical Transactions, Vol. XV. Part I., mentions several cases of inflamed veins after bleeding; among which, obliteration of the basilic and median basilic, p. 16 ; of the cephalic, p. 23 ; of the median basilic, p. 27. He also saw enormous thickening, with increased vascu- 
larity in the jugular vein of a horse, p. 48 ; and mentions another instance seen by Sims, p. 129. T.]

(3) According to Ribes, the erysipelas is especially seated in the extremities of the veins, which, however, is difficult to determine.

(4) Borillaud goes so far as to consider typhus and putrid fever as inflammation of the veins, which is certainly incorrect; for I have examined during war time a hundred cases which have died of typhus, and very seldom seen more than a slight inflammatory state of the veins. Bouillaud incorrectly esteems as inflammatory, the red colouring of the reins which occurs in typhus and putrid fevers, both in men and animals, which his countrymen, Trousseau and Rigot, had previously noticed in Archiv. Gén. de Méd. Oct. 1826 and July, 1827; putrefaction, frost, and air, also operate in reddening the veins of dead bodies.

(5) According to Ribes. I think, however, that that was not true inflammation, but merely red colouring, which I have observed in the few scorbutic cases I have seen, even in several patches.

(6) In persons with malignant bony caries, long continued ulcers of the legs, senile erysipelas, \&c. I have very often found the crural vein inflamed; whilst I write, I have a few such cases before me. I have also sometimes seen the veins inflamed, in the neighbourhood of scrofulous tumours running into suppuration ; in monkeys, which have died of tubercles, and inflanmation of the lungs; and in a dog, destroyed by distemper, I have found the pulmonary vein here and there inflamed.- [Lawrence saw inflammation and obstruction of the iliac veins in a man who died of cancer of the rectum.-v. Lee, On inflammation of the veins of the uterus, Med. chir. Trans. Vol. XV. Part II. p. 431. - Inflammation of the veins of the lower extremity excited by malignant ulccration of the cervix uteri. v. W. Lawrence Med. chir. Trans. Vol. XVI. Part I. p. 58. - Inflammation of the cava; both common iliac veins and the whole right femoral vein inflamed, thickened and in parts loaded with adventitious membrane in a case of phthisis. v. T. H. Holberton, ib. p. 63. T.]

( 7 ) Most seldom, as it appears, in the skull; I have, however, seen two instances in the longitudinal sinus; in the former, after injury of the head and trepanning; in the second, in a large abscess of the brain. Other cases have been given by Abernethy, in Edinb. med. and surg. Journal, July, 1818.-Ribes in Revue Méd. July, 1825, p. 36; and Gendrin, Vol. II. p.31.

(8) Meckel gives good engravings of it, v. 'Tab. Anat. Path. Fasc. II. tab. 14, fig. $6-8$. As inflammation frequently produces obstruction of the veins, so on the contrary does it arise, not unfrequently, from pressure and stoppage of the veins; hence varices often inflame, and it is sometimes difficult to determine which is the eause, which the consequence, if simultaneously with phlegmatia alba dolens, or with long continued, great, partial œdema of a part, the principal vein is impervious, which I have very often found in the legs. D. Davis, in Med. Chir. Trans. Vol. XI1. Part II. p. 419-458, with engravings; and in London Med. Repros. new series, by Copland, Darwall, and Conolly, June and July, 1825, considers the obstruction of the veins of the pelvis, as the cause of phlegmasia alba dolens, in pregnant women; as Bouilland considers it the cause of local dropsy. v. Archiv. Gén. de Méd. July, 1823; May and June, 1824. In rare cases, these coagula in veins become loosened and detached, and give rise to dangerous consequences, especially nervous. v. Ribes. $-[R$. Lee, On phlegmasia dolens, Med. chir. Trans. Vol. XV. l'art I. p. 132, has shewn by numerous cases, that intlammation of the iliac and femoral veins unquestionably gives rise to that disease. And in Part II. same volume, that the inflammation commences in the uterine branches of the hypogastric, and extends to the iliac and femoral trunks. 'T.]

(9) Even the v. cava, especially the inferior. - Compare lihodius Mantissa anat. Observ. No. 21, p. 15.-T'h. Bartholims Observ. anat. Cent. II. Hist. 35. - Bontins de Medic. Indor. Observ. 1). 251. - Allinus Annot. acad. L. V1I. c. 9.-Haller in Opuscul. pathol. Obs. 24.-Winliter de vasor. lithiasi. 1. \$ 6, note a. - Baillie in 'Transact. of a Soc. for Improv. of med. Knowl. Vol. I. p. 127, 1). 5.-Wilson, ib. Vol. III. p. 65.5.-Vertel in Quatrième Rapport des travaux de la Soc. d'Agricult. du Doulss, p. 282, (the superior, from pressure of an aneu- 
rysinal aorta.)-Cline in Scarpa, Sull' Aneurysme, p. 15.-Marjolin in lis Diss. Paris, 1808, (the superior.)-Knape in Hufeland's Journ. der prakt. Heilk. 1813. Vol. XXXVI. Jan. p. 122. - Deckart D. s. descriptionem concretionis venæ cavæ superioris una cum ingente aortæ ascendentis aneurysmate, etc. 4to. Berlin, 1823, with plates. He mentions also, p. 4, a case of obliteration of the inferior cava to be found in the Berlin Mus.-My Selt. Beob. Part I. p. 65, (the superior in an aneurysm.) - The vena anonyma has been seen closed by the pressure of an aneurysm. v. Pattison in American medic. Recorder. Philad. 1820 , Vol. III. No. 2.-The jugular vein, Haller in Pr. de aortæ venæque cavæ gravioribus quibusdam morbis observ. Gött. 1749, p. 6 ; and in Opusc. pathol. Obs. 23, tab. 19.-Simpson in Edinburgh medical Essays, Vol. V. p. 337.-G. Young, v. IIodgson, p. 533. - Lardner in the Edinburgh med. and surg. Journ. 1811, Vol. VII. Part XXVII. p. 407 (from considerable thickening of the pharynx.) I have found the left deep jugular vein closed from the pressure of a large glandular swelling which surrounded it ; and the external vein consequently very much enlarged. - The sinus falciformis has been seen closed from pressure of a fungus of the dura-mater three fingers broad.- Palletta Exercit. Pathol. Vol. I. p. 94. - The sinus transversus. v. Abercrombie.-The iliac vein found obliterated, by Morgagni, Epist. LVI. 10 ; twice by Hodgson, p. 530 ; myself once in a large tumour of the ovarium. - Forbes in Medic. chir. Trans. Lond. 1827, Vol. XIII. Part II.- I have found the femoral vein ailherent five times; once in a large femoral rupture, once in a scrofulous swelling of the lymphatic glands, and three times in malignant ulceration and œdema of the leg. The smaller veins are not unfrequently found impervious.-[In phleginasia dolens, the common iliac vein with its subdivisions and the upper part of the femoral resembled a ligamentous cord, and not distinguishable from the surrounding cellular substance. v. R. Lee in Med. chir. Trans. Vol. XV. Part I. p. 136.-Also in the same volume, the following are some of the cases mentioned by Arnott: Obliteration in basilic and median basilic, after bleeding, p. 16 ; cephalic obliterated after bleeding, p. 23 ; median basilic obliterated after bleeding, p. 27.-Obliteration of the left iliac vein, by pressure of an encephaloid tumour surrounding it, is mentioned by Reynaud in Journ. hebdom. de Médec. Vol. II. p. 84; and at p. 110 he gives a case of obliteration of the superior vena cava from pressure of an aneurysm. T.]

(10) Superficial suppuration on the internal surface of the veins is not rare; sometimes, the vein being closed to a greater distance above and below, by adhesive inflammation, a kind of abscess, or long hollow swelling, is produced; in other cases the enlarged veins burst by ulceration, and fatal hemorrhage ensues. v. Portal Cours d'Anatom. Med. Vol. III. p. 354, (the superior cava near the auricle.)-Cerutti Beschreib. der pathol. Präpar. zu Leipz. No. 746, (two lenticular apertures in the inferior cava.) I have once observed fatal effusion of blood into the intestine from ruptured vena portæ. v. My Verzeichn. No. 2559.Rupture of the splenic vein, with fatal effusion of blood into the stomach, has been observed several times; I saw one instance of it in the Hunterian Museum in London, and another in Sandifor't's, at Leyden. - Fatal rupture of the gastroepiploic vein has been noticed by Ware in New England Jnurn. of Med. and Surg. new series, Vol. IV. July, 1820.-One case of rupture of the gluteal vein, in psoas abscess. v. Rust's Magaz. f. d. ges. Heilk. Vol. I. p. 48.

(11) Bichat, in his Anat. generale et pathologique, improperly denies the occurrence of ossification in the veins. Instances of it are related by Morgagni. Epist. LXIV. g. - Ruysch Thes. anat. VIII. No. 58.-Salzmann D. de ossificat. præternat. p. 27. Argentor. 1720.-Ephem. N. C. Dec. II. Ann. X. Obs. 175, (on the coronary vein of the heart).-Murray in Act. med. Suec. Upsal. 1783, Vol. I. p. 3.-Walter Observ. anatom. p. 45. tab. 9.-Meckel v. Sasse D. de vasor. sanguifer. inflammatione, p. 38, Halæ, 1797, (a diseased vein creaked in cutting.) -Baillie, Transact. of a Soc. for Improv. of med. Knowledge. Vol. I. p. 134-Lobstein, v. Mém. de la Soc. des Sc. Agricult. et Arts cle Strasb. Vol. I. p. 341, note; and Compte rendu sur son Museum anatomique, Strisb. 1820, p. 115. No. 452 (the vena portæ.) -Cruveilhier Essai sur l'Anat. pathol. Vol. II. p. 70.IIip. Clocquet in Dict. des Sc. médical. Vol. XXIV. p. 295 (the brachial vein.)Cerutti No. 855 and 856.-Landgran in Ars Berättelse om Svenska Läkare- 
Sällskapets Arbeten, 1827, p. 31.-I have never myself seen ossification of the veins; but I saw, in the Anat. path. Mus. at Vienna, a splenic vein, No. 547, a vena portæ, No. 2484, the brachial and femoral veins of an old man and woman, and also, in the Veterinary School at Munich, the preputeal veins of a horse ossified.

\section{$\S 208$.}

SPURIOUS FORMATIONS of several kinds also occur occasionally in the veins. To these belong, the rare observation of ENCYsTED TUMOURS, ${ }^{1}$ FATTY SWELlings, ${ }^{2}$ and Hydatids, ${ }^{3}$ upon and in them; the equally uncommon depositions of TUBERcULAR MASSES on their coats in affections of the neighbouring lymphatic glands, ${ }^{4}$ and lastly, sarcomatous Tunours, ${ }^{5}$ which either originate primarily in them, or extending from the neighbouring parts, perforate the walls of the larger veins and enter into their cavities.

(1) For instance, in the venæ cavæ. v. Bresl. Samml. Suppl. II. p. 168.

(2) Under the internal coat of the vena portæ in a man, who had been affected with jaundice and cancer of the stomach. v. Honoré in Rev. Médic. franç. et étrang. 1823.

(3) The case of Peyer's, in Misc. Acad. N. C. Dec. II. note 7, 1688, p. 385, who found a flat hydatid in the vena portæ of a pig, appears rather to be a distoma hepaticum.-Andral, the younger, found in a man, who had many hydatids in the lungs, also several large hydatids in the pulmonary veins. v. Bulletin des Sc. par. la Soc. philom. 1823, p. 15.-Magendie's Journ. de Physiologie, Vol. III. No. 1. p. 69 ; and in Andral's Clinique médicale, Vol. III.

(4) I have observed this several times in such way, that the scrofulous matter had penetrated the coats of the vein and filled up its cavity. In other parts scrofulous ulceration had more or less destroyed the arteries and veins.

(i) In a man who had scirrhus of the stomach, a mass larger than a hazelnut was found in the expanded splenic vein. v. Hodgson, p. 524.- $\Lambda$ sarcomatous swelling in a girl of nine years old, was attached by a neck to the superior cava, and filled it up. v. Wolf in Rust's Magaz. f. d. ges. Heilk. Vol. XIV. p. 570. - In a person who died of vomiting of blood, a yellow pulpy swelling on the lesser curvature of the stomach, and a similar one in the vena portæ, by which it was filled. v. Ward in the London Med. Reposit. Vol. XX. Oct. 1823.-Medullary sarcom penetrated in two cases into the vena cava. v. Velpeau in Revue Méd. franç et étrang. 1825, Vol. I. p. 217-240, and 343-360.-In the Anat. pathol. Mus. at Vienna, I saw a large polypous-like growth, with a neck in the vena cava, behind a similarly diseased liver, No. 2513; and a medullary sarcom of the inferior cava, No. 3906; and a sarcomatous tumour in the superior cava, No. 4110:-lastly, I found a sarcomatous growth, of the size of a hazel-nut, in the vena cava, near the liver, in a stag, which I had kept for several years. v. No. 8747 of Bresl. Mus. - A branch of the vena cava had a cancerous-like appearance. v. Cliurchill in London med. and phys. Journ. March, 1827.

\section{$\$ 209$.}

Lastly, we often observe some irregularities in the veins with reference to their contents. Thus, as after death the $\mathrm{BLOOD}^{1}$ is especially found only in the veins, so any remarkable peculiarities in it deserve to be first mentioned. It sometimes varies as well in QUANTITY as in QUALITY; the former shews itself partly, in the great DEFICIENCY OF THE BLOOD, anamia, which we sometimes observe as a congenital vice 
in imperfect monsters, and is occasionally to such extent, that we are reminded of the similar state in the early stage of foetal existence and in the lower animals $;^{2}$ sometimes it is found as an acquired state, in many cachectic persons, in many fevers, in severe hemorrhages, in death from hunger: ${ }^{3}$ partly, in the TOO GREAT QUANTITY OF BLOOD, polyamia, plethora, which is occasionally observed in somes corpses, viz. in persons affected with the blue disease, in hydrophobic persons, and brutes. ${ }^{4}$ Anomalous colour, consistence, and composition, are vices of QUALITY in the blood, which not unfrequently occur; thus we often find it, for instance, too thin and pale after severe loss of blood, in leucophlegmatic dropsy, tubercular disease, diabetes, ${ }^{5}$ \&c.; in a person who was destroyed by the poison of prussic acid contained in nut-water, the blood had a remarkably lightblue colour ${ }^{\circ}$ in inflammation and consumption, it is very highly red-coloured, and, on account of the great quantity of coagulable lymph it contains, often firmly coagulated in the vessels; we find the blood very deep-coloured, actually black and very fluid, in the veins of persons affected with the blue disease, scurvy, jaundice, ${ }^{7}$ hydrophobia, yellow fever, the fever of mortified spleen, and carbuncle, in drowning or suspended respiration from other causes, so also in actual suffocation, and in men and animals destroyed by poisons; in melanosis, we find black flakes and even large clots of black pigment in the blood $;^{8}$ occasionally the blood is black and viscous, as though it were clayey, which has been observed sometimes in yellow fever, ${ }^{9}$ mortification of the spleen, \&c. In poisoning from sulphuric acid, the blood in some cases is completely coagulated in the vessels. ${ }^{10}$ The morbid composition of the blood and the mixture of foreign substances in it, frequently may be observed without any chemical analysis. ${ }^{11}$ Thus, for instance, is the quantity of fibrous matter contained in the blood of many corpses remarkably great or small; in others, we find the chyle not intimately mixed with the blood, ${ }^{12}$ or yellowish flakes of albumen in the black uncoagulated blood, ${ }^{13}$ or an unusually large and very readily discernible quantity of fat, ${ }^{14}$ especially in brandy-drinkers, ${ }^{15}$ \&c. Sometimes we find, without its being the consequence of putrefaction, a greater or less quantity of AIR in the veins, either like bladders mixed with blood, or alone, which distend them more or less completely; ${ }^{16}$ in many instances the air passes distinctly from without by apertures in the veins. ${ }^{17}$ Pus has been found several times in the veins, not produced by ulceration of their surface, but by effusion from neighbouring abscesses, and by absorption into the veins. ${ }^{18}$ Parasitic animals are also met with in the 
veins. ${ }^{19}$ We very frequently observe veIN-sTones, phlebolithi, ${ }^{20}$ that is, chalky concretions, deposited in the cavities of the veins, which occur especially in the veins of the urinary and generative organs, although sometimes also found in other parts, and are either little rounded stones composed of concentric layers of lime, situated loosely on the wider parts of the veins, or close calcareous cylinders entirely filling the veins to a greater or less extent. ${ }^{21}$ In a few instances, NEEDLES have been found in a vein. ${ }^{22}$

(1) Besler D. de sanguinis contributione secundum et præternaturam. Altd. 1631. - Steuerlin D. de morbis ex crasi sanguinis alterata oriundis. Altd. 1682.Albinus D. de pravitate sanguinis. Fr. 16\$9. - de Sandris De naturali et præternaturali sanguinis statu. 4to. Bonon. 1696.-Reichhelm D. de legitima particularum sanguinis earumque perturbata mixtura. L. B. 1702.-Rivinus and Bornholt D. de sanguinis pravitate. Ultraj. 1702.-Brinner D. de mala sanguinis temperie. Groning. 1707.-Otto D. de sanguinis humani constitutione naturali et præternaturali, 1735. - W. Hewson Experiments on the Blood, with some remarks on its morbid appearances, in Phil. Trans. 1770, p. 368.-Gruner D. Pathol. sanguinis. Jenæ, 1791. — J. Whiting D. de sanguine ægrorum. Edinb. 1816. van der Kolk Historia sanguinis coagnlantis, cum experimentis ad eam illustrandam institutis. 8vo. Groening, 1821.-J. Davy, Some observations on the buffy coat of the Blood, Sc. in Phil. Transact. 1822, p. 271.-W. Stoker Pathol. Obs. Part I. On Dropsy, Purpura and the Influenza of the latter year, and particularly on the morbid changes of the blood, \&c. 8vo. Dublin, 1823. - Ch. Scudamore, An Essay on the Blood, comprehending the chief eircumstances which influence its coagulation, the nature of the buffy coat, with a concise medical view of the state of the blood in diseases, Src. Svo. London, 1824.Koenig D. s. experimenta quædam circa sanguinis inflammatorii et sani qualitatem diversam instituta. 4tn. Bonnæ, 1824.-Spilta De sanguinis dignitate in pathologia restitnenda, etc. Svo. Rostoch. 1825 . - Koch D. de observationibus nonnullis microscopicis sanguinis cursum et inflammationem spectantibus, etc. Berol. 1825. - Belhome Beobachtungen über das Blut und die crusta inflammatoria, u. s. w. in the Revue médicale in v. Froriep's Notizen, Vol. VII. p. 247. - Heusinger 1 ter Bericht von der anthropotom. Anstalt. p. 7. 4to. Wurzburg, 1826. - Leuret Essai Sur l'altération du sang. Thèse médicale. 4to. Paris, 1826. - Trousseau and Dupuy Experiences sur les altérations du sang, considérés comme causes des maladies locales in Archiv. général de Médec. June-August, 1826. - Velpeau Recherches et Observations sur l'altération du sang dans les maladies in Revue médicale et Journal de Clinique. June, 1826. M. Junkelmann D. de cacochymicis sanguinis incleque oriundis ærgitudinibus. 4.to. Jenæ, 1827.-J. R. Burkhart Ueber das Blut und das $\Lambda$ thmen in physiol. und allgem. pathol. Hinsicht. 8vo. Basel, 1828.-Ribes in l'Anatomie pathol. Vol. I. p. 309. Paris, 1828.

(2) For instance, in the acephala; compare Meckel's Handb. der pathol. Anatomic, Vol. I. p. 170. - I have, however, observed a similar paucity of blood in other human and animal monsters, characterized by deficient development.

(3) I have seen many bodies which scemed almost bloodless, so that, with difficulty, we could only find any in the large venous branches; or, on the contrary, very little in the smaller blood-vessels.

(4) We find bodies, in which the quantity of blood is very remarkable, so that not merely is the heart and larger vessels, hut also all the smaller, gorged with blood, and on the slightest incision the blood pours out.-Krngenberg observed also this in a person who died of hydrophobia, who had been very freely bled. v. Horn's Archiv f. medic. Erfahrung, 1817, March and $\Lambda$ pril, p. 356.

(5) $\Lambda$ lso very pale in animals; for instance, in an ass which died of 
dropsy of the pericardium. v. Schwab Materialen zu einer pathol. Anatomie der Hausthiere. 1 te Lief. p. 10. - I have seen it also once very pale in a glandered horse, and in a dog which died of distemper. In diabetic persons, the blood has often been found chocolate-coloured, and the serum milky.Also in new-born infants I and others have found the blood chocolate-coloured. v. Billard. Traité des enfans nouveaux-nés, \&c. 4to. Paris, 1828.

(6) Schneider in Henke's Zeitschrift für die Staatsarzneik, 1825, Part II. p. $399, \mathrm{ff}$.

(7) If the blood be coagulated in the vessels, the serum appears very yellow, which, however, does not arise from the mixture of bile, as Deyeux and Parmentier, and later, Lassaigne, Meissner, and others have shewn. [W. Stevens, Observations on the blood in yellow fever, in which there is "a dissolved fluid" in place of blood as black as ink, and unfit for the purposes of life : A paper read before the College of Physicians, London. v. London Med. and Plyys. Journ. Vol. LXIII. T.]

(8) Bigot found in the veins of a horse a blackish substance as large as a hazel-nut. v. Lassaigne in Journ. de Chim. méd., de Pharm. et de Toxicol, June, 1827, p. 264.

(9) Savaresy De la fièvre jaune en général et particulièrement de celle qui a regné à la Martinique, p. 458, Neapel, 1809.

(10) viz. completely in a child. v. Meier in Henke's Zeitschrift für die Staatsarzneikunde, Vol. X. p. 302.-In the cutaneous vessels only of an embryon, in consequence of the water of the amnion being sour. My Selt. Beob. Part II. p. 152.

(11) In reference to the reception of extraneous substances into the blood, compare A.C. Mayer Ueber das Einsaugungsvermögen der Venen des grossen u. kleinen Kreislaufes in Meckel's Archiv für Physiol. Vol. II I. p. 485.-F. Tiedemann and L. Gmelin Versuche uiber die Wege, auf welchen Substanzen aus dem Magen und Darmkanal ins Blut gelangen. Heidelberg, 1820.-A. H. L. Westrumb in Meckel's Archiv f. d. Physiologie, Vol. V II. p. 525, and Physiol. Untersuchungen über die Einsaugungskraft der Venen. Hannover, 1825.-Quicksilver was found in the blood by Autenrieth and Zeller. v. Reil's Archiv. Vol. VIII. p. 213.-Schubarth in Horn's Archiv, 1823, (in a horse.) -Ekl saw it in the blood with his naked eye. v. Bericht über die Ergebnisse im chir. Klinikum zu Landshuth. 1826. - J. A. Buchner Toxikologie, p. 538, 2 d edit. Nurnb. 1827.Calson. v. von Froriep's Notizen. Vol. XVI. p. 144.- In a person poisoned with arsenic it was found in the blood. v. Adelmann in Harles's N. Jahrb. der deutschen Medicin u. Chir. Vol. I. Part I.-I have very often observed in the blood the smell of brandy and strong smelling medicines.

(12) In diabetes mellitus. v. Müller D. de diabete præsertim mellito. 8vo. Goett. 1822. - A white milk-like fluid in the blood of a female ass, which died soon after birth, found by Moiroud. v. Girard, Vatel, \&c. Recueil de Médec. vétérin. May, 1828, p. 233.

(13) In a person who died of yellow fever. v. Fr. Xav. Laso Colleccion de inspecciones anatomicas relativas a la fiebre amarilla. 4to. Cadiz, 1821. v. Gerson and Julius Magazin der ausl. Literatur. Jan, and Feb. 1823, p. 52.

(14) W. Hewson On the Blood, p. 110. Nürnberg, 1780.-Marcet found it in the serum of a diabetic patient, and Traill in serum of a person affected with Hepatitis. Compare Hünefeld Physiol. Chemie, Part II. p. 225.-Rayer in the blood of a person killed by choke-damp. v. Heidelberger Klin. Annalen, Vol. IV. Supplementheft, I. p. 160, 1828.

(15) J. Adams in Transact. of the med. and phys. Society of Calcutta, Vol. I. Calcutta, 1825. v. Taylor's Philos. Magaz. and Journ. Oct. 1826, p. 310. Traill, in Edinb. med. and surg. Journ. Vol. XVII. p. 319. - Fauthier and Bertrand in Archives générales de Médecine, Vol. XV. Sept. 1827.-I myself have found it twice very distinctly.

(16) Compare especially Morgagni, Epist. V. 17-30. - Nysten Recherches de Physiologie et de Chimie pathologiques. Paris, 1811.-J. Davy in Philos. Transact. 1823, Part II. - According to Briere v. Nouvelle Biblioth. 1826, Feb. and March, the air passed from the lungs into the arteries and veins, which, however, is not to be admitted.-I have found it without any suspicion of 
putrefaction. [Andral, Vol. II. p. 413, states that he has several times seen the blood remarkably frothy in some of the veins, or in the cavities of the heart, without there being any trace of putrefaction in the body; and seems inclined to think it takes place before death, but speaks of it with great caution. T.]

(17) After violent blood-letting.-In the blood-vessels of a person whose head was cut off. v. Testa, in operations on the neck, in which the jugular vein being injured, the air rushed, with a hissing noise, into the vein. v. Magendie in Journ. de Physiol. 1821, Vol. I. No. 2. p. 190. - Dupuytren in Archives générales de Médecine, July, 1824, p. 430 ; also v. above, $\$ 184$, note 3.

(18) Viz. in the inferior cava in abscess of the liver. v. Blancardi Observat. Cent. II. No. 73. - Ribes. v. Mém. de la Soc. med. d'emulation, Vol. VIII. Part II. p. 613.--Velpeau in Archives générales de Médec. 1824, Vol.VI. p. 227. -Gendrin Hist. Anat. des inflamm. I have also sometimes found pus in the femoral vein, in ulcers of the leg, without the vein being diseased.

(19) Viz. the strongylus inflexus in the pulmonary veins of a porpoise. v. $W$. Vrolik in Bydragen tot de natuurkundige wetenschappen versameld door van Hall, W. Vrolik en Mulder, D. I. No. 1. p. 77, Amsterd. 1826. - Two strongyli in the vena azygos of a porpoise. v. von Baer in Nov. Actis Acad. N. C. Vol. XIII. P. II. p. 560, Nat.-F. J. Schmitz D. de vermibus in circulatione viventibus. 8vo. Berol. 1826, with lithographic tables. The polystoma venarum, which Treutler, Obs. pathol. anat. p. 23, tab. 4, fig. 1-3, found in a vein of the foot of a man, was, as Rudolphi has remarked, probably a planaria, which had made its way in.

(20) Realdus Columbus De re anatomica, Lib. XV. p. 491, 8vo. Francof. 1593, (in the hemorrhoidal veins.) - Schenkii Observat. med. rar. L. III. § 2, Obs. 54, Francof. 1600. - Thom. Bartholinus Histor. anatom. rarior. Cent. III. Hist. 34, Vol. II. p. 71, with figs. (in the renai veins.) - Greisel Lapilli cum sanguine e vena prosilientes in Misc. Acad. Nat. Cur. Dec. I. Ann. I. 1670, p. 163; Ann. II. 1671 , p. 23. - Roesler De calculis in venis mesaraicis, ibid. Dec. I. Ann. III. 1671, p. 528. - Tulpius Observat. med. L. IV. cap. 22. 4th edit. 8vo. 1672, (in a dorsal vein.)-J. G. Walter Observat. anat. p. 44 and 45. fol. Berol. 1775, (in the veins of the bladder five, and in those of the vagina three, as large as peas.)-Sömmerring Addend. to Baillie, No. 5, p. 191, (on the urinary bladder.) Langstaff in Hodgson, p. 522, (three as large as peas on the veins of the uterus.)-Cruveilhier Essai sur l'A nat. pathol. Vol. II. p. 70, (two instances in the veins of the bladder; he also cites cases from Lobstein and Laennec, on the rectum, bladder, pubic and spermatic veins; as also from Dupuytren, on the pubic veins, and Tilorier, on the cutaneous veins of the thigh.)-J.F. Meckel Handb. der pathol. Anatomie, Vol. II. Part I. p. 190; and Tab. anat. pathol. Fasc. II. p. 13, pl. 14, fig. 4, 5, (once on the veins of the bladder.)-- F. Tiedemann in Meckel's Archiv für die Physiologie, Vol. IV. p. 215, with plates.-Kosenthal in Horn's Archiv. f. medic. Erfahrung, May and June, 1818, p. 404.-Cerutti Beschreibung der pathol. Präparate zu Leipzig, No. 600 and 601 , (from the plexus uterinus and vesioalis.) - Myself on venous stones, in my Selt. Beob. Part II. p. 72, No.32; and my Verzeichniss, No.4284, 4285. I have since also found them in the veins of the spermatic cord.-Bonillaud in Revue médicale française et étrangère, April, 1825, (sometimes in old varices of the lower extremities.)-Ehrmann Compte rendu des travaux anatomiques, Sc. Strasb. 1827, 1.38, (thirty-two in the veins of the prostate gland.) - I have found venous stones in almost all the large anatomical collections; the largest, however, which $I$ have seen was the size of a hazel-nut, and from the splenic vein, in the Anat. Mus, at Strasburgh.--John has given an analysis of them in Schweigger's Journ. f. Chemie und Physik, Vol. XII. p. 80, and Gmelin in Tiedemann, according to which, they consist principally of phosphate and carbonate of lime.

(21) Compare my Selt. Beob. and Verzeichn. No. 4286 and 4287. I also saw the veins of the large intestines of a horse affected with glanders, and disease of the bones in the veterinary school at Stockholm; perhaps also the case of $\mathrm{Wal}$ ter's, Observ. Anat. p. 45, tah. 9, above mentioned, in which the crural vein was filled with a large piece of lime. $\Lambda$ s to the origin of these phlebolithi, I cannot agree with Horlgson's opinion, that they pass from without, by a rapid absorption 
of the veins, nor Meckel's view, that they are produced like encysted tumours ; but rather adhere to the opinion of Tiedemann, that they are produced from and in the blood itself, for the reasons which I think I have made clear; this point is also supported by the rare observation of Ehrmann, according to which, some of the phlebolithi were still soft, and appeared to be formed from the fibrous matter of the blood; a mode of formation which Cruveilhier had previously noticed.

(22) In one branch of the brachial vein. v. Duverney in Mém. de Paris, 1702, Hist. p. 25; in a vein, Plot, Natural history of Staffordshire, \&c. v. Plouquet Repertor. Art. Vena.

\section{Fifth Chapter.}

\section{Of the Lymphatic Vessels and Glands.}

\section{$\$ 210$.}

As to the vices of formation and disorganization of the absorbing system, ${ }^{1}$ there is, on account of the delicacy of its structure, but little certainly known, and even this especially applies to the thoracic duct and the lymphatic glands, which latter, as coils or congeries of the absorbents, must be here considered together with them. As, however, the lymphatic system is so generally distributed in the bodies of men and the higher animals, and performs a principal part in the business of the change of substance in the organism, it is easy to see that in most general and local diseases it must be affected, partly idiopathically, partly deuteropathically; this is particularly observable in rickets, in tubercular disease in its widest sense, in syphilis, cancer, and plague. Organic vices of the absorbent system occur most frequently also in youth, when the vital activity is at the highest, but most rarely in old age, when the vegetative process gradually declines.

(1) Lossius D. de glandularum passionibus in genere. Witeb. 1682.-Fr. Schrader Lympha et glandulæ pathologice consideratæ. 4to. Helmst. 1686.J. Walker D. de glandularum morbis. Edinburgh, 1743._Russel CEconomia naturæ in morbis acutis et chronicis glandularum. London, 1755.-Diedrich de morbis glandularum. Lips. 1759.-Edm. Darwin, Experiments establishing a criterion between mucilaginous and purulent matter; and an account of the absorbent vessels of animal bodies in some diseases. 8vo. London, 1780 . J. C. Szombathy De morbis glandularum secundum ætates. Vien. 1782.-Assalini Essai médical sur les vaisseaux lymphatiques, avec le moyen de prévenir les effets venimeux des substances venimeuses. 8vo. Turin, 1787.-L. Formey D. de Systematis absorbentis pathologia. 8vo. Hal. 1788.-Wrisberg in Comment. Soc. Goetting, Vol. 1X. Part I. p. 136.-Ludwig D. Physiologorum atque pathologorum de systemate absorbente recentissima quædam decreta. Lips. 1789.-Pajol De Morbis vasor. absorbentium in Mém. dè la Soc. de Médec. de Paris, 1791, Vol. VII. and VIII.-D'Hame Idea pathologiæ systematis absorbentis. 8vo. Coloniæ, 1792. -De Koning D. de affectionibus morbosis systematis 
lymphatici. Lugd. Batav. 1793.-S. Th. Sömmerring De morbis vasor. absorbentium corporis humani. Traj. ad Moen. 1795.—Gilibert Essai sur le systême lymphatique dans l'état de santé et de maladie. Paris, 1804.-Alard Histoire d'une maladie particuliere au systême lymphatique frequente, etc. Sro. Paris, 1808, with plates. - Attenhofer Lymphatologie, oder Abhandlungen uber das lymphat. system und dessen Leiden. Wien, 1808.-W. Goodlad, A practical essay on the diseases of the vessels and glands of the absorbent system. 8vo. London, 1814.-Andral, fils, Observations sur les maladies du canal thoracique in Arclives générales de médecine. Dec. 1S24.-Reg. Lippi Illustrazioni fisiologiche e patologiche del sistema limfatico-chilifero, mediante la scoperta di un gran numero di communicazioni di esso col venoso. 4to. Firenze, 1825.Compare besides the anatomico-physiological writers on the absorbents, and the greater number of the works on scrofula, quoted at $\S 65$, note 1 .

\section{$\S 211$.}

As to the varieties in this system, they are just as frequent as in the venous, so that the comparison of the large absorbent trunks in different individuals, on the right and left side, often presents great variation in reference to their number and course. We most frequently observe such variations in the ductus thoracicus $;^{1}$ thus, for instance, it commences higher or lower in the belly, and also consists of more or less branches, divides at one or more points of its extended course into two or three branches, is double throughout its whole length, ${ }^{2}$ divided merely at the upper part, ${ }^{3}$ or empties itself at unusual points, ${ }^{*}$ \&c. Sometimes the larger absorbing vessels from the neck and arms terminate singly in the subclavian veins, so that then there is no common absorbing trunk on the right side. We observe it arched, not merely in distortion of the back, but also as consequent on its elongation in the normal state of the spine; sometimes very tortuous, or disturbed from its usual situation by tumours on the front of the vertebræ, by the vena cava taking an irregular course,${ }^{5}$ \&c. The number and situation of the absorbing glands sometimes varies; thus we find on the leg, as well as on the fore-arm, one or several unusual glands, or in many places, for instance in the groin and arm-pit, instead of many small, fewer but much larger glands.

(1) Haller Elem. Physiol. Vol. VII. p. 222, \$11.-Sabatier in Mémoires de Paris, 1780.-Jamus Bang De variationibus in ductu thoracico visis in Soc. med. Havn. Collectaneis, Vol. I. p. 82. - Sömmerring Vom Baue des menschlichen Körpers. 2d edit. Part IV. p. 583.

(2) It then usually empties itself into the right subclavian vein, but not always, and receives all the absorbents, which usually terminate in the lesser principal thoracic trunk.--Such cases were seen by $A$. $F$. Walther De ductu thoracico bipartito, etc. 4to. Lips. 1731, rec. in Halleri Disp. anat. Vol. I.-le Noble, Collins, Duvernoy, Winslow, Wium. v. Haller, who saw it twice; further TH. Bartholinus Anat. L. B. 1686, p. 620.-W. Cruilshank's Anatomy of the absorbing Vessels. - Sömmerring, p. 583, note 2.- I have twice found it completely double, and indeed in one instance both terminated on the left side in the jugular and subclavian vein; in the other on eacl side in the subclavian vein.

(3) 'The thoracic duct not unfrequently terminates on the left side of the neck 
by two or three branches; if it be divided further down, the right branch terminates in the right subclavian. Such cases were observed by Wium, Heuermann, Velse, Pequet, and Rolfink. v. Haller, p. 224. I have also seen the same in a wax model in the anatomical collection at Upsal.

(4) Not merely in persons with general transposition of the viscera; but sometimes also in others, it empties itself into the right subclavian vein.-Compare Haller, p. 223, note 1.-Meckel De vase lymphat. gland. conglob. 4to. Berol. 1757, p. 19.-Cruilsshank, The Anatomy of the absorbent Vessels of the human Body. 4to. Lond. 1786, 2d edit. 1790, p. 152.-Fleischmann Leichenöffnungen, p. 236, No. 75.-It has also been seen terminating entirely, or only by a single branch, in the vena azygos; the former is described by Albinus. v. Cruilcshank's Anatomy of the absorbing Vessels, 4to. London, 1786, and Mascagni Vasorum lymphaticorum corporis humani historia et iconouraphia. fol. Senis, 1787. v. Ludwig, Vol. III. p. 42. - Of the latter J.C. Bohl D. viæ lacteæ corporis humani historia. IRegiomont. 1741 .

(5) I have sometimes seen it thrust out of its place by exostoses, and in one case, by the inferior cava passing behind it and the aorta; the latter is engraven by Gurlt, D. de venar. difformitatibus. 4to. Vratislaviæ, 1819. Sometimes it is very much displaced by aneurysm of the aorta. v. Bayford in Medic. Obs. and Inquir. Vol. III. p. 18.

\section{$\S 212$.}

The sIzE of the absorbent vessels varies in the same way as that of the veins; thus in many individuals they are all very small and narrow, ${ }^{1}$ in other instances again they are all proportionally too wide, and more frequently vary from their usual sIzE only at particular parts of the body, inasmuch as, for example, in atrophic parts they are very much straightened, or are compressed at certain parts by adjacent swellings, or lastly, and which occurs more commonly, and is more frequently noticed, they are remarkably expanded at certain parts, either on account of the relaxation of their walls, or of mechanical obstruction to the progress of the lymph, that is, become Varicose, a state to which, in the most restricted sense, we apply the name cirsus, or ABSORBENT KNOTS. ${ }^{2}$ Those HYDATIDS which are connected with delicate and in part hollow threads, and are often in rows, for example, in the vascular plexuses of the cavities of the brain, in hydatid moles, \&c., perhaps arise from varicosity of the absorbent vessels. ${ }^{3}$ More apparent are the deviations from normal size in the lymphatic glands, which appear equally in two states, viz. diminution or wasting, and still more frequently, in several diseases, as idiopathic or sympathetic, and often very considerable swellings. The too great extension of the lymphatic vessels may also lead to their consequent RUPTURE OR BURSTING, ${ }^{4}$ whereby effusions and collections of lymph occur in the cellular tissue, producing the LYMPHATIC TUMOUR, tumor lymphaticus, ${ }^{5}$ so called; or, if the thoracic duct be torn, effusion of lymph into the mediastinum, hydrops lacteus, as it is named. ${ }^{6}$ Similar effusions of lymph also occur after wounDs ${ }^{7}$ of the larger trunks, the cure of which, on 
account of this effusion, is sometimes difficult; but when it takes place, it is always alone effected by adhesion and closing of the lymphatic vessels.

(1) For instance in dwarfs. v. Sồmmerring De morbis vasor. absorb. p. 42.

(2) Many instances of great varicosity of the absorbents are to be found in Wrisberg, and Cruikshank, and in Sömmering, $\$ 22$, Vasa absorbentia varicosa.$I$ have often observed it in the absorbents of the lungs, liver, intestines, pelvis, and of the lower extremities, either on account of compression or stoppage in their more superficial trunks and glands. I have a few times found the thoracic duct compressed by aneurysms of the aorta, or stretched by their lying beneath it; the same has been observed by Laennec Journ. de Médec. cont. Vol. XII. p. 159.-The thoracic duct has been once seen as thick as the finger. v. Cruilshank, p. 207, pl. 5. 2d cdit.-Baillie, in his Morbid Anatomy, p. 108, mentions one nearly as large as the subclavian vein, of which Sömmerring, in his Addenda to Baillie, gives another instance.-According to Baron these tubercles arise from enlargement and great development of the lymphatic vessels, or from the formation of little cysts in them. v. Delineations of the Origin and Progress of various changes of structure, \&c. 4to. Lond. 1828, with plates.

(3) Of this opinion, for example, is Bidloo De hydatidibus in Exercit. anat. chir. L. B. 1708. - Hufeland Ueber die Natur, Erkenntnissmittel und Heilart der Skrofelkrankheit. p. 382. Jena, 1795. - Rudolpki resp. Carger De ventriculis cerebri. Gryphiæ, 1786._Lüdersen D. de hydatidibus. Gött. 1808, p. 82.-This kind of hydatids seems to me, in some cases, rather to be connected with the extremities of the arteries.

(4) It is well known that the older writers erroneously derived consumption especially, and also scrofula, \&c. from rupture of the absorbents.

(5) Plencli Novum systema tumorum, p. 127. Viennæ, 1767. - A. Beinl Von einer eignen Art Lymphgeschwulst, und der zweckmässigsten Methode dieselbe zu heilen. 4to. Wien, 1801.-J. A. Schmidt Ueber den Grund der Törltlichkeit der Lymphgeschwülste, in the Abhandlungen der Joscphinischen Akademie, Vol. II. p. 327, Wien, 1801. - Nybleus præs. Ackermann D. de tumore lymphatico, Upsalæ, 1807.-Strunk D. de abscessu lymphatico, Goett. 1809.-Rust Abhandlung von den Lympli. geschwülsten in Harles's Jahrb. der deutschen Medicin und Chir. Vol. I. p. 155. Nürnberg, 1814. - Von Walther Ueber die wahre Natur der Lymphgeschwülste in his and Grïfe's Journal f. Chir. Vol. I. p. 584-611.Chelius in Textor's Neuem Chiron. Vol. I. p. 115-125.-G. Zembsch D. de tumore lymphatico. 8vo. Berol. 1826.-That Walther, and other surgeons of modern times, have very properly shewn the greater number of lymphatic abscesses to be no more than ulcers of a peculiar kind does not, according to my opinion, contradict the existence of lymphatic tumours from the causes here mentioned.

(6) Bassius Observationum Decas II. Observat. VII._Guiffart in Bartholinus Opera nov. p. 490 .

(7) J.Muys De vulnere vasculi lymphatici in Praxi medico. chirurg. p. 240, Amstel. 1695.-Ant. Nuck, De vulneribus vasor. lymphaticor. in Experimentis chir. L. B. Cap. 28, 1733; comp. Sömmerring, p. 52, § XXVII. I lave known a few cases of a free flow of lymph from wounds made in opening veins. On injuries of the thoracic duct, see the writers on medical jurisprudence; in one such case, the lymph continued to How, and produced a fistula. v. Fr. Hoffmann. $B$. aflectus rarissimus perpetui stillicidii succi nutritii, in Opusc. supp. II. 2.

$$
\S 213 .
$$

Vices of TeXture in the lymphatic system appear to be the same as those in veins; but they are naturally less easily observed. Inflammation, ${ }^{1}$ both of the abSORBENT VESSELS and GLANDS, is frequent; the former sometimes take on that state during life, giving the sensation and appearance of hardish, 
painful threads, producing reddish streaks in the skin, and in the dead body they appear, especially if the inflammation were chemical, more or less red, thickened, hardened, knotty, opake, less elastic, and if it be the ductus thoracicus ${ }^{2}$ even freely covered with a net-work of blood-vessels: the latter exhibit inflammation, especially by great swelling, ${ }^{3}$ compactness, and increased redness: commonly also we find the neighbouring cellular tissue inflamed at the same time. This inflammation of the lymphatic system is sometimes idiopathic, and is then very commonly produced in men and animals, partly by local, mechanical, and chemical irritation, partly by general disease of this system, viz. by scrofulous and tubercular disease; in other cases the inflammation of the absorbent and lymphatic glands is sympathetic, ${ }^{4}$ metastatic and even critical. ${ }^{5}$ This disease rarely runs immediately into SUPPURATION and MORTIFICATION, but it has rather a disposition to INDURATION, internal effusion, and consequent OBSTRUCTION ${ }^{6}$ and ADIESION, whence, subsequently, in part suppuration occurs, which indeed is frequently the case in scrofulous swellings produced by induration and stoppage of the branches of the absorbent vessels and lymphatic glands $;^{7}$ partly odematous swelling of those parts from which the reflux of the lymph is prevented; and, lastly, consumption frequently occurs. Continued pressure also easily effects adhesion of the absorbent vessels. The ductus thoracicus has also been several times observed obstructed or adherent from coagulated and exuded lymph. ${ }^{8}$ Lastly, the inflammatory irritation often gives rise to the conversion of the tissue of the absorbent vessels and glands into a cartilaginous mass, and a deposition of lime in their tissue. The latter is observed but rarely and very partially in the absorbent vessels $;^{9}$ on the contrary, in the lymphatic glands, especially in the bronchial and mesenteric glands of men and animals, ${ }^{10}$ it occurs frequently and largely, so that oftentimes they are completely converted into a stony mass.

(1) Here belong the endemic swelling of the legs, of Barbados. v. J. Hendy, Treatise on the glandular Disease of Barbados, proving it to be seated in the lymphatic system. London, 1784. J. Rollo, Remarks on the disease lately described by $D r$. Hendy, \&c. London, 1785. - Alard De l'inflammation des Vaisseux absorbens lymphatiques dermoides et souscutanés, maladie designé par les auteurs sous les différens noms d'Elephantiasis des Arabes, d'E.deme dur, de Maladie charnue, de Maladie glandulaire de Barbade, etc. 8vo. 2d edit. Paris, 1824. Fr. Fedeli De lymphangioitide, ejusque formis diversis. 8vo. Patavii, 1825. - Gendrin Histoire Anatomique des inflammations, 2 vols. 8vo. Paris, 1826.

(2) Two cases are found in Andral, and one in Gendrin, p. 70, 1001.

(3) Panus or Adenophyma.

(4) For instance,-in difficulty of cutting the teeth; in lying-in women, in the first secretion of milk in the breast; in the neighbourhood of many eruptive 
diseases of the skin,-malignant ulcers; in syphilis in the unguinal glands; in buboes, \&c. Compare J.D. Prophet D. de sympathica glandularum inflammatione. 8vo. Halæ, 1823.

(5) In typhus fever, and especially in the plague; although, according to some authors, the plague boil is not seated in the lymphatic glands, but in the neighbouring cellular tissue; compare $P$. Russell, Treatise of the Plague, 4to. London, 1791.-Larrey Mém. de Chir. Mil. Paris, 1812. In yellow fever, the plague bubo, bubones pestilentiales, are said to be very rare. A. Ramsay, however, found the lymphatic vessels opake, inelastic, widened, and thickened, in a person who had died of yellow fever. v. Edinburgh medic. and surg. Journ. 1812, Vol. VIII. Part IV.

(6) Not every lymphatic gland swollen by inflammation is, as the old writers thouglst, rendered impervious, but, on the contrary, rendered wider, as quicksilver will pass more easily through them than usual; but in the higher degrees of inflammation, and its consequences, as also in scrofulous, scirrhous, and other hardening, the glands are partially or completely obstructed.

(7) Compare $\$ 65$.

(8) Cruikshank.-Mascagni Vasor. lymphaticor. corporis humani Historia et Ichnographia. fol. Senis, 1787.-Assalini Versuch über die Krankheiten des lymphat. Systems, p. 41.-Walter in Mém. de l'Acad. de Berlin, 1786, p. 21.Poncy in Suviard's Recueil d'Observations chirurgicales. Observat. 3.-Watson in Philos. Transact. Vol. L. p. 392.-Astley Cooper in Medical Record and Researches from the papers of a private medical association. Vol. I. London, 1798, (three cases, in one ulceration and adhesion of the valves.)-Goodlad.-Hopfengärtner in Hufeland's Journ. d. prakt. Heilk. June, 1817.-Nasse Leichenöffnungen. 1te Reihe, p. 150.-Andral, third observation. - Lobstein Compte rendu sur les travaux anatomiques, etc. Strasb. 1824, p. 67, No. 131.-Baillie, the works of, ed. by Wardrop, London, 1825, Vol. I._Gendrin, p. 70, § 1001.

(9) To wit, Mascagni, p. 30.-Attenhofer.

(10) The glands sometimes contain one or several bony concretions; sometimes they are completely converted into stone, with a smooth surface; sometimes they have merely an external bony capsule; sometimes, finally, the lime in a state of pap is contained witlin the gland as in a kind of sac. Among animals I have found ossification of the glands in monkeys, dogs, sheep and horses.

\section{$\S 214$.}

Among the spurious Formations, it appears that the lymphatic system, on account of the delicacy of its structure and the small quantity of cellular tissue therein contained, is not disposed to the formation of ExCYSTED Tumours. The lymphatic glands, however, to a certain degree, not unfrequently assume the form of encysted tumours; thus they become converted by suppuration and absorption into membranous bags filled with bloody ichor, thin lymph, a secretion containing lime, \&c. The lymphatic system is affected with TUBERCULAR DISEASE the more frequently, as the latter is originally seated merely in it. 'The formation of a peculiar substance, similar' to white fresh cheese, is also here the peculiar characteristic of this discase, in which the lymphatic vessels often inflame, thicken, are stopped up with scrofulous matter, and are even converted into more or less long, thick, hard strings: the glands first inflame; subsequently, in consequence of the deposition of scrofulous matter, lauden, thicken, become pale, and at last soften fiom their centre and run into suppuration. Not 
unfrequently in those parts where the glands lie near each other, as, for instance, in the neck, on the spine and mesentery, many of them are converted into one large scrofulous swelling. SARCOM and CANCER $^{2}$ appear to occur primarily in the lymphatic system but very rarely; but not unfrequently secondarily, as the infection from the originally diseased parts is easily propagated to the neighbouring lymphatic glands agreeably to the course of the lymph. ${ }^{3}$ In medullary sarcom of the testicle we very frequently observe a similar sympathetic affection of the lymphatic glands on the spermatic cord, pelvis and spine, more or less high up, in which case also the ductus thoracicus frequently becomes at the same time affected. ${ }^{4}$

(1) Compare §65. I have myself observed some instances in which the thoracic duct, and the lymphatic glands in its neighbourhood, were scrofulous. Compare my Selt. Beob. Part II. No. 33, p. 76 . I have since seen some other instances.-Older cases may be found in Lieutaud, Hist. Anat. Med. Vol. II. p. 243, Obs. 770, 771, 771 a.-A. Cooper, (first and second case.)-Palletta Exercit. Pathol. p. 109, fig. 4.

(2) Compare $\$ 78$, note 7. According to Baron, Delineations of the origin and progress of various changes of structure, \&c. 4to. London, 1828, scirrhus should in all parts arise from a morbid change of the lymphatic vessels.

(3) To wit, from cancer of the breast in the axillary glands; of the lips and salivary glands in those of the neck; of the alimentary canal in those of the mesentery, and of the testicle in the pelvic glands, \&c. The latter I have also seen in sarcocele.

(4) A. Cooper, (third case.) - Rust in Horn's Archiv f. d. medic. Erfahrung, 1815 , p. $731-790$, (two cases.) - J. Wardrop, Observations on Fungus hæmatodes, Case 21-24.-Howship, Practical Observations in Surgery and morbid Anatomy, Case 94.-Gierl in Textor's Neuen Chiron. Vol. I. Part II. p. 273.Biermayer Museum anatomico-pathologicum, No. 535. I saw a second interesting case in the same Museum, in 1827, No.3906.-Breschet in Diction. des Scienc. médical. Vol. XX. Art. Hematode, p. 196, under the name Carcinome abdominal.-Keutel in Rust's Magazin f. d. ges. Heilkunde, Vol. XVI. p. 226.My Selt. Beob. Part II. p. 76, (since in another case.)-Dickson in Edinb. med. and surgic. Journ. A pril, 1825, No. 83.-Zink in Journ. compl. du Dict. des Sc. medicales, Vol. XXI. March, 1825.--Rissler in Ars Berättelse om Svenska LäkareSällskapets Arbeten, lemnad of Ekstroern. Stockh. 1825.-B. H. Coates in Philadelphia Journ. of the med. and phys. Sciences by Chapmann, Vol. IV. No. 2.Also in melanosis tuberculosa of the horse, $(\$ 67)$, an uninterrupted string of large swellings between the rump and the termination of the aorta. v. W. Cullen and R. Carswell in Transact. of the med. chir. Soc. of Edinburgh, 1824, Vol. I. No.13.

\section{$\S 215$.}

Lastly, in the lymphatic system we observe vicEs of CONTENTs, inasmuch as, by their absorbing activity, they are sometimes able to take up extraneous substances. Thus we find them not unfrequently filled with PUS, BLOOD, BILE, CANCEROUS ICHOR, ${ }^{1}$ and rendered very distinct by the darker colour of these fluids. The glands also sometimes assume an unnatural colour from the matters absorbed; thus, for instance, the glands in the neighbourhood of the liver are often completely yellow, those in the region of the spleen brownish, 
and the bronchial glands, especially, blackish from a juice similar to Indian ink, ${ }^{2}$ which in previous difficulty of breathing is often found very dark, and deposited in large quantity. We however find also sometimes, in other parts, single lymphatic glands or vessels blackish, particularly if melanosis be connected with schirrus and medullary sarcom. Lime has been several times found in the lymphatic vessels, and sometimes in such quantity that they are completely filled by it. ${ }^{3}$ In stonemasons and other persons who breathe much dust, it appears to be absorbed in the lungs and deposited in the bronchial glands. ${ }^{4}$ A stone has been once found in the ductus thoracicus. ${ }^{5}$ Intestinal worms, viz. filaria hominis bronchialis, Rud. have also been found in the absorbent vessels and lymphatic glands of the neck. ${ }^{6}$

(1) I have seen this several times, and this cannot offend the surgeons, as they derive fevers, affections of various kinds, and death from the irritation excited in the circulation by malignant pus and gangrenous ichor received into it. Compare the novel and interesting experiments of Velpeau, Gendrin, Leuret, Troussean, Dupuy, Hamont, Rochoux, \&rc. On the inoculation and injection of putrid blood and pus.

(2) G. Pearson, On the colouring matter of the black bronchial glands, and of the black spots of the lungs, in Phil. Trans. 1813.-Nasse in Meckel's Archiv f. d. Physiol. Vol. II. p. 445 .

(3) Portal in Lieutaud, Vol. II. p. 243 , Obs. 771 a, (the thoracic duct.)Cheston in Phil. Trans. 1780, Vol. LXX. p. 323, 578, (the thoracic duct.)一J. G. Walter in Mém. de l'Acad. des Sc. of Berlin, 1786 and 1787,p. 21, (the lympliatic vessels of the small intestines.-Maseagni, p. 29. - Cruikshank, p. 74.-Assalini, p. 52, (the thoracic duct.) - Goodlad, (the thoracic duct.) -Scarpa, On the expansion of bone and callus after fracture, translated into Latin, p. 63, 4to. Weimar, 1828 , (the absorbents of the lower extremities, in a boy affected with pxdarthrocacy.)

(4) Compare Portal Cours d'Anat. Medic. Vol. III. p. 511 ; Vol. V. p. 43.Sömmerring, p. 45.

(5) J. D. Scherb De calculo in ductu thoracico, 1729 ; reviewed in Haller's Diss. Pathol.

(6) Trentler in Observ. Pathol. Anat. Auctuar. ad Helminthologiam hum. corp. continentes, p. 10, tab. 2, fig. 3-7, Lips. 1793 ; he calls it Hamularia lymphatica, and Rudolphi now names it Hamularia subcompressa; it has, not however, been seen again in the animal, and therefore may be considered doubtful. 


\title{
TWEN'TIETH SECTION.
}

\author{
Of the Nervous System.
}

\section{First Chapter.}

\section{Of the Brain. ${ }^{1}$}

\section{A.-OF THE MEMBRANES OF THE BRAIN.}

$\S 216$.

It is very natural in the close connexion with which the membranes of the brain stand, on account of their situation and expansion in reference to the skull and the brain, that they should participate in almost all the malformations, diseases, and injuries of those organs; and as, on the one hand by isolation, they frequently prevent the extension of the diseases of the brain-case to the brain, and contrariwise of the brain to the bones, so on the other hand they sometimes produce mutual infection. Thus we find, for instance, in congenital as well as acquired malformation of the brain, the membranes naturally formed on a similar type; in abnormal situation of the brain, as in hernia cerebri and hydrencephalocele, the hernial sac is often formed of all the three membranes; and in penetrating wounds of the brain, its membranes are naturally injured with it. In hemicephaly, and often also in hydrencephalocele, in which more or less of the vault of the skull is deficient, the two external membranes are more or less consolidated with the here undeveloped general covering and fibrous parts, and produce, together with these, the membrane oftentimes very thin and transparent, which surrounds the brain. ${ }^{2}$ The membranes are very frequently affected sympathetically and secondarily in diseases of the skull and brain, although they are often the seat of idiopathic and primary diseases, whereby then especially, congestion, inflammation with its consequences, and effusion between them of various kinds of fluids are produced. Those frequent and important diseases which appear to belong especially to the nervous system, as many fevers, viz. yellow and typhus fever, diseases of the mind, nostalgia, epilepsy, convulsions, tetanus, delirium tremens, cephalalgia, palsy, apoplexy, \&c., have often, as either cause or consequence, vices of the brain as well as of the cerebral membranes. ${ }^{3}$ 
(1) Jason a Pratis De cerebr. morbis. 8vo. Basil, 1549.-Haller's Bibl. med. pr. Vol. I. p. 511. - Montagnana Consil. de ægritudinibus cerebri. Fr. 1604.Fr. Hildesheim Spicilegia de cerebri et capitis morbis internis. Fr. 1612.Thom. Willis Pathologiæ cerebri et nervosi generis specimen. Amstelod, 1663.Cuminius D. de cerebro ejusque pathologia in genere. Leid. 1684.-J. J. W'epfer Observationes medico-practicæ de affectibus capitis. Scaph. 1727.-de Büchner D. de morbis cerebri ex structura ejus anatomica deducendis. Erford, 1741.Lazerme De morbis internis capitis. Amstelod, 1748. - Payva Epicrisis de morbis cerebri et mentis qui extra cerebrum originem ducunt. 4to. Rom. 1751.Moor Pathologia cerebri. Amstelod, 1754. - Gennari De peculiari structura cerebri, nonnullisque ejus morbis. Parma, 1782.-Van der Haar Ueber die Beschaffenheit des Gehirns der Nerven und etlicher Krankheiten derselben. a. d. Holländ. Stendal, 1794.-A. Winclielmann D. hist. pathologiæ cerebri specimen primum. Göett. 1803.-Burdach Beiträge zur nähern Kenntniss des Gehirns in Hinsicht auf Physiologie, Medicin und Chirurgie, 2 parts. Leipzig, 1805 and 1806. - Th. Mills, of the morbid anatomy of the brain in typhus, or brain-fever, Sc. 2d edit. Dublin, 1818.-Hebreart Observ. sur quelques maladies du cervelet, du cerveau et de leurs membranes, \&c. Paris, 1819.-Joln Abercrombie, Pathological and practical researches on Diseases of the Brain, \&c. \&vo. Edinb. 1st ed. 1828, 2d 1829.- John Cook, A treatise on Nervous Diseases, Vol. I, on Apoplexy. Lond. 1820 ; Vol. II. on Palsy and on Epilepsy. 8vo. Lond. 1823.-Georget De la Physiologie du Systême nerveux et specialement du Cerveau; Recherches sur les maladies nerveuses en général et en particulier sur le Siège, la Nature et le Traitement de l'Hysterie, de l'Hypochondrie, de l'Epilepsie et de l'Asthme convulsif, Vol.II. Paris, 1821. - J. Swan, Observations on some points relating to the anatomy, physiology and pathology of the Nervous System. 8vo. Lond. 1822, with engravings.-J. C. Prichard, A treatise on the diseases of the Nervous System, Part I. comprising convulsive and maniacal affections, London, 1822.-Craigie, Observations on the patlological anatomy of the Human Brain, \&c. in Edinb. med. and surg. Journ. Jan. 1823, Vol. XVIII. p. 487; Vol. XIX. p. 63. - F. Lallemand Recherches anatomico-pathologiques sur l'encephale et ses dependances, 2 vols. Paris, 1824-29. - G. F.J. Salımen die Krankh. des Gehirnes und der Hirnhäute, pathol. diagnostisch betrachtet, Riga, 1825.-Guerin de Mamers Des irritations encephaliques et rachidiennes, \&c. Paris, 1825. - Th. Mills, An account of the morbid appearances exhibited on dissection in various Disorders of the Brain, Sc. Dublin, 1826. - Rob. Hooper, The morbid anatomy of the Human Brain. 4to. London, 1826, with 15 coloured plates. - Raikem Observations sur quelques maladies de l'encephale et particulièrement sur l'inflammation et ramollissement de cet organe, in Répert. gén. d'Anat. et de Physiol. pathologique, 1826, Vol. I. No. 2, p. 271-321; No. 3, p. 74. - A. L. J. Bayle Traité des maladies du cerveau et de ses membranes, Paris, 1826._J. G. Fourcade Maladies nerveuses des auteurs rapportées à l'irritation de l'encephale, des nerfs cerebro-rhachidiens et splanchiques avec ou sans inflanmations. Paris, 1826.-J. Sablairoles Recherches d'Anatonie et de Physiologic pathologiques, relatives à la prédominance et à l'influcnce des organes digestifs des enfans sur le cerveau. Montpellier, 1826. Bompard Considérations sur quelques maladies de l'encephale et de ses dependances, \&c. Paris, 1827.-A.Monro, The morbid Anatony of the Brain, Vol. I. Hydrocephalus. Edinb. 1827. - Compare the writers on INSANITY, especially Haslam, Observations on Insanity, with practical remarks on the disease, and an account of the appearances on dissection. 8vo. London, 1798. - J. E. Gredins's Melancholico-maniacorum et epjilepticorum quorundam, in ptochotropheo Waldhemiensi defunctorum sectiones in Lulwig's Adversar. med. pract. Lips. 1771, Vol. II. and III. and Sämmtl. medic. Schriften, edited by K. W. Greding, 2 vols. Greiz. 1790 and 1791.-Chiarugi Della Pazdia ingenere e in specie, con una centuria d'osservazioni, Vol. 111. 8vo. Firenze, 1794.-13. Hofrichter D. de locis in melancholia affectis, 8vo. Halix, 1797. - Brian Crowther, Practical remarks on Insanity, to which is added a commentary on the dissection of the brains of maniacs, Sc. Lond. 1811.-Audr. Marshall, The morbid A natomy of the l3rain in mania and hydropliobia, \&c. by S. Sanvey. Lond. 1815. - Spurzheim, Observations on the deranged manifestations of the mind, or insanity. London, 1817, with engra- 
vings. - Georget De la Folie. Paris, 1820. - Falret De l'hypochondrie et du suicide. Paris, 1822. - Buzorini Untersuch. üb. d. kürperl. Bedingung. der versch. Formen von Geisteskrankh. Svo. Ulm, 1824.-Neumann in Hufeland's Journ. d. prakt. Heilk. July, 1824, p. 3-64, (fifty cases.)-Pinel, fils, Quelques recherches sur le siège des altérations cérébrales; and observations thereon by Bouillaud in Magendie's Journ. de Physiologie, 1826, Vol. VI. No. 1, p. 19.Esquirol Allgemeine und specielle Pathologie und Therapie der Seelenstormingen deutsch von Hille nebst einem Anhange von Heinroth. Leipz. 1827. On A PoPLExy especially, Morgagni De sed. et causis morbor. Epist. II.-V.-Wepfer Hist. apoplecticorum observationibus et scholiis anatomico-medicis illustratæ. 4to. Scaplius. 1658, nov. edit. access. Auctuarium historiarum et observationum similium. Scaphus. 1675.-Kirkland, Commentary on apoplectic and paralytic affections, \&c. Lond. 1792.- - Portal Second Mémoire sur l'A poplexie in his Mémoir. sur la nature et le traitement de plusieurs maladies, Vol. II. No. 10.-Reil and Hausleutner De locis in apoplexia affectis, 8vo. Halæ, 1795.-J. Cheyne, Cases of A poplexy and Lethargy, with observations upon the comatose diseases. London, 1822.-Riobè Observations propres à resoudre cette question: L'Apoplexie dans laquelle il se fait un épanchement de sang dans le cerveau, est elle susceptible de guerison? Paris, 1814. - Rochoux Recherches sur l'A poplexie. Paris, 1814. - Bricheteau in Journ. compl. du Dict. des Sc. médicales, Vol. I. p. 129-152, and 289-317.- Moulin Traité de l'apoplexie, ou Hémorrhagie cérébrale, etc. Paris, 1819. Serres in Annuaire medico-chir. des hôpitaux et hospices civils à Paris, 1819.Romberg in Horn's Archiv für medic. Erfahrung. p. 405-447, May and June, 1823.-A. Ziegler Ueber den Schlagfluss in pathologisch anatomischer Hinsicht in Oken's Isis. Vol. XX. Part X. p. 851.-Compare further, Portal Sur la nature et le traitement de l'Epilepsie, 8vo. Paris, 1827.-Rob. Manisch, The Anatomy of Drunkenness. Svo. Glasgow, 1827, and Barkhausen Beobachtungen über den Säuferwahnsinn oder das Delirium tremens. 8vo. Brem. 1828. - Lastly, also many authors on Typhus.-Interesting single treatises on the Pathological Anatomy of the Brain are furnished by Th. Anderson, Pathological Observations on the Brain, in Transact. of the Soc. of Edinb. Vol. II. p. 17.-R. Powell, Some cases illustrative of the Pathology of the Brain, in Medical Transactions, Vol. V. p. 198. - Gilb. Blane in Transact. of the Soc. of Med. and Chir. knowledge, Vol. II. p. 192.-Labonardiere, in Sédillot's Recueil périod. de la Soc. de Méd. Vol. L. p. 261, 337, 363. - Rampont, ib. Vol. LV. p. 19. - Ever. Home in Philos. Transact. 1814, Part II. p. 469.-Nasse Zur nähern Kenntniss der organ. Gehirnkrankheiten in Horn's Archiv f. medic. Erfahrung, May and June, 1821, p. 375. - Duncan, jun. in Edinb. Med. and Surg. Journ. No. 68, July, 1821.Collections from the unpublished medical writings of the late C. H. Parry, Vol. I. p. 274, London, 1825.-Thilow in Pierer's Allgem. medic. Annalen, Nov. 1827, Part XI. p. 1441. - Earle On paraplegia in London Med. and Chir. Transact. 1827, Vol. XIII. No. 18.

(2) I can, however, almost always separate the continuation of the common integument from the dura mater as a thin transparent layer resembling the skin of the young embryon. Compare $\$ 44$, note 2 .

(3) In no instance do we find greater difficulty than in the brain, in making the result of dissection agree with the phenomena of disease previously exhibited. We often observe during life the most violent symptoms indicating affections of the brain, whilst the examination presents either none or very trivial vice in that organ; in other instances, on the contrary, we frequently observe manifold, very extensive and important anomalies in the brain and its membranes, of which, during life, there was not the least suspicion. It is especially important here to distinguish correctly which is cause or consequence of the preceding disease. Violent and repeated irritation of the brain, uccurring in fevers, madness, convulsions, headach, continued drunkenness, \&c., and metastatic affections of the brain in neighbouring eruptive diseases, gout, puerperal fever, \&c. easily produce congestion of blood, secretion of air and lymph, and states similar to those produced by inflammation. The kind of death itself, as well as the changes to which the body as a corpse is subjected, are here also worthy of notice. 


\section{$\S 21 \%$.}

As to the DURA MATER alone, it is affected indeed with the same irregularities as other fibrous parts $;^{1}$ but it exhibits many peculiarities dependent principally on its situation and connexion. Its FORM and SIZE depend generally on that of the skull and brain, and according as they are too small, undeveloped, too large, half doubled, awry, \&c. so are they in various ways abnormal. Sometimes the falciform process is entirely or only partially deficient, ${ }^{2}$ as is also the tentorium. ${ }^{3}$ Tolerably often we observe in the falciform process, especially towards its lower edge, more or less large openings, in consequence of which both hemispheres of the cerebrum may adhere to each other. When the two hemispheres of the cerebrum are unsymmetrical, it is placed awry, and sometimes pushed upwards and sidewards by swellings of various kinds. In hydrocephalus internus, hernia cerebri, and hydrencephalocele, the dura mater is sometimes generally or partially expanded to a great extent, ${ }^{4}$ although in both the latter diseases, it is sometimes also perforated by holes, through which the cerebral membranes and the brain itself protrude. The dura mater frequently varies from its normal THICKNEss : thus it appears atrophic, in parts even entirely absorbed, especially if longcontinued pressure have been made on it ${ }^{5}$ sometimes and more frequently it is remarkably and morbidly thickened, so that it produces indentations in the brain itself. ${ }^{6}$ It is remarkable that it has sometimes been observed, especially in diseases of the mind and in hydrophobia, unnaturally DRY, SHRIVELLED, AND EVEN PARCHMENT-LIKE. ${ }^{7}$ Its COLOUR also is sometimes irregular in men and animals, viz. transparent, grey, more or less red under inflammation; in contusion, suppuration, mortification, and other diseases, sometimes yellow, dusky, bluish, brownish, even blackish; in jaundice of a yellow colour, ${ }^{8}$ and in melanosis, spotted with black from the well-known pigment. ${ }^{9}$

(1) Compare Sect. VII. \$ 145-154.

(2) This is always the case if the cerebrum be undivided; see further on: if it be single in front, but divided behind, the falciform process first begins to appear where the division is, viz. at the coronal suture. The falx, however, sometimes appears in a well-formed brain to be completely or partially wasted by absorption.-Garengeot Splanchnologie, Vol. II. p.211.-Günz and Springsfeld. v. Burdach Beiträge, Vol. I. p. 87.-IIaller Op. minora, Vol. III. p. S6́3. Obs. 61.-Carlisle, v. Transactions of the Soc. for the improvement of med. and surg. Knowledge, Vol. I. p. 212, (in a woman twenty-nine years old it was completely absent.) - Alex. Ramsay, Anatomy of the Heart, Cranium, and Brain, p. 38. Edinb. 1803, found it entirely absorbed, and the two halves of the cerebrum united.

(3) If in monsters the posterior lobes of the cerebrum are deficient, the tentorium is also wanting. v. Eller and Roloff in Hist de l'Acad. des Sc. de Berlin, 1754, 1). 112. In a girl of seventeen years old, who was idiotic and 
motionless from birth, the hinder part of the tentorium was deficient. v. Gilbert. in Edinburgh Med. and Surg. Journ. No. 95, April, 1828, (from absorption, as the dura mater was also very much wasted at the base of the skull.)

(4) I have observed a rare case in a cyclopic pig, No. 2346 of my Verzeichn. ; here the cavity of the skull communicates with the large orbit by a wide aperture, through which the dura mater projects into it, and there forms at the hinder part a peculiar space, in which a part of the cerebrum is lodged.

(5) For instance, in tumours of various kinds; most frequently it arises from granulations of the brain, by which it is thus frequently perforated.

(6) I have seen it half an inch thick at some parts; which was also observed by Bonetus Sepulchretum anat. Vol I. p. 41 , Obs. 82 .

(7) Lieutaud, Hist. anat. med. Vol. II. Lib. III. Obs. 3, 16, 76, 165.-Bagliv De fibra motrice in Op. omn. Lib. I. cap. 5, p. 287. Antwerp, 1715. - Littre in Mém. de l'Acad. des Scienc. 1705.-Trecourt in Journ. de Médec. Vol. VI. p. 189. - Shrivelled up and like a half-dried bladder in a man who died of rupture of the stomach. v. B. Brown, in London med. Repos. 1822, Feb. Vol. XVII. No. 58, p. 108. This state is indeed a consequence of inflammation.

(8) Stoll, Ratio Medendi, Vol. III.-I have indeed but once seen it pale yellow, although I have dissected a dozen cases of jaundice; also in yellow fever it is found, though rarely, of a yellow colour.

(9) Bonetus. - Gendrin Histoire anatomique des inflammations. 2 vols. 8vo. Paris, 1826. - In an old man I have found a very large spot of a soot-like colour, without suspicion of mortification.

\section{$\S 218$.}

The connexion of the dura mater with the skull is often so far irregular, that it is either too firmly attached, and even perfectly adherent to certain parts of the brain-case, especially at the top of the skull, in consequence of previous inflammation; or, on the contrary, it is only loosely connected with the bones, so that in opening the head, the skull-cap falls off of itself. Rarely from internal causes, but more frequently from external concussion, is a part of the dura mater entirely separated from the skull, ${ }^{1}$ and then, in consequence of a collection of blood, of fluid or coagulated lymph, or of pus, ${ }^{2}$ it is expanded like a bladder; tumours also of various kinds, as exostoses, sarcoms, cancerous tumours, \&c. which grow from without into the cavity of the skull, often thrust the dura mater before them. ${ }^{3}$ Sometimes also the connexion of the dura mater and the skull is destroyed by collection of water between them, ${ }^{4}$ and even the two layers of the membrane itself are in rare cases separated from each other by water, pus, blood, and tumours. ${ }^{5}$ VICEs of CoNTINUITY arise not merely from penetrating, shot, thrust; and trepan wounds, but also very easily from indented and splintered pieces of the skull. Sometimes the dura mater is torn by very violent extension from within, as, for instance, in water of the head. ${ }^{6}$ As fibrous parts are but imperfectly reproduced, so is the dura mater also rarely restored after loss of substance; but there is usually formed in its stead, at those spots, a thick cellular tissue, which is closely connected with the newlyformed bone, or if the bone be not reproduced, it assumes a 
fibro-cartilaginous condition, and becomes consolidated into a common cicatrix with the general integuments, which in many cases produces only a weak membrane for the brain, and may therefore be easily burst from internal expansion. ${ }^{\text {? }}$

(1) Sometimes, as I have myself occasionally seen, on the opposite side to that on which the blow was received.

(2) Pus collects here also in consequence of inflammation, and without antecedent mechanical influence.

(3) Schneider D. de fungo lixematode. Berol. 1821.-Schwarzchild D. de fungis capitis. 4to. Heidelbergæ. 1825, with four lithogr. plates.-Sandifort Museum anatomicum, Vol. III. p. 158, No. 127. - Lisfranc in Nouv. Biblioth. méd. May, 1827.-Abercrombie, (fourth case,) p. 426.

(4) Bonetus Sepulchret. anatom. Lib. I. Sect. II. Obs. 45, p. 116.-Klinkosch Progr. quo hydrocephalum foetus rariorem cjusque causam proponit. Pragæ, 1773. -I have occasionally seen in hydropic children the flat bones of the skull completely separated by water from the dura mater. - Greding saw it in insane persons. v. Ludwig Adversaria med. pract. Vol. II. p. 469.-P. Frank Epit. de cur. hom. morbis. VI. 1, p. 161.-Voigtel Handb. Vol. II. p. 9, had also one case.

(5) To wit, from bloody serum, v. J. Paisley in Edinb. medic. Essays, Vol. III. p. 304; from seven ounces of blackish ichorous fluid, v. Biermayer Museum anat. pathol. No. 94 ; the dura mater was found separated, by coagulated blood, into two, and even three layers, v. Kilian Anat. Untersuchung des 9ten Hirnnervenpaares, p. 127 ; and Lobstein Compte rendu sur les travaux anatomiques. I. p. 56 ; the layer which is lined by the arachnoid coat was separated from it by pus, v. Vicq $D^{\prime} A z y r$ in Mém. de Paris, 1781, p. 497.

(6) We frequently find such rents in the cerebral membranes of hemicephalie monsters; in extensive hydrocephalus the water escapes by the nostrils, or penetrates through the sutures of the skull. v. Cavallini Collezione istorica di casi chirurg. 4to. Firenzi, Vol. II.-In one instance a large quantity of water flowed through the nose, and the membranes of the brain subsequently cracked; an external dropsical swelling was produced. v. J. Baron in Med. chir. Trans. Vol. III. Part I. No. 3.

(7) The dura mater burst in a violent fit of looping-cough, seven months after trepanning. v. E. Stanley, Med. chir. Trans. Vol. III. p. 24. ff.

\section{$\S 219$.}

Vices of TEXTURE in the dura mater are of proportionally rare occurrence. We often indeed see it injected and congested, when in a state of morbid irritation in fevers of various kinds, in cephalalgia, convulsions, epilepsy, hydrophobia, in staggers in the horse, \&c., or when the blood is retained in the vessels of the brain, as occurs in many kinds of death, but especially in that from suffocation. ${ }^{1}$ TRUE INFLAMMATION ${ }^{2}$ occurs idiopathically from internal causes but rarely $;^{3}$ more frequently from mechanical ${ }^{4}$ and chemical ${ }^{5}$ agency, or consecutively to caries of the skull, inflammation of the ear, suppuration of the brain, \&c. Inflammation of this membrane sometimes proceeds to the effusion on its outer surface of a FALSE MEMBRANE consisting of fibrous matter, and to ADHESION with the skull, ${ }^{6}$ with the other cerebral membranes, and even the brain itself; sometimes to suppuration, in which the pus is found between its layers, and on its inner or outer surface, and in 
the latter case may erode and perforate the skull ${ }^{7}$ sometimes it runs into GANGRENE; ${ }^{8}$ sometimes, lastly, into THICKENING and INDURATION, the latter of which may even assume the character of fibro-cartilage. ${ }^{9}$ Probably also ossirication of the dura mater arises from inflammatory irritation. ${ }^{10}$

(1) On varices of the veins of the dura mater, compare $\S 205$. On aneurism of the meningeal arteries, $\$ 196$, note 7 .

(2) Burdach Vom Baue und Leben des Gehirns. Vol. III. p. 18, in which he applies to this the name of Perimeningitis.

(3) The accounts of its inflammation in yellow fever, typhus, madness, \&c. for the most part originate in confusion between congestion and inflammation in the other cerebral membranes. Hooper, pl.1, gives an engraving of a portion of inflamed dura mater.

(4) After injuries of the head, not penetrating through the skull; viz. after contusion, concussion, cuts, extirpation of tumours, \&c. in consequence of the connexion of the vessels of the pericranium with the dura mater.

(5) After the imprudent use of the moxa, of the actual cautery, of corroding applications, of blows, in denudation from exposure to atmospheric air; in the latter case the inflammation of the dura mater which occurs is often a regenerating process. Although also in other persons, yet still more frequently in insane people. v. Greding, Vol. I. p. 293. Georget De la Folie, p. 486.

(6) I have occasionally found this on several distinct spots; it always appears after wounds of the brain.

(7) Such cases are described by Burserius, Morand, Brisseau, Pietsch, Marchetti, Barrere, and Abercrombie. M'Turk, in medical and phys. Journ. April, 1819; further, Fizeau in Nouv. Journ. de Médecine, Chir. et Pharm. Vol. XI. p. 523, and Roux, ib. Vol. XII. Sept. 1821; in the latter case, and in that of Morand, union occurred after trepanning. Concerning such cranial fistulas, comp. Marvide in Mémoires sur les sujets, proposes pour le prix de l'Academ. royale de Chir. Vol. IX. 1778, and Richter's chirurg. Bibliothek. Vol. IV. Pt. IV. p. 730.

(8) This seems to occur but rarely; I have never seen them, except in wounds of the brain which have become gangrenous, in cerebral abscesses, and in caries of the skull; the melanotic colouring of the dura mater, v. $\S 217$, note 9 , cannot be confounded with gangrene. Sometimes the dead dura mater exfoliates.

(9) To these belong the gummata in syphilitic persons, of which Lieutaud speaks, Vol. II. p. 372 . Lib. III. Obs. 205. It is difficult to determine where the pustulæ miliares, mentioned by Lieutaud, Lib. III. Obs. 16, belong; perhaps they were, at least in one case, purulent cysts. Sometimes fibrous matter is effused between the two layers of the dura mater, producing swellings which form for themselves pits in the brain; viz. Abercrombie, Case 6, p. 47, (half an inch thick, $5 \frac{1}{2}$ inches long, and $2 \frac{1}{2}$ inches wide.)

(10) Ossification of the dura mater itself is, according to my observations, as rare as that on the arachnoid coat lining it is common; as it is often firmly connected with the dura mater, which, by the pressure of the greater thickness of the bony concretion, is wasted; so, in careless examination, it is often improperly considered as a growth from the dura mater. Calcareous leposits, however, do occur in the dura mater itself, as I have seen a few times in diseases of the brain, in which the dura mater was studded with little bony points and flakes; for example, in an epileptic person, and in No. 3983 of my Verzeichn. Compare Albrecht præs. Boehmer D. de ossificatione duræ matris singulari observatione illustrata. 4to. Halæ, 1764. - Pohl Progr. de dura matre passim ossea facta. 4to. Lips. 1764.-Velten Casus aliquot memoratu digni ossificationum in membranis cerebri inventarum, D. Bonnæ, 1825, with two lithographic engravings. Compare further on $\$ 224$.

$\S 220$.

Lastly, to the sPurious FORMATIons, which in rare cases we observe on the dura mater, belong, first, FATTY and 
ENCYSTED TUMOURS, which sometimes are found only upon it, at other times between its layers, and contain even hair : ${ }^{1}$ next, SCROFULOUS TUMOURS, ${ }^{2}$ which are found on both sides of the internal cerebral membrane, as well as between its separate layers: and, finally, sarcomatous and cARCINOMATOUS TUMours, some of which, passing from without through the natural or morbid apertures in the skull, particularly through the orbits, perforate the dura mater, and produce on it, in the cavity of the skull, more or less large swellings; ${ }^{3}$ others arise from the bones of the skull, and some from the dura mater itself. To the latter kind especially belong Fungus of the DURA MATER, fungus dura matris. " This is a sarcom, and sometimes more closely resembles the so-called fleshy sarcom, sometimes more the medullary; it is of various colour and consistence, according as it belongs to one or other of these kinds, or is examined in the incipient firm, or subsequent spongy, fungous, inflammatory, and even suppurative state. Usually we find only one such swelling, sometimes, however, several $;^{5}$ at first they are small, but sometimes attain a very great size $;^{6}$ generally they are found on that part of the dura mater which lines the top of the skull, although sometimes also on that covering the lateral parts and base of the skull. If the fungus be situated on the outer surface of the dura mater, which is its most usual seat, ${ }^{7}$ it perforates the skull to a greater or less extent by absorption, and appears externally on the head; but should it be placed on the internal surface, it grows more or less into the cavity of the skull. We often also find fungus of the dura mater connected with osteosarcom of the skull, fungus cranii; thus the latter, either by participation of the dura mater in the disease, or by its fibres only being separated from each other, grows through them into the cavity of the skull. ${ }^{8}$

(1) For example, an adipose tumour with hair in the substance of the tentorium. v. Morgagni Epist. anat. XX. No. 58.-In a new-born child with large dropsy of the head, No. 2891 of my Verzeichn., I found, situated externally upon the skull, between the common integunient of the head, and the membrane formed by the dura mater and pericranium, many flat adipose swellings, with much black hair, and surrounded by fine cellular tissue; one of these tumours penetrated the dura mater, and was projected inwards in form of scveral similar swellings which lay on the dura mater and arachnoid coat;-two little fatty tumours, whence sprouted many hairs, were seen on the dura mater of a man which had been exposed by caries. v. Friclie Annalen der Chir. Abtheilung des allgemeinen Krankenhauses zu Hamburgh, Part I. 1828, p. 406. pl. 2.

(2) Lieuland, Lib. III. Obs. 218 a.-Baillie's Morbid Anatomy, p.' 432, and Sömmerring's Addenda, note 517, and a plate in Baillie's Engravings, Fasc. X. pl. 5.-My Selt. Beob. Part I. p. 108, No. 59; My Verzeichn. No. 2357.- Earle, On paraplegia in Med. Chir. Trans. Vol. XIII. Part. II. No. 18.

(3) For instance, Loder Observatio Anatomix tumoris scirrlosi in basi cranii 
reperti. 4to. Jenæ, 1779. $\rightarrow$ Pfranger D. Historia casus perrari de fungo duræ matris, prolapsum atque destructionem oculi bulbi efficiente. Erf. 1801.-A.B. Hertel D. patholog. anat. de cerebri et meningum tumoribus. 8vo. Berol. 1814, with plates.-Journal de Médecine continué, Vol. XVI. App. Bulletin, p. 83, (cancerous). - Landmann Comment. pathol. anat. exh. morbum cerebri oculique singularem. 4to. Lips. 1820, with three copper-plates, (according to the account, a cartilaginous tumour.)-My Selt. Beobachtungen, Part II. p. 86, No. 36.-My Verzeichn. No. 2356 (scirrhus of the neck projecting into the cavity of the skull), p. 88, No. 37.-My Verzeichn. No. 2353, (A medullary-sarcoma of the eye growing into the cavity of the skull, also described and represented in Benedict's Handbuch der prakt Augenheilkunde, Vol. II ; and a cancerous tumour of the eye which grew into the cavity of the skull. - MyVerzeichniss, No.2352.) - Panizza Annotazioni anat. chir. sul fungo midollare dell' occhio, \&c. fol. Pavia, 1821, with three plates. - Hasse D de fungo medullari. 4to. Berol. 1823 (from the orbit.) See below on the eye.

(4) Compare $\$ 122$, note 44.-The authors on Fungus Cranii-Amatus Lusitanus Centur. V. Obs. 8.-Camerarius in Ephem. N. Cur. Dec. II. Ann. VI. 1687, Obs. 99.-Cattier in Observ. medical. Obs. 15, p. 48.-Pohl in Actis eruditor. Lips. May, 1736. - Scheler præs. Baldinger D. de Epilepsia et capitis dolore ex tumore duræ matris scirrhoso et carie cranii ortis, p. 8. Jenæ, 1771-König in Ephem. Nat. Cur. Dec. II. Ann. I. No. 167.-Salzmann in Mém. de l'Acad. de Petersbourg, Vol. III. p. 275. - Wathen in Medical Observations and Inquiries, Vol. V._Viellard in Journ. de Médecine, Vol. XVIII. p. 533. v. Comment. Lipsiensis, Vol. XIII. p. 257. - Edinburgh medical Commentaries, Vol. II. p. 286.-Louis Mémoires sur les tumeurs fongueuses de la dure mère in Mém. de l'Acad. de Chir. Vol. V. p. 1. Paris, 1774, in which also cases by Ambr. Pare, Sievert, Robin, Rey, Legrand, Marrigues, Choppart, Volprecht, Jauchius, Grima, and Philippe, are related. - Gondange in Mémoires de Montpellier, Vol. I. 1776, Hist. p. 111 (on the base).-Acrel Chir. Vorfälle a. d. Schwed. von A. Murray, Vol. I. p. 40. Götting. 1777.- Steph. de Vigiliis de Crutzenfeld Biblioth. chirurg. Vol. I. p. 732. Wien, 1781.-Monro in Medical Trans. published by the college of Physicians in London, Vol. II. - Ed. Sandifort, compare $\$ 122$, note 44, and Mus. anat. Vol. II. tab. 25.-Baillie, Morbid A nat. p. 433, and S̈̈mmerring, Addenda, note 518.-J. G. Walter Anatom. Museum. 2d part, p. 112. 4to. Berlin, 1796, and Museum anatom. 4to. Berol. 1805, p. 131.- Siebold, compare \$122, note 44.-Jos. and Carl Wenzel Ueber die schwammigen Auswüchse auf der äussern Hirnhaut. fol. Mainz, 1811, with six engravings.-M. Baillie Engravings, p. 219. Fasc. X. pl. 5, fig. 1.-v. Walther in der Salzburger med. chir. Zeitung, 1813, Febr. p. 185.-Poilroux in Annal. de la Soc. de Médec. de Montpellier, Vol. XXXIII. p. 139.-Montagnon, ibid. Vol. XXXIV. p. 304.Hebreard in Bulletin de la Faculté de Médec.-Rudolphi, v. Hertel, p. 15.-Horn Archiv f. medic. Erfahrung, 1815, Part V. p. 838.-Langstaff in Med. chir. Transact. Vol. II. p. 288.-Biermayer Museum anat. pathol. No. 285.-J. G. Wolter D. cont. descriptionem tumoris duræ matris, cujus substantia cerebro non dissimilis erat. Duisburg, 1817.-Meckel Handbuch der pathol. Anatomie. Vol. II. 2. p. 324, ff. (three cases of his own, one on the exterior, two on the interior of the dura mater.) - Esquirol in Dict. d. Scienc. medical. Vol. VIII. Art. Demence. p. 201, (at the base, on the clivus.) - Windel D. de fungo duræ matris. 4to. Goett. 1819.-C. B. Tilanus D. de fungoso duræ meningis excrescente, etc. 4to. Traj. ad Rhen. 1819. - Palletta Exercitat. pathol. Vol. I. p. 93-104.- W. Walther in his and v. Gräfe's Journal f. Chir. und Augenheilk. Vol. I. Part I. Vol. II. Part II. Vol. V. Part I. - v. Klein, ibid. Vol. III. Part IV. p. 614.-Calliot, v. $\$ 122$, note 44 , (fungus cranii and duræ matris.)-Kilian Anat. Untersuchungen über das neunte Hirnnervenpaar, p. 127, 4to. Pesth, 1822, (congenital, in the Museum at Strasburgh.) - Larrey in Revue médicale. July, 1822. - Isenflamm Anatom. Untersuchungen, Erlangen, 1822, p. 166.-Wishart. Compare $\$ 122$, note 44 . - Weitzenmüller D. de fungo duræ matris. 8vo. Gryphiæ, 1823.-Esquirol in Archiv. génér. de Médec. Dec. 1823, (on the left temple.)-Revue encyclopedique, August, 1828, (on the right sinus as large as a walnut.) - Ritterich in Cerutt's Pathol. anatom. Museum. Vol I. Part IV. 
p. 5.- Fingtrinier in Archives générales de Médecine, May, 1824, (at the base of the skull on the bulb of the vein.)-Hesselbach, v. $\$ 122$, note 44 , (fungus cranii and duræ matris.)-Seerig Comment. nonnulla de fungi duræ matris origine et diagnosi. 4to. Vratislav. 1525, with three lithographic tables.H. Schwarzschild, v. \$122, note 44.-Ch. Mayo, in London medical and physical Journal, Vol. LVIII. p. 40S, (in the right temporal pit.)-Burdach Vom Leben und Bau des Gehirns. Vol. III. p. 2\$, $\$ 258$.-Hooper, pl. 7.-Churchill, in London medic. and physic. Journ. March, 1827, (on the inside of the dura mater).-G. Sundifort Museum anatomicum. Vol. 1II. p. 147, No. 39, (a very large swelling arising from the ala of the sphenoid.) -Riegling D. quædam ad Fungi duræ matris pathologiam. Svo. Berol. 1828. - Aljercrombie (in tentorium) $42 \mathrm{~d}$ case, p. 443, (on the base, large.)-Cheliws Ueber den schwammigen Auswuchs der harten Hirnhaut nach eigenen Erfahrungen. fol. Heidelberg, 1S2S, with lithographic plates, and in Dict. des Sciences médicales, Vol. VIII. p. 291, (on the clivus.) - I have, up to this time, only thrice met with fungus of the dura mater, one large and connected with fungus cranii, v. Selt. Beob. Part II. p. 82, No. 35, engraved in Seerig, tab. I.; a second small one on the top of the right orbit, No. 2280, of my Verzeichn.; and a third, also small, and on the greater falx, No. 2281 of my Verzeichn., engraved in Seerig, pl. 3, fig. 3; all three attached on the inner surface of the dura mater; - in the Anat. Mus. at Strasburg, I saw three cases of fungus of the dura mater in the region of the longitudinal sinus, two of which were upon the internal surface of the dura mater.

(5) Two cases were found by Walter and Klein; three by Sievert and Volprecht; four by Philippe and Meckel ; five by Wenzel and Baillie; fourteen by Ritterich; eighteen by Sandifort; many by Horn, Rudolphi, Wishart, \&c.

(6) For instance, as big as a man's fist, in a case by Burdach and myself; es large as a goose's egg, in Sandifort's; as a second head in Grim's.

(7) Wenzel improperly considers that it occurs only on this part.

(8) There has been much disputation concerning the original seat of fungus duræ matris: sometimes it has been ascribed, as by Louis and Wenzel, to the dirra mater; sometimes, as by Sandifort, Siebold, and more recently by von Walther, to the bones of the skull. But, in reality, it may arise in botll, and also in the pericranium; and, as the bones of the skull are only a living organ, in connexion with their external and internal periosteun, it must soon, more or less, comprise all these parts. Osteosarcom of the skull, or fungus cranii, to which von Wulther has recently liad the especial merit of drawing the attention, and fungus durx matris, are therefore merely different, although often simultaneously occurring forms of one and the same disease.

$$
\S 221 \text {. }
$$

The diseases of the ARACHNOID and VASCULAR COATS of the brain, which are best treated of together, ${ }^{1}$ are much more common than those of the dura mater, and naturally in closer connexion with the diseases of the brain, as that was with the diseases of the skull. But both these membranes, on account of their organic connexion with the brain and skull, are frequently sympathetically affected by their diseases. The most common pathological phenomena which have been noticed in them, are Morbid IrRITATION, ${ }^{2}$ and actual INFLAMMATION, both of which, with their numerous consequences, are observed in their various degrees as the cause and effect of many diseases. ${ }^{3}$ In particular, respecting INFLAMMATION OF THE MEMBRANES, meningitis $;{ }^{4}$ this is sometimes an IDIOPATHIC and PRIMARY disease, ${ }^{5}$ sometimes SYMPATHETIC 
and SECONDARY, as in injuries of the head, high fevers in men and animals, erysipelas of the head, many eruptive diseases, in severe burns, ${ }^{6}$ in hydrophobia, in gouty, puerperal, and other metastases, \&c.; further, it is sometimes ACUTE, sometimes rather CHronic, and, lastly, very different in reference to its extent, as it often affects merely defined spots, merely the part lining the external or the internal cavities of the brain, and sometimes all the membranes throughout their whole extent; most frequently it occurs on that part of the membranes covering the upper half of the hemispheres of the cerebrum, more rarely on its base.? True inflammation of the ARACHNOID COAT ALONE, arachnoiditis,${ }^{8}$ cannot be distinguished, on account of the deficiency of blood-vessels in this membrane; and the redness and injection which have been observed on it, arise from the inflamed subjacent mucous tissue, and the inflamed vascular coat of the brain, to which also must be referred, in part, the opacrity, THICKENING, and MILKY COLOUR of the arachnoid membrane, which have been commonly considered as marks of its inflammation. ${ }^{9} \quad$ But inflammation of the pia mater, which is naturally the same as inflammation of the surface of the brain, is distinguished by the usual signs of inflammation. ${ }^{10}$

(1) Because both are cellular membranes, and are perfectly consolidated, not merely in the coats of the brain, but in general are inseparably united in the greatest part of the circumference of the brain in adults; and they are always, however, in organic connexion throughout, by means of fibro-mucous tissue of various length; and lastly, because their diseases have similar symptoms, and generally appear in both at the same time, and of the same kind.

(2) Compare $\$ 51$. Great injection of the finer arterial and venous vessels, is presented by and originates in mere congestion, in which only the veins are filled; the distinction between morbid irritation and true inflammation is more difficult, the latter of which terms has been much too often employed by the supporters of Broussais.

(3) Compare $\$ 216$, towards the end.

(4) F. Herpin Thèse. Meningitis, ou Inflammation des membranes de l'Encephale. 8vo. Paris, 1803. - Parent-Duchatelet and Martinet Recherches sur l'Inflammation de l'Arachnoide cérébrale et spinale, ou histoire théorique et pratique de l'A raclinitis. 8vo. Paris, 1821.-Piorry De l'irritation encephalique des enfans, ou considérations sur les causes, les symptomes, et le traitement de la maladie designée successivement sous le nom de convulsions internes, d'hydrocephale, aiguë, d'arachnoidite, etc. 8vo. Paris, 1823.-A. Cucavaz D. de arachnoite. 8vo. Patav. 1825.-Senn Recherches anatomico-pathologiques sur la meningite aiguë des enfans et ses principales complications. Paris, 1825.-Bayle on Meningitis chronica in Revue medicale, Feb. 1825; and on Meningitis acuta, $i b .1827$, Vol. I. and II.-Tacheron Recherches anat. patholog. sur la médecine pratique, Vol. III. p. 4-36, Paris, 1823, under the name of Arachnoidite-Gendrin Hist. Anatom. des inflammations, 2 vols. 8vo. Paris, 1826.-Abercrombie, Path. and pract. obs. on diseases of the Brain and Spinal Marrow. p. 49.

(5) Perhaps also in phrenitis in men and animals, in many convulsions, in mad staggers in horses, \&c. According to Bayle, a chronic inflammation of these membranes is the most common cause of disturbance of the mind, with the exception of congenital idiotcy; in delirium tremens there is usually meningitis. v. Barkhausen Beobachtungen über den Saüferwahnsinn, oder das delirium tremens. Bremen, 1828. The same is also said to be the case in Nostalgia, 
v. Larrey Recueil de Mémoires de Chirurgie. Paris, 1827 ; -also in softening of the stomach. v. Camerer Versuch über die Natur der krankhaften Magenerweichung, Stuttgard, 1828; lastly, also, castration in sheep and fowls often produces inflammation of the brain and cerebral membranes. v. Faneau Delacour in Journ. Univers. des Sc. Méd. June, 1824.

(6) In a child, who died the third day after having been scalded with hot water, over almost the whole body, I found distinct meningitis; Eklund also found, in three persons who were burnt by the explosion of gumpowder, congestion of blood in the cavity of the skull. v. Ars Berättelse om Svenska LäkareSällskapets Arbeten, lemnad of Ekström. Stockholm, 1827, p. 55.

(7) I have, however, seen it here also very distinctly several times.

(8) Not arachnitis, as inflammation of the arachnoid coat is called.

(9) It has always appeared so to me, on the closest examination, and I have found the redness produced by the vessels of the mucous tissue, and the pia mater, lying beneath the arachnoid; I do not, however, deny, that in the arachnoid itself a peculiar state, similar to the inflammation of other parts, may occur; at least, thickening, loosening, and deposition of plastic lymph, in its tissue, is a frequent phenomenon.

(10) As the pia mater, in a healthy state, is also extremely vascular, so we must not, as is commonly done, take every great injection of it for inflammation.

\section{\$222.}

'To the most important anatomico-pathological phenomena of the cerebral membranes belong the changes which are produced by morbid irritation and inflammation in relation to the QUANTITY and QUALITY of the SECRETED FLUIDS. The examples are rare in which, without suspicion of putrefaction, AIR is found between the two layers of the arachnoid coat, as well as between it and the vascular coat, whereby they are separated, in bladder-like spots. ${ }^{1}$ Or there may be too little serum, and the membranes therefore appear ALMOST DRY and SHRIVELLED TOGETHER. The opposite vice, or an UNNATURAL COLLECTION OF A WATERY OR LYMPH-LIKE SECRETION, between the membranes and in the ventricles, is very common. This appears, in many cases, to take place during the agony of death, and even immediately after death, ${ }^{2}$ partly as the product of many diseases and weakness preceding death. $^{3}$ In the so-called SERous APOPLEXY, apoplexia serosa, palsy and death are commonly produced by pressure of the serum effused between the membranes of the brain and into the cavities, although the effusion does not seem to be the cause of this discase. ${ }^{4}$ Should the quantity of water found in the cavity of the skull be greater, we call it INTERNAL DROPSY OF THE HEAD, INTERNAL WATERY HEAD, hydroceplealus internus, ${ }^{5}$ which is again divided into Dropsy of THE CEREBRAL MEMBRANES, hydrops membranarum cerebri, ${ }^{6}$ and DROPSY OF THE VENTRICLES, hydrops ventriculorum cerebri, both of which, as is natural, often occur at the same time. In the former kind, which is much more rare than the latter, and usually to a less extent, the water is contained in the 
bag of the arachnoid coat, that is, between the outer layer connected with the dura mater and the inner which envelopes the brain $;^{8}$ and the arachnoid then produces, in rare cases, as a congenital vice, elongated bags, which protrude through holes in the skull, and have much resemblance to hydrencephalocele. ${ }^{9}$ The water is less frequently contained in closed bags of the arachnoid coat, ${ }^{10}$ between it and the vascular membrane, or between the latter and the brain. ${ }^{11}$ But in dropsy of the ventricles, which is the most common, and the kind which produces almost all the large watery heads, the water is collected in the bags of the arachnoid and vascular membranes which line the cavities of the brain, so that it is either contained in all or the greater number of the cerebral cavities at the same time, which is most commonly the case, or only in one of them. ${ }^{12}$ The cause of this collection of water in the head is usually an inflammatory state of the membranes and of the brain itself, which may produce this effect at every period of life; but naturally only in the embryon, ${ }^{13}$ and in young. children on account of the yielding of the skull, can lead to a great effusion of water, whilst at a later period, when the skull cannot be further expanded, there is no room for a large collection of water. From this and other causes, internal dropsy of the head is sometimes an acute, sometimes a chronic disease, which in the latter instance sometimes even wears itself out in riper age ${ }^{14}$ and often acquires an enormous size. ${ }^{15}$ The effused serum is generally quite pale, thin, and clear, although sometimes light brown, turbid, flocculent, containing albumen, and of a yellowish or red colour from the blood mingled with it. ${ }^{16}$

(1) Compare §51. - Morgagni De sed. et caus. morbor. Epist. IV. 19, 26, 35 ; V. 17. 19 ; VIII. 9; IX. 9 ; X. 17 ; XIV. 35 ; XLVIII. 38 ; LIII. 26 ; LIV. 39, 49; LVII. 14.- Halliday D. de pneumatosi. Edinb. 1806.-Briere in Nouvelle Biblioth. de Médec. Feb. and March, 1826.-1 have several times seen it without suspicion of putrefaction; twice in persons who died of tetanus, as Morgagni in the latter case, and once in a paraplegic person. Compare also Portal Cours d'Anat. Méd. Vol. IV. p. 70, ff.

(2) I have very often found this in persons who had been hanged, drunk, and in one case of a person destroyed by choke-damp; several times also in people who had quickly died from injury of the head. I have met with a quantity of similar cases in the reports of the morbid examinations at the Royal Medical College, and have particularly remarked some cases in which great extravasation of water into the cerebral cavities, and between the membranes, had occurred in persons destroyed by strangulation and by blows on the head, which was considered by less experienced practitioners as a morbid state existing previous to the injury.

(3) To wit, in acute fevers, especially yellow and typhus fever, scarlet fever, measles with affections of the head, diseases of the mind, nostalgia, epilepsy, convulsions, tetanus. v. Speranza in Anno clinico-medico. Parma, 1823-24.Delirium tremens, hydrophoby, softening of the stomach, asthma, consumption, rickets, and various cachectic diseases, distemper in dogs, sleepy staggers in horses, diabetes mellitus. v. von Stosch Versuch einer pathologie und therapie des 
diabetes mellitus, p. 103, Berlin, 1828. - Also in drunkards and old people serum is frequently found between the membranes and in the cavities of the brain; this is, however, by no means to be regarded in the latter as an abnormal condition; as J. Carson has observed, on the circulation of the blood in the head, Edinb. med. and surg. Journ. No.79, 1824, April, p. 261. - The EAsY SEPARATION of the vascular membrane from the brain, which is observed in some bodies, seems to me to originate in the effusion of lymph beneath the pia mater loosening their connexion. Compare Camerarius D. de apospasmate piæ matris. Tubingæ, 1722.-Mechanical causes, however, as concussion, may produce this loosening.

(4) There is no proportion between the quantity of fluid effused and the violence of the symptoms prior to death, and the more or less speediness of the latter; compare Morgagni De sed. et caus. morb. Lib. I. Epist. IV. : often is the quantity of fluid much less in this than in other diseases, in which no, or very indistinct, symptoms of pressure of the brain exist.-Abercrombie, p. 253, a'so loolds, that extravasation is not the cause but the consequence of apoplexy.[Abercrombie says 'sometimes.' 'T.]-Probably apoplexy and exudation arise from one and the same cause.

(5) The INTERNAL, to distinguish it from the EXTERNAL, hydrocephalus extermus or ozdema capitis, in which the water is found between the skull and the external teguments. As to writers, compare de Plouquet Repertor. Art. Hyclrops capitis, Reuss Repert. Commentat. Vol. XIII. and Dictionnaire des Sciences médicales, Artic. Hydrocephale, and above, $\$ 122$, note $10 .-$ The most valuable of the modern writers are MIorgngni, Epist. XII.-Kaltschmid Progr. de hydrocephalo interno raræ magnitudinis. Jenæ, 1752. - Fothergill in Medical Observations and Inquiries, 1771, Vol. IV. - Klinkosch Pr. de hydrocephalo fotus rariori ejusque causa. Praz. 1773. - Ludwig D. de hydrope cerebri puerorum Lips. 1774.-Odier Némoires sur l'Hydrocephale interne ou l'Hychropisie des $V$ entricules du cerveau in Hist. de la Soc. de Médecine à Paris, 1779, p. 194.G. Flajani Osservazioni pratiche sopra I'Amputazione, l'Idrocefalo, etc. Roma, 1791. - Quin Abhandlung über die Gehirnwassersucht. Leipz. 1792. - Bader Geschichte der Wassersucht der Gehirnlïhlen oder des Schlagflusses der Kinder. Francof. 1794. - Murray resp. Schulzen D. fous hydrocephalo interno corrupti descrintio. Upsal. 1797. - Kreysio D. de liydrocephali inflammatorii pathologia. Viteb. 1800. - J. B. Bott D. de hydrocephalo. Edinb 1800. - Moffut and Armstrong D. de apoplexia hydrocephalica. Edinb. 1700. - Hopfengärtuer Untersuchungen über die Natur und Behandlung der verschiedenen Arten der Gchirnwassersucht. Stuttgard, 1802. - Afzelius resp. Rislachi, D. Hydrops ventriculorum cerebri historiis morbi et sectionibus cadaverum illustratus. 4to. Upsal. 1804.-J. Young D. de hycirocephalo interuo. Edinb. 1S04.-T. Ferris and E. Sullivan D. de hydrocephalo interno. Edinb. 1805. - J. R. Lucas, D. de liydroceplialo acuto. Edinb. 1805. - J. and $C$. Wenzel Bemerkungen über die Hirnwassersucht. 4to. Tubingen, 1806.- P. Lee D. de apoplexia hydrocephalica. Sdinb. 1807.-Bonsfield D. de hydrocephalo acuto. Edinb. 1807.-Ralston D. de hydrocephalo. Edinb. 1808. - M Creery, D. de hydrocephalo acuto. Edinb. 1808. - Brown, D. de apoplexia hydrocephalica. Edinb. 1808. - J. Rand, jun. Observations on the Hydrocephalus internus in Medical Communicat. of the Massachusetts med. Soc. Vol. I. p. 69. Boston, 1808.-Cheyne, On Hydroccphalus acutus, or water in the head. 2d edit. Dublin, 1819.-Formey, Von der Wassersucht der Gehirnhölılen. Berlin, 1810.-Sanders, I). de hydroceplihalo acuto interno. Edinb. 1810.-Ferrai and Stormoulh, D. de hydroceplialo acuto. Edinb. 1811.-Autenrieth D. Observat. de hydrocephalo acuto, etc. Tubing. 1811.v. Portenschlag-Ledermayer Ueber den Wasserkopf. Wien, 1812. - LöbensteinLöbel Die Erkenntniss und Heilung der Gehirnentzündung, des innern Wasserkopfes und der Krampfkrankheiten in kindlichen Alter. Leipzig, 1813._Gölis Prakt. Ablıandl. iiber dic vorziiglichsten Krankheiten des kind!. Alters. 1st. Vol. von der hitzigen Gehirnhöhlenwassersucht. 2d Vol. vom innern chron. Wasserkopfe und den verschichenen Arten des äussern Wasserkopfes. Wien, 1815 and 1818. 2d edit. Wien, 1821.-J. Ferguson I). de hyclrocephalo. Edinb. 1816.-11. Guthrie and J. Wylic D). D. de hydroceplablo acuto. Edinb. 1816.- 
Yeat, A statement of the early symptoms which lead to the disease termed water on the brain. 8vo. London, 1815; and an Appendix to the same, with cases. London, 1819. - Coindet Mémoire sur l'hydrencephale, ou cephalite interne hydrencephalique. Paris, 1817. - Hecker Antiquitates hydrocephali. Berol. 1817. - Abercrombie in Edinb. med. and surg. Journ. Vol. XIV. p. 292.J. Inglis, D. de hydrocephalo. Edinb. 1817. - J. Squair, D. de hydrocephalo acuto. Edinb. 1817. - Fillans, D. de Hydrocephale acuto. Edinb. 1818. Brachet Essai sur l'hydrocephalite ou Hydropisie aiguë des ventricules du cerveau. Svo. Paris, 1818.- - de Leon D. de hydrocephalo. Edinb. 1819.-Schütz D. de hydrocephalo acuto, $\delta$ vo. Halæ, 1819.-J. S. Boettger D. de hydrope cerebri. 8vo. Berol. 1819.- - Reusch D. de hydrocephalo. 8vo. Berol. 1820.-Moulin Traité de l'A poplexie ou hémorrhagie cérébrale, considerations nouvelles sur les hydrocéphales; description d'une hydropisie cérébrale particulière aux vieillards. 8vo. Paris, 1819. - Mathey Recherches sur les charactères distinctifs, et sur le traitement de l'hydrocephale interne in Journ. de Médec. cont. Vol. XI. p. 651.-Duffin and H. Symes D. D. de hydroceplaalo. Edinb. 1821.- Stansfield D. de hydrocephalo acuto. Edin'b. 1821.-Clendinning D. de hydrocephalo acuto. Edinb. 1821.-Levi D. brevis de Hydroc. tractatio. Berol. 1822. - R. Johnston, D. de hydrocephalo. Edinb. 1823. - Barry D. de hydrocephalo acuto. Edinb. 1823. - Campe D. de hydrocephalo acuto. 8vo. Halæ, 1823. - Weber D. de hydrocephalo. Wirceb. 1823 , s. - Dörrer D. de hydrocephalo chronico senili. 8vo. Wirceb. 1826.-Mitivie Beobachtungen und Bemerkungen iiber die hitzige Gehirnhöhlenwassersucht bei den Kindern, nach d. Fr. von $G$. Wendt. Leipz. 1823.-A.J. Wenzel D. de hydrocephalo congenito. 8vo. Berol. 1823.Ritter Morbi hydrocephali historia. 8vo. Berol. 1824. - Kiens D. de hydrocephalo chronico. 8vo. Riga, 1825. - Rabe D. de hydrocephalo ventriculorum cerebri acuto. 8vo. Berol. 1824. - Fischer D. de hydrocephalo acuto. Svo. Berol. 1824.-Bergmann anat. pathol. Untersuchungen über Hirnwassersucht in Nasse's Zeitschrift für die Anthropologie, Part I. 1825. - Bamberg D. de hydrocephalo acuto. 8vo. Berol. 1826. - Ayre, Researches into the nature and treatment of Dropsy in the brain, chest, abdomen, ovarium, and skin. Lond. 1826. - Duges in Fphémérides médicales de Montpellier, 1826. - Rudolphi Ueber den Wasserkopf vor der Geburt, in Abhandl. der K. Akad. der Wissenschaften. Berlin, 1826-7, p. 1, pl. 1, 2, and 6, (in the last plate a beautiful engraving of the brain.) - E. Ehrenberg D. exl. Hydropis cerebri casum rarissimum. 4to. Berol. 1826, with engravings. - E. W. Otto D. de hydrope cerebri acuto. 4to. Leipz. 1827.- A. Monro, The Morbid anatomy of the Brain, Vol. I. Hydrocephalus. Edinb. 1827. - Mills in Dublin Transactions of the Association of Physicians, Vol. V. 1828.-Levrat A perçus theor. et prat. sur les causes, la nature et le traitement de l'Hydrocephale aigüe maladie particulière du premier age. Lyons, 1828. - J. Brevis D. de hydrope ventriculorum cerebri acuto. 8vo. Berol. 1828. - C. Himly Demonstratio hydrocephali humani memorabilis in Comment. Soc. reg. Scient. Goting. recentior. Vol. VI. Class. physic. p. 61 ; and Lansenbeck De cerebro aqua ingenti sacciforme distento, cum nondum perfecto conferendo, ib. p. 73, pl. 1-5, (engravings of the brain.)-Meckel has collected many individual cases in his Handb. der pathol. Anatomie, Vol. I. p. 260, ff.Burdach Vom Leben und Bau des Gehirns, Vol. III. p.514. - Some interesting, or, from their anatomical investigation, very instructive cases are given in the Edinb. med. and surg. Journ. Vol. II.p. 369.-Clarke, Vol.V.p.264; Vol.VIII. p. 364; Vol. IX. p. 398 ; Vol. XI. p. 453. - Coley in Vol. XIV. p. 401 ; Vol. XVII. p. 240,471 and 510 ; Vol. XIX. p. 173 - Breschet in Magendie's Journal de Physiol. Vol. I. p. 92 ; Vol. II. p. 269 ; Vol. III. p. 241.-Bulletin de la Faculté de Médec. Vol. VII. p. 332. - Archives générales de Médecine, July, 1823.-Howship, Pract. observ. in Surgery and morbid Anatomy (twentysixth case, with an engraving of the brain.)-Baxter in Medical Repository, new series, New-York, 1817, Vol. IV. Part III. (100 ounces of water in the brain.)Tacheron, Vol. III. p. 37-59.-Baron in Bulletin de la Société de Médec. Vol. IV. p. 432. - Ulrich and Mayer in Meckel's Archiv f. die Physiologie, Vol. VI. p. 523, and Vol. VII. p. 423.-Georget in Nouv. Journ. de Médec. Vol. VII. p. 193.-Seeger in Rust's Magazin, Vol. II.-Krüger-IIansen in Graefe 
and Walther's Journ. der Chir. Vol. IV. p. 541, (congenital, nineteen inches in circumference.)-Wetter in Harles's Rhein. Jahrb. fur Med. und Chir. Vol. III. Part III. p. 65.-J. Glover in Chapmann's Philadelphia Journal of the med. and phys. Sciences, Vol. II. No. 1, (between the membranes.)-Duncan, jun. in Trans. of the med-chir. Soc. of Edinb. Vol. I. 1824, No. 7, (136 ounces of water in the arachnoid and in the ventricles, the hemispheres very much separated from each other.)-Millar and Robertson, ib. Vol. II. 1826. - Pascoli Uebersicht über das im Jahre, 1825-6, in der medic. prakt. Schule zu Inspruck geflogene Heilverfahren, Inspruck, p. 81, 1827, (the child, aged one year, weighed twenty-five and a half pounds; its head alone weighed twenty-one pounds.) Internal hydrocephalus happens frequently among beasts, and often to a great extent in calves, horses and sheep; much less frequently in dogs, cats and pigs. Of other animals no examples are known to me.

(6) Also hydrops cerebri externus, and hydrocephalus internus, in old people, which dropsy of the ventricles cannot. We may also call it hydrocephalus meningeus. - Meckel, Handbuch der pathol. anat. Vol. I. p. 264, calls this external dropsy of the head, in contradistinction to dropsy of the ventricles, which, however, may easily give rise to confusion of ideas. According to Monro, the water from the ventricles may be effused into the membranes by rupture, which, however, at least is not in general the case. v. Monro, Observations on the eye, the ear, and the brain, p. 38.-Even in one case of congenital dropsy of the brain, No.2891 of my Verzeichn. in which there was an aperture, no water escaped.

(7) Also hydrops cerebri, hydrops cerebri internus, and hydrocephalus encephalodes.-Gall distinctly pointed out that all the large dropsies of the head belonged to this kind.

(8) Observations of good cases are given by Wepfer Observat. anat. de apoplexia. Hist. XIII. and XIV.-Kaltschmid.-Loftie in Medic. Observat. and Inquiries, Vol. V. No. 13, p. 121. - Wrisberg, v. Salzburg. medic. chir. Zeitung. Vol. I. 1805, p. 88.-Hartell, ib. p. 94:-Mier in Samml. auserles Abhandl. zum Gebr. prakt. Aerzte. Vol. XI. p. 214.-Flajani, Hufeland, Glover, and Duncan, Sc. In the cases of Kaltschmid, Loftie, Flajani, and Glover, water was found merely between the skull and the brain; in the others also at the same time water in the cavities of the brain. I have several instances of the latter kind; of the former I have found but two in new-born children.

(9) Penada Saggio d'osservazioni e memorie, ctc. 4to. Padua, 1793, (large on the occiput.)-Textor in Neuen Chir. Vol. I. Part III. p. 469, (on the fontanel, apparently without connexion with the brain.)-Meckel Descriptio monstrorum nonnullorum, p. 52, 4to. Lipsiæ, 1826.-As in hydrencephalocele the protruded bag of the brain is sometimes merely membranous, it requires a close examination, though the watery cyst, which was cured by ligature, might at least in part belong here. v. E. Thompson in London Medical Repository, Nov. 1824.- In a monster which had dropsy with an undivided brain, No. 2888, of my Verzeichn., the very expanded arachnoid having fallen together, protruded on the templc through a liole in the dura mater and the membrane of the skull to the general tegument, and here formed at first sight an encysted tumour; perhaps water had been previously contained in it; the pia mater passed smoothly before the inner opening, and contributed somewhat, as well as the brain, to the formation of this tumour.

(10) Metzger Biga Observat. p. 3. - E. Ehrenberg, p. 16, and an engraving ; the watery cyst was situated between the other parts of the hemispheres of the cerebrum.-Meckel Descript. monstr. nonnull. p. 57. 4to. Iipsia, 1826.

(11) Morgagni relates many instances. I myself have also found some, although in these cases it appears to me that the quantity of water is always but small. Compare Camerarius.

(12) A. Portal Sur une hydropisic particulière des ventricules lateraux du cerveau, etc. in Mém. de Paris, 1770 , p. 240 . - In adults I have seen occasionally water in the lateral ventricles, though never in great quantity. In some children which had watery heals, I have seen one hemisphere of the brain much more distended by water than the other, althongh there was water both in it and in the middle ventricle. In liydrops cerebri hydatidosus the partial expansion of 
one ventricle is naturally more common.-E. Home observed a considerable quantity of water in the third ventricle, and in the septum lucidum, without there being any in the lateral ventricles. v. Baillie's Morbid Anatomy, p. 447.- In an idiot five ounces of water were in one case found in the cavity of the septum lucidum. v. Vingtrinier in Revue Médic. franç. et étrang. Vol. VIII. p. 299304, July, 1822 .

(13) Chronic water in the head is so frequently congenital that Meckel, Handbuch der pathol. Anat. Vol. I. p. 260, allows of no other. I know, however, no reason why the causes of water in the head should not operate just as much immediately after as before birth ; and there are really many cases given of water in the head occurring in healthy children of one, two, or more years old, after falls, blows, metastases of eruptive diseases, \&c. The formation of water in the head of the fœtus is especially important in midwifery, as perforation of the head is often necessary. Compare Hebenstreit D. de capitonibus. Lips. 1743. v. Haller Select. Diss. Anat. Vol. V I.- - Very small embryons have been seen with water in the head, viz. Osiander Annalen der Entbindungslehr-anstalt zu Göttingen, Vol. I. Part II. p. 58, 61, and Handbuch der Entbindungsk. Part II. p. 291, (in embryons two or three months old.) - Rudolphi, tab. 1, fig. 1, (in an embryon about two months old.) I have a similar case before me, No.2938. - A description and plate of a six weeks' old fotus, with water in the head, is given by Meckel Descriptio monstr. nonnull. p. 83, pl. 5, fig. 2. 4to. Lips. 1816. - Probably also here belongs the case by Mende, in Nov. Act. Acad. Nat. Cur. Vol. XI. Part II. p. 443 , pl. 53, fig. 2 ; although the author considered the brain healthy. Sometimes there is a marked disposition to water in the head, as several sisters have been affected with this disease. v. Portal, Vol. IV. p. 73. - Odier Med. chir. Abhandl. a.d. Fr. Leipz. 1798.-Recueil périod. Vol. VI. p. 289.-P. Frank De cur. hom. morb. Epitome, Vol. IV. p. 337; (five sisters died in their first year of acute hydrocephalus.)-Goelis mentions that in one family three, in another seven sisters had water in the head.-In another case seven sisters were affected with this disease, of which only the youngest was cured. v. Rolph in London med. Repos. Sept. 1824.

(14) Even to the twenty-fourth year, v. Riedlin in Ephem. Nat. Cur. Cent. I. and II. Obs. 29 ;-Schmitt in Salzburg. med.chir. Zeitung, 1800, Vol. IV. p. 233 ; to the twenty-fifth year, v. Howship; - to the twenty-ninth year, v. Michaelis in Medical Communications, Vol. I. No. 25 ; - to the thirtieth year, v. van Swieten Commentar. p. 123, § 1217 ;-Büttner Beschreibung des innern Wasserkopfes und des ganzen Beinkörpers einer von ihrer Geburt bis ins 31te Jahr krank gewesenen Person weiblichen Geschlechts, Königsb. 1773 ;-Thunberg, v. Reisen in Afrika und Asien, v. Magazin von neuern Reisebeschreibungen, Vol. IV. p. 250 ; - to the forty-third year, v. Schneider in Annalen der Wetterauischen Gesellschaft, Vol. I. No. 24 ; - to the forty-fifth year, v. Aurivillius, resp. Ekmark De hydrocephalo interno 45 annor. Upsal. 1763, in Sandifort Thesaurus, Vol. II. No. 14 ; - -to the forty-eighth year, v. Osthoff Kleine Beiträge, Vol. I. No. 4; even to the fifty-third year, v. Gall Anat. et Physiol. du Systême nerveux en général, etc., p. 25, with a plate of the brain.

(15) Instances of very large watery heads in new-born children are given in Marcorel Mémoires prés. à l'Academie, Vol. IV. p. 458.-Murray.-Stein Geburtshülfl. Wahrnehmungen, Vol. I. No. 161.-Wrisberg, p. 92, (seven pints of water, the circumference of the head $30 \frac{1}{2}$ inches.)-Osiander Annalen der Entbindungsanstalt, Vol. I. Part II. p. 59. - Krüger-Hansen and Pascoli.-There is a remarkable case in Bresl. Mus. v. No. 2891, of my Verzeichn., which, though shrivelled up in spirits, measures even now 19 inches.-Old cases of large collections of water in the head are collected in Portal, Vol. IV. p. 73. In a child a year and a quarter old, the head measured 32 inches round, and contained fourteen pints and a quarter. v. Schwäbischer Merkur, 1807, p. 310.In a boy of sixteen years, 31 inches. v. Millar and Robertson.--In another, seventeen years, $24 \frac{1}{2}$ inches. v. Blumenbach Medic. Biblioth. Vol. III. p. 626, 1788. - In a girl of eighteen, $26 \frac{\mathbf{I}}{2}$ inches. v. Hufeland's Journal, May, 1823, p. 129. - In the case of Aurivillius, the head contained eighteen pints of water.In that of Büttner, twenty pints.-In that mentioned in Ephem. Nat. Cur. 
Dec. III. Ann. I., as much as twenty-four pints. The circumference amounted to 29 inches, in a case of Warner's. v. Benj. Gooch, Cases and pract. remarks on Surgery, Vol. I. p. 37, 29 inches.-In that of Büttner, 30 inches.--In one of

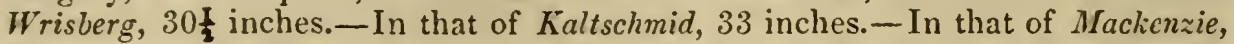
Illustrations of Phrenology, Edinb. 1820, p. 24, pl. 6, fig. 3, as much as 36 English inches.-Monro saw one of 50 inches in circumference. v. Outlines of the Anatomy of the Hum. Body, Vol. I. p. 361.-I have mentioned above, § 122 , note 10 , several good cases. Sometimes the membranes and the brain are so expanded by the water, that the light may be seen through the head, which I have often noticed; or that the membranes have burst and the water been effused beneath the external tegument of the head, v. Cavallini Collezione istorica di casi chirurgici, Vol. II. 4to. Firenze, 1764; and John Baron in Medico-chir. Trans. London, 1817, Vol. VIII. Part I. No. 3; Meckel Anat. physiol. Beobachtungen und Untersuchungen, Halle, 1S21, p. 135;-or it has escaped through the nose, v. Kaltschmid De nervis opticis in cadavere latis inventis, Jcnæ, 1752, in Haller's Disp. pathol. Vol. I. p. 375.-John Bron._Miller and Robertson, (an aperture was found above, to the right, and before the crista galli.) Perhaps here also belongs the case in Meckel Descriptio monstror. nonnullor. p. 57.- It has been already observed, that tearing of dropsical brains and their membranes is not rare.

(16) It has been improperly supposed, that the water here secreted in disease could be chemically distinguished by the coagulation of its contained albumen with acid and alcohol, from the healthy secretion of the brain, which, however, is never properly secreted in sufficient quantity for examination. - Yeats, p. 107.-Analysis of the fluid of watery heads is given by Jordan in Crell's Chem. annalen, 1801, Part VII. p. 50 ; Part VIII. p. 115 - Mirabelli and Schreger in Horket's Archiv, Vol. I. Part II. p. 256.-Marcet in General views of the composition of animal fluids, by Berzelius, p. 55. London, 1S12. - Breschet et Barrucl, in Magendie's Journ. de Physiol. Vol. I. No. 1. p. 95.-Haldat s. Dict. des Sc. médical. art. Hydrocephale.-If it have been tapped, which treatment has been employed as a mean of cure, it easily is reproduced; compare Lizars in Edinb. med. and surg. Journ. 1821, Vol. XVII. p. 243 and 471 ; compare v. Graefe and $v$. W'alther's Journ. d. chir. Vol. IV. Part K. p. 140.

\section{$\S 223$.}

In other cases, especially if the preceding inflammatory irritation have been violent, no distinct watery exudation has been observed between the cerebral membranes, but a more mucous and ALBUMINOUS-LIKE STATE, ${ }^{1}$ or a still thicker puriform PLASTIC LYMPH, which overspreads larger or smaller patches of the membranes, or sometimes forms FALSE MENBRANES. ${ }^{2}$ If the plastic lymph be more firmly coagulated, it gives rise to the various $A$ DHESIONS and UNIONS ${ }^{3}$ of the membranes, to their very distinct THICKENING and INDURATION, ${ }^{4}$ as well also as, probably, to the production of the so-called CEREizRAL GRANULATIONS Or PACCHIONIC GLANDS. ${ }^{5}$ The latter are little roundish light-coloured corpuscules, of different consistence, and of the size of grains of millet, hemp, and even of little peas, which are found in greater or less number very commonly in the neighbourhood of the longitudinal sinus, although also on other parts of the arachnoid and vascular membranes, and not unfrequently, passing outwards from these, they penetrate through the dura mater itself. 
(1) Often, also, in rheumatic affections of the head, in drunkenness, and in puerperal fever; sometimes the exudation resembles the buff of the blood in colour and consistence. Compare Portal, p. 79.

(2) Morgagni, Epist. LII. 8.-Wrisberg in Haller's Physiologie, note 74.Baillie, p. 431, and Sömmerring, ilid. note 514.-Baillie gives a plate, in Engravings, Fasc. X. p. 215, pl.4, fig. 1 ; and Hooper, pl. 1.-In a maniac, who had a very violent attack, a thick false membrane was found.-Biermeyer. v. Museum anat. pathol. No. 202. - Flormann in Svenska Läkare-Sällskapets Handlingar, Vol. VI. p. 219, (which covered the whole of the left hemisphere.) I have found it a few times, but almost always in the temporal region, attached sometimes more to the dura-materal layer, sometimes more to the cerebral layer of the arachnoid coat, sometimes between the latter and the vascular coat; on the latter, it has been several times found by Alercrombie, p. 51, 53, $56-61$

(3) Baillie, p. 245, and Soemmerring consider adhesion of the dura mater with the other cerebral membranes very rare, and this is, in reality, partially true, if we compare the arachnoid, in this respect, with the pleura or peritoneum. I have, however, found such union several times, sometimes fibrous and ligamentous-like, sometimes compact, and in large streaks. In congenital water of the head, and in tumours within the cavity of the skull, I have occasionally found extensive adhesions between the two layers of the arachnoid coat. Not unfrequently adhesions of that part of the membrane which lines the cavities of the brain also occur, as I have seen in diseases of the mind, in tumours, suppuration, and partial dropsy of one ventricle. Compare Morgagni, Epist. I. 14. IX. 25.-Portal, Vol. IV. p. 91, and Esquirol, in Dict. des Sc. Méd. Vol. VIII Art. Demence, who observed adhesion of the membrane lining the lateral ventricles, in fifty-four mad persons, and also in others who were not insane.

(4) This thickening is often very distinct, and occurs both on the arachnoid and vascular membrane; in the former case, the thick membrane passes smoothly over the convolutions of the brain, in the latter it penetrates into the depressions between them. The membranous lining is also not unfrequently remarkably thickened. v. Portal, Vol. IV. p. 91.-Greding found the arachnoid and pia mater thickened in eighty-six out of a hundred insane people, in eighteen out of twenty-four melancholic, and in twenty-two out of thirty idiots. Esquirol, Pinel, Georget, \&c., also often found it thickened in diseases of the mind. The pia mater is often apparently found thickened, on account of turgescence and rigidity of its vessels, as N'eumann has properly observed, who found it but once actually thickened out of fifty mad people. v. Hufeland's Journ. July, 1824. p. 57, It is natural that the membranes should consequently lose their transparency, and become whitish or yellowish.

(5) Glandulæ Pacchionianæ. v. Pacchioni, Op. omn. p. 125, Romæ, 1741.Granulations cérébrales. v. Bichat Anat. gén. Vol. III. p. 59.-Portal, Cours d'Anat. Médec. Vol. IV. p. 10, 44, first pointed them out as somewhat morbid; then more fully and completely in Wenzel De penitiori structura cerebri, Cap. 1 . -Compare Rosenthal in Horn's Archiv, 1818, p. 406; he considers them as a product of the veins. Also in the vascular plexuses of the ventricles they are not unfrequent; and also, in an epilectic person, Abercrombie, p. 315, found such a concretion in the vascular plexus, as large as a hazel-nut.

\section{$\S 224$.}

More rare than the hitherto-mentioned results of morbid irritation and inflammation in the arachnoid membrane of the brain is ULCERATION, which is however naturally more commonly superficial ulceration of the brain rather than of the just-mentioned membranes. ${ }^{1}$ As rare also is the termination in MoRTrFICATION, which here occurs only secondarily, especially after severe injuries, and abscesses of the brain, \&c. So much the more 
frequent, as consequent on morbid irritation, are found sToNY and BONY CONCRETIONS ${ }^{2}$ in the arachnoid membrane. They are commonly seen on the external surface of the fold covering the dura mater, especially in the region of the vertex and on the falciform process, and often attain a very considerable size. Usually they are flat and splinter-like, although often tubercular and roundish, so that they penetrate into depressions of the brain, and even into the skull. They are very bulky, so that the investing layer of the arachnoid coat is often much thrust inwards or even entirely absorbed. ${ }^{3}$ In rare cases they are produced, as in other serous membranes, in necked processes or bags, which project from the external layer into the cavity of the arachnoid coat. ${ }^{4}$ Sometimes also the cerebral granulations give rise to bony concretions, as lime is secreted within them. ${ }^{5}$ The bony concretions between the arachnoid and vascular coat, ${ }^{6}$ as well as in that part of it which lines the cavities of the brain and produces the plexuses, are more rare and generally smaller. ${ }^{7}$

(1) I have seen a few cases, in which, after injury of the head, and suppuration in the ear, the cerebral membranes, which were secondarily inflamed, suppurated, without the brain appearing actually to be affected; in another case, without this complication, a case of meningitis was connected with a large collection of pus between the arachnoides and pia mater, at the base of the brain. A few interesting cases of suppuration are mentioned by Abercrombie, p. 58. Case 13 and Case 15, p. 61 . Or superficial suppuration, v. The Brain. The cerebral membranes often become yellow, greenish, brown, even blackish from suppuration and gangrene. We must not confound herewith the yellow colour which has been seen a few times in jaundice. v. Morgagni Epist. XXVII. 7.Buzzi in Italian. Biblioth. Vol. III. Part II. p. 96. - Dubrevil in Ephémérides médicales de Montpellier, Aug. 1826, (in an embryon three months old.)

(2) Compare $\$ 219$, note 10 . These bony concretions are very frequently considered the cause of headache, dizziness, epilepsy, apoplexy, insanity, suicide, \&c. ; but, as I think, cause and effect are here often confounded, as the flow of blood and morbid irritation, which occur in these diseases, as often give rise to morbid deposition of lime. Advanced age also appears to me to have no greater disposition thereto, than, that irritation of the brain more frequently occurs at that, and especially at a later period of life. I find, therefore, in the bodies of many old persons brought here for dissection, the formation of bone hardly more frequent in the ccrebral membranes than in middle life, and usually only when other traces of affections of the head are present at the same time. On the contrary, I find large bony concretions also in young people who have died of disease of the brain; indeed, I have seen them congenital, to wit, very large in No. 2888 of my Verzeichu.; several instances of their existence also in children and young persons, are given by different writers. I have never found them in animals, though I have examined so many of their heads; nor, if I be not mistaken, are there any examples of them in any collection.

(3) I have found these modifications in various ways, viz. almost three inches long, and half an inch thick; round, of the size of a hazel-nut, or nutmeg. Compare No. 2277, 3123, 3975-3990 of my Verzcichn. and besides several interesting cases. In Dr.Locher's collection at Zurich, I saw a piece of bone, as big as the palm of the hand, on the dura mater. I have never found it on the tentorium, and therefore consider it very rare, although examples are given. v. Lientaul, Part II. p. 324, Lib. III. Obs. 50; some instances in Voigtel 
Handb. der path. anat. Vol. II. p. 26.-Hutchinson in Med. chir. Trans. Vol. II. p. 113. - Good engravings of such bony concretions are given by Scheid D. de duobus ossiculis in cerebro humano. Argentorati, 1687. - Baillie, Engravings, Fasc. X. pl. 4, fig. 2 and 3.-Hooper, The morbid Anatomy of the human Brain, pl. 5.-According to van der Boon Mesch, these concretions on the arachnoid consist especially of carbonate of lime; those on the dura mater of phosphate of lime (?) v. Schroeder van der Kolk Observat. anat. pathol. et pract. argumenti. Fasc. I. p. 34. Amstelod. 1826.

(4) See my Selt. Beob. Part II. p. 81, and No. 2276 of my Verzeichn. Compare $\$ 81,154$, note 7, \&c.-Here also seems to belong Cruveilhier's case. v. Essai sur l'Anat. path. Vol. II. p. 21; and perhaps also that of Fabricius, Cent. I. Obs. 81, p. 27, and Greding, Vol. II. p. 97.

(5) I myself have never seen this, though several instances are mentioned by Greding in Ludwig's Adversar. med. pract. Vol. II. Part III. p. 483.

(6) Haller De corp. hum. fabrica. Vol. VIII. p. 33 ; and in Op. minor. Vol. III. p. 363. - Vicq d'Azyr in Mém. de Paris, 1781, p. 498. - Sandifort Observ. anat. pathol. J. III. p. 45. - Cheselden Anat. of the human Body, p. 221.-Greding in Ludwig's Advers. med. pract. Vol. II. p. 428.-Bichat Anatomie générale, Vol. IV. p. 536.-Meckel Handb. der pathol. A nat. Vol. II. Part II. p. 206.-I have only found it here twice. v. Verzeichn. No.3991.Hooper, Part V., gives an engraving.

(7) Laennec also found it on the outer surface of the membrane lining the ventricles, but Kerkring and Merklin on the inner. v. Dict. des Sc. Méd. Vol. IV. p. 127.-Less frequently in the plexus choroides. v. Süe Osteologie de Monro, p. 20, note.-Greding's Sämmtl. medic. Schriften, Vol. I. p. 314.-Sömmerring Addenda to Baillie, p. 267 and 268. - Walter, Anatom. Museum, Vol. I. p. 155, No. 309.-Chabert, Flandrin, and Huzard Vollständ. Handb. der Vieharzneik. Vol. I. p. 420. - Powel, in Medical Transactions, Vol. V. p. 234, (earthy concretion.)Esquirol in Dict. des Scienc. médicales, Vol. VIII. Artic. Demence (a cyst containing lime.) - Asprey in London med. and physic. Journ. (on each side, one as large as a pea.) - I have also sometimes found earthy and bony concretions in the plexus.)-Bergmann found, in the plexus of a mad person, about fifty little crystals. v. Nasse Zeitschrift f. Anthropologie, 1823, Part II. p. 416, and twenty cases of sand-like formation in the plexus. v. Mende Beob. und Bemerkung. aus der Geburtshülfe und gerichtl. Medic. Vol. III. Gött. 1826.

\section{$\S 225$.}

To the more important sPURIous FORMATIONS which are sometimes found in the arachnoid membrane and the external surface of the vascular membrane of the brain, belong especially the various kinds of TUMOURs which easily become injurious by pressure on the brain. These are, first, HYDATIDS ${ }^{1}$ of different number and size, which in rare cases occur on the free upper surface of the arachnoid, between it and the vascular membrane, and very commonly and numerously in the plexuses of the lateral ventricles of the brain $;^{2}$ next, a kind of CYLINDRICAL, Or CLUB-LIKE PROCESSES Or NECKED BAGS, peculiar to serous membranes, arising from the arachnoid which lines the dura mater, and containing in their loose extremities commonly lymphatic concretions, gelatinous, bony, and cartilaginous matter; ${ }^{3}$ further, true ENCYSTED TUMOURs, ${ }^{4}$ and lastly, not very rarely, TUBERCLES, ${ }^{5}$ by the breaking up of which CIRCUMSCRIBED BAGS OF PUS Or ENCYSTED ABSCESSES MaY arise on the surface of the brain. 
(1) Compare Lüdersen D. de hydatidibus. Goett. 1808, p. 10. - Morgagni Epist. XII. 6. - Lieutaud, Vol. II. p. 310 ; Lib. III. Obs. 4 and 4 a. - Fischer Hist. Tæniæ hydatigenæ, $\$ 21$, tab. I. - Several examples are collected by Burdach Beiträge, Sc. Vol. II. p. 107 and 287.-I have found them a few times, but am unable to mention any thing certain as to the pathological phenomena.-Esquirol found a large hydatid in the arachnoid of an insane patient, v. p.291.Were the miliary cysts which Pagenstecher, v. Harles's Neue Rhein. Jahrbücher der Medicin und Chirurg. Vol. XII. Part III. p. 1, saw on the arachnoid, hodatids?

(2) I found them in persons subject to insanity, epilepsy, headache, \&c.; also, however, in many others. - We often see many of them attached by fine threads, or single large ones, which separate the walls of the ventricles fiom each other.-A single large hydatid was found by Devaux in the right lateral ventricle of a person who died of nostalgia. v. Fournier Recueil de Méd. Chir. et Pharm. Milit. Vol. XI. p. 24S. - Rendtorff saw a large hydrops vesicularis in the right ventricle of a girl eight years old. v. Hufeland's Journ. d. prakt. Heilk. Dec. 1823, p. 46 , with a plate.-Headington found a very large hydatid in the left ventricle. v. Abercrombie, p. 436.

(3) Compare the preceding $\$$, note 5 . - I have found this anomaly three times. - In No. 2276 of my Verzeichn., there were found, besides the large bony concretions attached by threads, and in sacs with necks, four long appendages, with little blood-vessels in their necks, and a collection of turbid jelly in their thicker depending extremities. - No. 2278, from a horse, is similar, in which there are five appendages, about two inches in length, from which some cylindrical processes, similar to those of the gurnards, are produced.-In a third case, a long roundish tumour, filled with thick yellow jelly, is attached to a thin stem.-Doubtless, the finger-like appendages mentioned by Lobstein, Compte rendu sur les travaux Anatomiques, Strasburg, 1820, p. 50, belong here.

(4) For instance, in the late Duke of Saxe Gotha, one about six inches long and three broad upon the right hemisphere. v. Dorl and Ziegler in von Froriep's Notizen, Vol. X. p. 89.-Esquirol once found a cyst containing fatty matter on the plexus choroides.

(5) Baillie's Morbid Anatomy, p. 438. - Leveille found in an idliot tubercles as large as an egg between the dura mater and arachnoidea; read in the sitting of the Academy of Medicine, Aug. 10, 1824.-Many smaller tubercles on the vascular coat of a person who died of paraplegia. v. Earle on paraplegia, in Med. chir. Transac. 1827, Vol. XIII. No. 18. - Abercrombie, (seventy-ninth case,) p. 173.-Tubercles which have their origin in the ccrebral membrane frequently appear to lie on the surface of the brain, of which I shall make mention further on. I have scen this distinctly in two cases.

\section{$\S 226$.}

Lastly, as to what belongs to vices of CONTENTs of the arachnoid and vascular membrane, it has been already above noticed, in speaking of the COLLECTIONS OF LYMPHATIC SECRETions to which inflammation of this membrane usually gives rise. We frequently find between the two layers of the arachnoid, although also between it and the vascular membrane, a considerable quantity of PUs, which may be here poured out from ulcers of the membranes, as well also as from the surface of the brain, and cerebral abscesses which have burst. We not unfrequently see in the just-mentioned situations, in injuries of the head and in apoplexy, COLLECTIONS OF BLOOD, in very different quantities. ${ }^{1}$ Even PURE QUicksilver, ${ }^{2}$ EXTRANEOUS BODIES which having penetrated from without and 
remained here for a long time, ${ }^{3}$ and Parasitic animals, ${ }^{4}$ have been observed in and upon the membranes of the brain.

(1) Little bloody specks have been seen on this membrane in severe meningitis; a few times also petechiæ. v. Stoll Ratio Medendi, Part II. p. 406, in petechial fever.-Wood in a girl who died of purpura. v. von Froriep's Notizen, Vol. VIII. Nu. 8, p. 127, (according to the report, in the dura mater, also between it and the lining layer of the arachnoidea.)-Effusions of blood are considerable in contusions of the cerebral membranes, and rupture of the dura mater, in which case the blood seems to be collected in a cyst in the arachnoid. In apoplectic persons also we often find the blood in a cyst of the arachnoid, not unfrequently between it and the pia mater, as well as beneath the latter. See further on the brain.-Lobstein, p. 46, found, in two maniacs, the arachnoid thickened and consisting of several layers, between which blood was effused; the brain had also become very much compressed. This seems to be an undescribed disease.

(2) Muralt Observ. chir. Basil. 1691, No. 208.-Panarolus A rcanor. Fasc. II. - Boneti Sepulchretum anat. Vol. I. p. 64, Obs. 114._Lieutaud, Hist. anat. med. L. III. Sect. VIII. Obs. 558-562. Compare $\$ 73$, note 8 .

(3) For instance, bullets, pins. Flajani found in a Russian, thirty years old, a needle two inches long in the cavity of the skull, close to the falx. v. Valentin Voyage médicale en Italie. Nancy, 1\$22. See below.

(4) The Gamasus marginatus. The worms in the brain described by old writers are merely threads of plastic lymph, which have been mistaken for them. It is true that fly maggots may find their way into the cavity of the skull through badly tended wounds of the head, but this will never occur at the present time.

\section{B.-OF THE BRAIN ITSELF.}

\section{$\S 22 \%$}

The BRAIN, together with the rest of the nervous system, is proportionally subjected to but few and rare malformations and diseases; and even those pathological conditions, which we consider especially grounded in this system, as mental and nervous diseases, appear but in very rare instances to have their primary seat in it. ${ }^{1}$ But so much the more important are their organic vices, as besides the disturbance of the peculiar functions of this system, they are frequently, by their great influence upon the formative and reproductive activity of the organism, not merely detrimental to life, ${ }^{2}$ but also, if they exist previously in the embryon, they have the greatest influence upon its development, and therefore appear to be the cause of many vices of formation in the foetus. ${ }^{3}$

(1) Compare, for instance, the above quoted writers on Diseases of the Mind, and especially Esquirol in Dict. des Sciences Médic. Vol. VIII. p. 289; Vol. XXXII. p. 172, and his Therapie der Seelenstörungen, translated into German by Hille, p. 235 and 483, in which he mentions, that in the examination of the bodies of 277 insane persons he found but seventy-seven with vices of the brain; Pinel (the father) but sixty-eight out of 161. v. Magendie's Journal de Physiol. Vol. VI. No. I. p. 50; also Georget, De la Folie, did not find vices of the brain in one half of insane cases. Bayle considers chronic inflammation of the brain as the most frequent cause of diseases of the mind, excepting congenital idiotcy. Many of the vices of the brain which have been observed 
are certainly only the consequence, and not the cause, of diseases of the mind. According to Flourens, diseases of the mind, as they are generally the consequence of organic vices, can only be connected with vices of the cerebrum. According to Casaivieilh and Boucher's Observations in diseases of the Muscular System, viz. epilepsy and catalepsy, the medullary substance is affected; but in the true diseases of the mind the grey substance. v. Briere in Nouv. Biblioth. de Méd. Dec. 1825.

(2) It is known that insane persons rarely become old, and that they are often affected with consumption.

(3) As the nervous system is, at every period of life, so intimately connected with the functions of circulation, secretion, and nutrition, so it is well known to have in the embryon the greatest influence upon the growth and proportional form of its several parts. Hence we also see the most varied formation of the face and the extremities connected with hemicephaly, hydrencephalocele, with singleness of the brain, spina bifida, \&c., as I have already observed in several parts of my Selt. Beob., and since can confirm by copious collections of recent observations. And it is very satisfactorily shewn, especially by Tiedemann in Beobachtungen ïber die Beschaffenheit des Gehirnes und der Nerven in Missgeburten. v. Zeitschrift für Physiolog., edited by Tiedemann, G. R. Treviranus, and L. C. Treviranus, Vol. I. Part I. p. 56-110; Vol. III. Part I. p. 1-44.

\section{$\S 228$.}

To malformations of the brain belong, especially, the TOTAL Or PARTIAL DEFICIENCY of this organ, ${ }^{1}$ either when the vault of the skull is simultaneously deficient, or even when that exists. To the former state is commonly applied the name of DEFICIENT BRAIN, hemicephalia, or anencephalia. ${ }^{2}$ In both instances the cause of deficiency is dropsy of the brain at a very early period, which sometimes continues to enlarge till it bursts and is discharged, at other times is only more or less retarded in its external or internal formation. ${ }^{3}$ In proportion as this disease affects the embryon at an earlier or later period, must the effect be very different. In hemicephalic monsters the brain is sometimes completely and entirely wanting, and the base of the skull, which alone exists, is merely covered with fine membranes, in which the origin of the cerebral nerves is attached; sometimes we find, covered with a thin membrane consisting of the common integuments and the dura mater, a larger or smaller rudiment of brain, occasionally mingled with hydatids, mostly broken to pieces, fallen together, soft, discoloured, soaked in effused blood, as it were macerated, and very imperfect in its internal organization; ${ }^{4}$ sometimes, lastly, there is a part of the top of the skull present, but always less arched than natural, and there is then also a part of the brain tolerably normal, whilst another part lies loosely, and more or less destroyed, as in the preceding state, is torn or cicatrized. In those embryons, however, which are not hemicephalic, and are born with the top of the skull properly arched and even too large, the brain appears to be sometimes entirely, or for the most part deficient, 
as, on account of the great degree of dropsy, the cerebral membranes, instead of being filled with brain, are, on the contrary, filled with water, so that, when, after the evacuation of the water, the head is opened, its cavity appears empty; usually, however, we find in its base more or less of the base of the brain, as also the anterior columns of the spinal cord, the cerebral tubercle, pons varolii, limbs, crura cerebri, and rudiments of the great ganglions, thalami optici and corpora striata. $^{5}$ In monsters with deficient face or with very small skulls, more or less of the fore part of the brain, even the whole cerebrum, is sometimes wanting, so that merely the cerebellum, and the oblong marrow, terminating in front in a rounded form, are present $;{ }^{6}$ or the brain, even if completely existing, is still so imperfectly developed, that its normal divisions and internal organs are more or less lost. ${ }^{7}$ The DEFICIENCY OF INDIVIDUAL SMALL PARTS OF THE BRAIN, with the otherwise normal form of the brain and of the face, is very rare. ${ }^{8}$ The opposite vice, the EXCESS OF NUMBER in the parts of the brain, or the partial DUPLICITY of the brain, is very common in double monsters, and exhibits the same modifications as the consolidation of the two heads, so that, either according as the duplicity affects merely the fore or hind part of the skull, \&c., so the brain also is only more or less double at its fore or hind part, or, when in some heads the cavity of the skull is double, two brains also are found, of which the one is sometimes very imperfect on account of the confined space. ${ }^{9}$ Very rarely do we find in otherwise single brains, certain of their parts double or supernumerary. ${ }^{10}$

(1) Compare Reuss Repertor. Comment. Vol. X. p. 124-126, and p. 279.de Plouquet Repertor. Art. Cerebrum deficiens, (the greater number of these cases relate to hemicephaly.) - Geoffroy Saint-Hilaire in Mém. du Museum d'Histoire naturelle, Vol. XII.-J. H. Beck Ueber den ursprïnglichen Hirnmangel und über die Pathologie und Therapie des Gehirnblutflusses. Nürnberg, 1826, (on hemicephaly.) - Dujés in Ephémérides médicales de Montpellier, July, 1826, (on agenesia of the brain and congenital paralysis.) v. Casauvieilh in Archives générales de Médecine, May and July, 1827.

(2) Also called acephalia spuria, acrania, microcephalia, \&c. Compare above, $\S 122$, and on monsters. - Concerning the state of the brain v. Meckel Handb. der pathol. Anatomie, Vol. I. p. 195-260.-Instead of the name Hemicephali, for these monsters, Béclard, in Bulletin de la. Fac. de Médec. 1815, p. 448, makes use of the name å $\sigma \kappa v \phi o \iota$, and Meckel, in Anat. physiol. Beob. p. 79, that of àvopoфot.

(3) The more hemicephalic cases I have examined, the stronger is my conviction of the truth of the view which I took in my Monstror. sex humanor. anat. et physiol. disquisitio. 4to. Francof. ad V. 1811; and in Selt. Beob. Part I. p. 41.-Morgagni, Epist. anat. XX. Art. 56, and 57, and De sed. et caus. morbor. Epist. XII. 5-8. Epist. XLVIII. 50.-Haller Op. min. Vol. III. p. 136.Sandifort Anat. Infantis cerebro destituti. L. B. 1784.- Penada Saggio di Osservazioni e Memorie, Vol. II. p. 55, were previously of this opinion, as also Meckel Handb. der pathol. Anatomic, Vol. I. p. 254, and Anat. physiol. Beobachtun-

$$
\text { C } \mathrm{C} 2
$$


gen und Untersuchungen. Halæ, 1822.-Rudolphi Ueber den Wasserkopf vor der Geburt.-Tiedemann, Vol. III. Part I. p. 35, and others, have supported it, both by their authority and by the grounds and comparisons which they have brought forward. If the various retarded formations are frequently connected with this malformation, it shews, as I think, not the originality of deficient brain; as water in the head, if it attack the embryon at an early period, may equally have, as a consequence, retardation of the development. I recently found an embryon six weeks old, which had hemicephaly, singleness of the brain, which was compressed, discoloured, and two large transverse slits in the parietes of the head. v. 8821 , Bresl. Mus. On account of these slits, adhesion of the hemicephalic heads with the membranes of the ovum easily occurs. v. Pole in Lond. med. and phys. Journ. Vol. III. 1800, p. 397 and 497.-Geoffroy Philosophie anatomiq. p. 155. Paris, 1822.-Cerutti Rarior. monstri in museo anat. Lips. adservati descriptio anat. 4to. Lips. 1827.-C. E. Rudolphi D. Monstror. trium præter naturam cum secundinis coalitor. disquisitio. 4to. Berol. 1829, with plates. I have also had an opportunity of examining a similar case.

(4) In but very few cases, is there a difference to be observed between the cortical and medullary substance, but the whole consists rather of grey substance : if the brain be complete, some of its parts appear tolerably normal, although the hemispheres of the cerebrum are almost always diseased.

(5) Compare on Water of the Head, Kerkring. v. Lieutaud, Vol. II. Iib. III. Obs. 332.- Santorini v. Morgagni, Epist. XII. 6.-Bromel in Actis lit. Suecia, 1725 , p. 93, Comment. Soc. Götting. Vol. IV. p. 113.-Feiler Ueber angeborene menschliche Missbildungen. Landsh. 1820, p. 5, note.-Béclard in Magendie Journ. de Physiol. Vol. II. p. 273.-I have myself seen one instance in a human foetus, and a few of calves and sheep, in which the whole cavity of the skull was filled with a mere watery cyst, at the bottom of which only was there cerebral substance. Two imperfect descriptions of total deficiency of the brain in a boy of ten years old and a newly-born child, are given by Martel in Gazette de Santé. v. Hufeland's Journal, Octob. 1823, and 'd'Alquen in Harles's Rhein. Westphäl. Jahrb. für Medic. und Chir. Vol. X. Part I. 1825, p. 77 ; both cases seem to be nothing more than a high degree of water in the brain. Breschet once saw, in a child of three years and a half old, merely a thin membrane filled with water, instead of the entire outer side of the left henisphere. v. Archives générales de Médec. July, 1823.

(6) To wit, Carlisle in Philos. Trans. 1801, Part I. p. 139-144, in a lamb, of which one ventricle was very large, probably from dropsy. I have seen a similar case in a lamb, but the cerebellum was only rudimentary.

(7) Bianchi Storia del mostro di due corpi, p. 100, 8vo. Torino, 1748, (the corpus callosum, septum, fornix, cornua ammonis, pine and plexus choroides were wanting, the medulla oblongata and pons varolii slightly developed.)-Eller in Mém. de l'Academie de Berlin, p. 112, 1754, (the brain small, without divisions, pyramids, olives, the appendix cerebri, and several other parts malformed.)Klinkosch Pr. quo anatomen partus capite monstroso proponit. 4to. Prag, 1766, rev. in Diss. med. select. Pragens. Vol. I. No. 12, p. 199, (most of the inner part, and also the first six pairs of nerves are deficient.) Malacarne in Mém de la Soc. méd. d'Emulation, Paris, 1S03, (in a blind child the optic beds were wanting, together with the eye-balls and optic nerves.) - Rudolphi in Abhandl. der Berliner Akademie der Wissenschaften für das Jahr 1814-15, p. 185, Berl. 1815, (with the right eye, the optic bed of the same side was depressed, and lying loosely on the base, and very much malformed.)

(8) In two idiots, the posterior cornua of the lateral ventricles and the pes hippocampi were wholly deficient. v. Ch. Hastings in London med. Repos. Jan. and May, 1817. - In rare cases also merely the latter, which I have seen in an epileptic patient; Wenzel also speaks of it, De penitiori structura cerebri. 'The pineal gland is said to have been wanting several times, which is to be ascribed for the most part to its wasting, or even to carcless examination. In rare cases, the acervulus cerebri has been missed. The observations on congenital absence of the appendage and valve of the brain are also equally doubtful. 
(9) I have once seen, in a double calf monster, merely the tuber annulare and the medulla oblongata existing of the cerebellum; in a double lamb, there was only the anterior thick and rounded part of the medulla oblongata. v. Barkow Monstra animalium duplicia. Vol. I. p. 70, 4to. Lips. 1828.-In the Bresl. Mus. No. 3058 and 8226 , are the skulls of two lambs, single in front, but double behind; in which, on account of the unsymmetry of the skull, the one posterior half of the brain is much smaller than the other. Sometimes the duplication of the brain is distinguished merely by the increased size of its anterior or posterior extremity. I thus found, in No.2907, two cerebella and one cerebrum, of which the hinder were twice as thick as the front lobes. If there be but a single cavity in the conjoined skulls of double-headed monsters, the two brains, when they exist, are sometimes partially consolidated, viz. by the two hemispheres in a duck. v. Tiedemann, Vol. III. Part I. p. 5, pl. 2, fig. 3 and 4; sometimes they are separate, and only lie beside each other, as in the cases given by Klein in Harles's Jahrbüchern der deutsch. Medic. und Chir. Nürnb. 1813, Vol. III. Part I. p. 17 ; by Barkow D. de monstris duplicibus verticibus inter se junctis, 4to. Berol. 1821, with plates; and myself in one case, No. 2914 of my Verzeichn.

(10) Viz. the pes hippocampi major and the fimbria double. v. Sömmerring Hirn und Nervenlehre, p. 42, note 7.-I have twice found a double commissura mollis of the optic beds. - A double pine. v. Wenzel, pl.4, fig. 2. - A pair of unnatural ganglia between the pons varolii and the pyramids. v. Tiedemann, Vol. I. Part I. p. 73. pl.6, fig. 1.-Brain sand, acervulus, also in animals, viz. in the fallowdeer. v. Sommerring and Nich. Lisignolo D. de lapillis vel prope vel intra glandulam pinealem sitis, p. 10. Moguntiæ, 1785.-Greve Bruchstiucke zur vergleichenden anatomie und physiologie, p. 23, Oldenburgh, 1818; and in a goat, v. Malacarne Encefalatomia di alcuni quadrupedi, p. 31. Mantov. 1795.

\section{$\S 229$.}

The brain exhibits remarkable variation in its NORMAL SIZE, both as to SMALLNESS and LARGENESS. There are indeed observed both men and animals, in which the skull and brain are at birth proportionally too SMALL to the body, in consequence of previous imperfect development, or do not become so till after birth, since, in their growth, they do not keep pace with the other parts of the organism. Thus, for instance, we observe in many idiots the whole brain remarkably small. ${ }^{1}$ The brain is often generally, though more frequently only locally, very much diminished by external pressure; thus in hydrocephalus meningeus, we find, as a congenital state, the brain sometimes exceedingly small, and lying squeezed up in the cavity of the skull $;^{2}$ and it is very common, that the brain is compressed and wasted to a greater or less extent by indentations of the skull, by exostosis, by the expansion of the frontal and sphenoidal sinuses, by tumours of various kinds, by thickening of the membranes and collections of lymph, pus, and blood, between the latter, often to a very great extent; ${ }^{3}$ even isolated parts, as the pineal gland and the appendage of the brain, are then perhaps totally wasted. Just as fiequently is the substance of the brain wasted, if long continued pressure from within operate upon it, as in dropsy of the ventricles and tumours in the brain; indeed, as has been already mentioned 
in dropsy of the head, the greatest part of the brain may be in this way destroyed. ${ }^{4}$ Although the brain, as well as the other parts of the nervous system, wastes so little in general consumption, it is however generally diminished, both in old age, and also in certain diseases, ${ }^{5}$ or more commonly it is atrophic only at particular parts, as in the cerebellum, in isolated and ganglionic parts, as in the striated bodies, ${ }^{6}$ the optic beds, ${ }^{7}$ the quadrigeminal bodies, ${ }^{8}$ the tubercle of the brain, the pineal gland, ${ }^{9}$ and the appendage of the brain, ${ }^{10} \& \mathrm{c}$. We also find it frequently compressed from mechanical in. fluences, viz. violent concussion of the brain. ${ }^{11}$ Not less common is the opposite vice, or the IRREGULAR LARGE SIZE of the brain. This is either the consequence of hypertrophy of the organ, or of a more mechanical extension by the fluids contained within it. The former kind is especially produced in rickets, and in rare cases may occur even before birth, so that then the growth of the brain sometimes prevents the formation of the skull, in the same way as in hemicephaly, and the cerebrum covered by its membranes rests upon the base of the skull; ${ }^{12}$ sometimes only a part of the brain protrudes through the openings of the skull and forms a hernia cerebri $i^{13}$ sometimes, lastly, the brain merely enlarges the otherwise normal skull. Frequently, the rickety hypertrophy of the brain occurs first at birth, and attains often a very great extent $;^{14}$ perhaps also brains, which have been much expanded by dropsy in youth, become subsequently, in rare instances of this disease, cured by increased deposition of cerebral substance, and thus retain their morbid size. We therefore sometimes find in adults brains, otherwise normal, possessing an unnatural size and weight. ${ }^{15}$ The second kind of enlargement of the brain occurs most frequently, and to the greatest extent, from the collection of water in the cavities of the brain, whereby usually the whole cerebrum, though sometimes also merely certain parts of it, are very much expanded, more rarely and in a less degree by dropsy of the substance of the brain itself, ${ }^{16}$ by determination of blood to the brain and by the deposition of other morbid substances, viz. scrofulous matter, \&c. In many instances, we observe the size of the brain too large relatively to that of the skull, so that it is compressed within it, and on the removal of the skull-cap, distinctly expands by its elasticity. ${ }^{17}$ Sometimes the increase of mass and enlargement is confined to a single part of the brain; this is usually connected with vice of texture, and occurs most commonly in the optic beds, quadrigeminal bodies, the pineal gland, the funnel, and cerebral appendage ${ }^{18}$ sometimes, however, one of 
the optic beds, or one of the quadrigeminal bodies, is, though otherwise normal, too large, especially if that on the other side is atrophic. ${ }^{19}$

(1) Hippocrates long since considered microcephaly as the cause of idiotcy.Willis Cerebri anatome in Op. omn. p. 14, fig. 4. 4to. Amstel. 1682. - Roederer De cerebro observ. p. 5. Gött. 1758.-Greding in Ludwig's Adversar. Vol. III. p. 549. - Siebold, v. Journal f. Geburtshiilfe, Vol. I. p. 259-265, and 272-278. Sandifort Museum anatomicum, Vol. III. p. 365, No. 443.-Compare the writers on insanity and cretinism mentioned at $\S 122$, note $15-17$. - The cerebellum was found small in a cretin, by $V$.Malacarne, Sul gozzi e sulla stupidità che in alcuni paési gli accompagna. Torino, 1789. - I also once found the brain very small in an epileptic person. v. Selt. Beob. Part 1. p. 106. - I think that that form of congenital internal chronic water in the head which Goelis describes, p. 27 and 51, in which the skull was small, the sutures and fontanels ossified, the temples too pointed, laterally compressed, \&c., belongs here; and that the small quantity of water which is occasionally found in the cavities of the brain was only collected at a later period of life.-I have at least dissected a child of this kind, in which the phenomena, during life, coincided with those mentioned by Goelis, but there was no water in the brain. The mere pressure of the too early closed skull upon the brain produces disposition to disease.

(2) Kaltschmid De hydrocephalo interno, p. 57, Jenæ, 1752, in Haller's Disp. pathol. VII. p. 484.-Mier in Samml. auserl. Abhandl. XI. p. 214, (the brain as large as a hen's egg, and as firm as a kidney.) - Meckel Anat. pliys. Beobachtungen und Untersuchungen, p. 135. Halle, 1822. - Glover in Chapmann's Philadelphia Journal, Vol. II. No. 1.-I have also seen two cases. Also in hemicephaly, with undistended, untorn, perfect, but depressed brain, hydrops meningeus seems to have existed. v. Monstror. sex anat. et physiol. disquisitio, p. 20.

(3) The pressure comes on so gradually, that it may be very great, without producing paralysis or disturbance of the mind, as I have observed in a case. v. Selt. Beob. PartII. p. 85.- -Great compression of the brain was observed by Walther Salzb. med. chir. Zeitung, 1813, Feb. p. 185, (fungus cranii.) - Esquirol in Archives générales de Médecine. Dec. 1823, (medullary sarcom of the temporal region;) and in Dict. des Sc. médicales, Vol. VIII. p.291, (a fibrous tumour on the clivus.)--Hesselbach Beschreibung der pathol. Präparate zu Würzburg, p. 63, No. 642, (fungus cranii, and duræ matris.) - Ch. Mayo, in London medical and physical Journal, Vol. LVIII. p. 408, (medullary sarcom in the right temporal region.)-G. Sandifort Museum anat. Vol. III. p. 156, No. 127, (fungus cranii.) Schindler in Rust's Magazin f. die ges. Heilkunde, 1825, Vol. XXV. Part II. p. 267, (fungus cranii.) - Lisfranc in Nouvelle Biblioth. méd. May, 1827, (bloody fungus.) - Horn's Archiv f. medic. Erfahrung, 1815, p. 854, (expansion of the frontal and neighbouring sinus.)-Panizza in Annotazioni anat. chir. sul fungo midollare dell' occhio. Pavia, 1821. - Ward in London medical Repository, Sept. 1823. - Vingtrinier in Archives générales de Médecine, May, 1824. Neumann in Infeland's Journal, July, 1824, No.45, p. 46.

(4) This, however, does not appear to be necessarily the case.-I once saw a case of dropsy of the head examined, in which the bulk of the brain was not in the least diminished. This is also the case with No. 2891 of my Verzeiclnn. Perhaps the morbid irritation of the brain, which produces the secretion of water, sometimes at first causes an increase of nourishment in the brain.Osiander, Annalen, Vol. I. Part II. p. 59, found the brain of a child, which had water in the head, weighing a pound. - Breschet indeed, in Magendie's Journ. de Physiol. expérim. Vol. I. No. 1. p.95, found it decidedly heavier than the heal thy brain of a child of the same age.

(5) I have seen this in one case, in idiotcy occurring in later years in consequence of excess. After various fevers and insanity, it is sometimes compressed; Savaresy found it diminished in yellow fever, sometimes a sixth of its circumference, v. his work, De la Fièvre jaune, p. 158. Neapel, 1809.-In a diabetic patient. v. Horn Archiv f. med. Erfahrung, Vol. XXII. 
(6) Viz. Morgagni, Epist. IX. 20, XI. 11, LX. 4; in a person affected with convulsions the left was very much wasted. v. Wenzel De penitiore cerebri structura, p. 102 and 136. Biermayer Mus. Anat. pathol. No. 247; in an idiot I found both very flat. Marshall's assertion, that in hemiplegia the corpus striatum of the other side is always diseased, is not verified by experience.

(7) In long-continued blindness of one eye, one of the optic beds is often wasted, and generally that on the opposite, though also on the same side. v. Sommerring in Hessischen Beiträgen, Vol. II. IV., in Blumenbach's Medic. Biblioth. II. 2, and Nocthig D. de decussat. nervor. optic. Mogunt, 1786. Michaelis Ueber die Durchkreuzung der Selinerven. Halla, 1790. Wenzel De penitiori structura cerebri, p. 115 and 117. Rudolphi in Abhandl. der Akadem. der Wissenschaft. zu Berlin, 1814 and 1815 , p. 195, in two men, a horse, and an ox. I have twice found the optic beds atrophic on opposite sides, and once both very flat in the previously mentioned idiot. They were found very small by Ramsay, Anatomy of the beart, cranium, and brain, p. 45. Edinburgh, 1803. In two insane persons, both the optic beds were found diminished by Romberg, 1823, in Zeitschrift für die Anthropologie, by Nasse, Part III. p. 214 and 219.

(8) King in Philos. Transact. 1686, No. 185, p. 230. la Peyronie in Mém. de l'Acad. des Sc. de Paris, p. 208, 1741, (on account of tumour compressing it.) Blane s. Auserl. Abhandl. z. Gebr. f. prakt. Aerzte, Vol. XX. p. 564 (from a similar cause.) Swan, Dissertation on the treatment of morbid local affections of nerves, Chap. 4. London, 1820, once found in a dog, which had the right foreleg paralytic, the left corpus quadrigeminum remarkably diminished; also in blind persons the corpora quadrigemina participated in the atrophy. Weber also found the corpora quadrigemina, together with the cerebellum and pons varolii, smaller on the left side.

(9) Morgagni, Epist. VIII. 12, LXIX. 10, LXX. 5. Wenzel Ueber den Hirnanliang fallsüchtiger personen, p. 41, 44, 46, 49, 59, 65. Also in blind persons and animals it was sometimes found too small, together with the optic beds.

(10) Morgagni, Epist. III. 6, IV. 19, 26, 35, IX. 20, XII. 2, XXV. 10, XXXVII. 30, LVII. 14. Wenzel, p. 41, 65, 74, 76. It is frequently seen too small in water of the head.

(11) Littre in Mém. de l'Acad. de Paris, 1705, p. 54. Morgagni Epist. LI. 9. Sabatier, v. Orfila Léçons de Médec. légale, 2d edit. Vol. II. p. 447 . Schuhmacher Medic. chir. Bemerk. p. 392. Kopenhagen, 1808.-Lorry Mémoires présentés; Vol. IIJ. p. 365, (in an experiment on a dog.) - Bauner in Posewitz Journ. $\mathrm{f}$. Medic. Herborn, 1799, Vol. I. No.2, (in a living person.) I have dissected seven persons killed immediately by falling from scaffolds, but have only seen collapse of the brain in one instance. In no case has it been seen as a certain mark of concussion.

(12) Hebenstreit De capitonibus rev. in Haller's Coll. Diss. anat. Vol. V I. p. 335, fig. 3.-Penchienati in Mém. de Turin, Vol. IV. p. 118. - de Sidorowicz D. conspectus rerum medicar. Instituti Vindobon. puerperiis solventium dicati, p.73, 8 vo. Viennæ, 1826, with an engraving, (the calvaria is deficient, the brain very large; unequal in its hemispheres, and contains distinctly water in the left half, as I saw in the Anat. Path. Mus. at Vienna, where the preparation, No. 3744, is ;) probably the case observed by Mende belongs here, if it be not hydrocephalus encephaloides. $\quad \therefore$. Nov. Act. Acad. Nat. Cur. Vol. XI. Part II. p. 443, tab. 53, fig. 2.-Tiedemann, pl. 8 and 9. It is clear, from comparison of several cases, that this condition may be connected with water in the head, and may run, on the one hand, into hemicephaly, on the other, into hernia cerebri.

(13) Compare $\$ 231$.

(14) In a child a year old, the lorain was so increased, without loss of substance, that the cavities were diminished, the skull exceedingly expanded, and all the plienomena of water in the head produced. v. Meckel's Handbuch der pathol. Anat. Vol. I. p. 298. $\Lambda$ similar still stronger case, of a child four years and a half old, is mentioned by Scoutelen in Archives générales de Médec. Vol. VII. June.

(15) To wit, four or five pounds in woight, and more. v. Haller Elem. Pliysiol. 
Vol. IV. p. 10. - Sõmmerring Hirn- und Nervenlehre, 2 d edit. p. 19, $\$ 24$.

Rudolphi Physiologie, Vol. II. p. 11.

(16) Gölis Von der hitzigen Gehirnhöhlen-Wassersucht, 2d edit. p. 212.

(17) I have twice seen this to such extent, that the elasticity of the brain thrust up the solid calvaria at certain points, by bursting asunder slight fractures; the one case occurred in an epileptic patient, v. my Selt. Beob. Part I. p. 106 ; the other in a body brought into the anatomical theatre, of which I have no account. - Fahner's Beiträge zur prakt. und gerichtl. Arzneikunde. Stendal, 1799. Dessessarz, v. Samml. auserles. Abhandl. und Gebr. f. prakt. Aerzte. Vol. XVIII. p. 99. - Vering in Nasse's Zeitschrift für die psychische Heilk. 1820. In many cases there seems to arise, in consequence, compression of the brain, and phenomena like those in water of the head. Such were observed by Cheyne, Quin, and Warren. v. above on Water on the Head, § 222 ; further, Laennec.-Jadelot in Journ. de Médec. Vol. VI. p. 3. - Mongenot, ib. Vol. IX. p. 287 and 369.Gölis.-Scoutelen.-Similar observations on epileptics are made by Portal Observations sur la nature et traitement de l'Epilepsie. 8vo. Paris, 1827. That in apoplexy, the brain often, after the removal of the calvaria, expands, by the congestion of blood in that organ, is well known.

(18) As the accounts of organic disease of the pine, and appendage of the brain, are rarely sufficiently accurate, I shall here give some instances of their enlargement, so that we may be able to refer to them in the following notes. The PINE was found morbidly enlarged by Drelincourt in Mangeti Theatr. anat. L. IV. c. 2, p. 309, (as big as an egg, and stony.) - Morgagni, Epist. I. 14; X. 17; XXI. 24; XXXVII. 30 ; LIX. 15 ; LXI. 2 ; LXII. 15.-Lieutaud Hist. anat. méd. L. III. Obs. 177, (as large as a walnut;) 210, (four times too large, and full of pus ;) 381 , (three times larger than usual.)-Desportes Histoire des maladies de St. Domingue, Vol. II. p. 209, Paris, 1770, (as large as an egg.) - Sömmerring Addenda to Baillie's Morbid Anatomy, p.263, note 561, (sometimes expanded with water.) - Angeli Osservaz. med. prat. e chirurg. Imola 793, Vol.I. p. 27, (spongy, stony, filled with yellowish serum.)-Greding Sämmtl. medic. Schriften, u. s. w. Vol. I. p. 318.-Blane, in Transact. of a Society for the Improvement, \&c. London, Vol. II. p. 16, (as large as a nutmeg, and scrofulous.)-Meckel D. Archiv f. d. Physiologie, Vol. J. p. 644, with engravings, pl. 5, fig. 4 and 5, (in a child of nine years old, as large as a middling-sized nut.) - Tübinger Blätter, Vol. III. p. 51, (very large, and full of hydatids.)I have twice seen it as large as a hazel-nut, and hardened by inflammation; in glandered horses it is sometimes swollen. v. Chabert Vom Rotz der Pferde im Vollständ. Handb. der Vieharzeneikunst von Chabert, Flandrin and Huzard, Vol. I. p. 370, Berlin, 1798. - The INFUNDibulum is seen much expanded in dropsy of the ventricles; in one such case, its canal was so wide in a child as to admit the finger. v. J. Jeffray in London medical Repository, 1822, April, p. 275. - Swelling of the APPENDAGE OF THE BRAIN was observed by RaymondVieussens Novum vasorum corp. human. systema, p. 248, Amstel. 1705. - de Haen Ratio Medendi. Vol. VI. cap. 6, p. 271.-Leveque-Lasource in Sédillot's Journ. gèn de Méd. Vol. XXXVII. p. 368.-Greding, p. 282.-Baillie, Morbid Anatomy, p. 460, 4th. edit. 8vo. London, 1812. - Chaussier Procès verbal de la distribution des prix des élèves sages femmes de l'hospice de maternité, 1812 , p. 107, (in a new-born child, larger than in an adult.) -E. Edholm in Svenska Läkare-Sällskapets Handlingar, Vol. I. Part I. p. 32 and 41.-Horn's Archiv f. med. Erfahrung, 1815, Part III. p. 463, (very large, hard, and suppurating within.) - Oppert D. de vitiis nervorum organicis, p. 16, Berol. 1815, (very large, and filled with pus.) - Ward in London medical Repository, Sept. 1823, Vol. XX. p. 217. - Rullier in Archives générales de Médecine, October, 1823, p. 302, (the size of a small hen's egg.) $-P$. Rayer Observations sur les maladies de l'appendice soussphenoidal du cerveau. ibid. Nov. p. 350, (an inch and a half in diameter.) - Neumann in Hufeland's Journal, July, 1824, p. 46, No. 45, (in its stead a large steatom.)-Abercrombie, p. 429, (a case of Powel's; it was very soft, and five or six times too large;) and p. 430, (a case observed by Hay, as big as a walnut.)-Perhaps here also belongs Pfeuffer's case in IIenke's Zeitsclurift f. Staatsarzneikunde, 1822, Vol. III. p. 84, 
(a large bean-shaped tumour, rising from the Turkish saddle into the brain.)In the Anat. path. Mus. at Vienna, I saw an instance of great bladder-like expansion of the Turkish saddle, in consequence of induration and hydatid swelling of the appendage of the brain; I have occasionally found the latter swollen, and apparently inflamed. I may here remark, that I have by no means found the appendage diseased and swollen by inflammation in idiopathic epilepsy, as $J$. Wenzel asserts. v. his Beobacht. über den Hirnanhang fallsüchtiger personen, edited by C. Wenzel, 4to. Mainz, 1810; in the review of Wenzel in the Jenaischen Literat.-Zeitung, I have mentioned this, and subsequently have confirmed it; the same was noticed by Kelch Beiträge zur pathol. Anatomie, p. 103.-Neckel Handb. der menschlichen Anatomie. Vol. III. p. 600, and Neumann, p. 62 ; it seems also that the morbid state of the appendage in epilepsy is rather accidental, and may be either cause or consequence of this disease.

(19) In diseases of the eye the optic beds are also swollen. v. Böhmer Observ. anat. rarior. Halæ, 1766 , Obs. 3.-Ford in Med. Comm. Vol. I. 1784.Serres found in several idiots the anterior pair of the quadrigeminal bodies more developed than the posterior. v. Anatomie du Cerveau, Vol. II. p. 334, note 1.-Wenzel, De penitiori structura cerebri, p. 125 and 126, also saw the cerebral ganglia too large.

\section{$\S 230$.}

The FORM of the brain generally answers to that of the skull, and is therefore as often and as variously irregular as that organ. The cerebrum especially is found malformed; sometimes its length, breadth, or height is generally too great or too small, sometimes it varies only in particular regions. Thus, for example, in idiots the firont lobes are usually small and shallow, and both sides of the cerebrum impressed; in rickety persons, on the contrary, the front lobes are often very thick, as the great projection of the forehead already shews; in many cretins the brain is flat and broad; in dropsy of the ventricles the upper part of the cerebrum especially is much expanded, whilst the base of the brain remains tolerably natural-sized, \&c. Not unfrequently are the two halves of the brain formed very unsymmetrically, so that the one of them is generally, or only in many of its diameters, very much larger than the other $;^{1}$ obliquity of the skull and diseases on one side of the brain often give rise to this. Tumours of very different kinds and size produce deep pits in the upper surface of the brain. Sometimes the brain varies remarkably in reference to its convolutions and plates; one kind of deficient development presents its upper surface completely smooth, or exhibiting only few and flattened elevations ; ${ }^{2}$ this has been several times observed in idiots, in whom also the number of plates in the cerebellum is very much diminished; ${ }^{3}$ the convolutions are frequently destroyed by expansion, especially in dropsy of the ventricles $;^{4}$ the opposite proportions also occur, although more rarely, in which the convolutions are small, numerous, and the clefts unusually deep, so that they almost penetrate 
into the ventricles. ${ }^{5}$ The most remarkable malformation of the brain is the sIMPLICITy of the cerebrum, so that it appears either entire, or divided only at the fore part. 'Thus we find it in all human and animal monsters with cyclopy, and in those with great and total deficiency of the face, and then in most cases only the fore part of the cerebrum exists, whilst its hinder lobes are either very short or entirely wanting, so that the cerebellum, the quadrigeminal bodies, and even the optic beds, are seen uncovered, and many of the internal parts, as the corpus callosum, the fornix, the septum of the ventricles, and the little commissures of the brain are wanting ${ }^{6}{ }^{6}$ usually also dropsy of the brain exists, in the early occurrence of which we may probably seek for the cause of this malformation. ${ }^{7}$ We also sometimes find the cerebrum undivided in hemicephaly $;^{8}$ hemicephaly connected with cyclopy, ${ }^{9}$ and simplicity of the brain also with malformation of the face, viz. wolf's-mouth, which probably is congenitally connected with dropsy of the brain. ${ }^{10}$ The cerebrum has, however, been seen undivided without any such malformation. ${ }^{11}$ The unnatural simplicity also sometimes occurs in the interior of the brain, thus in rare instances the striated body, the optic bed, is completely united with that of the other side, or the latter unusually connected, to wit, by two commissures, or by the epithelium, which is extended from one to the other. The opposite vice is the absence of the commissures, and the consequent division of the brain. ${ }^{12}$ Lastly, we sometimes also find certain little portions of the brain varying from their usual form.

(1) A few remarkable instances have been recently published: Rudolphi found in a child which had neither nose nor right eye, the right side of the brain, on which also the four first pairs of nerves were deficient, very imperfect, and different from the left. v. Abhandl. d. Akad. der Wissensch. zu Berlin für die Jahre 1814 and 1815, p. 105, Berlin, 1818, with four engravings. $-M$. J. Weber Specimen malæ conformationis encephali, capitis et pelvis viri, in Nov. Act. Acad. Nat. Cur. Vol. XIV. p. 109, tab. 10-14, (the left hemisphere of the cerebrum is too large, and on the contrary that of the cerebellum much diminished.) In hemicephaly, hernia cerebri and hydrencephalocele, cyclopy and internal water of the head, which are merely similar malformations, we often find a remarkable difference in the form and size of the two hemispheres. In insane persons also, there is often found great unsymmetry of the brain. v. Greding Vol. II. p. 525, 595, and Vol. III. p. 453.-Esquirol in Dict. des Scienc. médical. Vol. VIII. Art. Demence, p. 289, ff.

(2) I have seen this several times in monsters; it has been found in idiots by Greding. v. Ludwig's Advers. med. pract. Vol. III. p. 613.-Jadelot, in an idiotic child, in a paper read in the Academie de Médecine, Aug. 10, 1824.- Myself, in an idiot of two years old.-Fewer convolutions in idiots. v. Desmoulins Anatomie des systêmes nerveux des animaux à vertébres, Vol. II. p. 605, Paris, 1825.Flattening of the convolutions of the brain in a cretin was seen also by $J . C$ Schiffner in Medic. Jahrbuch d. k. k. Oesterr.-Staats, Vol. VI. Part IV. in undivided brains; in cyclopy especially the convolutions are often entirely, or for the most part, deficient. v. good engravings in I'iedemann. 
(3) Malacarne Neuro-encefalatomia. Pavia, 1791. Compare Reil's Archiv. Vol. III. p. 494 , (the number of these folds varies from 600 to 700 .)

(4) This was first noticed by Hunauld in Mém. des Sc. de Paris, 1740, p. 375 , and Morgagni Epist. XII. 14.

(5) I have seen this a few times, the skull is always very small in such cases; compare my Selt. Beob. Part I. p. 106._- In the Empress Maria Feodorowna of Russia, all the convolutions were very deep, and distinctly separated from each other; v. Medic. chir. Zeitung, 1829, Vol. I. p. 110.

(6) Compare, also, many of the older observations which I have mentioned below on the eye; a few of my own remarks on the brain of cyclops in my Selt. Beob. Part I. p. 49, but especially Speer D. de Cyclopia s. unione partium capitis in statu normali disjunctarum. Halæ, 1819. $F$. Tiedemann Beobachtungen über Missbildungen des Gehirns und seiner Nerven in der Zeitschrift für Physiologie von Fr. Tiedemann, G. R. and L. C. Treviranus, Vol. I. Part I. p. 56-110; and J.F. Meckel Ueber die Verschmelzungsbildungen in s. Archiv fiir Anatomie und Physiologie, 1826, No. II. p. 238. In all the cases of cyclopy which I have examined up to this time, and which will be mentioned in another part, I have found singleness of the cerebrum in men, beasts, and birds, and indeed, in No. 2233, 2234, 2344-2346, 2885-2887, 2974, 2977-2980, 2983, $3045,3046,8440,8738,8740,8741,8744$, and 8812 of Bresl. Mus.; and de la Rue alone has found the brain properly formed in a cyclops, v. Samml. auserles. Wahrnehmungen, a. d. Arzneikunde, 1763, Vol. VII. p. 295, which is very doubtful.-Also, in cyclopic monsters, connected with deficient eyes, nose, and framework of the upper jaw, simplicity of the cerebrum occurs; such cases were seen by Klinkosch Progr. quo anatomen partus capite monstroso proponit, Prag. 1766, and Diss. med. select. Pragens, Vol. I. No. 12. (deficient eyes, nose, and malformation of the mouth.)-Osiander Handb. d. Entbindungskunst, Vol. I. Part II. p. 520, (in deficiency of the eyes, nose, and the existence of a trunk;) and, myself, in seven cases, viz. No. 2341, 2888, 2950, 3044, 8021, 8068, and 8297 of Bresl. Mus. The reviewer of Tiedemann in the Medic. chir. Zeitung, 1825 , No. 47 , p. 408 , found simplicity of the brain, in an approach to cyclopy; viz. deficient nose, and the existence of a proboscis, together with both eyes; I have also found like circumstances in a monstrous pig, No. 8812.

(7) Compare my Selt. Beob. Part I. p. 49. In all the cases which I have since observed and described, I have found either actual dropsy, or the most distinct traces of it ; the cerebrum conmonly forms a semilunar body, sloping backwards, between which and the cerebellum, a large watery sac is formed of the arachnoidea and pia mater; on the base of which the large cerebral ganglia, one or both of the quadrigeminal bodies, and the entrance to the single cavity of the cerebrum, are found distinctly filled with water. As this thin sac is usually pretty firmly attached to the skull, it is torn by opening the head, and may therefore often not be observed above the water; - this state, however, is distinctly mentioned in many of the older cases of cyclopy.-J. F. Meckel also observed, in several cases, the connexion of dropsy of the ventricles with cyclopy. v. Anat. physiol. Beobacht. und Untersuch. p. 145, and Descriptio Monstror. nonnull. p. 83, 4to. Lips. 1826. In the latter, pl. 5, fig. 2 , he has engraved the vcry rare case of cyclopy in a hydrocephalic embryon of six weeks old.

(8) My Selt. Beob. Part I. p. 12, 37, 49, and since in a few cases.

(9) Denys Verhandelingen over het Ampt der Vroed meester. Leyden. p. 198, fig. 7 and 8.-Lenhossel in Harles's Rhein. Jahrb. Vol. I I I. Part I. p. 1. A case in the anatom. Mus. Zurich. v. Meckel Anat. physiol. Beobachtungen und Untersuchungen, p. 102, and Archiv f. Anatomie u. Physiologie, 1826, No. 2, p. 266.No. 8742 of Bresl. Mus. is hemicephaly connected with a state bordering on cyclopy, and merely a higher degree of that just mentioned, viz. deficient eyes, and great shortening of the upper jaws.

‥ (10) Three examples are descrihed and engraved by Tiedemenn, p. 72, tab. (i) fig. 2-5. I consider it extremely fortunate, that out of more than a dozen cases of wolf s-jaw which I have examined with great attention, I have only found in one child, in which however the eyes were at the same time deficient, the brain undivided. v. my Verzeichn. No.2888; in all the other cases it was 
natural, although, as I have here previously remarked, the olfactory nerves are often deficient, and the cleft in a few instances less deep, and the falx very small.

(11) Bianchi Storia del monstro di due corpi, p. 100, Turin, 1750, (in a child of seven years.) - Whether the case of Carlisle, in Transact. for the Improv. of med. and chir. Knowledge, Vol. II. p. 212, belongs here, or to adhesion of the two hemispheres with wasting of the falx, seems to me doubtful.

(12) Deficiency of the corpus callosum was observed by Reil, v. his Archiv für die physiologie, Vol. II. p. 341. - Meckel Handbuch der pathol. Anat. Vol. I. p. 301.-Wenzel, De penitiori structura cerebri, p. 302, and the review of it in Wiener allgem. Litt. Zeitung, 1813, No.39, p.613, (a few times.) - Cerutti found merely the posterior part cleft, but describes one case, v. Beschreib. der pathol. Präparate zu Leipzig, 1819, No.829, p. 206.-It has been already mentioned, that it may be wanting in singleness of the cerebrum, and in severe dropsy of the head, from mechanical causes; a case of the latter kind is described by Nägele, in Heidelb. Klin. Annal. Vol. I. Part IV. p. 510. The commissura mollis of the optic beds is often totally wanting, or there is merely a little tubercle in its place, v. Greding, Sämmtl. Schriften, Vol. II. p. 322. The cerebellum has also been once seen uncommonly deeply cleft by the falx, v. Plancus De monstris, Venet. 1749 ; and Kelch once saw the transverse groove so deep, that the cerebellum seemed to be double. v. Beiträge zur pathol. Anat. No. 43, p. 90.

\section{\$231.}

As the brain is surrounded by the firm skull and almost completely fills up its cavity, so, naturally, are variations in reference to its POSITION, in proportion to that of many other organs, just as rare as that is confined. The vicious position of the brain, therefore, in the interior of the skull, occurs only with simultaneous compression and diminution of the organ, inasmuch as tumours of various kinds sometimes distinctly displace one part of it. ${ }^{1}$ The change in the position of the brain frequently arises from its protrusion externally through openings in the skull, which is called RUPTURE OF THE BRAIN, hernia cerebri, encephalocele. ${ }^{2}$ This may be either congenital or may arise subsequently. The former seems to consist in a morbid partial enlargement of the brain, WATERY RUPTURE OF THE BRAIN, hydrencephalocele, which if not in all, is certainly in most cases produced by dropsy of the brain, rather than by a deficient development of the bones of the skull, which is much rather only a consequence of it. $^{3}$ According as the aperture in the skull is larger or smaller, and the protruding part of the brain and the collection of water is greater or less, the size and form of the rupture varies. ${ }^{4}$ Some forms of the disease gradually run into hemicephaly, as frequently a large portion of the skull is wanting, and the protruding portion of brain is covered only by very thin membrane; in other instances the opening in the skull is but very small, and the swelling, consequently, but small or attached to a narrow neck. So much of the brain is frequently protruded, that but very little more remains in the cavity of the skull, and the skull is, there- 
fore, small and flat; in rare cases, particularly if the cerebral rupture be small, the head appears even unnaturally large. Equally various is the seat of the cerebral rupture; in by far the most frequent examples is it found on the back of the head, as the brain is protruded through the enlarged occipital hole, and the cleft upper cervical vertebra, or through a hole in the squamous part of the occipital bone, or, lastly, in the lambdoidal suture $;^{5}$ less frequently is the tumour situated on the top of the head, especially at the great fontanel, ${ }^{6}$ more rarely on the sides of the skull, ${ }^{7}$ on the forehead, ${ }^{8}$ or, most rarely of all, it penetrates into the nostrils, ${ }^{9}$ the orbits, ${ }^{10}$ or the sphenoidal sinuses. ${ }^{11}$ The rupture of the brain which is not congenital ${ }^{12}$ thus arises: the brain being expanded by its own elasticity, or by increased determination of blood, protrudes through apertures which have been naturally or artificially made in the skull. This kind is proportionally more rare than the congenital, and usually also of much less size.

(1) Large exostoses, fungus of the cerebral membranes, \&cc., thrust one hemispliere with the falx much to the other side. Medullary sarcom in the orbit which makes its way backwards into the cavity of the skull, and expansion of the frontal sinuses, remove the anterior lobes of the cerebrum so much from their natural situation, that they lie where the middle lobes are naturally found. The hemispheres of the cerebrum were in one case separated by water, four inches from each other, v. Case of hydrocephalus with bifid brain by $A n d r$. Duncan, jun., with a description of the malformation, by the late John Gordon, in Transact. of the med. chir. Soc. of Edinb. 1824, Vol. I.

(2) Le Dran Observat. de Chirurgie, Vol. I. Obs. I. Paris, 1731, first employed the term ENCEPIALOCELE.-Ferrand Mémoires sur l'encephalocele, ou hernic du cerveau, in Mlém. de l'Acad. de Chir. Vol. V. Mém. p.60.-Guyenot, ib. Mém. p. S65. - Corrinus D. de hernia cerebri. Argentor. 1749, in Haller's Coll. Diss. anat. Vol. II. p. 330, with a good engraving.-la Motte D. de encephalocele. Paris, 1763.-Held D. de hernia cerebri. Giessæ, 1777. - Salleneuve D. de hernia cerebri. Argentor. 1781.--Thiering D. de hernia cerebri. Gott. 1792.-le Roy in Verhandel. van het Genotsch. te Antwerpen. D. III. Bl. 252. - Meckel Vom Itirnbruche in Handb. der pathol. Anatomie, Vol. I. p. 301 ; and in Archiv f. die Physiologie, Vol. VII. p. 139, ff.-Nägele Ueber den angeborenen Hirnbruch und die Kopfblutgeschwülste Neugeborener in Infcland's Journal der prakt. Heilk. May, 1822, p. 3.-Geoffroy Philosophie anatomique. Paris, 1822, (in several places.) - Single observations are also noticed in de Plouquet Repertorinm, Art. Cerebri Hernia; and the following writers, J. van Mekern Observationes medic. chirurg. Cap. 7. Amstel. 1682. - Fabricii Hildani Observ. Cent. VI. Obs. 17, 18.-Lechel in Ephem. Acad. Nat. Cur. Dec. II. Ann. II. p. 363. Lentin Observ. med. Fasc. II. p. 71. Cellæx, 1770. - Jacoby, v. Lobstein and Beyckert D. de nervis cluræe matris, 1).33. Argentor. 1772. - Deslandes, v. Journal de Médec. Vol. XXVI. p. 74. - Saxtorph in Collectan. Soc. Med. Havn. Vol. II. p. 280, tab. 5. - L. E. Selneider Chirurg. Geschichten. Vol. X. p. 10. Chemnitz, 1785.-P'enada in Saggio d'Osservazioni e Memorie, Vol. I. p. 15. Padova, 1793. - Klein Monstror. quor. descriptio. p. 1. Stuttg. 1795. - Tenghil in Medical Facts and Observations, Vol. VII. No. 23.-Jan. Inurhof in Nicuwe Vaterl. Lettercaff. D. I. Part XI. p. 158, with a plite. - Dessanlt auserles. chir. Wahrnehmungen, Vol. VII. p. 26.- - Bang Abhandlung. iiber eine Missgeburt, deren Gehirn in einem leutel auf dem Riicken hing, u.s.w. a. d. Dän. von Mendel Copenh. and Leipz. 1801.-Hull in Mem. of the Soc. of Manchester, 1802, Vol. V. Part II. p. 195. - Walter Muscum anat. Berol. 1803, p. 275, No. 1625 and 
1626. - Blumenbach Geschichte u. Beschreibung der Knochen, 2d edit. p. 124, note c.-Stein Geburtshiilfl. Wahrnehmungen, Vol. I. p. 346. Marburg, 1807.Osiander in Götting. gelehrt. Anzeiger, 1812, No. 139. Two cases were observed in the year 1813 by Lallement, and Battos related in Richerand Nosographie chirurg. 4th edit. Vol. II. p. 319; and a third in a girl of twenty-two, Lallement in Bulletin de la Soc. de Méd. de Paris, Vol. III. p. 351.-Béclard in Bulletin de la Faculté de Médec. Vol. III. note g. p. 292. - Gistrén in Svenska LäkareSällskapets Handlingar, Vol. II. Part I. p. 166, 170, with a plate.-Kelch Beiträge zur patholog. Anatomie, p. 95, No. 67.-Autenrieth in Tübinger Blättern, Vol. II. p. 273.-Biermayer Museum anat. pathol. No. 5, p. 300.-Busch Samml. auserl. Beobacht. p. 52, pl. 7. Marb. 1817.-Seidel Index Musei anat. Kiliens. 1818, p. 55.-Earle in Medico-chir. Transact. Vol. VII. p. 427, (four instances, of which one of Clarke's; in the first the puncture was made without injury ; in the second death occurred immediately on the incision.-Palletta Exercitationes pathologicæ, Vol. I. p. 127, tab. 2. Mediolan. 1820.-Oestreich. unedic. Jahrb. Vol. V. Part II. p. 68. - Textor in his Neuen Chiron. Vol. I. Part III. p. 469.-Isenflamm Anatomische Untersuchungen, p. 131. Erlang. 1822.-Schnieber in Rust's Magazin f. d. ges. Heilk. Vol. X1II. p. 279.-Rathke in Meckel's Archiv f. d. Physiol. Vol. VII. p. 481, pl.5.- Seerig D. de hydrencephaloceles specimine eximio, 4to. Vratislaviæ, 1822, with lithogr. plates.-Goodeve in Macleod's London med. and physical Journal. Vol. L. Sept. 1823.-Kolbmann in $v$. Siebold's Journ. f. Geburtshülfe, Vol. IV. Part I. 1823.-Z. Thomson in London medical Repository, Nov. 1824, (was cured by ligature.)-Hesselbach Beschreib. der pathol. Präparate, p. 196. Würzb. 1824. - Martini in Ripertorio nedico-chirurgico di Torino, No. 59, Nov. 1824. - Burkart D. de monstro humano notabili. 8vo. Triburgi, 1825.-Moschner Conspectus partuum in Lechodochio Pragensi celebratorum, p. 109. Pragæ, 1826. - Wedemeyer in v. Gräfe and v. Walther's Journ. d. Chir. 1826, Vol. IX. Part I. (in a man eighteen years old.)-Merye in Archives gén de Médec. July, 1827.-Ehrmann in Répert. gén. d'Anatom. et de Physiol. pathol. Vol. IV. Part I. p. 25.-Hohl D. de Microcephalia, 8vo. Halæ, 1827, and in Niemeyer's Zeitschr. f. Geburtsh. u. prakt. Medic. 1828, Vol. I. Part I. No. 2.Pring in Edinb. med. and surg. Journ. Vol. IX. p. 14.-Billard Traité des Maladies des Enfans nouveaux-nés, \&c. 8vo. Paris, 1828.-J. F. Mecleel has described several cases, viz. one in his Pathol. Anatomie, Vol. I. p. 292; a second and third, in two sisters, in D. Archiv f. d. Physiol. Vol. VII. p. 99, ff; and ibid. p. 143 ; a fourth and, lastly, a fifth in Descriptio monstror. nonnullor. p. 76 , in a calf. Up to this time I have examined twelve cases of hernia cerebri, or hydrencephalocele; one in which the hernial sac was adherent to the membranes of the ovum, and described by Kïstner in Bereicherungen für die Geburtshülfe und für die Physiologie und Parthologie des Weibes und Kindes von Choulant, Haase, Küstner, und Meissner, Vol. I. p. 35, Leips. 1821.-The second, No. 2929 of my Verzeichn. described by Seerig. Three other cases I have mentioned in my Selt. Beob. Part II. p. 157, tab. 3, fig. 3. Compare No. 2928, 2971 and 3088, of my Verzeichn. The other cases are No. 2903, 3087, 8017, 8227, 8365, (calf), 8441, (calf), and 2346 (cyclopic pig.) I have seen several calves in the museums ; also Blueland Descript. Musei anat. p. 405, No. 2552 and 2543, has described a few such cases. The hernia cerebri approximates to partial dislocation of the brain with large cavities in birds, in which the bony expansion is often imperfectly ossified. Compare above, $\S 122$, note 11, and my Verzeichn. No. 2286 and 2287 ; and also on ectopy of the brain, an observation of Geoffroy St. Hilaire, in Archiv. génér. de Médec. July, 1827, in which he considers the adhesion of intestines lying external to their cavities as the principal cause of monstrosity, whilst really it is always the consequence.

(3) Altlough, in some cases, perhaps also mere hypertrophy may give rise to hernia of the brain, yet, naturally, dropsy is its cause ; therefore, almost all the cases which have been well examined have shewn this: I have also found it as the cause in all the cases which I myself have observed. In the case related by Penada, a very considerable quantity of water dribbled frorn the hernia ; and, in that of Earle, the water was always reproduced after the hernia was tapped. The great conformity between hernia cerebri and hemicephaly, and its 
gradual transition into the latter, their simultaneous existence, v. Sandifort, Mus. Anat. pl. 126 ; - the connexion of hernia cerebri with the dropsy, which I find in No. 2346 of Bresl. Mus. and with large dropsy of the head, as in Meckel's first case, and No. 2928, which I observed,-no less support this view. Large dropsies of the head sometimes exhibit several membranous spots, extremely thin and expanded, or actual slits; in which case, external watery bags are formed, similar to those in hernia cerebri, v. $\S 222$, notes 9 and 15 . In a few rare instances where the water has escaped, and the brain has seemed to fall together, cicatrices have been found, v. Meckel, Descriptio monstr. nonnull. p. 57, and Billard. The water is, in rare cases, contained merely between the membranes, which then also merely form the hernia, hydrencephalocele meningea, which Textor and Thomson have well testified; more frequently the water is found in one or both the cavities, which are very much elongated at a particular spot, which, often, by the extreme thinning of the brain at this part, so that hardly more than the membranes are distinct, renders it very difficult to be distinguished during life ; though such thin cerebral sacs, perhaps, will bear the ligature. In rare cases of hydrencephalocele, the water seems to exist simultaneously in the brain and in the membranes, as it does in water of the head. As congenital hernia cerebri always commences before the cranial bones are united, so it is manifest why it is most frequently seated in the membranous interspace of the skull, though, in rare cases, it also penetrates between the ununited bones, when, in consequence of deficient ossification, or absorption from the pressure of dropsy, or of the gid in sheep, holes are produced. I also see that Dr.E. A.W. Himly, in his Darstellung des dualismus am normalen $u$. abnormen menschlichen Körper, u. s. w. Hanover, 1829, thinks he has triumphantly confuted the views put forward in this and the preceding section, relative to the congenital connexion between water on the brain, hemicephaly, cyclopy, and hernia cerebri. This is not the place to controvert the loose statements of the author, and this gentleman will, with the same propriety, get rid of the many observations here collected, which do not well suit his dualism, as easily, by a note of interrogation, as he has already done with one of my observations in this place.

(4) Sometimes it is very large, even larger than all the rest of the head; in some cases also it is divided into two halves, by the less yielding falx and sinus, or by a tendinous band; for example, in Trew's case, v. Comment. Nov. 1738, p. 412.-Thiebault, v. Descult Journ. de Chir. Vol. III. p. 327.-Penada, Béclard, Palletta, and Kolbmann, \&c. The apparent duplicity of the hernia cerebri is distinguished from the actual which has, in a few cases, been seen; viz. by myself, in its commencement in No.2771, and its completion in No. 8017, in which it was divided into two halves. - Martini, Ehrman, \&c.;-in the case of Billard's a second hernia cerebri seems to have been produced above the cicatrix.

(5) Of twelve cases, I have found six in which the hernia cerebri occurred on the back of the head, where it has been also seen by Corvinus, Trew, van Mckern Fabric. Hildanus, Lechel, Jacoby, (in an adult in whom a part of the longitudinal sinus lay in the aperture,) Deslandes, Gardner, Tenghil, Dessault, Bang, Hull, van der Laar, Siebold, Merye, Penada, Klein, Blumenbach, Gistrèn, Lallement, Battos, Earle (in four cases,) Meckel (in three cases,) Isenflamm, Seiclel, Rathke, Thomson, Moschner, Burkhardt, Kolbmann. I also saw two beautiful examples at Carus's, at Dresden. The cause of this frequency of the hernia cerebri in the occiput is partly, as Meckel, Archiv. f. Physiol. Vol. VII. p. 139, has observed, that this region of the head of the embryon of itself juts out, partly that the occipital bone consists of several pieces, which become united only at a late period; and that the water contained in the posterior horn of the ventricle, in the four cavities formed by the processes of the dura mater on the occipital bone, may be operated on by greater power than at other parts, or where it forms rather an inclined plane.

(6) Hernia cerebri verticalis in Corvinus. I have met with it here in calves, in two instances, viz. in No. 3088, 8365 (not directly in the middle, but rather to the right side ;) further, Held, Schneider, Stein, Walther, Autenrieth, Textor, Biermayer, Hohl, and Murtini, \&c.; in the latter, there was a hole in both parietal bones. The cases of Detharding and le Dran seem, as Nägele has very properly observed, to belong to bloody tumours. 
(7) Hernia cerebri lateralis in Corvinus. Ferrand in Mém. de l'Acad. de Chir. Vol. XIII. p. 102, (on the lateral fontanel.)-Béclard (right temple.)-Oestreich. medic. Jahrb. Vol. V. Part II. p. 68, (between the right parietal and temporal bone,) perhaps the same case which I found in the Anat. path. Mus. at Vienna, No. 3223. J.F. Meckel, in the former, (between the mastoid process of the temporal and the articular portion of the occipital,) and the latter (in the right temporal region.) Billard (in the left temporal region.)

(8) Henckel Samml. medic. u. chir. Anmerkungen, Berl. Vol. VII. p. 50.Mém. de l'Academ. de Chir. Vol. XV. p. 442.-Saxtorph́, Osiander, Béclard, Kelch, Schneiber, and myself in two cases, v. No. 2928 and 8017 . I also saw a similar case in the Anat. path. Mus. at Vienna, No. 1537.

(9) Lycosthenes Chronic. XVI. de prodig. et ostentis. - Richter, v. Götting. Anzeigen. 1801, p. 441.-Commentat. Soc. Scient. Götting. Vol. XV. p. 81, and in the medic. chir. Bemerkungen, edited by A. G. Richter, Chap. 5. Berl. 1813. In Ehrmann's case the water projected like a bladder in the region of the deficient nose.-In the Anat. path. Mus. at Vienna I saw a hernia cerebri protruding through the cribriform plate into the nose.

(10) I have observed this in a cyclopic pig, No. 2346 of my Verzeichn. A considerable portion of the brain, covered with dura mater, pressed through an opening in the skull into the single large orbit, and lay there so close to the large eye-ball that there was a flat pit formed for it at the fore part of the latter.

(11) Klinkosch Progr. quo anatomen partus capite monstroso proponit, 4to. Prag. 1766, rev. in Diss. med. select. Pragens, Vol. I. No. 12, p. 199. The much expanded cerebral appendage of a dropsical brain, covered with dura mater, penetrated through the body of the sphenoid bone into the nose. Perliaps an indication of it is the case of Kelch's, who found the cerebral appendage lying in the sphenoidal sinus, Beiträge zur pathol. Anatomie, No. 7 , p. 5 ; and that of Béclard's, who found a considerable aperture in the body of the sphenoid of a child with a large hernia cerebri. I refer here to the cases of cleft of the sphenoid bone which has been sometimes observed in hemicephaly. v. My Selt. Beob. Part I. p. 46.

(12) Compare the surgical collections and manuals; also several cases in de Plouquet Repertor. Art. Cerebri hernia._Fantoni Observat. anat. med. p. 172. Venet. 1713.-Janieson in Ingram, Practical Cases and Observations on Surgery, p. 85, London, 1751, (seven months after fracture of the bones by whoopingcough).-Don. Monro in Medical Transact. London, 1772, Vol. II. p. 353.Ferrand Mémoire sur l'encephalocele in Mém. de l'Acad. de Chir. Vol. V. No. 2, p. 60.--Le Roy in Verhandel. van het Genootsch.-te Antwerpen. D. III. p. 252.-Edin. med. and Surgic. Journ. Vol. IX. p. 14, and Vol. XII. p. 22.Workman in the Medical Repository, 1815, Vol. III. No. 18.-Stanley in London med. chir. Transact. 1817, Vol. VIII. P. 1, p. 12.-Turner Thackrah in Fothergill's London medic. and physic. Journ. Vol. XLV. March, (cured by ligature.)-Jam. Spalding in the New England Journ. of Med. and Surg. Boston, Jan. 1820, Vol. IX. (cured by repeated excisions.) J. Lipschitz D. Encephaloceles acquisitæ cum abscessu cerebri observatio. 8vo. Regiom, 1828. It is vexatious that in several of these and other cases, the observers have not made sufficient distinction between hernia prolapsus and fungus cerebri.

\section{\$232.}

The brain also varies in numerous ways from its regular COLOUR ${ }^{1}$. The brain at its first formation is not divided into grey and white substance; and this state is observed still remaining in new-born children, especially if other deficient development exist. In other instances there is a disproportion of the grey and white substance, so that sometimes the one, sometimes the other predominates. As the blood contained in 
the brain very much conduces to its colouring, so must its greater diminution, increase or change, most frequently produce irregular colouring of the brain. Thus we observe in cachectic persons of different kinds, in those who have been mad for a long time, \&c., the grey substance of the brain, according to the deficiency of blood, unusually PALE, or more frequently, from the greater quantity of blood, VERY DEEPLY coloured. The latter is naturally very often the case in apoplectic, hanged, drunken persons, \&c.; and occurs in a very high degree, as the congested venous blood is sometimes simultaneously very dark, or actually extravasated and mingled with the substance of the brain, in which cases, dark-red, bluish, or purplecoloured spots have been observed both in the cortical and medullary substance. If it be rather arterial blood which is congested in the brain, for instance, in morbid irritation and true inflammation, it is coloured Too RED either generally or in spots; still, however, the medullary substance, on account of its greater whiteness, is but rarely of a very red colour, but more generally pale or rosy-red, unless there be simultaneous effusion of blood. If, in severe diseases of the brain, the blood be decomposed, or the morbid pigment alone be secreted, the brain not unfrequently appears discoloured in the most various ways, but also in both substances; for instance, pale or dusky-yellow, orange, brown, greyish-green, slate, and even here and there soot-coloured. ${ }^{2}$ But it is interesting that in jaundice, the substance of the brain participates rarely or never in the yellow colour of the other organs. ${ }^{3}$

(1) Morgagni in many places.-Billard in Archives générales de Médecine, Vol. IX. Dec. 1825. - Lallemand Recherches Anatomico-pathologiques sur l'Encephale et ses dépendances. 8vo. Paris, 1824-29.

(2) These are the morbid colours which I have myself observed in various shades in men and animals. - I have also occasionally seen, in different vices of texture, although even without these, a deposition of melanotic pigment in defined patches.

(3) Stoll Ratio Medendi, Vol. IJI. Part II., maintains the yellow colour of the brain in jaundice, although it might be merely the membranes and the serum between them, and not the mass of the brain itself. I have never seen the nervous mass of the brain coloured in jaundice; and among the moderns I find no satisfactory case of it.

\section{$\S 233$.}

The CONSISTENCE of the brain is not unfrequently morbidly changed, that is, diminished or increased, and even both states occur simultaneously in different parts. The Diminution of CONSISTENCE OR SOFTENING OF THE BRAIN, encephalomalacia, ${ }^{1}$ is observed throughout the brain without suspicion of any chemical change after death, and seems to be then, as in other parts, according to their esssential principle, the consequence 
of a not well-understood change of the cohesive power, and of the normal firmness of the organ. It has been found too soft, for instance, often in malignant adynamic fevers, ${ }^{2}$ and the various animal epidemics $;^{3}$ further, in rickets and tubercular disease of men and animals, in consumption of the lungs, diabetes, and other similar diseases $;{ }^{4}$ again, in mental diseases, ${ }^{5}$ but especially in dropsy of the brain. ${ }^{6} \mathrm{We}$, however, observe more frequently, and also more distinctly, the softening on certain parts of the brain in consequence of true inflammation, both primarily and secondarily, which, for example, occurs frequently around tumours in the brain, or in apoplexy in the neighbourhood of extravasated blood. ${ }^{7}$ It is to be observed, that the consistence of the brain is very much diminished in suppuration and gangrene. Not unfrequent is the opposite state, or INDURATION OF THE BRAIN, ${ }^{8}$ which equally occurs either generally or partially, and in very different degrees. Long continued or often recurring morbid irritation, certain not satisfactorily understood chemical changes, and various inflammatory states, seem most commonly to produce irregular hardness of the brain. This is often so great, that the brain may be very much handled, without breaking, that it becomes very elastic, and that it then commonly appears more distinctly fibrous than usual; thus it is found not unfrequently in typhus, ${ }^{9}$ and especially in chronic and quiet mad persons, ${ }^{10}$ in many epileptic persons, cretins, ${ }^{11}$ apoplectic patients, and persons long affected with head-ach, \&c. Sometimes is the induration, especially the partial, so very great, that it assumes a caseous and callous, and even a cartilaginous hardness. ${ }^{12}$ The consistence of the brain is also in rare cases diminished by concussion $;^{13}$ also in poisoning with sulphuric acid. ${ }^{14}$

(1) Rostan Recherches sur une maladie, encore inconnue, qui a reçu le nom de Ramollissement du Cerveau. Paris, 1820. - Cruveilhier La Médecine éclairée par l'anatomie pathologique. Cal. I. Paris, 1821. - Gendrin in Annales de l'ecole médicale, July, 1823. - Lallemand, first letter, in which he also quotes Recamier, Bayle, and Cayol.-A. G. Herbst D. de encophalomalaxia. Halæ, 1825.-Luzzani D. de encophalomalacia. 8vo. Monachii, 1826. - Rostan Traité élémentaire de Diagnostic, etc. Vol. II. Paris, 1827. - Guibert in Revue médicale, March, 1828.-Many observations are found in Morgagni, Home, \&c., and collected by Burdach, Vom Baue des Gehirns, Vol. III. p. 534-538, to which many new ones of his own are added.

(2) Viz. Marc. Ant. Jemina De febre, anno 1783-84, Monteregali epidemica. v. Brera's Sylloge. Vol. X. p. 218 and 247.

(3) Sagard Von einer besondern Schaafseuche in den Auserlesenen Beiträgen zur Thierarzneikunde, Part I. p. 94.

(4) To wit in a syphilitic person after violent use of mercury. v. Wedemeyer in Rust's Magazin f. die ges. Heilk. Vol. IX. Part III. p. 549 ; in persons who had been long subjected to confinement. v. Monro, The morbid Anatomy of the Brain, Vol. I. p. 35 and 160.-I have seen the brain softerred in many men and animals, who died of cachexiæ.-Rodet once saw the greater part of the brain

D D 2 
softened in a horse. v. Journ. compl. du Dict. des Sciences médicales, Vol. XXIV. p. 39.- Serres, the cerebellum in a monkey. v. Magendie's Journ. de Physiologie, Vol. IJ. No. 3, p. 265.

(5) Greding in Ludwig's Adversar. Vol. II. p. 533, and Vol. III. p. 662. Haslam, Observations on Madness and Melancholy, Sc. Cases 4, 10, 18, 26, 28, 30, 37. Lond. 1809. - Georget De la Folie, p. 488. Paris, 1820. - Esquirol in Dict. des Scienc. médical. Vol. VIII. Art. Demence, (in twenty-nine cases the cerebrum, in seventeen the cerebellum.)-Sometimes in epileptics. v. Portal Sur la nature et le traitement de l'Epilepsie. - Sometimes also in cretins.-Hertwig found in at least a hundred horses, affected with sleepy staggers, the brain very soft, dirty, yellow, and usually fluids in the ventricles. v. Hecker's Liter. Annal. d. ges. Heilk. May, 1826 , p. 5 .

(6) In dropsy of the ventricles, the septum, fornix, corpus callosum, and the substance of the brain around the ventricles, are often resolved into a kind of jelly or pap; also in the symptomatic water in the ventricles, which occurs in madness, fever, \&c. the mass of the brain is too soft. 'This is not less the case in sheep affected with the gid.

(7) Compare the greater number of writers referred to in note 2, as well as many others cited below, $\$ 235$, on apoplexy. In inflammation of the membranes of the brain, we find sometimes merely the outer layer of the brain softened to an inconsiderable depth, and the same within, if the epithelium of the ventricles be inflamed. In animals also, inflammatory softening occurs, especially in mad staggers in the horse.

(8) Morgagni, Epist. VIII. 2, et seq. Epist. LXI. 8. - Meckel in Mém. de l'Academie de Berlin, 1766, (also found it specifically lighter.) - Portal Cours d'Anatomie médicale, Vol. IV. p. 90.-Pinel, fils, Recherches d'anatomie pathologique sur l'endurcissement du systême nerveux, Paris, 1822; and Recherches sur les causes physiques de l'aliénation mentale in Magendie's Journ. de Physiologie, 1826, No. 1, p. 44.-Bouillaud Observations et Reflexions sur l'induration générale de la Substance de Cerveau, considérée comme un des effets de l'encephalite générale aiguë, in Archives générales de Médecine, Paris, 1825, August and Scptember. Many individual cases are collected by Burdach, p. 538, ff. I have seen also a few very remarkable instances, v. Selt. Beob. Part II. p. 93, on the infundibulum, and more recently in a woman who died of tetanus, witl preceding fixed pain in the head. Some examples of great partial hardening may be found in Ephem. Acad. Nat. Cur. Dec. III. Ann. IV. p. 148, (in the cerebellum.)-Morgagni Epist. IX. 25, (the anterior lobe of the right hemisphere.)-Pyl Aufsätze u. Beobachtungen a. d. gerichtl. Arzneiwissenschaft. Vol. VII. p. 89, (two-thirds of the right hemisphere.)-Portal Observations sur la nature et le traitement de l'Apoplexie, p. 144, Paris, 1811.-Meckel D. Archiv f. Physiologie, Vol. I. Part I. p. 644, (hardening, swelling of the pine.)-Howship's Practical Observations in surgery and morbid anatomy, Cases 31 and 32, (the cerebrum.)-Castellier in Journ. de Méd. Chir. et Pharm. May, 1815, (cartilaginous in the cerebellum, accompanied with a hole in the occipital bone.) - Hutchinson, v. Horn's Archiv 1821, Part I. p. 376, (a hardened spot in the left hemisphere.)-Monro, (in the anterior lobe of the left hemisphere, and adhering to the dura mater.) - Bergmann, v. Nasse's Zeitschrift fiir Anthropologie, p. 4.15, 2 parts, (both optic beds, in a paralytic and squinting child.) - Wedemeyer in Rust's Magazin f. d. ges. Heilk. Vol. XIX. Part II. p. 227.-Lallemand, $2 d$ letter, p. 285, case 30, (a part of the left hemisphere as hard as cheese.)Heusinger in Zeitschrift für organ. physik. April, 1828, Vol. II. Part IV. p. 382, (the valve of the brain cartilaginous, with a layer of fat upon it.) Abercrombic, 2l edit. case 18 (the corpora olivaria, the crus cerebelli, and the tubercula mamillaria cartilaginous,) and p. 446.-A case of Anderson's, p. 453, from Medical Repository, Vol. III. (liardening of the cerebcllum.) IIardening of the infundibulum is described by $G$. Sandifort in Museum anat. Vol. III. p. 148, No. 40.

(9) Stoll Ratio Mcilendi, Vol. I. p. 185.-Chambon de Montaux Observ. clin. Paris, 1789, Obs. 29. - - Rudolphi Physiologie, Vol. I. p. 93, (indeed in thirty bodies from iyphus.) In the epiclemic typhus of the years 1809 and 1812-13, 
I dissected a great number of bodies which had died of that disease, and found hardening of the brain, especially in those which died within the first week; in many of those which died at a later period, I found great softening. I do not know whether this is constant. Compare also Gaudet Recherches sur l'endurcissement général de l'encephale, considéré comme une des causes materielles des fièvres dites ataxiques. Paris, 1825.

(10) Morgagni, Epist. anat. med. VIII. 4-18.-Greding in Ludwig's Adversaria, Vol. II. p. 533.-Hunter and Baillie, Morbid anatomy, p. 443.-Sömmerring's Addend. to ib.-Plenciz Acta et Observata medica. Prag, 1733, (in a melancholic person.)--Loder in Bucholz's Beiträgen zur gerichtlichen Arzneigelahrtheit, Weimar, 1790, Vol. III. p. 237, (in an idiot.) - Pyl Aufsätze u. Beobachtungen aus der gerichtl. Arzneiw. Vol. VII. No. 10, (in an idiot.) - Haslam (out of thirty-seven insane persons, in nine.)-Marshall (of twenty-two, in sixteen cases.) - Romberg in Horn's Archiv. 1823, Part I. (in several cases.) - Neumann in Hufeland's Journ. July, 1824, p. 59, (in seven cases.) - Bleuland Descriptio Musei anatomici. Traj. ad Rh. 4to. 1826, p. 200, No.997, (in a maniac of sixty years the brain was discoloured, very hard and dry, and apparently without blood-vessels.) - Esquirol, (in many cases.) - Pinel, in Magendie's Journ. de Physiol. 1826, No. I. p. 80, says, that in chronic and incurable insanity, the brain becomes very hard and fibrous, and the grey substance at the same time very pale; I have found this a few times very remarkably in epileptic persons ; Portal also sometimes found it hardened; in acute epilepsy this is said to be always the case. v. Joseph Adams, in Transact. of the Medic. Soc. of London. 1817, Vol. I. Part II. No. 1.

(11) Foderé Traité du Goître et Crétinisme, \&c. Paris, Ann. VIII. It is, however, by no means constant, as he thinks.

(12) That it has been seen quite dry and crumbling, is indeed either from confusion with ossification, or it is an exaggeration. What the ancients called scirrhus, belongs, for the most part, either here or to scrofulous deposition in the brain.-In two cases 1 have found the brain very hard, indeed almost all the small vessels of the brain ossified and stuck into it like pins; one of these cases is related in my Selt. Beob. Part II. No. 39, p. 93.

(13) Boyer Traité des Maladies Chirurgicales, Vol. V. chap. 1.

(14) Willudovius found the whole surface of the brain as hard as coagulated albumen several lines deep, communicated by Remer in Hufeland's Journal, Sept. 1819 , p. 61 . - I have since had the opportunity of examining a similar case, in which, though the hardening was somewhat less, it was still merely external, as a proof of the permeability of the membranes; the smell also in opening the skull was sour. I take this opportunity of mentioning that I have several times perceived a strong smell of medicine in opening the skull; in three instances in which death was produced by drinking brandy, the brain smelt strongly of spirits, but in one instance only it appeared to me to be too firm. The smell of spirits was, in one instance, found in no other part of the body, but only in the cavities of the brain. v. Rust's Magazin f. d. ges. Heilk. 1827, Vol. XXV. Part I. p. 125.

\section{$\S 234$.}

The contrnuity of the brain may be, as is well known, destroyed in various ways by SWORD, STAB, SHOT WOUNDS, and CONTUSIONs ; and sometimes the instrument inflicting the injury, sometimes the compressed and splintered portions of the skull penetrate into it. Often indeed is a not inconsiderable Loss of SUBSTANCE borne without loss of life, and even of the usual functions of this organ. ${ }^{1}$ It is interesting, that contusions and actual TEARING ${ }^{2}$ of the brain sometimes occur, in consequence of injuries of the head which do not penetrate, but merely jar the head, and that these are found not only 
on the part which is struck, but also in parts which are distant and opposite. ${ }^{3}$ Such tearings and divisions of the substance of the brain occur not unfrequently in apoplectic persons, from the effusion of blood. Large collections of water in the ventricles also give rise to tearing of the septum of the ventricles, the fornix, \&c.; indeed a dropsical brain may even burst on one side and discharge its water. ${ }^{4}$ If the wounds of the brain are mere cut-and-thrust wounds, they are often HEALED BY ADHESION; but if they are connected with loss of substance, they are healed by GRANULATION, by which the previously lost substance is gradually restored. ${ }^{5}$ If the granulations be too great and luxuriant, the morbid mass protrudes through the aperture in the skull, and forms the so-called Fungus of THE BRAIN, fungus cerebri. ${ }^{6}$

(1) Compare the works on Injuries of the Head and the Surgical Writers especially.-Yonge Wounds of the Brain proved curable, 12mo. London, 1682.Behrens De vulnere cerebri non semper et absolute lethali. Francof. 1733.Teubeler pracs. de Bücliner D. de vulneribus cerebri non semper et absolute lethalibus. Halæ, 1750.-Hennequin D. sur les lésions traumatiques du cerveau in Diss. souten. à l'Ecole de Méd. de Paris, An. VII. et VIII. No. 7.-C. G. Spiessbach D. de singularibus quibusdam cerebri cordisque vulneribus. Vratisl. 1812.-Copland Hutchinson, Practical Observations in Surgery, London, 1826, Treatise 4. - B. Brodie in Medico-chir. Transact. Vol. XIV. London, 1828. Many cases have been collected by Burdach vom Baue und Leben des Gehirns, Vol. III. p. 501, ff. Compare Amemann Versuche über das Gehirn und Rückenmark. Gött. 1787.

(2) Zittmann Medicina forensis. Cent. V. case 33. Francof. 1706.-Wilmers, v. Richter's Chirurg. Biblioth. Vol. V. Part IV.-IIenkel Medecin. u. chirurg. Beobacht. Berl. 1779. Obs. 66. - Ollenrodt in Arnemann's Magazin f. die Wundarzneiwissenschaft. Vol. I. Part II. p. 119. - Bernt Beiträge zur gerichtl. Arzneikunde, Vol. IV. p. 237, (they are said also to occur in epilepsy.) A. Cooper, Lectures on Surgery, edited by Tyrrel, Vol. I. p. 263.

(3) 'This, for satisfactory reasons, is much more rare than on the skull.

(4.) Compare above, $\S 222, \S 228$, and $\S 231$, note 3 .- I made one very rare observation in a child, with large clropsy of the head, and other malformation. v. my Verzeichn. No. 2891 ; both ventricles were very much expanded with water, but especially the left; and the posterior lobe of the brain, on that side, has, at its outermost extremity, an aperture, nearly three lines in diameter, roundisl, flat, lined with pia mater, passing into the cavity of the ventricle. 'The origin of this was a little hard encysted tumour of the arachnoid, lying loosely in it, which, moving close over the aperture, had prevented the escape of the water. 'The brain is No. 8814 of Bresl. Mus.

(5) The loss of substance in the brain, however, in rare cases, is healed without reproduction, especially if the penetrating piece of bone remain and occupy the place of the depressed brain.

(i) Sand and Stolz D. de fungo Cerebri. Reyiom. 1700 ; rev. in Haller's Coll. Disp. chir. Vol. I. No. 9.-Conrad D. de hydrocephalo cum fungo cerebelli. Argent. 1778.-C. D. Wiudel D. de fungo cerebri et durx matris. 4to. Goett. 1s $109 .-$ Many cases are collected in de Plonquet's Repertor. Art. Cerebri fungus; and in Burdach, p. 550.-Compare the works on Surgery.-There is an interesting case described in Lond. ned. and physical Journ. 1. 369. 
$\S 235$.

Among the vices of Texture in the brain, which occur more commonly perhaps on the right side than on the left, and in hemiplegic persons are found generally on the opposite side to the palsy, INFLAMMATION OF THE BRAIN, encephalitis, ${ }^{1}$ and the IRRITATIVE and APOPLECTIC CHANGES, so likely to be confused with it, deserve the first mention, both on account of their activity and importance. This is partly consequent on external mechanical causes, as actual wounds, contusion and concussion of the brain, partly from internal causes, and may be either an idiopathic and secondary disease, as in many fevers, eruptive diseases, diseases of the ears, and organic vices of the brain, viz. extravasated blood, tubercles and tumours of various kinds. Rarely or never is the whole brain, but usually only a part of it, affected, and the disease is seated either in the vascular membrane which covers the surface or lines the cavities of the brain, as well as in the layer of brain immediately beneath, ${ }^{2}$ or in the cortical substance, or lastly, in the larger collections of medullary matter and the interior more important parts of the brain. A more or less deep red colour of the substance of the brain extending generally throughout it, or streaky and spotty, originating not merely in congestion of certain vessels, but also affecting the whole mass in the diseased parts; certain intense red spots, which depend on the effusion of little portions of blood, and changes of consistence distinctly morbid, as well as of the neighbouring cerebral substance, ${ }^{3}$ characterize inflammation in this organ. Similar, although decidedly different, is the condition of the brain in the MORBID IRRITATION which often accompanies ardent fevers, especially typhus, ${ }^{4}$ acute eruptive diseases,${ }^{5}$ nostalgia, ${ }^{6}$ epilepsy, ${ }^{7}$ drunkenmadness, ${ }^{8}$ tetanus, ${ }^{9}$ convulsions, hydrophobia, softening of the stomach, ${ }^{10}$ painter's colic, ${ }^{11} \&$ c. ${ }^{12}$ perhaps even first occurs in the agony of death; here also turgescence is seen, and great and often bright red injection of the brain, but not the general red colouring, the spot-like effusion of blood, and the change of consistence. ${ }^{13}$ In SANGUINEOUS APOPLEXY, apoplexia sanguinea, ${ }^{14}$ as it occurs spontaneously in fevers attended with coma, in injuries of the head, in cases of suffocation, \&c., we find either, in rare cases, a stagnation of the blood produced from mere congestion, in some parts or in the whole of the venous system of the brain, which exhibits itself even in the external examination of the brain, as well as in transverse sections by the spouting out of the blood at distinct points $;^{15}$ or usually with simultaneous great vascularity of the brain, an actual Ex- 
TRAVASATION OF BLOOD at certain parts. This may be trifling or very considerable, fluid or coagulated, and sometimes between the membranes, sometimes under the vascular coat on the surface of the brain, sometimes in the ventricles, ${ }^{16}$ and sometimes, lastly, which is the most common, in the substance of the brain itself. In the latter case the extravasated blood is occasionally mingled with the substance of the brain, ${ }^{17}$ so that it appears as it were drenched in blood, or more commonly the blood is effused in particular cavities, ${ }^{18}$ which are sometimes connected with the cavities or surface of the brain by means of tears. These extravasations of blood in the substance of the brain occur most frequently in the striated bodies and in the hemispheres of the cerebrum, much less frequently in the cerebellum and in the oblong marrow. ${ }^{19}$ The effusion of blood naturally takes place from the smallest vessels of the cerebral substance, and those cases are but rare, and mostly originating in mechanical influence, when the large vessels of the membranes, of the plexuses, or of the brain itself, have prodiced effusion of blood by their rupture. ${ }^{20}$ If the apoplectic attack have not been soon fatal, the effusion of blood between the membranes or into the cavities, if it be not great, is either absorbed, or, irritating the brain like an extraneous body, operates on it and produces various changes, as inflammation of the neighbouring cerebral substance, greater or less, or even pap-like softening of the surrounding parts, yellowish, brownish, and more or less red colouring of the adjacent substance of the brain. Lastly, also, a false membrane is often formed by inflammatory exudation, which surrounds the extravasated blood like a bag or capsule. ${ }^{21}$ In the latter case, in which there is a disposition to cure, a serum is secreted from the newly-produced sac, by which the blood being thinned and rendered looser, its absorption is forwarded, and either a true cicatrix of the diseased part of the brain ensues, or a little cavity remains, of which the walls are connected by fibres of loose plastic lymph, and in which is found a little hard coagulum of discoloured cruor, fibrous matter, coagulated albumen, or nothing more than a little watery secretion.

(1) Fischer D. de cerebri ejusque membranarum inflammatione et suppuratione occulti1, 1781. - van der Belen D. de cerebri ejusque membranarum inflammatione et suppurat. occulta. Lovan. 1784.-Noelken D. de cephalitide. Fiford, 1798. Constantin D. de Encephalitide. Lips. 1800. - Haartmann D. Encephalitidis diagnosi. A bo. 1802. - Pontin in Vettenskaps. Jurn. för Läkare och Fältskärrer, Vol. I. Part II. p. 7, Stockholm, 1S07. - Thom D. de encephalitide. Giess 1810.-Ducrot Essai sur la cephalite ou inflammation du cerveau. 4to. Paris, 1812.-Mulin D. de encephalitide. 8vo. Halx, 1817.-V. Furtner D. de variis Encephalitides speciebus. 8vo. Landishuti, 1818. - Bleynie Sur l'inflammation du cerveau. Paris, 1819.--J. H. Alleyne D. de inflammatione longa cerebri. 
Edinb. 1822.-Bouillaud 'Traité clinique et physiologique de l'encéphalite, ou inflammation du cerveau et de ses suites, telles que le ramollissement, la suppuration, les absces, les tubercules, le squirre, le cancer, etc. 8vo. Paris, 1825.-C. F. Bellingeri Storia delle Encefalitidi, che furono epidemiche in Torino nell' anno 1824. Torino, 1825. - Itard Memoire sur les phlegmasies cérébrales in Mém. de l'Acad. de Médec. de Paris, Vol. I. No.4. 1828.-On inflammation of the brain in cattle, v. Archiv f. Thierheilk, Vol. IV. Part I. Zurich, 1828. - On secondary inflammation of the brain, arising from diseases of the ear, v. Lallemand, Vol. II. p. 233, ff.-Abercrombie and Itard Traité des Maladies de l'oreille. - Upon the inflammatory state of the appendage of the brain, v. Wenzel Ueber den Hirnanhang fallsuichtiger Personen. Mainz, 1810.

(2) Compare $\$ 221$.

(3) Especially softening, which, if I be not mistaken, was first remarked by Vetter, in his Aphorismen aus der pathol. Anatomie, p. 31, $\$ 21$.

(4) Several of the older writers leld inflammation of the brain as the proximate cause of typhus fever, viz. Willis, Chirac, Werlhof, Silva, Fracassini, Marteau de Grandvilliers, in Journ. de Médec. 1758, Vol. VIII. p. 275. - Donald Monro; more recently, Reil, de Plouquet Expositio Nosologica Typhi. Tübingen, 1800.Constantin, but especially Marcus, in Lphemeriden der Heilkunde, Vol. I. p. 1. Bamberg, 1811, and ibid. in Röschlaub Ueber den Typhus. Bamberg, 1814.-H. Clutterbuck, An inquiry into the seat and nature of fever, $2 d$ edit. London, 1825, and the modern French School have supported this view more or less. The cause of malignant intermittent fever has also been sought for in inflammation of the brain, viz. Forti, Therapeutice speciales ad febres perniciosas, 4to. Francof. et Lipsix, 1756.-Comparetti, Riscontri medici delle febbri larvate, periodiche, perniciose, Padua, 1795, and Itard. Opposed to this opinion very properly are many, viz. Ludwig, Adversaria medico-practica, Vol. I. Part 1. p. 188.-Hufeland and Himly, Biblioth. der prakt. Heilk. July, 1812, p. 45.Horn, Archiv f. medicin. Erfahrung. September, 1812, p. 296; March and April, 1813, p. 317.-Friedreich, Werth der Leichenöffnungen zur Bestimmung Typhus sey Hirnentzündung. Würzb. 1814.

(5) In small-pox, measles, scarlet-fever, \&c., also in sheep-pox, v. Hurtrel d'Arboval, Traité de la clavelée, etc. Paris, 1822.

(6) Larrey, Recueil de Mémoires de Chirurgie. Paris, 1821.

(7) Portal.

(8) J. Frank, Nasse, Abercrombie, also Sutton, on Delirium tremens.-Lind De delirio tremente sic dicto observationum series; cum epicrisi de morbi indole ac natura. Copenh. 1823.-Rob. Macnish, The anatomy of drunkenness. Glasgow, 1827.-Barkhausen, Beobachtungen ïber den Säuferwahnsinn, oder das Delirium tremens. Bremen, 1828.

(9) Speranza, in Anno clinico-medico. Parma, 1823-4.-E. Blasius, Ueber den Leichenbefund bei am Tetanus Verstorbenen, in Rust's Magazin f. die ges. Heilk. 1828. Vol. XXVII. Part I. p. 53.

(10) Camerer, Vers. über die Natur der krankhaft. Magenerweichung. Stuttg.

(11) Benj. Palais, Traité pratique sur la colique metallique, etc. Paris, 1825. - Renauldin, in Journ. compl. du Dict. des Sc. médical. Vol. XXII. p. 297.

(12) According to Faneau-Delacour, as consequent on castration of fowls and sheep. v. Journ. univ. des Scienc. médical. June, 1824.

(13) But indeed this distinction applies only generally to the just mentioned diseases, in which, in some cases, there is complication of different kinds, and a gradual transition to true inflammation.

(14) Also hæmorrhagia cerebri, apoplexia cerebralis, \&c. As to the writers on this subject, compare Reuss Repertor. Vol. XII. p. 56.-de Plouquet Repertorium, and Burdach, Vol. III. p. 506, ff.-Wepfer Observationes anat. ex cadaveribus corum, quos sustulit apoplexia; nov. edit. access. Auctuarium historiarum et observationum similium. Scaphus, 1675, and Observat. ined. pract. de affectibus capitis internis et externis. Scaphus, 1727.-Morgagni, Epist. II., III., and LX.-J. G. Walter Von den Kranklieiten des Bauchfells und dem Schlagfluss, 4to. Berl. 1785.-B. Ch:ındler, An inquiry into the various theories and methods 
of cure in Apoplexies and Palsies. Svo. Cant. 1785.-Zulimi, De apoplexia præsertim nervea commentarius. 8vo. Lipsiæ, 1790.-Kirkland a Commentary on apoplectic and paralytic Affections. London, 1791.-Burdach Die Lehre v. Schlagfluss u. s. w. Leipz. 1806.-Sander D. de Apoplexia. Goett. 1807.-De de la Vauterie D. sur l'Apoplexie, considérée specialement comme l'effet d'une phlegmasie de la substance cérébrale. Paris, 1S07.-Foderé, De apoplexia disquisitio. Avenione, 1808.-Portal Observations sur la nature et le traitement de l'apoplexie et sur les moyens de la prévenir. Paris, 1811.-Montain 'Traité de l'apoplexie. Paris, 1811.-Cheyne, Cases of Apoplexy and Lethargy, with Observitions upon the comatose Diseases. Lond. 1812. - Riobé Observations propres à resoudre cette question: L'Apoplexie dans laquelle il se fait un épanchement de sang dans le cerveau, est elle susceptible de guerison? Paris, 1814.-Rochosx Recherches sur l'apoplexie. Paris, 1814._Hopf Versuch eines Umrisses der Hauptgattungen des Schlagflusses und ihrer Behandlung. Stuttg. 1817.-Leune De A poplexia. Svo. Lips. 1817. - Serres Nouvelle division des Apoplexies in Annuaire med. chir. des Hôpitaux et Hospices civiles de Paris. 4to. 1817. - Bricheteau in Journ. compl. du Dict. des Scienc. médic. July, 1819. Vol. I. p. 129-152, and 289-317.-Moulin Traité de l'A poplexie, ou Hemorrhagie cérébrale, etc. Paris, 1819.-Richelmi Versuch einer. Abhandl. üb. die Apoplexie u. s. w. a. d. Fr. von E. A. Gräfe. Berl. 1821.-Romberg in Horn's Archiv, 1823. I.-Tacheron Recherches anatomico-pathologiques, Vol. III. p. 386-485. - Mertzdorf in Rust's Magazine, Vol. XIV. Part II.$J$. Carson on the circulation of the blood in the head, in Edinb. med. and surg. Journ. No. 79, p. 258, April, 1824._Lallemand Recherches Anatomico-pathologiques sur l'Encephale, Sc. 8vo. Paris. 1824-29.-Beck Ueber den ursprünglichen Hirnmangel und üb. die Pathologie u. Therapie des Gehirnblutflusses. Nürnb. 1826. - L . F. Bravais in Revue médic. franç. et étrangère, Vol. I. and II. 1827.More recently, at Edinburgh, have appeared Dissertations on Apoplexia sanguinea, by J. Barclay, 1805, Sainsbury, 1809, Prendergast, 1812, Hannay, 1812, A. Hunter, 1813, Miln, 1814, Bagrie, 1815, Goring, 1816, Burnie, 1818, Ballingall, 1S19, Annan, 1820, Walsh, 1820, F. Travers, 1822, M. Baillie, 1823.

(15) Morgagni, Epist. X. 17, 18.

(16) In these cases the vessels of the plexus choroides are usually burst, v. Morgagni, Epist. II. 9, 11, 15,22; Epist. III. 11; Epist. LXII. 7 ; or the blood extends from the neighbouring cavities filled with blood into the ventricles, by canals and clefts : here we sometimes find so large a quantity of blood collected, that the ventricle is very much expanded, or the septum, the fornix, \&c., burst. According to Morgagni, these extravasations occur more frequently on the right than on the left side; perhaps the flow of blood is stronger there, for which reason, as has been already mentioned, vices of other kinds are said to be more common on the right side.

(17) Morgagni, Epist. V. 6, 7.-Lallemand, Letter I.

(18) Wepfer and Morgagni were acquainted with these and their canals into the ventricles, or up to the surface of the brain. Compare Morgagni, Epist. III. $7,9$.

(19) Several cases of extravasation into the cerebellum are described by Serres Recherches sur les maladies organiques du cervelet in Magendie's Journal de Physiologie, Vol. II. No. 2, p. 172 ; No. III. p. 219.-I have up to the present time, among the great number of apoplectic cases which I have examined, found but twice extravasation in the cerebellum; the one case I have described in my Selt. Beob. Part II. p. 97.

(20) That diminished elasticity which the otherwise thin cerebral arteries exhibit in disease and old age produces a disposition to tearing, and consequent extravasation of hlood, is well known; and more recently Bouilland, in Mém. de la Société Médec. d'Emulation de I'aris, Vol. IX. No. 5, 1826, has described a chronic inflammation of the cerebral vessels as a common cause of apoplexy; but this is merely a preparatory cause, and many mortal effusions from blows occur without any morbid condition of the arteries of the brain, as frequently as that occurs without any apoplexy. A peculiar congestion of blood in the brain, which in many cases terninates in effusion of water, in other cases in extravasation of 
blood, or even in both, appears to be the principal cause. It is interesting, however, that hypertrophy of the left heart, without narrowing of the aorta, as I have three times observed, gives rise to apoplexy.-Legallois in Bulletin de la Fac. de Médec. de Paris. Ann. XIII. p. 69. - Bricheteau, p. 17.-Lallemand, Vol. I. p. 43, 91, \&c.-Bursting of aneurysms of the cerebral and meningeal arteries, (v. above, $\S 196$, note 7 ; and Serres in Archiv. gén. de Méd. Vol. XI. March, 1826; and in Magendie's Journal de Physiol. Vol. VI. p. 82, No. 1,) or of the sinuses of the brain, ( $v$. above, $\S 206$,) give rise to effusion of blood into the cavity of the skull. Perhaps stoppage of the sinuses by fibrous matter or suppuration, which has in a few instances been seen, may be enumerated ainong the causes of their bursting.

(21) Cheyne considers this as a false membrane surrounding the extravasated blood; but Riobe was the true discoverer. Compare farther Rochoux, Raisin Sur les kystes apoplectiques, in the Journ. gén. de Méd. 1820, and Cruveilheir Essai sur l'Anatomie pathologique, Vol. I. p. 204.-Lobstein, Compte rendu sur les travaux anatomiques, p. 51 , confirms it, as $I$ can also from several of my own observations.

\section{$\S 236$.}

Not unfrequently we observe, consequent upon preceding inflammation of the brain, sUPPURATION of this organ, ${ }^{1}$ either as a primary or secondary affection. The former commonly occurs partly from internal causes, and from all those which could originate in a primary inflammation of the brain, but especially often in certain scrofulous dispositions; partly from external mischief, as concussion and actual wounds of the brain. ${ }^{2}$ Secondary suppuration, however, is found in rare cases in acute fevers, in extravasation of blood, inflamed tumours of the brain, and caries of the skull; most frequently, however, in consequence of inflammatory and suppurative diseases of the ear. ${ }^{3}$ The hemispheres of the cerebrum are most usually the seat of suppuration, although it may be also observed in most other parts of the brain. In all these cases, the suppuration appears, either as an open, more or less broad, ULCER penetrating the outer or inner surface of the organ, or hidden in the interior of the cerebral substance itself. In the latter instance, we perceive the pus sometimes poured out in the substance of the brain, and mingled with it, sometimes in several spots simultaneously, which are more extensive and run together, sometimes, lastly, collected into one or several abscesses. The grey substance with which the pus mingles appears pale and yellowish, the white substance more distinctly yellow, or yellowish-green, and almost always more or less softened; so also do the parts surrounding the abscesses become naturally softened, injected, and discoloured in various ways; not unfrequently by the inflammatory exudation, is produced a tolerably firm cyst around the collected pus, a TRUE ENCYSTED ABSCESS, which, however, in other cases appears to arise from suppuration of an isolated tumour. In rare cases, abscesses of the brain discharge their pus by bursting or by fistulous 
openings into the cavities of the brain, on its surface, and still further, externally by natural or carious apertures in the skull, into the nose, the ears, ${ }^{4} \& c$.

(1) Camerarius D. de vomica cerebri. Tïb. 1711.-Bianchi Storia medica d'un apustema nel lobo destro del cerebello. Rimini, 1751.-J. Plancus Storia medica d'un apostema nel cerebello. Rimini, 1752. - Nebcl Pr. de abscessibus cerebri a causa externa ortis. Heidelb. 1790.-Edinb. med. and surg. Journ. Vol. XVIII. p. 505 ; many single cases are found in Bonetus, Morgagni, Lieutaud, in de Plouquet's Repertor., Reuss Repertor. Comment. Vol. XII. p. 78; Vol. XV. p. 107; in Home.-Powell in Transact. of the College of Physicians, Vol. V. p. 198.-Burdach, Vol. III. p. 520-528.-Lallemand, Letters 2, 3 and 4;-in Abercrombie and in Hooper. - A few instances are related in Horn's Archiv f. medic. Erfahrung. 1813, March and April, p. 238, (in the cerebellum.) - Schallgruber in Allg. med. Annalen, 1814, August, p.557, (on the right hemisphere, together with a tumour.) - le Fils in Rust's Magazin, Vol. V. Part II. p. 235, (in the cerebellum.)Langier in Recueil de Méd., Chir. et Pharm. milit. Vol. VIII. 1820, p. 179, (in the cerebellum.) - Bush in London med. and phys. Journal, 1823, Decemb., (a large encysted abscess.)-Hamilion in Transact. of the med. chir. Soc. of Edinb. 1824, No. 22.-Dickson in London med. Repository, Oct. 1824, (unexpectedly.) Velpeau in Archives générales de Médecine, Vol. VII. Januar. (in the Medulla oblongata.)-Roloff in Nasse's Zeitschrift für die Anthropologie, 1825, Part III. p. 172, (in one hemisphere without destruction of mental activity.) - $A$. Cooper's Lectures by Tyrrel, Vol. I. (several interesting cases.)-Bellmer D. de cerebelli degenerationibus. 4to. Bonnæ, 1825, (in the cerebellum; he also cites similar older cases.)-Cruveilheir in Nouvelle Bibliotheque, Novemb. 1826, (in the left hemisphere.) -Nasse, 1826, Part III., (in the left hemisphere, without loss of mind.) Thilow in Pierer's Allgem. medic. Annalen, 1827, November, p. 1441.-Travers. v. Magazin der ausländ. Liter. d. ges. Heilk. Jan. and Feb. 1828. $-F$. Jones in London ined. and surg. Journal, 1828, Vol. L. p. 543.-Good engravings are given in Baillie Engravings, Fasc. X. p. 221, pl. 6.-Hooper, pl. 9.-Abscess in the brain of horses is described in Correspond. vétérin. Vol. II. p. 94; by Schwab Materialien zu einer pathol. Anatomie der Hausthiere, 1st part, p. 9; by Dupuy and Vatel Journ. prat. de Méd. vétér. Nov. 1827, p. 531.

(2) In such cases the brain is sometimes lost in considerable quantities by suppuration. In a young man who received a wound with a pitchfork, and was subsequently trepanned, a pultaceous mass as big as one's fist daily protruded from the aperture in the latter stage of the disease; after death I found the wounded hemisphere had suppurated away.

(3) That the diseases of tlie internal ear are, in many instances, communicated to the brain, is well known; but, oftentimes, affections of the ear and brain may occur simultaneously, and from the same cause. It is difficult to determine this, as large aliscesses of the brain frequently exist for a long while, without either mental or bodily disturbance; and this indeed su much the more, as the Otorrhöe serves the purpose of counter-irritation. In many cases, also, the affection of the brain seems to be primary, and that of the ear secondary; compare the following cases, in which simultaneous suppuration of the internal ear and abscess of the brain were observed; viz.-Bonetus and Lieutaud; further, Morgagni, Epist. XIV. 3 and 5.-Mögling in Ephem. Nat. Curios. Cent. VI. Obs. 21.-Laubius ib. Cent. VII. Obs. 401, Cent. VIII. Obs. 21.-Gontard in Hist. de l'Acad. des Scienc. de Paris, 1756.-Ballonius Opera omnia. Vol. I. 1. 196, 4to. Genev. 1762. -Leblanc in Journ. de Médec. Vol. XVII. p. 455. - Stoll Prælect. p. 149. v. Mohrenheim Beobachtungen. Vol. I. p. 98, Wien 1780.-Schumacher Medic. chir. Bemerkungen. Kopenh. p. 381, 1800._P'Portal Cours d'Anat. médic. Vol. IV. p. 39.-Murray D. Abscessus auris internæ olsservatio. Upsal. 1796. v. Rudolphi's Sclıwed. Annalen. Part I. p. 110.-Sabatier Médecine operatoire, Vol. IIl. p. 10, 2d edit. 1811.-Medical Commentaries, Vol. II. p. 180.-Frank Interpret. clinicæ, Vol. 1. p. 142.-Brodie in Transict. of a Soc. for Improvement, \&c. Vol. III. p. 106.-Rusl's Magaz. Vol. II. Part II. 1).311, and Vol. IV. Part I. 
p. 197.-Parkinson in London medical Repository, January to May, 1817.-O' Brien in Transact. of King's and Queen's College, Dublin, Vol. II. p. 309._Palletta Exercit. pathol. Vol. I. p. 2.-Itard Traité des maladies de l'oreille et de l'audition, p. 70. Paris, 1821.-Duncan in Edinb. med. and surg. Journal, Vol. XVII. p. 331, July, 1821, fourth and fifth case. I have described six instances in my Selt. Beob. Part II. p. 96. - Holst in Magazin für Naturvidenskaberne, 1st Part, Christiania, 1825. - Lallemund, Vol. II. p. 239 and 306.-Abercrombie, p. 41, $\mathrm{ff}$. - Hoffmann Otorrhcea cerebralis primaria in Haries's N. Jalırb. der deutsch, Medic. u. Chir. 2 Supplement. p. 43, 1827.

(4) It is so natural to assume, from analogy with the examples in other parts, that abscesses in the brain may penetrate tlie skull by external fistulous openings, that it is merely respect to Morgagni's opinion, which is not, however, general, but only meant for his own two cases, which has induced Lallemand to hold the cerebral abscesses connected with the caries of the ear always secondary. But that it may be also primary, Brodie, Itard, and myself in my Selt. Beob. Part II. p. 96, (before I was aware of the latter's opinion,) and Hoffmann have endeavoured to show by reasoning and examples. If inflammation of the ear precede that of the brain, why, on the contrary, should not that of the brain precede that of the ear? and the rather, as abscesses of the hemispheres descend into the lowest part of the middle lobes, and here come in contact with the petrous bone, into which the pus, on account of the thinness of the covering of the semicircular canals and drum, might easily penetrate; the effort of all abscesses towards external parts can hardly find a more favourable outlet. If the abscess be in the cerebellum below the tentorium, the pus penetrates into the internal auditory passage, or makes its way out by an aperture behind the ear. v. Itard, p. 254, Obs. 22, and Abercrombie, case 3, p. 35 . I have already mentioned above, that in suppuration of the cerebral membranes, the pus sometimes passes through fistulous openings in the skull ; the same also occurs in abscesses of the brain at other parts, as well as on the ear. v. Hill, Cases of Surgery, p. 130.-Pretty, in London Med. Repository, Vol. XX. Sept. 1823, (through the frontal bone.) - Rosenthal Abliandl. a. d. Gebiete der anat. physiol. und pathol. Berlin, 1824. - Syme, in Edinb. med. and surg. Journal, July, 1828, (on the forehead.)-Lithell in Svenska LäkareSällskapets Handlingar, Vol. VII. p. 220, (on the left parietal bone.)-Duncan, in case sixth, (through the sphenoid and temporal bone.)-Raikem in Répert. gén. d'Anat. et de Physiol. pathol. Vol. I. No. 2, p. 295, (through the petrous and sphenoid bones, and the nose) ; - similar cases to the latter are described by C. G. Frank in Ephem. Nat. Cur. Dec. II. Ann. VI. Obs. 193, (flow of pus from the nose through a carious sphenoid bone.) - Bartholin Histor. anat. Cent. II. Hist. 34, Cent. VI. Hist. 13.- Thoner in Haller's Bibl. med. pract. Vol. II I. p. 22.-Leblanc. - Sometimes in abscess of the brain the skull is not penetrated, but only eroded. v. Lieutaud Lib. III. Obs. 1131.-Horn's Archiv f. med. Erfahr. p. 288, March and April, 1813. A steatoma of the brain, also, by its irritation, gave rise to caries of the auditory organ. v. Neumann in Hufeland's Journal, 1824, p. 14.-Lallemand is not quite correct, when he says, p.282, that pus never penetrates any other way than through the ear. The notion of the priority of abscesses of the brain to the affections of the ear is also supported, by the fact, that in several of the abovementioned cases the disease was a consequence of injury of the head, which had affected the brain more than the ear.

\section{$\$ 237$.}

Proportionally is the brain rarely found MoRTIFIED, and then almost always from external injury alone, in which having been bruised, it inflames, and sinks, or when injuries of the head have been improperly treated. The substance of the brain is then found dissolved, foetid, ${ }^{2}$ orange-brown, and even grey and blackish coloured. Mortification of the brain appears to arise very rarely from internal causes, and we must take 
especial care to distinguish the great softening and deep colour of the brain from gangrene. ${ }^{3}$

(1) Lyserus D. de sphacelo cerebri. Lips. 1656.

(2) It is an interesting circumstance, that the brain, without being gangrenous, sometimes has a very disagreeable smell, which I have observed in a few cases, when, upon putrefaction of the brain, the stink was indescribable. Similar cases have been observed by Morgagni, Epist. VII. 9 ; XIV. 5.-Greding Sämmtl. Medic. Schrift. Vol. I. p. 306.

(3) I have not yet seen gangrene of the brain from these causes, and I believe that death would ensue before active inflammation of the brain could run into gangrene. The observations on gangrene, in the old writers, are therefore all extremely doubtful, because, till the present time, softening of the brain was called putrefaction and mortification, and all dark colouring of the brain esteemed gangrenous.-Even Abercrombie, if I do not mistake him, considers the proper softening of the brain as analogous to gangrene.

\section{\$238.}

Another and equally rare vice of texture in the brain, is the DEPOSITION OF CARTILAGE AND OF LIME in its tissue, and the consequent production of more or less large and numerous CARTILAgINOUs, BONY, and stony CONCRETIONS in it. ${ }^{1}$ Frequent morbid irritation and chronic inflammation of the brain, gout, and tubercles in the brain, seem to give rise most commonly to this change of texture. The lime is in such cases found either in very small quantity, scattered about like sand in one part of the brain, so that it grates when cut through; or it is collected in larger quantity at one spot, so that it assumes a chalky or gypsum-like appearance, and a certain degree of brittleness; or lastly, it forms separate bodies of very different forms, which are deposited in the substance of the brain, and sometimes even contained in delicate cysts, which, according to their appearance and solidity, we are accustomed to call fibro-cartilaginous tumours, ${ }^{2}$ bony or stony concretions. ${ }^{3}$ A true ossification of the brain, that is, its conversion into bony substance, is never found, but it is always rather a removal of the nervous mass.

(1) The fabulous accounts of the older writers respecting the entire, or almost entire conversion of the brain of men and animals into bone or stone, if indeed they are founded on any observation, may perlıaps always be referred to great enostosis of the skull. Comp. \$ 122, note 27 and 28.-Further, Seb. Scarabicii Historia cercbri bovini in lapidem mutati. Patav. 1655.-To these belong also probably the completely stony human brains, in the fossil collection at Iisbon. v. Domeier in Journ. d. ausländ. med. literat. by IIufeland, Schreger, and Harles, Vol. I. p. 258.

(2) Compare $\$ 239$, note 1.

(3) J. Kentmann De calculis in hominibus. 8vo. Tigur. 1565.-Miscell. Acal. Nat. Cur. Dec. II. Ann. I. Obs. 32, p. 76, 1682, (a stony concretion, as large as a bean, from the brain of a fallow-(leer.)-Schelhammer, ib. 1). 332.-Chr. Yaler De ossiculo in cerebro nato, ib. Dec. III. $\Lambda$ n. IX. and X. p. 294. $-T y$ son, in Phil. Trans. 1697, No. 228, \%. 5.35, (in the quadrigeminal bocly.)-Drelincourt in Manget's Theatro anat. I. IV. C. II. p. 309, (the pine as large as a hen's egr, 
and stony.) - Littre in Mém. de l'Academ. de Paris, 1705, p. 55, (the cerebellum and part of the medulla oblongata chalky.)-Blegny Zodiac. Gallic. Obs. 14, p. 87, (a stone, as large as a bean, at the junction of the optic nerves.) - Veratti in Comment. Bononiens, Vol. II. Part I. p. 184. - Hunauld in Mémoir. de l'Acad. des Sciences de Paris, 1734, p. $4 \pm$ and 59.-Lieutaud, ib. 1737, p. 51 and 71 ; and Hist. anat. med. L. III. Obs. 179, p. 56,4 . (on the cerebellum of an epileptic person, and in the pine.) - Deidier Traite des tumeurs contre nature, Paris, 1738, p. 351, (in the left striated body.) - Adami D. de causis quibusdam specialibus apoplexiæ, etc. Halæ, 1764, (a stone as large as a pigeon's egg.) Compare Meckel in Mém. de Berlin, 1754.-Greding v. Ludwig's Adversar. med. pract. Vol. II. p. 448, and Vol. III. p. 658. - de Haen Ratio Medendi, Vol. II. p. 186, (the infundibulum full of lime.)-Schweikhard Medic. gerichtl. Beobacht. Vol. III. p. 304. Strasb. 1789, (the hinder part of the hemisphere full of sand.)Metzger D. continens bigam Obs. anat. pathol. p. 3. Regiom. 1792, (pons varolii ossified.)-Mursinna Medic. chir. Beobacht. p. 115. Berl. 1796, (a tumour in the corpus callosum.) - F.J.Walter Anat. Museum, Vol. I. No. 291. p. 145,-Caldani Opusc. anat. p. 51. Patav. 1803, (a stone in the optic beds.) -J. and C. Wenzel De penitiori structura cerebri, p. 104 and 105, (an earthy kernel in the tumour.) The Reviewers in Leipz. Lit. Zeitg. 1813, No. 25, p. 103, found small grains of sand in the appendage of the brain. - Home, in Philos. Transact. 1814, Part II. p. 469-486, (many earthy substances in the cerebellum and limbs of the brain in an idiot boy.) - Boyer v. Cruveilhier Essai sur l'Anat. pathol. Vol. II. p. 84.Schallgruber Aufs. u. Beobacht. p. 59, Grätz 1816, (grains of sand in a tumour.) Prochaska in Oestreich. med. Jahrb. 1819, Vol. V. Part III. p. 83, with plates, (a large stony concretion.) - Hutchinson, in Med. chir. Transact. Vol. IV. p. 202, (in a tumour of the brain, fat, cartilage, and bone.) - Nasse in his appendix to Abercrombie, translated by De Blois, p. 16, Bonn, 1821, (a tumour in the cerebellum, with patches of lime and coagulated lymph alternately.) - Andral in Magendie's Journ. de physiol. Vol. II. p. 110, (in a consumptive person, a chalky concretion as large as a pea in the upper part of the left hemisphere.-Tacheron, Vol. III. p. 380, (a tumour, which grated when cut.) - Neumann in Hufeland's Journ. July, 1824, p. 28, (stony concretions in the hemisphere under the pia mater, one of which was almost as large as a pea.)-Rosenthal Abhandl. a d. Gebiete der Anatomie, Physiologie u. Pathologie, p. 113. Berl. 1824, (a splinter of bone in the cerebellum.)-Abr. Berg præs. Weber Observatio tumoris et ossificationis cerebelli, ossificationem substantiæ cerebralis et phænomena morbi illustranda. 4to. Lips. 1826.-Bergmann in Mende Beobacht. u. Bemerk. a. d. Gebertshülfe u. gerichtl. Medicin. Vol. III. Gött. 1826, (a tumour in the base of the left ventricle, consisting of many sandy round bodies and soft substances, as large as a walnut.)-Hooper, The morbid Anatomy of the human brain, \&c. tab. 12, has engraved a bony tumour from the brain.-In the Bresl. Mus. there is a large tumour, No. 2295, from the brain, containing earthy matter in many parts; and No. 8425, an irregular bony concretion, an inch and a half long, and almost an inch thick, which was found in macerating a skull, and probably belonged to a tumour in the brain.-In the Anat. pathol. Mus. at Vienna, I saw No. 2331 and 2361, two round smooth stones, as large as peas, which had the appearance of vein-stones, but without any accompanying history. Were they vein-stones from a sinus?-I also saw there a very firm brain from an epileptic person, with extensive ossification in one hemisphere, and a pine, the greater part of which was stony.

\section{§239.}

On account of their frequency as well as their consequences, SPURIOUS FORMATIONS of various kinds are very important morbid phenomena in the brain. As they for the most part produce a mass as solid as the brain, are also frequently separated from it by a distinct membranous cyst, indeed even only 
embedded in it; they commonly excite, by their irritation, inflammation, softening, or suppuration in the neighbouring parts, and then seem, as it were, separated from the other parts of the brain; we apply to them the but little characteristic names of NODEs, nodi, CEREBRAL TUMOURs, tumores cerebrales, ${ }^{1}$ \&c. Although in many cases it is difficult to distinguish them, as the colour, size, consistence, and texture vary exceedingly, and they run so gradually into each other, it seems, however, that they may in general be divided into encysted tumours, tubercles, and sarcoms. To the former kind belong the WATERY BAGS, hygromata, and HYDATIDS, ${ }^{2}$ found in the substance of the brain, which either lie tolerably exposed on the surface, or are found buried in the interior of the brain, and vary in size from that of millet seed, to that of a small apple, \&c.; if they be small, sometimes numerous, but if larger, commonly single. To these hydatids and watery cysts, are connected the cysts which contain mucous-like, albuminous and bloody secretions of different consistence; lastly, true fatty and gritty tumours which contain fatty and albuminous substances. $^{3} \quad$ Tubercular aFfEctions of the brain ${ }^{4}$ are common, not merely in youth, but also in more advanced life. The characteristic tubercular mass is sometimes deposited pretty regularly in the substance of the brain at one spot, and gives it a yellowish white and firm character; sometimes it affects a part of the brain in a granular and more distinct form; lastly, it sometimes forms isolated and tolerably large roundish knobs, which are not unfrequently surrounded by delicate cellular membranous coverings. The colour and consistence of these tubercles is very different, as they are observed at first in their hard, irritated, inflammatory, softened, and even purulent state. ${ }^{5}$ The sarcom has, either as in the other parts of the body, the nature of the general or fleshy sarcom, and then consists of a tissue of cellular substance, minute vessels, cysts, and inorganized albuminous masses, \&c., or rather, that of MEDULLARY SARCom. ${ }^{6}$ True scirrhus and cancer never occur primarily in the brain."

(1) Lieutaud, Vol. II. Lib. III. Obs. 194-224.-A. Salomon D. de quibusdam cerebri tumoribus, Edinb. 1810.-A. B. Hertel D. de cerebri et meningum tumoribus, 8vo. Berol. 1814, with plates, (three cases contributed by Rudolphi.)C. E. J. Ilammer pros. Rosenmiiller D. anat. pathol. s. tumorum morbosorum in cerebro observationes novas, 4to. Iips. 1817, with plates.-Nasse Ueber Geschwülste im Gehirn, appendix to Abercrombie, Patholog. and Pract. Remarks on diseases of the Brain and Spinal Marrow, translated into German by de Blois, Bonn, 1821.-C. L. H. Calow D. de tumoribus cerebri, 4to. Berol. 1826, with plates.-Burdach Vom Baue u. I,eben des Gehirns, Vol. III. p. 543-550.Of the numerous individual cases, the following are most important: Fel. Plater. Observ. I,ib. I. p. 13 and 108. - Boneti Sepulclıretum anat. L. I. Sect. 1, Obs. 56, 63, Sect. 2, Obs. 53, Sect. 3, Obs. 29.-Willis 1)e scorbuto, Cap. III. § 4.J. Harderi 
Apiarium, p. 238, Obs. 58, 4to. Basil, 1687, (in the cerebellum and medulla oblongata.) -Jon. Rhodii Observat. medicar. Cent. I. Observ. 55, Patav. 1757, (in one ventricle.) -Wagner in Ephem. Acad. Nat. Curiosor. Dec. II. Ann. X, and Vallisnieri, $i b$. Cent. VIII. App. p. 72, (in the right ventricle.)-Lancisi De subit. mort. p. 39, (scirrhus in the medulla oblongata,) and De noxiis paludum effluviis, L. II. Epist. III. cap. 6, p. 218, (a wlite, hard, granular-like body in the cerebellum.)-Mém. de l'Acad. de Scienc. de Paris, 1705, No. 13, (in the cerebellum and medulla oblongata.) - Santorini Observationes, p. 51.-Fantoni Opuscula med. et physiol. p. 87 and 202, 4to. Genuæ, 1738, (as large as a walnut, in the brain.) -la Peyronie, $i b .1741$, p. 208, (in the fourth ventricle, as large as an egg.) -Buonav. Perotti in Raccolta d'Opusculi scientifici e fisiologici in Venezia, Vol. XLVII. 1751, p. 339, (as large as a nut, in the right hemisphere.)-Zinn in Comment. Soc. reg. Scientiar. Goetting. Vol. II. 1752, (two cases in children.) Mém. de l'Acad. des Sc. de Paris, 1754, p. 63, (in the right hemisphere, as large as a hen's egg.) - Huber Pr. observat. aliquot. anat. Cassellis, 1760, (in a child, in the medullary substance of one hemisphere.)-Meckel in Mém. de l'Acad. de Berl. 1754, p. 70, (a scirrhus in the cerebrum,) 1761, p. 61, (in the cerebellum,) 1764, p. 84, (a scirrhus in the left hemisphere.) - Morgagni Epist. LII. 15, (scirrhus in the cerebellum.)-Röderer Pr. de cerebri scirrho. Goett. 1762. Galli in Atti dell' Acad. delle Scienze di Siena, Vol. II. p. 210, (one as large as a hen's egg, in the right ventricle.)-Haller Opera minora, Vol. III. Obs. 1, p. 282, (scirrhus cerebelli.) - Marcot in Mém. de la Soc. de Montpellier, Vol. I. p. 334, Lyon, 1766, (scirrhus.) - Brown Cheston, Pathological Inquiries and Observations in Surgery, \&c. p. 142. 4to. Lond. 1756, (a fungous growth.)Forlani Rarior. obs. med. anat. Vol. I. p. 49, Senis, 1769, (an encysted tumour, in the left ventricle.) -Baader in Sandifort's Thesaurus Dissert. Vol. III. p. 38, (a fatty body as large as a walnut, in the right lemisphere.)-Richter's Chir. Bibliotl. Vol. II. Part I. p. 159.-Desportes in Histoire des maladies de St. Domingue, Vol. II. p. 209, Paris, 1770, (an encysted tumour, with fat in the pine as large as an egg.) - Greding in Ludwig's Advers. med. pract. Vol. II. Part II. p. 492, (large, in the right hemisphere.) - Brisseau in Samml. chir. Bemerkungen, Vol. I. p. 198, (an encysted tumour as large as a hen's egg, in the cerebellum.) Meier in Baldinger's Magazin, Vol. IV. Part I. p. 1.-Leveling D. de carie cranii militis quondam venerei. 4to. Ingolst. 1777.-J. Conrad De hydrocephalo cum fungo cerebelli conjuncto. 4to. Argentor. 1778. - Schmucker Samml. vermischt. chir. Schriften, Vol. I. p. 247, (as large as a nutmeg, in the left ventricle.)Baumes in Journ. de Médec. 1791, June. - Nasse, in Abercrombie, has collected the following cases, two of his own; in one, twenty-one tubercles in the cerebrum; and in the other, a tumour in the cerebellum. Further, Reil Memorabil. clinica. Fasc. III. p. 39, (several tubercles in the cerebrum and cerebellum.)-Blane, in Transact. of a Soc. for the improvement of medic. and surg. Knowledge (in the brain and pine).-Wenzel De penitiori struct. cerebri, p. 104, 105. -Earle in Medic. chir. Transact. Vol. III. p. 59, 1812, (several in the hemispheres in a boy.) -Hutchinson, ibid. Vol. II. p. 113; and Vol. IV. p. 197, (three cases.)-Powel in Medic. Transact. Vol. V. 219, 234, 241.-Farre in Samml. auserl. Abhandl. f. prakt. Aerzte. Vol. XXV. p. 21.-Merat in Bulletin de la Fac. de Médec. de Paris, 1815, No. 4, p. 335, (three cases.)-Cruveilhier Essai sur l'anat. pathol. Vol. I. p. 300, (encysted tumour in the left hemisphere.)Meckel Handb. der pathol. Anatom. Vol. II. Part II. p. 329, (in the left ventricle.)-Rosenmüller in Hammer, p. 17, (in the right hemisphere two as large as hazel-nuts.) -Bock, ibid. p. 25, (one as large as an egg, in the right hemispliere of a boy;) p. 28, (scirrhi in the cerebrum andcerebellum of ascrofulous child.) Buchanan in Edinb. med. and surg. Journ. Vol. VIII. p. 276.-Steinbuch in Hufeland's Journal, Aug. 1815, Vol. XLI. Part II. p. 104.-Arvers in Bullet. de la Fac. de Méd. de Paris, 1815, No. I. p. 260.-Chomel in Nouv. Journ. de Méd. March, 1818, p. 1.-Rose in London med. Repos. 1819, No. 61, p. 12.-Besides the already mentioned cases, Abercrombie has also cited the following, case 82, p. 175, (an encysted tumour in the cerebellum.)-Lathum in Med. and phys. Journ. July, 1826, (in the cerebellum.)-Plinque Bibliotlieque, Part III. p. 348, (in the cerebellum, as large as a pigion's egg.)-Bouillaud 
Traité de l'Encephalite, 1825, (a scirrhus in the right hemisphere.)-Chambers in Med. and phys. Journ. July, 1826, (in both hemispheres, and in the cerebellum.) - Cruveillier in Nouv. Biblioth. de Medec. Nov. 1825, (a scirrhus in the right hemisphere.) Hay, case 14, (the size of a walnut, on the Turkish saddle.) Coindet Sur l'hydrocephale, p. 98, (a hard tumour on the pons varolii.)-Hay, case 20, (tumour as large as an orange.)-Rochoux Sur l'A poplexie, (a tubercle as large as a nut, in the cerebellum.) - Beilby, case 27, (one as large as an egg between the cerebral membranes in a child.)-Bouillaud, case 32, (many large scrofulous tumours in a boy in both hemispheres.)-Yelloly in Med. chir. Transact. I. p. 181, (on the pons varolii and medulla oblongata.)-Rostan Recherches sur le ramollissement du cerveau. Paris, 1820, (in the right hemisphere a cancerous-like tumour as big as a turkey's egg.)-Gooch in Abercrombie, p. 437, (two encysted tumours.)-Edinburgh Journal. Vol. XI. p. 470, (in the pons varolii.) - Bulletin de la Faculté de Médec. de Paris, May, 1816, (as large as a hen's egg, in the left hemisphere.)-Hawkins in Med. and physical Journal, 1826, (many scrofulous tumours on the cerebrum and cerebellum.)-Camell in Medical Repository, Vol. VII. p. 92, (on and in the cerebellum.) - Hunter, case 40, (as large as a pigeon's egg in the right hemisphere.)-Medico. chir. Transact. Vol. IV. p. 188, (as large as a hen's egg in the left hemisphere.)-Rostan, case 44, (an egg-shaped tumour in the right liemisphere.) Some other cases" are:-Salmade in Sédillot's Recueil périodique de la Soc. de Medec. de Paris. Vol. XXVII. p. 153, (in the left hemisphere.) Fribault and Marechal ibid. Vol. XLIV. p. 369, (scirrhus cerebri).-Thomann Annal. der klinischen Anstalt zu Würzburg für das Jahr. 1800. Würzb. 1803, (on the pons,) with a plate.-Donald Monro in Medic. Transact. Vol. II. p. 325.J. de Roose in Verhandlingen van het Genootsch. te Antwerpen. D. I. Bl. 109. Salter in Edinb. med. and surg. Journ. Vol. XI. p. 469, (in the pons.)-Kelch Beiträge zur pathol. Anatomie, Berl. 1813, No. 64, (on the cerebellum, perhaps only the flock enlarged); No. 66.-Horn in his Archiv f. med. Erfahrung, 1813, March and April, p. 238, (as large as a pigeon's egg, on the pons.)-Rudolphi, $i b$. p. 508, (an encysted tumour in the right hemisphere.) - Edholm in S venska LiikareSällskapets Handlingar, Vol. I. p. 41, Stockh. 1813, (as large as a walnut, scirrhus of the gland. pituitaria.) - Schallgruber in Allg. medic. Annalen, 1814, August, p. 557, die Aufs. und Bcobachtungen im Gebiete der Heilkunst. p. 59. Grätz. 1816, (in the right hemisphere.) - E. Home in Philos. Transact. 1814, Part II. p. 469-485; Sect VII. (four cases.) -Zetterström in Svenska Lakäre-Sällskapets Handlingar, 1815, Vol. II. Part II. p. 175.-Trafvenfell, ib. p. 191, (in the left hemisphere, as large as a hen's egg.) - Nysten in Bulletin de la Faculté de Méd. 1816 , p. 183, (in a child three years old.) - Bicrmayer Nuseum anat. pathol. No.74, (a scirrhus.) - Cruveilheir Essai sur l'anatomic patholog. Vol. II. p. 80, (a. fibro-cartilaginous tumour in the right hemisphere.)-Meckel in Archiv f. d. Physiol. Vol. III. p. 196, (in both hemispheres fatty and yellowish.) - Wespthal D. s. descriptionem tumoris in ventriculo cerebri laterali inventi, with illustrative engravings. 4to. Kiliæ, 1817, (in the right ventricle, large.)-Rust Magazin f. d. gesammte Heilkunde, Vol. V. Part I. p. 165, (encysted tumour.)-Hebreart in Bulletin de la Fac. de Mélec. 1817, p. 399, in Annuaire medico-chir. Paris, 1819, (several cases.)-Cerutti Beschreib. der patholog. Präparate, No. 822, 823, and 827.-Parent-Duchatelet and Martinet Recherches sur l'inflammation de l'arachnoide. p. 439, 463. Paris, 1821.- Niel in l'Observateur Provençal des Scienc. medicales. Vol. II. p. 29, Marseille, 1821, (a medullary swelling as big as one's fist.)-Fd. Nenley, v. Sammlung auserlesener Abhandlungen e.um Gebrauch für praktische Aerzte, Vol. XXVII. p. 226. - Mitivie, ib. p. 467.-J. G. Wishart in Edinburgh medical and surgic. Journal, July, 1822, p. 393.-Itard Von den Krankh. des Gehirns. a. d. Fr. Weimar, 1822, p. 78, (several small scirrhi.) Blicke in London medical Repository, 1822. - Andral in Magendie's Journal de Plhysiologie, Vol. II. p. 105.-Pfeufer in Henke's Zeitschrift f. Staatsurzmeikunde, 1822, Part III. p. 84, (bean-shaped, lying upon the Turkish saddle, between the hemispheres.) - Lebidois in Archives générales de Médec. Paris, July, 1823, (as large as a hen's egg, in the right hemispliere.) - Krukenberg Jahrbiicher der ambulator. Klinik zu Halle, 1823, Vol. I1. Sect V1. No. 1, (two 
cases, in the one as large as a Borsdorf apple, in the right hemisphere.) - Picdagnel in Magendie's Journ. de Physiol. Vol. III. p. 247, (scveral large knots.) - Tacheron Recherches anat. pathologiques, Vol. III. p. 45 and 381, (tubercles in a child.) - Rezzio in Ripertorio med. chir. di Torino, 1823, (an encysted tumour.) - Ward, in London med. Repository, September, 1823, Vol. XX. p. 217, (a tumour projecting from the region of the mucous gland,) and April and June, 1824, (two instances in the cerebellum.)-Ollivier, Traité de la moëlle épinière et de ses maladies, \&c. 2 vols. 8 vo. Paris, gives several instances of tumours in the medulla oblongata. - Rosenthal Abhandlungen aus dem Gebiete der Anatomie, Physiologie, und Pathologie, p. 113, Berlin, 1824, (in two scrofulous children in the cerebellum, and in an adult, in the neighbourhood of the striated bodies.) - Hesselbach Beschreibung. der pathol. präpar. zu Wurzburg, 1824, p. 361, No. 267, 275; p. 398, No. 241.--Schneider D. de magna quadam encephali destructione ejusque sequelis, 8vo. Berol. 1823, (three steatomatous tumours in the left hemisphere.)-Ozanam in Journ. compl. du Dict. des Sc. Médec. Aug. 1824, (six scirrhous knots, as large as hazel-nuts, on the left hemisphere, with caries of the skull.)-Ahlberg and A. Retzius in Ars-Berättelse om Svenslza Läkare-Sällskapets Arbeten, lemnad af Eckström, 1825, (a tumour as big as a hazel-nut, in the corpus rhomboideum cerebelli.)--Fr. Bellmer D. de cerebelli degenerationibus, 4to. Bonnæ, 1825, (tubercular knots in the cerebrum and cerebellum in the first case; and in the third, a knot as large as a nut in the cerebellum.) - Berg præs. Weber Observatio tumoris et ossificationis cerebelli, \&c. 4to. Lips. 1826. - Bergmann, v. Mende Beob. und Bemerk. a. d. Geburtshülfe und gerichtl. Medicin. Vol. III. Gött. 1826, (in the left hemisphere, containing earth.) - $R$. Wade, in London Med. and Physic. Journ. May, 1826, (a hard, lightish brown tumour, as big as an egg, in the left hemisphere.) -Tiand and Dubreuil in Ephémérides médicales de Montpellier, Vol. I. April 1826, (on the left side of the cerebellum, and on the medulla oblongata.)R. Hooper, The Morbid Anatomy of the human Brain, \&c. pl. 6, 11, 12, and 13. - Pagenstecher in Harles's N. Rhein. Jahrb. d. Medic. u. Chir. Vol. XII. Part III. p. 1, (a tumour on the left hemisphere.) - Monro, The morbid anatomy of the Brain, Vol. I. chap. 5, Edinb. 1827.--de la Motte, in Philadelphia Journ. of the Med. and Phys. Sciences, Aug. 1827.--Cruveilhier Anatomie pathol. 2 livrais. pl. 6, (several cases, fatty tumours, also two cases of Dupuytren and Leprestre.)Dav. Mayer D. de cerebri tumoribus, 4to. with plates, Berol. 1829. I have found tumours in the brain eight times, of the scrofulous or steatomatous kind. Compare Selt. Beob. Part I. p. 107 ; Part II. p. 94. Verzeichn. No. 22952300 ; since then, another case, No. 8502 of Bresl. Mus. viz. several scrofulous knots in the cerebellum.

(2) On hydatids of the cerebral membranes, compare $\$ 225$.-On hygroma and hydatids in the brain itself, v. Lieutaud, L. 11I. Sect. 3, Obs. 194.-There are also instances in Lancisi De subitan. mort. L. I. Cap. 11, p. 35. - Schwencke D. rari casus explicatio anat. med. Hag. 1737. v. Haller's Coll. Diss. pr. Vol. VII. No. 260.-Fantoni Opusc. med. et physiol. 1738, p. 22. - Schaarschmidt Medic. und chir. Nachrichten, Vol. III. p. 363. - Kaltschmid De nervis opticis in cadavere latis inventis. Jenæ, 1752. - Berdot in Actis Helvet. phys. med. Vol. V. p. 183, (a very large watery cyst.) - Goutard in Journ. de Médec. Vol. IV. p. 132. - Morgagni Epist. Anat. I. 20. - Forlani Obs. med. pract. Anat. Senis, 1769. - Balme in Journ. de Médec. Vol. XLI. p. 526. - Hufeland's Journal, Vol. V. p. 813.-Portal Cours d'Anatomie Médic. Vol. IV. p. 41, 72. - Pyl Aufsätze und Beobachtungen aus der gerichtl. Arzneiwissenschaft, Vol. II. p. 37. - Medical Repository, Vol. III. v. Abercrornbie, p. 440, case 39. - Wenzel Ueber den Hirnanhang fallsüchtiger personen, p. 74. Ib. De penitiori structura cerebri, p. 114. - E. Home, first case. - Morrah in Med. Chir. Trans. Vol. II. p. 260. - Horn's Archiv. 1815, Part V. p. 842.Biermayer Museum anat. pathol. No. 247 and 285. - Tübinger Blätter f. Naturwissenschaft und Arzneikunde, Vol. III. p. 51, (in the pine.) -Headington in Edinb. med. and surg. Journ. Vol. XV. p. 504. - Morrah in Med. chir. Trans. Vol. II. p. 262. - Cerutti Beschreibung der pathol. Präpar. No. 822 and 823. - Rostan Recherches sur le ramollissement du cerveau, Cap. 10, p. 166.- 
Rentclorf D. de hydatidibus in corp. hum. præesertim in cerebro repertis, p. 36 . Svo. Berol. 1822, with plates.-Romberg in Nasse's Zeitschrift, 1822. Part III. p. 195. - Neumam in Hufeland's Journal, July, 1824, p. 29.-Jacobi, 1st case, (in the pons.)-Calow, 2d case, (in the pons, as large as a hen's egg.)-Bailey in London medical Repository, Feb. 1826, (one large and several small in the fourth ventricle.) Hooper, pl. 14.-Nordblad in Ars-Berättelse om Srenska Läkare-Sällskapets Arbeten, lemnad af Eckström, p. 37. Stockholm, 1827, (on the striated bodies as large as a bean.) - Abercrombie, p. 175, case 82 ; in Bresl. Mus. there are two instances, No. 8694, (one as large as a hazcl-nut,) and No. 8704, (an encysted tumour, consisting of fatty substance and hydatids.) - It has been already mentioned above, in speaking of apoplexy, that after the absorption of the blood, cysts are sometimes found filled with serum.

(3) The contents of encysted tumours vary as much in the brain as in those of other parts; mucous and albuminous secretions, in various degrees of coagulation, are commonly found in them. Sometimes the albumen is almost coagulated, deposited in concentric layers, and even mingled with eartlyy parts. Often, with the albumen, there is a large quantity of fat mingled, which is never yellow, but similar to tallow, (stearine, and perhaps also cholesterine, ) light, greyish, and smeary, forming a substance not very dissimilar to brain. Sometimes these fatty tumours have a silvery or shining white lustre, especially their cysts, viz. in some cases of Rudolphi, Braun, Parent-Duchatelet, and the three cases of Cruveilhier's. -I also found, in a tumour of the cerebral membrane, containing hair, which protruded through an aperture in the lemisphere into the ventricle, its cyst shining like mother-of-pearl. v. $\$ 234$, note $4 .-J$. Veratti once found, in the lateral ventricle of a woman, a knot of hair as big as a pea, mingled with small white granules, (probably fat.) v. Comment. Bononiens. Vol. II. Part I. p. 184. - The thickness of the cyst varies not less, sometimes it is very inconsiderable, especially in fatty tumours, and in other cases of cartilaginous hardness.

(4) The greater number of tumours of the brain have this character, and almost all which I have examined in a recent state belong here. - Of the cases quoted in note 1 , those which appear to me may be properly included here are those of Zinn, Huber, Morgagni, Ep. LII. 15, Haller, Nasse, 1st case, Reil, Blane, Earle, Merat, Rosenmiüler, Bock, Abercrombie, 1st edit. p. 226, case 1 and 2, Bouilland, Chambers, Hay, Rochoux, Hawlins, Camell, Powell, Rudolphi s. Hertel in two cases, Horn, 1813, p. 238, Rostan, Mitivie and Deslandes in Parent-Duchatelet, Piedagnel, Tacheron, Rosenthal, Hesselbach, No.398, Schneider-Baillie Morbid Anatomy, p. 44.2, under the name of white firm substance. - Sömmerring's addenda to Baillie, note 537.-Bellmer, in 1st case.-Baumes Ueber die Erblichkeit der Skrofeln u. Beispiele von Skrofeln im Gehirne. v. Hufeland's Ncueste Annalen der franz. A. W. Vol. II. No. XI. p. 73. - Ch. Bell, Anatomy of the human Body, Vol. III. p. 36.-Biermayer Museum anat. pathol. No. 544, (in the cerebellum.) -Lobstein Compte rendu, etc. p. 51. - Ozanam in Journ. compl. clu Diction. des Scienc. médic. Vol. XIX. p. 189. - Berard in Magendie's Journ. de Physiologie, Vol. V. No. 1 and 2, p. 17. - Mitivie Beobacht. und Bemerk. iiber die hitzige Gehirnhöhlenwassersucht. Leipz. 1823, (several cases of his own; he consiclers tubercles not unfrequently the cause of dropsy of the brain.) - Gendrin Recherches sur les tubercles du cerveau et de la moëlle épinière in Anmales de l'école médicale. Jan. 1823.-Bertin in Ephémérides médicales de Montpellier, Vol. I. April, 1826, (in the cerebellum of a boy ten years old.) - Chambers in London med. and phys. Journ. July, 1826.-Earle in Medico-chir. Transact. Vol. XIII. Part II. London, 1827.-Huillier in Ephem. médic. de Montpellier, Vol. V I. Sept. 1828. - Evans in Edinb. medic. and surg. Jommal, April, 1828.Guibert in Revue médic. franç. et étrangère, June, 1828, (in the cerebellum, three cáses.)-Good plates are given in Baillie's Engravings, Fasc. $X$. pl. 7, 227; and in Hooper, pl. 11 and 12. - Tubercles also occur in animals. - Dupuy De l'aflection tuberculeuse, p. 265, Paris, 1817 , mentions a tuberculous glandula pincalis in a hor'se. - I saw large tubercles, one of which was as big as one's fist, from the lateral ventricle of a horse; and from oxen in the veterinary school at Munich. $I$ also once found tubercles in the brain of a monkey. 
(5) Sometimes they are homogeneous, tough, whitish, and hard; sometimes partially or generally soft, running into suppuration; many of the cerebral abscesses quoted are indeed suppurating tubercles.

(6) Several of the tumours cited in note 1 may belong here; but to medullary sarcom especially the following. v. J.Wardrop, Observations on Fungus Hæmatodes, or Soft Cancer, \&c. p. 30,-35, 47, 59, 74, 8vo. London, 1809, (several cases simultaneous with medullary sarcom of the eye.) - Lerminier Ueber eine carcinomatöse Affection des Gehirnes in Annuaire medico-chir. des Hôpitaux, \&c. 1819, No. 4, p. 225.-Rostan, p. 84, Obs. 20, (he calls it cancer.)-Panizza Annotazioni anat. chir. sul fungo midollare dell' occhio, etc. Pavia, 1828, (in a boy, simultaneous with medullary fungus of the eye.)-Tacheron, Vol. III. p. 380.-Wedemayer in Rust's Magazin f. d. ges. Heilk, Vol. XIX. Part II. p. 222, (in the left hemisphere.)-John Hunter, in Medico-chir. Transact. Vol. XIII. Part I. with a plate, London, 1825, (particularly in the optic couches of a girl of seventeen years.)-Gregory in London medical and physical Journal, Decbr. 1825. Latham in London medical and physical Journal, Vol. LVI. or new series, Vol. I. July, 1826, (descending from the cerebellum into the spinal canal.)-Pagenstecher.-Martin Ware, ibid. Vol. LVIII. p. 502, (with medullary sarcom of the eye.)-I have described three cases, viz. two in the right hemispliere, and one in the appendage. v. My Selt. Beob. Part II. p. 90, No. 38 and 39; Verzeichn. No. 2291-93; the former of these is also described by Arnold, D. s. fungi medullaris in cerebro inventi exemplum, etc. 8vo. Vratislaviæ, 1822., I saw in the Anat. pathol. Mus. at Vienna, one case of medullary sarcom of the cerebral appendage.

(7) The numerous cases of scirrhus in the brain arise, as I think, generally from inflammatory and tubercular indurations, from fibrocartilaginous tumours, and from sarcoma. They may perhaps occur secondarily from cancer in the orbit, as well as be communicated from the neck to the brain, althougl, so far as I know, this has not been observed.

\section{\$240.}

Lastly, the brain is also sometimes subject to vicEs of CONTENTS, inasmuch as not merely are morbid secretions of different kinds frequently found in the cavities, and in the substance of the brain, but sometimes also EXTRANEOUS sUBSTANCES, first, PARASITIC ANIMALS, viz. MITES, gamasus marginatus, ${ }^{1}$ and of the entozoa, in men, monkeys, and pigs, the cysticercus cellulosa, Rud. $;^{2}$ in sheep, antelopes, and oxen, the coenurus cerebralis, Rud. ${ }^{3}$ and in rare instances in man, the ecrinococcus hominis, Rud.: ${ }^{4}$ secondly, all hard substances which have accidentally entered the brain, as needles, bullets, dagger and sword points, splinters of bone, \&c., which sometimes remain for a long time and even for life, without inconvenience ${ }^{5}$; in the latter case, they are often, as in other parts, enclosed in a plastic bag.

(1) Herrmann Mém. aptérologique. fol. Strasb. 1804, Fasc. VI. pl. 6.

(2) They rarely occur in the brain, so that I have never found them; there is, however, an old preparation, No. 2304, in the Bresl. Museum, in which a quantity of cysticerci are loosely embedded in the cortical substance of the brain beneath the vascular coat.-Compare Rudolpli Entozoorum hist. naturalis u. Synopsis, p. 180 and 546.-Further, Bremser Ueber lebende Würmer in lebenden Menschen. Wien, 1819.-K. Himly, in his and Hufeland's Journ. Decemb. 1809, p. 116, pl. 3. - Hopfengärtner, ibid. Vol. LI. Part IV. p. 32. - Romberg in Nasse's Zeitschrift f. die Anthropologie, 1823, Part III. p. 197. - Rosenthul, 
p. 114.-Bremser found it in a cercopithecus, p. 237, and Rudolphi Synopsis, p. 547 ; they are frequently found in pigs. - Flormann found them in a pig, affected with the gid, not merely on the membranes and in the substance of the brain, but also twenty of them loose in the right ventricle. v. Kongl. Vet. Acad. Handlingar, p. 132. Stockholm, 1815.

(3) They are especially frequent in sheep affected with the gid, in the lateral ventricles; sometimes also in mad staggers in the fourth ventricle, although rarely in the substance of the brain. I liave recently found such a cyst in the right hemisphere of the cerebellum, near its external surface. If the cyst become large, or there are two or three of them, the brain is very much expanded, and the skull itself at the spot absorbed or expanded like a bladder.

(4) I found one in the lateral ventricles of the brain weighing two pounds and three drachms, in which there were seventy-one echinococci. v. Rentdorf, p. 36.Perlaps the case found by Burnall in the $\Lambda$ ppendix to Baillie's Morbid Anatomy was similar.

(5) Compare the surgical writers. Interesting cases are found in Boneti Medic. septentr. collat. Part I. p. 59 (a sword point fourteen years); and Biblioth. chir. Cent. I. Obs. 73, (the point of a poniard five years.)-Zacutus Lusitamus Opera. Vol. II. L. B. 1657, Prax. med. admirand. Lib. I. p. 2, Obs. 6, (a piece of the blade of a knife eight years.)-Anel in Mém. de l'Acad. de Chir. Vol. II. p. 131, (a bullet in the region of the pine some years.)-Quesnay, $i b$. (a bullet a year.)Le Dran Observations de Chirurgie, p. 127. Paris, 1731, (a bullet one year in the region of the saddle); p. 161, (small shot discharged on the thirty-seventh day, the person recovered.) - Volaire in Journ. de Médec. Vol. XX. 1764, p. 553, (a bullet two years.) -Morand Opuscules de Chirurgie, Vol. 1. p. 59, Paris, 1768, (a bullet nine years and a half.) - Brisseau Sammlung. chirurg. Bemerk. Gotha, 175s, Vol. I. p. 171, (a piece of iron which had been thrust in during trephining made its appearance again after four months.) - Vater, ib., Vol. II. p. 305, (a small shot seven weeks.) -Schmucker Samml. vermischt. chir. Schriften. Vol. I. p. 277, Berl. 1785, (a bullet four munths.)-Majault in Journ. de Médec. Vol. XLI. p. 82, (the point of an arrow nine years.)-Camperdon in Samml. fiir Wunclirzte, Vol. II. p. 112, (a piece of the but of a firelock three months.) Sala in Dict. des Sciences médic. Vol. VII. p. 50, (the point of a sword during the whole life, without inconvenience.) - Paroisse in Opuscules de Chirurgie, p. 1, Paris, 1806, (a soldier who received a bullet into his head, through the temple, was cured.) -Langlet in Bulletin de la Faculté de Médecine. Dec. 1810. p. 233 (a bullet eighteen months.) - Reich in Hufeland's Journal, 1815, (a bullet nine months)._Fance in Journ. de Méd. Chir. et Plarm. milit. par Biron et Fournier, Paris, 1816, Vol. II. (a bullet a-year after the external wound closed.) -Zinck, ib., Vol. XII. 1822, p. 221, (a pebble which had been shot seventeen months.) - Kirby, Dublin hospital Reports, Src. Vol. II. 1818, (a large piece of a bullet several months). - Utforlig och med ojäfagtiga intyganden verificera Berättelse, \&c. 8vo. Stockholm, 1818, (two screws which had been shot in twenty-one years and three quarters, without inconvenience.) -Krüger-Hansen in v. Grüfe and $v$. Walther's f. Chir. Vol. III. Part IV. p. 627, (forty large small shot, without inconvenience.) - Busch in Petersburger Abliandl. a. d. Gebiete. der Heilkunde, Part II. 1823, p. 215, (a piece of a gun-stock, the man walked on foot with it 180 wersts, 130 miles.) - Rogers in Med. chir. Trans. Vol. XIII. No. 2, 1827, (a piece of the stock of a camnon three inches long, and three ounces in weight, twenty-one days.) - Instances of pins in the brain are mentioned by Portal Cours d'A natomic Médic. Vol. IV. p. 101. - Mrenne in Turtra Bullet. des. Sc. Médic. Vol. V. p. 317, and Flajani, v. Valentin Voyage médical en Italic. Nancy, 1822. 


\section{Second Chapter.}

\section{Of the Spinal Marrow.}

\section{A. - OF THE MEMBRANES OF THE SPINAL MARROW.}

\section{$\$ 241$.}

The membranes of the sprnal marrow are, as is well known, the same as those of the brain, and would consequently require but little particular observation, were it not that in a pathological view, there are certain peculiarities, which arise principally from the different proportions of the brain and spinal marrow to their bony investments, ${ }^{2}$ as well also as from the peculiar form, disposition, and structure of the spinal marrow. It therefore seems proper to mention only the points in which they agree with the cerebral membranes, and to dwell on their peculiarities.

(1) Compare the works quoted at $\$ 216$, and the works on diseases of the spine, $\S 135 . \ldots J$. P. Frank Oratio de vertebralis columnæ in morbis dignitate. Paviæ, 1791 ; v. Samml. für prakt. Aerzte, Vol. XV. p. 284.-J. B. Mayer D. de sano et morboso medullæ spinalis statu. 8vo. Vindeb. 1808.-Alex. Demussy Histoire de quelques affections de la colonne vertébrale et du prolongement rhachidien de l'encéphale. Paris, 1812.-V. Racchetti Della struttura, delle funzione e delle malattie della midolla spinale. Milano, 1816.-Asch præs. Mcckel D. de vitiis quibusdam medullæ spinalis minus cognitis. 4.to. Halæ, 1816. $J$. Abercrombie on diseases of the spinal marrow in Edinb. med. and surg. Journ. Vol. XIV. p. 42.-Ollivier Essai sur l'anatomie et les vices de conformation de la moëlle épinière chez l'homme. Diss. inaug. Paris, 1823, and 'T'raité de la moëlle épinière et de ses maladies, \&c. Paris, 1824 and 1827; translated into German, with additions, by J. Radius. Leipz. 1824.-C. L. Stapf Spec. inaug. s. conspectum morborum medullæ spinalis. 4to. Tübing. 1824.-Koreff Alfection de la moëlle épinière. Paris, 1825.-Hutin in Nouvelle Biblioth. 1828, Jan. and Feb.

(2) It is well known that not merely the arachnoid and vascular coats are nuch more loosely comnected with the spinal marrow than with the brain; but also the dura mater of the spinal cord is not so firmly attached to the bones as that of the brain. Injuries and diseases of the spinal bones, therefore, are not so immediately communicated to the membranes of the central nervous system as in the head; but in the greater mobility of the vertebræ, and on their looser structure, depend many peculiar morbid effects on the spinal marrow.

\section{\$242.}

The SIZE and FORM of the membranous bags investing the spinal marrow are in general proportioned to that of the spinal canal and marrow itself, and may therefore with these be irregular in various ways. The ExTENsion which the cerebral 
membranes are subjected to so frequently and to such extent in water of the head and rupture of the brain, \&c., occurs also in the membranes of the spinal marrow under similar circumstances; more rarely however, and of course less extensively, although it is almost always congenital, as the early closing up of the spinal canal very much opposes its subsequent formation. In reference to DISCOLORATION ${ }^{1}$ and vicEs OF CONSISTENCE, the membranes of the spinal marrow resemble those of the brain, and, as other irregularities, are observed more seldom on the former than on the latter. ${ }^{2}$ VICEs of continuity occur distinctly not merely from thrust, cut, and shot wounds, but also from splinters of bone in fracture of the spine, which, however, on account of their looser connexion, less frequently occur than in the membranes of the brain; they arise also from violent concussion and extension: the latter occurs particularly in cleft spine. ${ }^{3}$

(1) Dubrevil v. Ephémérides médicales de Montpellier, Aug. 1826, found in an embryon of three months, the arachnoides and pia mater of the brain and spinal cord yellow.

(2) It appears to me, that this is not only founded on the rare dissection of the spinal canal, and the difficult examination of the spinal cord; but that vicious states of the medulla spinalis are extremely rare: I have myself opened many spinal canals, and not unfrequently seen them opened, but I have found disorganizations in them proportionally less frequent than in the skull. I have often merely found morbid effusion of fluid. - Ollivier, p. 77 , is also of opinion, that the spinal cord is one of the least affected organs.

(3) Compare below, on the Spinal Marrow, $\$ 246$ and 247.

\section{$\$ 243$.}

Inflammation and its consequences deserve the first notice among vices of texture in the spinal membranes. Here also must be distinguished that state of morbid irritation and congestion which commonly occurs, as in acute fevers, in many eruptive diseases, hydrophobia, tetanus, epilepsia spinalis, convulsions, paraplegia, \&c., from true inflammation, which, however, occurs also in the same diseases. ${ }^{1}$ To the latter applies in general, all that has been said about the several membranes of the brain; it is not unfrequently followed by the EFFUSION OF PLASTIC LYMPH, ${ }^{2}$ distinct THICKENING, ${ }^{3}$ CONSOLIDATION of the several membranes with each other, and with the spinal canal ; ${ }^{4}$ Ulceration, and also mortification. In rare instances we find, on the arachnoid coat of the spinal marrow, CARTILAGINOUS and BONY CONCRETIONS, which, on account of the mobility of the spine, are not large, but mostly small, sometimes appear as numerous scales or leaves, especially in the region of the back and on its posterior surface. ${ }^{\text {s }}$ Hydatids, ${ }^{6}$ TUBERCULAR ${ }^{7}$ and sarcomatoiss TUMOURs ${ }^{8}$ on the spinal membranes, are still more rare. 
(1) Unpractised anatomists easily mistake the redness which the under surface of the fibrous coat frequently exhibits, as an indication of inflammation; which redness, however, generally arises merely from the numerous veins here situated, in which, by the position of the corpse on the back, the blood collects according to the laws of gravitation.

(2) The bodies found in the cerebral membranes, under the name of Pacchionic glands, or granulations of the brain, appear to be deficient in the spinal membranes.

(3) I have found, in a few instances, the dura mater of the spinal marrow thickened a few lines in spots, from the chronic inflammation arising from caries of the vertebræ.-Abercrombie, p. 365, mentions, from the London Med. Obs. and Inquir. Vol. III. a case of hardening of the spinal membranes; a less degree of thickening and opacity in the arachnoid of the spinal marrow, is not unfrequent.

(4) This adhesion of the dura mater with the spinal canal occurs most commonly in spina bifida. I have, however, occasionally seen it at different parts without this.

(5) I consider it rare, because I have never myself found it, and it is therefore much more rare than in the cavity of the skull. Examples are given by Morgagni, Epist. XXV. 9, (one as large as a gourd-seed.) - Sömmerring addenda to Baillie, p. 24.8, note 524, (almost cartilaginous, thickened, chalk-like spots.)Chaussier in Bulletin de la Faculté de Médec. Vol. V.p. 154, (bony concretions.) -Esquirol, $i b$. p. 426, (in an epileptic patient, many little bony plates.)-Horn in Archiv f. medicin. Erfahrung. March and April, 1813, p. 237, (many bony scales in a person who died of tabes dorsalis.) The same case is described and engraved in Hertel D. de cerebri et meningum tumoribus. 8vo. Berol. 1811, with engravings.-J. F. Meckel Handb. der menschlichen Anatomie, Vol. III. p. 603. - Brayne, in London medical Repository, July, 1820, (in two persons who died of tetanus.) - Swan, Observations on some points relating to the anatomy, physiology, and pathology of the nervous system, Cap. 7, London, 1822, (cartilaginous spots in one healthy, and another epileptic person.) - Lobstein Compte rendu, \&c. p. 54, (little cartilaginous laminæ.) - Ollivier, p. 344, (many pieces of cartilage in a woman.) - Velpeau in Archives générales de Médecine, Jan. 1825; and in Magendie's Journ. de Physiologie, 1826, No. 2, p. 138, (cartilaginous plates in a paraplegic person.) -- Barbier v. Abercrombie, p. 373, I saw cartilaginous plates on the spinal arachnoid coat, in the museum at St. Thomas's Hospital, London, in the museum at Pavia, and in the Anat. path. Mus. at Vienna. The nerves within the spinal canal had a chalky appearance, whilst situated in an abscess in this region. v. Harrison, in London med. and physical Journ. May, 1823, Vol. XLIX.-Ollivier, p. 344, also observed little bony concretions on the external surface of the spinal dura mater.

(6) Esquirol, p. 426, (many hydatids in a cyst of the arachnoid.)-Chaussier, in two cases; in one, between the dura mater and the spinal canal, and in connexion with a large hydatid cyst in the chest and belly; and Proces verbal, \&c. 1807, v. Journal de Médecine continué, Vol. XIV. p. 231; and in a note to the 40th letter of his edition of Morgagni De sed. et caus. morbor. new edit. Lutet. 1822. - Reydellet in Dict. des Scienc. médic. Vol. XXXIII. p. 564, (it arose from a tumour connected externally with the spinal canal.) - Mirault, in Ollivier, p. 360.-In a sheep, v. Fischer in Miscell. Acad. Nat. Cur. Dec. III. Ann. II. Obs. 53.

(7) Ollivier, p. 345 , in two cases. Cases from Bayle, Gendrin, and Harder are related by Abercrombie, p. 371 ; one case is also described by Serres, in Anat. comp. du Cerveau, Vol. II. p. 234.--Wittfeld in Horn's Archiv., May and June, 1827, (as large as a bean.)

(8) Knox in London medical Observations and Inquiries, Vol. III. p. 160, (fungus duræ matris.) - Philipps in New medical Journal, Vol. I. p. 144, (medullary sarcom of the membranes and the spinal cord.)-Horn in his Archiv f. medic. Erfahrung. 1815, Vol. V. p. 838, (a sarcomatous tumour on the dura mater of a person who died of tabes dorsalis.) - Reid in Transact. of the association of the King's and Queen's College of Physicians in Ircland, Vol. I. Dublin, 1817, (a 
white mass resembling brain, in a boy who died of tetanus.)-Ollivier, p. 175, (eighteenth case.) - Velpeau, (a reddish yellow tumour, of the consistence of brain, compressing the front of the spinal cord between the sixth and third cervical vertebra.-Doublis in Mém. de l'Acad. Roy. de Med. de Paris, Vol. I. 1828, No. 2, (according to the description, cancer between the layers of the arachnoid in the region of the tenth dorsal vertebra.)-Monod in Nouv. Biblioth. médic. May, 1827, (a lobular fibrous swelling between the arachnoid and pia mater.

\section{$\$ 244$.}

As FLurDs of different kinds are found collected between the cerebral membranes, so is this not unfrequently the case with the spinal membranes. Of course the MORBID contents are found in the bag formed by the arachnoid membrane; although not unfrequently also between it and the vascular membrane, which is here but loosely connected with it, and also sometimes between the dura mater of the spinal marrow and the spinal canal. As to the causal proportions of such extravasations, that which has been already said in reference to the cerebral membranes applies to those of the spine; we are not, however, to consider all the fluids here collected as the product of disease of the spinal membranes, as they may descend from the cavity of the skull and even from the cavities of the brain. ${ }^{1}$ Those preceding diseases which commonly are situated in the spinal marrow, as tetanus, epilepsy, paraplegia, $\& c$., great injection of the cerebral membranes and other conditions allow us to conclude sometimes with tolerable certainty on the primary and idiopathic affections of the spinal membranes. 'To the irregular contents of these membranes belong, first, coLLECTIONS OF AIR, ${ }^{2}$ which are in some cases here observed without any suspicion of putrescence; next, a large or smaller quantity of water and lymphatic fluid, a kind of DROPSY OF THE SPINE, hydrorrhachis, ${ }^{3}$ either as an acute or chronic disease; it may occur alone, or in connexion with dropsy of the head, and if in high degree, usually produces palsy by pressure on the spinal marrow; then pus, which is here collected either in ulceration of the spinal marrow and its membranes, ${ }^{4}$ or from the cavity of the skull, ${ }^{5}$ from carious vertebræ; ${ }^{6}$ as well also as effused from abscesses in the neighbourhood ; ${ }^{7}$ lastly, also BLOODY FLUID and PURE BLOOD in a fluid or coagulated form, arising both from injuries affecting the spine, and from internal causes. ${ }^{8}$

(1) According to Magendie, v. his Journ. de Physiologie, Vol. V. No. 1 and 2, 1. 27 ; Vol. VII. No. 1, p. 1 and 66 ; Vol. VIII. No. 2 and 3, p. 211.

(2) Ollivier, p. 269, calls it Pnenmalorachis,' and gives several instances of it; also Briere, v. Nouv. Biblioth. Feb. and March, 1826, observed it. 1 lave several times found air between the spinal membranes, but I would not venture to declare, as the bodies were not quite fresh, that the air was the product of an exhalation during life.

(?) Respecting the peculiar, or commonly only so called dropsy of the spinal canal, or spina biticli, see further on $\S 216$. On dropsical collections in the 
spine, v. Morgagni Epist. IV. 7, 21, 24, 30; V. 11; X. 13, 17; XI. 13, 15 ; XV. 6; XXI. 47 ; XXXVIII. 34; LIV. 49; LXI. 2, \&c.-Pet. Frank De curand. hom. morb. Lib. VI.-Copeland, Observations and symptoms of the diseased spine, \&c.-Itard in Dict. des. Scienc. médic. Art. Hydrorrhachis. Vol. XXII. - Ollivier, p. 248, and Abercrombie, p. 358. In order to show the collection of water, it is necessary to make a cautious opening of the spinal canal and skull. I have found this several times in animals; viz. in monkeys and dogs, especially in tubercular disease; in sheep with the gid; I have also found, in a stag which I kept for many years, and which at last was attacked with palsy of the hinder limbs, a considerable quantity of water in the spinal canal.- [I lately examined the body of a boy who had died of tetanus, and found four drachms of water in the araclinoid. T.]

(4) In a great number of persons who were bed-ridden, I have found the spinal membranes inflamed in the sacral region, and much pus collected between them.

(5) I have observed this in two instances; also in a man who had suppuration of the cerebral membranes after injury of the head, and in another man with cerebral abscess. A similar one to the last is mentioned by Denmark in Med. Chir. Trans. Vol. V.

(6) So also, in destruction of the spine, originating from intervertebral disease, as well also as from the bones themselves, pus is frequently effused into the canal of the spine, and produces paralysis of the lower half of the body, by pressure on the spinal cord. Similar cases are described by Brodie in Pathol. and surgical observations on diseases of the Joints. Cap. VI.; and Velpeau in Archives générales de Médecine. Vol. VII. March.

(7) I have seen lumbar abscesses occasionally without caries of the lumbar vertebræ effuse pus into the spinal canal through the intervertebral holes.Harrison found one psoas abscess communicating with another on the opposite side through the vertebræ. Effusion of pus from a psoas abscess into the vertebral canal is described by J. Jackson in New England Journ. of Med. and Surgery, Vol. V. Boston, 1816. From a cancerous ulcer, with palsy of the legs.-Franke in Kausch's Memorabilien der Heilkunde, Staatsarzneikunde und Thierheilkunde, Vol. III. No.6. From ulceration of the covering of the sacrum, Lisfranc v. Heidelberg klinische Annalen, Vol. IV. 1828 ; 'Supplement, p. 143. In horses and cattle, inflammatory tumours in the neck, and in horses, ulcers on the withers, sometimes effuse pus into the spinal canal. Compare $\S 135$, note 56 .

(8) Effusion of blood into the spinal canal appears by no means so rare as is usually supposed. I have seen it, not merely in four cases in persons who, in consequence of falling from a great height, were killed by concussion of the brain and spinal cord, and in a boy who had been struck violently several times upon the back with a piece of wood; but also frequently in apoplectic, or hanged persons, in one who died of tetanus, and in children which were destroyed in difficult delivery. We must however be careful in cases in which the blood is fluid, and often during the opening the spinal canal, effused from the numerous gorged veins which are wounded around the spinal marrow, not to mistake it for a morbid phenomenon. In a boy who had suffered severe concussion of the neck, ten months after, blood was found in the spinal canal. v. Howship, Practical Observations on Surgery, \&c. case 30; in a boy who died of hydrophobia, lumps of black blood found in the spinal canal, v. A.T. Thomson, Med. Chir. Trans. Vol. XIII. p. 2, 1827. In apoplexy the blood is sometimes found effused simultaneously in the skull and spinal canal, of which long since, Bonnet Sepulchret. Anat. Lib. I. Sect. II. p. 84, and Morgagni, Epist. III. 2 ; also, recently, Ollivier, case 32 . It also occurs in the apoplexia spinalis, or medullaris, in the spinal column alone.-Duverney v. Duhamel in Reg. Scient. Acad. hist. An. 1632, Sect. V. Cap. II. p. 264.-Boerhaave Prælect. ad Institut. $\$ 501 .-$ Brera and Harles Ueber die Entzündung des Rückenmarkes, p. 26, Nürnb. 1814. - Chevalier in Medico-chir. Transact. Vol. II. No. 9.-In a horse from violent exertion, v. Journ. de Médec. continut. P. 150, Feb. 1811. 


\section{B.-OF THE SPINAL MARROW ITSELF.}

\section{$\S 245$.}

The Formation OF THE SPINAL MARRow is sometimes IMPERFECT in a high degree; for although its total and congenital absence occurs only in those rare monsters of which the whole trunk is deficient ; $^{1}$ yet, in acephalous monsters, it is deficient at the upper part, in proportion to the deficiency of the neck, breast, and belly; and in those monsters of which the lower part of the vertebral column is deficient, so also is there absence of that part of the spinal cord. ${ }^{2}$ The spinal marrow, more commonly, seems to be absent, in which case, it has been so destroyed and its development so retarded before birth by dropsy, ${ }^{3}$ either in itself or its membranes, that there is often only. found a very imperfect rudiment of it, or merely of its coverings. The opposite vice, or an EXCESS of FORMATION, occur's only in double monsters, in which, with a double spine, their exists a double spinal marrow, or the single spinal marrow exhibits, at its upper or lower extremity, the trace of a corresponding duplication, according as the duplicity is at the upper or lower part of the body. ${ }^{4}$

(1) For instance, monsters consisting merely of a head, or one limb, though there appears sometimes, even in these, a rudiment of the spinal marrow, as in the cases of Rudolphi, read before the Academy of Berlin, June, 1S16;-and $J$. Iayn D. monstri unicum pedem referentis descriptio anatomica, Berlin, 1S24, with engravings;-even in the most shapeless monsters, which appear to be, as it were, merely a lump of flesh, with few or no intestines, traces of a spinal cord have been found, to wit, Bland in Philos. Transact. 1781, Part I. p. 363, and G. Vrolik Mémoires sur quelques sujets interessans d'Anatomie et de Physiologic, 4to. Amsterd. 1822. The account given by Clarke, in Plilos. Transact. 1793, Part II. p. 154-164, that in an accphalous monster, the spinal marrow and all the nerves were deficient, probably arose from an imperfect examination.

(2) As in the calves, No. 1009 and 1060, described by G. Sandifort, Museum anatomicum, Vol. III. p. 294. If in animals the tail be monstrously deficient, the extremity of the spinal cord is also wanting. Burdach observed this in a dog. v. Meckel's Archiv f. Physiol. Vol. IV. p. 80, and I have seen it in a dog, a calf, and a fowl, without the tail bones.

(3) Compare further on.

(4) The spinal cord divides at an angle for the two heads, or the two hinder limbs, into two equal parts, of which, however, where one head is smaller than the other, Sc., that branch of the cord is also smaller. Sometimes the cord is larger, previous to the point of division, and the indication of division shows itself by a groove in the central line. Those cases are rare in which, after having divided, the spinal cord again unites, and sometimes divides anew. v. Barliow Monstra animalium duplicia, etc. Vol. I. pl. 7, fig. 1, 4to. Lips. 1828 ; or in which the lower end of the spinal cord divided into two has a third, as it were, inserted. v. Barkow, fig. 2 ; or, lastly, when in a double mouster, in which both bodies are united by the trunk, the caudal extremity of one spinal cord is imperfectly attached to the other. v. 'Tichemann in his, and $\boldsymbol{H} . \boldsymbol{B}$. and $L . C$. Treviranus Zeitschrift für P'lysiol. Vol. III. Part I. pl. 3, fig. 2. 
$\S 246$.

The spinal marrow deviates, in various ways, from regular SIZE and FORM. In general, it corresponds to the length and form of the spinal column, thus may it be too long, too short, curved, \&c., in proportion to the other parts of the body; sometimes it is unnaturally THIN, either throughout or only at certain parts. This vice is sometimes original and congenital, especially in correspondence with monsters with deficient or distorted heads and limbs $;^{1}$ sometimes a later, that is, a morbid diminution, a wasting, occurs, as is commonly the case in DORSAL CONSUMPTION, tabes dorsualis or myelophtisis. $^{2}$ In the latter case the spinal marrow appears in some places indented, as it were knotty. ${ }^{3}$ Sometimes it is to a greater or less extent very thin, when it is COMPRESSED by the neighbouring bones, ${ }^{4}$ by the thickened intervertebral substance, by bony concretions and thickening of the membranes of the spinal marrow, by varicose swelling of the veins in the vertebral canal, by aneurysm of the vertebral arteries at their exit from their canals, ${ }^{5}$ by hydatids, and other swellings, ${ }^{6}$ and by fluids effused in the vertebral canal. The opposite vice, irregular size, is also sometimes observed, in which case the spinal marrow is, congenitally, EXTREMELY THICK at certain parts, ${ }^{7}$ or is morbidly swollen at one part, or lastly, it still remains in newborn children unnaturally LONG, as in the early stage of foetal existence, and extends more or less further down into the lumbar and even into the sacral region. ${ }^{8}$ The form of the spinal marrow is principally and most frequently affected by DROPSY OF THE SPINAL MARROW, hydrorrhachis, hydrorrhachia, which is also called CLEFT SPINE, spina bifida, when connected with an open state of the spinal canal. ${ }^{9}$ As the time of the origin of this disease, its extent, complication, and degree is different, so does also the state of the spinal marrow and its membranes vary remarkably. Naturally it is a congenital disease, connected with cleft of the vertebral canal, and is often naturally complicated with hemicephaly ${ }^{10}$ hydrencephalocele, ${ }^{11}$ and internal dropsy of the head, ${ }^{12}$ and is for the most part very fatal from paralysis $;^{13}$ in rare cases, however, it has been seen occurring after birth and even in adults. ${ }^{14}$ In the most severe form of the disease, the spinal marrow is entirely wanting, and we find merely the membranes fallen together, usually slit at one or more spots, or even more or less degenerated and adherent to each other, forming sometimes a closed sac filled with lymph. ${ }^{15}$ In the subsequent stages of this disease we observe also rudiments of the spinal marrow, little pultaceous masses of medullary substance and blood, or 
loose and separate nervous bundles, or the anterior columns running parallel but separate from each other, or the spinal marrow, as in the early state of the fœetus, open behind, broad and flat, \&c. In the milder and more common state of the disease there is found only on one, or very rarely on two, ${ }^{16}$ distinct spots, a more or less large swelling containing water, sometimes flat, sometimes semilunar or necked, the sides of which are formed by the expanded spinal membranes, often adherent and otherwise morbid, which are protruded through the cleft in one or more vertebræ, and commonly connected with the very thin and extended common integuments. ${ }^{18}$ The watery swelling is most frequently observed in the lumbar region, ${ }^{19}$ more rarely in the sacral, ${ }^{20}$ and dorsal, least commonly in the cervical, except in the case of coexisting hemicephaly or hydrencephalocele, in which the spina bifida always occurs in the neck, and from this point protrudes more or less outwards. ${ }^{21}$ The seat of the water is naturally in the spinal marrow itself, which at this part is very much expanded, broken up, and even entirely destroyed, and usually exhibits the canal, in its axis, open and expanded up to the brain; sometimes also the water is contained at the same time between the membranes of the spinal marrow, or in the most uncommon cases in them alone, whilst the spinal marrow itself is observed healthy, or merely compressed. ${ }^{22}$ Sometimes the swelling also contains hydatids. Lastly, dropsy of the spinal marrow occurs also in rare cases without any external swelling, and without cleft in the spinal column, so that the canal in the axis of the spinal marrow, which in man is naturally closed, becomes more or less widely expanded by the water, with coexisting increased thickness of the marrow itself, ${ }^{23}$ or the water is poured out only in the substance of the marrow itself, ${ }^{24}$ and one spot of the organ becomes distinctly swollen.

(1) In acephalous monsters, the upper extremity of the spinal cord often terminates, like the spinal column, very thin or pointedly; with the fore extremities the upper, with the hind extremities the lower enlargement of the spinal cord is deficient, and also with deficient limb on that side the enlargement is wanting. Serres found this in a child, a calf, and a lizard, of which the fore leg was wanting; and in two children, two cats, and a dog, without hind legs. v. his Anatomic comparée du Cerveau dans les quatre classes des animaux vertèbres. Vol. I. p. 107, Paris, 1824.-Tiedemann, p. 2, saw in a human monster without limbs, the spinal cord too small and thin by about half; -in a similar child, No. 2892 of my Verzeichn., I found it also very thin and without the enlargements. In other monsters with small limbs, it was very slender and without the enlargements; lastly, in a calf, of which the left fore leg was wanting, and which $I$ had kept alive two years, the cervical eulargenent was perfectly normal on the right, but totally wanting on the left side. v. No. 2312 of my Verzeiclin.

(2) The whole spinal cord is rarely atrophic throughout, but usually only a part of it, viz. the lower extremity.-Compare Schelhammer D. de tabe dorsali, Jenx, 1691.-Practical Essay on the Tabes dorsalis, London, 1748. - Brendel D. de tabe dorsuali, Goett. 1749, and in Opusc. med. cur. Wrisberg, Part 1I. p. 179, 
Goett. 1769.-Lewis, Essay upon the tabes dorsalis, London, 1758.-Pcrcy D. on the lues venerea, gonorrhoea and tabes dorsalis, London, 1787.-de Plouquet et resp. Williardts D. Exemplum singularis morbi paralytici, Tübingæ, 1806.Loewenhard D. de myelophtisi chronica vera et notha, 8vo. Berol. 1812, with plates.-Chr. v. Weidenbach D. de tabe dorsuali, with plates, Berol. 1817.Schesmer D. Tabis dorsualis adumbratio pathologica, 8vo. Berol. 1819, with plates.-Gossow D. de tabe dorsuali, 8vo. Berol. 1825.-Guil. Horn D. de tabe dorsuali prælusio, 4to. Berol. 1827; in which, besides the cases of Horn's, the individual cases of others are very well noted.-Koreff found the spinal cord extremely thin in a person who clied of paralysis. v. Magendie's Journ. de Physiologie, Vol. IV. p. 372 , Oct. 1824.

(3) This induced Gall to consider the spinal cord as a kind of ganglionic chain. $v$. Weidenbach has engraved a striking example of this kind at the lower end of the spinal cord. We not unfrequently find, without any disease, the spinal marrow terminating in one or two knotty tubercles. In a person who lad died in consequence of onanism, the spinal marrow was very much wasted, and the nervous threads seemed as if unravelled; the nervcus matter in the nerves of the cauda equina was also at the same time wasted. v. Rust's Magazin f. d. ges. Heilk. Vol. XXII. Part III. p. 476, with plates.

(4) For instance, if the spine be very much curved, has exostoses, some of the vertebræ dislocated, and is swollen or carious, as in spondylarthrocacy, \&c. compare $\$ 135$, note 43 and 51.-Further, Dubrevil in Ollivier, p. 192, and $C . H$. Paryy, (in both cases the origin of the spinal cord was compressed by displacement of the first vertebra.) - Abercrombie, p. 383, relates several similar cases.

(5) Howship, Practical Observations in Surgery and Morbid Anatony, Lond. 1815, p. 59.

(6) A tumour, originating from the cerebellum, descended into the vertebral canal behind the spinal cord, to the origin of the sixth cervical nerve. v. Latham in London Med. and Phys. Journal, new series, Vol. I. July, 1826.

(7) If the neck be very short, the upper enlargement of the spinal cord is lost in the brachial nerves, and the whole cervical portion is then, as in shortnecked beasts, extremely thicl. - Serres once saw in a monster without legs, but with very powerful arms, the cervical portion of the cord remarkably large.

(8) This is particularly frequent in the case of spina bifida, as I have several times noticed; and as many others have also found it, viz. Apinus v. Hochstetter D. de spina bifida, Altdorf, 1703.-Trew in Commerc. Lit. Norimb. 174i. Morgagni, Epist. XII. 16.-Hoin in Mém. de l'Academ. de Dijon, Vol. II. p. 106.-Hutchinson, in New London med. Journ. 1792, Vol. I. p. 338. Grashuys v. Neue Sammlung für Wundärzte, Part X. p. 180-J. F. Meckel Handb. d. Pathol. Anat. Vol. I. p. 354. - Béclard in Ollivier, p. 111.-Also, without cleft spine, viz. in two children without feet, but with tails, it went to the tail-bones; and in two cats and a dog without hind legs, but with extremely long and large tails, the spinal cord was much larger in the lumbar and sacral region than usual. v. Serres.

(9) Also hydrorrhachitis according to Sauvages Nosolog. metl. 4to. Vol. II. p. 497. - On the state of the spinal column in this disease, compare $\S 135$, and also its note 25 , in which are quoted several papers on spina bifida.-On the seat of the water, and the state of the spinal cord, compare Morgagni, Epist. XII. and Pet. Frank De curand. hom. morb. L. VI. Part I. p. 198, (he divides it into hydrorrhachia incolumis, and dehiscens, and the latter again into generalis and partialis, viz. cervicalis, dorsalis, \&c.)-Bodin D. sur le spina bifida. Paris, Ann. IX. p.8.-Terris Considerations générales et observations particulières sur le spina bifida in Journ. gén. de Médec. 1806, Vol. XXVII. p. 162.--Instances of sisters having spina bifida are mentioned by Orth $\mathrm{D}$. de quibusclam tumoribus tunicatis ext. in Haller's Coll. Diss. med. chir. Vol. V. p. 412.-Burgius in Ephem. Acad. Nat. Cur. Dec. II. Ann. VI. Obs. 58. - Henkel Neue med. u. chir. Anmerk. Part IV. p. 54; and Michaelis in Richter's Chir. Biblioth. Vol. XVII. p. 133.Of the very numerous cases, the most perfect are in Moeckel De hydrorrhachitide Commentatio. Lips. 1822. I mention only some of the most remarkable and novel, viz. Ruysch Obs. anat. chir. Obs. $34-36$; and Thesaur. anat. 
VIII. Part I. No. 2. - Littre in Mém. de l'Acad. des Scienc. 1701. - Bidloo Exercit. anat. chir. Dec. II. No. 7, with.plates, p. 187, pl. 1 and 2. - Mery, in Mém. de l'Acad. des Sc. 1712. Obs. anat. 6.-Trew.-Acrel in Svenska Vetensk. Acad. Handlingar, p. 287, 1748._Morgagni, Epist. XII.16.-Camper Diss. de hydrope in Diss. X. Vol. II. ; and Auserl. Abhandl. f. prakt. Aerzte, Vol. XVI. p. 446.-Böhmer Obs. anat. rar. Fasc. II. Præf. p. viii._Portal in Mém. de l'Acad. des Sc. p. 238, 1770 ; and Cours d'Anat. médic. Vol. II. p. 304._Sandifort in Obs. anat. pathol. L. III. cap. 1. p. 10; in Obs. anat. pr., in Exercit. acad. L. II.; and in Museum anat. with good engravings, tab. 124. - Hutchinson. - Siebold in Chir. Tageb. Nürnb. 1792. XXXIX. p. 84, etc. Recent cases in Callisen Systema chir. hodiern. Vol. II. p. 46, Havn. 1800.-Oberteuffer in Stark's Neuem Archiv f. d. Geburtsh. Vol. II. Part IV. p. 624.- Stoll v. Posewitz Journ. f. d. Med. u. Chir. Part I. Giess. 1802.-B. Bell, in System of Surgery, Vol. V.-Abernethy, Surg. and physiol. Essays, Part I. p. 75.-Okes, An account of spina bifida, with remarks on the method of treatment proposed by Abernethy, Cambridge, 1810. - Sherwood in Medic. Repository of original Essays, Vol. I. 1812-13.-Meckel Handb. d. pathol. Anatomie, Vol. I. p. 355 and 357.-Racchetti.-A. Cooper, in Med. chir. Transact. Vol. II. p. 324.-Lobenwein De monstrosa genitalium deformitate et spina bifida commentatio in Mém. de l'Academ. imp. des Sc. de Petersb. 1817, Vol. VI.-Pliny-Hayes, in New England Journal of Medicine and Surgery, Boston, July, 1817, (in the sacral region.)-Palletta Exercit. pathol. Cap. 10. Art. 3, Mediol. 1820. - Nenendorf D. de spinæ bifidæ curatione radicali. Berol. 1820, with observations by Berndt. - Vaccà Berlinghieri Storia di una idrorachia. Pavia, 1820.-A. F. A. Foerster D. de spina bifida, 8vo. Berol. 1820.-Bened. Trompei v. Omodei's Annali universali di Medicina. Vol. XV. Luglio, 1820; and Locock, in Edinb. med. and surg. Journ. Vol. XVII. p. 251, (the child lived to six years, and was punctured several times.) - Brewerton, ib. Vol. XVIII. p. 378, July, 1821, (a double spina bifida.) - Jukes, in London med. and phys. Journal, p. 106, Feb. 1822, (a very large tumour in a girl of nineteen). - Gittermann in Harles's Rhein. Jahrbuichern, Vol. V. Part I. p. 4.-Jos. Frank Prax. med. univ. præcept. Vol. I. Part II. Sect. II. cap. 4. $\$ 16 .-N_{y}$ blaeus in Abhandl. d. K. Schwedischen Akademie, 1822, Part II. p. 343.-Carus zur Lehre von Schwangerschaft u. Geburt. Part I. p. 227, 8vo. Leipz. 1822.-Dugés in Revue médicale française et etrangère. Paris, April, 1823, p.370.-Breschet v. Hasper in Hufeland's Journ. April, 1823, p. 59.-Urquhart in American medical Recorder, July, 1823. v. Gerson and Julius Magazin der ausl. Lit. Jan. and Feb. 1824, p. 131, (the large tunour burst, and death ensued,) - Baron in London medical Repository, Vol. XXI. No. 128, Aug. 1824, (the cyst was several times punctured, but filled again.) - Lindsay in London medical Repository, January, 1826, (the tumour was often burst, although the child was thirteen years old.)-Heusinger Berichte von der anthropotomischen Anstalt zu Würzb. 1st Treatise, 1826, p. 50.-Fuber Duor. monstror. humanor. descriptio anatomica. 4to. Berol. 1827, with two engravings.-Potthoff D. s. descriptionem casus rariss. spinam bifidam totalem et columnam vertebralem antrorsum insigniter curvatam exhibentis. Berol. 1827, with three engravings.-London medic. Gazette, December, 1827, (cured by puncture.) - E. A. W. Himly Darstellung des Dualismus am normalen und abnormen menschlichen Körper. p. 191, Hannov. 1829, (as big as a child's head on the sacrum). I have had three-and-thirty opportunities of examining spina bifida. v. my Selt. Beob. Part I. p. 66, No. 2313 of my Verzeichn., (in the lumbar region, cured); No. 2314, (in the lumbar region of a calf); No. 2955, (on the whole spine of a sheep); No. 3314 and 3315, (in the lumbar and sacral regions); No. 3316 , (sacral region); No. 3317 and 3318 , (in the lumbar region in two calves); No. 3319 , (on the extremity of the sacrum in a calf); No. 8011, (on the rump); No. 8869, (in the lumbar region); of Bresl. Mus. The other cases were connected with the vices of the brain.

(10) It is well known that half the hemicephalic monsters, both human and animal, have also spina bifida. In the Breslau Collection, such is the case with twenty-one such monsters, viz. No. 2868-2875, 2881-2S83, 2967, 2996, 3802, $3003,3041,8016,8017,8024,8063$, and 8833.

(11) Viz Bidloo, in the first case.-P'enada, in Saggio d'osservazioni c memoric, 
etc. Palova, 1793, T. I. Obs. 1.-van der Laar Observ. chirurg. obstetr. anat. med. L. B. 1794, No. 3.-Geoffroy Philosophie Anatomique, Vol. I. Yaris, 1822. - Seerig D. de hydrencephaloceles specimine eximio. 4to. Vratisl. 1822, with engravings, (is No. 2929 of Bresl. Mus.) - Burkart, D. de monstro humano notabili. 8vo. Friburg, 1825.-Merye, in Archiv. génér. de Méd. July, 1827.Potthoff.

(12) Boneti Sepulchret. anat. L. I. Sect. XVI. addend. Obs. 4. - Mayer in Ephem. N. C. Cent. 1. Obs. 127.-Brunner, ib. Dee. III. Ann. I. Obs. 152 and 11.-Murray, Fotus hydrocephalo interno correpti descriptio. Upsal, 1797.Stoll Ratio Medendi, Part VII. p. 217._Morgagni Epist. XII. 9.—Grewe, v. Samml. auserles. Abhandl. f. prakt. Aerzte, Vol. VIII. p. 584.-Fielitz in Richter's Chir. Biblioth. Vol. IX. p. 155.-Portal, Baron, Pliny-Hayes, and Vaccà Berlinghieri. This connexion is so eommon, that Acrel has improperly imagined it to be continual.

(13) There are, however, many instances given of such children living several years, and even reaching puberty, viz. one of the cases mentioned by Acrel and Palletta was seventeen years-eighteen, Henderson's-nineteen, Jukes's-twenty, in one of Apinus, Hochsietter, Sc.; Warner's Observations in Surgery, p. 136. London, 1784,-twenty-eight years with spontaneous separation by gangrene, in a case of Camper's - even fifty years, v. Schwagermann, Ontleedheelkund. Verhandel. Amst. 1767.

(14) Pet. Frank. Delect. Op. Med. Vol. II. p. 9\%. Lipsiæ, 1791, (in a man forty-five years old.)-Reydellet, in Dict. des Sc. Méd. Vol. XXXIII. p. 564, (in an adult from hydatids.)

(15) I have seen this in several hemicephalic monsters-a similar state of the spinal cord oecurs, however, without cleft of the spinal column, v. Mery in Mém. de l'Acad. des Sc. 1704. p. 29. - Morgagni Epist. anat. XX. p. 56.-Anselin in Journ. de Médec. Vol. XXXV. p. 336.-Saxtorph Gesammelte Schriften u. s. w. Vol. I. p. 477. 4to. Kopenh. 1803.-G. Lieber D. Monstri molæ specimen præ se ferentis descriptio anatom. 4to. Berol. 1821, with plates, (the brain and spinal cord were entirely wanting, and there was merely a membranous bag in place of bone, the lympl contained in which, had either become absorbed by remaining in spirits of wine, or had flowed out during the examination.)

(16) P. Frank De cur. hoin. morb. L. VI. Part I. p. 215. - Brewerton in Edinb. mel. and surg. Journ. Vol. XVII. p. 378, (two cysts in the lumbar region lying close to each other, and opening by two apertures into the spinal canal.)

(17) The size of the cleft in the spine varies very consicierably; generally several of the vertebræ are open, more rarely but one, or there is found only a small round hole in one bone, by which the tumour is connected with the spinal canal. v. Ruysch, Observat. anat. Chir. Obs. XXXVI. and Acrel. Those cases are also equally rare, in which, with tlie bones healthy, the tumour projects between the vertebræ. v. Mohrenheim and Portal.

(18) In many cases the tumour falls together, as it were cicatrizes, the skin thickens, inflames, adheres, is discoloured by coagulated blood, \&c. - In other cases it is tense, and varies from the size of a nut to that of a child's head, or thereabouts, and expands to bursting or mortification.

(19) This arises from the circumstance, that at the period of the usual origin of this disease, the spinal canal at this part is constantly widened; and that in the later origin and situation of the water within the cavity of the arachnoid, the lower end of the sheath comprises the dura mater.

(20) Although by no means so rare as Ruysch and Morgagni, Epist. XII. 9, lrave supposed. Sometimes the tumour includes the lower end of the spinal canal, which is often deficient at this part.-I have seen this twice, in calves without tails.-van Doeveren also observed it in a calf. v. Specimen Observ. acad. 4to. L. B. 1765, pl. 4 , fig. $2 .-V$ rolik also saw it in a child, with other malformations. v. Mémoires sur quelques sujets interessans d'Anatomic et de Physiol. Amsterd. 1822, p. 76 and 77 , with plates.

(21) The dropsy of the cervical portion of the spinal marrow is then only a process from that of the brain, and the degenerated brain is immediately connected with the destroyed or diseased origin of the spinal marrow, which is sometimes 
perfectly normal below. In this simultaneous destruction of the cervical portion of the spinal marrow, whence the nerves of the neck arise, lies, according to my opinion, the cause of the frequent want, or the extreme shortness of the nech in hemicephalic monsters. This is confirmed by the fact, that in those hemicephalics, in which merely the brain, or only the cerebrum, is diseased or destroyed, the neck is always proportionally long.

(22) Such observations are described by Zwinger in Ephem. Acad. N. C. Cent. VII. Obs. 29. - Linck in Act. Nat. Cur. Vol. I. Obs. 74. - Huermann Vermischte Bemerkungen u. Untersuchungen a. d. ausübend. Arzneiwiss. Vol. I. 1. 304.-Acrel, Palletta, Vaccò-Berlinghieri and Urquhart.

(23) For instance, Morgagni Adv. anat. VI. Obs. 14, p. 18 ; and Santorini, il)., (as large in an adult as to admit the point of the little finger.)-Porlal in Mém. le l'Acal. de Sc. 17:2, p. 4\$1, (in an adult); and Cours d'Anat. Med. Vol. IV. 1). 66, (in a new-born child); and p.118, (in an adult.) - Not merely in hemiceplialy and hydrencephalocele have I found the upper part of the spinal cord very broad, hollow, and containing water; but also in hydrocephalic children; and in two calves with very large dropsical heads, the canal of the spinal cord was much expanded with water throughout its whole length. - Gall's observation of two lateral canals in the spinal cord, seems to me not to be entirely relied on. v. Anat. et pliysiol. du Systême nerveux, p. 51.

(2.) P. Frank De cur. hom. morbis. L. VI. Part I. p. 202, observed it twice. And I once found, in a dropsical person, portions of the spinal marrow swollen, and oedematous, some inches in lengtl.

\section{$\S 24 \%$.}

A vicious position of the spinal marrow arises, in rare cases, from the already mentioned hydrorrhachis, so that the spinal marrow expanded by the water itself, or compressed by the collection of water between the membranes, is more or less protruded through the cleft in the spine, and thus a kind of RUPTURE OF THE SPINAL MARROW, hernia medulle spinalis, is produced. ${ }^{1}$ Those cases are more rare in which the spinal marrow deviates a little from its natural position in consequence of morbid destruction of its bony walls. ${ }^{2}$ As to colove, the spinal marrow varies sometimes in a similar manner as the brain, and in vices of texture it seldom exhibits the natural colour; we find it also, but rarely, however, discoloured without change of structure, for instance, yellow in jaundice. ${ }^{3}$ More frequently is the consistence of the spinal marrow irregular, inasmuch as it becomes soFTENED, pulpy, even entirely broken up and mingled with blood, ${ }^{3 *}$ generally, or more commonly only in spots, in consequence of diseases which destroy its coherence, especially dropsy, suppuration, inflammation. ${ }^{4}$ Or on the contrary, it becomes too FIRM and HARD; the latter we observe in a less degree, and with diminution of the circumference, in dorsal consumption, with thickening also in chronic inflammation of the organ. ${ }^{5}$ In consequence of the protected situation of the spinal marrow, diminution of consistence does not give rise to vices of CONTINUITY, but these originate either in penetrating, cut, and thrust, and especially in gunshot wounds, or without such wounds in fiacture and 
dislocation of the vertebræ, ${ }^{6}$ as well as also from mere extension and concussion." In such cases the marrow sometimes protrudes largely through the opening in the pia mater. Small wounds of the spinal marrow may in rare cases even heal. ${ }^{8}$

(1) For instance, Tulpius in Observ. med. L. III. cap. 29 and 30.-Apinus in Ephem. Acad. Nat. Cur. Dec. III. Ann. IX. Obs. 180; and Hochstetter.Hoin in Mémoires de l'Acad. de Dijon, Vol. II. - Sandifort. - Mohrenheim Beobachtungen verschied. chir. Vorfälle, Vol. I. p. 172. - Palletta. - Moeckel, fig. 3. - Carus Zur Lehre von Schwangerschaft und Geburt. Part 1. p. 227. - I liave found this dislocation in three instances. - More commonly protrusion of the spinal nerves is seen, which project far out of the spinal canal, and are lost on the walls of the tumour. - A few instances also have been found, in which, through a cleft in the bodies of the vertebræ, a part of the œsophagus had slipped into the vertebral canal, and displaced the spinal cord. v. Lallemand Observations pathologiques, p. 29, Paris, 1818, with plates ; and Geoffroy SaintHilaire in Annales des Sciences naturelles, Vol. XIII. p. 246, March, 1828.

(2) Ferro De carie vertebrarum et medulla spinali libere in abdomine fiuctuante historia in Nov. Act. Acad. Nat. Cur. Vol. VIII. p. 123.-Lecat Traite du mouvement musculaire, Vol. XXII. tab. 3. Berl. 1765.-Phillips in New London medic. Journal, Vol. I. Part II. p. 2. 1792; compare Richter's Chirurg. Biblioth. Vol. XV. p. 77.

(3) Lobstein on Kirrhonose in Compte rendu sur les travaux anatomiques, p. 53, and in Répert. général d'Anat. et de Physiol. etc. Vol. I. No. I. p. 143. pl. 4. Paris, 1826. Compare above $\$ 39$, note 2 .

(3*) [Effusion of blood into the centre of the spinal cord opposite the last dorsal nerves, after violent exertion, death in thirty-seven days. v. Nouv. Bibl. Méd. Nov. 1829. T'.]

(4) Ephem. Acad. Nat. Cur. Dec. II. Ann. VI. Obs. 58.-Morgagni, Epist. LXX. 5, (very soft in a person who died of scirrhus pylori.)-J.P. Frank De curand. hom. morb. L. II. p. 49, (as suppuration.)-Gautier de Claubry in Journ. gén. de Méd. par Sédillot. Voì. XXXII. June, p. 129.-Portal Cours d'Anat. méd. Vol. IV. p. 116, (in the right half.)-Horn in his Archiv f. medic. Erfahrung. 1815. Part V. p. 838 , (pultacecus in a person who died of tabes dorsualis.) Esquirol in Leroux Journ. de Médec. 1817, Vol. XXXIX. p. 424, (in many epileptic persons, especially the lower extremity.) - Dublin Transact. of the Association of Physicians, Vol. I. p. 1, (two cases which died of tetanus.)Georget De la Folie, p. 492. Paris, 1820.-Rostan Recherches sur une maladie encore peu connue, qui a reçu le nom de ramollissement du Cerveau. Paris, 1820, (six examples.) - Pinel in Magendie's Journal de Physiol. Vol. I. No. 1, p. 54, (in two insane persons, the greater part dissolved.) - Rullier, ib. Vol. III. No. 2, p. 173. - Harrison in London med. and phys. Journ. Vol. XLIX. May, 1823, (two psoas abscesses communicated with the vertebral canal.) - Ollivier, cases 43-46, 48 and 50.- Serres in Magendie's Journ. de Physiologie, Vol. V. No.3, p. 254; and in Archives générales de Médec. August, 1825, (the anterior columns of the spinal cord in a paraplegic patient.) - Hertzberg in Rust's Magazin f. d. ges. Heilk. Vol. XX. Part II. p. 376, (the lower half.) - Ahlberg and A. Retzius in Ars-Berättelse om Svenska Läkare-Sällskapets Arbeten, lemnad af Ekström, 1825, (in a man who had paralysis without loss of sensation in the feet, the anterior columns were softened in their lower third.) - Royer Collard, v. Magendie's Journal de Physiologie, Vol. III. No. 2, p. 157, April, 1823, (the anterior columns of the spinal marrow of a man whose legs had been motionless and bent up seven years, but in which there was still sensation.)-Louis Mémoires ou Recherches anat. pathol. Paris, 1826, p.410, (several cases with caries of the spine.)-Jeffreys in London medical and physical Journal, July, 1826, (three cases of softening after fracture of the vertebrx.) - Fuchs, communicated by Locher Balber, in Hecker's Liter. Annalen d. ges. Heilk. Oct. 1826 , 1). 244, (pultaceous in two children who dicd of hydrophobia.) - Vering in l'ust's Magazin, Vol. XXII. Part II. p.562, (some time after the injury.) - T'hom. Molison in Transact. of the med. chir. Soc. of Edinburgh, Vol, III. Part I. 1. 173, 
(in a man with aneurysma aortæ.) - Gendrin Histoire Anatomique des Inflammations, case 150.-I'enables Dissect. II. p. 99, quoted by $v$. Stosch Versuch einer Pathologie u. Therapie des Diahetes mellitus. Sro. Berl. 1828, p. 10t, (in a diabetic person, softened and hardened here and there.)-Nouvelle Biblioth. Aug. 1823, (witl 1 caries and tubercles in the vertebra.) - Abercrombie, case 126-129, p. 341 and 346.-I have several times observed softening of the spinal marrow to a high degree, especially accompanying caries of the spine, although twice also without it; the first case was a person affected with scurvy, who had been very much chilled in bathing, and became paraplegic; the other was a man of whom I could learn nothing more than that he had become paraplegic. [Hart in Dublin Hosp. Rep. Vol. V. p. 522 ; an abscess in the centre of the spinal ntarrow of a child extending throughout the whole dorsal portion. T.] 'This disease also occurs in animals, viz. in epizoetics, in the dorsal disease of horses, in tubercular disease, and from unknown cause, with paralysis of the legs. Sagar thus found it in a clisease among sheep, v. Auserles. Beiträge zur Thierarzneik. Vol. I. p. 49 ; in horses, v. Dupuy in Journ. gén. de Médlec. 1820 ; and in a rabid cow, Jan. 1821, Vol. LXXV. p. 82. - Compare also Lallenand Recherches Anatom. pathol. sur l'Encephale et ses Dependances, (extremely distinct in the enlargements of the spinal marrow, especially in the lower, in horses.) -- Greve Erfahrungen und Beobachtungen über die Krankheit. der Hansthicre, Vol. II. p. 6, (in a horse, to the length of four ells, and as thin as milk.) - Barthelemy, v. Archives gén. de Médec. Aug, 1823, (in a rabid horse.)--Bouiey in Recueil de Médec. vétérin. Vol. I. p. 2S, (the anterior column of the spinal marrow in a horse, with palsy of the hind leg.)

(5) The ancients called this in part scirrhus. - Portu!, (the cervical portion of the cord as hard as cartilage.) - Lond. Med. Obs. and Inq. Vol. III. (in the Count de Lordat, the cervical portion swollen and hardened.) - Clot Recherches et Observations sur le Spinitis. Montpell. 1S20, (the cervical portion swollen and of cartilaginous firmness.) -- Bergamaschi Sulla Mielitide stenica, \&c. Pavia, 1820, (sccond, fourth, and eighth cases.) - Velpeau in Revue Médic. franç. et étrang. Vol. II. p. 247, (the lumbar enlargement like cartilage.) In epileptic and insane persons, the spinal cord has been found several times too hard. v. Esquirol and Pinel. - Ollivier, p. 301. -- Gendrin, Vol. II. 1. 137, case 150 , (hardened and softened in spots.)

(6) On injuries of the spinal cord and its membranes, I refer to the writers on surgery and forensic medicine, also to Ollivier and Abercrombie: Autenrieth D. Observ, de læsione neclullæ spinalis. Tubingæ,1811.--Pallelta Exercitationes pathologicæ, p. 231, and Casper Uëber die Verlezzungen des Ruckenmarks und ilır Lethalitätsverhäiltniss in Rust's Magazin, Vol. XIV. Part III. und besonders abgedruckt. Berlin, 1823. I have myself seen the spinal marrow suashed, in three cases, in which workmen had fallen from great heights, and the vertelur:e of the neck were broken, and, in one instance, half torn through by a bullet. In the account of the morbid examinations kejt at the Breslan MIedical College, I have also found three cases of injury of the spinal marrow, in one of which, a bullet, passing throngla the dorsal portion of the spine, had torn the spinal cord through ; in the second, a bullet had torn through one vertehral artery, and the whole of the spinal narrow in the first vertebra; and in the third case, the bullet had so torn the cord in the lower part of the back, that only one little nervous band connected the upper and lower portions: in all these eases death cnsued either immediately, or very soon after, but in the latter, the man lived half a year. Sometimes, from a fill or from a blow, fic. we find the spinal cord torn through, either with or without rupture of the nembranes, v. E. Home, Philos. 'Trans. 1S1.t.--1I. Cline, in the case in which he first removed by operation a part of the broken vertebra. - Mayward, in New Lngland Journ. of Medicine and Sulgery, Boston, Jan. 1815, Vol. IV. No. 1, (in the dorsal region, the man (lied on the nineteenth day.) -- Rust, in Maratz 1. ges. Heilk. Vol. Xlll. l'art 111. p. 5i.1, (cut through, as it were, by the fracture of several vertebra.) -Sinan, Olserv. on the Anatomy, Physiology, and Pathology of the Nervous System, Chap. 8, London, 1822, (fracture of the second dorsal vertebra, with division of the spinal marrow, fatal on the fourteenth day.)--Wrallace in Dublin 
'Transactions of the Association of Pliysicians, Vol. V. 1828, (from a fall out of window, fracture of the third and fourth dorsal vertebre, and the extremities of the spinal marrow, half an inch apart; died on the ninth day.)

(7) It is thought that in partus Agrippinus, if the feet are violently pulled, death often ensues hy rupture of the spinal marrow, which is probable, as midwives and bunglers have pulled off even the head. One person, who behaved horribly by seizing hold of the neck, tore through the medulla oblongata without injuring the bones. v. G. Bonsdorf resp. Wegelius De anatomicam Veneficii arsenico peracti investigationem sistens. 4to. Abo, 1817. - By a fall on the head the spinal marrow was torn from the skull. v. von Walther in his ant v. Grïfe's Journ. f. Chirurg. Vol. III. Part II. p. 199. - The spinal marrow was torn through in a child which was run over, although it lived thirteen months after, and died of the croup. v. C. Bell, Observations on Injuries of the spine, \&c. 4to. London, 1824.

(8) The experiments on animals by Arnemann. v. Versucle iiber das Gehirn und R. M. p. 195, von P'revost, Larrey and Flourens. v. Heusinger's Zeitschrift für die organische Physik. Vol. II. Part III. gives instances of cicatrization of wounds of the spinal marrow; perhajs here also belong the cases of the human subject mentioned by Morgagni, Epist. LIII. 23, and Boyer Traité des Maladies chirurgicales, Vol. VII. p. 9.

\section{$\S 248$.}

Vices of texture of the spinal marrow are generally similar to those of the brain. In most instances, INFLAMmaTION OF THE SPINAL MARROW, myelitis, ${ }^{1}$ which occurs partly as consequence of injuries and diseases of the vertebræ and their ligaments, partly as an idiopathic disease, in greater or less connexion with its membranes, gives rise to them. The seeming apoplectic effusion of blood in the tissue of the spinal marrow itself, frequently arising from congestion of blood, and from morbid irritation, must be distinguished from this active inflammation of the spinal marrow. ${ }^{2}$ The diseases in which the spinal marrow exhibits, especially, the traces of existing irritation and inflammation are, many fevers ${ }^{3}$ and eruptive discases, ${ }^{4}$ hydrophobia, ${ }^{5}$ painter's colic, ${ }^{6}$ epilepsy, ${ }^{7}$ trismus, ${ }^{8}$ tetanus, ${ }^{9}$ St. Vitus's dance, ${ }^{10} \& \mathrm{c}$. The spinal marrow in such cases often exhibits a rosy-red colour with some dusky spots and streaks, enlargement of the minute vessels, injection of its membranes, oftentimes distinct swelling, and always more or less variation from its usual consistence, namely, hardening or more commonly softening, or complete dissolution into a discoloured fluid frequently mingled with blood. More rarely does the inflammation of the spinal marrow appear to run into true suppuration ; ${ }^{11}$ small abscesses even have been found in it. ${ }^{12}$ Still more unfrequently does gangrenous destruction occur on the spinal marrow; never indeed primarily, but only in defined spots: the deposition of lime on it does not seem ever to take place. Spurious formatrons in the spinal marrow are very uncommon, viz. tumours, tubercles, and sarcoms. ${ }^{13}$ In a few instances, only, have cxtrancous bodies been observed to remain for some time in this organ." 
(1) Called also Rhachialgia, Rhachialgitis, Spinitis, Notaëomyelitis, \&c.; and perhaps most significantly Rharhiomyelitis. v. Galenus De locis affect. Cap. VI.Allen Synopsis univ. Med. Part I. p. 165.-J. P. Frank Oratio de vertebralis columnæ in morbis dignitate. Paviæ, 1791, and De curand. hom. morbis. L. II. $\$ 141$, ff. p. 48.-Haefner D. de inflammatione medullæ spinalis. Marburg, 1799.-Bergamaschi Osserv. sulla inflammazione della spinale midolla, Sc. 4to. Pavia, 1810.-Brera Della Rachialgite cenni patologici in Atti dell' Academia Italiana di Scienze, Lit. e Art., Vol. I. Part I. p. 246, Livorno, 1810; and Brera and Harles, Ueber die Entziindung des R. M., from the 2d Vol. of IIarles's Jahrb. de Med. und Chir. abgedrucht. Nürnb. 1S14. - Nieb Sur le Spinitis in Corvisart's Journ. de Médec. 1812. - Spangenberg in Horn's Archiv f. med. Erfahrung. 1813, p. 4.-Macari in Annales de la Soc. de Médec. de Montpellier, Vol. XX. p. 5.-Ronander in Svenska Läkare-Sällskapets Handlingar. Vol. VI. p. 224, (a case of inflammation of the brain and spinal cord in a man.) - Funk Die Riickenmarksentziindung, inaugural Treatise, 2d edit. Svo. Bamberg, 1819, with adclitions. Bamberg, 1825. - Klohs D. de myelitide, Halæ, 1820. - Clot Recherches et Observations sur le Spinitis. Montpellier, 1820._Pinel in Magendie's Journal de Physiologie, Vol. I. No. I. p. 54.-Nybläus in Abhandl. der K. Schwed. Akademie, Jahrg. 1822, Part II. p. 343.-Sonnenkalb in der Dresdner Zeitschrift für Natur-und Heilkunde, 1823, Vol. III. Part I. p. 65-110.-L. Wolf Beobachtıng einer chronischen Entzïndung des R. M. mit ungewöhnlichem Ausgange, nebst Bemerkungen darüber. Hamburg, 1824._Friederich D. de myelitide. 8 vo. Berol. 1825.-Graf De Myelitidis Nosographia. 4to. Regiom, 1823, (with two cases of his own.) - Machiewitz Observationes de rachialgitide, pneumoniam et præsertim pleuritidem dorsalem mentiente in Comment. Soc. phys. med. Mosquens, Vol. III. Part II. p. 158, Mosquæ, 1825, (three cases.)-A case of inflammation of the spinal marrow, with enlargement and softening from rupture of four nerves of the brachial plexus, is described by Flaubert in Répert. gén. d'Anat. et de Physiol. pathologiques, Vol. III. Part 1. p. 102, ff., 1827.-Gassaud in Journal univ. des Scienc. medic. April, 1828.-Compare also Reydellet in Diction. des Scienc. médical. Vol. XXXIII. p. 538, Rachetti, Ollivier and Abercrombie.

(2) I have twice seen this in the cervial region of old persons : in one case the blood was in little spots in the spinal marrow; in the other, in a spot where the marrow was softened and torn, a lump of blood was formed almost as big as a pea; in both cases there was also effusion of blood between the membranes, and the vertebral veins very much expanded.- Home, in Phil. Trans. 1814, found blood effused within the spinal marrow from external injury.-Ollivier, p. 241.-Jones saw great injection of the surface of the spinal marrow with diminished sensation. v. Edinb. med. and surg. Journ. Vol. XXI. p. 81 and 83.

(3) Chaussier, Girard (in oxen and sheep.) Ollivier, p. 375, in the latter. I myself have seen, in a few cases of typhus, the pia mater and adjacent spinal cord strongly injected; similar cases are also described by Brera and Rachetti.

(4) I have seen this very distinctly in a person aged twenty-two years, who died of malignant small-pox.

(5) Matthey in Journ. gén. de Méd. Vol. XLIV.p. 279.-Johnson in London med. chir. Journal and Review, October, 1827.-Clot.-Trolliet Nouv. Traité de rage, ctc. v. Ollivier, p. 373.-Meniere in Archiv. général. de Médec. Decemb. 182S. - In oxen and horses, Dupuy and Barthelemy.

(6) Astrue and Sauvages were previously of this opinion, which has been confirmed by recent observations. v. B. P'ulais 'Traité pratique sur la colique metallique, etc. Paris, 1825 , and Renauidin in Journ. Compl. du Dict. des Scienc. Méel. Vol. XXII. p. 247.

(7) The older writers, for instance, Fr. IHoffmam, had already derived convulsions from diseases of the spinal marrow, and Harles mentions an epilepsia spinalis.Pnchelt also Die individuelle constitution und ihr Finfluss auf die Entstehung und den charakter der Krankheiten, Leipz.1823, an epilepsy of the spinal marrow.Essquirol, v. Leronx Journ. de Médlec. 1817, Vol. XXXIX. 1). 124, frequently found the spinal marrow in a state of irritation in epileptic persons. Swan also found the spinal membranes inflamed in a child who died of convulsions, and adherent 
in a case of epilepsy. v. Observations on some points relating to the anatomy, physiology, and pathology of the nervous System, London, 1822, Chap. 7.

(8) J. Thomson found in all the negro children who died of trismus, in Jamaica, the spinal cord and its membranes inflamed. v. Edinb. med. and surg. Journ. No. LVII. 1818, Nov.-d'Outrepont also found the same in five children. v. Abhandl. und Beiträge Geburtshülfl. Inhalts, Part I. p. 24.2. Würzburg, 1822.

(9) It is well known that heretofore Galen, Willis, Fr. Hoffmann, Burserius, and subsequently Marcus and many others, derived tetanus from affections of the spinal marrow ; and indeed, at other times inflammation of the spinal marrow and tetanus have been considered identical. Tetanus has been seen to arise after violent concussion of the spinal cord, v. Stoll Ratio Medendi, Vol. I. p. 298, and $J$. P. Frank, p. 276. Traces of violent irritation and inflammation were found in tetanus by Brera Prospetto di risultamenti ottenuti nella clinica medica dell' Università di Padova nell' Anno 1816 e 1817.-Reid in Dublin Transact. of the Association of Physicians, etc. Vol. I. p. 1, and On the nature and treatment of Tetanus and Hydrophobia. Dublin, 1817. - Bergamaschi Sulla mielitide stenica, ossia inflammazione della midolla spinale e sul Tetano, loro iclentita, metodo di cura e malattie secondarie che ne derivano, Osservazioni. Pavia 1820.-Duncar, jun. in Edin. med. and surg. Journal, Vol. XVII. p. 332.-Parent-Duchatelet and Martinet Recherches sur la Meningitis, etc. Paris, 1821. - Speranza in Anno clinico medico. Parma. 1823-24.-Pelletier in Revue médicale franç. et étrangère, 1827, Nov. and Decemb.-Blasius in Rust's Magazin f. die gesammte Heilk. Vol. XXVII. Part I. p. 53.

(10) Harles's, p. 41, 57, 58.

(11) In a case of pædarthrocacy, I found the pia mater of the spinal cord inflamed, thickened and ulcerated at the diseased part ; in fractures of the vertebræ it has also been seen inflamed and suppurating. v. Jeffreys, in London med. and phys. Journ. July, 1826.-Destruction of a portion of the spinal marrow by suppuration in psoas abscess, which had been effused into the spinal canal, is related by Jackson. v. Neue Samml. auserl. Abhandl. z. Gehr. prakt. Aerzte, Vol. VI. Part III. No. 1.-Spontancous suppuration was seen by Brera in many cases; it was completely destroyed, togetler with the seventh dorsal vertebra, by suppuration in a case of Heckscher's. v. Wolf. p. 142.

(12) Velpeau in Revue médic. franç. et étrang. Vol. II. p. 247, (an abscess in the right column of the cervical portion of the cord, three inches long and a couple of lines broad, and a smaller one in the left column.)-Gendrin.

(13) Phillips in New London med. Journal, 1792, Vol. I. p. 144, (a medullary sarcom of the spinal marrow and its membranes.)-Loewenhard D. de myeloplithisi chronica vera et notha, 8 vo. Berl. 1817, with plates, (a sitrcomatous tumour.) - Cerutli in Pathol. anat. Museum, Vol. I. Part II. p. 23, pl. 10, (a hard yellowish tumour in the cervical portion, as large as a pigeon's egg, indeed a tubercle.) -Sonnenkalb in Dresdner Zeitschrift für Natur-u. Heilk. Vol. III. Part I. (is the last case.) - Wolf, p. 20, (a large medullary sarcorn, which had projected from without, and formel two tumours on the spine.)-Velpeau in Archives général. de Médec. 1825, Jan. (a flat yellowish red growth on the front of the spinal marrow, between the sixth cervical and third dorsal vertebra.)

(14) The broken point of a dagger was seen by Cuvilliers, and communicated by Ferrein in Mém. de l'Acad. des Sc. 1743, Obs. 9, Collect. acad. Vol. IX. in 4to. p. 233. A small shot in the spinal marrow of a bird. v. Eplrem. Acad. Nat. Cur. Dec. II. Ann. X. Obs. 34 .

\section{Third Chapter.} Of the Nerves.

$\S 249$.

'The NERVEs, ${ }^{1}$ although generally subjected to few vices of structure, exhibit no less, in rare cases, variexuss in respect to 
their number, origin, course, comnexion, \&c., of which we shall here notice the most important. The total WANT of NERves never seems to occur in monsters, however imperfect they may be, as the organs which are formed always possess some nerves. ${ }^{2}$ Frequently, however, is there a WANT OF SINGLE OR SEVERAL NERVEs, as, not merely in monsters of which certain parts are deficient, the nerves which are naturally appropriated to or are connected with them are totally or partially missed, ${ }^{3}$ but even in those which are present and are imperfectly formed, as in deficiency of the mass of muscles of the limbs, the nerves are deficient. ${ }^{4}$ Most frequently are the ANTERIOR NERVES OF THE BRAIN deficient, and principally indeed in those monsters with imperfect formation of the nose, the eyes, and the face ${ }^{5}$ we also see, especially in such monsters, the OLFACTORY NERVES deficient ${ }^{6}$ this, however, occurs also, in rare instances, in otherwise well-formed persons. ${ }^{7}$ The optic NERVES stand also in a similar relation to the eyes, so that when these are entirely deficient, both optic nerves are also absent $;^{8}$ but if the eye on one side only be wanting, the nerve on that side is alone deficient, ${ }^{9}$ and also in cyclopic malformations, according as the consolidation of both eye-balls varies, so does that of the optic nerves into one. ${ }^{10}$ VICES OF THE THIRD, FOURTH, AND SIXTII pairs of Nerves, as well also as the FIRST branch of the FIFTI PAIR, are also usually connected with the total want or the deformity of the eyes. ${ }^{11}$ In one cyclopic monster with nearly total absence of the face, the FACIAL NERve did not exist. $^{12}$ In very imperfect organs of hearing, the AUDiTory NERVE has been missed. ${ }^{13}$ Where the tongue has been deficient, there has been noticed not merely deficiency of the LINGUAL BRANCII OF THE FIFTH PAIR OF NERVES, but also of the Muscular lingual nerve. ${ }^{14} \quad$ The opposite vice or excess of number of the nerves, occurs, when we notice, as is proper, the uncommon and too early division of a nerve into its branches, not, however, but with excess of the parts with which it is connected, ${ }^{15}$ and this is then generally to a certain extent dependent on their form; thus, for instance, with a supernumerary vertebra we have a spinal nerve too many; a sixth finger, which is perfectly organized, has also an uncommon digital nerve, \&c.; in double monsters, of which the head, belly, or limbs, are simultaneously consolidated of two, we find in their parts, according as they differ in the greater or less degree of their consolidation, the nerves either completely double or divided, or donble and anastomosing at certain points, or lastly, double at their origin, but passing singly from their junction. ${ }^{16}$ Lastly, the number of branches from 


\section{the sympathetic nerve going to different organs, has been, in} diseases of the latter, observed to be diminished or increased. ${ }^{17}$

(1) Of the great number of writers on diseases of the nerves, as they are generally of little consequence for pathological anatomy, I notice only the following:-Karl Oppert D. de vitiis nervorum organicis. 4to. Berol. 1815.Jos. Swan, A Dissertation on the Treatment of morbid local affections of the Nerves, London, 1820.- P. J. Descot Dissertation inaugurale sur les affections locales des nerfs, 4to. Paris, 1822, and since enlarged and published in 8vo. 1825.-Or the varieties of the nerves, compare the manuals of Sömmerring, Meckel, A. C. Bock Die Rückenmarksnerven, u. s. w. Leipz. 1827, and Dubrevil in Ephém. Médic. de Montpellier, Vol. V. May, 1827.

(2) Clarle's case of total deficiency of the nervous system. v. Philos. Trans. 1793, Part II. p. 154-164, seems to me not to be relied on; it was probably not thoroughly dissected.

(3) Deficiency of the nerves is always in causal and connected proportion to malformation, because the formative principle seems to spring from them; thus, for instance, in acephalous monsters, not merely are the nerves of the head and the upper part of all the nerves, but also the tenth and eleventh pairs, and the frenic nerves, in rare cases, wanting when there is a distinct chest, lungs, and diaphragm. The number of spinal nerves depends on the vertebræ; hence, in acephalous and hemicephalous monsters with but few cervical vertebro, in monsters with imperfect development of the hinder part of the spine, or even in otherwise perfectly formed men and animals, of which one or other vertebræ is deficient, one or several pairs of nerves are wanting. In monsters, of which the extremities are deficient or imperfect, the deficiency of the limbs is always connected with that of the nerves; thus in single fingers and toes, hand and foot, fore arm and leg, their nerves are also wanting; if the whole limb be deficient, so also is the brachial and lumbo-sacral plexus, and without any branches being given off, except those to the adjacent parts of the trunk; lastly, if with deficient arm the region of the shoulder be wanting, or below the one half of the pelvis, so the above-mentioned nervous plexuses are wanting, and there proceed from the vertebral holes merely some posterior threads to the muscles of the neck, and the undermost layer of the muscles of the back. In the not uncommon human monsters of which the radius of the fore arm and the thumb are deficient, the radial nerve terminates at the elbow-joint, or passes down merely as a single thin thread to the back of the hand. In a roe which had no fore legs, and of which the hind legs were much distorted, the obturator and crural nerves were wanting; but the ischiatic was large. v. Serlo D. Monstror. extremitatibus carentium exempla tria, p. 20. Berol. 1826. Lastly, in syren monsters sometimes, on the contrary, the ischiatic nerves are wanting, and are replaced by the anterior nerves.

(4) I liave seen a case of this kind in one lower extremity.-Meckel, Handbuch der pathol. Anat. Vol. I. p. 173, found neither muscle nor nerve in the right lower extremity of an acephalous monster. The same was also noticed by Breschet on the right lower extremity, v. Med. chirurg. Trans. Vol. IX. p. 433, 1818, and by Chaussier, v. Bullet. de la Faculté de Médec. Vol. V. p. 405.-In a sheep, neither of the lind legs had either muscles or nerves. v. Schroeder van der Kolk Observat. anatom. pathol. et practici argumenti, Fasc. I. p. 9. Amstel. 1826. In accessory parts of monsters the nerves are frequently wanting; thus in a child, from the pit of whose stomach the arms and bones of a parasite, No. 2913 of Bresl. Mus., were produced, I could find no nerves; and they were also wanting in a calf, two geese, and several fowls, on the pelves of which supernumerary legs were attached; also in two instances of children with a sixth finger.- Mayer found in a parasite, on the breast of a child in which there were arms and bones, no other nerves than a delicate thread from the renal plexus. v. von Gräfe and v. Walther's Journ. d. Chir. 1827. Vol. X. Part I. p. 44.

(5) Prochask found, in a cyclopic child, only the third, seventh, and eighth pairs of nerves. v. Abhandl. der böhm Gesellschaft. Jahrgang, 1788, p. 230, Prag. 1789. - Carlisle missed, in a lamb which had no face, not only the cere- 
brum, but all the nerves, except the sixth and seventh pairs. v. Phil. Trans. 1801, Part I. p. 139-144. In a monstrous sheep without a face, and with a very small skull, and in which there was merely the hinder part of the brain, I observed that the first six pairs of nerves were totally wanting;--in a cyclopic dog, Magendie could not find the anterior five pairs of cerebral nerves, v. Journ. de Physiol. Vol. I. No. 4, p. 374; - and in a cyclopic lamb, Meckel could not find the first five pairs of nerves. v. Archiv fiir Anatomie u. Physiologie, 1826, No. 2, p. 263. - Klinkosch found in a clild with one eye, without a nose, and with other deformity of the face, the first six pairs of the nerves deficient, the external branches of the fifth pair however existed, but the inner were wanting. v. Progr. quo anatomen partus capite monstroso proponit. 4to. Prag. 1766; rev. in Diss. med. select. Pragens. Vol. I. No. 12, p. 199. In a child without lungs, the second, third, fourth, and sixth pairs of nerves were deficient. v. Malacarne I. Sistemi del ccrpo umano e la reciproca influenza loro indagati, p. 90, 4to. Padova, 1803. In a child with deficiency of the right eye, the nose, and other malformation of the face, the first, fourth, and sixth nerves were totally wanting on the right side. v. Rudolphi in den Abhandlungen der Akademic d. Wissenschaften in Berlin für das Jahr 1814 u. 1815, p. 185. Berlin, 181s.Tiedemann saw in a dog, without eyes, the second, third, fourth, and sixth pairs of nerves wanting. v. Zeitschrift für Physiol. Vol. I. Part I. p. 76. In monsters with very imperfect face, with deficient lower jaw, \&c., some branches of the fifth pair are wanting, and also other nerves going to the face.

(6) This occurs in consequence of the olfactory nerves originating from the anterior part of the brain, which is often affected with water, and are at first hollow, and connected with the lateral ventricles. The olfactory nerves are not merely deficient in all cyclopic monsters which have no nose, or in its stead a kind of proboscis (I have found this confirmed in above a dozen monsters which I have examined), but also in those monsters which approach to cyclopy, by the eyes being too closely approximated, \&c., v. the review of Tiedemann, in the Med. Chir. Zeit., 1825, No. 47, p. 408; and I have found it in a monstrous pig, No. $\delta 812$ of Bres. Mus.; further in other monsters, generally with distortion of the face, and of the nose in particular, as in two lambs, No. 2950 and 8021 ; also in a child, No. 8297 of this collection; and Sömnerring, in a child with only a single nostril, and a very small crybriform plate to the ethmoid bone. v. D. de basi encephali in Ludwig's Scriptores neurologici minores, Vol. 11 . p. 4; and also his Adderida to Baillie, p. 263, note 563; also sometimes in hemicephalous monsters, v. my Monstror. sex humanor. anat. et physiol. disquisitio, Francof. 1811, in the first, second, and, after repeated examination, also in the fourth case,-Selt. Beob. Part I. p. 13 and 47, and lastly, since that time, in some other hemicephala of the Bresl. collection.-Patrix Traité sur le cancer et sur les maladies des voies uterines, in Considérations générales, p. 18. - C. E. lindolpli Monstror. trium præter naturam cum secundinis coalitorum disquisitio. 4to. Berol. 1829, with three plates (in three cases.) - Lastly, alse, not very rarely in children with hare-lip and wolf's-mouth. v. Lavagna in Giornale di Nedicina prat. da Brera, 1813, Vol. IV. Part III. - Tiedemann, in three cases. v. Zeitschrift für Physiologie, Vol. I. Part I. p. 72.-Blandin is said to have seen it in every case of wolf's-mouth, v. von Froriep's Notizen, Vol. XV I. p.64, which, however, is by no means the case, as, in thirteen instances of wolf's-mouth with harelip, only in five was the olfactory nerve wanting, to wit, in No. 2328, 2858, 2891, 2898, and 2939 of my Verzeichn.

(7) Valentin in Eph. Acad. Nat. Cur. Ann. IX. and X. p. 4.29.-Rosemmïller De nervorum olfactorior. defectu P'rogr. zu v. Martius D. de lepra taurica. Lips. 1816, (there were found instead only two little eminences in the sylvian pits.) - Rucdolphi v. Blaurock I). de nervorum sensuum defectu, p. 1S, Svo. Berol. 1S28, (the right was entirely wanting, the left rudimentary where it lost itself in the arachnoides.)

(8) Compare note 5.-Further Vicq d'Azyr Mém. de la Soc. de Médec. 1776, p. 315. - Weidele, v. Schmiclt in Himly's and Schmide's Ophthahmologischer Bibliothek, 1805, Vol. III. Part I. 1. 170.-Osiander, Handh. der Einthindungskunst, 1.520, Vol. 1. Obs. 6, Tïhingen, 1818, (in one kind of eyclopss).- 
Lobstein De nervi sympathetici hum. fabrica et usu, p. 53, 4to. Argentor. 1823. However, also in cyclops with tolerably well-formed eye no optic nerve has been found, viz. Mery in Mém. de l'Acad. des Sc. 1709. p. 18.-Riviera in Brugnatelli's Giorn. d. med. Pavia, 1795, Vol. I. p. 225. Even Magendie is said to have missed it, although the retina existed; one might doubt, that in these cases the nerve was very thin, and being torn through was overlooked: the absence of the optic nerve in one kind of cyclops is certain, it is described by Ehrmann, v. Répert. gén. d'Anatom. et de Phys. pathol. Vol. IV. Part I. p. 5.

(9) Rudo'phi.

(10) There are, indeed, sometimes two optic nerves from the brain, which pass unnaturally close to each other, without decussating, to the great eye-ball, which they enter on either side, or they both unite in front in one common nerve for the single eye ; or, but one nerve arises from the brain, and divides itself anteriorly into two branches for the two eye-balls lying in a single orbit, as Rudolphi saw in two cyclopic pigs. v. Ruben, Descriptio anatomica capitis foetus equini cyclopici, p. 12, 4to. Berol. 1824, and Meckel, in one cyclopic sheep and two cyclopic pigs. v. Archiv für Anatomie und Physiologie, 1826, No. II. p. 247 and 248 ; or, and which is most commonly the case, there is only a single optic nerve from the brain, which, however, is very large at the hinder part, but passes singly to the brain. I found the latter the case in all the instances which have come under my observation, and only in No. 2344 was the optic nerve double at its origin. See, on the formation of the optic nerve in cyclops, Tiedemann, Meckel, and J. Müller, Zur vergleichenden Physiologie des Gesichtssinnes, p. 160. Leipz. 1826.

(11) Compare the cases quoted above at note 5.- In that of Ehrmann's, the third pair of nerves was, however, said to be present. I could not find the fourth pair in a cyclopic pig, No. 2346, which had all the other nerves except the olfactory; in a human cyclopic monster the fourth pair was deficient, and the sixth did not reach the orbit, but was connected merely with the sympathetic nerve. v. Eller and Roloff, in Hist. de l'Acad. des Sc. de Berlin, p. 112. 1754.

(12) Tiedemann, p. 87.

(13) I have seen this very rare case in a monstrous sheep. v. my Selt. Beob. Part I. p. 37. - Valsalva saw a hemicephalic monster which had no auditory nerve, nor any opening for it in the petrous bone; it is also curious that two other children of this woman were deaf. v. Morgagni Epist. XLVIII. 48; a similar case is also described by Lobstein De nervo sympathetico, p. 54, $\$ 69$.

(14) Tiedemann. p. 87 and 89.

(15) I have already remarked, at note 4, that accessory parts are not necessarily supplied with nerves.

(16) Several satisfactory cases, and plates of such cases, are given by Barliow, Monstra animalium duplicia per anatomen indagata, Vol. I. 4to. Leipz. 1828, who has taken much trouble in examining the nerves. The external examination of such monsters allows us to speak pretty certainly of their nerves; the nervi vagi and sympathici alone sometimes surprise us by their arrangement. In a monster which was double at the upper part, but single below, with two vertebræ lying close to each other, but perfectly distinct, the internal sympathetic nerves which were united beneath had no ganglia, because the spinal nerves on that side were deficient. v. Gibson in Phil. Trans. 1810, Part I. p. 123. In a janus-faced monster each face had its proper nerves from the two brains, \&c.

(17) Lobstein De nervi sympathetici hum. fabr. usu et morbis Comm. § 152154. 4to. Paris, 1823. I do not think it probable that there should be an actual increase or diminution in the number of branches, and I hardly necd recall how very difficult such examinations are, and how easily they may be mistaken.

\section{$\S 250$.}

The NERVES sometimes exhibit variations from their normal sIzE, which may be either congenital or acquired. 'The conGENITAL IRREGULAR SMALLNESS occurs not unfrequently, and 
is very often connected with morbid softening, colouring, and structure, and seems to originate oftentimes in the total absence or great imperfection of the organ to which the nerves belong. ${ }^{1} \quad$ In hemicephaly, hydrencephalocele, and internal dropsy of the head, the cerebral nerves, so long as they remain within the cavity of the skull, are very thin, as are the spinal nerves in spina bifiala at the diseased spot. More frequent is the ACQUIRED and later occurring DIMINUTION, or ATROPHY of the nerves, which but rarely, and only in a slight degree, participates in the general consumption of the body, ${ }^{2}$ and appears to stand in an equally imperfect relation to paralysis $;^{3}$ the organs of sense, however, seem to form an exception, as they waste, shorten, lengthen, \&c., both as cause and consequence of diseases of the organs of sense ; ${ }^{4}$ this has been observed most commonly and most completely in the optic nerves, of which sometimes only the part in front of the chicasma, often also the cerebral part of the nerve on the opposite or upon the same side, or lastly, on both sides, with or without optic beds and quadrigeminal bodies, have been found atrophic. ${ }^{5}$ Not unfrequently wasting of one or several nerves originates in pressure, arising from swellings of various kinds at their origins $;^{6}$ so also the nerves within the skull and the spine are compressed less severely by collections of water, by abscesses, extravasation of blood, and other causes, and external to these cavities by various kinds of swellings, dislocated bones, \&c. In many instances the causes of atrophy in certain nerves are more obscure. ${ }^{7}$ The opposite vice, the IRREGULAR INCREASED SIZE OF THE NERVES, is rarely congenital, ${ }^{8}$ but usually occurs later in various diseases, as inflammation, dropsy, cancer; in such cases it is naturally confined to single nerves, but is then sometimes so considerable, that the nerves exhibit a thickness three or four-fold greater than usual. $^{9}$

(1) In a child without eyes, No. 2888 of my Verzeich., I found the second, third, fourth, and sixth pairs of nerves, together with the first branch of the fifth pair, slender, withered, yellowish grey, and almost without nervous matter. In another monster, No. 8297 of the Mus., with deficient eyes, nose, and malformed face, the nerves, from the seventh to the eighth pair inclusive, were remarkably small. $-\Lambda$ monstrous sheep without a face, No. 8021 of the Mus., with deficient olfactory nerves, the following seven pairs very thin, and the riglst optic at the same time flattened. - A similar lamb, No. $80^{2}(0)$, had the olfactory and optic nerves not thicker than a hair, and withont any nervous matter; the following four pairs also thin, but containing some nervous matter.--In two children, a dog, and two calves, which were born with small and very imperfect eyes, I found the optic nerves, and in part also the optic heds, too small. v. No. 2:442, 2:3.13, 32:32, $323:$, $8267,8363,8364$, and 8603 , of Bresl. Mus. - In a cyclopic sheep without at congue, I found the fifth, ninth, and twelfth pairs of nerves very thin. v. my Selt. Beob. Part 1. 1.37. - In a human mouster, No.2885, the optic nerves without nervous matter and tubular. - In a moustrous jig, with a disposition to cyclopy, No. 8812, the fifth pair was too small; this was also the case with a 
child which had no lower jaw; and also a similar child, all the lingual nerves. v. Selt. Beob. Part II. p. 168. - In a similar monstrous sheep, No.8022, the third portion of the fifth pair was remarkably small, discoloured, and wanting nervous matter.-In some cases of hare-lip, and especially No. 2329 and 2896 of my Verzeich., I found the olfactory nerves too small.-In monsters which are entirely limbless, or have the limbs too small, the proper nerves to these are too small, as I have seen in several instances.-Dumeril observed the same in Marco Catozze, whose limbs, excepting the hands and feet, were deficient. v. Bullet. de la Soc. philomath. Vol. III. p. 122.

(2) Desmoulins in de Blainville's Journ. de Physiq. etc. p. 166, Feb. 1821, especially observes, that the nerves waste merely in the wasting of old persons, but not in young people; this is generally correct, although it has appeared to me, in some cases, as if the nerves, in young persons who liad died of tabes, were sometimes dryer, that is, contained less fat and serum. Whether they were also thin I could not determine, on account of the great relative variation which naturally exists in the bulk of the nerves of different individuals. - I have never, however, found them remarkably thin in such bodies.

(3) In hemiplegic and paraplegic persons, the nerves of the paralytic parts are very rarely found thinner than in those which can be moved voluntarily.Even if the paralysis have existed very long, and have occurred in very early youth, the nerves are sometimes apparently healthy. v. one such case in my Selt. Beob. Part II. p. 32.- It lowever appeared to me, in another case, in which, from earliest childhood, one leg was shorter and more slender than the other, as if its nerves were also more slender than those of the healthy foot, as was very natural. Sometimes also, in tabes dorsalis, the dorsal nerves are somewhat wasted.Koreff found, in one such case, the anterior roots of the nerves in a high degree atrophic. v. Magendie's Journ. de Physiol. Vol. IV. p. 372. Oct. 1824.

(4) The cause is sometimes in the brain and nerves; sometimes, on the contrary, on the organs of the senses. In a child which died of water in the liead, the olfactory nerves were too thin, brown, and hard. v. Jeffray in Lon(ion Med. Repos. p. 278, April, 1822. - The auditory nerves have also been seen atrophic in deaf persons. v. Fr. Hoffmann D. de auditus difficultate, $\$ 12$, (in a dog which was deaf.) - J. Haighton, in Mem. of the Medic. Soc. of London, 1792, Vol. III. p. 1.- ltard, in a deaf and dumb person. v. Traité des maladies de l'oreille. Paris, 1821.- In the body of an old woman, I found the left auditory nerve of a yellow colour, and much thinner than the right. I could not ascertain whether the woman was deaf, though probably she was, as the membrane of the drum was ossified, and the cavity of the drum and labyrinth filled with a thick reddish jelly.

(5) Compare the works on decussation of the optic nerves, and Vrolik in Mémoires sur quelques sujets intéressans d'Anat. et de Physiologie. trad. du Holl. par Fallot, Mémoire I. 4to. Amsterd. 1822.-Lieutaud Histor. anat. med. Lib. III. Obs. 1S8-191, tab. 2, p. 367.-Wasting of the optic portion alone I have seen in four cases;-further, Morgagni in several. v. Epist. anat. med. and De sel. et caus. morbor. Epist. XIII. 9 and 10 ; Epist. II. 30 ; Epist. LXIII. 6. Isenflamm Versuch einiger prakt. Anmerkungen ïber die Nerven. Erlang. 1774, $\$ 58$, p. 170.-Michaelis Ueber die 1)urchkreuzung der Selinerven in Grosse's Magazin zur Naturgeschichte des Menschen, Vol. II. Part I. p. 149; und als besondere Schrift. Halle, 1790.- Wenzel De penitior. cerebri struct. p. 116, 119, and 120.-Beer Lelre von den Augenkrankheiten. Vol. II. p. 50. Wien, 1792, (in all cases, in which one eye was destroyed by inflammation and suppuration.)Vrolik, p. 14, pl. 2, \&c.-On simultaneous atrophy of the cerebral portion of the nerve of the opposite side, v. Valsalva in Morgagni.-Sömmerring and Nöthig De decussatione nervorum opticorum. Mogunt. 1780, (also several cases of animals.) - Billmann in Blumenbach's medic. Biblioth. Vol. II. Part II. p. 391, (in a dog.) J. G. Walter von der Einsaugung und der Durchkreuzung der Sehnerven, Berl. 1794, (in three cases.)-Michaelis, (in several cases.)-Ackermann in Blumenbach's medic. Biblioth. Vol. III. Part II.-Rosenthal D. de oculi quibusclam jartibus. Gryphiæ, 1801, (in a horse and a jackdaw.) - Wenzel, p. 115.-Caldani Opusc. anat. 1. 35, Patav. 1S03.-Gallereux. v. Sédillot's Journ. géu. de Médecine, 
Vol. L. No. 216, p. 880. Aug. 1814.-Ebel and Clossius, (in horses.) v. Sümmerring's Addenda to Baillie, p. 178, note 380. - Magendie in Journ. de Physiol. expérim. Vol. III. No. 4, p. 376, 1823.-Rudolphi Grundriss der Physiol. Vol. II. Part I. p. 220.-I have also seen two cases of this kind, one in a man and the other in an owl which had been blinded by a shot in the eye.-A trophy of the optic nerve on the same side as the blind eye, throughout its whole length back to the brain, was seen by Vesalius De corp. hum. fabrica. L. IV. c. 4._Casalpinus, Rolfinck, Cheselden and Santorinus. v. Morgagni, Epist. XIII. 7.-Heiland in Ephem. Acad. Nat. Cur. Dec. III. Ann. VII. Obs. 157.- Meckel in Haller's Grundriss der Physiologie, p. 386.-Caldani, p. 33 and 36 ; and in Mem. della Soc. Ital. Vol. XII. Part II. p. 27 ; and my Selt. Beob. Part II. p. 89. -A case in which botl portions of the brain were wasted, in consequence of blindness of one eye, is described by Wenzel, p. 114. Cases aiso have been several times observed in which both eyes were blind, or both optic nerves throughout their whole length, together with the optic beds, were atrophic. v. Walter, p. 96.-Vrolik, (in a girl of fourteen years.)-Biermayer Mus. anat. path. p. 134, No. 564. Vindob. 1816; and my Verzeichn. No. 2350. In one such case it is said, that the optic portion of the nerve of the eye which was perfect, was atrophic, and that of the blind eye was natural. v. Magendie's Journ. de Phys. Vol. VIII. No. 1, p. 33.-On this point there is still much obscurity, and the contrary opinions seem to depend on this, that the disease originates sometimes from the eye, sometimes from the brain, and also on one or both sides; that it is sometimes a mere nervous disease, sometimes an inflammatory state, or disturbed nourishment of the eye; and that the course of the disease in men and animals is different. In the former it appears that the destruction of one eye produces consequent atrophy of the nerve much later than in heasts and bircls. v. Magendie, Vol. III. No. 4, p. 376. We also perhaps find a difference between man and different animals in reference to the propagation of the disease to the opposite side.

(6) Otto D. de morbis ab intumescentia et pressione nervorum per foramina ossium egredientium. Erford. 1799. Wasting of the olfactory nerve, without loss of smell, was seen by Mery. v. Progrès de la Médec. 1697. - Loder Progr. Observatio tumoris scirrhosi in basi cranii reperti. Jenæ, 1799, with plates. Sönmerring on Baillie, p. 263; and Addenda to Baillie, p. 177, note 379.Wenzel De penit. cerebri struct. p. 104, (second case.)-J. Ward in London medical Repository, Vol. XX. p. 217, September, 1823.-J. F. Meckel in D. Archiv f. d. Physiol. Vol. III. p. 196.-Béclarl in Magendie's Journ. de Physiol. Vol. V. No. 1 and 2, p. 17 ; and myself in three cases, v. Selt. Beob. Part II. p. 89 and 90 . Since then also in one case from medullary sarcom of the eye and nose. Compression of the optic nerve arises from aneurysm of the carotid arteries near the Turkish saddle, from swelling of the appendage of the brain. v. Rullier in Archives générales de Médecine, p. 302. October, 1823. From a malformed clinoid process; v. Sömmerring's Addenda to Baillie, p. 264, and from other tumours. Compare Boneti Sepulchret. anat. Lib. I. Sect. XVI. Obs. 1, 2, 10.-Blegny Zodiac. Gallic. Obs. 14, p. 81, (by a beanshaped bony coneretion.) - Paw Obs. anat. rarior. II. P. 5, (hydatid.)-T. Plater Observationum, Vol. I. Lib. III. p. 102. Basil, 164.1._Haller Elem. Physiol. Vol. IV. p. 297.-Mouro Prælect. medicæ, \&c. p. 27. Lond. 1776.-Boehmer Observ. anat. rar. Fasc. II. Obs. 3.-Sabourant in Prix de Chirurg. XI. p. 96. Several cases are related by Voigtel, from Wandeler, de Hacn, Ford, and Ferro, v. Pathol. Anat. Vol. I. p. 679. - Flor. Caldani Observat. anatom. Patav. 1803, with engravings. - Powel in Medic. Transact. Vol. V. E Esquirol in Dict. les Sc. inédic. Vol. VIII. p. 291. - Hay in Abercrombie, p. 430.-J. Wartl. - Leveille, read at a sitting of the Acad. de Médec. of Paris, 10th Aug. 1821.-Schneider D. de magna quadam encephali destructione ejusque sequelis. 8vo. Berol. 1821.Rust's Magazin f. d. ges. Heilk. Vol. V. Part. 1. p. 165._Béclard.-de la Motte, in Philadelphia Journal of the medieal and physical Sciences, August, 1S27.Monendie in Journ. de Plyysiol. Jan. 1S28, Vol. VIII. p. 27.-D. Meyer D. de cerebri tumoribus. 4to. Berol. 1829, with engravings. A. A. G. Rhodius 1). s. Casum singularem de Amaurosi cranii ostcosteatomate offecta. 410. B(rol. 1829), with plates. I once found in a man who had been aftected with amaurosis of 
the right eye, the optic nerve compressed by a serofulous tumour just before its entrance into the orbit. v. my Selt. Beob. Part I. p. 108; in other cases it was compressed, together with the nerves following up to the eleventh pair, by a scirrhous tumour, v. Selt. Beob. Part II. p. 86, or by medullary sarcom of the appendage of the brain, p.93. The third, fifth, and sixth nerves were, in one instance, compressed by a hard tumour. v. Landmann Comm. path. anat. exh. morbum cerebri oculique singularem. Lips. 1820. 'The fifth pair was found atrophic and compressed by tumours. v. Fribault and Marechall in Journ. génér. đe Médec. Vol. XLIV. Aug. 1812, (in a person with face-ache, tic doloureux).Desmoulins in Magendie's Journ. de physiol. Vol. V. No. 1 and 2, p. 21 (with loss of smelling although the olfactory nerve was healthy.)-Hay in Abercrombie, p. 432 , case 20, (the seventh pair was compressed; the sight and hearing diminished.) Wasting of the fifth pair, with total destruction of the seventh and eighth, from a tumour, is described by $D$. Meyer D. de cerebri tumoribus. 4to. Berol. 1829 , with engravings. In a man with double vision, paralysis of the right side, and distortion of the left eye towards the nose, the left uervus oculum abducens was pressed by a tumour. v. Yelloly in Med. chir. Trans. Vol. I. p. 181. Tlie seventh pair was compressed at its entrance into the petrous bone by a tumour, in an old man. v. J. H. Wishart in Edin. med. and surg. Journ. By pus in the fallopian canal. v. Bellingeri in Annali universali di Medicina, March, 1827. In one instance a tumour of cartilaginous hardness was situated on the auditory nerve. v. Sandifort Obs. anat. path. Lib. I. Chap. IX. p. 117. tab. 8. fig. 5, 6, 7. The nervus vagus has been seen compressed and wasted several times. v. Cappel D. le epilepsia e tumore nervo vago inhærente. Helmst. 1781 (the cerebral end.) - Biermayer Muscum anat. pathol. No.186, (by an ossified pointed absorbent gland, situated behind the left lung, tetanus and death.) It and the frenic nerve, in a person who died with difficulty of breathing, surrounded by tuberculous glands, and wasted at the lower part, was observed by Andral Nouvelle Biblioth. mécl. No. 7, 1826.-Dupuy v. Journ. gén. de Méd. p. 5, April, 1821, and Jan. 1825, imagines that the so-called crib-biting of horses arises from the pressure of the nervi vagi above the superior laryngeal nerve, and was confirmed in some cases. Sometimes we find the spinal nerves compressed by tumours; hence arises paralysis of the lower extremities from hydatid tumours in the spinal canal. v. Chaussier in the note to the fortieth letter of his edition of Morgagni De sed. et caus. morbor. Paris, 1822. In a woman with paralysis of one arm and of the feet, the anterior left roots of the nerves at the lower part of the neck were compressed and wasted by a tumour. v. Valpean in Magendie's Journ. de Physiol. No. JI. p. 138, 1826. A tumour in the canal of the spine compressed the anterior roots of the nerves, and produced imperfect paralysis and violent pain of the feet. v. Monod in Nouv. Biblioth. Méd. May, 1827. Several instances of compression of the vocal and frenic nerves, and also of the branches of the sympathetic, from tubercles, aneurysm, \&c., are described by Lobstein De nervi sympathetici humani fabrica usu et morbis comment. $\$ 145,147$, and 156. 4to. Paris, 1823. [In Mus. St. Thomas's Hospital a scrofulous tumour in the dorsal portion of the spinal marrow produced paralysis with loss of sensation in the lower extremities. T.]

(7) Swan, for instance, found in a man who had taken violent medicines, and at last was subject to canine hunger, that the œsophageal branches of the tenth pair were wasted and morbid; and in consumptive cases the trunks of the nervi vagi wcre frequently extremely thin. v. his Observations on some points relating to the anat. phys. and pathol. of the Nervous System, Chap. II.

(8) As the thickness of the nerves varies exceedingly in different individuals, the consiclerable size which appears to have been noticed, viz. in the often-cited cases of Liumonier in Journ. de Médec. Vol. XXXVI. p. 259, hardly belong here. It is an interesting circumstance, however, that the sympathetic nerves and the ganglia have been found unusually large, as for instance, by Cayre and Pinel. v. Nouv. Journ. de Médec. Vol. IV. p. 40-45, (in eight cases.)-Romberg found, in a girl who was an idiot from birth, the nerves in proportion to the brain very large and firm, but especially the ganglionic system of the belly, very large. v. Zeitschrift f. die Anthropologie, 1823, Part III. p. 224.-Lobstein De 
nervi sympathetici humani fabr. usu et morb. Comment. p. 55, $\$$ 70, 4to. Paris, 1823, (in two cases.) - A. Duncan, Reports of the practice in the Clinical Wards, Sic. London, 1819, also found them (three or four) too thick in a diabetic patient.-In a hemicephalic monster, Meckel found the sympathetic nerve double its usual size. v. Descrip. monstr. nonnull. 4to. Lips. 1826, p. 21; althongh I remembered these cases in dissecting idiots and hemicephalic monsters, I have never observed the size of the ganglionic system such as is stated, nor was it remarkable; it also appears that it is not constant.

(9) In a child who died of chronic water in the head, the fourth pair of nerves was unusually thick and white, and the optic nerves wasted. v. Jeffray, in Lond. Med. Repos. p. 278, April, 1822. - In neuralgia and imperfect paralysis, the nerves have been sometimes seen thickened, not merely in ischias nervosa Cotugnii, but also in others. v. Petit in Mém. de Chir. de l'Acad. royale, Vol. I. p. 90.-Cirillo Prakt. Bemerkungen üb. dier vener. Krankheiten. Leipz. 1790, p. 134.-C.Wenzel Ueber Induration, u. s. w. p. 50, Mainz, 1S15.-Swan, chap.4.Serres, in Magendie's Journ. de Physiol. Vol. V. No. 3, p. 233, found in a man, the right side of whose face was paralytic, the ganglion of the fifth pair swollen, and the nerves otherwise discased. In the foot of a man, which was affected with clephantiasis, the tibial nerve was uncommonly thickened, irregular, and its sheath especially swollen. v. Chelius in Heidelberger klin. Annalen. Vol. II. Part III. p. 359, pl. 2.- In a few cases of old chronic inflammation, thickening and partial suppuration of the leg, I have seen the ischiatic nerve remarkably thickened, and at the same time greyish yellow and semi-transparent; a very painful enlargement of the nervus tibialis posticus was seen by Barkow Ueber Nervenanschwellungen in Nov. Act. phys. med. Acad. Nat. Cur. XIV. and $A$. Cooper's Lectures, Vol. I. p. 44. - Thickening of the saphenous nerve in the neighbourhood of a varicose saphenous vein. v. Gendrin Histoire Anatomique des Inflammations, 2 vols. 8 vo. Paris, 1826. - Several instances of partial thickening of the sympathetic nerve are mentioned by Lobstein.

\section{$\S 251$.}

We but rarely observe important variations as to the Form, POSITION, and RAMIFICATION in the nerves. 'Thus, for instance, occasionally we miss one of the usual roots of the oLFACTORY NERVE; it has been found in new-born children, especially in those having watery heads, as in the young foetus, too thick and hollow, ${ }^{1}$ or, in a deaf and dumb person, merely its bulb twice as thick as in the normal state, ${ }^{2}$ \&c. More frequently do the origin and course of the oPTIC NERVES vary in cyclopic monsters $;^{3}$ in these, ${ }^{4}$ and in hemicephalic cases, ${ }^{5}$ the optic nerves have been noticed completely distinct and without a commissure, in an otherwise normally formed brain. ${ }^{6}$ As an approximation to this state, they have been seen several times, in dropsy of the brain, as it were torn asunder, and instead of crossing, connected only by a transverse portion of nerve. ${ }^{7}$ From the point of decussation, there arose in one instance a pointed medullary process projecting forwards, ${ }^{8}$ \&c. The rour Following NERVES of both sides in cyclops run unnaturally close to each other. 'The THIRD NERVE sometimes varies in reference to its branching and its twigs to the optic ganglions, thus, for instance, it sends off the long root to it. ${ }^{9}$ Among the varieties of the FIFTH PAIR, the not unfrequently early separation and dis- 
tinct course of the frontal, infra orbitar, and maxillary branches, is important in practice. The OUTER OCULO-MUSCULAR NERVE sometimes gives off' the nasal branch instead of the fifth pair. ${ }^{10}$ The nervus recurrens of the auditory nerve, in abnormal position of the neighbouring arteries, sometimes also exhibits an unnatural course. ${ }^{11}$ The sUbLINGUAL NERVE, in one instance, passed through the vertebral artery, which was cleft for it. ${ }^{2}$ The SPINAL NERVES are sometimes subject to variation; this is especially the case in the extremities. In one monster, which wanted the sacrum and coccyx, the ISCHIATIC NERVE proceeded through a large aperture between the fifth lumbar vertebra and the iliac bone. ${ }^{13}$ In deficient formation of the pericardium the course of the PHRENIC NERve was found abnormal. ${ }^{14}$ The SYMPATHETIC NERVE is also found varying in different ways, and not rarely curved with the spine, or thrust out of its course by tumours on the spine. In one instance, owing to the absence of the lingual branch of the fifth pair, and of the sublingual nerve, the sympathetic nerve gave off branches from the cervical ganglions to the tongue and its muscles. ${ }^{15}$

(1) I have seen this a few times; in a hemicephalic monster, No. 8016, the hemispheres were very pointed in front, and reached to the crybriform plate, extending almost to the olfactory tubercles, as in animals.

(2) A. Meckel in J. F. Meckel's Archiv für Anat. u. Physiol. 1828, No. II. p. 169 .

(3) Compare $\$ 249$, note 10.

(4) Ol. Borrich. v. Acta med. Vol. I. Obs. 93, Havn. 1671.-Littre in Mém. de l'A cad. des Sc. de Paris, 1717, p. 285.-Albrecht Eph. Acad. Nat. Cur. 1744, Vol. VII. p. 363, Obs. 102.-Eller and Roloff in Hist. de l'Acad. des Sc. de Berlin, 1754, p. 112.-Riviera Storia di un Monoculo, etc. p. 12, 8vo. Bologna, 1793. - Ulrich and Heymann in Meckel's D. Archiv f. die Physiolog. Vol. VI. p. 522. - Ullersperger Pathol. anatom. Beschreibung zweier Missgeburten. 8vo. Würzb. 1822. - Tiedemam in Zeitschrift für Physiologie, Vol. I. Part I. p. 80, etc.

(5) Prochaska Annotat. acad. Fasc. III. p. 175.-Klein Spec. inaug. anat. hist. Monstror. quorundam descriptio, p. 16, Stut'gard, 1795.-In my Monstror. sex humanor. anat. et physiolog. disquisitio, p. 8, Francof. ad Viadr. 1811; and since then in two cases. - Kelch Beiträge zur pathol. Anatomie, p. 85. Berl. 1813. I have already, in another part of my Selt. Beob. Part I. p. 43, pointed out the causal connexion of water in the hcad with this anomaly.

(6) Vesalius De corp. hum. fabr. L. IV. c. 4.-Fabricius ab Aquapendente De Oculo. Part III. cap. 11.-Valverde Anat. del corpo umano. Lib. VII. c. 3.Caldani Opuscula anat. p. 40. Patav. 1803.

(7) Osthoff Kleine Beiträge zur Erweiterung des med. Wissensch. p. 146. Duisb. 1804.-Breschet in Archives générales de Médecine, July, 1823; I have found this occasionally under similar circumstances, and saw one such case with Professor Provençal, at Montpellier.

(8) Sömmerring and Nöthig, fig. 4 .

(9) Morgagni Epist. anat. XV1. \$ 59. - Meckel De quinto pare nervorum, $\$ 48$.

(10) v. my Selt. Beobach. Part I. p. 108.

(11) Stedmann, in Edinb. med. and surg. Journal, No. 77, Oct. 1823, saw in a man whose subclavian artery arose from the arch of the aorta, and passed to the right arm between the gullet and the spine, the right deficient, and the branches which supplied the place of the laryngeal arising from the middle of the neck above. A similar case was observed by Harles, ib. April, 1826. In a man whose 
aorta turned first to the right side, the right nervus recurrens passed under the arch of that vessel, but the left on the ductus arteriosus Botalli, up to the larynx. v. Sandifort Mus. Anat. Vol. I. p. 273 ; Vol. II. pl. 107, fig. 1 and 2.

(12) I saw a wax model of this case in the Anatomical Museum of the Josephine Academy at Vienna.

(13) Friedlieb Monstrosi foetus descriptio atque delineatio, p. 39. pl. 6. fig. 1. 4to. Altonæ, 1803.

(14) In the totally absent pericardium Baillie saw the left phrenic nerve passing down close behind the breast-bone. v. Transactions of a Society for the improvement of medical and chirurgical Knowledge, Vol. I. p. 91.- In two cases, v. my Selt. Beob. Part II. p. 44, and in No. 2874, my Verzeichn.; with deficiency of the left side of the pericardium, the left phrenic nerve was curved forwards and to the right; a similar case is given by Breschet in Répertoire gén. d'Anat. et de Physiologie pathol. 1826, Vol. I. Call. I. p. 215, pl. 5. - In a child with prolapse of the heart and deficient pericardium, the phrenic nerves passed on the outer side of the great vesscls. v. Hatan, D. de ectopia cordis casu illustrata, p. 13. 4to. Bonnæ, 1825.

(15) Lobstein, § 66, p. 53.

\section{\$252.}

The colour of THE NERves is found irregular in various ways, and especially occurs in vicious structure. Thus atrophic or softened nerves usually lose their gloss and whiteness, become partly opake, grey, or yellowish, or rather greyish-yellow; contused or inflamed nerves appear more or less red throughout, or spotted and streaked with red; in ulcers and in mortified parts, the nerves are usually more or less discoloured; in great destruction, viz. in gangrene, in complete atrophy, in the cancerous-like state especially, we observe them at certain spots of different shades of brown and rust colour. In jaundice, they participate very little or not at all in the discoloration. ${ }^{1}$

(1) I have occasionally found in new-born children, which had perhaps died a short time before birth, the medullary part of the brain, spinal cord, and some of the great nerves, as the ischiatic, here and there of a light yellow colour; and Lobstein, p. 166, \$159, found one child in which the spinal marrow was of a citron yellow, and the sympathetic nerve of a similar colour, in spots; upon Kirrhonose, compare above, $\$ 39$, note 2.

\section{$\S 253$.}

Not less is the consistence of the nerves sometimes morbidly changed, that is, either decreased or increased; the former is the most frequent, and the nerve, instead of being firm and elastic, becomes soft, WITHERED, SHRIVELLED, EASILY TORN, and sometimes as if it had been MACERATED.' In some cases, the nervous sheaths exhibit a tolerably normal firmness, but the several nervous bundles are separated from each other, and as it were loosened. In other cases, however, the medullary part of the nerve especially is softened, as if it had been immersed in a solution of kali, so that the discoloured medullary substance has no fibres, but runs out from a divided nerve like a thin pulp, like jelly, or even like water. Sometimes at certain 
spots the nerves are entirely deprived of medulla, and the hollow sheaths alone remain; such are not unfrequently seen within the cavity of the skull and spine, in children with cyclopy, hemicephaly, hydrencephalocele, internal water of the head, and spina bifida. ${ }^{2}$ Further, a higher degree of inflammation seems, as in the brain and spinal marrow, and also in the nerves, capable of producing a softening and fluid state of their substance. The opposite vice, or INDURATION, occurs much more rarely in the nerves, and seems to be especially produced in chronic inflammation by the deposit of plastic matter in the cellular tissue, which glues together the separate nervous bundles. Atrophic nerves also appear to be too dry and hard; sometimes the nervous sheath only appears to be thickened and too hard. A true conversion of the nervous substance into cartilage and bone cannot take place. ${ }^{3}$

(1) Atrophic and paralysed nerves, especially the optic, have frequently this appearance; the lower extremity of a divided nerve is also withered; in dropsy the nerves are sometimes partially too soft. v. Autenrieth, D. observationes in hydrothoracem virorum, p. 20. Tuib. 1 s09.

(2) Morgagni, Epist. LII. 31, had already found the optic nerve of an atrophic eye so hollow, that when cut through he compared it to an artery. In hemicephalic monsters, I also remarked this very early, and pointed out the connexion of water in the head in reference to the nerves. v. Monstror. sex human. anatom. et physiol. disquisitio, p. 21, Francof. a. V. 1811; and since then have often found it confirmed. More recently I have seen in a cyclopic monster, No. 2885 of Bresl. Mus. one of the optic nerves large, with its sheath very firm, but when cut through, quite hollow and deficient in nervous matter.

(3) As by bony and stony concretions upon and in the nerves, \&c.

\section{$\S 254$.}

Vices of Continuity are very common in the nerves, as, from their extensive distribution, they participate in every trifling injury; they are then sometimes cut through, torn asunder, or only imperfectly separated and contused, tied together, cut, pierced, \&c. If the nerves be stretched gradually, they often yield remarkably, as in many swellings of joints, in exopthalmus, \&c., without having their functions destroyed; but if they be suddenly and violently extended, as by many bony tumours, by aneurysm, \&c., they are more injured, and can even be torn through without breach of continuity in the neighbouring parts. ${ }^{1}$ If the larger nerves be wounded, there sometimes arise, besides the necessary palsying of the part with which they are connected, not merely active and continued neuralgia and sympathetic affections, ${ }^{2}$ but also similar organic phenomena, as in other injured soft parts, viz. swelling, redness, effusion of coagulable lymph, and union. If a nerve be completely divided, both its extremities swell, but especially the upper, 
the peripheric part of the nerve becomes thinner, even slightly discoloured, and the effused lymph unites both ends into a more or less large and solid knot, consisting of cellular tissue, in which, after sometime, some new irregular variously connected nervous threads are produced. In instances of more considerable loss of substance in a nerve, the ends are either not united, and cicatrize with a permament swelling, with loss of sensation and motion in the more distant portion; or if they be but slightly separated from each other, they may be united by a newly-produced, but, in that case, thin interposed substance. In amputated limbs we find the ends of the nerves at first, to a greater or less extent, swollen, inflamed, spotted or deep red from the blood effused in their sheaths, but subsequently subsiding into a greyish, thick, tolerably firm, and not more fibrous-like knot, from which delicate fibres spring for nerves; if the end of a nerve remain bare after amputation, it inflames violently, and is gradually covered with very sensible granulations. We not unfiequently observe in the scar, after amputation, several of the nerves adhering in a loop ; for instance, the upper end of the nervus vagus united with the fifth cervical nerve. ${ }^{3}$

(1) Flaubert, Mémoire sur plusieurs cas de luxation, etc. in Répert. gén. d'Anat. et de Physiol. pathologiques, 1827, Vol. III. Part I. p. 102, mentions a case of tearing of the last four nerves of the brachial plexus from the spinal marrow, in consequence of violent extension in attempting to reduce a dislocation of the upper arm; the patient lived eighteen days.-Lobstein, p. 165, §158, states that he has frequently seen the ganglionic nerves in the belly torn by large tumours.

(2) For instance, if a nerve be included in the ligature applied on artery-if a nerve be injured in bleeding.-Wardrop saw a case of severe neuralgia subsequent to puncture of the nerve of one of the fingers. v. Med. Chir. Trans. Vol. XII. p. 205. Similar symptoms occur from contusion of the popliteal nerve, and the application of quicksilver to it. v. C. Bell, Surgical Observations, \&c. p. 440. London, 1816.- In another case, the symptoms were so severe after contusion of the radial nerve, that amputation was required. v. Denmark in London med. chir. Transact. 1813, Vol. IV. p. 48.

(3) v. Flourens in Annales des Scienc. naturelles. Vol. XIII. Févr. 1825, p. 113. On the union and reproduction of nerves, v. Fontana, Traité sur le Venin de la Vipere, Vol. II. p. 177. Florence, 1781. - Michaclis, Ucber die Regeneration der Nerven, a letter to Pet. Camper. Kassel, 1795. - Arnemann, Ueber die Reproduction der Nerven, Göttingen, 1786, and Versuche ïber die Regeneration in lebenden Thieren. Vol. I. Göttingen, 1787, with pl.-Alex. Monro, Observations on the structure and functions of the nervous system, p. 81,83 . -Cruilshank, Experiments on the nerves, particularly on their Reproduction, in Phil. Transact. 1795, Vol. I. p. 177, (he seems to lave been the first who instituted accurate experiments with Ilunter.)-Baronio in Memorie di Matematica e Fisica Jella Soc. Ital. Vol. IV. p. 480. Verona, 1788. -1 Haighton in Phil. 'Iransact. 1795. Part I. 1) 190. - Mayer in Reil's Arehiv f. d. Plhysiol. Vol. 11. p. 41\%. - van Home De iis, que in partibus membri prasertim osseis amputatione vulneratis notanda sunt, p. 33. L. B. 1803.-Swan and Descot.lireschet in Dict. des Se. médicales. Vol. V. Art. Cicatrice.-Larrey in lievue médicale france et étrang. March, 182\%, (also compressed,) and in Amales des Sic. naturelles, $A$ pril, 1827, Vol. X. 1) 439. - Prevost in Mémoires de la Soc. de I'hysique: et d'Histuire naturelle de Gencre, 1826, Vol. I._Ekström 
and Retzius in Ars-Berättelse om Svenska-Läkare-Sällskapets Arbeten, p. 20, Stockh. 1827, experiments on the division and reproduction of the nervus plantaris in horses. [G, Langstaff, Practical Observations on the healthy and morbid conditions of stumps, in Med. Chir. Trans. Vol. XVI. p. 128. T.]

\section{$\S 255$.}

It does not appear remarkable that there should be, from the great rarity of their organic diseases and from the delicacy of their structure, great obscurity as to the VICES OF TEXTURE IN THE NERVES. INFLAMMATYON OF NERVES, neuritis, ${ }^{1}$ occurs not merely in consequence of injuries or exposure, but also spontaneously and from internal causes, and is known by swelling, injection, and more or less extensive redness, with which there is also usually softening or loosening, as well also as hardening and thickening of the tissue, sometimes even adhesion to the neighbouring parts; so that very many of the above described vices of colour and consistence in the nerves appear to be produced, in the greater number of instances, by preceding acute or chronic inflammation. We must, however, distinguish the accidental colouring of a nerve which arises from congestion of blood in a part, or from effused blood in the neighbourhood, from true inflammation. ${ }^{2}$ Suppuration and MORTIFICATION do not appear to arise primarily in the nerves; still, however, they are not unfrequently in part ultimately destroyed by these diseases, although they often resist them for a pretty long while. ${ }^{3}$ Various spurious formations frequently occur in the nerves, to which we usually apply the general name, NERvous SWELlings, tumores nervorum, neuromata ${ }^{4}$ from their external appearance, as it is difficult to determine their texture. These vary exceedingly in number, sizc, position, and texture; usually there is found but one, though sometimes also several, and even very many in the same individual $;^{5}$ their size varies from that of a corn of hemp or wheat, to that of a walnut, an egg, and in some cases of a small melon; ${ }^{6}$ most commonly they produce, during life, little and very painful knots in and upon the membrane of the nerve ${ }^{7}$ there have been however found nervous knots on many of the cerebral, spinal, and even on the ganglionic nerves. ${ }^{8}$ Finally, as to the structure of these nervous tumours, they"are usually fatty, encysted, or fibro-cartilaginous, which are situated in the cellular tissue of the nerves, and tear asunder and separate from each other several nervous bundles, which are otherwise healthy: in other instances, there are tubercular or other masses of coagulated albumen attached at a particular part of the diseased nervous sheath; in still other cases the medulla of the nerve appears to be diseased; this especially occurs in sarcomatous and cancerous swellings of the 
nerves, in which the whole nerve is here and there swollen, hardened, knotty, discoloured, and degenerated in a greater or less degree throughout both its sheath and medulla. ${ }^{9}$

(1) De Plouquet D. de myositide et neuritide. 4to. Tübing. 1790.-Nasse D. de neuritide. 4to. Halæ, 1801.-Home in Trans. of a Soc. for the improvement of med. and surg. Knowledge, Vol. II. No. 11. - Bettoli in Giorn. della Soc. med. chir. di Parma, Vol. II. p. 256.-Martinet Mémoire sur l'inflammation des Nerfs. Paris, 1824; and in Revue Médic. franç. et étrang. 1824, Vol. I I. p. 329-354.Dugés Sur la neurite puerperale, etc. ib. Vol. III. p. 157-179.-Gendrin Histoire anatom. des Inflammations.--On the inflammation of nerves in hydrophobia, in the vicinity of the bitten part, Autenrieth $\mathrm{D}$. de hactenus prætervisa nervorum lustratione in sectionibus hydrophoborum, Tübingen, 1802, has espccially treated.Brandreth, in Edinb. med. and surg. Journ. April, 1825, No. 83, saw in a case of hydrophobia, considerable inflammation throughout a large portion of the nerve.- Hertwig found only in two out of many mad dogs, the nervi vagi and sympathetici reddened at certain spots. v. Hufeland's Journ. 1828, Supplement, p. 55.-Reil Ueber Erkenntniss und Cur. der Fieber, Vol. IV. p. 56, found, in a case of typhus, several of the nerves inflamed, and improperly considered this accidental complication as the cause of the disease, whilst it was, at the utmost, its consequence. - Weinhold also found inflammation of the nerves in nervous fever. v. Kritische Blicke auf das Wesen des Nervenfiebers und seiner Behandlung. Dresd. 1814.-It is not surprising that acute neuralgiæ, viz. tic doloureux, prosopalgia, ischias nervosa, \&c. should be considered as arising from inflammation of the medullary part and sheaths of the nerves; this may indeed occur in some cases, but by no means in all.-Some interesting cases, besides those already mentioned, are described in Swan and Descot. - Serres in Magendie's Journ. de Physiologie, 1825, Vol. V. No. 3, p. 233, (the ganglion gasseri, and the larger parts of the fiftl pair of nerves.) - Ahlberg and Retzius in Ars-Berättelse om Svenska Läkare-Sälskapets Arbeten, lemnad af Ekström, 1826, (the ganglia of the lumbar nerves.) - Pelletier in Revue médicale franç. et étrangère, Nov. 1827, (the ulnar and median nerves in tetanus, after compound fracture of the arm.) Lobstein has seen the sympathetic nerves inflamed several times.

(2) Practical anatomists will readily grant how difficult it is to decide, whether the nervous sheaths and the nervous matter are only apparently or actually inflamed on account of irritation, congestion, extravasation of blood, \&c. I have only seen actual inflammation of nerve up to this time, in consequence of accidental or intentional injury.-Morgagni once saw, in the axis of the ischiatic nerve, a long vessel filled with blood, almost a line thick. v. Epist. LXX. 10.

(3) Morgagni, Epist. L. 11 and 55, found, in a popliteal ancurysm, the nerve here situated almost completely destroyed, which I also have noticed in a similar case. In a large tumour running into suppuration in the region of the parotid gland, one part of the facial nerve was completely destroyed. v. Billard in Archives de Médec. Vol. VI. p. 347.

(4) Spangenberg Ueber Nervenanschwellungen in IIorn's Archiv f. med. Erfahrung. Vol. V. p. 306. - Alexander D. de tumoribus nervorum. 4to. Lugd. Bat. 1810.-J. L.Aronssohn D. Observations sur les tumeurs developpées dans les nerfs. 4to. Strasb. 1822.-Barkow Bemerkungen ïber die Nervenanschwellungen in Nov. Act. pliys. med. Acad. Nat. Cur. Vol. XIV. Part II. p. 515, pl. 32, with engravings. - Some cases, besides those already quoted in Swan and Descot. Further Valsalva, v. Morgagni, Epist. I. 15. - Cheselden Anatomy of the luman Body, p. 256, pl.28, 1741. - Petit in Mémoires de l'Academ. de Chir. Vol. I. p. 90. - Pet. Camper in Demonstrat. anat. pathol. L. 1. Cap. 2. §5. - van Gesscher Ueber natur u. Heilart der verschichenen Arten von Geschwiilsten. p. 65. Icipz. 1787.-Ev. Home in 'I'ransact. of a Soc. for the improvement of med. and surg. Knowledge, Vol. II. No. 11, p.152.- Bisset in Mem. of the medic. Soc. of London, Vol. III. p. 58.-Encyclopedie méthodique de la Chirurgie, Vol. II. p. 412. - Bichat Allgemeine Anatomic iibers. v. I'faff, 'T'll. I. I'art I. p. 303.Marandel in Bulletin de la Soc. de Médec. $\left.\Lambda_{1}\right)$. zum Journ. de Médece contiuné, 
Vol. XI. - N'cunann in von Siebold's Samml. chir. Beobachtungen, Vol. I. p..54.-Mojon and Covercelli, ib. Vol. I. Part III.-Adelmann, ib. Vol. III. p. 177. -Weinhold Ideen über die abnormen Metamorphosen der Highmorshöhle. Leipz. 1810.-Odier in Manuel de Médecine pratique, p. 278 and 362. Paris and Geneva, 1811. - Gooch, Cases and practical Remarks in Surgery, Vol. II. Ch. Bell, Operative Surgery, Vol. II. p. 161.-Zagorsky in Mémoires de Petersburg, Vol. III. p. 219. - Rudolphi, v. Oppert. - Sédillot in Journ. général de Médecine. A ôut, 1814, p. 380.-Schiffner in Den Oestreich. medic. Jahrbüchern, Vol. IV. Part IV. p. $77-90$; and Vol.VI. Part IV. p. 44-54, with engravings, (very many on several of the cerebral, spinal, and ganglionic nerves of two brothers, who were cretins.) - Heineke D. de mastodynia nervosa. 8vo. Berol. 1821, with engravings. - Berndt in Rust's Magazin f. d. ges. Heilk. Vol. XIII. Part I. p. 159. - Wernery in Hufeland's Journ. der prakt. Heillk. May, 1823, p. 107. Lobstein de Nervi sympathetici hum. fabr. et morbis. \$ 157. - Ollivier Ueber das Rückenmark, u. s. w. d. v. Radius, p. 2. 12mo. Leipz. 1824. Beobachtung 27.Hesselbach Beschreibung der pathol. Präparate zu Würzburg, 1824, p. 361, No. 274, p. 362, No.596, 641. - Ehrmann Compte rendu sur les travaux anatomiques, p. 36. Strasb. 1827. - G. Sandifort Museum anatomicuin, Vol. III. p. 148, No. 41. - Cruveilhier Anatomie pathologique, Livraison, I. Paris, 1828, pl.3. - Pring, v. Abercrombie.-I have, up to the present time, found three nervous knots, and all of them small, one as large as a clate seed on the median nerve, another as big as a pea, and a third of the size of a vetch seed on a cutaneous nerve. v. Verzeich., No. 2317, 2318, and $\$ 853$.

(5) To wit, in the cases of Schiffner, Criveilhier, Barkow. Richerand found a nerve, forming a whole row of spindle-like swellings. v. Descot, p. 118.

(6) This was found by Dubois in the median nerve. v. Spangenberg. As large as a hen's egg and thereabouts, described by Alexander, Home, Aronssohn, Heineke, Ehrmann, and Sandifort.

(7) Wood, On painful subcutaneous Tubercle, in Edinb. med. and surg. Journ. Vol. VIII. p. 283 and 4.29, and Jaumes D. sur une espèce de tumeur squirrheuse enkystée, attribuée mal-à-propos à une affection des nerfs. Paris, 1828. Both writers consider that they were not nervous tumours, but fibro-cellular or cartilaginous tumours, which, surrounded by hardened and thickened cellular tissue, indented themselves into the nerves; but I doubt this very much, as in the instances before me, the knots are distinctly situated in the nerves themselves, and not in the tissue of their coat; the extreme pain which they give rise to also opposes this view, as numerous other and large swellings press upon the cutaneous nerves, and stretch them, without giving rise to similar symptoms. Observations on this kind of knot are given by Cheselden, Camper, Bisset, Siebold, Neumann, Swan, Descot; similar cases are related by Portal Cours d'Anat. médicale, Vol. IV. p. 247.-Pearson, in Medical Facts and Observations, Vol. VI. p. 95.-J. Thomson, in Edinb. med. and surg. Journal, Vol. VIIJ. p. 289.-Newbigging, p. 289. - Gillespie, ib. - Marshall Hall, ib. Vol. XI. p. 466. -Windsor, ib. Vol. XVII. p. 261.-Nicod Nouv. Journ. de Médecine, Nov. 1818.-Cases of Marjolin, Chaussier, and Fabricio, mentioned by Descot, p. 106.-Jacopi Prospetto della Scuola di Chirurgia pratica, Vol. I. cap. 9, Milano, 1813. - Monteggia Instituz. chir. Vol. II. cap. 14, p. 197. Milano, 1813, \&c.

(8) For instance, in the optic nerve of a blind person, a small hard knot, rather larger than a hemp-seed. v. Sédillot Journ. de Médecine, Vol. L. Aug. 1814, p. 380.-In the fifth nerve, Dupuytren, v. Descot, p. 20 ; Leveque Lassource. v. Dict. des Scienc. médic. Art. Cancer.-Weinhold.--Schiffner.--On the facial nerve, Schiffner, and Wishart in Edinb. med. and surg. Journ. July, 1822. On the auditory nerve, Schiffner. - On the pneumogastric nerve, Schiffner and Barkow. - On the recurrent nerve of Willis, Schiffner. - - On the brachial nerve, Cheselden, Petit, Home, Gooch, Delaroche, and Petit Radel, v. Diction. de Chir. de l'Encyclop. méthod. Art. Tumeur, Dubois, v. Spangenberg, Alexander, Odier, Aronssohn, Heineke, Hesselbach, Sandifort, Fring, and myself. - On the dorsal and lumbar nerves, Ollivier and Schiffner.-- On the nerves of the lower extremities, Valsalva, Schiffner, Spangenberg, Bell, Ehrmann, Berndt, Hesselbach, Wernery. - On the abdominal nerves, de Haen, v. Lieutaud Hist. Anat. med. L. II. 
Sect. 6, Part II. p. 251, Obs. 787 ; and Descot, p. 120 and 121.-. On the sympathetic nerve and its ganglions, v. Bichat, Lobstein, Hesselbach and Cruveilhier.

(9) This occurs in all the nerves, but most frequently in the optic, which I have noticed several times. I have, however, once seen it on the ischiatic nerve, at its origin, and in the suprascapular nerve, which was affected and degenerated into knots, by an osteosarcom situated in the upper arm; regarding the latter, v. my Selt. Beob. Part I. p. 83, pl. 2. I can, after what lias been stated above concerning medullary sarcom, perhaps here notice how incorrect the opinion is, which consider's this as a degeneration of the nervous medulla.

\section{$\S 256$.}

Lastly, we also occasionally observe irregularities in the nerves as to their contents. Thus the cellular tissue, which forms the nervous sheaths and connects the several fibrils of a nerve, is here, as elsewhere, affected with INFILTRATION OF WATER, LYMPH, BLOOD, \&c.; this is most commonly and distinctly the case in the larger nerves, viz. in the ischiatic, which has been found not unfrequently dropsical after active neuralgia, probably depending on chronic inflammation. ${ }^{1}$ STONY AND BONY CONCRETIONS ${ }^{2}$ have also been observed in rare cases on the nervous sheaths and in the cellular tissue of nerves, but are extraneous to the nervous matter. In a few instances, there has been observed a peculiar irritation in the nerves, from Extraneous bodies which have accidentally entered them and remained there for a long period. ${ }^{3}$

(1) Dom. Cotunni De ischiade nervosa commentarius, Neapol. 1764, reviewed in Sandifort's Thesaurus, Vol. II. No. 19, p. 403-451. Wien, 1770. Neapol. 1780. Leipzig, 1793. Further, the other works on this disease, on Prosopalgia and Neuralgia in general.

(2) For instance, on the optic nerve, Bleguy Zodiac. Gall. Ann. I. April, Obs. 11, p. 81.-- Cheneau Obs. med. Lib. I. cap. 1, Obs. 2, Lyons, 1673. Schurig Lithologia, p. 100, 250.--Walter Observ. anat. 1. 42, on the suprascapular nerve.--Rudolphi v. Oppert. On a tumour of the first dorsal nerve, v. Ollivier Traité de la Möelle Epinière, \&c. case 27. On the phrenic nerve, Camper in Snip De lithotomia. 4to. Amstel. 1761.

(3) A piece of a ball in the radial nerve. v. $A$. Denmark, in Med. chir. Trans. Vol. IV. p. 48, for which the arm was amputated. A piece of porcelain remaining in the cheek fourteen years produced tic doloureux, which subsided on the removal of the extrancous body. v. Jeffreys, in London med. and phys. Journal.

LND OF VOL. I. 




24

088 E3 1831, Copy 2 
